\title{
Verkeersongevallen: een rechtseconomisch, empirisch en positiefrechtelijk onderzoek naar de werking van aansprakelijkheid, verzekering en veiligheidsregulering in het verkeer
}

Citation for published version (APA):

van Dam, M. (2001). Verkeersongevallen: een rechtseconomisch, empirisch en positiefrechtelijk onderzoek naar de werking van aansprakelijkheid, verzekering en veiligheidsregulering in het verkeer. [Doctoral Thesis, Maastricht University]. Boom Juridisch. https://doi.org/10.26481/dis.20011214md

Document status and date:

Published: 01/01/2001

DOI:

10.26481/dis.20011214md

Document Version:

Publisher's PDF, also known as Version of record

Please check the document version of this publication:

- A submitted manuscript is the version of the article upon submission and before peer-review. There can be important differences between the submitted version and the official published version of record. People interested in the research are advised to contact the author for the final version of the publication, or visit the DOI to the publisher's website.

- The final author version and the galley proof are versions of the publication after peer review.

- The final published version features the final layout of the paper including the volume, issue and page numbers.

Link to publication

\footnotetext{
General rights rights.

- You may freely distribute the URL identifying the publication in the public portal. please follow below link for the End User Agreement:

www.umlib.nl/taverne-license

Take down policy

If you believe that this document breaches copyright please contact us at:

repository@maastrichtuniversity.nl

providing details and we will investigate your claim.
}

Copyright and moral rights for the publications made accessible in the public portal are retained by the authors and/or other copyright owners and it is a condition of accessing publications that users recognise and abide by the legal requirements associated with these

- Users may download and print one copy of any publication from the public portal for the purpose of private study or research.

- You may not further distribute the material or use it for any profit-making activity or commercial gain

If the publication is distributed under the terms of Article 25fa of the Dutch Copyright Act, indicated by the "Taverne" license above, 


\section{VERKEERSONGEVALLEN}




\section{Promotores:}

Prof. dr. M.G. Faure LL.M.

Prof. mr. G.E. van Maanen

\section{Beoordelingscommissie:}

Prof. mr. T. Hartlief (voorzitter)

Prof. dr. H. Cousy (Katholieke Universiteit Leuven)

Prof. mr. J.M. Smits

Dit onderzoek werd gesteund door de stichting voor Recht en Openbaar Bestuur (REOB), welke deel uitmaakt van de Nederlandse Organisatie voor Wetenschappelijk Onderzoek (NWO).

\section{(C) 2001 Martien van Dam}

Alle rechten voorbehouden. Niets uit deze uitgave mag worden verveelvoudigd, opgeslagen in een geautomatiseerd gegevensbestand, of openbaar gemaakt, in enige vorm of op enige wijze, hetzij elektronisch, mechanisch, door fotokopieën, opnamen, of enige andere manier, zonder voorafgaande schriftelijke toestemming van de uitgever.

Voorzover het maken van kopieën uit deze uitgave is toegestaan op grond van artikel 16b Auteurswet 1912 jo. het Besluit van 20 juni 1974, Stb. 351, zoals gewijzigd bij Besluit van 23 augustus 1985, Stb. 471 en artikel 17 Auteurswet 1912, dient men de daarvoor wettelijk verschuldigde vergoedingen te voldoen aan de Stichting Reprorecht (Postbus 882, $1180 \mathrm{AW}$ Amstelveen). Voor het overnemen van gedeelte(n) uit deze uitgave in bloemlezingen, readers en andere compilatiewerken (artikel 16 Auteurswet 1912) dient men zich tot de uitgever te wenden.

No part of this book may be reproduced in any form, by print, photo print, microfilm or any other means without written permission from the publisher.

ISBN 9054541490 


\section{Voorwoord}

Diegenen die het al hebben gedaan, weten dat het schrijven van een proefschrift zelf een individuele aangelegenheid is. Ook is bekend dat daarbuiten weinig tijd overblijft om de 'eenzaamheid' te verdrijven. Een woord van dank is daarom op zijn plaats aan de personen die daarin zijn geslaagd en aan de personen die anderszins aan de totstandkoming van dit boek hebben bijgedragen.

Dat zijn allereerst mijn promotores, prof. dr. M.G. Faure en prof. G.E. van Maanen. Dankzij hen heb ik dit onderzoek mogen uitvoeren. Prof. dr. M.G. Faure heeft mij de wetenschap, in het bijzonder de rechtseconomie, ingereden, terwijl prof. mr. G.E. van Maanen er mede voor zorgde dat ik niet teveel van de weg van het onderzoek afweek. Ik dank hen voor hun inspirerende en enthousiaste begeleiding.

Daarnaast gaat mijn dank uit naar prof. mr. T. Hartlief, prof. dr. H. Cousy en prof. mr. J.M. Smits voor hun bereidheid om in de leescommissie plaats te nemen en het manuscript van (gedetailleerd) commentaar te voorzien. Dank ook aan prof. mr. C.C. van Dam voor het kritisch meelezen van het manuscript.

Bijzondere lof verdient Marjo Mullers, secretaresse van het 'Maastrichts Europees instituut voor Transnationaal Rechtswetenschappelijk Onderzoek' (METRO), voor de zorg die zij heeft besteed aan het 'camera ready' maken van het manuscript. Ook dank aan mijn kantoorgenote Nathalie Kroon voor haar hulp bij het maken van de summary.

Ik dank het Instituut METRO voor de gastvrijheid die ik heb genoten tijdens en na mijn dienstverband als OIO. Ook dank ik mijn ex-collega's van METRO en mijn huidige kantoorgenoten van Schaap \& Partners voor hun belangstelling en voor de gezelligheid tijdens mijn onderzoek en bij de voltooiing van dit boek.

Bijzondere dank gaat uit naar mijn familie en mijn (volleybal) vrienden, wier geduld ik ernstig op de proef heb gesteld. $\mathrm{Zij}$ verdienen lof voor hun betrokkenheid bij de voortschrijding van het onderzoek en voor de aangename afleiding die zij mij hebben bezorgd. De laatste loodjes zijn zoals gewoonlijk het zwaarst. Lieve Karin, bedankt voor al je steun.

Ten slotte dank ik mijn ouders voor het vertrouwen dat zij in mij hebben gesteld. Ook verdienen zij alle lof voor bun onvolprezen en niet aflatende steun en betrokkenheid tijdens mijn onderzoek en bij de voltooiing daarvan. Dit boek draag ik daarom aan jullie op. 
Dit onderzoek is op 1 maart 2001 afgerond. Hiema verschenen literatuur en jurisprudentie zijn slechts incidenteel verwerkt.

Martien van Dam 


\section{Inhoudsopgave}

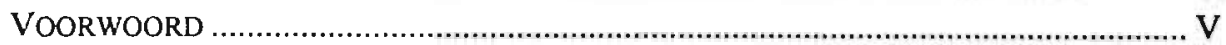

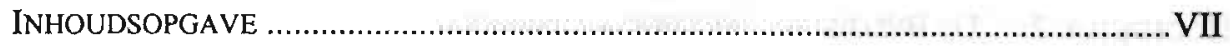

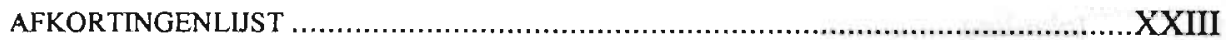

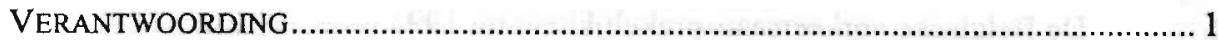

1. Probleemstelling ......................................................................... 2

2. Het positieve recht, belang van het onderzoek ..................................... 2

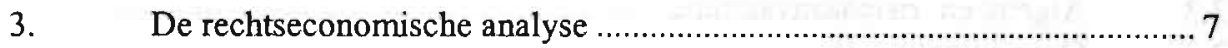

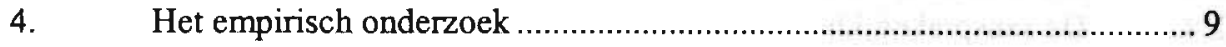

5. De methode van onderzoek............................................................ 10

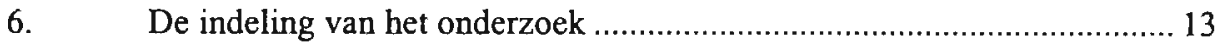

\section{DEEL 1 EEN POSITIEFRECHTELIJKE ANALYSE VAN DE} VERKEERSAANSPRAKELIJKHEID

HOOFDSTUK 1: DE FRANSE VERKEERSAANSPRAKELIJKHEID …........................... 17

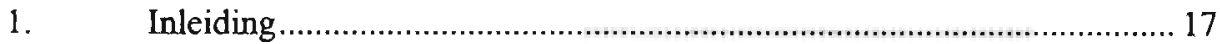

2. De verkeersaansprakelijkheid vóór de 'loi Badinter' ............................. 17

3. De 'loi Badinter': een korte voorgeschiedenis ..................................... 20

4. De 'loi Badinter': een positiefrechtelijke analyse ................................... 21

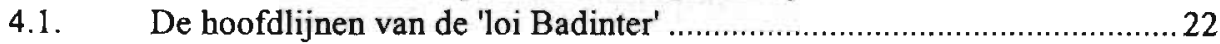

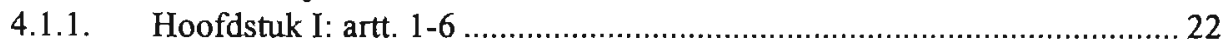

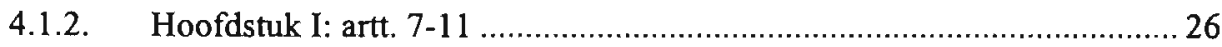

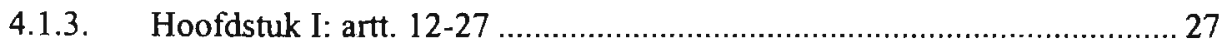

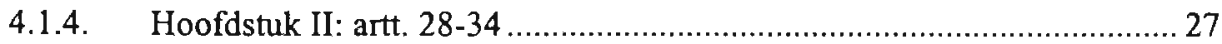

4.2. De betrokkenheid ('implication') van het motorrijtuig...........................22

4.2.1. Contact tussen slachtoffer en een motorrijtuig in beweging ....................29

4.2.2. Contact tussen slachtoffer en een stilstaand motorrijtuig ....................... 30

4.2.3. Afwezigheid van een fysiek contact tussen slachtoffer en motorrijtuig ... 31

4.3. De eigen schuld ('faute inexcusable') van het niet-gemotoriseerde

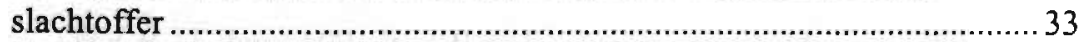

4.4. Het regres na de invoering van de 'loi Badinter' .................................... 36

4.4.1. De regresprocedure binnen de 'loi Badinter' ......................................... 37

4.4.2. De regresprocedure volgens het 'Protocole d'Accord'............................ 38 
5. De praktische werking van de wet Badinter ....................................... 40

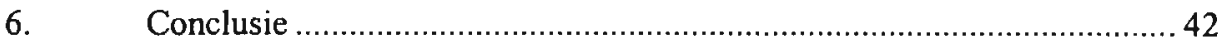

HOOFDSTUK 2: DE BELGISCHE VERKEERSAANSPRAKELIJKHEID............................4 45

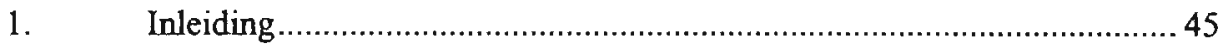

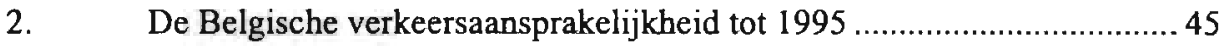

2.1. De foutaansprakelijkheid van artikel 1382 BW: Algemeen ....................46

2.2. Overmacht in het verkeer.............................................................. 48

2.3. Verkeersongevallen en de 'medeaansprakelijkheid' van het slachtoffer ...50

2.3.1. Algemeen: risicoaanvaarding ......................................................... 50

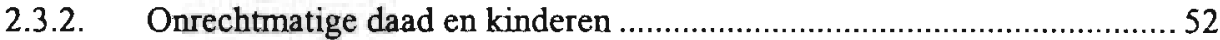

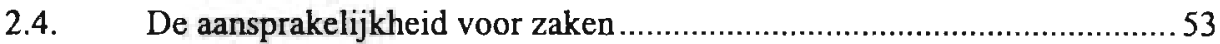

2.5. De motorrijtuigverzekering en de foutaansprakelijkheid ........................55

3. De voorgeschiedenis van de nieuwe Belgische regeling …................... 57

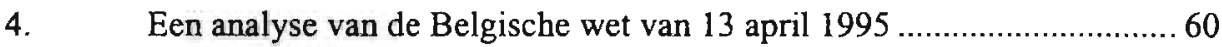

4.1. De reikwijdte van artikel 29bis ............................................................61 61

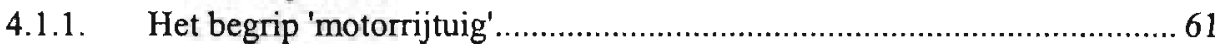

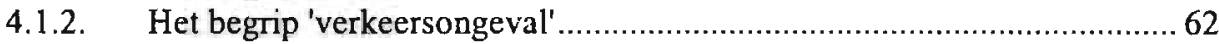

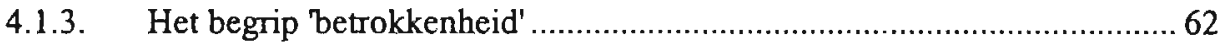

4.2. De personen die gerechtigd zijn tot schadevergoeding ............................64

4.3. De schadevergoeding op basis van artikel 29bis ...................................6 65

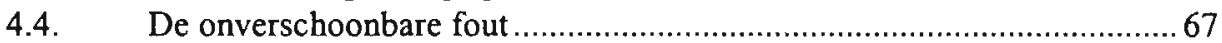

4.4.1. De onverschoonbare fout in de Belgische rechtspraak .......................... 70

4.5. Het verhaalsrecht van de WAM-verzekeraar......................................... 71

4.6. Het subrogatierecht van de sociale verzekeraars .................................. 72

4.7. De handhaving van het aansprakelijkheidsrecht ................................. 73

5. De juridische grondslag van de Belgische regeling ............................... 74

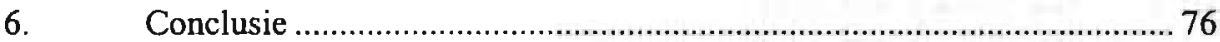

HOOFDSTUK 3: DE NEDERLANDSE VERKEERSAANSPRAKELIJKHEID …..................79

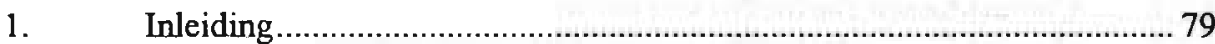

2. De toepassing van artikel 6:162 BW (oud: $1401 \mathrm{BW}$ ) bij verkeersongevallen

3. De ontwikkeling van artikel 185 WVW 1994 (oud: 31 WVW) ..............81 81

3.1. Overmacht in de zin van artikel 185 WVW (31 WVW oud): Algemeen . 82

3.2. De eigen schuld bij ongemotoriseerden van 14 jaar en ouder: de $50 \%$-regel. 
3.3. Overmacht en eigen schuld bij kinderen jonger dan 14 jaar: de $100 \%$-regel

3.4. De positie van de verhaalzoekende verzekeraar ................................... 93

3.4.1. Geen algemene billijkheidscorrectie ten behoeve van de regresnemer.....93

3.4.2. De concrete beoordeling van de vordering van de regresnemer ............... 94

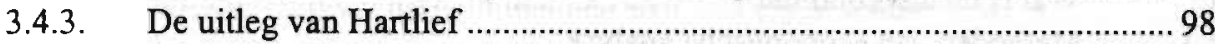

4. De literatuur en de verkeersaansprakelijkheid ....................................... 100

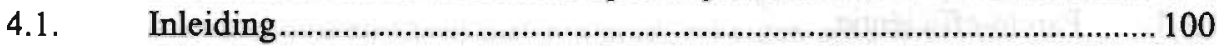

4.2. Bloembergen en een aanvullende verkeersverzekering voor personenschade

4.3. Van Wassenaer van Catwijck en de verkeersverzekering ....................... 103

4.4. Andere auteurs over de verkeersaansprakelijkheid............................... 105

5. De wetgever en de verkeersaansprakelijkheid .................................... 109

5.1. De Rapporten van de Studiegroep Verkeersaansprakelijkheid............... 109

5.2. De Notitie Verkeersaansprakelijkheid ................................................. 111

6. Het wetsvoorstel Verkeersongevallen en de plannen van Minister

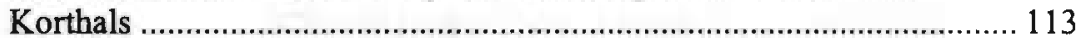

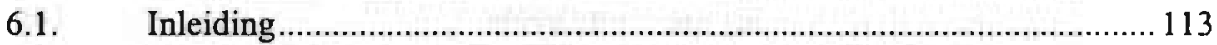

6.2. Welke categorieën verkeersdeelnemers worden beschermd? ................115

6.2.1. Memorie van Toelichting …........................................................... 116

6.2.2. Het commentaar in de literatuur ........................................................ 117

6.2.3. De beschermingsomvang in de plannen van Minister Korthals............. 119

6.2.4. Het commentaar in de literatuur .................................................. 120

6.3. 'Betrokkenheid', 'opzet of bewuste roekeloosheid' en 'roekeloosheid' .... 120

6.3.1. Het begrip 'betrokkenheid' in het wetsvoorstel Verkeersongevallen ...... 120

6.3.2. Het commentaar in de literatuur .................................................... 122

6.3.3. 'Opzet of bewuste roekeloosheid' in het wetsvoorstel

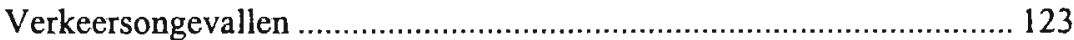

6.3.4. Het commentaar in de literatuur ..................................................... 124

6.3.5. De 'roekeloosheid' in de plannen van Korthals ................................... 125

6.3.6. Het commentaar in de literatuur ...................................................... 127

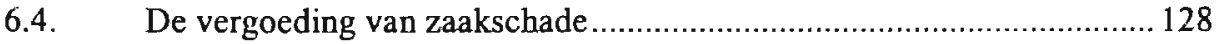

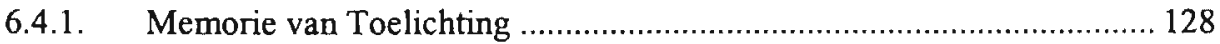

6.4.2. Het commentaar in de literatuur ..................................................... 129

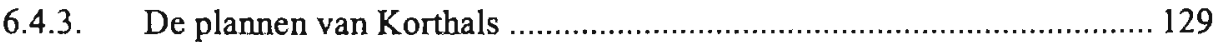

6.5. De schade van de gemotoriseerde verkeersdeelnemer: reflexwerking ... 130

6.6. Regresrechten en verzekeringspremies ........................................... 130

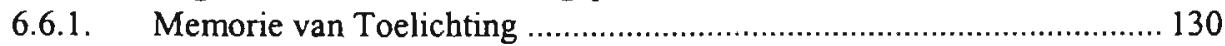

6.6.2. Het commentaar in de literatuur ..................................................... 132

7. Conclusie 
HOOFDSTUK 4: RECHTSECONOMIE: EEN INTRODUCTIE

1. Wat is rechtseconomie?

1.1. Methoden van economische analyse............................................... 140

1.2. Het efficiëntiecriterium binnen de economische analyse...................... 141

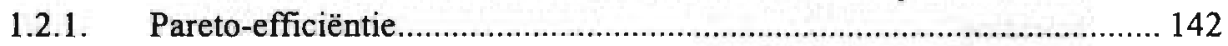

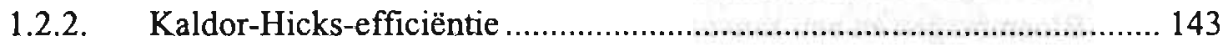

2. Het efficiëntiecriterium binnen de ongevalssituatie.............................. 144

2.1. Efficiëntie in het ongevallenrecht ................................................. 144

2.2. Doelstellingen binnen de economische analyse van het

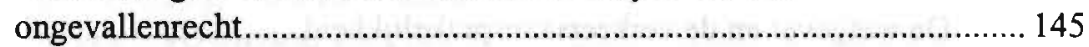

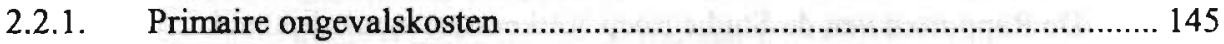

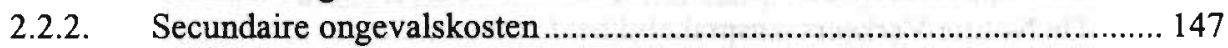

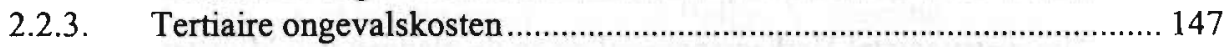

3. Het economisch model van het ongevallenrecht................................ 148

3.1. Veronderstellingen in het ongevallenrecht ...................................... 149

3.2. Het economisch optimum ........................................................... 150

4. Het Coase-Theorema ….................................................................... 153

HOOFDSTUK 5: DE ECONOMISCHE ANALYSE VAN HET

AANSPRAKELIJKHEIDSRECHT

1. Inleiding: aansprakelijkheidsregels................................................... 159

2. De structuur van de economische analyse van het aansprakelijkheidsrecht

3. Unilaterale ongevallen: het niveau van zorg ................................... 162

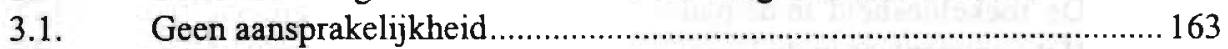

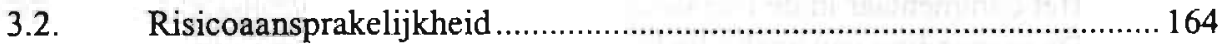

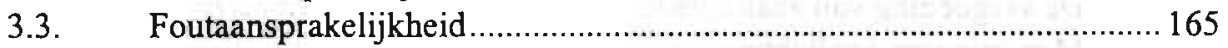

3.4. Conclusie I: Aansprakelijkheidsregels vergeleken .............................. 166

4. Unilaterale ongevallen: het activiteitsniveau ....................................... 166

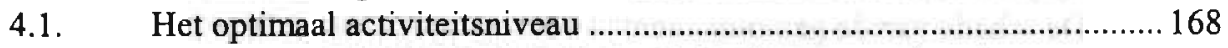

4.2. Welke aansprakelijkheidsregel is efficiënt bij een optimaal zorg- en

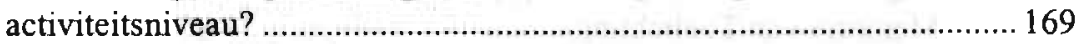

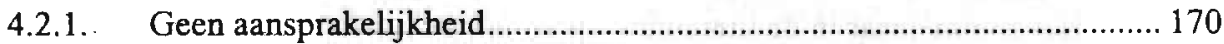

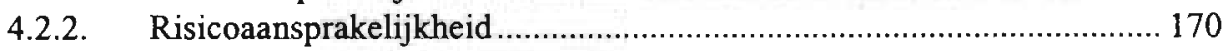

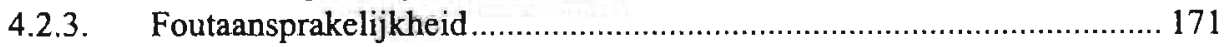


5. Conclusie II: Unilaterale verkeersongevallen geëvalueerd

6. Bilaterale ongevallen: het niveau van zorg ....................................... 173

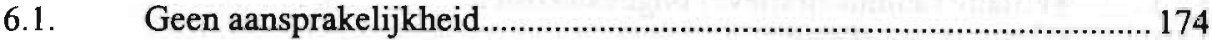

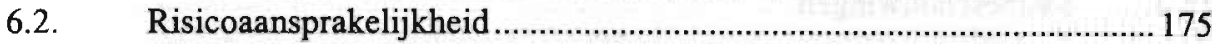

6.3. Risicoaansprakelijkheid met een absoluut eigen schuldverweer ............ 176

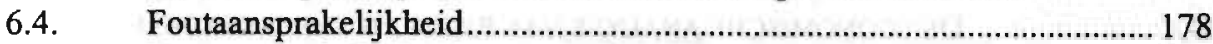

6.5. Foutaansprakelijkheid met een absoluut eigen schuldverweer ............... 179

6.6. Foutaansprakelijkheid met een gradueel eigen schuldverweer ............... 182

6.7. Risicoaansprakelijkheid met een gradueel eigen schuldverweer ............ 183

7. Conclusie III: Aansprakelijkheidsregels vergeleken.............................. 184

8. Bilaterale ongevallen: het activiteitsniveau ……................................. 185

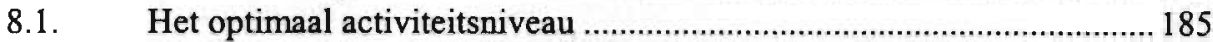

8.2. Welke aansprakelijkheidsregel is efficiënt bij een optimaal zorg-en activiteitsniveau?

8.2.1. Risicoaansprakelijkheid met een absoluut eigen schuldverweer ........... 187

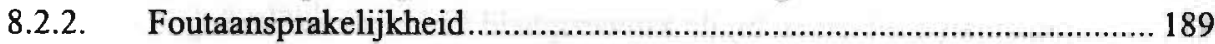

9. Conclusie IV: Bilaterale ongevallen geëvalueerd ................................. 191

10. Andere factoren die van invloed zijn op de keuze tussen fout- en risicoaansprakelijkheid en verdere verfijningen van het model

10.1. Informatieproblemen bij de bepaling van de zorgvuldigheidsnorm ....... 194

10.1.1. De rechter beschikt over onvolledige informatie omtrent de werkelijk uitgeoefende zorg.....

10.1.2. De rechter heeft geen volledige informatie over de zorgvuldigheidsnorm

10.1.3. Onoplettendheid bij de dader en het slachtoffer

10.1.4. Onzekerheid bij de dader ten aanzien van de zorgvuldigheidsnorm....... 197

10.1.5. Voorzienbare fouten bij de keuze van de zorgvuldigheidsnorm............. 197

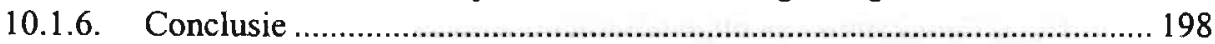

10.2. Het classificeren van niveaus van zorg ............................................. 198

10.2.1. De gevolgen voor de optimale zorg en de zorgvuldigheidsnorm........... 199

10.2.2. De gevolgen voor de aansprakelijkheid ............................................... 201

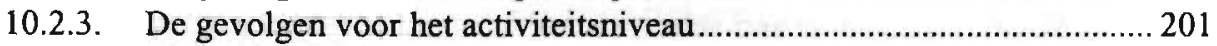

10.2.4. Het treffen van bepaalde voorzorgsmaatregelen................................. 202

11. Conclusie V: Nogmaals fout- en risicoaansprakelijkheid vergeleken .... 204

12. Algehele conclusie van de economische analyse van het aansprakelijkheidsrecht in het licht van de centrale probleemstelling ....................206

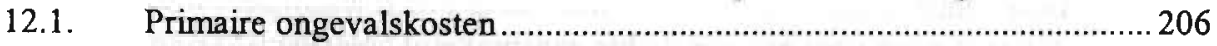

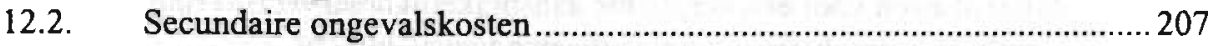

12.2.1. Optimale compensatie van het verkeersslachtoffer............................... 208

12.2.2. De invloed van insolvabiliteit van de automobilist op de preventie ....... 208 
12.2.3. Distributionele gevolgen van de keuze voor een aansprakelijkheidsregel

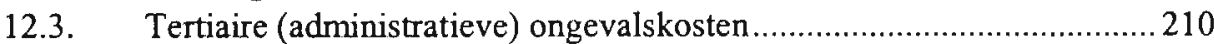

12.4. Slotbeschouwingen.

HOOFDSTUK 6: DE ECONOMISCHE ANALYSE VAN RISICO EN VERZEKERING EN ANDERE COMPENSATIEMECHANISMEN .

1. Inleiding

2. De economische analyse van risico ................................................ 215

2.1. De houding van partijen ten aanzien van risico ................................. 215

2.2. Het afwentelen van risico ............................................................ 216

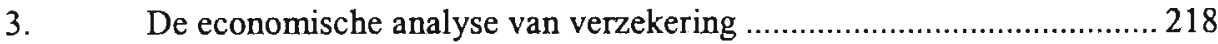

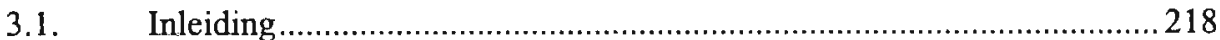

3.2. De verschillende vormen van verzekering ......................................... 221

4. Informatieproblemen bij de aanwezigheid van een verzekering............. 222

4.1. Morele risico ('moral hazard'): Algemeen .......................................... 223

4.1.1. Het morele risico en de controle door de verzekeraar........................... 224

4.1.1.1. De controle van het gedrag van de verzekerde ....................................225

4.1.1.2. De controle via een gedeeltelijke verzekeringsdekking ....................... 226

4.1.2. De informatiekosten voor een verzekeraar bij de controle van het

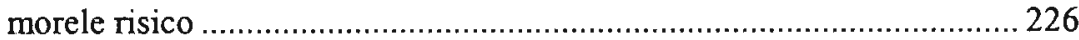

4.1.3. Conclusie morele risico: de verschillende controle-instrumenten

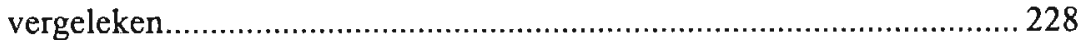

4.1.4. De controle van het morele risico binnen het verkeersongevallenrecht.. 229

4.2. Anti-selectie ('Adverse Selection'): Algemeen ……........................... 230

4.2.1. Het probleem van de asymmetrie in informatie .................................... 231

4.2.2. Instrumenten ter beperking van de anti-selectie ............................... 234

4.2.2.1. Het differentiëren van ongevalsrisico's ............................................ 234

4.2.2.2. Andere remedies tegen het proces van anti-selectie ........................... 235

4.3. Morele risico en anti-selectie vergeleken ........................................236

4.4. Het onderscheid tussen 'third party' en 'first party' verzekering .............. 237

4.5. Morele risico en de anti-selectie binnen de autoverzekering .................. 238

5. De regulering van verzekeringsmarkten .............................................2 239

5.1. De theorie van de verplichte verzekering ..........................................240

5.1.1. Verzekeringsplicht en de verhoging van het nut...................................241

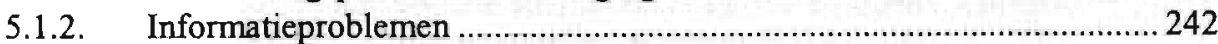

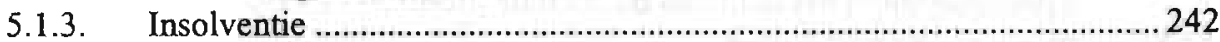

5.1.4. Alternatieven voor een verplichte aansprakelijkheidsverzekering.......... 243

5.1.5. Verplichte verzekering in het verkeersongevallenrecht ........................ 245

5.2. De beperking van aansprakelijkheid................................................. 246 
5.2.1. De verzekerbaarheid van risico's als argument voor limitering .............. 247

5.2.2. De wenselijkheid van een beperking van de aansprakelijkheid.............. 248

5.2.3. Aansprakelijkheidsbeperking in het verkeersongevallenrecht ...............249

5.3. De economische analyse van verzekeringsmarkten..............................250

5.3.1. Vraag en aanbod binnen een concurrerende verzekeringsmarkt............ 250

5.3.2. Economische gevolgen van een concentratie op de verzekeringsmarkt . 251

5.3.3. Concurrentie en verplichte verzekering ................................................. 253

5.4. Het belang van concurrentie op de markt voor autoverzekeringen......... 254

6. Alternatieve compensatiemechanismen en eerste partij verzekeringen .. 256

6.1. Economische voorwaarden voor invoering van een schadefonds...........257

6.2. Een schadefonds als vervanging voor een systeem van aansprakelijkheid en verzekering........................................................... 258

6.2.1. Een schadefonds versus een verzekering ........................................... 258

6.2.2. Fondsvorming versus aansprakelijkheid ................................................ 260

6.2.3. Een schadefonds als waarborg ............................................................. 260

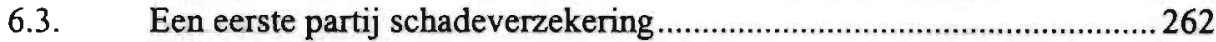

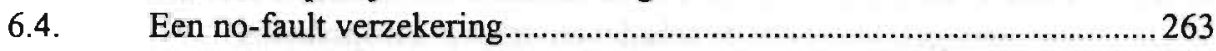

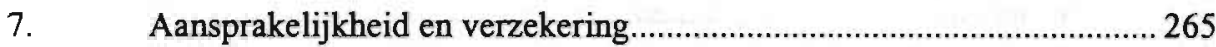

7.1. Het belang van de koppeling tussen aansprakelijkheid en verzekering ..266

7.2. Aansprakelijkheidsregels en de houding ten aanzien van risico:

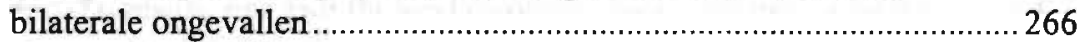

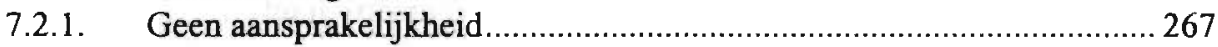

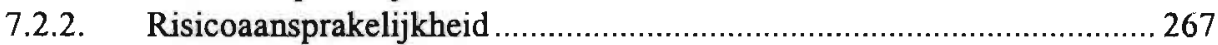

7.2.3. Risicoaansprakelijkheid met een absoluut eigen schuldverweer ........... 268

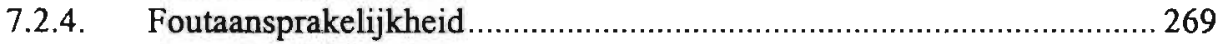

7.3. Aansprakelijkheidsregels en de beschikbaarheid van verzekering:

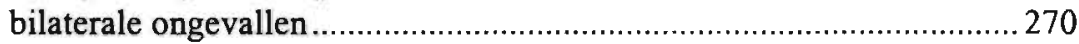

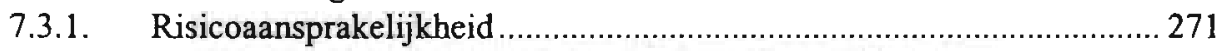

7.3.2. Risicoaansprakelijkheid met een absoluut eigen schuldverweer ........... 273

7.3.3. Foutaansprakelijkheid .................................................................... 274

7.4. De invloed van verzekering op de aansprakelijkheidsvraag ................2275

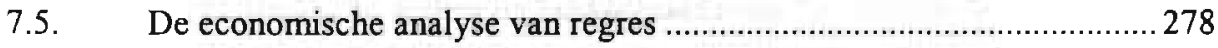

8. Conclusie aansprakelijkheid en verzekering binnen het kader van de

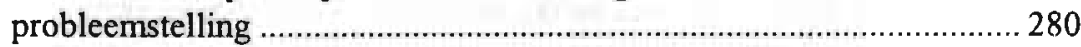

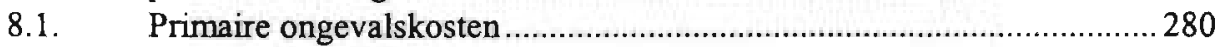

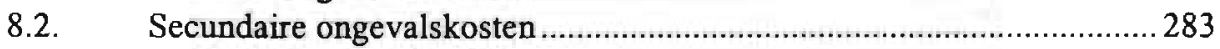

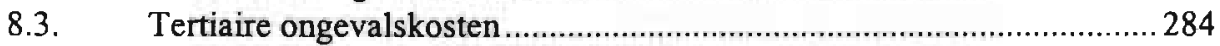

8.4. Conclusie: preventie en compensatie in het licht van de verkeersaansprakelijkheid. 
HOOFDSTUK 7: DE ECONOMISCHE ANALYSE VAN VEILIGHEIDSREGULERING

1. Inleiding

2. De 'public interest' theorie

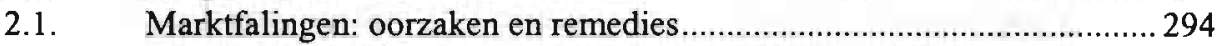

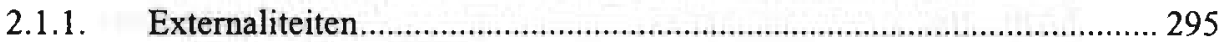

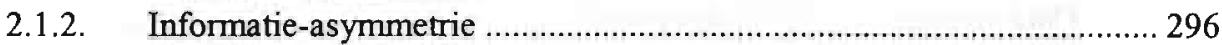

2.1.2.1. Voorbeelden van informatie-asymmetrie binnen de productmarkt........ 296

2.1.2.2. Regulering als remedie voor informatie-asymmetrie.......................... 298

2.2. Conclusie: kanttekeningen bij de economische welvaartstheorie ...........300

3. De economische theorie van veiligheidsregulering …......................... 302

3.1. De criteria voor veiligheidsregulering ….......................................... 303

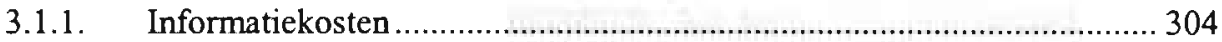

3.1.1.1. Welke partij kan over betere risico-informatie beschikken?................. 305

3.1.1.2. Welke partij bezit de betere risico-informatie? ................................... 306

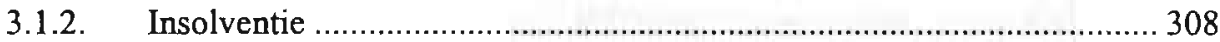

3.1.3. De onmogelijkheid om de schadeveroorzaker aansprakelijk

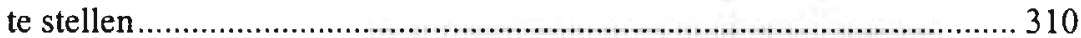

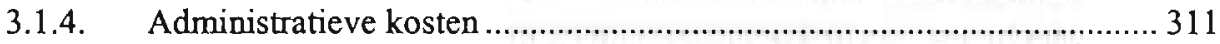

3.2. Een combinatie van aansprakelijkheid en veiligheidsregulering ........... 313

3.2.1. Naleving van de veiligheidsnorm bevrijdt niet van aansprakelijkheid ... 313

3.2.2. Moet overtreding van de veiligheidsnorm automatisch tot aansprakelijkheid leiden?

3.2.3. Een gecombineerd gebruik toegepast op het onderscheid in aansprakelijkheidsregels

3.3. Aansprakelijkheid en veiligheidsregulering toegepast op het verkeersongevallenrecht

3.3.1. De preventie via aansprakelijkheidsregels in het verkeer ....................... 319

3.3.2. De werking van ex ante veiligheidsregulering in het verkeer............... 321

3.3.2.1. De preventieve werking van ex ante veiligheidsregulering .................. 321

3.3.2.2. De handhaving en controle van ex ante veiligheidsregulering .............. 322

3.3.3. Een combinatie van aansprakelijkheid en veiligheidsregulering in het verkeer

4. Alternatieve economische theorieën van overheidsregulering............... 326

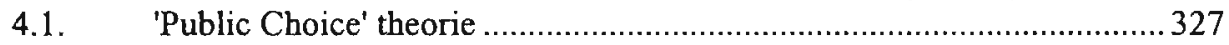

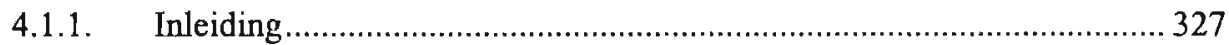

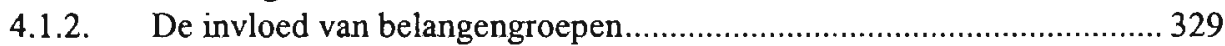

4.1.2.1. De voorwaarden voor een effectieve lobbying …............................... 330

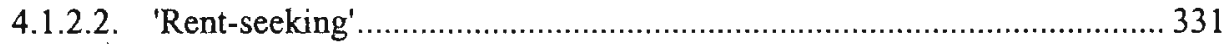

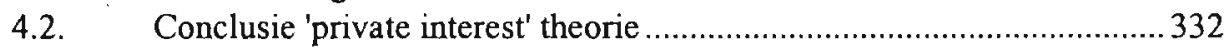

4.3. Kanttekeningen bij de 'private interest' theorie ....................................333

5. Veiligheidsregulering en de concurrentie tussen belangengroepen ......... 334 
6. Toetsing 'public interest' en 'private interest' aan de verkeersveiligheid. 336

6.1. De invloed van verzekeraars, autofabrikanten en slachtoffergroepen ....337

6.2. De verkeersveiligheid en het lobbyproces: toepassingen........................ 338

HOOFDSTUK 8: ALGEHELE SCHEMATISCHE CONCLUSIE VAN HET ECONOMISCH

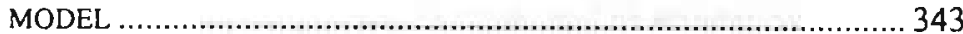

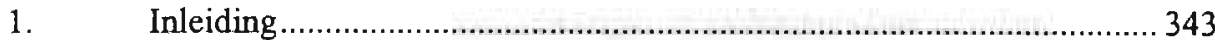

2. De economische analyse van verkeersongevallen: algemeen .................343

3. Preventie van verkeersongevallen (primaire ongevalskosten) ............... 344

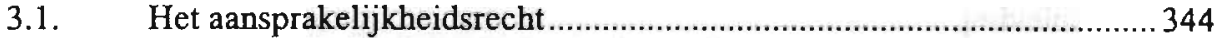

3.2. Ex ante veiligheidsregulering in het verkeer...................................... 344

3.3. Aansprakelijkheid en veiligheidsregulering …................................... 345

4. Verzekering en compensatie (secundaire ongevalskosten) .................... 345

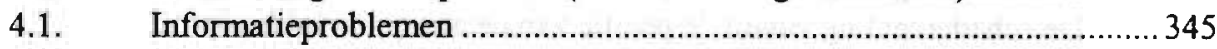

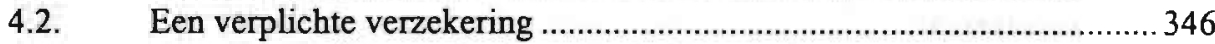

4.3. Concurrentie binnen de autoverzekeringsmarkt ...................................346

4.4. Alternatieve compensatiemechanismen ................................................. 346

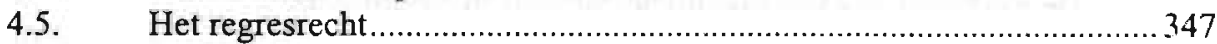

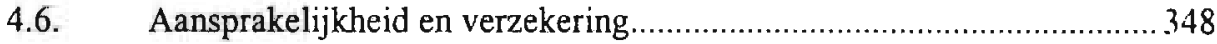

5. Administratieve kosten (tertiaire ongevalskosten) ….......................... 348

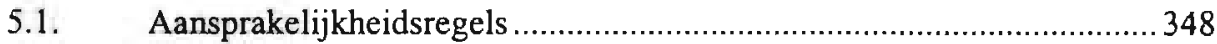

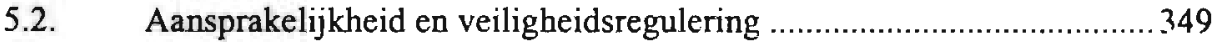

5.3. Aansprakelijkheid en verzekering................................................. 349

6. Aansprakelijkheid, verzekering en veiligheidsregulering gezamenlijk

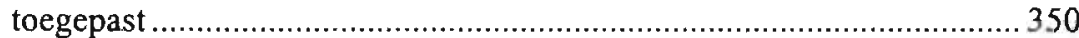

6.1. Een gecombineerd gebruik van instrumenten ....................................350

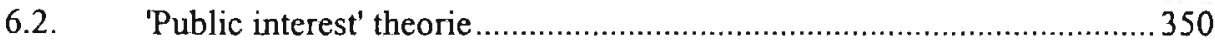

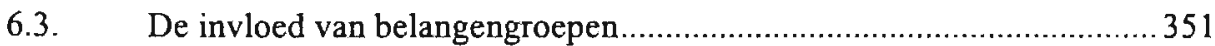

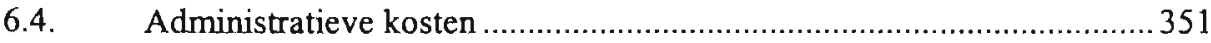

7. Aansprakelijkheid, verzekering, veiligheidsregulering en de optimale preventie en compensatie van verkeersongevallen ............................... 352

8. Belangrijke toetsvragen voor het empirisch onderzoek ....................... 353

DEEL 3 HET ECONOMISCH MODEL EMPIRISCH GETOETST …......... 355

HOOFDSTUK 9: VERKIERSONGEVALLEN: ALGEMEEN ......................................... 357

1. Inleiding. 
2. De cijfers omtrent verkeersongevallen

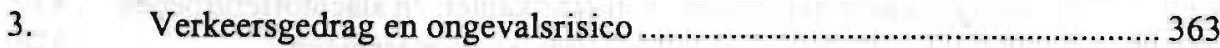

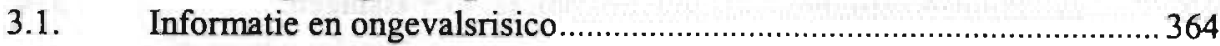

3.2. Ongevalsrisico en leeftijd: een objectieve benadering .......................... 365

3.3. De subjectieve benadering van het ongevalsrisico ................................ 368

3.4. Voetgangers en hun ongevalsrisico .................................................... 370

4. Conclusie: verkeersgedrag en ongevalsrisico ..................................... 371

HOOFDSTUK 10: DE EMPIRISCHE TOETSING VAN AANSPRAKELUKHIEIDSREGEI.S ... 375

1. Inleiding. 375

2. De praktische werking van aansprakelijkheidsregels in Nederland........ 376

2.1. De schaderegeling vanuit de positie van de rechter ............................. 377

2.2. De schaderegeling vanuit de positie van het slachtoffer ......................... 378

2.3. De schaderegeling vanuit de positie van de aansprakelijkheidsverzekeraar.

2.4. Het belang van deze studies voor het onderhavige onderzoek 382

3. De werking van aansprakelijkheidsregels in Noord-Amerika en Canada

3.1. De preventie van aansprakelijkheidsregels in het verkeer 385

3.2. De schaderegeling bij verkeersongevallen in Noord-Amerika en Canada 388

3.2.1. De vergoedingsmogelijkheden voor een verkeersslachtoffer ................ 389

3.2.2. De compensatie van verkeersslachtoffers in de praktijk ...................... 392

3.2.2.1. De eigen schuld van het verkeersslachtoffer...................................... 393

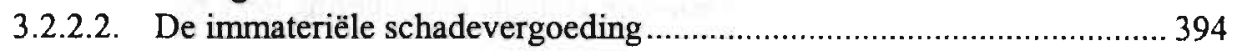

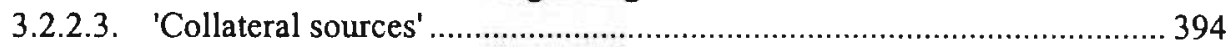

3.2.2.4. De verhouding tussen kleine en grote schadebedragen......................... 395

3.2.3. Verkeersaansprakelijkheid: 'Corrective Justice' ................................... 397

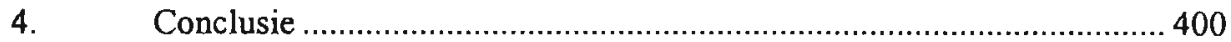

HOOFDSTUK 11: DE EMPIRISCHE ANALYSE VAN RISICO EN VERZEKERING............. 403

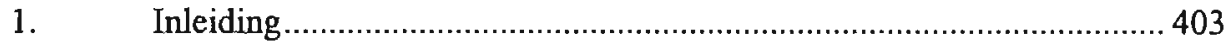

2. De Amerikaanse markt voor autoverzekeringen.................................... 404

2.1. De verschillende beschikbare verzekeringsvormen .............................404

2.2. De opkomst van de no-fault verzekering ......................................... 406

3. De controle van het morele risico binnen de Amerikaanse

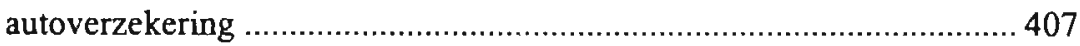

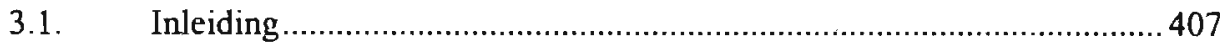


3.2. Ex ante risicodifferentiatie en een ex post premieaanpassing. 408

3.3. De praktische effecten van ex ante risicodifferentiatie en een ex post premieaanpassing...

3.3.1. De effectiviteit van het gebruik van classificatievariabelen

3.3.2. De werking van een aantal classificatiesystemen voor autoverzekering 411

3.4. Autoverzekering en de controle van het morele risico.

4. Bonus-malus systemen in Europa …....................................................... 415

4.1. De BMS-structuur in Nederland, België en Frankrijk .......................... 417

4.2. Enkele praktische implicaties van een BMS-regime ............................. 419

4.2.1. De bonus-malus verdeling binnen een BMS ........................................4 420

4.2.2. De 'honger naar een bonus' ............................................................. 421

4.2.3. De elasticiteit van een BMS........................................................... 422

4.3. Bonus-malus systemen en de preventie van verkeersongevallen.............424

4.3.1. De preventiedoelstelling van een BMS .............................................. 424

4.3.2. Het belang van een ex ante premiedifferentiatie binnen een BMS ........ 425

4.3.2.1. Het gebruik van ex ante classificatievariabelen ................................. 426

4.3.2.2. De toepassing van een eigen risico binnen een BMS ......................... 427

4.3.3. De ex post controle van het ongevalsrisico...........................................430

4.3.4. Conclusie: ex ante risicodifferentiatie versus ex post controle ............... 433

5. De regulering van de markt voor autoverzekeringen ..............................434

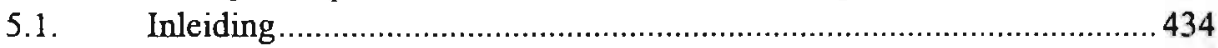

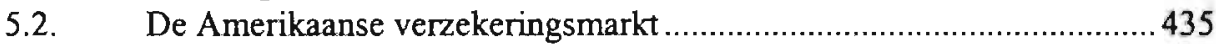

5.2.1. Regulering van de Amerikaanse verzekeringsmarkt........................... 435

5.2.2. Concurrentie op de markt voor autoverzekeringen in Noord-Amerika .. 438

5.2.3. De invloed van regulering op de werking van de autoverzekeringsmarkt in Massachusetts............................................................................ 438

5.2.3.1. Prijsregulering binnen de verzekeringsmarkt van Massachusetts.......... 439

5.2.3.2. De gevolgen van een strikte prijsregulering voor de werking van de verzekeringsmarkt in Massachusetts.................................................... 441

5.2.3.3. Verzekeringsregulering en de preventie van verkeersongevallen.......... 443

5.3. De regulering van de markt voor autoverzekeringen in Engeland en

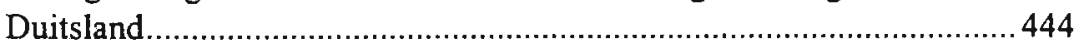

5.3.1. De Engelse markt voor autoverzekeringen ....................................... 445

5.3.2. De regulering van de autoverzekeringsmarkt in Duitsland................... 447

5.3.3. Het empirisch onderzoek van Finsinger en Adams ............................. 450

5.3.3.1. Ongevalsstatistieken in Duitsland en Engeland .....................................450

5.3.3.2. Productdifferentiatie binnen de markt voor autoverzekering in

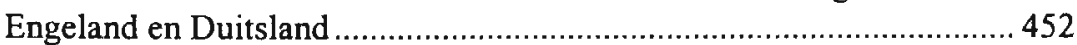

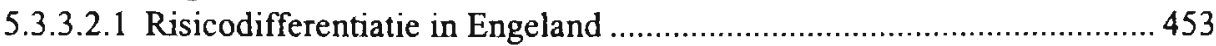

5.3.3.2.2 Regulering van de verzekerings-voorwaarden in Duitsland .................. 454

5.3.4. Concurrentie versus regulering en de preventie van verkeersongevallen. 
6. Conclusie: autoverzekering en de preventie van verkeersongevallen..... 458

HOOFDSTUK 12: DE EMPIRISCHE TOETSING VAN VEILIGHEIDSREGULERING IN HET VERKFER 463

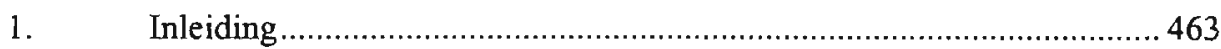

2. De veiligheid van de inzittenden van een auto ................................... 464

2.1. Het gebruik van de autoveiligheidsgordel ........................................465

2.2. De invloed van de autoveiligheid op het aantal verkeersslachtoffers ..... 467

2.2.1. De preventieve effecten van de autoveiligheidsgordel in Canada .......... 468

2.2.2. Amerikaans onderzoek naar de effecten van de autoveiligheidsgordel .. 470

2.2.3. Passieve autoveiligheidssystemen ('passive restraints') ........................ 471

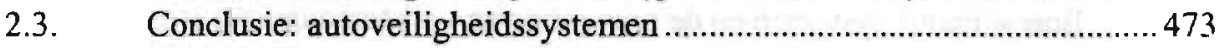

3. De invloed van de autoveiligheid op het verkeersgedrag: 'offsetting

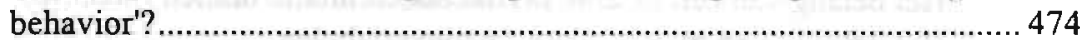

3.1. Het empirisch onderzoek van Peltzman............................................... 474

3.2. Ander empirisch onderzoek naar 'offsetting behavior'.......................... 476

3.3. Kritiek op de 'offsetting behavior'-theorie en het onderzoek van Peltzman 478

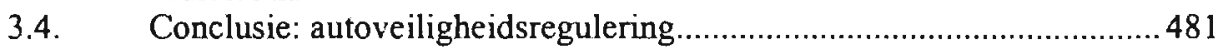

4. Alcohol en verkeersongevallen..................................................... 482

4.1. Alcoholgebruik en ongevalsrisico .................................................. 482

4.2. De preventie van alcoholgebruik in het verkeer ...................................483

4.2.1. De ademanalysetest .................................................................. 484

4.2.2. Het effect van administratieve en strafrechtelijke sancties ...................486 486

4.3. Het controlebeleid ten aanzien van het rijden onder invloed .................. 488

4.3.1. De prijs van alcohol en verkeersongevallen ....................................... 489

4.3.2. De toepassing van een minimumleeftijd voor de consumptie van

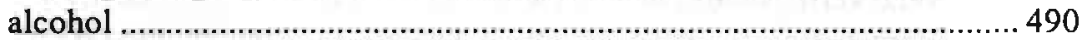

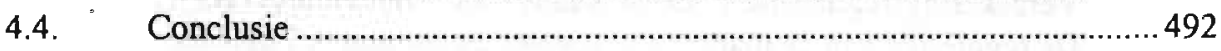

5. Maximumsnelheid en de preventie van verkeersongevallen ................. 493

5.1. Maximumsnelheid en het ongevalsrisico................................................493

5.2. De handhaving van de maximumsnelheid .......................................... 495

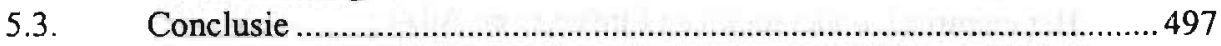

6. Veiligheidsregulering in het verkeer en lobbying ................................. 498

7. Conclusie: veiligheidsregulering in het verkeer......................................499 
HOOFDSTUK 13: EEN NO-FAULT VERZEKERING EN ANDERE COMPENSATIEMECHANISMEN

1. Inleiding.

2. Een overzicht van een aantal rechtstelsels met een no-fault verzekering

2.1. Nieuw-Zeeland en het no-fault compensatiefonds voor verkeersslachtoffers

2.2. De invoering van een verplichte eerste partij no-fault verzekering in Australië.

2.3. Het 'zuivere' no-fault regime van de Canadese provincie Quebec........... 507

2.4. Aansprakelijkheid versus no-fault in de Verenigde Staten ..................... 509

2.4.1. Het aansprakelijkheidsregime voor verkeersschade ............................ 510

2.4.2. De verschillende no-fault systemen in de Verenigde Staten.................. 511

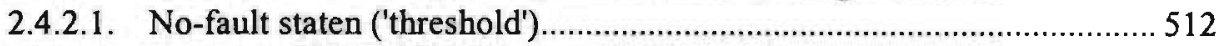

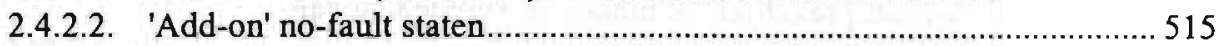

3. No-fault versus aansprakelijkheid: het empirisch onderzoek ................ 516

3.1. Aansprakelijkheid versus no-fault: de preventie van verkeersongevallen.

3.1.1. De preventieve effecten van no-fault in de VS ................................. 517

3.1.1.1. De visie van Elisabeth Landes ................................................................ 517

3.1.1.2. De kritiek op het onderzoek van Landes............................................. 519

3.1.1.3. Het onderzoek van Sloan, Reilly and Schenzler ................................ 522

3.1.2. Preventie binnen het no-fault compensatiefonds in Nieuw-Zeeland ...... 523

3.1.3. De preventieve werking van de no-fault verzekering in Australië......... 525

3.1.4. De preventieve effecten van het zuivere no-fault systeem in Quebec .... 527

3.1.5. Conclusie: no-fault versus aansprakelijkheid en de preventie van verkeersongevallen

3.2. No-fault versus aansprakelijkheid: de vergoeding van verkeersschade...531

3.2.1. De omvang van de schadevergoeding binnen een no-fault regime........ 531

3.2.1.1. Het empirisch onderzoek van Carroll en Kakalik ...............................551

3.2.1.2. Het empirisch onderzoek van Rolph, Hammit en Houchens ................. 533

3.2.1.3. De empirische analyse van Dewees, Duff en Trebilcock ..................... 535

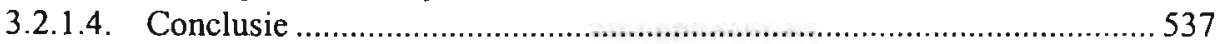

3.2.2. De afwikkeling van de schade binnen een no-fault regime ................... 538

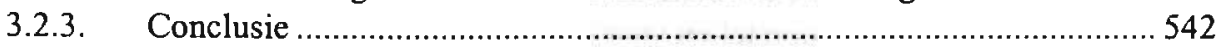

3.3. No-fault versus aansprakelijkheid: de kosten ..................................... 542

3.3.1. De kosten van de schaderegeling binnen no-fault en aansprakelijkheid. 543

3.3.2. De (premie)kosten van een autoverzekering binnen no-fault ................ 544

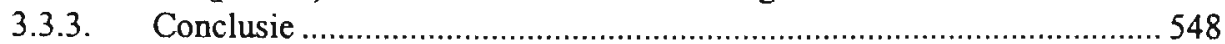

4. Conclusie: no-fault verzekering versus aansprakelijkheid................... 549 
HOOFDSTUK 14: CONCLUSIE EMPIRIE F.N THEORIE

1. Inleiding.

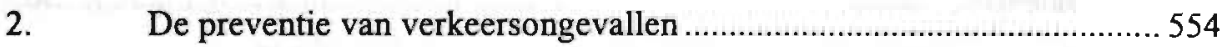

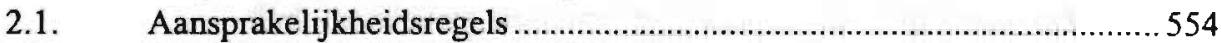

2.2. Preventie via de verzekeringsvoorwaarden...........................................554

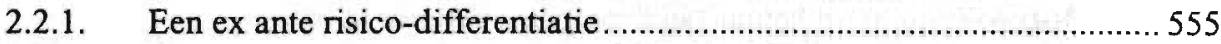

2.2.2. Een ex post aanpassing van de polisvoorwaarden ............................. 556

2.2.3. Een combinatie van een ex ante risicodifferentiatie en een ex post controle

2.3. Veiligheidsregulering en de preventie van verkeersongevallen..............557

2.4. De invloed van belangengroepen........................................................559

2.5. Verzekeringsregulering en de preventie van verkeersongevallen.......... 560

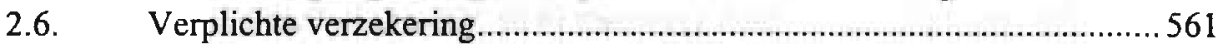

3. De rol van aansprakelijkheid binnen de vergoeding van verkeersschade.

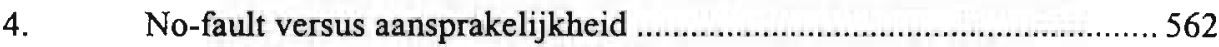

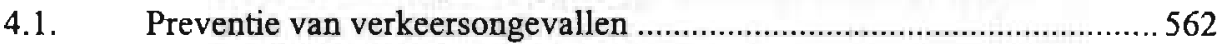

4.2. Compensatie van verkeersslachtoffers.................................................56

4.3. De administratieve kosten................................................................ 564

5. Aansprakelijkheid, verzekering, veiligheidsregulering en de optimale preventie en compensatie van verkeersongevallen

DEEL IV.

HoOfDSTUK 15: DE TOETSING VAN DE FRANSE EN BELGISCHE EN

NEDERLANDSE VERKEERSAANSPRAKELIJKHEID AAN DE ECONOMISCHE EN EMPIRISCHE ANALYSE ..................................... 567

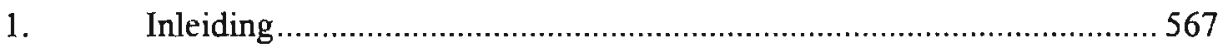

2. De verkeersaansprakelijkheid in Frankrijk, België en Nederland...........559

2.1. De vergoeding van verkeersslachtoffers in Frankrijk ...........................569

2.2. De Belgische WAM-regeling (art. 29bis) ..........................................5 570

2.3. Het Nederlandse wetsvoorstel (1997) ............................................. 571

2.4. De Nederlandse voorstellen voor een verkeersverzekering ...................551

2.5. Het systeem 'Van Maanen'................................................................ 572

3. De economische toetsing van het positieve recht en aanverwante

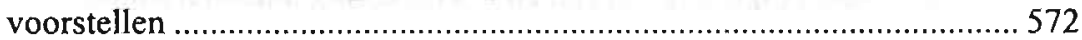

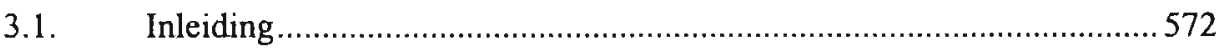


3.2. Primaire ongevalskosten (preventic)

3.2.1. Een systeem van risicoaansprakelijkheid met een eigen schuldverweer.

3.2.1.1. De resultaten van het theoretisch en empirisch onderzoek

3.2.1.2. De economische toetsing van de (voorstellen van) verkeersaansprakelijkheid

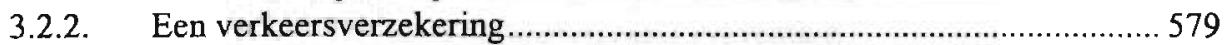

3.2.2.1. De resultaten van het theoretisch en empirisch onderzoek .................. 579

3.2.2.2. De economische toetsing van de voorstellen tot 'verkeersverzekering' .. 580 3.3. Secundaire ongevalskosten (schadevergoeding) ....................................582

3.3.1. Een systeem van risicoaansprakelijkheid met een eigen schuldverweer 582

3.3.1.1. De resultaten van het theoretisch en empirisch onderzoek ................... 582

3.3.1.2. De economische toetsing van de (voorstellen van)

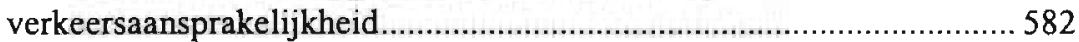

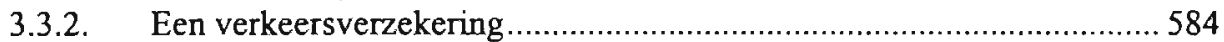

3.3.2.1. De resultaten van het theoretisch en empirisch onderzoek ................... 584

3.3.2.2. De economische toetsing van de voorstellen tot 'verkeersverzekering' .. 585

3.4. Tertiaire kosten (administratieve kosten)...........................................586

3.4.1. Een systeem van risicoaansprakelijkheid met een eigen

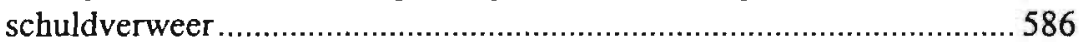

3.4.1.1. De resultaten van het theoretisch en empirisch onderzoek ................... 586

3.4.1.2. De economische toetsing van de (voorstellen van)

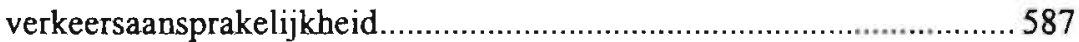

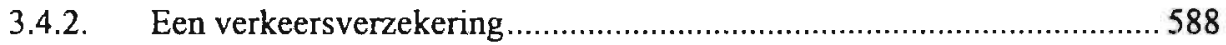

3.4.2.1. De resultaten van het theoretisch en empirisch onderzoek .................... 588

3.4.2.2. De economische toetsing van de voorstellen tot 'verkeersverzekering' .. 588

4. Een verkeersverzekering of (risico)aansprakelijkheid? ........................589

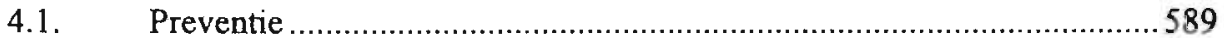

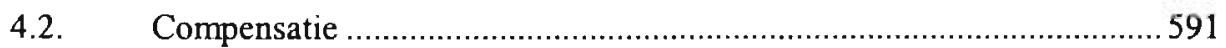

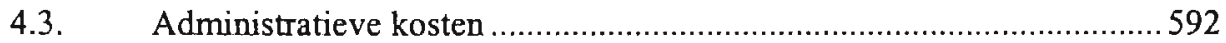

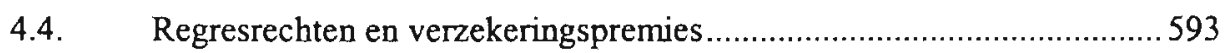

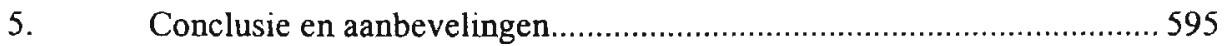

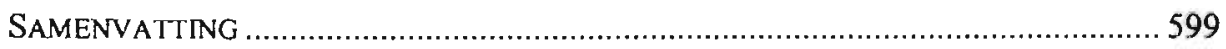

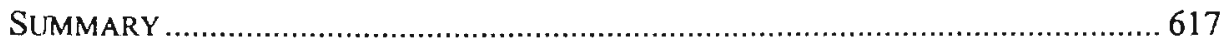

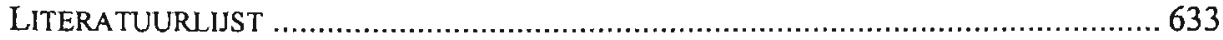

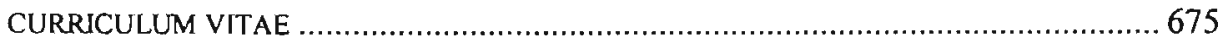




\section{Afkortingenlijst}

\begin{tabular}{|c|c|}
\hline$A \& V$ & Aansprakelijkheid en Verzekering \\
\hline $\mathrm{AA}$ & Ars Aequi \\
\hline AAW & Algemene Arbeidsongeschiktheidswet \\
\hline $\mathrm{ABP}$ & Algemeen Burgerlijk Pensioenfonds \\
\hline Ac. An. \& Prev. & Accident Analysis and Prevention \\
\hline A-G & Advocaat-Generaal \\
\hline ANW & Algemene Nabestaandenwet \\
\hline ANWB & Algemene Nederlandse Wielrijdersbond \\
\hline $\begin{array}{l}\text { art. } \\
\text { artt. }\end{array}$ & $\begin{array}{l}\text { artikel } \\
\text { artikelen }\end{array}$ \\
\hline AVP & Aansprakelijkheidsverzekering voor Particulieren \\
\hline AWBZ & Algemene Wet Bijzondere Ziektekosten \\
\hline BEF & Belgische Frank \\
\hline BJE & Bell Journal of Economics \\
\hline BMS & Bonus-malus systeem \\
\hline Bull. Ass. & Bulletin des Assurances (Tijdschrift voor Verzekeringen) \\
\hline Bull. civ. & Bulletin des arrêts de la Cour de Cassation, chambre civil \\
\hline Bull. crim. & Bulletin criminelle \\
\hline BVVO & Beroepsvereniging der Verzekeringsondernemingen \\
\hline BW & Burgerlijk Wetboek \\
\hline Cass. & Hof van Cassatie \\
\hline Cass. Ass. plen. & Cour de cassation (asssemblée plénière) \\
\hline Cass. 2e civ. & Cour de cassation ( $2 \mathrm{e}$ chambre civil) \\
\hline Cass. Ch. mixte & Cour de cassation (chambre mixte) \\
\hline $\mathrm{Cc}$ & Code civil \\
\hline CCA & $\begin{array}{l}\text { Contact Commissie Aansprakelijkheidsverzekering voor } \\
\text { bedrijven en particulieren }\end{array}$ \\
\hline Comm. & Commentaires \\
\hline Corr. & Correctionele rechtbank \\
\hline Crim. & Cour de cassation (chambre criminelle) \\
\hline $\mathrm{D}$ & Receuil Dalloz Sirey \\
\hline d.d. & de dato \\
\hline $\begin{array}{l}\text { De Verz. } \\
\text { diss. }\end{array}$ & $\begin{array}{l}\text { Tijdschrift voor Verzekeringen (Bulletin des Assurances) } \\
\text { dissertatie }\end{array}$ \\
\hline DJ & Dalloz jurisprudence \\
\hline EG & Europese Gemeenschap \\
\hline FFSA & Fédération Francaise des Sociétés d'Assurances \\
\hline Gaz. Pal. & Gazette du Palais \\
\hline Gedr. St. & Gedrukte Stukken \\
\hline HR & Hoge Raad der Nederlanden \\
\hline ICLQ & International and Comparative Law Quarterly \\
\hline
\end{tabular}


Inv.

IRLE

IZA

JCP

JF

JLMB

JLE

JLS

JO

J. Risk \& Ins.

JT

Jur.

LGDJ

LSA

MJ

MLDA

MPH

$\mathrm{NbBW}$

NJ

NJB

NJV

nr.

nt.

NTBR

NVVA

OVS

PACS

Parl. Hand.

Parl. St.

Pemba

\section{RAP}

$\mathrm{Rb}$.

RECIEL

Resp. civ. et ass.

Rev. trim. dr. civ.

RJE

RGAR

RM Themis

r.o.

RvdW

RVV
Invoeringswet

International Review of Law and Economics

Instituut Ziektekostenvoorziening Ambtenaren

Juris-classeur Périodique (Semaine juridique)

Jura Falconis

Revue de Jurisprudence de Liège, Mons et Bruxelles

Journal of Law and Economics

Journal of Legal Studies

Journal officiel de la république Française

Journal of Risk and Insurance

Journal des tribunaux

Jurisprudentie

Libraire générale de droit et de jurisprudence

Vereniging van Letselschade Advocaten

Maastricht Journal of European and Comparative Law

Minimum Legel Drinking Age

Miles Per Hour

Nieuwsbrief BW

Nederlandse Jurisprudentie

Nederlands Juristenblad

Nederlandse Juristenvereniging

nummer

noot

Nederlands Tijdschrift voor Burgerlijk Recht

Nederlandse Vereniging van Automobielassuradeuren

Overeenkomst Vereenvoudigde Schaderegeling

Protection assurée du conducteur et des siens

Parlementaire Handelingen

Parlementaire Stukken

Premiedifferentiatie en marktwerking in de arbeidsonge-

schiktheidsverzekering

Règlement d'Application Pratique

Rechtbank

Review of European Community \& International Environmental Law

Responsabilité civile et assurance

Revue trimestrielle de droit civil

Rand Journal of Economics

Revue Générale des Assurances et des Responsabilités

Rechtsgeleerd Magazijn Themis

rechtsoverweging

Rechtspraak van de Week

Reglement Verkeersregels en Verkeerstekens 
RW

SER

Somm.

suppl.

SVI

TBBR

TBH

TK

TRV

TSR

TvP

TVP

UCV

VA

$\mathrm{Vb}$

VKJ

VR

Vrb

WA

WAM

WAM (België)

WAO

WPNR

WVW

YLJ
Rechtskundig Weekblad

Sociaal-Economische Raad

Sommaire

supplement

Schadeverzekering Inzittenden

Tijdschrift voor Belgisch Burgerlijk Recht (Revue Générale de Droit Civil Belge)

Tijdschrift voor Belgisch Handelsrecht

Tweede Kamer der Staten-Generaal

Tijdelijke regeling verhaalsrechten

Tijdschrift voor Sociaal Recht (Revue de Droit Social)

Tijdschrift voor Privaatrecht

Tijdschrift voor Vergoeding Personenschade

Uitgebreide Commissie Vergadering

Verzekeringsarchief

Het verzekeringsblad

Verkeersrecht (België)

Verkeersrecht (Nederland)

Verzekeringsrechtelijke berichten

Wettelijke Aansprakelijkheid

Wet Aansprakelijkheidsverzekering Motorrijtuigen

Wet betreffende de verplichte aansprakelijkheids-

verzekering inzake motorrijtuigen

Wet op de Arbeidsongeschiktheidsverzekering

Weekblad voor Privaatrecht, Notariaat en Registratie

Wegenverkeerswet

Yale Law Journal 



\section{Verantwoording}

'De aanrijding van een motorrijtuig, waardoor hetzij aan menschen, al of niet inzittenden van dat motorrijtuig, hetzij aan dieren, hetzij aan voorwerpen, hetzij aan andere motorrijtuigen, schade wordt veroorzaakt, is een handeling van den bestuurder van dat rijtuig, waardoor deze - en anderen met hem - in de verplichting wordt gesteld om, indien die schade aan de menschen, dieren of voonwerpen door zijn schuld is veroorzaakt, deze te vergoeden. De bestuurder immers handelt zoowel in strijd met de wettelijke voorschriften, waarbij de veiligheid van het verkeer gewaarborgd wordt, als met de zorgvuldigheid, die hem tegenover de andere weggebruikers in het verkeer betaamt.'.

Het bovenstaande citaat geeft aan dat 65 jaar geleden reeds over de verkeersaansprakelijkheid werd nagedacht, hoewel een verkeersongeval in de jaren ' 30 van de vorige eeuw nog een tamelijk zeldzaam verschijnsel was. Sindsdien hebben maatschappelijke ontwikkelingen en de voortschrijding van de techniek er toe bijgedragen dat verkeersongevallen in onze huidige samenleving een gegeven zijn. ${ }^{2}$ Daarbij wordt vaak veel schade en leed veroorzaakt. ${ }^{3}$

In het laatste decennium van de twintigste eeuw heeft de aansprakelijkheid in het verkeer zich steeds meer ontwikkeld in de richting van een bescherming van het niet-gemotoriseerde verkeersslachtoffer. ${ }^{4}$ Deze slachtofferbescherming heeft een voorlopig hoogtepunt gekregen in een wetsvoorstel verkeersongevallen dat op 24

1. Belinfante, De burgerrechtelijke gevolgen van de aanrijding met automobielen, p. 1 .

2. In Nederland vonden tussen 1990 en 1997 jaarlijks 1075-1240 dodelijke verkeersongevallen plaats (daling 1997 t.o.v. $1990-13,3 \%$ ) en waren er gemiddeld 18.000 verkeersongevallen met letsel waarbij ziekenhuisopname noodzakelijk was. Tussen 1994 en 1997 was jaarlijks sprake van gemiddeld 80.000 verkeersongevallen waarbij de spoedeisende hulp van een ziekenhuis moest worden ingeroepen. Zie CBS, Verkeersongevallen 1997, p. 82, 89 en 93; Statistics of Road Traffic Accidents in Europe and North America, 1995, p. 8.

3. Tussen 1990 en 1997 bedroeg in Nederland het aantal verkeersdoden jaarlijks 1150-1400 (daling 1997 t.o.v. 1990, -15,5\%) en waren er jaarlijks gemiddeld 20.000 verkeersgewonden met ziekenhuisopname. Tussen 1994 en 1997 bedroeg het aantal verkeersgewonden dat voor spoedeisende hulp naar een ziekenhuis moest jaarlijks gemiddeld 100.000. Zie CBS. Verkeersongevallen 1997, p. 12, 22 en 88; Statistics of Road Traffic Accidents in Europe and North America, 1995, p. 11.

4. Aan het begin van de jaren "90 van de vorige eeuw heeft de Hoge Rad in een aantal arresten het risico van een aanrijding tussen een motorrijtuig en een fietser of voetganger geheel (kinderen tot 14 jaar) of gedeeltelijk (volwassenen) bij de houder van het motorrijtuig gelegd. Zie onder andere: HR 1 juni 1990, NJ 1991, 720 (Ingrid Kolkman); HR 31 mei 1991, NJ 1991, 721 (Marbeth van Uitregt); HR 28 februari 1992, NJ 1993, 566 (IZA/Vrerink) en HR 22 mei 1992. NJ 1992, 527 (ABP/Winterthur). Daamaast kan worden verwezen naar de Notitie Verkeersaansprakelijkheid, Tweede Kamer, 1989-1990, 21528, nr. 1, waarin de Minister van Justitie met betrekking tot eventueel nieuw in te voeren wetgeving een voorkeur uitsprak voor een systeem van risicoaansprakelijkheid aan de zijde van de houder van een motorrijtuig voor de schade van de niet-gemotoriseerde verkeersdeelnemer. 
november 1997 door de toenmalige Minister van Justitie aan de Tweede Kamer werd aangeboden. ${ }^{5}$

\section{Probleemstelling}

Het centrale thema van dit onderzoek heeft betrekking op de vraag welke combinatie van aansprakelijkheid, verzekering en veiligheidsregulering kan leiden tot een optimale preventie van verkeersongevallen, waarbij tevens een optimale compensatie aan verkeersslachtoffers kan worden gegarandeerd. Het gaat derhalve om een combinatie van preventie en compensatie. Preventie heeft betrekking op de economische doelstelling van minimalisering van de maatschappelijke kosten van verkeersongevallen. ${ }^{6}$ Compensatie ziet op de vraag hoe verkeersslachtoffers schadeloos kunnen worden gesteld. Deze probleemstelling zal met behulp van drie typen van analyse worden uitgewerkt. Dit betreft enerzijds een positiefrechtelijke analyse en anderzijds een rechtseconomische analyse die samen met een empirische analyse van het economisch model de basis zal vormen voor de toetsing van het positieve recht en aanverwante voorstellen.

\section{Het positieve recht, belang van het onderzoek}

Naast de ontwikkelingen in de jurisprudentie ten aanzien van de bescherming van niet-gemotoriseerde verkeersslachtoffers, wordt ook vanuit de juridische literatuur sinds een aantal decennia getracht om de wetgever te bewegen tot een hervorming van het verkeersaansprakelijkheidsrecht. ${ }^{7}$ Verder kan worden gewezen op een recent

5. Vaststelling en invoering van afdeling 8.14.1 (verkeersongevallen) van het Burgerlijk Wetboek, Tweede Kamer, 1997-1998, nr. 1-3. Inmiddels is ten gevolge van de Tweede Kamerverkiezingen van mei 1998 een ander kabinet aangetreden. De huidige Minister van Justitie Korthals heeft het wetsvoorstel van zijn voorgangster ingetrokken en heeft aangekondigd met een eigen voorstel te komen, waarvan een voorlopige uitwerking kan worden gevonden in een brief van 16 juni 1999, TK 1998-1999, 25759, nr. 5 (H). Zie ook NJB, 1999, p. 1292-1293; Vaststelling van de begroting van de uitgaven en de ontvangsten van het Ministerie van Justitie voor het jaar 1998, TK 1997-1998, 25600 VI, nr. 74; VR, 1998, p. 297. Zie verder Engelhard en Van Maanen, Aansprakelijkheid voor verkeersongevallen, voor een analyse van het wetsvoorstel Sorgdrager in vergelijkend perspectief.

6. In een recent SER-advies d.d. 15 oktober 1999 , p. 20-21 worden de totale kosten die voortvloeien uit verkeersongevallen voor 1993 geschat op 12 miljard gulden. Hoogeboom, VR, 1992, p. 317-321 geeft een schatting van de maatschappelijke kosten van verkeersongevallen in Nederland voor 1989 van 8,5 miljard gulden. Volgens het CBS, Verkeersongevallen 1997, p. 7 wordt het aantal verkeersongevallen met gewonden of uitsluitend materiële schade geraamd op 1,75 miljoen. De kosten hiervan bedragen ongeveer 10 miljard gulden.

7. Bloembergen en Van Wassenaer van Catwijck kunnen worden beschouwd als de belangrijkste exponenten hiervan. Zie ondere andere: Bloembergen, Naar een nieuw ongevallenrecht, oratie, $\mathrm{p}$. 3-31; Bloembergen, NJB, 1973, p. 961-971 en p. 998-1009; Van Wassenaer van Catwijck, Verkeersverzekering, oratie, p. 1-78; Van Wassenaer van Catwijck, VA, 1988, p. 321-377; Van 
verschenen SER-advies getiteld: 'Investeren in verkeersveiligheid'. ${ }^{8}$ Hierin wordt onderzocht langs welke wegen de maatschappelijke kosten als gevolg van verkeersonveiligheid kunnen worden verminderd en op welke wijze een meer evenwichtige verdeling van baten en lasten van verkeersonveiligheid tot stand kan worden gebracht.

In het wetsvoorstel verkeersongevallen dat in 1997 door de toenmalige Minister van Justitie is ingediend, wordt gekozen voor een bescherming van die verkeersslachtoffers 'voor wie de behoefte daaraan het sterkst gevoeld wordt', namelijk voetgangers, fietsers, passagiers en werknemers-bestuurders. ${ }^{9}$ Het wetsvoorstel houdt in dat bij een verkeersongeval met een motorrijtuig, de bezitter of houder van dit motorrijtuig risicoaansprakelijk is voor de personenschade van de niet-gemotoriseerde verkeersdeelnemers en de passagiers. Voor de personenschade van de bestuurderswerknemers rust op de werkgever een risicoaansprakelijkheid. De aansprakelijkheid van de bezitter van motorrijtuig respectievelijk de werkgever komt geheel te vervallen indien het slachtoffer opzettelijk of bewust roekeloos het ongeval heeft veroorzaakt. $^{10}$

Met het voomoemde wetsvoorstel wordt weliswaar een hervorming van de verkeersaansprakelijkheid beoogd, maar daarmee wordt een aantal knelpunten van het huidige stelsel niet geheel weggenomen. Binnen de huidige regeling wordt in beginsel uitgegaan van een schuldaansprakelijkheid op basis van artikel 6:162 $\mathrm{BW}$. Voor niet-gemotoriseerde verkeersslachtoffers (voetgangers en fietsers) geldt de bescherming van artikel 185 WVW, maar deze is niet volledig. " Hoewel het wetsvoorstel fietsers en voetgangers, maar ook passagiers en bestuurders-werknemers in beginsel een volledige bescherming biedt, blijven ongevallen tussen twee motorrijtuigen,

Wassenaer van Catwijck, Naar een Europees verkeersschaderecht, afscheidsrede, p. 3-6. Zie ook C.C. van Dam, Zorgvuldigheidsnorm en aansprakelijkheid, diss., p. 248-250 en p. 264; Hartlief en Tjittes, Verzekering en aansprakelijkheid, p. 128-134.

8. Publicatie SER, nummer 13 van 15 oktober 1999. Zie Van Velthoven, Veilig verkeer in Nederland, VR 2000, p. 313-321, voor een kritisch commentaar op dit rapport.

9. Memorie van Toelichting. TK 1997-1998, 25759, nr. 3, p. 2.

10. Memorie van Toelichting, TK, 1997-1998, nr. 3, p. 2. In zijn brief van 16 juni 1999, TK $1998-$ $1999,25759, \mathrm{nr} .5$ (H), geeft de huidige Minister van Justitie Korthals aan dat hij voomemens is om met name de opzet of bewuste roekeloosheid in hoofde van het slachtoffer af te zwakken, door de aansprakelijkheid van het gemotoriseerde verkeer reeds te laten vervallen bij 'gewone' roekeloosheid van het slachtoffer.

11. Kinderen tot 14 jaar hebben recht op een volledige schadevergoeding (100\%), tenzij aan de zijde van het kind sprake is geweest van opzet of aan opzet grenzende roekeloosheid. Vanaf 14 jaar geldt dat de bestuurder van een motorrijtuig overmacht aannemelijk moet maken en wanneer hij daarin niet slaagt dat hij, ondanks een beroep op eigen schuld, minimaal $50 \%$ van de schade van de fietser of voetganger moet vergoeden. Zie met name HR 1 juni 1990, NJ 1991, 720 (Ingrid Kolkman); HR 31 mei 1991, NJ 1991, 721 (Marbeth van Uitregt); HR 28 februari 1992, NJ 1993, 566 (IZA/Vrerink); HR 24 december 1993, NJ 1995, 236 (Anja Kellenaers). 
voor wat betreft de schade die door de bestuurder wordt geleden, ongevallen tussen twee fietsers en ongevallen tussen een fietser en een voetganger onder artikel 6:162 $\mathrm{BW}$ vallen. ${ }^{12}$

Een tweede probleem hangt samen met de eenzijdige verkeersongevallen, waarbij een motorrijtuig tegen een object botst of van de weg raakt. ${ }^{13}$ Op basis van het wetsvoorstel kan de passagier zijn schade veelal van de verzekeraar van de houder van het motorrijtuig vergoed krijgen, de bestuurder heeft die mogelijkheid in beginsel niet. $^{14}$

In de derde plaats leidt de schadeafwikkeling na een verkeersongeval tot hoge kosten, omdat niet alleen de aansprakelijkheid moet worden vastgesteld maar ook de omvang van de schade. Bij de schadeafwikkeling zijn veel instanties betrokken, zoals schaderegelaars, deskundigen, advocaten, rechtsbijstandverzekeraars aan de zijde van het verkeersslachtoffer, de aansprakelijkheidsverzekeraar van de dader en soms de rechter die in laatste instantie moet oordelen over de aansprakelijkheid. Daarnaast moet met name bij ernstiger letsel worden gewacht op de medische eindtoestand. Dit heeft tot gevolg dat de schadeafhandeling een kostbare en langdurige aangelegenheid kan zijn.

Een vierde probleem hangt samen met de omvang van de schadevergoeding die het slachtoffer uiteindelijk krijgt uitgekeerd. In de meeste gevallen ontvangt het slachtoffer een vergoeding uit 'eigen bron' namelijk via particuliere en sociale verzekeringen. Vooral bij ernstige verkeersongevallen is een vergoeding uit 'eigen bron' vaak lang niet voldoende om de gehele schade te vergoeden. Alleen wanneer het slachtoffer de aansprakelijkheid van de veroorzaker aantoont en hij zelf geen schuld heeft aan het ongeval, kan sprake zijn van een volledige schadeloosstelling. ${ }^{15}$

In de vijfde plaats tenslotte, vormen de regresrechten binnen de Nederlandse verkeersaansprakelijkheid een niet onbelangrijk maatschappelijk probleem. Doordat regresnemende instanties in het kader van artikel 185 WVW geen beroep openstaat op

12. Memorie van Toelichting, TK, 1997-1998, nr. 3, p. 6; Statistics of Road Traffic Accidents in Europe and North America, 1995, p. 45.

13. In 1992 bedroeg in Nederland het aantal eenzijdige verkeersongevallen bijna $20 \%$ van het total. Zie Statistics of Road Traffic Accidents in Europe and North America, 1995, p. 45. Het aantal verkeersdoden bij eenzijdige verkeersongevallen met een motorrijtuig was in $199631,9 \%$ van het totaal aantal verkeersdoden in dat jaar, in 1997 was dit aandeel opgelopen naar $33,2 \%$. Zie CBS, Verkeersongevallen 1997, p. 80-81.

14. Memorie van Toelichting, TK 1997-1998, 25759, nr. 3, p. 3. De bestuurder kan hiervoor een inzittendenverzekering afsluiten die de door hem geleden personenschade dekt.

15. Memorie van Toelichting, TK 1997-1998, 25759, nr. 3, p. 5. Van Wassenaer van Catwijck, Verkeersverzekering, p. 8, heeft berekend dat in $197519 \%$ van de in het verkeer geleden schade onvergoed bleef. 
de door de Hoge Raad ontwikkelde billijkheidsregels, dienen zij onder het huidige recht terug te vallen op de 'gewone' regels van artikel 185 VWV en artikel 6:101 BW om de schade die zij aan het slachtoffer hebben uitgekeerd op de veroorzaker daarvan te kunnen verhalen. ${ }^{16}$ In het beoogde wetsvoorstel wordt artikel $185 \mathrm{WVW}$ geschrapt en wordt in artikel 6:197 BW geregeld dat door regresnemende instanties geen beroep kan worden gedaan op de bescherming van bepaalde groepen verkeersslachtoffers uit het wetsvoorstel, zodat zij alleen op basis van artikel 6:162 BW de aan het slachtoffer gedane uitkeringen op de aansprakelijke dader kunnen verhalen. ${ }^{17}$

Het voorgaande brengt mee dat binnen het huidige stelsel van verkeersaansprakelijkheid in Nederland meerdere vergoedingsregimes van toepassing zijn. Daarbij ligt in het kader van artikel $185 \mathrm{WVW}$ de nadruk op de bescherming van bepaalde groepen verkeersslachtoffers, in casu fietsers en voetgangers. In het beoogde wetsvoorstel 1997 wordt deze bescherming uitgebreid naar passagiers en bestuurderswerknemers. De plannen van Minister Korthals, die eind 1999 nog niet hebben geresulteerd in een concreet wetsvoorstel, zien eveneens op de bescherming van voornoemde groepen verkeersslachtoffers, met dien verstande dat reeds gewone, niet bewuste, roekeloosheid leidt tot een algeheel verval van de aansprakelijkheid van de motorrijtuigbezitter. ${ }^{18}$

Voor bestuurders van een motorrijtuig, ${ }^{19}$ en voor de regresnemende instanties blijft na de invoering van nieuwe wetgeving, uitgaande althans van de plannen van Minister Korthals, artikel 6:162 BW de enige aansprakelijkheidsregel, met daarbij de eerder geschetste problemen ten aanzien van de vaststelling van de schuldaansprakelijkheid. Een belangrijk argument van de wetgever om in het beoogde wetsvoorstel een volledige bescherming aan bestuurders en aan regresnemende instanties te onthouden, is een te grote premiestijging (WAM-verzekering) die met de invoering van een dergelijk stelsel van verkeersaansprakelijkheid gepaard zou gaan. ${ }^{20}$

16. Memorie van Toelichting, TK 1997-1998, 25759, nr. 3, p. 9-10. De Hoge Raad heeft in een aantal arresten de positie van de regresnemende instanties nader bepaald. Zie HR 2 juni 1995, NJ 1997, 700 (Marloes de Vos); HR 2 juni 1995, NJ 1997, 701 (Quafa el Ayachi); HR 2 juni 1995, NJ 1997, 702 (Pierre Wildiers); HR 5 december 1995, NJ 1998, 400 (Said Hyati); HR 5 december 1997, NJ 1998, 401 (Marleen Timmermans); HR 5 december 1997, NJ 1998, 402 (Pierre Wildiers II).

17. Memorie van Toelichting, TK 1997-1998, 25759, nr. 3, p. 10-12 en p. 30.

18. Brief van 16 juni 1999 , TK 1998-1999, 25759 , nr. 5 (H), p. 2-5.

19. In 1992 bedroeg het aantal verkeersdoden onder bestuurders van een motorrijtuig $51,5 \%$ van het total aantal verkeersdoden; het relatief aantal verkeersgewonden onder bestuurders van een motorrijtuig was $50,4 \%$ van het totaal. Zie Statistics of Road Traffic Accidents in Europe and North America, 1995, p. 77.

20. Memorie van Toelichting, TK 1997-1998, 25759, nr. 3, p. 30-31. Zie ook de brief van de Minister van 16 juni 1999, TK 1998-1999, 25759, nr. 5 (H), p. 5. 
In het kader van de positiefrechtelijke analyse zal in een rechtsvergelijkend perspectief aandacht worden besteed aan de verkeersaansprakelijkheid in Frankrijk en België. In Frankrijk is sinds 1985 de 'loi Badinter' van kracht. ${ }^{21}$ Hierin wordt de aansprakelijkheid en de schadevergoeding geregeld ten aanzien van verkeersongevallen waar een motorrijtuig bij betrokken is. De bezitter van een motorrijtuig is risicoaansprakelijk voor de schade van het slachtoffer, zonder dat een beroep op overmacht of een gedraging van een derde mogelijk is. ${ }^{22}$ Een beroep op de eigen schuld van het slachtoffer is nog wel mogelijk indien deze 'faute' onverschoonbaar ('inexcusable') is en als de enige oorzaak van het ongeval kan worden aangemerkt. Voor bepaalde groepen slachtoffers, personen beneden de 16 jaar, boven de 70 jaar en personen die voor het ongeval reeds $80 \%$ invalide waren, geldt een automatische vergoeding van de geleden schade, waarbij alleen in het geval van opzet de vergoedingsplicht komt te vervallen. ${ }^{23}$

In België is op 1 juli 1995 een wet van kracht geworden, waarin een quasi-automatische vergoeding van de schade van bepaalde slachtoffers van verkeersongevallen is geregeld. In navolging van de 'loi Badinter' worden met name de zogenaamde 'zwakke' verkeersdeelnemers beschermd, in casu fietsers, voetgangers en passagiers. ${ }^{24}$ De aansprakelijkheidsverzekeraar van het motorrijtuig dat bij een verkeersongeval betrokken ${ }^{25}$ is, vergoedt daarbij de geleden personenschade van elk nietgemotoriseerd slachtoffer of zijn rechthebbenden. ${ }^{26}$ Verkeersslachtoffers hebben, evenals in Frankrijk, geen recht op schadevergoeding wanneer zij een onverschoonbare fout hebben begaan die tevens de enige oorzaak van het verkeersongeval is geweest. ${ }^{27}$ Aan kinderen beneden de 14 jaar kan geen onverschoonbare fout worden tegengeworpen. ${ }^{28}$

21. 'Loi no 85-677 du 5 juillet 1985 tendant à l'amélioration de la situation des victimes d'accidents de la circulation et à l'accélération des procédures d'indemnisation', Joumal officiel de la republique Française, 6 juillet 1985 et Juris-classeur Périodique (Semaine juridique), 1985, III, 57405.

22. Artikel 2 van de 'loi Badinter'.

23. Artikel 3 van de 'loi Badinter'.

24. Wet van 13 april 1995 tot wijziging van artikel 29 bis van de wet van 21 november 1989 betreffende de verplichte aansprakelijkheidsverzekering inzake motorrijtuigen, Parl. St., Kamer, 1993-1994, nr 1422/1, p. 1-5.

25. Voor de uitleg van het begrip 'betrokkenheid' wordt aansluiting gezocht bij de uitleg die daaraan door het Franse Hof van Cassatie is gegeven. Zie daarover Parl., St., Senaat, 1993-94, nr. 980/1, p. 33 en nr. 980/3, p. 15 en p. 30; Bocken en Geers, TvP, 1996, p. 107; Tuerlinckx, TvP, 1996, p. 20-23.

26. Artikel 29bis lid l paragraaf 1 van de Belgische WAM-wet.

27. Artikel 29bis paragraaf 1 lid 5 van de Belgische WAM-wet. Lid 6 is ontleend aan de uitleg die het Franse Hof van Cassatie aan de 'faute inexcusable' heeft gegeven en stelt dat 'Enkel de opzettelijke fout van uitzonderlijke ernst, waardoor degene die ze begaan heeft zonder geldige 
Van belang voor het onderhavige onderzoek is het feit dat in Frankrijk, en in mindere mate in België, reeds ervaring is opgedaan met een risicoaansprakelijkheid in het verkeer ofwel een quasi-automatische vergoeding voor verkeersschade. Daarnaast kan uit het Nederlandse wetsvoorstel worden opgemaakt dat de Minister van Justitie zich heeft laten inspireren door de 'loi Badinter' en door artikel 29bis van de Belgische WAM-wet die weer sterk is gericht op de Franse wet. ${ }^{29}$ Dit betekent dat in het kader van de positiefrechtelijke analyse een goede vergelijking kan worden gemaakt tussen de Franse en Belgische wet en de Nederlandse (wets)voorstellen van verkeersaansprakelijkheid. Aangezien geen enkel Europees land een systeem van verkeersverzekering kent, is op dat terrein geen vergelijking mogelijk. Daarom zal in dit onderzoek worden uitgeweken naar met name Noord-Amerika, waar veel ervaring is opgedaan met verschillende systemen van no-fault vergoeding.

\section{De rechtseconomische analyse}

De kern van de economische analyse van het recht is dat rechtsregels worden gezien als instrumenten van gedragsbeïnvloeding. ${ }^{30}$ Aansprakelijkheidsregels kunnen aan potentiële veroorzakers van schade prikkels geven tot voorzichtig gedrag. Wanneer een individu schade aan een ander toebrengt en gedwongen wordt om die ander schadeloos te stellen, zal hij trachten zijn gedrag te wijzigen waardoor de kans op schade vermindert of zelfs geheel verdwijnt. ${ }^{31}$ Daarnaast geldt dat rekening moet worden gehouden met het gedrag van het slachtoffer, omdat ook hij het ongevalsrisico kan beïnvloeden. Deze preventiegedachte staat centraal binnen de economische analyse van het aansprakelijkheidsrecht. In dit kader wordt onderzocht welke aansprakelijkheidsregel aan de betrokken partijen optimale prikkels geeft om de schade te voorkomen. ${ }^{32}$

Binnen de preventiedoelstelling van de economische analyse ${ }^{33}$ komt, naast het aansprakelijkheidsrecht, ook de vraag aan de orde in hoeverre veiligheidsregulering kan bijdragen aan een optimale preventie van verkeersongevallen. Hoewel beide instrumenten kunnen bijdragen aan de preventie van verkeersongevallen, is een onder-

reden wordt blootgesteld aan gevaar waarvan hij zich bewust had moeten zijn, is onverschoonbaar'.

28. Artikel 29 bis paragraaf 1 lid 7 van de Belgische WAM-wet.

29. Dit blijkt met name uit de Memorie van Toelichting, TK 1997-1998, 25759, nr. 3, p. 38-40, waarin voor de uitleg van het begrip 'betrokkenheid' in het beoogde wetsvoorstel wordt verwezen naar de Franse rechtspraak daaromtrent.

30. Zie Wagenaar, Gedrag, de oorzaak van verkeersonveiligheid, VR, 1988, p. 57-59, die ook nieteconomische aspecten van gedragsbeïnvloeding in het verkeer belicht.

31. Mackaay, AA, 1990 , p. $141-142$.

32. In het kader van het ongevallenrecht is daartoe reeds onderzoek verricht door Shavell, Accident Law, p. 5-32 en Faure en Van den Bergh, Objectieve Aansprakelijkheid, p. 62-100.

33. Zie Faure en Van den Bergh, Objectieve aansprakelijkheid, p. 19-20. 
scheid tussen aansprakelijkheid en veiligheidsregulering dat het eerste instrument voor wat betreft haar werking pas in beeld komt nadat zich een verkeersongeval heeft voorgedaan en de rechter zich een oordeel vormt over de uitgeoefende zorg door partijen. Het vooruitzicht om op deze wijze ex post aansprakelijk te zijn voor de schade kan van invloed zijn op de verkeersveiligheid omdat ex ante schadeveroorzakend gedrag wordt voorkomen. Veiligheidsregulering heeft een ex ante karakter in die zin dat de werking daarvan reeds kan doen gelden voordat een verkeersongeval is ontstaan. Met behulp van regelgeving ten aanzien van de maximumsnelheid, de autoveiligheidsgordel, verkeerslichten en verkeersborden, kan de verkeersveiligheid worden verhoogd. ${ }^{34}$

De aanwezigheid van een verzekering, waarmee in het kader van de compensatiedoelstelling $^{35}$ aan het verkeersslachtoffer een schadeloosstelling kan worden gewaarborgd, heeft indirecte gevolgen voor de preventieve werking van aansprakelijkheidsregels. De aansprakelijkheid voor de schade rust weliswaar primair op de dader, maar is veelal gedekt door een verzekering. Uitgaande van de veronderstelling dat een verzekering de rol van het aansprakelijkheidsrecht voor een groot deel heeft overgenomen, zal derhalve de vraag moeten worden onderzocht in hoeverre een verzekerde via de polisvoorwaarden en met behulp van premiedifferentiatie kan worden aangezet tot voorzichtig gedrag. Daarbij kan een onderscheid worden gemaakt tussen een derde-partij-aansprakelijkheidsverzekering ('third party insurance'), die de schade namens de dader aan het slachtoffer uitkeert, en een eerstepartij-schadeverzekering ('first party insurance') die de schade krachtens overeenkomst tussen slachtoffer en verzekeringsmaatschappij aan het slachtoffer vergoedt. ${ }^{36}$

Samenvattend kan worden gesteld dat de rechtseconomie een belangrijke bijdrage kan leveren aan de hervorming van de verkeersschadeproblematiek. Daarbij geldt dat de economische analyse aanvullend kan werken ten opzichte van de positiefrechtelijke analyse door naast de compensatie van verkeersslachtoffers ook een optimale preventie van verkeersongevallen als uitgangspunt te hanteren. Bij compensatie spelen aansprakelijkheid en verzekering een rol, bij preventie staan aansprakelijkheid, verzekering en veiligheidsregulering centraal. ${ }^{37}$

34. Faure en Van den Bergh, Objectieve aansprakelijkheid, p. 142-167; Shavell, Accident Law, p. 277-286.

35. Zie Faure en Van den Bergh, Objectieve aansprakelijkheid, p. 19-20.

36. Faure en Van den Bergh, Objectieve aansprakelijkheid, p. 101-141; Shavell, Accident Law, p. 186-261.

37. Faure en Van den Bergh, Objectieve aansprakelijkheid, p. 22, omschrijven het ongevallenrecht als thet geheel van regels die ertoe kunnen bijdragen ongevallen te vermijden (preventie) en de, ondanks de genomen voorzorgsmaatregelen, veroorzaakte schade te vergoeden (compensatie)'. Zie ook Faure en Van den Bergh, Liever geen slachtoffer dan een door het recht beschermd slachtoffer, Intermediair, 18 december 1987, p. 9-13. Zie voorts voor een rechtseconomische 


\section{Het empirisch onderzoek}

Het is van belang om de theoretische conclusies van de rechtseconomische analyse aan de praktijk te toetsen. Op deze wijze kan worden beoordeeld of het recht, in de vorm van aansprakelijkheidsregels, verzekeringsvoorwaarden en veiligheidsregulering, ook daadwerkelijk van invloed is op het verkeersgedrag en op het aantal verkeersongevallen en verkeersslachtoffers. Daarom zal, binnen het kader van de centrale probleemstelling, aandacht worden besteed aan empirisch onderzoek dat op het terrein van het verkeersongevallenrecht is verricht. Dit onderzoek zal worden beperkt tot een kritische analyse van reeds beschikbaar onderzoeksmateriaal. Met het empirisch onderzoek wordt slechts beoogd om aan de hand van statistisch materiaal na te gaan of de juridische instrumenten uit de probleemstelling van invloed kunnen zijn op de preventie van verkeersongevallen en op de compensatie van verkeersslachtoffers.

De empirische literatuur is voornamelijk afkomstig uit Noord-Amerika, Canada, Australië, Engeland en Duitsland. Een belangrijke reden hiervoor is dat in deze jurisdicties veel onderzoek is gedaan naar aansprakelijkheid, verzekering en veiligheidsregulering. Dit geldt in mindere mate voor Nederland, waar de meest recente empirische studies naar de verkeersaansprakelijkheid dateren uit de jaren '70 van de vorige eeuw. ${ }^{38}$ Vooral in Noord-Amerika en Canada is ervaring opgedaan met variaties op de afwikkeling van verkeersschade, in het bijzonder met betrekking tot de no-fault verzekering, op basis waarvan verkeersslachtoffers ongeacht de schuldvraag schadeloos worden gesteld. Daarbij geldt dat slechts enkele jurisdicties, onder algehele afschaffing van de aansprakelijkheid, een zuivere no-fault verzekering (bijvoorbeeld de Canadese provincie Quebec) hebben ingevoerd. Veel Amerikaanse staten houden naast de invoering van een no-fault verzekering de mogelijkheid open om op basis van onrechtmatige daad een aansprakelijkheidsvordering voor verkeersschade in te stellen. Andere staten hebben geen no-fault verzekering ingevoerd en handhaven daarmee een systeem van aansprakelijkheid en verzekering voor de vergoeding van verkeersschade. Door de aanwezigheid van verschillende stelsels

visie op de verkeersaansprakelijkheid: Nentjes en Dijkstra, NJB, 1993, p. 951-954; Van den Bergh, in Verkeersaansprakelijkheid in Belgie en Nederland, p. 27-74; Visscher en Van den Bergh, NJB, 1998, p. 122-127; Van Velthoven, VR, 2000, p. 313-322.

38. Zie onder anderen Bloembergen, Hers-van Oven, Vinke en Van Wersch, Duizend Botsingen, 1972; Bloembergen en Van Wersch, Verkeersslachtoffers en hun schade, 1973; De Growt, Schaderegeling bij verkeersongevallen, 1979. Ten aanzien van bepaalde vormen van veiligheidsregulering zal wel worden verwezen naar recent Nederlands onderzoek daaromtrent. 
van verkeersaansprakelijkheid en het beschikbare onderzoeksmateriaal is derhalve een goede empirische vergelijking mogelijk. ${ }^{39}$

Aangezien de literatuur afkomstig is uit verschillende jurisdicties, zal het empirisch onderzoek mede een rechtsvergelijkende component bevatten. De rechtsstelsels worden daarbij niet uitvoerig geanalyseerd, maar volstaan zal worden met een korte uiteenzetting van het relevante rechtssysteem.

\section{De methode van onderzoek}

De centrale vraag van dit onderzoek zal, als gezegd, worden uitgewerkt met behulp van drie typen van analyse, namelijk een positiefrechtelijke, een rechtseconomische, en een empirische.

In het kader van de positiefrechtelijke analyse zal de verkeersaansprakelijkheid in Frankrijk, België en Nederland worden beschreven. Daarnaast wordt ten aanzien van Nederland ingegaan op een aantal alternatieve voorstellen op het terrein van de verkeersaansprakelijkheid. De beschreven stelsels en voorstellen zullen aan het eind van dit onderzoek worden getoetst aan de uitkomsten van de rechtseconomische analyse en het empirisch onderzoek.

Binnen de rechtseconomische analyse van het verkeersongevallenrecht zullen aan de hand van een economisch model de drie genoemde juridische instrumenten worden geanalyseerd. Daarbij wordt voornamelijk aansluiting gezocht bij het economisch model van het ongevallenrecht zoals dit door een aantal auteurs is ontwikkeld. ${ }^{40}$

In het onderhavige onderzoek ligt de nadruk op een neutrale beschrijving van de neoklassieke theorie van het ongevallenrecht. ${ }^{41}$ Het neoklassieke model, waarover veel toegankelijke literatuur beschikbaar is, ${ }^{42}$ richt zich op de concrete toepassing

39. Zie onder anderen Dewees, Duff and Trebilcock, Exploring the Domain of Accident Law, p. 394 en p. 412-439; Sloan, Reilly and Schenzler, IRLE, 1994, p. 53-71.

40. In dat kader kunnen worden genoemd: Shavell, Accident Law, p. 5-32 en p. 186-261; Faure en Van den Bergh, Objectieve aansprakelijkheid, p. 62-141; Calabresi, The Costs of Accidents, 1970.

41. De rechtseconomie kent verschillende scholen op basis waarvan het recht wordt geanalyseerd. Zie voor een vergelijkende analyse van deze scholen: Teijl en Holzhauer, Wisselende perspectieven in de rechtseconomie, diss., 1997.

42. Zie onder anderen: Calabresi, The Costs of Accidents, 1970; Shavell, Accident Law, 1987; Landes and Posner, The Economic Structure of Tort Law, 1987; Posner, Economic Analysis, 1992. De neoklassieke theorie wordt ook wel vereenzelvigd met de Chicago-school of Law and Economics, omdat gedurende de jaren ' 70 van de vorige eeuw vanuit Chicago cen belangrijke impuls aan de ontwikkeling van de rechtseconomie is gegeven. Zie Teijl en Holzhauer, Wisselende perspectieven in de rechtseconomie, p. 87-88. 
van het recht, waarbij enerzijds bruikbaar materiaal wordt geleverd voor een oordeel over de efficiëntie van bijvoorbeeld de aansprakelijkheid in het verkeer en anderzijds normatieve vragen worden beantwoord die in het kader van een hervorming van het verkeersongevallenrecht van belang kunnen zijn. Het neoklassieke model geeft geen antwoord op alle vragen. Een theorie die in de toekomst mogelijk van belang kan worden is de 'Game Theory', een speltheoretische benadering waarin globaal de interactie tussen een aantal spelers, bijvoorbeeld een automobilist en een voetganger en de invloed van het recht op het gedrag van deze spelers wordt geanalyseerd. ${ }^{43}$ Deze speltheorie zal in dit onderzoek verder niet worden toegepast. ${ }^{44}$

De neoklassieke theorie analyseert de vraag op welke wijze het recht de gedragingen van de bij een ongeval betrokken partijen kan beïnvloeden. Onderzocht wordt met name of aansprakelijkheidsregels tot een minimalisering van de maatschappelijke kosten van ongevallen, zijnde de som van de verwachte schade en de kosten van zorg, kunnen leiden. De keuze voor een bepaalde ansprakelijkheidsregel wordt verder bepaald door de vraag of alleen de dader het ongevalsrisico kan beïnvloeden (unilateraal) of dat dader én slachtoffer prikkels moeten krijgen om efficiënte zorg aan te wenden (bilateraal). Binnen het economisch model van het aansprakelijkheidsrecht wordt verondersteld dat dader en slachtoffer rationeel handelende individuen zijn die volledige informatie bezitten omtrent het verkeersrisico. Deze veronderstelling zal in een later stadium van de analyse worden genuanceerd, waarbij wordt onderzocht welke gevolgen fouten en vergissingen inzake het risico bij dader en slachtoffer, maar ook bij de rechter die moet oordelen over de zorgvuldigheid, kunnen hebben voor de efficiëntie van aansprakelijkheidsregels. ${ }^{45}$

In het economisch model van het aansprakelijkheidsrecht wordt eerst verondersteld dat dader en slachtoffer neutraal staan ten opzichte van het ongevalsrisico. In een tweede deeltheorie, namelijk de economische analyse van risico en verzekering, wordt onderzocht welke houding dader en slachtoffer ten aanzien van het ongevalsrisico kunnen innemen. Afhankelijk van deze risicohouding zal een vraag naar een verzekering bestaan. De beschikbaarheid van een verzekering heeft echter gevolgen voor het gedrag van dader en slachtoffer. Uitgaande van de veronderstelling dat deze effecten negatief zijn (morele risico), zal een verzekeraar op basis van de beschikbare informatie maatregelen moeten nemen om het ongevalsrisico van de verzekerde te kunnen beïnvloeden en te controleren. Naast deze informatieproblemen wordt ook

43. Zie daarover onder anderen Baird, Gertner and Picker, Game Theory and the Law, p. 6-31; Picker, Law and Economics Working Paper, 1993, p. 1-20.

44. Zie Van den Bergh en Visser, NJB, 1998, p. 112-127 voor een toepassing van de speltheorie op het verkeer.

45. Shavell, Accident Law, p. 73-85; Faure en Van den Bergh, Objectieve aansprakelijkheid, p. 9093; Th.S. Ulen, Rational Victims - Rational Injurers; Cognition and the Economic Analysis of Law, Paper, p. 1-52. 
de invloed van regulering op de verzekering onderzocht, waarbij zal worden ingegaan op de theorie van de verplichte verzekering, een beperking van de aansprakelijkheid en het belang van concurrentie op de verzekeringsmarkt. Met behulp van de verzekeringseconomie zal tenslotte de vraag worden beantwoord in hoeverre als gevolg van de aanwezigheid van een verzekering de werking van aansprakelijkheidsregels wordt beïnvloed of gewijzigd, zowel op het terrein van de preventie van verkeersongevallen als ten aanzien van de compensatie van verkeersslachtoffers. ${ }^{46}$

In het kader van de analyse van het derde juridische instrument, namelijk de veiligheidsregulering, is een drietal economische theorieën van (overheids)regulering van belang. In de eerste plaats de 'public interest' theorie, waarbinnen regulering tot doel heeft de totale maatschappelijke welvaart te verhogen. Daarbij wordt onderzocht welke wetgeving de overheid vanuit het algemeen belang kan uitvaardigen om bepaalde tekortkomingen van het marktmechanisme ${ }^{47}$ te corrigeren. ${ }^{48}$ Een tweede theorie van regulering heeft meer concreet betrekking op de analyse van het ongevallenrecht. Daarin wordt met behulp van een aantal criteria de verhouding tussen veiligheidsregulering en aansprakelijkheid onderzocht. Hierbij staat de vraag centraal of met veiligheidsregulering ten opzichte van aansprakelijkheid een betere preventie van verkeersongevallen kan worden bereikt of dat daarvoor een combinatie van beide instrumenten nodig is. ${ }^{49}$ In de derde plaats is de 'private interest' theorie van belang. Deze theorie tracht te verklaren waarom de politieke besluitvorming soms leidt tot wetgeving die niet in het algemeen belang is, maar eerder onder invloed van bepaalde lobbygroepen tot stand komt ('public choice'). ${ }^{50}$ Binnen het kader van het verkeersongevallenrecht zal worden onderzocht of, ten gevolge van de invloed van lobbygroepen, de regulering van de verzekeringsmarkt en van de verkeersveiligheid tot bepaalde inefficiënties leidt op het terrein van de preventie van verkeersongevallen.

Uit het voorgaande kan worden opgemaakt dat bij de rechtseconomische analyse van het verkeersongevallenrecht een keuze is gemaakt voor een viertal theorieën, namelijk de neoklassieke theorie ten aanzien van het aansprakelijkheidsrecht en de veiligheidsregulering, de theorie van de verzekeringseconomie, de theorie van overheidsregulering in algemene zin en de 'public choice' theorie. Met behulp van deze theo-

46. Shavell, Bell Joumal of Economics, 1982, p. 120-132; Shavell, Accident Law, p. 206-215; Calabresi, Costs of Accidents, p. 39-67; Faure en Van den Bergh, Objectieve aansprakelijkheid, p. 101-141.

47. In de Engelstalige literatuur wordt in dit verband gesproken over 'market failures'. Zie onder anderen: Ogus, Regulation, p. 28-30; Peltzman, JLE, 1976, p. 211-212. 'Market failures' zal hiema worden vertaald als 'marktfalingen'.

48. Faure en Van den Bergh, Objectieve aansprakelijkheid, p. 144-147.

49. Shavell, JLS, 1984, p. 357-374; Faure en Van den Bergh, Objectieve aansprakelijkheid, p. 152161.

50. Faure en Van den Bergh, Objectieve aansprakelijkheid, p. 147-152. 
rieën kan een goede algemene verklaring worden gegeven voor de vraag of het recht de verkeersrisico's kan beïnvloeden, maar ook of daarmee de verkeersveiligheid kan worden verhoogd. Daarnaast kan worden gesteld dat deze theorieën overeenstemmen met het doel van dit onderzoek zoals dat in de centrale probleemstelling is verwoord. Door de samenvoeging van de analyse van aansprakelijkheid, verzekering en veiligheidsregulering ontstaat tevens een theoretisch kader dat direct kan worden getoetst aan de praktijk, in casu het beschikbare empirisch materiaal.

De empirische analyse van het verkeersongevallenrecht volgt in grote lijnen de methode van de economische theorie. In het kader van de preventiedoelstelling wordt achtereenvolgens onderzocht of aansprakelijkheid, verzekering en veiligheidsregulering ook daadwerkelijk van invloed kan zijn op het verkeersgedrag, het aantal verkeersongevallen en het aantal verkeersslachtoffers. Met betrekking tot de compensatiedoelstelling wordt nagegaan of een systeem van aansprakelijkheid en verzekering een optimale schadevergoeding aan het slachtoffer kan garanderen. Ten aanzien van zowel de preventie- als de compensatiedoelstelling wordt een vergelijking gemaakt tussen een systeem van aansprakelijkheid en verzekering en een no-fault vergoedingssysteem voor verkeersschade, waarin het aansprakelijkheidsrecht (deels) is afgeschaft. Daarbij gaat het om de vraag welke effecten een no-fault verzekering heeft op het aantal verkeersongevallen, de compensatie van verkeersslachtoffers en de kosten van het betreffende systeem. Met betrekking tot de uitkomsten van deze analyse zal steeds worden nagegaan bij welke theoretisch gemaakte veronderstellingen aansluiting kan worden gevonden.

\section{De indeling van het onderzoek}

Het onderhavige onderzoek bestaat uit drie delen. Deze hebben betrekking op een positiefrechtelijke, een rechtseconomische en een empirische analyse, waarna in het laatste hoofdstuk de economische toetsing van de verkeersaansprakelijkheid en de eindconclusies volgen.

In deel I wordt aandacht besteed aan de positiefrechtelijke analyse van de verkeersaansprakelijkheid. Daarbij komen achtereenvolgens Frankrijk (hoofdstuk 1), België (hoofdstuk 2) en Nederland (hoofdstuk 3) aan de orde.

In deel II gaat het om de economische analyse van het verkeersongevallenrecht. Daarbij zullen in hoofdstuk 4 eerst de belangrijkste begrippen en uitgangspunten van de rechtseconomie worden uiteengezet, waarna de drie instrumenten uit de probleemstelling worden geanalyseerd. In hoofdstuk 5 staat de vraag centraal welke aansprakelijkheidsregel dader en slachtoffer kan aanzetten tot een optimaal zorg- en activiteitsniveau in het verkeer. In hoofdstuk 6 volgt een economische analyse van risico en verzekering. Naast de bestudering van een aantal informatieproblemen zal ook de invloed van regulering op de verzekering worden onderzocht. Ten slotte 
wordt de vraag beantwoord welke combinatie van aansprakelijkheid en verzekering tot een optimale preventie en compensatie van verkeersongevallen kan leiden. Naast een systeem van aansprakelijkheid en verzekering, zal verder aandacht worden besteed aan alternatieve compensatiemechanismen. In hoofdstuk 7 wordt een aantal economische theorieën van (overheids)regulering beschreven, namelijk de 'public interest' theorie, de 'private interest' theorie en de theorie van veiligheidsregulering. In het kader van de theorie van veiligheidsregulering zal de vraag van belang zijn op welke wijze een gecombineerd gebruik van aansprakelijkheid en veiligheidsregulering van invloed kan zijn op de preventie van verkeersongevallen. In hoofdstuk 8 wordt met behulp van een aantal stellingen de rechtseconomische analyse samengevat, waarbij tevens een aantal vragen wordt geformuleerd ten behoeve van het empirische onderzoek.

In deel III staat de weergave alsmede een kritische analyse van het beschikbare empirisch onderzoek centraal. In hoofdstuk 9 wordt allereerst een aantal statistische gegevens met betrekking tot verkeersongevallen en verkeersslachtoffers gepresenteerd en zal een aantal empirische studies met betrekking tot het verkeersgedrag en het ongevalsrisico worden beschreven. Hierna zullen de drie juridische instrumenten uit de probleemstelling stapsgewijs worden geanalyseerd. In hoofdstuk 10 zal de preventieve werking van ansprakelijkheidsregels en de compensatoire werking van aansprakelijkheid en verzekering worden onderzocht. In hoofdstuk 11 wordt ingegaan op de preventieve werking van de verzekeringsvoorwaarden en de invloed van verzekeringsregulering op de preventie van verkeersongevallen. In hoofdstuk 12 komt de empirische analyse van veiligheidsregulering in het verkeer aan de orde. In hoofdstuk $13 \mathrm{zal}$ de werking van de no-fault verzekering ten opzichte van het aansprakelijkheidsrecht worden geanalyseerd. In hoofdstuk 14 zal deel III worden afgesloten met een toetsing van de uitkomsten van het empirisch onderzoek aan de conclusies van de rechtseconomische theorie.

Het onderzoek zal in deel IV (hoofdstuk 15) worden afgesloten met een toetsing van het positieve recht aan de uitkomsten van de rechtseconomische en empirische analyse. Naast de stelsels van Frankrijk, België en Nederland zal daarin ook aandacht worden besteed aan voorstellen in de Nederlandse literatuur en het wetsvoorstel Sorgdrager in samenhang met de plannen van Korthals. 


\section{Deel I:}

\section{Een positiefrechtelijke analyse van de verkeersaansprakelijkheid}

In dit eerste deel van het onderhavige onderzoek zullen de regelingen op het terrein van de verkeersaansprakelijkheid in Frankrijk, België en Nederland worden geanalyseerd. Daarbij ligt de nadruk op aspecten van aansprakelijkheid en verzekering en een combinatie van beide instrumenten. In dit kader zijn onder andere de volgende positiefrechtelijke vragen van belang: Wordt de verkeersaansprakelijkheid in beide landen beheerst door aansprakelijkheid of verzekering? Speelt de eigen schuld van het verkeersslachtoffer nog een rol van betekenis? Wat is de functie van het regres binnen deze systemen van verkeersaansprakelijkheid?

Binnen de positiefrechtelijke analyse zal in een rechtsvergelijkend perspectief aandacht worden besteed aan de verkeersaansprakelijkheid in Frankrijk en België. Een argument hiervoor is een verwijzing naar de aanstaande wetswijziging in Nederland. ${ }^{51}$ Het Nederlandse wetsvoorstel is inhoudelijk voornamelijk gebaseerd, althans sterk gelijkend op de Franse 'loi Badinter' van $1985^{52}$ en op de Belgische wet inzake verkeersaansprakelijkheid van $1995,{ }^{53}$ die weer sterk is gericht op de Franse wet.

In de volgende hoofdstukken zal de toepasselijke wetgeving en jurisprudentie ten aanzien van de verkeersaansprakelijkheid in Frankrijk (hoofdstuk 1), België (hoofdstuk 2) en Nederland (hoofdstuk 3) worden uiteengezet. In deel IV (hoofdstuk 15) van dit onderzoek zal de betreffende wetgeving in deze landen en een aantal verwante Nederlandse voorstellen worden getoetst aan de uitkomsten van de economische analyse van het verkeersongevallenrecht uit deel II en III.

51. Op 26 november 1997 is door de toenmalige Minister van Justitie Sorgdraget het wetsvoorstel verkeersongevallen aan de Tweede Kamer aangeboden: Vaststclling en invoering van afdeling 8.14.1 (verkeersongevallen) van het Burgerlijk Wetboek, Tweede Kamer, 1997-1998, 25759, nr. 1-3. De huidige Minister van Justitie Korthals heeft inmiddels het wetsvoorstel van zijn voorgangster ingetrokken en aangekondigd met een eigen voorstel te komen, waarvan een voorlopige uitwerking kan worden gevonden in een brief van 16 juni 1999, TK 1998-1999, 25759, nr. 5 (H). Zie ook NJB, 1999, p. 1292-1293.

52. Loi no 85-677 du 5 juillet 1985, J.O. 6 juli 1985.

53. Wet van 13 april 1995 tot wijziging van artikel 29 bis en tot opheffing van artikel 29ter van de wet van 21 november 1989 betreffende de verplichte aansprakelijkheidsverzekcring inzakc motorrijtuigen, Belgisch Staatsblad, 27 juni 1995. 



\section{Hoofdstuk 1: De Franse verkeersaansprakelijkheid}

\section{Inleiding}

In Frankrijk is op 1 januari 1986 een bijzondere wetgeving aangaande de schadevergoeding bij verkeersongevallen in werking getreden. ${ }^{54}$ Deze 'loi Badinter' regelt de aansprakelijkheid en de schadevergoeding ten aanzien van verkeersongevallen waar een motorrijtuig bij betrokken is. Met deze regeling wordt onder andere een risicoaansprakelijkheid gevestigd op de bestuurder of houder van een motorijtuig zonder dat een beroep op overmacht of een gedraging van een derde mogelijk is. ${ }^{55}$ In dit hoofdstuk zal allereerst een kort overzicht worden geschetst van de situatie vóór 1986 (paragraaf 2) alsmede de ontstaansgeschiedenis van de 'loi Badinter' (paragraaf 3). Daarna zal een positiefrechtelijke analyse van de 'loi Badinter' worden gepresenteerd (paragraaf 4). In paragraaf 5 zal vervolgens worden ingegaan op de praktische werking van deze wet en in paragraaf 6 volgen tot slot enkele concluderende opmerkingen.

\section{De verkeersaansprakelijkheid vóór de 'loi Badinter'}

Tot 1986 kende het Franse aansprakelijkheidsrecht geen bijzondere wettelijke regeling ten aanzien van verkeersongevallen. De aansprakelijkheid en de schadevergoeding naar aanleiding van een verkeersongeval werden beheerst door artikel 1382 juncto 1384 C.c., in het bijzonder artikel 1384 lid 1 C.c. ${ }^{56}$ Daarin is een min of meer zelfstandige risicoaansprakelijkheidsregel opgenomen voor schade veroorzaakt door een zaak die een persoon onder zich heeft. ${ }^{57}$ In dat kader rustte tot 1982 op de houder of bestuurder van een motorrijtuig een vermoeden van aansprakelijkheid. ${ }^{58}$ In een standaardarrest uit $1930^{59}$ heeft het Franse Hof van Cassatie geoordeeld dat de houder ('gardien') niet meer aan aansprakelijkheid kan ontkomen door aan te tonen dat een 'faute' ontbrak. Dit betekende dat de schade die was veroorzaakt door het gebruik van het motorrijtuig door de houder moest worden vergoed, tenzij deze bewijst

54. 'Loi no 85-677 du 5 juillet 1985 tendant à l'amélioration de la situation des victimes d'accidents de la circulation et à l'accélération des procédures d'indemnisation', J.O., 6 juillet 1985 et J.C.P., 1985, III, 57405.

55. Artikel 2 van de 'loi Badinter'.

56. 'On est responsable non seulement du dommage que l'on cause par son propre fait, nais encore de celui qui est causé par le fait des personnes dont on doit répondre, ou des choses que l'on a sous sa garde'.

57. 'La responsabilité du fait des choses'.

58. 'Une présomption de responsabilitė'. Chabas, Le droit des accidents de la circulation, p. 17-20; De Haas en Hartlief, Verkeersaansprakelijkheid, p. 26; Ulrix, RW, 1985-1986, p. 1624.

59. Het zogenaamde Jand'hcur-arrest, Cass. chambres réunies, 13-2-1930 (Jand'heur II), D., 1930, 1, 57 note Ripert. 
dat sprake was van overmacht ('cas fortuit' of 'force majeure'), eigen schuld van het slachtoffer ('fait de la victime') ofwel schuld van een derde ('fait d'un tiers'). In het kader van overmacht diende de houder van het motorrijtuig aan te tonen dat het ongeval te wijten was aan een van buiten komende oorzaak ('extériorité') die onvoorzienbaar en onvermijdbaar ('imprévisible et irrésistible') was. De eigen schuld van het slachtoffer alsmede de schuld van een derde kon de houder/bestuurder alleen dan van aansprakelijkheid bevrijden wanneer dit de enige oorzaak was van het ongeval. Wanneer de eigen schuld van het slachtoffer niet de enige oorzaak was van het ongeval, dan volgde een verdeling van de schade naar de mate waarin de partijen aan de oorzaak van het ongeval hadden bijgedragen. ${ }^{60}$

In 1982 werd door het Franse Hof van Cassatie het befaamde Desmares-arrest gewezen. Daarin werd een beroep op de eigen schuld van het slachtoffer aanzienlijk ingeperkt mede door de overweging dat:

\begin{abstract}
'Seul un événement constituant un cas de force majeure exoneré le gardien de la chose, instrument du dommage, de la responsabilité par lui encourue par application de l'article 1384 alinéa ler du Code civil...dès lors, le comportement de la victime, s'il n'a pas été pour le gardien imprévisible et irrésistible, ne peut l'exonérer, même partiellement'. ${ }^{61}$
\end{abstract}

Een beroep op de eigen schuld van het slachtoffer was hierdoor alleen nog mogelijk indien het gedrag van het slachtoffer onvermijdbaar en onvoorzienbaar was. In het laatste geval is sprake van overmacht en wordt de houder van het motorrijtuig van zijn aansprakelijkheid bevrijd. De houder wordt nu ook niet meer vermoed aansprakelijk te zijn, maar hij is aansprakelijk, tenzij sprake is van overmacht. Tevens valt met de bovengenoemde uitspraak de mogelijkheid tot een verdeling van de schade weg; het is een alles-of-niets-systeem geworden. Wanneer derhalve het gedrag van slachtoffer A 'imprévisible et irrésistible' was voor de houder B en beiden lijden

60. Zie Viney, L'indemnisation des victimes d'accident de la circulation, p. 3-4; Chabas, Le droit des accidents de la circulation, p. 17-26 voor een overzicht van de jurisprudentie na het Jand'heur-arrest; Viney et Jourdain, Traité de droit civil, p. 1087-1091; Tunc, La responsabilité civil, p. 72; C.C. van Dam, Zorgvuldigheidsnorm en aansprakelijkheid, diss., p. 28-29; Sterk, Verhoogd gevaar in het aansprakelijkheidsrecht, diss., p. 7; De Haas en Hartlief, Verkeersaansprakelijkheid, p. 26; Engelhard en Van Maanen, Aansprakelijkheid voor verkeersongevallen, p. 21; Ulrix, RW, 1985-1986, p. 1624-1627; Redmond-Cooper, I.C.L.Q., 1989, p. 502-505, die, ten onrechte, stelt dat met het Jand'heur arrest een algemeen beginsel van foutloze aansprakelijkheid ten aanzien van verkeersongevallen werd geïntroduceerd.

61. Cass. 2e civ., 21 juli 1982, D., 1982, 449 en J.C.P., 1982, II, 19861, note Chabas. Zie Chabas, Le droit des accidents de la circulation, p. 26; Viney et Jourdain, Traité de droit civil, p. 1094; Overeem, VR, 1984, p. 49-55; C.C. van Dam, Zorgvuldigheidsnorm en aansprakelijkheid, p. 29. 
schade dan krijgt B zijn schade volledig vergoed en A krijgt niets. Indien echter geen sprake was van overmacht dan krijgen A en B hun volledige schade vergoed. ${ }^{62}$

Vanuit de lagere rechtspraak in Frankrijk is veel kritiek gekomen op dit arrest, maar de afwijkende uitspraken van de Hoven werden veelal door de cassatierechter in laatste instantie gecorrigeerd. ${ }^{63}$ Ook in de doctrine werd het Desmares-arrest gemengd ontvangen. In dat kader dient met name de kritiek van Geneviève Viney te worden gememoreerd. Zij pleitte ervoor om naar aanleiding van het Desmares-arrest een verwerping van het eigen schuldverweer te beperken tot die gevallen waarin sprake was van een wettelijk verplichte aansprakelijkheidsverzekering. Daarnaast zou volgens haar wel een beroep op eigen schuld mogelijk moeten zijn ingeval van een opzettelijke of onverschoonbare ('intentionelle ou inexcusable') fout aan de zijde van het slachtoffer. ${ }^{64}$

In 1987 keerde de Franse cassatierechter weer enigszins op haar schreden terug door te oordelen dat:

'Le gardien de la chose instrument du dommage est partiellement exonéré de sa responsabilité s'il prouve que la faute de la victime a contribué au dommage..$^{65}$

Hiermee stond een beroep op de eigen schuld van het slachtoffer weer gedeeltelijk open voor de houder van de zaak (motorrijtuig). De houder was daarbij alleen van zijn aansprakelijkheid bevrijd, wanneer de 'faute de la victime' de enige oorzaak van het ongeval was en dit gegeven voor de houder tevens onvermijdbaar en onvoorzienbaar was. Deze laatste ontwikkeling in de cassatierechtspraak was echter grotendeels het gevolg van de invoering van de 'loi Badinter' in 1986, waarin een (beperkt) beroep op de eigen schuld van slachtoffer uitdrukkelijk is opgenomen. ${ }^{66}$

62. Notitie Verkeersaansprakelijkheid, TK, 1989-1990, 21 528, nr. 2, p. 2; Sterk, Verhoogd gevaar in het aansprakelijkheidsrecht, p. 48-50. Zie over het Desmares-arrest en de verdere nasleep daarvan: Viney, L'indemnisation des victimes d'accidents de la circulation, p. 8-9; Overeem, VR, 1985 , p. 99-103, met betrekking tot de reikwijdte van dit amest; Lambert-Faivre, Droit des assurances, p. 542-544; Engelhard en Van Maanen, Aansprakelijkheid voor verkeersongevallen, p. 22; Ulrix, RW, 1985-1986, p. 1627-1628; Redmond-Cooper, I.C.L.Q., 1989, p. 505-506; Downes, French Lessons on Motor Accident Compensation, p. 173-179.

63. Zie voor een overzicht van deze jurisprudentie: Chabas, Le droit des accidents de la circulation, p. 26-29. Zie ook Viney, L'indemnisation des victimes d'accidents de la circulation, p. 8.

64. Viney, J.C.P., 1984, I, no. 3155, noot 19-20. Zie ook Overeem, VR, 1985, p. 99-100.

65. Cass. 2e civ., 6 april 1987, 6 amêts, J.C.P., 1987, II, 20828, note F. Chabas, D., 1988, 32, Bull. civ. 1987, nr. 86. Chabas, Le droit des accidents de la circulation, p. 29; Viney, L'indemnisation des victimes d'accidents de la circulation, p. 9; Viney et Jourdain, Traité de droit civil, p. 1095; Lambert-Faivre, Droit des assurances, p. 543-544.

66. De Haas en Hartlief, Verkeersaansprakelijkheid, p. 27. Zie over de 'loi Badinter' paragraaf 4. 


\section{De 'loi Badinter': een korte voorgeschiedenis}

Uit de vorige paragraaf kan worden opgemaakt dat de ontwikkeling van de verkeersaansprakelijkheid in Frankrijk vooral via de jurisprudentie beeft plaatsgevonden. Deze jurisprudentie heeft zich sterk ontwikkeld in het voordeel van het verkeersslachtoffer, met als voorlopig hoogtepunt het eerder besproken Desmares-arrest. Door de Franse overheid zijn echter tot aan het begin van de jaren ' 80 van de vorige eeuw weinig initiatieven ontplooid ten behoeve van een bijzondere wettelijke regeling voor de vergoeding van verkeersschade. Het enige wetgevende initiatief heeft op het terrein van de verzekering plaatsgevonden, met de invoering in de jaren '50 van de vorige eeuw van een waarborgfonds voor het wegverkeer (1951) en een verplichte WAM-verzekering (1958). ${ }^{67}$

Sinds 1965, dus nog vóór het Desmares-arrest, zijn door Andre Tunc reeds voorstellen gedaan om tot een bijzondere regeling van de verkeersaansprakelijkheid te komen. Hij pleitte daarbij voor een afschaffing van de aansprakelijkheid. Daarnaast diende volgens hem de aansprakelijkheidsverzekering geheel te worden vervangen door een verkeersverzekering die alle personenschade van het verkeersslachtoffer alsmede de schade aan het motorrijtuig vergoedt. De juridische begrippen overmacht en schuld spelen binnen deze voorstellen geen rol meer, behalve in geval van opzet ('une faute intentionnelle') door het slachtoffer. Alle verkeersslachtoffers, zowel gemotoriseerd als niet-gemotoriseerd, behoren binnen dit systeem in beginsel volledig schadeloos gesteld te worden door ofwel de verzekeraar van het voertuig waarin het slachtoffer zich bevond, ofwel door de verzekeraar van het voertuig waaraan de schade kan worden toegeschreven. ${ }^{68}$ Naar aanleiding van dit zogenaamde 'Tunc project' werd door de toenmalige Minister van Justitie, Jean Foyer, in 1965 een commissie gevormd om te onderzoeken of een vorm van verkeersverzekering mogelijk was. Onder invloed van de kritiek van de verzekeraars, die vooral waarschuwden voor een onwenselijke premieverhoging, werd dit project echter ingetrokken. ${ }^{69}$

67. Lambert-Faivre, Droit des assurances, p. 539-541; Chabas, Le droit des accidents de la circulation, p. 13-14; Engelhard en Van Maanen, Aansprakelijkheid voor verkeersongevallen, p. 21; Notitie Verkeersaansprakelijkheid, TK, 1989-1990, 21528, nr. 2, p. 1-2.

68. Een voorstel van die strekking is opgenomen in Tunc (dir.), Pour une loi sur les accidents de la circulation, p. 13-16. Een gewijzigd voorstel is, na het commentar van een aantal wetenschappelijke en verzekeringsspecialisten, in hetzelfde boek opgenomen op p. 273-276. Zie verder Tunc, Rev. trim. dr. civ., 1967, 82; Tunc, Traffic Accident Compensation: Law and Proposal. Zie over de voorstellen van Tunc ook: Viney, L'indemnisation des victimes d'accidents de la circulation, p. 5-6; Chabas, Le droit des accidents de la circulation, p. 68-71; Viney et Jourdain, Traité de droit civil, p. 1091-1092; Ulrix, RW, 1985-1986, p. 1628-1629; De Haas en Hartlief, Verkeersaansprakelijkheid, p. 27. 
Tussen 1965 en 1985 zijn er verschillende andere voorstellen gedaan voor een hervorming van de verkeersaansprakelijkheid in Frankrijk, onder andere vanwege de verzekeraars en de advocatuur. ${ }^{70}$ Pas in 1981 werden door de Franse wetgever de eerste stappen gezet op weg naar een meer definitieve wettelijke regeling. Daartoe werd op initiatief van de Minister van Justitie Robert Badinter, in hetzelfde jaar, een commissie geïnstalleerd onder leiding van $\mathrm{M}$. Bellet, president van het Hof van Cassatie. De leden van deze commissie, waaronder ook Tunc, wisten echter niet tot overeenstemming te komen omtrent een wetteksten behoeve van een hervorming van de verkeersaansprakelijkheid. ${ }^{71}$ Het werk van de commissie Bellet resulteerde in 1982 echter wel in een rapport, waarin een aantal uitgangspunten voor een wettelijke regeling werden geformuleerd. De Minister van Justitie, Badinter, besloot echter om het rapport niet openbaar te maken en daarmee een publiek debat uit te lokken. Hij koos daarentegen voor een voorzichtige circulatie ervan binnen de rechterlijke macht, de wetenschap en andere belanghebbenden. Op deze wijze wist Badinter een wetsvoorstel tot stand te brengen dat, om door het parlement aanvaard te kunnen worden, uiteindelijk een compromis betrof. De inspanningen van Badinter leidden in 1985 tot een bijzondere wet, die op 5 juli van dat jaar door het Franse parlement ('Assemblée Nationale') unaniem werd aanvaard. ${ }^{72}$

\section{De 'loi Badinter': een positiefrechtelijke analyse}

De 'loi Badinter ${ }^{13}$ die op 1 januari 1986 van kracht werd was een compromis tussen een automatisch vergoedingssysteem en een gedeeltelijke handhaving van het aansprakelijkheidsrecht. De belangrijkste doelstelling van de wet Badinter, die binnen het Franse aansprakelijkheidsrecht als een autonome regeling wordt beschouwd, ${ }^{74}$ is

70. Door Viney, L'indemnisation des victimes d'accidents de la ciruclation, p. 7 en Chabas, Le droit des accidents de la circulation, p. 71-74 worden deze en andere voorstellen opgesomd en kort beschreven. Zie ook Vincy et Jourdain, Traité de droit civil, p. 1093-1095; Lambert-Faivre, Droit des assurances, p. 541-542.

71. Zie daarover Chabas, Le droit des accidents de la circulation, p. 74-75. Zie Viney, L'indemnisation des victims d'aceidents de la circulation, p. 7.

72. Tunc, MJ, 1996, p. 332; Chabas, Le droit des accidents de la circulation, p. 75-81; LambertFaivre, Droit des assurances, p. 544-545; Redmond-Cooper, I.C.L.Q., 1989, p. 507-508; Ulrix, RW, 1985-1986, p. 1629; De Haas en Hartlief, Verkeersaansprakelijkheid, p. 27-28.

73. Loi no 85-677 du 5 juillet 1985, J.O., 6 juillet 1985 et J.C.P., 1985, III, 57405.

74. Zie daarover Jourdain, Gaz. Pal., 1995, p. 3-4; Le Tourneau et L. Cadiet, Droit de la responsabilité, p. 905-906; Lambert-Faivre, Droit des assurances, p. 564-572; De Haas en Hartlief, Verkeersaansprakelijkheid, p. 29-31. Viney, L'indemnisation des victimes daccidents de la circulation, p. 17-21 en Viney et Jourdain, Traité de droit civil, p. 1100-1104, verwijzen naar een aantal beslissingen van het Franse Hof van Cassatic, waarin werd bepaald dat de wet Badinter bij uitsluiting toepassing vindt met betrekking tot de vordering van het slachtoffer die schade heeft geleden ten gevolge van een verkeersongeval waarbij een motorijtuig is betrokken. Zie Cass. 2e civ., 19 novembre 1986, Bull. civ., II, nr. 165, p. 112; Cass. 2e civ., 4 mai 1987, Bull. civ., II, nr. 87. 
om de schadevergoeding van verkeersslachtoffers te verbeteren, alsmede de tijdspanne waarbinnen deze slachtoffers dienen te worden gecompenseerd te versnellen. ${ }^{75}$

De wet Badinter bestaat uit vier hoofdstukken. Hoofdstuk I (artt. 1-27) bevat regels omtrent de vergoeding van schade aan verkeersslachtoffers. Dit hoofdstuk is opgedeeld in drie afdelingen, die betrekking hebben op respectievelijk regels ten aanzien van het recht op schadevergoeding (artt. 1-6), verplichtingen van de verzekeraars en het Waarborgfonds (artt. 7-11) en regels met betrekking tot het aanbod van schadevergoeding (artt. 12-27). Hoofdstuk II (artt. 28-34) geeft regels in het kader van de verhaalsrechten van derden ('tiers payeurs') die het slachtoffer bebben gecompenseerd. Hoofdstuk III (artt. 35-45) is gereserveerd voor bepaalde procedureregels en een aantal andere bijzondere maatregelen onder andere ten aanzien van de verjaring. Hoofdstuk IV (artt. 46-48), tenslotte, geeft een aantal overgangsregels die mede verband houden met het tijdstip van invoering van de wet Badinter. ${ }^{76}$

In deze paragraaf zal de wet Badinter, aan de hand van een aantal wetsartikelen, op hoofdlijnen worden geanalyseerd. ${ }^{77}$ Daarnaast zal aandacht worden besteed aan een aantal bijzondere aspecten van deze wet, namelijk de betrokkenheid van een motorrijtuig ('implication'), de schuld van het slachtoffer ('faute inexcusable'), alsmede de positie van derden-betalers ('tiers payeurs'). Met name ten aanzien van de uitleg van de eerste twee begrippen heeft in de jurisprudentie en de literatuur lang onduidelijkheid bestaan.

\subsection{DE HOOFDLINEN VAN DE 'LOI BADINTER'}

\subsubsection{Hoofdstuk I: artt. 1-6}

Artikel $1^{78}$ van de wet Badinter geeft het toepassingsgebied van deze regeling weer. Het moet gaan om een verkeersongeval waarbij een motorrijtuig (een auto, een mo-

75. Dit komt vooral tot uitdrukking in de titel: 'tendant à l'amélioration de la situation des victims d'accidents de la circulation et à l'accélération des procédures d'indemnisation'.

76. Viney, Lindermnisation des victimes d'accident de la circulation, p. 9-11; Viney et Jourdain, Traité de droit civil, p. 1095-1100; De Haas en Hartlief, Verkeersaansprakelijkheid, p. 28-29.

77. Voor een meer gedetailleerde weergave van de wet Badinter kan onder anderen worden verwezen naar: Viney, L'indemnisation des victimes d'accidents de la circulation, p. 17-155; Chabas, Le droit des accidents de la circulation, p. 83-329; Dixième aniversaire de la loi Badinter; Bilan et perspectives, Resp. civ. et ass., 1996, p. 1-48; Le Toumeau et Cadiet, Droit de la responsabilité, p. 905-938; Spécial Responsabilité Civile, Gaz. Pal., 18-20 juin 1995, p. 1-33; Viney et Jourdain, Traité de droit civil, p. 1104-1190; Lambert-Faivre, Droit des assurances, p. 548-615 en p. 641-663.

78. 'Les dispositions du présent chapitre s'appliquent, même lorsqu'elles sont transportées en vertu d'un contrat, aux victimes d'un accident de la circulation dans lequel est impliqué un véhicule 
torfiets of een landbouwvoertuig) is betrokken, wil een slachtoffer voor een vergoeding van de schade in aanmerking komen. Dit artikel vindt eveneens toepassing wanneer een motorrijtuig is betrokken bij een ongeval op een privé-terrein, een akker, een skipiste of in het kader van een sport op een gesloten auto- of motorcircuit, indien daarbij aanwezige toeschouwers schade lijden. ${ }^{79}$ Ongevallen met treinen of andere voertuigen op rails zijn van toepassing van artikel 1 uitgesloten. ${ }^{80}$

In artikel $2^{81}$ is bepaald dat de bestuurder of houder van het motorrijtuig jegens het slachtoffer geen beroep op overmacht noch een gedraging van een derde mag doen. Dit betekent dat wanneer het ongeval is veroorzaakt door bijvoorbeeld een glad wegdek, de bestuurder/houder van het motorrijtuig het slachtoffer toch schadeloos dient te stellen. De (aansprakelijkheids)verzekeraar die in het kader van de wet $\mathrm{Ba}-$ dinter de schade aan het slachtoffer heeft uitgekeerd, behoudt echter wel een verhaalsrecht op de schuldige derde, bijvoorbeeld degene die de gladheid heeft veroorzaakt. $^{82}$

In de eerste alinea van artikel $3^{83}$ worden de personen opgesomd die voor een quasiautomatische schadevergoeding in aanmerking komen. In het algemeen gaat het daarbij om fietsers, voetgangers alsmede passagiers die werden vervoerd door het bij

terrestre à moteur ainsi que ses remorques ou semi-remorques, à l'exception des chemins de fer et des tramways ciruclant sur des voies qui leur sont propres'.

79. Cass. 2e civ., 5 mars 1986, Bull. civ., II, nr. 28, 25 juin 1986, D., 1987, somm., 87 en 10 mai 1991, Bull. civ., I, nr. 137 (akker); Paris, 5 juillet 1989, J.C.P., 1989, II, 21384, note Chabas (privétertein); Crim., 16 juillet 1987, Bull. crim., nr. 294 (gesloten circuit), Cass. 2e civil, 13 janvier 1988, Bull. civ., II, nr. 11, (rallyrace), Cass. 2e civil, 10 mars 1988, Bull. civ., I, nr. 59 (motor-cross), Cass. 2e civil, 8 janvier 1993, Bull. civ., nr. 5 (ongeval op gesloten circuit buiten wedstrijdverband); Grenoble, 9 février 1987, D., 1987, p. 245, note Chabas (skipiste). Zie Viney et Jourdain, Traité de droit civil, p. 1108-1109, noot 68-69; Jourdain, Gaz. Pal., 1995, p. 14, noot 18-19; Le Tourneau et Cadiet, Droit de la responsabilité, p. 908; Sterk, VR, 1997, p. 199, noot 15-18.

80. Zie voor een uitleg van dit artikel onder anderen: Chabas, Le droit des accidents de la circulation, p. 83-94 en 109-111; Viney, L'indemnisation des victimes d'accident de la circulation, p. 62-72; Viney et Jourdain, Traité de droit civil, p. 1104-1128; Le Tourneau et Cadiet, Droit de la responsabilité, p. 907-908 en p. 910-916; Jourdain, Gaz. Pal., 1995, p. 4-7; Lambert-Faivre, Droit des assurances, p. 549-564; Perez, VR, 1986, p. 169; Hulst, NJB, 1992, p. 695-698; Sterk, VR, 1997, p. 198. 'Zie over het begrip 'betrokkenheid' ('implication') verderop in paragraaf 4.2.

81. 'Les victimes, y compris les conducteurs, ne peuvent se voir opposer la force majeur ou le fait d'un tiers par le conducteur ou le gardien d'un véhicule mentionné à l'article ler'.

82. Chabas, Le droit des accidents de la circulation, p. 145-156; Viney, L'indemnisation des victimes d'accidents de la circulation, p. 32-35; Viney et Jourdain, Traité de droit civil, p. 1144-1147; Chabas, Gaz. Pal., 1995, p. 17-18; Perez, VR, 1986, p. 169; De Haas en Hartlief, Verkeersaansprakelijkheid, p. 31; Hulst, NJB, 1992, p. 698-699; Ulrix, RW, 1985-1986, p. 1630.

83. 'Les victimes, hormis les conducteurs de véhicules terrestres à moteur, sont indemnisées des dommages résultant des atteintes à leur personne qu'elles ont subis, sans que puisse leur être opposée leur propre faute à l'exception de leur faute inexcusable si elle a été la cause exclusive de l'accident'. 
het ongeval betrokken motorrijtuig. Wanneer deze verkeersdeelnemers bij een ongeval met een motorrijtuig betrokken raken, dienen zij schadeloos te worden gesteld. Een beroep op de eigen schuld van het slachtoffer is daarbij niet meer mogelijk, tenzij deze schuld onverschoonbaar is ('faute inexcusable') en als de enige oorzaak ('cause exclusive de l'accident') van het ongeval kan worden aangemerkt.

Artikel 3, 2e alinea ${ }^{84}$ geeft een opsomming van personen die binnen de groep potentiële verkeersslachtoffers nog eens extra worden beschermd. Personen beneden de 16 jaar, personen boven de 70 jaar en personen die voor het ongeval reeds $80 \%$ invalide waren, worden altijd volledig schadeloos gesteld, zonder dat een beroep op een onverschoonbare fout van deze benadeelden mogelijk is.

Voor alle verkeersslachtoffers geldt dat in het geval zij de schade opzettelijk hebben veroorzaakt ('a volontairement recherché le dommage'), te bewijzen door de schadeplichtige, aan hen een vergoeding van de schade zal worden onthouden ( $3 \mathrm{e}$ alinea). ${ }^{85}$

Artikel 4 regelt de schade die door de bestuurder van het motorrijtuig wordt geleden. De bepaling stelt dat 'wanneer de bestuurder van het motorrijtuig een fout (onzorgvuldig gedrag) heeft begaan zijn eigen schade in het geheel niet of slechts gedeeltelijk zal worden vergoed. ${ }^{86}$ Dit betekent dat voor de schade van een slachtofferbestuurder een risicoaansprakelijkheid met een mogelijkheid van eigen schuld geldt. Bij de uitleg van deze bepaling werd door het Franse Hof van Cassatie aanvankelijk geoordeeld dat een slachtoffer-bestuurder zijn eigen schade zal moeten dragen indien zijn 'faute' onvoorzienbaar en onvermijdbaar (overmacht) was voor de andere bestuurder, die daarvan wel de bewijslast draagt. De schade van een slachtoffer-bestuurder blijft in ieder geval voor rekening van de bestuurder zelf wanneer zijn

84. 'Les victimes désignées à l'alinéa précédent, lorsqu'elles sont âgées de moins de seize ans ou de plus de soixante-dix ans, ou lorsque, quel que soit leur âge, elles sont titulaires, au momoent de l'accident, d'un titre leur reconnaissant un taux d'incapacité permanente ou d'invalidité au moins égal à 80 p. 100, sont, dans tout les cas, indemnisées des dommages résultant des atteintes à leur personne qu'elles ont subis'.

85. 'Toutefois, dans les cas visés aux deux alinéas précédents, la victime n'est pas indemnisée par l'auteur de l'accident des dommages résultant des atteintes à sa personne lorsqu'elle a volontairement recherché le dommage qu'elle a subi'. Chabas, Le droit des accidents de la circulation, p. 156-165; Viney et Jourdain, Traité de droit civil, p. 1148-1150; Le Toumeau et Cadiet, Droit de la responsabilité, p. 921-922; De Haas en Hartlief, Verkeersaansprakelijkheid, p. 33-35; Chabas, Gaz. Pal, 1995, p. 18-19. Zie over de eigen schuld van de niet-gemotoriseerde verkeersdeelnemer meer uitvoerig in paragraaf 4.3 .

86. 'La faute commise par le conducteur du véhicule terrestre à moteur a pour effet de limiter ou d'exclure l'indemnisation des dommages qu'il a subis'. Onder druk van de verzekeraars, met het argument van een stijging van de verzekeringspremies, werden bestuurders van een quasjautomatische vergoeding onder deze regeling uitgesloten. Zie Tunc, MJ, 1996, p. 330. 
'faute' de enige oorzaak was van het ongeval. ${ }^{87}$ Een slachtoffer-bestuurder die een 'faute' heeft gemaakt komt daarnaast alleen voor een (gedeeltelijke) vergoeding in aanmerking wanneer de andere bestuurder ook een fout heeft gemaakt. ${ }^{88}$ In een aantal recente arresten werd door het Franse Hof van Cassatie echter een meer objectief criterium voor de eigen 'faute' van een slachtoffer-bestuurder geïntroduceerd. ${ }^{89}$ Sindsdien oordeelt het Hof van Cassatie dat een slachtoffer-bestuurder in beginsel recht heeft op schadevergoeding, behalve wanneer hijzelf een 'faute' beging die heeft bijgedragen aan het ontstaan van de schade. ${ }^{90}$ In dat kader geldt dat wanneer de eigen 'faute' van een slachtoffer-bestuurder de enige oorzaak was van het ongeval, dit nog niet betekent dat zijn schade geheel voor eigen rekening komt. ${ }^{91}$

Het voorgaande brengt echter mee dat een slachtoffer-bestuurder minder wordt beschermd dan het niet-gemotoriseerde verkeersslachtoffer. De particuliere verzekeraars in Frankrijk zijn hieraan tegemoet gekomen met de introductie van een stelsel, waarbij aan de bestuurder een 'garantie avance sur recours' wordt gegeven. Deze zogenaamde PACS-verzekering ('Protection assurée du conducteur et des siens') is een eerste partij verzekering, waarmee een bestuurder, tegen een additionele premie, ${ }^{92}$

87. Zie onder andere Cass. 2e civ., 7 juillet 1993, Bull. civ, II, nr. 244; Cass. 2e civ., 20 juillet 1993, Bull. civ., II, nr. 266; Cass. 2e civ., 8 novembre 1993, Bull. civ., II, nr. 317; Cass. 2e civ., 24 november 1993, Bull. civ., II, nr. 333; Cass. 2e civ., 11 janvier 1995, Bull. civ. II, 1; 31 mai 1995, Resp. civ. et ass., 1995, comm., nr. 233. Viney, Resp. civ. et ass., 1996, p. 7, noot 23; Viney et Jourdain, Traité de droit civil, p. 1163-1164, noot 321-322.

88. Cass. 2e civ., 17 février 1993, Bull. civ. II, 63; Cass. 2e civ., 24 novembre 1993, Bull. civ. II, nr. 334; Cass. 2e civ., 6 juillet 1994, Bull. civ., 178; Cass. 2e civ., 2 novembre 1994, Bull. civ. II, 209. Viney, Resp. civ. et ass., 1996, p. 7 noot 24; Viney et Jourdain, Traité de droit civil, p. 1164, noot 323. Zie voor een overzicht van de werking van artikel 4 onder anderen: Viney, L'indemnisation des victimes d'accidents de la circulation, p. 40-43; Chabas, Le droit des accidents de la circulation, p. 177-185; Le Toumeau et Cadiet, Droit de la responsabilité, p. 917 921; Chabas, Gaz. Pal., 1995, p. 21-23; Lambert-Faivre, Droit des assurances, p. 600-606; Viney et Jourdain, Traité de droit civil, p. 1162-1164; Engelhard en Van Maanen, Aansprakelijkheid voor verkeetsongevallen, p. 51-52; De Haas en Hartlief, Verkeersaansprakelijkheid, p. 32-33; Sterk, VR, 1997, p. 199-200.

89. Cass. crim. 22 mai 1996, Bull. crim., nr. 211, D., 1997, p. 138 note F. Chabas: 'Chaque conducteur même non fautif est tenu d'indemniser l'autre, sauf limitation ou exclusion par suite d'une faute commise par ce dernier'. Viney et Jourdain, Traité de droit civil, p. 1165; Engelhard en Van Maanen, Aansprakelijkheid voor verkeersongevallen, p. 52-53.

90. Cass. Ch. mixte, 28 mars 1997, Bull. ch. mixte, nr. 1, D. 1997, 294, note H. Groutel; Cass. 2e civ., 6 mai 1997, Bull. civ., II, nr. 126 et 127, D. 1997, p. 503, note H. Groutel; Cass. 2e civ., 2 juillet 1997, Bull. civ., II, nr. 213, D., 1997, p. 183.

91. Zie voor een overzicht van deze recente rechtspraak: Viney et Jourdain, Traité de droit civil, p. 1165-1167; Le Toumeau et Cadiet, Droit de la responsabilité, p. 920; Lambert-Faivre, Droit des assurances, p. 590-600; Engelhard en Van Maanen, Aansprakelijkheid voor verkeersongevallen, p. 52-53.

92. De jaarlijkse additionele premie voor een dergelijke verzekering bedraagt, afhankelijk van de omvang van de dekking, ongeveer FF 300-1.000. Het aantal bestuurders dat over deze PACS- 
volledige dekking verkrijgt voor zijn eigen letselschade. De PACS-verzekeraar vergoedt de letselschade van de bestuurder na verrekening van hetgeen door de bestuurder is ontvangen van zijn sociale verzekeraar. De Pacs-verzekeraar keert derhalve alleen de eigen schade van de bestuurder uit en niet de vordering van de regresnemende sociale verzekeraar. De vergoeding van de PACS-verzekeraar kan worden beschouwd als een voorschot op het verhaal ('garantie avance sur secours'), waarbij de verzekeraar na uitkering contractueel wordt gesubrogeerd in de rechten van de bestuurder. Het verhaalsrecht, waarbij de Pacs-verzekeraar de uitgekeerde schade aan de bestuurder geheel of gedeeltelijk kan verhalen op de verzekeraar van de aansprakelijke derde, is vastgelegd in artikel 33 e alinea van de wet Badinter. ${ }^{93}$

\subsubsection{Hoofdstuk I: artt. 7-11}

Met de invoering van de 'loi Badinter' is verder een aantal wijzigingen aangebracht in de 'Code des assurances', waarmee deze laatste meer in overeenstemming werd gebracht met de doelstellingen van de wet Badinter. De artikelen 7-11 van de wet Badinter geven een overzicht van de gewijzigde artikelen uit de 'Code des assurances' $^{.94}$ Hierin is een aantal verplichtingen van de verzekeraar respectievelijk het Waarborgfonds opgenomen. Daaronder valt onder andere de verplichting aan de verzekeraar om de aansprakelijkheid te dekken van iedere persoon die het motorrijtuig onder zich heeft of zelfs zonder toestemming van de rechthebbende bestuurt. De verzekeraar behoudt in deze gevallen wel een verhaalsrecht op de veroorzaker van het ongeval (artikel 8). ${ }^{95}$ Artikel 10 bevat een andere wijziging ten gunste van het slachtoffer. Het waarborgfonds kan namelijk buiten de schadeplichtige om een regeling treffen met het slachtoffer. ${ }^{96}$

verzekering beschikt wordt geschat op ongeveer $50 \%$. Zie De Haas en Hartlief, Verkeersaansprakelijkheid, p. 60; Tunc, MJ, 1996, p. 336, noot 9; Fredericq, in Een Salomons oordeel, p. 49-54.

93. De Haas en Hartlief, Verkeersaansprakelijkheid, p. 58-60; Tunc, MJ, 1996, p. 336, noot 9; Viney, L'indemnisation des victimes d'accidents de la circulation, p. 107-109; Lambert-Faivre, Droit des assurances, p. 607-609; Notitie Verkeersaansprakelijkheid, TK, 1989-1990, 21528, nr. 2, p. 4; Fredericq, in Een Salomons oordeel, p. 49-54.

94. Afdeling II van hoofdstuk 1, 'Disposition relatives à l'assurance et au fonds de garantie'. Zie daarover meet uitvoerig Chabas, Le droit des accidents de la circulation, p. 201-225 en Viney, L'indemnisation des victimes d'accidents de la circulation, p. 87-106 ten aanzien van de aansprakelijkheidsverzekering voor motorrijtuigen in het algemeen.

95. Artikel L. 211-1 van de 'Code des assurances'.

96. Artikel 1. 420-3 van de 'code des assurances'. Zie over de rol van het Waarborgfonds: Appietto, Gaz. Pal., 1988, p. 121-127; Durry, VR, 1991, p. 29-34; Viney, L'indemnisation des victimes d'accidents de la circulation, p. 144-155; Le Toumeau et Cadiet, Droit de la responsabilité, p. 938; Lambert-Faivre, Droit des assurances, p. 664-680. 


\subsubsection{Hoofdstuk I: artt. 12-27}

Een van de belangrijkste vernieuwingen van de wet Badinter is opgenomen in de artikelen $12-27 .{ }^{97}$ Daarin wordt onder andere bepaald dat de verzekeraar verplicht is om binnen 8 maanden na het ongeval aan het slachtoffer dat lichamelijke schade heeft geleden een definitief aanbod tot schadevergoeding ('l'offre d'indemnité') voor te leggen. ${ }^{98}$ Wanneer de omvang van de schade niet direct kan worden vastgesteld ('consolidation') dient de verzekeraar binnen 3 maanden een voorlopig aanbod te doen. $\mathrm{Na}$ de vaststelling van de schade ('consolidation') rest de verzekeraar nog 5 maanden om een aanvullend aanbod te doen. ${ }^{99}$ Op het niet doen van een aanbod staat als sanctie een verdubbeling van het wettelijke rentepercentage, ingaande op de dag dat het aanbod had moeten worden gedaan (art. 16). Wanneer de rechter achteraf oordeelt dat door de verzekeraar een te laag aanbod is gedaan (manifestement insuffisante), dan kan de verzekeraar worden veroordeeld tot de betaling van een boete aan het Waarborgfonds. Deze boete is gelijk aan $15 \%$ van de omvang van de schadevergoeding die door de rechter wordt vastgesteld (art. 17). ${ }^{100}$

\subsubsection{Hoofdstuk II: artt. $28-34$}

Artikel 28-34 (hoofdstuk II) van de wet Badinter bevat algemene regels voor het regres van derden-betalers ('recours des tiers payeurs'), in casu instellingen en organen die op grond van een wettelijke of contractuele verplichting de personenschade van een verkeersslachtoffer in eerste aanleg vergoeden. ${ }^{101}$ Het verhaalsrecht is van toepassing op uitkeringen in het kader van ziekte-, invaliditeits- en overlijdensverzekeringen, maar niet ten aanzien van ouderdoms-, bijstands- en werkeloosheidsverzekering. Artikel 29 geeft een limitatieve opsomming van de werkgeversinstellingen

97. Afdeling III van hoofdstuk 1: 'De l'offre d'indermité'.

98. Artikel 12 le alinea bepaald dat 'l'assureur qui garantit la responsabilité civile du fait d'un véhicule terrestre à moteur est tenu de présenter dans un délai maximum de huit mois à compter de l'accident une offre d'indemnité à la victime qui a subi une atteinte à sa personne. Lin cas de décès de la victime, l'offre est faite à ses héritiers et, s'il y a lieu, à son conjoint'.

99. Artikel 12, 4e alinea bepaald dat 'Elle peut avoir un caractère provisionnel lorsque l'assurcur n'a pas, dans les trois mois de l'accident, été informé de la consulidation de l'état de la victime. L'offre définitive d'indemnisation doit alors être faite dans un délai de cinq mois suivant la date à laquelle l'assureur a été informé de cette consolidation'.

100. Chabas, Le droit des accidents de la circulation, p. 225-256; Vincy, Lindemnisation des victimes d'accidents de la circulation, p. 113-143; Le Tourneau et Cadiet, Droit de la responsabilité, p. 929-934; Lambert-Faivre, Droit des assurances, p. 655-663; Pcrez, VR, 1986, p. 170-172; Tunc, MJ, 1996, p. 331; De Haas en Hartlief, Verkeersaansprakelijkheid, p. 55-56.

101. Hoofdstuk II getiteld: 'Des recours des tiers payeurs contre les personnes tenues a réparation d'un dommage résultant d'une atteinte à la personne'. Het betreft hiet met name vitkeringen van de particuliere werkgever en de overheid als werkgever. 
en -organen aan wie een verhaalsactie toekomt. ${ }^{102}$ Aan werkgevers komt daarnaast op grond van artikel 32 een zelfstandig verhaalsrecht toe voor het werkgeversaandeel in de afgedragen verzekeringspremies ten aanzien van door hen betaalde salarissen. ${ }^{103}$ Buiten de in artikel 29 opgesomde instanties en op grond van het subrogatoire karakter dat aan hun verhaalsacties wordt verleend (art. 30), is een additioneel regresrecht uitgesloten voor uitkeringen die op grond van een wettelijke, contractuele of statutaire verplichting zijn gedaan en is elke daarmee strijdige bepaling nietig. ${ }^{104}$ Een uitzondering hierop is het verhaal van de PACS-verzekeraar die een voorschot op de schadevergoeding aan het slachtoffer, in casu de verzekerde bestuurder, heeft uitgekeerd. De PACS-verzekeraar mag daarbij slechts het saldo vorderen dat resteert, nadat de derden-betalers uit art. 29 verhaal hebben genomen. ${ }^{105}$

\subsection{DE BETROKKENHEID ('IMPLICATION') VAN HET MOTORRIJTUIG}

Hoewel met de wet Badinter de positie van verkeersslachtoffers, niet-zijnde een bestuurder van een motorrijtuig, sterk is verbeterd, heeft deze regeling in de jaren na de invoering ervan geleid tot een aantal interpretatieproblemen. In dit kader zal in deze paragraaf worden ingegaan op de problemen die in de rechtspraak zijn gerezen met betrekking tot de betrokkenheid ('implication') van het motorrijtuig bij een verkeersongeval. ${ }^{106}$ In de paragraaf $4.3 \mathrm{zal}$ een overzicht worden gepresenteerd van de

102. Zie voor een overzicht hiervan: Engelhard en Van Maanen, Aansprakelijkheid voor verkeersongevallen, p. 63-64; Lambert-Faivre, Droit des assurances, p. 451-452; Perez, VR, 1986, p. 172; De Haas en Hartlief, Collectivering en institutionalisering van regres, p. 82-84.

103. Artikel 32: 'Les employeurs sont admis à poursuivre directement contre le responsable des dommages ou son assureur le remboursement des charges patronales afférentes aux rémunérations maintenues ou versées à la victime pendant la période d'indisponibilité de celle-ci. Ces dispositions sont applicables à l'Etat par dérogation aux disposition de l'article 2 de l'ordonnance nr 59-76 du 7 janvier 1959 précitée'.

104. Artikel 33, le en $2 \mathrm{e}$ alinea stellen dat 'Hormis les prestations mentionnées aux articles 29 et 32 , aucun versement effectué au profit d'une victime en vertu d'une obligation légale, conventionnelle ou statutaire n'ouvre droit à une action contre la personne tenue à réparation du dommage ou son assureur' en 'Toute disposition contraire aux prescription des articles 29 et 32 et du présent article est réputée non écrite à moins qu'elle ne soit plus favorable à la victime'.

105. Artikel 33, 3e alinea bepaald dat 'Toutefois, lorsqu'il est prévu par contrat, le recours subrogatoire de l'assureur qui a versé à la victime une avance sur indemnité du fait de l'accident peut être exercé contre l'assureur de la personne tenue à réparation dans la limite du solde substitant après paiements aux tiers visés à l'article 29. Il doit être exercé, s'il y a lieu, dans les délais impartis par la loi aux tiers payeurs pour produire leurs créances'. Zie over het verhaalsrecht van derden-betalers: Perez, VR, 1986, p. 172; Chabas, Le droit des accidents de la circulation, p. 291-305; Lambert-Faivre, Droit des assurances, p. 447-463; De Haas en Hartlief, Collectivering en institutionalisering van regres, p. 84-87; Engelhard en Van Maanen, Aansprakelijkheid voor verkeersongevallen, p. 64-65; De Haas en Hartlief, Verkeersaansprakelijkheid, p. 58-60; Notitie Verkeersaansprakelijkheid, TK, 1989-1990, 21528, nr. 2, p. 4 en 9. Het regres zal in paragraaf 4.4 nader aan de orde komen.

106. Zie Sterk, VR, 1997, p. 198. 
jurisprudentie ten aanzien van de eigen schuld ('faute inexcusable') van het nietgemotoriseerde verkeersslachtoffer. In paragraaf $4.4 \mathrm{zal}$ ten slotte aandacht worden besteed aan de praktische werking van het regresrecht van derden-betalers ('tiers payeurs').

Een belangrijke voorwaarde voor aansprakelijkheid op grond van de wet Badinter is de betrokkenheid ('implication') van het motorrijtuig bij een verkeersongeval. ${ }^{107} \mathrm{De}$ discussie in de rechtspraak spitst zich daarbij vooral toe op de begrippen 'beweging' (van het voertuig) en 'fysiek contact' (tussen het voertuig en het slachtoffer). In de literatuur wordt een verder onderscheid gemaakt tussen respectievelijk contact van het slachtoffer en een motorrijtuig in beweging (1), contact van het slachtoffer met een stilstaand motorrijtuig (2) en een afwezigheid van elk contact tussen het slachtoffer en een motorrijtuig (3). De Franse cassatierechter geeft over het algemeen een ruime uitleg aan het begrip 'implication', waarbij overigens de causaliteit niet geheel wordt verlaten. Het motorrijtuig dient namelijk wel een bepaalde rol bij het ontstaan van het ongeval te hebben gespeeld. ${ }^{108}$

\subsubsection{Contact tussen slachtoffer en een motorrijtuig in beweging}

Zodra er contact is tussen een slachtoffer en een motorrijtuig in beweging is volgens de Franse rechtspraak altijd sprake van 'betrokkenheid'. Daarbij is het niet van belang op welke wijze het motorrijtuig in beweging bij een verkeersongeval betrokken is geraakt en of het daarbij een actieve dan wel passieve rol heeft gespeeld. ${ }^{109}$ Een voorbeeld waarin 'implication' van het motorrijtuig werd aangenomen, betrof een jong meisje dat langs een rijdende bromfiets van een vriendin liep, waarbij haar sjaal in het achterwiel van de bromfiets verstrikt raakte, met het gevolg dat zij ten val kwam en letsel opliep. ${ }^{110}$ Van 'implication' is eveneens sprake wanneer een persoon tegen een rijdende vrachtwagen wordt aangeslingerd, ${ }^{111}$ maar ook in het geval dat een onbekende derde tegen de geparkeerd staande auto van A aanrijdt, waardoor de

107. Zie daarover Sterk, Verhoogd gevaar in het aansprakelijkheidsrecht, p. 51-59; Viney, L'indemnisation des victims d'accident de la circulation, p. 22-31; Chabas, Le droit des accidents de la circulation, p. 94-114; Viney et Jourdain, Traité de droit civil, p. 1119-1128; Le Toumcau et Cadiet, Droit de la responsabilité, p. 912-915; Lambert-Faivre, Droit des assurances, p. 553558; Engelhard en Van Maanen, Aansprakelijkheid voor verkeersongevallen, p. 30-31; De Haas en Hartlief, Verkeersaansprakelijkheid, p. 30-31.

108. Viney et Jourdain, Traité de droit civil, p. 1121-1123; Notitie Verkeersaansprakelijkheid, TK, 1989-1990, 21528, nr. 2, p. 5; Jourdain, Gaz. Pal., 1995, p. 8-9; Le Toumeau et Cadiet, Droit de la responsabilité, p. 912-913; Philippe en Meysmans, TvP, 1995, p. 414-416.

109. Viney, L'indemnisation des victimes d'accident de la circulation, p. 24; Tuerlinckx, TvP, 1996, p. 22; P. Jourdain, Rev. trim. dr. civ., 1988, p, 781.

110. Cass. 2 e civ., 19 fevrier 1986, Bull. civ., II, nr. 19. Tuerlinckx, TvP, 1996, p. 22-23.

111. Cass. 2e civ., 26 novembre 1986, D. 1987, 128, note Groutel. 
auto van $\mathrm{A}$ in beweging komt en de eveneens geparkeerd staande auto van $\mathrm{B}$ raakt. $^{112}$

\subsubsection{Contact tussen slachtoffer en een stilstaand motorrijtuig}

Ten aanzien van de vraag in hoeverre het contact tussen een verkeersslachtoffer en een stilstaand motorrijtuig 'implication' oplevert, is uit de jurisprudentie een ontwikkeling af te leiden in de richting van een ruimere uitleg van het begrip betrokkenheid. In de literatuur wordt daarbij een onderscheid gemaakt tussen een geparkeerd staand voertuig ('voiture en stationnement') en een voertuig dat (tijdelijk) stilstaat omdat de verkeerssituatie daarom vraagt ('voiture en ârret'). ${ }^{113}$ In het kader van het laatste werd door het Franse Hof van Cassatie onder andere geoordeeld dat sprake is van 'betrokkenheid' van een bij een halte stilstaande bus, waarvan een passagier bij het uitstappen ten val komt en schade lijdt. ${ }^{114}$ Later werd bepaald dat bij stilstaande motorrijtuigen alleen sprake kan zijn van 'betrokkenheid', wanneer het betreffende motorrijtuig de doorgang van het verkeer belemmerde. ${ }^{115}$ Met betrekking tot geparkeerd staande motorrijtuigen werd aanvankelijk bepaald dat voor het aannemen van 'betrokkenheid' het slachtoffer moest aantonen dat het motorrijtuig het verkeer (in casu het slachtoffer) heeft gehinderd ('peturber la circulation'). ${ }^{116}$ Dit leidde onder andere tot het oordeel dat een tegen de rijrichting in geparkeerd motorrijtuig geen verkeershinder veroorzaakte en derhalve geen 'betrokkenheid' opleverde omdat het foutief parkeren geen invloed had op het ontstaan van het ongeval. ${ }^{117}$ In 1994 werd door het Hof van Cassatie het criterium van verkeershinder ten opzichte van het slachtoffer verlaten, door 'betrokkenheid' aan te nemen van een correct geparkeerd

112. Cass. 2e civ., 21 mai 1990, D. 1991, 123. Zie voor andere voorbeelden: Sterk, Verhoogd gevaar in het aansprakelijkheidsrecht, p. 5l-53; Viney, L'indemnisation des victimes d'accident de la circulation, p. 27-28; Chabas, Le droit des accidents de la circulation, p. 103-105; Jourdain, Gaz. Pal., 1995, p. 9; Viney et Jourdain, Traité de droit civil, p. 1123-1124; Le Toumeau et Cadiet, Droit de la responsabilité, p. 913-914; Lambert-Faivre, Droit des assurances, p. 554; Philippe en Meysmans, TvP, 1995, p. 416-417; Sterk, VR, 1997, p. 199; Sterk, VR, 1998, p. 66.

113. Zie onder anderen Chabas, Le droit des accidents de la circulation, p. 105-109; Sterk, Verhoogd gevaar in het aansprakelijkheidsrecht, p. 54-57; Lambert-Faivre, Droit des assurances, p. 554556; Philippe en Meysmans, TvP, 1995, p. 419-421; Tuerlinckx, TvP, 1996, p. 23-25.

114. Cass. 2e civ., 7 juin 1989, Bull. civ., II, nr. 122; Cass. 2e civ., 11 octobre 1989, Bull. civ., II, nr. 163.

115. Cass. 2e civ., 7 juin 1990, Bull. civ., II, nr. 124. Sterk, Verhoogd gevaar in het aansprakelijkheidsrecht, p. 57.

116. Cass. 2 e civ., 21 juilliet 1986, Bull. civ., Il, 113 (3 arrêts).

117. Cass. 2 civ., 7 oktobre, 1987, D. 1987, p. 206 en Cass. 2e civ., 7 juin 1990, D.J. 1991, p. 124 (geen 'betrokkenheid' van een goed verlichte vuilniswagen die 's nachts tegen de rijrichting in stilstond). Anders: Cass. 2e civ., 9 mai 1990, D.J. 1991, p. 124 (wel betrokkenheid van een vrachtwagen die in het donker zonder licht langs de openbare weg was geparkeerd, terwijl andere vrachtwagens op die plaats in de berm stonden). Viney, L'indemnisation des victimes d'accident de la circulation, p. 28-30; Sterk, Verhoogd gevaar in het aansprakelijkheidsrecht, p. $54-56$. 
motorrijtuig, dat door een bromfietser met zijn stuur werd geschampt waarna deze in botsing kwam met een tegemoetkomende auto. ${ }^{118}$ In 1995, ten slotte, werd door het Hof van Cassatie eenzelfde criterium geïntroduceerd voor zowel geparkeerde als stilstaande motorrijtuigen. Het Hof oordeelde dat het voldoende is dat er contact is geweest tussen een niet-bewegend voertuig, in dit geval een correct geparkeerde vrachtwagen, en het slachtoffer, een fietser die in de regen tegen de vrachtwagen aanreed, om 'betrokkenheid' aan te kunnen nemen. Daarbij werd door het Hof uitdrukkelijk overwogen dat andere omstandigheden die aan het ontstaan van het ongeval hebben bijgedragen niet van belang zijn. ${ }^{119}$

\subsubsection{Afwezigheid van een fysiek contact tussen slachtoffer en motorrijtuig}

Met betrekking tot de ongevallen waarbij in het geheel geen sprake is van fysiek contact tussen het slachtoffer en een motorrijtuig in beweging, is door het Franse Hof van Cassatie ten aanzien van de 'implication' geen vastomlijnd criterium ontwikkeld. In de literatuur wordt naar aanleiding van de rechtspraak van het Hof geconcludeerd dat het slachtoffer ten bewijze van 'implication' dient aan te tonen dat:

'Le véhicule du défendeur a joué un $<<$ rôle quelconque dans l'accident $\gg>$ ou qu'il est $\ll$ intervenu de quelque manière que ce soit $\gg>$ ou $\ll<$ à quelque titre que ce soit $\gg$ dans la réalisation de l'accident. En $\mathrm{Ce} \ll$ rôle $\gg$, cctte $\ll<$ intervention quelconque $\gg$ que l'on exige n'est autre qu'un rôle causal entendu au sens où le véhicule doit avoir été une condition nécessaire de l'accident'. ${ }^{120}$

Voor het aannemen van 'implication' is derhalve niet alleen de aanwezigheid van een motorrijtuig noodzakelijk, maar geldt tevens dat dit motorrijtuig een zekere rol moet hebben gespeeld bij het ontstaan van het verkeersongeval. ${ }^{121}$ Hierna zal een aantal voorbeelden uit de Franse rechtspraak worden gegeven, waarin afhankelijk van de

118. Cass. 2e civ., 23 mars 1994, Bull. civ., II, nr. 100 (2 arêts). Zie Tuerlinckx, TvP, 1996, p. 23-25; Philippe en Meysmans, TvP, 1995, p. 419-421; De Haas en Hartlief, Verkeersaansprakelijkheid, p. 30 .

119. Cass. 2e civ., 25 janvier 1995, Bull. civ., nr. 27. Zie ook Cass. 2 e civ., 12 juin 1996, Bull. civ., П, nr. 147. Viney et Jourdain, Traité de droit civil, p. 1124-1125; Sterk, VR, 1997, p. 199 en VR, 1998, p. 66-68; Jourdain, Gaz. Pal., 1995, p. 9; Le Toumeau et Cadiet, Droit de la responsabilité, p. 914; Lambert-Faivre, Droit des assurances, p. 555-556; Engelhard en Van Maanen, Aansprakelijkheid voor verkeersongevallen, p. 31.

120. Viney et Jourdain, Traité de droit civil, p. 1126; Jourdain, Gaz. Pal., 1995, p. 9 met verwijzing naar Cass. 2e civ. 1 mars 1989, Rev. trim. dr. civ., 1989, p. 568; Cass. 2e civ., 10 mai 1991, Bull. civ., II, nr. 135; Cass. 2e civ., 17 juillet 1991, Bull. civ., Il, nr. 225; Cass. 2e civ., 15 mai 1992, Bull. civ., II, nr. 139; Cass. 2e civ., 28 juin 1995, Bull. civ., II, nr. 203; Cass. 2e civ., 5 février 1992, Resp. civ. et ass., 1992, comm. nr 182.

121. Sterk, VR, 1998, p. 68-69; Engelhard en Van Maanen, Aansprakelijkheid voor verkeersongevallen, p. 31 . 
concrete situatie werd geoordeeld over de 'betrokkenheid' van een motorrijtuig bij een verkeersongeval zonder dat sprake was van een fysiek contact met het slachtoffer. $^{122}$

In een aantal arresten werd door het Franse Hof van Cassatie bijvoorbeeld betrokkenheid' aannemelijk geacht in situaties waarbij een verkeersdeelnemer A (slachtoffer) wordt 'gehinderd' door verkeersdeelnemer B, waarop A reageert met een bepaalde verkeersmanoeuvre die hem schade berokkent. ${ }^{123}$ In een arrest uit 1990 werd door het Hof het criterium van verkeershinder ('pertuber la circulation') geïntroduceerd. ${ }^{124}$ In een ander arrest werd voor 'implication' vereist dat het motorrijtuig een actieve rol had gespeeld. ${ }^{125}$ In 1993 oordeelde het Hof dat het slachtoffer ten bewijze van 'implication' kan volstaan met aan te tonen dat het motorrijtuig op enigerlei wijze een rol heeft gespeeld bij het ontstaan van het ongeval. ${ }^{126}$

Viney en Jourdain constateren dat in een meerderheid van de arresten geen 'implication' wordt afgeleid uit de enkele aanwezigheid van het motorrijtuig op de plaats van het ongeval of uit het enkel samengaan van de handeling van het motorrijtuig en het ongeval. Daarnaast wordt volgens hen in zijn algemeenheid 'implication' afgewezen,

122. Zie over deze rechtspraak: Sterk, Verhoogd gevaar in het aansprakelijkheidsrecht, p. 57-59 en VR, 1997, p. 199; Philppe en Meysmans, TvP, 1995, p. 422-424; Viney, L'indemnisation des victimes d'accidents de la circulation, p. 30-31; Le Toumeau et Cadiet, Droit de la responsabilité, p. 914-915; Lambert-Faivre, Droit des assurance, p. 556-558; Jourdain, Gaz. Pal., 1995, p. 9-10; Tuerlinckx, TvP, 1996, p. 25-27; Sterk, VR, 1998, p. 68.

123. Cass. 2e civ., 28 mai 1986, D. 1987, 160 (Auto A sneed auto B de weg af waardoor deze moest uitwijken en tegen een boom terechtkwam: precieze toedracht onduidelijk: 'implication' van A); Crim. civ., 21 juin 1988, Bull. crim., nr. 279 (Een automobilist wordt verblind door de koplampen van een brommer en verliest de macht over het stuur: geen andere omstandigheden vastgesteld: 'implication' van bromfietser); Cass. 2e civ., 14 december 1987, Bull. civ., II, nr. 264 (Bromfietser komt ten val tengevolge van een inhaalmanoeuvre van een vrachtwagen: geen nadere feiten: vermoeden van 'implication' van vrachtwagen). Anders: Cass. 2e civ., 8 fevrier 1989, Bull. civ., nr. 176 (Bromfiets A wordt door bromfiets B gevolgd en komt ten val, geen bewijs van tysiek contact, geen 'implication' van B).

124. Cass. 2 e civ., 3 uktubre 1990, Resp. civ. et ass., 1990, comm, 414. Dit betrof een geval waarbij een auto moest uitwijken voor een spookrijder en in de berm over de kop sloeg; een voorval dat door een getuige werd bevestigd.

125. Cass. 2 e civ., 15 janvier 1997, J.C.P., 1997.II.22883, note Chabas.

126. Cass. 2e civ., 20 januari 1993, Bull. civ., II, nr. 19 (auto rijdt achteruit en komt tot stilstand voordat hij door een voetganger wordt waargenomen. De voetganger doet bij het zien van de auto een paar stappen achteruit en komt ten val); Cass. 2e civ., 25 mai 1993, Resp. civ. et ass., 1993, comm., nr. 314 (kettingbotsing waarbij niet kon worden vastgesteld welk voertuig het slachtoffer daadwerkelijk had geraakt). 
indien het slachtoffer er niet in slaagt te bewijzen dat het motorrijtuig een bepaalde rol heeft gespeeld bij het ontstaan van het verkeersongeval. ${ }^{127}$

\subsection{DE EIGEN SCHULD ('FAUTE INEXCUSABLE') VAN HET NIET-GEMOTORISEERDE SLACHTOFFER}

Op grond van artikel $32 \mathrm{e}$ alinea van de wet Badinter, genieten fietsers, voetgangers en inzittenden beneden 16 jaar, boven 70 jaar of met minstens $80 \%$ invaliditeit, een zeer bijzondere bescherming ten aanzien van de vergoeding van hun verkeersschade. $\mathrm{Zij}$ ontvangen een automatische vergoeding, tenzij sprake was van een opzettelijke fout in de zin van artikel 3 3e alinea. Een bestuurder van een motorrijtuig is daarbij van aansprakelijkheid bevrijd, wanneer hij aantoont dat het slachtoffer de schade opzettelijk heeft veroorzaakt, bijvoorbeeld in het kader van een poging tot zelfdoding of een vrijwillige verminking. ${ }^{128}$

Ten aanzien van andere niet gemotoriseerde verkeersslachtoffers (fietsers, voetgangers en inzittenden tussen 16 en 70 jaar) geldt dat zij in beginsel een volledige vergoeding van hun personenschade ontvangen, tenzij het slachtoffer een onverschoonbare fout ('faute inexcusable') heeft begaan die tevens als de exclusieve oorzaak van het verkeersongeval kan worden aangemerkt ('si elle a été la cause exclusive de l'accident'). Wanneer het laatste ('faute inexcusable' en 'cause exclusive') wordt aangenomen, heeft dit een algeheel verval van de schadevergoedingsplicht aan de zijde van de schadeveroorzaker tot gevolg. Na de invoering van de wet Badinter bleek echter grote onduidelijkbeid te bestaan over het begrip 'faute inexcusable', mede omdat hieraan door de wetgever geen nadere uitleg was gegeven. Uit de rechtspraak van het Franse Hof van Cassatie, waarvan hier een aantal voorbeelden wordt gepresenteerd, kan echter worden opgemaakt dat een beroep op de 'faute inexcusable' van het slachtoffer tegenwoordig weinig kans van slagen meer heeft. ${ }^{129}$

127. Viney et Jourdain, Traité de droit civil, p. I127. Met een verwijzing naar Cass. 2e civ., 10 mai 1991, Bull. civ., Il, nr. 135 en 136; Cass. 2e civ., 25 mai 1994, Bull. civ., II, nr. 133; Cass. 2e civ., 8 février 1995, Bull. civ., II, nr. 43.

128. Viney et Jourdain, Traité de droit civil, p. 1149; Chabas, Gaz. Pal., 1995, p. 18-19; Chabas, Le droit des accidents de la circulation, p. 174-177; Le Toumeau et Cadiet, Droit de la responsabilité, p. 928; Viney, L'indemnisation des victimes d'accidents de la circulation, p. 4344; Lambert-Faivre, Droit des assurances, p. 592 en p. 597-598; Engelhard en Van Maanen, Aansprakelijkheid voor verkeersongevallen, p. 35; De Haas en Hartlief, Verkeersaansprakelijkheid, p. 33.

129. Zie voor een overzicht van deze rechtspraak: Viney et Jourdain, Traité de droit civil, p. 11501157; Viney, L'indemnisation des victimes d'accident de la circulation, p. 44-48; Chabas, Le droit des accidents de la circulation, p. 165-174; Le Toumeau et Cadiet, Droit de la responsabilité, p. 924-927; Lambert-Faivre, Droit des assurances, p. 592-596; Chabas, Gaz. Pal., 1995, p. 19-21; Tuerlinckx, TvP, 1996, p. 50-57; Sterk, Verhoogd gevaar in het aansprakelijk- 
In 1987 werd door het Franse Hof van Cassatie in een elftal uitspraken aan het begrip 'faute inexcusable' de volgende beperkte uitleg gegeven:

'Seule est inexcusable au sense de l'article 3, la faute volontaire d'une exceptionnelle gravité, exposant sans raison valable, son auteur à un danger dont il aurait dû avoir conscience'. ${ }^{130}$

Dit betekent dat de vrijwillige fout ('une faute volontaire') van het slachtoffer van een uitzonderlijke ernst ('d'une exceptionnelle gravité') dient te zijn, waarbij hij zich zonder een geldige reden aan een gevaar blootstelt ('exposant sans raison valable à un danger'), een gevaar waarvan hij zich tevens bewust diende te zijn ('un danger dont il aurait dû avoir consience'). ${ }^{13}$

In latere arresten werd deze beperkte uitleg van de eigen schuld van het slachtoffer door het Hof van Cassatie ten aanzien van bepaalde concrete situaties verder uitgewerkt. Voorbeelden waarbij op basis van de concrete gedragingen van het slachtoffer géén 'faute inexcusable' werd aangenomen hadden onder andere betrekking op personen die een verkeerslicht ${ }^{132}$ of een algemeen stopteken negeren, ${ }^{133}$ een éénrichtingsstraat inrijden in de verboden richting, ${ }^{134}$ een openbare weg onder gevaarlijke omstandigheden oversteken op een plaats waar dat verboden is, ${ }^{135}$ of zich anderszins onvoorzichtig gedragen op de openbare weg. ${ }^{136}$ Voorbeelden waarin wèl tot een 'faute inexcusable' van het slachtoffer werd gekomen hadden betrekking op situaties, waarin een voetganger een auto(snel)weg oversteekt, hetzij via de vangrails of de middenberm, terwijl een voetgangerstunnel of anderszins een beschermde over-

heidsrecht, p. 59-61; Engelhard en Van Maanen, Aansprakelijkheid voor verkeersongevallen, p. 36-37; De Haas en Hartlief, Verkeersaansprakelijkheid, p. 33-35; Sterk, VR, 1997, p. 200.

130. Cass. 2 e civ., 20 julliet 1987 , Bull. civ., II, nr. 160 en 161; Cass. 2 e civ., 8 janvier 1988, Bull. civ., ll, nr. 1 en 22.

131. Viney, L'indenmisation des victimes d'accident de la circulation, p. 44-45; Chabas, Le droit des accidents de la circulation, p. 169-170; Sterk, Verhoogd gevaar in het aansprakelijkheidsrecht, p. 60; Redmond-Cooper, I.C.L.Q., 1989, p. 517-518; Sterk, VR, 1997, p. 200; Notitie Verkeersaansprakelijkheid, TK, 1989-1990, 21528, nr. 2, p. 5. Zie ook Le Tourneau et Cadiet, Droit de la responsabilité, p. 924-927; Tuerlinckx, TvP, 1996, p. 52-57; Engelhard en Van Maanen, Aansprakelijkheid voor verkeersongevallen, p. 36-37 voor een uitwerking van deze criteria.

132. Cass. 2e civ., 20 avril 1988, Bull. civ., II, nr, 86; Cass. 2e civ., 16 novembre 1988, Bull. civ., II, nr. 217 arrêt nr. 2.

133. Cass. 2e civ., 24 février 1988, Bull. civ., II, nr. 48; Cass. 2e civ., 14 avril 1988, Bull. civ., II, nr. 78.

134. Cass. 2e civ., 8 novembre 1993, Bull. civ., Il, nr. 315 .

135. Onder andere Cass. 2e civ., 11 juillet 1988, Bull. civ., nr. 163; Cass. 2e civ., 29 mars 1989, Bull. civ., nr. 85; Cass. 2 e civ., 23 juin 1993, Bull. civ., nr. 218.

136. Cass. 2e civ., 12 novembre 1987, Bull. civ., II, nr. 222; Cass. 2e civ., 16 novembre 1988, Bull. civ., II, nr. 217, arret nr. 1; Cass. 2e civ., 9 janvier 1991, Bull. civ., Il, nr. 1; Cass. 2e civ., 22 janvier 1992, Bull. civ., II, nr. 22. 
steekplaats in de nabijheid aanwezig is. ${ }^{137}$ In een arrest uit 1996 werd door het Hof echter geen 'faute inexcusable' aangenomen van een aantal voetgangers dat 's nachts in de regen een autosnelweg overstak, zonder daarbij gebruik te maken van de nabij gelegen beschermde oversteekplaats. ${ }^{138}$

In 1995 bleek het Hof van Cassatie nog verder te kunnen gaan in de beperking van het beroep op een 'faute inexcusable'. Het ging hier om een dronken voetganger die 's nachts in donkere kledij gestoken midden op een drukke rijweg liep, terwijl hij een lift naar huis probeerde te krijgen. Hoewel de feitelijke omstandigheden in het nadeel van het slachtoffer waren, werd door het Hof geen 'faute inexcusable' aangenomen. ${ }^{139}$ Tunc stelt naar aanleiding van dit arrest dat in het kader van wet Badinter de uitzondering op de automatische schadevergoeding van niet-gemotoriseerde verkeersslachtoffers, namelijk een onverschoonbare fout, door deze rechtspraak is weggenomen. ${ }^{140}$

Concluderend kan worden gesteld dat, nu door het Franse Hof van Cassatie onder geen enkele omstandigheid een 'faute inexcusable' van het slachtoffer meer wordt aanvaard, ook een beroep op de 'faute inexcusable' als 'cause exclusive' veelal niet zal kunnen slagen. ${ }^{141}$ Dit geldt temeer daar zelfs een geringe fout aan de zijde van de bestuurder van het motorrijtuig ${ }^{142}$ ofwel andere omstandigheden (slecht weer, gebreken aan het voertuig of het wegdek) die aan het ontstaan van het verkeersongeval

137. Cas. 2e civ., 20 Juillet 1987, Bull. civ., Il, nr. 161; Cass. 2 e civ., 15 juin 1988, Bull. civ., Il, nr. 138, 2 arrêts; Cass. 2e civ., 7 juin 1989, Bull. civ., II, nr. 121, D. 1989, p. 559; Cass. 2e civ., 7 mars 1990, Bull. civ., Il, nr. 52; Cass. 2e civ., 13 février 1991, Bull. civ., II, nr. 50; Cass. 2e civ., 8 janvier 1992, Bull. civ., Il, nr. 1; Cass 2e civ., 23 juin 1993, Bull. civ., Il, nr. 217; Cass. 2e civ., 6 decembre 1995, Bull. civ., II, nr. 300.

138. Cass. 2e civ., 7 février 1996, Bull. civ., Il, nr. 33.

139. Cass. Ass. plen. 10 november 1995, D. 1996, p. 633; Rev. trim. dr. civ., 1996, p. 187

140. Tunc, MJ, 1996, p. 335. Hij constateert ook dat sinds dit arrest alle uitspraken van lagere rechters waarin op basis van een 'faute inexcusable' aan het slachtoffer een schadevergoeding werd onthouden in cassatie zijn vernietigd. Zie ook Viney et Jourdain, Traité de droit civil, p. 1154 1155.

141. Zie echter Cass. 2e civ., 7 juin 1989, Bull. civ., II, nr. 120/ Cass. 2e civ., 23 juin 1993, Resp. civ. et assur. comm. nr. 341/ Cass 2e civ., 6 décembre 1995, Bull. civ., II, nr. 300 (de bestuurder had zelf geen fout gemaakt); Cass. 2 e civ., 20 juillet 1987, Bull. civ., II, nr. 161/ Cass. 2 e civ., 13 février 1991, Bull. civ., II, nr. 50; Cass. Ze civ., 27 octobre 1993, Bull. civ., II, nr. 295 (het gedrag van het slachtoffer was voor de bestuurder 'imprévisible et irrésistible' geweest). Zie daarover Chabas, Gaz. Pal., 1995, p. 20-21; Viney et Jourdain, Traité de droit civil, p. 1156.

142. Cass. 2e civ., 8 octobre 1986, Bull. civ., II, nr. 136; Cass. 2 e civ., 6 avril 1987, Bull. civ., II, nr. 82; Cass. 2e civ., 4 juillet 1990, Gaz. Pal., p. 209; Cass. 2 c civ., 8 novembre 1993, Bull. civ., II, nr. 316. Zie Viney et Jourdain, Traité de droit civil, p. 1156; De Haas en Hartlief, Verkeersaansprakelijkheid, p. 34. 
hebben bijgedragen, een beroep op een 'faute inexcusable' van het slachtoffer, ook als 'cause exclusive' blokkeren. ${ }^{143}$

\subsection{HET REGRES NA DE INVOERING VAN DE 'LOI BADINTER'}

Aan het slot van deze analyse van de wet Badinter zal in deze paragraaf de positie van regresnemende verzekeraars aan de orde komen. Daarbij zal de nadruk liggen op de regresprocedure tussen de sociale verzekeraars (slachtoffer) en de aansprakelijkheidsverzekeraars (motorrijtuigbestuurder), zoals deze is vastgelegd in respectievelijk de wet Badinter en het 'Protocole d'accord'. ${ }^{144}$

In hoofdstuk II (artikel 28-34) van de wet Badinter is de algemene regeling met betrekking tot het regres bij verkeersongevallen opgenomen. Uit artikel 28 volgt dat de verhaalsmogelijkheden niet zijn beperkt tot verkeersongevallen, maar dat de artt. 2934 van toepassing zijn op alle uitkeringen die strekken tot de vergoeding van personenschade. Artikel 29 geeft vervolgens een limitatieve opsomming van de instellingen en organen aan wie een verhaalsrecht toekomt. Dit zijn de sociale verzekeringskassen ('Les Caisses de Sécurité sociale'), de Staat en publiekrechtelijke organen die als werkgever uitkeringen verstrekken. Daarnaast is een verhaalsrecht toegekend aan sociale en particuliere verzekeraars die namens een bedrijf een verplicht sociaal verzekeringssysteem beheren en op grond daarvan uitkeringen verstrekken in het kader van een schadevergoeding. Tenslotte is ook aan bepaalde andere sociale en particuliere verzekeraars, de zogenaamde 'mutuelles', een verhaalsrecht toebedeeld. Deze verzekeraars verschaffen veelal een aanvullende dekking voor medische kosten en revalidatie. $^{145}$

143. Le Tourneau et Cadiet, Droit de la responsabilite, p. 927; Engelhard en Van Maanen, Aansprakelijkheid voor verkeersongevallen, p. 35.

144. 'Le Protocole assureurs-organismes sociaux du 24 mai 1983'. Dit akkoord wordt ook wel het 'Protocol Bergeras' genoemd, naar de voorzitter van de commissie die het tot stand heeft gebracht. Zie over het 'Protocol Bergerac', alsmede een overzicht van de regrespraktijk vóór en nà de wet Badinter onder anderen: De Haas en Hartlief, Collectivering en institutionalisering van regres, p. 75-105; Lambert-Faivre, Droit des assurances, p. 651-663; Chabas, Le droit des accidents de la circulation, p. 257-305.

145. De Haas en Hartlief, Collectivering en institutionalisering van regres, p. 83-84; Chabas, Le droit des accidents de la circulation, p. 292-305; Lambert-Faivre, Droit des assurances, p. 451-452; Engelhard en Van Maanen, Aansprakelijkheid voor verkeersongevallen, p. 63-64; Perez, VR, 1986, p. 172. 


\subsubsection{De regresprocedure binnen de 'loi Badinter'}

De regresprocedure binnen de Franse verkeersaansprakelijkheid is, als gezegd, gebaseerd op twee pijlers, namelijk de artikelen 12-27 ('de l'offre d'indemnité') ${ }^{146}$ van de wet Badinter en het 'Protocol d'accord'. Het aanbod tot schadevergoeding ('l'offre d'indemnité) door de aansprakelijkheidsverzekeraars heeft tot doel een snellere afwikkeling van de verkeersschade van het slachtoffer te bereiken. Daartoe is voor de aansprakelijkheidsverzekeraar een aantal verplichtingen opgenomen, waarvan de belangrijkste is dat de verzekeraar op korte termijn een aanbod tot schadevergoeding aan het slachtoffer moet doen. Deze regeling is ook van belang voor de sociale verzekeraars, omdat daarin termijnen worden gesteld waarbinnen deze verzekeraars hun vordering bij de aansprakelijkheidsverzekeraar moeten indienen. In het 'Protocol d'accord' uit 1983 zijn afspraken opgenomen tussen aansprakelijkheidsverzekeraars en sociale verzekeraars met betrekking tot de wijze waarop het regres bij verkeersongevallen kan worden uitgeoefend. ${ }^{147}$

In het kader van 'l'offre d'indemnité' heeft het verkeersslachtoffer de plicht om aan de motorrijtuigverzekeraar alle gegevens ter beschikking te stellen die betrekking hebben op de vergoedingen die hij van de betrokken sociale verzekeraars ('les Caisses de Sécurité sociale') ontvangt. De motorrijtuigverzekeraar kan namelijk pas een aanbod tot schadevergoeding doen wanneer hij op de hoogte is van de omvang van de regresvorderingen van de sociale verzekeraar. De motorrijtuigverzekeraar heeft de plicht om aan het slachtoffer een 'notice d'information' te verstrekken. Hierin is informatie opgenomen met betrekking tot de personen die recht hebben op schadevergoeding, alsmede een overzicht van het verdere verloop van de procedure. Daarnaast dient de verzekeraar het slachtoffer de gelegenheid te geven tot inzage in het proces-verbaal van de politie en het slachtoffer erop te wijzen dat deze zich kan laten bijstaan door een advocaat. ${ }^{148}$ Ten slotte rust op de motorrijtuigverzekeraar de

146. Deze buitengerechtelijke procedure ten aanzien van het aanbod tot schadevergoeding werd eerst uitgewerkt in het 'Décret nr. 86-15 du 6 janvier 1986' aangevuld met 'l'arrêté du 20 novembre 1987', alvorens in 1988 te worden gecodificeerd in de artikelen L. 211-9 Vm L. 211-25 en R. 211-29 t/m R. 211-44 van de 'Code des assurances'. Zie Vincy, L'indemnisation des victimes d'accident de la circulation, p. 168-171 en p. 181-193; Lambert-Faivre, Droit des assurances, p. 655.

147. De Haas en Hartlief, Collectivering en institutionalisering van regres, p. 90-91; Chabas, Le droit des accidents de la circulation, p. 266-267; Viney, L'indemnisation des victimes d'accidents de la circulation, p. 113-118; Lambert-Faivre, Droit des assurances, p. 651-663; Van Maanen en Nelissen, in Verkeersaansprakelijkheid in Belgiè en Nederland, p. 208-211.

148. Artikel 13 loi Badinter: ' A l'occasion de sa première correspondance avec la victime, l'assureur est tenu, à peine de nullité relative de la transaction qui pourrait intervenir, d'informer la victime qu'elle peut obtenir de sa part, sur simple demande, la copie du procès-verbal d'enquête de police ou de gendarmerie et de lui rappeler qu'elle peut à son libre choix se faire assister d'un avocat et, en cas d'examen médical, d'un médicin'. 
plicht om aan de betrokken sociale verzekeraar melding te doen van het aanbod tot schadevergoeding aan het slachtoffer. ${ }^{149}$

De sociale verzekeraars hebben, op grond van artikel 14 , na het aanbod tot schadevergoeding van de motorrijtuigverzekeraar nog vier maanden om hun vordering bij deze verzekeraar in te dienen. ${ }^{150}$ Wanneer zij zich niet tijdig melden bij de motorrijtuigverzekeraar dan komt hun regresrecht te vervallen. Hierop zijn twee uitzonderingen mogelijk. In de eerste plaats kan de termijn van vier maanden worden verlengd, wanneer de omvang van de schade-uitkering aan het slachtoffer nog niet definitief is vastgesteld ('consolidation'), waardoor de vordering van de sociale verzekeraar een voorlopig karakter draagt. ${ }^{151}$ In de tweede plaats kan de sociale verzekeraar een verval van het regresrecht voorkomen door het indienen van een gerechtelijke vordering. ${ }^{152}$

\subsubsection{De regresprocedure volgens het 'Protocole d'Accord'}

In het kader van de regresprocedure tussen motorrijtuigverzekeraars en sociale verzekeraars is in 1983 een 'Protocole d'accord' tot stand gekomen. ${ }^{153}$ Daarin zijn afspraken opgenomen met betrekking tot de afwikkeling van het regres bij verkeersongevallen. De doelstellingen van dit 'Protocole' hebben betrekking op:

1. Een versnelling van de regresprocedure tussen de sociale verzekeraar, voor wat betreft de schade van het verkeersslachtoffer, en de aansprakelijkheidsverzekeraar van de veroorzaker van het ongeval, zijnde motorrijtuigen en fietsers;

149. Artikel 14 le alinea loi Badinter: 'Dès lors que l'assureur n'a pu, sans qu'il y ait faute de sa part, savoir que l'accident avait imposé des débours aux tiers payeurs visés aux articles 29 et 33 de la présente loi, ceux-ci perdent tout droit à remboursement contre lui et contre l'auteur du dommage. Toutefois, l'assureur ne peut invoquer une telle ignorance à l'égard des organismes versant des prestations de sécurité sociale'.

150. Artikel $142 \mathrm{e}$ alinea: 'Dans tout les cas, le défaut de production des créances des tiers payeurs, dans un délai de quatre mois à compter de la demande émanant de l'assureur, entraine déchéance de leurs droits à l'encontre de l'assureur et de l'auteur du dommage'.

151. Artikel $143 \mathrm{e}$ alinea: 'Dans le cas où la demande émanant de l'assureur ne mentionne pas la consolidation de l'état de la victime, les créances produites par les tiers payeurs peuvent avoir un caractère provisionnel'.

152. De Haas en Hartlief, Collectivering en institutionalisering van regres, p. 91-93; Viney, L'indemnisation des victimes d'accidents de la circulation, p. 117-121; Chabas, Le droit des accidents de la circulation, p. 228-230; Van Maanen en Nelissen, in Verkeersaansprakelijkheid in Belgiê en Nederland, p. 209. Zie ook Le Toumeau et Cadiet, Droit de la responsabilité, p. 930 933 en Lambert-Faivre, Droit des assurances, p. 655-663 voor een uitwerking van 'l'offre d'indemnité' in het kader van artikel L. 211-8 t/m L. 211-25 'Code des assurances'.

153. 'Protocole d'accord concemant le recouvrement des créances des organismes de protection sociale auprès des entreprises d'assurance à la suite d'accidents causés par des véhicules terrestres a moteur et par des bicyclettes'. Zie De Haas en Hartlief, Verkeersaansprakelijkheid, p. 41; Lambert-Faivre, Droit des assurances, p. 651. 
2. Een vereenvoudiging van de regresprocedure tussen sociale verzekeraars en aansprakelijkheidsverzekeraars, waardoor eventuele gerechtelijke procedures kunnen worden vermeden; en

3. Het bereiken van een snellere schadeloosstelling van het verkeersslachtoffer.

$\mathrm{Na}$ de invoering van de wet Badinter in 1986 werd dit 'Protocole', voor wat betreft de verkeersongevallen met motorrijtuigen, aangevuld met de procedure ('l'offre d'indemnité') uit hoofdstuk I, afdeling 3 (artikel 12-27) van de wet Badinter, met name ten aanzien van de daarin genoemde termijnen. ${ }^{154}$

De methode ter bespoediging van het regres tussen aansprakelijkheidsverzekeraars en sociale verzekeraars volgens het 'Protocole d'accord' heeft betrekking op een vereenvoudigde afhandeling van individuele regresdossiers volgens een vaste procedure. Het bijzondere karakter van dit 'Protocole' komt tot uiting in het gebruik van een vrij abstract baremastelsel, waarbinnen de omvang van de regresvordering wordt berekend met behulp van standaarden (baremas) ten aanzien van aansprakelijkheid, letselschade en eventueel toekomstige kosten. De procedure van het 'Protocole' heeft een geheel eigen karakter zonder dat daarbij de rechten van het verkeersslachtoffer worden aangetast. De verhouding tussen het verkeersslachtoffer en de motorrijtuigverzekeraar blijft beheerst door de wet Badinter. Daarbij geldt dat de vergoeding die het slachtoffer reeds van zijn sociale verzekeraar heeft ontvangen, in mindering zal worden gebracht op de door de aansprakelijkheidsverzekeraar uit te keren schadevergoeding.

In het kader van artikel 1 van het 'Protocole' hebben de aansprakelijkheidsverzekeraar en de sociale verzekeraar de plicht om elkaar over en weer zo spoedig mogelijk de benodigde informatie te verschaffen aangaande een individueel dossier. Daarmee kan een versnelde uitkering van de schade door de aansprakelijkheidsverzekeraar aan het verkeersslachtoffer worden bewerkstelligd en voor de sociale verzekeraar is deze informatie van belang om zijn regresrecht te kunnen uitoefenen. In het 'Protocole' worden geen termijnen genoemd waarbinnen de verzekeraars de betreffende informatie aan elkaar kenbaar dienen te maken. Bij de toepassing van de wet Badinter gelden echter de daarin genoemde termijnen en sancties (artt. 12-27).

De hoofdlijnen van het 'Protocole d'accord' zijn in zeven artikelen weergegeven en worden nader uitgewerkt in het 'Règlement d'Application Pratique' (RAP) van 1 juni 1983. Dit uitvoeringsreglement bevat een limitatieve opsomming van de feitelijke omstandigheden, de te gebruiken bewijsmiddelen en de schadeposten die de grondslag vormen voor de berekening van de regresvordering. Alle overige omstandigheden worden daarbij buiten beschouwing gelaten. Het baremastelsel wordt voortdu-

154. De Haas en Hartlief, Collectivering en institutionalisering van regres, p. 93-96. 
rend aangepast aan de ontwikkelingen op het terrein van de rechtspraak en de wetgeving. De wet Badinter heeft in dat kader geresulteerd in een verdere aanpassing en verbetering van het 'Protocole d'accord'. ${ }^{155}$

\section{De praktische werking van de wet Badinter}

Naar aanleiding van het 10-jarig bestaan van de 'loi Badinter' werd op 8 en 9 juni 1995 een congres georganiseerd. ${ }^{156}$ Tijdens dit congres werden door vertegenwoordigers uit de rechtspraktijk, verzekeringen en de wetenschap de gevolgen van de wet Badinter geëvalueerd. Het algemene oordeel over 10 jaar 'loi Badinter' was zeer positief bij zowel verzekeraars, advocaten, rechters als hoogleraren. Betoogd werd dat de schadevergoeding aan niet-gemotoriseerde verkeersslachtoffers beter is gewaarborgd. De premies voor autoverzekeringen zijn in verhouding tot de kosten van levensonderhoud niet noemenswaardig gestegen. Daarnaast is ook het aantal gerechtelijke procedures met betrekking tot verkeersongevallen na 1986 aanzienlijk gedaald. Dit was met name het gevolg van de in de wet opgenomen verplichte transactieprocedure, die vooral tot doel had om de overbelasting van de rechtelijke macht tegen te gaan. Daarnaast had ook de advocatuur alle reden om tevreden te zijn, aangezien zij zowel binnen de transactieprocedure als binnen een eventuele gerechtelijke procedure een belangrijke rol blijven spelen.

De positieve ontwikkelingen naar aanleiding van de invoering van de wet Badinter blijken ook uit statistische gegevens. Zo is het aantal verkeersongevallen sinds 1985 gedaald, zowel in verhouding tot een toename van de verkeersdichtheid als in absolute cijfers. ${ }^{157}$ Daarnaast komen op grond van de wet Badinter meer verkeersslachtoffers voor een vergoeding in aanmerking. Verder worden niet-gemotoriseerde verkeersslachtoffers binnen de wet Badinter volledig vergoed, terwijl dit voor 1985

155. De Has en Hartlief, Collectivering en institutionalisering van regres, p. 95-103; Chabas, Le droit des accident de la circulation, p. 266-267; Lambert-Faivre, Droit des assurances, p. 651654; Van Maanen en Nelissen, in Verkeersaansprakelijkheid in Belgiẽ en Nederland, p. 210-211.

156. 'Dixième anniversaire de la loi Badinter sur la protection des victimes d'accidents de la circulation; bilan et perspectives'. Een verslag van dit colloquium kan worden gevonden in Resp. civ. et ass., 1996, p. $1-48$.

157. Het aantal verkeersongevallen met letsel is volgens de statistieken tussen 1985 en 1992 met ongeveer $28 \%$ (van ruim 191.000 in 1985 naar ruim 143.000 in 1992) gedaald, terwijl het aantal auto's met bijna 14\% toenam (van ruim 21 miljoen in 1985 naar ruim 24 miljoen in 1992). In 1992 bedroeg echter het aantal verkeersdoden per 1 miljoen inwoners in Frankrijk 157, terwijl dit aantal in bijwoorbeeld Nederland 'slechts' 85 was. Zie Statistics of Road Traffic Accidents in Europe and North America, 1995, p. 7 en p. 106-108. Deze statistische cijfers zeggen uiteraard weinig over de invloed van de 'loi Badinter' op het aantal verkeersongevallen. Volgens Tunc, MJ, 1996, p. 337, staat de daling van het aantal verkeersongevallen niet in direct verband met de hervorming van de verkeersaansprakelijkheid in Frankrijk. 
veelal niet het geval was. ${ }^{158}$ Bestuurders van een motorrijtuig profiteren minder van de bescherming van de wet Badinter. $\mathrm{Na}$ invoering van de wet Badinter ontvangt een kleine meerderheid (58\%) van het aantal bestuurders dat slachtoffer wordt van een verkeersongeval een schade-uitkering. ${ }^{159}$ Dit betekent dat de positie van een slachtoffer-bestuurder na de invoering van de 'loi Badinter' nog niet optimaal is. ${ }^{160}$ Weliswaar heeft de PACS-verzekering tot een verbetering van de vergoeding van de personenschade van een slachtoffer-bestuurder geleid, toch blijkt uit schattingen dat slechts $50 \%$ van de bestuurders een dergelijke verzekering heeft afgesloten. ${ }^{161}$

Naast een verbeterde schadevergoeding werd met de 'loi Badinter' ook een versnelde afwikkeling van de schade aan verkeersslachtoffers beoogd. Uit onderzoek blijkt echter dat de termijn waarbinnen verkeersslachtoffers worden gecompenseerd nauwelijks korter is geworden. Vóór 1986 duurde het 21 maanden vanaf het ontstaan van het ongeval voordat een schikking tussen de verzekeraar en het slachtoffer tot stand kwam. Na de invoering van de wet Badinter bedroeg deze periode nog steeds 20 maanden. Bij een gerechtelijke procedure tussen de verzekeraar en het slachtoffer steeg de periode waarbinnen een schikking tot stand kwam zelfs van 31 maanden naar 40 maanden. Daar tegenover staat dat het aantal zaken dat voor de rechter wordt gebracht is gedaald van ongeveer $27 \%$ vóor 1986 tot gemiddeld $10 \%$ in de periode erna. ${ }^{102}$

158. Tunc, MJ, 1996, p. 338-339, wijst er op dat de schadevergoeding naar aanleiding van een gerechtelijke procedure veelal hoger uitvalt dan bij een transactie tussen het verkecrsslachtoffer en de aansprakelijkheidsverzekeraar. Dit wordt veroorzaakt doordat de tabellen, waaruit gegevens omtrent de schadevergoeding kunnen worden afgeleid, nog niet voldoende zijn ontwikkeld. Volgens Tunc is dit echter wel nodig om het risico op een onrechtvaardige transactie te verminderen. Zie ook Neher Schraub, Resp. civ. et ass., 1996, p. 14-15; Lambert-Faivre, Resp. civ. et ass., 1996, p. 19-20.

159. Tunc, MJ, 1996, p. 337.

160. Volgens de statistieken vormen de bestuurders van een motorrijtuig nog altijd een meerderheid in het aantal dodelijke verkeersslachtoffers, namelijk $59,4 \%$ in 1992 ten opzichte van de fietsers, voetgangers en passagiers gezamenlijk $40,6 \%$. Zie Statistics of Road Traffic Accidents In Europe and North America, 1995, p. 65.

161. Zie De Haas en Hartlief, Verkeersaansprakelijkheid, p. 60; Frederica, in Een Salomons oordeel, p. 52-53. Zie ook Viney et Jourdain, Traité de droit civil, p. 1188-1190, voọr een analyse van de knelpunten van de 'loi Badinter', met name ten aanzien van de positie van de bestuurder.

162. Badinter, Resp. civ. et ass., 1996, p. 2-3, stelt dat het aantal zaken dat voor de rechtbank en het hof van beroep wordt gebracht met respectievelijk $33,7 \%$ en $30,7 \%$ is gedaald. Fédération Francaise des Sociétés d'Assurance (FFSA): Les entretiens de l'assurance, 1995, Atelier 17: Indemnisation transactionnelle ou indemnisation judiciaire? in Tunc, MJ, 1996, p. 338. Zie ook Neher Schraub, Resp. civ. et ass., 1996, p. 14-15. De Haas en Hartlief, Collectivering en institutionalisering van regres, p. 92-93, stellen dat het aantal buitengerechtelijke schikkingen na de invoring van de wet Badinter met $5 \%$ is toegenomen tot $80 \%$, terwijl de schade gemiddeld 2 tot 3 maanden sneller wordt uitgekeerd. 


\section{Conclusie}

Met de invoering van de 'loi Badinter' en de naar aanleiding hiervan ontwikkelde jurisprudentie is in Frankrijk na ruim 13 jaar een redelijk functionerend systeem tot stand gekomen. Met name ten aanzien van de niet-gemotoriseerde verkeersslachtoffers heeft dit stelsel de vorm van een quasi-automatische schadevergoeding gekregen. Een beroep op overmacht of de schuld van een derde was voor de bestuurder al uitgesloten op basis van artikel 2 van de 'loi Badinter'. Daarnaast is de eigen schuld ('faute inexcusable') van het slachtoffer (16-70 jaar) door het Franse Hof van Cassatie dermate beperkt uitgelegd, dat daarop door de bestuurder bijna geen beroep meer kan worden gedaan. Dit betekent dat waar bij de invoering van de 'loi Badinter' aanvankelijk sprake was van een risicoaansprakelijkheid met een eigen schuldverweer, deze grondslag zich in de jurisprudentie heeft ontwikkeld tot een bijna absolute aansprakelijkheid voor de bestuurder of houder van een motorrijtuig. Weliswaar is hiermee de vergoeding van niet-gemotoriseerde verkeersslachtoffers verbeterd, toch blijkt dat de schade, ondanks de verplichte transactieprocedure, niet veel sneller wordt uitgekeerd.

De bestuurder van een motorrijtuig blijft na de invoering van de 'loi Badinter' voor de vergoeding van zijn schade aangewezen op een regel van foutaansprakelijkheid. Hierbij wordt voor de eigen 'faute' van een slachtoffer-bestuurder een objectief criterium gehanteerd, waardoor hij niet geheel van een schadevergoeding verstoken blijft. Daarnaast heeft de eerste partij PACS-verzekering aan een verbetering van de schadeloosstelling van een slachtoffer-bestuurder bijgedragen, hoewel de verzekeringsdichtheid met ongeveer $50 \%$ niet hoog is.

Naast de rol van niet-gemotoriseerde verkeersslachtoffers en de bestuurders is in het kader van de 'loi Badinter' ook de positie van de regresnemende instanties, die de schade in een eerste fase aan het slachtoffer uitkeren, van belang. Met betrekking tot de regresprocedure is voor hen naast de 'loi Badinter' (l'offre d'indemnité') ook het tussen sociale- en motorrijtuigverzekeraars gesloten 'Protocole d'Accord' (aangepast aan de termijnen van de 'loi Badinter') van toepassing. Dit betekent dat de motorrijtuigverzekeraars zowel te maken hebben met het verkeersslachtoffer zelf, wiens schadevergoeding is gebaseerd op de bijna absolute aansprakelijkheid van de 'loi Badinter', als met de regresnemende instanties in het kader van het 'Protocole d'Accord'. De laatste regeling is gebaseerd op een abstract baremastelsel, waarbinnen de omvang van de schadevergoeding wordt berekend aan de hand van standaarden ten aanzien van aansprakelijkheid, letselschade en eventuele kosten.

Uit het voorgaande kan worden opgemaakt dat binnen de verkeersaansprakelijkheid in Frankrijk nog altijd verschillende systemen voor de vergoeding van verkeersschade van toepassing zijn, waarbij een onderscheid geldt in aansprakelijkheidsregels en in vergoedingsmechanismen. Dit doet de vraag rijzen of niet een stroomlijning mo- 
gelijk is door bijvoorbeeld de invoering van een verkeersverzekering, waarbij onder afschaffing van de aansprakelijkheid de schade automatisch aan het verkeersslachtoffer wordt uitgekeerd.

Tunc wijst in een recent artikel nogmaals op de voordelen van een dergelijke eerste partij verzekering. Wanneer de inzittenden, bestuurders en passagiers, van een motorrijtuig voor de geleden schade een beroep doen op hun eigen verzekeraar, kan een besparing op de administratieve kosten worden bereikt. Daarnaast kan volgens Tunc met een verkeersverzekering een verbetering optreden in de relatie tussen slachtoffers een verzekeraars. Een verkeersverzekering blijft echter een derde partij karakter dragen voor de schade van de fietser en voetganger. ${ }^{163}$

Mede naar aanleiding van het eerder genoemde congres in 1995 wordt door Tunc geconcludeerd dat de 'loi Badinter' functioneel goed werkt. Hij constateert ook dat de invoering van een verkeersverzekering voor alle verkeersslachtoffers, inclusief bestuurders, op termijn mogelijk moet zijn. Volgens Tunc zijn hiervoor zowel binnen de rechtswetenschap als binnen de verzekeringswereld steeds meer aanhangers te vinden. De vraag die met name door verzekeraars wordt gesteld is of voor een algehele verkeersverzekering nieuwe wetgeving nodig is ('Loi Badinter II'), of dat met een quasi-verplichte eerste partij verzekeringsdekking (PACS) kan worden volstaan. Het probleem bij de uitvoering van beide voorstellen blijft volgens Tunc echter het grote aantal verkeersdoden en verkeersgewonden onder bestuurders van motoren en bromfietsen. ${ }^{164}$

163. Tunc, MJ, 1996, p. 339-340; Tunc, in Towards a European Civil Code, p. 461-471. Zie hoofdstuk 15 voor een toetsing van de Franse verkeersaansprakelijkheid aan de uitkomsten van de rechtseconomische theorie en het empirisch onderzoek.

164. Zie Tunc, MJ, 1996, p. 339; Bancel, Resp. civ. et ass., 1996, p. 22-23. 



\section{Hoofdstuk 2: De Belgische verkeersaansprakelijkheid}

\section{Inleiding}

Van belang bij de analyse van de Belgische verkeersaansprakelijkheid is de wet van 30 maart 1994 die op 1 januari 1995 in werking trad. ${ }^{165}$ Deze regeling bleek echter een aantal tekortkomingen te bevatten en werd daarom geheel gewijzigd in de wet van 13 april 1995 die op 1 juli 1995 van kracht is geworden. ${ }^{166}$ Deze wet die veelal verkort wordt omschreven als 'artikel 29 bis WAM-regeling', omvat de vergoeding van bepaalde slachtoffers van verkeersongevallen, in het bijzonder de zogenaamde zwakke verkeersdeelnemers, zijnde fietsers, voetgangers en passagiers. De aansprakelijkheid voor de schade van het slachtoffer rust op de aansprakelijkheidsverzekeraar van de bestuurder of houder van het betrokken motorrijtuig.

In dit hoofdstuk staat de Belgische verkeersaansprakelijkheid centraal. In paragraaf 2 zal aan de hand van een aantal juridische begrippen de situatie vóór de wetswijziging worden beschreven, waarna in paragraaf 3 een weergave volgt van de ontstaansgeschiedenis van artikel $29 \mathrm{bis}$ WAM-regeling. In paragraaf $4 \mathrm{zal}$ een analyse van de meest recente Belgische regeling (wet van 13 april 1995) worden gepresenteerd. Daarin zal tevens aandacht worden besteed aan de praktische werking van artikel $29 \mathrm{bis}$, onder andere met een verwijzing naar een aantal rechterlijke uitspraken. In paragraaf 5 zal worden ingegaan op de discussie die in de Belgische literatuur wordt gevoerd ten aanzien van de juridische grondslag van artikel 29 bis WAMregeling. Dit hoofdstuk zal in paragraaf 6 worden afgesloten met een aantal concluderende opmerkingen.

\section{De Belgische verkeersaansprakelijkheid tot 1995}

In België werd tot 1995 de vaststelling van de aansprakelijkheid en de schadevergoeding naar aanleiding van een verkeersongeval geregeld door het gemene recht, in het bijzonder via artikel 1382 van het Burgerlijk Wetboek. ${ }^{167}$ Dit hield in dat een verkeersslachtoffer de veroorzaker van de schade diende aan te spreken op grond

165. Wet van 30 maart 1994 houdende sociale bepalingen, waarbij in de wet van 21 november 1989 betreffende de verplichte aansprakelijkheidsverzekering inzake motorrijtuigen cen nieuw hoofdstuk Vbis werd ingevoegd met als titel 'Vergoeding van bepaalde slachtoffers van verkeersongevallen' (artikel 29bis en 29ter). Belgisch Staatsblad 31 maart 1994. Zie daarover Claassens en Van Schoubroeck, VR, 1997, p. 359; De Haas en Hartlief, Verkeersaansprakelijkheid, p. 66-67; Engelhard en Van Maanen, Aansprakelijkheid voor verkeersongevallen, p. 23.

166. Belgisch Staatsblad, 27 juni 1995. Zie Claassens en Van Schoubroeck, VR, 1997, p. 359; De Haas en Hartlief, Verkeersaansprakelijkheid, p. 67.

167. Artikel 1382 BW luidt: 'Elke daad van de mens, waardoor aan een ander schade wordt veroorzaakt, verplicht degene door wiens schuld de schade is ontstaan, deze te vergoeden'. 
van een onrechtmatige daad. Op het slachtoffer rustte de bewijslast dat de veroorzaker schuld (onder andere onvoorzichtigheid of nalatigheid) had aan het verkeersongeval, waarbij tevens een causaal verband tussen de fout en de schade moest worden aangetoond. Het enkele feit dat door een bepaald risico, bijvoorbeeld autorijden schade werd veroorzaakt, een aanrijding, leverde daarbij nog geen bewijs van een fout op. Aan de schadeveroorzaker stond verder een beroep op overmacht open, terwijl de eigen schuld van het slachtoffer kon leiden tot een overeenkomstige vermindering van de schadevergoeding. De foutaansprakelijkheid van artikel $1382 \mathrm{BW}$ blijft naar huidig recht van toepassing op de gevallen die niet door artikel $29 \mathrm{bis}$ WAM-regeling worden geregeld. ${ }^{168}$

Naast artikel 1382 BW kon vóór 1995 door het verkeersslachtoffer ook een beroep worden gedaan op artikel $1384 \mathrm{BW}$ lid 1, waarin de aansprakelijkheid voor (gebrekkige) zaken is geregeld. Ingevolge dit artikel is een persoon ook aansprakelijk voor de schade die wordt veroorzaakt door zaken die hij onder zijn bewaring heeft. Het slachtoffer behoeft daarbij geen fout van de bewaarder te bewijzen, maar kan volstaan met het aantonen van een gebrek van de zaak (motorrijtuig). ${ }^{169}$

In deze paragraaf zal een aantal elementen van de foutaansprakelijkheid en aansprakelijkheid voor zaken, toegepast op verkeersongevallen, nader worden bestudeerd. Het gaat daarbij in het bijzonder om de begrippen overmacht, de eigen schuld van het slachtoffer en het gebrek van de zaak. Aan de hand van voorbeelden uit de rechtspraak zal een overzicht worden geschetst van de uitleg die door de Belgische rechter aan deze begrippen is gegeven. ${ }^{170}$

\subsection{DE FOUTAANSPRAKELIJKHEID VAN ARTIKEL 1382 BW: ALGEMEEN}

De grondslag van de aansprakelijkheid van artikel $1382 \mathrm{BW}$ wordt gevonden in het foutbegrip. Dit omvat een objectief element, het onrechtmatig handelen, alsmede een subjectief element, de toerekenbaarheid (schuld) van de onrechtmatige daad aan de dader. ${ }^{171}$

168. Zie daarover verderop in paragraaf 4.7.

169. Schuermans en Simoens, TvP, 1978, p. 1087. Dit in tegenstelling tot het Franse recht, waar in het Jand'heur arrest op grond van artikel 1384 lid I C.c. een vermoeden van aansprakelijkheid werd aangenomen voor de houder van de zaak. Zie paragraaf 2 van hoofdstuk 1 .

170. Zie voor een overzicht van de Belgische rechtspraak over de onrechtmatige daad in het bijzonder ook ten aanzien van verkeersongevallen: VandenBerghe, Van Quickenbome en Hamelink, TvP, 1980, p. 1139-1475; VandenBerghe, Van Quickenbome, Geelen, en Decoster, TvP, 1987, p. 1255-1615; VandenBerghe, Van Quickenbome en Wynant, TvP, 1995, p. 1115-1534.

171. VandenBerghe, Van Quickenbome en Hamelink, TvP, 1980, p. 1146-1147; VandenBerghe, Van Quickenborne, Geelen en Decoster, TvP, 1987, p. 1263-1264; VandenBerghe, Van Quicken- 
De overtreding van een bepaalde wettelijke norm, bijvoorbeeld een verkeersregel, kan veelal voldoende zijn voor het aannemen van aansprakelijkheid mits de overtreding bewust is begaan. Het slachtoffer behoeft in deze gevallen enkel de overtreding van de betreffende norm aan te tonen. ${ }^{172}$ Het naleven van de verkeersregels leidt echter nog niet tot een bevrijding van de aansprakelijkheid, wanneer bepaalde gedragingen die daarmee verband houden schade veroorzaken. ${ }^{173}$

Naast de naleving van een specifiek omschreven norm wordt door artikel $1382 \mathrm{BW}$ mede de uitoefening van een algehele zorgvuldigheid vereist. Het gedrag wordt in dat kader door de rechter getoetst aan de algemene zorgvuldigheid. Deze zorgvuldigheid binnen het maatschappelijk verkeer verwijst volgens Schuermans en Simoens naar:

'het geheel van regels van het maatschappelijk leven, de moraal de gebruiken, de techniek, die niet zijn geformuleerd in wetteksten. Het beoordelingscriterium is dat van de bonus pater familias, van de normale zorgvuldige en voorzichtige persoon die zich in dezelfde omstandigheden bevindt. ${ }^{174}$

Een onderdeel van dit abstracte criterium wordt gevormd door de vraag of de schade voorzienbaar had moeten zijn. Hierbij wordt voor de beoordeling van de aansprakelijkheid het concrete gedrag van de schadeveroorzaker getoetst aan de zorgvuldigheidsnorm, gelet op de feitelijke omstandigheden van het geval. Daarnaast wordt rekening gehouden met het gegeven dat de schade weliswaar voorzienbaar was, maar dat de dader heeft nagelaten om, ter vermijding van de schade, in de concrete omstandigheden de vereiste zorg in acht te nemen.

Een bestuurder van een motorrijtuig, die in druk stadsverkeer, zonder zijn snelheid aan te passen, onvoldoende afstand bewaart tot zijn voorganger, moet bijvoorbeeld kunnen voorzien dat deze laatste plotseling remt doordat een derde voertuig afwij-

bome en Wymant, TvP, 1995, p. 1122-1123. Zie ook VandenBerghe, TvP, 1984, p. 127-145; De Haas en Hartlief, Verkeersalansprakelijkheid, p. 63-66.

172. Een bestuurder overtreedt bijvoorbeeld artikel 31 van de Wegcode wanneer hij bij dichte mist in het donker zijn motorrijtuig onverlicht achterlaat, Rb. Antwerpen, 25 september 1990, VKJ, 1991, 63. VandenBerghe, Van Quickenbome en Wynant, TvP, 1995, p. 1155-1157. Zie ook VandenBerghe, Van Quickenborne, Geelen en Decoster, TvP, 1987, p. 1273-1274.

173. Een besturder die bij groen licht een kruising oprijdt dient rekening te blijven houden met zijn medeweggebruikers of andere voorzienbare obstakels, Brussel, 2 juni 1989, R.G.A.R., 1990, nr. 11675 in VandenBerghe, Van Quickenbome en Wynant, TvP, 1995, p. 1171. Zie ook VandenBerghe, Van Quickenbome en Hamelink, TvP, 1980, p. 1154-1155.

174. Schuermans en Simoens, TvP, 1978, p. 1086 met verwijzing naar onder andere Cass., 30 april 1976, Arr. Cass., 1976, 980, R.W., 1976-1977, alsmede naar R.O. Dalcq, Traité de la responsabilité civile, I, Brussel 1967, nr. 262 en 266. Zie ook VandenBerghe, Van Quickenbome en Wynant, TvP, 1995, p. 1172-1173; Cornelis, RW, 1998-1999, p. 522-523. 
kend rijgedrag vertoont. ${ }^{175}$ Een bestuurder van een motorrijtuig moet voorzien dat het roken van pijp tijdens het autorijdende kans op ongevallen verhoogt. ${ }^{176}$ Een bestuurder die met matige snelheid rijdt en een bijzondere voorzichtigheid aan de dag legt is echter niet aansprakelijk, wanneer een kind van 5 jaar dat ten tijde van het ongeval voor de bestuurder niet zichtbaar was, onverwachts de straat oversteekt. ${ }^{177}$

Bij de beoordeling van het gedrag van de bestuurder wordt ook rekening gehouden met externe omstandigheden zoals tijd, plaats en klimaat. ${ }^{178}$ Wanneer bijvoorbeeld ijzel voorzienbaar is, moet een bestuurder daar rekening mee houden. ${ }^{179}$ De bestuurder die een schooluitgang of een zebrapad nadert moet zijn snelheid aanpassen zodat hij tijdig kan stoppen. ${ }^{180}$

Voor de bepaling van het causaal verband tussen de fout en de schade wordt door de Belgische rechtspraak de zogenaamde 'equivalentieleer', zij het met enige beperkingen, toegepast. Deze leer, waarbij alle oorzaken van de schade als gelijkwaardig worden beschouwd, houdt globaal in dat de onrechtmatige daad 'noodzakelijkerwijs' tot schade heeft geleid. Dit is veelal het geval wanneer bij afwezigheid van de fout, de schade zoals deze zich concreet heeft voorgedaan, niet zou zijn ontstaan. ${ }^{181}$

\subsection{OVERMACHT IN HET VERKEER}

De onrechtmatige gedragingen die het gevolg zijn van de aanwezigheid van een onvoorzienbare gebeurtenis of een rechtvaardigingsgrond, zoals een noodsituatie, kunnen overmacht opleveren. Daarbij geldt dat de overmachtssituatie niet door het onzorgvuldige gedrag zelf in het leven is geroepen of dat een actieve bijdrage is gele-

175. Brussel, 24 februari 1990, R.G.A.R., 1991, nr. 11827.

176. Brussel, 15 december 1988 geciteerd in VandenBerghe, Van Quickenborne en Wynant, TvP, 1995, p. 1175-1176, alsmede p. 1178-1181 voor andere voorbeelden uit de rechtspraak. Zie ook VandenBerghe, Van Quickenbome, Geelen en Decoster, TvP, 1987, p. 1283-1287.

177. Brussel, 26 maart 1992, De Verz., 1992, 753, in VandenBerghe, Van Quickenborne en Wynant, TvP, 1995, p. 1181-1186.

178. VandenBerghe, Van Quickenborne en Wynant, TvP, 1995, p. 1186-1187.

179. Brussel, 19 maart 1986, R.G.A.R., 1987, nr. 11306.

180. Brussel, 15 december 1989, R.G.A.R., 1991, nr. 11828 in VandenBerghe, Van Quickenborne en Wynant, TvP, 1995, p. 1204-1208. Zie ten aanzien van de voorzienbaarheid eveneens: VandenBerghe, Van Quickenbome, Geelen en Decoster, TvP, 1987, p. 1283-1311; VandenBerghe, Van Quickenbome en Hamelink, TvP, 1980, p. 1155-1170.

181. Schuermans en Simoens, TvP, 1978, p. 1088 met een verwijzing naar onder andere Cass., 19 maart 1976, Arr. Cass., 1976, 847 en Cass., 30 oktober 1973, Arr. Cass., 1974, 250; Storme, VR, 1990, p. 225-228; De Haas en Hartlief, Verkeersaansprakelijkheid, p. 74-75. Zie ook VandenBerghe, Van Quickenbome en Wynant, TvP, 1995, p. 1451-1469; VandenBerghe, Van Quickenborne, Geelen en Decoster, TvP, 1987, p. 1515-1534; VandenBerghe, Van Quickenbome en Hamelink, TvP, 1980, p. 1347-1386, voor een analyse van de equivalentieleer met een bespreking van de rechtspraak waarin deze leer al dan niet letterlijk wordt toegepast. 
verd aan het ontstaan daarvan. Binnen de overmachtssituatie dient verder op dezelfde wijze te zijn gehandeld als van een zorgvuldig persoon in dezelfde omstandigheden kan worden verwacht. Indien de schade werd veroorzaakt door toeval, overmacht, fout van het slachtoffer of de daad van een derde, is er sprake van een 'vreemde oorzaak'. Wanneer het gedrag van de veroorzaker tot de schade heeft geleid, kan deze zich slechts bevrijden door een beroep op een rechtvaardigingsgrond (noodtoestand) en niet op het bestaan van een 'vreemde oorzaak'. Elke externe omstandigheid kan overmacht opleveren, mits deze omstandigheid voor de schadeveroorzaker onvoorzienbaar en onvermijdbaar is. ${ }^{182}$

Met betrekking tot een beroep op overmacht in verkeerssituaties wordt veelal geoordeeld over de vraag of bepaalde ongunstige weersomstandigheden, zoals strenge vorst, een zware storm of ijzel, in het concrete geval een onvoorzienbare gebeurtenis opleveren. ${ }^{183}$ Een plaatselijke, onverwachte en beperkte ijzelplek kan een beroep op overmacht door de bestuurder rechtvaardigen. Een hevige storm die eens in de paar jaar voorkomt is daarentegen niet als uitzonderlijk te beschouwen en daardoor niet onvoorzienbaar, zodat een beroep op overmacht in deze gevallen veelal is uitgesloten. $^{184}$

Naast een onvoorzienbare gebeurtenis kunnen zich ook gevallen voordoen die een inbreuk op een bepaalde zorgvuldigheidsnorm rechtvaardigen omdat zij niet alleen onvermijdbaar zijn maar in de gegeven omstandigheden ook toelaatbaar. Van een dergelijke noodsituatie kan sprake zijn indien de veroorzaker ten aanzien van een bepaald gevaar geen andere mogelijkheid heeft dan een onzorgvuldige handeling te verrichten ten behoeve van het veiligstellen van een ander, hoger, 'maatschappelijk' belang. In het verkeer kan zich een noodsituatie voordoen wanneer door een autobestuurder een uitwijkmanoeuvre moet worden uitgevoerd om een ongeval te voorkomen. ${ }^{185}$ Het mislukken van een dergelijke manoeuvre levert daarbij pas aansprake-

182. VandenBerghe, Van Quickenborne en Wynant, TvP, 1995, p. 1264-1267; Storme, VR, 1990, p. 228; Bocken, TvP, 1984, p. 332-333 en p. 342.

183. VandenBerghe, Van Quickenbome en Wynant, TvP, 1995, p. 1267 met een verwijzing naar Cass., 13 mei 1982; Arr. Cass. 1981-1982, 1134, J.T., 1982, 712.

184. VandenBerghe, Van Quickenbome en Wynant, TvP, 1995, p. 1268 met een verwijzing naar: Luik, 31 oktober 1990, J.T., 1991, 66; Rb. Nijvel, 21 november 1985, R.G.A.R., 1987, nr.11; Rb. Brussel, 5 mei 1987, R.G.A.R., 1988, nr. 11; Brussel, 6 november 1987, VKJ, 1988, 236, waarin een fietser bij het rechts afslaan onverwacht ten val kwam op het moment dat een auto hem dicht was genaderd. De rechter oordeelde dat sprake was van overmacht voor de autobestuurder aangezien deze situatie hem volkomen verraste en derhalve onvoorzienbaar was.

185. Brussel, 22 juni 1987, VKJ, 1988, 66: 'Een onvermijdelijke uitwijkmanoeuvre die overeenstemt met de reactie die ieder normaal en voorzichtig bestuurder in dezelfde omstandigheden zou hebben gehad, leidt niet tot aansprakelijkheid, zelfs indien achteraf en uit een grondig onderzoek zou blijken dat de aard en de hevigheid van de reactie niet optimaal was', 
lijkheid op wanneer de uitvoering ervan onrechtmatig is geweest, niet wanneer deze slechts onhandig of gevaarlijk was. ${ }^{186}$

Ten slotte is in het kader van overmacht de vraag van belang of een lichamelijk gebrek van de bestuurder ('malaise aan het stuur') als een rechtvaardigingsgrond kan worden beschouwd. In de Belgische rechtspraak geldt dat een bestuurder die plotseling onwel wordt en een verkeersongeval veroorzaakt, slechts van aansprakelijkheid is bevrijd wanneer hij voldoet aan de overmachtscriteria van onvoorzienbaarheid en zorgvuldigheid. Een bestuurder die eerder een hartaanval heeft gehad en blijvende hartproblemen heeft, waarvoor hij nog regelmatig wordt behandeld, neemt echter een 'onverantwoord risico' door toch aan het verkeer te blijven deelnemen. Hij moet voorzien dat hij tengevolge van een nieuwe hartaanval een verkeersongeval kan veroorzaken, waardoor voor hem geen beroep op overmacht openstaat. ${ }^{187}$

\subsection{VERKEERSONGEVALLEN EN DE 'MEDEAANSPRAKELUJKHEID' VAN HET SLACHTOFFER}

\subsubsection{Algemeen: risicoaanvaarding}

Wanneer in het kader van artikel $1382 \mathrm{BW}$ de schade mede wordt veroorzaakt door het slachtoffer dan volgt een verdeling van de schade tussen de dader en het slachtoffer waardoor de laatste geen volledige schadevergoeding ontvangt. In de Belgische rechtspraak wordt deze regel eveneens toegepast wanneer de fout van het slachtoffer vrij licht is in verhouding tot de fout van de bij het ongeval betrokken dader. ${ }^{188}$

In de Belgische rechtspraak en literatuur is de fout van het slachtoffer, met name in verkeerssituaties, voor een belangrijk deel vervat in het leerstuk van de risicoaanvaarding. ${ }^{189}$ Daarbij wordt het standpunt ingenomen dat de risicoaanvaarding van

186. Bergen, 12 maart 1991, VKJ, 1992, 33; Brussel, 22 juni 1987, VKJ, 1988, 159 in VandenBerghe, Van Quickenbome en Wynant, TvP, 1995, p. 1269-1271.

187. In die zin: Gent, 25 februari 1986, T.G.R., 1986, 64; Brussel, 2 oktober 1990, R.G.A.R., 1993, nr. 12179; Brussel 21 april 1986, RW, 1987-1988, 922 in VandenBerghe, Van Quickenborne en Wynant, TvP, 1995, p. 1277-1278. Zie ten aanzien van overmacht ook VandenBerghe, Van Quickenborne, Geelen en Decoster, TvP, 1987, p. 1357-1369; VandenBerghe, Van Quickenbome en Hamelink, TvP, 1980, p. 1203-1212.

188. Cass., 28 september 1989, Arr. Cass., 1989-90, 130 in VandenBerghe, Van Quickenborne en Wynant, TvP, 1995, p. 1481. Anders: Cass., 16 februari 1970, Pas., 1970, 529 in Simoens, RW, 1980-1981, p. 1983, waarin de onvoorzichtigheid van de voetganger niet opwoog tegen de latente onrechtmatigheid, het zonder verlichting met hoge snelheid rijden, van de bestuurder van de motor.

189. In Belgiê is de rechtspraak tot de invoering van artikel 29bis WAM-wet in 1995 het leerstuk van risico-aanvaarding blijven toepassen om te bepalen in hoeverre een persoon, die een bewust risico heeft genomen, in aanmerking kan komen voor schadevergoeding. Zie over de discussie 
het slachtoffer een toepassing is van artikel $1382 \mathrm{BW}$ ten aanzien van gevaarlijke situaties en dus niet als een zelfstandige rechtsfiguur kan worden beschouwd. Risicoaanvaarding wijst derhalve op een onrechtmatige daad (fout) van het slachtoffer, hetgeen een gehele of gedeeltelijke aansprakelijkheid van het slachtoffer voor zijn eigen schade tot gevolg kan hebben. Aangetoond moet worden dat het slachtoffer nagelaten heeft de nodige voorzorgsmaatregelen te treffen om zijn schade te vermijden. Slechts bij vastgestelde overtreding van de zorgvuldigheidsnorm kan het slachtoffer (mede) aansprakelijk worden gesteld. ${ }^{190}$

De theorie van de risicoaanvaarding heeft vooral ten aanzien van verkeersongevallen aanleiding gegeven tot een stroom van rechtspraak, waarvan de uitkomsten niet altijd even billijk genoemd kunnen worden. In deze rechtspraak werd vooral aan passagiers van een motorrijtuig de aanvaarding van een risico verweten met het gevolg dat zij een deel van hun schade zelf moesten dragen. Dit is bijvoorbeeld het geval met de passagier die aanvaardt mee te rijden met een persoon waarvan hij weet of moet weten dat deze, door overmatig drankgebruik, niet meer in staat moet worden geacht om op een veilige wijze een voertuig te besturen. ${ }^{191}$ Het verzuim van de passagier om de veiligheidsgordel te dragen kan ook leiden tot een vermindering van de schadevergoeding. De rechters houden hierbij overigens wel rekening met de vraag of het niet-dragen van de veiligheidsgordel heeft geleid tot een verzwaring van de ongevalsschade. ${ }^{192}$ Tenslotte leidt ook het meerijden met een bestuurder die op grond van zijn leeftijd nog geen motorrijtuig mag besturen tot risicoaanvaarding met een vermindering van de schadevergoeding voor de passagier, voor zover deze daarvan op de hoogte diende te zijn. ${ }^{193}$

ten aanzien van risicoaanvaarding meer uitvoerig: VandenBerghe, Van Quickenborne en Wynant, TvP, 1995, p. 1242-1252.

190. Zie daarovet VandenBerghe, Van Quickenborne en Wynant, TvP, 1995, p. 1242-1253 en p. 1262-1264.

191. Zie onder andere: Brussel, 6 mei 1992, De Verz., 1993, 44; Corr. Gent, 10 februari 1984, De Verz., 1986, 441. In VandenBerghe, Van Quickenbome en Wynant, TvP, 1995, p. 1482-1483 worden meer voorbeelden uit de rechtspraak geciteerd. Daaruit blijkt dat de passagier veelal $33 \%$, 50\%, maar in sommige gevallen ook $100 \%$ van zijn schade zelf dient te dragen.

192. Zie onder andere: Brussel, 24 april 1987, De Verz., 1988, 518; Antwerpen, 12 april 1990, VKJ, 1990, 263 in VandenBerghe, Van Quickenbome en Wynant, TvP, 1995, p. 1483. Uit de daarin geciteerde rechtspraak blijkt dat het niet-dragen van een veiligheidsgordel door de passagier leidt tot een vermindering van de schadevergoeding met $25 \%, 33 \%, 50 \%$ en soms ook $100 \%$.

193. Onder andere, Gent, 24 december 1982, RW, 1986-87, 1094; Bergen, 14 mei 1992, De Verz., 1992, 769 in VandenBerghe, Van Quickenborne en Wynant, TvP, 1995, p. 1483-1484, Uit de daarin geciteerde rechtspraak blijkt dat het meerijden met een bestuurder die niet de vereiste leeftijd heeft bereikt tot een vermindering van de schadevergoeding met $25 \%-50 \%$ kan leiden. Zie ten aanzien van de eigen schuld van het slachtoffer eveneens: VandenBerghe, Van Quickenbome, Geelen en Decoster, TvP, 1987, p. 1541-1550; VandenBerghe, Van Quickenborne en Hamelink, TvP, 1980, p. 1400-1414; Storme, VR, 1990, p. 229. 


\subsubsection{Onrechtmatige daad en kinderen}

Bij de beoordeling van de onrechtmatige daad van een kind wordt in beginsel geen rekening gehouden met de leeftijd van een kind. De begane fout dient namelijk te worden getoetst aan het gedrag van de 'voorzichtige burger', zonder rekening te houden met subjectieve omstandigheden. Toch wordt in de Belgische rechtspraak het schadeveroorzakende gedrag van het kind indirect getoetst aan de leeftijd en de individuele bekwaamheid van het kind. ${ }^{194}$

Anderzijds dient een bestuurder van een motorrijtuig in het verkeer een bijzondere voorzichtigheid en zorgvuldigheid in acht te nemen ten aanzien van kinderen. Een bestuurder moet bijvoorbeeld in de buurt van een school voorzien dat een kind van 7 jaar en 5 maanden buiten de oversteekplaats voor voetgangers de straat oversteekt. ${ }^{195}$

Door de Belgische rechtsleer en rechtspraak wordt algemeen aanvaard dat schuldonbekwaamheid geen aansprakelijkheid oplevert en een beroep op de eigen schuld van het slachtoffer blokkeert. Dit betekent dat een minderjarig kind slechts aansprakelijk kan worden gehouden indien de onrechtmatige daad aan hem persoonlijk kan worden toegerekend. Bij de feitelijke beoordeling of een kind schuldbekwaam is wordt rekening gehouden met het onderscheidingsvermogen, de leeftijd en de 'jaren des onderscheids' van het betreffende kind.

Een gebrek aan onderscheidingsvermogen sluit elke fout uit, waarbij de leeftijd vaak van doorslaggevend belang is. Dit is met name het geval bij zeer jonge kinderen; zij hebben onvoldoende onderscheidingsvermogen, beschikken nog niet over de 'jaren des onderscheids' en zijn derhalve schuldonbekwaam. ${ }^{196}$

Of een kind voldoende onderscheidingsvermogen bezit wordt door de rechter verder beoordeeld aan de hand van het concreet aanwezige gevaar. Een kind van 7 jaar kan niet worden verweten dat het de straat is overgestoken om zijn moeder bij te houden. ${ }^{197}$ In een andere uitspraak werd aan een kind van 7 jaar wel voldoende onderscheidingsvermogen toegekend. Het kind had zich bij het oversteken van een rijbaan bewust moeten zijn van het gevaar. ${ }^{198}$

194. Zie VandenBerghe, Van Quickenborne en Wynant, TvP, 1995, p. 1208.

195. Zie Brusse], 15 decmber [989, R.G.A.R., 1991, nr. 11828 in VandenBerghe, Van Quickenborne en Wynant, TvP, 1995, p. 1272.

196. Onder andere: Brussel, 21 maart 1984, R.G.A.R., 1985, nr. 10978; Corr. Luik, 25 november 1991, De Verz., 1993, 60. VandenBerghe, Van Quickenborne en Wynant, TvP, 1995, p. 1220.

197. Brussel, 29 mei 1985, R.G.A.R., 1987, nr. 11203.

198. Rb. Nijvel, 20 maart 1985, T.B.B.R., 1987, 86. 
Kinderen in de leeftijd van 11-14 jaar hebben niet dezelfde verkeerservaring als volwassenen. $\mathrm{Zij}$ dienen zich echter wel bewust te zijn van hun kwetsbaarheid als fietser en van de gevaren van het verkeer, waarbij zij bepaalde verkeersregels in acht moeten nemen, zoals het uitkijken met oversteken. ${ }^{199}$ Een 12 -jarig kind dat al fietsend met hoge snelheid op een voetpad een voetganger aanrijdt begaat een aan hem toerekenbare fout in zin van artikel $1382 \mathrm{BW} .^{2(1)}$

De vraag of een kind over de 'jaren des onderscheids' beschikt wordt door de Belgische rechtspraak feitelijk beantwoord zonder dat een verband kan worden gelegd met de leeftijd van het kind. ${ }^{2 n 1}$

\subsection{DE AANSPRAKELIJKHEID VOOR ZAKEN}

In artikel 1384 lid 1 van het $\mathrm{BW}$ is het volgende geregeld:

'Men is aansprakelijk niet alleen voor de schade welke men veroorzaakt door zijn eigen daad, maar voor die welke veroorzaakt wordt door de daad van personen voor wie men moet instaan, of van zaken die men onder zijn bewaring heeft'.

Artikel 1384 lid 1 heeft zich in België ontwikkeld tot een algemeen vermoeden van aansprakelijkheid ten laste van de bewaarder van de zaak. Het slachtoffer dient, voor de vaststelling van de aansprakelijkheid van de bewaarder, naar Belgische recht aan te tonen dat sprake is van een gebrek in de zaak, ${ }^{202}$ alsmede de aanwezigheid van een causaal verband tussen het gebrek en de schade. Dit bewijs van een gebrek volgt niet automatisch uit het feit dat met de betreffende zaak schade is veroorzaakt en ook vestigt artikel 1384 lid $1 \mathrm{BW}$ geen vermoeden van een gebrek in de zaak. ${ }^{203} \mathrm{Het}$ slachtoffer kan het gebrek van de zaak bewijzen door aan te tonen dat de schade niet zou zijn ontstaan zonder de aanwezigheid van een gebrek, dat de aanwezigheid van

199. Rb. Leuven, 25 maart 1987, VKJ, 1988, 49; Corr. Leuven, 25 juni 1991, De Verz., 1991, 946 in VandenBerghe, Van Quickenbome en Wynant, TvP, 1995, p. 1208-1209 en p. 1221.

200. Rb. Brussel, 28 maart 1989, T.B.B.R., 1990, 247 in VandenBerghe, Van Quickenbome en Wynant. TvP, 1995, p. 1221. Zie over de onrechtmatige daad bij kinderen eveneens: VandenBerghe, Van Quickenborne, Geelen en Decoster, TvP, 1987, p. 1284-1285 en p. 1308-1311; VandenBerghe, Van Quickenbome en Hamelink, TvP, 1980, p. 1170-1175.

201. Zie VandenBerghe, Van Quickenbome en Wynant, TvP, 1995, p. 1220-1221

202. Zie daarover in algemene zin: Comelis, TvP, 1984, p. 299-319, met cen bespreking van cen aantal arresten van het Hof van Cassatie.

203. VandenBerghe, Van Quickenbome en Wynant, TvP, 1995, 1281-1285 en p. 1311-1312 met een verwijzing naar onder andere: Cass., 28 september 1984, Ar. Cass., 1984-1985, 163; Luik, 27 juni 1988, R.G.A.R., 1992, nr. 12009; Cass., 16 oktober 1986, Ar. Cass., 1986-1987, R.W., 1986-87, 2090; Cass. 7 november 1980, Arr. Cass., 1980-81, 271, R.W., 1980-81, p. 1708. Zic ook De Haas en Hartlief, Verkeersaansprakelijkheid, p. 65-66. 
het gebrek de enige mogelijke oorzaak is geweest van het ongeval en dat het ongeval niet het gevolg was van een vreemde oorzaak. ${ }^{204}$

Wanneer is vastgesteld dat de schade die het slachtoffer heeft geleden is veroorzaakt door een gebrek in de zaak, kan de bewaarder daarvan zich niet van zijn aansprakelijkheid bevrijden door te stellen dat hij geen fout heeft begaan. De bewaarder moet bewijzen dat de veroorzaakte schade het gevolg is van een vreemde oorzaak, namelijk toeval, overmacht, de daad van een derde of van het slachtoffer. ${ }^{205}$ De daad van een derde die in direct verband staat met het gebrek in de zaak sluit de aansprakelijkheid op grond van artikel 1384 lid 1 BW niet uit en leidt daarbij slechts zelden tot een volledige vrijstelling van de aansprakelijkheid van de bewaarder. ${ }^{206}$ Het gegeven dat de schade is veroorzaakt door zowel een fout van het slachtoffer als door een gebrek in de zaak, leidt niet tot de conclusie dat de bewaarder van de gebrekkige zaak daarvoor niet meer aansprakelijk gehouden kan worden. ${ }^{207}$

Het Belgische Hof van Cassatie blijft vasthouden aan het vereiste dat voor de aanname van een gebrek de zaak een abnormaal kenmerk dient te vertonen, waarmee in bepaalde omstandigheden schade kan worden veroorzaakt. Het gebrek dient tevens direct met de zaak te zijn verbonden. Noodzakelijk is verder dat het gebrek de structuur van de zaak heeft aangetast. Andere oorzaken van het gebrek spelen geen rol bij de toepassing van artikel 1384 lid $1 \mathrm{BW}$. Het is bijvoorbeeld van weinig belang of het gebrek het gevolg is van ouderdom of gebrekkig onderhoud. Verder is evenmin relevant de vraag of het betreffende gebrek een structurele of een mechanische oor-

204. Het beweerde gebrek mag niet uit het ongeval zelf worden afgeleid, bijvoorbeeld wanneer een auto twee uur na de montage van nieuwe banden slipt en een ongeval veroorzaakt, Brussel, 20 mei 1985, VKJ, 1985, 193, RW, 1985-86, 1493. Zie VandenBerghe, Van Quickenbome en Wynant, TvP, 1995, p. 1326-1330 met een verwijzing naar: Antwerpen, 7 november 1990, R.G.A.R., 1992, nr. 12047; Cass. 17 januari 1985, Ar. Cass., 1984-85, 645, R.W., 1985-86, 1100 .

205. VandenBerghe, Van Quickenbome en Wynant, TvP, 1995, p. 1332-1334 met een verwijzing naar Cass., 13 mei 1993, Arr. Cass., 1993, 493; Cass., 5 juni 1987, Arr. Cass., 1986-87, 1354, VKJ, 1988, 224 in het kader van de vreende corzaak en Rb. Brugge, 26 september 1988, RW, 1990-91, 371: Antwerpen, 7 december, RW, 1989-90, 780, ten aanzien van slechte weersomstandigheden.

206. VandenBerghe, Van Quickenbome en Wynant, TvP, 1995, p. 1337.

207. VandenBerghe, Van Quickenborne en Wynant, TvP, 1995, p. 1335 met een verwijzing naar Cass., 26 maart 1992, Arr. Cass., 1991-92, 721, waarin werd geoordeeld dat wanneer een fout van het slachtofffer en een gebrek in de zaak hebben geleid tot schade, de bewaarder van de zaak niet tot een volledige schadevergoeding kan worden veroordeeld zonder te onderzoeken in hoeverre de fout van het slachtoffer in causaal verband staat met de ontstane schade. 
zaak heeft of het gevolg is van slijtage. Ten slotte speelt de vraag of het gebrek zichtbaar dan wel verborgen is ook geen rol. ${ }^{208}$

\subsection{DE MOTORRIJTUIGVERZEKERING EN DE FOUTAANSPRAKELIJKHEID}

In 1956 is in België in het kader van de Benelux-overeenkomst een stelsel van verplichte aansprakelijkheidsverzekering voor alle motorrijtuigen ingevoerd. ${ }^{209}$ Deze wet werd recent in zijn geheel vervangen door de Wet van 21 november 1989, ${ }^{210}$ waarbij overigens de toepasselijke aansprakelijkheidsregels ongewijzigd bleven.

De WAM-wet vestigt een verplichting tot verzekering van de aansprakelijkheid op de eigenaarhouder of bestuurder van een motorrijtuig, waarmee zowel letsel- als zaakschade aan derden wordt toegebracht. ${ }^{211}$ De verzekeringsdekking is onbeperkt, behalve in gevallen van zaakschade bij derden en brand, waarvoor een beperking geldt tot 5 miljoen BEF. ${ }^{212}$ De WAM-wet geeft verder het slachtoffer een rechtstreekse vordering tegen de aansprakelijkheidsverzekeraar van het motorrijtuig. ${ }^{213}$

Gegeven het karakter van een aansprakelijkheidsverzekering dient de motorrijtuigverzekeraar slechts dan de schade te vergoeden wanneer de verzekerde aansprakelijk kan worden gehouden. Hiervoor gelden de regels van de foutaansprakelijkheid, respectievelijk de aansprakelijkheid voor gebrekkige zaken van artikel 1382 en 1384 lid $1 \mathrm{BW}$, zoals deze in de voorgaande paragrafen zijn beschreven. Op de aansprakelijkheidsverzekeraar rust daarentegen geen vergoedingsplicht wanneer kan worden bewezen dat overmacht of toeval de enige oorzaak van het ongeval is geweest. ${ }^{214}$

208. VandenBerghe, Van Quickenbome en Wynant, TvP, 1995, p. 1313-1319 met een verwijzing naar onder andere: Cass., 19 september 1985, Ar. Cass., 1985-86, 66, R.W., 1986-87, 2246; Cass., 13 mei 1993, Arr. Cass. 1992-93, 493; Cass., 11 december 1986, Arr. Cass., 1986-87, 486; Brussel, 12 november 1987, RW, 1988-89, 1170; Bergen 25 februari 1986, R.G.A.R., 1989, nr. 11483. Zie over de aansprakelijkheid voor gebrekkige zaken ook: VandenBerghe, Van Quickenborne, Geelen en Decoster, TvP, 1987, p. 1369-1377 en p. 1392-1415; VandenBerghe, Van Quickenbome en Hamelink, TvP, 1980, p. 1212-1219 en p. 1228-1254; Bocken, TvP, 1984, p. 382-384.

209. Wet van 1 juli 1956 betreffende de verplichte aansprakelijkheidsverzekering inzake motorrijtuigen, Belgisch Staatsblad, 15 juli 1956.

210. Wet van 21 november 1989 betreffende de verplichte aansprakelijkheidsverzekering inzake motorrijtuigen, Belgisch Staatsblad, 8 december 1989. Zie daarover Bocken en Geers, TvP, 1996, p. 94-102.

211. Artikel 2 paragraaf 1 en artikel 3 paragraaf 1 van de Wet van 21 november 1989.

212. Artikel 3 van de Wet van 1 juli 1956 en artikel 5 van de Modelpolis. Zie Claassens, RW, 1977, p. 147. Op basis van artikel 16 van de Wet van 21 november 1989 geldt ingeval van brand een beperking tot 50 miljoen BEF. Zie Bocken en Geers, TvP, 1996, p. 94.

213. Wet van 1 juli 1956, artikel 6; Wet van 21 november 1989 , artikel 12.

214. Poté, Handboek verkeerswetgeving, p. 760; Bocken en Geers, TvP, 1996, p. 96. 
Samen met de invoering van WAM-wet in 1956, werd bij Koninklijk Besluit van 5 januari $1957^{215}$ een Gemeenschappelijk Waarborgfonds, 'Fonds commun de garantie automobile', opgericht. Dit fonds wordt gevoed door middel van jaarlijkse bijdragen van de aansprakelijkheidsverzekeraars naar rato van hun premie-inkomsten binnen de bedrijfstak. ${ }^{216}$ Een verkeersslachtoffer kan in het algemeen een beroep doen op het Waarborgfonds, wanneer het een schadegebeurtenis betreft waarop de WAMwet van toepassing is en indien het motorrijtuig van de aansprakelijke tegenpartij aan de verzekeringsplicht van de WAM-wet is onderworpen. ${ }^{217}$

De vraag of de verplichte motorrijtuigverzekering van invloed kan zijn op de aansprakelijkheid en de schadevergoeding bij een verkeersongeval, wordt in de Belgische rechtsleer en de rechtspraak negatief beantwoord. Het feit dat één van de betrokken partijen over een verzekering beschikt wordt niet van belang geacht bij de toetsing van de onrechtmatige daad van artikel $1382 \mathrm{BW}$ en zelfs gezien als strijdig met de beginselen van de foutaansprakelijkheid. ${ }^{218}$

Een aantal auteurs acht het echter niet uitgesloten dat de rechtspraak in bepaalde gevallen rekening zal houden met de aanwezigheid van een verzekering. Ten aanzien van verkeersongevallen kunnen zich immers situaties voordoen, waarbij de ene partij (bijvoorbeeld de fietser) niet verzekerd is en slechts een lichte fout heeft begaan, terwijl de wederpartij (automobilist) over een verplichte verzekering beschikt. Daarnaast kan volgens de auteurs de aanwezigheid van een verplichte verzekering mogelijk een rol vervullen bij een hervorming van de verkeersaansprakelijkheid. ${ }^{219}$

Er is slechts één rechterlijke uitspraak bekend waarin de rechter in het kader van een verkeersongeval de aanwezigheid van een aansprakelijkheidsverzekering een rol laat spelen. ${ }^{220}$ Het betrof hier een ongeval tussen een verzekerd motorrijtuig en een nietverzekerd motorrijtuig, waarbij enkel sprake was van zaakschade. De bestuurders van de betrokken motorrijtuigen hadden volgens de rechter allebei een fout gemaakt en werden daarom allebei veroordeeld tot de vergoeding van de schade van de wederpartij. Daarbij werd door de rechter overwogen dat 'bij het beoordelen van de fout

215. Belgisch Staatsblad, 10 januari 1957.

216. Artikel 49 van de Wet van 9 juli 1975 betreffende de Controle op de Verzekeringsondernemingen.

217. Artikel 80 van de Wet van 9 juli 1975 betreffende de Controle op de Verzekeringsondernemingen ingevoerd bij K.B. van 16 december 1981, Belgisch Staatsblad, 26 januari 1982, geeft een opsomming van de gevallen waarin het Waarborgfonds tussenkomt. Zie over de werking van het Waarborgfonds: Poté, Handboek Verkeerswetgeving, p. 763-771; Bocken en Geers, TvP, 1996, p. 95; Bocken, TvP, 1984, p. 342 en p. 390-391.

218. Vandenberghe, Van Quickenborne, Geelen en Decoster, TvP, 1987, p. 1264.

219. Simoens, RW, 1980-81, p. 2030-2031; Dalcq, J.T., 1983, p. 317-322; Simoens, TvP, 1984, p. 417-427 en p. $456-460$.

220. Vredegerecht te Merksem, 9 april 1981, RW, 1981-1982, p. 1279-1281. 
men niet kan voorbijgaan aan het bestaan van een verzekering tot spreiding van het (verkeers)risico'. 221

Simoens stelt in een kritische noot onder bovengenoemde beslissing dat de rechter geen goed voorbeeld heeft gebruikt om tot de voomoemde overweging te komen. Het ging immers om een ongeval tussen twee motorrijtuigen en er was slechts sprake van een geringe blikschade. Zijns inziens kan de aanwezigheid van een (verplichte) verzekering wel worden meegewogen met betrekking tot bijvoorbeeld een ongeval tussen een verplicht verzekerde automobilist en een veelal niet-verzekerde fietser. Naast de mogelijk geringe fout van de fietser, zal de rechter daarbij ook rekening kunnen houden met de aanwezigheid van een verzekering indien de omvang van de schade aanzienlijk is, zoals bij letsel- en overlijden. Bij zaakschade zal volgens Simoens de invloed van de verzekering een minder belangrijke rol spelen. ${ }^{222}$

\section{De voorgeschiedenis van de nieuwe Belgische regeling}

In deze paragraaf zal een overzicht worden gegeven van de belangrijkste gebeurtenissen die uiteindelijk hebben geleid tot de invoering van artikel 29bis WAMregeling bij wet van 13 april 1995. Daarbij ligt de nadruk op de meest recente ontwikkelingen. 223

Terwijl vóór de Tweede Wereldoorlog de vergoeding van verkeersslachtoffers vooral was gericht op de aansprakelijkheid, ${ }^{224}$ verplaatste de aandacht zich na de Tweede Wereldoorlog naar de verplichte verzekering, die gestalte kreeg in de Wet van 1 juli $1956 .{ }^{225}$ Daarmee was echter nog geen oplossing gevonden voor de, in de ogen van velen, gebrekkige schaderegeling naar aanleiding van een verkeersongeval. Een onderzoek van de Belgische Beroepsvereniging der Verzekeringsondememingen (BVVO) uit 1968 wees bijvoorbeeld uit dat, met de aansprakelijkheidsregeling van

221. Vredegerecht te Merksem, 9 april 1981, RW, 1981-82, p. 1281.

222. Simoens, RW, 1981-82, p. 1282-1285. Zie ook Storme, VR, 1990, p. 229.

223. Zie voor een algemeen historisch overzicht van het aansprakelijkheidsrecht in Belgie, ook ten aanzien van verkeersongevallen: Simoens, RW, 1980-1981, p. 1961-1990 en 2025-2036 en voor een analyse van de ontstaansgeschiedenis van artikel 29bis: Hauferlin en Claassens, Bull. Ass. De Verz., 1995, p. 9-30; Dekyndt, Bull. Ass. - De Verz., 1995, p. 30-41.

224. Zie daarover Simoens, RW, 1980-81, p. 1976-1977 en p. 1985-1987; Fagnart, R.G.A.R., 1994, 12388-2; Hauferlin en Claassens, in Bull. Ass. - De Verz., 1995, p. 10-11.

225. Wet van 1 juli 1956 betreffende de verplichte burgerrechtelijke aansprakelijkheidsverzekering inzake motorrijtuigen, Belgisch Staatsblad, 15 juli 1956, in 1989 in zijn geheel vervangen door de Wet van 21 november 1989, zonder dat daarbij echter de grondslag van de aansprakelijkheid werd gewijzigd. 
artikel 1382 , de vergoeding van vooral jonge verkeersslachtoffers vaak te wensen overliet. $^{226}$

Op 18 maart 1968 werd bij Koninklijk Besluit een commissie ${ }^{227}$ geïnstalleerd die in 1971 met een aantal hervormingsvoorstellen kwam. Volgens deze commissie diende de foutaansprakelijkheid te worden gehandhaafd ten aanzien van alle gevallen waarin de schuld kon worden aangetoond. Daarnaast moest een vermoeden van fout worden gecreëerd ten nadele van de bestuurder en ten behoeve van alle derden, maar wel met een beperking van de schadevergoeding. Aan deze voorstellen werd echter geen concrete uitwerking, in de vorm van een wetsvoorstel, gegeven. ${ }^{228}$

Hoewel het sindsdien ten aanzien van de problematiek van de verkeersaansprakelijkheid niet geheel stil bleef, ${ }^{229}$ werd pas na de invoering in 1985 van de 'loi Badinter' in Frankrijk een nieuwe aanzet gegeven tot een hervorming van de verkeersaansprakelijkheid in België. ${ }^{230}$ Aan het begin van de jaren ' 90 werd in dat kader door een aantal parlementsleden een wetsvoorstel tot invoering van een nieuw artikel 1385 bis BW ingediend. ${ }^{231}$ Hierin werd ten laste van het gemotoriseerde verkeer een objectieve aansprakelijkheid gevestigd bij verkeersongevallen met een fietser of voetganger. $^{232}$

226. Claassens en Van Schoubroeck, in Verkeersaansprakelijkheid in Belgiē en Nederland, p. 77.

227. Deze zogenaamde 'Verkeersongevallencommissie' was belast met een 'onderzoek van de vraagstukken die verkeersongevallen doen rijzen, inzake aansprakelijkheid, verzekering en vergoeding van het slachtoffer'. Zie Simoens, J.F., 1994, p. 535. De verschijning in 1966 van 'La sécurité routière' van $\mathrm{A}$. Tunc was overigens mede de aanleiding tot de installatie van deze commissie.

228. Simoens, J.F., 1994, p. 535-536; Dalcq, J.T., 1994, p. 666; Hauferlin en Claassens, in Bull. Ass. De Verz., 1995, p. 11-12. Zie verder Schuermans en Simoens, TvP, 1978, p. 1123-1139 voor een overzicht van de verschillende hervormingsvoorstellen tot ongeveer eind jaren '70.

229. Getuige de dissertatic van Simoens, Vergoeding voor verkeersslachtoffers, 1979; Cousy en Claassens (ed.), Verkeersschade en verzekering: Revolutie of evolutie?, 1981; Simoens, TvP, 1984 , p. $456-460$.

230. Een onderdeel hiervan betrof een in 1985 georganiseerde studiedag door de automobilistenbond VAB-VTB en het instituut voor Sociaal Recht van de K.U. Leuven met als centrale thema 'Naar een betere vergoeding van niet-gemotoriseerde verkeersslachtoffers'. Onder dezelfde titel in boekvorm verschenen, met bijdragen van Poté, Claassens, Simoens en Vasnick. Zie verder Bocken en Geers, TvP, 1996, p. 79; Claassens en Van Schoubroeck, in Verkeersaansprakelijkheid in Belgiê en Nederland, p. 77-78; Hauferlin en Claassens, in Bull. Ass. - De Verz., 1995, p. 12-13.

231. Artikel $1385 \mathrm{BW}$ was in 1804 ingevoerd en betrof een risicoaansprakelijkheid voor dieren, in het bijzonder paarden, zijnde de vervoersmiddelen van de $19 \mathrm{e}$ eeuw. Aangezien de auto als het vervoermiddel van de 20 e eeuw werd beschouwd, leek een opname van een aanvullend artikel 1385bis niet meer dan logisch. Zie Simoens, J.F., 1994, p. 535; Bocken en Geers, TvP, 1996, p. 79 , noot 40 .

232. Zie respectievelijk Parl. St., Kamer, 1989-1990, nr. 926/1, p. 1-6 (J. Ansoms); Parl. St., Kamer, 1990-1991, nr. 1658/1 (M. De Meyer); Parl. St., Kamer, Buitengewone Zitting, 1991-1992, nr. 
In 1994 besloot de Belgische regering echter het initiatief naar zich toe te trekken. Met de indiening op 9 februari 1994 van artikel 41 van het Voorontwerp van de Sociale Programmawet werd aan boek III, Titel IV, Hoofdstuk II van het Burgerlijk Wetboek een artikel 1385 bis toegevoegd. ${ }^{233}$ Daarin was bepaald dat de eigenaar of houder van een motorrijtuig in de zin van de WAM-wet (objectief) aansprakelijk is voor de lichamelijk schade van de fietser en voetganger, veroorzaakt door een verkeersongeval waarbij een motorrijtuig is betrokken. ${ }^{234}$ Behalve de bescherming van de zwakke weggebruiker lagen ook belangrijke budgettaire overwegingen aan deze regeling ten grondslag. De schade die tengevolge van een verkeersongeval wordt geleden komt namelijk voor een groot deel ten laste van de sociale zekerheid, in het bijzonder de ziekteverzekering. Met de invoering van deze risicoaansprakelijkheid, wordt de schadelast indirect verschoven naar de aansprakelijkheidsverzekeraar van het motorrijtuig. Daarnaast kunnen volgens de regering de lasten van de sociale zekerheid worden verlicht, doordat aan de ziekteverzekeraar een subrogatierecht is toegekend ${ }^{235}$ voor de schade die zij aan de zwakke weggebruiker heeft uitgekeerd. ${ }^{236}$

Tijdens de behandeling van dit voorstel in de Senaatscommissie voor Justitie bleek de invoering van het begrip 'objectieve aansprakelijkheid' echter op bezwaren te stuiten. De vraag was of de genoemde budgettaire doelstelling van de regering niet ook bereikt kon worden door middel van een systeem van automatische vergoeding ten laste van de aansprakelijkheidsverzekeraar van het motorrijtuig. Door de senatoren Erdman en Vandenberghe werd mede daarom een voorstel ingediend om de regeling te verplaatsen van het Burgerlijk Wetboek naar de WAM-wet. ${ }^{237}$ Aldus geschiedde en in het kader van artikel 45 van de Wet houdende sociale bepalingen van 30 maart 1994 werd een nieuwe regeling opgenomen in de Wet van 21 november 1989 betreffende de verplichte aansprakelijkheidsverzekering inzake motorrijtuigen (WAM-wet). ${ }^{238}$ Aan de WAM-wet werd vervolgens een nieuw hoofdstuk Vbis,

286/1, p. 1.6 (Ansoms); Parl. St., kamer, Buitengewone Zitting, 1991-1992, nr. 380/1 (J. Demol). Zie Claasens en Van Schoubroeck, in Verkeersaansprakelijkheid in Belgiè en Nederland, p. 78, nont 9; Bocken en Geers, TvP, 1996, p. 79-80; Dalcq, J.T., 1994, p. 666; Simoens, J.F., 1994, p. 534; Hauferlin en Claassens, in Bull. Ass. - De Verz., 1995, p. 13-15.

233. Parl. St., Senaat, 1993-1994, nr. 980/1, p. 63, in Bocken en Geers, TvP, 1996, p. 80.

234. Paragraaf 1 van artikel 1385 bis BW. Zie voor een commentaar op deze versie: Simoens, J.F., 1994, p. 532; Dalcq, J.T., 1994, p. 666, noot 10.

235. Artikel 76quater paragraaf 2 van de Wet op de ziekte- en invaliditeitsverzekering. Zic Simoens, J.F., 1994, p. 534 .

236. Memorie van Toelichting, Parl. St., Kamer, 1993-1994, nr 980/1, p. 35. Zic Bocken en Geers, TvP, 1996, p. 80; Dalcq, J.T., 1994, p. 667.

237. Parl. St. Senaat, 1993-1994, nr. 980-3, p. 22 en 40 (Verslag Arts) en nr. 980/3, p. 24.

238. Belgisch Staatsblad, 31 maart 1994, p. 8877. 
'Vergoeding van bepaalde slachtoffers van verkeersongevallen' (artikel 29bis en 29 ter), toegevoegd. ${ }^{239}$

Nog geen week na de vaststelling van deze regeling werd op initiatief van het parlementslid Ansoms een wetsvoorstel ingediend voor een herziening van artikel 29 bis. ${ }^{240}$ Deze herziening had onder andere betrekking op een wijziging van het begrip 'onverschoonbare fout' en op een verruiming van de bescherming naar passagiers. Dit leidde uiteindelijk tot een gewijzigd artikel 29bis WAM-wet, dat bij Wet van 13 april 1995 op 1 juli 1995 in werking is getreden. ${ }^{241}$

\section{Een analyse van de Belgische wet van 13 april 1995}

Aan de hand van de herziene Belgische regeling van 13 april 1995 wordt in deze paragraaf een overzicht gegeven van de hoofdlijnen van de regeling van de vergoeding van verkeersschade voor met name zwakke weggebruikers, zoals deze is opgenomen in artikel 29 bis WAM-regeling. Dit artikel bestaat uit vijf paragrafen, waarin onder andere wordt aangegeven wat de reikwijdte van artikel $29 \mathrm{bis}$ is, welke verkeersdeelnemers in aanmerking komen voor een quasi-automatische schadevergoeding en de vraag wie de schade van de zwakke verkeersdeelnemer dient te vergoeden. Daarnaast zijn de begrippen 'betrokkenheid' en 'onverschoonbare fout' van belang. ${ }^{242}$

De voornoemde vragen en begrippen worden hierna geanalyseerd. Daarbij zal echter, gegeven de recente invoering van artikel $29 \mathrm{bis,} \mathrm{de} \mathrm{nadruk} \mathrm{liggen} \mathrm{op} \mathrm{de} \mathrm{uitleg} \mathrm{die}$ door de doctrine en de parlementaire geschiedenis aan deze regeling is gegeven. ${ }^{243}$ Met behulp van een recent verschenen onderzoek zal daarnaast een aantal praktische

239. Bocken en Geers, TvP, 1996, p. 81; Claassens en Van Schoubroeck, in Verkeersaansprakelijkheid in Belgie en Nederland, p. 79; Hauferlin en Claassens, in Bull. Ass. - De Verz., 1995, p. 15 16. Zie voor een analyse van dit 'oude artikel 29bis WAM-wet: Dalcq, J.T., 1994, p. 667-672; Simoens, RW, 1994-1995, p. 114-120; Fagnart, R.G.A.R., 1994, 12388/3-16; Freriks en Diercxsens, VR, 1995, p. 168-169; Huys en Simoens, TSR, 1994, p. 230-245.

240. Wetsvoorstel tot wijziging van artikel 29 bis van de Wet van 21 november 1989 betreffende de verplichte aansprakelijkheidsverzekering inzake motorrijtuigen, Parl. St., Kamer, 1993-1994, nr. $1422 / 1$, p. 1-5.

241. Wet van 13 april 1995 tot wijziging van artikel 29 bis en tot opheffing van artikel 29 ter van de Wet van 21 november 1989 betreffende de verplichte aansprakelijkheidsverzekering inzake motorrijtuigen, Belgisch Staatsblad, 27 juni 1995. Zie Bocken en Geers, TvP, 1996, p. 69, noot 1 en p. 81; Claassens en Van Schoubroeck, in verkeersaansprakelijkheid in Belgie en Nederland, p. 79; Faure en Hartlief, VR, 1995, p. 257; Tuerlinckx, TvP, 1996, p. 6-7; Philippe en Meysmans, TvP, 1995, p. 406.

242. Deze begrippen zijn direct overgenomen uit de Franse 'loi Badinter'. Zie Tuerlinckx, TvP, 1996, p. 11.

243. Deze parlementaire geschiedenis heeft mede betrekking op de voorbereiding van eerdere versies van een wettelijke regeling. Zie paragraaf 3 van dit hoofdstuk. 
kanten van artikel 29 bis worden belicht. ${ }^{244}$ Dit betreft de ervaringen van rechters, verzekeraars en advocaten met de nieuwe regeling, alsmede verwijzingen naar reeds verschenen rechtspraak.

\subsection{DE REIKWIJDTE VAN ARTIKLLL 29BIS}

Artikel 29 bis van de Belgische WAM-wet is van toepassing op verkeersongevallen waarbij een motorrijtuig is betrokken. Paragraaf 1 lid 1 van dit artikel luidt als volgt:

'Bij een verkeersongeval waarbij een motorrijtuig betrokken is, wordt met uitzondering van de stoffelijke schade, alle schade veroorzaakt aan elk slachtoffer of zijn rechthebbenden en voortvloeiend uit lichamelijke letsels of het overlijden, vergoed door de verzekeraar die de aansprakelijkheid dekt van de eigenaar, de bestuurder of de houder van het motorrijtuig overeenkomstig deze wet'.

In de eerste zin van dit artikel ligt een drietal begrippen besloten die in de literatuur nader worden ontleed, namelijk 'motorrijtuig', 'verkeersongeval' en 'betrokkenheid'. ${ }^{245}$

\subsubsection{Het begrip 'motorrijtuig'}

Paragraaf 3 van artikel 29 bis luidt als volgt:

'Onder motorrijtuig moet worden verstaan ieder voertuig bedoeld in artikel 1 van deze wet (WAM-wet) met uitzondering van rolstoelen met een eigen aandrijving die door gehandicapten in het verkeer kunnen worden gebracht'.

In artikel 1 van de WAM-wet worden motorrijtuigen omschreven als

'rij- of voertuigen, bestemd om zich over de grond te bewegen en die door een mechanische kracht kunnen worden gedreven, zonder aan spoorstaven te zijn verbonden; al wat aan het rij- of voertuig is gekoppeld (aanhangwagens), wordt als een deel ervan aangemerkt'.

Dit laatste artikel heeft derhalve betrekking op motorrijtuigen, aanhangwagens en bromfietsen. Uit artikel 1 WAM-wet kan verder worden opgemaakt dat ongevallen

244. Claassens en Van Schoubroeck, in Verkeersaansprakelijkheid in Belgiě en Nederland, p. 75-111 en p. 253-291. Zie ook Claassens en Van Schoubroeck, VR, 1997, p. 359-363; Decroes, RW, 2001, p. 1257-1267.

245. Zie onder anderen: Tuerlinckx, TvP, 1996, p. 11-27; Bocken en Geers, TvP, 1996, p. 104-108; De Haas en Hartlief, Verkeersaansprakelijkheid, p. 68-69; Engelhard en Van Maanen, Aansprakelijkheid voor verkeersongevallen, p. 32-33. 
met trams en treinen, zijnde voertuigen die zich over spoorstaven bewegen, zijn uitgezonderd van de toepassing van artikel 29bis. De uitzondering in paragraaf 3 van artikel 29 bis ten aanzien van gehandicapten die zich in een rolstoel voortbewegen houdt mede verband met hun kwetsbaarheid in het verkeer. ${ }^{246}$

\subsubsection{Het begrip 'verkeersongeval'}

In het kader van artikel 29 bis wordt door de Belgische rechtsleer en rechtspraak, mede gebaseerd op een aantal uitspraken van het Benelux Gerechtshof, een ruime uitleg gegeven aan het begrip 'verkeersongeval'. Ingevolge de rechtspraak van het Benelux Gerechtshof verwijst een ongeval naar de deelname van een voertuig aan het verkeer. Daarbij geldt onder andere dat de ontstane schade kenmerkend moet zijn geweest voor de schadeveroorzaking door een motorrijtuig in het verkeer ${ }^{247}$ In een andere uitspraak werd geoordeeld dat de WAM-verzekeraar slechts dekking behoeft te verlenen indien er een oorzakelijk verband bestaat tussen de veroorzaakte schade en de deelneming van het motorrijtuig aan het verkeer. ${ }^{248}$

\subsubsection{Het begrip 'betrokkenheid'}

Voor de toepassing van artikel 29 bis wordt in paragraaf 1 lid 1 verder gesteld dat een motorrijtuig bij een verkeersongeval 'betrokken' dient te zijn. Simoens betreurt het dat dit begrip niet nader is omschreven. Hierdoor ontstaan volgens hem dezelfde interpretatieproblemen als in Frankrijk het geval was. ${ }^{249}$ Andere auteurs zijn echter van mening dat de Belgische rechtspraak voor de concretisering van het begrip 'betrokkenheid' inspiratie kan vinden bij de uitleg die daaraan door de Franse Hof van Cassatie is gegeven. $\mathrm{Zij}$ verwijzen in dat kader ook naar de parlementaire voorbereiding van artikel 29 bis. Hierin wordt door de Minister opgemerkt dat het voor het aannemen van 'betrokkenheid' bij een verkeersongeval niet noodzakelijk is dat het motorrijtuig in beweging is of dat het ongeval werd veroorzaakt door de aanraking van het slachtoffer met een motorrijtuig. Evenmin is van belang of het motorrijtuig

246. Zie hierover Bocken en Geers, TvP, 1996, p. 105; Simoens, RW, 1995-96, p. 219; Tuerlinckx, TvP, 1996, p. 11-14; Comelis, RW, 1998-1999, p. 525.

247. Benelux Gerechtshof, 23 oktober 1984, RW, 1984-85, p. 1009; Cass. 12 juni 1989, RW, $1989-$ 90, p. 230.

248. Benelux Gerechtshof, 10 december 1990, Jur. Benelux Gerechtshof, 1990, 121, RW, 1990-91, p. 1048; Cass. 8 maart 1977, Arr. Cass., 1997, 735; Luik, 13 mei 1993, De Verz., 1993, p. 581. Claassens en Van Schoubroeck, in Verkeersaansprakelijkheid in België en Nederland, p. 92-94; Bocken en Geers, TvP, 1996, p. 104-105. Zie ook Tuerlinckx, TvP, 1996, p. 14-20 en Comelis, RW, 1998-1999, p. 524-525, voor een verder onderscheid tussen verkeersongevallen op openbare terreinen en privé-terreinen, verkeersongevallen tijdens wedstrijden en verkeersongevallen in het kader van de Arbeidsongevallenwet.

249. Simoens, RW, 1995-96, p. 219. Zie over de 'implication' in de Franse 'loi Badinter' paragraaf 4.2 van hoofdstuk !. 
al dan niet regelmatig aan het verkeer heeft deelgenomen. ${ }^{250}$ Dit betekent dat, in navolging van de Franse rechtspraak, een verkeersongeval met een motorrijtuig in beweging bijna altijd 'betrokkenheid' oplevert, ook wanneer het slachtoffer niet wordt geraakt. Daarbij kan bijvoorbeeld worden gedacht aan een fietser die door het passeren van een motorrijtuig ten val komt. ${ }^{251}$

De beantwoording van de vraag of sprake is van betrokkenheid bij een verkeersongeval van een stilstaand of geparkeerd voertuig kan echter tot interpretatieproblemen leiden. ${ }^{252}$ Tuerlinckx stelt voor om in deze gevallen te volstaan met het bewijs dat het voertuig een zekere, al dan niet hinderlijke, rol heeft gespeeld bij het ontstaan van het verkeersongeval. Het slachtoffer dient te bewijzen dat er zich een verkeersongeval heeft voorgedaan waarbij hij schade heeft geleden, ongeacht of de schade ook daadwerkelijk door dat betrokken motorrijtuig is veroorzaakt. ${ }^{253}$ Bocken en Geers zijn van mening dat de 'betrokkenheid' moet worden beoordeeld aan de hand van de vraag of de deelname aan het verkeer van het motorrijtuig een noodzakelijke voorwaarde was voor het ontstaan van het ongeval. Daarbij staat volgens hen de vraag centraal of dit ongeval ook zou hebben plaatsgevonden zonder dat het voertuig aan het verkeer had deelgenomen. ${ }^{254}$

Claassens en Van Schoubroeck concluderen naar aanleiding van hun onderzoek dat er weinig praktische problemen zijn bij de interpretatie van het begrip betrokkenheid'. Daarvan is vrijwel altijd sprake indien een aanraking met een motorrijtuig heeft plaatsgevonden of wanneer kan worden aangetoond dat het motorrijtuig in be-

250. Parl. St., Senaat, 1993-94, nr. 980/1, p. 33 en 980/3, p. 15 en 30. Zie Bocken en Geers, TvP, 1996, p. 107; Tuerlinckx, TvP, 1996, p. 20-23; Claassens en Van Schoubroeck, VR, 1997, p. 361; Comelis, RW, 1998-1999, p. 525-526, die stelt dat van betrokkenheid sprake kan zijn wanneer het motorrijtuig een 'nodige, maar voldoende voonwaarde voor het verkeersongeval (en dus van de schade) was'.

25I. Parl. St., Senaat, 1993-94, 980/3, p. 15. Bocken en Geers, TvP, 1996, p. 106-107. Zie voor een analyse van het begrip 'betrokkenheid' met verwijzingen naar de Franse rechtspraak: Philippe en Meysmans, TvP, 1995, p. 405-438; Philippe, in Lindemnisation automatique de certaines victimes d'accidents de la circulation, p. 52-73; Decroess, RW, 2001, p. 1257-1263. Zie ook Burgerlijke Rechtbank te Mechelen, 2 mei 2000, RW, 2001, p. 1282-1283, noot C. van Schoubroeck.

252. Zie echter Politierechtbank te Kortrijk, 14 oktober 1998 en Politierechtbank te Brugge, 9 november 1998, TBH, 1999, p. 218-221. In beide uitspraken wordt, met een verwijzing naar de evolutie in de Franse rechtspraak en de bedoeling van de Belgische wetgever om de ruimst mogelijke bescherming te bieden aan voetgangers en fietsers, betrokkenheid aangenomen van een regelmatig geparkeerd voertuig, waarmee een fietser in aanraking komt tengevolge waarvan de fietser lichamelijke schade lijdt.

253. Tuerlinckx, TvP, 1996, p. 23-27; Claassen en Van Schoubroeck, VR, 1997, p. 361; Politierechtbank Hasselt, Afdeling Beringen, 24 december 1996, Bijnens-Gielen/ASLK verzekeringen, in Verkeersaansprakelijkheid in Belgie en Nederland, p. 278-279.

254. Bocken en Geers, TvP, 1996, p. 108, verwijzen hiermee naar de 'equivalentieleer'. Zie daarover paragraaf 2.1 van dit hoofdstuk. 
weging is. Een praktijkvoorbeeld waarin betrokkenheid werd aangenomen had betrekking op een voetganger die, tengevolge van het claxonneren van een bestuurder van een motorrijtuig, schrikt, struikelt en ten val komt. Daarnaast is sprake van betrokkenheid wanneer een passagier bij het uitstappen wordt aangereden door een andere auto, ${ }^{255}$ of bij het uitstappen zijn enkel breekt. ${ }^{256}$

Gesteld kan worden dat de regeling van artikel 29 bis WAM ertoe heeft geleid dat de vergoedingsplicht van de WAM-verzekeraar is losgekoppeld van het klassieke aansprakelijkheidsrecht. De vergoedingsplicht van de WAM-verzekeraar ontstaat al wanneer een motorrijtuig betrokken is bij een verkeersongeval. Verder geldt dat met betrekking tot de vergoedingsplicht van de WAM-verzekeraar de concrete gedragingen van de automobilist geen rol spelen.

\subsection{DE PERSONEN DIE GERECHTIGD ZIJN TOT SCHADEVERGOEDING ${ }^{257}$}

Terwijl paragraaf 1 lid 1 van artikel 29 bis spreekt van '...alle schade veroorzaakt aan elk slachtoffer of zijn rechthebbenden...', wordt hierop in paragraaf 2 van hetzelfde artikel een beperking aangebracht:

'de bestuurder van een motorrijtuig en zijn rechthebbenden kunnen zich niet beroepen op de bepalingen van dit artikel'.

In de doctrine wordt hieruit afgeleid dat bij een verkeersongeval met een motorrijtuig iedere niet-gemotoriseerde verkeersdeelnemer, in casu fietsers, voetgangers en passagiers, voor een vergoeding op basis van artikel $29 \mathrm{bis}$ in aanmerking kan komen. ${ }^{258}$ Daarnaast kunnen personen die zich bijvoorbeeld op rolschaatsen, te

255. Claassens en Van Schoubroeck, in Verkeersaansprakelijkheid in Belgiě en Nederland, p. 93, met een verwijzing naar een uitspraak van de Politierechtbank te Charleroi, 18 oktober, 1996, JLMB, 1997, 58; VKJ, 1997, 108. Zie echter Politierechtbank Hasselt, 24 december 1996, in Verkeersaansprakelijkheid in België en Nederland, p. 278-279, waarin de rechter geen betrokkenheid aannam voor een aanrijding tussen een bromfiets en twee fietsers waarbij een derde fietser uit stilstand ten val kwam.

256. Politierechtbank Hasselt, 4 september 1997, Houbrechts Ingrid/Axa Belgium NV, TBH, Actualiteit, 1997, p. 807-808, noot C. van Schoubroeck. De rechter oordeelde onder andere: 'Het begrip betrokkenheid onderstelt een zekere relatie tussen het voertuig en het ongeval. Een voertuig kan betrokken zijn bij een verkeersongeval, zonder daarbij effectief aan de oorzaak te liggen van de schade van het slachtoffer. Het oorzakelijk verband tussen het ongeval en de schade (te onderscheiden van het oorzakelijk verband tussen 'de fout' en de schade) staat vast'.

257. Bocken en Geers, TvP, 1996, p. 108, spreken in dit kader van 'verzekerden'.

258. De uitbreiding van de bescherming naar passagiers brengt mee dat ook verkeersongevallen tussen motorrijtuigen en eenzijdige verkeersongevallen onder de toepassing van artikel 29 bis worden gebracht. Zie Simoens, RW, 1995-1996, p. 219; De Haas en Hartlief, Verkeersaansprakelijkheid, p. 69-70; Engelhard en Van Maanen, Aansprakelijkheid voor verkeersongevallen, p. 38-39 en p. 47-48. 
paard of op ski's voortbewegen, een beroep doen op artikel $29 \mathrm{bis}$. Verder geldt de bescherming van dit artikel ook voor bestuurders en passagiers van trams en treinen die het slachtoffer zijn geworden van een verkeersongeval. ${ }^{259}$

Ten aanzien van de term 'bestuurder' in de zin van paragraaf 2 van artikel 29 bis, wordt door de Belgische doctrine aansluiting gezocht bij de Franse jurisprudentie inzake de 'loi Badinter'. ${ }^{260}$ Door Simoens wordt in het algemeen gesteld dat een bestuurder een persoon is die ten tijde van het verkeersongeval de controle uitoefende over het motorrijtuig. In deze optiek worden bijvoorbeeld een automobilist die uit zijn wagen wordt geslingerd en vervolgens wordt aangereden door een ander voertuig, respectievelijk de automobilist die bij het afsluiten van zijn wagen wordt aangereden niet als een bestuurder gezien. ${ }^{261}$ Andere Belgische auteurs spreken van een 'kinetische kracht' van het voertuig dat in het verkeer wordt gebracht op het ogenblik van het ongeval. Hierbij wordt een persoon als een bestuurder beschouwd, wanneer hij door middel van bepaalde handelingen in staat is om de 'kinetische kracht' van zijn voertuig ten tijde van het ongeval bewust en daadwerkelijk te beünvloeden. ${ }^{262}$

\subsection{DE SCHADEVERGOEDING OP BASIS VAN ARTIKEL $29 \mathrm{BIS}^{26.3}$}

Artikel 29bis paragraaf 1 bepaalt dat: '...alle schade veroorzaakt aan elk slachtoffer of zijn rechthebbenden en voortvloeiend uit lichamelijke letsels of het overlijden...' wordt vergoed. Lichamelijke schade wordt daarbij ruim geïnterpreteerd en verwijst naar de medische kosten, inkomensschade en andere economische schade. ${ }^{264}$ Daarnaast kunnen ook bepaalde vormen van psychische schade die het gevolg zijn van

259. Trams en treinen zijn immers geen motorrijtuig in de zin van artikel 1 van de WAM-wet. Tuerlinckx, TvP, 1996, p. 31-32; Bocken en Geers, TvP, 1996, p. 108-109; Simoens, RW, 19951996, p. 219-220; Claasens en Van Schoubroeck, VR, 1997, p. 360.

260. Daarin wordt, afhankelijk van de concrete omstandigheden van het geval, het begrip 'bestuurder' beperkt uitgelegd, zonder dat daarvoor eenduidige criteria zijn geformuleerd. Zie Tuerlinckx, TvP, 1996, p. 33-39, voor een overzicht van deze jurisprudentie alsmede voor een aantal voorbeelden uit de Belgische rechtspraak.

261. Simoens, RW, 1995-1996, p. 220; Parl. St., Senaat, 1993-1994, Memorie van Toelichting, nr. 980/1, p. 33-34; De Haas en Hartiief, Verkeersaansprakelijkheid, p. 70.

262. De Rode, in L'indemnisation automatique de certaines victimes d'accidents de la circulation, $p$. 84-85. Zie Claasens en Van Schoubroeck, in Verkeersaansprakelijkheid in Belgie en Nederland, p. 84-87 en Cornelis, RW, 1998-1999, p. 527-529, voor een discussie ten aanzien van de uitsluiting van de bestuurder zelf en van de bestuurder als zijnde de rechthebbende van een verkeersslachtoffer.

263. Bocken en Geers, TvP, 1996, p. 113 spreken van 'gedekte schade'.

264. Politierechtbank Hasselt, 23 februari 1996, O.M. en Somers/Leysen; Mega NV e.a., in Verkeersaansprakelijkheid in Belgiê en Nederland, p. 261-264: 'Het begrip schade aan de mens omvat naar het gevoelen van de rechtbank de medische kosten, het inkomstenverlies van de schadelijder en zijn morele schade'. 
het verkeersongeval, zoals slaap- en eetstoornissen, voor een vergoeding in aanmerking komen. ${ }^{265}$

De rechthebbenden van het slachtoffer kunnen vergoeding vorderen van de door hen geleden persoonlijke schade of 'terugkaatsende' schade. Wanneer het slachtoffer tengevolge van het verkeersongeval komt te overlijden, dan hebben zijn nabestaanden recht op bijvoorbeeld een vergoeding van de begrafeniskosten en van de economische schade als gevolg van het wegvallen van de inkomsten die het slachtoffer binnenbracht. Zowel het slachtoffer als zijn rechthebbenden hebben verder recht op een vergoeding van immateriële schade, zoals gederfde levensvreugde en andere pijn en smart. $^{266}$

Op basis van artikel 29 bis is geen vergoeding van zaakschade mogelijk. Een uitzondering hierop vormt de schade aan functionele prothesen zoals een kunstheup, het verlies van een kunstbeen of een gebit. ${ }^{267}$ Deze worden ingevolge paragraaf 1 lid 2 van artikel 29 bis als lichamelijke schade beschouwd. Het moet daarbij steeds gaan om een prothese 'die met het lichaam is verbonden', of om 'voorwerpen die onontbeerlijk zijn voor het behoorlijk kunnen functioneren'. ${ }^{268}$

Ingevolge artikel 29 bis paragraaf 1 lid 1 wordt de schade 'vergoed door de verzekeraar die de aansprakelijkheid dekt van de eigenaar, bestuurder of houder van bet motorrijtuig overeenkomstig deze wet'. Hieruit kan worden opgemaakt dat het niet van belang is wie de schade heeft veroorzaakt. Het gaat om een vergoedingsplicht aan de zijde van de aansprakelijkheidsverzekeraar. Daarnaast zijn ook de Staat en

265. Parl. St., Senaat, 1993-94, nr. 980/3, p. 13; Simoens, RW, 1994-1995, p. 118.

266. Parl. St., Senaat, 1993-1994, nr. $980 / 3$ p. 29 en nr. 980/1, p. 32. Tuerlinckx, TvP, 1996, p. 41; Cornelis, RW, 1998-1999, p. 526-527; De Haas en Hartlief, Verkeersaansprakelijkheid, p. 75-76.

267. In de rechtsleer worden ook brillen, gehoorapparaten, de rolstoel van een gehandicapte of de stok van een blinde beschouwd als een functionele prothese in de zin van artikel 29bis paragraaf 1 lid 2. Zie Denoel, in Bull. Ass. - De Verz. 1995, p. 72; Van de Sype, in Bull. Ass. - De Verz., 1995, p. 61-62; Claassens en Van Schoubroeck, VR, 1997, p. 361. Zie ook Politierechtbank te Kortrijk, 14 oktober 1998, TBH, 1999, p. 218-220, waarin het ging om schade aan een bril; Politierechtbank te Brugge, 9 november 1998, TBH, 1999, p. 220-221, waarin het schade aan een gebit betrof.

268. Parl. St., Kamer, 1993-94, nr. 1422/5, p. 3. Claassens en Van Schoubroeck, in Verkeersaansprakelijkheid in Belgie en Nederland, p. 97; Tuerlinckx, TvP, 1996, p. 39-41; De Haas en Hartlief, Verkeersaansprakelijkheid, p. 73-74; Engelhard en Van Maanen, Aansprakelijkheid voor verkeersongevallen, p. 43-44. Een aantal auteurs is van mening dat zaakschade eveneens op grond van artikel 29 bis moet worden vergoed, omdat in veel gevallen sprake zal zijn van een samenloop met lichamelijke schade. Zie Dalcq. J.T., 1994, p. 669; Bocken en Geers, TvP, 1996, p. 114. 
andere instellingen, die op grond van artikel 10 WAM-wet zijn vrijgesteld van de verplichte verzekering, tot vergoeding gehouden. ${ }^{269}$

Voor alle gevallen die worden beschreven in artikel 80 van de wet van 9 juli 1975 betreffende de Controle der Verzekeringsondernemingen, kan een beroep worden gedaan op het Gemeenschappelijk Waarborgfonds, zoals bij het ontbreken van een verzekering of een failliete verzekeraar. Een uitzondering op het voorgaande zijn de verkeersongevallen die door toeval (overmachtsituaties) zijn ontstaan. In deze gevallen blijft de WAM-verzekeraar vergoedingsplichtig. ${ }^{270}$

Wanneer twee of meerdere motorrijtuigen bij een verkeersongeval zijn betrokken, zijn de betrokken WAM-verzekeraars hoofdelijk ('in solidum') aansprakelijk voor de schade van het slachtoffer. De benadeelde kan daarbij naar keuze één van de betrokken WAM-verzekeraars aanspreken voor de totale omvang van de geleden scha$\mathrm{de}^{271}$

\subsection{DE ONVERSCHOONBARE FOUT}

In artikel 29 bis paragraaf 1 lid 5-7 wordt het begrip 'onverschoonbare fout' geregeld. Lid 5 is als volgt geformuleerd:

'Slachtoffers die een onverschoonbare fout hebben begaan die de enige oorzaak was van het ongeval, kunnen zich niet beroepen op de bepalingen van het eerste lid'.

Verkeersslachtoffers die een onverschoonbare fout hebben begaan die ook nog de enige oorzaak was van het ongeval hebben derhalve geen recht op schadevergoeding. Met de woorden 'enige oorzaak' wordt beoogd het slachtoffer een vergoeding te waarborgen wanneer zijn onverschoonbare fout samengaat met een fout van de bestuurder van het motorrijtuig, een fout van een derde, uitzonderlijke weersomstandigheden of de slechte toestand van de weg. ${ }^{272}$

269. Artikel 29bis paragraaf 1 lid 4.

270. Artikel 29 bis paragraaf 1 lid 3 WAM-wet.

271. Tuerlinckx, TvP, 1996, p. 41-45; Simoens, RW, 1995-1996, p. 220; Bocken en Geers, TvP, 1996, p. 111-113; Claasens en Van Schoubroeck, in Verkeersaansprakclijkheid in Beigie en Nederland, p. 87-89; Van de Sype, in Bull. Ass. - De Verz., 1995, p. 60-61; Comelis, RW, 1998 1999, p. 531-532; Denoell, in Bull. Ass. - De Verz., 1995, p. 87-89; Claasens en Van Schoubroeck, VR, 1997, p. 360-361; Decroës, RW, 2001, p. 1263-1265. De Haas en Hartlief, Verkeersaansprakelijkheid, p. 71-72.

272. Gedr. St., Kamer, 1993-94, nr. 1422/5, p. 8; Gedr. St., Senaat, 1994-95, nr. 1317/2, p. 6; Gedr. St., Senaat, 1993-94, nr. 980/3, p. 34; Simoens, RW, 1995-1996, p. 221 ; Bocken en Geers, TvP, 1996, p. 110-111; Tuerlinckx, TvP, 1996, p. 48; Claassens en Van Schoubrock, VR, 1997, p. 
Het begrip onverschoonbare fout, 'faute inexcusable', is overgenomen uit de 'loi Badinter'. De omschrijving van het begrip onverschoonbare fout is daarnaast rechtstreeks ontleend aan de uitleg die het Franse Hof van Cassatie daaraan heeft gegeven. ${ }^{273}$ Lid 6 van paragraaf 1 luidt:

'Enkel de opzettelijke fout ('la faute volontaire') van uitzonderlijke ernst, waardoor degene die ze begaan heeft zonder geldige reden wordt blootgesteld aan een gevaar waarvan hij zich bewust had moeten zijn, is onverschoonbaar'. ${ }^{274}$

Voor de concrete toepassing van 'de opzettelijke fout' is het volgens Simoens voldoende dat het slachtoffer de verkeersregels bewust heeft overtreden, zonder dat overigens sprake is van onoplettendheid. ${ }^{275}$ Tuerlinckx meent dat de 'faute volontaire' verkeerd is vertaald door 'opzettelijke fout' ('faute intentionelle') in plaats van een 'vrijwillige fout'. De opzettelijke fout impliceert volgens haar immers dat het slachtoffer het gevaar bewust heeft opgezocht. ${ }^{276}$ Cornelis stelt daarom dat opzet niet is vereist maar wel dat het slachtoffer uit vrije wil de fout beging. ${ }^{277}$

De vraag of een fout van een 'uitzonderlijke ernst' is wordt door Tuerlinckx, met een verwijzing naar de Franse rechtspraak, slechts in zeer uitzonderlijke gevallen bevestigend beantwoord. Het gaat daarbij met name om situaties waarin het slachtoffer zich aanwijsbaar roekeloos heeft gedragen of om verkeersongevallen waarbij het slachtoffer een zware verkeersovertreding heeft begaan. ${ }^{278}$

Met de voorwaarde dat de fout 'zonder geldige reden' moet zijn begaan, wordt volgens Simoens onder anderen de verkeersdeelnemer beschermd die zelf slachtoffer wordt van een verkeersongeval, terwijl hij op een zeer onzorgvuldige wijze uitvoering geeft aan de hulpverlening van een ander verkeersslachtoffer. ${ }^{279}$

361-362; De Haas en Hartlief, Verkeersaansprakelijkheid, p. 72-73; Engelhard en Van Maanen, Aansprakelijkheid voor verkeersongevallen, p. 39-40.

273. Dit blijkt ook uit de parlementaire behandeling van artikel $29 \mathrm{bis}$. Daarbij wordt verwezen naar de 11 arresten van de Franse Cour de Cassation van 20 juli 1987. Zie Parl. Hand., Senaat, 2 maart 1994, 1355; Parl. St., Senaat, 1993-94, nr. 980/3, p. 33 en 37; Bocken en Geers, TvP, 1996, p. 109-1 10; Simoens, RW, 1995-1996, p. 220; Denoêl, in Bull. Ass. - De Verz., 1995, p. 85-86.

274. De omschrijving die het Franse Hof van Cassatie daaraan in de arresten van 20 juli 1987 heeft gegeven luidt: 'Seule est inexcusable, la faute volontaire d'une exceptionnelle gravité, exposant sans raison valable son auteur à un danger, dont il aurait dû avoir conscience'. Zie daarover verder paragraaf 4.3 van hoofdstuk 1.

275. Simoens, RW, 1995-1996, p. 221.

276. Tuerlinckx, TVP, 1996, p. 50 en p. 52-53, met vourbeelden uit de Franse rechtspraak.

277. Comelis, RW, 1998-1999, p. 529.

278. Tuerlinckx, TvP, 1996, p. 53-54.

279. Simoens, RW, 1995-1996, p. 221; Tuerlinckx, TvP, 1996, p. 54-55. 
Bij de beoordeling van de vraag of het slachtoffer 'zich bewust had moeten zijn van bet gevaar' wordt naar aanleiding van de Franse jurisprudentie abstract nagegaan of het voor elk weldenkend persoon onmogelijk zou zijn geweest om zich te realiseren aan welk gevaar hij zich blootstelt. ${ }^{280}$ Dit komt volgens Cornelis neer op een tekortschieten in een algemene zorgvuldigheid ten aanzien van het gevaar. ${ }^{281}$ Volgens Tuerlinckx kan voornoemde formulering worden geconcretiseerd naar de persoonlijke omstandigheden van het slachtoffer, bijvoorbeeld met betrekking tot ouderen en gehandicapten die op grond van artikel 29 bis geen bijzondere bescherming ontvangen. ${ }^{282}$

Aan kinderen jonger dan 14 jaar kan geen onverschoonbare fout worden tegengeworpen, waardoor hun schade tengevolge van een verkeersongeval automatisch wordt vergoed. Lid 7 van paragraaf 1 luidt:

'Het bewijs van onverschoonbare fout is niet toegelaten ten aanzien van slachtoffers jonger dan 14 jaar'.

Bij de voorbereiding van artikel 29 bis werd gepoogd deze extra bescherming, naar Frans voorbeeld, uit te breiden tot personen ouder dan 70 jaar en personen die meer dan $80 \%$ gehandicapt zijn. De Minister vond echter dat dergelijke uitzonderingen teveel de indruk wekken dat deze personen onbekwaam zijn om aan het verkeer deel te nemen. Daarnaast was de Minister van mening dat voor deze personen in de praktijk een oplossing diende te worden gezocht, rekening houdend met de individuele omstandigheden. ${ }^{283}$

Met betrekking tot de onverschoonbare fout wordt door Cornelis gesteld dat deze binnen het Belgische rechtssysteem nooit de 'enige oorzaak' van een verkeersongeval kan zijn. Dit hangt volgens hem samen met de aanwezigheid van de 'equivalentietheorie', waarbinnen geen keuze kan worden gemaakt tussen de verschillende oorzaken die tot een verkeersongeval hebben geleid. In Frankrijk wordt daarentegen de theorie van de adequate oorzaak toegepast, waarbij in de woorden van Cornelis geldt dat:

'Wanneer tussen verschillende noodzakelijke maar voldoende (conditio sine qua non)voorwaarden, vereist om tot een welbepaald verkeersongeval te komen, wel (in tegenstelling tot de equivalentietheorie) een keuze kan worden gemaakt, zodat slechts ćén van die voorwaarden als adequate oorzaak wordt

280. Gedr. St., Senaat, 1993-94, nr. 980/3, p. 34. Tuerlinckx, TvP, 1996, p. 52 en 55.

281. Comelis, RW, 1998-1999, p. 529.

282. Tuerlinckx, TvP, 1996, p. 55-56.

283. Gedr. St., Kamer, 1993-94, nr. 1422/5, p. 13; nr. 1422/1, p. 1-2 en 4; nr. I422/3, p. 2. Zie Tuerlinckx, TvP, 1996, p. 47-48 en p. 56; Simoens, RW, 1995-1996, p. 221; Engelhard en Van Maanen, Aansprakelijkheid voor verkeersongevallen, p. 40-41. 
gekwalificeerd, wordt het - onder omstandigheden - wel mogelijk de onverschoonbare fout van het slachtoffer als enige schade-oorzaak aan te duiden'. ${ }^{284}$

\subsubsection{De onverschoonbare fout in de Belgische rechtspraak}

De voorwaarden voor het aannemen van een onverschoonbare fout aan de zijde van het slachtoffer dienen cumulatief vervuld te zijn, waarbij een dergelijke fout tevens de enige oorzaak van het ongeval moet zijn geweest. In de praktijk blijkt dat de aansprakelijkheidsverzekeraars zich hiervan niet altijd bewust zijn. Zo wordt bijvoorbeeld nog veel discussie gevoerd over gevallen waarin een slachtoffer onder invloed verkeerde of als passagier meerijdt met een dronken bestuurder of zijn veiligheidsgordel niet droeg. Daarnaast wordt het overtreden van bepaalde verkeersregels, zoals het rijden door rood licht of het zonder uitkijken een drukke weg oversteken, door verzekeraars gezien als een onverschoonbare fout. Claassens en Van Schoubroeck stellen dat in al deze gevallen geen onverschoonbare fout in de zin van artikel 29bis paragraaf 1 lid 5-6 kan worden aangenomen. ${ }^{285}$

In het kader van het begrip 'onverschoonbare fout' wordt door hen verwezen naar een drietal rechtelijke uitspraken, die echter nog betrekking hadden op de oude versie van artikel 29 bis waarin de onverschoonbare fout nog niet nader was omschreven. In een eerste uitspraak wordt de vraag of het slachtoffer een onverschoonbare fout heeft begaan min of meer genegeerd, gegeven 'de banaliteit van de fout'. Het betrof hier een fietser die op een fietspad in de verkeerde rijrichting ter hoogte van benzinestation in aanrijding kwam met een auto die net bij deze benzinepomp wilde wegrijden. $^{286}$

In een tweede geval was bij een studentenoptocht op de weg één van de studenten, die een andere studente op zijn rug droeg, aangereden door een auto die, gelet op de omstandigheden, een te hoge snelheid had. De rechter oordeelde dat geen sprake was van een onverschoonbare fout aan de zijde van het slachtoffer en gaf daarbij de volgende uitleg:

'Gelet op de omstandigheden van plaats en tijd en de wetmatigheid van massale volksconcentraties kan in casu, in hoofde van het slachtoffer geen sprake zijn van een vrijwillige en bijzonder zware fout. De rechtbank wenst erop te wijzen dat het duidelijk de intentie van de regelgever is geweest het begrip on-

284. Comelis, RW, 1998-1999, p. 529-530. Hiermee zijn volgens hem het 5e $\mathrm{tm} 7 \mathrm{~m}$ lid van artikel 29 bis dan ook 'gedoemd een dode letter te blijven'.

285. Claassens en Van Schoubroeck, in Verkeersaansprakelijkheid in Belgiê en Nederland, p. 95-96. Zie voor een overzicht van de rechtspraak inzake de onverschoonbare fout ook Van Schoubroeck, VanderSpikken, Jocque en Cousy, TvP, 1998, p. 324-325.

286. Politierechtbank Hasselt, 23 februari 1996, in Verkeersaansprakelijkheid in Belgie̋ en Nederland, p. 261-264. 
verschoonbare fout uiterst beperkt op te vatten en de mogelijkheden van inroeping ervan minimaal te houden'. ${ }^{287}$

Een derde casus, tenslotte, had betrekking op een aanrijding tussen een auto en een fietser, die met een walkman op, vanuit een zandweg, zonder uit te kijken de weg opreed en vlak voor de auto linksaf sloeg. De fietser wist dat de automobilist hem niet kon zien, maar reed toch zonder te stoppen de voorrangsweg op, waarbij hij de geldende voorrangsregels negeerde. De rechter oordeelde dat in dit geval sprake was van een onverschoonbare fout aan de zijde van de fietser met de overweging dat:

'De invoering van een bijzondere vergoedingsregeling in het voordeel van de zwakke weggebruiker niet kan betekenen dat deze weggebruiker zelfs niet de minst elementaire regels van voorzichtigheid heeft na te leven'.

Daarnaast beantwoordt het roekeloze rijgedrag van de fietser volgens de rechter aan de omschrijving die aan het begrip 'onverschoonbare fout' in het nieuwe artikel 29 bis is gegeven. ${ }^{288}$

Naar aanleiding van deze laatste beslissing wordt door Claassens en Van Schoubroeck opgemerkt dat van het slachtoffer verwacht mag worden dat deze zich bewust blijft van zijn verantwoordelijkheden in het verkeer. Daarbij moet volgens hen steeds op basis van de concrete omstandigheden worden beoordeeld of de criteria van de onverschoonbare fout zijn vervuld. De onderhavige uitspraak was daarnaast gebaseerd op de oude tekst van artikel 29bis, zodat de rechter volgens Claassens en Van Schoubroeck niet behoefde in te gaan op de vraag of de onverschoonbare fout van de fietser de enige oorzaak was van het ongeval. ${ }^{289}$

\subsection{HET VERHAALSRECHT VAN DE WAM-VERZEKERAAR}

In artikel 29bis wordt aan de WAM-verzekeraar en het Motorwaarborgfonds een verhaalsrecht toegekend op de aansprakelijke derde. Paragraaf 4 lid 1 luidt:

287. Politierechtbank Hasselt, 24 mei 1996, O.M. en Libens; Landsbond Liberale Mutualiteiten e.a./Haesevoets; N.V. Royale Belge, in Verkeersaansprakelijkheid in België en Nederland, p. 27l-275.

288. Politierechtbank Tumhout, 22 april 1997, Colin/R.V.S. Verzekeringen en Nationaal Verbond Socialistische Mutualiteiten/R.V.S. Verzekeringen, in Verkeersaansprakelijkheid in België en Nederland, p. 289-291 en in VKJ, 1997, 250.

289. Claassens en Van Schoubroeck, in Verkeersaansprakelijkheid in Belgiē en Nederland, p. 96-97, Zie in dat verband nog Politierechtbank Tumhout, 27 januari 1997, O.M. en Verbracken e.a.I Ruberecht; N.V. AG 1824, in Verkeersaansprakelijkheid in Belgie en Nederland, p. 282-288. Hierin overwoog de rechter 'dat zelfs wanneer in hoofde van de burgerlijke partij een onverschoonbare fout zou bewezen zijn, dit geen afbreuk zou doen aan haar recht op volledige vergoeding van de lichamelijke schade, vermits zij alleszins niet de enige oorzaak van het ongeval is geweest'. 
'De verzekeraar of het gemeenschappelijk waarborgfonds treden in de rechten van het slachtoffer tegen de in het gemeen recht aansprakelijke derden'.

Wanneer de WAM-verzekeraar de schade aan het verkeersslachtoffer heeft vergoed, kan hij de schade verhalen op degene die schuldig is aan het verkeersongeval. Dit subrogatierecht kan bijvoorbeeld worden uitgeoefend tegen een fietser die een bestuurder van een auto tot een uitwijkmanoeuvre dwingt, waarbij een andere fietser wordt aangereden en waarvan de schade door de WAM-verzekeraar van de bestuurder wordt vergoed. ${ }^{290}$ Daarnaast kan de WAM-verzekeraar op basis van artikel 16 lid 2 WAM-wet een contractueel verhaalsrecht uitoefenen tegen de eigen verzekeringsnemer of de verzekerde. ${ }^{291}$ In artikel 25 van de Modelpolis wordt hiervan een aantal voorbeelden opgesomd, zoals de schorsing van de dekking wegens het nietbetalen van de premie, alsmede het onbevoegd besturen of laten besturen van een motorrijtuig. ${ }^{292}$

\subsection{HET SUBROGATIERECHT VAN DE SOCIALE VERZEKERAARS}

Het verhaalsrecht van de sociale verzekeraar voor de schade van het verkeersslachtoffer is naar aanleiding van de invoering van artikel 29 bis beperkt tot enkele instellingen, namelijk de ziekteverzekeraar en de arbeidsongevallenverzekeraar. ${ }^{293}$

Ten behoeve van het verhaalsrecht van de arbeidsongevallenverzekeraar is in de Arbeidsongevallenwet een aantal aanvullende bepalingen opgenomen, waarmee een lacune werd opgevuld die was ontstaan met de invoering van artikel $29 \mathrm{bis}^{294}$ Artikel 46 en 47 van de Arbeidsongevallenwet hebben namelijk alleen betrekking op de samenloop tussen arbeidsongevallen en het aansprakelijkheidsrecht, waartoe ook verkeersongevallen werden gerekend. Door de invoering van artikel $48 \mathrm{bis}$ en 48 ter is het recht van subrogatie van de arbeidsongevallenverzekeraar in overeenstemming gebracht met artikel 29bis. Dit betekent dat wanneer een werknemer als fietser,

290. Zie Tuerlinckx, TvP, 1996, p. 58-62; Simoens, RW, 1995-1996, p. 222; Bocken en Geets, TvP, 1996, p. 114-116.

291. Dit verhaalsrecht wordt uitgewerkt in artikel 39 onder 4. van de Modelpolis. Zie Tuerlinckx, TVP, 1996, p. 59.

292. Claassens en Van Schoubroeck, in Verkeersaansprakelijkheid in België en Nederland, p. 101 103 en p. 257-258; Denoël, in Bull. Ass. - De Verz., 1995, p. 101-103; Claassens en Van Schoubroeck, VR, 1997, p. 362.

293. Zie Huys en Simoens, TSR, 1994, p. 237-245, voor een analyse van het subrogatierecht in het kader van het 'oude' artikel 29 bis.

294. Dit betreft de artikelen 48 bis en 48 ter ingevoerd bij artikel 8 van de sociale programmawet van 29 april 1996, Belgisch Staatsblad, 30 april 1996. Zie Bocken en Geers, TvP, 1996, p. 71, noot 6. Hiermee werd in de Arbeidsongevallenwet een nieuwe afdeling 6 bis opgenomen getiteld: 'Samenloop met de vergoeding toegekend overeenkomstig artikel $29 \mathrm{bis}$ van de wet van 21 november 1989 betreffende de verplichte aansprakelijkheidsverzekering inzake motomijtuigen'. Bocken en Geers, TvP, 1996, p. 81-82. 
voetganger of passagier tijdens het werk of op weg van en naar het werk schade lijdt tengevolge van een verkeersongeval, de arbeidsongevallenverzekeraar, die deze schade in eerste instantie vergoed, hiervoor regres kan uitoefenen bij de WAM-verzekeraar van het betrokken motorrijtuig. ${ }^{295}$

Op basis van de Belgische Ziektewet ${ }^{296}$ is het grootste deel van de Belgische bevolking verzekerd tegen medische kosten tengevolge van ziekte of invaliditeit. In de Ziektewet is eveneens een regresrecht opgenomen, waarbij geldt dat de toepassing van de Arbeidsongevallenwet voorrang heeft op de vergoedingen die in het kader van Ziektewet worden uitgekeerd. ${ }^{297}$ Artikel 136 paragraaf 2 van de Ziektewet bepaalt dat de ziekteverzekeraar voor de uitkeringen aan zijn verzekerde een subrogatierecht toekomt niet enkel op grond van het gemene recht, maar ook op basis van elke andere Belgische of buitenlandse wetgeving. Deze algemene subrogatieregel levert volgens de rechtsleer ook een verhaal op tegen de WAM-verzekeraar die, in het licht van artikel $29 \mathrm{bis,} \mathrm{de} \mathrm{schade} \mathrm{van} \mathrm{het} \mathrm{niet-gemotoriseerde} \mathrm{verkeersslachtoffer}$ dient te vergoeden. Dit betekent dat wanneer een fietser, voetganger of passagier bij een verkeersongeval gewond raakt, zijn sociale verzekeraar de naar aanleiding daarvan uitgekeerde vergoedingen via een regresvordering kan verhalen op de WAMverzekeraar van het betrokken motorrijtuig. ${ }^{298}$

\subsection{DE HANDHAVING VAN HET AANSPRAKELIJKHEIDSRECHT}

Met de invoering van artikel 29 bis zijn niet alle vorderingen tengevolge van een verkeersongeval afgedekt. Dit volgt uit paragraaf 5 van artikel 29bis:

'De regels betreffende de burgerrechtelijke aansprakelijkheid blijven van toepassing op alles wat niet uitdrukkelijk bij dit artikel wordt geregeld'.

In de Belgische literatuur wordt de volgende opsomming gegeven van de gevallen die buiten artikel 29 bis blijven en die derhalve via de foutaansprakelijkheid van artikel $1382 \mathrm{BW}$ dienen te worden geregeld.

295. Bocken en Geers, TvP, 1996, 85-88.

296. Wet betreffende de verplichte verzekering voor geneeskundige verzorgingen en uitkeringen van 9 augustus 1963, bij Koninklijk Besluit van 14 juli 1994 gecoördineerd, artikel 37 paragraaf 1.

297. Artikel 136 paragraaf 2 lid 4-8 van de Ziektewet.

298. Bocken en Geers, TvP, 1996, p. 89-91; Claassens en Van Schoubroeck, VR, p. 362-363; Claassens en Van Schoubroeck, in Verkeersaansprakelijkheid in Belgie̋ en Nederland, p. 103104; Decroes, RW, 2001, p. 1265-1267; De Haas en Hartlief, Verkeersaansprakelijkheid, p. 8889; Engelhard en Van Maanen, Aansprakelijkheid voor verkeersongevallen, p. 62-63. Zie ook Politierechtbank Hasselt, 24 mei 1996, in Verkeersaansprakelijkheid in Belgie en Nederland, p. 271-275, waarin de WAM-verzekeraar werd veroordeeld tot terugbetaling van de door het ziekenfonds aan het slachtoffer uitgekeerde bedragen. 
1. De schade die een bestuurder van een motorrijtuig lijdt. In artikel 29 bis paragraaf 2 wordt gesteld dat een bestuurder geen beroep kan doen op de bepalingen in dit artikel; ${ }^{299}$

2. De vergoeding van zaakschade, ook van de niet-gemotoriseerde weggebruiker (schade aan kleding of fiets). Paragraaf 1 lid 1 spreekt van 'lichamelijke letsels of het overlijden' en 'met uitzondering van de stoffelijke schade';

3. De schade bij ongevallen tussen niet-gemotoriseerde verkeersdeelnemers;

4. De schade die door het niet-gemotoriseerde verkeer, de fietser, de voetganger of de passagier wordt veroorzaakt;

5. De regresvorderingen van instellingen niet zijnde een arbeidsongevallenverzekeraar of ziekteverzekeraar; ${ }^{300}$

6. De vorderingen van de WAM-verzekeraar tegen de aansprakelijke derde; en

7. De vaststelling van de schade, de begroting van de schade en de wijze van schadevergoeding. ${ }^{301}$

\section{De juridische grondslag van de Belgische regeling}

In paragraaf 1 lid 8 van artikel 29 bis wordt gesteld dat:

'Deze vergoedingsplicht wordt uitgevoerd overeenkomstig de wettelijke bepalingen betreffende de aansprakelijkheidsverzekering in het algemeen en de aansprakelijkheidsverzekering voor motorrijtuigen in het bijzonder, voor zover daarvan in dit artikel niet wordt afgeweken'.

De Belgische wetgever trachtte, zonder daarover zelf een uitspraak te doen, hiermee een einde te maken aan de discussie in de doctrine ten aanzien van de grondslag van artikel 29 bis. ${ }^{302}$ Gebleken is echter dat binnen de rechtsleer deze grondslag nog steeds niet eenduidig wordt geïnterpreteerd. ${ }^{30.3}$ Daarbij ligt de nadruk op de vraag of artikel $29 \mathrm{bis}$, gegeven de opname in de WAM-wet, betrekking heeft op aansprakelijkheid of dat met dit artikel een bijzondere regeling van verzekering wordt gecreeerd.

299. Zie voor kritiek op deze uitsluiting onder anderen: Dalcq, J.T., 1994, 669-670; Fagnart, R.G.A.R., 1994, 12388, nr. 31.

300. Bocken en Geers, TvP, 1996, p. 84-85 en p. 91-93.

301. Zie voor een overzicht van de handhaving van de burgerlijke aansprakelijkheid ten aanzien van verkeersongevallen: Bocken en Geers, TvP, 1996, p. 116-117 en p. 125-126; Simoens, RW, 1995-1996, p. 222-223; Tuerlinckx, TvP, 1996, p. 57-58. Claassens en Van Schoubroeck, in Verkeersaansprakelijkheid in Belgiè en Nederland, p. 89-91; De Haas en Hartlief, Verkeersaansprakelijkheid, p. 74

302. Schoorens, R.G.A.R., 1995, 12443, p. 19; Claassens en Van Schoubroeck, VR, 1997, p. 359.

303. Hierbij dient te worden opgemerkt dat deze discussie zowel betrekking heeft op de eerste versie van artikel 29 bis van 30 maart 1994 als op tweede versie van artikel 29 bis van 13 april 1995 , waarbij in de eersite versie paragraaf 1 lid 8 nog niet was opgenomen. 
Bocken en Geers menen dat met artikel 29 bis 'een wettelijke persoonsverzekering met een indemnitair karakter ten behoeve van voetgangers, fietsers en passagiers' is ingevoerd, gebaseerd op de aansprakelijkheidsverzekering van de WAM-wet. ${ }^{304} \mathrm{Si}$ moens spreekt van een 'persoonsverzekering met een indemnitair karakter', zijnde 'een rechtstreekse verzekering met een beding ten behoeve van derden, namelijk de passagiers, de voetgangers en de fietsers aan wie eventueel schade wordt berokkend door het motorrijtuig en die, buiten elk aansprakelijkheidsverband om, de eigenlijke verzekerden zijn'. ${ }^{305}$ Tuerlinckx leidt uit de formulering van paragraaf 1 lid 8 af dat artikel 29 bis gelet op zijn structuur als een aansprakelijkheidsverzekering moet worden beschouwd in de zin van de artikelen 77-89 van de Verzekeringswet van 25 juni 1992. Dit betekent volgens haar dat het verkeersslachtoffer voor zijn schade, op grond van artikel 12 WAM-wet, een rechtstreekse vordering heeft op de WAMverzekeraar van de bestuurder van het motorrijtuig of op het Gemeenschappelijk Motorwaarborgfonds. ${ }^{306}$

Met name in de Franstalige Belgische doctrine wordt de opvatting gehuldigd dat artikel 29 bis als een aansprakelijkheidsverzekering moet worden beschouwd, die is gebaseerd op een regel van objectieve aansprakelijkheid. Deze regeling wordt daarbij gezien als een hervorming van de aansprakelijkheidsregels van artikel 1382-1386 BW met betrekking tot verkeersongevallen. De objectieve aansprakelijkheid is verder direct gekoppeld aan de verplichte motorrijtuigverzekering, waardoor de regeling het karakter van een 'assurance oblige' krijgt. Deze opvatting wordt uitgewerkt door te stellen dat de aansprakelijkheidsverzekeraar vergoedingsplichtig is, dat artikel 29 bis in de WAM-wet is opgenomen en dat artikel 29bis paragraaf 1 lid 8 bepaald dat de vergoedingsplicht overeenkomstig de regels van de aansprakelijkheidsverzekering dient te worden uitgevoerd. ${ }^{307}$

Cornelis tenslotte, meent dat artikel 29 bis een objectieve aansprakelijkheid vestigt ten laste van de WAM-verzekeraar, het Gemeenschappelijk Waarborgfonds en de instellingen die op grond van artikel 10 WAM-wet zijn vrijgesteld van de verplichte verzekering. Deze instanties worden door hem gezien als schuldenaren op wie in het

304. Bocken en Geers, TvP, 1996, p. 118.

305. Simoens, RW, 1995-1996, p. 219. Zie ook Fredericq. Bulletin d'information de l'AIDA, 1994, p. 70-71, die een gelijkaardige mening als Simoens, Bocken en Geers is toegedaan. 7ic voor een kritiek hierop: Schoorens, R.G.A.R., 1995, 12443, p. 1-20, die artikel 29 bis karakteriseert als een autonome wettelijke verbintenis.

306. Tuerlinckx, TvP, 1996, p. 9-10.

307. Zie Dalcq, R.G.A.R, nr. 7, 1995, 12484-1/12484-4; Dubuisson, in L'indemnisation automatique de certaines victimes d'accidents de la circulation, p. 13-18; Fagnart, R.G.A.R., 1994, 12388-5. 
kader van artikel 29 bis een wettelijke vergoedingsplicht rust om de schade te vergoeden die tengevolge een verkeersongeval wordt geleden. ${ }^{308}$

Uit de parlementaire geschiedenis naar de totstandkoming van artikel 29 bis blijkt dat niet gekozen is voor de invoering van een objectieve aansprakelijkheid, maar voor een vergoedingssysteem via de aansprakelijkheidsverzekering van het motorrijtuig. ${ }^{309}$ Hieruit kan worden opgemaakt dat artikel 29 bis betrekking heeft op een quasi-automatische schadeloosstelling van de fietser, voetganger of passagier, binnen het raamwerk van de aansprakelijkheidsverzekering voor motorrijtuigen. De regeling krijgt daarmee zowel het karakter van een aansprakelijkheids- als van een vergoedingssysteem, waarbij de opname in de WAM-wet enige verwarring oproept. Hoewel het in beginsel gaat om een vergoeding van de schade van niet-gemotoriseerde verkeersslachtoffers, wordt voor een deel het aansprakelijkheidsrecht weer binnengehaald met de begrippen 'onverschoonbare fout' en de 'betrokkenheid' van het motorrijtuig. Aan de andere kant kan worden gesteld dat artikel $29 \mathrm{bis}$ een risicoaansprakelijkheid vestigt op de bestuurder, eigenaar of houder van een motorrijtuig. De bestuurder van een motorrijtuig zal, gegeven de uitleg van de begrippen 'betrokkenheid' en 'onverschoonbare fout', bijna altijd aansprakelijk zijn. De vergoedingsplicht rust echter rechtstreeks op de motorrijtuigverzekeraar, waardoor de bestuurder of houder als de eventueel aansprakelijke persoon wordt gepasseerd. ${ }^{310}$

\section{Conclusie}

Op basis van de gegeven analyse van de Belgische verkeersaansprakelijkheid kan worden geconcludeerd dat vóór 1995 de vergoeding van verkeersschade grotendeels werd geregeld door de foutaansprakelijkheid van artikel $1382 \mathrm{BW}$, waarbij de fietser en voetganger en de bestuurder van een motorrijtuig als min of meer gelijkwaardige verkeersdeelnemers werden beschouwd. Wanneer een niet-gemotoriseerde verkeersdeelnemer een ongeval mede had veroorzaakt was deze, voor (een deel van) zijn schade, veelal aangewezen op eigen eerste partij vergoedingsbronnen.

Sinds 1995 geldt dat een bestuurder van een motorrijtuig via zijn aansprakelijkheidsverzekering in bijna alle gevallen verantwoordelijk wordt gehouden voor de

308. Zie Comelis. RW, 1998-1999, p. 534-537 voor een uitwerking van deze opvatting. Zie ook Huys en Simoens. TSR, 1994, p. 234-236, met betrekking tot het 'oude' artikel 29 bis.

309. De aanvankelijk voorgestelde nieuwe regeling in artikel 1385 bis BW werd immers gewijzigd in die van artikel 29 bis van de WAM-wet. Parl. St., Senaat, 1993-94, 980/3, p. 22, 24 en 40. Zie Bocken en Geers, TvP, 1996, p. 81; Faure en Harlief, VR, 1995, p. 258, alsmede paragraaf 3 van dit hoofdstuk.

310. Zie meer uitvoerig over de grondslagdiscussie van artikel 29bis: Bocken en Geers, TvP, 1996, p. 118-123; Schoorens, R.G.A.R., 1995, 12443/1-10; Faure en Hartlief, VR, 1995, p. 257-261; Comelis, RW, 1998-1999, p. 532-534. 
schade van de niet-gemotoriseerde verkeersdeelnemer. Artikel 29 bis staat, samen met de aansprakelijkheidsverzekering voor motorrijtuigen en het Gemeenschappelijk Waarborgfonds, garant voor een volledige schadevergoeding van deze verkeersslachtoffers. De bestuurder van een motorrijtuig kan geen beroep doen op artikel $29 \mathrm{bis}$ en is voor de vergoeding van zijn schade aangewezen op de foutaansprakelijkheid van artikel $1382 \mathrm{BW}$, de beschikbare sociale verzekeringen en een eventueel zelf af te sluiten eerste partij schadeverzekering. ${ }^{311}$

De vraag hoe artikel 29 bis in de praktijk zal werken is nog niet eenduidig te beantwoorden. Claasens en Van Schoubroeck stellen naar aanleiding van hun onderzoek dat de bekendheid met artikel 29 bis bij de organisaties die daarmee in de praktijk te maken krijgen en ook bij het grote publiek nog vrij gering is. Daarnaast blijkt dat de opgelegde vergoedingsplicht van de WAM-verzekeraar zonder bewijs van schuld nog zeer gevoelig ligt, dit in het licht van de traditionele foutaansprakelijkheid waarbij iemand schuldig moet zijn aan het ongeval. Verder blijven met name advocaten voor een aansprakelijkheidsverdeling pleiten. ${ }^{3 / 2}$ Claasens en Van Schoubroeck wijzen er op dat artikel 29 bis vooral om budgettaire redenen is ingevoerd, namelijk om de lasten van de sociale zekerheid te verschuiven naar de motorrijtuigverzekeraars. Ook stellen zij vast dat er een onvoldoende maatschappelijk debat is geweest voorafgaande aan de invoering van artikel 29 bis. $^{313}$

In het kader van artikel 29bis kan de vraag worden gesteld waarom, met een verwijzing naar de Franse 'loi Badinter', de begrippen 'onverschoonbare fout' en 'betrokkenheid' in deze regeling zijn opgenomen. Hiermee wordt immers toch weer een aantal verweermiddelen voor de WAM-verzekeraar ingebracht. Ondanks de strikte ('faute inexcusable') respectievelijk ruime ('implication') interpretatie van het Franse Hof van Cassatie, blijven deze begrippen de Franse rechtspraak bezighouden. Ook de omschrijving die in artikel 29bis paragraaf 1 lid 6 aan het begrip 'onverschoonbare fout' is gegeven zal tot problemen kunnen leiden.

Naast voornoemde juridische bezwaren kunnen ook vanuit rechtseconomisch perspectief kanttekeningen worden geplaatst bij de regeling van artikel $29 \mathrm{bis}$. Zo is bijvoorbeeld de vergoedingsplicht van de WAM-verzekeraar gegeven wanneer het verzekerde motorrijtuig betrokken raakt bij een verkeersongeval met een niet-gemotoriseerde. Dit betekent dat het persoonlijk gedrag en de eventuele fout van de automobilist geen rol meer speelt voor de vraag of op de WAM-verzekeraar een vergoedingsplicht rust voor de schade van de niet-gemotoriseerde. Samen met een strikte

311. Bocken en Geers, TvP, 1996, p. 127-128.

312. Claassens en Van Schoubroeck, in Verkeersaansprakelijkheid in België en Nederland, p. 78 en 84.

313. Claassens en Van Schoubroeck, in Verkeersaansprakelijkheid in Belgiè en Nederland, p. 101; Faure en Hartlief, VR, 1995, p. 257. 
interpretatie van de fout van het slachtoffer ontstaat een stelsel waarin de slachtofferbescherming overheerst ten opzichte van de preventie van verkeersongevallen, een onderwerp dat samen met de compensatie centraal staat in onderhavig onderzoek. De mogelijke gevolgen van deze regeling voor het gedrag van automobilisten en niet-gemotoriseerde verkeersdeelnemers is voorwerp van verder onderzoek. ${ }^{314}$

De Belgische wetgever heeft recent een wetswijziging in verband met artikel 29 bis ingevoerd. ${ }^{315}$ In de eerste plaats wordt het bereik van artikel 29 bis uitgebreid naar motorrijtuigen die gebonden zijn aan spoorstaven, ${ }^{316}$ waardoor alleen nog de strikt private terreinen van deze regeling zijn uitgezonderd. In de tweede plaats wordt in lid 1 de bestuurder van een motorrijtuig uitdrukkelijk van de bescherming van artikel 29 bis uitgesloten. In de derde plaats wordt naast de personenschade ook de kledingschade van het slachtoffer vergoed. In de vierde plaats wordt artikel $29 \mathrm{bis}$ ook van toepassing verklaard indien de bestuurder de schade opzettelijk heeft veroorzaakt.

De belangrijkste wijziging is dat lid 5-7 van artikel $29 \mathrm{bis}$, voorheen de regeling van de 'onverschoonbare fout', als volgt is vervangen:

'Slachtoffers die ouder zijn dan 14 jaar en het ongeval en zijn gevolgen hebben gewild, kunnen zich niet beroepen op de bepalingen van het eerste lid'.

Deze bepaling is veel strikter dan die van de 'onverschoonbare fout' en het lijkt erop dat alleen nog bij gedragingen van het slachtoffer die in buurt van zelfmoord komen het recht op schadevergoeding vervalt. ${ }^{317}$ Daarmee wordt artikel 29 bis vanuit het oogpunt van slachtofferbescherming verder geperfectioneerd en is met deze regeling in feite een verkeersverzekering voor de schadevergoeding van zwakke weggebruikers gecreëerd.

314. Zie hoofdstuk 15 voor een toetsing van deze regeling aan de uitkomsten van het rechtseconomisch en empirisch onderzoek die in respectievelijk deel II en III aan de orde komen.

315. Belgisch Staatsblad, 21 februari 2001. Zie ook de Belgische Kamer van Volksvertegenwoordigers, DOC. 50 02 10/001-007 (1999-2000); Parlementaire handelingen Senaat 2-478/1-4 (20002001). Zie daarover Simoens, RW, 2001, p. 1577-1586.

316. De verplichting tot schadevergoeding berust dan ingevolge het nieuwe lid 2 van artikel 29 bis op de eigenaar van het motorrijtuig.

317. Zie de toelichting bij het wetsvoorstel van 29 oktober 1999 in DOC $50210 / 001$ (1999-2000) p 5-6. 


\section{Hoofdstuk 3: De Nederlandse verkeersaansprakelijkheid}

\section{Inleiding}

Op 26 november 1997 is in Nederland door de toenmalige Minister van Justitie een wetsvoorstel verkeersongevallen bij de Tweede Kamer aangeboden. ${ }^{318}$ Dit voorstel behelst de vestiging van een risicoaansprakelijkheid van de bestuurder of houder van een motorrijtuig voor de schade van de fietser, voetganger en passagier. ${ }^{319}$ Verder is de werkgever risicoaansprakelijk voor de schade die zijn bestuurder-werknemer lijdt tengevolge van een verkeersongeval. ${ }^{320}$ Mede als gevolg van de parlementsverkiezingen in mei 1998 en het aantreden van een tweede 'paars' kabinet bleef de behandeling van dit wetsvoorstel vooralsnog achterwege. Inmiddels heeft de huidige Minister van Justitie Korthals bij brief aan de Tweede $\mathrm{Kamer}^{321}$ het wetsvoorstel van zijn ambtsvoorganger formeel ingetrokken. In dezelfde brief heeft hij globaal zijn eigen ideeën omtrent een eventueel door hem in te dienen wetsvoorstel uitgewerkt. ${ }^{322}$

In dit hoofdstuk wordt een globaal overzicht geschetst van de Nederlandse verkeersaansprakelijkheid, zoals deze zich de afgelopen decennia, tot aan de indiening van het zojuist genoemde wetsvoorstel, heeft ontwikkeld. Daarbij is gekozen voor een opzet waarin de problematiek van de verkeersaansprakelijkheid vanuit drie invalshoeken wordt benaderd. In een inleidende paragraaf 2 zal allereerst worden ingegaan op de rol van artikel 6:162 BW bij verkeersongevallen, waarna in paragraaf 3 de jurisprudentie van de Hoge Raad ten aanzien van artikel 185 WVW (oud: $31 \mathrm{WVW}$ ) wordt weergegeven. Een tweede invalshoek zal in paragraaf 4 aan de orde komen en heeft betrekking op de discussie binnen de doctrine ten aanzien van de verkeersaansprakelijkheid. Daarbij zal in het bijzonder aandacht worden besteed aan de voorstellen voor een verkeersverzekering van Bloembergen en Van Wassenaer van Catwijck die door hen in de afgelopen decennia naar voren zijn gebracht. ${ }^{323}$ Een derde invalshoek tenslotte hangt samen met de initiatieven die door de wetgever zijn genomen. In dat kader zal in paragraaf 5 eerst beknopt aandacht worden besteed aan

318. Vaststelling en invoering van afdeling 8.14.1 (verkeersongevallen) van het Burgerlijk Wetboek, Tweede Kamer, 1997-1998, 25 759, nr. 1-3.

319. Artikel 8:1203-1204 BW.

320. Artikel 8:1204 BW.

321. Brief van 16 juni 1999, TK 1998-1999, 25 759, nr. 5 (H). Zie ook NJB, 1999, p. 1292-1293; Vaststelling van de begroting van de uitgaven en de ontvangsten van het Ministerie van Justitie voor het jaar 1998, TK 1997-1998, 25600 VI, nr. 74.

322. TK 1998-1999, 25759 , nr. 5 (H), p. 2-6.

323. Deze 'altematieve' voorstellen zullen een belangrijke rol vervullen bij de toetsing van de Nederlandse verkeersaansprakelijkheid aan de economische theorie en het empirisch onderzoek (hoofdstuk 15). 
twee rapporten van de Studiegroep Verkeersaansprakelijkheid en de Notitie Verkeersaansprakelijkheid. Daarna worden in paragraaf 6 het wetsvoorstel van 26 november 1997 en de plannen van Korthals op een aantal hoofdlijnen beschreven, waarbij ook aandacht wordt besteed aan het commentaar van de doctrine op deze voorstellen. Dit hoofdstuk zal in paragraaf 7 worden afgesloten met een aantal concluderende opmerkingen.

\section{De toepassing van artikel 6:162 BW (oud: $1401 \mathrm{BW}$ ) bij verkeersongevallen}

Het uitgangspunt in de Nederlandse verkeersaansprakelijkheid is dat de schade tengevolge van een verkeersongeval wordt vergoed op basis van de schuldaansprakelijkheid van artikel 6:162 BW. Ondanks de aanwezigheid van de bijzondere regeling in artikel $185 \mathrm{WVW}$ is het regime van artikel 6:162 BW nog altijd van toepassing op ongevallen tussen motorrijtuigen onderling, fietsers onderling en ongevallen tussen fietsers en voetgangers.

Wanneer bijvoorbeeld twee motorrijtuigen (A en B) met elkaar in botsing komen, dienen de inzittenden van motorrijtuig $A$ voor hun geleden schade de bezitter of houder van motorrijtuig B aan te spreken op grond van onrechtmatige daad. De vereisten voor onrechtmatigheid in het verkeer hebben betrekking op a) een inbreuk op een recht (beschadigen van een zaak, toebrengen van letsel of veroorzaken van overlijden), b) het handelen in strijd met een wettelijke plicht (de overtreding van een verkeersregels) en c) een handelen in strijd met de maatschappelijke zorgvuldigheid (gevaarzettend rijgedrag). ${ }^{324}$ Verder dient door de benadeelde te worden aangetoond dat de veroorzaker van de schade schuld heeft aan het ongeval, hetgeen inhoudt dat de onrechtmatige daad aan de schadeveroorzaker kan worden toegerekend. Daarvan kan ook sprake zijn indien het gedrag van de schadeveroorzaker te wijten is aan een oorzaak die krachtens de wet of de verkeersopvattingen voor de rekening van de veroorzaker kont. ${ }^{325}$

De schadeveroorzaker kan een beroep doen op overmacht, het ontbreken van subjectieve schuld in de zin van verwijtbaarheid, waarvoor hij feiten en omstandigheden dient te stellen. Wanneer een aangesproken bestuurder bijvoorbeeld een vergissing heeft gemaakt in een lastige verkeerssituatie, die de benadeelde bestuurder door zijn eigen rijgedrag in het leven heeft geroepen (error in extremis) kan dat onder omstan-

324. Elzas, Handboek Schaderegeling Motorrijtuigen, Aansprakelijkheid wegens onrechtmatige daad, $211-3 \mathrm{vm} 211-6$.

325. Bij een bestuurder die pas zijn rijbewijs heeft gehaald en door onervarenheid een verkeersongeval veroorzaakt, ontbreekt wellicht de verwijtbaarheid, maar op grond van de verkeersopvattingen dient het ongeval toch aan hem te worden toegerekend. Zie Elzas, Handboek Schaderegeling Motorijtuigen, 211-6 t/m 211-8. 
digheden een geslaagd beroep op overmacht opleveren. Wanneer een inzittende van een motorrijtuig een bestuurder van een (ander) motorrijtuig aansprakelijk stelt, zal de aangesproken bestuurder voor een geslaagd beroep op overmacht aannemelijk moeten maken dat hem rechtens geen enkel verwijt treft. ${ }^{326}$

Indien de inzittenden van bijvoorbeeld motorrijtuig A niet slagen in het bewijs van het maatschappelijk onbetamelijke gedrag van de bestuurder van motorrijtuig B of zij hebben eigen schuld aan het ongeval, ${ }^{327}$ dan zullen de slachtoffer-inzittenden in motorrijtuig A hun schade geheel of gedeeltelijk zelf moeten dragen. ${ }^{328}$

\section{De ontwikkeling van artikel 185 WVW 1994 (oud: 31 WVW)}

Bij de invoering van de Wegenverkeerswet van 1951 is in artikel $31^{329}$ een bijzondere regeling opgenomen voor verkeersongevallen waarbij door motorrijtuigen schade wordt toegebracht aan niet-gemotoriseerde verkeersdeelnemers. ${ }^{330}$ Artikel 31 is in de Wegenverkeerswet van $1994^{331}$ vervangen door artikel 185 . Het eerste lid van dit artikel luidt:

'Indien een motorrijtuig waarmee op een weg wordt gereden, betrokken $[\mathrm{MvD}]$ is bij een verkeersongeval waardoor schade wordt toegebracht an, niet door dat motorrijtuig vervoerde, personen of zaken, is ... de eigenaar van het motorrijtuig of - indien er een houder van het motorrijtuig is, de houder verplicht om die schade te vergoeden, tenzij aannemelijk is dat het ongeval te wijten is aan overmacht, daaronder begrepen het geval dat het is veroorzaakt

326. Elzas, Handboek Schaderegeling Motorrijtuigen, 211-9 en 21 1-26a t/m 211-28. Zie ook HR 15 januari 1993, NJ 1993, 568 (Puts/Ceha).

327. Het niet dragen van een autogordel of het als passagier meerijden met een dronken bestuurder kan bijvoorbeeld tot een vermindering van de toe te kennen schadevergoeding leiden. Zie bijvoorbeeld HR 12 oktober 1990, NJ 1992, 620.

328. Zie over (de gevolgen van) verkeersongevallen op basis van het regime van artikel 6:162 $\mathrm{BW}$ (oud: $1401 \mathrm{BW}$ ) onder anderen: Elzas, Handboek Schaderegeling Motorrijtuigen, 211-1 $\mathrm{dm} 211$. 38; C.C. van Dam, LSA 1998, p. 23-45; Polak, Inleiding tot het wegenverkeersrecht, 1987; C.C. van Dam, VR, 1985, p. 261-264; C.C. van Dam, Aansprakelijkheidsrecht, p. 278-280.

329. Dit artikel diende ter vervanging van artikel 25 van de Motor- en Rijwielwet uit 1905. Zie hierover: Engelhard en Van Maanen, Aansprakelijkheid voor verkeersongevallen, p. 14-16; Bouman, VR, 1987, p. 85; Clausing, TvP, 1978, p. 1019-1021.

330. Lid 1 van artikel 31 WVW luidt: Indien door een botsing, aan- of overrijding met een motorrijtuig, waarmede op een weg wordt gereden, schade wordt toegebracht aan, niet door dat motorrijtuig vervoerde, personen of zaken, is, behoudens de beperking in het vijfde lid, de eigenaar van het motorrijtuig of, indien er een houder van het motorrijtuig is, de houder verplicht om die schade te vergoeden, tenzij aannemelijk is dat die botsing- aan-of overrijding is te wijten aan overmacht, daaronder begrepen het geval dat zij is veroorzaakt door iemand, voor wie onderscheidenlijk de eigenaar of de houder niet aansprakelijk is. Staatsblad, 1994, nr. 475. Deze wet is op 1 januari 1995 van kracht geworden. 
door iemand, voor wie onderscheidenlijk de eigenaar of de houder niet aansprakelijk is'. ${ }^{332}$

Vanaf het begin van de jaren '70 van de vorige eeuw is door de Hoge Raad in een reeks van arresten uitleg gegeven aan artikel $185 \mathrm{WVW}$ ( $31 \mathrm{WVW}$ oud). In deze paragraaf zal een overzicht worden gegeven van de jurisprudentie van de Hoge Raad. Daarbij ligt de nadruk op de begrippen overmacht, dat verband houdt met de vestiging van aansprakelijkheid, en eigen schuld, ${ }^{333}$ van belang bij bepaling van de omvang van de vergoedingsplicht.

Opgemerkt kan worden dat met name sinds het begin van de jaren ' 90 van de vorige $e^{2 e u w}{ }^{334}$ de ontwikkeling in de rechtspraak van de Hoge Raad heeft geleid tot een onderscheid tussen niet-gemotoriseerden beneden 14 jaar en boven 14 jaar. Dit komt vooral tot uiting bij de begrippen overmacht en eigen schuld, waaraan sinds 1990 met name ten aanzien van kinderen beneden 14 jaar een dermate beperkte uitleg is gegeven dat daarop vrijwel geen beroep meer mogelijk is. ${ }^{335}$

In paragraaf 3.1 zal een aantal algemene criteria voor een beroep op overmacht worden opgesomd en uitgewerkt aan de hand van een aantal casusposities die aan het oordeel van de Hoge Raad werden onderworpen. In paragraaf 3.2 volgt een overzicht van de jurisprudentie in het kader van de eigen schuld bij ongemotoriseerden ouder dan 14 jaar. In paragraaf 3.3 zullen overmacht en de eigen schuld bij kinderen beneden 14 jaar worden behandeld. Tenslotte zal in paragraaf 3.4 aandacht worden besteed aan de positie van de regresnemende verzekeraars.

\subsection{OVERMACHT IN DE ZIN VAN ARTIKEL 185 WVW (31 WVW OUD): ALGEMEEN}

Een eigenaar of houder van een motorrijtuig is op grond van artikel 185 WVW (31 oud) aansprakelijk voor de schade van een niet-gemotoriseerde verkeersdeelnemer, tenzij hij overmacht aannemelijk kan maken. In 1942 bepaalde de Hoge Raad reeds dat een gebrek aan het motorrijtuig geen overmacht oplevert, ook wanneer aan de

332. Zie Van Wassenaer van Catwijck, VR, 1995, p. 197-198; Hartlief, TvP, 1996, p. 1285-1288; De Haas en Hartlief, Verkeersaansprakelijkheid, p. 160-162.

333. In 1992 is bij de invoering van het (N)BW artikel 31 WVW lid 6, waarin de eigen schuld van het slachtoffer was geregeld, vervangen door artikel 6:101 BW. Zie daarover later in paragraaf 2.2.

334. Engelhard en Van Maanen, Verkeersongevallen, p. 17 spreken van de 'roaring nineties'.

335. Voor een overzicht van de recente en minder recente jurisprudentie en commentaren ten aanzien van artikel 185 WVW (31 WVW oud): Hartlief, TvP, 1996, p. 1271-1335; Van Wassenaer van Catwijck, VR, 1994, p. 253-260; Van Wassenaer van Catwijck, in: CJHB (Brunner-bundel), p. 429-440; Hartlief en Tjittes, Verzekering en aansprakelijkheid, p. 123-137 en p. 143-151; Van Wassenaer van Catwijck, VR, 1992, p. 181-185; Schut, Onrechtmatige daad, p. 140-149; AsserHartkamp 4-III, p. 205-222; Spier, preadvies NJV, 1996, p. 207-234; De Haas en Hartlief, Verkeersaansprakelijkheid, p. 162-171; Elzas, Special Handboek, p. 77-86. 
eigenaar geen verwijt kan worden gemaakt ten aanzien van het ontstaan van het gebrek. ${ }^{336}$

Voor wat betreft het beroep op overmacht bij een verkeersongeval heeft de Hoge Raad in een drietal arresten ${ }^{337}$ criteria geformuleerd voor de vraag wanneer overmacht voor de bestuurder aannemelijk kan zijn. Voor een beroep op overmacht moet volgens de Hoge Raad:

'Aannemelijk zijn geworden dat, gezien de omstandigheden van het geval, aan de bestuurder rechtens ${ }^{338}$ geen enkel verwijt kan worden gemaakt terzake van de wijze waarop hij aan het verkeer heeft deelgenomen voorzover van belang voor de veroorzaking van het ongeval. Voor de beantwoording van de vraag of zulks het geval is, kunnen eventuele fouten begaan door andere weggebruikers - daaronder begrepen het slachtoffer zelf - alléén van belang zijn, indien zij voor de bestuurder van het motorrijtuig waarmee de aanrijding is veroorzaakt, zo onwaarschijnlijk waren, dat deze bij het bepalen van zijn verkeersgedrag met die mogelijkheid naar redelijkheid ${ }^{339}$ geen rekening behoefde te houden'. ${ }^{340}$

In het kader van de bewijslastverdeling ${ }^{341}$ is door de Hoge Raad verder bepaald dat niet de fietser of voetganger behoeft aan te tonen dat de motorrijtuigbestuurder een fout heeft begaan, maar dat op de bestuurder van een motorrijtuig de bewijslast rust ten aanzien van overmacht. In een reeds genoemd arrest uit 1982 overwoog de Hoge Raad daartoe:

'Dat niet de voetganger Wijman behoeft aan te tonen of aannemelijk te maken dat 'enige relevante door Corten (autobestuurder) begane verkeersfout', maar dat de automobilist Corten moet aannemelijk maken dat hem ten aanzien van zijn verkeersgedrag geen enkel verwijt treft'. ${ }^{342}$

336. HR 16 april 1942, NJ, 1942, 39 (Torenbout). Bouman, VR, 1987, p. 85-86.

337. HR 26 maart 1971, NJ 1971, 262 nt. GJS (Jan de Waard). Het ging hierbij om een ('slingerende') 9-jarige fietser die werd aangereden door de aanhangwagen van een vrachtauto; HR 24 december 1982, NJ 1983, 443, VR 1983, 40 (Wijman/Corten); HR 22 mei 1992, NJ 1992, 527, VR 1992, 94 (ABP/Winterthur).

338. Toevoeging in HR 23 mei 1986, NJ 1987, 482 nt. CJHB (Frank van Holsteijn); HR 22 mei 1992, NJ 1992, 527 (ABP/Winterthur). Zie ook HR 4 oktober 1996, NJ 1997, 147 (Dijksma/Loef); HR 11 novembet 1983, NJ 1984, 331, VR 1984, $8 \mathrm{nt}$. vWvC (Meppelse ree).

339. Toevoeging in HR 24 december 1982, NJ 1983, 443 (Wijman/Corten).

340. Bouman, VR, 1987, p. 86; Van der Nat, LSA 1992, p. 65-66. Zie ten aanzien van overmacht in de zin van artikel 31 WVW eveneens: HR 26 maart 1976, NJ 1976, 393, VR 1976, 57 (Yvonne Calis/Coortens); HR 24 januari 1986, NJ 1986, 377, VR 1986, 6 (Tulp/Habing).

341. Zie daarover C.C. van Dam, LSA 1998, p. 38-41.

342. HR 24 december 1982, NJ 1983, 443 (Wijman/Corten). Bouman, VR, 1987, p. 86; Spier, Preadvies NJV, 1996, p. 208-212. 
In ABP/Winterthur oordeelde de Hoge Raad dat de motorrijtuigbestuurder aannemelijk moet maken dat zijn voertuig geen gebreken vertoonde, dat hij zijn snelheid voldoende had aangepast en dat het ongeval ook zou hebben plaatsgevonden zonder gebreken of een niet-voldoende aangepaste snelheid. ${ }^{343}$

De hiervoor geformuleerde criteria zijn door de Hoge Raad in een aantal arresten uitgewerkt door aan te geven onder welke concrete omstandigheden voor een bestuurder van een motorrijtuig een beroep op overmacht aannemelijk kan zijn.

In het arrest Yvonne Calis/Doorten ${ }^{344}$ was de 6-jarig Yvonne Calis vanuit het struikgewas een fietspad opgelopen en in botsing gekomen met de auto van Doorten, die zijn voertuig, in strijd met de geldende verkeersregels, over dit fietspad verplaatste. De Hoge Raad oordeelde hier dat Doorten een verwijt kan worden gemaakt door met zijn auto over een fietspad te gaan rijden, waarmee hij zelf al een gevaarlijke situatie voor anderen creëerde. Dit betekent volgens de Hoge Raad dat met betrekking tot het betreden van het fietspad door Yvonne Calis:

'In beginsel kan worden gesteld dat een gebeurtenis als de onderhavige voor Doorten niet zo onvoorzienbaar was dat hij met een dergelijke gebeurtenis bij het in strijd met de wet berijden van een fietspad, geen rekening behoefde te houden'. ${ }^{345}$

In het arrest $\mathrm{W}_{\mathrm{ijman}} / \mathrm{Corten}^{346}$ was een voetganger (Wijman) tussen een rij stilstaande auto's de weg overgestoken, maar op het midden van de rijbaan even blijven staan om daarna toch vrij plotseling door te lopen vlak voor een met matige snelheid naderende auto (Corten). De Hoge Raad oordeelde dat, in het kader van een beroep op overmacht, de bestuurder van de auto rekening moet houden met de mogelijkheid dat de 'onvoorzichtige' voetganger, die voor hem niet onzichtbaar was, toch zal doorlopen.

In het $\mathrm{ABP} / \mathrm{Winterthur-arrest}{ }^{347}$ werd een voetgangster, die met haar vriendin op een fietspad liep, aangereden door een (opgevoerde) bromfiets die vanuit tegenovergestelde richting kwam en de plotseling naar links uitwijkende voetgangster niet meer kon ontwijken. De Hoge Raad verwierp in dit arrest de algemene stelling dat:

343. HR 22 mei 1992, NJ 1992, 527, VR 1992, 94. Harlief en Tjittes, NbBW, 1992, p. 67-68.

344. HR 26 maart 1976, NJ 1976, 393, VR 1976, 57.

345. Zie ook de noot van G.J. Scholten onder dit arrest, die stelt dat wanneer een bromfiets over dit fietspad had gereden, wat dus wel is toegestaan, het arrest van het Gerechtshof vermoedelijk niet was gecasseerd.

346. HR 24 december 1982, NJ 1983, 443, VR 1983, 40.

347. HR 22 mei 1992, NJ 1992, 527, VR 1992, 94. 
'Een bromfietser die een op een fietspad rechtuit voortlopende voetganger wil passeren, rekening heeft te houden met de mogelijkheid dat de voetganger zich plotseling in zijwaartse richting zal begeven'.

In het Hoogwerkersbakje-arrest ${ }^{348}$ was een bestuurder van een vrachtauto tegen een onder een viaduct hangend hoogwerkersbakje aangereden. Vanuit dit bakje werden schilderswerkzaamheden aan het viaduct verricht. Tengevolge van deze aanrijding raakte een van de schilders gewond. De rechtbank had geoordeeld dat op grond van de concrete omstandigheden de vrachtwagenchauffeur het hoogwerkersbakje niet kon bebben gezien. Daarnaast was de vrachtwagen in de gegeven omstandigheden voldoende voorzichtig geweest zodat van hem niet kon worden verwacht dat hij het hoogwerkersbakje moet hebben gezien. Dit betekent dat volgens de rechtbank de vrachtwagenchauffeur geen verwijt kan worden gemaakt, waarmee een beroep op overmacht derhalve zal kunnen slagen. Deze uitleg van het begrip 'overmacht' in de zin van artikel 31 WVW werd zowel door het Gerechtshof als door de Hoge Raad niet als onjuist beschouwd. ${ }^{349}$

In het arrest Plomp/Ketelaar ${ }^{350}$ was een fietser (Plomp) door het rode licht gereden en op een kruising in botsing gekomen met een bus (Ketelaar), die met een snelheid van 30 à $35 \mathrm{~km} / \mathrm{u}$ de kruising was genaderd en voor wie het licht op groen stond. Ketelaar was daarbij zijn snelheid aan het minderen omdat even voorbij de kruising een bushalte was waar Ketelaar wilde stoppen. Het Hof had geoordeeld dat aan de zijde van Ketelaar sprake was van overmacht in de zin van artikel 31 (oud) WVW. Ketelaar had zich volgens het Hof niet verwijtbaar gedragen door met een verminderde snelheid de kruising te naderen met de bedoeling om bij de bushalte direct na de kruising te stoppen. De snelheid waarmee Ketelaar reed was derhalve niet onverantwoord. Verder behoefde Ketelaar in de gegeven omstandigheden geen rekening te houden met de fout van Plomp, zijnde een volwassen fietser die ondanks het beperkte uitzicht door het rode licht de kruising was opgereden. Deze beslissing van het Hof werd door de Hoge Raad in stand gelaten. ${ }^{351}$

In het arrest Wijnings/Van Halderen ${ }^{352}$ was een volwassen voetganger (Wijnings) staande op de middenas van een drukke verkeersweg plotseling gevallen en aangereden door een passerende auto (Van Halderen). Wijnings werd aan het hoofd geraakt door de buitenspiegel van Van Halderen en is enige tijd later aan haar verwondingen overleden. Volgens de Hoge Raad had de Rechtbank ten aanzien van overmacht een

348. HR 20 november 1992, NJ 1993, 137.

349. In Hof Amsterdam, 26 januari 1995, VR, 1996, 67 werd daarentegen geen overmacht aangenomen in een soortgelijke ongevalssituatie omdat de vrachtwagenchauffeur de hoogwerker wel had waargenomen.

350. HR 16 februari 1996, NJ 1996, 393, VR 1996, 195

351. Zie daarover Hartlief, TvP, 1996, p. 1293-1294.

352. HR 5 december 1997, NJ 1998, 209 (Wijnings $N$ an Halderen). 
onjuiste maatstaf gehanteerd door te oordelen dat de afstand tussen Van Halderen en Wijnings niet een ongebruikelijk korte was. De Hoge Raad:

'Niet beslissend is of bedoelde afstand niet 'ongebruikelijk' was, maar of Van Halderen rechtens geen enkel verwijt kan worden gemaakt ten aanzien van de afstand die zij tussen haar auto en de voetgangers heeft aangehouden. Indien zich duidelijk zichtbaar op de as van de weg daar stilstaande voetgangers bevinden - die aldus in een kwetsbare positie verkeren - een autobestuurder bij het bepalen van de afstand waarop hij zal passeren, mede rekening dient te houden met hun mogelijk onverwachte gedragingen, waaronder reacties op het passeren van de auto zelf, waardoor die afstand op het laatste ogenblik kan worden bekort. Bij de beoordeling van het gedrag van de autobestuurder te dier zake is mede van belang of hij in de gegeven verkeerssituatie die afstand ruimer heeft kunnen nemen dan hij heeft gedaan. ${ }^{353}$

Samenvattend kan worden gesteld dat een beroep op overmacht in de zin van artikel 185 WVW (31 WVW oud) nog wel succes kan hebben, zij het in een beperkt aantal gevallen. ${ }^{354}$ De bestuurder van het motorrijtuig dient daarbij allereerst aan te tonen dat hem geen enkel verwijt treft. Hij mag dus zelf geen fouten hebben gemaakt. In de tweede plaats dient de bestuurder rekening te houden met de fout van de fietser of voetganger. De fout van de voetganger of fietser moet voor de bestuurder zo onwaarschijnlijk zijn dat hij daar in de concrete omstandigheden geen rekening mee kon houden. Dit betekent dat een bestuurder niet met alle fouten van de niet-gemotoriseerde weggebruiker rekening behoeft te houden. In de derde plaats moet worden geoordeeld of de bestuurder met de aanwezigheid van een fietser of voetganger rekening had moeten houden. ${ }^{355}$

\subsection{DE EIGEN SCHULD BIJ ONGEMOTORISEERDEN VAN 14 JAAR EN OUDER: DE $50 \%$-REGEL}

Wanneer is vastgesteld dat een bestuurder van een motorrijtuig geen beroep kan doen op overmacht, dient de vraag te worden onderzocht of het niet-gemotoriseerde slachtoffer (eigen) schuld heeft aan het ongeval. Sinds 1 januari 1992 is artikel 31

353. HR 5 december 1997, NJ 1998, 209, r.o. 3.4 (Wijnings/Van Halderen).

354. In HR 20 november 1992, NJ 1993, 137 (Hoogwerkersbakje) en HR 5 december 1997, NJ 1998, 209 (Wijnings/Van Halderen), wordt door de Hoge Raad nog overwogen dat een beroep op overmacht niet is beperkt tot gedragingen van de fietser of voetganger boven 14 jaar voorzover deze opzet of aan opzet grenzende roekeloosheid opleveren. Zie recent nog: HR 17 november 2000, NJ 2001, 200 (FBTO/Delta Lloyd).

355. Zic voor de hier weergegeven jurisprudentie en andere rechtspraak eveneens: Hartlief, TVP, 1996, p. 1292-1296; Bolt, VR, 1992, p. 175; Sterk, Verhoogd gevaar in het aansprakelijkheidsrecht, diss., p. 248-251; Van Wassenaer van Catwijck, VR, 1992, p. 181-183; C.C. van Dam, Zorgvuldigheidsnorm en aansprakelijkheid, diss., p. 187-189; De Haas en Hartlief, Verkeersaansprakelijkheid, p. 163-164. 
WVW lid $6^{356}$ komen te vervallen en is de algemene regeling van artikel 6:101 lid 1 BW van toepassing, waarbij de beslissing inzake de eigen schuld van het slachtoffer in twee fasen verloopt. De eerste fase (hoofdregel) luidt:

'Wanneer de schade mede een gevolg is van een omstandigheid die aan de benadeelde kan worden toegerekend, wordt de vergoedingsplicht verminderd door de schade over de benadeelde en de vergoedingsplichtige te verdelen in evenredigheid met de mate waarin de aan ieder toe te rekenen omstandigheden tot de schade hebben bijgedragen'. ${ }^{357}$

$\mathrm{Na}$ de boordeling van deze wederzijdse causaliteit kan de rechter in een tweede fase hierop een billijkheidscorrectie toepassen. Artikel 6:101 lid 1 BW stelt namelijk verder:

'...dat een andere verdeling plaatsvindt of de vergoedingsplicht geheel vervalt of in stand blijft indien de billijkheid dit wegens de uiteenlopende ernst van de gemaakte fouten of andere omstandigheden van het geval eist. ${ }^{358}$

In het arrest IZA/Vrerink ${ }^{359}$ is door de Hoge Raad de reikwijdte van de billijkheidscorrectie van artikel 6:101 lid $1 \mathrm{BW}$ aangegeven met betrekking tot een aanrijding tussen een volwassen fietser of voetganger en een motorrijtuig. Een 67-jarige voetgangster werd op een oversteekplaats voor voetgangers aangereden door een auto die werd bestuurd door Vrerink. Deze was met een snelheid van $40 \mathrm{~km} / \mathrm{u}$ de kruising genaderd, waarvan de verkeerslichten een geel knipperlicht vertoonden. De Hoge Raad:

'Wanneer de eigenaar van een motorrijtuig in beginsel krachtens artikel 31 WVW aansprakelijk is, omdat hij niet overmacht aannemelijk heeft gemaakt, doch er wel een fout van de fietser of voetganger is, zonder dat evenwel sprake is van opzet of aan opzet grenzende roekeloosheid, eist de billijkheid bij de verdeling van de schade over de betrokkenen dat tenminste 50 percent van de schade ten laste van het motorrijtuig wordt gebracht wegens de verwezenlijking van het daaraan verbonden gevaar. Dit brengt mee dat deze eige-

356. 'De rechter kan het bedrag der schadevergoeding beperken, wanneet aannemelijk is, dat het ongeval mede is te wijten aan de schuld van iemand, voor wien de eigenaar of houder niet aansprakelijk is'. Zie voor een arrest gebaseerd op dit artikel: HR 24 mei 1991, NJ 1991, 506 (Jacob Kodde).

357. Zie Spier, LSA 1997, p. 15-23, voor een bloemlezing uit de lagere rechtspraak met betrekking tot verkeersongevallen gebaseerd op artikel 6:162 BW. Zie ook Spier, Mon. Nieuw BW B-36, p. 89.

358. Bouman, LSA 1997 , p. 25-44 en p. 47-56 voor een bloemlezing uit de lagere rechtspraak na het Ingrid Kolkman-arrest; Van Wassenaer van Catwijck en Jongeneel, Eigen schuld en medeaansprakelijkheid, p. 139-149; Spiet, Mon. Nieuw BW B-36, p. 10-18. 
naar in ieder geval aansprakelijk is voor de helft van de schade van de fietser of voetganger. Ten aanzien van de andere helft is in beginsel beslissend in hoeverre de - foutieve - gedragingen van de eigenaar en de fietser of voetganger tot de schade hebben bijgedragen'.

In dit arrest wordt in feite artikel 6:101 lid 1 omgekeerd toegepast. De Hoge Raad hanteert eerst de billijkheidscorrectie (tweede fase artikel 6:101 lid 1 slot), op grond waarvan tenminste $50 \%$ van de schade voor rekening van de eigenaar van het motorrijtuig komt. De aanleiding hiervoor is gelegen in het enkele gevaar ('Betriebsgefahr') dat het rijden met een motorrijtuig op de weg meebrengt. Ten aanzien van de andere helft van de schade wordt teruggekeerd naar de hoofdregel van artikel 6:101 lid 1 , waarbij de schade op grond van de wederzijdse causaliteit wordt verdeeld.

De door het Hof toegepaste schuldverdeling, namelijk 1:4 in het voordeel van de automobiliste, gaf volgens de Hoge Raad geen blijk van een onjuiste rechtsopvatting. ${ }^{360}$ Dit lijkt te betekenen dat de voetgangster in concreto $60 \%$ van haar schade tegemoet kon zien, namelijk $50 \%$ billijkheid en $20 \%$ van de overige $50 \%$. Deze uitleg aan het arrest, voor wat betreft de schadeverdeling voor de overige $50 \%$, werd door een groot deel van de commentatoren aangehangen. ${ }^{361}$

In het arrest Anja Kellenaers ${ }^{362}$ werd door de Hoge Raad echter aangegeven hoe de overwegingen in het arrest IZA/Vrerink moeten worden uitgelegd. Anja Kellenaers, ten tijde van het ongeval 14 jaar en 8 maanden oud, reed met haar fiets vanaf het erf van haar woonhuis zonder op te letten de straatweg op. Door haar snelheid nam zij de bocht naar rechts te ruim en belandde op het midden van weg, waar zij in botsing kwam met de auto van Sikes, die met een snelheid van $50 \mathrm{~km} / \mathrm{u}$ op het midden van de weg kwam aangereden. Op deze weg gold een maximumsnelheid van $80 \mathrm{~km} / \mathrm{u}$.

Het Hof achtte de automobilist Sikes volledig aansprakelijk voor de schade van Anja, daarbij ten onrechte verwijzend naar de rechtspraak van de Hoge Raad ten aanzien van kinderen beneden de 14 jaar. ${ }^{363}$ Op grond hiervan besloot de Hoge Raad tot vernietiging van het arrest van het Hof daarbij overwegende:

360. Blijkens de overwegingen van de Hoge Raad had deze verhouding vooral betrekking op de schadeverdeling tussen de automobiliste en de regresnemende verzekeraar van het nietgemotoriseerde slachtoffer. Zie over het regres paragraaf 3.4.

361. Zie hierover onder anderen: Hijma, AA, 1992, p. 497-505; Hartlief, NJB, 1994, p. 353-356; Brunner in zijn noot onder IZA/Vrerink, NJ 1992, 566; Van Wassenaer van Catwijck, VR, 1994, p. 255-256; Spier, Preadvies NJV, 1996, p. 215-218; Bolt, VR, 1992, p. 178; Hartlief en Tjittes, NTBR, 1992, p. 117; Van Wassenaer van Catwijck, VR, 1992, p. 183; Van der Nat, LSA 1992, p. 79-82; Jordaans, Advocatenblad, 1992, p. 277-281; Hulst, NJB, 1992, p. 693-700.

362. HR 24 december 1993, NJ 1995, 236, nt. CJHB, VR, 1994, 52, nt. vWvC.

363. Zie daarover in de volgende paragraaf. 
'Na verwijzing zal immers opnieuw moeten worden beoordeeld of en in hoeverre in dit geval plaats is voor vermindering van de vergoedingsplicht in verband met de door hem ingeroepen eigen schuld van Anja aan het ongeval. Volgens HR 28 februari 1992, NJ 1993, 566 (IZA/Vrerink), zal daarbij op grond van de in artikel 6:101 lid 1 BW bedoelde billijkheid ten minste 50\% van de schade ten laste van Sikes moeten worden gebracht. Ingevolge dat arrest - zoals dit moet worden verstaan - zal vervolgens nog moeten worden nagegaan of wellicht naar de maatstaven van die bepaling meer dan $50 \%$ van de schade ten laste van Sikes moet worden gebracht, hetzij omdat zijn gedragingen in verhouding tot die van Anja voor meer dan 50\% tot de schade hebben bijgedragen - wat in de vaststaande omstandigheden weinig voor de hand ligt -, hetzij omdat de in artikel 6:101 Jid 1 bedoelde billijkheid, in het licht van alle omstandigheden van het geval, een zodanige verdeling eist dan wel eist dat de schade geheel ten laste van Sikes komt. Bij deze billijkheidsafweging dient ook te worden gelet op de voormelde door het hof vastgestelde omstandigheid betreffende de ontwikkeling van Anja'.

Uit dit arrest kan samen met het IZA/Vrerink-arrest het volgende worden opgemaakt. Met betrekking tot de vergoeding van de eigen schade van het slachtoffer ${ }^{364}$ blijft het uitgangspunt dat de bestuurder van een motorrijtuig op grond van de billijkheid (artikel 6:101 lid 1 in fine) voor 50\% aansprakelijk is voor de schade van de fietser of voetganger. Voor een eventuele vergoeding die hoger is dan $50 \%$ wordt artikel 6:101 echter opnieuw in zijn geheel in stelling gebracht. Dit betekent dat allereerst naar de wederzijdse causaliteit wordt gekeken (hoofdregel artikel 6:101 lid 1). Deze beoordeling van de causaliteit strekt zich daarbij uit tot de vraag in hoeverre de partijen aan het verkeersongeval hebben bijgedragen. Wanneer bijvoorbeeld de causale verhouding tussen Sikes en Anja Kellenaers 1:4 bedraagt, zoals in IZA/Vrerink het geval was, dan is Sikes slechts voor $20 \%$ aansprakelijk voor de schade van Anja Kellenaers. Sikes zal echter op grond van de billijkheidscorrectie toch $50 \%$ van de schade van Anja Kellenaers dienen te vergoeden. Indien echter de causale verhouding omgekeerd is, namelijk 4:1 in het nadeel van Sikes, zal hij $80 \%$ van de schade van Anja Kellenaers dienen te vergoeden. Is de verhouding 1:1 dan dient Sikes 50\% van de schade van Anja Kellenaers te vergoeden. ${ }^{365}$ Nadat een causale verdeling is vastgesteld kan de rechter op grond van artikel 6:101 lid 1 opnieuw een billijkbeidscorrectie toepassen gebaseerd op de bijzondere omstandigheden van het geval. Daarbij kan bijvoorbeeld rekening worden gehouden met de achtergebleven ontwikkeling van een kind, ${ }^{366}$ de mate van verwijtbaarheid van de gedragingen, ${ }^{367}$ het feit

364. Voor het regres geldt een andere regeling. Zie daarover paragraaf 3.4 .

365. Zie over deze uitleg: Hartlief, NJB, 1994, p. 353-356; Van Wassenaer van Catwijck, VR, [994, p. 255-256; Hartlief, TvP, 1996, p. 1299-1306.

366. Deze mogelijkheid werd door de Hoge Raad in het Anja Kellenaers-arrest mede overwogen: "het geval dat het betrokken kind de leeftijd van veertien jaar heeft bereikt, maar zich qua ontwikkeling niet wezenlijk onderscheidt van een kind beneden de leeftijd van veertien jaar'. Zie HR 24 december 1993, NJ 1995, 236, r.o. 3.4.4. 
dat het slachtoffer bejaard of invalide is, het niet-functioneren van de verkeerslich$\operatorname{ten}^{368}$ en de eventuele ernst van het opgelopen letsel. De slachtofferbeschenning van artikel $185 \mathrm{WVW}$ en de aan het rijden met een motorrijtuig verbonden gevaren zijn in dat kader algemene toetsingselementen die reeds in de eerste billijkheidscorrectie zijn verwerkt. ${ }^{364}$

Samenvattend kan worden gesteld dat bij een verkeersongeval tussen een motorrijtuig en een voetganger of fietser ouder dan 14 jaar in de zin van artikel 185 WVW, de bestuurder van het motorrijtuig, indien hij geen overmacht aannemelijk kan maken, op grond van de billijkheid voor minimaal $50 \%$ aansprakelijk is voor de schade van de fietser of voetganger. Dit is anders wanneer het gedrag van de fietser of voetganger opzet of aan opzet grenzende roekeloosheid meebrengt. De vraag of de bestuurder meer dan $50 \%$ van de schade van de fietser of voetganger dient te vergoeden, wordt beantwoord aan de hand van artikel 6:101 lid $1 \mathrm{BW}$, namelijk de wederzijdse causaliteit, de vraag in hoeverre partijen aan het verkeersongeval hebben bijgedragen, en de in een tweede fase eventueel toe te passen billijkheidscorrectie. ${ }^{370}$

\subsection{OVERMACHT EN EIGEN SCHULD BIJ KINDEREN JONGER DAN 14 JAAR: DE $100 \%$-REGEL}

Aan het begin van de jaren ' 90 van de vorige eeuw heeft de Hoge Raad in twee arresten geregeld hoe de begrippen overmacht en eigen schuld bij fietsers of voetgangers jonger dan 14 jaar dienen te worden geïnterpreteerd. ${ }^{371}$ Deze beslissingen komen neer op een vestiging van een risicoaansprakelijkheid zonder eigen schuld-

367. HR 2 juni 1995, NJ 1997, 700-702, VR, 1995, 145-147.

368. Zie daarover HR 19 oktober 1990, NJ 1991, 7 (Frank Randag).

369. Zie Hartlief, TvP, 1996, p. 1306-1307; Hartlief en Tjittes, Verzekering en aansprakelijkheid, p. 131-135. Zie over het Anja Kellenaers-arrest: Hijma, AA, 1994, p. 445-450; Spier, Preadvies NJV, 1996, p. 214-215; Du Perron en Verduyn, VR, 1994, p. 65-68; De Haas en Hartlief, Verkeersaansprakelijkheid, p. 165-166.

370. Hartlief en Tjittes, Verzekering en aansprakelijkheid, p. 132-135; Van Wassenaer en Jongeneel, Eigen schuld en mede-aansprakelijkheid, p. 145-146. Bij deze afweging op basis van de billijkheid volgend op de causale verdeling, kan ingevolge HR 10 november 2000, NJ 2000, 718 (LevobiVan den Bos), de omstandigheid dat een motorrijtuig in het verkeer voor andere verkeersdeelnemers een bijzonder gevaar oplevert, nog aan de orde komen.

371. In eerdere arresten had de Hoge Raad al geoordeeld dat jonge kinderen door hun impulsiviteit en onberekenbaarheid meer gevaar te duchten hebben van het gemotoriseerde verkeer dan volwassen fietsers of voetgangers. Verder brengt volgens de Hoge Raad de strekking van artikel 31 WVW mee dat kinderen dienen te worden beschermd tegen de extra risico's van het gemotorisecrde verkeer. Zie HR 30 juni 1978, NJ 1978, 685, nt. GJS, VR, 1979, 61 (Ebele Dillema); HR 23 nei 1986, NJ 1987, 482, nt. CJHB, VR, 1987, 36 (Frank van Holsteijn); HR 20 februari 1987, NJ 1987, 483, nt. CJHB, VR, 1987, 63 (Marcel Woestenburg). Zie over deze rechtspraak: Bouman, VR, 1987, p. 87; Van Wassenaer van Catwijck, VR, 1989, p. 253-255; Hartlief en Tjittes, VR, 1991, p. 1-2; Bouman, in Een Salomons oordeel, p. 35-38. 
verweer ten laste van de motorrijtuigbestuurder voor de schade van een fietser of voetganger beneden de 14 jaar.

In het Ingrid Kolkman-arrest uit $1990^{372}$ ging het om de eigen schuldvraag. Daarin werd Ingrid Kolkman (13 jaar) op een kruising aangereden door de bestelauto van Loohuis. Ingrid was vrij plotseling de voorrangsweg overgestoken alwaar Loohuis kwam aangereden. Loohuis had Ingrid wel zien staan maar niet verwacht dat zij zou oversteken. Het beroep op overmacht van Loohuis werd verworpen met de stelling dat niet alleen op grond van de 'concrete gedragingen van de fietser' maar eveneens uit de algemene ervaringsregels kan worden afgeleid dat Ingrid zal gaan oversteken. Deze ervaringsregels hebben betrekking op hetgeen in het algemeen van fietsende kinderen mag worden verwacht in een verkeerssituatie zoals die zich in deze casus voordeed.

Met betrekking tot de eventuele eigen schuld van Ingrid Kolkman stelt de Hoge Raad voorop dat niet meer artikel 31 lid 6 WVW mar artikel 6:101 lid 1 (N)BW beslissend is. Het Hof had daarbij wel de wederzijdse causaliteit (hoofdregel artikel 6:101 lid 1) toegepast, maar verzuimd om te onderzoeken of de billijkheid een andere verdeling eist (correctie, tweede fase artikel 6:101 lid 1). Ten aanzien van dit laatste verwijst de Hoge Raad naar eerdere uitspraken betreffende zeer jeugdige kinderen. ${ }^{373}$ Hierin is bepaald dat de eigenaar van een motorrijtuig bij een aanrijding met een jeugdige verkeersdeelnemer op grond van de billijkheid in beginsel volledig aansprakelijk is voor de schade van het kind, ook wanneer de gedragingen van het kind hebben bijgedragen aan het ontstaan van het ongeval. De Hoge Raad verwijst verder naar de impulsiviteiten onberekenbaarheid van jonge kinderen, het grotere gevaar waaraan zij zijn blootgesteld en de strekking van artikel $31 \mathrm{WVW}$ die kinderen beoogt extra te beschermen tegen de gevaren van het gemotoriseerde verkeer, waarvoor een verplichting tot verzekering bestaat. De Hoge Raad vervolgt met de volgende overweging:

'Dit uitgangspunt - waarbij mede in aanmerking moet worden genomen dat de gevolgen van een aanrijding in het bijzonder wanneer het, zoals in deze zaak, om blijvend lichamelijk letsel gaat, juist voor kinderen uitzonderlijk ingrijpend zijn - dient ook voor een kind van de leeftijd als in deze zaak aan de orde is, als juist te worden beschouwd, waarbij mede betekenis toekomt aan de omstandigheid dat in artikel 6:164 (N)BW een leeftijdsgrens van veertien jaren met betrekking tot de aansprakelijkheid van kinderen in het algemeen is aanvaard. Op grond van een en ander moet worden geoordeeld dat in een geval als het onderhavige de eigenaar van het motorrijtuig in beginsel volledig aan-

372. HR 1 juni 1990, NJ 1991, 720 nt. CJHB, VR 1992, 93nt. vWvC. Zie hierover Hijma, AA, 1991, p. $64-71$.

373. HR 30 juni 1978, NJ 1978, 685, VR 1979.61 (Fbele Dillema); HR 20 februari 1987, NJ 1987, 483, VR 1987, 63 (Marcel Woestenburg). 
sprakelijk is en dat van een vermindering van de schadevergoeding op grond van gedragingen van het kind slechts sprake kan zijn, wanneer die gedragingen opzet of aan opzet grenzende roekeloosheid ter zake van die aanrijding opleveren'.

In het Marbeth van Uitregt-arrest ${ }^{374}$ dat de Hoge Raad in 1991, een jaar na het Kolkman-arrest wees, staat de overmachtsvraag in de zin van artikel 31 WVW centraal. De 10-jarige Marbeth van Uitregt rijdt vanuit de uitrit van een woonhuis, zonder op te letten de weg op, waama zij wordt aangereden door de van rechtskomende auto van De Backer, die met de plaatselijke situatie bekend is.

De Hoge Raad verwijst opnieuw naar eerdere rechtspraak waarin een ontwikkeling is waar te nemen naar een betere bescherming van met name kinderen bij een verkeersongeval met een motorrijtuig en sluit aan bij het hiervoor beschreven Ingrid Kolkman-arrest, waarin de eigen schuld van het kind aan de orde was. De Hoge Raad overweegt vervolgens:

'De vraag of en wanneer gedragingen van een kind overmacht in de zin van artikel 31 lid 1 WVW opleveren, hangt ten nauwste samen met die of en wanneer zulke gedragingen in het kader van artikel 31 lid 6 WVW van deze bepaling behoren te leiden tot een vermindering van de aansprakelijkheid. Bij aanrijdingen tussen een motorrijtuig en een niet door dat motorrijtuig vervoerd kind beneden de veertien jaar moet derhalve - afgezien van gevallen van opzet of aan opzet grenzende roekeloosheid - worden aanvaard dat fouten van het kind die hebben bijgedragen aan de aanrijding - in de woorden van artikel 6:162 lid $3(\mathrm{~N}) \mathrm{BW}$ - voor rekening van de bestuurder komen en voor hem geen overmacht opleveren.

Het betekent voorts dat het voor de aansprakelijkheid op grond van artikel 31 lid 1 niet ter zake doet of de bestuurder van het motorrijtuig het kind al dan niet vóór de aanrijding heeft waargenomen [zoals nog wel van belang is geacht in Frank van Holsteijn MvD], respectievelijk of de bestuurder met de mogelijke aanwezigheid van kinderen rekening had moeten houden'.

Samenvattend kan worden gesteld dat met de arresten Ingrid Kolkman en Marbeth van Uitregt het risico van een aanrijding met een kind beneden de 14 jaar geheel voor rekening van de bestuurder van een motorrijtuig is gebracht. Dit betekent dat bij een aanrijding tussen een motorrijtuig en een kind de eigen schade van het kind volledig zal worden vergoed. Alleen wanneer het gedrag van het kind opzet of aan

374. HR 31 mei 1991, NJ 1991, 721, nt. CJHB, VR 1991, 119, nt. vWvC. Zie daarover Hartlief, NTBR, 1992, p. 70-73. 
opzet grenzende roekeloosheid oplevert zal een uitzondering op deze risicoaansprakelijkheid mogelijk zijn. ${ }^{375}$

\subsection{DE POSITIE VAN DE VERHAALZOEKENDE VERZEKERAAR}

\subsubsection{Geen algemene billijkheidscorrectie ten behoeve van de regresnemer}

De vraag of regresnemende particuliere en sociale verzekeraars op dezelfde wijze als de slachtoffers zelf profiteren van de bescherming van verkeersslachtoffers, is pas recent door de Hoge Raad beantwoord. In de periode voor 1990 werd veelal geen onderscheid gemaakt tussen de vordering van de gesubrogeerde verzekeraar en het slachtoffer zelf. In het Ebele Dillema-arrest ${ }^{376}$ kwam de op de billijkheid ten aanzien van de eigen schuld van het kind gebaseerde beslissing ten goede aan de vordering van het uitkeringsorgaan dat in eerste instantie de schade van het kind had vergoed. De Hoge Raad gaf hierbij echter niet aan of de eigen vordering van het kind een gelijke billijkheidswaarde had als de vordering van het ziekenfonds. Pas in het Ingrid Kolkman-arrest gaat de Hoge Raad meer concreet in op de positie van de regresnemende sociale verzekeraars. In een obiter dictum wordt door de Hoge Raad gesteld:

'Dat in het midden kan blijven of hetzelfde [de bescherming van kinderen in de zin van artikel $31 \mathrm{WVW}, \mathrm{MvD}$ ] behoort te gelden in het geval dat het kind terzake van zijn schade een uitkering heeft ontvangen van een particuliere of sociale verzekeraar en deze vervolgens voor de uitgekeerde bedragen verhaal op de eigenaar van het motorrijtuig zoekt, in welk geval de belangen van het kind zelf bij de uitslag van voormeld billijkheidsoordeel niet daadwerkelijk zijn betrokken. In dit geding is immers uitsluitend de bescherming van het aangereden kind aan de orde'. ${ }^{377}$

In het arrest IZA/Vrerink geeft de Hoge Raad een negatief antwoord op de vraag of de bescherming van artikel 31 WVW ook opgaat voor de vordering van de regresnemende sociale verzekeraar. De billijkheidsoverwegingen zijn voornamelijk be-

375. Brunner in zijn noot onder het Marbeth van Uitregt-arrest, NJ 1991, 721. Zie ook Hartlief, TvP, 1996, p. 1288-1292; Van Wassenaer van Catwijck, VR, 1994, p. 254-255; Bolt, VR, 1992, p. 176-178; Hartlief en Tjittes, VR, 1991, p. 2-4; Spiet, Preadvies NJV, 1996, p. 212-213; Van Wassenaer van Catwijck, VR, 1992, p. 181-182; Hartief en Tjittes, Verzekering en aansprakelijkheid, p. 126-128; Van der Nat, LSA 1992, p. 67-75; Van Wassenaer van Catwijck en Jongeneel, Figen schuld en mede-aansprakelijkheid, p. 143-145; Hartlief en Tjittes, NTBR, 1992, p. 115-116; Bouman, in Een Salomons oordeel, p. 41-44, De Haas en Hartlief, Verkeersaansprakelijkheid, p. 162-163.

376. HR 30 juni 1978, NJ 1978,685, VR 1979,61.

377. HR 1 juni 1990, NJ 1991, 720, slot r.o. 5.3. Zie daarover onder anderen: Van Wassenacr van Catwijck, noot bij het Ingrid Kolkman-arrest, VR 1990, 174; Hartlief en Tjittes, VR, 1991, p. 3; Hijma, AA, 1991, p. 70-71; C.C. van Dam, Kwartaalbericht Nieuw BW, 1990, p. 130; Bouma, LSA 1992, p. 37-39. 
doeld voor bet niet-verzekerde slachtoffer dat beschermd moet worden tegen de gevaren van het autoverkeer, waarvoor ingevolge de WAM-wet een verplichting tot verzekering bestaat. De Hoge Raad:

'Dit billijkheidsargument verliest evenwel zijn gewicht in geval de schade van het slachtoffer ten laste van een verzekeraar is gekomen, omdat het risico aan de zijde van het slachtoffer, zij het tegen een betaling van een premie, reeds door middel van een verzekering is gespreid'. ${ }^{378}$

De Hoge Raad verwijst daarbij naar Tijdelijke regeling verhaalsrechten van artikel 6:197 BW, waarin een onderscheid wordt gemaakt tussen de vordering van het slachtoffer zelf en van de regresnemende verzekeraar. Op basis van deze regeling kan door de regresnemende verzekeraars geen beroep worden gedaan op de risicoaansprakelijkheden van titel 6.3. van het BW, die voornamelijk dienen ter bescherming van de belangen van het slachtoffer. ${ }^{379}$

\subsubsection{De concrete beoordeling van de vordering van de regresnemer}

In een zestal arresten ${ }^{380}$ is door de Hoge Raad duidelijkheid verschaft over de vraag hoe de vordering van de regresnemende verzekeraar in het licht van artikel 185 WVW moet worden beoordeeld. In de arresten van 2 juni 1995 stelt de Hoge Raad voorop dat de billijkheidsregels ( $100 \%$ bij kinderen en $50 \%$ bij volwassenen) betrekking hebben op de verhouding tussen de verplicht verzekerde motorrijtuigbestuurder en de niet-verzekerde fietser of voetganger die anders de schade zelf zou moeten dragen. Vervolgens herhaalt de Hoge Raad de overweging uit het IZA/Vrerinkarrest, waarin werd gesteld dat de billijkheid niet van toepassing is voor de gevallen waarin het niet-gemotoriseerde verkeersslachtoffer wel over een eigen verzekering beschikt die de schade vergoed. De Hoge Raad wijst vervolgens een gelijke behandeling van de vordering van het slachtoffer zelf en de vordering van de regresnemende verzekeraar af met de overweging:

'Mede in aanmerking genomen dat beide (billijkheids)regels de resultante zijn van dezelfde rechtsontwikkeling ( $\mathrm{vgl}$. het arrest van 1992 rov. 3.7.) bestaat

378. HR 28 februari 1992, NJ 1993, 566, r.o. 3.8.

379. Zie Parlementaire geschiedenis Boek 6 (Inv. 3, 5 en 6), p. 1404; Van Maanen en Römers, De Tijdelijke regeling verhaalsrechten, p. 5-61; Van Maanen, Onrechtmatige daad (losbladig), Art. 197, aant. 1-13; Bouma, LSA, 1992, p. 27-37; Tjittes, NbBW, 1992, p. 10-12; Hartlief en Tjittes, NTBR, 1992, p. 118-120; De Haas en Hartlief, Collectivering en institutionalisering van regres, p. $39-44$.

380. HR 2 juni 1995, NJ 1997, 700-702, VR 1995, 145-147 nt. HAB; HR 5 december 1997, NJ 1998, 400-402, VR 1998, 28-30. Zie daarover De Haas en Hartlief, Verkeersaansprakelijkheid, p. 168171; Engelhard en Van Maanen. Aansprakelijkheid voor verkeersongevallen, p. 18-19; Hartlief en Tjittes, Verzekering en aansprakelijkheid, p. 144-147. 
voor een uiteenlopend regime ten aanzien van regresvorderingen dan ook geen genoegzame rechtvaardiging'.

De Hoge Raad geeft vervolgens aan hoe de regresvordering na verwijzing dient te worden beoordeeld, namelijk via de overmacht van artikel $185 \mathrm{WVW}$ en de eigen schuld van artikel 6:101 lid $1 \mathrm{BW}$. Omtrent de overmacht wordt door de Hoge Raad geen toelichting gegeven, maar voor de beoordeling daarvan kan volgens Hartlief worden verwezen naar het 'rechtens geen enkel verwijt'-criterium uit het $\mathrm{ABP} / \mathrm{Win}$ terthur-arrest, ${ }^{381}$ alsmede naar de overwegingen in het Plomp/Ketelaar-arrest. ${ }^{382}$ Wanneer het beroep op overmacht faalt komt het eigen schuldverweer aan de orde. Hiervoor gelden niet de $100 \%$ - en de $50 \%$-regel, maar is volgens de Hoge Raad in beginsel de hoofdregel van artikel 6:101 lid 1 beslissend. Dit betekent dat een causaliteitsafweging moet worden gemaakt tussen de mate waarin enerzijds het gedrag van het slachtoffer en anderzijds de wijze van rijden van de bestuurder van het motorrijtuig aan het ongeval hebben bijgedragen. De Hoge Raad:

'Bij deze beoordeling komt het derhalve niet aan op de verwijtbaarheid van een en ander. Weliswaar zal, naarmate de gedraging gevaarlijker is, de mate van verwijtbaarheid doorgaans toenemen, maar noodzakelijk is dit niet. Met name ten aanzien van jeugdige kinderen kan het geval zich zeer wel voordoen dat sprake is van hoogst gevaarlijk weggedrag, dat aan het kind nochtans niet kan worden verweten, gezien zijn - aan zijn leeftijd eigen - beperkte inzicht in het aan zijn gedragingen verbonden gevaar en zijn beperkt vermogen zich naar dat inzicht te gedragen.

Beoordeling van de mate van verwijtbaarheid komt eerst aan de orde bij toepassing van de in artikel 6:101 lid tevens vervatte billijkheidscorrectie. Niet uitgesloten is dat ook in gevallen als het onderhavige voor zodanige toepassing grond bestaat'. ${ }^{383}$

Met name naar aanleiding van de laatste zin werd in de commentaren op deze arresten de vraag gesteld welke rol artikel 6:101 BW en vooral de daarin vervatte billijk-

381. HR 22 mei 1992, NJ, 1992, 527, VR 1992, 94.

382. HR 16 februari 1996, NJ, 1996, 393, VR 1996, 195. Hartlief, TvP, 1996, p. 1314-1315. Zie ook paragraaf 2.1 van dit hoofdstuk.

383. HR 2 juni 1995, NJ 1997, 700-702, VR 1995, 145-147. Zie C.C. van Dam, NbBW, 1995, p. 9698; Hijma, WPNR 6216, 1996, p. 199-200; Hartlief, TvP, 1996, p. 1310-1320; Spier, noot bij HR 2 juni 1995, RvdW 1995, 118, A \& V, 1995, p. 119-121. In het vervolg op HR 2 juni 1995, NJ 1997 (Klaverblad/IZA) heeft het Hof Amhern 16 november 1999, NJ 2000, 727, geoordeeld dat op basis van de causaliteitsafweging van artikel 6:101 de gedragingen van de fietster voor $60 \%$ en de wijze van rijden van de autobestuurder voor $40 \%$ aan de schade van de fietster hebben bijgedragen. In het kader van billijkheidscorrectie oordeelde het Hof dat de over en weer te maken verwijten van de fietster en de autobestuurder tegen elkaar opwegen, zodat voor een andere verdeling op basis van de billijkheid geen aanleiding bestaat. 
heidscorrectie speelt binnen de regresprocedure. ${ }^{384}$ In een drietal recente arresten heeft de Hoge Raad zich hierover uitgesproken. ${ }^{385}$

Volgens de Hoge Raad is voor de bescherming van de fietser en voetganger in het gemotoriseerde verkeer een soort 'standaardisering' aanvaard, waarbij op basis van de billijkheidscorrectie van artikel 6:101 BW de 100\%-regel (voetgangers en fietsers beneden 14 jaar) respectievelijk de 50\%-regel (fietsers en voetgangers boven 14 jaar) geldt. Bij deze 'standaardisering' wordt door middel van een belangenafweging rekening gehouden met het grote gewicht van het persoonlijke belang van het nietgemotoriseerde slachtoffer zelf en het maatschappelijke belang van een behoorlijke slachtofferbescherming in vergelijking met de belangen van het gemotoriseerde verkeer. ${ }^{386}$ Verder draagt een 'standaardisering' bij aan de behoefte van een vlotte vaststelling van de aansprakelijkheid. Met betrekking tot de vordering van de regresnemer wordt door de Hoge Raad overwogen dat:

'Bij regresvorderingen is evenwel voor een standaardisering als die van voormelde rechtspraakregels geen plaats. Voor wat betreft het gedrag waarvoor regres genomen wordt, heeft het slachtoffer zijn schade vergoed gekregen. Er is hier derhalve geen reden om, in verband met de persoonlijke belangen van het slachtoffer en het maatschappelijk belang van een goede slachtofferbescherming, aan de omstandigheden aan de zijde van het kind het zeer zware gewicht toe te kennen dat tot de $100 \%$-regel heeft geleid, onderscheidenlijk aan de omstandigheden aan de zijde van het volwassen, niet-gemotoriseerde verkeersslachtoffer het zware gewicht dat tot de 50\%-regel heeft geleid. Ook is hier aan een zodanige standaardisering minder behoefte. In gevallen als het onderhavige staan doorgaans, zoals ook hier, twee verzekeraars tegenover elkaar, zulks in verband met de wettelijke verplichting aan de zijde van het motorrijtuig om de burgerrechtelijke aansprakelijkheid waartoe het motorrijtuig in het verkeer aanleiding kan geven, door verzekering te dekken. Verzekeraars moeten in beginsel in staat worden geacht om zelf door collectief overleg tot de door hen nodig geachte mate van standaardisering te komen'.

384. Naast vragen als: Profiteren de regresnemers nu wel of niet van de bijzondere bescherming voor niet-gemotoriseerde verkeersslachtoffers?; Wat is de betekenis van de toepassing van een billijkheidscorrectie binnen een regresprocedure? Zie daarover Hartlief, VR, 1998, p. 258; Bouman, LSA 1997, p. 39-41; Bouman, noot bij H.R. 2 juni 1995, VR, 1995, 147, p. 284-285; Hijma, AA, 1996, p. 38-40; Spier, in Regresrechten, Afschaffen, handhaven of uitbreiden, p. 41-44; Hartlief en Tjittes, NTBR, 1996, p. 32-34; Hartlief, NJB, 1996, p. 1047-1050.

385. HR 5 december 1997, NJ 1998, 400-402, VR 1998, 28-30. Zie daarover Van den Brink, NbBW, 1998, p. 26-28.

386. De Hoge Raad verwijst hiermee naar artikel 3:12 BW: 'Bij de vaststelling van wat redelijkheid en billijkheid eisen, moet rekening worden gehouden met algemeen erkende rechtsbeginselen, met de in Nederland levende rechtsovertuigingen en met de maatschappelijke en persoonlijke belangen, die bij het gegeven geval zijn betrokken'. 
De Hoge Raad geeft vervolgens aan hoe een regresvordering binnen het kader van artikel 6:101 BW, met name voor wat betreft de billijkheidscorrectie, moet worden beoordeeld:

'Het voorgaande brengt mee dat er voor regresvorderingen onvoldoende reden is om aan de toepassing van de maatstaven van art. 6:101 lid 1 door bijzonde$\mathrm{re}$, in de rechtspraak ontwikkelde regels nader vorm te geven. Zoals in de arresten van 2 juni 1995 is overwogen, leidt dit ertoe dat na de door dit artikel primair geëiste causaliteitsafweging ook de daarin opgenomen billijkheidscorrectie nog aan de orde kan komen en dat zulks - anders dan het middel voorstaat - niet beperkt is tot 'uitzonderlijke omstandigheden'. Rekening moet hier derhalve worden gehouden met alle relevante omstandigheden zowel aan de zijde van de bestuurder als aan de zijde van het verkeersslachtoffer, waaronder zowel de ernst van ieders fout als de mate waarin zijn gedragingen hem kunnen worden verweten. Het gewicht dat in dit verband aan dergelijke omstandigheden aan de zijde van het slachtoffer toekomt, is evenwel van geheel andere orde dan het zeer zware, onderscheidenlijk zware gewicht dat voor vorderingen van het slachtoffer zelf tot de 100\%-regel, onderscheidenlijk de $50 \%$-regel heeft geleid. De billijkheidscorrectie zal in de onderhavige gevallen doorgaans slechts tot bijstelling van beperkte omvang van het resultaat van de causaliteitsafweging kunnen leiden'.

De onderhavige casusposities hadden betrekking op verkeersongevallen tussen motorrijtuig en een niet-gemotoriseerd verkeersslachtoffer dat jonger was dan 14 jaar, ${ }^{387}$ zodat de Hoge Raad in dat kader overweegt:

'In geval van een kind van de lceftijd van minder dan veertien jaar kan cen dergelijke bijstelling met name geboden zijn, indien juist het beperkte inzicht van het kind in het aan zijn gedragingen verbonden gevaar en het beperkte vermogen zich naar dat inzicht te gedragen in overwegende mate tot het ontstaan van de aanrijding hebben bijgedragen, en zonder bijstelling een resultaat zou ontstaan dat onvoldoende recht doet aan het feit dat juist door dit beperkte inzicht en beperkte vermogen aan het kind nauwelijks een verwijt van zijn gedragingen kan worden gemaakt, terwijl het falen van een beroep op overmacht aan de zijde van het motorrijtuig hier impliceert dat aan de bestuurder daarvan rechtens in elk geval enig verwijt te maken valt. ${ }^{388}$

Voor de vordering van de regresnemer geldt derhalve het 'normale' regime van artikel 6:101 BW, waarbij na toepassing van de causale afweging ook 'ten behoeve van het slachtoffer' een billijkheidscorrectie aan de orde kan komen. Daarbij moeten over en weer (slachtoffer en bestuurder) alle relevante omstandigheden worden meegewogen, waaronder de emst van ieders fout en de mate waarin zijn gedragingen

387. Zie HR 5 december 1997 , NJ 1998, 400-402.

388. HR 5 december $1997, \mathrm{NJ} 1998,400$, r.o. 3.6 en 3.7 . 
hem kunnen worden verweten. Volgens de Hoge Raad zal echter een billijkheidscorrectie 'doorgaans' tot een beperkte bijstelling van de causale verdeling leiden, waarmee derhalve het gewicht van de eerder genoemde omstandigheden wordt beperkt. $^{389}$

\subsubsection{De uitleg van Hartlief $f^{390}$}

Hartlief illustreert de wijze van beoordeling van de regresvordering met behulp van het geval Anja Kellenaers, ${ }^{391}$ waarover na verwijzing door het Hof van Den Bosch werd geoordeeld. ${ }^{392}$ Het Hof wees uiteindelijk de vordering van het slachtoffer zelf volledig toe. De basis hiervoor werd gevormd door de individuele billijkheidscorrectie van artikel 6:101, in casu de achtergebleven ontwikkeling van het meisje en de ernst van het letsel.

Hoe zou nu in dit geval worden geoordeeld indien het een vordering van de regresnemende ziektekostenverzekeraar betreft? Uitgaande van een causale verdeling van $1: 2$, komt Hartlief tot een toewijzing voor $33 \%$ van vordering van de regresnemer. Deze zal echter, met een verwijzing naar de ' 5 december'-arresten, pleiten voor een correctie op voornoemde verdeling en kan daarbij volgens Hartlief in de casus van Anja Kellenaers de volgende omstandigheden aanvoeren:

'a) de beperkte mate van verwijtbaarheid aan de kant van het meisje nu zij slechts 14 jaar is en meisjes van die leeftijd zich niet steeds naar het in beginsel wel bij hun aanwezige inzicht in de gevaren van hun verkeersgedrag kunnen gedragen.

b) de beperkte mate van verwijtbaarheid aan de kant van dit meisje in het bijzonder nu zij geestelijk en lichamelijk is achtergebleven in haar ontwikkeling ten opzichte van leeftijdsgenootjes.

c) de ernst van de gevolgen'.

Hartlief meent dat in ieder geval de 'subjectieve' omstandigheden b en $\mathrm{c}$ niet tot een correctie ten behoeve van de regresnemer kunnen leiden, waardoor alleen de objectieve omstandigheid a resteert. Dit wordt volgens hem ook door de Hoge Raad gesuggereerd, maar daarbij wordt gesteld dat de correctie doorgaans beperkt blijft in

389. Hartlief, VR, 1998 , p. 260 , meent dat met deze overweging in het regres geen sprake meer is van de toepassing van het normale 6:101 regime. 'De omstandigheid dat het niet om het slachtofier zelf gaat, maar om een regresnemer kleurt dat normale regime'.

390. Hartlief, VR, 1998, p. 257-261. Zie ook Hartlief en Tjittes, Verzekering en aansprakelijkheid, p. 147-151.

391. HR 24 december 1993, NJ 1995, 236, VR 1994, 52.

392. Hof Den Bosch, 22 januari 1997, VR 1997, 63, p. 94-95. 
haar gevolgen. ${ }^{393}$ Hartlief stelt dat hierdoor in het geschetste geval uiteindelijk 40 . 45 of $50 \%$ zal moeten worden voldaan, waardoor naar het oordeel van de Hoge Raad een meer bevredigende oplossing resulteert dan wanneer alleen naar de causale verdeling wordt gekeken. ${ }^{394}$

Hartlief vraagt zich echter af of in regresvorderingen niet beter op basis van de causale verdeling kan worden afgerekend, waarbij alleen in zeer bijzondere gevallen plaats is voor een billijkheidscorrectie. ${ }^{395}$ Hij erkent dat een onderzoek naar de causale verdeling niet eenvoudig is, ${ }^{396}$ maar wanneer daarbij alleen wordt gekeken naar de mate van de objectieve gevaarzetting kan dit een vlotte afhandeling bevorderen en leiden tot een kostenbesparing. ${ }^{397}$ Het meewegen van de verwijtbaarheidsvraag zal naar de mening van Hartlief de regresprocedure (onnodig) compliceren, ${ }^{398}$ hoewel daarbij volgens Spier in beginsel geen extrafeitenonderzoek noodzakelijk is. ${ }^{399}$

Samenvattend kan worden gesteld dat de Hoge Raad met de voomoemde reeks arresten een sluitende rechtsontwikkeling heeft willen bereiken ten aanzien van artikel 185 WVW. Kinderen tot 14 jaar krijgen hun schade voor de volle $100 \%$ vergoed, tenzij hen opzet of aan opzet grenzende roekeloosheid kan worden tegengeworpen. Niet-gemotoriseerde verkeersdeelnemers boven 14 jaar krijgen op grond van de billijkheid $50 \%$ van hun schade vergoed. ${ }^{400}$ Voor een eventueel hogere vergoeding geldt het stappenplan van artikel 6:101 lid $1 \mathrm{BW}$ met een causale verdeling plus een eventuele billijkheidscorrectie op grond van de bijzondere omstandigheden van het geval. De regresnemende sociale verzekeraars die de schade aan het slachtoffer heb-

393. Zie hierover ook Hijma in zijn noot bij HR 5 december, 1997, NJ 1998, 402, sub 6.

394. Hartlief, VR, 1998, p. 260. Volgens Hijma in zijn noot bij HR 5 december 1997, NJ 1998, 402 sub $8, \mathrm{zal}$ in veel gevallen de regresvordering voor ongeveer $50 \%$ worden toegewezen.

395. Zie cok Harlief, NJB, 1996, p. 1049-1050; Bouman, LSA 1997, p. 40-41. Anders: Hijma in noot bij HR 5 december 1997, NJ 1998, 402, sub 5. en A-G Hartkamp, Conclusie bij HR 5 december 1997, NJ 1998, 400, sub 7, die geen voorstander zijn van een dergelijk 'derde' regime en daarentegen menen dat regresnemers eenzelfde beroep op de billijkheidscorrectie toekomt als aan andere rechtssubjecten vóór de ontwikkeling van de 100\%-en 50\%-regel.

396. Hartlief, VR, 1998, p. 261, noot 22; J. Spier, LSA 1997, p. 16-21, met voorbeeiden uit de lagere rechtspraak.

397. Hartlief, VR, 1998, p. 260; Hartlief en Tjittes, NTBR, 1996, p. 32.

398. Hartlief, VR, 1998, p. 260. Anders: A-G Hartkamp, in zijn conclusie voor HR 5 december 1997 , NJ 1998, 400 sub 7, die meent dat voor de enkele beantwoording van de causaliteitsvraag nu ook in elk verhaalsdossier een individuele beoordeling op basis van de feiten nodig is. Daamaast zal het alternatief, namelijk een bijzonder regime voor regresnemers, volgens hem niet tot eenvoudiger resultaten leiden dan het gewone regime van artikel 6:101.

399. Spier, in Regresrechten, Afschaffen, handhaven of uitbreiden, p. 43.

400. Engelhard en Van Maanen, Aansprakelijkheid voor verkeersongevallen, p. 17-18, wijzen in dit verband op de 'gevaarzettingsgrondslag' van artikel $185 \mathrm{WVW}$, op basis waarvan niet-gemotoriseerde verkeersslachtoffers worden beschermd tegen de risico's van het gemotoriseerde verkeer. Deze bescherming reikt verder naarmate de risico's groter zijn danwel de gevolgen ingrijpender zijn, met name ten aanzien van kinderen. 
ben uitgekeerd kunnen geen beroep doen op de $100 \%$ - en 50\%-regel. Voor hen geldt dat ten aanzien van het concrete ongeval moet worden beoordeeld of overmacht in de zin van artikel 185 WVW aan de zijde van de bestuurder kan worden aangenomen. Wanneer dit niet het geval is, dient artikel 6:101 lid $1 \mathrm{BW}$ in zijn geheel te worden toegepast. Hierbij geldt dat na het oordeel over de causale verdeling voor een billijkheidscorrectie ten behoeve van het slachtoffer, ondanks het feit dat alle relevante omstandigheden moeten worden meegewogen, doorgaans een beperkte ruimte bestaat.

\section{De literatuur en de verkeersaansprakelijkheid}

\subsection{INLEIDING}

De discussie in de literatuur over de verkeersaansprakelijkheid gaat ruim dertig jaar terug in de tijd en werd voor een belangrijk deel op gang gebracht door Bloembergen in zijn oratie ${ }^{401}$ en later ook door Van Wassenaer van Catwijck in zijn dissertatie. ${ }^{402}$ Beide auteurs hebben decennia lang gepleit voor een hervorming van de verkeersaansprakelijkheid in Nederland. In hun vele publicaties hebben zij zich sterk gemaakt voor een betere bescherming van verkeersslachtoffers die naar hun mening onvoldoende was vormgegeven en waarbij verkeersslachtoffers vaak onvoldoende werden gecompenseerd. ${ }^{403}$ Bloembergen meende dat een systeem van aansprakelijkheid gecombineerd met een verplichte WAM-verzekering te beperkt was om de doelstelling van slachtofferbescherming te verwezenlijken. ${ }^{404}$ Daarnaast waren naar zijn mening de kosten van uitvoering van het aansprakelijkheidssysteem zeer hoog, omdat het slachtoffer in een vaak langdurige en ingewikkelde aansprakelijkheidsprocedure moest aantonen dat de veroorzaker schuld had aan het ongeval. ${ }^{405}$ In de visie van Van Wassenaer was het geldende regime van verkeersaansprakelijkheid te traag, verouderd en was de uitkomst dermate onvoorspelbaar dat veelal sprake was van een loterij. Hoewel de voorzieningen aan de kant van de benadeelde

401. Bloembergen, Naar een nieuw ongevallenrecht, p. 1-31.

402. Van Wassenaer van Catwijck, Eigen schuld, 1971, p. 23-26, waarin hij als een eerste stap op weg naar een verkeetsverzekering pleitte voor de afschaffing van eigen schuld voor de letselschade van het niet-gemotoriseerde verkeersslachtoffer. Dit betekende dat bij een verkeersongeval door de WAM-verzekeraar geen beroep meer kon worden gedaan op de eigen schuld van de benadeelde, behoudens opzet of grove schuld en met uitzondering van zaakschade. Zie ook Van Wassenaer van Catwijck, Verkeersschade en eigen schuld, Symposium, 1972, p. 21-43.

403. Van Wassenaer van Catwijck, Verkeersverzekering, p. 8, berekende dat in 1975 naar schatting $19 \%$ van de totaal in het verkeer geleden personenschade onvergoed bleef.

404. Andere doelstellingen van een vergoedingssysteem voor verkeersschade zijn volgens Bloemberger de spreiding van de schade, de vergoedingsplicht van de schadeveroorzaker, de preventie van verkeersongevallen, de allocatie van kosten en efficiëntie. Zie Bloembergen, Naar een nieuw ongevallenrecht, p. 14-17 en NJB, 1973, p. 963-965.

405. Zie Bloembergen, Naar een nieuw ongevallenrecht, p. 14-17 en NJB, 1973, p. 963-965. 
veelal zorg droegen voor de schadevergoeding, vertoonden ook deze eerste partij verzekeringen de nodige tekortkomingen. Volgens Van Wassenaer bleven bepaalde groepen slachtoffers, zoals zelfstandigen, huisvrouwen en jeugdigen vaak van vergoeding verstoken. ${ }^{406}$

Zowel Bloembergen als Van Wassenaer hebben in hun geschriften als alternatief voor een systeem met aansprakelijkheid gepleit voor de invoering van een vorm van een verkeersverzekering. Deze voorstellen zullen in paragraaf 3.2 en 3.3 centraal staan. In paragraaf $3.4 \mathrm{zal}$ aandacht worden besteed aan ideeën die door andere rechtsgeleerde auteurs zijn geopperd.

\subsection{BLOEMBERGEN EN EEN AANVULLENDE VERKEERSVERZEKERING VOOR PERSONENSCHADE}

Het voorstel van Bloembergen behelst een beperkte vorm van een eerste partij verzekering voor personenschade, die een aanvullend karakter draagt ten opzichte van de reeds aanwezige sociale voorzieningen aan de zijde van het verkeersslachtoffer. ${ }^{407}$

Met betrekking tot de opzet van zijn voorgestelde systeem kiest Bloembergen voor een verkeersverzekering die door de eigenaar of bezitter van een motorrijtuig wordt afgesloten ten behoeve van een aanvullende vergoeding van de personenschade van de inzittenden van het motorrijtuig en van de schade van de fietsers en voetgangers die met het motorrijtuig in botsing komen.

De personenschade dient in de visie van Bloembergen door middel van vaste periodieke uitkeringen, afhankelijk van de leeftijd van het slachtoffer en de mate van arbeidsongeschiktheid, aan het slachtoffer te worden vergoed, zonder dat een direct verband behoeft te bestaan met de schade. ${ }^{408}$

De in beginsel verplichte aanvullende verkeersverzekering kan door zowel de particuliere verzekeraars als door een overheidsorgaan worden aangeboden. Voor de particuliere verzekeraars pleit onder andere de ervaring die zij hebben op het gebied van

406. Van Wassenaet van Catwijck, Verkeersverzekering, p. 7 en p. 29, noot 9-11. Zie ook Bloembergen, NJB, 1978, p. 698-699.

407. De fundamenten van zijn voorstel zijn neergelegd in: Bloembergen, Naar een nieuw ongevallenrecht, 1965, p. 1-31; NJB, 1973, p. 962-97I en p. 998-1009 en NJB, 1994, p. 117-123. Zie ook zijn kitische bespreking van de rapporten van de Studiegroep Verkeersaansprakelijkheid in NJB, 1978, p. 693-708 en NJB, 1980, 925-938.

408. Bloembergen, NJB, 1978, p. 701. Dit in de plaats van een som ineens, die volgens hem moeilijk welvaartsvast kan worden gemaakt. 
autoverzekeringen. Uitvoering door een overheidsorgaan betekent dat meer aan preventie zal kunnen worden gedaan. ${ }^{409}$

Met dit voorstel kan volgens Bloembergen de civiele aansprakelijkheid bij verkeersongevallen worden afgeschaft, behalve voor opzettelijk toegebrachte schade. ${ }^{410}$

De bescherming van slachtoffers bij zaakschade (aan motorrijtuigen) is minder noodzakelijk, zodat er geen reden is om deze onder te brengen in de door hem voorgestelde regeling. Wel dient volgens Bloembergen de schuldaansprakelijkheid ook bij zaakschade te worden afgeschaft, waarbij overigens blijvend rekening moet worden gehouden met de aan het rijden met een motorrijtuig verbonden gevaren. De WAM-verzekering kan voor groot deel verdwijnen, waarbij de eigenaar van het motorrijtuig op vrijwillige basis een cascoverzekering afsluit. Verzekeraars kunnen ook een cascoverzekering aanbieden die alleen de schade dekt die door de schuld van een derde is ontstaan, waarbij geen schade zal worden uitgekeerd ingeval van eigen schuld van de bestuurder van het motorrijtuig. ${ }^{411}$

Bloembergen pleit verder voor een algehele afschaffing van de verhaalsrechten van de particuliere en sociale verzekeraars. ${ }^{412}$ Regres is in zijn visie niet meer dan een 'vestzak-broekzak operatie', ${ }^{413}$ waarbij geld wordt overgeheveld van de ene zak (de WAM-verzekeraar) naar de andere zak (sociale- en volksverzekeraars). ${ }^{414}$ De kosten van het regres zijn zeer hoog en houden mede verband met de kostbare aansprakelijkheidsprocedures. ${ }^{415}$ Wanneer een algehele afschaffing van het regres niet mogelijk zal blijken, kan volgens Bloembergen ook worden gekozen voor collectieve afwikkeling van het regres. Door middel van een rechtstreekse betaling van een bedrag

409. Bloembergen, NJB, 1978, p. 706-707.

410. Bloembergen, NJB, 1973, p. 1000-1001.

411. Bloembergen, NJB, 1973, p. 1002-1005; Zie omtrent de zaakschade ook Bloembergen, NJB, 1980, p. 925-938, met een verwijzing naar buitenlandse stelsels (Quebec, Belgie, Michigan).

412. Bloembergen, NJB, 1973, p. 1005-1007, Naar een nieuw ongevallenrecht, p. 11-13, NJB, 1978, p. 703-704, waarin hij stelt dat tweederde van het bedrag dat door de WAM-verzekeraars voor persoonlijke schade wordt uitgekeerd naar de regresnemende instanties gaat en later in BW-krant Jaarboek, 1987, p. 13-36 en NJB, 1994, p. 1 17-123. Dit laatste artikel verscheen naar aanleiding van een SER-advies: Regresrechten in de sociale verzekeringen, Publikatie SER, nr. 14, 17 september 1993. Hierin werd voorgesteld om het regres dat reeds gold binnen de werknemersverzekering, uit te breiden tot de volksverzekeringen. Zie over dit advies Hartlief en Van Maanen, NTBR, 1994, p. 75-78.

413. Deze term is afkomstig uit Bloembergen, Schadevergoeding bij onrechtmatige daad, diss., nr. 254 en wordt uitgewerkt in Bloembergen, BW-krant Jaarboek, 1987, p. 26.

414. In de woorden van Bloembergen, NJB, 1994, p. 122: 'Het is alsof je in zakken verpakte stenen van de ene plaats naar de andere (beter haast; dezelfde; vestzak-broekzak) plaats vervoert door ze stuk voor stuk uit de zakken te halen en te vervoeren en ze dan ter plaatse van de bestemming weer in de zakken te doen'.

415. Bloembergen, NJB. 1994, p. 119-121. 
van de ene collectiviteit (WAM-verzekeraars) naar de andere collectiviteit (sociale fondsen) kan een besparing op de kosten worden bereikt. De financiering van een dergelijke collectivering zal door het gemotoriseerde verkeer moeten worden opgebracht via een toeslag op de verzekeringspremie. ${ }^{416}$ Daarnaast zal volgens Bloembergen buiten het aansprakelijkheidsrecht om, door middel van het beginsel 'de vervuiler betaalt', een heffing via de motorrijtuigbelasting aan de bezitters van een motorrijtuig kunnen worden opgelegd. ${ }^{417}$

In een interview met Ars Aequi in $1994^{418}$ wordt door Bloembergen gesteld dat, nu de wetgever de regresrechten niet wil afschaffen, de door hem voorgestane verkeersverzekering financieel niet meer haalbaar was. Ten behoeve van de invoering van een nieuw stelsel van verkeersaansprakelijkheid kan naar zijn mening door de wetgever aansluiting worden gezocht bij de rechtspraak van artikel 31 c.q. 185 WVW. Voor kinderen geldt sinds het Kolkman-arrest een risicoaansprakelijkheid voor de automobilist. Hij pleit voor een gelijke bescherming van volwassen fietsers en voetgangers, behoudens overmacht. Met een dergelijke regeling wordt in ieder geval bespaard op de uitvoeringskosten van het aansprakelijkheidsrecht, hoewel de vaststelling van de schade een vertragende factor blijft. Voor de inzittenden van een motornjtuig kan het huidige aansprakelijkheidsrecht worden gehandhaafd, aangevuld met een Schadeverzekering-Inzittenden (SVI) voor de bestuurder. Andere verplichte verzekeringen acht Bloembergen niet wenselijk. ${ }^{419}$

\subsection{VAN WASSENAER VAN CATWIJCK EN DE VERKEERSVERZEKERING}

In 1977 presenteerde Van Wassenaer in zijn oratie een concreet voorstel voor een verkeersverzekering. ${ }^{420}$ Naar aanleiding van een studiereis in 1988 door NoordAmerika en Canada, waar hij zich liet inspireren door de aldaar in de jaren '70 van

416. Zie Bloembergen, NJB, 1994, p. 122. Voor een dergelijke oplossing pleitte hij reeds in, VR, 1990, p. 330.

417. Bloembergen, NJB, 1994, p. 123. Op deze wijze kan de verkeersschade worden toegerekend aan de activiteiten van het gemotoriseerde verkeer. Zie daarover reeds Bloembergen, Naar een nieuw ongevallenrecht, p. 11-13. Zie ook Bloembergen, NTBR, 1998, p. 170, voor een herhaling van dit standpunt.

418. Interview met A.R. Bloembergen, AA, 1994, p. 217-223.

419. Bloembergen in AA, 1994, p. 222.

420. Van Wassenaer van Catwijck, Verkeersverzekering, p. 1-78. Hij had zich al in 1967 een voorstander van een verkeersverzekering getoond. Hij verwierp daarbij echter het voorstel van Bloembergen omdat dit toen op korte termijn niet haalbaar zou zijn. De WAM-verzekering was zijns inziens nog steeds noodzakelijk nu de collectieve voorzieningen aan de kant van het slachtoffer teveel lancunes vertoonden. Zie Handelingen NJV, 1967, deel II, p. 35. 
de vorige eeuw ingevoerde no-fault verzekering, heeft hij zijn voorstellen verder uitgewerkt. ${ }^{421}$

Van Wassenaer pleit, onder afschaffing van de aansprakelijkheid uit onrechtmatige daad, voor de invoering van een verplichte verkeersverzekering, die moet worden beschouwd als een aanvulling op de reeds aanwezige voorzieningen aan de zijde van het slachtoffer. De dekking onder de verkeersverzekering omvat de schade, tot een in de wet geregeld maximum of hoger indien de polisvoorwaarden daarin voorzien, die wordt geleden bij gebeurtenissen waar ingevolge artikel 2 lid 1 van de WAMwet een motorrijtuig bij betrokken is. Trams en treinen dienen hier volgens Van Wassenaer aan te worden toegevoegd, evenals zware vrachtwagens, bussen en tweewielerige motorrijtuigen. De schade van de bestuurders en inzittenden wordt vergoed door de eigen verkeersverzekeraar van het motorrijtuig en de schade van de fietser of voetganger door de verkeersverzekeraar van het betrokken motorrijtuig. ${ }^{422}$

De verplichte verkeersverzekering heeft vooral betrekking op de vergoeding van personenschade, namelijk medische kosten, inkomensschade, smartengeld, overlijdensschade en begrafeniskosten. ${ }^{423}$ Daarbij is een beroep op de eigen schuld van de benadeelde, behoudens opzet, niet meer mogelijk.

Om te voorkomen dat de premiestijging te groot wordt en om de ongevalsrisico's verzekerbaar te houden, zullen volgens Van Wassenaer beperkingen moeten worden gesteld aan de omvang van de te vergoeden personenschade. De medische kosten dienen daarbij in ieder geval zoveel mogelijk te worden vergoed. De vergoeding van inkomensschade kan echter aan een maximum worden gebonden. ${ }^{424}$ Ook de uitkeringen voor smartengeld kunnen worden beperkt, bijvoorbeeld door middel van een barema-stelsel. ${ }^{425}$

In het voorstel van Van Wassenaer is bij zaakschade de eigenaar van het motorrijtuig aansprakelijk, met uitzondering van de eigen schuld van een derde, toeval

421. Het verslag van deze studiereis is gepubliceerd in: Van Wassenaer van Catwijck, VA, 1988, p. 321-377; Van Wassenaer van Catwijck, Verkeersverzekering in Nederland, p. 1-63; Van Wassenaer van Catwijck, VR, 1989, p. 60-63. De resultaten van dit onderzoek zullen ook in hoofdstuk 10 aan de orde komen.

422. Van Wassenaer van Catwijck, VA, 1988, p. 356-358, Verkeersverzekering, p. 10 en p. 16 en VR, 1989 , p. 60 .

423. Van Wassenaer van Catwijck, VA, 1988, p. 354-355.

424. Van Wassenaer van Catwijck, Verkeersverzekering, p. 16-17, stelt voor om de maximumbedragen voor inkomenschae te relateren aan het premieloon op jaarbasis voor de WAO. Zie ook Van Wassenaer van Catwijck, VA, 1988, p. 345-347.

425. Van Wassenaer van Catwijck, VA, 1988, p. 350-351, die in dit verband verwijst naar het systeem van Quebec waar met sterk geschematiseerde bedragen wordt gewerkt. 
(geen gebrek), diefstal en wanneer het motorrijtuig niet in het bezit is van de eigenaar. ${ }^{226}$

De vergoeding van zaakschade kan volgens Van Wassenaer voor een deel, namelijk in die gevallen waarbij sprake is van een combinatie van zaakschade en personenschade, binnen de verplichte verkeersverzekering worden ondergebracht en voor het overige door de schadelijder in de vorm van een eerste partij cascoverzekering zelf worden gedragen. ${ }^{427}$ Daarnaast kan een besparing op de vergoeding van zaakschade worden bereikt door de uitbanning van de schuldvraag en door rekening te houden met het 'Betriebsgefahr' dat met het rijden van een motorrijtuig wordt gecreëerd. ${ }^{428}$

De regresrechten van de particuliere en sociale verzekeraars dienen in de visie van Van Wassenaer te worden afgeschaft nu uit cijfers is gebleken dat de opbrengst daarvan in het niet valt bij de totale inkomsten van de sociale verzekeraars. Daarnaast leent een verkeersverzekering zich ook niet voor regres, omdat daarvoor een ansprakelijke tegenpartij nodig is. Een collectivering van het regres met een afdracht tussen WAM-verzekeraars en particuliere en sociale verzekeraars acht Van Wassenaer niet uitgesloten, waarbij het regres kan worden bevroren op het geldende niveau. ${ }^{429}$

In een interview uit 1996 werd aan Van Wassenaer onder andere om commentaar gevraagd op een informeel voorontwerp van de regering waarin een risicoaansprakelijkheid voor de schade van de fietser en voetganger wordt geregeld en een Schadeverzekering-Inzittenden (SVI) met uitzondering van de bestuurder. $\mathrm{Hij}$ acht dit voorontwerp een grote stap vooruit, maar is het oneens met de uitzondering voor bestuurders. De eigenaar van het motorrijtuig betaalt immers de premie voor de SVI en het is volgens hem niet te verkopen dat deze vervolgens wordt uitgesloten van een vergoeding. ${ }^{430}$

426. Van Wassenaer van Catwijck, VA, 1988, p. 358 en p. $342-343$ met een verwijzing naar het geldende regime voor zaakschade in Quebec.

427. Van Wassenaer van Catwijck, VA, 1988, p. 351-352 en Verkeersverzekering, p. 11-13, waarin een kritiek op het voorstel van Bloembergen om de aansprakelijkheid voor zaakschade af te schatfen en de vergoeding daarwan onder te brengen in een vrijwillige cascoverzekcring.

428. Van Wassenaer van Catwijck, Verkeersverzekering, p. 13-16, Eigen schuld, p. 167-173 en VA, 1988 , p. 352-355.

429. Van Wassenaer van Catwijck, VR, 1990, p. 315-316; Bouman en Van Wassenaer van Catwijck, VR, 1993, p. 221 -227; Van Wassenaer van Catwijck, Naar een Europees verkeersschaderecht, p. 3-6; VA, 1988, p. 347-349 en Verkeersverzekering, p. 23-24 en p. 27.

430. Interview door Renckens en Van Leeuwen, VR, 1996, p. 249-251. 


\subsection{ANDERF AUTEURS OVER DE VERKEERSAANSPRAKELIJKHEID}

Behalve Bloembergen en Van Wassenaer van Catwijck hebben meer rechtsgeleerde auteurs de afgelopen decennia een bijdrage geleverd aan de discussie over de Nederlandse verkeersaansprakelijkheid. Hieronder volgt een kort overzicht van hun denkbeelden, waarbij tevens aandacht wordt besteed aan een rapport van de Raad voor de verkeersveiligheid.

Wachter is geen voorstander van een verkeersverzekering, maar pleit voor een regel van risicoaansprakelijkheid ten aanzien van letsel- en overlijdensschade. Het eigen schuldverweer ten opzichte van het slachtoffer dient te worden afgeschaft en de aansprakelijkheid van de gemotoriseerde beperkt. Afschaffing van het regres lijkt hem niet wenselijk; wel zou een collectivering mogelijk moeten zijn tussen verzekeraars onderling. Wachter stelt verder voor om de vergoeding van letselschade ten gevolge van een verkeersongeval over te hevelen van de WAM naar de WAO met behulp van een door de weggebruiker verplicht af te sluiten verzekering. Deze WAO-polis krijgt daarmee het karakter van een schadevergoeding ten behoeve van een derde, waarbij de bedrijfsvereniging de schade vergoed van de slachtoffers die anders door de WAM-verzekeraar zouden worden schadeloos gesteld. ${ }^{431}$

Salomons pleit in navolging van Van Wassenaer voor de invoering van een verplichte verkeersverzekering die door iedere bezitter van een motorrijtuig moet te worden afgesloten. Deze verzekering vergoed de tengevolge van een verkeersongeval geleden personenschade van de bestuurders en passagiers van een motorrijtuig en van de fietsers en voetgangers. De WAM-verzekering zal komen te vervallen. De verkeersverzekering heeft een aanvullend karakter bovenop de reeds uitgekeerde vergoeding op grond van de sociale en particuliere verzekeringen. Deze laatste hebben voor de uitgekeerde schade geen regresrecht op de verkeersverzekeraar. ${ }^{432}$

Van Dam geeft de voorkeur aan een verkeersverzekering boven een risicoaansprakelijkheid. Met een verkeersverzekering kan zijns inziens een betere bescherming van verkeersslachtoffers worden bereikt, omdat in meer gevallen een vergoeding wordt verkregen, waarbij de schade ook sneller wordt uitgekeerd. Een verkeersverzekering leidt zijns inziens wel tot een toename van het aantal claims. Een regel van risicoaansprakelijkheid, met de blijvende bewijsproblemen, is volgens Van

431. Wachter, RM Themis, 1975, p. 227-271 en VA, 1974, p. 191-196.

432. Salomons, VA, 1974, p. 197-202; Salomons, VR, 1978, p. 125-131 en VR, 1980, p. 73-78. Hierin pleit hij weliswaar voor een verkeersverzekering mar een risicoaansprakelijkheid acht hij ook zeker cen verbetering. Zie ook Hoekema, Vergoeding van verkeersschade, p. $43-46$ en p. 55-57, die cen vergelijkbaar voorstel voor een aanvullende verkeersverzekering presenteer. 
Dam niet een wezenlijke verbetering ten opzichte van de nu geldende strenge zorgvuldigheidsnorm. ${ }^{433}$

Het regres dient naar de mening van Van Dam in het kader van een optimale schadespreiding te worden gehandhaafd, met het gevolg dat de schade uiteindelijk door een afgebakende risicogroep wordt gedragen. Het doorberekenen van de kosten van aansprakelijkheid aan bepaalde activiteiten kan deze immers goedkoper of duurder maken, waarbij de voordelen steeds dienen te worden afgewogen tegen de toename van de administratieve kosten van het regres. ${ }^{434}$

Hartlief zoekt de oplossing voor de verkeersschadeproblematiek buiten het aansprakelijkheidsrecht om en pleit voor de invoering van een verkeersverzekering. Door de afschaffing van de aansprakelijkheid ontstaat volgens hem een laagdrempelig vergoedingssysteem met een ruim beschermingsbereik; zowel ongemotoriseerden, inzittenden van het eigen motorrijtuig als ook de bestuurder zelf profiteren mee. Daarnaast kan binnen een stelsel van verkeersverzekering worden gekozen voor een minder dan volledige schadeloosstelling.

In het voorstel van Hartlief biedt de verkeersverzekering, waarvan de premies worden opgebracht door het gemotoriseerde verkeer, een soort basisbescherming met een genormeerde vergoeding (percentages of forfaitaire) voor de geleden vermogensschade. Diegenen die meer bescherming wensen kunnen kiezen voor een extra verzekering, waarvan premie voor eigen rekening is. Het gaat hier derhalve om een combinatie van een 'third party' verzekering, de basisbescherming die ten laste komt van het gemotoriseerde verkeer en een 'first party' verzekering naargelang een potentieel verkeersslachtoffer een verdergaande bescherming wenst. Het aansprakelijkheidsrecht kan in de visie van Hartlief worden afgeschaft, met uitzondering van de beperkte afgebakende groep gevallen waarin een gemotoriseerde zich (ernstig) verwijtbaar heeft gedragen en het slachtoffer eigenlijk recht heeft op een hoger vergoedingsniveau, maar een beroep op een systeem van de verkeersverzekering daarvoor onvoldoende waarborgen biedt. ${ }^{435}$

Kottenhagen en Kottenhagen-Edzes stellen dat zowel de invoering van een risicoaansprakelijkheid als een verplichte verkeersverzekering leidt tot een kostenstijging. Van belang bij de keuze voor één van beide systemen is de vraag hoe ver de bescherming van verkeersslachtoffers moet worden uitgebreid. Gegeven de tendens

433. C.C. van Dam, Zorgvuldigheidsnorm en aansprakelijkheid, diss., p. 248-250 en p. 264.

434. C.C. van Dam, Zorgvuldigheidsnorm en aansprakelijkheid, diss., 1989, p. 243.

435. Hartlief, RM Themis 1999, p. 52-53; Hartlief, in Het belang van de dader, LSA 1999, p. 22-24; Hartlief, leder draagt zijn eigen schade, p. 41-42 en p. 68; Hartlief en Tjittes, Verzekering en aansprakelijkheid, p. 166; Hartlief, In Verkeersaansprakelijkheid in Belgie en Nederland, p. 189191. 
naar een handhaving en zelfs uitbreiding van de regresrechten pleiten zij in het kader van een nieuw stelsel van verkeersaansprakelijkheid voor een collectivering van het regres. Hiermee kan volgens hen een effectieve kostenallocatie worden bereikt tussen de voorzieningen aan de zijde van verkeersslachtoffers en het collectief van degenen door wie de verkeersschade moet worden gedragen, in casu de WAM-verzekeraars. $^{436}$

In zijn recent gepresenteerde voorstel ${ }^{437}$ wordt door Van Maanen de invoering beoogd van een gedifferentieerd verkeersaansprakelijkheidsregime gebaseerd op artikel $185 \mathrm{WVW}$. Daarbij geldt het vermogen van het voertuig (vrachtwagen/bus, auto, motor/bromfiets, fiets en voetganger) primair als maatstaf voor de gevaarzetting ('betriebsgefahr') die bepalend is voor de aansprakelijkheid. Naarmate het verschil in 'Betriebsgefahr' groter wordt geldt een ruimere aansprakelijkheid. Naast het Betriebsgefahr kan ook het rijgedrag medebepalend zijn voor de vraag wie uiteindelijk de schade moet dragen.

Binnen het systeem 'Van Maanen' is bij een aanrijding tussen gelijkwaardige gemotoriseerden een gewone foutaansprakelijkheid van toepassing. Bij een aanrijding tussen ongelijkwaardige motorrijtuigen wordt uitgegaan van een verscherpte aansprakelijkheid (weerlegbare foutpresumptie) in het nadeel van het zwaardere motorrijtuig. Bij een aanrijding tussen een motorrijtuig en een fietser geldt een risicoaansprakelijkheid met een beperkt beroep op overmacht en een normaal eigen schuldverweer tegenover de fietser. Een voetganger wordt binnen dit systeem het meest verregaand beschermd. Daarbij wordt uitgegaan van een (eenzijdige) risicoaansprakelijkheid ten laste van het motorrijtuig: alleen wanneer de voetganger een ernstige fout heeft begaan die de enige oorzaak is geweest van het ongeval (bijvoorbeeld plotseling voor een auto springen) blijft de schade voor eigen rekening. Bij een fietser versus een voetganger geldt tenslotte een risicoaansprakelijkheid met een normaal overmachts- en eigen schuldverweer.

Door de Raad voor de Verkeersveiligheid wordt in een sterk bekritiseerd rapport ${ }^{438}$ niet voor een risicoaansprakelijkheid noch voor een verkeersverzekering gekozen, maar voor een systeem van schuldaansprakelijkheid met een bijzondere aandacht voor de preventie. Met behulp van preventieve maatregelen dienen financiële prikkels te worden gecreëerd en het veilig rijden te worden bevorderd. Zonder onder-

436. Kottenhagen en Kottenhagen-Edzes, NJB, 1995, p. 1115-1123. Zie ook Kottenhagen-Edzes, NJB, 1998, p. 114-115.

437. Van Maanen, RM Themis, 1999, p. 54-56; Engelhard en Van Maanen, VR, 1999, p. 135-139.

438. Zie onder anderen: Blees, Vrb, 1995, p. 9-12; Renckens, De beursbengel, 1995, p. 18-20; Verbond van Verzekeraars, Vrb, 1994, p. 1470-1471; Bloembergen, VR, 1995, p. 1 -4 met een reactie hierop door Zeven namens de Raad, in VR. 1995. p. 136-I37; Kottenhagen en KottenhagenFdzes, NJB, 1995, p. 1120-1121. 
scheid tussen letselschade en andere materiële schade dient de schade van het slachtoffer binnen een vastgestelde termijn te worden vergoed. Bij grove schuld vindt geen uitkering plaats, mits binnen de gestelde termijn kenbaar gemaakt. Na uitkering aan het slachtoffer kunnen verzekeraars onderling verder procederen over een eventueel eenzijdige grove schuld. Het regres dient te worden gehandhaafd, maar kan in navolging van het Franse systeem via de collectiviteiten worden afgehandeld. ${ }^{439}$

Uit het voorgaande blijkt dat een meerderheid van de rechtsgeleerde auteurs een voorkeur uitspreekt voor een oplossing van de verkeersschadeproblematiek buiten het aansprakelijkheidsrecht om. Daarbij wordt gekozen voor een vorm van een verkeersverzekering. Met name Bloembergen en Van Wassenaer van Catwijck zijn de belangrijkste pleitbezorgers geweest voor een verkeersverzekering, reden waarom hun voorstellen meer uitvoerig aan bod zijn gekomen. Zoals hierna zal blijken staat de visie van de meerderheid van de doctrine lijnrecht tegenover de plannen van de wetgever. In paragraaf 5 en 6 zal blijken waarom de wetgever blijft vasthouden aan het aansprakelijkheidsrecht als grondslag voor de vergoeding van verkeersschade.

\section{De wetgever en de verkeersaansprakelijkheid}

In deze paragraaf zal de rol van de wetgever bij de hervorming van de verkeersaansprakelijkheid in Nederland centraal staan. Daarbij zal aan de hand van de Rapporten van de Studiegroep Verkeersaansprakelijkheid uit 1978 en 1980 en de Notitie Verkeersaansprakelijkheid uit 1990 een beknopt overzicht worden gegeven van de ontwikkelingen die hebben geleid tot het wetsvoorstel Verkeersongevallen dat op 24 november 1997 werd ingediend.

\subsection{DE RAPPORTEN VAN DE STUDIEGROEP VERKEERSAANSPRAKELUKKHEID}

Eind 1973, acht jaar nadat Bloembergen de eerste serieuze aanzet had gegeven voor een hervorming van de verkeersaansprakelijkheid, ${ }^{440}$ werd door de Minister van Justitie een Studiegroep Verkeersaansprakelijkheid geünstalleerd. Deze Studiegroep bestond uit vertegenwoordigers van de regering, assuradeuren en practici. Zij had tot taak om twee alternatieve systemen voor de vergoeding van verkeersschade te onderzoeken, namelijk een regime van risicoaansprakelijkheid en een verplichte verkeersverzekering. De centrale onderzoeksvraag was welke gevolgen de invoering van één van beide regimes zou hebben op de afwikkeling van verkeersschade en op de omvang van de premies voor motorrijtuigverzekeringen. Het onderzoek van De Studiegroep heeft geresulteerd in twee rapporten, waarvan de eerste (personenscha-

\footnotetext{
439. Raad voor de Verkeersveiligheid, Schuld en boete, 1994, p. 1-28.

440. Bloembergen, Naar een nieuw ongevallenrecht, 1965.
} 
de) in $1978^{441}$ verscheen en de tweede (zaakschade) in $1980 .{ }^{442}$ Deze rapporten zullen hierna op een aantal hoofdlijnen worden besproken. ${ }^{443}$

In het eerste Rapport (letselschade) wordt door de Studiegroep geen voorkeur uitgesproken voor een systeem van risicoaansprakelijkheid of een verplichte verkeersverzekering. ${ }^{444}$ Voor een risicoaansprakelijkheid pleit dat een dergelijk regime eenvoudig in een wet kan worden opgenomen omdat het aansluit bij reeds bestaande wettelijke regelingen en bij de in het buitenland geldende regelingen. Een voordeel van een verplichte verkeersverzekering is dat zowel de inzittenden als de houder van een motorrijtuig de mogelijkheid hebben om de eigen verzekeraar aan te spreken, waardoor een meer harmonieus model ontstaat. ${ }^{445}$

Voor een eventuele invoering van een risicoaansprakelijkheid of een verplichte verkeersverzekering worden door de Studiegroep de volgende algemene aanbevelingen gedaan:

- de eigen schuld van de benadeelde dient, behoudens opzet, te worden afgeschaft;

- de vergoeding van de schade van de inzittenden van een motorrijtuig dient bij een ongeval tussen twee of meer motorrijtuigen zoveel mogelijk naar één verzekeraar te worden gekanaliseerd. Bij een risicoaansprakelijkheid is dat de motorrijtuigverzekeraar van de tegenpartij; bij een verkeersverzekering is de eigen verzekeraar verantwoordelijk. Hiermee kan de schadeafwikkeling worden vereenvoudigd;

- de mogelijkheid om een andere weggebruiker op grond van een actie uit onrechtmatige daad aan te spreken moet komen te vervallen;

- het regresrecht van particuliere en sociale verzekeraars dient te worden afgeschaft;

- De bedoeling van een nieuw systeem is in de visie van de Studiegroep een aanvullende voorziening voor verkeersschade te verschaffen bovenop de reeds bestaande sociale, particuliere en volksverzekeringen. ${ }^{446}$

441. Rapport van de Studiegroep Verkeersaansprakelijkheid, Deel I, 1978.

442. Rapport van de Studiegroep Verkeersaansprakelijkheid, Deel II, 1980.

443. Voor een meer uitvoerige en vooral kritische bespreking van deze rapporten kan worden verwezen naar: Bloembergen, NJB, 1978, p. 693-708 en NJB, 1980, p. 925-938; Salomons, VR, 1978, p. 125-131 en VR, 1980, p. 73-78.

444. In Rapport Studiegroep, Deel I, bijlage 1, p. 54-63 is een voorontwerp voor een systeem van risicoaansprakelijkheid opgenomen. In Rapport Studiegroep, Deel I, bijlage 2, p. 64-98 is een vorrontwerp voor een verplichte verkeersverzekering uitgewerkt. Beide voorontwerpen worden artikelsgewijs toegelicht.

445. Rapport Studiegroep, Deel I, p. 48.

446. Rapport Studiegroep, Deel I, p. 48-49, alsmede p. 50-52 voor een beschrijving en eventuele oplossing van andere knelpunten. 
Ten aanzien van het tweede Rapport (zaakschade) wordt door de Studiegroep gesteld dat binnen de zaakschade bij verkeersongevallen een meerderheid wordt gevormd door cascoschade aan een motorrijtuig. Daarom was het onderzoek van de Studiegroep vooral gericht op de vraag welk vergoedingssysteem voor cascoschade het meest wenselijk is. ${ }^{447}$

Volgens de Studiegroep dient in het kader van een nieuwe regeling ter vergoeding van cascoschade te worden gestreefd naar een snellere en goedkopere schadeafwikkeling en naar een betere risicospreiding. ${ }^{448}$ Uiteindelijk spreekt een grote meerderheid $^{499}$ van de Studiegroep zich uit voor de wettelijke invoering van een barema-stelsel voor de vergoeding van cascoschade bij verkeersongevallen. ${ }^{450}$ Binnen dit stelsel wordt ten aanzien van veel voorkomende aanrijdingssituaties een schuldverdeling vastgelegd, gebaseerd op bestaande verkeersregels (RVV), met name de voorrangsregels. Alleen bijzondere omstandigheden, zoals de snelheid waarmee is gereden, alsmede opzettelijk veroorzaakte verkeersongevallen blijven buiten dit systeem. Voor deze niet-barema gevallen stelt de Studiegroep voor om het schuldbeginsel te handhaven. ${ }^{451}$

\subsection{DE NOTITIE VERKEERSAANSPRAKELIJKHEID}

Vanuit de literatuur en door de Tweede $\mathrm{Kamer}^{452}$ werd aan de Minister gevraagd wat hij met de voorstellen van de Studiegroep wenste te doen. Het duurde echter tot 1987 voordat op aandringen van de Vaste Commissie voor Justitie van de Tweede $\mathrm{Kamer}^{453}$ door de Minister nieuwe initiatieven werden ondernomen. Na een schrifte-

447. Rapport Studiegroep, Deel II, 1980, p. 7-8. Schade aan kleding en andere zaken dienen gelijk te worden behandeld als bij de eerder besproken personenschade. Schade aan wegmeubilair, gebouwen en andere zaken dienen binnen de eventuele wettelijke regeling voor zaakschade tc worden ondergebracht. Geen bijzondere aansprakelijkheidsregeling voor de schade aan loslopende dieren, met verwijzing naar artikel $1404 \mathrm{BW}$, de aansprakelijkheid van de eigenaar van het dier. Zie Rapport Studiegroep, Deel II, p. 23-24. Zie voor een kritisch commentaar op dit tweede deel van het Rapport: Bloembergen, NJB, 1980, p. 925-938; Salomons, VR, 1980, p. 73-78.

448. Rapport Studiegroep, Deel II, p. 15-17.

449. Zie voor een 'dissenting opinion': Neleman in Rapport Studiegroep, Deel II, p. 25-32, die pleit voor een algehele afschaffing van de aansprakelijkheid bij cascoschade.

450. Een ontwerp voor een dergelijke wettelijke regeling is opgenomen in bijlage 1 van het Rapport Studiegroep, Deel Il, p. 38-49. De Studiegroep zoekt hiermee aansluiting bij de gangbare systemen in het buitenland, met name die in Frankrijk en België.

451. Rapport Studiegroep, Deel II, p. 18-20. Bagage en andere zaken die met het motorrijtuig zijn verbonden kunnen eveneens binnen het baremasysteem worden ondergebracht. Zie Rapport Studiegroep, Deel II, p. 23-24.

452. Het betreft hier vooral een gedachtenwisseling in 1985 tussen Bloembergen en Regeringscommissaris Snijders, opgenomen in BW-krant jaarboek, 1987, p. 13-36.

453. Tijdens de Uitgebreide Commissie Vergadering van 1 juni 1987 werd door de Kamer, in het kader van de behandeling van de Tijdelijke Regeling Verhaalsrechten (artikel 6:197 BW), aan de Minister het verzoek gericht om een notitie op te stellen met een stellingname ten aanzien van 
lijke toezegging op 28 september 1987, werd door de Minister van Justitie op 27 april 1990 een notitie met betrekking tot de vergoeding van verkeersschade aan de Tweede Kamer aangeboden. ${ }^{454}$

In zijn notitie gaat de Minister uitvoering in op twee stelsels van verkeersaansprakelijkheid, namelijk een verplichte verkeersverzekering en een regime van risicoaansprakelijkheid. ${ }^{455}$ Beide systemen kunnen in de visie van de Minister voldoen aan het uitgangspunt van verbeterde bescherming van verkeersslachtoffer. ${ }^{456}$ Voor wat betreft de keuze tussen beide stelsels wordt door de Minister, met een verwijzing naar de ontwikkelingen in het buitenland, gesteld dat moet worden gestreefd naar een volledige vergoeding van het verkeersslachtoffer. ${ }^{457}$

De Minister concludeert dat een verplichte verkeersverzekering voordelen heeft. Deze hangen samen met de afschaffing van de schuldvraag, een meer harmonieuze schadeafwikkeling en met het gegeven dat meer slachtoffers een vergoeding ontvangen die veelal ook sneller wordt uitgekeerd. ${ }^{458}$ Daar staat echter tegenover dat een verkeersverzekering leidt tot een aanzienlijk premieverhoging voor de kwetsbare motorrijtuigen (bromfietsers en motoren). Verder heeft de bestuurder ook vrijwillige verzekeringsmogelijkheden, zodat deze binnen een verkeersverzekering in beginsel geen eigen vergoedingsbron nodig heeft. Tenslotte zal bij de invoering van een verkeersverzekering de premiestijging aanvaardbaar moeten blijven, maar daarvoor dienen vooral verkeersslachtoffers die ernstig letsel hebben geleden een deel van

een stelsel voor de vergoeding van verkeersslachtoffers, dit naar aanleiding van het Rapport van de Studiegroep Verkeersaansprakelijkheid. Zie Handelingen Tweede Kamer, 1986-1987, UCV 76 , pp. 7, 13, 19, 33-34.

454. Notitie Verkeersaansprakelijkheid, Tweede Kamer, 1989-1990, 21528, nr. 1. Zie voor een samenvatting van deze Notitie met commentaar van respectievelijk de ANWB, de NVVA, de Federatie van Bedrijfsverenigingen, de Vereniging van Nederlandse Zorgverzekeraars en van $M$. Dijkstra, VR, 1990, p. 281-293. Zie voor een verslag van een aan deze Notitie gewijd Symposium Verkeersaansprakelijkheid d.d. 9 november 1990, VR, 1990, p. 309-333.

455. Naast de resultaten van de Studiegroep Verkeersaansprakelijkheid wordt door de Minister in zijn Notitie ook verwezen naar het Rapport 'Geldelijke Ramingen Ander Stelsel' (GRAS) van de NVVA, waarin onder andere is berekend dat zowel een risicoaansprakelijkheid als een verkeersverzekering met een evenredige uitbreiding van het regres tot een aanzienlijke stijging van de schadelast zal leiden. Zie Notitie Verkeersaansprakelijkheid, TK, 1989-1990, 21528, nr. 1, p. 718.

456. Notitie Verkeersaansprakelijkheid, TK, 1989-1990, 21528, nr. 1, p. 27.

457. Notitie Verkeersaansprakelijkheid, TK, 1989-1990, 21528, nr. 1, p. 31-33. De Minister verwijst hier ook naar de EG-richtlijnen die ten aanzien van de WAM-verzekering een minimum-dekking voor personen- en zaakschade bij verkeersongevallen eisen.

458. Notitie Verkeersaansprakelijkheid, TK, 1989-1990, 21528 , nr. 1, p. 24-26. 
hun volledige schadevergoeding in te leveren, hetgeen de Minister niet wenselijk acht. ${ }^{459}$

Naar aanleiding van deze bezwaren spreekt de Minister een voorkeur uit voor een systeem van risicoaansprakelijkheid ten behoeve van alle verkeersslachtoffers. Een risicoaansprakelijkheid sluit volgens de Minister beter aan bij de bestaande aansprakelijkheidsverzekering en bij de in te voeren risicoaansprakelijkheden van boek 6 BW. Hierin ligt tevens een argument om de schade ten laste van het gemotoriseerde verkeer te brengen. Daarnaast zal een systeem van risicoaansprakelijkheid meer in overeenstemming zijn met de reeds bestaande stelsels in het buitenland. ${ }^{460}$ Tenslotte geniet een risicoaansprakelijkheid de voorkeur van de Minister omdat anders een onderscheid ontstaat tussen slachtoffers van verkeersongevallen en slachtoffers van andere ongevallen. ${ }^{461}$

De regresrechten dienen volgens de Minister zoveel mogelijk te worden gehandhaafd op het huidige niveau. Dit kan worden bereikt door de risicoaansprakelijkheid jegens niet-gemotoriseerde verkeersdeelnemers buiten de Tijdelijke regeling verhaalsrechten van artikel 6:197 BW te houden en de risicoaansprakelijkheid jegens gemotoriseerde verkeersdeelnemers in deze regeling onder te brengen. ${ }^{462}$

\section{Het wetsvoorstel Verkeersongevallen en de plannen van Minister Korthals}

\subsection{INLEIDING}

Na de publicatie van de Notitie verkeersaansprakelijkheid duurde het tot 1997 alvorens de regering met een concreet wetsvoorstel naar buiten trad. ${ }^{463}$ In de tussenliggende jaren heeft zich echter een aantal ontwikkelingen ten aanzien van het regres voorgedaan, waarmee in het uiteindelijke wetsvoorstel Verkeersongevallen rekening is gehouden. ${ }^{464}$ In 1993 is bijvoorbeeld door de SER geadviseerd om het regres uit te breiden naar de volksverzekeringen. ${ }^{465}$ Naar aanleiding van dit advies werd een wetsvoorstel opgesteld met het doel de regresrechten uit te breiden naar de volksver-

459. Notitie Verkeersaansprakelijkheid, TK, 1989-1990, 21528, nr. 1, p. 26-28.

460. Hierbij wordt onder andere verwezen naar Frankrijk, Duitsland, Zwitserland en Denemarken, waaraan sinds 1995 ook Belgie̋ kan worden toegevoegd. Zie daarover hoofdstuk 2.

461. Notitie Verkeersaansprakelijkheid, TK, 1989-1990, 21528, nr. 1, p. 28-30.

462. Notitie Verkeersaansprakelijkheid, TK, 1989-1990, 21528, nr. 1, p. 10-14 en p. 33-35.

463. Vaststelling en invoering van afdeling 8.14.1 (verkeersongevallen) van het Burgerlijk Wetboek, Tweede Kamer, 1997-1998, 25 759, nrs. 1-2, p. 1-5.

464. Memorie van Toelichting, TK, 1997-1998, 25759 , nr. 3, p. 11-12.

465. Publikatie SER nr. 14 d.d. 17 september 1993. Zie daarover Bloembergen, NJB, 1994, p. $117-$ 123; Hartlief en Van Maanen, NTBR, 1994, p. 75-78; Van der Horst, In volle verzekerdheid, p. 277-286. 
zekeringen, waarbij artikel 6:197 zodanig werd gewijzigd dat het regres alleen nog maar op basis van schuld kon worden genomen. Dit wetsvoorstel haalde het niet, aangezien door middel van een herziening van de verschillende in het voorstel genoemde volksverzekeringswetten reeds een regresrecht werd gecreëerd of uitgebreid. $^{466}$

In de Memorie van Toelichting bij het wetsvoorstel Verkeersongevallen wordt met een verwijzing naar het voorgaande gesteld dat, als gevolg van de uitbreiding van het regres ten laste van de WAM-verzekeraars en de wetenschap dat $95 \%$ van de verhaalsacties betrekking heeft op verkeersongevallen, de premies van de WAMverzekering sterk zullen toenemen. Volgens de regering zal dit kunnen leiden tot een toename van het aantal niet-verzekerde motorrijtuigen, een aantal dat verder zal stijgen indien een regeling wordt ingevoerd waarbij alle verkeersdeelnemers tegen de gevolgen van een verkeersongeval worden beschermd. ${ }^{467}$

Naar aanleiding van de hiervoor genoemde argumenten, de uitbreiding van het regres en de daaraan verwante premiestijging van de WAM-verzekering, is in het beoogde wetsvoorstel dat in 1997 door de regering aan de Tweede Kamer werd aangeboden niet gekozen voor een stelsel waarin alle verkeersdeelnemers (inclusief de bestuurders van een motorrijtuig) worden beschermd. De regering stelde daarentegen een systeem voor, waarbij alleen ten behoeve van bepaalde categorieën van verkeersdeelnemers, namelijk fietsers, voetgangers, passagiers en bestuurder-werknemers, een risicoaansprakelijkheid wordt ingevoerd. Het voorstel behelsde de opname van een nieuwe afdeling 1 in titel 14 van boek $8 \mathrm{BW}$ getiteld 'Verkeersongevallen', bestaande uit de artikelen 1202-1206. Daarnaast zou ten behoeve van de bescherming van de bestuurder-werknemer in boek $7 \mathrm{BW}$ een nieuw artikel 658a worden opgenomen. Als gevolg van de invoering van dit wetsvoorstel zou artikel 185 WVW komen te vervallen.

466. In dat kader kan onder andere worden verwezen naar de invoering van de Algemene Nabestaandenwet (ANW), Stb. 1995, 690, waarin artikel 61 voorziet in een regresrecht voor de Sociale Verzekeringsbank. Daamaast is met de invoering van de Wet Pemba (premiedifferentiatie en marktwerking in de arbeidsongeschiktheidsverzekering), Stb. 1997, 175, de Algemene Arbeidsongeschiktheidswet (AAW) komen te vervallen en voor wat betreft het regres geîntegreerd in artikel 90 Wet op de Arbeidsongeschiktheidsverzekering (WAO). Tenslotte is recent ook in artikel $65 \mathrm{~b}$ van de Algemene Wet Bijzondere Ziektekosten (AWBZ), Stb. 1999, 239, een verhaalsrecht opgenomen. Zie daarover: Janssen, VA, 1997, p. 155-162; Hartlief, in Regresrechten, Afschaffen, handhaven of uitbreiden, p. 4-8; Boot, in Regresrechten, Afschaffen, handhaven of uitbreiden, p. 89-92; Van Maanen en Hartlief, NTBR, 1994, p. 75-78; De Haas en Hartlief, Collectivering en institutionalisering van regres, p. 18-23; Bolt, Schadevergoeding (losbladig), Art. 108, aant. 89; Kremer, Hennekam en Van der Harst, VR, 1998, p. 292; Hartlief en Tjittes, Verzekering en aansprakelijkheid, p. 70-80 voor een overzicht van de diverse verhaalsrechten in het $\mathrm{Ne}$ derlandse recht.

467. Memorie van Toelichting, TK, 1997-1998, 25 759, nr. 3, p. 12. 
Inmiddels is dit wetsvoorstel door de huidige Minister van Justitie Korthals formeel ingetrokken en heeft hij in een brief aan de Tweede Kamer globaal zijn eigen ideeën voor een eventueel door hem in te dienen wetsvoorstel uitgewerkt. Deze plannen, die niet veel afwijken van het wetsvoorstel van zijn ambtsvoorgangster, hebben echter nog niet geresulteerd in een concreet wetsvoorstel. In deze paragraaf zal het 'oude' wetsvoorstel Verkeersongevallen samen met de plannen van Korthals worden geanalyseerd, waarbij de nadruk zal liggen op het wetsvoorstel. Dit hangt samen met feit dat het wetsvoorstel heeft geleid tot uitgebreide (kritische) beschouwingen in de literatuur, ${ }^{468}$ hetgeen van de plannen van Korthals nog niet kan worden gezegd. ${ }^{469}$ Daarnaast is in het wetsvoorstel een systeem voor de vergoeding van verkeersschade uitgewerkt, met daarbij een uitvoerige argumentatie van de keuzes die door de regering zijn gemaakt. ${ }^{470}$ Ten aanzien van de plannen van Korthals is nog niet geheel duidelijk welke kant het precies opgaat. Tot slot leent het uitgewerkte wetsvoorstel zich beter voor een toetsing ${ }^{471}$ aan de uitkomsten van het rechtseconomisch en empirisch onderzoek ${ }^{472}$ dan de plannen van Korthals.

Met betrekking tot de opzet van deze paragraaf zal een onderscheid worden gemaakt tussen de categorieën verkeersdeelnemers die in het beoogde wetsvoorstel worden beschermd (paragraaf 6.2), de begrippen 'betrokkenheid' en 'opzet en bewuste roekeloosheid' (paragraaf 6.3), de vergoeding van zaakschade (paragraaf 6.4), de reflexwerking (paragraaf 6.5) en de regresrechten (paragraaf 6.6). Bij de beschrijving van deze categorieën zal achtereenvolgens worden ingegaan op de Memorie van Toelichting bij het wetsvoorstel Verkeersongevallen, het commentaar in de literatuur naar aanleiding van het wetsvoorstel, de plannen van Korthals en het commentaar daarop in de literatuur.

468. Zie onder anderen: Verkeersaansprakelijkheid in Belgik en Nederland, T. Hartlief en M.G. Faure (red.), Groningen-Antwerpen, Intersentia, 1998, met bijdragen voor wat Nederland betreft van Hartlief (p. 147-196), Frenk (p. 113-130), Kottenhagen-Edzes (p. 131-146), Van Maanen en Nelissen (p. 197-216). Zie ook C.C. van Dam, VR, 1998, p. 353-358; Bloembergen, NTBR, 1998, p. 169-174; ANWB, VR, 1998, p. 33-37; Kottenhagen-Edzes, NJB, 1998, p. 109-115; Hartlief en Tjittes, Verzekering en aansprakelijkheid, p. 120-123, p. 137-143 en 151-165; Engelhard en Van Maanen, Aansprakelijkheid voor verkeersongevallen, p. 25-68; Bockwinkel en Van Gessel, AA, 1998, p. 34-42; De Haas en Hartlief, Verkeersaansprakelijkheid, p. 173-180; Kremer, Hennekam en Van der Harst, VR, 1998, p. 289-293; Van Maanen, NJB, p. 116-121; Elzas, Special Handboek, p. 11-67.

469. Zie voor een eerste kritiek op de plannen van Korthals: Hartlief, TVP, 1999, p. 73-74; Engelhard en Van Maanen, VR, 1999, p. 353-357; Nieuwenhuis, RM Themis, 1999, p. 357-358.

470. Zie Memorie van Toelichting, TK, 1997-1998, 25759 , nr. 3, p. 1-53.

471. Zie daarover hoofdstuk 15.

472. Zie hiema deel II en III, hoofdstuk 4-14 


\subsection{WELKE CATEGORIEËN VERKEERSDEELNEMERS WORDEN BESCHERMD?}

In het wetsvoorstel Verkeersongevallen is de bescherming van slachtoffers beperkt tot bepaalde groepen verkeersdeelnemers, namelijk fietsers, voetgangers, passagiers en bestuurder-werknemers. Voor deze categorieën verkeersslachtoffers wordt volgens de regering een verbeterde bescherming het meest nodig geacht. ${ }^{473}$ In dat kader wordt ten laste van de bezitter of houder van een motorrijtuig een risicoaansprakelijkheid voor de personenschade van de fietser, voetganger en passagier en ten laste van de werkgever een risicoaansprakelijkheid voor de personenschade van de bestuurder-werknemer voorgesteld. De bezitter kan geen beroep doen op overmacht en een beroep op de eigen schuld van het slachtoffer is beperkt tot gedragingen die ten tijde van het ongeval opzet of bewuste roekeloosheid opleveren. ${ }^{474}$

\subsubsection{Memorie van Toelichting}

Met betrekking tot de schade van de fietsers en voetgangers wordt de jurisprudentie van de Hoge Raad ten aanzien van artikel 185 WVW voor een belangrijk deel gecodificeerd en wordt de bescherming van deze slachtoffers uitgebreid. Volgens de regering past het om de fietser en voetganger een volledige schadevergoeding te garanderen, mede omdat bijvoorbeeld een ongeval tussen een fietser, die een lichte verkeersfout heeft begaan, en een auto in het algemeen grotere gevolgen heeft voor de fietser dan voor de automobilist. Deze gevolgen worden met het voorstel uitdrukkelijk toegerekend aan het autoverkeer. Daamaast is de bescherming van de fietser en voetganger mogelijk door de aanwezigheid van een verplichte aansprakelijkheidsverzekering aan de zijde van de motorrijtuigbestuurder. ${ }^{475}$

De passagier krijgt zijn schade van de WAM-verzekeraar van het motorrijtuig waarin hij zich ten tijde van het ongeval bevond, in bijna alle gevallen volledig vergoed. Dit geldt ook voor de eenzijdige verkeersongevallen, wanneer de schuld van de ver-

473. Memorie van Toelichting, TK, 1997-1998, 25 759, nr. 3, p. 2 en p. 12. Frenk, NbBW, p. 6-7; Frenk, NTBR, 1998, p. 199; Frenk, in Verkeersaansprakelijkheid in Belgiê en Nederland, p. 113115; Hartlief, in Verkeersaansprakelijkheid in Belgiê en Nederland, p. 148-157; KottenhagenEdzes, NJB, 1998, p. 109-111; Van Maanen, NJB, 1998, p. 116-117; Hartlief en Tjittes, Verzekering en aansprakelijkheid, p. 120-123; De Haas en Hartlief, Verkeersaansprakelijkheid, p. 173.

474. C.C. van Dam, VR, 1997, p. 353, spreekt van een 'zuivere' risicoaansprakelijkheid, met uitzondering van de gevallen waarin het motorrijtuig nict bij een verkeersongeval is betrokken danwel dat aan de zijde van het slachtoffer sprake is van opzet of bewuste roekeloosheid.

475. Memorie van Toelichting, TK, 1997-1998, 25759 , nr. 3, p. 2 en p. 13 en p. 16-18. Frenk, NbBW, 1998, p. 7, NTBR, 1998, p. 199-200 en in Verkeersaansprakelijkheid in Belgie en Nederland, p. 118-119; Hartlief, in Verkeersaansprakelijkheid in Belgiê en Nederland, p. 150-15l; Hartlief en Tjittes, Verzekering en aansprakelijkheid, p. 137-140; Elzas, Special Handboek, p. 54-58; Engelhard en Van Maanen, Aansprakelijkheid voor verkeersongevallen, p. 33-34; De Haas en Hartlief, Verkeersaansprakelijkheid, p. 174-175; Bockwinkel en Van Gessel, AA, 1998, p. 36-37; Kottenhagen-Edzes, in Verkeersaansprakelijkheid in Belgiẻ en Nederland, p. 132-134. 
oorzaker van het ongeval niet kan worden bewezen of geen schuldige voor het ongeval kan worden gevonden. Een argument voor de wettelijke bescherming van de passagier hangt samen met het feit dat deze niet de keuze heeft om zich voor zijn personenschade te verzekeren en ook voor hem de letselschade tengevolge van een verkeersongeval ingrijpend kan zijn. ${ }^{476}$

Op de werkgever rust een risicoaansprakelijkheid voor de schade door dood of letsel die door een bestuurder-werknemer bij een verkeersongeval wordt geleden, tenzij sprake is van opzet of bewuste roekeloosheid aan de zijde van de bestuurderwerknemer. De bescherming van de werknemer die uit hoofde van een arbeidsverhouding een motorrijtuig bestuurt vloeit voort uit het feit dat ook de werknemer doorgaans niet de bezitter of houder van een motorrijtuig is en dus ook niet de keuze heeft om een inzittendenverzekering voor zijn personenschade (SVI) af te sluiten. Ook dient de bestuurder-werknemer te worden beschermd tegen de risico's van het verkeer waaraan hij binnen het kader van zijn dienstverband kan worden blootgesteld. De werkgever wordt geacht voor zijn aansprakelijkheid van de schade van de bestuurder-werknemer een verzekering af te sluiten, omdat deze aansprakelijkheid niet onder de WAM-dekking valt en daardoor niet verplicht verzekerd is. ${ }^{4 ?}$

De bestuurder van een motorrijtuig, niet zijnde een werknemer, valt buiten de bescherming van het beoogde wetsvoorstel. De bestuurder zal derhalve zowel in de huidige als toekomstige situatie zijn schade op grond van artikel 6:162 BW moeten verhalen, waarbij hij de schuld van de wederpartij moet aantonen. Wanneer de bestuurder daar niet in slaagt of zelf schuld heeft aan het ongeval zal hij zijn schade geheel of gedeeltelijk zelf moeten dragen. Bij eenzijdige verkeersongevallen heeft de bestuurder veelal geen recht op schadevergoeding. De bestuurder kan ten behoeve van zijn personenschade een 'Schadeverzekering Inzittenden' (SVI) afsluiten. Deze SVI vergoedt rechtstreeks de door de bestuurder geleden materiële en immateriële schade ten aanzien van letsel of overlijden ongeacht of sprake is van een aanspra-

476. Memorie van Toelichting, TK, 1997-1998, 25 759, nr. 3, p. 2, p. 13 en p. 19-20. Frenk, NbBW, 1998 , p. 7-8, NTBR, 1998. p. 200-201 en in Verkeersaansprakelijkheid in Beigiê en Nederland, p. 120-121; Hartlief, in Verkeersaansprakelijkheid in Belgiê en Nederland, p. 152-153; Engelhard en Van Maanen, Aansprakelijkheid voor verkeersongevallen, p. 44-46; De Haas en Hartlief. Verkeersaansprakelijkheid, p. 176-177; Elzas, Special Handboek, p. 58-60; Hartlief en Tjittes, Verzekering en aansprakelijkheid, p. 158-161; Kremer, Hennekam en Van der Harst, VR, 1998, p. 290; Bockwinkel en Van Gessel, AA, 1998, p. 37-38.

477. Memorie van Toelichting. TK, 1997-1998, 25 759, nr. 3, p. 3, p. 13 en p. 20-23. Frenk, NbBW, 1998, p. 8, NTBR, 1998, p. 201-202 en in Verkecrsaansprakelijkheid in Belgiê en Nederland, p. 121-123; C.C. van Dam, VR, 1997, p. 357-358; Hartlief, in Verkeersaansprakelijkheid in Belgic en Nederland, p. 153-155; Hartlief en Tjittes, Verzekering en aansprakelijkheid, p. 161-165; Elzas, Special Handboek, p. 64-67; Engelhard en Van Maanen, Aansprakelijkheid voor verkeersongevallen, p. 49; Bockwinkel en Van Gessel, AA, 1998, p. 38-39; De Haas en Hartlief, Verkeersaansprakelijkheid, p. 177-179. 
kelijke partij. Aangezien de bestuurder de keuze heeft om een SVI aan te gaan en een passagier bijvoorbeeld niet, werd een uitbreiding van de slachtofferbescherming van het wetsvoorstel naar de motorrijtuigbestuurders door de regering minder dringend geacht. ${ }^{478}$

\subsubsection{Het commentaar in de literatuur}

In de literatuur wordt in de eerste plaats kritiek geuit op het feit dat bepaalde categorieën verkeersdeelnemers niet onder de voorgestelde regeling vallen en waarvoor in de Memorie van Toelichting nauwelijks uitleg wordt gegeven. Dit betreft ongemotoriseerde verkeersslachtoffers die bij een eenzijdig verkeersongeval zijn betrokken of bij een ongeval met andere niet-gemotoriseerden. ${ }^{479}$ Daarnaast valt iemand die op een terras, in een tuin of in een garage wordt aangereden ook niet onder de bescherming van het wetsvoorstel. ${ }^{480}$

In de tweede plaats wordt de keuze voor een risicoaansprakelijkheid ten gunste van de passagier weliswaar vanuit beschermingsoogpunt wenselijk geacht, maar volgens Hartlief kan ook een verplichte SVI-verzekering hiervoor een oplossing zijn. ${ }^{481} \mathrm{De}$ ANWB wijst op het feit dat de bescherming van de passagier beperkt is tot die van een motorrijtuig, terwijl bijvoorbeeld ook tram- en treinpassagiers emstige schade kunnen lijden bij een aanrijding met een motorrijtuig. ${ }^{482}$

In de derde plaats wordt erop gewezen dat de bestuurder bij een eenzijdig ongeval een beroep moet doen op eigen voorzieningen en anders op artikel 6:162 BW. Dit kan ertoe leiden dat een bestuurder met een deel van zijn schade blijft zitten, waarvoor hij zich zelf dient bij te verzekeren. Hartlief vraagt zich af of ook voor de bestuurder niet een extra bescherming wenselijk is. ${ }^{483}$ Van Dam meent dat de bestuurder in kwetsbaarheid niet of nauwelijks onderdoet voor de passagier, zodat de uit-

478. Memorie van Toeliching, TK, 1997-1998, 25 759, nr. 3, p. 3, p. 13 en p. 18-19. Frenk, in Verkeersaansprakelijkheid in Belgiê en Nederland, p. 119; C.C. van Dam, VR, 1997, p. 356-357; Hartlief, in Verkeersaansprakelijkheid in België en Nederland, p. 151-152; Engelhard en Van Maanen, Aansprakelijkheid voor verkeersongevallen, p. 48-49; Hartlief en Tjittes, Verzekering en aansprakelijkheid, p. 157-158; De Haas en Hartlief, Verkeersaansprakelijkheid, p. 173-174; Kottenhagen-Edzes, NJB, 1998, p. 112-113.

479. Hartlief, in Verkeersaansprakelijkheid in Belgie̋ en Nederland, p. 156-157.

480. ANWB, VR, 1998 , p. 35.

481. Hartlief, in Verkeersaansprakelijkheid in Belgie̋ en Nederland, p. 170-171.

482. ANWB, VR, 1998, p. 35.

483. Hartlief, in Verkeersaansprakelijkheid in Belgiê en Nederland, p. 175-176, 'Waarom aan de bestuurder een keuze opleggen en voor andere verkeersslachtoffers regulerend ingrijpen?' 
sluiting van de bestuurder vanuit de beschermingsgedachte niet geheel valt te verklaren. $^{484}$

In de vierde plaats wordt ten aanzien van de bestuurder-werknemer gesteld dat hiermee een persoon volledig wordt beschermd die, in tegenstelling tot bijvoorbeeld de passagier, wel degelijk invloed kan uitoefenen op het ontstaan van een verkeersongeval. ${ }^{485}$ Daarnaast heeft de werkgever, anders dan bij de aansprakelijkheid voor een veilige werkplek, slechts een beperkte invloed op de veiligheid van een motorrijtuig. ${ }^{486}$ Verder wordt een bestuurder-werknemer enerzijds beter beschermd dan een gewone werknemer, die op grond van artikel 6:758 BW zijn schade slechts vergoed krijgt wanneer de werkgever is tekortgeschoten. ${ }^{487}$ Anderzijds wordt de werknemer ook beter beschermd dan een gewone bestuurder, waarvan slechts een minderheid de beschikking heeft over een SVI-verzekering. ${ }^{488}$ Van Dam stelt zich de vraag of de risicoaansprakelijkheid van de werkgever vanuit de 'risque professionnel-gedachte' niet kan worden uitgebreid naar de schade van mobiele niet-gemotoriseerde werknemers die schade lijden anders dan door een verkeersongeval dan wel bij een verkeersongeval met een andere niet-gemotoriseerde verkeersdeelnemer. ${ }^{499}$ Ten slotte wordt gewezen op de afbakeningsproblemen bij de bescherming van de werknemer-bestuurder met name ten aanzien van de 'uitoefening van de werkzaamheden.'. ${ }^{40}$

\subsubsection{De beschermingsomvang in de plannen van Minister Korthals}

Korthals volgt zijn ambtsvoorgangster voor wat betreft de bescherming van bepaalde groepen verkeersdeelnemers. Ook in zijn plannen wordt uitgegaan van een risicoaansprakelijkheid ten laste van de bezitter van een motorrijtuig voor de personenschade van de fietser, voetganger en passagier, respectievelijk een risicoaansprakelijkheid van de werkgever voor de personenschade die door een werknemer bij een verkeersongeval wordt geleden. De bestuurders van een motorrijtuig krijgen ook in

\footnotetext{
484. C.C. van Dam, VR, 1997, p. 357.

485. Hartlief, in Verkeersaansprakelijkheid in Belgie en Nederland, p. 177.

486. C.C. van Dam, VR, 1998, p. 358.

487. Harlief, in Verkeersaansprakelijkheid in Belgiß en Nederland, p. 181. Zie ook Bier, VR 1998, p. 1-4 met betrekking tot de bescherming van de werknemer bij bedrijfsongevallen.

488. Kremer, Hennekam en Van der Harst, VR, 1998, p. 291.

489. C.C. van Dam, VR, 1998, p. 357-358. Zie ook Kremer, Hennekam en Van der Harst, VR, 1998, p. 289 , die in dit verband het voorbeeld noemen van een werknemer die in opdracht van de werkgever met de fiets door eigen schuld bij een eenzijdig verkeersongeval gewond raakt, waarvoor hij echter geen vergoeding ontvangt.

490. Kremer, Hennekam en Van der Harst, VR, 1998, p. 291; ANWB, VR, 1998, p. 37: Waar begint 'de uitoefening van werkzaamheden' en waar eindigt deze? Wanneer wordt de werkgever geacht een vergoeding te hebben gegeven voor een verzekering van de schade? Wat zijn wel of niet zakelijke kilometers?
} 
de plannen van Korthals geen extra bescherming, omdat zij goed in staat zijn hun eigen schade te verzekeren en om een onaanvaardbare premiedruk op de WAM-verzekering te vermijden. ${ }^{491}$

Een belangrijk verschil met het wetsvoorstel is dat Korthals in beginsel de schadevergoeding aan fietsers en voetgangers wil onthouden indien zij met een ernstig gebrek aan zorgvuldigheid (roekeloos) aan het verkeer deelnemen, met dien verstande dat dit verweer alleen geldt tegenover niet-gemotoriseerden van 14 jaar en ouder. Voor slachtoffers beneden de 14 jaar blijft het huidige regime (100\%-regel op basis van artikel $185 \mathrm{WVW}$ ) gehandhaafd. Bij passagiers zal in de visie van Korthals de grens van bescherming bij roekeloosheid in het algemeen moeten liggen. Ten aanzien van de bestuurder-werknemer is nog niet duidelijk waar de grens van bescherming zal komen te liggen, bij roekeloosheid in het algemeen, of bij bewuste roekeloosheid. ${ }^{492}$ Het voorgaande betekent in beginsel een belangrijke verruiming ten opzichte van opzet of bewuste roekeloosheid in het wetsvoorstel. ${ }^{493}$

\subsubsection{Het commentaar in de literatuur}

Hartlief meent dat Korthals met zijn plannen afstand neemt van het huidige recht ten aanzien van artikel $185 \mathrm{WVW}$, waarin een ongemotoriseerde van 14 jaar en ouder minimaal $50 \%$ van zijn schade vergoed krijgt. ${ }^{494}$ In de plannen van Korthals gaan deze verkeersdeelnemers er in bescherming op achteruit, terwijl bij een stelselherziening nu juist een verruiming van de bescherming was beoogd. De aansprakelijkheid van de gemotoriseerde vervalt immers in de plannen van Korthals al bij gewone roekeloosheid. Daamaast wordt voor verkeersslachtoffers jonger dan 14 jaar de huidige situatie $(100 \%)$ gehandhaafd, hetgeen leidt tot een zelfstandig regime voor deze groep verkeersdeelnemers. ${ }^{495}$

Engelhard en Van Maanen stellen dat in de plannen van Korthals de bezitter van een motorrijtuig zich slechts van zijn aansprakelijkheid kan bevrijden wanneer hij aantoont dat de roekeloosheid van het slachtoffer de enige oorzaak van het ongeval is geweest. Zij noemen dit het exclusiviteitsvereiste bij eigen schuld. Dit exclusiviteitsvereiste $\mathrm{zal}$ in hun visie aldus moeten worden opgevat dat de bezitter alleen wordt bevrijd indien vaststaat dat het aan zijn motorrijtuig inherente gevaar (de grondslag

491. TK 1998-199, 25 759, nr. 5 (H), p. 2 en 5.

492. TK 1998-1999, 25759, nr. 5 (H), p. $2-5$.

493. In de volgende paragraaf zal worden ingegaan op de uitleg die Korthals aan het begrip 'roekeloosheid' geeft.

494. Zie ook Nieuwenhuis, RM Themis, p. 358. Volgens hem bevat het voorgestelde systeem een belangrijke uitbreiding van de aansprakelijkheid van de automobilist ten opzicht van artikel 185 WVW.

495. Hartlief, TVP, 1998, p. 73 
voor de aansprakelijkheid) niet aan de totstandkoming van het ongeval heeft bijgedragen. Daarbij zal het om uitzonderingssituaties gaan. De intentie van het kabinet om meer gewicht toe te kennen aan de eigen schuld van het slachtoffer kan volgens hen beter worden bereikt met het normale eigen schuldverweer van artikel 6:101 $\mathrm{BW},{ }^{496}$

\section{3. 'BETROKKENHEID', 'OPZET OF BEWUSTE ROEKELOOSHEID' EN 'ROEKELOOSHEID'}

\subsubsection{Het begrip 'betrokkenheid' in het wetsvoorstel Verkeersongevallen}

In het wetsvoorstel Verkeersongevallen is het belangrijkste criterium voor de vaststelling van de aansprakelijkheid van de bezitter of houder de 'betrokkenheid' van het motorrijtuig bij een verkeersongeval. De bezitter kan, wanneer deze 'betrokkenheid' eenmaal is vastgesteld, een beroep doen op het gedrag van het slachtoffer. Verwijst dit gedrag naar opzet of bewuste roekeloosheid dan leidt dit tot een algeheel verval van de schadevergoedingsplicht van de bezitter, ook wanneer deze een fout heeft begaan. ${ }^{497}$ De bezitter of houder kan in vergelijking met artikel $185 \mathrm{WVW}$ derhalve geen beroep meer doen op overmacht; zijn gedrag is voor de vaststelling van de aansprakelijkheid niet langer relevant. ${ }^{498}$

In de Memorie van Toelichting wordt ten aanzien van het begrip 'betrokkenheid' verwezen naar artikel 29 bis paragraaf van de Belgische WAM-regeling en naar artikel 1 van de Franse 'loi Badinter'. Voor de uitleg van het begrip 'betrokkenheid' kan volgens de toelichting aansluiting worden gezocht bij de Franse rechtspraak ten aanzien van de 'implication'. ${ }^{499}$ Hoewel uit deze jurisprudentie blijkt dat het begrip 'betrokkenheid' moeilijk kan worden afgebakend, wordt in de Toelichting ten behoeve van de Nederlandse rechtspraak toch een aantal criteria opgesomd. ${ }^{500}$

In de eerste plaats is in het kader van de 'betrokkenheid' van belang dat een motorrijtuig 'in het verkeer' schade moet hebben toegebracht. Een auto die in een garage in brand vliegt of ontploft en schade veroorzaakt valt daar bijvoorbeeld niet onder. De schade tengevolge van verkeersongevallen op niet-openbare fabrieks- bouw- of ha-

496. Engelhard en Van Maanen, VR 1999, p. 356.

497. Dit is een wezenlijk verschil met het Franse en Belgische recht, waarin voor een verval van de vergoedingsplicht de 'faute inexcusable' respectievelijk de 'onverschoonbare fout' de enige oorzaak van het verkeersongeval moet zijn geweest. Zie respectievelijk paragraaf 4.3 van hoofdstuk 1 (Frankrijk) en paragraaf 4.4 van hoofdstuk 2 (België).

498. Memorie van Toelichting, TK, 1997-1998, 25759 , nr. 3, p. 37-38.

499. Zie Sterk, Verhoogd gevaar in het aansprakelijkheidsrecht, diss., p. 51-59; Sterk, VR, 1997, p. 197-201, alsmede paragraaf 4.2 van hoofdstuk 1. 
venterreinen kan op grond van de gevaarzetting ook betrokkenheid opleveren (artikel 2 lid 1 juncto 3 lid 1 WAM).

In de tweede plaats geldt volgens de Toelichting dat een regelmatig geparkeerd motorrijtuig niet bij een verkeersongeval betrokken kan zijn, omdat een dergelijk motorrijtuig niet aan het verkeer deelneemt. Dit geldt in beginsel evenzeer voor motorrijtuigen die foutgeparkeerd of te lang geparkeerd staan. ${ }^{501}$

In de derde plaats wordt door de Toelichting met een verwijzing naar de Franse rechtspraak gesteld, dat in ieder geval sprake is van betrokkenheid wanneer er contact is tussen het slachtoffer en een motorrijtuig in beweging. ${ }^{502}$ Dit geldt ook voor het contact tussen het slachtoffer en een motorrijtuig dat stilstaat bij een stoplicht, in een file of tengevolge van pech. Het motorrijtuig neemt in een dergelijke situatie wel deel aan het verkeer en kan als zodanig bij een verkeersongeval betrokken zijn. ${ }^{503}$

Wanneer het fysieke contact tussen een slachtoffer en een motorrijtuig ontbreekt, is volgens de Toelichting voor het aannemen van betrokkenheid vereist dat er een zekere band is tussen het motorrijtuig en het ongeval dan wel dat het motorrijtuig een actieve rol heeft gespeeld bij het ontstaan van het ongeval. Dit brengt mee dat betrokkenheid zal worden aangenomen van een motorrijtuig voor de schade van een fietser die door luchtverplaatsing ten val is gekomen. Er zal echter geen sprake zijn van betrokkenheid voor de schade van een voetganger die schrikt van een normaal startende automotor of van een motorrijtuig dat louter voorbijrijdt in een straat. ${ }^{504}$

\subsubsection{Het commentaar in de literatuur}

Sterk concludeert uit zijn vergelijking met de Franse rechtspraak inzake het begrip 'betrokkenheid', dat in Frankrijk betrokkenheid wordt aangenomen wanneer de aanwezigheid van het motorrijtuig een noodzakelijke voorwaarde was voor het ontstaan van het ongeval. Daarbij is niet van belang of het motorrijtuig een actieve dan wel een passieve rol heeft gespeeld en is ook het gedrag van de motorrijtuigbestuurder niet relevant. ${ }^{505}$

501. Memorie van Toelichting, TK, 1997-1998, 25759 , nr. 3, p. 38

502. Sterk, VR, 1998. p. 66.

503. Memorie van Toelichting, TK, 1997-1998, 25759 , nr. 3, p. 39.

504. Memorie van Toelichting, TK, 1997-1998, 25 759, nr. 3, p. 39-40. Frenk, NTBR, 1998, p. 202203 en in Verkeersaansprakelijkheid in Belgie en Nederland, p. 124-125. Zie over het begrip 'betrokkenheid' eveneens: C.C. van Dam, VR, 1997, p. 353-354; Hartlief, in Verkeersaansprakelijkheid in Belgie en Nederland, p. 162-164; Hartlief en Tjittes, Verzekering en aansprakelijkheid, p. 140-141; ANWB, VR, 1998, p. 35-36.

505. Sterk, VR 1998, p. 65-69. 
De opvatting in de Memorie van Toelichting dat een bomauto niet betrokken kan zijn omdat de schade dan niet in het verkeer is toegebracht, ${ }^{506}$ is in de visie van Sterk te beperkt en wijkt af van het Franse recht. Daar worden slachtoffers van een bomauto die zich op de weg bevindt wel beschermd door de 'loi Badinter'. ${ }^{507}$

Met betrekking tot een regelmatig geparkeerd motorrijtuig baseert de Memorie van Toelichting zich volgens Sterk ten onrechte op de Franse rechtspraak van vóór 1995. Daarna heeft het Franse Hof van Cassatie geoordeeld dat voor betrokkenheid slechts het contact relevant is, waarbij het gedrag van de motorrijtuigbestuurder in beginsel geen rol speelt. ${ }^{508}$ Sterk merkt in dit verband verder op dat in de Franse rechtspraak voor het aannemen van betrokkenheid bij geparkeerde en stilstaande motorrijtuigen eenzelfde criterium (contact) wordt gehanteerd. Hij pleit er dan ook voor om zowel bij geparkeerde als bij stilstaande motorrijtuigen (een ruimere) 'betrokkenheid' aan te nemen. ${ }^{509}$

\subsection{3. 'Opzet of bewuste roekeloosheid' in het wetsvoorstel Verkeersongevallen}

Wanneer de betrokkenheid van het motorrijtuig bij een verkeersongeval vaststaat kan de bestuurder of houder, om zich geheel van zijn vergoedingsplicht te bevrijden, een beroep doen op de opzet of bewuste roekeloosheid van het slachtoffer terzake van het ontstaan van de schade. ${ }^{510}$ Onder opzet wordt volgens de Toelichting verstaan:

'1. Willens en wetens handelen met het oogmerk om de schade te veroorzaken. 2. Het geval dat het slachtoffer weet dat de schade het zekere of noodzakelijke gevolg is van zijn handelen (zekerheids- of noodzakelijkheidsbewustzijn). 3. De situatie waarin iemand zich bewust is van de aanmerkelijke kans dat hij door zijn gedraging schade zal oplopen en dit waarschijnlijke gevolg accepteert (voorwaardelijke opzet of opzet als waarschijnlijkheidsbewustzijn)'.

506. Ook de ANWB, VR 1998, p. 35, vindt dit een te eng omlijnd criterium. Daamaast zal volgens de ANWB het begrip 'betrokkenheid' vragen blijven oproepen, omdat de band met het ongeval niet altijd duidelijk is.

507. Sterk, VR, 1998, p. 66. Ook in de visie van de ANWB, VR 1998, p. 35, dient de passagier die in een auto zit die explodeert te worden beschermd.

508. Sterk, VR, 1998, p. 67

509. Sterk, VR, 1998, p. 68

510. Zie daarover: Bolt, VR, 1998, p. 161-165 en meer algemeen Mendel, LSA 1998, p. 59-70; Mendel, In Volle Verzekerdheid, p. 113-124.

511. Memorie van Toelichting, TK, 1997-1998, 25 759, nr. 3, p. 42. Zie ook C.C. van Dam, Verzekering naar komend recht, preadvies, 1995, p. 72-74; Bolt, VR, 1998, p. 162-163; Mendel, LSA 1998, p. 60-62 en In Volle Verzekerdheid, p. 114-115. 
De laatstgenoemde gradatie (voorwaardelijke opzet) kan zich volgens de Toelichting voordoen bij een fietser die, wetende dat zijn gedraging tot een ongeval kan leiden, bewust een verkeersweg in de verboden richting opfietst tegen het gangbare verkeer in. Bewuste roekeloosheid heeft betrekking op 'de situatie waarin iemand zich bewust is van de aanmerkelijke kans dat zijn gedraging tot schade zal leiden, maar denkt dat dit gevolg zal uitblijven'. Hiervan kan volgens de Toelichting sprake zijn wanneer een fietser tijdens de spits bewust door een rood licht rijdt om een drukke verkeersweg over te steken. Dit ter onderscheiding van onbewuste roekeloosheid waarbij de fietser of voetganger zich misschien wel realiseert dat hij de verkeersregels overtreedt maar zich niet bewust is van het feit dat dit gedrag tot een ongeval kan leiden. ${ }^{512}$ Bij de beoordeling of sprake is van opzet of bewuste roekeloosheid dient naar de concrete omstandigheden ten tijde van het ongeval te worden gekeken Aan kinderen en personen met een geestelijke stoornis zal volgens de Toelichting zelden opzet of bewuste roekeloosheid kunnen worden verweten, omdat zij zich in vele gevallen niet van het gevaar van hun gedraging bewust zijn. ${ }^{513}$

Opzet of bewuste roekeloosheid van de passagier zal naar het oordeel van de Memorie van Toelichting niet snel worden aangenomen. De vraag of bijvoorbeeld het meerijden met een dronken bestuurder of het niet dragen van een autogordel of helm als opzet of bewuste roekeloosheid kunnen worden gekwalificeerd, hangt volgens de Toelichting af van de omstandigheden. Daarbij is het van belang of in de concrete situatie een ernstig gevaar in het leven is geroepen en de passagier zich bewust is geweest van dit gevaar. ${ }^{514}$

Het enkel tegenwerpen van opzet of bewuste roekeloosheid aan de zijde van de bestuurder-werknemer, ook al heeft deze zelf schuld aan het ontstaan van het verkeersongeval berust volgens de Memorie van Toelichting op de gedachte dat:

'....degene die uit hoofde van zijn arbeidsverhouding een motorrijtuig bestuurt, en daarbij aan de risico's van het gemotoriseerde verkeer wordt blootgesteld, niet mag worden tegengeworpen dat hij niet alle voorzichtigheid in acht heeft genomen die nodig is ter voorkoming van verkeersongevallen. Het is immers

512. Zie Mendel, LSA 1998, p. 63-64, over het onderscheid tussen 'bewuste roekeloosheid' en 'onbewuste roekeloosheid'.

513. Memorie van Toelichting, TK, 1997-1998, 25759 , nr. 3, p. 41 -43. C.C. van Dam, VR, 1997, p. 355: Bolt, VR, 1998, p. 163; Engelhard en Van Maanen, Aansprakelijkheid voor verkeersongevallen, p. 33-34; Hartlief, in Verkeersaansprakelijkheid in Belgie en Nederland, p. 159-160; Hartlief en Tjittes, Verzekering en aansprakelijkheid, p. 138-139.

514. Memorie van Toelichting, TK, 1997-1998, 25 759, nr. 3, p. 45. C.C. van Dam, VR, 1997, p. 355; Engelhard en Van Maanen, Aansprakelijkheid voor verkeersongevallen, p. 45; Kremer, Hennekam en Van der Harst, VR, 1998, p. 290; ANWB, VR, 1998, p. 36-37; Hartlief en Tjittes, Verzekering en aansprakelijkheid, p. 159-161. 
een ervaringsfeit dat het regelmatig deelnemen aan het verkeer tot een vermindering van de optimale voorzichtigheid leidtt. ${ }^{515}$

\subsubsection{Het commentaar in de literatuur}

Een aantal auteurs meent dat 'opzet of bewuste roekeloosheid' ruimer is dan 'opzet of aan opzet grenzende roekeloosheid', ${ }^{516}$ waardoor bepaalde verkeersfouten van de fietser, bijvoorbeeld het rijden door een rood licht, mogelijk wel 'bewuste roekeloosheid' opleveren met name bij slachtoffers vanaf 14 jaar. De Memorie van Toelichting maakt volgens hen onvoldoende duidelijk dat het om uitzonderlijke situaties moet gaan. Daamaast dient door de rechtspraak de reikwijdte van 'bewuste roekeloosheid' opnieuw te worden vastgesteld. ${ }^{517}$

Hartlief stelt dat bij opzet of bewuste roekeloosheid de vergoedingsplicht niet geheel moet komen te vervallen wanneer ook de bestuurder een fout heeft gemaakt. Hij verwijst naar het Belgische stelsel van artikel 29bis WAM-wet, waarin geldt dat de 'onverschoonbare fout' van de ongemotoriseerde de enige oorzaak van het ongeval moet zijn geweest. ${ }^{518}$

Verder wordt door Hartlief benadrukt dat de uitzondering van opzet of bewuste roekeloosheid bij passagiers een andere betekenis heeft dan bij fietsers en voetgangers. $\mathrm{Bij}$ de laatsten gaat het immers om een bijdrage aan het ontstaan van het ongeval, terwijl bij onvoorzichtig gedrag van een passagier doorgaans wordt gedacht aan het meerijden met een dronken bestuurder of het niet dragen van een helm. ${ }^{519}$ Bolt meent dat aan een passagier mogelijk wel opzet of bewuste roekeloosheid kan worden tegengeworpen wanneer deze instapt bij 'iemand die zo dronken is dat hij nauwelijks nog op zijn benen kan staan'. ${ }^{520}$

515. Memorie van Toelichting, TK, 1997-1998, 25759, nr. 3, p. 51. Hierin wordt verwezen naar regeling ten aanzien van arbeidsongevallen in artikel 7:658 BW (art. 7A:1638x BW oud) en de hierop gebaseerde rechtspraak, met name HR 27 maart 1992, NJ 1992, 496; HR 20 september 1996, NJ 1997, 198. Zie daarover Bier, NTBR, 1993, p. 22-24 en VR, 1998, p. 1-2; Bolt, VR, 1998, p. 162-164; Hartlief, in Verkeersaansprakelijkheid in Belgiè en Nederland, p. 180-181; Hartlief en Tjittes, Verzkering en aansprakelijkheid, p. 162-163.

516. Anders: Frenk, Verkeersaansprakelijkheid in Belgie en Nederland, p. 126.

517. Zie Hartlief, in Verkeersaansprakelijkheid in Belgiẻ en Nederland, p. 161; Bolt, VR, 1998, p. 162 en p. 164; Kottenhagen-Edzes, in Verkeersaansprakelijkheid in België en Nederland, p. 134136 en NJB, 1998, p. 111 , die verder meent dat de uitzondering van opzet of bewuste roekeloos. heid bij kinderen tot 14 jaar, naar Belgisch voorbeeld (artikel 29 bis paragraaf 1 lid 7 WAM), beter geheel kan worden afgeschaft.

518. Hartlief, in Verkeersaansprakelijkheid in Belgiê en Nederland, p. 161.

519. Hartlief, in Verkeersaansprakelijkheid in Belgie en Nederland, p. 171-172.

520. Bolt, VR, 1998, p. 164-165. 
Volgens de ANWB leidt de objectivering van de roekeloosheid in de zin dat het slachtoffer zich het gevaar had moeten realiseren tot het toelaten van een overmachts- en eigen schuldverweer, omdat bijna elke verkeersfout een gevaar oplevert. De ANWB pleit daarom voor de term 'voorwaardelijke opzet' of 'aan opzet grenzende roekeloosheid'. ${ }^{521}$

\subsubsection{De 'roekeloosheid' in de plannen van Korthals}

Korthals wenst met zijn plannen meer aandacht te geven aan de eigen schuld van met name de fietser en voetganger. In de woorden van Korthals:
'....het bevredigt niet het rechtvaardigheidsgevoel dat men schuldeloos de schade van de schuldige partij moet vergoeden, ook als het slachtoffer zich roekeloos heeft gedragen'. ${ }^{522}$

Daarom wordt in de plannen van Korthals het verweer van 'opzet of bewuste roekeloosheid' afgezwakt tot een 'ernstig gebrek aan zorgvuldigheid' ofwel 'roekeloosheid' van het slachtoffer. Verder geldt dat de vergoedingsplicht pas geheel komt te vervallen wanneer de (onbewuste) roekeloosheid van het slachtoffer de enige oorzaak van het ongeval is geweest. Gedragingen die in de visie van Korthals als roekeloos kunnen worden aangemerkt zijn: door een rood licht rijden, zonder verlichting rijden, voorrang nemen, dronken op de fiets zitten of zonder uitkijken de straat oversteken. Korthals meent dat slachtoffers die geen roekeloos gedrag kan worden verweten hun schade volledig vergoed moeten krijgen. Het gaat daarbij om slachtoffers die meer een 'fout van alledag' hebben begaan, zoals een inschattingsfout, een vergissing of een fout begaan in een 'moment van onachtzaamheid'. ${ }^{23}$

Korthals illustreert zijn uitleg van de begrippen 'roekeloosheid' en 'fouten van alledag' aan de hand van een aantal voorbeelden.

Een dronken man die slingerend van het café naar huis fietst en wordt aangereden gedraagt zich (onbewust) roekeloos, omdat hij door op de fiets te stappen zich niet heeft bekommerd om de mogelijke gevolgen van zijn dronkenschap in het verkeer.

Een studente die dagelijks op haar weg naar de universiteit een rood licht negeert, maar op een dag bij het betreffende verkeerslicht wordt aangereden, gedraagt zich roekeloos met het gevolg dat de aansprakelijkheid van de automobilist geheel vervalt.

521. ANWB, VR, 1998, p. 35-36.

522. TK 1998-1999, 25759 , nr. $5(\mathrm{H})$, p. 2.

523. TK 1998-1999, 25759 , nr. 5 (H), p. 2-3. 
Een man die op de fiets een naderende kruising wil oversteken en de snelheid van een van rechts aankomende auto verkeerd inschat en wordt aangereden, kan geen ernstig gebrek aan zorgvuldigheid worden verweten en krijgt $100 \%$ van zijn schade vergoed. ${ }^{524}$

Voor passagiers ligt de grens van bescherming ook bij gewone roekeloosheid. Korthals meent dat dit in de praktijk geen probleem zal zijn omdat de gedragingen van de passagier zelden bijdragen aan het ontstaan van de schade. Bij de gevallen waarin dit wel mogelijk is kan worden gedacht aan het niet dragen van een gordel of helm, gedragingen die in de visie van Korthals als roekeloos kunnen worden aangemerkt. ${ }^{525}$

\subsubsection{Het commentaar in de literatuur}

Door de literatuur wordt gewezen op de consequenties van de plannen van Korthals ten opzichte van het huidige recht van artikel $185 \mathrm{WVW}$. Enerzijds zal in bepaalde gevallen het verkeersslachtoffer, afhankelijk van de omstandigheden, geen schadevergoeding ontvangen, terwijl dit naar huidig recht nog minimaal $50 \%$ is. In het voorbeeld van de studente zou zij naar huidig recht nog minimaal 50\% van haar schade vergoed krijgen, terwijl zij in de plannen van Korthals niets krijgt. Anderzijds zal een verkeersslachtoffer in de plannen van Korthals altijd $100 \%$ schadevergoeding kunnen krijgen, bijvoorbeeld wanneer er geen overmacht is of de roekeloosheid van het slachtoffer niet de enige oorzaak van het ongeval is geweest, terwijl dat naar huidig recht maar $50 \%$ is. ${ }^{526}$

Een andere consequentie van de plannen van Korthals is dat de automobilist moet bewijzen dat het ongeval uitsluitend door het roekeloze gedrag van de fietser of voetganger is veroorzaakt. Dit brengt mee dat het overmachtsverweer van artikel 185 WVW naar voren treedt, ${ }^{527}$ met dien verstande dat wanneer de automobilist rechtens enig verwijt kan worden gemaakt de roekeloosheid van de fietser of voetganger niet meer de enige oorzaak van het ongeval is. Volgens een aantal auteurs betekent dit voor de automobilist een achteruitgang ten opzichte van het huidige recht. $^{528}$

Nieuwenhuis meent dat in de plannen van Korthals geen consistente lijn is te ontdekken tussen 'roekeloosheid' en 'fouten van alledag'. Voorrang nemen en zonder

\footnotetext{
524. TK 1998-1999, 25759 , nr. 5 (H), p. 3-4.

525. TK 1998-1999, 25759 , nr. 5 (H), p. 5.

526. Hartlief, TVP, 1999, p. 73 , met andere voorbeelden; Nieuwenhuis, RM Themis, 1999, p. $357-$ 358; Engelhard en Van Maanen, VR, 1999, p. 356.

527. Hierbij geldt het criterium dat de bezitter van het motorijtuig 'rechtens geen enkel verwijt' kan worden gemaakt. Zie daarover paragraaf 3.1 van dit hoofdstuk.

528. Zie daarover Nieuwenhuis, RM Themis, 1999, p. 357-358.
} 
uitkijken de straat oversteken hoeven niet roekeloos te zijn, maar kunnen ook het gevolg zijn een 'moment van onachtzaamheid', hetgeen dan een 'fout van alle dag' oplevert. $^{529}$

Volgens Engelhard en Van Maanen leidt het verweer van roekeloosheid als enige oorzaak van het ongeval bij passagiers tot vreemde resultaten. Een passagier die geen helm of gordel draagt, hetgeen roekeloos is, krijgt geen schadevergoeding. ${ }^{530}$ Omdat echter het niet dragen van helm of gordel vaak niet de enige oorzaak van het ongeval is geweest, wordt de passagier toch volledig schadeloos gesteld, hetgeen volgens hen niet de bedoeling van Korthals is geweest. ${ }^{531}$

\subsection{DE VERGOEDING VAN ZAAKSCHADE}

\subsubsection{Memorie van Toelichting}

Op voorwaarde dat de zaakschade samenvalt met de geleden personenschade, kan ingevolge het wetsvoorstel door de fietser, voetganger en passagier ook voor de zaakschade een beroep worden gedaan op de risicoaansprakelijkheid van de bezitter of houder van het motorrijtuig. De vergoeding van zaakschade heeft daarbij voornamelijk betrekking op de schade aan fiets, kleding en bagage. Volgens de Toelichting kan de schadeafwikkeling worden vereenvoudigd wanneer zowel zaakschade als personenschade onder eenzelfde regime van risicoaansprakelijkheid worden gebracht. ${ }^{532}$

De werkgever is ingevolge het wetsvoorstel risicoaansprakelijk voor zowel de personenschade als de zaakschade van de bestuurder-werknemer, ook wanneer de laatste alleen zaakschade heeft geleden. Daarbij wordt de vergoeding van zaakschade door de Toelichting beschouwd als een codificatie van de bestaande rechtspraak. ${ }^{533}$

Passagiers die alleen zaakschade lijden zijn voor een vergoeding daarvan aangewezen op artikel 6:162 BW. ${ }^{534}$ Voor niet-gemotoriseerden kan volgens de Toelichting de zaakschade echter omvangrijk zijn tengevolge van het 'Betriebsgefahr' van het autoverkeer. Om die reden is voor niet-gemotoriseerden die alleen zaakschade

529. Nieuwenhuis, RM Themis, 1999, p. 358.

530. Zie ook Hartlief, TVP, 1999, p. 73.

531. Engelhard en Van Maanen, VR, 1999, p. 355.

532. Memorie van Toelichting, TK, 1997-1998, 25 759, nr. 3, p. 26-27, p. 43 en p. 46 . Engelhard en Van Maanen, Aansprakelijkheid voor verkeersongevallen, p. 41-42.

533. HR 16 oktober 1992, NJ 1993, 264 (Bruinsma). Hierin werd geoordeeld dat de werknemer die in het kader van een arbeidsovereenkomst met zijn eigen auto een ongeval veroorzaakt, in beginsel recht heeft op een vergoeding door de werkgever van de (casco)schade aan zijn auto. Zie Memorie van Toelichting, TK, 1997-1998, 25759 , nr. 3, p. 4, p. 22, p. 27 en p. 51.

534. Engelhard en Van Maanen, Aansprakelijkheid voor verkeersongevallen, p. 45. 
hebben geleden in het wetsvoorstel een bijzondere regeling opgenomen. De strekking hiervan stemt overeen met die van artikel $185 \mathrm{WVW}$, zodat voor de vergoeding van alleen zaakschade derhalve de status quo blijft gehandhaafd. ${ }^{535}$

\subsubsection{Het commentaar in de literatuur}

Kottenhagen-Edzes meent dat het beter is om in alle gevallen de zaak- en personenschade van de niet-gemotoriseerde verkeersdeelnemer gelijk te behandelen. Daarnaast vraagt zij zich in verband met het criterium voor letselschade af wanneer zaakschade en personenschade precies samenvallen. Indien een dokter wordt geraadpleegd geldt dan reeds een risicoaansprakelijkheid voor zowel de letsel- als de zaakschade? Heeft daarentegen het slachtoffer letselschade geleden maar gaat hij daarvoor niet naar de dokter dan moet hij voor zijn zaakschade een beroep doen op de bijzondere, minder beschermende, regeling voor zaakschade in het wetsvoorstel. ${ }^{536}$

Kremer, Hennekam en Van der Harst pleiten voor een regime van schuldaansprakelijkheid ten aanzien van zaakschade. De beoogde regeling met betrekking tot de geleden zaak- en letselschade zal fraude in de hand werken nu een wettelijke omschrijving van letselschade ontbreekt. ${ }^{537}$ Een ander voorstel is om de risicoaansprakelijkheid bij zaakschade te beperken tot het bedrag van de letselschade om te voorkomen dat een fietser tegen een stilstaande auto valt en een nieuwe fiets of een nieuw jack claimt. ${ }^{538}$

\subsubsection{De plannen van Korthals}

Volgens Korthals moet een duidelijke scheiding worden aangebracht tussen de bescherming voor geleden personenschade en zaakschade. Hij meent dat een regeling waarbij een fietser die letselschade heeft geleden ook de schade aan zijn fiets of kleding vergoed krijgt, fraude in de hand zal werken. Een fietser zou na een ongeval zijn letselschade kunnen simuleren om de schade aan zijn fiets vergoed te krijgen. In de visie van Korthals moet daarom in het nieuwe aansprakelijkheidsregime voor de

535. Memorie van Toelichting, TK, 1997-1998, 25759 , nr. 3, p. 27, p. 43 en p. 46-47. Frenk, NbBW, 1998, p. 8-9, NTBR, 1998, p. 204 en in Verkeersaansprakelijkheid in Belgiẽ en Nederland, p. 127; Hartlief, in Verkeersaansprakelijkheid in België en Nederland, p. 164-165; De Haas en Hartlief, Verkeersaansprakelijkheid, p. 204-205; Hartlief en Tjittes, Verzekering en aansprakelijkheid, p. 141-142; Bockwinkel en Van Gessel, AA, 1998, p. 38; Elzas, Special Handboek, p. 60-62; Engelhard en Van Maanen, Aansprakelijkheid voor verkeersongevallen, p. 42; ANWB, VR, 1998, p. 37.

536. Kottenhagen-Edzes, in Verkeersaansprakelijkheid in België en Nederland, p. 137-138 en NJB, 1998, p. 111-112.

537. Zie ook C.C. van Dam, VR, 1997, p. 355-356, die eveneens waarschuwt voor de grensgevallen, waarin een 'schrammetje' aanleiding kan zijn om de verkreukelde dure mountainbike te claimen.

538. Kremer, Hennekam en Van der Harst, VR, 1998, p. 289. 
zaakschade van de ongemotoriseerde en de passagier de status quo worden gehandhaafd. $^{539}$

\subsection{DE SCHADE VAN DE GEMOTORISEERDE VERKEERSDEELNEMER: REFLEXWERKING ${ }^{\text {S40 }}$}

De vraag of de schade bij een verkeersongeval tussen bijvoorbeeld een auto en een fietser over en weer volgens dezelfde maatstaf moet worden afgewikkeld wordt in de Memorie van Toelichting bij het wetsvoorstel Verkeersongevallen negatief beantwoord. Dit zou namelijk betekenen dat een autobestuurder bij de beoogde risicoaansprakelijkheid vrijwel nooit zijn letselschade vergoed krijgt, hetgeen niet wenselijk wordt geacht. ${ }^{541}$

Verder is door Minister, rekening houdend met de opmerkingen van de Raad van State, ${ }^{542}$ besloten om ten aanzien van de reflexwerking geen regeling in het wetsvoorstel op te nemen. Volgens de Memorie van Toelichting ontbreekt het maatschappelijk draagvlak om een regeling te treffen waarbij een gemotoriseerde met zijn schade blijft zitten die door een niet-gemotoriseerde is veroorzaakt. Voor de schade van de gemotoriseerde blijven derhalve de regels van boek $6 \mathrm{BW}$ van toepassing, waarbij het volgens de Toelichting niet ondenkbaar is dat de rechter in het kader van de causale verdeling van artikel 6:101 BW rekening houdt met het 'Betriebsgefahr ${ }^{543}$ van een motorrijtuig in beweging. ${ }^{544}$

539. TK 1998-1999, 25759 , nr. $5(\mathrm{H})$, p. 6.

540. Zie over de reflexwerking naar huidig recht onder anderen: HR 6 februari 1987, NJ 1988, 57, VR 1987, 35; Kortmann, AA, 1987, p. 638-643; Hartlief en Tjittes, Verzekering en aansprakelijkheid, p. 152-154; Van Wassenaer van Catwijck, VR, 1994, p. 253-260; Bouman, VR 1994, p. 33-38; Bouman, In volle verzekerdheid, p. 199-211; Van Wassenaer van Catwijck en Jongeneel, Eigen schuld en mede-aansprakelijkheid, p. 99-106 en p. 146-149; Bouman, LSa 1997, p. 54-56; Hartlief, TvP, 1996, p. 1320-1325; Hartlief, WPNR 6062, 1992, p. 663-667; Van Wassenaer van Catwijck, in CJHB (Brunner-bundel), p. 435-440.

541. Memorie van Toelichting, TK, 1997-1998, 25759, nr. 3, p. 28-30.

542. Advies Raad van State en nader rapport, TK, 1997-1998, 25 759, B, p. 2 en p. 11-12.

543. Kremer, Hennekam en Van der Harst, VR, 1998, p. 290, verwachten dat hierover op dossiemiveau veel discussie zal blijven bestaan tussen AVP-verzekeraars en gemotoriseerden.

544. Memorie van Toelichting, TK, 1997-1998, 25 759, nr. 3, p. 29-30; Advies Raad van State, TK, 1997-1998, 25 759, B, p. 11; Frenk, NbBW, 1998, p. 9, NTBR, 1998, p. 205 en in Verkeersaansprakelijkheid in Belgiè en Nederland, p. 128-129; C.C. van Dam, VR, 1997, p. 354; Hartlief, in Verkeersaansprakelijkheid in Belgiê en Nederland, p. 186-187; Hartlief en Tjittes, Verzekering en aansprakelijkheid, p. 154-156; Van Dijk, VR, 1998, p. 132-133; Bockwinkel en Van Gessel. AA, 1998, p. 39; Elzas, Special Handboek, p. 62-63; Kottenhagen-Edzes, in Verkeersaansprakelijkheid in Belgiê en Nederland, p. 140-143. 


\title{
6.6. REGRESRECHTEN EN VERZEKERINGSPREMIES
}

\subsubsection{Memorie van Toelichting}

In het wetsvoorstel is ten aanzien van de regresrechten gekozen voor een stelsel waarbij de bescherming van verkeersslachtoffers niet ten goede komt aan de regresnemende sociale en particuliere verzekeraars en de overheid. Daarnaast kunnen regresnemende instanties als gevolg van de beoogde afschaffing van artikel 185 WVW, niet meer profiteren van de bescherming, die door de Hoge Raad in het kader van deze regeling aan hen is gegeven. ${ }^{545}$ Regresnemende instanties zullen na de invoering van de nieuwe regeling zijn aangewezen op de algemene onrechtmatige daad van artikel 6:162 BW, hetgeen een formele achteruitgang inhoud ten opzichte van artikel 185 WVW. Daarbij wordt in de Memorie van Toelichting niet uitgesloten geacht dat de rechter in het kader van de billijkheidscorrectie van artikel 6:101 lid 1 BW rekening houdt met het 'Betriebsgefahr' van het motorrijtuig dat aan het verkeer heeft deelgenomen. In dit verband wordt door de Toelichting verwezen naar het arrest Puts/Ceha, ${ }^{546}$ waarin de vordering naar aanleiding van een verkeersongeval tussen een motorrijtuig en een volwassen fietser was gebaseerd op de onrechtmatige daad van artikel $1401 \mathrm{BW}$ (oud). De Hoge Raad oordeelde hierin met een verwijzing naar het $\mathrm{ABP} /$ Winterthur-arrest en het IZA/Vrerink-arrest ${ }^{547}$ dat:

\begin{abstract}
'...in de eerste plaats dient te worden onderzocht of de bestuurder van het motorrijtuig terzake van de wijze waarop hij aan het verkeer heeft deelgenomen voor zover voor de veroorzaking van de aanrijding van belang, rechtens enig verwijt kan worden gemaakt; de fietser draagt hiervan de bewijslast. De bestuurder diende in beginsel rekening te houden met fouten van andere weggebruikers, dus ook met weggebruikers die in strijd met de verkeersregels handelen'. ${ }^{548}$
\end{abstract}

De Toelichting concludeert naar aanleiding hiervan dat het voor de aansprakelijkheid van de bestuurder van een motorijtuig niet veel zal uitmaken of de vordering is gebaseerd op artikel $185 \mathrm{WVW}$ dan wel artikel 6:162 BW. De door de Hoge

\footnotetext{
545. Zie paragraaf 2.4 van dit hoofdstuk.

546. HR 15 januari 1993, NJ 1993, 568.

547. Respectievelijk HR 22 mei 1992, NJ 1992, 527, r.0. 3.3; HR 28 februari 1992, NJ 1993, 566, r.u. 3.7.

548. HR 15 januari 1993, NJ 1993, 568, r.0. 3.2 en 3.3. Menorie van Toelichting, TK, 1997-1998, 25 759, nr. 3, p. 30-31. Zie in dit verband ook HR 11 november 1983, NJ 1984, 331 (Meppelse ree), waarin het ging om een regresactic.
} 
Raad geformuleerde strenge zorgvuldigheidsnorm op basis van de onrechtmatige daad zal daarbij ook in regresacties bepalend zijn voor de aansprakelijkheid. ${ }^{549}$

Een belangrijk argument om de regresrechten te beperken hangt volgens de Toelichting samen met de verwachte stijging van de premies van de WAM-verzekering. Deze mogen in de visie van de Minister niet onaanvaardbaar stijgen, omdat anders hoge kosten en handhavingsproblemen ontstaan met betrekking tot de verplichte WAM-verzekering. ${ }^{550}$ Tengevolge van de uitbreiding van de regresrechten naar de volksverzekeringen $^{551}$ zal de WAM-premie met ongeveer $9-17 \%$ stijgen. In de voorgestelde regeling van risicoaansprakelijkheid zal de premie met ongeveer $14 \%$ toenemen. Dit betekent dat de WAM-premie in totaal met $23-31 \%$ moet worden verhoogd. ${ }^{552}$ Deze stijging wordt in de Toelichting vanuit economisch oogpunt aanvaardbaar geacht en zal er niet toe leiden dat minder automobilisten hun verzekeringsplicht zullen nakomen. ${ }^{553}$

\subsubsection{Het commentaar in de literatuur}

Van Maanen en Nelissen voeren een aantal fundamentele bezwaren aan tegen voorgenomen beperking van de regresrechten. ${ }^{554}$ In de eerste plaats ontstaat hierdoor een niet-wenselijke 'sluipende' tweedeling in het aansprakelijkheidsrecht, ${ }^{555}$ die met name tot uitdrukking komt in de wijze van schadebehandeling. Het slachtoffer geniet een ruimere bescherming dan zijn verhaalzoekende verzekeraar, waarbij aan de vor-

549. Memoric van Toelichting, TK, 1997-1998, 25 759, nr. 3, p. 31. Zie Frenk, NbBW, 1998, p. 9, NTBR, 1998, p. 205; C.C. van Dam, VR, 1997, p. 354; Engelhard en Van Maanen, Aansprakelijkheid voor verkeersongevallen, p. 61-62; Hartlief, VR, 1998, p. 260-261; Bockwinkel en Van Gessel, AA, 1998, p. 39; Hartlief en Tjittes, Verzekering en aansprakelijkheid, p. 151-152; De Haas en Hartlief, Verkeersaansprakelijkheid, p. 180.

550. Memorie van Toelichting, TK, 1997-1998, 25 759, nr. 3, p. 30. Zie ook Hartlief, VR, 1998, p. 260.

551. Zie daarover pargraaf 6.1 dit hoofdstuk.

552. Memorie van Toelichting. TK, 1997-1998, 25 759, nr. 3, p. 14-15. Uit berekeningen van het Centrum voor Verzekeringstatistiek van het Verbond van Verzekeraars blijkt dat wanneer alle verkeersslachtoffers onder alle omstandigheden hun personenschade vergoed krijgen, hetzij via een risicoaansprakelijkheid, hetzij via een verkeersverzekering, de premies voor de WAMverzekering met $35 \%$ tot $40 \%$ zullen stijgen. Inclusief een uitbreiding van de regresrechten (premietoename 9-17\%) zal de premiestijging tussen $44 \%$ en $57 \%$ bedragen.

553. Memorie van Toelichting, TK, 1997-1998, 25759 , nr. 3, p. 15 en p. 35-36. Uit de Memorie van Toelichting kan niet worden opgemaakt wat de precieze premiestijging zal zijn bij het beperken van alle verhaalsacties van de regresnemende verzekeraars tot een vordering op grond van artikel 6:162 BW.

554. Van Maanen en Nelissen, in Verkeersaansprakelijkheid in Belgie en Nederland, p. 197-216; Van Maanen, NJB, 1998, p. 116-121 en de discussie tussen Kremer en Van Maanen in NJB, 1998, p. 609-611.

555. Hierop wordt ook gewezen door: Hartlief, VR. 1998, p. 260-261; Kremer, Hennekam en Van der Harst, VR, 1998, p. 292. 
dering van het slachtoffer een hoger 'zieligheidsgehalte' wordt toegekend. Dit strookt volgens Van Maanen en Nelissen niet met het uitgangspunt van het aansprakelijkheidsrecht, waarbij de onrechtmatig toegebrachte schade gewoon moet worden vergoed. Dit heeft weinig met 'zieligheid' te maken. Met het huidige voorstel worden volgens hen de grenzen van het aansprakelijkheidsrecht, overschreden en wordt in feite een verkeersverzekering gecreëerd onder de noemer van de risicoaansprakelijkheid. $^{550}$

In de tweede plaats dient de regresnemer door de afschaffing van artikel $185 \mathrm{WVW}$ zijn vordering te baseren op de schuldaansprakelijkheid van artikel 6:162 BW. Dit zal volgens Van Maanen en Nelissen leiden tot meer procedures, hogere maatschappelijke kosten en een grotere belasting van de rechterlijke macht. Het argument van de wetgever dat met de voorgestelde risicoaansprakelijkheid geen onderhandelingen over de schuldvraag meer nodig zijn, geldt derhalve niet voor de regresprocedure waar de schuldvraag via een zijdeur weer wordt binnengehaald. ${ }^{557}$

In de derde plaats wordt door Van Maanen en Nelissen de gevreesde premiestijging voor de WAM-verzekering bij een gelijkstelling van de vordering van het slachtoffer en zijn regresnemer ongegrond geacht. ${ }^{58} \mathrm{Zij}$ verwijzen daarbij naar Frankrijk en België waar de invoering van een nieuwe wettelijke regeling heeft geleid tot een verbetering van de positie van regresnemers en een versnelling van de verhaalsprocedures zonder dat sprake is geweest van een sterke premiestijging. Van Maanen en Nelissen pleiten derhalve voor een gelijkstelling van de vordering van de regresnemers met die van het verkeersslachtoffer, hetgeen naar hun mening meer recht zal doen aan het uitgangspunt van het beoogde wetsvoorstel, waarbij een risicoaansprakelijkheid wordt gerechtvaardigd in verband met de aan het gemotoriseerde verkeer verbonden gevaren. ${ }^{559}$

556. Van Maanen en Nelissen, in Verkeersaansprakelijkheid in Belgiè en Nederland, p. 198-202 en p. 206-207; Van Maanen, NJB, 1998, p. 118.

557. Van Maanen en Nelissen, in Verkeersaansprakelijkheid in België en Nederland, p. 202-203 en p. 205; Van Maanen, NJB, 1998, p. 118-119. Anders: Kremer, Hennekam en Van der Harst, VR, 1998, p. 292, die verwachten dat slechts in een beperkt aantal gevallen de claim van een regresnemer zal worden afgewezen.

558. Zij menen zelfs dat door de beperking van de verhaalsrechten de WAM-premies zullen dalen, terwijl aan de kant van de regresnemers de premies zullen stijgen. Zie Van Maanen en Nelissen, in Verkeersaansprakelijkheid in Belgie en Nederland, p. 211; Van Maanen, NJB, 1998, p. 120. Hartlief, VR, 1998, p. 261, acht deze premiestijging aan de zijde van de regresnemers niet onwenselijk. Daarmee wordt namelijk ook rekening gehouden met de gevaren die de verregaand beschermde ongemotoriseerden zelf in het leven roepen (afschaffing van het eigen schuldverweer), waardoor zij mogelijk terecht een deel van deze beschenningskosten zelf dragen.

559. Van Maanen en Nelissen, in Verkeersaansprakelijkheid in België en Nederland, p. 213-214; Van Maanen, NJB, 1998, p. 120-121. 
In aansluiting op de voorgaande kritiek kan ten aanzien van de voorgestelde regeling nog worden gewezen op een aantal cijfermatige onduidelijkheden. ${ }^{560}$ In de Memorie van Toelichting wordt ervan uitgegaan dat $95 \%$ van de regresacties betrekking heeft op ongevallen in het verkeer. Ten aanzien van het beoogde wetsvoorstel wordt een premiestijging voor de WAM-verzekering, inclusief de uitbreiding van het regres ( 9 $17 \%)$, verwacht van $23-31 \%$. In de nieuwe regeling zijn de regresnemende instanties, vanwege de afschaffing van artikel $185 \mathrm{WVW}$, echter aangewezen op artikel 6:162 BW. Dit heeft in beginsel een teruggang in de positie van de regresnemers tot gevolg. ${ }^{561}$ Niet duidelijk is welke gevolgen deze beperking van het regres heeft op de uiteindelijke premiestijging. Gegeven het percentage regresacties $(95 \%)$ bij verkeersongevallen, zou hier mogelijk sprake kunnen zijn van een minder grote premiestijging dan in de Memorie van Toelichting wordt voorspeld. ${ }^{562}$

\section{Conclusie}

De ontwikkelingen in de jurisprudentie van de Hoge Raad ten aanzien van artikel 185 WVW (artikel 31 WVW oud) hebben sinds het begin van de jaren '90 van de vorige eeuw geleid tot een verregaande bescherming van niet-gemotoriseerde verkeersslachtoffers. ${ }^{563}$ Daamaast wordt al meer dan 30 jaar vanuit de rechtsleer de beschermingsgedachte ten aanzien van verkeersslachtoffers benadrukt en gepleit om deze bescherming tot uitdrukking te brengen in een wettelijke regeling. ${ }^{564}$ In meerderheid wordt daarbij de voorkeur uitgesproken voor een vorm van verkeersverzekering, waarbij in grote lijnen de verzekeraar van het motorrijtuig moet opkomen voor de schade van de niet-gemotoriseerden en de inzittenden van het verzekerde voertuig, inclusief de bestuurder. ${ }^{565}$

Het wetsvoorstel Verkeersongevallen was derhalve vanuit historisch oogpunt een logische ontwikkeling geweest, met dien verstande dat de intrekking daarvan door

560. Zie ook C.C. van Dam, VR, 1997, p. 357.

561. De vraag is alleen hoe groot deze teruggang is, nu mogelijk via artikel 6:101 lid $1 \mathrm{BW}$ rekening kan worden gehouden met de gevaren die aan het motorrijtuigverkeer zijn verbonden ofwel met de mate van verwijtbaarheid van de niet-gemotoriseerde verkeersdeelnemer. Zie daarover Memorie van Toelichting, TK, 1997-1998, 25 759, nr. 3, p. 30 en Kremer, Hennekam en Van der Harst, VR, 1998, p. 292 en p. 293, noot 26.

562. Van Maanen en Nelissen, in Verkeersaansprakelijkheid in Belgiě en Nederland, p. 211, stellen dat door de teruggang in de positie van regresnemers de premie voor WAM-verzekering zal dalen.

563. Zie paragraaf 2 van dit hoofdstuk.

564. Zie paragraaf 3 van dit hoofdstuk.

565. Naar aanleiding van het beoogde wetsvoorstel wordt deze voorkeur opnieuw naar voren gebracht. Zie Hartlief, in Verkeersaansprakelijkheid in Belgię en Nederland, p. 187-192; C.C. van Dam, VR, 1997, p. 358; ANWB, VR, 1998, p. 33-35; Bloembergen, NTBR, 1998, p. 169-174; Hartlief, leder draagt zijn eigen schade, oratie, p. $40-42$ en p. 68 . In hoofdstuk 15 zal hier nader op worden ingegaan. 
de huidige Minister Korthals voor vertraging heeft gezorgd. In zijn brief van juni 1999 geeft Korthals weliswaar aan welke ideeën hij voor een nieuw wetsvoorstel heeft, maar halverwege het jaar 2001 zijn deze plannen nog altijd niet concreet geworden. Het is inmiddels wel duidelijk dat de wetgever de aansprakelijkheid als grondslag voor de vergoeding van verkeersschade lijkt te willen handhaven en de stap naar een verkeersverzekering te groot acht. ${ }^{566}$

In het wetsvoorstel Verkeersongevallen en in de plannen van Korthals is gekozen voor een risicoaansprakelijkheid ten behoeve van bepaalde categorieën verkeersdeelnemers die betrokken raken bij een verkeersongeval met een motorrijtuig. Daarbij ligt de nadruk op de meest 'kwetsbaren', namelijk de fietser, de voetganger, de passagier en de bestuurder-werknemer. Vanwege het kostenaspect, in casu een onverantwoorde stijging van de premies van de WAM-verzekering, blijkt een verdere uitbreiding van deze bescherming naar de bestuurder van een motorrijtuig, niet zijnde een werknemer, vooralsnog een stap te ver te zijn. Om de premiestijging van de WAM-verzekering beperkt te houden worden in het wetsvoorstel de regresrechten van particuliere en sociale verzekeraars bevroren op het niveau van artikel 6:162 $\mathrm{BW}$.

Op basis van het wetsvoorstel en de plannen van Korthals wordt een risicoaansprakelijkheid gevestigd ten laste van de bezitter van een motorrijtuig voor de personenschade van de fietser, voetganger en passagier en ten laste van de werkgever voor de personen- en zaakschade van de bestuurder-werknemer. De vergoeding van de zaakschade van de fietser en voetganger valt, voorzover deze niet samengaat met de geleden personenschade, onder een aansprakelijkheidsregime dat overeenstemt met artikel 185 WVW, waardoor een beroep op overmacht en eigen schuld mogelijk blijft. De schuldaansprakelijkheid van artikel 6:162 BW is van toepassing op de schade van de bestuurder, de zuivere zaakschade van de passagier, de vordering van de regresnemer die in eerste instantie de schade aan het slachtoffer heeft uitgekeerd, en op de schade van de fietser of voetganger die betrokken raakt bij een verkeersongeval met een andere niet-gemotoriseerde. ${ }^{567}$

566. TK 1998-1999, 25 759, nr. 5 (H), p. 4. Korthals acht hierbij van belang dat de sociale verzekeraars geen beroep kunnen doen op een verkeersverzekering, waardoor hun inkomsten sterk teruglopen. Zijn ambtsvoorgangster Sorgdrager verwijst in haar wetsvoorstel naar cijfers van het Centrum voor Verzekeringsstatistiek, waaruit blijkt dat de invoering van een verkeersverzekering zal leiden tot een stijging van de premies van de WAM-verzekering met $44-57 \%$ (inclusief de uitbreiding van de regresrechten met 9-17\%). Memorie van Toelichting. TK, 1997-1998, 25759 , nr. 3, p. 14-15.

567. Zie Kottenhagen-Edzes, in Verkeersaansprakelijkheid in Belgie en Nederland, p. 143-144 en NJB, 1998, p. 113, die het wetsvoorstel kwalificeert als een enigszins onoverzichtelijk en verbrokkeld geheel met meerdere mogelijke grondslagen voor het verhalen van verkeersschade. 
In de Memorie van Toelichting bij het wetsvoorstel wordt opgemerkt dat de voorgestelde regeling tot minder gerechtelijke procedures zal leiden. ${ }^{568}$ Dit is nog maar de vraag, nu met name de regresnemers voor hun verhaalsacties weer zijn aangewezen op artikel 6:162 BW. Dit leidt tot meer discussie en procedures omdat de verzekeraars onderling en de rechter daaromtrent nieuwe regels moeten opstellen. Daarnaast ontstaan mogelijk nieuwe discussies met betrekking tot begrippen als 'opzet of bewuste roekeloosheid' en 'betrokkenheid', en ten aanzien van de vraag wanneer letselen zaakschade samenvallen. ${ }^{569}$ De plannen van Korthals zullen hierin geen verbetering brengen, omdat hij weer nieuwe begrippen introduceert, zoals 'roekeloosheid' in plaats van 'bewuste roekeloosheid' en 'fout van alledag'.

Hoewel de wetgever het aansprakelijkheidsrecht als grondslag voor de vergoeding van verkeersschade handhaaft, is de vraag of daarbij nog wel sprake is van aansprakelijkheid. ${ }^{570}$ Het uitgangspunt is immers dat wanneer komt vast te staan dat een motorrijtuig betrokken is bij een verkeersongeval de aansprakelijkheid van de bezitter is gegeven. Deze aansprakelijkheid komt pas te vervallen wanneer het gedrag van het slachtoffer 'opzet of bewuste roekeloosheid' (wetsvoorstel) of 'gewone roekeloosheid als enige oorzaak van het ongeval' (plannen Korthals) oplevert. Ten aanzien van het laatste wordt in de literatuur de verwachting uitgesproken dat de rechter in de praktijk een strikte uitleg van het begrip 'roekeloosheid' zal hanteren. ${ }^{571}$ Dit betekent dat het doel dat Korthals met zijn plannen heeft, namelijk meer rekening houden met gedrag van slachtoffer, mede door het exclusiviteitsvereiste niet wordt gehaald. Het uiteindelijke resultaat is een stelsel van risicoaansprakelijkheid met een alles-of-niets-verweer, waarin ook geen plaats is voor een verdeling op grond van artikel 6:101 BW.

568. Memorie van Toelichting, TK, 1997-1998, 25759 , nr. 3, p. 2 en p. 35-36.

569. Elzas, VA, 1998, p. 3, verwacht ondanks de vermindering van de aansprakelijkheidsvragen een toename van het aantal geschillen, omdat meer slachtoffers hun aanspraken op een schadevergoeding geldend willen maken. Zie ook Van Dijk, VR, 1998, p. 129-131; Kremer, Hennekam on Van der Harst, VR, 1998, p. 290 en p. 293.

570. Zie met betrekking tot het wetsvoorstel Verkeetsongevallen: C.C. van Dam, VR, 1997, p. 358, die in dit verband spreekt van 'verzekeringsdekking voor personenschade in het verkeer'; Frenk, in Verkeersaansprakelijkheid in Belgiẻ en Nederland, p. 116-117, die meent dat het wetsvoorstel dicht tegen een verkeersverzekering aanleunt, doordat 'op de verzekeraar van de automobilist een vergoedingsplicht rust die louter is gebaseerd op de betrokkenheid van het motorrijtuig bij het ongeval'; Hartlief, in Verkeersaansprakelijkheid in Belgiê en Nederland, p. 188, die stelt dat het wetsvoorstel weinig meer met aansprakelijkheid te maken heeft. De aansprakelijkheid kan immers eenvoudig worden vastgesteld zonder dat enige tekortkoming van de schadeveroorzaker behoeft te worden aangetoond of dat de schadeveroorzaker een beroep kan doen op enig verweermiddel. Dit strookt volgens hem niet met de risicoaansprakelijkheden van afdeling 6.2.3. BW waarin nog wel bepaalde verweermiddelen mogelijk zijn. Zie ook Hartlief en Tjittes, Verzekering en aansprakelijkheid, p. 165-166.

571. Hartlief, TVP, p. 74. 


\section{Deel II: $\quad$ De economische analyse van het verkeersongevallenrecht}

In dit deel staat de economische analyse van het verkeersongevallenrecht centraal. Aan de hand van het economisch model van het ongevallenrecht ${ }^{572}$ zullen drie juridische instrumenten, namelijk aansprakelijkheid, verzekering en veiligheidsregulering, worden geanalyseerd. Onderzocht wordt of deze instrumenten al dan niet gecombineerd gebruikt kunnen bijdragen aan een optimale preventie van verkeersongevallen en een optimale compensatie van verkeersslachtoffers. ${ }^{573}$

In de eerste fase van het model zal de economische analyse van het aansprakelijkheidsrecht aan de orde komen (hoofdstuk 5). Deze omvat een onderzoek naar de vraag welke aansprakelijkheidsregel een verkeersdeelnemer kan aanzetten tot een optimaal zorg- en activiteitsniveau. Daamaast wordt onderzocht welke aansprakelijkheidsregel leidt tot een optimale preventie van verkeersongevallen alsook een optimale compensatie van verkeersslachtoffers. In deze fase van het onderzoek wordt verondersteld dat de aanwezigheid van een verzekering en de veiligheidsregulering nog geen rol spelen.

In hoofdstuk 6 zal de aandacht uitgaan naar de economische analyse van risico en verzekering. Wanneer wordt uitgegaan van de veronderstelling dat de verzekering de rol van het aansprakelijkheidsrecht voor een belangrijk deel heeft overgenomen, is het van belang te weten welke middelen een verzekeraar heeft om het gedrag van zijn verzekerde te controleren. Daarnaast zal de invloed van regulering op de verzekeringen worden onderzocht en wordt aandacht besteed aan alternatieve compensatiemechanismen. Ten slotte wordt de vraag beantwoord welke combinatie van aansprakelijkheid en verzekering tot een optimale preventie en compensatie van verkeersongevallen kan leiden.

In de laatste fase van het economisch model zal de invloed van veiligheidsregulering op het verkeersgedrag worden onderzocht (hoofdstuk 7). Daarbij zal een aantal theo-

572. Zie Faure en Van den Bergh, Objectieve aansprakelijkheid, p. 50-61 voor een beschrijving van de historische ontwikkeling van dit model. Voor wat betreft de ontwikkeling van het economisch model van het ongevallenrecht kan onder andere worden verwezen naar: Calabresi, Costs of Accidents, 1970; Shavell, Accident Law, 1987; Polinsky, Introduction, 1989; Posner, Economic Analysis, 1992, p. 163-216; Landes and Posner, Georgia Law Review, 1981, p. 851-924.

573. De auteurs die zich bezighouden met de economische analyse van het ongevallenrecht, gebruiken weliswaar voorbeelden met betrekking tot verkeerssituaties maar het door hen ontwikkelde model wordt daar niet geheel aan opgehangen. De rechtsgebieden waarop het model veelal wordt toegepast zijn met name de productaansprakelijkheid en de milieuaansprakelijkheid. Zie Faure en Van den Bergh, Objectieve Aansprakelijkheid, p. 205-364; Shavell, Accident Law, p. 47-72; Polinsky, Introduction, p. 91-106. 
rieën van overheidsregulering worden beschreven, namelijk de 'public interest' theorie, de 'private interest' theorie en de theorie van veiligheidsregulering. In het kader van de laatstgenoemde theorie zal worden onderzocht op welke wijze een gecombineerd gebruik van aansprakelijkheid en veiligheidsregulering van invloed kan zijn op de preventie van verkeersongevallen.

In hoofdstuk $8 \mathrm{zal}$ de economische theorie van het verkeersongevallenrecht in de vorm van stellingen worden samengevat, waarbij ook een aantal vragen wordt geformuleerd ten behoeve van het empirisch onderzoek in deel III.

De toetsing van het economisch model aan de Nederlandse verkeersaansprakelijkheid zal in een later stadium plaatsvinden (hoofdstuk 15). Om een gefundeerd oordeel daaromtrent te kunnen geven zijn nog andere vormen van analyse relevant, namelijk een empirische en een rechtsvergelijkende analyse. De laatste is in deel I behandeld terwijl de empirische analyse in deel III van dit onderzoek aan de orde zal komen. Met name de empirische gegevens kunnen het in dit deel ontwikkelde theoretische model eventueel aanpassen en nader concretiseren.

In hoofdstuk 4 zal via een korte introductie in de rechtseconomie een aantal relevante begrippen uit dit vakgebied nader worden toegelicht. In paragraaf 1 zal aandacht worden besteed aan de vraag wat de rechtseconomie in haar algemeenheid beoogt (1.1), welke methodologie wordt toegepast binnen de economische analyse (1.2) en wat het efficiëntiecriterium inhoudt (1.3). In paragraaf 2 volgt een algemene introductie in de economische analyse van het ongevallenrecht aan de hand van een opsomming van een aantal doelstellingen, die verband houden met de opzet van dit onderzoek (2.2). In paragraaf 3 zal het economisch model van het ongevallenrecht worden gepresenteerd. Hieraan ligt een aantal veronderstellingen ten grondslag. Deze zullen in paragraaf 3.1 worden opgesomd, waarna in paragraaf 3.2 het economisch optimum zal worden bepaald. Dit inleidende hoofdstuk zal in paragraaf 4 worden afgesloten met een bespreking van het Coase-theorema. 


\section{Hoofdstuk 4: Rechtseconomie: een introductie}

\section{Wat is rechtseconomie?}

De rechtseconomie kan worden beschouwd als een vakgebied, waarin wordt getracht on met behulp van economische begrippen en instrumenten het recht te analyseren. In dat kader wordt enerzijds onderzocht of en in hoeverre het recht een rol kan spelen bij het realiseren van bepaalde economische doelstellingen. Anderzijds kan de economie behulpzaam zijn bij de verklaring van juridische concepten, zoals rechtvaardigheid, redelijkheid, billijkheid. ${ }^{574}$

Oorspronkelijk beperkte de rechtseconomische analyse zich tot rechtsgebieden waarin van oudsher reeds gebruik werd gemaakt van economische begrippen, zoals de kartel- en mededingingswetgeving en het fiscaal recht. Binnen deze zogenaamde 'Old Law and Economics' had de economische analyse echter vooral een aanvullend karakter. Het betrof immers rechtsgebieden die reeds een duidelijke invloed uitoefenden op de werking van de markten en de economie. ${ }^{575}$

Sinds het eind van de jaren vijftig van de vorige eeuw houdt de rechtseconomie zich echter ook bezig met rechtsgebieden die tot dan toe exclusief tot het territorium van de jurist behoorden, zoals het aansprakelijkheidsrecht en het contractenrecht. De gedachte hierbij was dat de economie van invloed kon zijn op alle sociale interacties waarin bepaalde keuzes moeten worden gemaakt. De studie van de rechtseconomie breidde zich uit tot het gehele recht. ${ }^{576}$ Binnen deze 'New Law and Economics' worden de economie en de rechtswetenschap min of meer naast elkaar geplaatst, waarbij

574. Cooter en Ulen, Law and Economics, p. 3-4 merken overigens op dat de rechtseconomie voornamelijk een verklarende wetenschap is. Economische concepten kunnen worden gebruikt om het recht te verklaren maar zij kunnen de juridische concepten niet vervangen of elimineren.

575. Van den Bergh, in Rechtseconomie en recht, p. 9-11; Holzhauer en Teijl, Inleiding rechtseconomie, p. 3-4; Faure en Van den Bergh, Objectieve aansprakelijkheid, p. 17.

576. De modeme rechtseconomie, ontstaan aan het eind van jaren vijftig van de vorige eeuw in de Verenigde Staten, heeft daar vooral sinds de jaren zeventig van de vorige een dermate grote vlucht genomen dat het een belangrijk onderdeel is geworden van de juridische opleiding aan de meeste Amerikaanse universiteiten zoals Chicago, Harvard en Berkeley. In Europa heeft de rechtseconomie nog niet een dergelijke vaste voet aan de grond gekregen. Wel is sinds het begin van de jaren tachtig van de vorige een grote hoeveelheid literatuur op dit gebied verschenen en zijn ook verschillende succesvolle pogingen ondernomen om de rechtseconomie te laten integreren in het onderwijs. Zie voor een overzicht van de Europese literatuur en een schets van de ontwikkeling op het gebied van onderwijs en onderzoek o.a. De Geest, Economische analyse van het contracten- en quasi contractenrecht, diss., p. 23-24; Bouckacrt en De Geest (ed.), Bibliography of Law and Economics, p. 553-621; Mackaay, RM Themis, 1988, p. 412-418; Holzhauer en Teijl, AA, 1989, p. 248-252. 
beiden elkaar aanvullen. In dat kader kan de rechtseconomie als een 'interdisciplinaire' wetenschap worden beschouwd. ${ }^{577}$

Een van de uitgangspunten van de moderne rechtseconomie als gedragswetenschap, is de hypothese van het rationeel handelende individu (de zogenaamde 'Homo Economicus') die streeft naar een zo hoog mogelijk persoonlijk nut c.q. behoeftebevrediging. ${ }^{578}$ Voorts wordt verondersteld dat rechtsregels, door middel van prikkels, het gedrag van individuen kunnen beïnvloeden. Meer algemeen wordt daarbij onderzocht in hoeverre bepaalde ongevallen (ex ante) voorkomen kunnen worden. ${ }^{579}$ Één van de vragen bij de in dit onderzoek te verrichten economische analyse van het verkeersongevallenrecht zal bijvoorbeeld zijn in hoeverre verkeersdeelnemers aangezet kunnen worden tot het uitoefenen van efficiënte zorg, waardoor een minimalisering van de maatschappelijke kosten van ongevallen kan worden bereikt. ${ }^{580}$

\subsection{METHODEN VAN ECONOMISCHE ANALYSE}

Ten aanzien van de methodologie van de rechtseconomie wordt globaal een onderscheid gemaakt tussen een positieve economische analyse en een normatieve economische analyse. ${ }^{581}$ De positieve economische analyse houdt zich bezig met de verklaring van het recht zoals het is. Met behulp van begrippen als nuts- en welvaartsmaximalisatie wordt onderzocht in hoeverre bestaande rechtsregels econo-

577. Faure en Van den Bergh, Objectieve aansprakelijkheid, p. 17-18, die binnen de New Law and Economics' het recht als de hulpwetenschap beschouwen in tegenstelling tot de 'Old Law and Economics' waarbij de economie meer de hulpwetenschap was; Hondius, Schippers en Siegers, in Rechtseconomie en recht, p. 1-3; Posner, Economic Analysis, p. 21-22; Veljanovski, New Law and Economics, 1982, p. 5-16. Zie voor een historisch overzicht van de New Law and Economics': Mackaay, RM Themis, 1988, p. 411-420; Mackaay, NJB, 1991, p. 1505-1521; Cooter and Ulen, Law and Economics, p. 7.

578. Posner, Economic Analysis, p. 3-12; Holzhauer en Teijl, Inleiding rechtseconomie, p. 5-6; Bowles, Law and the Economy, p. 4-12. Schäfer und Ott, Lehrbuch der ökonomischen Analyse, p. 50-56. Zij spreken van de REM-hypothese, 'Der rationale egoistische Mensch'.

579. Van den Bergh, in Rechtseconomie en recht, p. 13; Faure en Van den Bergh, Objectieve aansprakelijkheid, p. 33-34; Veljanovski, in The Economic Approach to Law, p. 126-127.

580. Zie voor een historische uiteenzetting van de 'controverse' tussen de positiefrechtelijke analyse (rechtvaardigheid) en de economische analyse (preventie) van het aansprakelijkheidsrecht, Schwartz, Texas Law Review, 1997, p. 1802-1811; Landes en Posner, Economic Structure of Tort Law, p. 9-24; Landes and Posner, Georgia Law Review, 1981, p. 851-864.

581. Shavell, Accident Law, p. 1, makt een onderscheid tussen 'predictive questions' en 'normative questions'. De eerste hebben betrekking op het voorspellen van de effecten van het gebruik van rechtsregels en hangen samen met de positieve economische analyse. De 'normative questions' verwijzen naar het nut van bepaalde rechisregels. 
misch efficiënt genoemd kunnen worden. Daarnaast wordt getracht uitleg te geven aan het ontstaan van rechtsregels. ${ }^{582}$

Een positieve economische analyse leidt tot een normatieve economische analyse, wanneer naar aanleiding van het onderzoek wordt geconcludeerd dat bepaalde rechtsregels inefficiënt zijn. In een normatieve economische analyse wordt aan de hand van het efficiëntiecriterium de wenselijkheid van bepaalde rechtsregels beoordeeld. Daarbij wordt overigens wel enige voorzichtigheid betracht, nu aan het begrip efficiëntie weliswaar een belangrijke waarde wordt toegekend maar het niet tot algemene norm wordt verheven. $\mathrm{Bij}$ de normatieve economische analyse wordt ook met andere waarden rekening gehouden, zoals de verdeling van inkomens. ${ }^{583}$

\subsection{HET EFFICIÊNTIECRITERIUM BINNEN DE ECONOMISCHE ANALYSE}

De rechtseconomie is, als gezegd, een verklarende wetenschap, waarbij ten aanzien van het ongevallenrecht het efficiëntiecriterium een belangrijke rol vervult. Toegespitst op het aansprakelijkheidsrecht is het streven bijvoorbeeld om de maatschappelijke kosten zo laag mogelijk te houden. ${ }^{584} \mathrm{Bij}$ de invulling van het efficiëntiecriterium worden elementen gebruikt uit de welvaartstheorie. Binnen de economische welvaartstheorie, de klassieke theorie met betrekking tot overheidsregulering, wordt onderzocht op welke wijze de gezamenlijke welvaart van een groep individuen kan worden verhoogd. Met welvaart wordt gedoeld op het welzijn van een individu, voorzover dit welzijn naar economische termen, nuts- en welvaartsmaximalisatie, kan worden vertaald. Efficiëntie wordt in dat kader als instrument gebruikt om een dergelijk hoge welvaart te bereiken. De welvaartstheorie beziet daarbij niet de maatschappelijke waardetoedeling op zichzelf, maar de maatschappelijke kosten die het gevolg zijn van een bepaalde toedeling. ${ }^{585}$

582. Dit laatste hangt samen met een onderscheid dat binnen de positieve economische analyse door een aantal auteurs wordt gemaakt. Dit betreft een 'verklarende' analyse, waarin de uitleg van het ontstaan van rechtsregels centraal staat en de 'evaluerende' analyse, waarin de gevolgen van bepaalde rechtsregels worden bestudeerd. Bij dit laatste ligt de nadruk op empirische gegevens. Zie Van den Bergh, in Rechtseconomie en recht, p. 16-17; Holzhauer en Teijl, Inleiding rechtseconomie, p. 317-318.

583. Zie Faure en Van den Bergh, Objectieve aansprakelijkheid, p. 26-29; Van den Bergh, in Rechtseconomie en recht, 16-17; Holzhauer en Teijl, Inleiding rechtseconomie, p. 317-318; Posner, Economic Analysis, p. 23-28, stelt onder andere: 'There is more to justice than a concern with efficiency' en 'there is more to justice than economics', maar ook 'The demand for justice is not independent of its price'.

584. Calabresi, Costs of Accidents, p. 24.

585. Utton, The Economics of Regulating Industry, p. 5-6; Van den Doel en Van Velthoven, Democratie en welvaartstheorie, p. 18-19; Holzhauer en Teijl, Inleiding rechtseconomie, p. 6-7. Zie ten aanzien van de controverse tussen efficiëntie en rechtvaardigheid: Polinsky, Introduction, p. 7 10. Efficiêntie heeft zijns inziens betrekking op de grootte van de maatschappelijke koek; recht- 
Aan de hand van het efficiëntiecriterium wordt derhalve onderzocht in hoeverre rechtsregels kunnen bijdragen aan de verhoging van de maatschappelijke welvaart, dan wel dat bepaalde regels, deze welvaart, economisch gezien, verminderen of zelfs leiden tot verspilling. Efficiëntie ziet bijvoorbeeld op handelingen of rechtsregels waarvan de doelstellingen met zo min mogelijk middelen kunnen worden bereikt. ${ }^{586}$

Binnen de economische analyse wordt voornamelijk gewerkt met een tweetal criteria voor de bepaling van efficiëntie, namelijk het Pareto-criterium en het KaldorHicks-criterium. Deze concepten hebben beide betrekking op mogelijke verbeteringen van de maatschappelijke welvaart. Daarbij worden, gegeven een bepaalde verdeling van goederen, uitspraken gedaan over de optimale allocatie van deze goederen.

\subsubsection{Pareto-efficiëntie}

Pareto-efficiëntie kan worden omschreven als een maatschappelijke toestand, waarin het niet meer mogelijk is de situatie van 1 individu te verbeteren zonder dat deze potentiële verbetering nadeel toebrengt aan de belangen van derden. Van een Paretoefficiëntie is pas sprake wanneer de verbetering van de positie van 1 individu slechts mogelijk is als ten gevolge van deze verbetering minstens 1 of meerdere individuen worden benadeeld. Dit wordt ook wel allocatieve efficiëntie genoemd, namelijk een toestand waarbij het niet meer mogelijk is om het nut van een individu te verhogen zonder dat dit ten koste gaat van het nut van een ander individu. Pareto-efficiëntie ziet derhalve op het bereiken van een resultaat waarbij alleen winnaars zijn en geen verliezers. Sommigen verbeteren zich uiteindelijk terwijl niemand er slechter van wordt. ${ }^{587}$

Een Pareto-verbetering van een bepaalde maatschappelijke toestand is pas mogelijk wanneer overeenstemming bestaat ten aanzien van de individuele voorkeuren binnen een samenleving. Wanneer bijvoorbeeld geen enkel individu de voorkeur geeft aan toestand $\mathrm{Y}$ boven toestand $\mathrm{X}$, maar minstens 1 individu verkiest toestand $\mathrm{X}$ boven toestand $\mathrm{Y}$, dan moet worden getracht toestand $\mathrm{X}$ te bereiken boven toestand $\mathrm{Y}$. De

vaardigheid op de verdeling van deze koek tussen individuen. Rechtseconomen trachten de grootte van de koek te maximaliseren, waarbij de verdeling ervan aan de regelgever wordt overgelaten. Faure en Van den Bergh, Objectieve aansprakelijkheid, p. 49, menen dat de economische analyse een bepaald waardeconflict naar boven kan brengen, maar het is uiteindelijk aan de wetgever om een gemotiveerde keuze tussen efficiêntie en rechtvaardigheid te maken.

586. De Geest, Economische analyse van het contracten- en quasi contractenrecht, p. 470; Holzhauer en Teijl, Inleiding rechteconomie, p. 298.

587. Faure en Van den Bergh, Objectieve aansprakelijkheid, p. 38-39; Schäfer und Ott, Lehrbuch der okonomischen Analyse, p. 22-28; De Geest, Economische analyse van het contracten- en quasi contractenrecht, p. 469; Holzhauer en Teijl, Inleiding rechtseconomie, p. 7; Cooter and Ulen, Law and Economics, p. 10-12. 
overgang van toestand $\mathrm{Y}$ naar toestand $\mathrm{X}$, die voldoet aan de gestelde voorwaarden, wordt dan een Pareto-verbetering genoemd. Daarbinnen kan een individu echter een afwijkende voorkeur hebben omdat hij bijvoorbeeld binnen de efficiënte toestand inkomensverlies lijdt. ${ }^{588}$

\subsubsection{Kaldor-Hicks-efficiëntie}

Pareto-efficiëntie wordt echter vooral als een theoretisch leerstuk beschouwd. Bij elke verandering zal immers de situatie van minimaal enkele individuen zich in negatieve zin wijzigen. Een ander, meer praktisch hanteerbaar, criterium is de KaldorHicks efficiëntie. Hierbij wordt met bepaalde verdelingseffecten rekening gehouden.

Binnen het Kaldor-Hicks-criterium wordt een bepaalde beslissing, waarbij minstens 1 individu wordt benadeeld en minimaal 1 individu wordt bevoordeeld, als maatschappelijk wenselijk beschouwd, wanneer het mogelijk is om met behulp van de winst van de individuen die worden bevoordeeld het verlies van de benadeelden te compenseren, zonder dat de totale winst geheel verdwijnt. Bij deze toestand van Kaldor-Hicks efficiëntie is derhalve niemand slechter af en is minimaal 1 persoon in het voordeel. Er mogen wel verliezers zijn, zolang het effect voor de maatschappij als geheel positief is. ${ }^{589}$

Met betrekking tot de compensatie van de verliezers door de winnaars wordt in het midden gelaten of deze compensatie ook daadwerkelijk moet plaatsvinden. De compensatie waarvan binnen het Kaldor-Hicks-criterium wordt uitgegaan is derhalve vrij hypothetisch. Wanneer het verlies van de benadeelden effectief wordt vergoed is weer sprake van een Pareto-verbetering. Aan de andere kant zal een beleidswijziging die, zonder compensatie, Kaldor-Hicks efficiënt is de benadeelden niet in een betere positie brengen.

Een ander probleem bij het Kaldor-Hicks-criterium is dat het nut van verschillende individuen die bij een bepaalde beleidswijziging zijn betrokken moet worden gemeten, waarbij gebruik wordt gemaakt van interpersonele nutsvergelijkingen. Dit kan leiden tot berekeningsproblemen. Ondanks deze nadelen is het Kaldor-Hickscriterium een theoretische basis geworden voor verschillende kosten-baten analyses. Bij de berekening van bepaalde effecten van wetgeving wordt steeds meer gebruik

588. Faure en Van den Bergh, Objectieve aansprakelijkheid, p. 39; De Geest, Economische analyse van het contracten- en quasi contractenrecht, p. 470-472; Schäfer und Ott, Lehrbuch der okonomischen Analyse, p. 22-23.

589. Faure en Van den Bergh, Objectieve aansprakelijkheid, p. 39; Schäfer und Oth, Lehrbuch der ökonomischen Analyse, p. 29-35; De Geest, Economische analyse van het contracten- en quasi contractenrecht, p. 471; Holzhauer en Teijl, Inleiding rechtseconomie, p. 7; Cooter and Ulen, Law and Economics, p. 41-42. 
gemaakt van kosten-baten analyses. Daarbij gaat het onder andere om de vraag hoe door een kostenbesparing een zo hoog mogelijk welvaartspeil kan worden bereikt. ${ }^{590}$

\section{Het efficiëntiecriterium binnen de ongevalssituatie}

Nadat in de vorige paragraaf is uiteengezet wat de rechtseconomie in haar algemeenheid beoogt, zal in deze en de volgende paragraaf meer specifiek worden ingegaan op de economische analyse van het ongevallenrecht. ${ }^{591}$ Daartoe zal in paragraaf 2.1 een algemene omschrijving worden gegeven van het efficiëntiebegrip binnen het ongevallenrecht. In paragraaf 2.2 zullen vervolgens de doelstellingen van de economische analyse van het ongevallenrecht worden belicht.

\subsection{EFFICIËNTIE IN HET ONGEVALLENRECHT}

Binnen het ongevallenrecht wordt in het kader van efficiëntie in het algemeen verwezen naar het zo laag mogelijk houden van de totale maatschappelijke kosten van ongevallen. Deze kosten kunnen worden omschreven als de som van de kosten die gepaard gaan met het nemen van bepaalde voorzorgsmaatregelen ter voorkoming of beperking van ongevallen (de kosten van zorg) en de verwachte schade (ongevalskosten). De verwachte schade heeft daarin betrekking op de omvang van de schade vermenigvuldigd met de kans dat zich een ongeval voordoet. Daarbij geldt dat de kans op een ongeval en daarmee de schade kleiner wordt naarmate meer zorg wordt aangewend. Wanneer een automobilist bijvoorbeeld met een snelheid van $160 \mathrm{~km} / \mathrm{u}$ over een autoweg rijdt, zal hij meer moeite moeten doen om bepaalde hindermissen te vermijden en zal de kans dat hij betrokken raakt bij een verkeersongeval groot zijn. Wanneer dezelfde automobilist een snelheid van $70 \mathrm{~km} / \mathrm{u}$ aanhoudt zal de kans op een ongeval aanmerkelijk kleiner kunnen zijn, maar dit leidt wel tot kosten ('opportunity costs') bij de automobilist. Deze kosten bestaan uit tijdsverlies en de mogelijke ergernissen die daarmee gepaard kunnen gaan. ${ }^{592}$

590. Faure en Van den Bergh, Objectieve aansprakelijkheid, p. 40; Schåfer und Ott, Lehrbuch der okonomischen Analyse, p. 29-35; Van den Doel en Van Velthoven, Democratie en welvaartstheorie, p. 38-40. Holzhauer en Teijl, Inleiding rechtseconomie, p. 34; De Geest, Economische analyse van het contracten- en quasi contractenrecht, p. 471. Zie omtrent het onderscheid tussen Pareto-efficientie en Kaldor-Hicks efficiëntie eveneens: Posner, Economis Analysis, p. 13-16; Van den Doel en Van Velthoven, Democratie en welvaartstheorie, p. 42-45; Van Velthoven en Van Wijck, Recht en efficièntie, p. 13-23.

591. Het zal hier derhalve gaan om een ruime interpretatie van het begrip ongevallenrecht, waarvan niet alleen het aansprakelijkheidsrecht onderdeel uitmaakt, maar ook verzekering en veiligheidsregulering. In de Engelstalige literatuur wordt met de economische analyse van het ongevallenrecht verwezen naar 'accident law'.

592. Faure en Van den Bergh, Objectieve aansprakelijkheid, p. 31-32; E. van Schilfgaarde, AA, 1990, p. 148; Holzhauer en Teijl, AA, 1989, p. 249; Mackaay, NJB, 1980, p. 813-815. 


\subsection{DOELSTELIINGEN BINNEN DE ECONOMISCHE ANALYSE VAN HI:T ONGEVALLENRECHT}

De belangrijkste economische doelstelling van het ongevallenrecht is de hiervoor reeds genoemde minimalisering van de maatschappelijke ongevalskosten en komt overeen met het efficiëntiecriterium. Deze doelstelling zal in dit onderzoek worden uitgewerkt aan de hand van het onderscheid in ongevalskosten dat afkomstig is van Calabresi. ${ }^{593}$ Calabresi hanteert als uitgangspunt van de economische analyse van het ongevallenrecht de minimalisering van de som van de ongevalskosten (verwachte schade) en de kosten om ongevallen te voorkomen. Dit zijn de hoofddoelstellingen. Vervolgens geeft hij een drietal subdoelstellingen door een onderscheid te maken in primaire, secundaire en tertiaire ongevalskosten.

\subsection{Primaire ongevalskosten}

De primaire ongevalskosten hangen samen met een vermindering van het aantal en de ernst van ongevallen. De vermindering van deze primaire ongevalskosten kan volgens Calabresi worden bereikt via een 'general deterrence'-, respectievelijk een 'specific deterrence'-benadering.

In de eerste benadering wordt vooral vertrouwd op de werking van het marktmechanisme ten behoeve van de afschrikking van potentiële schadeveroorzakers. Wanneer een bepaalde activiteit duurder wordt gemaakt, zal dit tot een vermindering van het betreffende activiteitsniveau kunnen leiden. Aan deze 'general deterrence' benadering ligt de veronderstelling ten grondslag dat individuen juist zijn geïnformeerd over de kosten en baten van bepaalde alternatieve activiteiten. Daarnaast zal een individu die naar nutsmaximalisatie streeft de ongevalskosten die hij bij derden veroorzaakt willen minimaliseren, door rekening te houden met de nadelige gevolgen van zijn handelingen op andere individuen.

Binnen de 'general deterrence' kan op twee manieren een vermindering van de primaire ongevalskosten worden bereikt. In de eerste plaats kan een individu besluiten om een andere, veiliger, activiteit uit te oefenen (gedragswijziging), wanneer bij wordt gedwongen de totale ongevalskosten van de activiteit te dragen. In de tweede plaats kan ook worden besloten tot het veiliger maken van een bepaalde activiteit om te voorkomen dat een individu voor de totale ongevalskosten moet opkomen. Wanneer bijvoorbeeld de kosten van verkeersongevallen op het gemotoriseerde verkeer worden gelegd, zullen de kosten van autorijden stijgen en zal dit misschien leiden tot een vermindering van het activiteitsniveau, wanneer automobilisten kiezen voor een

593. Calabresi, Costs of Accidents, p. 24-31. In een later artikel omschrijft hij de doelstelling van het aansprakelijkheidsrecht als: 'minimizing the sum of accident costs and accident prevention costs', Calabresi, Yale Law Joumal, 1975, p. 656. 
andere, veiliger activiteit. Aan de andere kant kunnen fabrikanten de auto's veiliger maken en daarmee het autorijden goedkoper. Ook kunnen automobilisten hun rijgedrag aanpassen om te voorkomen dat zij de veroorzaakte schade moeten vergoeden. $^{594}$

Binnen de 'specific deterrence'- of 'collective deterrence'-benadering worden alle besluiten ten aanzien van de ongevalskosten collectief genomen, namelijk binnen een politiek besluitvormingsproces. In de meest extreme vorm zal de maatschappij als geheel beoordelen op welke wijze alsook de mate waarin een bepaalde gevaarlijke activiteit mag worden uitgeoefend. Bij de keuze voor 'specific deterrence' boven een 'general deterrence' wordt verder uitgegaan van een aantal veronderstellingen. In de eerste plaats geldt de veronderstelling dat individuen hun eigen nut niet kunnen bepalen. In de tweede plaats hebben ongevallen ook niet op geld waardeerbare gevolgen. In de derde plaats neemt een individu binnen een marktproces morele besluiten die niet in kosten of baten kunnen worden uitgedrukt. Een vierde veronderstelling heeft betrekking op de aanwezigheid van inkomensverschillen tussen de marktactoren. Een vijfde en laatste veronderstelling voor een 'specific deterrence'-benadering wordt gevonden in het gegeven dat sommige gevaarlijke activiteiten niet via het marktmechanisme kunnen worden geregeld. ${ }^{595}$

In werkelijkheid zal de 'specific deterrence' de vorm aannemen van een verbod op of een beperking van de uitoefening van bepaalde gevaarlijke activiteiten. Daarnaast kan worden overgegaan tot een invoering van veiligheidsvoorschriften die bij nietnaleving door middel van boetes kunnen worden gesanctioneerd. In de praktijk zal echter veeleer sprake zijn van een combinatie van een 'general deterrence'- en een 'specific deterrence'- benadering ten behoeve van een optimale preventie binnen het ongevallenrecht. Vertaald naar de opzet van dit onderzoek, kan derhalve worden gesteld dat in het kader van een vermindering van de primaire ongevalskosten de instrumenten aansprakelijkheid en verzekering betrekking hebben op een combinatie van een marktbenadering ('general deterrence') en een collectieve benadering ('specific deterrence'). Veiligheidsregulering kan vanuit een collectieve benadering het marktmechanisme beperken of bevorderen. ${ }^{596}$

594. Calabresi, Costs of Accidents, p. 72-74; Faure en Van den Bergh, Objectieve aansprakelijkheid, p. 52.

595. Calabresi, Costs of Accidents, p. 95-107.

596. Calabresi, Costs of Accidents, p. 113-129; Faure en Van den Bergh, Objectieve aansprakelijkheid, p. 52-53. Zie ook Cramton, Michigan Law Review, 1969, p. 424, die in het kader van de preventie van strafrechtelijke sancties 'general deterrence' omschrijft als de invloèd van sancties op de maatschappij als geheel, waarop de betreffende sancties betrekking hebben. 'Specific deterrence' heeft betrekking op het effect van strafrechtelijke sancties op de persoon die direct met de betreffende sanctie wordt geconfronteerd. 


\subsubsection{Secundaire ongevalskosten}

Een tweede subdoelstelling binnen de reductie van de maatschappelijke ongevalskosten heeft betrekking op de vermindering van de secundaire ongevalskosten. Deze kosten zien op een optimale spreiding van de schade die ten gevolge van het ongeval is ontstaan. De vermindering van de secundaire ongevalskosten hangt derhalve samen met een optimale compensatie aan slachtoffers van een ongeval. Deze subdoelstelling komt daarmee pas in beeld wanneer de vermindering van de primaire ongevalskosten geen resultaat heeft gebracht. ${ }^{597}$

Een reductie van de secundaire ongevalskosten kan met behulp van drie methoden worden bereikt. De eerste methode wordt wel de 'risk spreading method' genoemd en ziet op de spreiding van de schade over zoveel mogelijk individuen, alsmede over een lange periode. De tweede methode, 'deep pocket rule', heeft betrekking op het kanaliseren van de schade naar degene die deze het best kan dragen. Een derde methode houdt verband met de vermindering van de primaire ongevalskosten en tracht te bereiken dat de ongevalskosten worden gelegd bij de gevaarlijke activiteit waarmee deze kosten worden veroorzaakt. ${ }^{598}$

\subsubsection{Tertiaire ongevalskosten}

De derde subdoelstelling binnen de minimalisering van de maatschappelijke ongevalskosten hangt samen met de administratieve kosten van de behandeling van ongevallen. Deze tertiaire ongevalskosten ontstaan bij de uitvoering van de twee andere subdoelstellingen, namelijk de primaire en secundaire ongevalskosten. Een aansprakelijkheidssysteem kan pas efficiënt zijn in de zin van een vermindering van de primaire en secundaire ongevalskosten, wanneer een dergelijk systeem, in verband met de tertiaire ongevalskosten, ook betaalbaar is. Er is derhalve sprake van een efficiënt ongevallenrecht, wanneer de som van de primaire, secundaire en tertiaire kosten minimaal is. ${ }^{599}$

De minimalisering van de maatschappelijke kosten van ongevallen als efficiëntiedoelstelling zal in dit onderzoek om twee redenen niet absoluut kunnen worden gesteld. In de eerste plaats geeft Calabresi aan dat de maatschappij niet tegen elke prijs ongevallen kan en wil vermijden. Dit brengt mee dat binnen de doelstelling van mi-

597. Calabresi, Costs of Accidents, p. 27-28.

598. Calabresi, Costs of Accidents, p. 20-21 en p. 39-45.

599. Calabresi, Costs of Accidents, p. 24-28; Faure en Van den Bergh, Objectieve aansprakelijkheid, p. 51. Zie omtrent het gemaakte onderscheid in ongevalskosten eveneens: Schaffer und Ott, Lehrbuch der ökonomischen Analyse, p. 101-111; Veljanovski, in The Economic Approach to Law, p. 128-129; Emons, Working Paper, 1991, p. 10-11; Adams, Gefahrdungs- und Verschuldenshaftung, p. 17-22. 
nimalisering van de ongevalskosten moet worden gestreefd naar een situatie waarbij het totaal aantal ongevallen op een maatschappelijk aanvaardbaar niveau kan worden gebracht. Alle ongevallen op autowegen zouden bijvoorbeeld kunnen worden voorkomen wanneer een maximumsnelheid van $20 \mathrm{~km} / \mathrm{u}$ zou gelden. De maatschappij zal echter de kosten van een dergelijke maatregel te hoog vinden. ${ }^{600}$

In de tweede plaats zal dit onderzoek niet alleen betrekking hebben op het bereiken van een efficiënt verkeersongevallenrecht, zoals in de rechtseconomische analyse is aangegeven. Ook andere doelstellingen kunnen van belang zijn, zoals bijvoorbeeld slachtofferbescherming. Een efficiënt ongevallenrecht kan immers maatschappelijk onaanvaardbaar worden geacht. 601

\section{Het economisch model van het ongevallenrecht}

Binnen de economische analyse van het ongevallenrecht wordt gebruik gemaakt van een eenvoudig mathematisch model, dat als startpunt fungeert voor een verdere uitwerking naar met name het aansprakelijkheidsrecht. In dit model komt een aantal begrippen voor die reeds in eerdere paragrafen aan de orde zijn geweest. In formulevorm wordt dit model als volgt gepresenteerd:

$M=p(x, y) S+A(x)+B(y)$, waarbij

$\mathrm{M}=$ de maatschappelijke kosten van ongevallen;

$A=$ de dader of schadeveroorzaker;

$B=$ het slachtoffer;

$\mathrm{x}=$ het zorgniveau van de dader;

$y=$ het zorgniveau van het slachtoffer;

$\mathrm{p}=$ de waarschijnlijkheid dat zich een ongeval voordoet;

$\mathrm{S}=$ de omvang van de verwachte schade.

De uitwerking van het model verwijst naar de eerder omschreven efficiëntiedoelstelling van het ongevallenrecht, namelijk de minimalisering van de maatschappelijke ongevalskosten (M). Deze doelstelling kan worden bereikt wanneer zowel dader (A) als slachtoffer $(B)$ een optimaal zorgniveau $(x, y)$ uitoefenen. Bij de berekening van de maatschappelijke kosten dient verder rekening te worden gehouden met de omvang van de verwachte schade $(\mathrm{S})$ die binnen het model wordt vermenigvuldigd met

600. Calabresi, Costs of Accidents, p. 17; Faure en Van den Bergh, Objectieve aansprakelijkheid, p. 31.

601. Calabresi, Costs of Accidents, p. 26, stelt dat 'Justice must ultimately have its due'. 
de waarschijnlijkheid dat zich een ongeval voordoet (p), waarbij tevens rekening wordt gehouden met het zorgniveau van dader en slachtoffer $(x, y) .^{602}$

\subsection{VERONDERSTELLINGEN IN HET ONGEVALLENRECHT}

Binnen de economische analyse van het ongevallenrecht wordt, mede in het kader van de eerder beschreven doelstellingen, gewerkt met een aantal veronderstellingen. De economie als gedragswetenschap onderzoekt de keuzes die door individuen worden gemaakt en hoe deze keuzes worden beïnvloed door de lasten die aan hen worden opgelegd. Aansprakelijkheid, verzekering en veiligheidsregulering vormen een onderdeel van deze lasten. ${ }^{603}$

Een eerste veronderstelling heeft betrekking op het individu als 'homo economicus', het rationeel handelend individu die streeft naar nutsmaximalisatie. Individuen handelen daarbij alsof zij op een rationele wijze hun kosten minimaliseren. $\mathrm{Zij}$ reageren op een stijging van de kosten door een keuze voor een alternatief gedrag dat tegen lagere kosten kan worden aangewend. Wanneer als gevolg van bepaalde rechtsregels de kosten van ongevallen toenemen, wordt verondersteld dat degene die deze kosten draagt meer zorg zal uitoefenen wanneer dat kan leiden tot een kostenbesparing. ${ }^{604}$

Een tweede veronderstelling is eerder toegelicht en heeft betrekking op de aanwezigheid van een omgekeerd evenredig verband tussen de voorzorgsmaatregelen (kosten van zorg) en het aantal en de ernst van ongevallen. Daarbij wordt verondersteld dat meer zorg kan leiden tot minder ongevallen, waarbij een optimale afruil moet worden gevonden tussen de kosten van zorg en de verwachte ongevalskosten.

Een derde veronderstelling hangt samen met het gebruik van economische efficiëntie. Hierbij wordt verondersteld dat individuen de verwachte ongevalskosten zullen minimaliseren door maatregelen te nemen die het risico van schade verminderen. $^{005}$

Met betrekking tot de opzet van het eerste deel van dit onderzoek wordt ten aanzien van de economische analyse van het aansprakelijkheidsrecht verondersteld dat verzekering en veiligheidsregulering nog geen rol spelen. In dat kader geldt dan bijvoorbeeld de vraag welke aansprakelijkheidsregel leidt tot een minimalisering van de ongevalskosten. De analyse van het aansprakelijkheidsrecht zal resulteren in een

602. Zie onder anderen Faure en Van den Bergh, Objectieve aansprakelijkheid, p. 70-73; Faure en Van den Bergh, RW, 1987-1988, p. 1106; Shavell, Accident Law, p. 5-6.

603. Faure en Van den Bergh, Objectieve aansprakelijkheid, p. 33; Mackaay, NJB, 1980, p. 813.

604. Veljanovski, in The Economic Approach to Law, p. 128; Faure en Van den Bergh, Objectieve aansprakelijkheid, p. 33-34.

605. Veljanovski, in The Economic Approach to Law, p. 128-129. 
aantal theoretische conclusies. In een tweede fase van het onderzoek zullen deze conclusies worden getoetst aan het beschikbare empirisch onderzoek. De toepassing van aansprakelijkheidsregels op verkeersongevallen is echter niet alleen van invloed op de bij het ongeval betrokken partijen maar heeft ook neveneffecten naar de maatschappij als geheel. Dit betekent dat de aan het begin van deze alinea gemaakte veronderstelling in latere hoofdstukken zal worden genuanceerd zodat ook de verzekering en de veiligheidsregulering aan bod kunnen komen. ${ }^{606}$

Binnen het economisch model van het ongevallenrecht, zoals dat in dit onderzoek zal worden uitgewerkt, wordt uitgegaan van twee typen van actoren, namelijk daders en slachtoffers. Daders kunnen daarbij worden voorgesteld als automobilisten die schade toebrengen aan bijvoorbeeld een fietser als zijnde het slachtoffer. De dader en het slachtoffer nemen twee soorten van besluiten, namelijk of en hoe vaak zij aan een bepaalde activiteit deelnemen en het besluit ten aanzien van de mate van zorg die zij uitoefenen bij de deelname aan een activiteit. Het aantal afgelegde autokilometers is daarbij een voorbeeld van een activiteitsniveau en de voorzorgsmaatregelen die een automobilist neemt tijdens zijn deelname aan het verkeer bepalen zijn niveau van zorg. Voor de fietser komt het activiteitsniveau overeen met de vraag hoe vaak hij als fietser aan het verkeer deelneemt en met de voorzorgsmaatregelen tijdens het fietsen wordt zijn zorgniveau bepaald. ${ }^{607}$

\subsection{HET ECONOMISCH OPTIMUM}

In het voorgaande is meerdere malen gesteld dat de efficiëntiedoelstelling van het ongevallenrecht kan worden bereikt op een punt waar de maatschappelijke kosten minimaal zijn. In de vorige paragraaf is in formulevorm weergegeven waar de maatschappelijke kosten uit bestaan. Daaruit kan worden opgemaakt dat de maatschappelijke kosten kunnen worden geminimaliseerd wanneer de dader en het slachtoffer optimale zorg uitoefenen, rekening houdend met de waarschijnlijkheid van een ongeval en de verwachte schade. De vraag is echter waar de optimale zorg, het economisch optimum, van de dader en het slachtoffer kan worden bereikt. ${ }^{608}$ Hierbij wordt vooralsnog alleen rekening gehouden met het zorgniveau van dader en slachtoffer. Bij de analyse van het aansprakelijkheidsrecht zal dit echter verder worden uitge-

606. Faure en Van den Bergh, Objectieve aansprakelijkheid, p. 33-34. De uitbreiding van de economische analyse naar verzekering en veiligheidsregulering is vooral de verdienste van Steven Shavell. In een handboek uit 1987 heeft hij hiervan een volledig overzicht gegeven. Zie Shavell, Accident Law.

607. Shavell, Accident Law, p. 5.

608. Zie over het economisch optimum onder anderen: Faure en Van den Bergh, Objectieve aansprakelijkheid, p. 70-73; Holzhauer en Teijl, Inleiding rechtseconomie, p. 129-132; Shavell, Accident Law, p. 5-7; Diamond, JLS, 1974, p. 113-116; Landes and Posner, Georgia Law Review, 1981, p. $868-872$. 
werkt door ook het activiteitsniveau van dader en slachtoffer in het model te betrekken.

Voor de bepaling van het optimale niveau van zorg wordt in de rechtseconomische literatuur verwezen naar de vraag of een individu bij een bepaald zorgniveau al dan niet aansprakelijk kan worden gehouden voor de ontstane schade. Daarbij wordt veelal als uitgangspunt genomen een Amerikaanse uitspraak met betrekking tot een geval, waarin een duwvaartbak, die in een haven lag afgemeerd, door een storm lossloeg en een aanzienlijke schade veroorzaakte. ${ }^{609}$ Rechter Learned Hand oordeelde dat het ongeval voorkomen had kunnen worden indien er een uitkijkpost was neergezet. Hand maakte bij zijn oordeel gebruik van een formule waarin drie (economische) elementen een rol spelen. In de eerste plaats de waarschijnlijkheid dat zich een ongeval voordoet. In de tweede plaats dient rekening te worden gehouden met de omvang van de schade. In derde plaats moeten de kosten van voorzorgsmaatregelen in de beoordeling worden meegenomen. Rechter Learned Hand oordeelde dat de kosten van het neerzetten van een uitkijkpost lager zouden zijn geweest dan de nu ontstane schade. In dit geval werd de aansprakelijkheid vastgesteld aan de hand van de vraag of de kosten van zorg lager zijn dan de omvang van de schade vermenigvuldigd met de waarschijnlijkheid. ${ }^{610}$ In dat kader kan worden verwezen naar de formule in de vorige paragraaf. ${ }^{611}$

Door Brown is echter aangetoond dat de Hand-formule te absoluut is gesteld en in deze vorm tot inefficiëntie zal leiden. ${ }^{612} \mathrm{Hij}$ heeft deze Hand-formule aangepast en gesteld dat voor de berekening van de optimale zorg niet de totale kosten als uitgangspunt moeten worden genomen, zoals in de Hand-formule, maar dat de marginale kosten het bepalende criterium zijn. Deze stelling kan aan de hand van het volgende voorbeeld worden toegelicht.

In de eerste kolom van tabel 1 wordt een aantal zorgniveaus verondersteld die een individu zal uitoefenen. In de tweede kolom zijn de kosten van zorg opgenomen die

609. United States v. Caroll Towing Co., 159 F. 2d 169 (2d Cir. 1947). Zie daarover onder anderen Faure en Van den Bergh, Objectieve aansprakelijkheid, p. 56-58 en 72-73; Cooter en Ulen, Law and Economics, p. 360-362; C.C. van Dam, Zorgvuldigheidsnorm en aansprakelijkheid, diss., p. 222-223; Landes and Posner, Georgia Law Review, 1981, p. 884-885.

610. Zie voor overzicht van de Nederlandse rechtspraak waarin economische afwegingen een rol spelen: Holzhauer en Teijl, Inleiding rechtseconomie, p. 132-137; Kerkmeester, WPNR 6111, 1993, p. 767-773; C.C. van Dam, Zorgvuldigheidsnorm en aansprakelijkheid, p. 114-132; E. van Schilfgaarde, AA, 1990, p. 148-156. Zie voor een aantal voorbeelden van economische afwegingen in de Belgische rechtspraak: Faure en Van den Bergh, RW, 1987-1988, p. 1105-1119.

611. Zie voor een uitwerking van de Hand-formule: Posner, JLS, 1972, p. 29-96. Zie ook Stephen, European Journal of Law and Economics, 1994, p. 23-31, voor een kritische analyse van deze formule.

612. Zie Brown, JLS, 1973, p. 323-349. Dit is na hem door de rechtseconomische literatuur gevolgd. 
verband houden met de uitoefening van de verschillende zorgniveaus. In de derde kolom is de verwachte schade weergegeven die correspondeert met het zorgniveau en de kosten van zorg. Kolom 4, ten slotte, omvat de maatschappelijke kosten, zijnde de som van de kosten van zorg en de verwachte schade (kolom $2+$ kolom 3 ).

Tabel 1

\begin{tabular}{|c|c|c|c|}
\hline Zorgniveau & Kosten van zorg & Verwachte schade & Maatschappelijke kosten \\
\hline geen & 0 & 20 & 20 \\
\hline gemiddeld & 5 & 8 & 13 \\
\hline sterk & 10 & 6 & 16 \\
\hline
\end{tabular}

Bij een letterlijke toepassing van de 'Learned Hand rule' zal een individu aansprakelijk zijn wanneer de totale kosten van zorg lager zijn dan de verwachte schade. Dit betekent dat volgens tabel 1 aansprakelijkheid wordt aangenomen bij geen zorg $(0<20)$ en bij de uitoefening van gemiddelde zorg $(5<8)$. Volgens Brown zijn daarentegen niet de totale kosten maar de marginale kosten van belang voor de bepaling van de efficiënte zorg. Binnen deze zogenaamde 'incremental Learned Hand rule' wordt een persoon pas aansprakelijk gehouden wanneer de marginale kosten van een extra eenheid zorg kleiner zijn dan de marginale opbrengst van een extra eenheid zorg in de zin van een vermindering van de verwachte schade. ${ }^{613}$ In het gegeven voorbeeld betekent dit dat door de uitoefening van een gemiddelde zorg een optimaal resultaat wordt bereikt, waarbij de schadeveroorzaker, in tegenstelling tot de 'Leamed Hand rule', niet aansprakelijk wordt gehouden. Bij dit gemiddelde niveau van zorg bedragen de marginale kosten 5 ( 5 minus 0 ) eenheden tegen een marginale opbrengst in termen van een vermindering van de verwachte schade van 12 (20 minus 8) eenheden. De totale maatschappelijke kosten, namelijk de som van de kosten van zorg en de verwachte schade, zijn bij het gemiddelde zorgniveau eveneens het laagst (13). De uitoefening van sterke zorg is in het gegeven voorbeeld niet efficiënt, omdat de marginale kosten van zorg (5) hoger zijn dan de marginale opbrengst (2).

Naar aanleiding van het voorgaande kan worden gesteld dat de uitoefening van meer zorg de kans op een ongeval doet verminderen. Het uitoefenen van meer zorg leidt echter ook tot een stijging van de kosten die met de uitoefening van deze extra zorg gepaard gaan. De uitoefening van extra zorg leidt niet alleen tot een stijging van de kosten maar ook tot een vermindering van de opbrengst. In marginale termen uitgedrukt zal de uitoefening van zorg optimaal zijn zolang de marginale kosten lager zijn dan de marginale opbrengst waarmee de verwachte schade blijft afnemen. Het opti-

613. Brown, JLS, 1973, p. 332-335. 
male niveau van zorg wordt uiteindelijk gevonden op een punt waarop de marginale kosten van de laatst toegevoegde eenheid zorg precies gelijk zijn aan de vermindering van de verwachte schade die met deze toegevoegde eenheid zorg in verband staat. Bij dit economisch optimum zijn derhalve de maatschappelijke kosten minimasl.

Boven dit punt van optimale zorg zal volgens de economische analyse het aanwenden van extra zorg meer kosten dan dat het opbrengt in termen van een vermindering van de verwachte schade. De schadeveroorzaker wordt hierbij slechts aansprakelijk gehouden wanneer hij minder dan de optimale zorg heeft uitgeoefend. Efficiënte zorg staat echter niet gelijk met een zo hoog mogelijke zorg. Ook ligt het niveau van optimale zorg niet op een punt waar de verwachte schade het laagst is. ${ }^{614}$

In het kader van de economische analyse van het verkeersongevallenrecht zal bijvoorbeeld een verlaging van de maximumsnelheid van 80 naar $60 \mathrm{~km} / \mathrm{u}$, kunnen leiden tot een vermindering van het ongevalsrisico. Hetzelfde kan gelden voor een verdere verlaging van 60 naar $40 \mathrm{~km} / \mathrm{u}$. Bij een verlaging van de maximumsnelheid van 40 naar $20 \mathrm{~km} / \mathrm{u}$ wordt het effect op het ongevalsrisico echter minder omdat in dat geval andere kosten (tijdsverlies, ergernis) gaan meespelen. Het gaat er derhalve om een punt te vinden waarop de vermindering van de maximumsnelheid vanuit primair kostenoogpunt optimaal is. Dit kan worden bereikt op een punt waar een verlaging van de maximumsnelheid (meer preventiekosten) niet tot meer kosten leidt dan dat een dergelijke maatregel opbrengt, in termen van een verhoging van de veiligheid op de weg.

\section{Het Coase-Theorema}

Naar aanleiding van het voorgaande is een belangrijke vraag of de tussenkomst van het rechtssysteem noodzakelijk is om partijen die bij een potentieel ongeval kunnen worden betrokken aan te zetten tot optimale zorg. Ronald Coase heeft geleerd dat dit onder bepaalde voorwaarden niet noodzakelijkerwijs het geval is.

Ronald Coase wordt beschouwd als een van de grondleggers van de moderne rechtseconomie. Het door hem ontwikkelde 'theorema' wordt in het algemeen als startpunt

614. Faure en Van den Bergh, Objectieve aansprakelijkheid, p. 70-73; Shavell, Accident Law, p. 5-7; Bowles, Law and the Economy, p. 114-117; Veljanovski, in The Economic Approach to Law, p. 131-133; Cooter and Ulen, Law and Economics, p. 20-23; Faure, in Rechtseconomie en recht, p. $54-60$. 
genomen voor de economische analyse van het ongevallenrecht. ${ }^{615}$ Uit de literatuur kan de volgende omschrijving van het 'Coase-theorema' worden afgeleid:

'Op voorwaarde dat er geen transactiekosten zijn ('assumption of zero transaction costs') zal de toewijzing van bepaalde (eigendoms)rechten ${ }^{616}$ door middel van onderhandelingen, steeds tot een efficiënte oplossing leiden, ongeacht de toepasselijke rechtsregel'. ${ }^{617}$

Transactiekosten kunnen in het algemeen worden omschreven als beslissings-, onderhandelings- en informatiekosten. ${ }^{618}$ De afwezigheid van transactiekosten veronderstelt dat partijen die elkaar kennen in goede harmonie en kosteloos met elkaar kunnen onderhandelen, zonder dat sprake is van strategisch gedrag. ${ }^{619}$

Aan de hand van een voorbeeld kan het Coase-theorema worden toegelicht. Dit voorbeeld heeft betrekking op een fabriek die door de uitstoot van chemische stoffen schade toebrengt aan de was die bij vijf omwonenden van de fabriek buiten te drogen hangt. ${ }^{620}$ De omwonenden lijden een schade van elk \$ 75 , total $\$ 375$. De uitstoot kan worden voorkomen door het installeren van een filter in de schoorsteen van de fabriek à $\$ 150$ of elke omwonende kan worden voorzien van een elektrische droger van $\$ 50$ per stuk voor een totaalprijs van $\$ 250$.

Voor Coase zijn nu drie vragen van belang:

615. De basis hiervoor heeft Coase ontwikkeld in The Problem of Social Cost, JLE, 1960, p. 1-44. Zie Parisi, European Joumal of Law and Economics, 1995, p. 149-173, voor een historisch overzicht van het Coase-theorema en de impact van dit 'theorema' op de rechtseconomische literatuur.

616. Calabresi and Melamed, Harvard Law Review, 1972, p. 1089-1128, hebben de toewijzing van (eigendoms)rechten verder uitgewerkt door een onderscheid te maken naar 'property rules', waarbij een absoluut eigendomsrecht wordt toegekend; 'liability rules', waarbinnen de toewijzing van een recht kan worden getransfereerd onder betaling van een schadevergoeding, en 'inalienability' dat betrekking heeft op onvervreemdbare rechten. Zie omtrent dit onderscheid ook: Veljanovski, in The Economic Approach to Law, p. 134-135; Holzhauer en Teijl, Inleiding rechtseconomie, p. 46-49; Faure en Van den Bergh, Objectieve aansprakelijkheid, p. 64-65.

617. Faure en Van den Bergh, Objectieve aansprakelijkheid, p. 65; Van den Bergh, in Rechtseconomie en recht, p. 19; Bowles, Law and the Economy, p. 26-27; Holzhauer en Teijl, Inleiding rechtseconomie, p. 28-29; Veljanovski, in The Economic Approach to Law, p. 129-130.

618. Polinsky, Introduction, p. 12, geeft de volgende omschrijving: 'In general, transaction costs include the costs of identifying the parties with whom one has to bargain, the costs of getting together with them, the costs of the bargaining process itself, and the costs of enforcing any bargain reach'. Zie ook Cooter and Ulen, Law and Economics, p. 84-87.

619. Bij strategisch gedrag verliest het Coase-theorema zijn geldigheid. Zie Veljanovski, New Lawand- Economics, p. 53-53; Polinsky, Introduction, p. 18-20.

620. Voorbeeld ontleend aan Polinsky, Introduction, p. 11-12. Zie ook Coase, JLE, 1960, p. 8-15, waarin hij zijn theorema uitwerkt aan de hand van een aantal voorbeelden uit de Amerikaanse rechtspraak. 
1. Wat is de efficiënte oplossing indien geen rechten worden toegewezen? Moet de filter er komen? Wat is de opbrengst bij de installatie van de filter in termen van de omvang van de schade?

2. Wat is de efficiënte oplossing bij de veronderstelling dat de omwonenden een recht op schone lucht krijgen toegewezen?

3. Wat is de efficiënte oplossing indien de fabriek het recht krijgt op het vervuilen van de lucht?

Bij de beantwoording van vraag 1 , geen toewijzing van rechten, zal rekening moeten worden gehouden met de verwachte schade. Dit betekent dat de installatie van de filter een efficiënte oplossing zal zijn. Op deze wijze kan immers voor \$ 150 een schade van $\$ 375$ worden voorkomen, terwijl een dergelijke keuze ook goedkoper is dan de aanschaf van 5 drogers voor een totaalbedrag van $\$ 250$.

Bij de toewijzing van een absoluut recht op schone lucht aan de omwonenden (vraag 2) is de vraag of een efficiënte oplossing kan worden bereikt indien beide partijen kosteloos kunnen onderhandelen. In deze situatie zal eveneens worden gekozen voor de installatie van de filter voor een bedrag van $\$ 150$. De fabrikant zal immers meer kosten maken wanneer hij besluit tot het betalen van een schadevergoeding $\$ 375$ respectievelijk de levering van 5 drogers voor $\$ 250$.

Bij de toewijzing van een absoluut recht op vervuiling (vraag 3) hebben de omwonenden de keuze tussen het dragen van de totale schade van $\$ 375$, het aanschaffen van een droger voor een totaal bedrag van $\$ 250$ of het laten installeren van de filter voor $\$ 150$. Dit laatste is voor de omwonenden de goedkoopste oplossing, zodat zij gezamenlijk \$150 aan de fabrikant zullen overdragen voor de installatie van de filter. $^{621}$

Het bovenbeschreven voorbeeld geeft aan dat, ongeacht de toewijzing van een recht aan een van beide partijen, steeds een efficiënte uitkomst wordt bereikt. In alle gevallen bleek de installatie van een filter de goedkoopste oplossing te zijn. Daarbij is echter geen rekening gehouden met mogelijke distributionele effecten, die mede afhankelijk zijn van de vraag aan welke partij het recht wordt toegekend. Wanneer sprake is van een recht op schone lucht voor de omwonenden, lijdt de fabriek een verlies van $\$ 150$ voor de installatie van de filter. Omgekeerd zal, ten gevolge van de uitgave voor de filter, het inkomen van de omwonenden dalen indien de fabriek een recht heeft om de lucht te vervuilen. Dit betekent dat de keuze van de rechtsregel

621. Polinsky, Introduction, p. 11-12. 
van invloed is op de verdeling van inkomens, waarvan de omvang echter gelijk is aan de kosten van de meest efficiënte uitkomst $(\$ 150){ }^{622}$

In het voorgaande is uitgegaan van de meest ideale situatie, waarbij de transactiekosten nihil zijn en de partijen geen strategisch gedrag vertonen. In werkelijkheid zijn er echter wel transactiekosten en kan het strategisch gedrag van één of beide partijen niet worden uitgesloten.

In het gegeven voorbeeld kan worden verondersteld dat de omwonenden elk $\$ 60$ kwijt zijn om in vergadering bijeen te komen. Wanneer nu de omwonenden een recht hebben op schone lucht zal de fabriek opnieuw kiezen voor de installatie van een filter voor een prijs van $\$ 150$. Hiermee wordt in het kader van het Coasetheorema een efficiënte oplossing bereikt. Indien echter de fabriek een recht heeft om de lucht te vervuilen, zal elke omwonenden de keuze hebben tussen het dragen van de schade van $\$ 75$, het aanschaffen van een droger voor $\$ 50$ of samen met de andere omwonenden een filter aanschaffen voor $\$ 150$ plus de kosten van $\$ 60$ ( $\$ 150 / 5+\$ 60=\$ 90$ per omwonende) om bij elkaar te komen. De omwonenden zullen nu besluiten tot de aanschaf van een droger, zijnde de goedkoopste oplossing. Het effect van de aanwezigheid van transactiekosten is derhalve dat, om de kosten van een vergadering te vermijden, door de omwonenden voor een inefficiënte oplossing wordt gekozen. ${ }^{623}$

Ook de veronderstelling dat partijen in goede harmonie en oprecht met elkaar kunnen onderhandelen en zodoende tot een efficiënte oplossing van hun geschil kunnen komen, zal in werkelijkheid niet altijd gelden. De mogelijkheid bestaat namelijk dat partijen zich strategisch ten opzichte van elkaar gedragen. Een rationeel handelend individu zal zich niet tevreden stellen met een vanuit economisch oogpunt efficiënte oplossing, terwijl hij er bij een inefficiënte uitkomst financieel beter van kan worden. In het gegeven voorbeeld zal een deel van de omwonenden, ook bij afwezigheid van transactiekosten, misschien niet willen meebetalen aan de aanschaf van een filter, maar in plaats daarvan hun was binnen laten drogen. Of een van de omwonen-

622. Zie Polinsky, Introduction, p. 12; Faure en Van den Bergh, Objectieve aansprakelijkheid, p. 6567. Zie voor een analyse van het Coase-theorema ook: Bowles, Law and the Economy, p. 26-31; Mackaay, RM Themis, 1988, p. 420-422; Van Velthoven en Van Wijck, Recht en Efficiëntie, p. 76-81; Van den Bergh, in Rechtseconomie en recht, p. 18-20; Holzhauer en Teijl, Inleiding rechtseconomie, p. 28-39; Schäfer und Ott, Lehrbuch der 8konomischen Analyse, p. 80-83; Vetjanovski, in The Economic Approach to Law, p. 129-131; Posner, Economic Analysis, p. 8-10; Landes and Posner, Economic Structure of Tort Law, p. 31-38; Cooter and Ulen, Law and Economics, p. 79-84.

623. Polinsky, Introduction, p. 12-13; Van Velthoven en Van Wijck, Recht en efficiëntie, p. 79-81. 
den zal de anderen laten betalen voor de filter, waarvan hij uiteindelijk profiteert zonder dat het hem iets kost. ${ }^{624}$

Concluderend kan worden gesteld dat het Coase-theorema van toepassing is, wanneer een klein aantal partijen in goede harmonie tegen lage kosten met elkaar kan onderhandelen om een bepaald geschil tot een efficiënte oplossing te brengen. De vraag is nu in hoeverre het Coase-theorema voor het onderwerp van het onderhavige onderzoek, namelijk het verkeersongevallenrecht, een rol kan vervullen. Calabresi geeft in dat kader een eenvoudig voorbeeld waaruit blijkt hoe het Coase-theorema in zijn meest ideale vorm bij verkeersongevallen kan werken.

In dit voorbeeld wordt verondersteld dat een automobilist een voetganger aanrijdt en een schade van $\$ 100$ veroorzaakt. ${ }^{625}$ Wanneer de auto zou zijn uitgerust met sponsen bumpers zal de verwachte schade kunnen dalen tot $\$ 10$. Deze sponsen bumpers zijn echter $\$ 50$ duurder dan gewone bumpers. Bij afwezigheid van transactiekosten zal de automobilist een paar sponsen bumpers installeren, ongeacht of hij aansprakelijk wordt gesteld. Wanneer de automobilist aansprakelijk is zullen zijn totale kosten $\$ 60$ bedragen, zijnde $\$ 50$ voor de sponsen bumpers en $\$ 10$ schadevergoeding. Dit is lager dan de totale maatschappelijke kosten van $\$ 100$. De voetganger zal, wanneer de automobilist niet aansprakelijk is en hij dus zijn eigen schade moet dragen, $\$ 50$ betalen voor de sponsen bumpers. In dat geval heeft hij een kostenpost van $\$ 60$ $(\$ 50+\$ 10)$, een bedrag dat ook lager is dan de totale maatschappelijke kosten van $\$ 100$. In beide gevallen zijn de preventiekosten lager dan de totale maatschappelijke kosten, in casu de verwachte schade van $\$ 100$. $^{626}$

In werkelijkheid zijn verkeersdeelnemers vreemden van elkaar, waardoor de transactiekosten zo hoog kunnen zijn dat het onderling afsluiten van een contract met betrekking tot de gevolgen van een verkeersongeval onmogelijk wordt. Een automobilist kan bijvoorbeeld niet vooraf onderhandelen met elke potentiële voetganger of fietser die hij eventueel zal aanrijden. Dit betekent dat bij verkeersongevallen niet meer aan de voorwaarden van het Coase-theorema kan worden voldaan, zodat een

624. Zie over strategisch gedrag binnen het Coase-theorema: Schåfer und Ott, Lehrbuch der ökonomischen Analyse, p. 85-86; Polinsky, Introduction, p. 18-20; Faure en Van den Bergh, Objectieve aansprakelijkheid, p. 66-67; Holzhauer en Teijl, Inleiding rechtseconomie, p. 32-34.

625. De maatschappelijke kosten (M) zijn in deze casus gelijk aan de omvang van de schade (S) vermenigvuldigt met de kans dat zich een verkeersongeval voordoet (p). Zie paragraaf 3 van dit hoofdstuk.

626. Calabresi, Costs of Accidents, p. 136-138. 
ingrijpen van het recht nodig zal zijn in de vorm van aansprakelijkheid of (veiligheids)regulering. ${ }^{627}$

Samenvattend kan worden gesteld dat wat het Coase-theorema leert is dat de optimale zorg in vrije onderhandelingen automatisch kan worden vastgesteld als de transactiekosten nul zijn. Daarmee kan het Coase-theorema worden beschouwd als een nuttige inleiding op de economische analyse van het aansprakelijkheidsrecht en de (veiligheids)regulering. Toch kan ook de vraag worden gesteld wat de praktische betekenis is van het Coase-theorema, niet alleen voor de verkeersaansprakelijkheid maar ook voor de aansprakelijkheid in het algemeen nu, zoals hiervoor aangegeven, vrije onderhandelingen tussen partijen zelden mogelijk zijn.

Het Coase-theorema heeft vanuit theoretisch oogpunt het grote voordeel dat onderzocht kan worden welke oplossing partijen zouden hebben bereikt indien vrije onderhandelingen mogelijk waren geweest. Die informatie kan voor de rechter of de wetgever die in plaats van de betrokken partijen de optimale zorg vaststelt uiteraard van groot belang zijn. Dit komt ook overeen met het rechtseconomisch inzicht dat de rechter en de wetgever geacht worden de marktoplossing na te bootsen.

627. Faure en Van den Bergh, Objectieve aansprakelijkheid, p. 68-69; Polinsky, Introduction, p. 39; Bowles, Law and the Economy, p. 109-112; Holzhauer en Teijl, Inleiding rechtseconomie, p. 119. 


\section{Hoofdstuk 5: De economische analyse van het aansprakelijkheidsrecht}

\section{Inleiding: aansprakelijkheidsregels}

In het vorige hoofdstuk is aan de hand van een aantal basisbeginselen een inleiding gepresenteerd van de economische analyse van het ongevallenrecht. Een van de elementen die daarbij uitvoerig aan de orde is geweest is het economisch optimum. Dit optimum, zo is gesteld, kan worden bereikt op een punt waar de marginale kosten van zorg gelijk zijn aan de marginale opbrengst in termen van een vermindering van de verwachte schade. $\mathrm{Bij}$ het economisch optimum zijn de maatschappelijke kosten minimaal en wordt door dader en slachtoffer een optimaal niveau van zorg uitgeoefend. $^{628}$

In aansluiting hierop is het Coase-theorema beschreven. In een ideale situatie, waarin sprake is van twee partijen die tegen relatief lage kosten kunnen onderhandelen, zal zonder ingrijpen van het recht een optimale uitkomst worden bereikt. Ten aanzien van verkeersongevallen is echter gesteld dat onderhandelingen waarbij elke potentiële verkeersdeelnemer betrokken wordt te hoge transactiekosten meebrengt. ${ }^{629}$ Dit betekent dat bij verkeersongevallen niet meer aan de voorwaarden van het Coase-theorema kan worden voldaan, zodat een tussenkomst van het rechtssysteem nodig zal zijn.

Deze tussenkomst van het recht zal in dit hoofdstuk worden uitgewerkt met een analyse van het aansprakelijkheidsrecht. ${ }^{630}$ Daarbij staat onder andere de vraag centraal welke aansprakelijkheidsregel voldoende prikkels geeft aan dader en slachtoffer om het eerder gevonden optimale niveau van zorg aan te wenden. In de economische analyse van het (verkeers)ongevallenrecht wordt in beginsel een onderscheid ge-

628. Brown, JLS, 1973, p. 333. Zie ook paragraaf 3.2 van hoofdstuk 4.

629. Brown, JLS, 1973, p. 326 en 335; Faure en Van den Bergh, Objectieve aansprakelijkheid, p. 73; Cooter and Ulen, Law and Economics, p. 261-262; Demsetz, JLS, 1972, p. 13-28. Zie cok paragraaf 4 van hoofdstuk 4

630. De economische analyse van het aansprakelijkheidsrecht is onder ander uitgewerkt door: Brown, JLS, 1973, p. 323-349; Diamond, JLS, 1974, p. 107-164; Posner, JLS, 1972, p. 29-96; Shavell, JLS, 1980, p. 1-25; Landes and Posner, Georgia Law Review, 1981, p. 851-924; Shavell, Accident Law, p. 1-32; Faure en Van den Bergh, Objectieve aansprakelijkheid, p. 62-100; Polinsky, Introduction, p. 39-52; Posner, Economic Analysis, p. 163-216; Green, BJE, 1975, p. 553-574; Adams, Gefährdungs und Verschuldenshaftung, p. 36-119; Faure, in Rechtseconomie en recht, p. 60-71; Landes and Posner, Economic Structure of Tort Law, p. 54-84; Endres, Oknomische Grundlagen des Haftungsrecht, 1991; Schafer und Schonenberger, Strict Liability versus Negligence, Recht und Ökonomie, 1997, nr. 34, p. 1-29. Voor wat Nederland betreft kan worden verwezen naar Van Veldhoven en Van Wijck, Recht en efficientie, p. 131-180; Holzhauer en Teijl, Inleiding rechtseconomie, p. 119-144. 
maakt tussen drie rechtsregels, namelijk geen aansprakelijkheid, risicoaansprakelijkheid en foutaansprakelijkheid. ${ }^{631}$

Geen aansprakelijkheid verwijst naar de situatie waarin de dader in het geheel niet gehouden is om de schade van het slachtoffer te vergoeden. Deze situatie is in de komende analyse van belang omdat een dergelijke regel van invloed kan zijn op de prikkels van zorg die het slachtoffer in acht moeten nemen.

Bij een regel van risicoaansprakelijkheid zal de dader in beginsel de schade (totale ongevalskosten) aan het slachtoffer moeten vergoeden. Daarbij is niet van belang of de schadeveroorzaker zelf een fout heeft gemaakt of zich anderszins onzorgvuldig heeft gedragen. De deelname aan een bepaalde activiteit waaruit schade voortvloeit zal reeds voldoende zijn voor aansprakelijkheid.

Foutaansprakelijkheid, ten slotte, heeft betrekking op die gevallen waarin de dader de schade aan het slachtoffer moet vergoeden, indien hij niet de door het recht vereiste zorg (zorgvuldigheidsnorm) in acht neemt. ${ }^{632}$

Het bovengenoemde economisch onderscheid tussen aansprakelijkheidssystemen houdt derhalve verband met de vraag in hoeverre rechtsregels (ex ante) aan dader en slachtoffer prikkels kunnen geven ten behoeve van de uitoefening van optimale zorg. Binnen de positiefrechtelijke analyse verwijst het onderscheid tussen fout- en risicoaansprakelijkheid naar de door de rechter te verrichten toetsing van het gedrag van de schadeveroorzaker aan de zorgvuldigheidsnorm. Bij foutaansprakelijkheid is het noodzakelijk dat de dader zich aan de zorgvuldigheidsnorm heeft gehouden, terwijl bij risicoaansprakelijkheid een dergelijke toetsing in beginsel overbodig is. ${ }^{633}$

631. In navolging van Faure en Van den Bergh zal hier het begrip 'foutaansprakelijkheid' (afkomstig uit de Code Civil-traditie) in plaats van 'schuldaansprakelijkheid' worden gebruikt, met name omdat het objectieve foutvereiste binnen de economische analyse een belangrijke rol speelt, terwijl de schuldaansprakelijkheid meer vanuit een subjectief kader werkt.

632. Zie voor het economisch onderscheid tussen risico- en foutaansprakelijkheid onder anderen: Cooter, Joumal of Economic Perspectives, 1991, p. 12-16; Bowles, Law and the Economy, p. 109; Mackaay, NJB, 1980, p. 816.

633. Van Schilfgaarde, AA, 1990, p. 149. Volgens haar gaat het bij het economische onderscheid om het vereiste van onzorgvuldig gedrag voor aansprakelijkheid, terwijl het juridisch onderscheid meer uitgaat van het vereiste van de onzorgvuldige dader. Zie over het juridisch onderscheid tussen schuld/fout- en risico: C.C. van Dam, Zorgvuldigheidsnorm en aansprakelijkheid, diss., p. 7 en 189-190; Van Maanen, Onrechtmatige daad, diss., p. 38-43 en 192-195; Faure en Van den Bergh, Objectieve aansprakelijkheid, p. 167-170, met betrekking tot het Belgische recht. 


\section{De structuur van de economische analyse van het aansprakelijkheidsrecht}

Binnen de analyse van het aansprakelijkheidsrecht zal worden gewerkt met een aantal veronderstellingen. Deze veronderstellingen houden verband met de opzet van de analyse in dit hoofdstuk.

Zoals in het vorige hoofdstuk ten aanzien van het economisch model ${ }^{6.34}$ is aangegeven zal worden uitgegaan van twee partijen, dader en slachtoffer, die bij een ongeval zijn betrokken. De dader wordt daarbij voorgesteld als een automobilist die schade toebrengt aan een fietser als slachtoffer.

In de meest eenvoudige vorm van het eerder beschreven economisch model wordt verondersteld dat alleen de dader invloed kan uitoefenen op het ongevalsrisico, waarbij alleen het slachtoffer schade lijdt. In de economische analyse wordt in dat kader gesproken van unilaterale ongevalssituaties. ${ }^{635}$

Binnen het unilaterale ongevalsmodel wordt eerst onderzocht welke aansprakelijkheidsregel efficiënt is wanneer alleen rekening wordt gehouden met het niveau van zorg van de dader (paragraaf 3 ). Vervolgens wordt nagegaan waar economisch gezien het optimaal activiteitsniveau kan worden bereikt, waama wordt onderzocht welke aansprakelijkheidsregel het best overeenkomt met dit optimale activiteitsniveau van de dader. Ten slotte wordt de vraag beantwoord welke aansprakelijkheidsregel binnen een unilateraal model leidt tot een optimaal zorg- en activiteitsniveau van de dader (paragraaf 4 en 5).

In een tweede fase van de economische analyse van het aansprakelijkheidsrecht wordt de veronderstelling dat het slachtoffer geen invloed kan uitoefenen op het ongevalsrisico genuanceerd, waardoor het model een bilaterale vorm krijgt. ${ }^{636}$ In eerste instantie wordt onderzocht welke aansprakelijkheidsregel zowel dader als slachtoffer kan aanzetten tot een optimaal niveau van zorg. Daarbij zal ook aandacht worden besteed aan een aantal afgeleide vormen van de risicoaansprakelijkheid en foutaansprakelijkheid, zoals de toevoeging van een eigen schuldverweer ten opzichte van het slachtoffer (paragraaf 6 en 7). Vervolgens zal worden bekeken welke aansprakelijkheidsregel bij het optimale activeitsniveau van dader en slachtoffer kan worden gevonden. Ten slotte wordt de vraag beantwoord welke aansprakelijkheidsregel da-

634. Zie paragraaf 3 van hoofdstuk 4 .

635. 'Unilateral case'. Zie Shavell, Accident Law, p. 6; Faure en Van den Bergh, Objectieve aansprakelijkheid, p. 73.

636. 'Bilateral case'. Zie Shavell, Accident Law, p. 9; Faure en Van den Bergh, Objectieve aansprakelijkheid, p. 82. 
der en slachtoffer kan aanzetten tot een optimaal zorg- en activiteitsniveau (paragraaf 8 en 9).

Binnen de analyse van het aansprakelijkheidsrecht gelden verder de volgende algemene veronderstellingen:

- de efficiënte zorg is gelijk aan de juridische zorgvuldigheidsnorm;

- de dader en het slachtoffer zijn rationeel handelende individuen die in staat worden geacht om hun eigen optimale zorg- en activiteitsniveau vast te stellen;

- De dader en het slachtoffer beschikken over volledige informatie omtrent zowel het ongevalsrisico als het gedrag van de wederpartij.

- De door de rechter vastgestelde zorgvuldigheidsnorm is voor elk slachtoffer en voor elke dader gelijk.

- Het verwachte nut voor elk soort dader en elk soort slachtoffer is homogeen.

- De aanwezigheid van een verzekering speelt geen rol; dader en slachtoffer worden verondersteld risiconeutraal te zijn. ${ }^{637}$

In paragraaf $10 \mathrm{zal}$ een aantal van deze veronderstellingen worden genuanceerd, waarbij aandacht wordt besteed aan de vergissingen die zowel de rechter als de dader en het slachtoffer kunnen maken ten aanzien van de juridische zorgvuldigheidsnorm. Daamaast zal worden ingegaan op de problemen bij de classificatie van zorgniveaus, wanneer wordt gesteld dat niet elk soort dader of elk soort slachtoffer in staat is om aan de door de rechter omschreven zorgvuldigheidsnorm te voldoen.

In dit hoofdstuk zal, binnen het door Calabresi gemaakte onderscheid, de aandacht voornamelijk uitgaan naar een vermindering van de primaire ongevalskosten. In de slotparagraaf $12 \mathrm{zal}$ het onderscheid in ongevalskosten meer uitvoerig aan de orde komen, waarbij de vraag centraal staat of, in het kader van aansprakelijkheid, de som van de vermindering van de primaire (preventie), secundaire (compensatie) en tertiaire ongevalskosten tot een minimalisering van de totale maatschappelijke ongevalskosten leidt.

\section{Unilaterale ongevallen: het niveau van zorg}

In deze paragraaf zal worden onderzocht welke aansprakelijkheidsregel efficiënt is indien alleen de dader optimale zorg moet aanwenden. Hierbij wordt verondersteld dat alleen het slachtoffer schade lijdt. Voor het onderzoek naar de efficiënte aansprakelijkheidsregel, waarbij achtereenvolgens geen aansprakelijkheid, risicoaan-

637. Zie hicrover onder anderen: Faure en Van den Bergh, Objectieve aansprakelijkheid, p. 69-70; Landes and Posner, Georgia Law Review, 1981, p. 867-868; Cooter and Ulen, Law and Economics, p. 95; Landes and Posner, Economic Structure of Tort Law, p. 56-57. 
sprakelijkheid en foutaansprakelijkheid aan de orde komen, zal gebruik worden gemakt van de gegevens in tabel $1 .{ }^{638}$

Tabel 1

\begin{tabular}{|c|c|c|c|c|}
\hline $\begin{array}{c}\text { Niveau van opti- } \\
\text { male zorg }\end{array}$ & $\begin{array}{c}\text { Niveau van door het } \\
\text { recht vereiste zorg }\end{array}$ & $\begin{array}{c}\text { Kosten } \\
\text { van zorg }\end{array}$ & $\begin{array}{c}\text { Verwachte } \\
\text { schade }\end{array}$ & $\begin{array}{c}\text { Maatschappe- } \\
\text { lijke kosten }\end{array}$ \\
\hline geen & snel rijden & 0 & 20 & 20 \\
\hline gemiddeld & matige snelheid & 5 & 8 & 13 \\
\hline sterk & langzaam rijden & 15 & 3 & 18 \\
\hline
\end{tabular}

Het optimale niveau van zorg ligt daar waar de maatschappelijke kosten minimaal zijn. Dit is in tabel 1 bij de uitoefening van een gemiddelde zorg, die overeenkomt met een matige snelheid. Wanneer de dader tegen een toename van de kosten van zorg met 5 eenheden, van geen zorg naar een gemiddelde zorg opschuift, zal de verwachte schade met 12 eenheden dalen. Wanneer de dader echter een sterk zorgniveau aanwendt, zullen de kosten van zorg stijgen met 10 eenheden, terwijl de verwachte schade slechts met 5 eenheden afneemt. De uitoefening van sterke zorg is derhalve inefficiënt.

\subsection{GEEN AANSPRAKELUJKHEID}

Wanneer de dader niet wordt afgeschrikt door aansprakelijkheid zal hij geen zorg uitoefenen en zal een regel van geen-aansprakelijkheid tot een inefficiënte oplossing leiden. Het slachtoffer draagt in deze situatie zijn eigen schade, aangezien hij deze niet kan verhalen op de dader.

In tabel 1 zijn de maatschappelijke kosten minimaal bij uitoefening van gemiddelde zorg. De dader zal bij geen-aansprakelijkheid echter geen zorg aanwenden, zodat de maatschappelijke kosten hoger (20) zijn dan in de economisch optimale situatie (13). Een regel van geen-aansprakelijkheid zal alleen efficiënt zijn indien de dader door het uitoefenen van zorg het ongeval niet kan voorkomen, een situatie waarin een ongeval onafwendbaar is. Vanuit economisch oogpunt zou het in dit geval zelfs efficiënt kunnen zijn wanneer de dader geen zorg uitoefent. ${ }^{639}$

638. Deze tabel is ontleend aan Shavell, Accident Law, p. 7 en Polinsky, Introduction, p. 40.

639. Zie hierover Faure en Van den Bergh, Objectieve aansprakelijkheid, p. 73-74; Shavell, Accident Law, p. 8. Het aansprakelijkheidsrecht kan overigens wel van nut zijn om de dader tot een activiteitswijziging te bewegen. Zie daarover paragraaf 4 van dit hoofdstuk. Volgens Calabresi, YLJ, 1975 , p. 657, kan een regel van geen aansprakelijkheid alleen efficiēnt zijn indien alleen het slachtoffer het best in staat moet worden geacht om efficiênte zorg uit te oefenen ter voorkoming 
In het verkeer zal een automobilist zich, wetende dat hij niet aansprakelijk kan worden gesteld voor een verkeersongeval, minder of in het geheel niet zorgvuldig gedragen. In tabel 1 zal hij derhalve kiezen voor snel rijden. ${ }^{640}$

\subsection{RISICOAANSPRAKELIJKHEID ${ }^{641}$}

Uit het voorgaande volgt dat voor de beantwoording van de vraag of de dader kan worden aangezet tot de uitoefening van een optimaal zorgniveau de tussenkomst van een rechtsregel nodig is. Deze tussenkomst kan de vorm aannemen van een aansprakelijkheidsregel waarbij de schade van het slachtoffer naar de dader wordt verschoven.

Bij een stelsel van risicoaansprakelijkheid is de dader aansprakelijk voor de gehele schade van het slachtoffer ongeacht de zorg die hij uitoefent. De schade wordt daarbij gezien als een, door de dader ten opzichte van het slachtoffer veroorzaakt, negatief extern effect dat door middel van een risicoaansprakelijkheid volledig door de dader kan worden geïnternaliseerd. Er vindt derhalve een afwenteling plaats voor elk geval waarin de dader een ongeval veroorzaakt.

Gegeven het feit dat bij een regel van risicoaansprakelijkheid de totale ongevalskosten (schade) voor rekening zijn van de dader, heeft hij een prikkel om optimale zorg uit te oefenen. Dit betekent dat de dader streeft naar een minimalisering van de maatschappelijke kosten die voor hem gelijk zijn aan de kosten van zorg. In het kader van tabel 1 kiest de dader voor de uitoefening van een gemiddelde zorg, zijnde het zorgniveau waar de maatschappelijke kosten minimaal zijn (13).

van een ongeval. Daamaast kan, bij afwezigheid van transactiekosten het slachtoffer de dader uitkopen om het ongeval te voorkomen. Zie ook Landes and Posner, Georgia Law Review, 1981, p. 872-873 en Landes and Posner, Economic Structure of Tort Law, p. 62, die een regel van geen aansprakelijkheid als een echte aansprakelijkheidsregel beschouwen omdat deze de prikkels van zorg van partijen beinvloedt.

640. Hoewel bij deze analyse wordt uitgegaan van de veronderstelling dat alleen het slachtoffer (fietser) schade lijdt, kan een automobilist zelf ook schade lijden waardoor hij zonder aansprakelijkheid toch wordt aangezet tot het uitoefenen van zorg. Bijna elk verkeersongeval krijgt daarmee een wederkerig karakter, waarbij ten behoeve van de preventie van verkeersongevallen matregelen nodig zijn die rekening houden met de aanwezigheid van de fietser. Zie onder anderen Leong, IRLE, 1989, p. 105-111 en Arlen, IRLE, 1990, p. 233-239, voor een uitwerking van een economisch model, waarin zowel het optimale zorgniveau alsook de efficiëntie van aansprakelijkheidsregels wordt geanalyseerd ten aanzien van situaties waarin zowel dader als slachtoffer schade lijden.

641. 'Strict liability', een rechtsregel die in de gangbare Angelsaksische literatuur verwijst naar de situatie waarin de dader steeds gehouden is om de schade aan het slachtoffer te vergoeden. De variaties op deze rechtsregel, zoals die in genoemde literatuur naar voren komen, bijvoorbeeld 'absolute liability' of 'no-fault', zullen hier buiten beschouwing blijven. 
Binnen een unilaterale ongevalssituatie leidt een regel van risicoaansprakelijkheid derhalve tot een efficiënt resultaat. Wanneer daarnaast wordt verondersteld dat de rechter over voldoende informatie beschikt met betrekking tot de omvang van de werkelijk geleden schade, zal het slachtoffer ook volledig worden gecompenseerd. ${ }^{642}$

Een automobilist die zich ervan bewust is dat de volledige schade voor zijn rekening komt zal alle benodigde maatregelen nemen om het ongeval te voorkomen. Hij kiest derhalve voor een matige snelheid. Daarbij wordt verondersteld dat de fietser geen enkele invloed kan uitoefenen op het ongevalsrisico.

\subsection{FOUTAANSPRAKELIJKHEID ${ }^{643}$}

Naast een regel van risicoaansprakelijkheid kan, binnen een unilateraal ongevalsmodel, ook een regel van foutaansprakelijkheid de dader aanzetten tot een optimaal zorgniveau. Bij een regel van foutaansprakelijkheid is de dader aansprakelijk voor de schade van het slachtoffer, indien hij een fout begaat. Dit betekent dat de dader verzuimd heeft om een bepaalde door het recht vereiste zorgvuldigheid in acht te nemen. Deze juridische zorgvuldigheidsnorm, die de dader moet naleven om te kunnen bepalen of deze een fout heeft gemaakt, wordt door het rechtssysteem bepaald en indien nodig vastgesteld door de rechter.

Het efficiënte niveau van zorg wordt, zoals aangegeven, gevonden op een punt waar de maatschappelijke kosten minimaal zijn. Wanneer vervolgens wordt verondersteld dat deze efficiënte zorg gelijk is aan de juridische zorgvuldigheidsnorm, is de dader aansprakelijk indien hij minder dan de efficiënte zorg uitoefent, ongeacht de zorg die het slachtoffer heeft aangewend. Hieruit volgt dat, wanneer de efficiënte zorg gelijk is aan de zorgvuldigheidsnorm, de dader optimale zorg zal uitoefenen.

In de tweede kolom van tabel 1 is ten aanzien van de zorg van een automobilist een aantal niveaus weergegeven die verband houden met de juridische zorgvuldigheidsnorm. Bij de uitoefening van een gemiddelde zorg zijn de maatschappelijke kosten minimaal. Verondersteld wordt dat deze gemiddelde zorg gelijk is aan het rijden met een matige snelheid. Indien de zorgvuldigheidsnorm (matige snelheid) gelijk is aan de efficiënte zorg en wanneer de rechter over volledige informatie beschikt omtrent de zorg die de dader in acht moet nemen, dan zal de automobilist niet aansprakelijk

642. Faure en Van den Bergh, Objectieve aansprakelijkheid, p. 75; Shavell, Accident Law, p. 8; Shavell, 1980, p. 11; Polinsky, Introduction, p. 41; Landes and Posner, Georgia Law Review, 1981, p. 873; Landes and Posner, Economic Structure of Tort Law, p. 63.

643. 'Negligence liability'. In de Angelsaksische en rechtseconomische literatuur wordt hiermee verwezen naar de situatie waarin de dader in het algemeen wordt geacht de schade te vergoeden indien hij niet voldoet aan de door het recht omschreven zorgvuldigheidsnorm. In het Nederlands recht wordt dit ook wel schuldaansprakelijkheid genoemd. 
zijn wanneer hij met een matige snelheid rijdt. Indien een automobilist daarentegen kiest voor snel rijden is hij aansprakelijk voor de schade van het slachtoffer. Lang. zaam rijden is voor de automobilist niet efficiënt aangezien hij bij het rijden met een matige snelheid reeds van aansprakelijkheid is bevrijd. Daarnaast zal het voor de automobilist die streeft naar nutsmaximalisatie te duur zijn om meer zorg aan te wenden omdat de marginale kosten van langzaam rijden (10) hoger zijn dan de opbrengst (5) in termen van een vermindering van de verwachte schade. ${ }^{644}$

\subsection{CONCLUSIE I: AANSPRAKELIJKHEIDSREGELS VERGELEKEN}

Uit het voorgaande kan voorlopig worden geconcludeerd dat binnen een unilaterale ongevalssituatie, waarbij alleen het zorgniveau van de dader van belang is, zowel een regel van risicoaansprakelijkheid als een regel van foutaansprakelijkheid tot een efficiënt resultaat leiden.

$\mathrm{Bij}$ een regel van risicoaansprakelijkheid geldt dat de automobilist een prikkel zal hebben om een optimaal niveau van zorg uit te oefenen, omdat de totale ongevalskosten voor zijn rekening komen. Een voorwaarde voor het bereiken van een efficiente uitkomst bij risicoaansprakelijkheid is dat de totale ongevalskosten (schade) gelijk zijn aan de werkelijk geleden schade. Een regel van foutaansprakelijkheid geeft aan de automobilist eveneens een prikkel om optimale zorg uit te oefenen, mits de efficiënte zorg gelijk is aan de juridische zorgvuldigheidsnorm.

\section{Unilaterale ongevallen: het activiteitsniveau}

In deze paragraaf zal worden verondersteld dat naast het zorgniveau ook het activiteitsniveau van de dader van invloed is op het ongevalsrisico. Daarbij staat de vraag centraal welke aansprakelijkheidsregel de dader kan aanzetten tot een optimaal zorgen activiteitsniveau. ${ }^{645}$

In het verkeer kan ten aanzien van het activiteitsniveau worden gedacht aan de mate waarin verkeersdeelnemers gebruik maken van de auto, de fiets en het aantal kilometers dat met deze vervoersmiddelen wordt afgelegd. Daamaast speelt ook een rol in hoeverre verkeersdeelnemers te voet gaan of ervoor kiezen de bus of de trein te nemen. Ten slotte kan in het algemeen worden gesteld dat, naarmate er meer auto's worden geproduceerd, de mogelijkheid dat met deze auto's aan het verkeer wordt

644. Faure en Van den Bergh, Objectieve aansprakelijkheid, p. 76-77; Shavell, Accident Law, p. 8; Polinsky, Introduction, p. 41-42; Landes and Posner, Georgia Law Review, 1981, p. 873-874; Landes and Posner, Economic Structure of Tort Law, p. 63-64.

645. Zie Faure en Van den Bergh, Objectieve aansprakelijkheid, p. 78-80; Shavell, Accident Law, p. 21-26; Polinsky, Introduction, p. 46-49. 
deelgenomen toeneemt. Verder kan worden verondersteld dat door een verhoging van het activiteitsniveau (autorijden) de kans op ongevallen evenredig zal toenemen.

De vraag op welke wijze de dader, naast een optimaal zorgniveau, kan worden aangezet tot de uitoefening van een economisch aanvaardbaar activiteitsniveau houdt mede verband met de door de rechter te bepalen zorgvuldigheidsnorm. Daarbij kan rechter rekening houden met bepaalde typen van activiteit. Indien bijvoorbeeld een bepaalde gevaarlijke activiteit in strijd wordt geacht met een algemene zorgvuldigheidsnorm, is het voldoende om te stellen dat aan de betreffende activiteit is deelgenomen om tot een niet-naleving van de zorgvuldigheidsnorm te komen. Veronderstel de situatie dat door ijzel de wegen spiegelglad zijn geworden en het gelet daarop niet zorgvuldig wordt geacht om zonder grondige reden de weg op te gaan. In zo'n geval kan de rechter reeds tot een schending van de zorgvuldigheidsnorm oordelen, wanneer bijvoorbeeld een automobilist de weg opgaat enkel om te onderzoeken of de banden van zijn auto wel een goed profiel hebben, waarbij hij vervolgens een aanrijding veroorzaakt.

Bij de beoordeling van het activiteitsniveau geldt, evenals bij de bepaling van het zorgniveau, dat door de rechter bij de beoordeling van de zorgvuldigheidsnorm niet met elke vorm van activiteit rekening kan worden gehouden. Enerzijds is het voor rechter niet eenvoudig om het optimale activiteitsniveau te bepalen, anderzijds is het voor de rechter wel noodzakelijk om een oordeel te geven omtrent het werkelijk uitgeoefende activiteitsniveau. Wanneer in het verkeer bijvoorbeeld wordt uitgegaan van de activiteit autorijden, kan de rechter wel bepalen dat een automobilist voorzichtig moet rijden (zorg), maar niet wat het optimaal aantal kilometers is dat een automobilist op een dag mag afleggen (activiteit). Het is echter, na enig rekenwerk, wel mogelijk om achteraf een oordeel te geven over het aantal afgelegde kilometers. ${ }^{646}$

Alvorens in paragraaf 4.2 de vraag wordt beantwoord welke aansprakelijkheidsregel de dader kan aanzetten tot een optimaal zorg-en activiteitsniveau, zal in de volgende paragraaf (4.1) eerst worden onderzocht waar het optimaal activiteitsniveau kan worden gevonden.

646. Shavell, JLS, 1980, p. 22; Faure en Van den Bergh, Objectieve aansprakelijkheid, p. 78; Shavell, Accident Law, p. 21. Landes and Posner, Georgia Law Review, 1981, p. 876, stellen dat 'A court in an automobile-accident case would consider whether the defendant had driven carefully when the accident occured but it would not consider whether the trip was really necessary in the sense that the benefits of the trip exceeded all of its costs including expected accident costs'. Zie ook Landes and Posner, Economic Structure of Tort Law, p. 66. 


\subsection{Het OPTIMAAL ACTIVITEITSNIVEAU}

Bij de analyse van het zorgniveau in unilaterale ongevalssituaties is gesteld dat de dader bij de uitoefening van zorg rekening houdt met twee kostenfactoren, namelijk de kosten van zorg en de verwachte ongevalskosten, waarbij de dader ernaar streeft om de som van deze kosten te minimaliseren.

Bij de uitoefening van een activiteit wordt door de dader ook rekening gehouden met het nut dat hij daarvan heeft. Dit betekent dat een toename van het activiteitsniveau van de dader gepaard gaat met een evenredige stijging van zowel de verwachte ongevalskosten als van het nut dat de dader heeft van de extra uitgeoefende eenheden activiteit. De doelstelling van de dader is er derhalve op gericht een activiteitsniveau aan te wenden waarbij hij zijn nut kan maximaliseren, rekening houdend met de kosten van zorg en de verwachte ongevalskosten. Het optimale activiteitsniveau is vanuit economisch oogpunt gelijk aan het hoogste extra nut dat de dader van de uitoefening van een activiteit verkrijgt minus de kosten van zorg en de verwachte ongevalskosten. ${ }^{647}$ Dit kan met behulp van de gegevens uit tabel 2 worden toegelicht. ${ }^{648}$

Tabel 2

\begin{tabular}{|c|c|c|c|c|}
\hline $\begin{array}{c}\text { Activiteits- } \\
\text { niveau }\end{array}$ & $\begin{array}{c}\text { Totale } \\
\text { nut }\end{array}$ & Kosten van zorg & $\begin{array}{c}\text { Totale ongevals- } \\
\text { kosten }\end{array}$ & $\begin{array}{c}\text { Maatschappelijke } \\
\text { welvaart }\end{array}$ \\
\hline 0 & 0 & 0 & 0 & 0 \\
\hline $1(20 \mathrm{~km})$ & 40 & $3(50 \mathrm{~km} / \mathrm{u})$ & 10 & 27 \\
\hline $2(40 \mathrm{~km})$ & 60 & $6(60 \mathrm{~km} / \mathrm{u})$ & 20 & 34 \\
\hline $3(60 \mathrm{~km})$ & 69 & $9(70 \mathrm{~km} / \mathrm{u})$ & 30 & 30 \\
\hline $4(80 \mathrm{~km})$ & 71 & $12(80 \mathrm{~km} / \mathrm{u})$ & 40 & 19 \\
\hline $5(100 \mathrm{~km})$ & 70 & $15(90 \mathrm{~km} / \mathrm{u})$ & 50 & 5 \\
\hline
\end{tabular}

In de eerste kolom is het activiteitsniveau van de dader, niveau $1 \mathrm{t} / \mathrm{m} 5$, weergegeven. Tussen haakjes staat het corresponderende aantal afgelegde autokilometers, oplopend van $20 \mathrm{t} / \mathrm{m} 100$ kilometer. In de tweede kolom is het totale nut van de dader weergegeven, dat overeenkomt met de verschillende activiteitsniveaus. De gefingeerde cijfers in deze kolom geven aan dat het totale nut van de dader toeneemt naarmate hij meer autokilometers aflegt. Het extra nut dat de dader geniet van een verhoging van zijn activiteitsniveau daalt echter totdat ook het totale nut afneemt. In de derde kolom staan de kosten van zorg die samenhangen met de verschillende

648. Voorbeeld naar Shavell, Accident Law, p. 23-24. 
snelheden waarmee de dader rijdt. De kosten van zorg stijgen evenredig met de genoemde snelheden, waarmee wordt aangegeven dat een hogere snelheid tot hogere kosten leidt. De vierde kolom geeft de verwachte ongevalskosten weer. In de vijfde kolom wordt de maatschappelijke welvaart aangegeven. Deze maatschappelijke welvaart heeft betrekking op het maximale nut dat de dader bij de uitoefening van de activiteit kan verkrijgen en is daarmee gelijk aan het totale nut minus de kosten van zorg en de verwachte ongevalskosten. ${ }^{649}$

Aan de hand van tabel 2 kan nu worden onderzocht waar het optimaal activiteitsniveau van de dader wordt gevonden. Daarbij geldt dat de dader zijn activiteit zal verhogen zolang het marginale nut daarvan de verwachte ongevalskosten overtreft. In tabel 2 leidt een verhoging van de activiteit van niveau 0 naar 1 tot een nutstoename van 40 , tegen een stijging van de totale ongevalskosten met 3 (kosten van zorg) +10 (verwachte schade) $=13$. De maatschappelijke welvaart bij activiteitsniveau 1 bedraagt derhalve $40-13=27$. De verhoging van de activiteit van niveau 1 naar 2 resulteert in een nutstoename van $20(60-40)$, terwijl de totale ongevalskosten stijgen met $3+10=13$. Bij dit activiteitsniveau bedraagt de maatschappelijke welvaart $60-26=34$. Bij activiteitsniveau 3 is nutstoename slechts 9 eenheden. De stijging van de totale ongevalskosten bedraagt echter $3+10=13$ en de maatschappelijke welvaart daalt naar 30. Dit brengt mee dat activiteitsniveau 2 optimaal is. Bij dit niveau is de maatschappelijke welvaart het hoogst en is de marginale toename van het nut hoger dan de marginale stijging van de som van de kosten van zorg en de verwachte ongevalskosten. Bij het optimale activiteitsniveau zal door de dader 40 kilometer worden afgelegd tegen een snelheid van $60 \mathrm{~km} / \mathrm{u}^{650}$

\subsection{WELKE AANSPRAKELIJKHEIDSREGEL IS EFFICIËNT BIJ EEN OPTIMAAL ZORG- EN ACTIVITEITSNIVEAU?}

In het voorgaande is het optimaal activiteitsniveau gevonden op een punt waar de maatschappelijke welvaart uit het oogpunt van de dader het hoogst is. In deze paragraaf zal worden onderzocht welke invloed aansprakelijkheidsregels kunnen hebben op zowel het zorg- als het activiteitsniveau van de dader. Daarbij komen achtereenvolgens een regel van geen aansprakelijkheid, risicoaansprakelijkheid en foutaansprakelijkheid aan de orde.

649. Shavell, Accident Law, p. 21, noot 28, merkt op dat de eerder gebruikte doelstelling minimalisering van de maatschappelijke ongevalskosten een onderdeel is van de bij het activiteitsniveau gebruikte doelstelling van optimalisering van de maatschappelijke welvart: 'If we imagine the level of activity to be held constant, as we assumed was the case above, then maximization of the utility derived from the activity less total accident costs is obviously equivalent to minimization of total accident costs'.

650. Zie Shavell, Accident Law, p. 22; Polinsky, Introduction, p. 48, waarin deze een soortgelijke tabel weergeeft; Faure en Van den Bergh, Objectieve aansprakelijkheid, p. 79 tabel 4, die is ontleend aan Polinsky. 


\subsubsection{Geen aansprakelijkheid}

Bij de analyse van zorg is geconcludeerd dat wanneer de dader niet aansprakelijk is, hij geen prikkel heeft om zorg uit te oefenen. Zonder de dreiging van aansprakelijkheid zal de dader ook zijn activiteitsniveau blijven verhogen, wanneer dit voor hem extra nut oplevert, ondanks het feit dat dit maatschappelijk niet wenselijk is. Dit betekent dat zolang het marginaal nut van een activiteit hoger is dan de kosten van zorg plus de verwachte ongevalkosten de dader de activiteit zal blijven uitoefenen.

Omdat een automobilist bij een regel van geen-aansprakelijkheid geen zorg zal uitoefenen zal hij, voor wat betreft het activiteitsniveau, dus veel autokilometers willen afleggen met een hoge snelheid. In het kader van tabel 2 zal de automobilist bij geen-aansprakelijkheid het activiteitsniveau 4 uitoefenen. Dit levert hem immers het hoogste nut (71) op, zonder dat hij rekening behoeft te houden met de kosten van zorg en de verwachte ongevalskosten. De automobilist zal bij dit activiteitsniveau een afstand van 80 kilometer afleggen tegen een snelheid van $80 \mathrm{~km} / \mathrm{u}$. Uitgaande van het optimale activiteitsniveau 2 , is een regel van geen-aansprakelijkheid derhalve een inefficiënte oplossing. ${ }^{651}$

\subsubsection{Risicoaansprakelijkheid}

Bij een regel van risicoaansprakelijkheid zal de dader zowel een optimaal zorg-als activiteitsniveau aanwenden ten behoeve van een maximalisering van de maatschappelijke welvaart. Hij zal immers in beginsel de gehele schade van het slachtoffer moeten dragen. De dader kiest daarbij voor een optimaal niveau van zorg omdat daarmee zijn verwachte ongevalskosten worden geminimaliseerd, gegeven de uitoefening van een bepaalde activiteit. De dader zal daarnaast ook een optimaal activiteitsniveau aanwenden. Bij elke activiteit die de dader uitoefent zal hij ernaar streven om de som van de kosten van zorg en de verwachte schade lager te houden dan het extra nut dat hij van de uitoefening van de activiteit heeft.

In tabel 2 kiest de automobilist bij een risicoaansprakelijkheid voor activiteitsniveau 2. Bij dit activiteitsniveau geniet de automobilist het hoogste nut, waarbij hij rekening moet houden met de kosten van zorg en de verwachte schade. Dit betekent dat de automobilist een afstand van 40 kilometer zal afleggen met een snelheid van 60 $\mathrm{km} / \mathrm{u}$. Een regel van risicoaansprakelijkheid leidt derhalve tot een optimaal resultaat, waarbij ook de maatschappelijke welvaart het hoogste niveau bereikt. ${ }^{652}$

651. Shavell, Accident Law, p. 22-23.

652. Shavell, Accident Law, p. 23; Faure en Van den Bergh, Objectieve aansprakelijkheid, p. 79; Polinsky, Introduction, p. 47-48; Landes and Posner, Georgia Law Review, 1981, p. 875-877; 


\subsubsection{Foutaansprakelijkheid}

Bij de analyse van het zorgniveau is gesteld dat de dader, om aan een foutaansprakelijkheid te ontsnappen, een optimaal zorgniveau zal aanwenden, mits dit niveau van zorg gelijk is aan de juridische zorgvuldigheidsnorm. In deze gevallen zal de dader bij de uitoefening van optimale zorg geen schadevergoeding behoeven te betalen. Dit heeft echter wel gevolgen voor het activiteitsniveau van de dader. Wanneer de dader de juridische zorgvuldigheidsnorm naleeft, heeft hij weinig reden om rekening te houden met de economische gevolgen die zijn deelneming aan een bepaalde activiteit heeft op de verwachte ongevalskosten. Hij zal in dat geval bij de uitoefening van een activiteit alleen rekening houden met zijn verwacht nut, minus de kosten van zorg. ${ }^{653}$

Wanneer in tabel 2 wordt verondersteld dat de juridische zorgvuldigheidsnorm gelijk is aan het optimale activiteitsniveau 2 , zal de automobilist bij een regel van foutaansprakelijkheid aan deze zorgvuldigheidsnorm naleven, omdat hij daarmee van aansprakelijkheid is bevrijd. Dit betekent dat de automobilist zijn activiteitsniveau zal opvoeren indien de marginale toename van zijn nut hoger blijft dan de marginale stijging van de kosten van zorg, zonder dat hij rekening behoeft te houden met de marginale toename van de ongevalskosten. Daarmee zal de objectieve kans op een verkeersongeval weliswaar toenemen, maar zolang de automobilist zorgvuldig blijft rijden zal hij toch niet aansprakelijk zijn. Wanneer de automobilist derhalve zijn activiteit verhoogt van niveau 1 naar niveau 2, zal de nutsstijging 20-3=17 bedragen. Een verhoging van de activiteit van niveau 2 naar 3 leidt tot een marginale nutstoename van 9-3=6. Een verdere verhoging van de activiteit naar niveau 4 zal leiden tot een marginale daling van het nut met $2-3=-1$. Een nutsmaximaliserende automobilist, die geen prikkel heeft om zijn activiteit optimaal aan te wenden, kiest derhalve voor activiteitsniveau 3. Bij dit niveau zijn de marginale opbrengsten, in termen van nut, hoger dan de marginale kosten, in termen van zorg.

Concluderend kan worden gesteld dat een regel van foutaansprakelijkheid tot een inefficiënt resultaat leidt. In tabel 2 is de maatschappelijke welvaart het hoogst bij een activiteitsniveau 2. De automobilist kiest bij een regel van foutaansprakelijkheid echter voor activiteitsniveau 3, waarbij een daling optreedt van de maatschappelijke welvaart met 4 eenheden (34-30).

Shavell, JLS, 1980, p. 2-3 en p. 11. Zie ook Posner, Economic Analysis, p. 165-167, voor een uitwerking met betrekking tot productaansprakelijkheid.

053. Zic Shavell, Accident Law, p. 23-24; Faure en Van den Bergh, Objectieve aansprakelijkheid, p. 79-80; Polinsky, Introduction, p. 48-49; Shavell, JLS, 1980, p. 2 en p. 11-12. 


\section{Conclusie II: Unilaterale verkeersongevallen geëvalueerd}

In het voorgaande is uitgegaan van een unilateraal ongevalsmodel waarbij is verondersteld dat alleen de automobilist invloed kan uitoefenen op het ongevalsrisico. Deze veronderstelling is overigens niet geheel onrealistisch, omdat in de praktijk zeker situaties denkbaar zijn waarin slachtoffers weinig tot niets aan het ontstaan van een verkeersongeval kunnen doen. Een fietser heeft bijvoorbeeld geen invloed op de verwachte ongevalskosten wanneer hij wordt aangereden door een auto die een rood verkeerslicht negeert. Een fietser kan er eveneens weinig aan doen wanneer hij wordt aangereden door een dronken automobilist. Een automobilist die, rijdend over een provinciale weg, de macht over het stuur verliest, in botsing komt met een fietser en vervolgens in de sloot langs de kant van de weg beland, heeft als enige invloed op het ontstaan van een dergelijk ongeval. Uit deze voorbeelden blijkt dat binnen het verkeersongevallenrecht aan de automobilist prikkels kunnen worden gegeven om het ongevalsrisico, waar andere verkeersdeelnemers geen invloed op hebben, te reduceren. Binnen deze unilaterale ongevalssituatie is onderzocht welke aansprakelijkheidsregel aan de automobilist prikkels kan geven ten behoeve van de aanwending van een optimaal zorg- en activiteitsniveau.

In het kader van het zorgniveau is geconcludeerd dat zowel een regel van risicoaansprakelijkheid als een regel van foutaansprakelijkheid onder voorwaarden tot een optimale uitkomst kunnen leiden. Bij een regel van risicoaansprakelijkheid geldt de voorwaarde dat de schadevergoeding (totale ongevalskosten) aan het slachtoffer gelijk moet zijn aan de werkelijk geleden schade. Bij een regel van foutaansprakelijkheid dient de juridische zorgvuldigheidsnorm gelijk te zijn aan de efficiënte zorg om een optimaal resultaat te kunnen bereiken.

Bij de analyse van het activiteitsniveau is gebleken dat ten behoeve van een verhoging van de maatschappelijke welvaart en van een vermindering van de ongevalskosten, een regel van risicoaansprakelijkheid de voorkeur beeft boven een regel van foutaansprakelijkheid. Bij een regel van risicoaansprakelijkheid draagt de automobilist de verantwoordelijkheid voor de totale ongevalskosten. De minimalisering van deze ongevalskosten is voor de automobilist een reden om zowel een optimaal zorgals activiteitsniveau uit te oefenen.

Bij een regel van foutaansprakelijkheid zal de automobilist geen optimaal activiteitsniveau uitoefenen. De automobilist is bij een dergelijke rechtsregel door naleving van de juridische zorgvuldigheidsnorm van aansprakelijkheid bevrijd. Gegeven het feit dat het voor de rechter niet eenvoudig is om het activiteitsniveau in de zorgvuldigheidsnorm op te nemen, zal de automobilist de neiging hebben om een te hoog activiteitsniveau aan te wenden. Van een automobilist kan bijvoorbeeld worden verwacht dat hij zich aan de verkeersregels houdt (zorg), maar de mate waarin hij met zijn auto deelneemt aan het verkeer (activiteit) is minder eenvoudig te beoorde- 
len. Wel zijn gevallen denkbaar, waarin het uitoefenen van een gevaarlijke activiteit op zich reeds voldoende is om tot een verbod ervan over te gaan. Een voorbeeld hiervan is de ontzegging van de rijbevoegdheid voor een dronken automobilist en voor de automobilist die meerdere malen wordt betrapt op een overtreding van de verkeersregels. In het algemeen zal de rechter alleen rekening houden met het zorgniveau van de dader, omdat de bepaling van het activiteitsniveau of de beoordeling van de daadwerkelijk uitgeoefende activiteit vaak niet mogelijk is. De rechter is bijvoorbeeld niet in staat om via de zorgvuldigheidsnorm te signaleren hoeveel keer per jaar de automobilist aan het verkeer mag deelnemen. Daarnaast streven niet alle autobestuurders naar eenzelfde niveau van nutsmaximalisatie, waardoor de rechter daaromtrent geen objectieve standaard kan vaststellen. ${ }^{654}$

\section{Bilaterale ongevallen: het niveau van zorg}

In deze paragraaf zal de economische analyse van het ongevallenrecht worden uitgebreid naar een bilaterale ongevalssituatie. Dit betekent dat naast de rol van de dader ook het gedrag van het slachtoffer wordt verondersteld van invloed te zijn op het ongevalsrisico.

In tabel $3^{655}$ is weergegeven wat de invloed is van het uitoefenen van zorg door een automobilist en een fietser op de vermindering van de verwachte schade respectievelijk de reductie van de maatschappelijke ongevalskosten. In kolom 1 is het niveau van zorg van de automobilist en de fietser weergegeven, in kolom 2 de kosten die beide partijen moeten maken voor het aanwenden van zorg. Kolom 3 geeft aan wat de invloed is van de uitoefening van zorg op de vermindering van de verwachte schade. In kolom 4 zijn de totale maatschappelijke ongevalskosten opgenomen, zijnde de som van de kosten van zorg en de verwachte schade.

654. Zie Shavell, Accident Law, p. 24-25; Faure en Van den Bergh, Objectieve aansprakelijkheid, p. 80-81; Polinsky, Introduction, p. 49-50; Posner, Economic Analysis, p. 160-165; Landes and Posner, Georgia Law Review, 1981, p. 875-877; Schäfer und Ott, Lehrbuch der okonomischen Analyse, p. 136-145 en p. 170-173; Van Velthoven en Van Wijck, Recht en efficientie, p. 144159; Landes and Posner, Economic Structure of Tort Law, p. 67-69; Holzhauer en Teijl, Inleiding rechtseconomie, p. 127-128; Cooter and Ulen, Law and Economics, p. 272-275.

655. Ontleend aan Shavell, Accident Law, p. 11. Zie ook Faure en Van den Bergh, Objectieve aansprakelijkheid, p. 82. 
Tabel 3

\begin{tabular}{|c|c|c|c|c|c|}
\hline \multicolumn{2}{|c|}{ Niveau van zorg } & \multicolumn{2}{c|}{ Kosten van zorg } & $\begin{array}{c}\text { Verwachte } \\
\text { schade }\end{array}$ & $\begin{array}{c}\text { Maatschappelijke } \\
\text { kosten }\end{array}$ \\
\hline automobilist & fietser & automobilist & fietser & & \\
\hline geen & geen & 0 & 0 & 26 & 26 \\
\hline geen & zorg & 0 & 4 & 20 & 24 \\
\hline zorg & geen & 5 & 0 & 18 & 23 \\
\hline zorg & zorg & 5 & 4 & 10 & 19 \\
\hline
\end{tabular}

Naar aanleiding van tabel 3 kan worden gesteld dat efficiëntie kan worden bereikt wanneer zowel de automobilist als de fietser zorg uitoefenen. De verwachte schade zal met 16 eenheden verminderen en de maatschappelijke ongevalskosten bereiken een minimaal niveau op 19 eenheden. Voor de automobilist geldt dat de aanwending van zorg 5 eenheden kost, terwijl de vermindering van de verwachte schade, afhankelijk van de vraag of de fietser ook zorg uitoefent, respectievelijk 8 (26-18) en 16 (26-10) eenheden bedraagt. Omgekeerd geldt dat wanneer de fietser, tegen de kosten van 4 eenheden, zorg uitoefent, zijn verwachte schade, afhankelijk van de uitoefening van zorg door de automobilist, met $6(26-20)$ en $16(26-10)$ eenheden kan verminderen.

In deze paragraaf staat de vraag centraal in hoeverre aansprakelijkheidsregels een bijdrage kunnen leveren aan het uitoefenen van efficiënte zorg door zowel de automobilist als de fietser. Daarbij zullen onder andere een regel van geen-aansprakelijkheid, risicoaansprakelijkheid, risicoaansprakelijkheid met een eigen schuldverweer en een regel van foutaansprakelijkheid, alsmede een aantal afgeleide vormen van deze aansprakelijkheidsregels aan de orde komen.

\subsection{GEEN AANSPRAKELUKHEID}

In een stelsel van geen aansprakelijkheid zal de automobilist geen prikkel hebben om zorg uit te oefenen. De fietser, wetende dat hij zijn eigen schade zal moeten dragen, zal daarentegen wel een argument hebben om zorg aan te wenden. Uit tabel 3 kan worden opgemaakt dat de fietser bij de uitoefening van zorg zijn verwachte schade met 6 eenheden (26-20) kan verminderen tegen een kost van 4 eenheden. Doordat alleen de fietser een prikkel heeft om zorg aan te wenden ontstaat een nietefficiënte uitkomst. De maatschappelijke ongevalskosten zijn in tabel 3 immers het laagst wanneer beide partijen zorg uitoefenen. 
Shavell is van mening dat bij een regel van geen-aansprakelijkheid toch een evenwicht kan ontstaan. Het is zijns inziens in het belang van het slachtoffer om zorg te betrachten, gegeven het feit dat de dader dat niet zal doen. Het is echter ook in het belang van de dader om geen zorg uit te oefenen, wetende dat het slachtoffer dit wel zal doen. ${ }^{656}$

Het uitgangspunt in een bilateraal ongevalsmodel is echter om een aansprakelijkheidsregel te vinden die aan zowel de automobilist als de fietser, die bij een verkeersongeval betrokken raken, voldoende prikkels geeft om efficiënte zorg uit te oefenen. In dat kader leidt een stelsel van geen aansprakelijkheid niet tot een optimaal resultaat. ${ }^{657}$

\subsection{RISICOAANSPRAKELIJKHEID}

Binnen de analyse van de unilaterale ongevalssituatie is reeds gesteld dat de dader bij een regel van risicoaansprakelijkheid in beginsel verantwoordelijk is voor de gehele schade van het slachtoffer, waardoor hij een prikkel zal hebben om zorg uit te oefenen. ${ }^{658}$

In een bilateraal ongevalsmodel, zoals dat hier wordt beschreven, is ook de rol van het slachtoffer van belang. Bij een regel van risicoaansprakelijkheid krijgt het slachtoffer in beginsel zijn schade volledig vergoed. Dit leidt tot de theoretische conclusie dat het slachtoffer bij een regel van risicoaansprakelijkheid sec geen prikkel zal hebben om zorg uit te oefenen.

Op basis van de gegevens uit tabel 3 zal de automobilist bij een regel van risicoaansprakelijkheid kiezen voor de uitoefening van zorg. Wanneer hij geen zorg uitoefent, en de fietser ook niet, dan is hij aansprakelijk voor een verwachte schade van 26 eenheden. Indien de automobilist wel zorg uitoefent dan kan hij de verwachte schade reduceren van 26 eenheden naar 18 eenheden. Zijn verwachte aansprakelijkheid daalt met 8 eenheden, tegen een toename van de kosten van zorg met 5 eenheden. Aangezien het slachtoffer geen prikkel heeft om zorg aan te wenden ontstaat in het kader van tabel 3 een inefficiënte uitkomst. Een dergelijke oplossing, minimali-

656. Shavell, Accident Law, p. 11 noot 8.

657. Faure en Van den Bergh, Objectieve aansprakelijkheid, p. 83; Brown, JLS, 1973. p. 328; Adarns, Gefährdungs- und Verschuldenshaftung, p. 48-50.

658. Zie paragraaf 2.2 van dit hoofdstuk. 
sering van de maatschappelijke kosten, wordt pas bereikt wanneer zowel de automobilist als de fietser zorg uitoefenen. ${ }^{659}$

\subsection{RISICOAANSPRAKELIJKHEID MET EEN ABSOLUUT EIGEN SCHULDVERWEER ${ }^{660}$}

Wanneer het slachtoffer binnen een regel van risicoaansprakelijkheid geen prikkel van zorg heeft kan een systeem worden toegepast dat rekening houdt met het gegeven dat ook het gedrag van het slachtoffer van invloed is op het ongevalsrisico, bijvoorbeeld een risicoaansprakelijkheid met een eigen schuldverweer. Daarbij is de dader aansprakelijk is voor de schade van het slachtoffer, tenzij deze eigen schuld heeft aan het ongeval. Daaronder vallen ook maatregelen die het slachtoffer heeft genomen om zijn schade te beperken. ${ }^{661}$ In de economische analyse zal in beginsel worden uitgegaan van een absoluut eigen schuldverweer aan de zijde van het slachtoffer. Dit betekent dat wanneer het slachtoffer zelf niet de vereiste zorg (zorgvuldigheidsnorm) uitoefent of geen schadebeperkende maatregelen heeft genomen, de aansprakelijkheid van de dader geheel komt te vervallen en het slachtoffer zijn eigen schade zal moeten dragen. ${ }^{662}$ Het slachtoffer heeft derhalve een prikkel om optimale zorg aan te wenden, mits deze efficiënte zorg gelijk is aan de juridische zorgvuldigheidsnorm. ${ }^{663}$

Shavell stelt dat binnen een stelsel van risicoaansprakelijkheid met een absoluut eigen schuldverweer een optimaal evenwicht kan ontstaan omdat zowel dader als slachtoffer worden aangezet tot een efficiënt zorgniveau. De dader, wetende dat het slachtoffer optimale zorg zal uitoefenen, zal een prikkel hebben om zorg aan te wenden. De dader is immers voor de gehele schade van het slachtoffer aansprakelijk wanneer deze efficiënte zorg uitoefent. Omdat de dader aldus optimale zorg aanwendt, zal ook het slachtoffer tot optimale zorg worden aangezet om te voorkomen dat aan hem eigen schuld wordt tegengeworpen waardoor hij zijn eigen schade moet

659. Zie Polinsky, Introduction, p. 43-45; Faure en Van den Betgh, Objectieve aansprakelijkheid, p. 83; Shavell, Accident Law, p. 11; Brown, JLS, 1973, p. 328; Adams, Gefahrdungs- und Verschuldenshaftung, p. 50-51.

660. In de Common Law wordt deze aansprakelijkheidsregel omschreven als een 'strict liability with a defense of contributory negligence'. Daarbij geldt dat een 'contributory negligence' van het slachtoffer leidt tot een verval van aansprakelijkheid bij de dader. In de 'civil law' is bij eigen schuld in beginsel sprake van een beperking van de vergoedingsplicht. Zie daarover Van Wassenaer en Jongeneel, Eigen schuld en mede-aansprakelijkheid, p. 17-24.

661. Zie daarover Shavell, Accident Law, p. 144-146.

662. Een vergelijking met het Nederlandse wetsvoorstel Verkeersongevallen leert dat ook daarin de eigen schuld van het slachtoffer tot een algeheel verval van de aansprakelijkheid van de bezitter van het motorrijtuig leidt met dien verstande dat het eigen schuldverweer geen oordeel over de zorgvuldigheid van het slachtoffer inhoudt maar alleen wordt gekeken of het gedrag van het slachtoffer opzet of bewuste roekeloosheid oplevert. Zie paragraaf 6 van hoofdstuk 3 .

663. De eigen schuld wordt hierbij beschouwd als een vorm van foutaansprakelijkheid van het slachtoffer. Zie Faure en Van den Bergh, Objectieve aansprakelijkheid, p. 84, noot 50. 
dragen. Op deze wijze kan volgens Shavell een optimaal resultaat worden bereikt, mits zowel dader als slachtoffer een efficiënt niveau van zorg aannemen en de juridische zorgvuldigheidsnorm gelijk is aan de efficiënte zorg. ${ }^{664}$

Een regel van risicoaansprakelijkheid met een absoluut eigen schuldverweer, toegepast op verkeerssituaties, kan opnieuw worden toegelicht aan de hand van tabel 3, die hier ten behoeve van overzichtelijkheid nogmaals wordt weergegeven.

Tabel 3

\begin{tabular}{|c|c|c|c|c|c|}
\hline \multicolumn{2}{|c|}{ Niveau van zorg } & \multicolumn{2}{c|}{ Kosten van zorg } & $\begin{array}{c}\text { Verwachte } \\
\text { schade }\end{array}$ & $\begin{array}{c}\text { Maatschappelijke } \\
\text { kosten }\end{array}$ \\
\hline automobilist & fietser & automobilist & fietser & & \\
\hline geen & geen & 0 & 0 & 26 & 26 \\
\hline geen & zorg & 0 & 4 & 20 & 24 \\
\hline zorg & geen & 5 & 0 & 18 & 23 \\
\hline zorg & zorg & 5 & 4 & 10 & 19 \\
\hline
\end{tabular}

Aan deze tabel liggen verder nog de volgende veronderstellingen ten grondslag:

- efficiënte zorg is gelijk aan de juridische zorgvuldigheidsnorm;

- de fietser heeft geen eigen schuld wanneer hij efficiënte zorg uitoefent.

Bij een regel van risicoaansprakelijkheid met een absoluut eigen schuldverweer is de automobilist in beginsel aansprakelijk voor de gehele schade van de fietser, tenzij deze laatste geen efficiënte zorg uitoefent. Dit betekent dat de automobilist, wetende dat hij risicoaansprakelijk is wanneer de fietser optimale zorg uitoefent, in tabel 3 zorg zal aanwenden. Door de uitoefening van een optimaal niveau van zorg kan de automobilist, tegen een toename van de kosten van zorg met 5 eenheden, de verwachte schade met 10 eenheden reduceren.

De fietser zal, wetende dat hij eigen schuld kan hebben aan het ongeval, ook zorg uitoefenen. Wanneer hij geen zorg aanwendt, dan draagt hij niet de kosten van zorg ( 4 eenheden), maar wel zijn eigen schade van 18 eenheden. Hierbij wordt ervan uitgegaan dat de automobilist wel zorg uitoefent. De fietser kan nu door zorg uit te oefenen (kosten 4 eenheden) zijn schade volledig vergoed krijgen.

664. Shavell, Accident Law, p. 12-13; Brown, JLS, 1973, p. 328; Landes and Posner, Economic Structure of Tort Law, p. 79-80. 
Binnen een bilaterale ongevalssituatie geldt derhalve dat een risicoaansprakelijkheid met een absoluut eigen schuldverweer zowel de automobilist als de fietser aanzet tot de uitoefening van een efficiënt zorgniveau. Bij dit niveau zijn de maatschappelijke ongevalskosten het laagst, namelijk 19 eenheden (tabel 3). ${ }^{665}$

\subsection{FOUTAANSPRAKELIJKHEID}

Binnen het unilaterale ongevalsmodel is betoogd dat bij foutaansprakelijkheid de dader efficiënte zorg zal uitoefenen teneinde aansprakelijkheid te vermijden. In een bilateraal ongevalsmodel, waarin wordt verondersteld dat ook het slachtoffer invloed heeft op het ongevalsrisico, zal bij een regel van foutaansprakelijkheid zonder een eigen schuldverweer ook het slachtoffer een prikkel hebben om optimale zorg aan te wenden. Wanneer de juridische zorgvuldigheidsnorm gelijk is aan de efficiënte zorg, zal de dader optimale zorg aanwenden teneinde te voorkomen dat hij aansprakelijk wordt gesteld. Het slachtoffer zal nu zijn eigen schade moeten dragen en wordt derhalve aangezet om ook optimale zorg aan te wenden. Hierbij geldt als voorwaarde dat het slachtoffer volledig is geïnformeerd en dat de dader steeds optimale zorg zal aanwenden. ${ }^{666}$

Wanneer de automobilist ingevolge tabel 3 geen zorg uitoefent en de fietser wel, is hij aansprakelijk voor de verwachte schade van de fietser ten bedrage van 20 eenheden. Indien de automobilist wel zorg uitoefent (kosten 5 eenheden) kan hij de verwachte schade volledig afschuiven naar de fietser. De fietser die weet dat de automobilist zorg uitoefent, met het gevolg dat hij zijn eigen schade (18 eenheden) moet dragen, zal nu ook kiezen voor de uitoefening van zorg. Daarmee kan de fietser zijn verwachte schade met 8 eenheden verminderen (marginale opbrengst), waarbij zijn marginale kosten van zorg slechts 4 eenheden bedragen.

In een bilaterale ongevalssituatie zal een regel van foutaansprakelijkheid derhalve tot een optimaal resultaat kunnen leiden, mits de juridische zorgvuldigheidsnorm gelijk is aan de efficiënte zorg en het slachtoffer volledig is geïnformeerd. In de woorden van Shavell:

'Drivers will be led to take due care; and bicyclists, knowing that they bear their losses, will decide to take appropriate care'. ${ }^{67}$

665. Faure en Van den Bergh, Objectieve aansprakelijkheid, p. 82-83; Polinsky, Introduction, p. 45; Shavell, Accident Law, p. 12-13; Adams, Gefăhrdungs- und Verschuldenshaftung, p. 56-59.

666. Zie Brown, JLS, 1973, p. 328 en 333; Faure en Van den Bergh, Objectieve aansprakelijkheid, p. 84; Adams, Gefährdungs- und Verschuldenshaftung, p. 52-56.

667. Shavell, Accident Law, p. 14. Zie ook Polinsky, Introduction, p. 45-46; Faure en Van den Bergh, Objectieve aansprakelijkheid, p. 84-85. 


\subsection{FOUTAANSPRAKELIJKHEID MET EEN ABSOLUUT EIGEN SCHULDVERWEER ${ }^{668}$}

Bij een gewone regel van foutaansprakelijkheid zal de rechter nagaan of de dader de door het recht vereiste zorgvuldigheid in acht heeft genomen. Wanneer deze zorgvuldigheidsnorm gelijk is aan de efficiënte zorg, zal de dader door uitoefening van de optimale zorg van aansprakelijkheid zijn bevrijd. Het slachtoffer, wetende dat hij zijn eigen schade moet dragen, zal nu ook worden aangezet tot het aanwenden van efficiënte zorg.

De toevoeging van een absoluut eigen schuldverweer aan een regel van foutaansprakelijkheid betekent dat de aansprakelijkheid van de dader voor de schade van het slachtoffer in stand blijft wanneer hij minder dan efficiënte zorg uitoefent, maar geheel vervalt indien ook het slachtoffer minder dan efficiënte zorg uitoefent. Anders gesteld, de dader die een fout heeft begaan zal niet aansprakelijk zijn voor de schade van het slachtoffer die ook een fout heeft begaan. De dader en het slachtoffer hebben beiden een prikkel om zorg uit te oefenen, wetende dat de andere partij dit ook zal doen. De toevoeging van een absoluut eigen schuldverweer geeft een extra prikkel aan het slachtoffer om een optimaal niveau van zorg in acht te nemen. ${ }^{669}$ Een regel van foutaansprakelijkheid met een absoluut eigen schuldverweer, toegepast op verkeerssituaties, kan aan de hand van tabel 4 worden toegelicht. ${ }^{670}$

Tabel 4

\begin{tabular}{|c|c|c|c|c|c|}
\hline \multicolumn{2}{|c|}{ Niveau van zorg } & \multicolumn{2}{c|}{ Kosten van zorg } & $\begin{array}{c}\text { Verwachte } \\
\text { schade }\end{array}$ & $\begin{array}{c}\text { Maatschappelijke } \\
\text { kosten }\end{array}$ \\
\hline automobilist & fietser & automobilist & fietser & & \\
\hline weinig & weinig & 4 & 2 & 40 & 46 \\
\hline weinig & veel & 4 & 5 & 35 & 44 \\
\hline veel & weinig & 7 & 2 & 29 & 38 \\
\hline veel & veel & 7 & 5 & 21 & 33 \\
\hline
\end{tabular}

Met betrekking tot deze tabel geldt het volgende:

668. In de Common Law wordt hiermee verwezen naar een 'negligence rule with a defense of contributory negligence' of een 'contributory negligence'. Zie Bolt, Loterij of rechtspraak?, p. 47-56 en p. 67-69, voor een vergelijking met het Nederlands recht.

669. Shavell, Accident Law, p. 14-15; Brown, JLS, 1973, p. 328; Faure en Van den Bergh, Objectieve aansprakelijkheid, 85-86; Landes and Posner, Economic Structure of Tort Law, p. 78-79.

670. Deze tabel kan als een uitwerking van tabel 3 worden aangemerkt. 
- efficiënte zorg is gelijk aan de juridische zorgvuldigheidsnorm;

- het uitoefenen van veel zorg door zowel de automobilist als de fietser komt overeen met efficiënte zorg. Bij dit economisch optimum zijn de maatschappelijke kosten het laagst (33);

- het uitoefenen van weinig zorg wordt gelijkgesteld aan het aanwenden van minder dan optimale zorg.

Bij een regel van foutaansprakelijkheid zonder een eigen schuldverweer is de automobilist aansprakelijk voor de schade van de fietser indien hij weinig zorg uitoefent. De automobilist kan zichzelf van aansprakelijkheid bevrijden door het aanwenden van veel zorg (kosten 3 eenheden). De fietser zal in deze situatie zijn eigen schade van 29 eenheden moeten dragen, tenzij ook hij veel zorg uitoefent. De fietser zal nu kiezen voor dit laatste, omdat hij daarmee zijn verwachte schade met 8 eenheden kan verminderen, terwijl de marginale kosten 3 eenheden zorg omvat.

De toevoeging van een absoluut eigen schuldverweer aan een regel van foutaansprakelijkheid betekent, als gezegd, dat de automobilist niet aansprakelijk is wanneer hij evenals de fietser minder dan efficiënte zorg (weinig zorg) uitoefent. In dat geval zal de fietser zijn eigen schade van 40 eenheden moeten dragen. De fietser kan echter door veel zorg uit te oefenen, waarvan de marginale kosten 3 eenheden bedragen, zijn verwachte schade met 5 eenheden verminderen. Dit heeft echter tot gevolg dat de automobilist aansprakelijk zal zijn voor een schade van 35 eenheden. De automobilist kan nu zijn aansprakelijkheid ontlopen door veel zorg (kosten 3 eenheden) uit te oefenen. In een dergelijke situatie zal de fietser opnieuw zijn eigen schade moeten dragen, waardoor hij een prikkel zal hebben om ook veel zorg (kosten 3 eenheden) aan te wenden. Hiermee kan de fietser zijn verwachte schade met 8 eenheden verminderen.

In de rechtseconomische literatuur wordt gesteld dat de toevoeging van een absoluut eigen schuldverweer aan een regel van foutaansprakelijkheid niet meer invloed heeft op het bereiken van een efficiënt zorgniveau bij dader en slachtoffer dan een gewone regel van foutaansprakelijkheid. Volgens Shavell hebben dader en slachtoffer bij een gewone regel van foutaansprakelijkheid beiden een prikkel om optimale zorg uit te oefenen. De dader ten behoeve van een vermijding van aansprakelijkheid en het slachtoffer om te voorkomen dat hij zijn eigen schade moet dragen. Er is volgens Shavell derhalve geen extra prikkel, in de vorm van een absoluut eigen schuldverweer, nodig om het slachtoffer aan te zetten tot het aanwenden van optimale zorg. ${ }^{671}$

Calabresi geeft de volgende opvatting weer:

671. Shavell, Accident Law, p. 15. Zie ook Polinsky, Introduction, p. 46. 
'If interpreted strictly, contributory negligence does nothing to further the objective of optimal deterrence. In particular, it does not avoid the danger of creating incentives to avoid accidents in relatively expensive ways'. ${ }^{672}$

Calabresi verwijst hiermee naar de extra kosten die moeten worden gemaakt om ook het gedrag van het slachtoffer zelf te controleren. Hij geeft het voorbeeld van een ongeval met een verwachte schade van $\$ 100$. De kosten van zorg voor de dader zijn $\$ 60$ en voor het slachtoffer $\$ 80$. Calabresi stelt dat een foutaansprakelijkheid met een absoluut eigen schuldverweer de prikkel tot zorg bij het slachtoffer legt, met het gevolg dat de kosten $\$ 80$ bedragen, terwijl met $\$ 60$ had kunnen worden volstaan.

Posner betoogt:

'Since efficiency is not improved by making the negligent injurer pay damages to the negligent victim, the common law traditionally allowed the cost of the accident to lie where it fell, in order to minimize the costs of administering the legal system. A transfer payment from injurer to victim will cost something to make, but will not increase the wealth of society by creating incentives to efficient behavior', ${ }^{673}$

Posner stelt dat een absoluut eigen schuldverweer zinvol is om te voorkomen dat een onzorgvuldige dader aansprakelijk is voor de schade van het slachtoffer die ook onzorgvuldig is geweest. Het verschuiven van de schade door het slachtoffer naar de dader is volgens Posner dan niet zinvol omdat dit geen invloed heeft op de prikkels van zorg bij dader en slachtoffer. Beide partijen hebben immers al prikkels tot zorg bij een gewone regel van foutaansprakelijkheid. Omdat de efficiëntie derhalve niet wordt verbeterd wanneer een onzorgvuldige dader de schade van een onzorgvuldig slachtoffer moet betalen is het volgens Posner beter om in de traditie van de 'common law' de schade daar te laten waar zij is ontstaan, in casu het slachtoffer. Teneinde de administratieve kosten van het rechtssysteem te minimaliseren. Betaling van schadevergoeding door de dader aan het slachtoffer brengt kosten mee, maar leidt niet tot een verhoging van de maatschappelijke welvaart door het creëren van prikkels van zorg. ${ }^{674}$

672. Calabresi, YLJ, 1975, p. 662. Zie ook Veljanorski, in The Economic Approach to Law, p. 133 en 142.

673. Posner, Economic Analysis, p. 171. Zie ook Chelius, JLS, 1976, p. 297.

674. Posner, Economic Analysis, p. 171; Faure en Van den Bergh, Objectieve aansprakelijkheid, p. 85-86. Zie omtrent deze aansprakelijkheidsregel eveneens: Landes and Posner, Georgia Law Review, 1981, p. 880-883; Adams, Gefährdungs- und Verschuldenshaftung, p. 59-65; I andes and Posner, Economic Structure of Tort Law, p. 73-77. 


\subsection{FOUTAANSPRAKELIJKHEID MET EEN GRADUEEL EIGEN SCHULDVERWEER ${ }^{675}$}

De toevoeging van een gradueel eigen schuldverweer aan een regel van foutaansprakelijkheid betekent dat, wanneer dader en slachtoffer beiden een fout hebben gemaakt en dus minder dan optimale zorg hebben aangewend, het slachtoffer zijn schade toch niet geheel zelf behoeft te dragen. Bij foutaansprakelijkheid met een gradueel eigen schuldverweer vindt namelijk een verdeling plaats die is gebaseerd op de verhouding tussen de door dader en slachtoffer werkelijk uitgeoefende zorg en de juridische zorgvuldigheidsnorm. Elk van beide partijen draagt, afhankelijk van de fout die is begaan, een deel van de verwachte schade van het slachtoffer. Dit deel kan groter of kleiner zijn, naar de mate waarin de zorgvuldigheidsnorm afwijkt van de werkelijk uitgeoefende zorg. ${ }^{676}$

Met een verwijzing naar tabel 4 kan worden gesteld dat wanneer de automobilist weinig zorg uitoefent en de fietser veel zorg aanwendt, de automobilist een prikkel heeft om ook veel zorg (kosten 3 eenheden) te nemen. Daarmee kan hij immers de verwachte schade met 6 eenheden reduceren. Dit heeft tot gevolg dat de fietser zijn eigen schade van 29 eenheden moet dragen, omdat hij weinig zorg uitoefent. Hij kan echter zijn niveau van zorg (kosten 3 eenheden) verhogen, waardoor hij zijn verwachte schade met 8 eenheden vermindert. Het resultaat is een evenwichtssituatie, waarin zowel de automobilist als de fietser optimale zorg uitoefenen, de verwachte schade het laagst is en de maatschappelijke kosten economisch optimaal zijn gereduceerd tot een niveau van 33 eenheden.

Shavell betoogt dat, wanneer de doelstelling is om partijen aan te zetten tot een optimaal zorgniveau, de toevoeging van een gradueel eigen schuldverweer niet efficiënter is dan een gewone foutaansprakelijkheid zonder een vorm van eigen schuld:

'Under both rules, if parties of one type take due care, then parties of the other type will reason that they alone will be found negligent if they fail to take due care. The allocation of accident losses when both injurers and victims are neg-

675. In de Common Law verwijst deze regel naar een 'comparative negligence rule'. Deze regel kan naar Nederlands recht worden vergeleken met artikel 6:101 lid $1 \mathrm{BW}$ (hoofdregel): 'Wanneer de schade mede het gevolg is van een omstandigheid die aan de benadeelde kan worden toegerekend, wordt de vergoedingsplicht verminderd door de schade over de benadeelde en de vergoedingsplichtige te verdelen in evenredigheid met de mate waarin de aan ieder toe te rekenen omstandigheden tot de schade hebben bijgedragen'. Zie daaorver Bolt, Loterij of rechtspraak?, p. 56-61 en p. 67-69.

676. Faure en Van den Bergh, Objectieve aansprakelijkheid, p. 86; Shavell, Accident Law, p. 15; Brown; JLS, 1973, p. 329-331; Diamond, JLS, 1974, p. 140-145; Adams, Gefahrdungs- und Verschuldenshaftung, p. 65-76; Rubenfield, JLS, 1987, p. 375-394, die stelt dat een 'comparative negligence' tot een betere uitkomst kan leiden dan een gewone foutaansprakelijkheid, wanneer beide partijen niet aan de zorgvuldigheidsnorm kunnen voldoen. 
ligent therefore turns out to be irrelevant to the calculations of parties in equilibrium'. ${ }^{677}$

Volgens Posner brengt deze aansprakelijkheidsregel mee dat een tussenkomst van het rechtssysteem noodzakelijk wordt om de betaling van de dader aan het slachtoffer te laten plaatsvinden. Dit veroorzaakt administratieve kosten, die geen enkel compenserend effect hebben in de prikkels van zorg. Er zijn voorts kostenverhogende factoren, zoals het onderzoek dat door rechter moet worden verricht naar de vraag welke fouten van dader en slachtoffer aan het ongeval hebben bijgedragen. Voor Posner is de vergoeding van schade ook geen doel van het aansprakelijkheidsrecht, maar slechts een middel om partijen tot efficiënt gedrag aan te zetten. Een foutaansprakelijkheid met een gradueel eigen schuldverweer is dan niet efficiënt en verhoogt de administratieve kosten zonder dat er een prikkel tot efficiënt gedrag mee wordt gecreëerd. Het distributionele voordeel van een foutaansprakelijkheid met een gradueel eigen schuldverweer is voor Posner irrelevant. Een dergelijke regel is alleen efficiënt wanneer het aansprakelijkheidsrecht als een verzekeringssysteem wordt beschouwd. Bij een absoluut eigen schuldverweer zal het slachtoffer geen schadevergoeding ontvangen en bij een gradueel eigen schuldverweer tenminste een gedeelte. Een gradueel eigen schuldverweer is derhalve vanuit de compensatiedoelstelling van het ongevallenrecht nuttig omdat, bij het ontbreken van een sociaal zekerheidsstelsel in de VS, het slachtoffer meer zekerheid heeft op een (gedeeltelijke) vergoeding van zijn schade. ${ }^{678}$

\subsection{RISICOAANSPRAKELIJKHEID MET EEN GRADUEEL EIGEN SCHULDVERWEER ${ }^{679}$}

Bij een regel van risicoaansprakelijkheid met een absoluut eigen schuldverweer is de dader in beginsel aansprakelijk voor de schade van het slachtoffer, tenzij de laatste de juridische zorgvuldigheidsnorm niet heeft nageleefd waardoor de aansprakelijkheid van de dader geheel vervalt. Zowel dader en slachtoffer hebben bij deze regel een prikkel om optimale zorg aan te wenden.

Bij een risicoaansprakelijkheid met een gradueel eigen schuldverweer is de dader aansprakelijk wanneer het slachtoffer de juridische zorgvuldigheidsnorm naleeft met betrekking tot de eigen schuld. Indien het slachtoffer echter minder dan de vereiste zorg heeft uitgeoefend, draagt hij niet zijn gehele schade doch slechts een deel af-

677. Shavell, Accident Law, p. 15-16.

678. Posner, Economic Analysis, p. 171-173; Faure en Van den Bergh, Objectieve aansprakelijkheid, p. 86-87. Zie ook Landes and Posner, Economic Structure of Tort Law, p. 80-82. Zie omtrent het onderscheid tussen 'contributory negligence' en 'comparative negligence' ook: Edlin, IRLE, 1994, p. 21-34; Haddock and Curran, JLS, 1985, p. 49-72. De rol van verzekeringen zal in hoofdstuk 6 nader worden belicht.

679. In de Engelstalige literatuur wordt deze regel als een 'strict liability with a defense of relative negligence' aangeduid. 
hankelijk van de verhouding tussen de door het slachtoffer werkelijk uitgeoefende zorg en de juridische zorgvuldigheidsnorm. Wanneer de zorgvuldigheidsnorm gelijk is aan de optimale zorg en het slachtoffer moet een groot deel van zijn schade zelf dragen, zal het slachtoffer, evenals de dader, een prikkel hebben om optimale zorg aan te wenden.

In aanvulling op tabel $4^{680}$ kan worden verondersteld dat de uiteindelijke schade 100 bedraagt en dat de fietser meer dan $30 \%$ van deze schade moet dragen indien hij weinig zorg aanwendt. Wanneer de automobilist veel zorg uitoefent zal ook de fietser worden aangezet om veel zorg aan te wenden. De fietser kan daarbij meer eenheden van de verwachte schade besparen dan dat het aanwenden van zorg voor hem kosten met zich meebrengt. In tabel 4 zal de fietser tegen marginale kosten van 3 eenheden zorg de verwachte schade met 8 eenheden kunnen reduceren. ${ }^{681}$

\section{Conclusie III: Aansprakelijkheidsregels vergeleken}

Uit het voorgaande kan worden opgemaakt dat in bilaterale ongevalssituaties zowel een regel van risicoaansprakelijkheid met een absoluut eigen schuldverweer als een gewone regel van foutaansprakelijkheid de automobilist en de fietser kan aanzetten tot het uitoefenen van optimale zorg. Een regel van risicoaansprakelijkheid zorgt ervoor dat de automobilist een efficiënt zorgniveau kiest om te voorkomen dat hij de schade van de fietser moet vergoeden. Toevoeging van een absoluut eigen schuldverweer geeft aan de fietser een prikkel om optimale zorg aan te wenden die hij, economisch gezien, zonder eigen schuldverweer niet zou hebben. Wanneer de fietser weet dat de automobilist ook efficiënte zorg neemt, zal ook hij efficiënte zorg uitoefenen om te voorkomen dat hij zijn eigen schade moet dragen. Bij een gewone regel van foutaansprakelijkheid geldt een soortgelijke argumentatie. De automobilist oefent zorg uit om aansprakelijkheid te vermijden. De fietser, dit wetende, zal ook zorg aanwenden om de verwachte schade, die hij anders zelf moet dragen, te reduceren. Beide verkeersdeelnemers worden derhalve aangezet tot een optimaal zorgniveau, waarbij de maatschappelijke ongevalskosten minimaal zijn. ${ }^{62}$

Naast de voornoemde rechtsregels is ook een aantal afgeleide vormen van aansprakelijkheid geanalyseerd. Daaruit is naar voren gekomen dat de toevoeging van

680. Zie paragraaf 6.5 .

681. Shavell, Accident Law, p. 10 en p. 14. Zie ook Adams, Gefährdungs- und Verschuldenshaftung, p. 77.

682. Zie Faure en Van den Bergh, Objectieve aansprakelijkheid, p. 89; Shavell, Accident Law, p. 16; Cooter, Joumal of Economic Perspectives, 1991, p. 22; Brown, JLS, 1973, p. 337-343; Faure en Van den Bergh, RW, 1987-1988, p. 1107 ; Emons, An Introduction to the Legal and Economic Theories of Torts, Working Paper, 1991, p. 16-17; Holzhauer en Teijl, Inleiding rechtseconomie, p. 124-126; Cooter and Ulen, Law and Economics, p. 275-279; Mackaay, AA, 1990, p. 141-147. 
zowel een absoluut- als een gradueel eigen schuldverweer aan een regel van foutaansprakelijkheid en een regel van risicoaansprakelijkheid met een gradueel eigen schuldverweer kunnen leiden tot een optimaal zorgniveau bij de automobilist en de fietser. Daarbij is ook geconstateerd dat deze aansprakelijkheidsregels niet meer invloed hebben op het bereiken van een efficiënt zorgniveau dan een gewone regel van foutaansprakelijkheid respectievelijk een risicoaansprakelijkheid met een absoluut eigen schuldverweer. De besproken afgeleide vormen van aansprakelijkheid leveren derhalve, economisch gezien, geen aanvullende bijdrage aan de prikkels van zorg bij de automobilist en de fietser.

\section{Bilaterale ongevallen: het activiteitsniveau}

Binnen de economische analyse van het verkeersongevallenrecht is voor het onderzoek naar de efficiëntie van aansprakelijkheidsregels, naast het zorgniveau van de automobilist en de fietser, mede van belang het activiteitsniveau dat door deze verkeersdeelnemers wordt uitgeoefend. Het gaat dan onder meer om de vraag in welke mate van auto, fiets of trein gebruik wordt gemaakt en om het nut dat een verkeersdeelnemer heeft van deelname aan het verkeer. ${ }^{683}$

In deze paragraaf zal eerst worden onderzocht waar in een bilateraal ongevalsmodel het optimaal activiteitsniveau van de automobilist en de fietser kan worden gevonden (8.1.). Vervolgens wordt ingegaan op de vraag welke aansprakelijkheidsregels aan zowel de automobilist als de fietser prikkels kan geven om een optimaal zorgen activiteitsniveau aan te wenden (paragraaf 8.2).

\subsection{HeT OPTIMAal aCtiviteitsNiveau}

Het nut van een verkeersdeelnemer hangt samen met de maatschappelijke welvaart die kan worden bereikt door deel te nemen aan het verkeer. De maatschappelijke welvaart wordt daarbij verondersteld het hoogst te zijn op het niveau, waarbij de verkeersdeelnemer het hoogste nut verwacht van zijn activiteit minus de kosten van zorg en de verwachte schade. ${ }^{684}$

Aan de hand van tabel $5 \mathrm{zal}$ worden nagegaan waar in een bilaterale ongevalssituatie het optimaal activiteitsniveau kan worden gevonden, waarbij een keuze bestaat tussen meerdere niveaus. In de eerste kolom zijn, oplopend van niveau $1 \mathrm{t} / \mathrm{m} 5$, een aantal activiteitsniveaus van een automobilist en een fietser weergegeven. In kolom 2 is het totale nut opgenomen dat de automobilist en de fietser genieten van de uit-

\footnotetext{
683. Zie daarover paragraaf 4 van dit hoofdstuk.

684. Zie Faure en Van den Bergh, Objectieve aansprakelijkheid, p. 87-88; Shavell, Accident law, p. 26; Polinsky, Introduction, p. 46; Diamond, JLS, 1974, p. 146-149; Adams, Gefahrdungs- und Verschuldenshaftung, p. 36-42.
} 
oefening van de activiteitsniveaus in kolom 1. In kolom 3 en kolom 4 zijn de kosten van zorg respectievelijk de totale ongevalskosten weergegeven. In kolom 5 is de maatschappelijke welvaart aangegeven. Deze maatschappelijke welvaart heeft betrekking op het maximale nut dat de automobilist en de fietser bij de uitoefening van een activiteit verkrijgen. Bij het activiteitsniveau 1 bedraagt de maatschappelijke welvaart 58 eenheden, zijnde het totale nut van de automobilist en de fietser $(45+35=80)$ minus de kosten van zorg van automobilist en fietser $(4+3=7)$ en de totale ongevalskosten (15). In kolom 6 is de omvang van het totale nut van de automobilist en de fietser aangegeven wanneer zij niet aansprakelijk zijn voor de totale ongevalskosten.

Tabel 5

\begin{tabular}{|c|c|c|c|c|c|c|c|c|c|}
\hline \multicolumn{2}{|c|}{$\begin{array}{c}\text { Activiteits- } \\
\text { niveau }\end{array}$} & \multicolumn{2}{|c|}{ Totale nut } & \multicolumn{2}{c|}{$\begin{array}{c}\text { Kosten van } \\
\text { zorg }\end{array}$} & $\begin{array}{c}\text { Totale } \\
\text { ongevals- } \\
\text { kosten }\end{array}$ & $\begin{array}{c}\text { Maatschap- } \\
\text { pelijke wel- } \\
\text { vaart }\end{array}$ & \multicolumn{2}{c|}{$\begin{array}{c}\text { Totale nut minus } \\
\text { kosten van zorg }\end{array}$} \\
\hline auto & fiets & Auto & fiets & auto & fiets & & & auto & fiets \\
\hline 0 & 0 & 0 & 0 & 0 & 0 & 0 & 0 & 0 & 0 \\
\hline 1 & 1 & 45 & 35 & 4 & 3 & 15 & 58 & 41 & 32 \\
\hline 2 & 2 & 65 & 55 & 8 & 6 & 30 & 76 & 57 & 49 \\
\hline 3 & 3 & 74 & 64 & 12 & 9 & 45 & 72 & 62 & 55 \\
\hline 4 & 4 & 75 & 65 & 16 & 12 & 60 & 48 & 60 & 53 \\
\hline 5 & 5 & 73 & 63 & 20 & 15 & 75 & 26 & 53 & 48 \\
\hline
\end{tabular}

Uit tabel 5 kan worden opgemaakt dat bij elke activiteit die de automobilist en de fietser uitoefenen de kosten van zorg met respectievelijk 4 (automobilist) en 3 (fietser) en de ongevalkosten met 15 eenheden stijgen. Dit betekent dat de totale marginale kosten bij de uitoefening van een extra activiteit steeds met 22 eenheden toenemen. Voor de fietser en de automobilist is het zinvol om een extra activiteit aan te wenden indien het extra nut dat beide daarvan genieten meer bedraagt dan 22 eenheden. Bij activiteitsniveau 2 is het extra nut voor de automobilist (65-45) en de fietser (55-35) gezamenlijk 40 eenheden. $\mathrm{Bij}$ het activiteitsniveau 3 bedraagt het totale marginale nut van automobilist (74-65) en fietser (64-55) gezamenlijk 18 eenheden. Aangezien deze marginale opbrengst lager is dan de marginale kosten van 22 eenheden, kan worden geconcludeerd dat het optimaal activiteitsniveau van de automobilist en de fietser wordt gevonden bij niveau 2. Bij dit activiteitsniveau is ook de maatschappelijke welvaart het hoogst (76).

Wanneer wordt gekeken naar het activiteitsniveau van de automobilist en de fietser afzonderlijk, kan worden geconstateerd dat ook hier, gemeten naar de verbouding 
tussen het extra nut en de extra kosten, activiteitsniveau 2 optimaal is. De totale marginale kosten van de uitoefening van een extra activiteit bedragen voor de automobilist 19 eenheden $(4+15)$ en voor de fietser 18 eenheden $(3+15)$. Bij het activiteitsniveau 2 bedraagt het marginale nut van de automobilist 20 eenheden (65-45) en bij niveau 3 slechts 9 eenheden (74-65). Voor de fietser is het marginale nut respectievelijk 20 eenheden (55-35) bij niveau 2 en 9 eenheden (64-55) bij activiteitsniveau 3 . Voor beide partijen afzonderlijk geldt derhalve dat bij de aanwending van activiteitsniveau 3 het extra nut ( 9 eenheden) niet opweegt tegen de totale marginale kosten, zijnde 19 eenheden voor de automobilist en 18 eenheden voor de fietser.

\subsection{WELKE AANSPRAKELUKHEIDSREGEL IS EFFICIËNT BUJ EEN OPTIMAAL ZORG- EN ACTIVITEITSNIVEAU?}

Bij de analyse van het zorgniveau is geconcludeerd dat er meerdere aansprakelijkheidsregels zijn die in bilaterale ongevalssituaties zowel aan de automobilist als aan de fietser prikkels kunnen geven tot het uitoefenen van een optimaal zorgniveau. Daarbij is ook gesteld dat een regel van foutaansprakelijkheid met een absoluut of een gradueel eigen schuldverweer en een regel van risicoaansprakelijkheid met een gradueel eigen schuldverweer, economisch gezien, geen extra bijdrage leveren aan de prikkels van zorg bij de automobilist en de fietser ten opzichte van een risicoaansprakelijkheid met een absoluut eigen schuldverweer en een gewone regel van foutaansprakelijkheid. In het kader van de centrale vraag van deze paragraaf, namelijk welke aansprakelijkheidsregel efficiënt is bij een optimaal zorg- en activiteitsniveau, zal de analyse zich daarom beperken tot een regel van risicoaansprakelijkheid met een absoluut eigen schuldverweer en een gewone regel van foutaansprakelijkheid.

\subsubsection{Risicoaansprakelijkheid met een absoluut eigen schuldverweer}

Een regel van risicoaansprakelijkheid met een absoluut eigen schuldverweer brengt mee dat de dader naast een optimaal zorgniveau ook een optimaal activiteitsniveau zal aanwenden. De dader zal, wetende dat de fietser efficiënte zorg uitoefent, ook een optimaal zorgniveau kiezen, omdat bij dit niveau de maatschappelijke kosten kunnen worden geminimaliseerd. Door eveneens een optimaal activiteitsniveau aan te wenden, kan de dader de totale kosten, in de vorm van aansprakelijkheidsbetalingen aan het slachtoffer, minimaliseren.

Voor het slachtoffer geldt dat hij onder een regime van risicoaansprakelijkheid met een absoluut eigen schuldverweer een prikkel heeft om efficiënte zorg uit te oefenen omdat hij anders zijn schade zelf zal moeten dragen. Gegeven het feit dat het slachtoffer bij de uitoefening van efficiënte zorg verzekerd is van de vergoeding van zijn schade, zal hij geen prikkel hebben om daarnaast een optimaal activiteitsniveau aan te wenden. Het slachtoffer houdt alleen rekening met de kosten van zorg die voor 
hem gelijk zijn aan de kosten van de uitoefening van een activiteit. Dit betekent derhalve dat de frequentie waarmee het slachtoffer aan een activiteit zal deelnemen enkel samenhangt met zijn totale nut minus de kosten van zorg. Daarmee ontstaat het gevaar dat het slachtoffer teveel activiteit zal aanwenden omdat hij geen rekening behoeft te houden met de totale ongevalskosten. In de woorden van Shavell met be. trekking tot verkeerssituaties:
'A bicyclist will go for a ride whenever the pleasure he would gain exceeds the disutility from having to exercise appropriate care, rather then only when the pleasure exceeds the disutility of exercising care plus the increment to expected accident losses. ${ }^{685}$

In tabel $5^{686}$ zal de automobilist worden aangezet om het optimale activiteitsniveau 2 uit te oefenen. De automobilist, die in beginsel aansprakelijk is voor de schade van de fietser, zal immers het marginale nut van de uitoefening van de activiteit vergelijken met de marginale kosten die hij daarvoor moet maken. Bij een verhoging van zijn activiteit van niveau 1 naar niveau 2 stijgt het nut van automobilist met 20 eenheden. De kosten van zorg (4) en verwachte ongevalskosten (15) tezamen nemen met 19 eenheden toe. Tussen activiteitsniveau 2 en 3 stijgt het nut slechts met 9 eenheden, terwijl de totale kosten opnieuw met 19 eenheden toenemen. De uitoefening van activiteitsniveau 3 is voor de automobilist niet optimaal, omdat het marginale nut lager is dan de marginale kosten die hij moet maken om dit extra activiteitsniveau te kunnen aanwenden. De automobilist zal derhalve het optimale activiteitsniveau 2 uitoefenen. Bij dit activiteitsniveau is de maatschappelijke welvaart het hoogst, zijnde het totale nut van de automobilist en de fietser afgezet tegen de kosten van zorg en de verwachte ongevalskosten.

De fietser zal bij een regime van risicoaansprakelijkheid met een absoluut eigen schuldverweer kunnen volstaan met het uitoefenen van efficiënte zorg om te vermijden dat hij zijn eigen schade moet dragen. Hij behoeft bij het aanwenden van zijn activiteit immers geen rekening te houden met de verwachte ongevalskosten, zolang hij optimale zorg uitoefent. Dit betekent dat de fietser alleen rekening zal houden met het nut dat hij geniet van de uitoefening van de activiteit minus zijn kosten van zorg. De fietser zal in tabel $5^{687}$ zijn activiteitsniveau opvoeren zolang zijn marginale nut hoger is dan zijn marginale kosten van zorg. Bij een verhoging van zijn activiteit van niveau 1 naar niveau 2 is zijn marginale nut 20 , terwijl de marginale kosten van zorg 3 bedragen. Een verhoging van activiteitsniveau 2 naar 3 levert de fietser een marginaal nut op van 9 eenheden, de marginale kosten van zorg bedragen 3 eenhe-

685. Shavell, Accident Law, p. 27-28. Zie ook Faure en Van den Bergh, Objectieve aansprakelijkheij, p. 88; Polinsky, Introduction, p. 50.

686. Zie paragraaf 8.1 .

687. Zie paragraaf 8.I. 
den. Bij een verhoging van de activiteit van niveau 3 naar 4 bedraagt het marginale nut 1 en de marginale kosten van zorg 3 eenheden. De fietser zal derhalve activiteitsniveau 3 aanwenden. Bij dit niveau is het marginale nut (9) groter dan de marginale kosten van zorg (3) en is ook het totale nut van de fietser het hoogst (55).

Geconcludeerd kan worden dat een regel van risicoaansprakelijkheid met een absoluut eigen schuldverweer tot een inefficiënt resultaat leidt. Zowel de automobilist als de fietser worden bij deze regel aangezet tot een optimaal zorgniveau. In het kader van het activiteitsniveau heeft echter alleen de automobilist een prikkel om zijn activiteit optimaal aan te wenden. De fietser zal zolang hij efficiënte zorg aanwendt zijn activiteitsniveau blijven verhogen tot een niveau waarop de stijging van het marginale nut niet meer opweegt tegen de marginale kosten van zorg. In tabel 5 geschiedt dit pas bij activiteitsniveau 3, terwijl het optimale activiteitsniveau in een bilaterale ongevalsituatie bij niveau 2 was vastgesteld. ${ }^{688}$

\subsubsection{Foutaansprakelijkheid}

Ten aanzien van activiteitsniveau in bilaterale ongevalssituaties zal worden uitgegaan van de veronderstelling dat de optimale zorg gelijk is aan de juridische zorgvuldigheidsnorm. Bij een regel van foutaansprakelijkheid zullen zowel dader als slachtoffer een efficiënt zorgniveau aanwenden. De dader heeft echter, wetende dat hij bij de uitoefening van optimale zorg niet aansprakelijk is voor de schade van het slachtoffer, geen prikkel om een optimaal activiteitsniveau aan te wenden. De dader zal zijn activiteitsniveau blijven opvoeren zolang het marginale nut daarvan de marginale kosten van zorg overstijgt.

Het slachtoffer zal bij een gewone regel van foutaansprakelijkheid optimale zorg aanwenden, om te vermijden dat hij zijn eigen schade moet dragen. Het slachtoffer zal echter, gegeven het gedrag van de dader, ook kiezen voor de aanwending van een optimaal activiteitsniveau. Daarbij zal het slachtoffer zijn activiteitsniveau verhogen zolang het extra nut dat hij daarvan heeft minus de kosten van zorg groter is dan de stijging van de totale ongevalskosten. ${ }^{689}$

In tabel $5^{6 \% 0}$ zullen de automobilist en de fietser bij het optimale activiteitsniveau 2 nutsmaximaliserend aan het verkeer deelnemen. Het nut van beide verkeers-

688. Zie hierover Shavell, Accident Law, p. 28; Faure en Van den Bergh, Objectieve aansprakelijkheid, p. 88; Polinsky, Introduction, p. 47-50; Landes and Posner, Georgia Law Review, 1981, p. 876-877; Shavell, JLS, 1980, p. 7; Landes and Posner, Economic Structure of Tort Law, p. 69 70.

689. Zie Faure en Van den Bergh, Objectieve aansprakelijkheid, p. 88; Shavell, Accident Law, p. 28; Polinsky, Introduction, p. 48-50; Shavell, JLS, 1980, p. 6-7. 
deelnemers is, rekening houdend met de kosten van zorg en de totale ongevalskosten, bij dit niveau het hoogst, evenals de maatschappelijke welvaart (76).

Bij een gewone regel van foutaansprakelijkheid kan de automobilist door inachtneming van de zorgvuldigheidsnorm aan aansprakelijkheid voor de schade van de fiet. ser ontsnappen. Dit betekent echter dat hij geen optimaal activiteitsniveau zal uitoefenen. In de veronderstelling dat de zorgvuldigheidsnorm overeenkomt met het optimale activiteitsniveau 2, zal de automobilist zijn activiteit opvoeren zolang het marginale nut hiervan groter is dan de marginale kosten van zorg, waarbij hij boven activiteitsniveau 2 geen rekening behoeft te houden met de ongevalskosten. Daarmee stijgt de objectieve kans op een verkeersongeval, maar wanneer de automobilist zorgvuldig blijft rijden zal hij toch niet aansprakelijk zijn. Een verhoging van de activiteit naar niveau 3 gaat voor de automobilist gepaard met een marginale toename van het nut met 9 eenheden tegen een marginale kostenstijging van 4 eenheden. Bij een stijging van de activiteit naar niveau 4 is de marginale nutstoename slechts 1 , terwijl de marginale kostenstijging 4 eenheden bedraagt. De automobilist zal derhalve activiteitsniveau 3 aanwenden, omdat bij dit niveau zijn marginale nut het hoogst is, rekening houdend met de kosten van zorg.

De fietser zal, nu de automobilist efficiënte zorg uitoefent, naast een optimaal zorgniveau ook een optimaal activiteitsniveau aanwenden, omdat hij anders voor zijn eigen schade moet opkomen. De fietser zal een activiteitsniveau kiezen waar zijn marginale nut, verminderd met de kosten van zorg én de totale ongevalskosten, het hoogst is. Wanneer de fietser in tabel $5^{691}$ zijn activiteit van niveau 1 naar niveau 2 verhoogt neemt zijn marginale nut met 20 eenheden toe, terwijl de som van de kosten van zorg en de totale ongevalkosten met $3+15=18$ eenheden stijgt, een positief verschil van 2 eenheden. Een verdere verhoging van zijn activiteit naar niveau 3 betekent voor de fietser een marginale toename van zijn nut met 9 eenheden, terwijl de totale marginale kosten nog steeds 18 eenheden bedragen, een nadelig verschil van 9 eenheden. De fietser zal, gegeven het gedrag van de automobilist, derhalve kiezen voor het optimale activiteitsniveau 2.

Samenvattend kan worden gesteld dat een gewone regel van foutaansprakelijkheid in een bilaterale ongevalssituatie niet tot een efficiënt resultaat leidt. Zowel de automobilist als de fietser worden aangezet tot een optimaal zorgniveau, maar de automobilist zal, bij de naleving van de zorgvuldigheidsnorm, geen prikkel hebben om een juist activiteitsniveau aan te wenden. De fietser zal echter, om te vermijden dat

691. Zie paragraaf 8.1 . 
hij in deze situatie zijn eigen schade moet dragen, naast een optimaal zorgniveau ook een optimaal activiteitsniveau uitoefenen. ${ }^{692}$

\section{Conclusie IV: Bilaterale ongevallen geëvalueerd}

Bij de analyse van de zorg- en activiteitsniveaus binnen een bilaterale ongevalssituatie is uitgegaan van een aantal veronderstellingen, waaronder dat de automobilist en de fietser volledig zijn geïnformeerd over elkaars gedrag, dat de juridische zorgvuldigheidsnorm gelijk is aan de efficiënte zorg en dat alleen het slachtoffer schade lijdt. Op basis daarvan kan een aantal voorlopige conclusies worden gepresenteerd.

In het kader van het zorgniveau van de automobilist en de fietser kan worden geconcludeerd dat zowel een regel van risicoaansprakelijkheid met een absoluut eigen schuldverweer als een gewone regel van foutaansprakelijkheid tot een optimale uitkomst kunnen leiden. Bij de eerstgenoemde aansprakelijkheidsregel heeft de automobilist een prikkel om optimale zorg aan te wenden, waarmee hij zijn verwachte aansprakelijkheid voor de schade van de fietser kan reduceren. De toevoeging van een absoluut eigen schuldverweer zal daarnaast ook de fietser aanzetten tot een efficiënt zorgniveau, om te vermijden dat de aansprakelijkheid van de automobilist vervalt en hij zijn eigen schade moet dragen. ${ }^{693} \mathrm{Bij}$ een gewone regel van foutaansprakelijkheid zal de automobilist een optimaal niveau van zorg aanwenden om te vermijden dat hij de schade van de fietser moet vergoeden. De fietser zal, dit wetende, ook een optimaal zorgniveau uitoefenen. ${ }^{694}$

De toevoeging van het activiteitsniveau aan het bilaterale ongevalsmodel leidt tot de conclusie dat bij een regel van risicoaansprakelijkheid met een absoluut eigen schuldverweer de automobilist een optimaal activiteitsniveau zal aanwenden. De fietser kan bij deze regel echter volstaan met de uitoefening van een efficiënt zorgniveau, waardoor hij een te hoog activiteitsniveau $\mathrm{zal}$ aanwenden. ${ }^{695} \mathrm{Bij}$ een gewone regel van foutaansprakelijkheid zal de fietser daarentegen wel een optimaal activiteitsniveau aanwenden. De fietser gaat ervan uit dat de automobilist optimale zorg zal uitoefenen, waardoor deze van aansprakelijkheid is bevrijd en de fietser zijn eigen schade moet dragen. De automobilist zal echter, ten behoeve van een maximalisering van zijn verwacht nut, bij de uitoefening van zijn activiteit alleen rekening

692. Zie Shavell, Accident Law, p. 28; Faure en Van den Bergh, Objectieve aansprakelijkheid, p. 88; Polinsky, Introduction, p. 49-50; Cooter, Journal of Economic Perspectives, 1991, p. 22-23.

693. Zie paragraaf 6.3 van dit hoofdstuk.

694. Zie paragraaf 6.4 van dit hoofdstuk.

695. Zie paragraaf 8.2.1 van dit hoofdstuk. 
houden met zijn kosten van zorg, waardoor hij uiteindelijk een te hoog activiteitsni. veau zal aanwenden. ${ }^{696}$

Concluderend kan worden gesteld dat voor wat betreft de uitoefening van een optimaal activiteitsniveau zowel een regel van risicoaansprakelijkheid met een absoluut eigen schuldverweer als een gewone regel van foutaansprakelijkheid tot een inefficiente uitkomst leiden. ${ }^{697}$ Volgens Shavell betekent dat er binnen een bilateraal ongevalsmodel geen 'first best solution' mogelijk. ${ }^{698}$

Indien echter met bepaalde andere factoren rekening wordt gehouden, kan mogelijk wel een keuze worden gemaakt tussen een risico- of een foutaansprakelijkheid. In de rechtseconomische literatuur wordt daartoe een aantal mogelijkheden aangedragen.

Landes and Posner noemen een aantal andere criteria die voor de invoering van een risicoaansprakelijkheid ten aanzien van bepaalde gevaarlijke activiteiten, zoals bijvoorbeeld autorijden, kunnen pleiten. Deze criteria hangen samen met de hoge omvang van de verwachte ongevalskosten van een bepaalde gevaarlijke activiteit, de onmogelijkheid om een ongeval te vermijden door het aanwenden van een hogere zorgvuldigheid, de mogelijkheid om het aantal ongevallen te reduceren door middel van een beperking of een wijziging van de betreffende activiteit. ${ }^{699}$

Calabresi en Hirschoff onderzoeken in hoeverre bij de keuze voor een regel van risicoaansprakelijkheid het beginsel van de zogenaamde 'cheapest cost avoider' van belang is. ${ }^{700}$ In dat kader wordt door hen de vraag gesteld welke partij in de beste positie is om een kosten-baten afweging te maken ten aanzien van haar zorg- en activiteitsniveau en daar ook naar te handelen. Bij een regel van risicoaansprakelijkheid gaat het volgens hen eerder om de vraag welke partij beter is geïnformeerd omtrent de risico's en de mogelijke alternatieven dan om vragen ten aanzien van de weging van de ongevals- en preventiekosten, waarbij veelal subjectieve informatie met betrekking tot de feiten noodzakelijk is. Zowel dader als slachtoffer kunnen in een betere positie zijn om een kosten-baten afweging van het ongevalsrisico te maken en

696. Zie paragraaf 8.2.2 van dit hoofdstuk.

697. Zie Faure en Van den Bergh, Objectieve aansprakelijkheid, p. 89-90; Shavell, Accident Law, p. 29; Polinsky, Introduction, p. 49-50; Schăfer und Ott, Lehrbuch der okonomischen Analyse, p. 202-203; Holzhauer en Teijl, Inleiding rechtseconomie, p. 129 en p. 134-135; Van Velthoven en Van Wijck, Recht en efficièntie, p. 159-169; Landes and Posner, Economic Structure of Tort Law, p. 69-70; Cooter and Ulen, Law and Economics, p. 279-281. Shavell, JLS, 1980, p. 7, stell dat de keuze tussen risicoaansprakelijkheid met een eigen schuldverweet en een foutaansprakelijkheid een keuze tussen 'the lesser of two evils' is.

698. Shavell, JLS, 1980, p. 19. Zie ook De Meza, IRLE, 1986, p. 107-113.

699. Landes and Posner, Georgia Law Review, 1981, p. 907-908; Landes and Posner, Economic Structure of Tort Law, p. 111-112.

700. Calabresi and Hirschoff, YLJ, 1972, p. 1055-1085. 
ter vermijding van het betreffende risico hun gedrag te wijzigen wanneer zich een emstig risico voordoet. ${ }^{701}$

Naar aanleiding van de voornoemde criteria kan de voorkeur uitgaan naar een regel van risicoaansprakelijkheid met een absoluut eigen schuldverweer wanneer, in het kader van de preventie, een wijziging van het activiteitsniveau van de fietser nietefficiënt is maar een activiteitswijziging van de automobilist wel. Daarnaast kan worden verondersteld dat de activiteit autorijden een groter gevaar met zich meebrengt dan de activiteit fietsen. Tenslotte kan ook het feit dat de automobilist over de betere informatie beschikt omtrent het gevaar dat hij met zijn activiteit kan creëren een argument zijn voor een regel van risicoaansprakelijkheid. ${ }^{702}$

Een gewone regel van foutaansprakelijkheid, daarentegen, zal de voorkeur verdienen wanneer een hogere zorgvuldigheid bij de automobilist belangrijker is dan een vermindering van zijn activiteitsniveau. Daarnaast kan worden gesteld dat in sommige situaties de fietser door de uitoefening van meer zorg of door wijziging van zijn activiteit beter in staat kan worden geacht om een ongeval te vermijden. Een voorbeeld hiervan is de fietser die, door in het donker gebruik te maken van licht op zijn fiets, eerder kan voorkomen dat een verkeersongeval ontstaat dan de automobilist die hem niet heeft kunnen zien. Wanneer het licht op zijn fiets een gebrek vertoont, zou de fietser kunnen kiezen voor een wijziging van zijn activiteit door te gaan wandelen of de bus te nemen. Een regel van foutaansprakelijkheid kan ten slotte ook de voorkeur hebben wanneer de rechter over volledige informatie beschikt om het optimale zorgen activiteitsniveau van de fietser te bepalen. ${ }^{703}$

\section{Andere factoren die van invloed zijn op de keuze tussen fout- en risicoaansprakelijkheid en verdere verfijningen van het model}

In het voorgaande is in het kader van de economische analyse van het verkeersongevallenrecht uitgegaan van een aantal veronderstellingen. Deze veronderstellingen hebben er toe bijgedragen dat het model tot op heden vrij eenvoudig kon worden gehouden. In de analyse is gebruik gemaakt van de volgende veronderstellingen:

\footnotetext{
701. Calabresi and Hirschoff, YLJ, 1972, p. 1060-1066.

702. Landes and Posner, Georgia Law Review, 1981, p. 877; Landes and Posner, Economic Structure of Tort Law, p. 70.

703. Zie ook Shavell, Accident Law, p. 29, die in dit verband het voorbeeld geeft van een moeder die met de kinderwagen langs een honkbalveld loopt terwijl daar een wedstrijd aan de gang is. Met deze activiteit die eenvoudig kan worden gewijzigd stelt zij zichzelf en haar kind echter onnodig bloot aan het gevaar dat een afdwalende bal hen zal verwonden. Zie ook Bowles, Law and the Economy, p. 111-112.
} 
- de efficiënte zorg is gelijk aan de juridische zorgvuldigheidsnorm;

- de dader en het slachtoffer zijn rationeel handelende individuen die in staat worden geacht hun eigen optimale zorg- en activiteitsniveaus vast te stellen;

- de dader en het slachtoffer beschikken over volledige informatie omtrent het gedrag van de wederpartij en ten aanzien van het ongevalsrisico;

- de rechter beschikt over voldoende informatie om de zorgvuldigheidsnorm van de dader en het slachtoffer te omschrijven. Deze zorgvuldigheidsnorm is daarbij voor elk soort dader en voor elk soort slachtoffer gelijk;

- het nut van elk soort dader en elk soort slachtoffer is homogeen. ${ }^{704}$

In werkelijkheid kunnen er echter fouten worden gemaakt bij de bepaling van de juridische zorgvuldigheidsnorm. Deze fouten ontstaan bijvoorbeeld wanneer de rechter zich vergist bij de bepaling van de zorgvuldigheidsnorm of de daadwerkelijk uitgeoefende zorg of indien de dader en het slachtoffer zich vergissen ten aanzien van de toepasselijke zorgvuldigheidsnorm. Daarnaast zijn ook de inspanningen (kosten) die de dader en het slachtoffer voor de uitoefening van hun zorg moeten leveren niet van een gelijk niveau. ${ }^{705}$

De hier genoemde voorbeelden, die verwijzen naar informatieproblemen aan de zijde van de rechter, de dader en het slachtoffer, zullen in deze paragraaf worden onderzocht en toegelicht. In paragraaf 10.1 zal worden ingegaan op mogelijke informatieproblemen bij de bepaling van de zorgvuldigheidsnorm. In paragraaf 10.2 wordt onderzocht of en in hoeverre de mogelijkheid bestaat om de verschillen in zorgniveaus tussen individuen te classificeren. $\mathrm{Na}$ deze analyse zal in paragraaf 11 de vraag worden beantwoord of de conclusies uit de vorige paragraaf met betrekking tot de efficiëntie van aansprakelijkheidsregels dienen te worden gewijzigd.

\subsection{INFORMATIEPROBLEMEN BLI DE BEPALING VAN DE ZORGVULDIGHEIDSNORM}

Wanneer de rechter geen volledige informatie heeft voor de bepaling van de actuele zorg van dader en slachtoffer kan zich een tweetal situaties voordoen, namelijk enerzijds het geval waarin de rechter de zorgvuldigheidsnorm hoger vaststelt dan de efficiënte zorg en anderzijds het geval waarin de rechter de zorgvuldigheidsnorm lager vaststelt dan de efficiënte zorg. Dit kan aan de hand van tabel $6^{706}$ worden geillustreerd.

704. Zie voor een overzicht van deze veronderstellingen: Faure en Van den Bergh, Objectieve ansprakelijkheid. p. 90-91; Haddock and Curran, JLS, 1985, p. 56-57; Brown, JLS, 1973, p. 327 en 333: ('alabresi, YLJ, 1975, p. 662; Veljanovski, in The Economic Approach to Law, p. 132.

705. Zie Bowles, Law and the Economy, p. 118; Landes and Posner, Georgia Law Review, 1981,p. 879-880; Haddock and Curran, JI.S, 1985, p. 63.

706. Voorbecld naar Shavell, Accident Law, p. 81. 
Tabel 6

\begin{tabular}{|c|c|c|c|c|}
\hline $\begin{array}{c}\text { Zorg- } \\
\text { niveau }\end{array}$ & $\begin{array}{c}\text { Kosten van } \\
\text { zorg }\end{array}$ & $\begin{array}{c}\text { Waarschijnlijkheid } \\
\text { van het ongeval }\end{array}$ & Verwachte schade & $\begin{array}{c}\text { Maatschappelijke } \\
\text { kosten }\end{array}$ \\
\hline geen & 0 & $20 \%$ & 20 & 20 \\
\hline gemiddeld & 5 & $12 \%$ & 12 & 17 \\
\hline sterk & 8 & $10 \%$ & 10 & 18 \\
\hline
\end{tabular}

In kolom 1 is een aantal zorgniveaus weergegeven, waarvan de kosten in kolom 2 zijn afgezet tegen de verwachte schade in kolom 4 . Kolom 3 geeft in de vorm van een percentage weer hoe groot de waarschijnlijkheid is dat zich een ongeval zal voordoen. In kolom 5 staan de maatschappelijke kosten die de optelsom vormen van de kosten van zorg en de verwachte schade. Verder wordt verondersteld dat de werkelijke schade, indien zich een ongeval voordoet, 100 zal bedragen.

Het optimale niveau van zorg in tabel 6 wordt gevonden op het punt waar de maatschappelijke kosten het laagst zijn. Dit komt overeen met de uitoefening van een gemiddeld niveau van zorg. Bij dit niveau van zorg zijn de marginale kosten van 5 eenheden lager dan de marginale opbrengst van 8 eenheden in termen van een vermindering van de verwachte schade. Bij sterke zorg zijn de marginale kosten (3) hoger dan de marginale opbrengst (2). Wanneer wordt verondersteld dat de zorgvuldigheidsnorm gelijk is aan de efficiënte zorg zal de dader derhalve een gemiddelde zorg uitoefenen.

In het kader van de gegevens uit tabel 6 kunnen zich de volgende informatieproblemen voordoen:

1. De rechter beschikt over onvolledige informatie omtrent de werkelijk uitgeoefende zorg (paragraaf 10.1.1);

2. De rechter heeft geen volledige informatie over de zorguuldigheidsnorm (paragraaf 10.1.2);

3. Onoplettendheid aan de kant van dader en slachtoffer (10.1.3 en 10.1.4);

4. Onzekerheid bij de dader ten aanzien van de zorgvuldigheidsnorm (10.1.5);

5. Voorzienbare fouten bij de keuze van de zorgvuldigheidsnorm (10.1.5).

10.1.1. De rechter beschikt over onvolledige informatie omtrent de werkelijk uitgeoefende zorg

Wanneer de rechter de actuele zorg bijvoorbeeld gelijk stelt met een zorgniveau van 0 (geen zorg) in tabel 6, zal de dader reeds aansprakelijk zijn wanneer hij een zorg van 1 eenheid aanwendt. De kosten van zorg zijn hierbij zeer gering, maar de maatschappelijke kosten zijn bij geen zorg hoger dan bij het optimale niveau van gemid- 
delde zorg, namelijk 20 ten opzichte van 17. Economisch gezien ontstaat hier derhalve een inefficiënt resultaat. De dader kan nu enerzijds, tegen hoge kosten, een extreem hoog niveau van zorg uitoefenen om te vermijden dat hij aansprakelijk wordt gesteld. Wanneer een automobilist bijvoorbeeld aansprakelijk wordt gehouden voor het met hoge snelheid veroorzaken van een verkeersongeval, terwijl hij in werkelijkheid met een matige snelheid heeft gereden, zal de automobilist waarschijnlijk stapvoets (hoge kosten) moeten rijden om het risico op een verkeersongeval te verminderen. Anderzijds kan de dader besluiten om, tegen lagere kosten, een gemiddeld zorgniveau aan te wenden. Dit heeft echter tot gevolg dat een foutaansprakelijkheid overgaat in een risicoaansprakelijkheid. ${ }^{707}$

\subsubsection{De rechter heeft geen volledige informatie over de zorgvuldigheidsnorm}

Wanneer de rechter geen volledige informatie heeft over de zorgvuldigheidsnorm ontstaat onzekerheid omtrent de vraag hoe de rechter de kosten van zorg en het effect van de uitgeoefende zorg op de vermindering van het ongevalsrisico zal beoordelen. De efficiënte zorg in tabel 6 is gelijk aan een gemiddeld zorgniveau. Wanneer wordt verondersteld dat dit zorgniveau overeenkomt met een snelheid van $50 \mathrm{~km} / \mathrm{u}$ en de rechter bepaalt dat een snelheid van $60 \mathrm{~km} / \mathrm{u}$ overeenstemt met de zorgvuldigheidsnorm, zal de automobilist zich aan deze laatstgenoemde, niet efficiënte, snelheid houden. De automobilist is immers bij de naleving van een dergelijk zorgvuldigheidsnorm reeds van aansprakelijkheid bevrijd. De rechter kan ook bepalen dat $40 \mathrm{~km} / \mathrm{u}$ een zorgvuldige snelheid is. De automobilist zal dan een snelheid van 40 $\mathrm{km} / \mathrm{u}$ aanhouden, tenzij de marginale kosten hiervan te hoog oplopen, waardoor het goedkoper kan zijn om de efficiënte zorg van $50 \mathrm{~km} / \mathrm{u}$ te volgen. De automobilist zal derhalve efficiënte zorg uitoefenen wanneer dit voor hem goedkoper is. Daarbij zal hij het risico om aansprakelijk te worden gesteld voor de totale ongevalskosten op de koop toenemen. ${ }^{708}$

\subsubsection{Onoplettendheid bij de dader en het slachtoffer}

Een derde probleem kan zich voordoen bij de dader of het slachtoffer zelf. Een automobilist zal bijvoorbeeld niet op elk moment de absolute controle hebben over zijn uit te oefenen zorg. Daarbij kan worden gedacht aan bepaalde situaties van onoplettendheid, bijvoorbeeld wanneer de automobilist wordt verblind door de laagstaande zon of plotseling moet niezen. Voor de fietser gelden deze momenten van onoplettendheid evenzeer. De rechter beoordeelt echter in het algemeen het zorgniveau van dader en slachtoffer op het moment van het ongeval. Hierdoor ontstaat bij de be-

707. Faure en Van den Bergh, Objectieve aansprakelijkheid, p. 91-92; Shavell, Accident Law, p. 7981.

708. Faure en Van den Bergh, Objectieve aansprakelijkheid, p. 92-93; Shavell, Accident Law, p. 82; Kahan, JLS, 1989, p. 432-434. 
trokken partijen onzekerheid over de vraag of zij wel of niet zorgvuldig genoeg zijn geweest. Gegeven deze onzekerheid zullen dader en slachtoffer mogelijk teveel zorg anwenden om er zeker van te zijn dat hun zorgniveau op het moment van het ongeval niet lager is dan de juridische zorgvuldigheidsnorm, met het gevolg dat zij voor de schade moeten opkomen. ${ }^{709}$

\subsubsection{Onzekerheid bij de dader ten aanzien van de zorgvuldigheidsnorm}

De onzekerheid met betrekking tot de juridische zorgvuldigheidsnorm kan tot gevolg hebben dat de dader aansprakelijk wordt gehouden, terwijl hij zelf, op grond van zijn uitgeoefende zorg, een andere mening is toegedaan. Wanneer de dader derhalve ten onrechte meent dat hij bepaalde voorzorgsmaatregelen moet treffen, dan zal hij meer dan de efficiënte zorg aanwenden om te voorkomen dat hij aansprakelijk wordt gesteld. Anderzijds kan de dader van mening zijn dat hij bepaalde voorzorgsmaatregelen niet behoeft te nemen, waardoor hij mogelijk wel aansprakelijk zal worden gehouden.

Een automobilist die bijvoorbeeld meent dat hij zijn snelheid niet behoeft te matigen omdat het volgens hem niet zo mistig is, kan door de rechter toch aansprakelijk worden gehouden voor de schade die ten gevolge van een ongeval in dichte mist is ontstaan. Een voorbeeld waarin de automobilist niet aansprakelijk zal zijn is de situatie waarin de automobilist meent dat hij zijn mistlamp moet gebruiken hoewel het zicht op de weg niet wordt beperkt door mist maar door hevige regenval. Hierdoor kan hij volstaan met het gebruik van zijn gewone lichten. ${ }^{710}$

\subsubsection{Voorzienbare fouten bij de keuze van de zorgvuldigheidsnorm}

In de laatste plaats kan zich de situatie voordoen waarbij dader en slachtoffer vooraf weten dat de efficiënte zorg zal afwijken van de juridische zorgvuldigheidsnorm. Wanneer bijvoorbeeld de automobilist op de hoogte is van het feit dat de zorgvuldigheidsnorm lager ligt dan de efficiënte zorg, zal hij door te voldoen aan de zorgvuldigheidsnorm aansprakelijkheid kunnen vermijden. De automobilist wordt daarentegen voor de keuze gesteld indien de zorgvuldigheidsnorm hoger ligt dan de efficiênte zorg. Hij kan trachten tegen hoge kosten de zorgvuldigheidsnorm in acht te nemen of hij kan, wanneer dit goedkoper is, de optimale zorg uitoefenen, waarbij hij

\footnotetext{
709. Faure en Van den Bergh, Objectieve aansprakelijkheid, p. 92; Shavell, Accident Law, p. 81-82.

710. Faure en Van den Bergh, Objectieve ansprakelijkheid, p. 92; Shavell, Accident Law, p. 83; Kahan, JLS, 1989, p. 437-439; Landes and Posner, Georgia Law Review, 1981, p. 880. Zie ook Diamond, JLS, 1974, p. 123-140, voor een theoretische uiteenzetting van de vraag welk zorgniveau efficient is, wanneer bij de betrokken partijen sprake is van een onderschatting respectievelijk een overschatting van de door de rechter vastgestelde zorgvuldigheidsnorm ten tijde van het ongeval.
} 
het risico loopt om aansprakelijk te worden gesteld. Kiest de automobilist voor deze laatste mogelijkheid dan wordt een regel van foutaansprakelijkheid in feite vervan. gen door een regel van risicoaansprakelijkheid. ${ }^{711}$

\subsubsection{Conclusie}

Concluderend kan worden gesteld dat binnen de geanalyseerde informatieproblemen die van invloed zijn op de bepaling van de zorgvuldigheidsnorm, de dader en het slachtoffer veelal geneigd zijn meer zorg uit te oefenen dan economisch (efficiënte zorg) of juridisch (zorgvuldigheidsnorm) wordt opgelegd. Daarbij wordt door dader en slachtoffer in het algemeen een afweging gemaakt tussen enerzijds het risico om aansprakelijk te worden gesteld of het moeten opkomen voor de eigen schade en anderzijds het dragen van de kosten van zorg. Dader en slachtoffer zullen zich in dat kader houden aan de juridische zorgvuldigheidsnorm, tenzij de kosten daarvan te hoog worden.

Het belang van de verschillende onzekerheden bij de bepaling van de zorgvuldigheidsnorm hangt in de praktijk vaak samen met het concrete ongeval waarbij zich bepaalde vergissingen voordoen. Daarbij kan worden gedacht aan een verkeersongeval waarvan te weinig getuigen waren om de juiste toedracht te kunnen achterhalen, of waarbij de rechter wordt geconfronteerd met een tekort aan informatie om het gedrag van de automobilist te kunnen beoordelen. De rechter verkeert hier derhalve in onzekerheid met betrekking tot de bepaling van de actuele zorg. De situaties waarin vergissingen door de rechter mogelijk zijn ten aanzien van de bepaling van de zorgvuldigheidsnorm doen zich volgens Shavell met name voor bij schade die ontstaat in de uitoefening van professionele beroepen, zoals bij chirurgen en bij het gebruik van nieuwe technologie. De rechter zal in deze gevallen, mede door een gebrek aan informatie, soms niet in staat zijn om de kosten en opbrengsten van zorg juist in te schatten. ${ }^{712}$

\subsection{HeT CLASSIFICEREN VAN NIVEAUS VAN ZORG}

In de inleiding van deze paragraaf is verondersteld dat de zorgvuldigheidsnorm voor elk soort dader en elk soort slachtoffer van een gelijk niveau is. In werkelijkheid zullen de inspanningen die dader en slachtoffer moeten verrichten om het ongevalsrisico te reduceren van persoon tot persoon verschillen. Deze inspanningen houden ver-

711. Shavell, Accident Law, p. 83; Faure en Van den Bergh, RW, 1987-1988, p. 1109-1110. Zie ook Diamond, JLS, 1974, p. 119-123, waarin hij de uitoefening van zorg bij een niveau van geenaansprakelijkheid vergelijkt met de uitoefening van zorg bij een gegeven zorgvuldigheidsnom.

712. Shavell, Accident Law, p. 82-83. Zie met betrekking tot de hier besproken informatieproblemen ten aanzien van de bepaling van de zorgvuldigheidsnorm: Cooter, Kornhauser and Lane, BJE, 1979, p. 366-373; Cooter and Ulen, Law and Economics, p. 284-286. 
band met de kosten die moeten worden gemaakt om de kans op een ongeval te verminderen, alsmede met de individuele bekwaamheden. Een persoon in de leeftijd van 70 jaar zal bijvoorbeeld meer moeite hebben om de stoep sneeuwvrij te maken dan een persoon van 30 jaar die nog in de kracht van zijn leven is. Een ouder persoon zal in deze situatie naar verhouding hoge kosten moeten maken voor weinig zorg, terwijl een jonger persoon tegen relatief lage kosten hoge zorg kan aanwenden.

De vraag of een bepaalde voorzorgsmaatregel, bijvoorbeeld sneeuwruimen, een bijdrage kan leveren aan de preventie van ongevallen, hangt bijvoorbeeld af van het aantal voetgangers dat van het 'schone' trottoir gebruik zal maken. Wanneer wordt verondersteld dat dagelijks 50 voetgangers van het trottoir gebruik maken, kan het voor een 30 -jarige lonend zijn om zijn stoep tegen lage kosten sneeuwvrij te maken. Voor een 70-jarige zullen de kosten van zorg (sneeuwruimen) sterk kunnen oplopen, waartegen de opbrengst, namelijk de vermindering van de kans dat een voetganger uitglijdt en zijn been breekt, mogelijk niet opweegt. ${ }^{713}$

In deze paragraaf zal met behulp van een aantal voorbeelden van verkeerssituaties worden nagegaan in hoeverre de verschillen in de kosten van zorg en bekwaamheden tussen individuen van invloed kunnen zijn op de vermindering van de ongevalskosten. Daarbij zal worden onderzocht wat de gevolgen zijn van de genoemde verschillen voor respectievelijk de naleving door dader en slachtoffer van de zorgvuldigheidsnorm (10.2.1), de aansprakelijkheid (10.2.2), het activiteitsniveau (10.2.3) en bepaalde andere voorzorgsmaatregelen (10.2.4), zoals de invloed van het gebruik van alcohol alvorens aan het verkeer wordt deelgenomen.

\subsubsection{De gevolgen voor de optimale zorg en de zorguuldigheidsnorm}

In een eerdere fase van de analyse is gesteld dat de optimale zorg van dader en slachtoffer samenhangt met de som van de kosten van zorg en de verwachte ongevalskosten. Hiervoor is echter opgemerkt dat de kosten van zorg mede afhankelijk zijn van de individuele kennis en bekwaamheden. Dit betekent dat het optimale niveau van zorg niet voor iedere dader of slachtoffer gelijk is. Een persoon A die reeds twintig jaar in het bezit is van een rijbewijs zal, op grond van zijn ervaring minder kosten maken om een hoog zorgniveau in het verkeer uit te oefenen. Dit in tegenstelling tot een persoon B, die kortgeleden zijn rijbewijs heeft gehaald en die bij een gebrek aan ervaring hoge kosten moet maken om in het verkeer een optimaal zorgniveau te kunnen aanwenden. Het efficiënte niveau van zorg van persoon $\mathrm{A}$ is derhalve hoger dan het efficiënte zorgniveau van persoon B. Daarbij lijkt het op het eerste gezicht niet optimaal om persoon B te dwingen een hoger zorgniveau uit te oefenen,

713. Shavell, Accident Law, p. 73-74; Faure en Van den Bergh, Objectieve aansprakelijkheid, p. 93; Posner, Economic Analysis, p. 151-152. 
omdat de marginale kosten van deze extra zorg niet opwegen tegen de opbrengsh, namelijk de vermindering van de verwachte schade. ${ }^{714}$

De verschillen in de efficiënte zorgniveaus van partijen kunnen ook gevolgen hebben voor de bepaling van de zorgvuldigheidsnorm door de rechter. Wanneer de rechter bij de beoordeling van de aansprakelijkheid over voldoende informatie beschikt omtrent de verschillen in kosten van zorg, is het mogelijk om de zorgvuldigheids. norm tegen lage kosten te individualiseren. De rechter zou bijvoorbeeld een jonger persoon eerder aansprakelijk kunnen houden voor een verkeersongeval dan een ouder persoon, hoewel aan beide individuen dezelfde objectieve nalatigheid kan worden verweten. Een voorbeeld van dit laatste is de situatie waarin beiden als voetganger de straat willen oversteken. De oudere persoon zal zich daarbij kunnen vergissen in de snelheid van de aankomende auto, terwijl de jonge persoon de genoemde snelheid wel goed inschat, maar toch besluit over te steken.

De individuele classificatie van de zorgvuldigheidsnorm wordt begrensd door de kosten die daarmee zijn gemoeid. Wanneer deze kosten hoger zijn dan de besparing die met individualisering kan worden bereikt, zal een verdere differentiatie niet meer optimaal zijn. Dit kan tot gevolg hebben dat de rechter een soort algemene zorgvuldigheidsnorm zal opstellen, waarbij een gemiddeld optimaal zorgniveau voor één groep individuen wordt geformuleerd. Deze zogenaamde 'bonus pater familias'standaard, kan echter voor een deel van de groep te hoog zijn en voor een ander deel te laag. ${ }^{715}$

Het voorgaande kan met behulp van een eenvoudig voorbeeld worden geîllustreerd. Daarin wordt verondersteld dat de verwachte ongevalskosten 100 bedragen en dat verder drie categorieën van autobestuurders binnen een groep verkeersdeelnemers van 30 jaar kunnen worden onderscheiden. Een eerste categorie bestuurders (A) moet hoge zorg, kostprijs 120, aanwenden om een verkeersongeval te voorkomen. Een tweede categorie bestuurders (B) kan tegen een kostprijs van 100 een verkeersongeval vermijden. Een derde categorie bestuurders (C) behoeft minder zorg, kostprijs 80 , aan te wenden om een verkeersongeval te voorkomen. Wanneer verder wordt verondersteld dat de kostprijs van 100 eenheden zorg overeenstemt met een gemiddeld zorgniveau dat gelijk is aan de juridische zorgvuldigheidsnorm, dan zullen alleen de bestuurders in categorie B hieraan kunnen voldoen.

Voor de bestuurders in categorie A ligt deze zorgvuldigheidsnorm te hoog in verhouding tot hun efficiënte zorgniveau. $\mathrm{Zij}$ kunnen alleen tegen hoge kosten (120) het ongevalsrisico verminderen. De personen die tot deze categorie behoren zijn bij-

714. Zie Faure en Van den Bergh, RW, 1987-1988, p. 1112.

715. Faure en Van den Bergh, Objectieve aansprakelijkheid, p. 94; Shavell, Accident Law, p. 74; Fatre en Van den Bergh, RW, 1987-1988, p. 1112-1113. 
voorbeeld bestuurders die lijden aan een geestelijke of lichamelijke tekortkoming, waardoor zij alleen tegen hoge zorgkosten een verkeersongeval kunnen vermijden. De bestuurders in categorie $\mathrm{C}$ zijn gezonde, zeer ervaren, autobestuurders die tegen lage kosten (80) hoge zorg kunnen aanwenden. De kostprijs voor naleving van de zorgvuldigheidsnorm bedraagt voor hen slechts 80 eenheden. Voor de bestuurders in categorie $\mathrm{C}$ geldt derhalve dat hun efficiënte zorgniveau hoger ligt dan de juridische zorgvuldigheidsnorm. $^{716}$

\subsubsection{De gevolgen voor de aansprakelijkheid}

De vaststelling van de zorgvuldigheid door de rechter, die voor een deel van de autobestuurders van 30 jaar te streng is en voor een ander deel te ruim, heeft gevolgen voor de beoordeling van de (fout)aansprakelijkheid. Hierbij wordt uitgegaan van de veronderstelling dat inachtneming van de zorgvuldigheidsnorm tegen een kostprijs van 100 de autobestuurder van aansprakelijkheid bevrijdt. Bij een regel van foutaansprakelijkheid zal deze zorgvuldigheidsnorm door zowel categorie $\mathrm{B}$ als $\mathrm{C}$ worden nageleefd, waarmee zij aan aansprakelijkheid zullen ontsnappen. Voor een autobestuurder in categorie A geldt dat hij alleen tegen relatief hoge kosten aan de zorgvuldigheidsnorm kan voldoen. Hij zal daarbij enerzijds kunnen kiezen voor aansprakelijkheid, wanneer de kosten daarvan lager zijn dan naleving van de zorgvuldigheidsnorm. Anderzijds zal de bestuurder in categorie A ook kunnen besluiten tot een activiteitswijziging. ${ }^{717}$ Indien de bestuurder in categorie A kiest voor aansprakelijkheid, zal voor hem een regel van foutaansprakelijkheid overgaan in een regel van risicoaansprakelijkheid.

Wanneer wordt uitgegaan van een regel van risicoaansprakelijkheid, zal de bestuurder in categorie $\mathrm{B}$ wederom de zorgvuldigheidsnorm in acht nemen om de verwachte ongevalskosten te reduceren. De bestuurder in categorie $\mathrm{C}$ zal echter het voor hem efficiënte niveau van zorg uitoefenen, dat hoger ligt dan de zorgvuldigheidsnorm. ${ }^{718}$

\subsubsection{De gevolgen voor het activiteitsniveau}

De opstelling van één zorgvuldigheidsnorm door de rechter met betrekking tot een bepaalde groep van autobestuurders heeft ook gevolgen voor het activiteitsniveau van sommige bestuurders binnen de groep. Wanneer de rechter een relatief strenge

716. Faure en Van den Bergh, Objectieve aansprakelijkheid, p. 95-96; Shavell, Accident Law, p. 7475; Posner, Economic Analysis, p. 167-168; Diamond, JLS, p. 149-160; Faure en Van den Bergh, RW, 1987-1988, p. 1113; Landes and Ponser, Economic Structure of Tort Law, p. 123131; Cooter and Ulen, Law and Economics, p. 286-288.

717. Zie over dit laatste hierna in paragraaf 10.2.3.

718. Faure en Van den Bergh, Objectieve aansprakelijkheid, p. 96. Zie ook Emons, Working Paper, 1991, p. 17-22. 
zorgvuldigheidsnorm vaststelt, kan een deel van de groep mogelijk worden weerhouden om de activiteit autorijden uit te oefenen. ${ }^{719}$ Dit geldt bijvoorbeeld ten aanzien van de bestuurders in categorie $\mathrm{A}$, die in het verkeer een hoog risico vormen, omdat zij alleen tegen hoge kosten aan de zorgvuldigheidsnorm kunnen voldoen. Voor deze autobestuurders is het maatschappelijk gezien misschien niet wenselijk om aan de activiteit autorijden deel te nemen, tenzij voor hen het nut daarvan hoger is dan de verwachte ongevalskosten.

De autobestuurder binnen categorie A die lijdt aan een lichamelijke of geestelijke tekortkoming zal derhalve een prikkel kunnen hebben om zijn activiteit te wijzigen. Hij vormt mogelijk een te hoog risico bij de deelname aan de activiteit autorijden, met als gevolg dat de verwachte ongevalskosten (schade) zeer hoog zullen zijn, zonder dat een potentieel slachtoffer hierop invloed kan uitoefenen. Het gegeven dat de betreffende autobestuurder kan worden aangezet tot meer zorg zal in deze situatie geen verandering brengen. De autobestuurder kan, onder dreiging van een risicoaansprakelijkheid, mogelijk alleen nog worden aangezet tot een activiteitswijziging, waarbij hij in plaats van de auto bijvoorbeeld gebruik maakt van het openbaar vervoer. $^{720}$

\subsubsection{Het treffen van bepaalde voorzorgsmaatregelen}

Een informatieprobleem dat sterke samenhang vertoont met de vraag of überhaupt aan een bepaalde activiteit wordt deelgenomen, heeft betrekking op de zogenaamde 'prior decisions'. ${ }^{721}$ Dit zijn voorzorgsmaatregelen die een individu besluit te nemen alvorens een activiteit wordt uitgeoefend. Daarbij speelt mede een rol de informatie waarover een individu beschikt omtrent het risico van een bepaalde activiteit. $\mathrm{De}$ genoemde voorzorgsmaatregelen zijn daamaast van invloed op de bekwaamheden van een individu om een voldoende niveau van zorg aan te wenden op het moment dat zich een ongeval kan voordoen. Hiermee wordt derhalve, naast de kosten van zorg en de verwachte ongevalskosten, een derde kostencomponent aan de analyse toegevoegd, namelijk de kosten van het nemen van voorzorgsmaatregelen.

Een voorbeeld van een voorzorgsmaatregel die van invloed kan zijn op de vermindering van het ongevalsrisico, is het al of niet gebruiken van alcohol voordat met de auto aan het verkeer wordt deelgenomen. Een autobestuurder die geen alcohol ge-

719. Faure en Van den Bergh, Objectieve aansprakelijkheid, p. 96; Shavell, Accident Law, 75.

720. Faure en Van den Bergh, RW, 1987-1988, p. 1117-1118 gebruiken in dit verband het voorbeld van een hartpatient die het advies van zijn dokter, om niet in de auto te stappen, in de wind slaat en toch de weg opgaat en als gevolg van een hartaanval een verkeersongeval veroorzaakt. Di hartpatient zal in dit geval nooit de gemiddelde zorg uit kunnen oefenen, zodat hij een prikkel heeft om van activiteit te veranderen en bijvoorbeeld de bus te nemen.

721. Shavell, Accident Law, p. 77. 
bruikt zal waarschijnlijk goed in staat zijn om zorgvuldig aan het verkeer deel te nemen. Een automobilist die zichzelf in staat acht om, na het gebruik van alcohol, aan het verkeer deel te nemen, zal echter, objectief gezien, de kans op een ongeval sterk kunnen verhogen.

De vraag is of een automobilist, in het kader van het treffen van een voorzorgsmaatregel, kan worden aangezet tot zorgvuldig gedrag. Daarbij kan gebruik worden gemaakt van een unilateraal ongevalsmodel, waarin wordt verondersteld dat de kosten van voorzorg 3 eenheden bedragen en waarbij de automobilist door uitoefening van voorzorg de kans op een ongeval met een verwachte schade van 100 , met $8 \%$ kan reduceren. Dit betekent dat de autobestuurder zal besluiten om de voorzorgsmaatregel uit te oefenen. De marginale opbrengst van 8 eenheden is immers hoger dan de marginale kosten van zorg van 3 eenheden. Volgens Shavell zullen bepaalde voorzorgsmaatregelen derhalve slechts efficiënt zijn:

'not only if its costs is sufficiently low, but also if its effect on the ability to take care results in a sufficiently high reduction in expected total accident costs'. ${ }^{722}$

In aansluiting op het voorgaande kan verder worden verondersteld dat de efficiënte zorg gelijk is aan de juridische zorgvuldigheidsnorm, die overeenstemt met het niveau van autorijden in nuchtere toestand. Dit heeft tot gevolg dat de automobilist zal worden aangezet om geen alcohol te gebruiken, waarmee hij zowel een efficiënt zorgniveau als een optimale voorzorgsmaatregel uitoefent en derhalve niet aansprakelijk kan worden gesteld.

Wanneer de automobilist geen voorzorgsmaatregel treft en wel besluit om na het gebruik van alcohol met de auto aan het verkeer deel te nemen, zullen voor hem de kosten om de zorgvuldigheidsnorm (nuchter autorijden) in acht te nemen hoog oplopen. Wanneer, in het kader van het eerder gegeven voorbeeld, de kosten van voorzorg 3 bedragen en de kosten van zorg 4 eenheden, zal de autobestuurder, tegen totale kosten van 7 eenheden, zorg uitoefenen. Daarmee kan hij een verwachte aansprakelijkheid van 10 eenheden reduceren tot 2 eenheden. De marginale opbrengst daarvan is hoger (8) dan de totale kosten van zorg en voorzorg (7). De automobilist zal in dit geval besluiten om geen alcohol te nuttigen alvorens hij met de auto aan het verkeer deelneemt. ${ }^{723}$ 


\section{Conclusie V: Nogmaals fout- en risicoaansprakelijkheid vergeleken}

Bij de bespreking van het unilaterale respectievelijk bilaterale ongevalsmodel is uitgegaan van de veronderstelling dat de juridische zorgvuldigheidsnorm optimaal kan worden bepaald. Naar aanleiding van de analyse in de vorige paragraaf kan echter worden gesteld dat fouten en onzekerheden ertoe kunnen bijdragen dat de rechter moeite heeft om de optimale zorgvuldigheidsnorm vast te stellen. Daarnaast worden de mogelijkheden voor de rechter om voor elke dader en slachtoffer een zelfde zorgvuldigheidsnorm vast te stellen beperkt door verschillen in kennis en bekwaamheden van dader en slachtoffer. Tenslotte zijn dader en slachtoffer in bepaalde situaties niet in staat om de optimale zorg uit te oefenen. Dit kan het gevolg zijn van onoplettendheid bij de dader of het slachtoffer maar ook van onzekerheden met betrekking tot de zorgvuldigheidsnorm, waardoor zij verzuimen om bepaalde zorgmaatregelen te treffen.

De genoemde informatieproblemen ten aanzien van de zorgvuldigheidsnorm en de problemen bij de classificatie van zorgniveaus kunnen leiden tot situaties waarin een dader eerder aansprakelijk wordt gehouden of bij een geringe zorg aan aansprakelijkheid kan ontsnappen. De rechter kan echter door de formulering van een algemene zorgvuldigheidsnorm ook bereiken dat een verkeersdeelnemer besluit om zijn activiteit te wijzigen. Daarnaast is een verband geconstateerd tussen fout en risico dat mede tot uiting komt in de schadevergoeding. Bij een regel van risicoaansprakelijkheid zal de automobilist rekening houden met de schade die door de uitoefening van zijn activiteit kan worden veroorzaakt. Binnen een regel van foutaansprakelijkheid zal de autobestuurder tot op zekere hoogte ook rekening houden met de verwachte schade die met de uitoefening van zijn activiteit gepaard gaat, omdat hij het risico loopt om (fout)aansprakelijk te worden gesteld. ${ }^{724}$

Naar aanleiding van de analyse van de classificatie van zorgniveaus en de informatieproblemen ten aanzien van de zorgvuldigheidsnorm, zullen in deze paragraaf de verschillende aansprakelijkheidsregels nogmaals worden vergeleken. Bij een regel van risicoaansprakelijkheid is de autobestuurder in beginsel gehouden de schade van de fietser te vergoeden. De automobilist zal derhalve streven naar een minimalisering van de totale ongevalskosten, waarbij hij een voor hem optimaal zorg- en activiteitsniveau zal aanwenden. De autobestuurder zal ook de juiste voorzorgsmaatregelen treffen, bijvoorbeeld geen alcohol gebruiken voordat hij aan het verkeer deelneemt. Wanneer derhalve alleen rekening wordt gehouden met het gedrag van

724. Shavell, Accident Law, p. 83-84; Cooter, Joumal of Economic Perspectives, 1991, p. 24-25. 
de autobestuurder dan zal een regel van risicoaansprakelijkheid tot een efficiënte uitkomst leiden. ${ }^{725}$

In een bilaterale ongevalssituatie zal, rekening houdend met het gedrag van het slachtoffer, ten aanzien van zowel een regel van risicoaansprakelijkheid met een absoluut eigen schuldverweer als een gewone regel van foutaansprakelijkheid onzekerheid kunnen ontstaan met betrekking tot de bepaling van de zorgvuldigheidsnorm. Dit kan met betrekking tot het eigen schuldverweer bijvoorbeeld tot gevolg hebben dat de fietser teveel of te weinig zorg uitoefent. Een zelfde probleem doet zich voor bij een regel van foutaansprakelijkheid, waarbij zowel het niveau van zorg van het slachtoffer als dat van de dader optimaal moet worden bepaald. Dit betekent dat de toevoeging van het onzekerheidselement bij de bepaling van de zorgvuldigheidsnorm de vergelijking tussen risicoaansprakelijkheid en foutaansprakelijkheid verder zal compliceren, waarbij een vergelijking tussen deze aansprakelijkheidsregels sterk afhankelijk is van het belang dat aan bepaalde factoren van onzekerheid wordt gehecht.

Wanneer bijvoorbeeld rekening wordt gehouden met de verschillen in bekwaamheden tussen dader en slachtoffer en de rechter stelt de zorgvuldigheidsnorm gelijk met die van een grote groep daders of slachtoffers, zullen er personen zijn voor wie deze norm te hoog dan wel te laag is. Daarbij is het mede van belang ten aanzien van welke soort activiteit een aansprakelijkheidsoordeel moet worden gegeven. Wanneer in dat kader de deelname aan het verkeer als uitgangspunt wordt genomen, kan worden gesteld dat bijvoorbeeld autorijden een groter gevaar meebrengt dan fietsen. Daarbij zal van een autobestuurder een grotere zorgvuldigheid kunnen worden geëist dan van een fietser. In de vorige paragraaf is aan de hand van een aantal voorbeelden angetoond dat niet elke autobestuurder in staat zal zijn om hetzelfde zorgniveau aan te wenden. Dit heeft tot gevolg dat in situaties, waarin een autobestuurder niet aan een bepaalde zorgvuldigheidsnorm kan voldoen, hij mogelijk gedwongen wordt om zijn activiteit te wijzigen en in plaats van met de auto zich met het openbaar vervoer te verplaatsen.

Aan de kant van de fietser lijkt een zekere differentiatie echter ook onvermijdelijk. Sommige fietsers zijn zich, bijvoorbeeld vanwege hun leeftijd of tengevolge van een lichamelijke tekortkoming, in veel gevallen niet bewust van de gevaren van het autoverkeer. In de vorige paragraaf is het voorbeeld genoemd van een ouder persoon, die soms meer moeite heeft om de snelheid van een aankomende auto juist in te schatten dan een jonger individu. Een andere categorie heeft betrekking op de groep jonge kinderen, die zich gezien hun leeftijd vaak niet bewust zijn van de gevaren van het autoverkeer en daarnaast ook niet in staat zijn om zich bij hun verkeersdeelname in

725. Shavell, Accident Law, p. 84-85. 
alle situaties zorgvuldig te gedragen. ${ }^{726}$ Binnen de groep fietsers bevinden zich der. halve ook categorieën, voor wie de zorgvuldigheidsnorm te streng kan zijn.

\section{Algehele conclusie van de economische analyse van het aansprakelijkheidsrecht in het licht van de centrale probleemstelling}

In dit hoofdstuk is het aansprakelijkheidsrecht geanalyseerd. Daarbij lag de nadruk op de vraag welke aansprakelijkheidsregel de automobilist en de fietser kan aanzetten tot een optimaal zorg- en activiteitsniveau. In dat kader is geconcludeerd dat het sterk afhangt van de omstandigheden aan welke aansprakelijkheidsregel de voorkeur wordt gegeven. Verder stond binnen de analyse van het aansprakelijkheidsrecht met name de preventiedoelstelling centraal, terwijl in het kader van de probleemstelling ook de vraag dient te worden beantwoord in hoeverre aansprakelijkheidsregels tot een optimale compensatie van verkeersslachtoffers kunnen leiden. In hoofdstuk 4 is dit uitgewerkt aan de hand van het door Calabresi gemaakte onderscheid in ongevalskosten. ${ }^{727}$ Dit onderscheid heeft betrekking op de primaire ongevalskosten, die verband houden met preventie, de secundaire ongevalskosten, die zien op een optmale spreiding van de schade en de tertiaire kosten die samenhangen met de administratieve kosten van een bepaald aansprakelijkheidsregime.

In deze slotparagraaf zal derhalve aan de hand van het onderscheid in ongevalskosten worden nagegaan welke aansprakelijkheidsregel, risicoaansprakelijkheid met een absoluut eigen schuldverweer of een gewone foutaansprakelijkheid, ${ }^{728}$ in theorie tot een optimale preventie en compensatie kan leiden, rekening houdend met de administratieve kosten. Daarnaast gaat het om de theoretische vraag waar de minimalisering van de som van deze ongevalskosten kan worden gevonden.

\subsection{PRIMAIRE ONGEVALSKOSTEN}

In dit hoofdstuk is, als gezegd, vooral uitgegaan van de preventieve werking van aansprakelijkheidsregels. Deze doelstelling stemt overeen met de minimalisering

726. Zie C.C. van Dam, Zorgvuldigheidsnorm en ansprakelijkheid, p. 216-219; C.C. van Dam, Kwartaalbericht Nieuw BW, 1990, p. 94; Faure en Van den Bergh, RW, 1987-1988, p. 1118 ; Mackaay, NJB, 1980, p. 816.

727. Calabresi, Costs of Accidents, p. 24-31. Zie paragraaf 2.2 van hoofdstuk 4.

728. In een eerdere fase van de analyse is gesteld dat de toevoeging van een absoluut of gradueel eigen schuldverweer aan een regel van foutaansprakelijkheid en een gradueel eigen schuldverweer aan een regel van risicoaansprakelijkheid economisch gezien geen additionele bijdrage levert $2 a n$ de prikkels van zorg bij de autobestuurder en de fietser ten opzichte van de hier genoende aansprakelijkheidsregels. Zie paragraaf 8.2 van dit hoofdstuk. 
van de primaire ongevalskosten, die ook wel worden omschreven als de som van de ongevalskosten en de kosten om ongevallen te voorkomen. ${ }^{729}$

Binnen het kader van deze preventiedoelstelling van verkeersongevallen, kan worden gesteld dat een regel van risicoaansprakelijkheid de voorkeur heeft wanneer het van belang is om het gedrag van de automobilist te controleren. Een ander argument voor een risicoaansprakelijkheid is mogelijk het gevaar dat het rijden met een auto meebrengt. De automobilist wordt hierbij aangezet tot een optimaal zorg- en activiteitsniveau.

In het bilaterale model van het verkeersongevallenrecht wordt echter ook belang gehecht aan de rol van de fietser. Dit betekent dat de toevoeging van een absoluut eigen schuldverweer, waarbij de aansprakelijkheid van de automobilist geheel vervalt indien de fietser de zorgvuldigheidsnorm niet naleeft, nodig is om de fietser aan te zetten tot een optimaal zorgniveau. Het nadeel van een absoluut eigen schuldverweer is echter dat de fietser geen prikkel heeft om een optimaal activiteitsniveau aan te wenden. Wanneer de rechter echter in staat is om tegen lage kosten te differentiëren naar zorgniveaus of een strenge algemene zorgvuldigheidsnorm formuleert, kunnen bepaalde fietsers worden gedwongen hun activiteit te wijzigen.

Wanneer het maatschappelijk gezien belangrijker is om het gedrag van de fietser te controleren, zal een gewone regel van foutaansprakelijkheid efficiënt kunnen zijn. Deze aansprakelijkheidsregel zal de automobilist aanzetten tot een optimaal zorgniveau en de fietser tot zowel een optimaal zorg-als activiteitsniveau. Het nadeel van een gewone regel van foutaansprakelijkheid is dat de automobilist,bij naleving van de zorgvuldigheidsnorm, geen optimaal activiteitsniveau zal uitoefenen.

Naar aanleiding van het voorgaande kan worden geconcludeerd dat voor wat betreft de vermindering van de primaire ongevalskosten geen definitieve keuze kan worden gemaakt tussen een risicoaansprakelijkheid met een absoluut eigen schuldverweer en een gewone foutaansprakelijkheid. De eerste aansprakelijkheidsregel zal een lichte voorkeur genieten, wanneer het vanuit maatschappelijk oogpunt belangrijker wordt gevonden om de gevaren van het autoverkeer te sturen, dan dat de fietser wordt aangezet tot een optimaal activiteitsniveau.

\subsection{SECUNDAIRE ONGEVALSKOSTEN}

Een tweede element binnen de minimalisering van de totale maatschappelijke ongevalskosten heeft betrekking op de optimale spreiding van de schade, waarvan de compensatie van het verkeersslachtoffer een onderdeel vormt. In deze paragraaf zal

729. Zie Calbresi, YLJ, 1975, p. 656 , 
derhalve de minimalisering van de secundaire ongevalskosten in verband met de preventie van aansprakelijkheidsregels aan de orde komen. In dat kader zal achtereenvolgens aandacht worden besteed aan de optimale compensatie van het slachtof. fer, de insolventie bij de dader en de distributionele gevolgen van de keuze voor een bepaalde aansprakelijkheidsregel. Daarbij geldt nog steeds de veronderstelling dat de aanwezigheid van een verzekering geen rol speelt.

\subsubsection{Optimale compensatie van het verkeersslachtoffer}

Een regel van risicoaansprakelijkheid zal aan de automobilist prikkels geven tot een optimaal zorg- en activiteitsniveau en het slachtoffer een integrale vergoeding van zijn schade kunnen garanderen. De toevoeging van een absoluut eigen schuldverweer is echter nodig om de fietser niet enkel aan te zetten tot optimaal zorgniveau, maar ook tot inspanningen om zijn schade zoveel mogelijk te beperken wanneer zich een ongeval heeft voorgedaan. ${ }^{730}$

Een gewone regel van foutaansprakelijkheid heeft het nadeel dat het verkeersslachtoffer niet in alle gevallen zijn schade vergoed krijgt. Wanneer de automobilist bij deze regel de zorgvuldigheidsnorm in acht heeft genomen, zal hij, mits de rechter volledig is geïnformeerd omtrent de zorgstandaard, van aansprakelijkheid en derhalve van het betalen van schadevergoeding zijn bevrijd. De fietser zal, wetende dat hij nu geen vergoeding ontvangt, optimale prikkels hebben tot het volgen van een optimaal zorgniveau en tot een beperking van zijn schade. Vanuit het oogpunt van compensatie geldt derhalve dat een risicoaansprakelijkheid met een absoluut eigen schuldverweer eerder een vergoeding van de schade aan het slachtoffer kan garanderen dan een gewone regel van foutaansprakelijkheid.

\subsubsection{De invloed van insolvabiliteit van de automobilist op de preventie}

Hiervoor is uitgegaan van de veronderstelling dat de automobilist de schade van het slachtoffer integraal kan vergoeden. Er kan echter sprake zijn van insolventie aan de zijde van de automobilist, waardoor hij niet aan zijn vergoedingsplicht kan voldoen. Deze onvermogendheid bij de automobilist zal, afhankelijk van de omvang van de schade en het type aansprakelijkheid, een negatieve invloed kunnen hebben op de prikkels van zorg. De automobilist zal bij insolventie de omvang van de aansprakelijkheid die zijn vermogen te boven gaat gelijk stellen met de aansprakelijkheid die met zijn vermogen overeenkomt. Wanneer de automobilist met een vermogen van 3.000 , aansprakelijk wordt gehouden voor een schade van 10.000 , zal hij dit bedrag van een gelijk niveau beschouwen als zijn vermogen van 3.000. Dit zal tot gevolg

730. Zie Shavell, Accident Law, p. 144-146 over de mogelijkheden tot beperking van de schade aan de zijde van het slachtoffer. 
hebben dat de automobilist enerzijds een te hoog activiteitsniveau uitoefent en anderzijds te weinig prikkels van zorg heeft. ${ }^{731}$

Veronderstel dat de kans op een ongeval met een verwachte schade van 100 kan worden gereduceerd van $25 \%$ naar $15 \%$. Indien de kosten van zorg 5 eenheden bedragen, zal het aanwenden van zorg voor de automobilist optimaal zijn. De marginale opbrengst van de uitoefening van zorg $(25-15=10)$ is immers hoger dan de marginale kosten (5). Bij een regel van risicoaansprakelijkheid zal een automobilist met een lager vermogen dan 50 echter geen prikkel hebben om zorg uit te oefenen, omdat de marginale opbrengst $(12,5(25 \% \times 50)$ minus $7,5(15 \% \times 50)=5)$ bij dit vermogen gelijk is aan de marginale kosten (5).

Bij een gewone regel van foutaansprakelijkheid kan de automobilist aansprakelijkheid vermijden door het aanwenden van optimale zorg. In het gegeven voorbeeld zal de automobilist geen prikkel van zorg hebben wanneer zijn vermogen minder dan 20 bedraagt. Bij dit vermogen is de kans om aansprakelijk te worden gesteld in verhouding tot zijn vermogen $(25 \% \times 20=5)$ gelijk aan de kosten van zorg (5). Bij een gewone regel van foutaansprakelijkheid zal de automobilist bij een lager vermogen, evenals bij een regel van risicoaansprakelijkheid, derhalve een prikkel hebben om geen zorg aan te wenden. De automobilist heeft bij een gewone foutaansprakelijkheid een belangrijker argument om efficiënte zorg uit te oefenen. Daarmee kan hij immers geheel aan aansprakelijkheid ontsnappen. ${ }^{732}$

De insolventie aan de zijde van de automobilist heeft ook gevolgen voor zijn activiteitsniveau. Bij een gewone regel van foutaansprakelijkheid geldt, ook bij de afwezigheid van insolventie, dat de automobilist door het uitoefenen van optimale zorg van aansprakelijkheid is bevrijd, waardoor hij geen motief heeft om een optimaal activiteitsniveau aan te wenden. Wanneer de automobilist bij een regel van risicoaansprakelijkheid, gegeven de negatieve verhouding tussen zijn vermogen en de totale ongevalskosten, geen prikkel heeft om zorg uit te oefenen, zal hij ook geen optimaal activiteitsniveau aanwenden. De automobilist zal immers zijn activiteit opvoeren zolang zijn nut, in casu zijn vermogen, hoger is dan de som van de kosten van zorg en de verwachte ongevalskosten. ${ }^{733}$

Met betrekking tot de bovenbeschreven unilaterale ongevalssituatie kan derhalve worden gesteld dat bij insolventie van de autobestuurder een gewone regel van foutaansprakelijkheid op het terrein van de preventie tot een betere uitkomst leidt dan een regel van risicoaansprakelijkheid.

\footnotetext{
731. Shavell, IRLE, 1986, p. 45.

732. Zie hierover Shavell, Accident Law, p. 167-169; Landes and Posner, JLS, 1984, p. 421; Shavell, IRLE, 1986, p. 46-49; Beard, RJE, 1990, p. 626-634.

733. Landes and Posner, JLS, 1984, p. 422.
} 
De gevolgen van de insolventie bij de automobilist kunnen als volgt worden vertaald naar de positie van de fietser, in het bijzonder met betrekking tot de vergoeding van zijn schade. Bij een regel van risicoaansprakelijkheid met een absoluut eigen schuldverweer geldt dat de fietser, afhankelijk van het vermogen van de automobilist, vermoedelijk nog wel een deel van zijn schade vergoed krijgt, mits hijzelf aan de zorgvuldigheidsnorm heeft voldaan. De fietser zal derhalve een prikkel blijven behouden om zorg aan te wenden ten behoeve van een beperking van zijn verwachte schade. Bij een gewone regel van foutaansprakelijkheid zal de automobilist door naleving van de zorgvuldigheidsnorm van aansprakelijkheid zijn bevrijd. Dit betekent dat de fietser in een dergelijke situatie van een vergoeding van zijn schade blijft verstoken. Hij zal echter wel worden aangezet tot een optimaal zorgniveau om zijn verwachte schade zoveel mogelijk te vermijden.

\subsubsection{Distributionele gevolgen van de keuze voor een aansprakelijkheidsregel}

De keuze voor een risicoaansprakelijkheid met een absoluut eigen schuldverweer of een gewone regel van foutaansprakelijkheid is ook van invloed op de verdeling van inkomens bij de automobilist en de fietser. Deze distributionele gevolgen verschillen al naar gelang de uitgeoefende zorg door de automobilist en de fietser. Ten aanzien van een regel van risicoaansprakelijkheid met een absoluut eigen schuldverweer kan worden gesteld dat de schade in alle gevallen door de automobilist zal worden gedragen, tenzij de fietser minder dan de vereiste zorg heeft uitgeoefend. Bij een gewone regel van foutaansprakelijkheid geldt dat de fietser zijn eigen schade draagh, tenzij de automobilist, ongeacht het gedrag van de fietser, de zorgvuldigheidsnorm niet naleeft. Hieruit kan worden geconcludeerd dat een risicoaansprakelijkheid met een absoluut eigen schuldverweer op het terrein van de inkomensverdeling vooral in het voordeel van de fietser zal werken, wanneer hij ervan uit mag gaan dat hij in de meeste gevallen zijn schade krijgt vergoed. Bij een gewone foutaansprakelijkheid is dit omgekeerd, omdat de fietser, afhankelijk van het gedrag van de automobilist, veelal zijn eigen schade moet dragen. ${ }^{734}$

\subsection{TERTLAIRE (ADMINISTRATIEVE) ONGEVALSKOSTEN}

In het kader van de minimalisering van de totale maatschappelijke kosten van verkeersongevallen, zal in deze paragraaf worden onderzocht welke invloed de administratieve kosten in theorie hebben op de vermindering van de primaire en secundaire ongevalskosten en omgekeerd. Deze tertiaire kosten kunnen worden onderverdeeld in de kosten die verband houden met het aantal aansprakelijkheidsprocedures, en de informatiekosten die betrekking hebben op het onderzoek dat de rechter moet verrichten om tot een oordeel over de aansprakelijkheid te kunnen komen. 
Ten aanzien van de informatiekosten kan worden gesteld dat een gewone regel van foutaansprakelijkheid leidt tot hoge kosten omdat de rechter voor de automobilist moet onderzoeken in hoeverre de door hem uitgeoefende zorg overeenstemt met de zorgvuldigheidsnorm. Een regel van risicoaansprakelijkheid met een absoluut eigen schuldverweer heeft het voordeel dat een dergelijk onderzoek met betrekking tot het gedrag van de automobilist niet nodig is. Daartegenover staat dat de werkelijk uitgeoefende zorg van de fietser wel moet worden beoordeeld.

Met betrekking tot de omvang van de kosten van aansprakelijkheidsprocedures wordt in het economisch model gesteld dat een regel van risicoaansprakelijkheid met een absoluut eigen schuldverweer tot meer procedures aanleiding kan geven, aangezien mogelijk elk verkeersongeval tot een gang naar de rechter leidt. Bij een gewone regel van foutaansprakelijkheid zal alleen een procedure worden aangespannen, omdat de automobilist in beginsel minder dan de efficiënte zorg heeft aangewend. Tijdens een gerechtelijk geschil zal echter de bepaling van de zorgvuldigheidsnorm voor de automobilist en fietser kostenverhogend kunnen werken, terwijl dit bij een risicoaansprakelijkheid met een absoluut eigen schuldverweer alleen voor de uitgeoefende zorg van de fietser geldt. ${ }^{735}$

Samenvattend kan worden gesteld dat in theorie de toepassing van een regel van risicoaansprakelijkheid met een absoluut eigen schuldverweer tot meer rechtsgedingen leidt, terwijl bij een gewone regel van foutaansprakelijkheid de gemiddelde kosten per rechtszaak hoger zijn. ${ }^{736}$ Hieruit kan worden afgeleid dat, wanneer rekening wordt gehouden met de administratieve kosten, de keuze voor een bepaalde aansprakelijkheidsregel afhangt van de vraag welke kostenbesparing vanuit maatschappelijk oogpunt het meest gewenst is. Wanneer een groter belang wordt gehecht aan een besparing op de informatiekosten zal de voorkeur uitgaan naar een regel van risicoaansprakelijkheid met een absoluut eigen schuldverweer; een gewone regel van foutaansprakelijkheid zal prevaleren wanneer de minimalisering van de gerechtskosten als doelstelling wordt gehanteerd.

Met Shavell kan derhalve worden gesteld dat:

'In sum, then, the comparison of the size of administrative costs under the two forms of liability is ambiguous as a theoretical matter'. ${ }^{737}$

735. Faure en Van den Bergh, Objectieve aansprakelijkheid, p. 98-99; Landes and Posner, Economic Structure of Tort Law, p. 65-66; Landes and Posner, Georgia Law Review, 1981, p. 874-875; Cooter and Ulen, Law and Economics, p. 288-290; Polinsky, Introduction, p. 50-51.

736. Shavell, Accident Law, p. 264.

737. Shavell, Accident Law, p. 264. 


\subsection{SLOTBESCHOUWINGEN}

Resumerend kan worden gesteld dat het sterk van de omstandigheden afhangt of een voorkeur wordt uitgesproken voor een gewone foutaansprakelijkheid dan wel een risicoaansprakelijkheid met een absoluut eigen schuldverweer. In het kader van de primaire ongevalskosten is, uitgaande van de opvatting dat een groter belang word gehecht aan de controle van de gevaren van het autoverkeer dan van het fietsverkeer, een lichte voorkeur gegeven aan een risicoaansprakelijkheid met een absoluut eigen schuldverweer. De combinatie van de primaire en de secundaire ongevalskosten heeft geleerd dat een gewone regel van foutaansprakelijkheid de automobilist en de fietser meer zal aanzetten tot een optimaal zorgniveau, terwijl de compensatie van de fietser bij een risicoaansprakelijkheid met een absoluut eigen schuldverweer beter is gegarandeerd dan bij een gewone regel van foutaansprakelijkheid. Ten aanzien van de tertiaire kosten geldt dat voor wat betreft de vermindering van de kosten van aansprakelijkheidsprocedures een gewone regel van foutaansprakelijkheid de voorkeur heeft, terwijl ten behoeve van een reductie van de informatiekosten een regel van risicoaansprakelijkheid met een absoluut eigen schuldverweer tot een betere uitkomst leidt dan een gewone regel van foutaansprakelijkheid. De administratieve kosten kunnen overigens bij een gewone regel van foutaansprakelijkheid lager zijn dan bij een risicoaansprakelijkheid met een absoluut eigen schuldverweer. Dit is het geval wanneer in het kader van de distributionele gevolgen wordt uitgegaan van de veronderstelling dat de fietser bij een gewone foutaansprakelijkheid in de meeste gevallen zijn eigen schade moet dragen, omdat de automobilist voldoet aan de zorgvuldigheidsnorm, waardoor er weinig verplaatsing van schade zal plaatshebben, ${ }^{738}$

De conclusies ten aanzien van de economische analyse van het aansprakelijkheidsrecht hebben nog een voorlopig karakter. Met name ten aanzien van de administratieve kosten, de insolventie van de automobilist en de distributionele gevolgen van aansprakelijkheid is verondersteld dat de aanwezigheid van een verzekering geen rol speelt. In het volgende hoofdstuk zal daarom de economische analyse van het verkeersongevallenrecht worden uitgebreid met een tweede juridisch instrument, namelijk de verzekering.

738. Zie Calabresi, YLJ, 1975, p. 666, noot 22. 


\section{Hoofdstuk 6: De economische analyse van risico en verzekering en andere compensatie- mechanismen}

\section{Inleiding}

In het vorige hoofdstuk is een economische analyse van het aansprakelijkheidsrecht gegeven. Daanuit is naar voren gekomen dat een risicoaansprakelijkheid met een absoluut eigen schuldverweer en een gewone foutaansprakelijkheid niet tot een optimale preventie en compensatie van verkeersongevallen leiden. Binnen de analyse van het aansprakelijkheidsrecht is verondersteld dat dader en slachtoffer ongevoelig zijn voor het ongevalsrisico. Wanneer deze veronderstelling van risiconeutraliteit wordt genuanceerd, zal moeten worden onderzocht op welke wijze partijen kunnen worden beschermd tegen de risico's van het ontstaan en de gevolgen van een ongeval. Daarnaast moeten dader en slachtoffer hun risico kunnen afwentelen op een derde. Dit kan onder andere door middel van het afsluiten van een verzekeringsovereenkomst. In dit hoofdstuk wordt daarom het tweede juridische instrument, namelijk de verzekering, binnen de economische analyse geïntroduceerd. Daarbij zal de vraag centraal staan welke invloed de verzekeringsovereenkomst kan hebben op het gedrag van de verkeersdeelnemer en op de efficiëntie van aansprakelijkheidsregels. ${ }^{739}$

In paragraaf $2 \mathrm{zal}$, in de veronderstelling van de afwezigheid van een verzekering, worden ingegaan op de economische analyse van risico. Daarbij zal worden nagegaan welke houding een individu ten opzichte van het risico kan hebben en zal worden ingegaan op de vraag op welke wijze hij dit risico kan afschuiven wanneer er geen mogelijkheid tot verzekeren zou bestaan.

In paragraaf 3 wordt, in het kader van de economische theorie van verzekering, de vraag beantwoord waarom individuen zich verzekeren en welke positieve en negatieve effecten de aanwezigheid van een verzekering mee kan brengen. Vervolgens $\mathrm{zal}$ in het kort het belang van een optimaal functionerende verzekeringsmarkt worden geschetst, waama een overzicht zal worden gegeven van de verschillende soorten verzekeringen.

739. De economische analyse van risico en verzekering is onder andere uitgewerk! door: Faurc en Van den Bergh, Objectieve aansprakelijkheid, p. 101-141; Shavell, Accident Law, p. 186-245; Polinsky, Introduction, p. 53-58 en 67-74; C.C. van Dam, Zorgvuldigheidsnorm en aansprakelijkheid, diss., p. 205-245; Faure en Van den Bergh, preadvies, 1990, p. 16-47; Endres, Okonomische Grundlagen des Haftungsrecht, p. 174-190. Daarnaast zal gebruik worden gemaakt van aanverwante artikelen die bepaalde declonderwerpen binnen de econornische analyse van verzekering verder uitdiepen. 
In paragraaf $4 \mathrm{zal}$ worden ingegaan op een tweetal informatieproblemen, die binnen de economische theorie van verzekering een belangrijke rol spelen, namelijk 'moral hazard' en 'anti-selection'. Naast een omschrijving van deze begrippen bevat deze paragraaf een mogelijk antwoord op de vraag welke preventieve instrumenten een verzekeraar heeft om deze informatieproblemen te beperken.

In paragraaf 5 staat de regulering van verzekeringsmarkten centraal. Daarbij zullen onder andere de theorie van de verplichte verzekering en de wettelijke beperking van de aansprakelijkheid aan de orde komen. Vervolgens zal in het kader van de economische analyse van verzekeringsmarkten aandacht worden besteed aan het belang van concurrentie respectievelijk de economische gevolgen van een concentratie op de verzekeringsmarkt.

In paragraaf 6 wordt een theoretische analyse van alternatieve compensatiemechanismen gepresenteerd. Daarbij zal de aandacht uitgaan naar een schadefonds voor slachtoffers van een ongeval en naar de zogenaamde no-fault verzekering die sinds de jaren ' 70 van de vorige eeuw in met name Noord-Amerika opgeld doet.

In paragraaf 7 zal worden teruggekoppeld naar hoofdstuk 5 en wordt de vraag beantwoord of de conclusies ten aanzien van de economische analyse van het aansprakelijkheidsrecht onder invloed van de aanwezigheid van een verzekering moeten worden gewijzigd. Daarbij zal blijken dat de keuze voor een bepaalde aansprakelijkheidsregel mede van invloed is op de aanwezigheid van verschillende soorten verzekering. In de woorden van Shavell:

'The allocation of risk associated with the use of a liability rule depends on insurance coverage, and the latter depends on the liability rule since the rule determines in part the risks parties face. ${ }^{740}$

In paragraaf 8 volgt tenslotte een algehele conclusie van de economische analyse van aansprakelijkheid en verzekering in het licht van de centrale probleemstelling. Daarbij wordt de vraag wordt beantwoord welke combinatie van aansprakelijkheid en verzekering kan leiden tot een vermindering van de primaire, secundaire en tertiaire ongevalskosten.

740. Shavell, BJE, 1982, p. 120. 


\section{De economische analyse van risico}

\subsection{DE HOUDING VAN PARTIJEN TEN AANZIEN VAN RISICO}

Binnen de economische analyse van het aansprakelijkheidsrecht is onder andere uitgegaan van de veronderstelling dat dader en slachtoffer neutraal staan ten opzichte van het ongevalsrisico. In werkelijkheid zal een individu zich echter willen beschermen tegen bepaalde gevaren. Ten aanzien van de risico's in het verkeer kan bijvoorbeeld worden gesteld dat een fietser niet zonder links of rechts te kijken een drukke verkeersweg zal oversteken. Een fietser zal trachten te voorkomen dat hij door een auto wordt aangereden. Een automobilist zal zich eveneens bewust kunnen zijn van het ongevalsrisico, wanneer hij bij dichte mist of gladheid zijn snelheid aanpast aan de omstandigheden. Dit betekent dat ten aanzien van het verkeersongevallenrecht kan worden verondersteld dat een fietser en een automobilist een afkeer hebben van risico, ofwel risicoalvers zijn. Naast deze risiconeutraliteit en risicoaversie wordt in de economische analyse een derde vorm onderscheiden. Deze kan het best worden omschreven als een houding, waarbij een individu een voorkeur heeft voor risico. ${ }^{741}$

Met behulp van een eenvoudig voorbeeld kunnen de verschillende vormen van risico worden toegelicht. Daarbij heeft een individu een keuze uit de volgende situaties:

1. er is een kans van $10 \%$ op een schade van 1.000 gulden;

2. een kans van $25 \%$ op een schade van 400 ; en

3. zekerheid op een schade van 100 .

In al deze gevallen bedraagt de verwachte schade (p.S) 100 . Voor iemand die risiconeutraal is zal het niet uitmaken welke situatie zich zal voordoen. Een persoon die graag een gokje waagt en derhalve risicozoekend is, zal kiezen voor de eerste mogelijkheid. Een individu die een afkeer heeft van risico zal daarentegen de voorkeur geven aan de $100 \%$ zekerheid op een lagere schade van 100 .

De houding die partijen ten aanzien van risico innemen, wordt verder bepaald door de absolute waarde van het risico. Bij de eerste situatie geldt dat de waarschijnlijkheid op een schade van 1000,1 bedraagt, bij de tweede 0,25 en bij de derde situatie 1 . Hoe hoger de absolute waarde van het risico, hoe eerder een risicoavers

741. Gesteld kan worden dat het hier beschreven onderscheid in de houding ten aanzien van risico vrij absoluut is. Daarbinnen zijn allerlei gradaties mogelijk, zoals lichte voorkeur c.q. afkeer, sterke voorkeur c.q. sterke afkeer, maar deze zullen hier zoveel mogelijk buiten beschouwing blijven. 
persoon derhalve zal kiezen voor de met deze hoge waarde overeenstemmende schade. $^{742}$

Ten aanzien van de gevaren in het verkeer is gesteld dat een gemiddelde verkeersdeelnemer een afkeer zal hebben van het risico op een verkeersongeval. Daarbij kan echter worden gesteld dat een individu reeds een bepaald risico neemt door aan het verkeer deel te nemen, waarmee hij in zekere zin een risiconeutrale of zelfs een risicozoekende houding kan aannemen. Risiconeutraal kan daarbij verwijzen naar het gegeven dat een verkeersdeelnemer zich wel bewust is van de gevaren van het verkeer, maar neutraal staat ten aanzien van de kans dat hij bij een verkeersongeval betrokken zal raken. Een verkeersdeelnemer die het risico min of meer bewust opzoekh is bijvoorbeeld de fietser die zonder naar links of naar rechts te kijken een drukke verkeersweg oversteekt of de automobilist die bij dichte mist een hoge snelheid blijf aanhouden.

Het belang van de bovenbeschreven vormen van risico in het verkeer ligt met name bij de vraag in hoeverre een verkeersdeelnemer bereid is het risico van verkeersdeelname al dan niet bewust zelf te dragen (risiconeutraal of risicovoorkeur), of dat hij alleen aan het verkeer wil deelnemen op voorwaarde dat voor hem het risico op een ongeval zoveel mogelijk wordt gereduceerd (risicoavers). Wanneer wordt uitgegaan van de veronderstelling dat een verkeersdeelnemer een afkeer heeft van risico, zal de vraag moeten worden beantwoord op welke wijze een verkeersdeelnemer het ongevalsrisico kan verminderen. Hij zal trachten het risico op de een of andere wijze af te schuiven, hetzij op een andere persoon, hetzij op een verzekeraar. De eerste mogelijkheid zal in de volgende subparagraaf worden besproken, de tweede optie zal vanaf paragraaf 3 worden geanalyseerd.

\subsection{HET AFWENTELEN VAN RISICO}

Naar aanleiding van het voorgaande kan worden gesteld dat met name een individu met een afkeer van risico belang zal hechten aan de vraag of hij een bepaald risico

742. Zie voor een mathematische uitenzetting van de risicotheorie onder anderen: Shavell, Accident Law, p. 186-190; Faure en Van den Bergh, Objectieve aansprakelijkheid, p. 103-108; Polinsly, Introduction, p. 53-55; K.J. Arrow, Aspects of the Theory of Risk-Bearing, p. 28-34. De auturs leggen bij hun bespreking van de verschillende vormen van risico een verband tussen het nut th het vermogen van een individu bij de verschillende vormen van risico. Uitgaande van de veronderstelling dat bij een toename van het vermogen het marginale nut zal afnemen, wordt onder. zocht hoe een individu zich in het kader van deze veronderstelling ten opzichte van het risicozl gedragen. Daarbij wordt aangetoond dat een individu bij een afnemend marginaal nut en ean stijgende welvaart een afkeer heeft van risico. Verder wordt gesteld dat een risicoavers individu die streeft naar nutsmaximalisatie de situatie zal verkiezen die hem de hoogst mogelijke zekr. heid verschaft. Ten aanzien van een risicoavers individu geldt dat het verwacht nut van zekerheid boven onzekerheid groter is. Zie ook Holzhauer en Teijl, Inleiding rechtseconomie, p. 148-153. 
kan afschuiven op een derde. In deze paragraaf zal daartoe een aantal theoretische mogelijkheden worden besproken, waarbij vooralsnog de eventuele aanwezigheid van een verzekering buiten beschouwing wordt gelaten.

Een individu kan door middel van bepaalde voorzorgsmaatregelen het risico reduceren. Het risico op een uitslaande brand kan bijvoorbeeld worden verminderd met het aanbrengen van niet-brandbaar materiaal of door de aanwezigheid van een brandblusser. Het risico op een verkeersongeval kan bijvoorbeeld worden weggenomen, wanneer in het geheel niet aan het verkeer wordt deelgenomen. In het vorige hoofdstuk is in dat kader aangetoond dat een automobilist voor wie de zorgvuldigheidsnorm te strikt is, kan worden gedwongen om zijn activiteit te wijzigen en bijvoorbeeld gebruik te maken van het openbaar vervoer. ${ }^{743}$ Wanneer toch aan het verkeer wordt deelgenomen, kan het ongevalsrisico worden verminderd door bijvoorbeeld als fietser eerst naar links en rechts te kijken alvorens een drukke verkeersweg over te steken.

Naast het treffen van bepaalde voorzorgsmaatregelen ten behoeve van een reductie van het ongevalsrisico, kan het individuele risico ook worden gespreid of verschoven naar andere individuen. Daarbij geldt het uitgangspunt dat, bij een gelijkblijvend individueel vermogen, een verschuiving van het risico kan leiden tot een verhoging van de maatschappelijke welvaart. Dit laatste kan gelden wanneer bijvoorbeeld een risicoavers individu het risico kan afwentelen op een risiconeutraal persoon of een persoon die minder risicoavers is. Dit kan met behulp van een voorbeeld worden geillustreerd.

Wanneer een risicoavers persoon (A) een kans loopt van $10 \%$ op een schade van 1.000 , zal hij bijvoorbeeld 100 kunnen betalen aan een risiconeutraal persoon $B$ die misschien beter in staat is om het risico te dragen. Voor persoon A betekent deze betaling dat het risico van $10 \%$ wordt omgezet in een zekerheid dat hij geen schade zal lijden, waarbij tevens zijn nut kan worden verhoogd. Voor de risiconeutrale persoon $B$ heeft deze transactie geen negatieve gevolgen, omdat het voor hem geen verschil maakt of hij 100 gulden ontvangt of dat ook hij $10 \%$ kans loopt op een schade van 1.000. Een dergelijke overeenkomst, waarbij een verschuiving van het risico van $A$ naar $B$ plaatsheeft, kan derhalve leiden tot een verhoging van de maatschappelijke welvaart. Een verdere welvaartstijging kan worden bereikt wanneer A bijvoorbeeld 110 aan B betaalt. Het nut van A zal daarbij nog immer hoger zijn dan wanneer hij zelf bloot zou staan aan het risico. Voor B leidt deze transactie tot een voordeel van 10.

743. Zie paragraaf 9.2 van hoofdstuk 5. 
Naast deze verschuiving zal ook een spreiding van het risico tot een stijging van de maatschappelijke welvaart kunnen leiden. Wanneer persoon A en persoon B beide risicoavers zijn en B neemt geen deel aan een risicovolle activiteit, zal een verdeling van het risico over beide partijen de maatschappelijke welvaart kunnen verhogen. De spreiding van het risico kan daarnaast de omvang van de schade, waaraan persoon B anders bloot zou staan, reduceren. ${ }^{744}$

Behalve een verhoging van de maatschappelijke welvaart kan een spreiding of een verschuiving van het risico ook voorkomen dat een risicoavers individu niet aan een maatschappelijk wenselijke, maar risicovolle, activiteit deelneemt. Een persoon die als gevolg van zijn afkeer van risico bijvoorbeeld in het geheel niet aan het verkeer wenst deel te nemen kan, door middel van een verschuiving of een spreiding van zijn risico, ervan worden weerhouden binnen te blijven.

\section{De economische analyse van verzekering}

\subsection{INLEIDING}

In de vorige paragraaf is uiteengezet welke theoretische mogelijkheden een risicoavers individu heeft om zijn risico te verminderen, te verschuiven of te spreiden. Daarbij is gebleken dat de maatschappelijke welvaart kan worden verhoogd, wanneer een risicoavers persoon bereid is tegen betaling het risico over te dragen op een ander persoon die risiconeutraal is of minder afkerig staat ten opzichte van het risco. In de economische analyse van het ongevallenrecht betekent een dergelijke transactie dat een risicoavers persoon zijn economisch nut zal willen maximaliseren door middel van het afsluiten van een verzekeringsovereenkomst, waarbij een verzekeraar tegen betaling van een som geld (premie) bereid is het risico van de verzekerde over te nemen. Arrow omschrijft een verzekeringscontract als volgt:

'It is an exchange of money now for money payable contingent on the occurrence of certain events' ${ }^{745}$

Een verzekering is derhalve een overeenkomst, waarbij de verzekerde een bedrag aan premie aan de verzekeraar betaalt, in ruil waarvoor hij bescherming ontvangt te-

744. Zie Faure en Van den Bergh, Objectieve aansprakelijkheid, p. 109-111; Shavell, Accident Lat. p. 190-191; Polinsky, Introduction, p. 53-55; Van Velthoven en Van Wijck, Recht en efficiëntie. p. $46-48$.

745. Arrow, Aspects of the Theory of Risk-Bearing, p. 45. Arrow stelt op p. 29 verder, met een vior. beeld uit de effectenhandel, dat het feit dat mensen zich verzekeren op zichzelf reeds een bevertiging is van het vermoeden van risicoaversie. De massale aanwezigheid van, al dan niet rerplichte, verzekeringen in het verkeer, heeft mogelijk ook te maken met een vermoeden van ristcoaversie aan de zijde van de verkeersdeelnemer. 
gen toekomstige schade, die tengevolge van een ongeval zou kunnen ontstaan. Uit dit laatste kan worden opgemaakt dat het gaat om de kans dat zich een ongeval zal yoordoen. Priest stelt:

'Insurance requires that the loss be probabilistic, either as to whether or not it occurs at all or as to when the loss occurs'. ${ }^{746}$

Bij de economische analyse van de verzekering, die hierna centraal staat, zal in een eerste fase worden uitgegaan van de ideale situatie, waarin aan een risicoavers individu een nutsmaximaliserende verzekeringspolis wordt aangeboden. Een dergelijke optimale verzekeringsovereenkomst is van toepassing indien aan de volgende voorwaarden wordt voldaan:

- Op de verzekeringsmarkt is sprake van een optimale concurrentie, opdat de verzekerden bij aankoop kunnen kiezen uit verschillende verzekeringspolissen. ${ }^{747}$

- De verzekeraar beschikt over voldoende informatie omtrent de te verzekeren risico's, waardoor hij in staat is het gedrag van de verzekerde optimaal te controleren.

- De verzekeraar verleent een volledige dekking tegen een actuarieel juiste premie. Dit houdt in dat de verzekeraar een bedrag aan premie vaststelt dat overeenkomt met de verwachte ongevalskosten en waarbij deze premie een juiste afspiegeling vormt van het individuele ongevalsrisico. Wanneer een verzekerde bijvoorbeeld $5 \%$ kans loopt op een schade van 1.000, zal in de ideale situatie de actuarieel juiste premie 50 bedragen. ${ }^{748}$

- De verzekerde kan geen invloed uitoefenen op het ongevalsrisico. Een voorbeeld hiervan is de schade die ontstaat door factoren van buitenaf waarop de verzekerde geen invloed heeft, zoals bij een orkaan of een zware storm. Het gegeven dat een persoon tegen deze risico's is verzekerd verandert vrijwel niets aan de mogelijkheid dat zich een dergelijk onverwacht risico voordoet.

In al deze gevallen is het efficiënt wanneer de verzekeringspolis volledige dekking biedt. $\mathrm{Bij}$ een minder dan volledige dekking zal een risicoavers persoon immers onvoldoende bescherming krijgen tegen het risico dat hij juist zou willen vermijden. Meer dan volledige dekking zal in deze gevallen ook niet optimaal zijn. De verzekerde zal dan een hogere premie moeten betalen voor een verzekerde som die hoger ligt dan de werkelijk te verwachten schade. Voor een risicoavers persoon die bij-

\footnotetext{
746. Zie Priest, YLJ, 1987, p. 1539-1540.

747. Zie Shavell, Accident Law, p. 197. In pragraaf 5 zal het belang van concurrentie op de verzekeringsmarkt worden toegelicht.

748. Zie Faure en Van den Bergh, Objectieve aansprakelijkheid, p. 112; Shavell, Accident Law, p. 192; Priest, YLJ, 1987, 1540; Holzhauer en Teijl, Inleiding rechtseconomie, p. 153-156.
} 
voorbeeld $5 \%$ kans loopt op een schade van 1.000 (premie 50), zal een dekking van 1.500 tegen een bijbehorende premie van 75 niet optimaal zijn. ${ }^{749}$

Een positief effect van de aanwezigheid van een verzekering ligt derhalve in het ge. geven dat een risicoavers persoon zijn risico kan afschuiven op een verzekeraar, waarmee, op grond van de genoemde voorwaarden, een verhoging van de maat. schappelijke welvaart kan worden bereikt.

In werkelijkheid echter zal, mede als gevolg van bepaalde informatieproblemen, veelal geen sprake zijn van een ideale verzekeringssituatie. Een verzekeraar zal bij het vaststellen van de premie rekening moeten houden met factoren die tot gevolg kunnen hebben dat de premie hoger uitvalt dan de actuarieel juiste premie. In de eer. ste plaats geldt dat een verzekeraar ook een zekere afkeer van risico heeft. In de tweede plaats zijn er administratieve kosten. In de derde plaats zal een verzekeraar een reserve-kapitaal moeten vormen, omdat de premie-inkomsten niet altijd gelijk zijn aan de schade-uitkeringen. In de vierde plaats zal een verzekeraar de verwachte schade slechts kunnen vergoeden wanneer een voldoende aantal personen zich bij een verzekeraar aansluit, zodat de premie-inkomsten voldoende zijn om de schade te vergoeden. Echter, het afsluiten van een groot aantal verzekeringscontracten brengt ook hoge transactiekosten mee. In de vijfde plaats zal erover gewaakt dienen te worden dat de concurrentie op de verzekeringsmarkt te beperkt wordt, hetgeen kan leiden tot een verdere verhoging van de werkelijke premie ten opzichte van de actuarieel juiste premie. ${ }^{750}$

Wanneer derhalve de totale administratieve kosten te veel stijgen, waardoor de voordelen van risicospreiding niet meer opwegen tegen de transactiekosten, zal het aanbieden van een verzekering niet meer optimaal zijn. In dit hoofdstuk zal echter vooralsnog worden uitgegaan van een volkomen concurrerende verzekeringsmarkt: er zijn geen transactiekosten en de verzekeraar kan, door het aanbieden van een premie die overeenstemt met de verwachte ongevalskosten, een optimale dekking van zijn kosten bereiken.

Een andere nuancering van de ideale verzekeringssituatie hangt samen met het gegeven dat een verzekeraar vaak niet over volledige informatie beschikt omtrent de

749. Zie Shavell, Accident Law, p. 193-194; Faure en Van den Bergh, Objectieve aansprakelijkheid, p. 111-113. Zij tonen met behulp van een vergelijking tussen het individuele nut en het individu. ele inkomen aan dat een risicoaverse verzekerde het hoogste nut geniet wanneer hij voor onvoorzienbare risico's een volledige dekking ontvangt. Zie ook Van Velthoven en Van Wijck, Recht en efficiëntie, p. 48-49.

750. Arrow, Am. Econ. Rev., 1963, p. 960. Zie ook Faure en Van den Bergh, Objectieve aansprakelijkheid, p. 112; Shavell, Accident Law, p. 192; Priest, YLJ, 1987, p. 1540. Naast de hier ge noemde 'loading costs' zal een verzekeraar mogelijk ook rekening houden met een winstmarge die het verschil tussen de werkelijke premie en de actuarieel juiste premie verder zal verhogen. 
bij de verzekering aangesloten risico's. Een verzekerde weet bijvoorbeeld in veel gevallen vaak meer over de invloed die hij op het risico kan uitoefenen dan zijn verzekeraar. Wanneer in een dergelijke situatie een volledige dekking beschikbaar is, zal de verzekerde mogelijk geen prikkel hebben om het ongevalsrisico te reduceren. Dit kan leiden tot negatieve effecten, zoals morele risico en anti-selectie. Deze informatieproblemen, die mede verband houden met het gedrag van de verzekerde, zullen in paragraaf 4 worden geanalyseerd. ${ }^{751}$

\subsection{DE VERSCHILLENDE VORMEN VAN VERZEKERING}

In deze subparagraaf zullen de belangrijkste vormen van verzekering worden genoemd, die in de praktijk van het verkeersongevallenrecht een rol spelen. Daarbij kan globaal een onderscheid worden gemaakt tussen een eerste-partij verzekering ('first party insurance') en een derde-partij verzekering ('third party insurance').

De 'first party insurance' heeft betrekking op een verzekering aan de zijde van de dader of het slachtoffer zelf. Dit kan in de eerste plaats een schadeverzekering zijn, die de schade tegen bijvoorbeeld brand of diefstal dekt. In de tweede plaats kan door het slachtoffer een volksverzekering of een sociale verzekering worden afgesloten. Deze verzekering geeft bijvoorbeeld dekking tegen ziektekosten, inkomstenderving en andere vormen van letselschade die ten gevolge van een verkeersongeval kunnen ontstaan.

De 'third party insurance' dekt het risico dat de schadeveroorzaker voor de schade van derden dient op te komen. Deze verzekering heeft over het algemeen de vorm van een aansprakelijkheidsverzekering, waarmee de aansprakelijkheid voor de schade die de veroorzaker aan een derde (het slachtoffer) heeft toegebracht wordt gedekt. Een andere vorm van een derde-partij verzekering is de zogenaamde schadeverzekering voor inzittenden, die door de bestuurder of eigenaar van een motorrijtuig wordt afgesloten. Deze verzekering keert, ingeval van letsel dat is veroorzaakt door een verkeersongeval, een vooraf vastgesteld bedrag aan de benadeelde inzittenden uit, ongeacht de aansprakelijkheid en de omvang van de schade. ${ }^{752}$

\footnotetext{
751. Faure en Van den Bergh, Objectieve aansprakelijkheid, p. 102-103.

752. Zie C.C. van Dam, Zorgvuldigheidsnorm en aansprakelijkheid, p. 205-206; Hartlief en Tjittes, Preadvies, N.J.V., 1990, p. 58; Hartlief en Tjittes, Verzekering en aansprakelijkhcid, p. 114-119; Bouman en Van Wassenaer van Catwijck, VR, 1993, p. 221-227; Elzas, Handboek Schaderegeling Motorrijtuigen, 205-4a.
} 


\section{Informatieproblemen bij de aanwezigheid van een verzekering}

In deze paragraaf zal de, in het kader van de ideale verzekeringsovereenkomst, gemakkte veronderstelling dat een verzekerde geen invloed kan uitoefenen op het ongevalsrisico worden genuanceerd. In werkelijkheid zal een verzekerde bijvoorbeeld vaak beter op de hoogte zijn van het ongevalsrisico dan zijn verzekeraar. Dit brengt mee dat een verzekeraar met een tweetal informatieproblemen kan worden geconfronteerd, namelijk morele risico en anti-selectie. ${ }^{753}$

Het morele risico ('moral hazard') ziet op de situatie waarin een verzekeraar over onvoldoende informatie beschikt om het risico van de verzekerde juist in te schatten, waardoor deze bij een volledige verzekeringsdekking minder zorgvuldig zal worden. Daarnaast houdt het morele risico verband met het gevaar dat een verzekerde onder invloed van de beschikbaarheid van een verzekering meer gebruik zal maken van bepaalde voorzieningen die door de betreffende verzekering worden vergoed. ${ }^{754}$

Een proces van anti-selectie ('adverse selection') ontstaat wanneer een verzekeraar, door een gebrek aan informatie ten aanzien van de aangesloten risico's, slechts een premie kan vaststellen die overeenkomt met het gemiddelde risico binnen een bepaalde groep. Binnen deze risicogroep kunnen zich echter personen bevinden voor wie de premie, in verhouding tot hun persoonlijk risico, te hoog is. Deze verzekerden kunnen besluiten om de risicogroep te verlaten, waardoor de minder goede risico's overblijven. Dit kan leiden tot een premiestijging, waardoor andere verzekerden, die met een te hoge premie worden geconfronteerd, op hun beurt de risicogroep zullen verlaten. Uiteindelijk kan de situatie ontstaan, waarin alleen de slechte risico's overblijven, met het gevolg dat deze risico's onverzekerbaar worden. Dit lijkt een onafwendbaar proces. In een latere paragraaf zal echter worden aangetoond dat er instrumenten zijn, bijvoorbeeld premiedifferentiatie, die dit proces, dat zelfs kan leiden tot een verzekeringscrisis, ${ }^{755}$ kunnen afremmen.

In het vervolg van de economische analyse van verzekering zullen het morele risico en het proces van anti-selectie verder worden toegelicht. Daarbij staat de vraag cen-

753. Zie Mackaay, NJB, 1980, p. 817.

754. Van Velthoven en Van Wijck, Recht en efficiêntie, p. 49.

755. Priest, YLJ, 1987, p. 1521-1590, heeft aangetoond dat het blijvend verzekeren van onverzekerbs. re risico's een verzekeringscrisis kan veroorzaken, met als gevolg inefficientie, verminderende welvaart en het probleem dat slachtoffers geen volledige schadevergoeding meer ontvangen. Zie ook Faure en Van den Bergh, Objectieve aansprakelijkheid, p. 103; Faure en Van den Berght, preadvies, 1990, p. 16-18; Holzhauer en Teijl, Inleiding rechtseconomie, p. 147; Faure, in Rechtseconomie en recht, p. 82-86. 
traal hoe een verzekeraar met dit probleem omgaat en welke instrumenten aan hem ter beschikking staan om deze informatieproblemen te beheersen.

\subsection{MORELE RISICO ('MORAL HAZARD'): ALGEMEEN}

Met Polinsky kan het morele risico als volgt worden omschreven:

'The provision of insurance may increase the probability of a loss or the size of the loss because the insured person has less of an incentive to take precautions. $^{756}$

Polinsky geeft daarbij het voorbeeld van een fototoestel, dat tegen diefstal is verzekerd. Wanneer een verzekerde dit weet, zal hij misschien minder moeite doen om te vermijden dat het fototoestel wordt gestolen. Hij zal het fototoestel bijvoorbeeld gemakshalve eerder op de achterbank van zijn auto laten liggen dan dat hij de moeite neemt om het onzichtbaar in de bagageruimte van de auto te deponeren. ${ }^{757}$

Naast de beschikbaarheid van verzekeringsdekking op zichzelf kan het morele risico nog op een tweetal andere wijzen ontstaan. In de eerste plaats zal het gegeven dat de verzekeringsdekking de omvang van de schade overtreft een verzekerde niet alleen kunnen aanzetten tot minder zorgvuldig gedrag maar mogelijk ook tot het veroorzaken van schade. Wanneer het fototoestel 300 waard is, maar voor 400 tegen nieuwwaarde verzekerd blijkt te zijn zal de eigenaar er vermoedelijk weinig problemen mee hebben wanneer het toestel wordt gestolen. ${ }^{758}$

In de tweede plaats kan een vorm van morele risico ontstaan, wanneer de beschikbaarheid van een verzekering leidt tot een overmatig beroep op de verzekeringspolis. Een persoon die is verzekerd tegen ziektekosten zal, wanneer hij zich wat grieperig voelt, misschien eerder een huisarts raadplegen, wetende dat dit consult wordt vergoed, dan wanneer hij niet verzekerd zou zijn. ${ }^{759}$

Binnen de economische analyse wordt gesteld dat de beschikbaarheid van een verzekering, een aansprakelijkheids- dan wel een schadeverzekering, er niet toe zal leiden dat de prikkels van zorg geheel worden weggenomen. Een verzekerde die bij een ongeval betrokken raakt zal immers ook eigen schade kunnen hebben. Wanneer

\footnotetext{
756. Polinsky, Introduction, p. 56. Zie ook Shavell, QJE, 1979, p. 541; Faure en Van den Bergh, Objectieve aansprakelijkheid, p. 114; Shavell, Accident Law, p. 194-195.

757. Polinsky, Introduction, p. 56.

758. Zie Shavell, Accident Law, p. 194. Hij voegt hier aan toe dat een verminderde zorgvuldigheid kan leiden tot een ongewenste premiestijging.

759. Arrow, Am. Econ. Rev., 1963, p. 941-973; Adams, Gefährdungs- und Verschuldenshaftung, p. 226; Faure en Van den Bergh, Objectieve aansprakelijkheid, p. 115-116; Pauly, Am. Econ. Rev., 1968 , p. 531-537.
} 
sprake is van een aansprakelijkheidsverzekering zal de verzekerde een prikkel to! zorg behouden. Bij een schadeverzekering kan hetzelfde gelden, bijvoorbeeld wanneer het fototoestel een hoge emotionele waarde voor de verzekerde heeft. ${ }^{760}$

De aanwezigheid van het morele risico veronderstelt dat de beschikbaarheid van een verzekering de preventieve werking van het aansprakelijkheidsrecht voor een belangrijk deel wegneemt. De schade die ten gevolge van een ongeval ontstaat, word dan niet meer door de veroorzaker zelf betaald, maar in plaats daarvan door zijn verzekeraar. Dit heeft tot gevolg dat een verzekeraar via de beschikbare verzekering voldoende prikkels van zorg aan de verzekerde moet geven. ${ }^{761}$ In de volgende sub. paragrafen zal worden onderzocht welke maatregelen een verzekeraar kan nemen orn het morele risico te beperken. ${ }^{762}$

\subsubsection{Het morele risico en de controle door de verzekeraar}

Vanuit het standpunt van de verzekeraar is het morele risico vooral een informatieprobleem. In de ideale situatie beschikt de verzekeraar over volledige informatie omtrent de gedekte risico's, zodat een volledige dekking optimaal is. Dit is ongeacht of de informatie ex-ante, bij aankoop van een verzekering, of ex-post, bij de indiening van een schadeclaim, wordt verkregen. ${ }^{763}$

Uitgaande van de veronderstelling dat de verzekerde vaak beter is geïnformeerd omtrent het ongevalsrisico zal de verzekeraar echter, bij een gebrek aan volledige informatie ten aanzien van de gedekte risico's, een gemiddelde premie berekenen. Dit heeft tot gevolg dat de verzekerde, indien mogelijk, slechts een niveau van zorg zal uitoefenen dat overeenkomt met de gemiddelde premie. Een verzekerde zal op deze wijze kunnen besparen op zijn kosten van zorg, hetgeen leidt tot een morele risico voor dat deel van de premie dat niet door zijn verzekeraar kan worden gecontroleerd. Dit kan schade tot gevolg hebben, die via premieverhogingen zal worden afgewenteld op de medeverzekerden die hun kosten van zorg (verder) zien stijgen. Adams formuleert dit probleem aldus:

760. Faure en Van den Bergh, Objectieve aansprakelijkheid, p. 116. Bowles, Law and the Economy, p. 120 , stelt dat de prikkels van zorg geheel kunnen verdwijnen wanneer bijvoorbeeld de bestuurder van een motorrijtuig betrokken raakt bij een verkeersongeval, waarbij hij de beschikking heeft over zowel een aansprakelijkheidsdekking voor de schade van de derde als een verzekeringsdekking voor zijn eigen schade.

761. C.C. van Dam, Zorgvuldigheidsnorm en aansprakelijkheid, p. 219-220.

762. De vraag in hoeverre een volledige verzekeringsdekking de prikkels van zorg bij dader en slachtoffer daadwerkelijk negatief beïnvloedt, zal worden onderzocht bij de bespreking van het empirisch materiaal in deel III, in het bijzonder hoofdstuk 11.

763. Faure en Van den Bergh, Objectieve aansprakelijkheid, p. 120. Shavell, QJE, 1979, p. 542. 
'Auch wenn im Durchschnitt Verletzer und Opfer den durchschnittlichen erwarteten Schaden mit ihren Prämienzahlungen tragen müssen, besteht für jeden einzelnen Versicherungsnemer der Anreiz, seine Sorgfalt bis auf das von der Versicherung zu beobachtenden Mass herabzumindern, da die hierbei eingesparten Kosten ihm voll zugute kommen, während er den hierdurch von ihm zusätzlich verursachten Schaden infolge der Durchschnittsbildung fast vollständig als externen Effekt auf seine Mitversicherten überwalzen kann.. ${ }^{764}$

Adams geeft ook aan wat de gevolgen kunnen zijn van de afwenteling van het morele risico op de medeverzekerden:

'Das sich aus einem solchen Anreiz ergebende Verhalten aller Versicherungsnehmer führt dann zu einem geringeren Sorgfaltsniveau und zu einer höheren durchschnittlichen Prämie als sie von allen Versicherungsnehmern gewollt war, gegeben man hätte die Sorgfaltsvorkehrungen aller Beteiligten beobachten und in die jeweilige individuelle Prämie einbeziehen können'. ${ }^{765}$

\subsubsection{De controle van het gedrag van de verzekerde}

Naar aanleiding van het voorgaande is de vraag derhalve welke middelen de verzekeraar heeft om het morele risico (verder) te beperken en aan de verzekerde prikkels te geven tot het uitoefenen van optimale zorg. In de economische analyse worden daarvoor twee instrumenten genoemd. ${ }^{766}$

In de eerste plaats kan een verzekeraar het gedrag van de verzekerde controleren. Dit kan door in de verzekeringspolis op te nemen dat een schade-uitkering achterwege blijft indien de verzekerde verzuimt om aan bepaalde voorwaarden te voldoen. Daarnaast kan dekking worden uitgesloten, wanneer blijkt dat de verzekerde onvoldoende zorg heeft uitgeoefend en als gevolg daarvan schade is ontstaan ofwel deze hoger is uitgevallen. Tenslotte kan een verzekeraar het gedrag van de verzekerde ook controleren door middel van een premieaanpassing. ${ }^{767}$

In paragraaf 4.1 is het voorbeeld gegeven van het fototoestel dat tegen diefstal is verzekerd. Daarbij kan worden verondersteld dat het neerleggen van het toestel in de bagageruimte het risico op diefstal tot nul reduceert, terwijl de kans op diefstal 1 bedraagt indien het toestel op de achterbank blijft liggen. De verzekeraar kan met deze gegevens het morele risico in de premie verdisconteren, door te dreigen met een pre-

\footnotetext{
764. Adams, Gefahrdungs- und Verschuldenshaftung, p. 226. Zie ook Faure en Van den Bergh, Objectieve aansprakelijkheid, p. 116.

765. Adams, Gefährdungs- und Verschuldenshaftung, p. 226.

766. Faure en Van den Bergh, Objectieve aansprakelijkheid, p. 116-118.

767. Ten aanzien van autoverzekeringen kan worden gedacht aan het daarbinnen veel gehanteerde bonus-malus-systeem. Zie daarover verderop in paragraaf 4.1.4.
} 
premietoeslag wanneer de verzekerde nalaat om het toestel op een veiliger plaats, in casu de bagageruimte, te deponeren. De verzekerde zal nu een kosten-baten afwe. ging maken en het toestel pas in de bagageruimte neerleggen wanneer het nut hiervan hoger is dan de premieverhoging die het gevolg is van achterlaten van het fototoestel op de achterbank van de auto. ${ }^{768}$

\subsubsection{De controle via een gedeeltelijke verzekeringsdekking}

Een tweede instrument dat door de verzekeraar kan worden gebruikt om het morele risico te controleren is het gedeeltelijk blootstellen van de verzekerde aan het ongevalsrisico. Daarvoor kan de verzekeraar de omvang van de dekking lager vaststellen dan de te verwachten schade. De verzekeraar verleent bijvoorbeeld slechts dekking voor een bedrag van 500 , terwijl de verwachte schade 1.000 zal bedragen. Verder kan de verzekeraar de voorwaarde in de polis opnemen, dat pas boven een bepaald minimumbedrag zal worden uitgekeerd. Hiermee wordt derhalve een eigen risico aan de zijde van de verzekerde geïntroduceerd. Ten slotte kan de verzekeraar ook vastleggen dat bij elk willekeurig schadegeval een bepaald percentage van de schade, ongeacht de omvang hiervan, voor rekening van de verzekerde blijft. ${ }^{769}$ Deze controlemethoden, waarbij de verzekerde ofwel zijn premie ziet wijzigen, ofwel het risico gedeeltelijk zelf moet dragen, zorgen ervoor dat de verzekerde een prikkel behoudt om zich zorgvuldig te gedragen.

\subsubsection{De informatiekosten voor een verzekeraar bij de controle van het morele risico}

Om de vraag te kunnen beantwoorden welke van de beschreven controle-instrumenten het meest efficiënt is, dient rekening te worden gehouden met de informatiekosten die een verzekeraar moet maken om het gedrag van de verzekerde te controleren. ${ }^{770}$ Shavell stelt dat het observeren van zorg door de verzekeraar vaak onmogelijk of te kostbaar is. Hij vervolgt:

'Under that assumption, the degree to which it is desirable to reduce coverage and subject the insured to risk would depend on the incentive thereby created

768. Polinsky, Introduction, p. 56; Faure en Van den Bergh, Objectieve aansprakelijkheid, p. 117.

769. Faure en Van den Bergh, Objectieve aansprakelijkheid, p. 117; Shavell, Accident Law, p. 195196; Pauly, Am. Econ. Rev., 1968, p. 535-537. Raviv, Am. Econ. Rev., 1978, p. 84-96, condtdeert naar aanleiding van een rechtseconometrische analyse dat een Pareto-optimaal verzekeringscontract bestaat uit een vrijgesteld bedrag (eigen risico) met een soort co-verzekering bovenop dit eigen risico, waarbij verzekeraar en verzekerde gezamenlijk het risico en de kosten dragen. Zie ook Shavell, QJE, 1979, p. 541-562 voor een onderzoek naar de vTaag welke van de hier genoemde controle-instrumenten het meest optimaal is.

770. Faure en Van den Bergh, Objectieve aansprakelijkheid, p. 118-121. 
to exercise care, and such an incentive would in turn depend on the cost of taking care'. ${ }^{771}$

In de ideale situatie waarin de verzekeraar over volledige informatie beschikt met betrekking tot de zorg die door de verzekerde wordt uitgeoefend, is tegen lage kosten een optimale controle van het gedrag van de verzekerde mogelijk. Hiermee kan het morele risico worden geminimaliseerd. De verzekerde zal voorzorgsmaatregelen nemen, zolang de kosten hiervan lager zijn dan de opbrengst in termen van vermindering van de verwachte schade. Daamaast zorgt een volledige verzekeringsdekking ervoor dat het nut van de verzekerde kan worden gemaximaliseerd. ${ }^{772}$

In het voorbeeld van het fototoestel kan de verzekeraar tot een premieverlaging overgaan wanneer de verzekerde besluit om het toestel in de bagageruimte op te bergen, in plaats van deze op de achterbank te laten liggen. Daamaast kan de verzekeraar de hoogte van de premie aanpassen wanneer blijkt dat de verzekerde in het verleden veelvuldig de diefstal van een fototoestel heeft geclaimd. De verzekeraar kan tenslotte ook dekking bij diefstal uitsluiten, indien de verzekerde niet aan de voorwaarde voldoet om het fototoestel in de bagageruimte te leggen.

Uitgaande van de meer realistische veronderstelling dat de verzekeraar geen volledige informatie heeft, is een optimale controle van het gedrag van de verzekerde bijna niet mogelijk. Hierbij kan een onderscheid worden gemaakt tussen een controle ex ante, bij het afsluiten van een verzekeringsovereenkomst en een controle ex post, wanneer door de verzekerde een schadeclaim wordt ingediend. Bij een controle vooraf (ex ante) zal de verzekeraar onderzoek moeten verrichten naar alle personen die een verzekeringsovereenkomst afsluiten. Bij een controle achteraf (ex post) is bet voldoende dat de verzekeraar nagaat wanneer door de verzekerde een schadeclaim wordt ingediend. Een niet volledig geïnformeerde verzekeraar zal zowel ex ante als ex post hoge kosten moeten maken om het gedrag van de verzekerde optimaal te kunnen controleren. ${ }^{773}$

Wanneer een verzekeraar derhalve over weinig of zelfs in het geheel geen informatie beschikt, zijn er voor hem in beginsel geen mogelijkheden om de verzekerde te sturen door middel van een premieaanpassing of een bijstelling van de polisvoorwaar-

\footnotetext{
771. Shavell, QJE, 1979, p. 541.

772. Shavell, Accident Law, p. 195; Faure en Van den Bergh, Objectieve aansprakelijkheid, p. 118119; Polinsky, Introduction, p. 56-57; Shavell, QJE, 1979. p. 553.

773. Zie voor het onderscheid tussen ex-ante en ex-post controle: Shavell, QJE, 1979, p. 542 en 550 551; Priest, YLJ, 1987, p. 1547-1548; Adams, Gefährdungs- und Verschuldenshaftung, p. 224225.
} 
den. ${ }^{774}$ Dit betekent dat een volledige dekking kan leiden tot een vergroting van het morele risico. De verzekerde heeft nu geen prikkel om zorg aan te wenden, de pre. mies zullen hoog zijn en het nut van de verzekerde laag. In het voorbeeld van het fototoestel zal het geen verschil maken of het toestel op de achterbank of in de bagage. ruimte ligt. ${ }^{775}$

Een oplossing hiervoor is het verlenen van een gedeeltelijke dekking. De verzekerde wordt daarbij voor een deel blootgesteld aan het ongevalsrisico, waardoor de informatiekosten voor de verzekeraar en de premie voor de verzekerde kunnen worden gereduceerd. De verzekeraar in de casus van het fototoestel kan bijvoorbeeld beslui. ten om de dekking van het toestel ingeval van diefstal te verlagen van 300 (volledige dekking) naar 200 (gedeeltelijke dekking). De verzekerde zal nu ingeval van diefstal een deel van de schade (100) zelf moeten dragen, zodat hij een prikkel van zorg zal hebben om te voorkomen dat het fototoestel wordt gestolen. ${ }^{776}$

\subsubsection{Conclusie morele risico: de verschillende controle-instrumenten vergeleken}

Naar aanleiding van de analyse van het morele risico kan worden geconcludeerd dat wanneer de verzekeraar volledig is geïnformeerd omtrent het gedrag van de verzekerde een optimale controle tegen lage kosten mogelijk is, mits de premie een juiste afspiegeling vormt van de verwachte ongevalskosten.

In werkelijkheid heeft de verzekeraar geen of weinig informatie met betrekking tot het gedrag van de verzekerde, zodat een combinatie van premieaanpassingen of vervalbedingen c.q. zorgplichtbepalingen en een gedeeltelijke dekking nodig is om de verzekerde aan zetten tot de uitoefening van zorg. Hierbij zal rekening moeten worden gehouden met de kosten van zorg en de informatiekosten aan de zijde van de verzekeraar. Wanneer ervan wordt uitgegaan dat door een gebrek aan informatie een differentiëring van risico's hoge kosten meebrengt, zal derhalve een combinatie van een gedeeltelijke dekking en de juiste polisvoorwaarden tot een vermindering van het morele risico kunnen leiden. ${ }^{777}$

774. Shavell, Accident Law, p. 196, noot 17, stelt dat een verzekeraar, ter bevordering van de prikkels van zorg, in de polisvoorwaarden kan opnemen dat de hoogte van premie in de toekornst afhankelijk zal zijn van de in het verleden geclaimde schade.

775. Shavell, Accident Law, p. 196.

776. Shavell, Accident Law, p. 196, toont aan dat een gedeeltelijke dekking een verzekerde kan aanzetten tot het uitoefenen van meer zorg, waardoor ook het nut van deze verzekerde kan worden gemaximaliseerd. Zie ook Faure en Van den Bergh, Objectieve aansprakelijkheid, p. 120-121.

777. Marshall, Am. Econ. Rev., 1976, p. 889-890. Zie daarover ook Holzhauer en Teijl, Inleiding rechtseconomie, p. 156-158. 
In de veronderstelling dat de verzekerde over betere informatie beschikt en de verzekeraar een gebrek aan informatie heeft wordt door Shavell het volgende overwogen:

'The level of coverage provided in policies that maximize expected utility under present assumptions are those that strike the best balance between the advantage and the disadvantage of lowering coverage from full coverage, namely, those that balance the creation of incentives to reduce risk on the one hand and the increased exposure to risk on the other. The expected utility maximizing level of coverage will be the greatest level that will still leave the insured bearing enough risk to induce him to take the risk-reducing action'. ${ }^{778}$

Het voordeel van een gedeeltelijke dekking, de handhaving van de prikkel van zorg, moet derhalve hoger zijn dan het nadeel, namelijk een situatie waarin een risicoavers persoon wordt blootgesteld aan risico. De omvang van de gedeeltelijke dekking zal daamaast afhankelijk moeten zijn van de kosten van zorg van de verzekerde. ${ }^{779}$

\subsubsection{De controle van het morele risico binnen het verkeersongevallenrecht}

Met betrekking tot de controle van het morele risico binnen de autoverzekering kan worden gesteld dat een controle vooraf (ex ante) veelal hoge kosten meebrengt. Het gedrag van een automobilist is vooraf moeilijk te sturen en zijn rijgedrag kan zich nog wijzigen nadat de verzekeringspolis is afgesloten. ${ }^{780}$ Daamaast geldt dat een groot aantal individuen bij een autoverzekering is aangesloten, waarbij de omvang van een gemiddelde autopolis relatief laag is. Dit betekent dat een autoverzekeraar hoge kosten moet maken om voor elke autobestuurder geïndividualiseerde polisvoorwaarden op te stellen, zodat veelal gebruik wordt gemaakt van een standaardpolis die op een grote groep autobestuurders van toepassing is. ${ }^{781}$

Uit het voorgaande kan worden afgeleid dat een ex post controle van het morele risico bij een autoverzekering meer aangewezen lijkt. Aangezien ook daarbij geldt dat de verzekeraar geen volledige informatie heeft omtrent het gedrag van de verzekerde, zal moeten worden onderzocht welke middelen een autoverzekeraar heeft om het morele risico bij een automobilist te controleren.

\footnotetext{
778. Shavell, Accident Law, p. 196-197.

779. Faure en Van den Bergh, Objectieve aansprakelijkheid, p. 121-122.

780. Ten aanzien van een brandverzekering zal een controle vooraf beter zijn, waarbij de vraag van belang is of er voldoende beveiliging bestaat tegen brand, omdat na een brand het bewijsmateriaal van de getroffen voorzorgsmaatregelen vermoedelijk vernietigd zal zijn. Zie Faure en Van den Bergh, Objectieve aansprakelijkheid, p. 120; Shavell, QJE, 1979, p. 550-551.

781. Shavell, QJE, 1979, p. 561; Faure, NJB, 1995, p. 1229-1230; Jost, IRLE, 1996, p. 271.
} 
In de eerste plaats kan de autoverzekeraar het gedrag van de automobilist controle. ren met behulp van een premieaanpassing. Deze correcties kunnen de vorm aanne. men van een bonus-malussysteem, waarbij aan de automobilist, afhankelijk van zijn schadeverleden, een korting dan wel een toeslag op zijn verzekeringspremie word opgelegd. De verzekeraar past hierbij derhalve een soort ex post premiedifferentiatie toe. Een roekeloze autobestuurder zal derhalve onder dreiging van een toeslag op zijn verzekeringspremie kunnen worden aangezet tot de uitoefening van meer zorg.

In de tweede plaats kan de automobilist gedeeltelijk worden blootgesteld aan het ongevalsrisico. ${ }^{782}$ Daartoe wordt door een autoverzekeraar veelal gebruik gemaakt van een eigen risico, waarvan de omvang wordt verrekend met de uiteindelijke schadeclaim. Hierbij geldt dat een automobilist met een afkeer van risico voor de gegeven dekkingsomvang precies voldoende prikkels heeft om zorg uit te oefenen ter vermijding van een verkeersongeval. Daarnaast moet het voordeel van het eigen risico hoger zijn dan het nadeel in de zin van een blootstelling aan het ongevalsrisico van de automobilist. $^{783}$

\subsection{AnTI-SElectie ('AdVERSE SELECTION'): AlgEMEEN}

Naast het morele risico kan een verzekeraar ook worden geconfronteerd met het proces van anti-selectie dat betrekking heeft op het door de verzekeraar op een juiste wijze groeperen van risico's. Een dergelijke groepering is nodig omdat voor een verzekeraar de administratieve kosten van een individualisering van het risico, waarbij voor elke individuele verzekerde een premiebedrag wordt vastgesteld dat overeenstemt met de verwachte schade, te hoog zijn. Daarnaast geldt in beginsel dat de aangesloten risico's binnen een groep van een gelijke waarde zijn. Wanneer zich echter een schadegeval voordoet kan blijken dat een verzekeraar bij de uitkering van de schade wordt geconfronteerd met alle daarmee verbonden risico's. Het is bijvoorbeeld verzekeringseconomisch niet optimaal om, ten behoeve van een brandverzekering, in één straat een rij huizen onder een en dezelfde brandpolis te laten vallen. ${ }^{784}$

Behalve dat de aangesloten risico's onafhankelijk zijn van elkaar, is het ook van belang dat een verzekeraar de verschillende risico's indeelt binnen strak omlijnde risicogroepen, waarvan individuen met een gelijk risico deel uitmaken. Dit heeft het voordeel dat een verzekeraar voor elke risicogroep een premie kan vaststellen, die

782. De blootstelling aan het ongevalsrisico kan daarbij zowel ex ante als ex post plaatshebben. Ex post kan bijvoorbeeld de verhoging van het eigen risico een reactie zijn op het schadeverleden van de autobestuurder.

783. Zie hierover onder anderen: C.C. van Dam, Zorgvuldigheidsnorm en aansprakelijkheid, p. 220; Adams, Gefährdungs- und Verschuldenshaftung, p. 232-235; Bowles, Law and the Economy, p. 122.

784. Priest, YLJ, 1987, p. 1540; Faure en Van den Bergh, Objectieve aansprakelijkheid, p. 122-123. 
een juiste afspiegeling vormt van de verwachte schade van de individuele leden van de groep. Aan elke risicogroep kan derhalve een optimale premie worden opgelegd die in verhouding staat tot het gemiddelde risico. In de ideale situatie zal voor elk individu binnen de risicogroep de verzekering aantrekkelijk blijven. In werkelijkheid zal, doordat de premie is gebaseerd op het gemiddelde risico, sprake kunnen zijn van goede en slechte risico's.

In de inleiding van deze paragraaf (4) is beschreven hoe uit de scheve verhouding tussen goede en slechte risico een proces van anti-selectie kan ontstaan, waarbij uiteindelijk alleen de slechte risico's overblijven, die over het algemeen een sterke vraag naar een verzekering zullen hebben. Het proces van anti-selectie kan volgens Priest leiden tot een verzekeringscrisis ofwel een ineenstorting van de verzekeringsmarkt, waarbij sprake zal zijn van een aanzienlijk welvaartsverlies. ${ }^{785}$ Een risicoavers individu heeft geen mogelijkheid meer om tegen betaling van een premie zijn risico af te schuiven. Een verzekeraar kan de risico's niet meer optimaal groeperen omdat er te weinig verzekerden zijn waarover het totale risico kan worden gespreid. $^{786}$

Een verzekeraar heeft derhalve behoefte aan ex ante informatie om de verzekerde risico's zo optimaal mogelijk te groeperen. De verzekerde kan bij het verschaffen van dergelijke informatie behulpzaam zijn. Dit is ook in zijn eigen belang, omdat hij hierdoor een lagere premie kan betalen. Het proces van anti-selectie ontstaat echter juist als gevolg van een asymmetrie in informatie tussen verzekerde en verzekeraar, waardoor deze laatste niet in staat is om de potentieel verzekerden op een juiste wij$z e$ in risicogroepen onder te verdelen. ${ }^{787}$

\subsubsection{Het probleem van de asymmetrie in informatie}

Het probleem van asymmetrische informatie kan meer algemeen worden uiteengezet aan de hand van de zogenaamde 'markttheorie' van Akerlof. Deze heeft in zijn, vooral binnen de rechtseconomische literatuur, bekend geworden artikel 'The Market

785. Priest, YLJ, 1987, p. 1521-1590. Hij geeft hierin een beschrijving van de verzekeringscrisis zoals die zich in de jaren tachtig op een aantal deelgebieden in het Amerikaanse aansprakelijkheidsrecht heeft voltrokken. Hij verwijst daarbij met name naar terreinen als medische aansprakelijkheid, milieuaansprakelijkheid en overheidsaansprakelijkheid.

786. Faure en Van den Bergh, preadvies, 1990, p. 16-17; Faure en Van den Bergh, Objectieve aansprakelijkheid, p. 123; Priest, YLJ, 1987, p. 1540-1541; Van Velthoven en Van Wijck, Recht en efficiêntie, p. 49-50.

787. Faure en Van den Bergh, preadvies, 1990, p. 17; Faure en Van den Bergh, Objectieve aansprakelijkheid, p. 123. 
for 'Lemons', ${ }^{788}$ uiteengezet hoe het probleem van asymmetrische informatie met be. trekking tot de markt voor goederen en diensten kan worden aangepakt. Een 'lemon' wordt door Akerlof beschouwd als een product met weinig impact en nauwelijks geschikt voor consumptie. Dit kan tot gevolg hebben dat de 'lemon', door zijn slechte kwaliteit in vergelijking met andere producten, via het prijsmechanisme van de markt wordt geweerd. Er ontstaat echter een probleem wanneer de consument niet op de hoogte is van de slechte kwaliteit van de 'lemon', waardoor het prijsmechanisme niet meer automatisch tot een optimale allocatie zal leiden. ${ }^{789}$ Daarnaast kan worden gesteld dat de consument door een gebrek aan informatie vaak niet in staat is om een onderscheid te maken tussen de kwaliteit van de verschillende producten, met het mogelijke gevolg dat hij geen juiste aankoopbeslissing zal nemen. Dit kan tot gevolg hebben dat de slechte producten de goede producten uit de markt drijven. Akerlof heeft dit informatieprobleem uitgewerkt aan de hand van de markt voor auto's.

Op deze markt kunnen volgens hem vier soorten voertuigen worden onderscheiden, namelijk nieuwe auto's met respectievelijk een goede en slechte (citroenen) kwalitit en tweedehands auto's met een goede en slechte kwaliteit. Een consument zal bij de aankoop van een nieuwe auto niet weten of het een goede of slechte auto is. Wanneer hij echter binnen een paar maanden voor meerdere reparaties naar de garage terug moet, kan de consument tot de conclusie komen dat hij een auto van slechte kwaliteit heeft gekocht. Bij de aankoop van een tweedehands auto is deze kwaliteitsonzekerheid in vergelijking met een nieuwe auto waarschijnlijk nog groter.

Dit leidt tot een probleem van informatie-asymmetrie, aangezien de verkoper van de nieuwe en tweedehands auto's doorgaans wel op de hoogte is van de kwaliteit van de voertuigen. Omdat de consument geen onderscheid kan maken tussen goede en slechte kwaliteit, blijft voor hem de prijs van de verkochte auto gelijk. De werkelijke waarde van een nieuwe auto is echter niet dezelfde als die van een tweedehands auto. Zou dit wel het geval zijn, dan kan een consument besluiten om een tweedehands auto van slechte kwaliteit in te ruilen voor een nieuwe auto. De kans dat hij hiermee een auto van goede kwaliteit koopt is groter dan de kans dat zal blijken dat hij een auto van slechte kwaliteit heeft aangeschaft. ${ }^{790}$

De bovengenoemde informatie-asymmetrie op de markt voor auto's heeft volgens Akerlof gevolgen voor de kwaliteit van auto's die op deze markt worden aangebo-

788. Akerlof, QJE, 1970, p. 488-500. Zie ook Priest, YLJ, 1987, p. 1564-1567, die zijn analyse van het probleem van de informatie-asymmetrie in het bijzonder toepast op de markt voor auto's mal vierwielaandrijving.

789. Zie Faure en Van den Bergh, Objectieve aansprakelijkheid, p. 123.

790. Akerlof, QJE, 1970, p. 489-490. 
den. Daarbij kan een proces ontstaan waarin de slechte auto's de goede auto's van de markt verdringen. Faure en Van den Bergh spreken in dat kader van:

'een cumulatief proces van kwaliteitsvermindering dat zijn oorsprong vindt in de onvolkomen informatie over kwaliteit in hoofde van de kopers'. ${ }^{791}$

Voor de verkoper, die wel op de hoogte is van het kwaliteitsverschil, zal het geen verschil maken of hij een goede of een slechte auto verkoopt. Daardoor zal ook de prijs van een goede auto niet veel afwijken van de prijs van een slechte auto. Dit leidt ertoe dat de verkoper geen prikkel zal hebben om auto's van goede kwaliteit aan te bieden. Op de markt zullen derhalve auto's van een gemiddelde kwaliteit tegen een gemiddelde prijs worden aangeboden. Goede kwaliteit wordt immers door de kopers, als gevolg van hun gebrek aan informatie, niet herkend. Zij kunnen de verkopers daarnaast ook niet belonen door hen een betere prijs te betalen.

Wanneer dit proces zich voortzet, zal bijvoorbeeld een eigenaar van een goede tweedehands auto zijn voertuig niet meer op de markt aanbieden. Hij weet dat hij voor zijn auto slechts een gemiddelde prijs zal ontvangen die lager ligt dan hij, gezien de kwaliteit van de auto, zou mogen verwachten. In een volgende fase van dit proces zullen ook de aanbieders van auto's met een gemiddelde kwaliteit niet meer tot verkoop overgaan, omdat deze kwaliteit niet meer overeenstemt met de prijs die zij bij verkoop van hun auto kunnen verwachten. Uiteindelijk zullen alleen de auto's met een lage kwaliteit overblijven. De consument herkent immers enkel de aangeboden gemiddelde kwaliteit en is, door de asymmetrie in informatie, niet in staat om deze kwaliteit positief te beïnvloeden. Daarnaast is het voor de consument ook niet mogelijk om de individuele aanbieder van slechte auto's af te straffen, omdat hij op de gemiddelde kwaliteitsdaling van alle aanbieders reageert en niet op die van een enkele verkoper. ${ }^{792}$

De beschrijving van het proces van dalend kwaliteitsaanbod op de markt voor auto's laat zich goed vertalen naar het probleem van anti-selectie binnen de verzekeringsmarkt. ${ }^{793}$ Ook tussen een verzekerde en een verzekeraar is immers sprake van een asymmetrie in informatie, waarbij de verzekerde in het algemeen over betere informatie omtrent het ongevalsrisico beschikt dan zijn verzekeraar. In het kader van de markttheorie kan de verzekeraar worden beschouwd als de koper van informatie met betrekking tot de risico's die hij wenst te verzekeren. Omdat de verzekerde, als verkoper, over betere informatie beschikt, weet een verzekeraar niet of zich slechte of

\footnotetext{
791. Faure en Van den Bergh, Objectieve aansprakelijkheid, p. 124.

792. Faure en Van den Bergh, Objectieve aansprakelijkheid, p. 124-125.

793. Akerlof, QJE, 1970 , p. 492-499, past zijn theorie onder andere toe op verzekeringen (in het bijzonder met betrekking tot medische zorg), werknemers uit minderheidsgroeperingen en kredietmarkten in ontwikkelingslanden.
} 
goede risico's bij zijn polis zullen aansluiten. Hij wordt derhalve gedwongen om een gemiddelde premie te berekenen. Voor de slechte risico's, die nu een relatief lage premie gaan betalen, kan dit een reden zijn om een verzekering af te sluiten. Voor de goede risico's is het in deze situatie echter niet optimaal om verzekeringsdekking te vragen, aangezien voor hen de premie te hoog kan zijn. Dit kan leiden tot een proces van anti-selectie, waarbij de goede en minder goede risico's de groep zullen verlaten en op termijn alleen de slechte risico's overblijven. ${ }^{794}$

\subsubsection{Instrumenten ter beperking van de anti-selectie}

Wanneer een verzekeraar, door een gebrek aan informatie de aangesloten risico's niet optimaal kan groeperen, kan een proces van anti-selectie ontstaan. Wanneer daarbij de variatie in risico's, namelijk de verhouding tussen de goede en slechte risico's, te groot wordt, kan dit proces zelfs leiden tot de onverzekerbaarheid van bepaalde risico's. ${ }^{795}$

In antwoord op het proces van anti-selectie zal een verzekeraar derhalve moeten trachten om zoveel mogelijk informatie te verzamelen ten behoeve van een zo beperkt mogelijke samenstelling van de risicogroepen. Daarnaast is het voor de verzekeraar van belang om de goede risico's binnen de groep te houden. ${ }^{796}$

\subsubsection{Het differentiëren van ongevalsrisico's}

Een verzekeraar kan het proces van anti-selectie vertragen door middel van het differentiëren van risico's. Binnen de autoverzekering is het bijvoorbeeld gebruikelijk om de individuele risico's te differentiëren naar onder andere leeftijd, woonplaats, beroep, schadeverleden, veiligheid van de auto en het jaarlijks aantal afgelegde kjlometers. ${ }^{797}$

Voor wat betreft de differentiatie naar leeftijd kan worden gesteld dat jonge 'onervaren' autobestuurders een hogere risicofactor in het verkeer vormen dan hun oudere 'ervaren' collega's, waardoor zij een relatief hoge premie betalen voor hun verzekering. Op basis hiervan kan een verzekeraar besluiten om jonge automobilisten in een aparte risicogroep onder te brengen. Daarmee kan worden voorkomen dat 'ervaren'

794. Faure en Van den Bergh, Objectieve aansprakelijkheid, p. 125; Schäfer und Ott, Lehrbuch der okonomischen Analyse, p. 408-411; Holzhauer en Teijl, Inleiding rechtseconomie, p. 159-160.

795. Priest, YLJ, 1987, p. 1553, spreekt van 'unraveled risk pools'. Zie ook Faure en Van den Berght, Objectieve aansprakelijkheid, p. 126-127.

796. Priest, YLJ, 1987, p. 1541-1543.

797. C.C. van Dam, Zorgvuldigheidsnorm en aansprakelijkheid, p. 225-226, stelt dat 'hoe fijnmazigr de differentiatie, hoe efficiênter de verzekering'. Zie ook Priest, YLJ, 1987, p. 1545. 
autobestuurders de risicogroep, waarin zich ook jonge automobilisten bevinden, verlaten en op zoek gaan naar een verzekeringspolis met een lagere premie.

Ook binnen de groep jonge autobestuurders bevinden zich echter chauffeurs die weinig brokken maken en chauffeurs die vaak bij een ongeval zijn betrokken. Gesteld kan worden dat een groot aantal ernstige verkeersongevallen door een klein deel van deze groep wordt veroorzaakt. Dit heeft tot gevolg dat een meerderheid meebetaalt aan het risico dat door de minderheid van de groep wordt gecreëerd. Mackaay spreekt in dit verband van een 'cross-subsidisation' van de lage risico's naar de hoge risico's binnen de groep, van veilige bestuurders naar roekeloze bestuurders. $^{798}$

Een oplossing voor dit probleem is een verdere beperking van de risicogroep, maar de vraag is of een verzekeraar, in verband met de kosten van een verdere differentiatie, daartoe bereid is. De verzekeraar zal over informatie moeten beschikken om de slechte risico's eruit te kunnen lichten. Daarnaast zullen de administratieve kosten van een verdere risicodifferentiatie op een bepaald punt niet meer opwegen tegen de opbrengst van een verdere premieverlaging. Mackaay formuleert dit aldus:

'The differentiation can be expected to go on until the additional measurement cost of further differentiation is just equal to the premium reduction which can be offered to the newly differentiated better risk groups. ${ }^{799}$

\subsubsection{Andere remedies tegen het proces van anti-selectie}

Wanneer de kosten van een verdere differentiatie derhalve te hoog worden en niet meer in verhouding staan tot de aangeboden premie, kan een verzekeraar met een aantal maatregelen trachten de polisvoorwaarden aantrekkelijker te maken zodat de goede risico's binnen de groep blijven.

In de eerste plaats kan een verzekeraar besluiten om het eigen risico (franchise) te verhogen. Voor de goede risico's binnen de groep is een hoger eigen risico minder kostbaar dan een premiestijging, omdat zij beter in staat zijn om de waarschijnlijkheid van een ongeval in te schatten. Voor de slechte risico's wordt met een verhoging van het eigen risico bereikt dat zij een prikkel krijgen om het ongevalsrisico te reduceren.

798. Mackaay, Economics of Information and Law, p. 192-193. Latin, CaLR, 1985, p. 728, wijst op de mogelijkheid dat roekeloze autobestuurders ook kunnen besluiten tot de ankoop van een lagere verzekeringsdekking of een activiteitswijziging. Dit laatste kan echter leiden tot een keuze voor een activiteit waaraan niet minder risico's zijn verbonden dan autorijden, bijvoorbeeld motorrijden.

799. Mackaay, Economics of Information and Law, p. 192. Zie ook Faure en Van den Bergh, Objectieve aansprakelijkheid, p. 127. 
In de tweede plaats kunnen de goede risico's binnen de groep worden gehouden door een verlaging van het gezamenlijke dekkingsplafond onder een bepaalde verzekeringspolis. Voor een verzekerde met een verwachte schade die lager ligt dan dit plafond zal een dergelijke maatregel geen reden zijn om de groep te verlaten. De slech. te risico's krijgen echter een additionele prikkel om het ongevalsrisico te verminderen. $^{800}$

In de derde plaats kan een verzekeraar het verzekerd bedrag verlagen. Voor de goede risico's heeft dit weinig gevolgen. Zij hebben, gegeven het lage risico dat zij vormen, genoeg aan een laag verzekerd bedrag met een aanverwant lage premie. De hoge risico's zullen echter een prikkel hebben om het risico te verminderen. ${ }^{801}$

In de vierde plaats ten slotte, heeft de verzekeraar de mogelijkheid om in de polis specifieke uitsluitingen op te nemen. In dit kader kunnen bepaalde schadegevallen van dekking worden uitgesloten, tenzij de verzekerde bepaalde maatregelen neemt om het risico te reduceren. $\mathrm{Bij}$ een autoverzekering kan worden gedacht aan het uitsluiten van de dekking van bepaalde strafbare handelingen, zoals het rijden onder invloed, die aan een eventuele schadeclaim ten grondslag liggen. ${ }^{802}$

\subsection{MORELE RISICO EN ANTI-SELECTIE VERGELEKEN}

Wanneer een verzekerde over betere informatie omtrent het ongevalsrisico beschikt dan zijn verzekeraar, zullen bij een volledige verzekeringsdekking de prikkels van zorg van de verzekerde verminderen. De verzekeraar kan dit probleem van het morele risico verminderen door de verzekerde gedeeltelijk bloot te stellen aan het risico en door de premie aan te passen.

Het proces van anti-selectie ontstaat wanneer de verzekeraar door een gebrek aan informatie niet in staat is om de bij hem aangesloten risico's optimaal te groeperen en genoodzaakt is om een gemiddelde premie aan te rekenen. Hierdoor zal het verschil tussen de goede en slechte risico's te groot worden en zullen de goede risico's, voor wie de premie niet overeenstemt met het individuele risico, de groep verlaten. Een verzekeraar kan dit proces afremmen door middel van risicodifferentiatie of, wanneer dit te kostbaar wordt, met behulp van aantrekkelijke polisvoorwaarden trachten

800. Priest, YLJ, 1987, p. 1573.

801. Priest, YLJ, 1987, p. 1574.

802. Faure en Van den Bergh, Objectieve aansprakelijkheid, p. 126-128; Faure en Van den Bergh, preadvies, 1990, p. 17. Gravelle, IRLE, 1991, p. 23-41, onderzoekt de economische effecten van strenge verzekeringsvoorwaarden op de vermindering van het proces van anti-selectie, met name voor wat betreft het bestraffen van fraude en verzwijging. Zie ook Mulder en Weseman, SWOV, R-94-29, voor een studie naar de mogelijkheden en haalbaarheid van een snelheidsclausule in de verzekeringsvoorwaarden. 
de goede risico's binnen de groep te houden. Deze laatste maatregelen zullen aan de slechte risico's een extra prikkel geven om het ongevalsrisico te verminderen. ${ }^{803}$

Het verband tussen morele risico en anti-selectie komt onder andere tot uiting in het gegeven dat de aanwezigheid van het morele risico kan leiden tot een vergroting van het probleem van anti-selectie. Wanneer een verzekeraar door een gebrek aan informatie niet in staat is om het morele risico afdoende te controleren, kan dit leiden tot een te grote variatie in risico's binnen de groep verzekerden. Daarmee wordt de verdere differentiëring van risico's bemoeilijkt, hetgeen voor sommige verzekerden een relatieve stijging van de premie tot gevolg kan hebben. Voor bijvoorbeeld een automobilist die alleen in het weekend aan het verkeer deelneemt kan deze premiestijging te groot worden in verhouding tot zijn individuele risico, waardoor hij de risicogroep zal verlaten. Dit leidt derhalve tot een proces van anti-selectie. ${ }^{804}$

\subsection{HET ONDERSCHEID TUSSEN 'THIRD PARTY' EN 'FIRST PARTY' VERZEKERING}

Bij de analyse van het morele risico en de anti-selectie is geen rekening gehouden met de vraag welke vorm van verzekering voorhanden is. In een eerdere paragraaf is in dat kader een onderscheid gemaakt tussen een 'third party' verzekering en een 'first party' verzekering. ${ }^{805}$ Een 'third party' verzekering dekt de aansprakelijkheid van de dader die schade toebrengt aan het slachtoffer en zal hierna als een aansprakelijkheidsverzekering worden aangeduid. Een 'first party' verzekering dekt de schade van het slachtoffer, de autobestuurder of de fietser, zelf en zal hierna schadeverzekering worden genoemd.

In het algemeen wordt gesteld dat een verzekeraar bij een schadeverzekering over betere informatie kan beschikken met betrekking tot het gedrag van de verzekerde. Met een schadeverzekering staat een verzekeraar in direct contact met zijn verzekerde, waardoor de premie op een juiste wijze kan worden afgestemd op het individuele ongevalsrisico. Bij een aansprakelijkheidsverzekering geldt echter dat het ongevalsrisico van de verzekerde dader mede afhankelijk is van het gedrag van het slachtoffer die zijn schade van de aansprakelijkheidsverzekeraar van de dader krijgt vergoed. Een aansprakelijkheidsverzekeraar zal veelal geen informatie hebben omtrent het gedrag van het slachtoffer, een persoon die zich min of meer toevallig aandient wanneer zich een ongeval voordoet. ${ }^{806}$

\footnotetext{
803. Zie Holzhauer en Teijl, Inleiding rechtseconomie, p. 160.

804. Faure en Van den Bergh, preadvies, 1990, p. 17-18; Faure en Van den Bergh, Objectieve aansprakelijkheid, p. 125-126; Priest, YLJ, 1987, p. 1546-1547.

805. Zie paragraaf 3.2 van dit hoofdstuk.
}

806. Zie C.C. van Dam, Zorgvuldigheidsnom en aansprakelijkheid, p. 220. 
Dit verschil tussen een aansprakelijkheidsverzekering en een schadeverzekering is mede van invloed op de aanpak van de problemen van morele risico en anti-selectie. $\mathrm{Bij}$ een schadeverzekering kan de verzekeraar tegen lage kosten aan de hand van bepaalde karakteristieken van de individuele verzekerden, zoals beroep, leeftijd, schadeverleden en de veiligheid van het te verzekeren object, de risico's differentiëren. De schadeverzekeraar heeft derhalve de mogelijkheid om, met behulp van statistie. ken die betrekking hebben op het schadeverleden, de risicogroepen zo nauw mogelijk te definiëren, waardoor een schadeverzekering voor lage risico's aantrekkelijk wordt. ${ }^{807}$ Daamaast is een betere controle van het morele risico mogelijk, omdat een schadeverzekeraar in het algemeen alleen informatie nodig heeft omtrent het gedrag van de verzekerde zelf.

Bij een aansprakelijkheidsverzekering is een dergelijke afbakening van risico's veel duurder. De aansprakelijkheidsverzekeraar beschikt immers over weinig informatie met betrekking tot het gedrag van het slachtoffer dat bij een ongeval met de verzekerde dader betrokken kan raken. Daarnaast is bij een aansprakelijkheidsverzekering sprake van schade-uitkeringen aan niet bij de verzekering aangesloten individuen, waardoor de controle van het morele risico van de verzekerde zelf wordt bemoellijkt. Wanneer een verzekeraar ten behoeve van een vermindering van het morele $\mathrm{n}$ sico vervolgens overgaat tot een premieaanpassing zonder rekening te houden met de hoge of lage risico's, zal dit kunnen leiden tot een proces van anti-selectie. ${ }^{808}$

\subsection{MORELE RISICO EN DE ANTI-SELECTIE BINNEN DE AUTOVERZEKERING}

Het probleem van het morele risico is in een eerdere paragraaf reeds getoetst aan het verkeersongevallenrecht. ${ }^{809}$ Daarin is geconcludeerd dat een autoverzekeraar met behulp van zowel een premieaanpassing, via een bonus-malussysteem, als een gedeeltelijke dekking, in de vorm van een eigen risico, het gedrag van de autobesturrder kan controleren. In het kader van het tegengaan van het proces van anti-selectie is gesteld dat met behulp van zowel een risicodifferentiatie als aantrekkelijke polisvoorwaarden de goede risico's binnen de verzekeringspolis kunnen worden geholden, waarbij tegelijk aan de slechte risico's optimale prikkels van zorg kunnen worden gegeven.

Met betrekking tot het onderscheid naar type verzekering is gesteld dat bij een schsdeverzekering een verzekeraar over meer directe informatie kan beschikken ten aanzien van het individuele ongevalsrisico dan bij een aansprakelijkheidsverzekering Dit betekent dat een schadeverzekeraar de autobestuurders kan indelen in een grous met jonge 'onervaren' autobestuurders en een groep met oudere 'ervaren' autobe-

807. Faure en Van den Bergh, preadvies, 1990, p. 17; Priest, YLJ, 1987, p. 1557.

808. Priest, YLJ, 1987, p. 1558.

809. Zie paragraaf 4.1 .4 van dit hoofdstuk. 
stuurders. Daarnaast kan de schadeverzekeraar de aangesloten risico's verder differentiëren naar het aantal afgelegde autokilometers, het type auto, schadeverleden en het aantal gemaakte verkeersovertredingen. De autobestuurder heeft verder de keuze om zijn letselschade bij dezelfde autopolis onder te brengen, of hiervoor een andere verzekering af te sluiten. Deze verschillende technieken kunnen eraan bijdragen dat bijvoorbeeld individuen die weinig autorijden en daardoor een laag risico vormen binnen de risicogroep worden gehouden.

Hoewel de vorenbedoelde risicodifferentiatie in beginsel ook mogelijk is binnen een aansprakelijkheidsverzekering, kan een aansprakelijkheidsverzekeraar slechts indirect invloed uitoefenen op het gedrag van de automobilist. De autobestuurder is immers aansprakelijk voor de schade die hij aan het slachtoffer, bijvoorbeeld de fietser, toebrengt. Het ongevalsrisico van deze fietser kan niet door de aansprakelijkheidsverzekeraar worden gecontroleerd, aangezien deze persoon onbekend is voor de verzekeraar en de identiteit ervan pas zal blijken bij een verkeersongeval met een verzekerde automobilist. Uitgaande van de stelling dat een aansprakelijkheidsverzekeraar over minder directe informatie beschikt dan een schadeverzekeraar, betekent dit dat een optimale risicodifferentiatie door de aansprakelijkheidsverzekeraar alleen tegen hoge kosten kan worden uitgevoerd. ${ }^{810}$

In theorie kan worden geconcludeerd dat een schadeverzekeraar, die de schade van de autobestuurder dekt, over meer betrouwbare informatie beschikt ten aanzien van het ongevalsrisico van de individuele bestuurder. Een schadeverzekeraar is daardoor beter in staat om het morele risico te controleren en om het proces van anti-selectie af te remmen. De aansprakelijkheidsverzekeraar kan het gedrag van de autobestuurder veel minder optimaal controleren. De ansprakelijkheidsverzekeraar dient immers rekening te houden met het gedrag van de fietser, die veelal door een toeval bij een verkeersongeval met de verzekerde autobestuurder is betrokken geraakt.

\section{De regulering van verzekeringsmarkten}

In de vorige paragraaf is uitvoerig stilgestaan bij een aantal informatieproblemen, waarmee een verzekeraar kan worden geconfronteerd indien een verzekeringsdekking voorhanden is. Ervan uitgaande dat een verzekerde invloed kan uitoefenen op het ongevalsrisico, is onderzocht welke instrumenten aan een verzekeraar ter beschikking staan om deze informatie-asymmetrie, die van de genoemde veronderstelling het gevolg is, te verminderen.

810. Zie hierover Priest, YLJ, 1987, p. 1558, die een onderscheid maakt tussen een 'first party' verzekering voor de automobilist en een 'third party' verzekering van een fabrikant van auto's. 
In deze paragraaf zal de economische analyse van verzekering worden uitgebreid met de theoretische vraag welke invloed overheidsregulering kan hebben op de wer. king van de verzekeringsmarkt en de efficiëntie van de verzekeringsovereenkomst. Daartoe kan de wetgever onder meer gebruik maken van een tweetal instrumenten, namelijk een verplichte verzekering (paragraaf 5.1) en een beperking van de aan. sprakelijkheid (paragraaf 5.2). De invoering van een verplichte verzekering word vaak beargumenteerd met de stelling dat een combinatie van een risicoaansprakelijkheid met een verplichte verzekering een volledige schadevergoeding aan het slachtoffer kan garanderen. Daarnaast wordt met een verplichte verzekering voorkomen dat de schadeveroorzaker in geval van insolventie niet aan zijn schadever. goedingsplicht kan voldoen. Een beperking van de aansprakelijkheid wordt nogal eens bepleit door de verzekeraars die menen dat bepaalde risico's vanwege de ge. brekkige voorspelbaarheid en grote omvang van de verwachte schade, anders onverzekerbaar dreigen te worden. In paragraaf $5.3 \mathrm{zal}$ de veronderstelling, dat op de verzekeringsmarkt steeds sprake is van een volledige concurrentie, worden genuanceerd. Daarbij zal de vraag aan de orde komen wat de effecten kunnen zijn van een beperking van de mededinging en een concentratie op de verzekeringsmarkt voor de efficiëntie van de verzekeringsovereenkomst. De analyse zal in paragraaf 5.4 worden afgesloten met een bespreking van het belang van concurrentie op de markt voor autoverzekeringen.

\subsection{DE THEORIE VAN DE VERPLICHTE VERZEKERING}

Een verplichte aansprakelijkheidsverzekering kan worden omschreven als een instrument waarbij een individu een bepaalde activiteit (bijvoorbeeld autorijden) alleen mag uitoefenen, wanneer de aansprakelijkheid voor schade, die het gevolg is van de uitoefening van de betreffende activiteit, door een verzekering is gedekt. ${ }^{811}$

Binnen de algemene theorie van verzekering is gesteld dat een verzekering een instrument is dat ten aanzien van een bepaalde activiteit het nut van een individu met een afkeer van risico kan verhogen. ${ }^{812}$ Uitgaande van dit gegeven rijst de vraag of de voordelen van een verzekering zo groot zijn dat een verplichte verzekering wenselijk geacht kan worden. Voor een beantwoording van deze vraag zal eerst worden uitgegaan van de veronderstelling dat geen verplichte aansprakelijkheidsverzekering aanwezig is.

811. Faure en Van den Bergh, preadvies, 1990, p. 24.

812. Zie paragraaf 3 van dit hoofdstuk. 


\subsubsection{Verzekeringsplicht en de verhoging van het nut}

Teneinde te kunnen beoordelen wat de effecten van een verzekeringsplicht zijn, zal eerst in het algemeen de houding ten aanzien van het risico, alsmede de bereidheid om een verzekering af te sluiten worden bekeken. De houding ten aanzien van risico kan uiteenlopen van sterk risicoavers tot risiconeutraal of zelfs risicozoekend. Daarbinnen zijn echter allerlei gradaties mogelijk. Een individu met een volledige afkeer van risico zal een verzekering willen aangaan die hem een volledige dekking verschaft. Een persoon met een minder sterke risicoaversie zal genoegen nemen met een minder dan volledige verzekeringsdekking. Een risiconeutraal individu, ten slotte, zal, op voorwaarde dat hij volledig is geïnformeerd, geen behoefte hebben aan verzekeringsdekking. Dit betekent dat alleen een persoon met een volledige afkeer van risico zijn verwacht nut kan verhogen met het afsluiten van een verzekeringsovereenkomst.

Wanneer via regelgeving een verplichte verzekering wordt opgelegd, zal dit kunnen leiden tot een welvaartsverlies. Voor een risiconeutraal persoon, een minder risicoavers individu of een persoon met een geringe vraag naar verzekering, zal een dergelijke verplichting niet leiden tot een verhoging van het verwacht nut. Indien deze individuen worden gedwongen om een verzekering af te sluiten zal voor hen de premie onevenredig hoger liggen dan de waarde die overeenkomt met de verwachte ongevalskosten en het individuele ongevalsrisico (actuarieel faire premie).

Een verplichte verzekering kan daarnaast, mede als gevolg van de verschillende individuele graden van risicoaversie, leiden tot een discrepantie tussen (vermogende) personen die anders geen verzekering zouden nemen en (minder vermogende) personen voor wie wel een vraag naar verzekering bestaat. Wanneer bepaalde vermogende individuen geen vraag naar verzekering hebben, zal een systeem van een verplichte verzekering niet leiden tot een verhoging van hun verwacht nut. Een verzekeringsplicht zal in dat geval eerder leiden tot hoge administratieve kosten, zonder dat daarmee de maatschappelijke welvaart wordt verhoogd.

Samenvattend kan worden gesteld dat, wanneer individuen volledig zijn geïnformeerd omtrent het verwachte risico en derhalve zelf kunnen bepalen of zij een verzekeringsovereenkomst aan willen gaan, er economisch gezien weinig reden is om een verzekering verplicht te maken. ${ }^{813}$

813. Zie Faure en Van den Bergh, Objectieve aansprakelijkheid, p. 304; Faure en Van den Bergh, preadvies, 1990, p. 25-26. 


\subsubsection{Informatieproblemen}

In werkelijkheid zullen individuen veelal geen volledige informatie hebben omtrent het verwacht risico. Een individu kan zich bijvoorbeeld vergissen in zijn houding ten aanzien van het risico, waardoor hij zich niet of onvoldoende verzekert. Daarnaast kan een individu niet op de hoogte zijn van de beschikbaarheid van een verzekering, met als gevolg dat hij geen verzekering afsluit, ondanks het gegeven dat een derge. lijke transactie zijn verwacht nut kan verhogen. Deze informatieproblemen kunnen een argument zijn om tot de invoering van een verplichte aansprakelijkheidsverzekering over te gaan. ${ }^{814}$

Naast de voornoemde informatieproblemen aan de zijde van de potentieel verzekerde, kunnen ook informatieproblemen aan de zijde van de verzekeraar aanleiding zijn voor de invoering van een verplichte verzekering. In de vorige paragraaf is in dat kader het proces van anti-selectie geanalyseerd. Daarin werd verondersteld dat de verzekerde beter geïnformeerd is omtrent het verwacht risico dan zijn verzekeraar. Als gevolg van deze informatie-asymmetrie heeft een verzekeraar moeite om de risicogroepen op een juiste wijze af te bakenen. ${ }^{815}$

Wanneer aan alle potentiële schadeveroorzakers een verplichte verzekering wordt opgelegd, kan worden voorkomen dat een proces van anti-selectie ontstaat, waarbij de goede risico's de groep verlaten. Daarmee kan echter een welvaartsverlies ontstaan, omdat een verplichte verzekeringspolis voor de goede risico's niet zal leiden tot een maximalisering van het verwacht nut. $\mathrm{Zij}$ betalen immers een relatief hoge gemiddelde premie.

Binnen de rechtseconomische literatuur wordt voor een dergelijk welvaartsverlies een oplossing gevonden in de vorm van een sociale verzekering, die door de overheid wordt verstrekt. Hierbij wordt verondersteld dat de overheid op een goedkope wijze de benodigde informatie omtrent het ongevalsrisico kan verzamelen. De overheid kan deze informatie daarnaast ook doorgeven aan de particuliere verzekeraars. $^{816}$

\subsubsection{Insolventie}

Naast de afwenteling van de eerdergenoemde informatieproblemen kan een verplichte verzekering ook een goede oplossing zijn voor de mogelijke insolventie van

814. Faure en Van den Bergh, Objectieve aansprakelijkheid, p. 305; Faure en Van den Bergh, preadvies, 1990, p. 29.

815. Zie paragtaaf 4.2 van dit houfdstuk.

816. Zie hierover onder anderen: Pauly, QJE, 1974, p. 44-62; Faure en Van den Bergh, Objectieve aansprakelijkhcid, p. 307-308; Faure en V'an den Bergh, preadvies, 1990, p. 29-30. 
de schadeveroorzaker. ${ }^{817}$ Wanneer zich een ongeval voordoet, waarbij de omvang van de schade hoger is dan het vermogen van de dader, zal de schade van het slachtoffer voor een deel onvergoed blijven. Het slachtoffer zal derhalve een beroep moeten doen op de aanwezige eigen voorzieningen, waarmee de schade echter indirect naar de gemeenschap (de belasting- en premiebetaler) wordt verschoven.

Een belangrijker probleem bij insolventie is dat de dader bij de uitoefening van zijn zorg- en activiteitsniveau onvoldoende rekening zal houden met de negatieve externe effecten, zijnde de verwachte schade, die door zijn activiteit kunnen worden veroorzaakt. Een verplichte aansprakelijkheidsverzekering kan in deze gevallen garanderen dat het slachtoffer volledig schadeloos wordt gesteld, ook wanneer de dader insolvabel blijkt te zijn. De schadeveroorzaker betaalt, ten behoeve van deze verplichte verzekering, vooraf een premiebedrag dat overeenkomt met de verwachte schade. ${ }^{818}$

Een verplichte verzekering kan daarnaast wenselijk zijn vanuit de positie van de niet-vermogende dader met een volledige afkeer van risico die een sterke vraag naar verzekering heeft. Met een verzekeringsplicht kan echter ook worden voorkomen dat bijvoorbeeld een risiconeutrale dader als gevolg van zijn insolventie te weinig zorg zal uitoefenen. Daarbij geldt de voorwaarde dat de aansprakelijkheidsverzekeraar in staat is om binnen een concurrerende verzekeringsmarkt het gedrag (morele risico) van de verzekerde effectief te controleren. ${ }^{819}$

In een eerder stadium van deze analyse is echter gesteld dat, door een gebrek aan informatie bij de verzekeraar, een controle van het morele risico niet optimaal kan zijn. Dit betekent dat een verplichte verzekering negatieve effecten kan hebben op het niveau van zorg van de schadeveroorzaker. Deze zal nu minder zorg aanwenden dan zonder de aanwezigheid van een verplichte verzekering het geval zou zijn. ${ }^{820}$

\subsubsection{Alternatieven voor een verplichte aansprakelijkheidsverzekering}

De voomoemde nadelige effecten van een verplichte aansprakelijkheidsverzekering kunnen in de eerste plaats worden tegengegaan wanneer een goed geïnformeerd

\footnotetext{
817. Zie Polborn, IRLE, 1998, p. 141-146, voor een analyse van de verhouding tussen cen verplichte verzekering en de insolventie van de dader (een onderneming).

818. Faure en Van den Bergh, Objectieve aansprakelijkheid, p. 305-306; Faure en Van den Bergh, preadvies, 1990, p. 26. Zie ook Shavell, Accident Law, p. 240-241 voor een analyse van de vraag naar een aansprakelijkheidsverzekering bij de afwezigheid van een verzekeringsplicht.

819. Jost, IRLE, 1996, p. 263.

820. Shavell, IRLE, 1986, p. 53-55; Faure en Van den Bergh, preadvies, 1990, p. 30; Faure en Van den Bergh, Objectieve aansprakelijkheid, p. 305-306; Shavell, Accident Law, p. 242; Bowles, Law and the Economy, p. 119-121; Holzhauer en Teijl, Inleiding rechtseconomie, p. 161. Zie ook paragraaf 4.1 en 4.1.1 van dit hoofdstuk.
} 
slachtoffer een eigen schadeverzekering afsluit. Daarmee kan het slachtoffer rekening houden met de mogelijkheid dat een insolvabele schadeveroorzaker niet in staat is om hem volledig schadeloos te stellen.

Indien het slachtoffer zich echter niet vrijwillig wenst te verzekeren, zijn er twee beleidsmaatregelen die aan het slachtoffer een voldoende compensatie kunnen garan. deren, namelijk een verplichte schadeverzekering aan de zijde van het slachtoffer en de instelling van een waarborgfonds door de overheid.

De eerstgenoemde maatregel legt aan het slachtoffer de verplichting op om, ter dek. king van zijn eigen verwachte schade, een schadeverzekering af te sluiten. Gegeven de informatievoordelen van een schadeverzekering boven een aansprakelijkheidsverzekering, ${ }^{821}$ zal bij een schadeverzekering aan de zijde van het slachtoffer een betere risicodifferentiatie mogelijk zijn. Daarbij kan de verzekeraar een onderscheid maken naar bijvoorbeeld het inkomen, de leeftijd en het beroep van een verzekerde, waardoor de premie een zo goed mogelijke afspiegeling vormt van het verwachte ongevalsrisico en een proces van anti-selectie kan worden tegengegaan. ${ }^{822}$

Aan een verplichte schadeverzekering aan de zijde van het slachtoffer zijn echier ook nadelen verbonden. In de eerste plaats zal, wanneer een dergelijke verzekering van overheidswege via de sociale zekerheid wordt verstrekt, sprake zijn van hoge administratieve kosten alsmede van inefficiënties ten gevolge van de werking van de bureaucratie. Deze problemen zullen echter een minder grote rol spelen indien een schadeverzekering via de particuliere markt wordt aangeboden.

In de tweede plaats zal de invoering van een verplichte schadeverzekering niet in hel voordeel van elk slachtoffer zijn. Wanneer een potentieel slachtoffer bijvoorbeeld in zeer geringe mate aan een bepaalde activiteit deelneemt, zal een verzekeringsplichi zijn verwacht nut niet verhogen. Daarnaast kan worden gewezen op het verband tussen de houding ten aanzien van risico en de vraag naar een verzekering. Een risiconeutraal slachtoffer zal, indien volledig geïnformeerd, bijvoorbeeld geen verzekering afsluiten, met het gevolg dat een verzekeringsplicht kan leiden tot een welvaartsverlies. ${ }^{823}$

Naast de invoering van een verplichte schadeverzekering kan de overheid ook besluiten tot de instelling van een waarborgfonds voor de vergoeding van ongevals. slachtoffers. Potentiële schadeveroorzakers betalen daarbij een soort heffing aan dit waarborgfonds. Uit dit fonds worden vervolgens de toekomstige slachtoffers van eहh

821. Zie paragraaf 4.4 van dit hoofdstuk.

822. Faure en Van den Bergh, preadvies, 1990, p. 27; Shavell, Accident Law, p. 242-243.

823. Faure en Van den Bergh, preadvies, 1990, p. 27; C.C. van Dam, Zorgvuldigheidsnorm on ansprakelijkheid, p. 205-206; Faure en Van den Bergh, Objectieve aansprakelijkheid, p. 312-313. 
ongeval vergoed, enkel indien achteraf wordt geconstateerd dat de schadeveroorzaker te weinig vermogen heeft om het slachtoffer schadeloos te stellen, of ondanks de verzekeringsplicht heeft verzuimd zich te verzekeren.

Een eerste voordeel van een waarborgfonds heeft betrekking op het gegeven dat een dergelijk fonds alleen uitkeert wanneer de schadeveroorzaker insolvent blijkt te zijn. Hierdoor blijft de preventieve werking van aansprakelijkheidsregels bestaan. In de tweede plaats is bij een waarborgfonds het probleem van het morele risico minder groot en zijn de administratieve kosten lager, omdat niet bij elk schadegeval wordt uitgekeerd. In de derde plaats zal de heffing die alle potentiële schadeveroorzakers aan het waarborgfonds moeten betalen lager zijn dan de premie bij een verplichte verzekering. Voor een risiconeutrale dader zal het nutsverlies derhalve geringer zijn dan bij een verplichte aansprakelijkheidsverzekering. ${ }^{824}$

\subsubsection{Verplichte verzekering in het verkeersongevallenrecht}

In het voorgaande is een algemeen overzicht gegeven van de economische voor- en nadelen van een verplichte verzekering. Een dergelijke verzekeringsplicht kan bijvoorbeeld het verwacht nut van een individu met een volledige afkeer van risico verhogen, alsook bepaalde informatieproblemen wegnemen. Daarnaast kan een verplichte verzekering op twee manieren een remedie zijn tegen de aanwezigheid van insolventie bij de dader. Enerzijds kan met behulp van een verzekeringsplicht worden voorkomen dat het slachtoffer, ten gevolge van de insolventie van de dader, zijn schade niet volledig vergoed krijgt. Anderzijds zal een verplichte verzekering een oplossing kunnen zijn voor een mogelijke verminderde zorgvuldigheid, 'underdeterrence', bij de insolvente dader. Op voorwaarde dat een verzekeringsplicht samengaat met een effectieve controle van het morele risico, kunnen derhalve de prikkels van zorg bij de dader behouden blijven. ${ }^{825}$

Naar aanleiding van deze theoretische overwegingen kan de vraag worden gesteld in hoeverre een verzekeringsplicht binnen de autoverzekering wenselijk is. Aan het begin van dit hoofdstuk is uitgegaan van de niet onrealistische veronderstelling dat een gemiddelde autobestuurder een afkeer heeft van risico. ${ }^{826}$ Wanneer daamaast wordt gesteld dat het inkomen van een gemiddelde automobilist relatief laag is en de verwachte schade een grote omvang kan hebben, zal met de invoering van een verzekeringsplicht het welvaartsverlies beperkt kunnen blijven. Een tweede argument voor

\footnotetext{
824. Faure en Van den Bergh, preadvies, 1990, p. 28; Faure en Van den Bergh, Objectieve aansprakelijkheid, p. 313; Shavell, IRLE, 1986, p. 55; Holzhauer en Teijl, Inleiding rechtseconomie, p. 161-162. In paragraaf $6 \mathrm{zal}$ worden ingegaan op de economische analyse van cen schadefonds.

825. Hierbij geldt verder dat de controle van het morele risico beter mogelijk is met een verzekering dan met alleen aansprakelijkheid.

826. Zie paragraaf 2.1 van dit hoofdstuk.
} 
een verplichte aansprakelijkheidsverzekering voor motorrijtuigen hangt samen me het feit dat een autobestuurder bijvoorbeeld niet weet dat een verplichte verzekering zijn verwacht nut kan verhogen. Wanneer wordt verondersteld dat de overheid dens informatie wel heeft, krijgt een verzekeringsplicht echter wel een patemalistisch l2 $_{2}$ rakter. Een derde argument ten slotte, houdt verband met mogelijke insolventieproblemen bij de vergoeding van verkeersschade. Wanneer het inkomen van de ation bestuurder lager is dan de verwachte schade, zal een verplichte aansprakelijkheilic verzekering wenselijk kunnen zijn. ${ }^{827}$

Gegeven het bilaterale karakter van een verkeersongeval kan echter ook hier de vraag worden gesteld of bijvoorbeeld een schadeverzekering aan de zijde van bat slachtoffer niet tegen lagere kosten kan worden uitgevoerd. Het voordeel van eto dergelijke eerste partijverzekering is dat de verzekeraar over meer directe infomatie beschikt om het morele risico en het proces van anti-selectie te controleren. Daar. naast geldt ook ten aanzien van verkeersslachtoffers de reële veronderstelling vanrsicoaversie. Wanneer deze verzekering tenslotte niet vanwege de overheid wort verstrekt maar door de particuliere verzekeringsmarkt wordt aangeboden, kumnen ook administratieve kosten en inefficiënties op het terrein van de bureaucratie wo: den vermeden.

\subsection{DE BEPERKING VAN AANSPRAKELIJKHEID}

Een tweede instrument waarmee de overheid, naast een verzekeringsplicht, de verze keringsmarkt kan reguleren is de invoering van een beperking van de aarspis kelijkheid. Een economisch argument voor een dergelijke aansprakelijkheidsbeperking is het gevaar dat bepaalde risico's onverzekerbaar dreigen te worden indien ext onbeperkte aansprakelijkheid van toepassing zou zijn. Dit gevaar heeft dan voord betrekking op de aansprakelijkheid voor risico's die betrekkelijk weinig voorkomen maar waarbij de omvang van de verwachte schade en het aantal potentiële slachtof fers zeer hoog is. ${ }^{828}$ Ook bij autoverzekeringen kan een beperking van anspride

827. Zie Jost, IRLE, 1996, p. 263-267, voor een analyse van de verhouding tussen insolventic, vi plichte verzekering en de controle van het morele risico. Zie ook Faure en Van den Berght, 0 . jectieve aansprakelijkheid, p. 309-310.

828. Voorbeelden hiervan zijn kemongevallen en olieverontreiniging. Bij deze zogenaande 'catasto fe-risico's' gaat een beperking van de aansprakelijkheid vaak samen met een verplichte verzers ring, omdat bij deze risico's de eventuele vergoeding aan het slachtoffer gewaarborgd moet bli; ven. Zie Faure en Van den Bergh, preadvies, 1990, p. 20-24; Faure en Van den Bergh, Objectio ve aansprakelijkheid, p. 338-342. Zie daar uitvoerig over Vanden Borre, Efficiênte preventie compensatie van catastroferisico's, diss. 2001. Priest, YLJ, 1987, p. 1582-590, stelt dat de vata keringscrisis in de Verenigde Staten mede is beinnvloed door het feit dat bepaalde vormen in aansprakelijkheid onverzekerbaar dreigden te worden. Als voorbeelden noemt hij onder mitet de aansprakelijkheid voor nucleaire risico's, productaansprakelijkheid en beroepsaanspraterif
heid. 
lijkheid nodig zijn om de verzekerbaarheid mogelijk te maken. Daarnaast dient ook bij autoverzekeringen het gevaar van insolventie te worden beperkt en de vergoeding aan het slachtoffer gewaarborgd te blijven.

\subsubsection{De verzekerbaarheid van risico's als argument voor limitering}

Een belangrijk argument voor de wetgever om, al dan niet op aandrang van de verzekeraars, te besluiten tot een beperking van de aansprakelijkheid hangt derhalve sterk samen met de vraag naar de verzekerbaarheid van risico's. Behalve de reeds genoemde omvang van de verwachte schade, wordt binnen de economische analyse nog een aantal andere argumenten genoemd voor de beoordeling van de verzekerbaarheid van risico's. Deze factoren liggen allereerst op het terrein van het morele risico respectievelijk de anti-selectie. ${ }^{829}$

Wanneer het morele risico door een verzekeraar niet optimaal kan worden gecontroleerd, kan het verwachte ongevalsrisico toenemen en dreigt het gevaar dat het risico niet meer kan worden verzekerd. ${ }^{830}$ Een mogelijke oplossing hiervoor is de invoering van een verbod op het afsluiten van een verzekering. ${ }^{831}$ Een voordeel van een dergelijk verbod is dat de preventieve werking van het aansprakelijkheidsrecht in stand blijft. De schadeveroorzaker behoudt een prikkel om een optimaal zorgniveau uit te oefenen. Een nadeel van een verzekeringsverbod is dat een dader met een afkeer van risico, geen mogelijkheid heeft om dit risico af te schuiven. Dit kan ertoe leiden dat een schadeveroorzaker een bepaalde maatschappelijk wenselijke activiteit niet meer zal uitoefenen. ${ }^{832} \mathrm{Bij}$ een niet-optimale controle van het morele risico is echter een combinatie van een verzekeringsverbod en een onbeperkte aansprakelijkheid toch te prefereren boven een verplichte aansprakelijkheidsverzekering met een beperking van de aansprakelijkheid. Bij deze laatste combinatie blijft immers het gevaar van het morele risico aanwezig. ${ }^{83}$

In het kader van het proces van anti-selectie is het uitgangspunt gehanteerd dat de verzekerde beter op de hoogte is van het verwachte risico dan zijn verzekeraar. Daarbij is gesteld dat het proces van anti-selectie in het ergste geval kan leiden tot de onverzekerbaarheid van bepaalde risico's. ${ }^{834}$ Een verzekeraar dient derhalve de risicogroepen zo klein mogelijk te houden, waarbij de premie zoveel mogelijk is afge-

829. Zie paragraaf 4 van dit hoofdstuk.

830. Faure en Van den Bergh, Objectieve aansprakelijkheid, p. 347.

831. In de vorige eeuw gold in veel landen van West-Europa nog een verbod op het afsluiten van een aansprakelijkheidsverzekering. Een dergelijke verzekering werd immoreel bevonden en dus niet wenselijk geacht. Een ander argument was de angst dat de afschrikkende werking van het aansprakelijkheidsrecht zou verminderen. Zie hieromtrent Shavell, Accident Law, p. 214-215.

832. Shavell, IRLE, 1986, p. 53-54.

833. Jost, IRLE, 1996, p. 261-262.

834. Zie hierover paragraaf 4.2 van dit hoofdstuk. 
stemd op het individuele risico. Daarnaast kan een verzekeringsplicht voorkomen dat de goede risico's de groep verlaten, maar dit heeft het ongewenste effect dat dea: goede risico's een te hoge premie betalen in verhouding tot hun verwachte risico.:

Ook de voorspelbaarheid van het risico en de verwachte schade zijn van invloed on de verzekerbaarheid van risico's. Voor een inschatting van de schadeomvang is hes in beginsel noodzakelijk dat de verzekerbare risico's zich veelvuldig voorioen waarbij de verwachte schade niet te hoog is. Een verzekeraar heeft daardoor via is wet van de grote getallen de mogelijkheid om tot een juiste spreiding van het risio te komen. ${ }^{836}$

Samenvattend kan worden gesteld dat de verzekerbaarheid van het risico niet allet afhankelijk is van de omvang van de schade, maar mede wordt bepaald door het m. rele risico, de anti-selectie, en de voorspelbaarheid van het risico en de verwachiz schade zelf. Deze informatieproblemen kunnen derhalve de beschikbaarheid van eta verzekering beperken.

\subsubsection{De wenselijkheid van een beperking van de aansprakelijkheid}

Bij de analyse van het aansprakelijkheidsrecht is gesteld dat aansprakelijkheid. regels de dader kunnen aanzetten tot de uitoefening van optimale zorg. ${ }^{837}$ Ingevolge het economisch model staat deze zorg in direct verband met de verwachte schade. Wanneer de aansprakelijkheid wordt beperkt tot een bepaalde schadeomvang, zald direct van invloed zijn op de zorgvuldigheid van de dader. Deze zal zijn zorgavean aanpassen aan het met deze beperkte aansprakelijkheid overeenkomende schadde drag. Dit niveau van zorg zal daarmee lager zijn dan het niveau waarmee de total ongevalskosten kunnen worden geminimaliseerd. Wanneer de werkelijke omvang van de schade hoger is dan het bedrag waarvoor de dader (beperkt) aansprakelijk is zal de dader geen prikkel hebben om meer zorg aan te wenden. Daarmee leidt teen beperking van de aansprakelijkheid tot een inefficiënte uitkomst voor wat betreft de

835. Zie Faure en Van den Bergh, Objectieve aansprakelijkheid, p. 344-345 en Faure en Van da Bergh, preadvies, 1990, p. 20-21.

836. Zie Schmit, JRI, 1986, p. 320-329, voor een opsomming van de vereisten voor de verzekertum heid van risico's. Zie verder Faure en Van den Bergh, Objectieve aansprakelijkheid, p. 345; $\mathrm{Cl}$ van Dam, Zorgvuldigheidsnorm en aansprakelijkheid, p. 225. Faure en Van den Bergh, prad vies, 1990, p. $21-22$, stellen dat voor risico's die zich minder frequent voordoen, bijvoorbeld ex kemongeval, via een herverzekering een zekere spreiding kan worden bereikt. Door middel wi een zogenaamde 'pooling' kan verder het risico worden samengevoegd. Daar staat tegenover th het nucleaire risico een hoge mate van onvoorspelbaarheid in zich draagt, waardoor de verzkte baarheid wordt belemmerd.

837. Zie daarover paragraaf 3 van hoofdstuk 5.

838. Daarbij wordt de waarschijnlijkheid, $p$, die verband houdt met het zorgniveau van de dader tr menigvuldigd met de omvang van de schade, S. Zie paragraaf 3 van hoofdstuk 4. 
zorgvuldigheid van de dader. Daamaast zal een dergelijke maatregel leiden tot een minder dan volledige schadevergoeding voor het slachtoffer. De ansprakelijkheid is immers beperkt tot een lager bedrag dan de door het slachtoffer werkelijk geleden schade. ${ }^{839}$

De negatieve effecten van een aansprakelijkheidsbeperking kunnen worden voorkomen door de aansprakelijkheid onbeperkt te laten en deze vervolgens te combineren met een beperkte verzekeringsdekking. De dader behoudt hierbij een prikkel om optimale zorg uit te oefenen, althans voor het deel van het risico dat niet door de verzekering is gedekt. Het nadeel bij een dergelijke regeling kan zijn dat de dader voor het niet gedekte risico insolvent zal blijken te zijn. Dit probleem kan echter worden ondervangen door middel van een waarborgfonds. Voor het slachtoffer geldt derhalve dat zijn eventuele schadevergoeding blijft gewaarborgd. ${ }^{840}$

\subsubsection{Aansprakelijkheidsbeperking in het verkeersongevallenrecht}

Verkeersongevallen hebben een hoge frequentie, waarbij het relatief gezien om lage schadebedragen gaat. Dit betekent dat een autoverzekeraar gebruik kan maken van de wet van de grote getallen om tot een juiste spreiding van verkeersrisico's te komen. Daarbij kan met behulp van de totale premieopbrengst in principe de volledige schade worden vergoed. Een autoverzekeraar bepaalt de omvang van de premie aan de hand van een rekenkundige som, waarbij het totaalbedrag van het verwachte aantal schadegevallen, de omvang van de verwachte schade en de administratieve kosten wordt gedeeld door het aantal verzekerden. Om het verwachte aantal schadegevallen en de verwachte schadeomvang te kunnen berekenen, maakt een autoverzekeraar gebruik van statistische gegevens. Deze zijn redelijk betrouwbaar wanneer het gaat om een kwantitatief hoog aantal schadegevallen, zoals bijvoorbeeld verkeersongevallen. ${ }^{841}$

Wanneer wordt verondersteld dat verkeersrisico's goed verzekerbaar zijn, lijkt er weinig reden te zijn om de aansprakelijkheid van de autobestuurder bij wet te beperken. Een autobestuurder met een afkeer van risico zal derhalve zijn aangewezen op een volledige verzekeringsdekking. Het nadeel van dergelijke aansprakelijkheidsverzekering met een volledige dekking is dat, gegeven de informatieproblemen aan de zijde van de aansprakelijkheidsverzekeraar, het morele risico en de anti-selectie

839. Zie Jost, IRLE, 1996, p. 261-262. De gevolgen van een aansprakelijkheidsbeperking voor het onderscheid in fout- en risicoaansprakelijkheid zal in paragraaf 7 aan bod komen.

840. Zie Faure en Van den Bergh, preadvies, 1990, p. 24.

841. Zie C.C. van Dam, Zorgvuldigheidsnorm en aansprakelijkheid, p. 225; Atiyah, Accidents, Compensation and the Law, p. 252-255 en p. 451. Priest, YLJ, 1987, p. 1582, steit in zijn analyse van de verzekeringscrisis in Noord-Amerika nadrukkelijk dat de autoverzekeringsmarkt, zowel het eerste partij-als het derde partij gedeelte, onaangetast is gebleven door de verzekeringscrisis. 
niet optimaal kunnen worden gecontroleerd. Dit betekent dat een verplichte volledi ge verzekeringsdekking met een onbeperkte aansprakelijkheid geen efficiënt instr. ment is om de autobestuurder aan te zetten tot zorgvuldigheid. Vanuit preventiel oogpunt zal derhalve een beperkte verzekeringsdekking met een onbeperkte aan sprakelijkheid de voorkeur hebben, ${ }^{842}$ zodat de autobestuurder voor het deel van bet ongevalsrisico dat niet door de verzekering is gedekt een prikkel van zorg behoudt. Wanneer de autobestuurder voor het niet-gedekte risico insolvent blijkt te zijn kan enerzijds een waarborgfonds uitkomst bieden. Anderzijds kan het slachtoffer ool een beroep doen op de beschikbare eigen voorzieningen, bijvoorbeeld een schade. verzekering, om te voorkomen dat hij geen volledige schadevergoeding ontvangt.

\subsection{DE ECONOMISCHE ANALYSE VAN VERZEKERINGSMARKTEN}

Uit de voorgaande analyse is onder andere naar voren gekomen dat een verplicble verzekering een middel kan zijn om te voorkomen dat een insolvente dader niet aan zijn vergoedingsplicht kan voldoen. Daarnaast wordt aan een potentiële schadeveroorzaker met een afkeer van risico bescherming geboden tegen het ongevalsisico. Vervolgens is betoogd dat een beperking van de aansprakelijkheid een negatieve in vloed kan hebben op de zorgvuldigheid van de dader (autobestuurder). Daarbij is vanuit preventieoogpunt een voorkeur uitgesproken voor een beperkte verzekeringsdekking gecombineerd met een onbeperkte aansprakelijkheid.

In deze paragraaf zal een derde aspect van verzekeringsregulering aan de orde knmen. Binnen de economische analyse is steeds uitgegaan van de veronderstelling dat op de verzekeringsmarkt sprake is van een volledige concurrentie, waarbij verzekerden kunnen kiezen uit verschillende verzekeringspolissen. In werkelijkheid blijkt dat deze concurrentie door verschillende maatregelen wordt beperkt, hetzij vanwege de overheid, hetzij door het verzekeringsbedrijf zelf. Dit betekent dat moet worden or derzocht welke economische effecten een dergelijke concentratie kan hebben op de efficiëntie van de verzekeringsovereenkomst alsook op het ongevallenrecht.

\subsubsection{Vraag en aanbod binnen een concurrerende verzekeringsmarkt}

Binnen een ideale verzekeringsovereenkomst kan de verzekeraar de premie optimal afstemmen op het individuele risico van een verzekerde. ${ }^{843}$ Als gevolg van inform: tieproblemen zoals het morele risico en de anti-selectie is een verzekeraar echter niet in staat om het gedrag van de verzekerde optimaal te controleren. ${ }^{844}$ Door de toevoe-

842. Keeton and Kwerel, JLE, 1984, p. 149-179, pleiten voor een verplichte verzekering met enn $\mathrm{g}^{6}$ deeltelijke dekking plus een subsidie voor bepaalde categorieen van bestuurders ten behoever 12 de aankoop van een hogere verzekeringsdekking.

843. Zie paragraaf 3 van dit hoofdstuk.

844. Zie paragraaf 4 van dit hoofdstuk. 
ging van het mededingingsproces aan de analyse wordt verondersteld dat de concurrentie op de verzekeringsmarkt aan verzekeraars prikkels geeft om de juiste informatie te verzamelen waardoor een optimale afstemming van de premie met de verwachte schade mogelijk wordt. Dit betekent dat op de verzekeringsmarkt sprake is van een werkzame mededinging ('workable competition') wanneer de prijs die de verzekeraar voor zijn diensten vraagt niet te zeer afwijkt van de actuarieel juiste premie verhoogd met de administratieve kosten ${ }^{845}$

De prijs van een verzekering komt op een concurrerende verzekeringsmarkt tot stand via het proces van vraag en aanbod. Een potentiële verzekerde zal daarbij een polis willen afsluiten tegen een goede prijs (premie). De verzekeraar is degene die een verzekeringspolis aanbiedt en de prijs daarvan bepaalt aan de hand van de gegevens die de potentielle verzekerde aan hem verstrekt. De collectieve vraag naar een verzekering kan zeer hoog zijn, in het bijzonder wanneer op individuen de verplichting rust om zich te verzekeren. Daarbij is het voor een verzekeraar eenvoudig om tegen lage kosten het aanbod van verzekeringspolissen uit te breiden. Dit betekent enerzijds dat een stijging van de collectieve vraag naar een verzekering niet behoeft te leiden tot een premieverhoging. Anderzijds zal een eventuele premiestijging wel afhankelijk zijn van de toename van de verwachte schade, een element dat nauw verwant is met de hoogte van de premie. Daarnaast zal bij een individuele vraag naar een verzekering een premieaanpassing wel mogelijk zijn. ${ }^{846}$

\subsubsection{Economische gevolgen van een concentratie op de verzekeringsmarkt}

Wanneer tengevolge van overheidsregulering of zelfregulering van het verzekeringsbedrijf de mededinging op de verzekeringsmarkt wordt beperkt, zal een verzekeraar minder rekening houden met eventuele concurrenten. Daardoor kan een concentratie binnen de verzekeringsmarkt ontstaan, waarbij slechts enkele verzekeraars de markt controleren. Wanneer daarnaast wordt uitgegaan van de veronderstelling dat een verzekeraar streeft naar winstmaximalisatie, zal op een geconcentreerde markt het premiebedrag hoger liggen dan de verwachte schade, verhoogd met de administratieve kosten en een winstmarge.

Een concentratie op de verzekeringsmarkt heeft in de eerste plaats tot gevolg dat het kleine aantal verzekeraars dat op deze markt opereert een hogere premie zal vragen dan binnen een concurrerende markt als optimaal (actuarieel fair) is bestempeld. ${ }^{847}$ Het feit dat, ten gevolge van een concentratie op de markt de premie relatief te hoog wordt, betekent overigens niet noodzakelijk dat er dan ook geen vraag naar verzeke-

\footnotetext{
845. Faure en Van den Bergh, Objectieve aansprakelijkheid, p. 326.
846. Adams, Gefahrdungs- und Verschuldenshaftung, p. 215-216; Faure en Van den Bergh, Objectieve aansprakelijkheid, p. 326.

847. Zie paragraaf 5.3.1 van dit hoofdstuk
} 
ring meer zal zijn. Dat is afhankelijk van de graad van risicoaversie. Ten aanie van een sterk risicoavers individu kan bijvoorbeeld worden verondersteld dat deat bereid is een premie te betalen die hoger ligt dan zijn verwachte schade. Dit beteken dat wanneer deze persoon een volledige dekking van zijn verwachte schade ven een premiestijging tot een verhoging van zijn verwacht nut kan leiden, als dat metd. schade overeenkomt. Een persoon met een minder sterke afkeer van risico zal ias entegen, bij zijn keuze voor een verzekeringspolis mogelijk slechts een gedeeltelijk dekking van zijn verwacht risico wensen, met een aanverwant lage premie. Indien het premiebedrag hoger wordt dan de verwachte schade, zal deze persoon mogelifit naar een andere verzekeraar willen overstappen of zich misschien afvragen of bij niet beter af is zonder een verzekering. Binnen een geconcentreerde verzekering.markt wordt echter de overstap naar een andere verzekeraar bemoeilijkt. Een po. soon met een minder sterke afkeer van risico wordt hierdoor uiteindelijk gedwongan om een premie te betalen die hoger ligt dan hetgeen hij op een concurrerende mart verschuldigd zou zijn. ${ }^{848}$

Een tweede economisch gevolg van een concentratie op de verzekeringsmarkt is dxt een verzekeraar geen prikkel zal hebben om de verzekerde risico's op een zo opt. maal mogelijke wijze te differentiëren. De verzekeraar zal op een geconcentreerde verzekeringsmarkt een premiebedrag vaststellen dat gelijk is aan de verwachte schede, verhoogd met de administratieve kosten én een winstmarge. Afhankelijk van zija marktpositie zal de verzekeraar immers ook rekening houden met zijn winst, die tij in de premie zal trachten te verdisconteren. Wanneer derhalve wordt uitgegaan van het gegeven dat een verzekeraar geen prikkel heeft om de aangesloten risico's te ififerentiëren, zal hij ook niet worden angezet om het morele risico te controleren Een van de remedies tegen het morele risico hangt immers samen met verstrekken van gedifferentieerde verzekeringspolissen. Indien een 'monopolistische' verzekerex in het kader van zijn streven naar winstmaximalisatie in alle vrijheid de omvang va de premie kan vaststellen, zal de prikkel tot een controle van het morele risico grt tendeels verdwijnen. Dit kan tot gevolg hebben dat ook het gedrag van de verzekede zich in negatieve zin wijzigt. ${ }^{849}$

Een derde economisch gevolg van een concentratie op de verzekeringsmarkt hangt samen met de regulering van standaardvoorwaarden in de verzekeringspolissen. Een juridisch argument dat voor de invoering van verplichte standaardvoonvarden wordt gebruikt ligt in de sfeer van de bescherming van de consument, die daardor tegen lage informatiekosten een juiste verzekeringspolis kan aanschaffen. Econo misch gezien hebben standaardvoorwaarden echter het ongewenste neveneffect der de differentiatie in het polisaanbod gering is, waardoor de keuzemogelijkheden vol

848. Faure en Van den Bergh, preadvies, 1990, p. 31; Faure en Van den Bergh, NJB, 1993, p. 266.

849. Faure en Van den Bergh, Objectieve aansprakelijkheid, p. 327; Faure, VA, 1993, p. 15.16. 
de consument in werkelijkheid worden beperkt. Dit kan tot gevolg hebben dat een potentieel verzekerde, afhankelijk van zijn houding ten aanzien van risico, zal besluiten om geen verzekering aan te gaan, omdat dit zijn verwacht nut niet zal verhogen.

In de vierde plats ten slotte, wordt een beperking van de concurrentie via prijsafspraken of een concentratie als argument voor de bescherming van de kleine verzekeraars gebruikt. Aan de ene kant kan het wenselijk zijn om ten aanzien van de dekking van omvangrijke risico's via pooling een gezamenlijke dekking van deze risico's te bereiken. Een dergelijke pooling kan een positief effect hebben op de concurrentie omdat kleine verzekeraars het gezamenlijk kunnen opnemen tegen de grote verzekeraars. De vraag of een proces van pooling ook daadwerkelijk tot meer concurrentie zal leiden, hangt af van de vraag of de consument profiteert van een toename in het polisaanbod, waarbij de premie op een concurrentieel niveau blijft. Aan de andere kant kan met behulp van prijsafspraken worden voorkomen dat een kleine verzekeraar niet meer aan zijn verplichtingen kan voldoen. ${ }^{851}$ Op deze wijze kan een beperking van de concurrentie garant staan voor een controle van het morele risico. Een kleine verzekeraar zal echter om in de markt te kunnen blijven, elk risico dat zich aandient verzekeren, waardoor hij geen prikkel heeft om het morele risico afdoende te controleren. ${ }^{852}$

\subsubsection{Concurrentie en verplichte verzekering}

In paragraaf 5.1 is een aantal voor- en nadelen van een verplichte verzekering opgesomd. Een voordeel van een verplichte verzekering hangt samen met een vermindening van het insolventierisico bij de dader. Daarnaast kan een verplichte verzekering bepaalde informatieproblemen bij de schadeveroorzaker wegnemen. Een verplichte verzekering leidt echter tot een minder optimale controle van het morele risico, waardoor mogelijk negatieve effecten ontstaan met betrekking tot het zorg- en activiteitsniveau bij een verzekerde.

Wanneer sprake is van een concentratie op de verzekeringsmarkt, bestaat het gevaar dat mensen zich, afhankelijk van hun houding ten aanzien van het risico, niet meer verzekeren. Dit betekent dat zij weliswaar een optimale prikkel van zorg behouden,

850. Faure en Van den Bergh, NJB, 1993, p. 266; Faure, VA, 1993, p. 16. Zie ook Harrington and Doerpinghaus, JRI, 1993, p. 59-84.

851. Het gevaar van insolventie lijkt in werkelijkheid weinig realistisch, aangezien in veel Westeuropese landen aan verzekeraars strenge eisen worden gesteld op bijvoorbeeld het gebied van minimumkapitaal, die moeten garanderen dat zij aan hun verplichtingen kunnen voldoen. Zie daarover Adams, Grefährdungs- und Verschuldenshaftung, p. 249-251, met betrekking tot Engeland en Duitsland.

852. Faure en Van den Bergh, Objectieve aansprakelijkheid, p. 330-331; Faure en Van den Bergh, preadvies, 1990 , p. $30-31$ 
maar dit kan tegelijk leiden tot insolventieproblemen, waardoor een optimale schedeloosstelling aan het slachtoffer in het gedrang komt. Als gevolg van een beperking van de concurrentie kunnen de verzekeraars hoge winsten maken waardoor de premies zullen stijgen. Daarnaast hebben de verzekeraars te weinig prikkels on de ver zekerde risico's op een juiste wijze te differentiëren en om het morele risico affioen de te controleren. Dit zal uiteindelijk kunnen leiden tot een stijging van de max schappelijke ongevalskosten. ${ }^{853}$

De invoering van een verplichte verzekering binnen een geconcentreerde verzte. ringsmarkt zal tot verdere inefficiënties kunnen leiden. Een potentieel verzekeró heeft hierbij niet de vrijheid om, afhankelijk van zijn risicohouding en de aangtonden verzekeringsvoorwaarden, geen verzekering aan te gaan dan wel eenvoudigna een andere verzekeraar over te stappen. Adams stelt dat een combinatie van een ve. plichte verzekering en kartelvorming niet in het belang is van de consument. ${ }^{84}$

Een combinatie van een verplichte verzekering en de aanwezigheid van een gecos centreerde verzekeringsmarkt heeft ook gevolgen voor de positie van de verzeke raars. Enerzijds kunnen zij als belangengroep invloed uitoefenen op de wetgerea voor gunstige regelgeving. ${ }^{855}$ Anderzijds kan een verzekeringsplicht ook in het $n$ deel van de verzekeraars zijn. Wanneer bijvoorbeeld een combinatie van een weth lijke verzekeringsplicht en een acceptatieplicht geldt, kan dit nadelige effecten bet ben op de winstmarges van de verzekeraars.

\subsection{HET BELANG VAN CONCURRENTIE OP DE MARKT VOOR AUTOVERZEKERNGEN}

Naar aanleiding van de economische analyse van de verzekeringsmarkt kan worde geconcludeerd dat een hoge concentratie op de verzekeringsmarkt uiteindelijk ke leiden tot een stijging van de maatschappelijke kosten van ongevallen. In deze pur graaf zal het belang van de aanwezigheid van concurrentie op de markt voor attor verzekeringen nader worden uitgewerkt.

Bij de analyse van het morele risico is geconstateerd dat de controle van het gedrag van de autobestuurder, door een gebrek aan informatie aan de zijde van de autover zekeraar, vaak niet optimaal is. ${ }^{856}$ In het voorgaande is daarnaast gesteld dat ter concentratie op de verzekeringsmarkt het morele risico verder kan versterken. $D$ betekent derhalve dat het concurrentieproces mede van belang is om het morele isitco te reduceren. Daarbij geldt dat het concurrentieproces een noodzakelijke nar geen voldoende voorwaarde is; de aanwezigheid van concurrentie kan het morele ti-

853. Faure en Van den Bergh, Objectieve aansprakelijkheid, p. 330.

854. Adams, Gefahrdungs- und Verschuldenshaftung, p. 215.

855. Zie daarover meer uitvoerig hoofdstuk 7.

856. Zie paragraaf 4.1.4 van dit hoofdstuk. 
sico niet geheel wegnemen. Hiervoor kan een aantal argumenten worden aangevoerd.

In de eerste plaats kunnen autoverzekeraars elkaar beconcurreren door de verzekeringsnemer te belonen voor goed gedrag. Wanneer een autobestuurder door een grotere zorgvuldigheid de verwachte schade kan reduceren, zal hij hiervoor kunnen worden beloond met een premieverlaging. Anderzijds kan een premieverhoging worden opgelegd, wanneer de autobestuurder minder zorgvuldig is geweest. Een voorbeeld van een dergelijk preventie-instrument is de toepassing van een bonusmalussysteem, waarbij de premie wordt aangepast aan de hand van het schadeverleden van de autobestuurder. Met behulp van een bonus-malussysteem kan, nadat zich een verkeersongeval heeft voorgedaan, informatie worden verkregen ten aanzien van de omvang van de verwachte schade van een autobestuurder en de uitgeoefende zorg bij de deelname aan het verkeer. Hiermee kan een bepaalde mate van individualisering worden bereikt, waarbij tevens een proces van anti-selectie kan worden tegengegaan. $^{857}$

In de tweede plaats kan het morele risico worden verminderd door de invoering van een eigen risico bij de autobestuurder of door het verzekerde risico te binden aan een bepaald maximum bedrag. De autobestuurder zal voor het deel van het ongevalsrisico dat niet door de verzekering is gedekt een prikkel tot zorg behouden. Met behulp van een gedeeltelijke verzekeringsdekking kan eveneens de anti-selectie worden tegengegaan. De goede risico's zullen hierbij genoegen nemen met een gedeeltelijke dekking met een aanverwant lage premie, terwijl de slechte risico's een optimale prikkel tot zorg verkrijgen. Daarbij zal echter rekening moeten worden gehouden met de kosten van zorg in verbouding tot het nadeel van een gedeeltelijke dekking. ${ }^{858}$

Een derde element dat binnen een concurrerende verzekeringsmarkt kan leiden tot een vermindering van het morele risico is het regresrecht. Wanneer bijvoorbeeld aan de aansprakelijkheidsverzekeraar een regresrecht op de schadeveroorzaker wordt verleend, kan worden voorkomen dat een onzorgvuldige verzekerde (schadeveroorzaker) de nadelen van zijn gedrag afwentelt op zijn medeverzekerden. ${ }^{859}$

De bovenbeschreven remedies kunnen echter pas zinvol zijn indien op de markt voor autoverzekeringen sprake is van een werkzame concurrentie. Door dit mededingingsproces kan een verzekerde autobestuurder worden beloond met een premie-

\footnotetext{
857. Adams, Gefahrdungs- und Verschuldenshaftung, p. 227-228 en 235.

858. Adams, Gefährdungs- und Verschuldenshaftung, p. 232-233; Faure en Van den Bergh, Objectieve aansprakelijkheid, p. 327-328. aansprakelijkheid, p. 328 . Zie verder paragraaf 7.5 voor een economische analyse van regres.
} 
verlaging, wanneer hij door een grotere zorgvuldigheid de verwachte schade hetef kunnen verminderen. Daamaast kan worden verondersteld dat een verzekering dz preventieve functie van het aansprakelijkheidsrecht overneemt, waardoor de verze. keraar als gevolg van de aanwezigheid van concurrentie zal worden aangezet toteten vermindering van het morele risico. Aansprakelijkheidsregels kunnen daarbij humel. ficiëntie behouden wanneer door het mededingingsproces wordt gewaarborgd dat de verzekeraar, tegen een premie die overeenstemt met de verwachte schade, het rision overneemt van de autobestuurder met een afkeer van risico. ${ }^{860}$

Concluderend kan worden gesteld dat een bepaalde mate van concurrentie op de markt voor autoverzekeringen wenselijk is, om te voorkomen dat de ongevalskoster toenemen. Daarnaast is het concurrentieproces van belang om het morele risico en de anti-selectie terug te dringen. Op een concurrerende markt zullen verzekerass immers worden aangezet om een verzekeringspolis aan te bieden warbij de premi: een juiste afspiegeling vormt van de verwachte schade van de individuele autobsstuurder. Wanneer de autobestuurder zorgvuldig is geweest zal hij worden beloont met een premieverlaging. Op een geconcentreerde verzekeringsmarkt daarentegen zal de voorzichtige autobestuurder moeten bijdragen aan de kosten die het gevolg zijn van verkeersongevallen die door roekeloze chauffeurs worden veroorzakk. Di voorzichtige autobestuurder wordt niet beloond voor zijn goede verkeersgedrag met het mogelijke gevolg dat hij zich op termijn ook minder zorgvuldig zal gaan getra gen. Daarnaast kan gelden dat een 'monopolistische' verzekeraar onderhandelt vani' een winstoogmerk. Hij zal daarbij waarschijnlijk niet bereid zijn om met de lage verwachte schade, alsmede de daaraan verwant lage premie, van de zorgvuldige varkeersdeelnemer rekening te houden. ${ }^{861}$

\section{Alternatieve compensatiemechanismen en eerste partij verzekeringen}

In deze paragraaf zal een aantal alternatieve compensatiemechanismen aan de orde komen, namelijk een schadefonds, een waarborgfonds, een schadeverzekering een no-fault verzekering. ${ }^{862}$ De centrale vraag daarbij is hoe een optimale compenstie van het slachtoffer samen met een handhaving van de preventieve zorgvuldighti: kan worden bereikt.

860. Adams, Gefährdungs- und Verschuldenshaftung, p. 237; Faure en Van den Bergh, Objection aansprakelijkheid, p. 328.

861. Faure en Van den Bergh, Objectieve aansprakelijkheid, p. 329; Adams, Gefährdungs- und Ve schuldenshaftung, p. 253-254.

862. Zie ook paragraaf 5.1.4, waarin de schadeverzekering en het waarborgfonds ats altematierc voor een verplichte aansprakelijkheidsverzekering aan de orde kwamen. 
In eerste instantie (paragraaf 6.1 en 6.2) zal worden bekeken in hoeverre een uitkering via een door de overheid in te stellen schadefonds de vergoeding door de private verzekeringsmarkt als geheel kan vervangen. ${ }^{863}$ Een schadefonds kan vanuit rechtseconomisch perspectief een radicale oplossing zijn om een optimale preventie en compensatie ook ten aanzien van verkeersongevallen te krijgen. Gegeven dit perspectief is het van belang om de werking van een schadefonds te onderzoeken. ${ }^{864}$

In paragraaf 6.3 zal worden onderzocht of een eerste partij schadeverzekering aan de zijde van het slachtoffer tot een optimale compensatie en preventie kan leiden.

In paragraaf 6.4 ten slotte, zal de aandacht uitgaan naar een no-fault verzekering. Dit is een vergoedingsmechanisme dat de schade van het verkeersslachtoffer vergoedt ongeacht of de dader dan wel het slachtoffer een fout heeft begaan. Daarbij kan, afhankelijk van de vraag of de handhaving van het aansprakelijkheidsrecht behouden blijft, sprake zijn van een no-fault vergoeding tot een bepaald bedrag, waarboven het aansprakelijkheidsrecht geldig blijft, tot een algehele afschaffing van de aansprakelijkheid, waarbij de schadevergoeding geheel via de no-fault verzekering plaatsheeft.

\subsection{ECONOMISCHE VOORWAARDEN VOOR INVOERING VAN EEN SCHADEFONDS}

Wanneer de overheid besluit tot de invoering van een schadefonds of een ander compensatiemechanisme waarbij de vergoeding via een systeem van aansprakelijkheid en verzekering al of niet geheel wordt afgeschaft zal, in het kader van de economische analyse, aan een aantal voorwaarden moeten zijn voldaan.

In de eerste plaats is het van belang dat, wanneer met de invoering van een schadefonds een volledige schadevergoeding aan het slachtoffer wordt gegarandeerd, van een eventuele aansprakelijkheidsstelling of bijdrageplicht voldoende prikkels blijven wtgaan naar zowel de dader als het slachtoffer om zich zorgvuldig te gedragen. Dit betekent mede dat met het schadefonds een optimale preventie kan worden bereikt wanneer de verwachte ongevalskosten zoveel mogelijk worden gelegd bij degene die het risico ook kan beïnvloeden.

863. Zie voor een economische analyse van dergelijke fondsen: Faure en Hartlief, RECIEL, 1996, p. 321-327; Faure en Hartlief, Verzekering en de groeiende aansprakelijkheidslast, p. 291-301; Faure, Rapport Verbond van Verzekeraars, 1995, p. 10-18; Faure en Hartlief, RM Themis, 1998 p. 211-228.

864. Zie Sugarman, Working Paper Series, 1993, p. I-12, die een dergelijk radicale oplossing bepleit. Hij stelt voor om de aansprakelijkheidsverzekering voor motorrijtuigen te vervangen door ecn fonds voor de vergoeding van de personenschade van verkeersslachtoffers. Dit schadefonds wordt gevoed door het opleggen van een toeslag bij het tanken van benzine ('Pay at the Pump') en een registratieheffing per auto. 
Een tweede economische voorwaarde voor de invoering van een schadefonds hood verband met een optimale differentiatie van risico's. Daarbij dienen de slechte $\mathrm{r}$. sico's een hogere bijdrage aan het fonds te leveren dan de goede risico's. Metbetuly van een dergelijke risicodifferentiatie kan worden voldaan aan een belangrijke dor! stelling van het ongevallenrecht, namelijk de minimalisering van de maatschappeli. ke ongevalskosten.

In de derde plaats zal bij de invoering van een schadefonds rekening moeten worden gehouden met de distributionele gevolgen. Dit betekent dat met name personen en instellingen die invloed kunnen uitoefenen op het ongevalsrisico aan het schade. fonds zullen moeten bijdragen. ${ }^{865}$

\subsection{EEN SCHADEFONDS ALS VERVANGING VOOR EEN SYSTEEM VAN AANSPRAKELUKHEID EN VERZEKERING}

Wanneer de theorie van verzekering wordt afgezet tegen het alternatief van fonks. vorming kunnen zich verschillen voordoen. Daarbij spitst de discussie zich met m. me toe op de vraag of een schadefonds dienst moet doen voor toekomstige schade of eerder voor schade die in het verleden is ontstaan. Ten aanzien van een fonds datal. leen de schade uitkeert die in het verleden is ontstaan, kan bijvoorbeeld worden ge steld dat een dergelijke ex post vergoeding een beperkte invloed heeft op de preventieve zorgvuldigheid. Dit betekent dat alleen nog kan worden geoordeeld over de vraag welke persoon of instelling het meest aan de ontstane schade heeft bijgedragen en derhalve vanuit het oogpunt van rechtvaardigheid is gehouden tot een bijdrage aan het schadefonds.

Een belangrijker onderscheid tussen verzekering en een schadefonds heeft betrelking op vraag of een fonds de schadevergoeding via een systeem van aansprakeliik. heid en verzekering geheel moet vervangen. Deze vraag zal hier worden uitgeweth, waarbij wordt uitgegaan van de veronderstelling dat een schadeveroorzaker over ofvoldoende vermogen beschikt om de schade van het slachtoffer te vergoeden.

\subsubsection{Een schadefonds versus een verzekering}

Indien binnen de private verzekeringsmarkt geen regeling kan worden getroffen voor een optimale schadeloosstelling aan het slachtoffer, kan het alternatief van ew schadefonds naar voren worden geschoven. Een argument voor de invoering van een dergelijk schadefonds heeft betrekking op de anwezigheid van bepaalde risions waarvoor binnen de private verzekeringsmarkt geen of zeer moeilijk dekking ben

865. Zie hierover Faure en Hartlief, Verzekering en de groeiende aansprakelijkheidslast, p. 292.

866. Faure en Hartlief, Verzekering en de groeiende aansprakelijkheidslast, p. 292-293; Faurt th Hartief, RM Themis, 1998, p. 214. 
worden verkregen. De verzekeraars ontberen bijvoorbeeld de noodzakelijke informatie om een juiste risicocalculatie uit te voeren.

Wanneer in deze gevallen wordt gekozen voor de invoering van een schadefonds ter vervanging van de compensatie via de private verzekeringsmarkt, geldt de voorwarde dat de beheerder van een schadefonds wel de beschikking heeft over de benodigde risico-informatie. Daarnaast is het van belang dat een schadefonds, dat wordt gevoed met een verplichte wettelijke bijdrage, tegen lagere kosten kan functioneren dan de private verzekeringsmarkt. Ten aanzien van dit laatste kan echter worden gesteld dat de aanwezige kennis en ervaring bij commerciële verzekeraars met betrekking tot de calculatie van ongevalsrisico's, waardoor een verzekeringspolis tegen lagere transactiekosten kan worden afgesloten, ${ }^{867}$ niet in het voordeel zijn van een schadefonds. Faure en Hartlief geven het voorbeeld van de crisis in de sociale zekerheid, waarbij overheidsinterventie en de daarmee gepaard gaande bureaucratie hebben geleid tot hoge kosten. ${ }^{868}$

Daamaast zullen ook de problemen van morele risico en anti-selectie vermoedelijk niet beter door een schadefonds kunnen worden tegengegaan. Voor een vermindering van het morele risico is het noodzakelijk dat de instantie die het schadefonds beheert, voldoende informatie heeft om de bijdrage aan het fonds optimaal te kunnen afstemmen op het verwachte ongevalsrisico. In het voorgaande is echter beargumenteerd dat de commerciële verzekeraars meer ervaring hebben met risicocalculatie en derhalve over betere middelen beschikken om de benodigde informatie te verzamelen.

Een schadefonds kan mogelijk wel een bijdrage leveren aan de vermindering van het proces van anti-selectie. Met behulp van de verplichte bijdrage aan het schadefonds iedereen wordt geacht mee te doen - kan worden voorkomen dat de lage risico's de groep verlaten. Voor een dergelijke vermindering van de anti-selectie is reeds een wetgevend instrument voorhanden waarvoor ook een verzekeringsmarkt bestaat, tamelijk een verplichte verzekering. ${ }^{869}$ Dit betekent derhalve dat de oprichting van

\footnotetext{
867. Zie daarover Faure en Hartlief, Verzekering en de groeiende aansprakelijkheidslast, p. 294-295, die deze argumenten uitwerken in het kader van een 'risicospreidingsovereenkomst', waarbij door een aantal bedrijven binnen een bepaalde branche een fonds wordt opgericht voor de dekking van bepaalde risico's. Skogh, JRJ, 1989, p. 726-732, heeft beargumenteerd dat commerciêle verzekeringscontracten enerzijds worden aangegaan om het risico weg te nemen en anderzijds worden beschouwd als een instrument om de transactiekosten te kunnen reduceren. Zie ook Faure, In Volle Verzekerdheid, p. 247-260 voor een uitgewerkt voorbeeld van een 'risicospreidingsoverenkomst'.

868. Faure en Hartlief, Verzekering en de groeiende aansprakelijkheidslast, p. 295: Faure en Hartlief NJB, 1998, p. 1140-1141

869. Zie paragraaf 5.1 van dit hoofdstuk voor een economische analyse van de verplichte verzekering.
} 
een geheel nieuw systeem van een schadefonds vermoedelijk niet goedkoper zal dan een verplichte verzekering. ${ }^{870}$

\subsubsection{Fondsvorming versus aansprakelijkheid}

Binnen het aansprakelijkheidsrecht kunnen zich problemen voordoen bij de vasstst. ling van de aansprakelijkheid en door eisen inzake de onrechtmatigheid en de cals. liteit. Dit kan tot gevolg hebben dat slachtoffers niet volledig schadeloos wordenge steld of zelfs in het geheel geen vergoeding ontvangen. Daarnaast kan de lange tijlkduur van een gerechtelijke procedure, mede als gevolg van bewijsproblemen, tot tha ge kosten leiden.

Een mogelijke oplossing voor deze bewijsproblemen is een systeem van risicaaansprakelijkheid. Hierbij is in ieder geval de vergoeding aan het slachtoffer ge waarborgd. Een risicoaansprakelijkheid kan echter negatieve effecten hebben op di preventieve zorgvuldigheid, afhankelijk van het type ongeval dat moet worden voorkomen. Binnen de economische analyse van het aansprakelijkheidsrecht is ten onderscheid gemaakt tussen een unilateraal ongeval, waarbij slechts één partij ir. vloed kan uitoefenen op het ongevalsrisico, en een bilateraal ongeval, waarbij thie partijen invloed hebben op de ongevalskosten. Een risicoaansprakelijkheid zal to een efficiënter resultaat leiden bij een unilateraal ongeval dan bij een bilateraal or geval. $^{871}$

Wanneer wordt besloten om in plaats van een risicoaansprakelijkheid een schade fonds in te voeren, zal eveneens een automatische schadevergoeding aan het slath offer zijn gewaarborgd. Indien daarbij echter de causaliteitseis wordt uitgeschakel zal een uitkering uit het fonds worden gedaan ongeacht de vraag of degene die an het fonds heeft bijgedragen de schade ook daadwerkelijk heeft veroorzaakt. Daar naast zal een hogere bijdrage van de participanten moeten worden gevraagd wannetr het aantal uitkeringen uit het schadefonds explosief toeneemt. Ten slotte zal ook de bijdrage aan het fonds niet voor iedere participant hetzelfde zijn. Het voorgannie brengt mee dat een schadefonds belangrijke nadelen heeft op het terrein van depre ventieve zorgvuldigheid. ${ }^{872}$

\subsubsection{Een schadefonds als waarborg}

In het voorgaande is geanalyseerd of een schadefonds een systeem van aanspintkelijkheid en verzekering als geheel kan vervangen. Daarbij is geconstateerd dat of

870. Faure en Hartlief, Verzekering en de groeiende aansprakelijkheidslast, p. 296; Mackaay, NBB, 1980, p. 818. Zie ook Faure en Hartlief, RM Themis, 1998, p. 215-218.

871. Zie hoofdstuk 5 voor een economische analyse van het aansprakelijkheidsrecht.

872. Faure en Hartlief, Verzekering en de groeiende aansprakelijkheidslast, p. 296-297. 
nadelen van de invoering van een dergelijk fonds ten opzichte van de handhaving van de private verzekeringsmarkt veelal groter zijn dan de voordelen. Een schadefonds zal vermoedelijk alleen kunnen worden gebruikt voor risico's waarvoor geen verzekering beschikbaar is of voor schade die in het verleden is ontstaan en waarbij geen persoon of instelling meer kan worden gevonden die deze schade heeft veroorzaakt en derhalve tot vergoeding is gehouden. ${ }^{873}$

Naar aanleiding hiervan kan worden onderzocht in hoeverre een schadefonds kan worden ingevoerd als een aanvulling op een systeem van aansprakelijkheid en verzekering. Een schadefonds krijgt in dat een kader een soort waarborgfunctie voor die gevallen waarin de verzekeringsmarkt voor bepaalde risico's geen dekking kan of wil verlenen of wanneer sprake is van insolventieproblemen. ${ }^{874}$

Een waarborgfonds heeft, ten opzichte van een schadefonds, het voordeel dat de kosten lager zijn wanneer de vergoeding via een systeem van aansprakelijkheid en verzekering blijft bestaan. Daarnaast kan in aanmerking worden genomen dat een warborgfonds niet bij elk schadegeval behoeft uit te keren. Dit betekent dat de preventieve werking van aansprakelijkheid en verzekering blijft gehandhaafd, waardoor de negatieve gevolgen voor de preventie die bij een schadefonds naar voren traden, kunnen worden verminderd.

In het kader van de analyse van de verplichte verzekering is gesteld dat als gevolg van insolventieproblemen bij de schadeveroorzaker zowel een verplichte verzekering als een waarborgfonds van nut kunnen zijn. Bij de invoering van een waarborgfonds is het probleem van het morele risico minder groot en behoudt de schadeveroorzaker de mogelijkheid om, afhankelijk van de mate van risicoaversie, vrijwillig een aansprakelijkheidsverzekering aan te gaan. Daarnaast zal de heffing die potentiële schadeveroorzakers aan het waarborgfonds moeten betalen belangrijk lager zijn dan bijvoorbeeld de premie voor een verplichte verzekering. ${ }^{875}$

Wanneer echter geen insolventieprobleem aanwezig is, kan de vraag worden gesteld of een waarborgfonds wel noodzakelijk is om een optimale compensatie aan het slachtoffer te garanderen. Het antwoord hierop kan mogelijk bevestigend zijn, wanneer bijvoorbeeld na een verkeersongeval de identiteit van de schadeveroorzaker niet kan worden achterhaald, waardoor het slachtoffer met een deel van zijn schade blijt zitten. Voor dergelijke gevallen kan een waarborgfonds derhalve van nut zijn.

\footnotetext{
873. Dit betreft de zogenaamde 'sluipende schade'. Zie daarover Faure en Hartlief, Verzekering en de groeiende aansprakelijkheidslast, p. 298-301.

874. Faure en Hartlief, Verzekering en de groeiende aansprakelijkheidslast, p. 298; Faure en Hartlief, RM Themis, 1998, p. 213-214.

875. Zie Faure en Van den Bergh, preadvies, 1990, p. 28; Faure en Van den Bergh, Objectieve aansprakelijkheid, p. 313-314; Shavell, IRLE, 1986, p. 55. Zie ook paragraaf 5.1 van dit hoofdstuk.
} 


\subsection{EEN EERSTE PARTIJ SCHADEVERZEKERING}

Binnen de analyse van de verplichte verzekering is ook aandacht besteed aan het in. strument van een eerste partij schadeverzekering. Daar werd een dergelijke verplich te verzekering gepresenteerd als een alternatief voor de gevallen waarin de schade. veroorzaker insolvent blijkt te zijn. Een schadeverzekering heeft echter ook een a a tal andere voordelen boven een systeem van een aansprakelijkheidsverzekering in de eerste plaats heeft een schadeverzekering, gegeven de informatievoordelen re een schadeverzekering boven een aansprakelijkheidsverzekering, ${ }^{876}$ het voordel din een goede risicodifferentiatie mogelijk is. Dit betekent dat een schadeverzekern een beter onderscheid kan maken naar factoren die direct verband houden met ds persoon van de verzekerde, waarbij de premie een zo goed mogelijke afspiegeling vormt van de verwachte schade. Daarmee kan niet alleen het morele risico beter worden gecontroleerd maar ook een proces van anti-selectie worden tegengegaan.

Wanneer een verplichte schadeverzekering bijvoorbeeld door de overheid via deswciale zekerheid beschikbaar wordt gesteld, kan sprake zijn van hoge administratier? kosten en inefficiënties ten gevolge van de werking van de bureaucratie. Deze problemen zijn echter minder groot wanneer een schadeverzekering door de particulier verzekeringsmarkt wordt aangeboden. Een verplichte schadeverzekering is der. naast, in termen van een eventuele nutsmaximalisatie, ook niet in het voordel ve elk potentieel slachtoffer. Dit betreft de gevallen waarin deze bijvoorbeeld in 2 zx geringe mate aan een bepaalde activiteit deelneemt of wanneer het slachtoffer risionneutraal is en derhalve een geringe vraag naar een verzekering heeft. ${ }^{877}$

Op het terrein van de schadevergoeding heeft een schadeverzekering het vordiel boven een aansprakelijkheidsverzekering dat het slachtoffer minder kosten betooth te maken om de schade bij de aansprakelijke derde te verhalen. Afhankelijk vand omvang van de verzekeringsdekking zal daarnaast aan het slachtoffer een opimal schadeloosstelling kunnen worden gegarandeerd. Voor de verzekeraars is derhalie een optimale schadespreiding mogelijk, gegeven het eerste partij karakter van th schadeverzekering. ${ }^{878}$

Een ander voordeel van een schadeverzekering ten opzichte van een ansprakelily heidsverzekering is dat het slachtoffer voor zijn schade bij zijn eigen verzekerart th recht kan, waarmee een relatief snelle schadeafwikkeling is gewaarborgd. Wanner echter de sociale zekerheid als vergoedingsmechanisme wordt gebruikt kunnend de

876. Zie paragraaf 4.4 van dit hoofdstuk.

877. Zie Faure en Van den Bergh, preadvies, 1990, p. 27; Shavell, Accident Law, 242-243; CC. Dam, Zorgvuldigheidsnorm en aansprakelijkheid, p. 205-206; Faure en Van den Bergh, Objec tieve aansprakelijkheid, p. 312-313; Faure en Hartlief, NJB, 1998, p. 1139-1142.

878. Zie Bowles, Law and the Economy, p. 123-124. 
kosten stijgen ten gevolge van de bureaucratische uitvoering van een dergelijk van overheidswege beheerst systeem. Hierbij worden de premies veelal omgeslagen over een groot aantal personen, waardoor een beperkte risicodifferentiatie wordt toegepast. Het is daarom van belang dat de particuliere markt de uitvoering van de schadeverzekering op zich neemt in plaats van de overheid. Een verzekeringsplicht kan daarbij het gevaar wegnemen dat bepaalde personen niet kunnen worden verzekerd.

\subsection{EEN NO-FAULT VERZEKERING}

Gedurende de jaren ' 70 van de vorige eeuw is een groot aantal staten in NoordAmerika en Canada overgegaan tot de invoering van een no-fault verzekering. Een dergelijke verzekering wordt daar in verschillende vormen toegepast, afhankelijk van de mate van handhaving van het aansprakelijkheidsrecht. ${ }^{879}$ In deze paragraaf zal de theorie van no-fault worden geanalyseerd, waarbij het aansprakelijkheidsrecht geheel is afgeschaft. Een dergelijke zuivere no-fault verzekering kan worden beheerd door een overheidsinstelling dan wel door de particuliere verzekeringsmarkt.

Een zuivere no-fault verzekering kan globaal worden omschreven als een vergoedingssysteem, waarbinnen een autobestuurder indirect via zijn verzekeraar en ongeacht de schuldvraag, financieel verantwoordelijk wordt gesteld voor de personenschade van de inzittenden van het verzekerde voertuig en van de fietser of voetganger waarmee het verzekerde voertuig in botsing komt. In ruil voor deze verantwoordelijkheid ontvangt de autobestuurder ${ }^{880}$ vrijstelling van aansprakelijkheid voor personenschade van andere derden, zoals de bestuurders en passagiers van andere voertuigen. $^{881}$

Een no-fault verzekering garandeert derhalve een optimale compensatie van verkeersslachtoffers, ongeacht de schuld van de schadeveroorzaker dan wel de eventuele eigen schuld van het slachtoffer. Het karakter van een dergelijke no-fault verzekering is echter tweeledig. Het bevat enerzijds een derde partij verzekeringsdekking voor de schade van de passagier, de fietser en de voetganger en anderzijds een eerste partij verzekeringsdekking voor de schade van de autobestuurder zelf. ${ }^{882}$

879. In hoofdstuk $13 \mathrm{zal}$, in het kader van de empirische analyse, de werking van een no-fault verzekering meer uitvoerig aan de orde komen. Daarbij zal ook aandacht worden besteed aan de no-

880. Ten behoeve van de eenvoult renter in in witgegaan van de autobestuurder als degene die de no-

881. Zie hizekering afsluit, in werkelijkheid zal dit de bezitter of eigenaar van het voertuig zijn. onder anderen: Witt and Umutia, JRI, 1983, p. 631; Kochanowski and Young, JRI,

882. 195, p. 270; Cummins and Weiss, GPRI, 1991, p. 21 ; Putto, VR, 1973, p. 25-28. 
Bij een no-fault verzekering is de compensatie aan het slachtoffer niet gebaseerd op het gedrag van de autobestuurder. Daarnaast zal ten gevolge van de uitsluiting ba aansprakelijkheid de preventie van verkeersongevallen op een andere wijze moetten plaatsvinden. Devlin stelt dat in ieder geval een bepaalde mate van premiedifferent. atie tussen de verzekerden noodzakelijk is om de problemen van morele risico enar. ti-selectie zoveel mogelijk te vermijden. Deze risicodifferentiatie zal moeten zijn gebaseerd op zowel individuele karaktereigenschappen als op het rijgedrag van de autobestuurder. Ten aanzien van een risicodifferentiatie ex ante, bijvoorbeeld nar leeftijd en geslacht, geldt volgens haar dat voor het eerste partij gedeelte (de schade van de autobestuurder) een betere risicoafbakening mogelijk is dan voor het derde partij gedeelte (de schade van fietser, voetganger en passagier) van de no-fault verzekering.

Een ex post differentiatie zal in de visie van Devlin problematischer zijn, aangezim de vergoeding onder een no-fault verzekering geen verband houdt met aansprakelijkheid, zodat een differentiatie op basis van schuld niet voor de hand lijkt te liggen De ex post premieaanpassing zal daardoor een ander karakter dragen en volgers haar eerder zijn gebaseerd op bijvoorbeeld een strafpuntensysteem, het antal vit keersovertredingen of het schadeverleden van de bestuurder. ${ }^{883}$

Chapman and Trebilcock stellen dat door de afschaffing van een aansprakelijk: heidsvordering minder schadeveroorzakers zullen worden gedwongen om de kosten van de activiteit (ongeval) die zij aan derden toebrengen zelf te dragen, waardoorde prikkels van zorg tegenover derden zullen verminderen. Een no-fault verzekering met toepassing van een risicodifferentiatie kan volgens hen een deel van deze eigen kosten van onzorgvuldig gedrag internaliseren, maar de kosten die aan derden worden toegebracht zullen niet in de premie tot uitdrukking komen. ${ }^{884}$

Wanneer wordt verondersteld dat het aansprakelijkheidsrecht een belangrijke ol vervult binnen de preventie van verkeersongevallen, zal de invoering van een nofault verzekering tot meer verkeersongevallen kunnen leiden. Als gevolg van de af schaffing van aansprakelijkheid zal de vergoeding aan het slachtoffer dat zelf $200 \mathrm{~F}^{\mathrm{b}}$. vuldig is geweest minder volledig zijn, waardoor in theorie de marginale prikkes van zorg bij het slachtoffer zullen toenemen. De zorgvuldigheid van de schade veroorzaker daarentegen zal kunnen afnemen, omdat hij niet meer aansprakelijk voor de totale ongevalskosten. Om te voorkomen dat het aantal verkeersongevallen toeneemt zal derhalve een premiedifferentiatie noodzakelijk zijn. Daamaast dientan

883. Devlin, IRLE, 1990, p. 200-201; McEwin, IRLE, 1989, p. 13-14.

884. Chapman and Trebilcock, Working Paper, 1991, p. 28. 
ook financiële prikkels te worden opgelegd teneinde het activiteitsniveau te optimaliseren. ${ }^{88}$

\section{Aansprakelijkheid en verzekering}

In deze paragraaf zal het in hoofdstuk 5 geanalyseerde ansprakelijkheidsrecht aan de theorie van risico en verzekering uit dit hoofdstuk worden gekoppeld. Daarbij zal de vraag centraal staan welke aansprakelijkheidsregel efficiënt is wanneer rekening wordt gehouden met de houding ten aanzien van risico en de beschikbaarheid van een verzekering. ${ }^{8.9}$

Het ongevallenrecht heeft niet alleen betrekking op de vraag hoe het verwachte ongevalsrisico kan worden verminderd, maar ook op de vraag hoe de verdeling van de schade dient plaats te vinden. In dat kader zal worden onderzocht welke combinatie van ansprakelijkheid en verzekering kan leiden tot een optimale zorgvuldigheid én een optimale verdeling van de schade. Daarbij zal enerzijds worden uitgegaan van twee aansprakelijkheidsregels, namelijk een risicoaansprakelijkheid, waarbij de dader in beginsel de gehele schade aan het slachtoffer moet vergoeden, en een foutaansprakelijkheid, die betrekking heeft op de gevallen waarin de dader de gehele schade an het slachtoffer moet vergoeden, indien hij niet aan de zorgvuldigheidsnorm voldoet. Anderzijds zullen twee vormen van verzekering aan bod komen, zijnde een schadeverzekering en een aansprakelijkheidsverzekering. ${ }^{887}$

lo paragraaf 7.1 zal allereerst het belang van een koppeling tussen aansprakelijkheid in verzekering worden benadrukt. Vervolgens zal worden nagegaan welke aansprakelijkheidsregel binnen een bilaterale ongevalssituatie (verkeer) efficiënt is (paragraaf 7.2), wanneer alleen rekening wordt gehouden met de houding ten aanzien van het ongevalsrisico. Hierna zal worden onderzocht welke aansprakelijkheidsregel hinnen een bilaterale ongevalssituatie (verkeer) efficiënt is (paragraaf 7.3), onder invloed van de aanwezigheid van een verzekering. Afgesloten zal worden met een analyse van de invloed van verzekering op de aansprakelijkheidsvraag (paragraaf 7.4) en een economische analyse van regres (paragraaf 7.5).

\footnotetext{
885. Dewees, Duff and Trebilcock, Exploring the Domain of Accident Law, p. 22 en p. 67, noot 70. In hoofdstuk 10 zullen de preventieve effecten van een no-fault verzekering empirisch worden onderzocht.

886. Skavell, BJE, 1982, p. 120-132 heeft als eerste getracht de vraag te beantwoorden in welke mate een combinatie van aansprakelijkheid en verzekering tot een efficiënt ongevallenrecht kan leiden. Zie ook Polinsky, Introduction, p. 67-74; Faure en Van den Bergh, Objectieve aansprakelijkheid, p. 28-37.

887. Shavell, BJE, 1982, p. 120; Shavell, Accident Law, p. 206.
} 


\subsection{HET BELANG VAN DE KOPPELING TUSSEN AANSPRAKELIJKHEID EN VERZEKERING}

Binnen de analyse van het aansprakelijkheidsrecht is verondersteld dat de dader het slachtoffer neutraal staan ten opzichte van het ongevalsrisico. In dit hoofdstuki i deze veronderstelling genuanceerd door het uitgangspunt te hanteren dat een genildeld individu een afkeer heeft van het risico om bij een ongeval betrokken te raken Vervolgens is gesteld dat een risicoavers persoon zijn nut kan verhogen, wanneer bi de mogelijkheid heeft om het risico af te schuiven, hetzij op een risiconeutral pr. soon, hetzij op een verzekeraar.

Bij het streven naar een zo hoog mogelijke maatschappelijke welvaart is het van be lang om zowel een risicoaverse dader als een risicoavers slachtoffer tegen het onge valsrisico te beschermen. In dat kader spelen binnen dit onderzoek de ongevallen een rol, waarin individuen schade toebrengen aan andere individuen en waarbij ds. ders en slachtoffer worden verondersteld een afkeer te hebben van het risico. ${ }^{888}$

In hoofdstuk 2 is aangegeven dat aansprakelijkheidsregels van invloed kunnen zijp op de preventie en op de verdeling van het ongevalsrisico. Een verzekeringsovereth komst kan een additionele bijdrage leveren aan een optimale spreiding van de schde. Daarnaast kan met behulp van een voorziening in of een aanpassing van de polisvoorwaarden een positieve verandering worden bereikt op het terrein van de proventie.

Aansprakelijkheid en verzekering beïnvloeden elkaar wederzijds. De preventie end? verdeling van het risico die het gevolg is van de toepasselijke ansprikelijkheidsregel, zijn afhankelijk van de hoogte van de verzekeringsdekking. De ofr vang van deze verzekeringsdekking is echter weer afhankelijk van de toepasselije aansprakelijkheidsregel, die voor een deel de omvang van het risico bepaalt waram dader en slachtoffer zijn blootgesteld. De toevoeging van risico en verzekering ant de economische analyse van het ongevallenrecht heeft verder aangetoond dat de risicohouding van partijen mede van invloed kan zijn op de efficiëntie van ansprale lijkheidsregels. $^{889}$

\subsection{AANSPRAKELIJKHEIDSREGELS EN DE HOUDING TEN AANZIEN VAN RISICO: BILATERALE ONGEVALLEN}

In een bilaterale ongevalssituatie wordt uitgegaan van het gegeven dat zowel de de der als het slachtoffer invloed kunnen uitoefenen op het ongevalsrisico. Voor dete

888. Shavell, Accident Law, p. 207. 888. Shavell, Accident Law, p. 207.
889. Shavell, BJE, 1982, P. 120-121; Faure en Van den Bergh, Objectieve aansprakelijkheid, p. 12 -
I29. 
oordeling van de efficiëntie van aansprakelijkheidsregels, is het van belang welke houding dader en slachtoffer ten aanzien van het risico innemen. Daarbij geldt vooralsnog de niet geheel onrealistische veronderstelling van afwezigheid van een verzekeringsdekking. Hiervoor kan een aantal argumenten worden genoemd. Enerzijds kunnen de hoge administratieve kosten in verhouding tot het geringe risico een reden zijn om geen verzekering aan te bieden. Anderzijds kunnen als gevolg van de hoge bedrijfskosten van een verzekeringsonderneming de premies te hoog worden, waardoor zelfs een risicoavers individu niet meer bereid is om een verzekering af te sluiten. $^{890}$

\subsubsection{Geen aansprakelijkheid}

Wanneer de dader niet wordt bedreigd met een mogelijke aansprakelijkheidsstelling, zal hij minder dan efficiënte zorg en een te hoog activiteitsniveau uitoefenen. Voor de dader met een afkeer van risico zal het voordelig zijn om de schade niet te hoeven vergoeden. Het slachtoffer zal, ongeacht zijn houding ten aanzien van risico, zijn eigen schade moeten dragen. Dit is echter niet optimaal, wanneer het slachtoffer een afkeer heeft van risico en er geen verzekeringsdekking voorhanden is. Mocht dit laatste wel het geval zijn dan zal de dader toch geen prikkel hebben om het risico te reduceren. Daarom kan worden gesteld dat het aansprakelijkheidsrecht van belang is om de dader aan te zetten tot zorgvuldig gedrag. ${ }^{891}$

\subsubsection{Risicoaansprakelijkheid}

Bij een regel van risicoaansprakelijkheid zal de dader, in afwezigheid van een aansprakelijkheidsverzekering, de schade aan het slachtoffer steeds vergoeden. Met betrekking tot de verdeling van het risico zal een optimale uitkomst worden bereikt wanneer de dader risiconeutraal is. De dader zal een optimaal zorg- en activiteitsniveau aanwenden. Het slachtoffer zal, ongeacht zijn houding ten aanzien van het ongevalsrisico en onder de voorwaarde dat de omvang van de vergoedingsplicht gelijk is aan het verwacht verlies, volledig worden gecompenseerd. De dader neemt in deze verhouding derhalve het gehele ongevalsrisico op zich en verschaft tegelijk een verzekering aan het slachtoffer voor de geleden schade. ${ }^{892}$

Wanneer de dader een afkeer heeft van het risico, kan echter een minder optimale uitkomst ontstaan. Indien daarbij de voorwaarde blijft gelden dat de omvang van de vergoedingsplicht gelijk is aan het verwachte verlies, bestaat het gevaar dat de dader aan een te groot risico wordt blootgesteld. De afkeer van risico kan de dader er toe

\footnotetext{
80. Polinsky, Introduction, p. 67-68; Shavell, Accident Law, p. 208; Faure en Van den Bergh, Objectieve aansprakelijkheid, p. 129.

891. Shavell, Accident Law, p. 208

892. Polinsky, Introduction, p. 69; Holzhauer en Teijl, Inleiding rechtseconomie, p. 172-173.
} 
aanzetten om teveel zorg uit te oefenen om van ansprakelijkheid bevrijd te blijen Een risicoaverse dader zal daarnaast een te laag activiteitsniveau aanwenden of ken zelfs besluiten om de, maatschappelijk wenselijke, activiteit in het geheel niet uit te oefenen. Een autobestuurder zal bijvoorbeeld heel voorzichtig rijden wanner hij risicoavers en onverzekerd is. In het extreme geval kunnen individuen besluiter om geen auto meer te rijden of zelfs in het geheel geen auto aan te schaffen. ${ }^{893}$

Een oplossing voor deze problematiek kan, bij afwezigheid van een aansprolse lijkheidsverzekering, worden gevonden in het tot een bepaalde hoogte beperken vas de aansprakelijkheid. Daardoor zal de omvang van de vergoedingsplicht lager zip dan de werkelijk geleden schade. De risicoaverse dader zal derhalve niet meer tat gehele risico behoeven te dragen, waarbij zijn prikkel tot zorg voor een belangin] deel behouden blijft. ${ }^{894}$ Een aansprakelijkheidsbeperking betekent voor het slacthof fer dat hij een deel van zijn schade zelf moet dragen. Wanneer het slachtoffer risica neutraal is, zal deze daar ongevoelig voor zijn, zodat een optimaal resultaat kan wor. den bereikt. Indien het slachtoffer echter ook een afkeer heeft van het risico, zl vermoedelijk een verdeling van de schade een 'second best solution' kunnen zijn h h de woorden van Polinsky:

'Thus, if both parties are risk averse and insurance is not available, there may be a trade off between the desired allocation of risk and the desired behaviour of the driver. ${ }^{895}$

\subsubsection{Risicoaansprakelijkheid met een absoluut eigen schuldverweer}

Uit de vorige paragraaf is gebleken dat een regel van risicoaansprakelijkheid tot en optimale preventie en risicospreiding kan leiden wanneer de dader risicoavers is 20 het slachtoffer risiconeutraal. Naast een beperking van de aansprakelijkheid kan ook de toevoeging van een absoluut eigen schuldverweer aan de zijde van het slachtoffich daaraan een bijdrage leveren. De dader met een afkeer voor risico zal nu niet het ge hele risico behoeven te dragen, maar behoudt tegelijk een prikkel tot zorg. De to voeging van een absoluut eigen schuldverweer zal, mits de juridische zorguldig. heidsnorm gelijk is aan de efficiënte zorgstandaard, daarnaast een risiconeutral slachtoffer aanzetten tot een efficiënt zorgniveau.

In werkelijkheid kan echter worden uitgegaan van de niet-onrealistische veros: derstelling dat zowel dader als slachtoffer in veel ongevalssituaties een afkeer vin risico hebben. Daarnaast mist de rechter de benodigde informatie om de zorguldirg.

893. Zie Shavell, Accident Law, p. 209; Faure en Van den Bergh, Objectieve aansprakelijkheid, 130 131; Shavell, BJE, 1982, p. 124.

894. Shavell, Accident Law, p. 210.

895. Polinsky, Introduction, p. 70. 
heidsnorm en de werkelijk uitgeoefende zorg te bepalen. Dit betekent dat, bij de afwezigheid van een verzekering, geen efficiënte aansprakelijkheidsregel kan worden gevonden waarbij de dader en het slachtoffer ook worden aangezet tot de uitoefening van een optimaal activiteitsniveau. Met betrekking tot dit laatste kan in het algemeen worden opgemerkt dat een individu zich, ten aanzien van de keuze voor de uitoefening van een bepaalde activiteit, veelal zal laten leiden door zijn houding ten aanzien van risico. ${ }^{896}$

Bij een regel van risicoaansprakelijkheid met een absoluut eigen schuldverweer zal de dader met een sterke afkeer van risico nog altijd een groot risico lopen om aansprakelijk te worden gesteld. Een oplossing met behulp van een beperking van de aansprakelijkheid zal betekenen dat de dader minder dan de werkelijk geleden schade behoeft te vergoeden. Indien het slachtoffer echter ook een afkeer van risico heeft, zal hij ten gevolge van het absoluut eigen schuldverweer hetzij teveel zorg uitoefenen, hetzij een lager activiteitsniveau aanwenden om te voorkomen dat hij zijn eigen schade moet dragen. Dit probleem kan groter worden indien onzekerheid bestaat ten aanzien van de juridische zorgvuldigheidsnorm.

\subsubsection{Foutaansprakelijkheid}

Bij een regel van foutaansprakelijkheid kan de dader aansprakelijkheid vermijden door te voldoen aan de juridische zorgvuldigheidsnorm, mits deze gelijk is aan de efficiënte zorg. Wanneer de dader een afkeer van risico heeft en het slachtoffer risiconeutraal is, zullen bij deze regel geen problemen ontstaan met betrekking tot het teveel uitoefenen van zorg door de dader of het nemen van onjuiste beslissingen ten aanzien van de deelname aan maatschappelijk wenselijke activiteiten. Een regel van foutaansprakelijkheid kan derhalve tot een optimale uitkomst leiden, wanneer het slachtoffer, als gevolg van zijn risiconeutraliteit, ongevoelig is voor het dragen van zijn eigen schade.

Indien het slachtoffer, evenals de dader, een afkeer heeft van het risico, zal echter ook bij een foutaansprakelijkheid een minder optimaal resultaat worden bereikt. $\mathrm{Da}$ der en slachtoffer zullen, bij onzekerheid omtrent de zorgvuldigheidsnorm, teveel of te weinig zorg aanwenden om het ongevalsrisico te ontlopen. Daarnaast zullen dader en slachtoffer geen juiste keuzes maken voor wat betreft de uitoefening van hun activiteit. Als gevolg van hun afkeer van risico bestaat zelfs het gevaar dat zij minder

\footnotetext{
896. Faure en Van den Bergh, Objectieve aansprakelijkheid, p. 135; Polinsky, Introduction, p. 69-70; Shavell, BJE, 1982, p. 121; Shavell, Accident Law, p. 210.
} 
frequent of in het geheel niet aan bepaalde maatschappelijk wenselijke activiteite zullen deelnemen. ${ }^{897}$

In het kader van een 'second best' oplossing kan in dergelijke gevallen, ten behoeve van een vermindering van het ongevalsrisico, worden gekozen voor een strengere ridische zorgvuldigheidsnorm ten opzichte van de efficiënte zorgstandaard. Wannert bijvoorbeeld in het verkeer een snelheid van $50 \mathrm{~km} / \mathrm{u}$ optimaal is, maar de juridisch zorgvuldigheidsnorm wordt bepaald op $30 \mathrm{~km} / \mathrm{u}$, zal een autobestuurder eerder aan sprakelijk kunnen worden gesteld. Voor een risicoavers slachtoffer geldt nu dat ix een dergelijk strenge norm $(30 \mathrm{~km} / \mathrm{u})$ zijn kansen op schadevergoeding zullen to: nemen. Voor een autobestuurder heeft deze strenge zorgvuldigheidsnorm echter ho neveneffect dat hij mogelijk teveel zorg zal aanwenden, hoewel dit per besturder verschillend is. Een automobilist $\mathrm{zal}$ in beginsel een snelheid van $30 \mathrm{~km} / \mathrm{u}$ aanhol. den, tenzij de marginale kosten van zorg te hoog worden. Hierdoor kan het mis schien goedkoper zijn om de optimale snelheid van $50 \mathrm{~km} / \mathrm{u}$ te volgen, waarbij de autobestuurder het risico om aansprakelijk te worden gesteld op de koop to. neemt. ${ }^{898}$

Samenvattend kan worden gesteld dat binnen een bilaterale ongevalssituatie, bij de afwezigheid van een verzekering, de voorkeur zal uitgaan naar een regel van rision aansprakelijkheid, wanneer het slachtoffer risicoavers is en de dader risiconeutral of beter in staat is om het risico te dragen dan het slachtoffer. Een regel van foutansprakelijkheid geniet de voorkeur wanneer de dader risicoavers is en het slachtofifir risiconeutraal of een minder sterke afkeer heeft van het risico dan de dader. ${ }^{899}$

\subsection{AANSPRAKELIJKHEIDSREGELS EN DE BESCHIKBAARHEID VAN VERZEKERNG: BILATERALE ONGEVALLEN}

In deze paragraaf zal worden onderzocht welke invloed de toevoeging van een ver zekering kan hebben op de efficiëntie van aansprakelijkheidsregels binnen een bi laterale ongevalssituatie (verkeer). De vraag of de dader een aansprakelijkheidsver zekering en het slachtoffer een schadeverzekering aangaat, is afhankelijk van bu houding ten aanzien van risico en de toepasselijke aansprakelijkheidsregel. De dader met een afkeer van risico zal bijvoorbeeld ter afwending van het risico een aanspitikelijkheidsverzekering met een volledige dekking afsluiten. Het slachtoffer dat ter

897. Shavell, Accident Law, p. 210; Polinsky, Introduction, p. 69-70; Faure en Van den Bergh, 06jo tieve aansprakelijkheid, p. 131; Shavell, BJE, 1982, p. 126.

898. Faure en Van den Bergh, Objectieve aansprakelijkheid, p. 131-132; Shavell, BJE, 1982, p. 12 Zic ook paragraaf 10.1 van hoofdstuk 5 .

899. Shavell, BJE, 1982, p. 121; Shavell, Accident Law, p. 210; Polinsky, Introduction, p. 69. Zieol Nell and Richter, GPRI, 1996, p. 244-249 voor een mathematische analyse van aansprakelijber en de houding ten aanzien van risico in een unilaterale ongevalssituatie met veel slachtofites. 
afkeer van risico heeft zal een eerste partij schadeverzekering afsluiten. De vraag of dader en slachtoffer überhaupt een verzekering aangaan hangt af van de toepasselijke rechtsregel. In dat kader zullen achtereenvolgens een regel van risicoaansprakelijkheid, een regel van risicoaansprakelijkheid met een absoluut eigen schuldverweer en een regel van foutaansprakelijkheid aan bod komen.

Bij de economische analyse van aansprakelijkheid en verzekering zal in beginsel worden uitgegaan van de veronderstelling dat een verzekeringspolis wordt aangeboden tegen een actuarieel juiste premie op een concurrerende verzekeringsmarkt. De verzekeraar heeft verder geen administratieve kosten en de premie-inkomsten zijn gelijk aan de schade-uitkeringen. Daarnaast zal de verzekeraar het gedrag van de verzekerde optimaal kunnen controleren en zijn de premie en de andere polisvoorwaarden juist afgestemd op de door de verzekerde te nemen voorzorgsmaatregelen..$^{900}$

\subsubsection{Risicoaansprakelijkheid}

In het kader van de voornoemde veronderstellingen zal een regel van risicoaansprakelijkheid tot een optimaal resultaat leiden. De dader met een afkeer van risico zal een aansprakelijkheidsverzekering afsluiten met een volledige dekking. De verzekeraar kan het gedrag van de dader optimaal controleren, waarbij de dader optimale zorg zal uitoefenen. Het slachtoffer krijgt ongeacht zijn houding ten aanzien van risico de geleden schade integraal vergoed, zodat hij zelf geen schadeverzekering zal afsluiten. ${ }^{901}$

In werkelijkheid wordt de efficiëntie van een regel van risicoaansprakelijkheid door een aantal factoren beïnvloed. Daarbij kunnen zich de volgende situaties voordoen.

In de eerste plaats kan sprake zijn van een situatie waarin de dader een afkeer van risico heeft en de verzekeraar, door een gebrek aan informatie, het gedrag van de dader niet optimaal kan controleren. Dit betekent dat de aanwezigheid van een aansprakelijkheidsverzekering met een volledige dekking mogelijk tot een verminderde zorgvuldigheid bij de dader leidt, waarmee het probleem van het morele risico ontstaat. Een remedie tegen dit probleem is het verlenen van een gedeeltelijke verzekeringsdekking. Voor de dader met een afkeer van risico is een gedeeltelijke verzeke-

900. Shavell, BJE, 1982, p. 127; Faure en Van den Bergh, Objectieve aansprakelijkheid, p. 132; Polinsky, Introduction, p. 70; Shavell, Accident Law, p. 210; Faure en Van den Bergh, preadvies, 1990, p. 37. Zie ook Nell en Richter, GPRI, 1996, p. 249-252 voor een mathematische analyse van aansprakelijkheid en verzekering.

901. Shavell, Accident Law, p. 211; Shavell, BJE, 1982, p. 128; Polinsky, Introduction, p. 70-71; Faure en Van den Bergh, Objectieve aansprakelijkheid, p. 132; Faure en Van den Bergh, preadvies, 1990, p. 37; Holzhauer en Teijl, Inleiding rechtseconomie, p. 174-175. 
ringsdekking in combinatie met een risicoaansprakelijkheid echter geen optimale oplossing. Hij zal enerzijds voor het niet gedekte risico een prikkel tot zorg behouden. Anderzijds zal de dader als gevolg van de gedeeltelijke verzekeringsdekking ten dele blootgesteld blijven aan het ongevalsrisico. Dit kan ertoe leiden dat de dader mede door zijn afkeer van risico toch geen efficiënte zorg uitoefent, maar misschien eerder teveel zorg aanwendt, afhankelijk van de omvang van het risico waaraan hij is blootgesteld. ${ }^{902}$ Wanneer voorts geldt dat de omvang van de vergoedingsplicht gelijk is aan het verwachte verlies, bestaat het gevaar dat de dader aan een te groot risico wordt blootgesteld.

In de tweede plaats kan zich de situatie voordoen, waarin de dader neutraal staat ten opzichte van het ongevalsrisico en de verzekeraar het gedrag van de dader niet optmaal kan controleren. De dader zal nu geen aansprakelijkheidsverzekering afsluiten, omdat hij daarmee zijn verwacht nut niet kan verhogen. Daarnaast zullen voor hem de kosten van een verzekering, mede in verband met het morele risico, te hoog worden in vergelijking met zijn verwachte ongevalskosten zonder verzekeringsdekking. Een regel van risicoaansprakelijkheid zal onder deze omstandigheden efficiënt kunnen zijn. De dader zal een optimaal niveau van zorg aanwenden en het slachtoffer zal, mits de dader over voldoende vermogen beschikt, verzekerd zijn van een volledige schadevergoeding. ${ }^{903}$

In de derde plaats ten slotte, kan de situatie worden onderscheiden waarin de dader risiconeutraal is en de verzekeraar zijn gedrag optimaal kan controleren. De dader zal, gegeven zijn neutrale houding ten aanzien van risico, geen vraag hebben nar een verzekering. Wanneer de dader derhalve geen aansprakelijkheidsverzekering afsluit, wordt hij bij een regel van risicoaansprakelijkheid verantwoordelijk gehouden voor de totale ongevalskosten, zodat hij optimale zorg zal uitoefenen om deze kosten te minimaliseren. Indien een aansprakelijkheidsverzekering wordt aangeboden $z a l$, als gevolg van de optimale controle door de verzekeraar, de dader eveneens een efficiënt zorgniveau aanwenden. Het slachtoffer krijgt, ongeacht zijn houding ten aanzien van risico, in beide gevallen zijn schade volledig vergoed. ${ }^{904}$

Samenvattend kan worden gesteld dat, gegeven de afkeer van risico bij de dader, de beschikbaarheid van een aansprakelijkheidsverzekering wenselijk is. Het slachtoffer zal, binnen de gemaakte veronderstellingen, bij een regel van risicoaansprakelijkheid steeds volledig worden gecompenseerd, ongeacht of de dader een aansprakelijkheidsverzekering heeft. Voor het slachtoffer is de vraag welke invloed een ansprakelijkheidsverzekering heeft op het gedrag van de dader en op de omvang van het

902. Polinsky, Introduction, p. 70; Shavell, Accident Law, p. 211-212; Shavell, BJE, 1982, p. 128; Faure en Van den Bergh, Objectieve aansprakelijkheid, p. 133-134.

903. Shavell, BJE, 1982, p. 127; Faure en Van den Bergh, Objectieve aansprakelijkheid, p. 133.

904. Shavell, BJE, 1982, p. 127; Faure en Van den Bergh, Objectieve aansprakelijkheid, p. 133. 
ongevalsrisico niet van belang. Het gegeven dat een risicoaverse dader kiest voor een ansprakelijkheidsverzekering kan tot de conclusie leiden dat de dader met een dergelijke verzekering maatschappelijk gezien beter af is. ${ }^{905}$

\subsubsection{Risicoaansprakelijkheid met een absoluut eigen schuldverweer}

Bij een regel van risicoaansprakelijkheid met een absoluut eigen schuldverweer zal de dader met een afkeer van risico een aansprakelijkheidsverzekering met een volledige dekking afsluiten, waarbij hij wordt aangezet tot een efficiënt zorgniveau. Ondanks de anwezigheid van een absoluut eigen schuldverweer zal het slachtoffer geen schadeverzekering afsluiten. Hij krijgt immers, ongeacht zijn houding ten aanzien van het risico en op voorwaarde dat hij voldoet aan de zorgvuldigheidsnorm met betrekking tot zijn eigen gedrag, de schade volledig vergoed. ${ }^{906}$

Deze ideale situatie wordt echter negatief beönvloed wanneer eerder gemaakte veronderstellingen worden genuanceerd. Daarbij geldt enerzijds de situatie waarin de juridische zorgvuldigheidsnorm niet gelijk is aan de efficiënte zorgstandaard en anderzijds de situatie waarbij een verzekeraar geen volledige controle heeft over het gedrag van de verzekerde. Dit laatste kan het gevolg zijn van een asymmetrie in informatie tussen verzekeraar en verzekerde. Wanneer onder deze omstandigheden een volledige verzekeringsdekking blijft gehandhaafd, zal dit negatieve gevolgen hebben voor de zorgvuldigheid. Een oplossing van dit probleem van morele risico is het verlenen van een gedeeltelijke dekking, maar dit leidt tot een minder ideale uitkomst voor wat betreft de verdeling van het risico en de efficiëntie van aansprakelijkheidsregels.

Een regel van risicoaansprakelijkheid met een absoluut eigen schuldverweer zal bij een gedeeltelijke verzekeringsdekking voor een risicoaverse dader tot gevolg kunnen hebben dat hij aan een te hoog risico wordt blootgesteld. De dader behoudt wel een prikkel tot zorg en hij zal een juiste keuze maken met betrekking tot de uitoefening van zijn activiteit. Voor het slachtoffer kan echter de onzekerheid omtrent de zorgvuldigheidsnorm aanleiding zijn om een schadeverzekering af te sluiten. Bij een dergelijke verzekering kan, ingeval van een volledige dekking en een niet-optimale controle, ook sprake zijn van een morele risico. Dit betekent dat het slachtoffer geen optimale zorg zal uitoefenen.

906. Zie hierover Shavell, BJE, 1982, p. 131. 


\subsubsection{Foutaansprakelijkheid}

Wanneer de juridische zorgvuldigheidsnorm gelijk is aan de efficiënte zorgstar. daard, zal een regel van foutaansprakelijkheid tot een optimaal resultaat leiden. $D_{e}$ dader zal daarbij, ongeacht zijn houding ten aanzien van het risico, de zorgvuldig. heidsnorm in acht nemen. De dader zal ook geen vraag hebben naar een verzekering, omdat hij door naleving van de zorgvuldigheidsnorm reeds aansprakelijkheid kan vermijden. Wanneer de dader heeft voldaan aan de zorgvuldigheidsnorm, zal het slachtoffer zijn eigen schade moeten dragen. Een slachtoffer met een afkeer van het risico zal zich daartegen willen beschermen door middel van eigen schadeverzeke. ring, althans wanneer een optimale controle van het morele risico mogelijk is. ${ }^{907}$

Indien de juridische zorgvuldigheidsnorm niet gelijk is aan de efficiënte zorgstandaard, zal de analyse tot een minder optimale uitkomst leiden. Daarbij kan de situatie ontstaan waarin de dader en het slachtoffer weliswaar de zorgvuldigheidsnom in acht nemen, maar toch aansprakelijk worden gehouden respectievelijk voor de eigen schade moeten opkomen. Dit wordt veelal veroorzaakt door vergissingen van de rechter bij de bepaling van de zorgvuldigheidsnorm of de werkelijk uitgeoefende zorg. ${ }^{908}$

Een dader $^{909}$ die neutraal staat ten opzichte van het ongevalsrisico zal geen verzekering aangaan. De dader kan, indien hij een laag risico vormt, bijvoorbeeld worden ingedeeld bij een groep van slechte risico's, waardoor zijn premie te hoog wordt in verhouding tot zijn verwachte schade. Daarnaast kan ook de controle door de verzekeraar niet optimaal zijn, met het gevolg dat een risiconeutrale dader met zijn lage risico het onzorgvuldige gedrag van andere verzekerde daders subsidieert. Dit kan voor een risiconeutrale dader een reden zijn om zijn verzekering op te zeggen of in het geheel geen verzekeringsovereenkomst af te sluiten. Deze vorm van anti-selectie heeft weliswaar tot gevolg dat de dader wordt blootgesteld aan het risico op fouten en vergissingen bij de bepaling van de zorgvuldigheidsnorm, maar aangezien hij $\mathrm{n}$ siconeutraal is zal hij daar ongevoelig voor zijn. ${ }^{910}$

Wanneer dader en slachtoffer echter beide een afkeer van risico hebben, zullen zij bij onzekerheid ten aanzien van de zorgvuldigheidsnorm mogelijk een te hoog of te laag zorgniveau aanwenden. Dader en slachtoffer zullen derhalve, ten behoeve van

907. Polinsky, Introduction, p. 71; Shavell, BJE, 1982, p. 130; Faure en Van den Bergh, Objectieve aansprakelijkheid, p. 134; Shavell, Accident Law, p. 212; Faure en Van den Bergh, preadvies, 1990, p. 37; Holzhauer en Teijl, Inleiding rechtseconomie, p. 175-176.

908. Zie daarover paragraaf 10 van hoofdstuk 5 .

909. Voor 'dader' kan ten deze ook 'slachtoffer' worden geschreven.

910. Faure en Van den Bergh, Objectieve aansprakelijkheid, p. 134-135; Shavell, Accident Law, P 213; Polinsky, Introduction, p. 72-73. 
een bescherming tegen dergelijke onzekerheden, respectievelijk een aansprakelijkheidsverzekering en een schadeverzekering afsluiten. Indien echter ook de controle van het morele risico niet optimaal is, kan de onzekerheid omtrent de zorgvuldigheidsnorm niet optimaal door de verzekeraar worden gecorrigeerd. Dit betekent dat een regel van foutaansprakelijkheid niet tot een optimaal resultaat leidt, waarbij onduidelijk blijft hoe de verdeling van het risico moet plaatsvinden.

\subsection{DE INVLOED VAN VERZEKERING OP DE AANSPRAKELIJKHEIDSVRAAG}

In het voorgaande is vanuit rechtseconomisch perspectief de verhouding tussen aansprakelijkheid en verzekering onderzocht. Daarbij is aandacht besteed aan een aantal factoren die van invloed zijn op de efficiëntie van aansprakelijkheidsregels, namelijk de houding van partijen ten aanzien van risico en de beschikbaarheid van verzekeringsdekking. Met betrekking tot het laatste kan worden gesteld dat daders met een afkeer van risico een verzekering afsluiten bij een regel van risicoaansprakelijkheid; risicoaverse slachtoffers bij een regel van foutaansprakelijkheid.

In de juridische literatuur is in de afgelopen decennia veel aandacht besteed aan de invloed van verzekering op het aansprakelijkheidsrecht. ${ }^{911}$ Het gaat dan echter niet om de vraag of de beschikbaarheid van een verzekering moet leiden tot een voorkeur voor een risico- dan wel een foutaansprakelijkheid. Veeleer wordt daarbij onderzocht of de aanwezigheid van een verzekering bij een van de partijen moet leiden tot de conclusie dat de desbetreffende partij de schade, die ten gevolge van een ongeval is ontstaan, moet dragen.

Dit wordt aan de hand van twee begrippen toegelicht, namelijk 'assurance oblige' en 'assurabilite oblige'. ${ }^{12}$ Het laatste begrip heeft betrekking op de vraag of, bij de bepaling van de aansprakelijkheid, een van de betrokken partijen zich had behoren te verzekeren. Bij 'assurance oblige' gaat het om de vraag welke partij zich, binnen het kader van het oordeel over de aansprakelijkheid, daadwerkelijk heeft verzekerd. Omgekeerd kan het voorkomen dat de onverzekerde dader niet aansprakelijk is, omdat het slachtoffer over een schadeverzekering beschikt. ${ }^{913}$

\footnotetext{
911. In de jaren vijftig is hiermee reeds een begin gemaakt. Zie Drion, Verzekering en aansprakelijkheidsrecht, oratic, p. 3; Ehrenzweig, Law and Contemporary Problems, 1950, p. 445455; Van Gerven, RW, 1962-63, p. 777-792; Simoens, RW, 1980-1981, 2026-2035; Simoens, TvP, 1984, p. 417-460. Voor wat betreft de meer recente literatuur kan onder andere worden Verwezen naar: Hartlief en Tjittes, Verzekering en aansprakelijkheid, p. 21-34 en C.C. van Dam,

912. Zie daaroheidsnorm en aansprakelijkheid, p. 207-208, 232-234 en 240-244.

913. Faure en Van Simoens, RW, 1980-1981, 2026-2028.

sprakelijkheid, Bergh, preadvies, 1990, p. 37 en 40; Hartlief en Tjittes, Verzekering en aan-
} 
De vraag of de aanwezigheid van een verzekering een rol moet spelen bij het oor deel over de aansprakelijkheid wordt in de juridische literatuur niet ontkennend be antwoord. Daarbij wordt verwezen naar Nederlandse en Belgische rechtspraak waarin het om gevallen gaat van een (verplicht) verzekerde dader die schade toe brengt aan een onverzekerd slachtoffer. Vanuit het oogpunt van slachtofferbescher ming is de dader dan gehouden om de schade van het slachtoffer te vergoeden. ${ }^{9.1}$ deze gevallen is de aanwezigheid van een verzekering slechts een van de omstar digheden die in het oordeel over de aansprakelijkheid kan worden meegewogen. De aanwezigheid van een verzekering speelt echter geen doorslaggevende rol bij de vraag wie uiteindelijk de schade dient te dragen. ${ }^{915}$

Naast de genoemde slachtofferbescherming wordt in de rechtseconomische litertuur nog gewezen op de zogenaamde 'deep pocket rule'. ${ }^{916}$ Hierbij wordt de opvalting gehuldigd dat de verwachte schade beter door een verzekeraar dan door een orverzekerd slachtoffer gedragen kan worden. Het aansprakelijkheidsrecht krijgt in deft kader vooral een herverdelend karakter, namelijk via de verzekeraar die over vol. doende vermogen beschikt om de schade aan het slachtoffer te vergoeden. ${ }^{917}$

Vanuit economisch perspectief kan een aantal bezwaren worden aangevoerd legen het beginsel van 'assurance oblige', op grond waarvan de aanwezigheid van een verzekering tot een bijna automatische aansprakelijkheid zal leiden, dan wel dat de aar sprakelijkheid vervalt omdat het slachtoffer zijn schade heeft verzekerd. ${ }^{918}$

In de eerste plaats kan worden gesteld dat wanneer het oordeel over de ansprakelijkheid wordt bepaald door de vraag wie van de betrokkenen zich heeft verzekerh de prikkels van zorg die van het aansprakelijkheidsrecht uitgaan zullen verminderen.

in Trier, 1994, p. 190; Trebilcock, Joumal of Law, Economics and Organisation, 1988, p. 243. 265.

914. C.C. van Dam, Zorgvuldigheidsnorm en aansprakelijkheid, p. 232-233, meent dat de annweis heid van een verplichte ansprakelijkheidsverzekering bij het rechterlijk oordeel moet worden betrokken. Daarmee kan een bijdrage worden geleverd aan een strengere zorgvuldigheidsnom.

915. Zie voor een overzicht: Hartlief en Tjittes, Verzekering en aansprakelijkheid, p. 21-34; Holdharer en Teijl, Inleiding rechtseconomie, p. 177-182; Van Wassenaer van Catwijck, VR, 1988,P 367-368 en voor Belgie: Simoens, RW, 1980-1981, p. 2025-2036. Zie ook Trebilcock, Joumal of Law, Economics and Organization, 1988, p. 243-249 voor een aantal voorbeelden uit de Anmel. kaanse, Canadese en Engelse rechtspraak.

916. Calabresi, Costs of Accidents, p. 39-50.

917. Faure en Van den Bergh, Objectieve aansprakelijkheid, p. 138; Faure en Van den Bergh, predvies, 1990, p. 40.

918. Hartlief en Tjittes, Verzekering en aansprakelijkheid, p. 5-7 en 13-16, wijzen, zij het op mas ju ridische gronden, het zelfstandig bestaan van een verzekering als grond voor aanspraklijkchel af. Wel stellen zij dat in het kader van de slachtofferbescherming betekenis kan toekomen and aansprakelijkheidsverzekering in de vestigingsfase, zeker wanneer het gaat om een verplict verzekering. 
Indien de potentielle dader in het bezit is van een aansprakelijkheidsverzekering, zal hij automatisch aansprakelijk worden gesteld. Omdat zijn aansprakelijkheidsverzekeraar de schade van het slachtoffer betaalt, zal dit een negatief effect hebben op de zorgvuldigheid van de dader. Een potentieel slachtoffer zal, wetende dat de verzekerde dader zijn schade vergoedt, ook minder zorgvuldig worden.

Een tweede economisch bezwaar tegen het toekennen van een beslissende betekenis aan het beginsel van 'assurance oblige', hangt samen met de houding ten aanzien van risico en daarmee met de vraag naar een verzekering. Een risiconeutrale dader die vijwillig een aansprakelijkheidsverzekering heeft afgesloten wordt geconfronteerd met een automatische aansprakelijkheidsstelling. Dit leidt tot een stijging van zijn premie, waardoor de dader zich in de toekomst mogelijk niet meer zal verzekeren. Voor de dader met een afkeer van risico, die ter afwenteling daarvan juist een verzekering heeft afgesloten, zal een automatische aansprakelijkheid met een premiestijging negatieve gevolgen hebben voor zijn vraag naar verzekering. Hoewel een verzekering zijn verwacht nut kan verhogen, zal een risicoaverse dader zich afvragen of hij, economisch gezien niet beter af is zonder een verzekering. ${ }^{919}$

In de derde plaats ten slotte, heeft een automatische aansprakelijkheid gevolgen voor de rol van de verzekeraar. De verzekeraar heeft, ten behoeve van de controle van het gedrag van de verzekerde, informatie nodig omtrent de zorg die een verzekerde uitoefent en het risico op een mogelijke aansprakelijkheid. Mede aan de hand van deze informatie wordt door de verzekeraar de omvang van de premie vastgesteld. Een automatische aansprakelijkheid leidt ertoe dat een verzekeraar de premie en de polisvoorwaarden slechts kan bepalen naar aanleiding van het risico dat zijn verzekerde in een ongeval met een niet-verzekerde betrokken zal raken. ${ }^{920}$

In de omgekeerde situatie, namelijk wanneer de onverzekerde dader niet aansprakelijk is omdat het slachtoffer zijn schade heeft verzekerd, ontstaan ook problemen op het terrein van de zorgvuldigheid. De rechter zal het gedrag van de dader niet meer controleren, maar enkel op grond van het feit dat het slachtoffer een schadeverzekering heeft oordelen dat de dader niet aansprakelijk is. Dit kan ertoe leiden dat de dader, wetende dat de schadeverzekeraar van het slachtoffer de schade vergoedt, geen prikkels van zorg meer krijgt. De schadeverzekeraar kan de schade niet meer afwentelen op de dader of zijn verzekeraar, hetgeen er op termijn toe zal leiden dat de premie onevenredig hoog wordt. Bij een risicoavers slachtoffer heeft dit in beginsel geen gevolgen voor zijn vraag naar verzekering, omdat hij in het andere geval zijn schade zelf zal moeten dragen.

\footnotetext{
919. Zie Faure en Van den Bergh, preadvies, 1990, p. 40-41; Faure en Van den Bergh, Objectieve

aansprakelijkheid, p. 139; Faure, in Rechtseconomie en recht, p. 86-89. sprakelijkheid, p. 139-140.
} 
Samenvattend kan worden gesteld dat het, economisch gezien, van belang is dat 20 . wel aansprakelijkheid als verzekering een bijdrage leveren aan een efficiënt onge vallenrecht. De aanwezigheid van een verzekering als grondslag voor de aansprake lijkheid in bilaterale ongevalssituaties is met een dergelijk belang in strijd en kan leiden tot een verhoging van het ongevalsrisico. Enerzijds wordt het slachtoffer be. loond met een schadeloosstelling voor zijn onzorgvuldige gedrag en zal hij, ongeacht zijn houding ten aanzien van het ongevalsrisico, geen verzekeringsdekking men. Anderzijds is de bescherming van een dader met een afkeer van risico niet gediend met een automatische aansprakelijkheidsstelling voor schade die buiten zijn schuld om is ontstaan. Een automatische aansprakelijkheid heeft derhalve ongewer. ste effecten op de preventie van ongevallen en op de optimale spreiding van de schade. ${ }^{921}$

\subsection{DE ECONOMISCHE ANALYSE VAN REGRES}

Wanneer als gevolg van een ongeval door het slachtoffer schade wordt geleden, $2 \mathrm{al}$ deze voor een groot deel door een eigen voorziening worden vergoed. Deze voorileningen bestaan uit een schadeverzekering (voor bijvoorbeeld ziektekosten) en een sociale- of volksverzekering. Deze eerste partij verzekeraars of uitkeringsinstanties zullen vervolgens voor het uitgekeerde bedrag verhaal willen nemen op de schadeveroorzaker of diens aansprakelijkheidsverzekeraar. ${ }^{922}$ In deze paragraaf zullen dere verhaalsrechten worden uitgewerkt aan de hand van de vraag of van de aanwerik heid van regres een preventieve werking kan uitgaan op het gedrag van de verzekerde. Het regres hangt daarmee nauw samen met de preventieve werking van aansprakelijkheidsregels en met de vraag naar de optimale verdeling van de schade via een verzekering. ${ }^{923}$

Ten aanzien van het gemaakte onderscheid in verhaalsrechten, kan allereerst de sith atie worden genoemd waarin de private- of sociale verzekeraar van het slachtoffie verhaal neemt op de aansprakelijke dader. Een dergelijk regres kan economisch effi. ciënt zijn, omdat de dader wordt geconfronteerd met de totale kosten van zjn schadeveroorzakende activiteit. Aan het slachtoffer zal een optimale schadeloosstelling kunnen worden gegarandeerd, mits de dader over voldoende vermogen beschilit Een uitsluiting van het regres in een dergelijke situatie heeft negatieve effecten op de zorgvuldigheid. De dader zal immers niet meer verantwoordelijk kunnen worden

921. Faure en Van den Bergh, Objectieve aansprakelijkheid, p. 140; Faure en Van den Bergh, preal. vies, 1990, p. $41-42$.

922. Hartlief en Tjittes, Aansprakelijkheid en verzekering, p. 63.

923. In de rechtseconomische literatuur is nog weinig gepubliceerd met betrekking tot het regs Verwezen kan worden naar: Gomez, Insurance Benefits, Insurance Subrogation and Inperfat Liability Rules, Paper, 1996, p. 1-24; Faure, in Regresrechten, afschaffen, handhaven of uither den, p. 45-71. 
gehouden voor de totale schade. Hij zal slechts een niveau van zorg aanwenden dat overeenkomt met de omvang van de schade waarvoor hij aansprakelijk is gesteld. ${ }^{924}$

Een tweede vorm van regres houdt verband met het verhaal door de private- of sociale verzekeraar van het slachtoffer op de aansprakelijkheidsverzekeraar van de dader. Wanneer de dader over een aansprakelijkheidsverzekering beschikt is het van belang dat hij blijft blootgesteld aan het risico dat door zijn schadeverwekkende activiteit wordt veroorzaakt. De aanwezigheid van regres geeft aan de aansprakelijkheidsverzekeraar een prikkel om via risicodifferentiatie of een premieaanpassing het regres door te berekenen in de polisvoorwaarden. De aansprakelijkheidsverzekeraar kan daarbij, bijvoorbeeld in het kader van de bonus-malus, besluiten tot een premieverhoging of anderszins preventieve matregelen van de dader eisen. Een uitsluiting van regres zou tot gevolg hebben dat de aansprakelijkheidsverzekeraar niet integraal verantwoordelijk is voor de schade die door de dader is veroorzaakt, waardoor hij geen prikkel zal hebben om het morele risico bij de dader terug te dringen. ${ }^{925}$

Een geheel ander type van regres heeft betrekking op het verhaal van de WAMverzekeraar op de verzekerde dader, bijvoorbeeld ingeval van opzet of grove schuld. Voor deze gedragingen wordt binnen een autopolis in beginsel geen dekking verleend. Toch is de WAM-verzekeraar in deze gevallen gehouden om de schade aan bet slachtoffer te vergoeden. De WAM-verzekeraar kan voor het uitgekeerde bedrag verhaal nemen op de eigen verzekerde, hetgeen kan worden beschouwd als een vorm van controle van het morele risico. Wanneer een verzekerde dader over een volledige aansprakelijkheidsdekking beschikt, zal hij misschien het gevaar bewust opzoeken en opzettelijk een ongeval kunnen veroorzaken. Het regres van de WAMverzekeraar is daarom een nuttig instrument ter controle van het morele risico, waarbij de dader met behulp van financiële prikkels kan worden aangezet tot zorgvuldig gedrag.

Naar aanleiding van het voorgaande kan worden gesteld dat vanuit preventief oogpunt de aanwezigheid van regres voordelen meebrengt. Regres kan, anders gezegd, leiden tot een vermindering van de primaire ongevalskosten. Daarnaast worden door het regres de kosten gelegd bij de verzekeraar van de schadeveroorzaker, hetgeen leidt tot een betere spreiding van het risico ofwel een vermindering van de secundaire ongevalskosten. Aan de uitoefening van regres zijn echter ook administratieve- of transactiekosten verbonden. Deze kosten hebben betrekking op de behandeling van regresclaims door de regresnemer en de aansprakelijkheidsverzekeraar. Wanneer deze tertiaire kosten hoger zijn dan de baten van het regres op het terrein van de preventie en risicospreiding, bestaat de kans dat de uitoefening van regres achterwege

\footnotetext{
924. Faure, in Regresrechten, afschaffen, handhaven of uitbreiden, p. 52; Gomez, Paper, 1996, p. 11 -

925. Faure, in Regresrechten, afschaffen, handhaven of uitbreiden, p. 52-53.
} 
blijft. Dit verklaart mede waarom verzekeraars in de praktijk niet altijd gebruik

ken van hun regresrecht en eerder pleiten voor een collectivering van het reges on een kostenbesparing te kunnen bereiken. ${ }^{926}$

\section{Conclusie aansprakelijkheid en verzekering binnen het kader van de probleemstelling}

In deze afsluitende paragraaf zal de economische analyse van aansprakelijkheid en verzekering worden teruggekoppeld naar de centrale probleemstelling van dit onder zoek. Daarbij zal de vraag worden beantwoord welke combinatie van an sprakelijkheid en verzekering kan leiden tot een optimale preventie van verkeerso gevallen alsmede een optimale compensatie van verkeersslachtoffers.

Bij de beantwoording van deze vraag zal, evenals bij de analyse van het ansppr kelijkheidsrecht in hoofdstuk 2, gebruik worden gemaakt van het door Calabresi gewerkte onderscheid in ongevalskosten. ${ }^{927}$ Dit onderscheid heeft betrekking op de primaire ongevalskosten, de secundaire ongevalskosten en de tertiaire ongevalskor ten. ${ }^{928}$ Voor het bereiken van een efficiënt verkeersongevallenrecht is het van belan dat de som van deze ongevalskosten, zijnde de totale maatschappelijke kosten, nimaal is.

In het licht van de economische analyse van risico en verzekering zal worden utge gaan van de veronderstelling dat een gemiddelde verkeersdeelnemer een afkeer het van het risico om bij een verkeersongeval betrokken te raken. Daamaast zal het we gangspunt gelden dat verkeersongevallen een bilateraal karakter hebben. Dit beth kent dat zowel de automobilist als de fietser worden verondersteld invloed te kumet uitoefenen op het ongevalsrisico.

\subsection{PRIMAIRE ONGEVALSKOSTEN}

In het kader van het onderscheid in ongevalskosten kan worden gesteld dat de pr maire ongevalskosten verband houden met de preventiedoelstelling van hel ver keersongevallenrecht. Binnen deze preventiedoelstelling is in dit hoofdstuk de rim beantwoord welke combinatie van aansprakelijkheid en verzekering de automobits en de fietser zal aanzetten tot een optimaal zorg- en activiteitsniveau.

926. Zie ten aanzien van de kosten van individueel regres en collectivering van regres: Boom, Harti en Spier, Regresrechten, afschaffen, handhaven of uitbreiden, in het bijzonder p. $27-33$ (Hart De individuele afhandeling van regresdossiers: een stand van zaken); p. $54-57$ en p. 63-69) (7ire, Regres in rechtseconomisch perspectief); p. 73-79 (Bloembergen, Collectivering van revte Zie ook De Haas en Hartlief, Collectivering en institutionalisering van regres, p. 1-7.

927. Calabresi, Costs of Accidents, p. 26-28. Zie ook paragraaf 12 van hoofdstuk 5.

928. Zie Shavell, Accident Law, p. 262; Bowles, Law and the Economy, p. 27. 
In paragraaf 7.3 is betoogd dat zowel een regel van risicoaansprakelijkheid met een absoluut eigen schuldverweer als een regel van foutaansprakelijkheid niet tot een optimaal resultaat zullen leiden. Daarbij is verondersteld dat geen optimale controle van het morele risico mogelijk is, alsook dat er onzekerheid heerst ten aanzien van de zorgvuldigheidsnorm. Deze onzekerheid kan in beginsel noch door de aansprakelijkheidsverzekeraar noch door de schadeverzekeraar optimaal worden gecorrigeerd. Dit betekent dat bij een regel van risicoaansprakelijkheid met een absoluut eigen schuldverweer de fietser geen efficiënte zorg zal uitoefenen en tevens een te hoog activiteitsniveau zal aanwenden. Bij een regel van foutaansprakelijkheid zullen zowel de automobilist als de fietser geen optimale zorg uitoefenen, terwijl de automobilist mogelijk een te hoog activiteitsniveau zal aanwenden.

De vraag die naar aanleiding hiervan kan worden gesteld is of onder bepaalde omstandigheden een andere uitkomst kan worden bereikt. In een eerder stadium van de analyse van risico en verzekering is betoogd dat een schadeverzekering betere mogelijkheden biedt om het morele risico te controleren dan een aansprakelijkheidsverzekering. Dit hing samen met het gegeven dat een schadeverzekeraar meer in direct contact staat met degene die schade lijdt, waardoor de premie beter kan worden afgestemd op het individuele ongevalsrisico. Een aansprakelijkheidsverzekeraar daarentegen zal niet alleen informatie nodig hebben met betrekking tot het gedrag van de automobilist, maar ook van de fietser aan wie de uiteindelijke schade moet worden vergoed. Deze informatie is voor een verzekeraar alleen tegen hoge kosten te verkrijgen. ${ }^{929}$ Welke gevolgen heeft dit nu voor de eerder besproken combinaties van aansprakelijkheid en verzekering?

In paragraaf 7.3.2 is ten aanzien van een regel van risicoaansprakelijkheid met een absoluut eigen schuldverweer gesteld dat, wanneer de automobilist risicoavers is en de controle van het morele risico niet optimaal kan worden uitgevoerd, een beperkte verzekeringsdekking de automobilist kan aanzetten tot een betere zorgvuldigheid. Voor de fietser met een afkeer van risico zal een schadeverzekering een betere controle van het morele risico mogelijk maken, waardoor via de polisvoorwaarden ook de onzekerheid omtrent de zorgvuldigheidsnorm beter kan worden gecorrigeerd.

Een regel van foutaansprakelijkheid heeft voor de automobilist het nadeel dat hij, als gevolg van de minder volledige controle door de aansprakelijkheidsverzekeraar en de onzekerheid omtrent de zorgvuldigheidsnorm, geen optimaal zorgniveau zal uitoefenen. Voor de fietser geldt echter dat bij een schadeverzekering de onzekerheid ontrent de zorgvuldigheidsnorm beter kan worden gecorrigeerd. Een volledige ver-

\footnotetext{
929. Priest, YLJ, 1987, p. 1557; Faure en Van den Bergh, preadvies, 1990, p. 17. Zie ook paragraaf
4.5 van dit hoofdstuk.
} 
zekeringsdekking met een juiste controle van het morele risico zal daamaast een vol. ledige schadevergoeding aan de fietser kunnen garanderen.

Een veronderstelling die mogelijk een ander licht werpt op de efficièntie van ar sprakelijkheidsregels is dat autorijden een meer risicoverhogende activiteit is in ve: houding tot de activiteit die de fietser uitoefent, waarbij derhalve de invloed vand fietser op het ongevalsrisico kleiner is dan die van de automobilist. De keuze your een bepaalde aansprakelijkheidsregel hangt derhalve samen met de vraag welke 2 tiviteit (autorijden of fietsen) het best kan worden beperkt.

Dit laatste brengt mee dat een regel van risicoaansprakelijkheid kan worden ingevoerd met het oog op de risicoverhogende activiteit van de automobilist. Deze z met een aansprakelijkheidsverzekering een optimaal zorg- en activiteitsniveau hr. nen aanwenden. De beperkte controle van het morele risico kan daarbij worden of gevangen met behulp van een ex ante differentiatie (bijvoorbeeld een premiedific rentiatie en een gedeeltelijke verzekeringsdekking), gecombineerd met een ex pos premieaanpassing via een uitgebalanceerd bonus-malussysteem. ${ }^{930}$ De toevoeging van een absoluut eigen schuldverweer, alsmede de onzekerheid ten aanzien vand zorgvuldigheidsnorm, zullen de fietser doen besluiten om ook bij risicoanspratise lijkheid een schadeverzekering af te sluiten. Het nadeel hierbij is dat de nit: optimale controle van het morele risico ook ten aanzien van een schadeverzekring kan blijven bestaan. Daarnaast zal ook de onzekerheid omtrent de zorgvuldigheilow norm niet volledig kunnen worden gecorrigeerd, met het gevolg dat de fietser get optimaal zorgniveau zal uitoefenen.

Bij een regel van foutaansprakelijkheid zal de fietser een schadeverzekering afsiiten, waarbij echter de onzekerheid omtrent de zorgvuldigheidsnorm alsmede th suboptimale controle van het morele risico aan een efficiënte uitkomst in de we staan. De automobilist zal, ten gevolge van de onzekerheid ten aanzien van de zorg vuldigheidsnorm, een ansprakelijkheidsverzekering afsluiten. Gegeven het derte partij karakter van een dergelijke verzekering zal een controle van het morele risio echter niet optimaal zijn.

In dit hoofdstuk werd ook aandacht besteed aan een alternatief compersstio mechanisme, namelijk een zuivere no-fault verzekering. ${ }^{931}$ De vraag die daarbij worden gesteld is of een dergelijke verzekering vanuit preventief oogpunt tegentor. kan komen aan de suboptimale werking van de voornoemde combinaties van art sprakelijkheid en verzekering. Een no-fault verzekering is een compensatiemecti nisme, waarbij de verzekeraar van de automobilist, de schade van respectievelijk te

930. Zie daarover paragraaf 4.1.4 van dit hoofdstuk.

931. Zie paragraaf 6.4 van dit hoofdstuk. 
inzittenden van het voertuig, de fietser en de voetganger vergoedt. Als gevolg van de afschaffing van de aansprakelijkheid zal de preventie van verkeersongevallen (afgezien van veiligheidsregulering) exclusief door de no-fault verzekeraar moeten worden gegarandeerd. Wanneer geen onderzoek plaatsvindt naar de oorzaak van het ongeval, is echter geen juiste premieaanpassing mogelijk. De preventie kan dan niet worden gebaseerd op de vraag of de automobilist schuld heeft gehad aan het ongeval; darvoor zal eerder gebruik worden gemaakt van bijvoorbeeld een strafpuntensysteem. ${ }^{932}$ Daarnaast geldt dat de fietser, bij afwezigheid van aansprakelijkheid, te weinig prikkels van zorg heeft en een te hoog activiteitsniveau zal aanwenden, omdat hij zijn schade automatisch krijgt vergoed.

Concluderend kan worden gesteld dat op theoretisch vlak ten behoeve van een vermindering van de primaire ongevalskosten geen van de besproken combinaties van aansprakelijkheid en verzekering en evenmin een no-fault verzekering tot een optimal resultaat zullen leiden. In het kader van de gegeven veronderstellingen, waarbij met name een rol is weggelegd voor de risicoverhogende activiteit van de automobilist ten opzichte van de activiteit van de fietser, kan mogelijk een lichte voorkeur uitgaan naar een risicoaansprakelijkheid met een absoluut eigen schuldverweer. Wanneer echter meer belang wordt gehecht aan de veronderstelling dat de controle van het morele risico beter kan worden uitgevoerd bij een schadeverzekering dan bij een aansprakelijkheidsverzekering, kan worden gekozen voor een regel van foutaansprakelijkheid. Bij deze regel zal de vergoeding voornamelijk plaatsvinden via de schadeverzekering van de fietser. Dit heeft het voordeel dat de controle van het morele risico en de anti-selectie eenvoudiger kunnen verlopen dan wanneer van een aansprakelijkheidsverzekering gebruik wordt gemaakt. ${ }^{933}$

\subsection{SECUNDAIRE ONGEVALSKOSTEN}

De vermindering van de secundaire ongevalskosten heeft betrekking op de vraag naar de optimale verdeling van het risico en naar de optimale spreiding en compensatie van de schade. Daarbij zal worden uitgegaan van de volgende veronderstellingen. De automobilist en de fietser hebben beiden een afkeer van risico. De controle van het morele risico is niet optimaal, maar kan bij een schadeverzekering beter worden uitgevoerd dan bij een aansprakelijkheidsverzekering.

Bij een regel van risicoaansprakelijkheid met een absoluut eigen schuldverweer zal het risico op een verkeersongeval voomamelijk door de automobilist worden gedragen. De automobilist zal een aansprakelijkheidsverzekering overeenkomen, waarbij hij via de juiste polisvoorwaarden kan worden aangezet tot een optimaal zorg- en ac-

\footnotetext{
932. Zie Devlin, IRLE, 1990, p. 200-201 ; McEwin, IRLE, 1989, p. 13-14.
933. Zie Faure en Van den Bergh, Objectieve aansprakelijkheid, p. 136-137
} 
tiviteitsniveau. De fietser krijgt in beginsel zijn schade volledig vergoed, maar zil gegeven de onzekerheid omtrent de zorgvuldigheidsnorm ten aanzien van zijn eigen gedrag, toch een schadeverzekering afsluiten. Daarbij geldt echter dat als gevolg va de suboptimale controle van het morele risico de fietser mogelijk te veel of te vein zorg zal aanwenden.

Een regel van foutaansprakelijkheid legt een minder grote verantwoordelijaltei voor het ongevalsrisico bij de automobilist. In de ideale situatie, waarbij de zorgyl. digheidsnorm gelijk is aan de efficiënte zorg, zal de automobilist aansprakelijhthe kunnen vermijden door aan de zorgvuldigheidsnorm te voldoen. De fietser zal zip eigen schade moeten dragen, waarvoor hij een schadeverzekering zal aangaan. Bi onzekerheid omtrent de zorgvuldigheidsnorm zal echter ook de automobilist en aansprakelijkheidsverzekering afsluiten. Als gevolg van de suboptimale controle va het morele risico zal hij mogelijk teveel of te weinig zorg uitoefenen.

Samenvattend kan worden gesteld dat ten aanzien van een vermindering van des. cundaire ongevalskosten geen voorkeur voor een combinatie van aansprakelijhthed en verzekering kan worden uitgesproken. Wanneer belang wordt gehecht and veronderstelling dat de automobilist en de fietser in gelijke mate bijdragen aan het ongevalsrisico en de controle van morele risico beter mogelijk is bij een schadererzekering dan bij een aansprakelijkheidsverzekering, kan een regel van foutaansppr kelijkheid een lichte voorkeur genieten. Indien echter wordt verondersteld dat de al tomobilist, hetzij beter in staat is om de schade te vermijden, hetzij een hoger onge valsrisico vormt dan de fietser, zal een risicoaansprakelijkheid met een absolut t: gen schuldverweer tot een beter, zij het nog altijd suboptimaal, resultaat leiden.

Ten behoeve van een vermindering van de secundaire ongevalskosten kan een the fault verzekering voordelen hebben boven een combinatie van ansprakelijkhid a verzekering. Afhankelijk van de omvang van de verzekeringsdekking is bij een fault verzekering de schadevergoeding aan de fietser optimal gewarborgd. Der compensatie is echter in beginsel niet gebaseerd op het gedrag van de automobilis of de fietser. De controle van het gedrag van de automobilist wordt daardoor b* moeilijkt en is bij de fietser zelfs geheel afwezig.

\subsection{TERTLAIRE ONGEVALSKOSTEN}

De tertiaire ongevalskosten hebben betrekking op een reductie van de adrim stratieve kosten die zijn verbonden aan het vaststellen van de aansprakelijkheide de schade en het onderzoek naar de vraag wie de schade zal moeten dragen. In derl paragraaf zal de vraag worden onderzocht welke invloed deze tertiaire kosten teb ben op de vermindering van de primaire en secundaire ongevalskosten. 
Bij de economische analyse van het aansprakelijkheidsrecht is ten aanzien van de administratieve kosten gesteld dat in theorie een regel van risicoaansprakelijkheid met een absoluut eigen schuldverweer tot meer rechtsgedingen leidt. Bij een regel van foutaansprakelijkheid zullen echter de gemiddelde kosten per rechtszaak, in verband met het onderzoek door de rechter naar de zorgvuldigheidsnorm, hoger zijn. ${ }^{934}$

Wanneer een verzekeringsdekking voorhanden is, dient echter de vraag te worden beantwoord welke invloed de aanwezige administratieve kosten hebben op het gecombineerd gebruik van aansprakelijkheid en verzekering. De stelling dat bij een regel van risicoaansprakelijkheid, ten opzichte van een regel van foutaansprakelijkheid, door de fietser meer schadeclaims bij de automobilist of diens aansprakelijkheidsverzekeraar zullen worden ingediend, kan worden genuanceerd wanneer de toevoeging van een absoluut eigen schuldverweer in aanmerking wordt genomen. De fietser zal bij een dergelijke regel mogelijk eerder een beroep doen op zijn eigen schadeverzekeraar, bijvoorbeeld wanneer onzekerheid heerst omtrent de zorgvuldigheidsnorm en de fietser in de veronderstelling verkeert dat hij onzorgvuldig is geweest. Deze procedure brengt echter ook administratieve kosten mee.

Bij een regel van foutaansprakelijkheid in combinatie met een onzekerheid ten aanzien van de zorgvuldigheidsnorm zal het slachtoffer een beroep doen op zijn schadeverzekering, waarmee echter ook administratieve kosten zijn gemoeid. De gang naar de rechter zal bij deze regel minder frequent worden gemaakt wanneer de verzekeraars onderling tot een schikking kunnen komen. Is dit niet het geval dan zal de rechter worden ingeschakeld, die echter opnieuw een onderzoek naar de zorgvuldigheid zal moeten verrichten. Daarnaast zal in de gegeven omstandigheden de aansprakelijkheidsverzekeraar bij zowel een risicoaansprakelijkheid als een foutaansprakelijkheid, ten behoeve van een mogelijke premieaanpassing, onderzoek willen verrichten naar de zorgvuldigheid van de automobilist. ${ }^{935}$

Samenvattend kan worden gesteld dat noch een regel van risicoaansprakelijkheid met een absoluut eigen schuldverweer noch een foutaansprakelijkheid tot een wezenlijke vermindering van de administratieve kosten zal leiden. Een regel van risicoaansprakelijkheid met een absoluut eigen schuldverweer kan mogelijk een lichte voorkeur hebben, wanneer het geschil zonder gerechtelijke tussenkomst door de verzekeraars onderling wordt beslecht. De onderhandelingen tussen verzekeraars kunnen echter ook langdurig zijn en tot hoge kosten leiden.

Een no-fault verzekering zal, voor wat betreft de administratieve kosten, een minder duur systeem kunnen zijn. Doordat de aansprakelijkheid is afgeschaft en de afwikke-

\footnotetext{
934. Shavell, Accident Law, p. 264; Faure en Van den Bergh, Objectieve aansprakelijkheid, p. 98-99.
935. Zie ook paragraaf 12.3 van hoofdstuk 5 .

935. 7ie Shavell, Accident Law, p. 265.
} 
ling van de schade in zijn geheel via de no-fault verzekering van de automobilist verloopt, zijn er in beginsel geen procedurekosten in verband met een eventueel ge rechtelijk geschil. Daarnaast zullen ook de kosten van controle voor de no-fault verzekeraar ten behoeve van een premieaanpassing lager zijn. Daarbij is veelal geen onderzoek naar de schuldvraag gebaseerd op aansprakelijkheid mogelijk, maar de controle van het morele risico kan wel worden gebaseerd op het schadeverleden van de autobestuurder of de eventueel gemaakte verkeersovertredingen.

In een eerder stadium van de analyse is aandacht besteed aan de economische analy: se van regres. ${ }^{936}$ Daarbij is gesteld dat de uitoefening van regres hoge tertiaire (admi. nistratieve en transactie)kosten mee kan brengen, die de voordelen op het terrein van de preventie zelfs kunnen overtreffen. Ten aanzien van zowel een regel van risicoaansprakelijkheid met een absoluut eigen schuldverweer als een regel van fouraansprakelijkheid kan worden verondersteld dat de uitoefening van individueel regres tot hoge kosten zal kunnen leiden. De kosten van regres bij een systeem van aansprakelijkheid en verzekering zullen verder toenemen indien de verzekeraars niet onderling tot een schikking komen en de rechter moet worden ingeschakeld. De invoering van een no-fault verzekering leidt in beginsel tot een afschaffing van het regres. Dit betekent enerzijds dat een discussie over de aansprakelijkheid achterwege blijft waardoor een besparing op de kosten wordt bereikt. Anderzijds zal, wanneer aan het regres in verband met aansprakelijkheid een belangrijke preventieve werking wordt toegekend, de afschaffing daarvan kunnen leiden tot een vermindering van de prikkels van zorg bij de automobilist.

\subsection{CONCLUSIE: PREVENTIE EN COMPENSATIE IN HET LICHT VAN DE VERKEERSAANSPRAKELUKHEID}

In een eerder stadium van de economische analyse is de minimalisering van de maatschappelijke kosten van ongevallen benadrukt. ${ }^{937}$ Deze maatschappelijke ongevalskosten omvatten de som van de primaire, secundaire en tertiaire ongevalskoster. Uit de individuele analyse van deze ongevalskosten kan worden opgemaakt dat ef geen eenduidige combinatie van aansprakelijkheid en verzekering kan worden aatrgewezen die tot een minimalisering van de genoemde ongevalskosten leidt. In deze slotparagraaf zal derhalve de vraag worden beantwoord welke combinatie van anssprakelijkheid en verzekering leidt tot een optimale preventie en compensatie in het licht van de totale maatschappelijke kosten van ongevallen. Daarbij zal worden uit gegaan van de volgende veronderstellingen:

936. Zie paragraaf 7.5 van dit hoofdstuk.

937. Zie paragraaf 2.2 van hoofdstuk 4. 
de automobilist en de fietser hebben beide een afkeer van risico;

- de controle van het morele risico is niet optimaal, maar zal bij een schadeverzekering beter kunnen worden uitgevoerd dan bij een aansprakelijkheidsverzekering;

- de juridische zorgvuldigheidsnorm is niet gelijk aan de efficiënte zorgstandaard.

Tabel 1

\begin{tabular}{|c|c|c|c|}
\hline $\begin{array}{c}\text { combinatie aansprake- } \\
\text { lijkheid/verzekering }\end{array}$ & primaire kosten & secundaire kosten & tertiaire kosten \\
\hline $\begin{array}{c}\text { nsicoaansprakelijkheid met } \\
\text { absoluut eigen schuld }\end{array}$ & niet-optimaal & optimaal & hoge kosten \\
\hline foutaansprakelijkheid & niet-optimaal & niet-optimaal & hoge kosten \\
\hline no-fault verzekering & $\begin{array}{c}\text { geen controle } \\
\text { preventie }\end{array}$ & optimaal & lage kosten \\
\hline
\end{tabular}

In tabel 1 is een tweetal combinaties van aansprakelijkheid en verzekering, alsmede een no-fault verzekering, afgezet tegen respectievelijk de primaire, secundaire en tertiaire ongevalskosten. Daaruit kan worden opgemaakt dat geen van de daarin genoemde combinaties tot een minimalisering van de maatschappelijke ongevalskosten leidt. Dit kan als volgt worden toegelicht.

Een regel van risicoaansprakelijkheid met een absoluut eigen schuldverweer is in het kader van preventie als niet-optimaal bestempeld, omdat geen optimale controle van het morele risico mogelijk is en de onzekerheid omtrent de zorgvuldigheidsnorm niet volledig kan worden gecorrigeerd. Wanneer echter wordt verondersteld dat de invloed van de automobilist op het ongevalsrisico hoger is dan die van de fietser kan mogelijk een lichte voorkeur worden uitgesproken voor een regel van risicoaansprakelijkheid met een absoluut eigen schuldverweer. De hogere invloed van de automobilist is in beginsel juist, maar daarmee kan het mogelijk onzorgvuldige gedrag van de fietser worden onderschat. De kosten van deze combinatie zijn hoog, ook wanneer de fietser bij afwezigheid van regres meer een beroep doet op zijn eigen schadeverzekering.

Een regel van foutaansprakelijkheid is zowel vanuit preventie- als vanuit compensatieoogpunt niet optimaal. Wanneer echter wordt verondersteld dat de onzekerbeid omtrent de zorgvuldigheidsnorm beter met een schadeverzekering dan met een aansprakelijkheidsverzekering kan worden gecorrigeerd, ontstaat een lichte voorkeur voor een regel van foutaansprakelijkheid. Daarnaast kunnen het mo anti-selectie beter worden sprakelijkheidsverzekering gecontroleerd bij een schadeverzekering dan bij een aanfoutaansprakelijkheid ech. Vanuit secundair kostenoogpunt kan met een regel van 
randeerd. De administratieve kosten van een systeem van foutaansprakelijkheid zijn hoog, ook indien de fietser een beroep doet op zijn eigen schadeverzekering en te. gres ontbreekt.

Een no-fault verzekering in strikte zin is niet zozeer een aansprakelijkheidssysteem maar een vergoedingssysteem. Een dergelijk regime waarborgt, onder afschaffing van de aansprakelijkheid, een optimale schadevergoeding van de fietser tegen lage administratieve kosten. Vanuit preventieoogpunt geldt echter dat bij een no-faulf verzekering de controle van de zorgvuldigheid in beginsel niet meer kan worden gebaseerd op de aansprakelijkheid voor de schade van de fietser. Dit betekent dat een automobilist op een andere wijze moet worden aangezet tot het uitoefenen van zorg, bijvoorbeeld via een strafpuntensysteem naar aanleiding van het aantal gemaakte verkeersovertredingen of via zijn schadeverleden. $\mathrm{Bij}$ het laatste kan worden gedacht aan een premieaanpassing, wanneer de automobilist naar aanleiding van een verkeersongeval een schadeclaim indient.

Samenvattend kan worden gesteld dat vanuit de preventiedoelstelling geen van de in tabel 1 genoemde combinaties tot een optimaal resultaat leidt. Een risicoaansprakelijkheiư met een eigen schuldverweer komt onder bepaalde voorwaarden het dichist in de buurt van de minimalisering van de primaire ongevalskosten. In het kader van de compensatiedoelstelling kan een no-fault verzekering als een 'second best solution' worden aangemerkt. Deze conclusies dragen echter een voorlopig karakter. Voor een meer definitief antwoord op de vraag naar de optimale preventie en compensatie van verkeersongevallen is de analyse van een derde instrument noodzakelijk. Deze regulering van de verkeersveiligheid zal in het volgende hoofdstuk aan de orde komen.

Tot slot van dit hoofdstuk kunnen met Dewees, Duff en Trebilcock een viertal beginselen worden genoemd waaraan een optimaal vergoedingssysteem voor verkeersschade moet voldoen:

1. Potentiële verkeersslachtoffers dienen te worden verzekerd tegen hun personenschade ten gevolge van een verkeersongeval. Daarbij is de fout van een derde of de causaliteitsvraag niet van belang. Van dekking dient te worden uitgesloten de schade van het slachtoffer die door eigen foutief handelen is veroorzaakt. Daarbij] kan worden gedacht aan roekeloosheid, grove schuld of opzet (roekeloos rijge. drag of zelfmoord);

2. De vergoeding van de verkeersschade dient te worden gecoördineerd met andere compensatiebronnen en zal enkel gelden voor materiële personenschade, warr van de omvang onbeperkt of met een hoge limiet moet zijn. Daarbij zal een percentage aan eigen risico of een vorm van medeverzekering moeten worden opge nomen om het morele risico bij de verzekerde te verminderen; 
3. De schadevergoeding moet binnen een strikte termijn worden uitgekeerd op basis van vereenvoudigde bewijsregels;

4. De premie voor een dergelijk vergoedingssysteem dient zoveel mogelijk in overeenstemming te zijn met de verwachte ongevalskosten die een verzekerde naar alle waarschijnlijkheid zal maken. Bij de bepaling van de premie zal derhalve rekening moeten worden gehouden met de zorg- en activiteitsniveaus van de verzekerde, de eigenschappen van de auto en de omvang van de verwachte scha$\mathrm{de}^{938}$ 



\section{Hoofdstuk 7: De economische analyse van veiligheidsregulering}

\section{Inleiding}

In de voorgaande twee hoofdstukken zijn twee juridische instrumenten geanalyseerd, namelijk aansprakelijkheid en verzekering. Deze instrumenten zijn in een eerste fase van de analyse onafhankelijk van elkaar behandeld. Aan het eind van het vorige hoofdstuk is vervolgens getracht de vraag te beantwoorden welke combinatie van aansprakelijkheid en verzekering kan leiden tot een optimale preventie van verkeersongevallen alsmede een optimale compensatie van verkeersslachtoffers. In dit hoofdstuk zal het derde instrument, de regulering van de verkeersveiligheid, aan de orde komen.

Regulering kan in het algemeen worden omschreven als het geheel van normen die de werking van de markt kunnen stimuleren, maar daarnaast ook de vrijheid van handelen van de marktpartijen of andere maatschappelijke actoren kunnen beperken. Binnen deze omschrijving kan een verder onderscheid worden gemaakt tussen marktregulering en overheidsregulering. Bij marktregulering worden de desbetreffende normen door middel van de werking van het marktmechanisme, het spel van vraag en aanbod, of het contractenrecht opgelegd. Eventuele verstoringen worden door de markt zelf hersteld.

Bij overheidsregulering grijpt de overheid, door middel van regels en wetten, rechtstreeks in de markt in. Naast het opleggen van normen beschikt de overheid ook over de middelen om de desbetreffende regels met behulp van sancties af te dwingen. De overheid tracht hiermee zowel het gedrag van de marktpartijen te beïnvloeden als tot een herverdeling van inkomen of tot een efficiënte marktwerking te komen. Ten slotte wenst de overheid in vele gevallen, mede ten behoeve van een collectief of algemeen belang, tot een correctie van bepaalde marktfalingen over te gaan. $9: 9$

Het bovengenoemde scherpe onderscheid tussen marktregulering en overheidsregulering behoeft in werkelijkheid enige nuancering. Het begrip regulering bevat namelijk zowel publieke als private elementen. Het marktmechanisme kan niet exclusief worden geïdentificeerd met het contractenrecht tussen de marktpartijen. Daarnaast heeft ook het publieke recht van de overheid private elementen in zich.

\footnotetext{
939. De Bijl en Van Damme, Regulering en zelfregulering in markten met kwaliteitsonzekerheid,
1997, p. 17 .
} 
Voorbeelden hiervan zijn deregulering en de overeenkomsten die de overheid $b$ nen de private markt aangaat. ${ }^{940}$

In het kader van dit onderzoek kan verder nog worden gewezen op de economishte analyse van aansprakelijkheid en verzekering. Hierbij werd de markt als referenti kader genomen, terwijl de werking van deze private verzekeringsmarkt mede wort beïnvloed door regelgeving vanwege de overheid. In dat verband zijn een verplichte verzekering, ${ }^{941}$ een beperking van de aansprakelijkheid ${ }^{942}$ en een schadefonds aan orde geweest. ${ }^{943}$

In dit hoofdstuk zal de vraag centraal staan of een rechtstreekse regulering van ri:ligheid, los van de aansprakelijkheid en de verzekering, van invloed is op een effitient verkeersongevallenrecht. Met behulp van een aantal economische theorieễn van overheidsregulering zal in eerste instantie worden getracht een verklaring te vinden voor de vraag waarom de overheid bepaalde wetgeving uitvaardigt. In dat kader ken een globaal onderscheid worden gemaakt tussen de 'public interest' (welvaarts)theorie en 'private interest' (belangengroep)theorie. ${ }^{944}$

De 'public interest' theorie zal in paragraaf 2 aan de orde komen en heeft betrekling op het uitvaardigen van regelgeving, die tot doel heeft de totale maatschappelije welvaart te verhogen. Aan de hand van de theorie van marktfalingen zal worden ge keken naar de mogelijkheden die de overheid op het terrein van de regulering heth om het feilen van de markt te corrigeren.

De 'private interest' theorie hanteert het uitgangspunt dat het politieke beslut vormingsproces in sterke mate wordt beïnvloed door belangengroepen binnen de samenleving. Deze theorie, die in paragraaf 4 aan de orde zal komen, tracht derhalle te verklaren waarom bij het opleggen van regelgeving vaak eerder deelbelangen tent rol spelen dan het algemeen belang. ${ }^{945}$

De verklarende analyse van regulering zal, binnen het kader van de bovengenoemte economische theorieën, zo ruim mogelijk worden geïnterpreteerd. Dit betekent dir alle aspecten van regulering onder de noemer overheidsregulering worden gebracti waar zowel de 'public interest' theorie als de 'private interest' theorie een verklaring voor trachten te vinden.

940. Ogus, Regulation: Legal Reform and Economic Theory, p. 1-3.

941. Paragraaf 5.1 van hoofdstuk 6.

942. Paragraaf 5.2 van hootdstuk 6 .

943. Paragraaf 6.1 en 6.2 van hoofdstuk 6.

944. Faure en Van den Bergh, Objectieve aansprakelijkheid p. 142.

945. Ogus, Regulation, p. 3-4; Utton, The Economics of Regulating Industry, p. 3-28; Faure en den Bergh, Objectieve aansprakelijkheid, p. 142-143. 
In paragraaf 3 zal een direct verband worden gelegd tussen de 'public interest' theorie en de verhouding tussen veiligheidsregulering en aansprakelijkheid. Deze verhouding zal aan de hand van de door Shavell ${ }^{946}$ ontwikkelde criteria voor veiligheidsregulering worden geanalyseerd. Hierbij zal worden onderzocht of met behulp van veiligheidsregulering een betere preventie van verkeersongevallen kan worden bereikt dan met het aansprakelijkheidsrecht, of dat een combinatie van beide instrumenten nodig is voor een optimaal resultaat. ${ }^{947}$

In paragraaf 5 en 6 zal, binnen het kader van de 'public interest' theorie en de 'private interest' theorie, worden ingegaan op de verhouding tussen veiligheidsregulering en de private verzekeringsmarkt. Het gaat hierbij om de vraag of de overheid beter in staat is om de preventie van verkeersongevallen te waarborgen dan de verzekeringsmarkt. Daamaast zal in het licht van de economische theorie van overheidsregulering aandacht worden besteed aan de mogelijke invloed van lobbygroepen op de totstandkoming van veiligheidsregulering in het verkeer.

In hoofdstuk $8 \mathrm{zal}$, in het kader van de centrale probleemstelling, de economisch theoretische analyse van het verkeersongevallenrecht worden afgesloten met een beantwoording van de vraag welke combinatie van aansprakelijkheid, verzekering en veligheidsregulering kan leiden tot een optimale preventie en compensatie van verkeersongevallen.

\section{De 'public interest' theorie}

Ten aanzien van de economische theorie van overheidsregulering is in de afgelopen decennia zeer veel literatuur verschenen. Zowel vanuit de politieke wetenschap als vanuit de economische wetenschap is de regulering door de overheid uitvoerig geanlyseerd. ${ }^{\text {g48 }}$ In deze paragraaf zal een eerste, economische theorie van overheidsregulering worden beschreven. Bij deze economische welvaartstheorie staat de vraag centraal warom de overheid besluit om regulerend op te treden. Geschiedt dit bijvorbeeld omdat de markt in de ogen van de wetgever niet in staat is om bepaalde belangen te beschermen, of omdat de markt anderszins niet optimaal functioneert?

Shavell, Liability for Harm versus Regulation of Safety, JLS, 1984, p. 357-374.

Twee voorbeelden van overheidsregulering in enge zin zijn bij de analyse van risico en verzeketing reeds aan de orde geweest, namelijk een verplichte verzekering en een beperking van de ansprakelijkheid. Zie respectievelijk paragraaf 5.1 en 5.2 van hoofdstuk 6 .

bjjdrage geleverdi Buce auteurs hebben aan deze stroom van met name economische literatuur een 1962; Shavell, Buchanan en Tullock, The Calculus of Consent, University of Michigan Press, The Theory of Eciability for Harm versus Regulation of Safety, JLS, 1984, p. 357-374; Stigler, tion, BJE, 1974, p. 335-358; Pation, BJE, 1974, p. 3-21; Posner, Theories of Economic Regula1976, 211-240, p. 335-358; Peltzman, Toward a More General Theory of Regulation, JLE, een historisch overzek Hagg, European Joumal of Law and Economics, 1997, p. 337-370, voor 
Binnen de economische welvaartstheorie, de klassieke theorie met betrekking overheidsregulering, wordt onderzocht op welke wijze de gezamenlijke welvaarive een groep individuen kan worden verhoogd. Met welvaart wordt gedoeld op welzijn van het individu, voor zover dit welzijn naar economische termen kan den vertaald. ${ }^{949}$ Het uitgangspunt binnen de economische welvaartstheorie is een on timaal functionerend marktmechanisme, waarbij sprake is van een volledige mede dinging en de producenten en consumenten over volledige product- en prijsinfom tie beschikken. De toetreding tot de markt van vragers en aanbieders is eenvoudige er is geen individuele aanbieder die een wezenlijke invloed uit kan oefenen op d: marktprijs. Een optimaal functionerend marktmechanisme leidt derhalve tot een optimale verdeling van goederen en diensten, zodat de wenselijkheid van overheidisgrijpen minder noodzakelijk wordt. ${ }^{950}$

\subsection{MARKTFALINGEN: OORZAKEN EN REMEDIES}

In werkelijkheid zal mede als gevolg van bepaalde externe effecten niet op dil markten sprake zijn van een volledige mededinging. In de tweede plaats zijn er be paalde producten en diensten waarvoor in het geheel geen markt bestat, de zoge naamde collectieve goederen. In de derde plaats kan er sprake zijn van een asymm. trie in informatie bij consumenten en producenten met betrekking tot prijs en por ducten.

Bovengenoemde marktfalingen die het ideaalbeeld verstoren, kunnen niet door th markt zelf of via het privaatrecht worden weggenomen. Dit kan voor de overtik een reden zijn om via regulering in te grijpen. ${ }^{951}$ In het kader van het onderhavis onderzoek naar verkeersongevallen, zullen in deze paragraaf twee marktfalingen w de orde komen, namelijk externaliteiten en informatie-asymmetrie. ${ }^{952} \mathrm{Na}$ een kots

949. Bowles, Law and the Economy, p. 165; Van den Bergh, in Rechtseconomie en recht, p. 2937 Van den Doel en Van Velthoven, Democratie en welvaartstheorie, p. 43; Ogus, Regulation, 15-28. Zie ook paragraaf 1.3 van hoofdstuk 4 voor een overzicht van de verschillende conowat van efficiẻntie binnen de economische analyse.

950. Utton, The Economics of Regulating Industry, p. 5-6; O'Connell, Welfare Economic Thean, 11; Van den Bergh, Economische analyse van het mededingingsrecht, p. 17; Van den Decle Van Velthoven, Democratie en welvaartstheorie, p. 45; Holzhauer en Teijl, Inleiding rati economie, p. 7-11; Van Velthoven en Van Wijck, Recht en efficiêntie, p. 28-39.

951. Van den Doel en Van Velthoven, Democratie en welvaartstheorie, p. 46; Faure en Van io Bergh, Objectieve aansprakelijkheid, p. 144; Utton, The Economics of Regulating Industry, p 5; Ogus, Regulation, p. 18-25 en p. 29-30; Holzhauer en Teijl, Inleiding rechtseconorric p t s Zie ook Dommering, in Informatierecht, p. 475-485, met een uitwerking naar het auteurstit de post en telecommunicatie, omroep en pers en de vrijheid van meningsuiting.

952. Zie voor een uitwerking van twee andere marktfalingen, namelijk monopolievorming m olle tieve goederen, onder anderen: Ogus, Regulation, p. 30-35; Utton, The Economics of Reglutis Industry, p. 7-10 en p. 15; O'Connell, Welfare Econonomic Theory, p. $55-59$ en p. 73-74; Vi den Bergh, Economische analyse van het mededingingsrecht, p. 20-21; Van Velthoven on 
beschrijving zal worden ingegaan op de mogelijke oplossingen voor deze marktimperfecties via overheidsregulering. In paragraaf 3 zullen deze marktfalingen worden uitgewerkt naar de analyse van veiligheidsregulering.

\subsubsection{Externaliteiten}

In de eerste plaats kan de aanwezigheid van externe effecten leiden tot marktimperfecties. Deze externe effecten kunnen ontstaan doordat individuen of instellingen bij de uitoefening van hun activiteit enkel rekening houden met hun eigen belangen (lasten en baten), zonder zich te bekommeren om de invloed die hun activiteit kan hebben op derden. Deze invloed kan zowel positief ${ }^{953}$ als negatief zijn. Voorbeelden van negatieve externe effecten zijn de verontreiniging door industrieën als gevolg van de uitstoot van chemische stoffen of de verkeersonveiligheid die door het rijden met een auto mogelijk kan worden veroorzaakt. ${ }^{954}$

Wanneer een extemaliteit negatief is, kan individu $\mathrm{A}$ aan wie hinder of overlast wordt toegebracht onderhandelen met de schadeveroorzaker B. In de ideale situatie waarin deze bilaterale onderhandelingen mogelijk zijn tegen lage transactiekosten, kan een optimale uitkomst worden bereikt. Bijvoorbeeld wanneer individu A kan worden gecompenseerd of individu B maatregelen neemt om de externaliteit op te heffen. ${ }^{955}$

Deze ideale onderhandelingssituatie wijzigt zich echter bij externaliteiten waarin meerdere partijen zijn betrokken of waarin partijen vreemden zijn voor elkaar. De aanwezigheid van (hoge) transactiekosten kan in dat geval voor de overheid aanleiding zijn om door middel van rechtsregels de gevolgen van externaliteiten te verminderen. De overheid kan derhalve, wanneer de marktpartijen daartoe niet in staat zijn, de externe effecten internaliseren. Daarbij beschikt de overheid over een aantal instrumenten.

Wijck, Recht en efficiëntie, p. 222-231; De Bijl en Van Damme, Regulering en zelfregulering in markten met kwaliteitsonzekerheid, 1997, p. 14-20; Faure en Van den Bergh, Objectieve aansprakelijkheid, p. 144-146; Van den Doel en Van Velthoven, Democratie en welvaartstheorie, p. 42-51; Van den Bergh, in Regulation of Professions, p. 21-33; Van den Bergh, TvP, 1986, p. 157-246.

953. Een voorbeeld hiervan is de ontwikkeling van een nieuw product, waarvan anderen profiteren door de werking van dit product verder te verfijnen, het zogenaamde 'free rider' effect. De proJucent die het product heeft ontwikkeld, kan deze voordelen echter niet meer verhalen. De welvart van derden wordt derhalve positief beînvloed. Zie Holzhauer en Teijl, Inleiding rechtseco-

954. Vomie, p. 15-16; Ogus, p. 21-22, met een voorbeeld uit het auteursrecht.

Economic en Van Velthoven, Democratie en welvaartstheorie, p. 46-47; O'Connell, Welfare Bijl en Vaneory, p. 82; Bowles, Law and the Economy, p. 166; Ogus, Regulation, p. 18-19; De p. 18; Hol Damme, Regulering en zelfregulering in markten met kwaliteitsonzekerheid, 1997,

955. Coase

Coase, JLE, 1960, p. 1-44; Nentjes, AA, 1990, p. 708-709. Zie ook paragraaf 4 van hoofdstuk 4. 
In de eerste plaats kan de overheid bij bepaalde informatietekorten de informatie ue de marktpartijen ter beschikking stellen. Hiermee kan de ongelijkheid in de onder. handelingspositie tussen partijen zodanig worden gecorrigeerd, dat daarmee de op timale werking van het Coase-theorema kan worden hersteld. ${ }^{956}$

In de tweede plaats kan de overheid ervoor zorgen dat bijvoorbeeld de eerderge noemde producent wel rekening zal houden met de hinder (schade) die hij bij derden veroorzaakt. Dit kan door gebruik te maken van het aansprakelijkheidsrecht. De is. voering van een aansprakelijkheidsregel kan de betreffende producent ertoe betre gen om de slachtoffers van de schade, die bijvoorbeeld het gevolg is van de uitstoon van gevaarlijke stoffen, te compenseren. De verkeersveiligheid kan mede worden bevorderd door de invoering van een aansprakelijkheidsregel, als gevolg waarvan d: automobilist meer rekening zal houden met zijn medeweggebruikers. ${ }^{957}$

In de derde plaats kan de overheid met behulp van meer directe, ex ante, ma2a. regelen proberen de negatieve externe effecten te verminderen. Onder de noeme van het algemeen belang kan een soort belasting worden opgelegd gelijk aan de ko: ten die aan derden wordt veroorzaakt, ofwel een boete bij overtreding van het ver. bod op de uitstoot van bepaalde chemische stoffen. Daarnaast kunnen subsiditix worden verstrekt ten behoeve van verder onderzoek naar de veiligheid van produ. ten of de veiligheid in het verkeer. Een andere vorm van direct overheidsingrijpen tenslotte, is de burgers wijzen op bepaalde gezondheidsrisico's, bijvoorbeeld metbetrekking tot alcohol en drugs. ${ }^{958}$

\subsubsection{Informatie-asymmetrie}

\subsubsection{Voorbeelden van informatie-asymmetrie binnen de productmarkt}

Het uitgangspunt bij een optimaal werkend marktmechanisme is dat de markt partijen volledige informatie hebben omtrent de producten die zij produceren, [io pectievelijk consumeren. In een dergelijke situatie kan derhalve het Coase-theormis zijn optimale werking behouden, waarbij de eventuele toepassing van een anspprakelijkheidsregel niet van invloed is op de efficiënte uitkomst. ${ }^{959}$

956. Zie hiema paragraaf 2.1.2 ten aanzien van de informatie-asymmetrie als marktaling.

957. Zie hoofdstuk 5 voor een economische analyse van het aansprakelijkheidsrecht.

Utton, The Economics of Regulating Industry, p. 8-9 en 15; Bowles, Law and the Econours p. 166-167; Faure en Van den Bergh, Objectieve aansprakelijkheid, p. 145. O'Connell, Welirir Economic Theory, p. 92 en p. 95-96; Ogus, Regulation, p. 21 en 35; Van Velthoven en $V$ ial Wijck, Recht en eficièntie, p. 40-42.

959. Zie Polinsky, Introduction, p. 97-99, voor een beschrijving van de werking van het Coss theorema binnen de productmarkt. 
In werkelijkheid zal de producent mogelijk wel informatie hebben ten aanzien van een bepaald product; bij de individuele consument ontbreekt deze informatie veelal. Dit kan een verstoring van de marktwerking tot gevolg hebben, omdat de consument door een gebrek aan informatie of soms verkeerde informatie geen juiste aankoopbeslissing kan nemen. ${ }^{960}$ Hieruit volgt dat ook de aanwezigheid van informatiegebreken in het marktproces kan leiden tot marktimperfecties. ${ }^{961}$ Daarbij moet worden angetekend dat het probleem van de informatie-asymmetrie zich op vele markten kan voordoen. In het kader van het aansprakelijkheidsrecht wordt hier echter specifiek gekeken naar productmarkten.

Met betrekking tot producten waarbij informatiegebreken kunnen ontstaan wordt een onderscheid gemaakt tussen zoekgoederen en ervaringsgoederen. Bij de eerste kan de onzekerheid met betrekking tot het aan te schaffen product gedeeltelijk worden weggenomen door informatie te verzamelen. Voorbeelden hiervan zijn de dagelijks boodschappen en de aankoop van een auto. De consument heeft de mogelijkheid om vooraf te zoeken naar een geschikte auto, waarbij eventuele gebreken, met behulp van de contractuele voorwaarden, achteraf kunnen worden hersteld. ${ }^{962}$

Bij ervaringsgoederen kan de waarde van het product pas na de aankoop worden vastgesteld. Verder worden ervaringsgoederen niet regelmatig aangeschaft of gebruikt, dan wel zijn aan dergelijke goederen hoogwaardige technische standaarden verbonden. Ten aanzien van ervaringsgoederen kan derhalve een probleem van informatie-asymmetrie ontstaan, ${ }^{963}$ tengevolge waarvan de consument slechts een gemiddelde prijs voor een product of aanbod wil betalen. Een producent die goede kwaliteit aanbiedt, zal echter niet bereid zijn om tegen een gemiddelde prijs een product te verkopen. Dit betekent dat alleen producten met een lagere kwaliteit worden aangeboden, die echter niet het gewenste nut opleveren. ${ }^{964}$

960. Ogus, Regulation, p. 38. 96. De basis voor de analyse van informatie-asymmetrie is gelegd door Akerlof, QJE, 1970, p. 488-
500 . Zie paragraaf 4.2.1 van hoofdstuk 6. Andere auteurs hebben vooral het belang van de aanwezigheid van informatie binnen de markt benadrukt. Zie Stigler, JPE, 1961, p. 213; Mackaay, Economics of Information and Law, 1982; Schwartz and Wilde, University of Pennsylvania Law Review, 1979, p. 630-682. Ogus, Regulation, p. 39-41, voor een analyse van informatieproblemen in een niet-gereguleerde markt.

962. Bowles, Law and the Economy, p. 168

963. Nelson, JPE, 1970, p. $111-329$, p. 168 meijer, NJB, 1994, p. 1239-329; Cave, Joumal of Consumer Policy, 1985, p. 335-351; Brenninktington, Economic Policy 1246; Quant, NJB, 1994, p. 1376-1380; Grout, Jewitt, Pong and Wit-

964. Zie Akeriof, QJE, Policy, 1994, p. 308-351.

cok De Bijl en Van 1970 , p. 488-500 voor een beschrijving van dit proces van anti-selectie. Zie 1997 , p. 19. 
Een subcategorie van de ervaringsgoederen zijn de professionele beroepen ${ }^{455}$ Nars het feit dat van de diensten van een advocaat, notaris of medicus niet regelmatig ge bruik wordt gemaakt, ${ }^{966}$ ligt in het aanbod van deze diensten tevens een wederzijt vertrouwenselement besloten. Een advocaat en zijn cliënt moeten elkaar kunnen vertrouwen om de zaak in het voordeel van de cliënt te kunnen beslechten. Professione le diensten worden daarom ook wel vertrouwensgoederen genoemd, ${ }^{967}$

In het kader van het onderhavige onderzoek kan nog worden gewezen op het belang van de informatie-asymmetrie voor de werkwijze van een verzekeringsmaatschappiti Deze is, ten behoeve van een juiste groepering van risico's, afhankelijk van de informatie die een potentieel verzekerde aan hem verschaft. Wanneer deze informate gebrekkig is, kan de verzekeraar het morele risico niet goed controleren. ${ }^{968}$ Het verschil met de hiervoor beschreven producten en diensten is echter dat de infomb. tietekorten zich niet aan de zijde van de afnemer, de consument, bevinden maar an de kant van de 'producent', de verzekeraar, die vaak slechter is geïnformeerd dande consument, in casu de potentiële verzekeringsnemer. Deze informatie-asymmetri ligt aan de basis van het proces van anti-selectie. ${ }^{969}$

\subsubsection{Regulering als remedie voor informatie-asymmetrie}

In het kader van de vraag of bij de aanwezigheid van een informatie-asymemtrie de overheid moet overgaan tot regulering en zo ja welke vorm deze regulering moet hebben, worden door Faure en Van den Bergh vier fasen van regulering onderscheiden. ${ }^{970}$ Daarbij wordt vanuit een 'public interest' perspectief de regelgering ingrijpender naarmate de informatietekorten toenemen.

In de eerste plaats kan de wetgever door regulering de informatievoorziening aan marktpartijen ten aanzien waarvan sprake is van een informatietekort verplicht ste. len. Aan de producent, die veelal beter is geïnformeerd, kan bijvoorbeeld de ver

965. Zie voor wat betreft de informatie-asymmetrie bij de professionele beroepen: Van den Berghti Regulation of Professions, p. $21-43$ en Faure en Van den Bergh, IRLE, 1991, p. 165-182.

966. Een uitzondering hierop is bijvoorbeeld het geval van een emstig ziek persoon die regelmatify behandeling nodig heeft of een persoon die met zijn advocaat een langdurige juridische w⿰纟勺 moet bewandelen, die jaren kan duren. In deze gevallen zal een relatie in de tijd ontstan, wa door de betreffende dienst meer een ervaringsgoed in de letterlijke zin wordt. Zie daarover fart en Van den Bergh, IRLE, 1991, p. 172.

967. Van den Bergh. in Regulation of Professions, p. 34-37; Faure en Van den Bergh, IRLE, 1991, P 171.

968. Faure en Van den Bergh, Objectieve aansprakelijkheid, p. 146. Zie ook paragraaf 4.1 van hoof stuk 6 voor een analyse van het morele risico.

969. Zie daarover paragraaf 4.2 van hoofdstuk 6.

970. Faure en Van den Bergh, IRLE, 1991, p. 173 en ook Van den Bergh, in Regulation of Prolas ons, p. 37-40. Deze vier stappen van regulering worden overigens geanalyseerd binnen het bedo van de regulering van vrije beroepen. 
plichting worden opgelegd om informatie met betrekking tot prijs en kwaliteit van een bepaald product aan de consument openbaar te maken. Een voorbeeld hiervan is de sigarettenverpakking, waarop, naast de vermelding van de hoeveelheid nicotine, dient te worden gewaarschuwd dat roken slecht is voor de gezondheid. ${ }^{971}$ In aanvulling op de verplichte informatievoorziening kan de overheid bijvoorbeeld ook overgaan tot het uitvaardigen van een verbod op misleidende reclame. ${ }^{972}$

In de tweede plaats kan de overheid, wanneer de consument verstoken blijft van bepaalde technische kennis die niet door bovengenoemde maatregelen kan worden verbeterd, overgaan tot bepaalde vormen van kwaliteitsregulering. Deze heeft betrekking op directe maatregelen, bijvoorbeeld kwaliteitscontrole en veiligheidsstandaarden, en indirecte maatregelen zoals het aansprakelijkheidsrecht. Een regel van risicoaansprakelijkheid kan bijvoorbeeld een aanvulling zijn op de gebrekkige informatie aan de zijde van de consument ten aanzien van de veiligheid van een product. ${ }^{973}$ Een argument om tot directe kwaliteitsregulering over te gaan ligt in de veronderstelling dat de overheid over betere informatie beschikt omtrent bepaalde veiligheidsstandaarden dan de private marktpartijen. ${ }^{974}$ Het opleggen van veiligheidsmattregelen met betrekking tot bijvoorbeeld auto's, zoals het dragen van een gordel, dienen de consument te beschermen tegen zijn eigen irrationeel geơrag. ${ }^{975}$

In de derde plaats kan regulering in verband worden gebracht met het afgeven van vergunningen of diploma's ten behoeve van de uitoefening van een bepaalde activiteit of een beroep. Een diploma (bijvoorbeeld een meesterstitel) kan worden verkregen door middel van het afleggen van bepaalde examens of door te voldoen aan bepaalde voorwaarden. Een vergunning geeft vervolgens aan degene die een wettelijk

971. De overheid kan ook zelf informatiecampagnes opzetten, waarin er bijvoorbeeld op wordt gewezen dat roken slecht is voor de gezondheid en dat alcohol en verkeersveiligheid niet samengaan. Zie daarover Utton, The Economics of Regulating Industry, p. 45-49.

972. Faure en Van den Bergh, IRLE, 1991, p. 173; Van den Bergh, in Regulation of Professions, p. 38; Utton, The Economics of Regulating Industry, p. 9-I1; De Bijl en Van Damme, Regulering en zelfregulering in markten met kwaliteitsonzekerheid, 1997, p. 19; Holzhauer en Teijl, Inleiding rechtseconomie, p. 17

973. Polinsky, Introduction, p. 101, stelt dat een regel van risicoaansprakelijkheid kan worden gezien als een substituut voor volledige productinformatie bij de consument.

974. Faure en Van den Bergh, IRLE, 1991, p. 173; Van den Bergh, in Regulation of Professions, 38; Bowles, Law and the Economy, p. 167-168; De Bij lering in markten met kwalitemy, p. 167-168; De Bijl en Van Damme, Regulering en zelfreguen paragraaf 3 hierna, voor wat bekerheid, 1997, p. 14. Zie ook Shavell, JLS, 1984, p. 357-374 heidsregulering en aansprakelijkheid.

975. Oqus, Regulation,

vidu het risico waram $51-53$ verwijst naar empirisch onderzoek, waaruit zou blijken dat een indivoegt hier vervolgens aan toe dachzelf blootstelt sterk onderschat ('mij kan niets gebeuren'). Hij leiden tot een verhoogd risico dat het niet dragen van de autogordel bij een mogelijk ongeval kan tingbetaler) worden gedragen. 
erkend diploma bezit het recht om een bepaalde activiteit of beroep (advocaat) uitte oefenen. ${ }^{976}$ Een rijbewijs, bijvoorbeeld, kan worden verkregen door het met goot gevolg afleggen van een rijexamen. De bezitter van het rijbewijs krijgt hiermee ete automatisch recht om aan het verkeer deel te nemen.

Een vierde en laatste stap in het reguleringsproces heeft betrekking op zelfreg lering. Ten aanzien van de vrije beroepen betekent dit concreet dat de beroepsgroep de interne regels zelf gaat opstellen en handhaven. Verder geldt dat de beroepsgroep zelf de toegang tot en de uitoefening van het betreffende beroep reguleert. De professionele beroepsorganisatie neemt daarbij de rol van de overheid als publieke ir stantie over. In het kader van de informatieproblematiek wordt beargumenteerd dat de beroepsorganisatie zelf de beste mogelijkheden heeft om de kwaliteit van de geboden diensten te controleren. De overheid zou daarbij niet beschikken over de gespecialiseerde informatie omtrent het functioneren van vrije beroepen. Daamaas heeft zelfregulering voordelen op het terrein van flexibilisering en worden de kosten van regulering door de groep zelf gedragen. ${ }^{977}$

\subsection{CONCLUSIE: KANTTEKENINGEN BIJ DE ECONOMISCHE WELVAARTSTHEORIE}

In de voorgaande beschrijving van de economische welvaartstheorie is het falen van de markt als argument voor overheidsoptreden gebruikt. Wanneer de naturlije krachten van de markt niet in staat zijn om een efficiënt resultaat te bereiken, lan met behulp van regulering worden getracht om een optimale welvaart voor di marktpartijen te realiseren. Daarbij is steeds uitgegaan van het gegeven dat de orerheid alleen ten behoeve van het algemeen belang het falen van de markt corrigert. In werkelijkheid heeft de overheid de neiging om ook in te grijpen in het markproces wanneer geen sprake is van marktfalingen. Dit kan betekenen dat aan de reglering andere argumenten ten grondslag liggen.

De overheid kan bijvoorbeeld tot regulering overgaan met het argument dat de marktuitkomst negatieve gevolgen heeft. Het feit dat de winkels op zondag velal gesloten dienen te blijven, hangt meer samen met religieuze en morele belangen, dan dat hiervoor vanuit de 'public interest' theorie een verklaring kan worden gegeven. Daarnaast is de regulering met betrekking tot antidiscriminatie en het gebruik val alcohol en drugs vaak ook niet het gevolg van bepaalde marktfalingen, hoewel

976. Faure en Van den Bergh, IRLE, 1991, p. 173; Van den Bergh, in Regulation of Professions, 38-39.

977. Zie Faure en Van den Bergh, IRLE, 1991, p. 173-175; Van den Bergh, in Regulation of Profics: ons, p. 39-40, ten aanzien van de voor- en tegenargumenten met betrekking tot de zelfiegulent! van vrije beroepen. Zie ook De Bijl en Van Damme, Regulering en zelfregulering in markte met kwaliteitsonzekerheid, 1997, p. 37-39.

978. Utton, The Economics of Regulating Industry, p. 4. 
zeker preventieve elementen in besloten liggen. Aan dergelijke regelgeving liggen eerder zogenaamde paternalistische argumenten ten grondslag. Paternalisme verwijst hierbij naar regelgeving die boven de individuele keuzes uitstijgt. De persoonlijke waarden van het individu worden in dit kader ondergeschikt gemaakt aan meer algemene waarden. $^{979}$

Hieruit kan worden afgeleid dat op een aantal terreinen sprake kan zijn van regulering waar dat misschien niet wenselijk is of waarbij regulering kan leiden tot inefficiênties. Dit kan echter ook het gevolg zijn van het feit dat bepaalde belangengroepen binnen de samenleving hun invloed aanwenden om voor hen welgevallige regelgeving tot stand te brengen. De economische welvaartstheorie besteedt echter geen andacht aan de invloed van belangengroepen op de totstandkoming van regulering. ${ }^{980}$ Hiervoor wordt in de economische analyse een aantal alternatieve verklaringstheorieën genoemd, die onder de noemer van de 'private interest' theorie in paragraaf 4 zullen worden uitgewerkt.

Een voorbeeld waarin de overheid juist afstand neemt en de regulering meer aan de markt zelf wil overlaten, zijn de dereguleringsoperaties die in de jaren tachtig van de vorige eeuw in gang zijn gezet. Vanuit de economische welvaartstheorie kan deregulering leiden tot een verlaging van de welvaart, wanneer de bestaande regelgeving nog voldoende efficiënt is. Daartegenover staat dat regels te star kunnen worden, waardoor de marktpartijen niet voldoende kunnen anticiperen op externe veranderingen. Dit betekent dat deregulering mogelijk wordt zodra de kosten van regulering de baten overstijgen of indien regulering door technologische ontwikkelingen wordt ingehaald. $^{981}$

Concluderend kan worden gesteld dat de 'public interest' theorie niet in staat is om een verklaring te geven voor regulering die anders dan ter correctie van marktfalingen wordt uitgevaardigd. De 'public interest' theorie kijkt ook niet naar de gevolgen van regulering; zij gaat ervan uit dat regulering efficiëntie genereert en heeft daarbij geen oog voor de achterliggende oorzaken van de betreffende marktfaling. De positieve economische theorie vloeit daarmee over in de normatieve theorie, die stelt dat regulering eenvoudigweg nodig is wanneer een faling van de markt wordt geconstateerd. Utton wijst er nog op dat de kosten van regulering moeten opwegen tegen de baten van een correctie van de marktfaling. Het gaat hierbij om de kosten van de administratieve handhaving van regels, die moeten worden afgezet tegen de transactiekosten van een marktoplossing. De werkelijke transactiekosten bij de on-

\footnotetext{
979. Bowles, Law and the Economy, p. 170-171; Burrows, IRLE, 1995, p. 495.
980. Utton, The Economics of Regulating Industry, p. 19-20. Zie ook Holzhauer en Teijl, Inleiding

981. Zie De Bijle, p. 18, voor andere voorbeelden

1997, p.j en Van Damme, Regulering en zelfregulering in markten met kwaliteitsonzekerheid,
} 
derhandelingen tussen marktpartijen kunnen hoog zijn wanneer meerdere partijen bij de onderhandelingen zijn betrokken. Daarnaast kan zich een 'free rider' probleem voordoen, waarbij de partijen die niet aan de onderhandelingen deelnemen profiteren van de uitkomsten van het onderhandelingsproces. ${ }^{982}$

\section{De economische theorie van veiligheidsregulering}

In de vorige paragraaf is een eerste algemene economische theorie met betrekking tot overheidsregulering gepresenteerd. Daaruit is gebleken dat regulering word gea zien als een oplossing voor bepaalde marktfalingen. In dat kader is beschreven welke vormen van regulering aan de overheid ten dienste staan om, vanuit macroeconomisch perspectief, deze marktfalingen te corrigeren. Daarbij wil de overheid met behulp van wetgeving trachten om een verhoging van de maatschappelijke welvaart te bereiken.

Bij deze analyse van de economische welvaartstheorie is echter niet uitgewerkt welke preventieve effecten de regulering ter correctie van marktfalingen kan hebben. In deze paragraaf zullen deze effecten nader worden onderzocht aan de hand van de economische analyse van regulering in enge zin, namelijk binnen het kader van bat ongevallenrecht. In dat verband zal speciale aandacht worden besteed aan twe marktfalingen uit de vorige paragraaf, namelijk externaliteiten en informatis asymmetrie.

De centrale vragen die in deze paragraaf aan bod komen, zijn in de eerste plaats of de overheid met behulp van veiligheidsregulering moet ingrijpen in de normale werking van de markt voor aansprakelijkheid en verzekering. Wanneer deze vraag be vestigend wordt beantwoord is een tweede vraag van belang. Uitgaande van de etrder beschreven economische doelstelling van het ongevallenrecht, zal moeten worden onderzocht op welke wijze de overheid de private markt dient te corrigeren.

In het kader van de vraag of de veiligheid beter via de markt voor aansprakelijherd en verzekering kan worden gewaarborgd, wordt door Calabresi gesproken van wan 'general deterrence'-benadering, waarbij ten aanzien van de preventie van ongevallan wordt vertrouwd op de werking van de markt. De vraag of de veiligheid enkel door middel van voorschriften vanwege de overheid kan worden gegarandeerd verwis. naar de 'specific deterrence'-benadering, waarbij de beslissingen met betrekking to de ongevalspreventie via het politieke besluitvormingsproces worden genomen.

982. Utton, The Economics of Regulating Industry, p. 14-20; Ogus, Regulation, p. 17-21, $41-420$ 56; Bowles, Law and the Economy. p. 175.

983. Zie Calabresi, The Costs of Accidents, p. 17-18; Faure en Van den Bergh, Objectieve annspolts lijkheid, p. 143. Cramton, Michigan Law Review, p. 424, verwijst met 'general deterence' num' 
In paragraaf 3.1 zal, na een beknopte inleiding, met behulp van een aantal economische criteria, worden ingegaan op de verhouding tussen veiligheidsregulering en aansprakelijkheid respectievelijk verzekering. Hierbij is de vraag van belang hoe deze criteria de keuze voor één van deze controle-instrumenten beïnvloeden. In paragraaf $3.2 \mathrm{zal}$ worden geanalyseerd wat de effecten zijn van een gecombineerd gebruik van aansprakelijkheid en veiligheidsregulering. In paragraaf 3.3 tenslotte, zal de economische theorie worden toegepast op het verkeersongevallenrecht. Hierbij zal onder andere worden ingegaan op de middelen die aan de overheid ten dienste staan om de veiligheid in het verkeer te bevorderen. Daarnaast zullen de preventieve effecten van deze veiligheidsnormen worden afgezet tegen de preventieve werking van het aansprakelijkheidsrecht.

\subsection{DE CRITERIA VOOR VEILIGHEIDSREGULERING}

De criteria die mede de keuze bepalen tussen het gebruik van het aansprakelijkheidsrecht en veiligheidsregulering zijn vooral door Shavell nader uitgewerkt. ${ }^{984}$ Daarbij moet worden vooropgesteld dat aansprakelijkheid kan worden beschouwd als een onderdeel van regulering. Dit betekent dat zowel de omvang als de vorm van aansprakelijkheid voorwerp kunnen zijn van regulering.

Het verschil tussen aansprakelijkheid en regulering komt echter vooral tot uiting in hun benadering ten aanzien van de controle van bepaalde risicovolle activiteiten. Aansprakelijkheid heeft in dit verband een meer privaat karakter, waarbij haar werking pas in beeld komt wanneer de schade is ontstaan en door het slachtoffer een actie tot schadevergoeding wordt ingesteld. ${ }^{985}$ Het vooruitzicht om op deze wijze ex post aansprakelijk te zijn voor de schade heeft daarmee een preventief effect, omdat ex ante schadeveroorzakend gedrag kan worden voorkomen. Veiligheidsregulering, bijvorbeeld in de vorm van standaarden, heeft vooral een publiek karakter. Deze vorm van directe regulering kan vooraf, ex ante, worden opgelegd, ongeacht het ontstaar van eventuele schade. ${ }^{986}$

\footnotetext{
de invloed van de opgelegde sanctie op de maatschappij als geheel, terwijl 'specific deterrence' verband houdt met het effect van de maatregel op het individu tot wie de sanctie is gericht.

984. Shavell, JLS, 1984, p. 357-374; Shavell, Accident Law, p. 277-286, alsmede voor een meer rechtseconometrische analyse, Shavell, RJE, 1984, p. 271-280. Zie ook Wittman, JLS, 1977, p. 193-211; Faure en Van den Bergh, Objectieve aansprakelijkheid, 152-161; Faure en Van den Bergh, GPRl, 1987, p. 107-111; Skogh, IRLE, 1982, p. 67-80; Kolstad, Ulen and Johnson, Am. Econ. Rev., 1990, p. 888-901.

985. Zie hoofdstuk 5 voor een economische analyse van het aansprakelijkheidsrecht.

986. Zie Faure en Van den Bergh, Objectieve aansprakelijkheid, p. 152-153; Shavell, Accident Law, p. 278-279; Skogh, IRLE, 1982, p. 74-75; Kolstad, Ulen and Johnson, Am. Econ. Rev., 1990, p. 888 voor het onderscheid tussen een ex ante en een ex post benadering. Zie verder Wittman, JLS, 1977, p. 193-211, voor een kosten-baten analyse van regulering.
} 
De vraag of een 'gevaarlijke' activiteit vooraf gereguleerd of door het aansprake. lijkheidsrecht moet worden gecorrigeerd, is zoals gesteld mede afhankelijk van een aantal criteria. Deze hebben achtereenvolgens betrekking op de informatiekosten het (on)vermogen van de schadeveroorzaker om de schade te vergoeden, de ormo. gelijkheid om de schadeveroorzaker aansprakelijk te stellen en de administatiere kosten. $^{987}$

Aan de hand van deze criteria heeft Shavell een economisch theoretische analyse ontwikkeld, waarbij naast de kosten en baten ook de preventieve effecten van aan. sprakelijkheid en veiligheidsregulering worden vergeleken. Bij deze analyse worden drie veronderstellingen gemaakt. In de eerste plaats wordt van een individu verwacht dat hij bij de deelname aan een bepaalde activiteit handelt in zijn eigen belang. Inde tweede plaats geldt dat de compensatie van het slachtoffer buiten beschouwing wordt gelaten, ${ }^{988}$ met het argument dat deze veelal door middel van een verzekening is gedekt. In de derde plaats ten slotte, zal worden verondersteld dat de overheid zich bij de keuze tussen aansprakelijkheid en regulering uitsluitend door het algemen belang laat leiden en dat ook de inhoud van de regulering door het algemeen belang wordt bepaald. Er wordt derhalve geen rekening gehouden met mogelijke compliatties bij de totstandkoming van regulering, bijvoorbeeld in het kader van de belar gengroeptheorie. ${ }^{989}$

In het vervolg van deze paragraaf zullen de bovengenoemde criteria één voor tén worden geanalyseerd. Daarbij kan met Shavell als doel van de analyse worden ge. formuleerd het vinden van een juiste wijze van controle die de maatschappelije welvaart kan maximaliseren. In samenhang hiermee staat het streven om, in het lio der van de vraag naar de wenselijkheid van aansprakelijkheid of regulering, een op timale preventie te bereiken. Daarbij zal ook een aantal relevante verzekeringsaspecten niet onvermeld blijven. ${ }^{990}$

\subsubsection{Informatiekosten}

Een eerste onderscheid tussen aansprakelijkheid en veiligheidsregulering word tgevormd door een verschil in risico-informatie tussen de bij een ongeval betrokken pirvate partijen en de regelgever. Dit verschil hangt samen met de opbrengst van etn activiteit, de kosten die moeten worden gemaakt om het risico te verminderen en met de kans dat het risico leidt tot schade en de emst van de verwachte schade. In tit kader dienen twee vragen te worden beantwoord. In de eerste plaats gaat het om de

987. Shavell, JLS, 1984, p. 357-374. Zie ook Holzhauer en Teijl, Inleiding rechtsecononie, p. $23^{3}$ 275 voor een uitwerking van deze criteria.

988. Er zal derhalve vooral worden gekeken naar een reductie van de primaire ongevalskosten.

989. Shavell. JLS, 1984, p. 357-358.

990. Shavell, JLS, 1984 , p. 358. 
meer theoretische vraag welke partij, de private of de overheid, over betere informatie ten anzien van het risico kan beschikken. In een tweede fase zal de vraag worden beantwoord welke partij uiteindelijk, afhankelijk van de omstandigheden, de betere informatie bezit om het risico op een juiste wijze te kunnen inschatten.

3.1.1.1. Welke partij kan over betere risico-informatie beschikken?

Met betrekking tot deze vraag zijn twee veronderstellingen van belang. In de eerste plaats kan worden verondersteld dat de direct bij het ongeval betrokken partijen optimale informatie bezitten om ten behoeve van een risicovermindering de juiste voorzorgsmaatregelen te nemen. Hieruit volgt een tweede veronderstelling, namelijk dat de private partijen het verwachte risico zelf kunnen controleren. Dit leidt tot de conclusie dat de voorkeur zal uitgaan naar een controle ex post, namelijk via het aansprakelijkheidsrecht. Bij een dergelijke controle achteraf wordt immers verondersteld dat de partijen zelf over de efficiënte zorg kunnen beslissen. Dit laatste geldt met name voor de potentiële schadeveroorzaker, hoewel ook ten aanzien van het potentiële slachtoffer kan worden gesteld dat hij meer direct bij de bron van het risico is betrokken. ${ }^{991}$

Een vergelijking van aansprakelijkheidsregels leert verder dat zowel een regel van nisicoaansprakelijkheid als een regel van foutaansprakelijkheid binnen de gegeven veronderstellingen tot een optimale uitkomst kan leiden. Bij een regel van risicoaansprakelijkheid zal de schadeveroorzaker, ten aanzien van zijn activiteitsuitoefening, volledig rekening houden met de verwachte ongevalskosten. ${ }^{992}$ Een regel van foutaansprakelijkheid zal, onder bepaalde voorwaarden, eveneens tot een optimale uitkomst kunnen leiden. De rechter dient daarbij enerzijds te beschikken over volledige informatie om de zorgvuldigheidsnorm vast te stellen. Anderzijds zal deze juridische zorgvuldigheidsnorm gelijk moeten zijn aan de efficiënte zorgstandaard, zodat de potentiële schadeveroorzaker wordt aangezet om de efficiënte zorg uit te oefenen. ${ }^{993}$ Ook wanneer de rechter niet over volledige informatie beschikt om de zorgvuldigheidsnorm vast te stellen kan een regel van foutaansprakelijkheid superieur zijn. ${ }^{994}$

\footnotetext{
991. Shavell, JIS, 1984, p. 283

992. Shavell, JLS, 1980 , p. $2-3$

993. Zie hoofdstuk 5 yoor een

994. Shavell, Accident

93 en paragraaf 10 wan p. 73-85; Faure en Van den Bergh, Objectieve aansprakelijkheid, p. 90 wordt betoogd dat van hoofdstuk 5. Zie voorts Ott und Schaffer, IRLE, 1997, p. 15-29, waarin ontuikkeld, ondanks het fechters op de lange termijn een efficiēnte zorgstandaard kan worden dige informatie beschikken.
} 
Hieraan is de voorwaarde verbonden dat de rechter, ex post oordelend, over meer informatie beschikt dan de wetgever, die deze informatie ex ante verzamelt. ${ }^{995}$

Wanneer derhalve wordt verondersteld dat de direct bij een ongeval betrokken partijen over optimale risico-informatie kunnen beschikken, zal de wetgever deze nisi. co-informatie vermoedelijk niet hebben. Dit betekent dat er een grote kans op vergissingen bestaat, indien de wetgever toch besluit om tot een ex ante veiligheidsegulering over te gaan. Daarbij zal een te hoge inschatting van het risico respectievelijk een te lage inschatting van de kosten van een risicovermindering kunnen leiden tot een te strenge veiligheidsstandaard. Omgekeerd kan een onderschatting van bet risico respectievelijk een overschatting van de kosten leiden tot een te ruime velijg. heidsstandaard. ${ }^{996}$

Wanneer echter de wetgever over betere informatie beschikt dan de private partijen en de rechter die over de zorgvuldigheidsnorm moet oordelen, zal de voorkeur uitgaan naar ex ante veiligheidsregulering. ${ }^{997}$

\subsubsection{Welke partij bezit de betere risico-informatie?}

In het kader van deze vraag kan worden gesteld dat, ten aanzien van een groot aantal ongevalssituaties, de direct betrokken partijen een soort 'natuurlijk' informatievoordeel hebben ten opzichte van de wetgever. De private partijen zijn immers degenen die aan een bepaalde 'gevaarlijke' activiteit deelnemen. Zij kunnen derhalve een be tere inschatting maken van het risico waaraan zij zich wensen bloot te stellen. Daarnaast zullen zij in een mogelijke ongevalssituatie ook beter kunnen bepalen welke maatregelen zij moeten nemen om de kans op een ongeval te verminderen. De rechter heeft, oordelend in een concreet geval, daarnaast ook een voordeel op de wetgever. De rechter zal immers voldoende feitelijke informatie van de betrokken partijen verkrijgen om de zorgvuldigheidsnorm te kunnen vaststellen. De wetgever, daarentegen, neemt in veel ongevalssituaties de zaken meer op een afstand waar. Dit heth tot gevolg dat de wetgever niet in staat is om de benodigde risico-informatie te ver zamelen en om te zetten in veiligheidsregulering, waarmee het gedrag van de privats

995. Shavell, JLS, 1984, p. 359; Shavell, Accident Law, p. 281; Faure en Van den Bergh, Objectiell aansprakelijkheid, p. 153. Zie ook Holzhauer en Teijl, Inleiding rechtseconomie, p. 277-279, mal een voorbeeld uit de Nederlandse rechtspraak.

996. Zie Ogus, IRLE, 1992, p. 411-421 voor een analyse van vergissingen en kosten bij de voorsptling van het risico in verband met regulering.

997. Shavell, JLS, 1984, p. 359; Shavell, Accident Law, p. 281; Faure en Van den Bergh, Objectich aansprakelijkheid, p. 154. Calabresi, YLJ, 1975, p. 656-671, gaat uit van een volledige inform tie bij de wetgever, waardoor een optimale preventie via regulering kan worden bereikt. is th

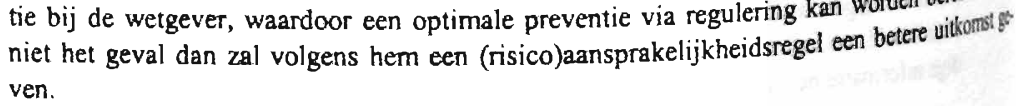


partijen in elke concrete ongevalssituatie kan worden geobserveerd en gecontroleerd 998

Er zijn echter ongevalssituaties denkbaar waarin de wetgever over betere informatie beschikt dan de direct betrokken partijen. Ten aanzien van de voorspelling van bepaalde ongevalsrisico's, zoals milieu- of gezondheidsrisico's, kan een zekere deskundigheid nodig zijn. Daarnaast kan de wetgever anderszins in het voordeel zijn omdat hij over de middelen beschikt om bepaalde informatie te verzamelen. De overheid makt voor haar informatieonderzoek gebruik van gemeenschapsgelden, waarbij de kosten derhalve over de gemeenschap worden gespreid. De resultaten van het onderzoek worden vervolgens omgezet in bepaalde veiligheidsstandaarden, waarvan de informatie direct aan de potentiële schadeveroorzakers ter beschikking kan worden gesteld. ${ }^{999}$

Voor een individuele schadeveroorzaker geldt echter dat hij hoge kosten moet maken om zelf de informatie omtrent dergelijke risico's te verzamelen, waardoor hij mogelijk onvoldoende prikkels zal hebben om daarvoor een investering te doen. Wanneer een potentiële schadeveroorzaker echter toch besluit om een informatieonderzoek naar complexe risico's te starten, bestaat de kans dat derden van zijn inspanningen profiteren, zonder dat zij daarvoor een prijs betalen. Een dergelijk 'free rider' probleem kan in theorie worden voorkomen, wanneer een aantal schadeveroorzakers zich gezamenlijk inspant om de benodigde informatie te verkrijgen. Daarbij is het van belang dat de individuele groepsleden in gelijke mate bereid zijn om te investeren in het informatieonderzoek. Is dit niet het geval dan ontstaat opnieuw een 'free rider' probleem, omdat de leden die niet wensen mee te werken zullen profiteren van de inspanningen van de andere groepsleden, zonder dat daar een prestatie tegenover staat. 1000

Samenvattend kan worden gesteld dat veiligheidsregulering vooral wenselijk is ten aanzien van complexe risico's, waarbij aan de zijde van de private partijen sprake is van informatietekorten en de overheid de gewenste informatie goedkoper kan verramelen dan de partijen zelf. Voor de minder complexe risico's kan gelden dat de private partijen beter zijn geïnformeerd dan de overheid, zodat dan de voorkeur zal uitgaan naar een aansprakelijkheidsregel. ${ }^{1001}$

\footnotetext{
Shavell, JLS, 1984, p. 360; Shavell, Accident Law, p. 281; Faure en Van den Bergh, Objectieve
aansprakelijkheid, p. 154.

1099. Faure en Van den Bergh, Objectieve aansprakelijkheid, p. 154.

1001. Holzhauer Tecident Law, p. 281-282; Shavell, JLS, 1984, p. 360.
} 


\subsubsection{Insolventie}

Een tweede onderscheid tussen aansprakelijkheid en regulering houdt verband ntet de situatie waarin de schadeveroorzaker over onvoldoende vermogen beschikt on de ontstane schade volledig te vergoeden. ${ }^{1002}$ Economisch gezien heeft dit tot gevol dat de schadeveroorzaker, onder de dreiging van een ex post aansprakelijkheid, meer zorg zal uitoefenen dan zijn vermogen toelaat. De schadeveroorzaker kan in dat geval voor niet meer aansprakelijk worden gesteld dan de omvang van zijn vermogen. Wanneer de verwachte schade te ver uitstijgt boven het vermogen van de schadeveroorzaker, zal van het aansprakelijkheidsrecht mogelijk onvoldoende preventieve werking ('underdeterrence') uitgaan. ${ }^{1003}$

Bij een ex-ante veiligheidsregulering zullen deze insolventieproblemen kunnen wor. den vermeden. Met behulp van vooraf opgelegde veiligheidsstandaarden kunnen de private partijen, bij hun deelname aan een gevaarlijke activiteit, worden aangezet to de uitoefening van de vereiste zorg. Wanneer een dergelijke controle vooraf gepaard gaat met bepaalde sanctiemiddelen, kan het gedrag van de partijen optimaal worden gestuurd. ${ }^{1004}$ Aan deze optimale ex ante controle van het risico is echter een aantal voorwaarden verbonden.

In de eerste plaats geldt dat de financiële sancties bij niet-nakoming van de ex-nnte veiligheidsstandaard niet te hoog mogen zijn, omdat anders het gevaar bestaat dat de schadeveroorzaker deze niet kan betalen. Dit betekent dat een voorkeur voor een ex ante veiligheidsregulering afhankelijk is van de verhouding tussen het vermogen van de schadeveroorzaker en de verwachte ongevalskosten. Hoe groter de kans dat de verwachte schade het vermogen van de schadeveroorzaker overtreft, hoe eerder ete beroep op veiligheidsregulering zal worden gedaan. ${ }^{1005}$ Naast het gebruik van finar. ciële sancties kunnen, ten behoeve van de handhaving van een bepaalde velitg heidsstandaard, ook andere vormen van sancties worden toegepast. Deze piet geldelijke sancties kunnen een positief effect hebben op de preventieve zorg vande schadeveroorzaker. Daartegenover staat dat de handhaving van dergelijke sanctio hoge maatschappelijke kosten met zich mee kan brengen. ${ }^{1006}$

In de tweede plaats dient erop te worden gewezen dat de vraag of het aansprater lijkheidsrecht, ingeval van insolventie, tot minder preventieve zorg leidt, afhankelin?

1002. Zie Shavell, IRLE, 1986, p. 45-58.

1003. Shavell, Accident Law, p. 279-280; Shavell, JLS, 1984, p. 360-361.

1004. Shavell, JLS, 1984, p. 360-361; Faure en Van den Bergh, Objectieve aansprakelijkheid, p. 134

1005. Shavell, JLS, 1984, p. 361; Faure en Van den Bergh, Objectieve aansprakelijkheid, p. 155; fal re, AA, 1990, p. 764-765.

1006. Shavell, CoLR, 1985, p. 1232-1262; Shavell, Accident Law, p. 279; Holzhauer en Teij], be ding rechtseconomie, p. 279-280. 
is van de toepasselijke aansprakelijkheidsregel. Bij een regel van foutaansprakelijkheid kan de schadeveroorzaker aansprakelijkheid vermijden door efficiënte zorg uit te oefenen. Dit betekent dat de kans op insolventie bij foutaansprakelijkheid klein is, mits de kosten van zorg niet hoger zijn dan het vermogen van de schadeveroorzaker. Bij een regel van risicoaansprakelijkheid is het insolventierisico groter omdat in beginsel de schadeveroorzaker de schade steeds moet vergoeden. Daarbij zal de prikkel tot zorg reeds wegvallen, indien de verwachte schade het vermogen van de veroorzaker overstijgt. ${ }^{1007}$ Het voorgaande brengt mee dat een remedie tegen insolventie eerder bij veiligheidsregulering ligt wanneer een risicoaansprakelijkheid toepasselijk is, dan wanneer sprake is van een regel van foutaansprakelijkheid.

In de derde plaats, tenslotte, speelt ook de aanwezigheid van een aansprakelijkheidsverzekering een rol. Het probleem bij een aansprakelijkheidsverzekering is echter dat een potentiële schadeveroorzaker veelal niet bereid zal zijn om een verzekering af te sluiten voor een bedrag aan aansprakelijkheid dat hoger ligt dan zijn vermogen. ${ }^{1008}$ De potentiële schadeveroorzaker met een eigen vermogen van bijvoorbeeld $20.000 \mathrm{zal}$ vermoedelijk geen verzekering aangaan voor een verwachte schade van 100.000. Hij kan immers, zonder de aanwezigheid van een verzekering, niet voor het verschil van 80.000 aansprakelijk worden gesteld. Dit betekent dat een aansprakelijkheidsregel in combinatie met een vrijwillige verzekering een onvoldoende preventief effect heeft op een insolvabele schadeveroorzaker. Een mogelijke oplossing hiervoor is het verplicht stellen van een aansprakelijkheidsverzekering. Daarbij is het van belang dat de verzekeraar met behulp van de verzekeringsvoorwaarden het gedrag van de verzekerde kan controleren. Wanneer deze controle optimaal is, zal de insolvente schadeveroorzaker worden aangezet tot de uitoefening van efficiënte zorg. Indien een dergelijke controle echter niet optimaal is, hetzij door een gebrek aan informatie bij de verzekeraar, hetzij vanwege de kosten, zal de insolvente schadeveroorzaker onvoldoende prikkels van zorg hebben. ${ }^{1009}$

Samenvattend kan worden gesteld dat het insolventierisico door een drietal maatregelen kan worden beperkt. In de eerste plaats kan de schadeveroorzaker met ex ante veiligheidsregulering worden aangezet tot optimale zorg. Daarbij geldt dat de financiêle sancties op de niet-naleving van de veiligheidsstandaard niet hoger mogen zijn dan het vermogen van de schadeveroorzaker. In de tweede plaats kan ook een regel van foutaansprakelijkheid een remedie zijn tegen het insolventierisico zolang de kosten van zorg niet hoger zijn dan het vermogen van de schadeveroorzaker. Tenslotte kan ook een (verplichte) aansprakelijkheidsverzekering, afhankelijk van de

\footnotetext{
1007. Shavell, IRLE, 1986, p. 47; Faure, AA, 1990, p. 765; Jost, IRLE, 1996, p. $261-262$.

1008. Zie Shavell, IRLE, 1986, p. 48; Keeton and Kwerel, JLE, 1984, p. 149.

Wittman, JLE, 1984, p. 361-362; Faure en Van den Bergh, Objectieve aansprakelijkheid, p. 155; van hoofdstuk 6 , p. 203-204; Jost, IRLE, 1996, p. 263-267 en p. 270. Zie ook paragraaf 4
} 
mogelijkheid tot een gedragscontrole bij de verzekeraar, het gevaar van insolventie verminderen.

\subsubsection{De onmogelijkheid om de schadeveroorzaker aansprakelijk te stellen}

Een derde onderscheid tussen aansprakelijkheid en veiligheidsregulering hangt samen met de situatie waarin de schadeveroorzaker door omstandigheden niet voor de schade aansprakelijk kan worden gehouden. De uitoefening van een gevaarlijke ar. tiviteit kan immers resulteren in een ongeval met een omvangrijke schade, warbij: de veroorzaker niet kan worden achterhaald. Dit betekent dat de preventieve nerking van het aansprakelijkheidsrecht sterk kan verminderen, waardoor de privale partijen minder zorgvuldig zullen worden. Door de invoering van veiligheidsregule. ring kunnen deze problemen mogelijk worden opgevangen. ${ }^{1010}$

Shavell wijst op een drietal redenen die meebrengen dat een schadeveroorzake soms niet civielrechtelijk kan worden aangesproken voor de ontstane schade hoenel hij deze wel heeft veroorzaakt. In de eerste plaats kan de schade over veel slachtof fers zijn verspreid. Hierdoor kan het voor een individueel slachtoffer met een geringe schade niet lonend zijn om zijn schade op de veroorzaker te verhalen. Een moge. lijke oplossing hiervoor is een gezamenlijke actie van de slachtoffers, waarmee op de proceskosten kan worden bespaard. Aan deze zogenoemde 'class action' kleff echter ook een aantal nadelen, waaronder de organisatiekosten en de kans op bel ontstaan van 'free rider' problemen. ${ }^{1011}$

In de tweede plaats wordt de verhaalbaarheid van de schade bemoeilijkt door betge geven dat de schade zich pas jaren na het ongeval kan voordoen. Dit kan tot gevols hebben dat nadat de schade is ontstaan de veroorzaker ervan onvindbaar is gewor den. Wanneer de dader wel kan worden gevonden doet zich het (bewijs)problem voor dat het slachtoffer een causaal verband moet aantonen tussen zijn schade ende activiteit van de persoon of instelling die deze schade heeft veroorzaakt. Dit cavsliteitsbewijs wordt verder bemoeilijkt, naarmate er meer tijdsverloop zit tussen bit ongeval en de schade. ${ }^{1012}$

In de derde plaats tenslotte, kan sprake zijn van meerdere schadeveroorzakers. Het slachtoffer verkeert daarbij in onzekerheid omtrent de vraag wie de schade daadiver. kelijk heeft veroorzaakt en dus aangesproken dient te worden. Daamaast kan ks slachtoffer van een onjuiste veronderstelling uitgaan, dat de schade niet door ent

1012. Boden, JLS, 1984, p. 515 . 
derde is veroorzaakt, maar meer het gevolg is van een 'natuurlijke oorzaak', bijvoorbeeld een slechte gezondheid. ${ }^{1013}$

Er zijn overigens nog meer redenen dan de door Shavell genoemde problemen die mee kunnen brengen dat een schadeveroorzaker civielrechtelijk niet kan worden aangesproken. In dit verband kan worden gedacht aan problemen met betrekking tot het juridisch bewijs van de aansprakelijkheid. Daarbij speelt het bewijs van schuld, maar ook van het causale verband een grote rol.

Met betrekking tot de bovenbeschreven verhaalsproblemen kan worden gesteld dat de kans groot is dat een aansprakelijkheidsvordering achterwege zal blijven. Dit heeft tot gevolg dat de preventieve werking van het aansprakelijkheidsrecht grotendeels zal verdwijnen. De invoering van een ex ante veiligheidsregulering zal nu noodzakelijk worden om de schadeveroorzaker tot de uitoefening van optimale zorg aan te zetten. Geconcludeerd kan worden dat, ten aanzien van de eerderbeschreven verbaalsrisico's, een ex ante veiligheidsregulering de voorkeur heeft boven het enkele gebruik van aansprakelijkheidsregels. ${ }^{1014}$

\subsubsection{Administratieve kosten}

In de vierde plaats tenslotte, zijn ook de administratieve kosten medebepalend voor de keuze tussen het aansprakelijkheidsrecht en een systeem van veiligheidsregulering. Bij de kosten van het aansprakelijkheidssysteem kan worden gedacht aan de kosten ten behoeve van het bereiken van een schikking dan wel de kosten van gerechtelijke procedures. De kosten van veiligheidsregulering hangen samen met de publieke uitgaven voor de handhaving en de controle van regelgeving. Daarnasst kunnen de kosten worden genoemd die de private partijen maken ten behoeve van de naleving van de betreffende regelgeving.

Binnen het kader van de administratieve kosten kan een viertal argumenten voor het gebruik van een aansprakelijkheidssysteem worden opgesomd. In de eerste plaats worden bij een dergelijk systeem enkel kosten gemaakt indien zich een schadegeval vordoet. Wanneer daamaast wordt verondersteld dat, afhankelijk van de activiteit die wordt uitgeoefend, een schadegeval zich niet frequent voordoet dan zullen de kosten laag zijn. In de optimale situatie, waarin partijen efficiënte zorg uitoefenen en er derhalve geen schade ontstaat, kunnen de kosten zelfs tot bijna nul dalen.

Een tweede argument voor het gebruik van het aansprakelijkheidsrecht houdt verband met de situatie waarin een recht op schadevergoeding is ontstaan. Bij een op-

1013. Zie S. Shavell, JLS, 1985, p. 587-609.

Fell, en $V_{a n}$ den Bergh, Objectieve aansprakelijkheid, p. 155; Shavell, JLS, 1984, p. 363; Sha-

vell, Accident Law, p. 280-281; Faure, AA, 1990, p. 765 
timaal functioneren van een regel van foutaansprakelijkheid, zal de potentiële scher deveroorzaker efficiënte zorg aanwenden. Het potentiële slachtoffer, dit wetende, zl]
derhalve een schadevergoedingsprocedure achterwege laten. ${ }^{1015}$

In de derde plaats kan worden gesteld dat een groot deel van de aansprekelijkheidsprocedures via een schikking worden opgelost en derhalve niet voor de rechter komen. Hierbij wordt een afweging gemaakt tussen de kosten van een schil. king en de kosten van een gerechtelijke procedure. Wanneer het aantal schikkingen de overhand krijgt, kan een besparing op de administratieve kosten worden be reikt. $^{1016}$

Een vierde en laatste argument voor een toepassing van het aansprakelijkheidsecti hangt samen met het gebruik van risicodifferentiatie. Met het aansprakelijkheidsrecht is een betere selectie mogelijk door bijvoorbeeld de aandacht te corcentreren op de schadeveroorzakers, waarvan wordt vermoed dat zij een hoog risico vormen. Een dergelijke differentiatie kan leiden tot een kostenbesparing, wanneer het mogelijk is om deze potentiële schadeveroorzakers intensief te controleren. ${ }^{107}$

Bij een systeem van ex ante veiligheidsregulering worden administratieve kosten gemaakt, ongeacht of zich een schadegeval voordoet, en ook wanneer de kans op schade gering is. Zelfs wanneer door middel van veiligheidsregulering een succesvolle preventie van de ongevalskosten kan worden bereikt, zijn voor de betreffende wetgeving toch reeds kosten gemaakt. Daarbij komt dat deze kosten in beginsel ove de gehele gemeenschap worden verspreid. De kosten van het aansprakelijkheids recht daarentegen zijn in beginsel slechts van invloed op het gedrag van de directbi een ongeval betrokken partijen.

Ten aanzien van veiligheidsregulering kan verder worden gesteld dat, bij afive zigheid van relevante informatie en gegeven de reeds vooraf ingecalculeerde kosten een risicodifferentiatie weinig zinvol lijkt. Wanneer de benodigde informatie whel aanwezig is, kan de aandacht mogelijk worden verlegd van de gehele risicogroep naar bepaalde individuele risico's. Hiermee kan een besparing op de kosten van handhaving en controle worden bereikt, hetgeen wel afhankelijk is van de mogelijiheid om de overtreder te identificeren en te vervolgen. Om daarbij de effectivitet van de handhaving te kunnen waarborgen, is een minimale intensiteit van de contro le noodzakelijk. Hieraan zijn echter ook kosten verbonden. ${ }^{1018}$

1015. Zie hoofdstuk 5 voor een economische analyse van het aansprakelijkheidsrecht.

1016. Shavell, JLS, 1984, p. 364.

1017. Shavell, Accident Law, p. 282.

1018. Zie hierover Wittman, JLS, 1977, p. 193. 
Uit het voorgaande kan worden geconcludeerd dat de administratieve kosten van een aansprakelijkheidssysteem over het algemeen lager zijn dan van een systeem van veiligheidsregulering. Een belangrijk argument hiervoor is dat het aansprakelijkbeidsrecht pas in actie komt wanneer schade ontstaat, terwijl bij veiligheidsregulering kosten worden gemaakt ongeacht of zich een schadegeval voordoet. ${ }^{1019}$

\subsection{EEN COMBINATIE VAN AANSPRAKELIJKHEID EN VEILIGHEIDSREGULERING}

Naar aanleiding van het voorgaande kan worden geconcludeerd dat in het algemeen geen duidelijke voorkeur voor een ex post aansprakelijkheidssysteem of een ex ante veiligheidsregulering kan worden uitgesproken. Uit de beschrijving van de criteria voor veiligheidsregulering komt naar voren dat de besproken informatieproblemen, met name voor wat betreft de dagelijkse activiteiten, en de administratieve kosten in het algemeen ten voordele van het aansprakelijkheidsrecht strekken. Wanneer sprake is van een insolventierisico, of van de onmogelijkheid om de schadeveroorzaker ansprakelijk te houden, zal veiligheidsregulering in veel gevallen de voorkeur hebben boven het gebruik van het aansprakelijkheidsrecht. Dit geldt ook wanneer de informatiekosten voor de direct betrokken partijen relatief hoog zijn.

D:t betekent dat aansprakelijkheid en veiligheidsregulering, binnen het kader van de besproken criteria, niet strikt gescheiden kunnen worden toegepast bij de controle val het ongevalsrisico. In deze paragraaf zal daarom worden onderzocht op welke wijze een gecombineerd gebruik van aansprakelijkheid en veiligheidsregulering tot ea betere preventie ${ }^{1020}$ van de ongevalsschade kan leiden. In dit kader zal eerst worden nagegaan in hoeverre de naleving van de veiligheidsnorm de dader van zijn aansprakelijkheid bevrijdt. Daarna zal de vraag of overtreding van de veiligheidsnorm automatisch tot aansprakelijkheid van de dader moet leiden aan de orde komen.

\subsection{Naleving van de veiligheidsnorm bevrijdt niet van aansprakelijkheid}

Wanneer de schadeveroorzaker bij naleving van de ex ante veiligheidsstandaard van aansprakelijkheid zou zijn bevrijd, zou hij vermoedelijk niet meer zorg uitoefenen dan door de veiligheidsnorm wordt vereist. Daarbij geldt dat de ex ante veiligheidsstandaard veelal is gebaseerd op niet-optimale informatie ten aanzien van het ongevalsrisico van de schadeveroorzaker. De overheid kan bijvoorbeeld niet inschatten wat de omvang is van de verwachte schade die met de activiteit waarvoor de standard is opgesteld aan derden kan worden toegebracht. Een deel van de potentiële Shavell, Accident Law, p. 282; Shavell, JLS, 1984, p. 363-364; Faure en Van den Bergh, Objec-
tieve aansprakelijkheid, p. 156.

De nadruk ligt bij deze analyse op een reductie van de primaire ongevalskosten. 
een efficiënt zorgniveau uit te oefenen en voor hen is een aanvullende aansprake lijkheidsregel misschien niet nodig. De veiligheidsstandaard is in hun geval geliji aan het optimale zorgniveau $\left(\mathrm{y}^{*}\right)$. Individuen met een hoog ongevalsrisico daarente gen, zullen vermoedelijk meer zorg moeten uitoefenen dan door de veiligheidssen. daard is vereist. Voor hen kan het aansprakelijkheidsrecht noodzakelijk zijn om her juiste niveau van zorg aan te wenden. ${ }^{1021}$

Het voorgaande brengt mee dat enerzijds een minimale veiligheidsnom nood. zakelijk is voor de gevallen waarin de overheid onvoldoende informatie heeft orer het ongevalsrisico. Met behulp van een dergelijke veiligheidsstandaard worden deelnemers aan een risicovolle activiteit aangezet tot een minimaal zorgniveau. Atrderzijds dient bovenop deze veiligheidsnorm het aansprakelijkheidsrecht aanvullend te worden toegepast. ${ }^{1022}$

Wanneer de naleving van de ex ante veiligheidsnorm zou bevrijden van aan. sprakelijkheid, zou de schadeveroorzaker onvoldoende prikkels hebben om meer in zorg te investeren, zelfs indien deze extra zorg kan leiden tot een verdere reductie van de verwachte ongevalskosten. Wanneer sprake is van een minimum veiligheidsstandaard, zal aansprakelijkheid voor een verdere blootstelling aan het risico zorgen waardoor de potentiële schadeveroorzaker een prikkel heeft om alle benodigde zorgmaatregelen te treffen. Daamaast kan aansprakelijkheid van belang zijn voor een vermindering van de invloed van belangengroepen. Indien deze pleiten voor een lage veiligheidsstandaard kan een aanvullend aansprakelijkheidsrecht voorkomen dat te weinig zorg wordt aangewend. Het aansprakelijkheidsrecht kan ten sotte worden gezien als een soort 'stopgap' voor de situaties die niet onder de veiligheids standaard vallen. ${ }^{1023}$ Ten aanzien van dit laatste mag volgens Rose-Ackerman ectice niet teveel macht aan de rechter worden gegeven:

'Courts should not idealize the pattern of common law regulation created by their past adjudications, but should see tort law as a stopgap pending future statutory regulation. If a regulatory statute is then passed, courts should

1021. Shavell, JLS, 1984, 365-366; Faure en Van den Bergh, Objectieve aansprakelijkheid, p. 156-15? Shavell, Accident Law, p. 286.

1022. Volgens Kolstad, Ulen and Johnson, Am. Econ. Rev., 1990, p. 891-892 is een gecombineed \&5 bruik ook noodzakelijk. Wanneer alleen een ex ante veiligheidsstandaard wordt gebruikt leid di volgens hen tot overregulering bij daders met een laag risico respectievelijk tot te weirig prit kels voor daders met een hoog risico.

1023. Faure en Ruegg, in Environmental Standards in the European Union, p. 56; Shavell, JLS, 1984 p. 365; Rose-Ackerman, Rethinking the Progressive Agenda, p. 123; Faure en Van den Bath GPRI, 1987, p. 110. 
resolve conflicts between tort doctrines and regulatory principles by according priority to the statutes'. ${ }^{1024}$

De invoering van een ex ante veiligheidsstandaard kan aan de rechter wel de informatie verschaffen die nodig is voor een beoordeling van de ex post aansprakelijkheid van de schadeveroorzaker. De rechter kan bijvoorbeeld van mening zijn dat naleving van de minimale veiligheidsstandaard onvoldoende is, wanneer door het slachtoffer wordt aangetoond dat in het concrete geval een hogere standaard van toepassing moet zijn. ${ }^{1025}$ Het gebruik van een minimale veiligheidsnorm heeft verder het voordeel dat de rechter alleen behoeft vast te stellen of de betreffende norm is overtreden om aansprakelijkheid te kunnen aannemen. Wanneer de schadeveroorzaker wel heeft voldaan aan de veiligheidsstandaard kan de rechter desondanks van oordeel zijn dat van de schadeveroorzaker extra voorzorgsmaatregelen konden worden geëist. De rechter heeft, wanneer hij de ex ante veiligheidsstandaard niet zelf behoeft vast te stellen, derhalve de mogelijkheid om verder te differentiëren naar risico's. $^{1026}$

\subsubsection{Moet overtreding van de veiligheidsnorm automatisch tot aansprakelijkheid} leiden?

Wanneer de ex ante veiligheidsstandaard gelijk is aan de efficiënte zorg, zal de overtreding van deze veiligheidsnorm tot aansprakelijkheid moeten leiden om aan de veroorzaker een prikkel van zorg te geven. Shavell stelt echter dat de kosten van naleving van de veiligheidsstandaard niet voor elk individu gelijk zijn. Daarbij kan het voor sommige potentiële daders zelfs inefficiënt zijn om de veiligheidsstandaard te volgen. De vraag is of deze personen automatisch aansprakelijk zijn wanneer zij de standaard overtreden. ${ }^{1027}$

In dat kader kan een vergelijking worden gemaakt met de 'bonus pater familias', de gemiddelde zorgvuldigheidsnorm in het aansprakelijkheidsrecht. ${ }^{1028} \mathrm{Bij}$ de economische analyse van het aansprakelijkheidsrecht is gebleken dat een volledig geïndividualiseerde zorgvuldigheidsnorm, hoewel een optimale oplossing, vanuit kostenoogpunt veelal niet mogelijk is. Hetzelfde kan gelden voor een geïndividualiseerde

\footnotetext{
1024. Rose-Ackerman, Rethinking the Progressive Agenda, p. 123; Rose-Ackerman, Am. Econ. Rev., Papers and Proceedings, 1991, p. 55

1025. Rose-Ackerman, Rethinking the Progressive Agenda, p. 124; Rose-Ackerman, Am. Econ. Rev. Papers and Proceedings, 1991, p. 55; Faure en Ruegg, in Environmental Standards in the Euro-

pean Union, p. 55.

Faure, Rechtseconomische kanttekeningen bij de deregulering van de arbeidsomstandigheden-

1027. Shavell, JLS, Sociaal Recht, 1995, p. 144; Posner, Economic Analysis, p. 168

1028. Zie daarover 1984, p. 365-366; Faure en Van den Bergh, GPRJ, 1987, p. 109-1 10.

10 van hoofdstuk 5 . Accident Law, p. 74; Posner, Economic Analysis, p. 167-168 en paragraaf
} 
ex ante veiligheidsstandaard. Wanneer bepaalde schadeveroorzakers tegen lage los. ten kunnen worden geïdentificeerd is een differentiatie mogelijk, zolang de opbreng. sten daarvan lager zijn dan de administratieve kosten van een verdere individualise. ring. De wetgever zal echter niet in staat zijn om een volledige differentiatie toe te passen, met het gevolg dat een gemiddelde veiligheidsstandaard zal worden $g e^{\circ}$ bruikt. $^{1029}$

Een gemiddelde veiligheidsstandaard kan echter voor bepaalde schadeveroorakers te hoog liggen, waardoor zij hoge kosten moeten maken om deze standaard te hur nen volgen. Door middel van een handhaving van een dergelijke veiligheidssar daard kan een individu, die niet aan deze standaard kan of wil voldoen, echter nof: den aangezet tot een activiteitswijziging. Voor de rechter geldt daamaast dat het vanuit administratief kostenoogpunt niet efficiënt is om in elk individueel gevalte beoordelen of de veiligheidsstandaard wel kon worden nageleefd. ${ }^{1030}$

Een van de argumenten om te kiezen voor ex ante veiligheidsregulering is dat de wetgever ten aanzien van sommige ongevalsrisico's over betere informatie beschilit om een efficiënte veiligheidsstandaard vast te stellen dan de direct betrokken partj. en. De wetgever kan deze informatie vervolgens beschikbaar stellen aan de privte partijen of de rechter, die het gedrag van de schadeveroorzaker ex post moet contoleren. Dit betekent dat de rechter reeds tot aansprakelijkheid kan besluiten zotra sprake is van een overtreding van de veiligheidsstandaard. ${ }^{1031}$ Veiligheidsregulering kan derhalve worden toegepast ten behoeve van een bepaling van de foutaansprakelijkheid. ${ }^{1032}$

\subsubsection{Een gecombineerd gebruik toegepast op het onderscheid in aansprakelijkheidsregels}

Hiervoor is betoogd dat een combinatie van aansprakelijkheid en veiligheidsto gulering wenselijk en soms zelfs noodzakelijk is om een optimale preventie van hat ongevalsrisico te kunnen bereiken. In deze subparagraaf zal dit gecombineerd ge bruik verder worden verfijnd naar het onderscheid tussen risicoaansprakelijkheid ta foutaansprakelijkheid.

1029. Faure en Ruegg, in Environmental Standards in the European Union, p. 54.

1030. Zie Posner, Economic Analysis, p. 167-168 en Shavell, Accident Law, p. 73-77, in het kade ve de 'reasonable man standard' binnen het aansprakelijkheidsrecht.

1031. Dit uitgangspunt wordt op een groot aantal rechtsterreinen, onder andere milieuaanspprateil. heid, gehanteerd. Zie C.C. van Dam, Zorgvuldigheidsnorm en aansprakelijkheid, p. 74-81; Fut en Ruegg, in Environmental Standards in the European Union, p. 54-55.

1032. Rose-Ackerman, Rethinking the Progressive Agenda, p. 127; Faure en Van den Bergh, GPR 1987, p. 110-111; Rose-Ackerman, Am. Econ. Rev., Papers and Proceedings, 1991, p. 56-57. 
Bij de anwezigheid van zowel een regel van foutaansprakelijkheid als een ex ante veiligheidsstandaard, bestaat de kans dat de dader tweemaal door de rechter wordt veroordeeld, namelijk via een strafrechtelijke sanctie en een betaling van schadevergoeding aan het slachtoffer. Dit is echter niet efficiënt, omdat de dader meer zal moeten betalen dan de maatschappelijke kosten van overtreding van de veiligheidsstandaard. De dader kan een dergelijke situatie vermijden door de naleving van de veiligheidsstandaard, mits deze standaard optimaal is vastgesteld. Hierdoor kan de rechter deze standaard op de juiste wijze gebruiken voor de bepaling van de foutaansprakelijkheid. Daarnaast kan de rechter onderzoeken of van de dader additionele veiligheidsmaatregelen, toegepast op de concrete ongevalssituatie, kunnen worden geêist. $^{1033}$

Bij een regel van risicoaansprakelijkheid dient de dader de totale ongevalskosten te dragen, waarbij de rechter slechts het verband tussen ongeval en schade behoeft vast te stellen. In combinatie met een ex ante veiligheidsregulering zal, mits de schadevergoedingsplicht van de dader gelijk is aan de veroorzaakte schade, een regel van risicoaansprakelijkheid een optimale schadevergoeding aan het slachtoffer waarborgen. De kans op een (risico)aansprakelijkheidsstelling zal daarnaast aan de dader een extra prikkel geven om de ex ante veiligheidsnorm te volgen. ${ }^{1034}$

Voor een antwoord op de vraag welke combinatie van veiligheidsregulering en aansprakelijkheid tot een optimale preventie van het ongevalsrisico leidt, is met name het eerder besproken insolventierisico bij de schadeveroorzaker van belang. ${ }^{1035}$ Wanneer een ex ante veiligheidsstandaard wordt opgelegd, kan de dader, die over onvoldoende vermogen beschikt om de schade te vergoeden, worden aangezet tot efficiënte zorg. ${ }^{1036}$

Bij een combinatie van een regel van risicoaansprakelijkheid en een ex ante veiligheidsstandaard kunnen echter insolventieproblemen ontstaan die weer kunnen leiden tot inefficiënties op het terrein van de preventie. Een mogelijke remedie tegen deze 'underdeterrence', is de invoering van een verplichte verzekering, waarmee in ieder geval de vergoeding aan het slachtoffer is gewaarborgd. Hieraan is echter de voorwaarde verbonden dat de aansprakelijkheidsverzekeraar het gedrag van de insolvabele schadeveroorzaker optimaal kan controleren. ${ }^{1037}$ Een nadeel van een combinatie van risicoaansprakelijkheid en een verplichte verzekering, is dat hiermee de ex ante reiligheidsregulering mogelijk buitenspel wordt gezet. Daarnaast zal een combinatie

\footnotetext{
1033. Faure, Sociaal recht, 1995, p. 144.

1034. Rose-Ackerman, Am. Econ. Rev., Papers and Proceedings, 1991, p. 56; Rose-Ackerman, Rethinking the Progressive Agenda, p. 125-126.

1035. Zie paragraaf 3.1.2 van dit hoofdstuk.

1036. Shavell, Accident Law, p. 286.

1037. Zie paragraaf 5.1 aw, p. 286.
} 
van veiligheidsregulering, risicoaansprakelijkheid en een verplichte verzekering tot hoge administratieve kosten kunnen leiden. ${ }^{1038}$

Bij een regel van foutaansprakelijkheid zal de schadeveroorzaker zorg blijven aap. wenden zolang de kosten daarvan zijn vermogen niet overstijgen. Dit betekent dat bij deze regel het insolventierisico lager zal zijn dan bij een regel van risicoaansprakelijkheid. ${ }^{1039}$ Daarnaast kan nog een viertal andere argumenten worden genoemd voor het gezamenlijk gebruik van foutaansprakelijkheid en een ex ante vejligheidsregulering.

In de eerste plaats kan een vooraf vastgestelde ex ante veiligheidsstandaard door de overheid aan de rechter ter beschikking worden gesteld. Hiermee krijgt de rechter reeds een zorgvuldigheidsnorm aangereikt, waarmee de eventuele foutaansprakelijk. heid eenvoudig kan worden bepaald. Daarbij kunnen mogelijke vergissingen worden beperkt.

In de tweede plaats kan een regel van foutaansprakelijkheid, gegeven de problemen bij de handhaving van de veiligheidsstandaard, een betere ondersteuning geven aan veiligheidsregulering dan een regel van risicoaansprakelijkheid.

In de derde plaats kan een dergelijk systeem aan het slachtoffer een prikkel geven om een schadevergoedingsprocedure aan te spannen. Het slachtoffer kan darbij met een bewijs van overtreding van de veiligheidsstandaard volstaan om de schadeveroorzaker aansprakelijk te houden. ${ }^{1040}$

In de vierde plaats tenslotte, kan de toepassing van een ex ante veiligheidsstandard naast een foutaansprakelijkheid bepaalde informatieproblemen bij de schadeveroorzaker omtrent de juridische zorgvuldigheidsnorm wegnemen. Daarbij is, voor het bereiken van efficiëntie, vereist dat de ex ante veiligheidsstandaard lager wordt vastgesteld dan de efficiënte zorg. Daarmee kan worden voorkomen dat de schadeveroorzaker steeds aan aansprakelijkheid ontsnapt wanneer hij de veiligheidsstandard heeft nageleefd. ${ }^{1041}$

1038. Faure en Van den Bergh, Objectieve aansprakelijkheid, p. 157; Faure en Van den Bergh, GPR, 1987, p. 109-111.

1039. Zie paragraaf 3.1 .2 van dit hoofdstuk.

1040. Faure en Van den Bergh, GRPI, 1987, p. 110-111; Faure en Van den Bergh, Objectieve aanspntkelijkheid, p. 158.

1041. Zie Kolstad, Ulen and Johnson, Am. Econ. Rev., 1990, p. 889 en 898-899. Zij hanteren overigens enkel de onzekerheid omtrent de foutstandaard als argument voor een gecombineerd go bruik van een ex ante veiligheidsstandaard en een regel van foutaansprakelijkheid. Daarbij vet. onderstellen zij dat ex ante regulering alleen moet worden gebruikt indien de kans voor de dada om aansprakelijk te worden gesteld nihil is. 

33. AANSPRAKELIJKHEID EN VEILIGHEIDSREGULERING TOEGEPAST OP HET
VERKEERSONGEVALLENRECHT

Ten aanzien van het verkeersongevallenrecht is eerder gesteld dat een potentiële dader en een potentieel slachtoffer vreemden zijn voor elkaar. Dit betekent dat zij, vanwege de hoge transactiekosten, niet vooraf kunnen onderhandelen over een evenwele schadevergoeding wanneer zich een verkeersongeval voordoet. ${ }^{1042}$ Hieruit volgt dat het recht moet tussenkomen om een verkeersdeelnemer aan te zetten tot efficiênte zorg. In hoofdstuk 5 is daartoe een eerste stap gezet door middel van een economische analyse van het aansprakelijkheidsrecht. Daarin is geconcludeerd dat ansprakelijkheidsregels, in theorie, een preventief effect kunnen hebben op het gedrag van verkeersdeelnemers. Daarbij is echter de ex ante veiligheidsregulering buiten beschouwing gelaten.

In deze paragraaf zal de vergelijking tussen aansprakelijkheid en veiligheidsregulering worden getoetst aan het verkeersongevallenrecht. Daarbij zal de vraag central staan of het ongevalsrisico in het verkeer moet worden geregeld door middel van een ex post aansprakelijkheid, een ex ante veiligheidsregulering of door een combinatie van beide instrumenten. Aan de hand van de criteria voor veiligheidsregulering zal allereerst worden bekeken welke theoretische voor- en nadelen het aansprakelijkheidsrecht heeft voor de preventie van verkeersongevallen (paragraaf 33.1). Vervolgens zal worden nagegaan welke argumenten pleiten voor een veiligheidsregulering in het verkeer (paragraaf 3.3.2). In paragraaf 3.3.3 ten slotte, zal worden onderzocht of, naar aanleiding van de voorafgaande analyse, een gecombineerd gebruik van aansprakelijkheid en veiligheidsregulering in het verkeer meer wenselijk is.

\subsection{De preventie via aansprakelijkheidsregels in het verkeer}

De vraag in hoeverre aansprakelijkheidsregels preventief kunnen werken in het verkeer zal worden beantwoord aan de hand van Shavell's criteria voor veiligheidsregulering. Deze criteria hebben respectievelijk betrekking op de informatiekosten, insolventie, de (on)mogelijkheid om de dader aansprakelijk te stellen en de admini-

Ten aanzien van de informatiekosten is eerder gesteld dat de direct betrokken partijen voor wat betreft de uitoefening van de meer dagelijkse activiteiten in het alge-

\footnotetext{
1042. Zie Coase, JLE, 1960, p. 1-44; Demsetz, JLS, 1972, p. 13; Wittman, JLS, 1977, p. 204-206; CaCoasc-theorem, 1975, p. 657-659. Zie ook paragraaf 4 van hoofdstuk 4 voor een analyse van het 1043. Zie patheorema. Zie paragraaf 3.1 van dit hoofdstuk voor een theoretische analyse van deze criteria.
} 
meen beter zijn geïnformeerd dan de overheid. ${ }^{1044}$ Veel verkeerssituaties behoren to de dagelijkse activiteiten, zodat zou kunnen worden gesteld dat de verkeersdeehe. mers zelf een betere kosten-baten analyse ten aanzien van het ongevalsrisico kumen maken dan de wetgever. Een autobestuurder kan bijvoorbeeld door middel van het uitoefenen van zorg een verkeersongeval vermijden.

De vraag is echter of een autobestuurder voldoende informatie heeft om alle factoren van zorg te controleren. Zaken die verband houden met de technische staat van de auto, zoals de remmen en de banden, kunnen door de bestuurder worden gecontroleerd, bijvoorbeeld via een regelmatige check-up in de garage. Dit geldt echter in mindere mate voor de omvang van de verwachte schade, die niet vooraf bij de autobestuurder bekend is. Daarbij kan ten aanzien van het rijgedrag van de autobestur. der sprake zijn van een onderschatting van het ongevalsrisico, waardoor deze zich vergist in de efficiënte zorgstandaard en mogelijk een te laag zorgniveau zal aarwenden. Hieruit vloeit voort dat een ex ante veiligheidsregulering nodig kan zijn om bepaalde informatietekorten te corrigeren.

Ten aanzien van bijvoorbeeld de snelheid waarmee wordt gereden en de veiligheid van derden, geldt ook dat de autobestuurder niet altijd de juiste beslissingen zal hurnen nemen. Daarvoor is hij aftankelijk van bepaalde externe factoren. Hierbij kan worden gedacht aan de situatie waarin de autobestuurder zich met zijn voertuig door een woonwijk verplaatst. In de relatie tussen de te nemen voorzorgsmaatregelen en de kans op schade heeft de autobestuurder vermoedelijk geen volledige informatie over bijvoorbeeld de samenstelling van de bevolking in de wijk, veel kinderen, of over eventuele verkeersrisico's, spelende kinderen. Dit betekent dat de autobestur der zijn snelheid niet optimaal kan aanpassen. Hierin zou een pleidooi kunnen liggen voor ex ante veiligheidsregulering, bijvoorbeeld door het plaatsen van verkeersborden of het aanleggen van verkeersdrempels.

Met betrekking tot het insolventierisico kan worden gesteld dat binnen het kader van het aansprakelijkheidsrecht de kans dat een autobestuurder de schade van bijvoorbeeld de fietser niet kan vergoeden aanwezig is. Voor zaakschade zal mogelijkenvijs kunnen gelden dat deze door de autobestuurder uit de eigen portemonnee kan worden betaald. Bij letselschade zal de autobestuurder, in de veronderstelling dat geen verzekeringsdekking voorhanden is, met een insolventieprobleem kunnen wordes geconfronteerd. Dit probleem kan zich in versterkte mate voordoen, wanneer blijk dat de fietser zwaar lichamelijk letsel, bijvoorbeeld een dwarslaesie, aan het ongerel heeft overgehouden. 
Met betrekking tot de vraag of de schade bij een verkeersongeval op de veroorzaker daarvan kan worden verhaald, kan worden gesteld dat een aansprakelijkheid voordelen biedt ten opzichte van veiligheidsregulering. De veroorzaker van de schade die aan de fietser wordt toegebracht is in veel gevallen eenvoudig te achterhalen. Daarbij is de geleden schade vaak direct zichtbaar en zijn er vermoedelijk geen grote causaliteitsproblemen. ${ }^{1045}$

In het kader van de administratieve kosten kan het gebruik van het aansprakelijheidsrecht eveneens voordeliger zijn dan een ex ante veiligheidsregulering. $\mathrm{Bij}$ het aansprakelijkheidsrecht worden immers alleen maar administratieve kosten gemaakt wanneer zich een verkeersongeval voordoet en als gevolg daarvan een aansprakelijkheidsvordering wordt ingesteld. ${ }^{1046}$

Samenvattend kan worden gesteld dat het aansprakelijkheidsrecht binnen de bovenbeschreven omstandigheden effectief kan werken. De direct bij een verkeersongeval betrokken partijen beschikken in veel, niet alle gevallen, over bepaalde controleerbare risico-informatie. Zij kunnen de waarde van hun verkeersdeelname tot op zekere hoogte goed inschatten en in bepaalde concrete verkeerssituaties zijn zij mogelijk beter in staat dan de wetgever om te bepalen hoe zij op gewijzigde omstandigheden moten anticiperen. ${ }^{1047}$

\subsection{De werking van ex ante veiligheidsregulering in het verkeer}

\subsection{De preventieve werking van ex ante veiligheidsregulering}

Binnen de voorgaande analyse is gebleken dat zich situaties kunnen voordoen, waarin $\mathrm{ex}$ ante veiligheidsregulering een betere preventie van verkeersongevallen kan warthorgen dan het ansprakelijkheidsrecht. Dit gegeven zal in deze subparagraaf worden uitgewerkt aan de hand van de vraag in hoeverre een veiligheidsregulering in het verkeer preventief kan werken.

In de eerste plaats kan worden gewezen op de beperkte invloed van het aansprakelijkheidsrecht op het verkeersgedrag. Aansprakelijkheid is namelijk enkel van toepassing wanneer zich een verkeersongeval heeft voorgedaan. Dit kan een argument

\footnotetext{
1045. Kolstad, Ulen and Johnston, Am. Econ. Rev., 1990, p. 894, stellen dat met betrekking tot verDaamaast kan de schig onzekerheid bestaat over de zorgvuldigheidsnorm bij aansprakelijkheid. sten van zorg bekend wordente redelijk goed worden ingeschat, mogen de kosten en opbrengdentie. Zie ook Shavell Acciden verondersteld en is er sprake van een grote hoeveelheid jurispruZie paragraai 3.4 ell, Accident Law, p. 283.

1047. Zie Sharaif 3.1,4 van dit hoofdstuk.

Zie Shavell, JLS, 1984, p. 366, voor een toetsing van de criteria voor veiligheidsregulering op

sing tussen twee voetgangers.
} 
zijn voor de invoering van veiligheidsregulering, omdat dit instrument wordt toege. past los van een mogelijk verkeersongeval.

Ten aanzien van het informatiecriterium kan in zijn algemeenheid worden betoogd dat het verkeersproces weliswaar complex is, maar dat de risico's ervan door de overheid relatief goed kunnen worden ingeschat in vergelijking met andere risicadragende activiteiten. Veel verkeersongevallen zijn vaak gewone botsingen, на2аr. van de schade redelijk voorspelbaar is en onder andere afhankelijk van snelheid, remmen, banden, lichten en andere autokenmerken en persoonskenmerken. Deze factoren kunnen relatief eenvoudig worden vastgelegd door middel van snelheidsegulering, veiligheidscontroles, rijbewijs en beperkingen op dronken rijden. ${ }^{1048}$ Hiern ligt derhalve een tweede argument voor een ex ante veiligheidsregulering besloten.

Hoewel de wetgever geen volledige informatie heeft omtrent het concrete risico op een verkeersongeval, kan de overheid dit risico met behulp van ex ante veiligheits. maatregelen mogelijk toch beïnvloeden. De overheid zal hiertoe, vanuit een 'pubiic interest' perspectief, overgaan omdat zij met betrekking tot bepaalde veiligheidsas pecten betere informatie bezit dan de direct betrokken verkeersdeelnemers. In devrige subparagraaf is het voorbeeld gegeven van een autobestuurder die, met zijn voertuig rijdend door een woonwijk, ten gevolge van een tekort aan informatie niet de juiste beslissingen kan nemen ten aanzien van bepaalde risico's. De overheid kn de bestuurder daarbij te hulp komen door bijvoorbeeld verkeersborden te plaatisen die de bestuurder waarschuwen voor spelende kinderen. Daarnaast kan worden ge dacht aan andere veiligheidsstandaarden, zoals het hanteren van een maximum snelheid, waarvan het effect wordt versterkt door middel van verkeersborden, een verbod op het gebruik van alcohol voordat aan het verkeer wordt deelgenomen, het dragen van een autogordel, verplichte autokeuringen (APK) en bijvoorbeeld het ge bruik van verlichting voor de fietser. Verder kan worden gewezen op regels die velligheid van de auto bevorderen, zoals goede remmen en banden. ${ }^{1049}$

\subsubsection{De handhaving en controle van ex ante veiligheidsregulering}

Naar aanleiding van de genoemde instrumenten van veiligheidsregulering, waarmet de overheid poogt de verkeersveiligheid te bevorderen, rijst de vraag in hoeverre deze maatregelen ook daadwerkelijk tot preventie van verkeersongevallen kunnen let. den. Het gaat hierbij dan met name om de handhaving en controle van ex anteverligheidsregulering.

1048. Skogh, IRLE, 1982, p. 75-76. Zie ook Skogh, in Essays in Law and Economics, p. 96-97.

1049. Zie Burrows, IRLE, 1995, p. 500-501. 
De overheid kan ten behoeve van de controle van de verkeersveiligheid in de eerste plaas gebruik maken van financiële sancties. Voor het bereiken van een optimaal effect van dergelijke sancties op het gedrag van verkeersdeelnemers en op de ongevalskosten heeft de overheid echter informatie nodig. Een intensieve controle van
het verkeersgedrag kan immers zeer kostbaar zijn, waarbij het ook van belang is da de pakkans voor de overtreder van de veiligheidsnorm hoog genoeg moet zijn. neer darbij de kosten van controle de baten overtreffen, zal dit tot gevolg hebben dat de handhaving van de verkeersregulering met de daaraan verbonden financiële sancties, niet efficiënt genoeg is. ${ }^{1050}$

De overheid kan echter de kosten van controle reduceren door gebruik te maken van etn differentiatie van controle naar het belang van de voorzorgsmaatregelen die motten worden genomen en naar de vereisten van de concrete situatie. In dat kader moet het bijvoorbeeld mogelijk zijn om op een lange bochtige weg met maximumsnelheden te variëren, met de intensiteit van de snelheidscontroles en met de hoogte van de boetes. Ten aanzien van financiële sancties geldt dat schade wordt toegebracht aan de overtreder van de veiligheidsnorm. Een dergelijke sanctie wordt gezien als een transactie, die geen negatieve herverdelingseffecten heeft, zolang zij, in verhouding tot het inkomen van de overtreder, laag wordt gehouden. ${ }^{1051}$

Er kunnen zich echter omstandigheden voordoen waarin financiële sancties onvoldoende effect hebben, bijvoorbeeld omdat de boete niet afdwingbaar is vanwege de insolventie van de overtreder. Daarnaast zullen financiële sancties, wanneer deze relatief laag worden gehouden, ten aanzien van bijvoorbeeld roekeloze chauffeurs of

1050. Shavell, JLS, 1984, p. 368; Shavell, Accident Law, p. 284; Skogh, in Essays in Law and Economics, p. 97.

105i. Skogh, IRLE, 1982, p. 74. Hij verwijst naar het Zweedse systeem, waarin voor roekeloze chauffeurs de boete kan worden verhoogd met een inkomensafhankelijke toeslag. In Duitsland geldt in de eerste plaats een strafrechtelijk boetesystcem. Deze is gebaseerd op het zogenaamde dagboetestelsel, 'Tagessatzsysteem', waarbij de geldstraf enerzijds wordt toegemeten aan de schuld en de emst van het misdrijf en anderzijds aan de economische toestand van de veroordeelde (paragraaf 40 van het Duitse Strafgesetzbuch). Een systeem dat ook relevant kan zijn voor bijvoorbeeld het veroorzaken van een dodelijk verkeersongeval, waarbij sprake was van alcoholgebruik. Een tweede boetesysteem heef betrekking op andere (verkeers-) overtredingen (zgn. 'Ordnungssidrigkeiten', paragraaf 17 van het Ordnungswidrigkeitengesetz). Hierbij geldt geen dagboetestelsel, maar wordt bij de bepaling van de boete ('Geldbusse') wel rekening gehouden met bepaalde economische factoren. Zie over het Duitse systeem onder anderen: Göhler, OrdnungsWidrigkeitengesetz, p. 103-120; Wijffels, Inkomensderving als geldstraf, p. 91-93; Jescheck und Weigend, Lehrbuch des Strafrechts, p. 56-60 en 770-774. Wittman, JLS, 1977, p. 207-209, stelt namelijk het betalen van een laag niveau is in vergelijking met de mogelijke ex post sanctie, tion, p. 75-86, analyseert de vevergoeding naar aanleiding van een ongeval; Polinsky, Introductredingen; Rasmusen, IRLE verhouding tussen controle en sanctie in het kader van parkeeroversuncties en de omvang van 1995, p. 101-108, onderzoekt de verhouding tussen strafrechtelijke 
notoire alcoholisten vaak niet het gewenste preventieve effect hebben. Dit zou a ders kunnen zijn wanneer bijvoorbeeld bovenop de standaard opgelegde boete aan roekeloze automobilisten, afhankelijk van hun inkomen, hogere boetes worden op gelegd die variëren met emst van de overtreding. ${ }^{1052}$ In de economische literaturn worden naast het opleggen van boetes alternatieve sancties genoemd, namelijk ten gevangenisstraf en andere vrijheidsbeperkende maatregelen, zoals het innemen van het rijbewijs. Het nadeel van een gevangenisstraf is dat bij het opleggen daarvan de maatschappij een groot deel van de kosten, waaronder het beheer van de gevangenissen, dient te dragen. Dit betekent dat een gevangenisstraf hogere maatschappelij. ke kosten meebrengt dan een financiële sanctie. ${ }^{1053}$

\subsubsection{Een combinatie van aansprakelijkheid en veiligheidsregulering in het verkeer}

In het voorgaande is vanuit preventief oogpunt een aantal voor- en nadelen van een het aansprakelijkheidsrecht respectievelijk de veiligheidsregulering opgesomd. Daaruit kan worden opgemaakt dat een keuze voor ofwel aansprakelijkheid ofuel veiligheidsregulering niet tot een optimale preventie van verkeersongevallen zal leiden. Bij de genoemde opsomming is vast komen te staan dat veiligheidsregulering een goede aanvulling is op het aansprakelijkheidsrecht en omgekeerd. Ten aanzien van dit laatste kan, in aanvulling op hetgeen in de vorige subparagraaf is opgemerk aangaande de handhaving van veiligheidsregulering, worden gesteld dat voor een effectieve veiligheidsregulering de pakkans voor de overtreder van de veiligheidsnom hoog genoeg moet zijn. Ten behoeve van een pakkans van bijvoorbeeld $100 \%$ is echter een intensieve controle noodzakelijk waarvan de kosten vermoedelijk niet opwegen tegen de baten. ${ }^{1054}$ Wanneer wordt uitgegaan van een lage pakkans bij verkeersovertredingen dient derhalve aan het aansprakelijkheidsrecht een aanvullende rol te worden toebedeeld. In deze subparagraaf zal daarom de veronderstelling dat een gecombineerd gebruik van aansprakelijkheid en veiligheidsregulering ten behoeve van een optimale preventie wenselijk lijkt verder worden uitgewerkt.

In de eerste plaats kan worden gesteld dat verkeersdeelnemers, als direct betrok. kenen, betere informatie hebben ten aanzien van het risico op een verkeersongeval. Veiligheidsregulering, afhankelijk van de handhaving en controle, is daamaast nodig

1052. Skogh, IRLE, 1982, p. 74, met een verwijzing naar het Zweedse systeem; Polinsky and Shvelh Am. Econ. Rev., 1991, p. 621. Zie ook Polinsky and Shavell, IRLE, 1998, p. 305-324, voor tht onderzoek naar de preventieve werking van sancties, indien rekening wordt gehouden met het strafrechtelijk verleden van de overtreder.

1053. Shavell, Accident Law, p. 279. Zie ook Becker, JPE, 1968, p. 169-217; Shavell, CoLR, 1985, P 1232-1262; Shavell, JPE, 1991, p. 1088-1108; Posner, CoLR, 1985, p. 1193-1231; Schwath Texas Law Review, 1997, p. 1811-1815; Levitt, IRLE, 1997, p. 179-192.

1054. Zie daarover Skogh, IRLE, 1982, p. 70; Cramton, Michigan Law Review, 1969, p. $432-435$. 
om deze informatie verder te optimaliseren. Daarbij is gewezen op het voorbeeld van de autobestuurder die niet alle mogelijke risico's overziet wanneer hij door een voor hem vreemde woonwijk rijdt. Dit voorbeeld past ook in het kader van verkersaspecten die moeilijk door de markt zelf kunnen worden geregeld, en waarvoor derhalve bepaalde vormen van veiligheidsregulering nodig zijn.

In de tweede plaats kan veiligheidsregulering, naast een ex ante controle, ook gebrikt worden voor een ex post uitkomst, bijvoorbeeld bij de bepaling van de aansprakelijkheid naar aanleiding van een verkeersongeval. Wanneer de schadeveroorzaker een bepaalde veiligheidsstandaard niet heeft nageleefd, bijvoorbeeld de maximumsnelheid, kan deze standaard door de rechter worden gebruikt voor de bepaling van de aansprakelijkheid. De rechter verkrijgt derhalve een informatievoordel, waardoor hij met zijn voertuig in beginsel geen kosten-baten analyse behoeft te maken met betrekking tot het concrete geval. ${ }^{1056}$

Er zijn echter factoren die noch door een ex post aansprakelijkheid, noch door een ex ante veiligheidsregulering of een combinatie van beide instrumenten kunnen worden gecontroleerd. Voor bijvoorbeeld een individuele verkeersdeelnemer is een verkersongeval een gebeurtenis die zich vrij zelden voordoet. ${ }^{1057}$ Dit betekent enerzijds dat een autobestuurder naarmate zijn activiteitsniveau toeneemt de kans op een ongeval lager zal inschatten, anderzijds is in het algemeen sprake van een onderschatting van de verkeersrisico's, waardoor een verkeersdeelnemer een te laag niveal van zorg zal aanwenden. Daarnaast kan in het verkeer sprake zijn van situaties, warin de automobilist of de fietser niet bij de les is, last heeft van dagdromerijen en bij wie de reflexen niet scherp zijn. Dergelijke gedragingen kunnen veelal niet door het aansprakelijkheidsrecht noch door veiligheidsregulering worden gecontroleerd. Dit leidt tot de conclusie dat, ondanks de voordelen van een combinatie van aansprakelijkheid en veiligheidsregulering, een gecombineerd gebruik van een ex post respectievelijk ex ante controle van het verkeersgedrag niet onder alle omstandigheden tot een optimale uitkomst zal leiden. ${ }^{1058}$

\footnotetext{
1055. Bumous, IRLE, 1995, p. 500.
1056. Rose-Ackerman, Rethinking the Progressive Agenda, p. 127; Faure en Ruegg, in Environmental
Standards in the European Union, Standards in the European Union, p. 55; Wittman, JLS, 1977, p. 208.

derzock waaruit Trebilcock, Exploring the Domain of Accident Law, p. 20, verwijzen naar onbotsing eens in de 61 dat de kans op een bijna ongeluk zich eens in de 500 mijl voordoet, een dodelijk verkeersongeval eenl, een ongeval met persoonlijk letsel eens in de 430.000 mijl en een view, 1969, p. 431-432, die stelt dat een ongeval met leten. Zie ook Cramton, Michigan Law Reen een dodelijk ongeval eens in de 18 miljoenal met letsel zich eens in de 225.000 mijl voordoet Wittman, JLS, 1977, p. 200 , hanteert als uitgangsumilen.

bonden sancties. Hij komt hanteert als uitgangspunt de ex-ante regulering met de daaraan ver-
} 


\section{Alternatieve economische theorieën van overheidsregulering}

In het kader van de economische welvaartstheorie is onderzocht op welke wijze overheid bepaalde marktfalingen door regulering kan corrigeren. Deze welvaarts. theorie is vervolgens uitgewerkt naar de economische theorie van veiligheidsreglu. ring, waarbij de verhouding tussen aansprakelijkheid en veiligheidsregulering is on derzocht. In dit kader is onder andere geconcludeerd dat, onder omstandigheden ter gezamenlijk gebruik van aansprakelijkheid en veiligheidsregulering wenselijk is om een optimale preventie van verkeersongevallen te bereiken.

Bij de invoering van (veiligheids)regulering spelen echter, naast het algemeen be. lang, de informatie- en administratieve kosten, ook bepaalde belangengroepen een rol. Deze belangengroepen trachten hun invloed aan te wenden om voor hen voor. delige wetgeving tot stand te brengen. Dit brengt mee dat de uiteindelijke uithons van het wetgevingsproces anders kan zijn dan in eerste instantie werd beoogd.

In deze paragraaf zal de 'private interest' theorie van overheidsregulering aan de orde komen. Binnen deze theorie wordt door de literatuur een verder onderscheid go maakt tussen de 'capture'-theorie, de economische reguleringstheorie en de 'public choice'-theorie. ${ }^{1059}$ Deze drie subtheorieën hebben gemeen dat zij een verkaring kunnen geven voor het feit dat sommige vormen van regulering enkel ten goede kamen aan bepaalde belangengroepen. ${ }^{1060}$

De 'capture' theorie gaat een stap verder dan de economische welvaartstheorie doon te stellen dat een correctie van marktfalingen gewenst kan zijn. De wetgever stat daarbij echter onder invloed van de industrie als belangengroep, die zij juist dout middel van regulering dient te controleren. Overheidsfunctionarissen handelen rationeel in hun relatie tot de industrie, die voor wat betreft de wetgeving en het ver schaffen van informatie de macht in handen heeft. De wetgeving die uiteindelijt to stand komt is dan ook vooral in het belang van de industrie zelf..$^{1061}$

een gebrek aan reflexen ertoe leiden dat een ex-ante controle niet ideaal is. Zie ook Cnrm Michigan Law Review, 1969, p. 432; Ogus, Regulation, p. 51-53; Latin, CaLR, 1985, 682-688.

1059. Zie over deze theorieèn onder anderen: Faure en Van den Bergh, Objectieve aansprakelijted p. 147-152; Utton, The Economics of Regulating Industry, p. 13-14 en 20-28; Ogus, Regubion, p. 57-75; Posner, BJE, 1974, p. 335-358; Stigler, BJE, 1971, p. 3-21; Peltzman, JLE, 1976, P $211-240$. 1060. Zie De Bijl en Van Damme, Regulering en zelfregulering in markten met kwaliteitsonzeketioli
1997, p. 17 .

1061. Zie over deze theorie: Ogus, Regulation, p. 57-58; Utton, The Economics of Regulating indust? p. 13-14 en p. 22-27; Faure en Van den Bergh, Objectieve aansprakelijkheid, p. 148; Passer. BJE, 1974, p. 341-343; Bowles, Law and the Economy, p. 176; Wilson, Joumal of Political Swdies, 1984, p. 204 en 210-211. 
In de economische reguleringstheorie, die voortbouwt op de 'capture' theorie, wordt een markt van vraag en aanbod op het gebied van regulering verondersteld. De overheid wordt als aanbieder van wetgeving beschouwd ten behoeve van de vragers, de belangengroepen, die meer voordelen zien in regulering vanwege de overheid dan in zelfregulering via de markt. In tegenstelling tot de 'capture' theorie gaat bij deze theorie het initiatief veelal uit van de industrie. Met betrekking tot de werking van de economische reguleringstheorie worden een aantal matregelen genoemd die ten voordele van de industrie kunnen werken, zoals subsidies, ${ }^{1062}$ de controle van de prijzen en een beperking van de toetreding tot de markt door middel van tariefbarrières, vestigingswetgeving en regelgeving via licenties. ${ }^{1063}$

In het vervolg van deze paragraaf zal, binnen het kader van onderhavig onderzoek, de nadruk liggen op de economische theorie van belangengroepen als onderdeel van de 'public choice' theorie. Beide theorieën zullen hierna in het kort worden uiteengezet.

\section{1. 'PUBLIC CHOICE' THEORIE}

\subsubsection{Inleiding}

De 'public choice' theorie kan worden beschouwd als een uitwerking van de beginselen van de 'capture' theorie naar een micro-economische analyse van het wetgevingsproces. ${ }^{1064}$ Een veronderstelling bij deze theorie is dat politiek gedrag vergelijkbaar is met marktgedrag. Binnen de markt wordt door een individu gestreefd naar nutsmaximalisatie, waarbij hij, afhankelijk van zijn welvaart en inkomen, een keuze kan maken voor een bepaald product. Deze keuze wordt mede beïnvloed door het recht, dat echter weer een product is van keuzes die collectief worden gemaakt, namelijk via de politieke markt. ${ }^{1065}$

1062. Zie Becker, QJE, 1983, p. 376-381 voor een rechtseconometrische benadering van de competitie tussen belangengroepen voor het verkrijgen van bijvoorbeeld een subsidie.

1063. Zie over deze theorie: Stigler, BJE, 1971, p. 4-6; Faure en Van den Bergh, Objectieve aansprakelijkheid, p. 151; Utton, The Economics of Regulating Industry, p. 20-22; Ogus, Regulation, p. 71-72 en p. 171-173; De Bijl en Van Damme, Regulering en zelfregulering in markten met kwaliteitsonzekerheid, 1997, p. 21-22. Zie voor een kritische weergave van deze theorie: Peltzman, JLE, 1976, p. 21 1-240 en Posner, BJE, 1974, p. 343-356.

1064. Buchanan en Tullock, The Calculus of Consent, 1962, hebben in dit kader baanbrekend werk verricht. Ook over de 'public choice' theorie is een stroom aan (economische) literatuur verschenen, waarvan hier genoemd kunnnen worden: Olsen, The Logic of Collective Action, 1971; McLean, Public Choice, 1987; Niskanen, JLE, 1975, p. 617-643; Mueller, Joumal of Economic Literature, 1976, p. 395-433; Buchanan, Joumal of Public Finance and Public Choice, 1983, p. 7 15; Wittman, JPE, 1989, p. 1395-1424; Tollison, Virginia Law Review, 1988, p. 339-371; Mit-

chel and Munger, American Joumal of Political Science, 1991, p. 512-546.
Ogus, Regulation, p. 58-59; Hoizhauer en Teijl, Inleiding rechtseconomie, p. 253-255. 
Aan de aanbodzijde van deze politieke markt bevindt zich de overheidsfunctionani die belast is met het opstellen van wetgeving. ${ }^{1066}$ De overheidsfunctionaris, polition of ambtenaar, kan worden gezien als een Homo Economicus die streeft naar maximalisering van zijn verwacht nut. Verder wordt verondersteld dat een politiou mede zijn eigen belangen nastreeft, die overeenkomen met het behalen van zoveet mogelijk stemmen bij de eerstvolgende verkiezingen. De politicus heeft echter le maken met belangengroepen, die hun invloed trachten aan te wenden ten behorert van wetgeving die aan hun belangen tegemoet komt. Een politicus zal deze belangen derhalve mee willen laten wegen bij het wetgevingsproces. Wanneer de belangen groepen daarbij een doorslaggevende rol vervullen bij een eventuele herverkiezing dient een politicus hiermee tevens zijn eigen belang. ${ }^{1067}$

Aan de vraagzijde van de politieke markt bevinden zich allereerst de individuele burger, die door middel van zijn stemgedrag bij de verkiezingen, een keuze maakt voor een bepaald beleid. Zijn invloed op de uiteindelijke regelgeving is echter be perkt. Voor een individuele kiezer geldt namelijk dat, ten behoeve van het onderzoek naar de effecten van een bepaald verkiezingsprogramma op zijn persoodilike welvaart, de informatiekosten zeer hoog kunnen zijn. ${ }^{1068}$ In de tweede plats bevin. den zich aan de vraagzijde van de politieke markt de belangengroepen, die een meet directe invloed kunnen uitoefenen op het wetgevingsproces.

De 'public choice' theorie tracht een economische verklaring te vinden voor het ge drag op de politieke markt ten behoeve van private belangen, alsmede voor de vraag in hoeverre individuele keuzes het stemgedrag bij de verkiezingen bepalen. Darabij zijn mede de gevolgde procedures bij de totstandkoming van wetgeving van be lang. ${ }^{1069}$ In het kader van het verkeersongevallenrecht ligt in deze paragraaf voord de nadruk op één aspect van de politieke markt, namelijk de invloed van belangengroepen op de totstandkoming van wetgeving. In paragraaf 6 zal blijken dat het lobbyproces voor bepaalde veiligheidsregulering in het verkeer mede van invloed ban zijn op de preventie van verkeersongevallen. ${ }^{1070}$

1066. Zie Buchanan and Tullock, The Calculus of Consent, 1962, p. 88-90, p. 125-126 en p. $131 \cdot 165$ en Ogus, Regulation, p. 59-62, voor een aantal verschillen tussen de politieke markt en de bs: sieke productmarkt.

1067. Faure en Van den Bergh, Objectieve aansprakelijkheid, p. 148-149.

1068. Peltzman, JLE, 1976, p. 213; Ogus, Regulation, p. 66; De Bijl en Van Damme, Regulering e zelfregulering in markten met kwaliteitsonzekerheid, 1997, p. 21; Holzhauer en Teijl, hlicith! rechtseconomie, p. 56-57.

1069. Buchanan and Tullock, The Calculus of Consent, 1983, p. 31-39.

1070. Zie Ogus, Regulation, p. 63-69, voor een overzicht van de verschillende vormen van pol handel en politieke transacties. 


\subsubsection{De invloed van belangengroepen}

Binnen de 'public choice' theorie wordt een belangrijke rol toebedeeld aan de invloed van belangengroepen op het wetgevingsproces. Deze invloed doet zich op verschillende terreinen gelden. Zo kan een belangengroep informatie beschikbaar stellen aan het electoraat ten aanzien van toekomstige wetgeving of aan politici die over een bepaald wetsvoorstel moeten stemmen. Daarnaast kan een belangengroep politieke campagnes financieren. Verder kan een belangengroep trachten om subsidies of een belastingverlaging bij de overheid los te weken.

Ogus makt globaal een onderscheid tussen twee typen van belangengroepen. Een eerste type vertegenwoordigt een meer afgebakend economisch belang, zoals professionele beroepen en producentenorganisaties. Een tweede type belangengroep tracht invloed aan te wenden op grond van bepaalde ideologische overwegingen. Voorbeelden hiervan zijn milieugroeperingen. ${ }^{1071}$ Aan deze twee typen van belangengroepen kan mogelijk nog een derde worden toegevoegd, namelijk organisaties die bepaalde consumentenbelangen verenigen.

Binnen de politieke markt worden de belangengroepen beschouwd als de vragers van wetgeving, terwijl de overheid geldt als de aanbieder daarvan. Bij dit spel van rraag en aanbod is de vraag van belang waarom de rol van een belangengroep zo sterk is bij de totstandkoming van wetgeving. Een tweede vraag die hierop aansluit is wat het effect is van hun lobbying ter beïnvloeding van de politieke besluitvorming.

Voor een antwoord op deze vragen wordt binnen de economische theorie een beroep gedaan op twee kostenbegrippen, namelijk informatiekosten en transactiekosten. ${ }^{1072}$ Transactiekosten hangen samen met de inspanning die een individu zich moet getroosten om bijvoorbeeld een bepaalde wetswijziging tot stand te brengen. Deze transactiekosten kunnen hoog zijn al naar gelang de vraag of een individu in staat is zich in een groep te organiseren.

Informatiekosten houden verband met de kosten die een individu moet maken om erachter te komen of bepaalde wetgeving een positieve of negatieve invloed heeft op zijn welvaart. Ook deze kosten kunnen, afhankelijk van de complexiteit van de betreffende regelgeving, hoog zijn. Een gemiddelde consument zal bijvoorbeeld hoge (informatie) kosten moeten maken om te kunnen inschatten wat de gevolgen van bepaalde regelgeving voor hem persoonlijk zijn. Daarnaast kan zich de situatie voordoen, dat de consument alleen tegen hoge transactiekosten in groepsverband kan

\footnotetext{
1071. Ogus, Regulation, p. 70

1072. Zie Peluman, JLE, 1976, p. 214, die een verband legt tussen de informatie- en transactiekosten en de winsten en verliczen van een belangengroep.
} 
opereren, ondanks het feit dat de groep mogelijk hetzelfde belang nastreeft. Ditbe tekent dat een consument vrijwel onmogelijk voor zijn eigen belang zal hunnet opkomen, bijvoorbeeld ten behoeve van een koopkrachtverbetering.

\subsubsection{De voorwaarden voor een effectieve lobbying}

Het voorgaande brengt mee dat wanneer een individu zich eenvoudig in groepster. band kan organiseren een besparing kan worden bereikt op de informatie- en tansactiekosten. Het voordeel van een belangengroep die tegen lagere kosten opereert is dat invloed kan worden uitgeoefend op het wetgevingsproces. ${ }^{1073}$ De vraag of eto dergelijke lobbying tot een succes leidt, in de vorm van gunstige wetgeving, is af. hankelijk van een aantal factoren.

In de eerste plaats dient een belangengroep klein van omvang te zijn om effectief it vloed te kunnen uitoefenen. Daarnaast is de mogelijkheid tot controle van eigen groepsleden van belang. Door middel van bepaalde groepsregels, bijvoorbeeld het heffen van contributie met daaraan verbonden financiële voordelen, kunnen eventivele 'free rider' problemen worden tegengegaan. ${ }^{1074}$ Een derde factor die de effectivitet van de lobbying kan verhogen is de homogeniteit van de belangengroep. Wanneer als groep een gemeenschappelijk belang wordt nagestreefd, zal verder worden be spaard op de transactiekosten.

Samenvattend kan worden gesteld dat kleine belangengroepen met een hoge mate van zelfregulering, die gebruik maken van strenge toegangsregels tot de groep, ef. fectief invloed kunnen uitoefenen op het wetgevingsproces. Voorbeelden hievian zijn bepaalde industrietakken en professionele beroepen. ${ }^{1075}$

Belangengroepen die een grote omvang hebben, kunnen ook invloed uitoefenen op het wetgevingsproces. $\mathrm{Zij}$ dienen daarbij goed georganiseerd te zijn en te beschilken over een vorm van zelfregulering om mogelijke 'free rider' problemen te omzelen. Een voorbeeld hiervan zijn de politieke partijen. ${ }^{1076}$ De belangen van bijvoorbeld grote consumenten- en milieugroeperingen zijn meer algemeen geformuleerd. Dit zou kunnen betekenen dat de invloed van deze belangengroepen, in vergelijking nat de hiervoor genoemde professionele belangengroepen, het minst ver reikt. Hier stat

1073. Faure en Van den Bergh, Objectieve aansprakelijkheid, p. 149-150; Stigler, BJE, 1971, p. 10.13 1074. Holzhauer en Teijl, Inleiding rechtseconomie, p. 264. Zie ook Becker, QJE, 1983, p. 392, wat een nuancering van deze stelling.

1075. Zie Faure en Van den Bergh, IRLE, 1991, p. 177.

1076. Zie echter Peltzman, JLE, 1976, p. 212-213, voor een nuancering. 
tegenover dat politici gevoelig kunnen zijn voor het gegeven dat dergelijke belangengroepen een groot aantal potentiële kiezers verenigen. ${ }^{1077}$

\subsubsection{2. 'Rent-seeking'}

Wanneer een belangengroep tegen lage informatie- en transactiekosten met succes een voor haar gunstige wetgeving tot stand brengt, kan zij economisch voordeel (rent) behalen. Dit betekent dat de welvaart van de invloedrijke belangengroep stijgt ten koste van de belangengroep die geen positieve invloed op het wetgevingsproces heeft kunnen uitoefenen. Bij deze laatste groep is derhalve sprake van een welvartsverlies. Binnen de economische analyse wordt het proces, waarbij bepaalde welvaartsoverdrachten kunnen ontstaan, met het begrip 'rent seeking' aangeduid. ${ }^{1078}$

De steun die belangengroepen aan politici wensen te geven is afhankelijk van de verhouding tussen de kosten van deze support en de opbrengst in de zin van het welvaartsvoordeel dat dit hen oplevert. Een belangengroep maakt daarbij niet alleen kosten om gunstige wetgeving tot stand te brengen, maar ook om de betreffende wetgeving in stand te houden. Dit laatste kan een verder welvaartsverlies voor de samenleving tot gevolg hebben. Een belangengroep zal derhalve slechts een lobbypolitiek bedrijven wanneer de kosten niet hoger zijn dan de opbrengst in termen van bet te verkrijgen welvaartsvoordeel. Daarnaast zal een belangengroep ook rekening moeten houden met andere belangengroepen die ook een succesvolle 'rent seeking' nastreven. ${ }^{1079}$

Vanuit de positie van de wetgever geldt dat, wanneer een politicus een bepaalde belangengroep bevoordeelt, hij ook rekening zal dienen te houden met belangengroepen die door de betreffende regelgeving worden benadeeld. Voor een politicus die streeft naar nutsmaximalisatie is immers alleen een toekomstige verkiezingsoverwinning van belang. Binnen de economische theorie wordt echter ook gesteld dat een eventueel welvaartsverlies ten gevolge van wetgeving over een grote groep zal zijn verspreid. Daamaast zal de individuele consument over het algemeen onwetend blijven van bepaalde wetswijzigingen, terwijl hij er vermoedelijk ook geen nadeel van ondervindt. Dit kan derhalve voor de wetgever aanleiding zijn om bepaalde belangengroepen door middel van wetgeving blijvend te bevoordelen. De wetgever

\footnotetext{
1077. Becker, QJE, 1983, p. 392; Ogus, Regulation, p. 70-71.

1078. Zie daarover Buchanan, in Toward a Theory of Rent-Seeking Society, p. 3-15, met name p. 7; Tollison, Kyklos, 1982, p. 575-602.

1079. Faure en Van den Bergh, Objectieve aansprakelijkheid, p. 150; Ogus, Regulation, p. 71-73; Holzhauer en Teijl, Inleiding rechtseconomie, p. 265-266; Utton, The Economics of Regulating Industry, p. 24-25. Zie ook Becker, QJE, 1983, p. 371-400, voor een analyse van de concurtentie tussen belangengroepen.
} 
gebruikt hierbij het argument dat regulering in deze gevallen het algemeen tolan dient, waarbij de consument of het slachtoffer er zeker niet slechter van wordt. ${ }^{100}$

\subsection{CONCLUSIE 'PRIVATE INTEREST' THEORIE}

Concluderend kan worden gesteld dat, terwijl de 'public interest' theorie uitging van een correctie van marktfalingen in het algemeen belang, binnen de 'private interest' theorie een dergelijke correctie vaak resulteert in wetgeving die voomamelijk onder invloed van private belangen tot stand komt. Daarbij gaat het niet meer alleen om het falen van de markt, maar ook om het falen van de overheid die geacht word het algemeen belang te dienen. ${ }^{1081}$

Bij de analyse van de 'public interest' theorie is het voorbeeld gegeven van de wirkelsluitingswetgeving, in het bijzonder het verbod voor de detailhandel om op zordag handel te drijven. ${ }^{1082}$ Binnen deze theorie kon voor dergelijke regulering geen verklaring worden gevonden, omdat deze vooral is gebaseerd op morele waarden en belangen en op paternalistische argumenten. De wetgeving die bepaalt dat aan de openingstijden van winkels beperkingen worden gesteld, kan echter ook onder invloed van belangengroepen, zoals middenstanders of religieuze groeperingen, tot stand zijn gekomen of worden gehandhaafd. Dit betekent dat een dergelijke vom van regulering met behulp van de 'private interest' theorie kan worden verklard, terwijl dat in het kader van de 'public interest' theorie niet mogelijk was. ${ }^{1083}$

Een ander voorbeeld, waarin het belang van de 'private interest' theorie tot uting komt, heeft betrekking op een aantal deregulerende maatregelen die de laatste jaren zijn uitgevoerd. Wanneer als gevolg van een dereguleringsproces de bescheming van de consument gehandhaafd kan blijven, zal de consument geen nadeel daarvan ondervinden. Voor de producenten kan deregulering echter negatieve gevolgen heb-

1080. Faure en Van den Bergh, Objectieve aansprakelijkheid, p. 150: 'Vaak wordt de vlag van het is gemeen belang' gebruikt om de lading van de welvaartsoverdracht te dekken'. Zie ook Utton, the Economics of Regulating Industry, p. 21.

1081. Faure en Van den Bergh, Objectieve aansprakelijkheid, p. 149.

1082. Zie paragraaf 2.2 van dit hoofdstuk.

1083. De Bijl en Van Damme, Regulering en zelfregulering in markten met kwaliteitsonzzkethei 1997 , p. 24, tonen aan dat de nieuwe winkeltijdenwet in Nederland, die op 1 juni $1996 \mathrm{~km}$ kracht werd, een voorbeeld is van regulering die met behulp van de 'private interest' theorie lat worden verklaard. De verruiming van de openingstijden kwam daarbij vooral tot stand onder it vloed van de lobby van consumenten en het grootwinkelbedrijf, terwijl de vakbeweging an de kleine zelfstandigen voor handhaving van de status quo waren. Zie ook Jaffer and Kay, in The Economics of Legal Regulation, p. 169-183, die een vergelijkbare verklaring geven voor de to standkoming van een ruimere winkeltijdenwet in Engeland in 1985. Van den Bergh, in the too nomics of Legal Regulation, p. 185-205, stelt dat de regelgeving ten aanzien van de detailhandel (vestigingswetgeving) in Belgie vooral moet worden gezien als het resultaat van de lobbying vat goed georganiseerde belangengroepen, in het bijzonder de middenstand. 
ben, onder andere in de vorm van een toename van de concurrentie, die zij juist via regulering trachten uit te schakelen. Een dereguleringsoperatie kan dus worden tegengewerkt door de lobby van invloedrijke belangengroepen, die de bescherming van de markt voor nieuwe toetreders wensen te behouden. Daar staat tegenover dat voor andere belangengroepen, die wel profiteren van deregulering, dit voordeel niet opweegt tegen de kosten van lobbying. Volgens Van Damme en De Bijl kan aan het feit dat binnen bepaalde sectoren tegen deregulering wordt gelobbyd de conclusie worden verbonden dat deze sectoren met de bestaande wetgeving nog altijd monopoliewinsten maken. ${ }^{1084}$

\subsection{KANTTEKENINGEN BIJ DE 'PRIVATE INTEREST' THEORIE}

Evenals bij de analyse van de 'public interest' theorie is gesteld, ${ }^{1085}$ kan ook de 'private interest' theorie geen zelfstandige verklaring geven voor de totstandkoming van bepaalde wetgeving. Er zijn immers vele vormen van regulering die in hun toepassing weer te zeer afhankelijk zijn van allerlei andere factoren, zoals tijd, informatiekosten en de ruimte op de toepasselijke markt. In de kritiek op de 'private interest' theorie wordt verder gesteld dat hierin het eigen belang van de politicus te eng wordt geinterpreteerd en tegelijk wordt geassocieerd met welvaartsmaximalisatie. Daardoor kan deze theorie beter worden toegepast op goed georganiseerde belangengroepen, zoals de industrie, dan op individuele politici en burgers. ${ }^{1086}$ Daarnaast spelen bij individuele burgers en politici ook andere, meer ideologische en morele waarden, een rol waarmee de economische analyse veelal geen rekening houdt. Wanneer het economische model van de politieke markt wordt uitgebreid met een breed scala aan persoonlijk motieven, zal derhalve aan de voorspellingen minder waarde toekomen. ${ }^{1087}$

Het voorgaande brengt mee dat bij overheidsregulering een gezamenlijke toepassing van de 'public interest' theorie en de 'private interest' theorie wenselijk is. Dit is van belang om de uiteindelijke beweegredenen die aan het overheidsingrijpen ten grondslag liggen te kunnen verklaren. Beide theorieën kunnen elkaar aanvullen: tezamen hebben zij een hogere verklarende waarde. ${ }^{1088}$

1084. De Bijl en Van Damme, Regulering en zelfregulering in markten met kwaliteitsonzekerheid, 1997, p. 22-24, met empirische voorbeelden ten aanzien van de nieuwe (Nederlandse) vestigingswetgeving en de winkeltijdenwet. Anders: Ogus, Regulation, p. 75, die meent dat noch de 'public interest' theorie, noch de 'private interest' theorie kan worden gebruikt om het proces van deregulering te verklaren.

1085. Zie paragraaf 2.2 van dit hoofdstuk.

1086. Zie Farber and Frickey, Law and Public Choice: A Critical Introduction, 1991, p. 26-33 in Ogus, Regulation, p. 73

1087. Ogus, Regulation, p. 73-74

[088. Ogus, Regulation, p. 75 
Binnen het kader van de 'public interest' theorie is bijvoorbeeld naar een verklaring gezocht voor veiligheidsregulering in het algemeen belang. Hierbij stond de maxi. malisering van de welvaart voorop. Met het uitvaardigen van veiligheidsregulering kunnen echter ook bepaalde belangengroepen worden bevoordeeld. Dit betekent de veiligheidsregulering naast het corrigeren van bepaalde marktfalingen, externaliteten of informatietekorten, ook de winsten van de producenten verder kan verhogen.

\section{Veiligheidsregulering en de concurrentie tussen belangengroepen}

In het kader van het algemeen belang ('public interest') kan de overheid overgaan to de invoering van bijvoorbeeld veiligheidsregulering. Wanneer dergelijke regulering rechtstreeks van invloed is op de belangen van de industrie, zal deze zich daar moge lijk eerst tegen verzetten ('private interest'). Een bepaalde belangengroep kan ook ton de conclusie komen dat de invoering van veiligheidsregulering niet kan worden voorkomen. Zij zal daarbij wel trachten invloed uit te oefenen om het wetgeringsproces zoveel mogelijk in haar voordeel te beslechten. Door middel van een derge lijke lobbying kan worden bereikt dat de regulering niet te strikt wordt, waamme wordt voorkomen dat zij negatieve gevolgen heeft voor de winst van de industie. Hierop geldt een aantal uitzonderingen.

In de eerste plaats pleiten industriële belangengroepen niet altijd voor minder stithe regulering. Zij kunnen bijvoorbeeld akkoord gaan met strengere regulering, warim zogenaamde 'grandfather clauses' zijn opgenomen. Met behulp van deze ciausules worden uitzonderingen gemaakt voor bestaande bedrijven in de markt, voor wie derhalve de 'oude', minder strenge, regels blijven gelden. De nieuwe toetreders tot de markt zijn echter wel onderworpen aan de nieuwe strenge regulering. ${ }^{1089}$ Daarnasst zullen niet alle ondernemingen binnen een bepaalde industrietak in gelijke mate van de nieuwe regulering profiteren. Dit betekent dat sprake is van een herverdeling van de welvaart tussen de concurrerende ondernemingen in de betreffende industie tak. $^{1090}$

In de tweede plaats hangt de keuze voor lobbying bij de industrie af van de polititese macht die de betreffende belangengroep binnen de markt bezit. In dat kader dienen de industriële lobbygroepen rekening te houden met zogenaamde 'countervaling

1089. Maloney and McCormick, JLE, 1982, p. 101; Van den Bergh, in The Economics of Legal Ref lation, p. 197; Ogus, Regulation, p. 169 en 172. Faure en Van den Bergh, Objectieve ansprits lijkheid, p. 163.

1090. Maloney and McCormick, JLE, 1982, p. 100-108. Ogus, Regulation, p. 172, stelt dat nakrith van bepaalde milieustandaarden voor grotere ondernemingen ('economics of scale', meer techlow logische kennis) goedkoper is dan voor kleinere ondememingen, waardoor de eersten en of currentievoordeel verkrijgen. 
powers' ${ }^{1091}$ Dit zijn belangengroepen, die in het kader van het algemeen belang, met de industrie concurreren ten behoeve van voordelige wetgeving. Naast de eerder genoemde belangengroepen, zoals consumenten en milieubeschermers, kan daarbij worden gedacht aan een derde type belangengroep die op de politieke markt latent een rol kan spelen.

Deze zogenaamde 'shadow interest' groep ${ }^{1092}$ kan worden beschouwd als een 'ad hoc' belangengroep die pas ontstaat wanneer zich een bepaalde gebeurtenis voordoet of kan voordoen, bijvoorbeeld een ongeval waarbij veel slachtoffers vallen. Indien deze slachtoffers zich vervolgens in groepsverband organiseren, kunnen zij door middel van een aansprakelijkheidsvordering tegen de schadeveroorzakers mogelijk indirect invloed uitoefenen op toekomstige veiligheidsregulering. Deze slachtoffergroepen gebruiken derhalve veeleer het rechtssysteem in plaats van de politieke lobby om een strengere veiligheidsregulering te bereiken. Hieruit kunnen vervolgens 'ad hoc' belangengroepen ontstaan die, ten behoeve van een bescherming van toekomstige slachtoffers, wel direct invloed trachten uit te oefenen op toekomstige veiligheidsregulering. ${ }^{1093}$

Binnen de welvaartstheorie is de nadruk gelegd op het conflict tussen de veroorzakers van externaliteiten en de slachtoffers daarvan. Ten aanzien van bepaalde extemaliteiten, bijvoorbeeld milieuvervuiling, kan het voorkomen dat de belangen van producenten en slachtoffers samenvallen. In het kader van de economische reguleringstheorie kan milieuwetgeving zelfs leiden tot de vorming van een coalitie tussen producenten en slachtoffers. Voor de slachtoffers geldt daarbij dat gestreefd moet worden naar een vermindering van de externaliteit, in casu milieuvervuiling. De producenten kunnen ook instemmen met een vermindering van de vervuiling, zolang dit niet ten koste gaat van hun winstmarge. Met behulp van bijvoorbeeld een 'grandfather clause' kan de toegang tot de markt worden beperkt. Hierbij worden de reeds aanwezige producenten uitgezonderd van de strengere milieuwetgeving, terwijl nieuwe toetredende producenten hier wel aan zijn onderworpen. ${ }^{1094}$

Samenvattend kan worden gesteld dat bij de totstandkoming van bijvoorbeeld veiligheidsregulering wordt gestreden tussen belangengroepen, die het algemene principe van regulering accepteren, maar vooral de omvang van regulering wensen te

1091. Zie Becker, QJE, 1983, p. 376-391, voor een algemeen kader ten aanzien van concurrentie tussen belangengroepen. Zie ook Hahn, Public Choice, 1990, p. 21-47, die ingaat op de concurrentie tussen industriěle belangengroepen en ideele belangengroepen met betrekking tot milieuregulering.

1092. Zie hierover Keenan and Rubin, IRLE, 1988, p. $21-36$.

1093. Keenan and Rubin, IRLE, 1988, p. 22-25.

Maloney and McCormick, JLE, 1982, p. 99-100; Stigler, BJE, 1971, p. 3; Peltzman, JLE, 1976, p. 211; Hahn, Public Choice, 1990, p. 27-28; Ogus, Regulation, p. 173. 
veranderen. De producenten willen winst blijven maken en pleiten daarbij voor toe gangsbeperkingen. ${ }^{1095}$ De belangengroepen die meer voor de slachtoffers opkomen streven naar een strengere regelgeving ten behoeve van een betere bescheming, Voor de overheid geldt daarbij dat een juist evenwicht moet worden gevonden tis. sen de verschillende belangen, waarbij zij met het oog op een mogelijke herverkie. zing beide groepen tevreden zal moeten stellen. ${ }^{1096}$ De aanwezige concurrentie hs. sen belangengroepen betekent overigens niet dat het lobbyproces altijd tot een nega tief eindresultaat zal leiden. De belangengroepen dienen elkaar daarbij zoveel moge lijk in het evenwicht te houden. Becker stelt, als representant van de Chicago-school dat er bij het lobbyproces geen sprake is van alles of niets, waarbij de meerderheid duidelijk wint en de minderheid duidelijk verliest. De concurrentie tussen belangergroepen kan volgens hem leiden tot een efficiënte uitkomst, hoewel sommige groepen nadeel van bepaalde wetgeving zullen ondervinden. ${ }^{1097}$

\section{Toetsing 'public interest' en 'private interest' aan de verkeersveiligheid}

Met betrekking tot de regulering van de verkeersveiligheid kan worden gesteld dat de overheid met verschillende belangen rekening dient te houden. Aan de ene zijde van het lobbyproces bevinden zich de verzekeraars en de autofabrikanten die streven naar winstmaximalisatie. Aan de andere zijde staan de belangengroepen die opkrmen voor de potentiële verkeersslachtoffers. In deze paragraaf zal allereerst wordes nagegaan welke belangen respectievelijk verzekeraars, autofabrikanten en de verkeersdeelnemers zelf in het algemeen nastreven en waarvoor zij mogelijkerwijs zulen gaan lobbyen (paragraaf 6.1). Vervolgens zal, met behulp van een aantal voor. beelden, de werking van het lobbyproces en de rol van de hiervoor genoemde actoren daarbij worden toegelicht (paragraaf 6.2).

1095. Maloney and McCormick, JLE, 1982, p. 109-121 geven empirisch bewijs voor de stelling dit veiligheidsregulering de winsten van de industrie kan verhogen.

1096. Van den Bergh, in The Economics of Legal Regulation, p. 200, stelt dat politici niet in het belars van één enkele belangengroep regelgeving zullen uitvaardigen, maar een evenwicht zokter waarin de marginale voordelen voor henzelf ook een rol zullen spelen. Zie ook Ogus, Regulation, p. 171-173 ten aanzien van 'standard-setting' bij milieuwetgeving.

1097. Becker, QJE, 1983, p. 373, 386 en 389. Dit wordt in het algemeen beschouwd als de visie vande Chicago-school. Anders: Tollison, Kyklos, 1982, p. 593-594; Crew and Rowley, Public Choich 1988, p. 49-67; Ogus, Regulation, p. 72-73, die stelt dat de Kaldor-Hicks efficiêntie die mel wit: geving via het democratisch proces kan worden bereikt, wordt gedwarsboomd door de invlaw van belangengroepen, waardoor uiteindelijk de minderheidsbelangen prevaleren. 


\subsection{DE INVLOED VAN VERZEKERAARS, AUTOFABRIKANTEN EN SLACHTOFFERGROEPEN}

Voor de verzekeraars als belangengroep geldt dat zij waar mogelijk zullen lobbyen voor regulering die de toegang tot en daarmee de concurrentie op de markt beperkt. Dit kan, afhankelijk van het type regulering, verschillende vormen aannemen. Enerzijds kunnen door de verzekeraars bepaalde vormen van regulering wel worden geaccepteerd, op voorwaarde dat de toegang tot de markt niet te ruim wordt. ${ }^{1098}$ Daarbij kan worden gedacht aan standaard verzekeringsvoorwaarden die door de overheid aan de markt worden opgelegd. Een dergelijke maatregel zal door de bestaande verzekeraars direct worden doorgegeven aan de consument, die nu weinig keuzemogelijkheden heeft. Daamaast zorgen deze standaardvoorwaarden ervoor dat de concurrentie van eventuele nieuwe toetreders tot de markt kan worden beperkt of zelfs uitgesloten. Anderzijds kunnen verzekeraars zelf de concurrentie beperken of uitsluiten door middel van standaard polisvoorwaarden of andere onderlinge afspraken. Dergelijke contracten wekken de indruk dat de marktwerking wordt verruimd, maar in werkelijkheid wordt de concurrentie van eventuele nieuwkomers sterk beperkt en de reeds op de markt aanwezige verzekeraars kunnen derhalve hun streven naar winstmaximalisatie blijvend handhaven.

De belangen van de autofabrikanten hangen, evenals bij de verzekeraars, samen met het streven om zowel de toegang tot als de concurrentie op de markt te beperken. Wanneer autofabrikant A ten opzichte van fabrikant B een technische voorsprong bezit, bijvoorbeeld ten aanzien van de veiligheid van auto's, zal A trachten om via het lobbyproces zijn voorsprong te handhaven. Fabrikant A zal in dat kader kunnen pleiten voor strengere veiligheidsregulering, waarbij de techniek waarover hij reeds beschikt via regulering verplicht wordt gesteld. Daarbij worden tegelijk zijn belangen ten opzichte van andere fabrikanten versterkt. Met behulp van de 'grandfather clauses', kan bijvoorbeeld worden voorkomen dat de nieuwe veiligheidsregulering voor fabrikant A te strikt wordt. Wanneer de betreffende uitzondering bestaat uit de handhaving van de 'oude' minder strenge veiligheidsregels, kan dit in het voordeel werken van fabrikant A. Nieuwe toetreders tot de markt, bijvoorbeeld autofabrikant $C$, zijn dan wel onderworpen aan de nieuwe strengere veiligheidsregulering. Voor de reeds op de markt aanwezige fabrikant $B$, die een technische achterstand heeft, zal de nieuwe veiligheidsregulering niet voordelig zijn. Hij zal nog steeds kosten moeten maken om aan de 'oude' veiligheidsregulering te voldoen. Fabrikant B zal derhalve tegen de nieuwe strengere veiligheidsregulering ageren om te voorkomen dat

1098. Op Europees niveau is hier bijvoorbeeld uitvoering aan gegeven door middel van een verordening waarin verzekeringsmaatschappijen worden vrijgesteld van het kartelverbod van artikel 85 EG-verdrag. Verordening van 21-12-1992 3932/92, EG-publikatieblad L 398/7 van 31 december 1992. Zie Faure en Van den Bergh, NJB, 1993, p. 261-267 voor een kritische analyse van deze verordening. Zie ook paragraaf 5.3 van hoofdstuk 6 . 
zijn technische achterstand verder toeneemt en zijn marktaandeel daalt. Fabrikant $A$ profiteert derhalve ten volle van de nieuwe veiligheidsregulering. Zijn marktaandeel zal verder kunnen toenemen en de toegang tot de markt wordt door de nieuwe regh lering verder beperkt. ${ }^{1099}$

Tegenover de belangengroepen van verzekeraars en autofabrikanten bevinden zick de belangengroepen die opkomen voor de verkeersdeelnemer in het algemeen en het verkeersslachtoffer in het bijzonder. De organisaties die opkomen voor de belangen van de automobilist zullen pleiten voor regulering die de auto's veiliger moet maken Daarnaast zullen zij lobbyen voor regulering die de mobiliteit van de automobilis moet verbeteren en die bijvoorbeeld het fileprobleem terugdringt. De belangengroepen die vooral aandacht wensen te geven aan de slachtoffers van een verkeersongeval zullen, ten behoeve van een verdere bescherming van deze slachtoffers, lobbyen voor strengere veiligheidsregulering, waaronder ook veiliger auto's.

Het voorgaande brengt niet mee dat in algemene termen kan worden gesteld wat in een concrete situatie het resultaat zou zijn van de invloed van de beschreven belar. gengroepen voor de inhoud van de veiligheidsregulering. Dat zal onder meer athangen van de effectiviteit van de verschillende belangengroepen alsook van hun relatieve kracht. Daarnaast zijn andere factoren van betekenis, zoals het organisatievermogen van de betrokken belangengroep en de informatiekosten voor het publiek om de 'rent seeking' te achterhalen. ${ }^{1100}$

\subsection{DE VERKEERSVEILIGHEID EN HET LOBBYPROCES: TOEPASSINGEN}

Wanneer autoverzekeraars op een sterk geconcentreerde verzekeringsmarkt opereren, zullen zij pleiten voor strengere veiligheidsregulering om het morele risico van roekeloze chauffeurs beter te kunnen controleren. De belangengroepen van verkersslachtoffers zullen, vanuit beschermingsoogpunt, echter ook belang kunnen hebben bij dergelijke veiligheidsregulering. Een voorbeeld hiervan is een verplichte verz kering. Voor de autoverzekeraars biedt een dergelijke maatregel het voordeel dat mits er geen acceptatieplicht is, de vraag naar verzekering verplicht wordt gesteld Bij de aanwezigheid van een verzekeringskartel kunnen de autoverzekeraars bover dien de controle over de vraag- en aanbodzijde van de verzekeringsmarkt handos ven, alsmede de concurrentie op en de toegang tot de markt beperken. Belangers. groepen van verkeersslachtoffers zullen mogelijk ook pleiten voor een verplichte verzekering aan de zijde van de schadeveroorzaker. Wanneer een dergelijke verze

1099. Maloney and McCormick, JLE, 1982, p. 100-108.

Zie paragraaf 4.1.2.1 van dit hoofdstuk voor een beschrijving van de criteria ten behoeve van effectieve lobbying. Zie ook Meier, JRI, 1991, p. 700-713, voor een analyse van de tolstantilo ming van verzekeringsregulering in de VS en de invloed daarop van de verzekeringsindustrie th belangengroepen van consumenten. 
keringsplicht bijvoorbeeld wordt gecombineerd met een regel van risicoaansprakelijkheid, is vanuit hun visie de vergoeding aan het verkeersslachtoffer optimaal gewarborgd. ${ }^{110}$

Een tweede voorbeeld waarbij de belangen van autoverzekeraars en slachtoffergroepen kunnen samenvallen heeft betrekking op bepaalde gedragingen van de automobilist, in het bijzonder opzet of dronken rijden. Autoverzekeraars zullen trachten om dergelijke gedragingen van aansprakelijkheidsdekking uit te sluiten, ${ }^{1102}$ ofwel deze via regulering verplicht te stellen om concurrentie op dat punt te vermijden. De schadeveroorzaker zal nu ingeval van opzet zelf de schade aan het slachtoffer moeten vergoeden. Een autoverzekeraar kan met de genoemde uitsluitingen voorkomen dat de schadelast stijgt en de winstmarges verwateren. Wanneer opzet of dronken rijden niet in de verzekeringspolis wordt opgenomen kunnen autoverzekeraars, die opereren op een sterk geconcentreerde verzekeringsmarkt, hun invloed aanwenden ten behoeve van strengere veiligheidsregulering om het morele risico van de roekeloze chauffeur beter te kunnen controleren.

De yerzekeraars kunnen binnen een geconcentreerde verzekeringsmarkt, ook zelf initiatieven nemen, bijvoorbeeld met behulp van standaardpolissen, om de betreffende gedragingen uit te sluiten. Wanneer deze uitsluitingen voor iedereen gelden, kan mogelijk de concurrentie van andere verzekeraars die dergelijke gedragingen wel wensen te verzekeren worden beperkt of uitgesloten.

De belangengroepen van verkeersslachtoffers hebben er alle belang bij dat opzet of dronken rijden ex ante wordt gereguleerd. Zij zullen derhalve hun invloed aanwenden om verkeersgedrag, waarbij de veroorzaker van een verkeersongeval onder invloed van alcohol verkeert of anderszins roekeloos rijgedrag vertoont, te reguleren.

Uit het voorgaande volgt dat de belangen van verkeersslachtoffers en autoverzekeraars kunnen samenvallen. Regulering van bijvoorbeeld opzet of dronken rijden kan vanuit 'public interest'-perspectief de efficiëntie bevorderen, waarbij een betere preventie van verkeersongevallen mogelijk wordt. Voor de autoverzekeraars zal dergelijke regulering de mogelijkheden tot een controle van het morele risico verbeteren en de concurrentie op de markt verder kunnen beperken.

In de derde plaats kan ook de automobielindustrie belang hebben bij bepaalde regulering. Op Europees niveau heeft Duitsland bijvoorbeeld lang getracht om de invoering van een katalysator voor auto's verplicht te stellen. Aangezien de Duitse autofabrikanten reeds met een katalysator werkten, zou dit hen, naast een technische voor-

1101. Zie hietovet paragraaf 5.3 van hoofdstuk 6 .

1102. Skogh, IRLE, 1982, p. 75 . 
sprong, ook een economisch voordeel kunnen opleveren ten opzichte van andere an tofabrikanten binnen de Europese Unie. ${ }^{1103}$

Een vierde voorbeeld, waarbij de invloed van belangengroepen een rol speelt, heef betrekking op het mogelijk ontstaan van een crisis binnen de markt voor autoverze keringen. Een dergelijke crisis zal zich kunnen voordoen bij een zeer sterke toename van de autopremies, bijvoorbeeld in een dichtbevolkte regio waarbinnen het aante verkeersongevallen sterk is gestegen. Dit kan leiden tot een politieke lobby voon hervorming van de verzekeringsregulering. De overheid heeft daarbij echter te maken met conflicterende belangen. Aan de ene kant bevinden zich de autoverzekeraars die bijvoorbeeld een beperking van de aansprakelijkheid wensen om de kosten te kunnen verminderen. Aan de andere kant staan de consumenten van een verzekeringspolis, die geen hoge premie willen betalen en ook de macht van de verzke ringsmarkt beperkt willen houden. ${ }^{1104}$

Naar aanleiding van het voorgaande kan de vraag worden gesteld welke positie de overheid vanuit een 'public interest' perspectief kan innemen met betrekking tot de regulering van de verkeersveiligheid. Daarbij dient te worden vooropgesteld dat de effecten van lobbying mede afhankelijk zijn van de omvang en de samenstelling van een belàngengroep. De belangen van verkeerssiachntoffers zijn bijvoorbeeld' over etn grote groep verspreid, terwijl de belangen van de autofabrikanten en de autoverzkeraars meer zijn afgebakend. Dit kan gevolgen hebben voor de invoering van bepaalde vormen van veiligheidsregulering in het verkeer.

Vanuit het oogpunt van slachtofferbescherming kan de overheid bijvoorbeeld hat voornemen hebben om een regel van risicoaansprakelijkheid gecombineerd mat strengere veiligheidsstandaarden voor auto's in te voeren. Deze maatregelen zullen worden toegejuicht door de belangengroepen van verkeersslachtoffers. Deze groe pen hebben weliswaar veel invloed, maar zij zijn over het algemeen slecht georganiseerd. Door hun grote omvang zijn de kosten hoog, waardoor het voor slachiofiergroepen moeilijk kan zijn om het lobbyproces ten gunste van een strengere vellig. heidsregulering te keren. Daamaast geldt dat de voordelen van deze veiligheidsregllering veelal over een grote groep zijn verspreid. ${ }^{1105}$

De oppositie tegen strengere veiligheidsregulering is mogelijk afkomstig van adto fabrikanten en autoverzekeraars. Zij zullen pleiten voor een afzwakking van een strengere veiligheidsregulering om hun marktpositie te kunnen behouden. Daamass

1103. Zie Van den Bergh, Faure en Lefevere, in Law and Economics of the Environment, p. 138.

1104. Zie Zycher, Regulation, 1990, p. 67-77. Hieruit bleek dat, ten gevolge van een crisis bimen de markt voor autoverzekeringen, de individuele burger invloed kon uitoefenen op de totsandoming van bepaalde regulering.

1105. Zie Ogus, Regulation, p. 70-71 en paragraaf 4.1.2.1 van dit hoofdstuk. 
kunnen bijvoorbeeld autofabrikanten, die nog niet over de vereiste expertise beschikken, mogelijk met succes gedaan krijgen dat de overheid een tijdelijke subsidie beschikbaar stelt om de eventuele aanloopverliezen te compenseren. Ten behoeve van de bescherming van de autoverzekeraars kan de overheid de effecten van een regel van risicoaansprakelijkheid afzwakken door deze te koppelen aan een verplichte verzekering. ${ }^{1106}$

De overheid zal echter, ten behoeve van een mogelijke herverkiezing, ook rekening willen houden met haar eigen belangen. Daarbij kan een verantwoordelijk politicus de neiging vertonen de belangen van verkeersslachtoffers te laten prevaleren, omdat zij een groter potentieel electoraat vormen.

Concluderend kan worden gesteld dat binnen het lobbyproces ten aanzien van het verkeersongevallenrecht sprake is van sterk conflicterende belangen die misschien op een beperkt aantal onderdelen van wetgeving tot overeenstemming kunnen worden gebracht. 


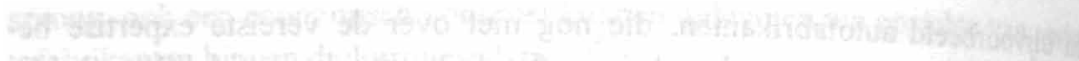

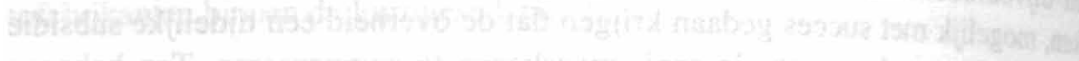

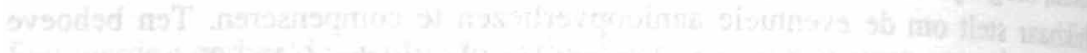

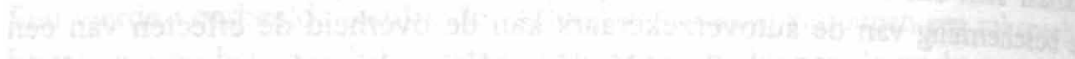

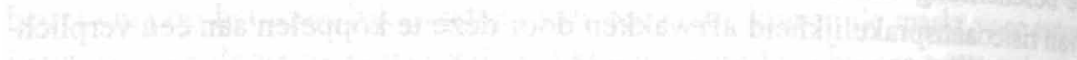

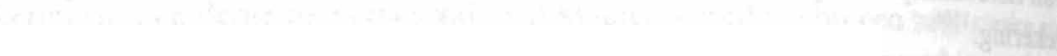

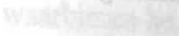

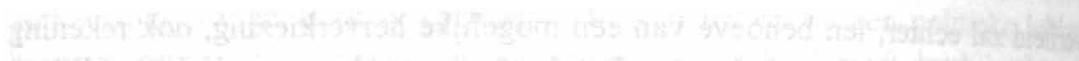

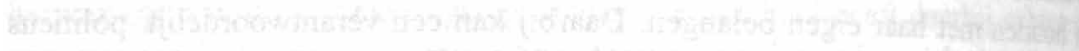

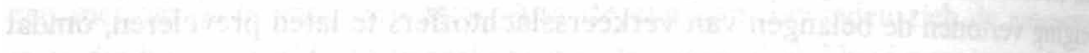

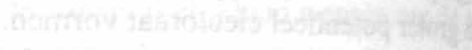

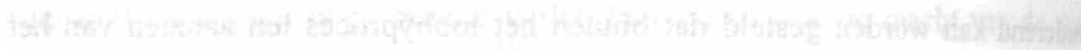

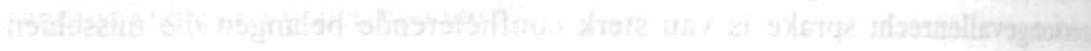

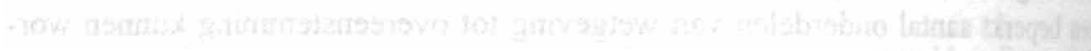

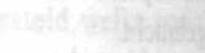

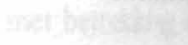

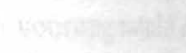

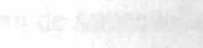

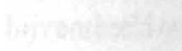

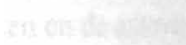

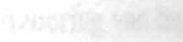




\section{Hoofdstuk 8: Algehele schematische conclusie van het economisch model}

\section{Inleiding}

In de voorgaande drie hoofdstukken is een uitvoerige beschrijving gegeven van drie juridsche instrumenten, namelijk aansprakelijkheid, verzekering en veiligheidsregulering, die tezamen het economisch model van het ongevallenrecht vormen. Deze juridische instrumenten zijn getoetst aan de centrale vraag of zij, al dan niet gecombineerd gebruikt, in theorie kunnen leiden tot een optimale preventie van verkeersongevallen en een optimale compensatie van verkeersslachtoffers.

In dit afsluitende hoofdstuk van de economische analyse zal worden nagegaan welke combinatie van aansprakelijkheid, verzekering en veiligheidsregulering optimaal is. Hierbij zal het reeds gemaakte onderscheid in ongevalskosten, namelijk de primaire ongevalskosten (preventie), secundaire ongevalskosten (compensatie) en tertiaire ongevalskosten (administratieve kosten) een centrale rol vervullen. Verder wordt in dit hoofdstuk gebruik gemaakt van theses, waarvan voor de uitwerking en de bijbehorende literatuur zal worden verwezen naar de relevante paragrafen.

In paragraaf $2 \mathrm{t} / \mathrm{m} 5$ zullen de conclusies ten aanzien van aansprakelijkheid, verzekering en veiligheidsregulering beknopt worden weergegeven. Vervolgens zal worden nagegaan welke factoren van belang zijn voor een gezamenlijke toepassing van deze juridische instrumenten (paragraaf 6). In paragraaf 7 zal een aantal combinaties van aansprakelijkheid, verzekering en veiligheidsregulering worden getoetst aan de centrale vraag van dit onderzoek. Tot slot van dit hoofdstuk zal in paragraaf 8 naar aanleiding van de economische theorie een aantal vragen worden geformuleerd die van belang zijn voor de analyse van het empirisch onderzoek in deel III.

\section{De economische analyse van verkeersongevallen: algemeen}

1. De economische doelstelling van het verkeersongevallenrecht is de minimalisering van de maatschappelijke kosten van verkeersongevallen. Deze kosten kunnen worden onderverdeeld in primaire ongevalskosten (preventie), secundaire ongevalskosten (compensatie), en tertiaire ongevalskosten (administratieve kosten). ${ }^{1107}$

2. Als uitgangspunt voor de economische analyse van het verkeersongevallenrecht kan het Coase-theorema worden genomen. Dit is van toepassing wanneer een

1107. Paragraaf 2.2 van hoofdstuk 4. 
klein aantal partijen, ingeval van een potentieel verkeersongeval, door middel van onderhandelingen tegen lage transactiekosten tot een optimale afspraak kin. nen komen over de aan te wenden preventieve maatregelen.

3. Wanneer verkeersdeelnemers vreemden zijn tegenover elkaar is onderhandele vooraf alleen tegen hoge kosten mogelijk. Daardoor zullen de voorwaarden van het Coase-theorema niet van toepassing zijn en wordt een tussenkomst van be recht noodzakelijk om allocatieve efficiëntie te bereiken. ${ }^{1108}$

\section{Preventie van verkeersongevallen (primaire ongevalskosten)}

\subsection{HET AANSPRAKELIJKHEIDSRECHT}

1. Zowel een regel van risicoaansprakelijkheid met een absoluut eigen schuliverweer als een gewone regel van foutaansprakelijkheid zullen de autobesturder en de fietser aanzetten tot een optimaal zorgniveau. Bij de eerstgenoemde aar sprakelijkheidsregel zal het slachtoffer echter geen optimaal activiteitsnivea aanwenden, terwijl dit bij een regel van foutaansprakelijkheid het geval is voor de autobestuurder. ${ }^{1109}$

2. Bij de meeste verkeersongevallen kan een regel van risicoaansprakelijkheid met een eigen schuldverweer een lichte voorkeur genieten. Daarmee wordt een grote belang gehecht aan de gevaren van het autoverkeer en aan de rol van de autobestuurder die bij deze regel eerder tot een optimaal activiteitsniveau kan worden aangezet. De toevoeging van een absoluut eigen schuldverweer aan de zijde van de fietser kan recht doen aan het gegeven dat een verkeersongeval een bilateraal karakter draagt, waarbij ook het slachtoffer (fietser) tot zorgvuldig gedrag diert te worden aangezet. ${ }^{1110}$

\subsection{EX ANTE VEILIGHEIDSREGULERING IN HET VERKEER ${ }^{1111}$}

1. Ten einde een optimale preventie van verkeersongevallen te bereiken is ook de toepassing van veiligheidsregulering noodzakelijk. Hoewel de autobesturder en de fietser als direct betrokkenen in beginsel over meer informatie beschikken omtrent het ongevalsrisico, kan voor sommige situaties gelden dat de wetgever de betere informatie bezit. Met behulp van veiligheidsnormen, bijvoorbeld ten aanzien van maximumsnelheid, fietsverlichting, alcoholgebruik en autogordel

1108. Paragraaf 4 van hoofdstuk 4 .

1109. Paragraaf 6.3, 6.4 en 8.2 van hoofdstuk 5 .

1110. Paragraaf 9 van hoofdstuk 5.

1111. Paragraaf 3.3.2 van hoofdstuk 7. 
kan de overheid direct invloed uitoefenen op het ongevalsrisico waaraan de autobestuurder en de fietser blootstaan.

2. Met betrekking tot deze veiligheidsnormen is het van belang dat de overheid controle uitoefent op de naleving ervan en inbreuken ontmoedigt met behulp van sancties. Financiële sancties zijn daarbij het meest effectief wanneer deze, in verhouding tot het inkomen van de overtreder, een relatief lage omvang hebben zodat voldoende afschrikking en geen negatieve herverdelingseffecten optreden. Wanneer bepaalde financiële sancties onvoldoende effect hebben kan een gevangenisstraf worden opgelegd, hoewel hiermee hogere maatschappelijke kosten zijn gemoeid. Alternatieve vrijheidsbeperkende maatregelen, zoals het innemen van het rijbewijs, kunnen echter tegen lagere kosten worden toegepast.

\subsection{AANSPRAKELIJKHEID EN VELLIGHEIDSREGULERING ${ }^{1112}$}

1. Een gecombineerd gebruik van aansprakelijkheid en veiligheidsregulering is wenselijk om een optimale preventie van verkeersongevallen te kunnen bereiken. Wanneer de autobestuurder en de fietser niet volledig zijn geïnformeerd aangaande het ongevalsrisico, kan veiligheidsregulering, afhankelijk van de handhaving en controle, de informatie verder optimaliseren.

2. Wanneer de schadeveroorzaker een veiligheidsnorm overtreedt, kan dit gegeven voor de rechter aanleiding zijn om de schadeveroorzaker aansprakelijk te houden voor de eventueel ontstane schade. Indien daarnaast wordt uitgegaan van een lage pakkans bij verkeersovertredingen, kan aan het aansprakelijkheidsrecht eveneens een belangrijke rol worden toebedeeld.

3. Een combinatie van aansprakelijkheid en veiligheidsregulering ten behoeve van de controle van het verkeersgedrag zal echter niet onder alle omstandigheden tot een optimale uitkomst leiden. Bepaalde oncontroleerbare factoren zoals dagdromerij en een gebrek aan reflexen, evenals een onderschatting van de verkeersrisico's zijn daarbij problemen die niet volledig door veiligheidsregulering en aansprakelijkheid kunnen worden ondervangen.

\section{Verzekering en compensatie (secundaire ongevalskosten)}

\subsection{INFORMATTEPROBLEMEN}

Wanneer een verkeersdeelnemer zijn afkeer voor het ongevalsrisico afwentelt op een verzekeraar, ontstaat een tweetal informatieproblemen, namelijk morele risico en an-

i112. Paragraaf 3.3 van hoofdstuk 7. 
ti-selectie. Het eerste probleem kan worden weggenomen met behulp van een ge deeltelijke dekking of een eigen risico en een aanpassing van de polisvoorwaarden Het probleem van anti-selectie kan worden tegengegaan via een sterke differentiatie van goede en slechte risico's en met behulp van aanvullende maatregelen die de goede risico's binnen de groep houden en de slechte risico's aanzetten tot meer zorg vuldigheid. Beide informatieproblemen kunnen binnen een schadeverzekering beter worden beheerst dan bij een aansprakelijkheidsverzekering, waar ook rekening meet worden gehouden met de gedragingen van derden. ${ }^{1113}$

\subsection{EEN VERPLICHTE VERZEKERING}

Een verplichte aansprakelijkheidsverzekering is van belang om informatieproblemen aan de zijde van de verkeersdeelnemer ten aanzien van het ongevalsrisico weg te nemen. Een verplichte aansprakelijkheidsverzekering kan daarnaast een goede re medie zijn tegen de 'underdeterrence' die door de insolventie van de autobesturder wordt veroorzaakt, op voorwaarde dat de verzekeringsplicht samengaat met een fectieve controle van het morele risico. Een alternatief voor een verplichte aansprakelijkheidsverzekering is een eerste partij verzekering aan de zijde van de schadelij. der, waarmee een betere controle van het morele risico en het proces van antselectie mogelijk is. ${ }^{114}$

\subsection{CONCURRENTIE BINNEN DE AUTOVERZEKERINGSMARKT}

De markt voor autoverzekeringen dient voldoende concurrerend te zijn om de vera keraar te kunnen aanzetten tot een juiste afstemming van de premie op het individue le ongevalsrisico van de autobestuurder. Door een individualisering van de polisvoorwaarden kan zowel het morele risico als het proces van anti-selectie worden is gengegaan. ${ }^{115}$

\subsection{ALTERNATIEVE COMPENSATIEMECHANISMEN}

1. Wanneer de vergoeding via een systeem van aansprakelijkheid en verzekering niet mogelijk is, hetzij vanwege insolventieproblemen, hetzij omdat voor bepalde risico's geen verzekeringsdekking kan worden afgegeven, kan een warborrs fonds een goede aanvulling zijn ten behoeve van een optimale compensatie van het verkeersslachtoffer. ${ }^{116}$

1113. Paragraaf 4 van hoofdstuk 6.

1114. Paragraaf 5.1 van hoofdstuk 6.

1115. Paragraaf 5.4 van hoofdstuk 6.

1116. Paragraaf 6.2 van hoofdstuk 6. 
2. Een schadeverzekering heeft als voordeel boven een aansprakelijkheidsverzekering dat een verzekeraar over meer directe informatie kan beschikken ten aanzien van het individuele ongevalsrisico. Dit betekent dat bij een schadeverzekering tegen lage kosten de risico's kunnen worden gedifferentieerd, waardoor ook een betere controle van het morele risico mogelijk is. Daarnaast kan, afhankelijk van de omvang van de verzekeringsdekking, aan het verkeersslachtoffer een optimale schadeloosstelling worden gegarandeerd. Tenslotte kan met een schadeverzekering een kostenbesparing worden bereikt doordat het slachtoffer voor een snelle schadeafwikkeling een beroep kan doen op zijn eigen verzekeraar. ${ }^{1117}$

3. In het kader van een zuivere no-fault verzekering, waarbij de aansprakelijkheid geheel is afgeschaft, wordt enerzijds de schade van de inzittenden van het voertuig, bestuurder en passagier, en anderzijds de schade van fietser en voetganger vergoed. Een no-fault verzekering geeft aan het verkeersslachtoffer een optimale compensatie, ongeacht de schuld van de schadeveroorzaker of de eigen schuld van het slachtoffer. ${ }^{118}$

4. Aangezien de schadevergoeding binnen een no-fault regime niet is gebaseerd op de aansprakelijkheid van de autobestuurder is een andere vorm van premiedifferentiatie noodzakelijk om de problemen van morele risico en anti-selectie te vermijden. Deze risicodifferentiatie kan ex ante worden gebaseerd op de individuele eigenschappen en op het rijgedrag van de autobestuurder. Een ex post premieaanpassing zal niet op basis van aansprakelijkheid kunnen worden uitgevoerd, maar kan worden gebaseerd op andere elementen, zoals op een strafpuntensysteem, het aantal verkeersovertredingen en het schadeverleden van de autobestuurder. ${ }^{1119}$

\subsection{HET REGRESRECHT}

De uitoefening van regres heeft op het terrein van de preventie het voordeel dat de ongevalskosten aan de schadeveroorzaker kunnen worden doorberekend. Wanneer door de eerste partij verzekeraar van de fietser regres wordt uitgeoefend op de aansprakelijke autobestuurder of op zijn aansprakelijkheidsverzekeraar, kan deze laatste via de polisvoorwaarden invloed uitoefenen op de preventieve zorgvuldigheid van de autobestuurder. Daarnaast kan de aansprakelijkheidsverzekeraar verhaal nemen op de autobestuurder ingeval van opzet of grove schuld. Deze laatste vorm van regres kan als een directe controle van het morele risico worden beschouwd. Wanneer echter de administratieve kosten van regres hoger zijn dan de baten op het terrein

\footnotetext{
1117. Paragraaf $4.4,4.5$ en 6.3 van hoofdstuk 6 .

1118. Paragraaf 6.4 van hoofdstuk 6.

1119. Paragraaf 6.4 van hoofdstuk 6.
} 

van de preventie, kan worden gepleit voor een collectivering van regres teneinde et
kostenbesparing te bereiken. ${ }^{1120}$

\subsection{AANSPRAKELIJKHEID EN VERZEKERING}

1. Wanneer wordt gekozen voor een regel van risicoaansprakelijkheid met een absoluut eigen schuldverweer, zal de autobestuurder een aansprakelijkheids. verzekering aangaan en zal de fietser, met het oog op de onzekerheid omtrent de zorgvuldigheidsnorm, een schadeverzekering overeenkomen. Bij risicoaanson: kelijkheid kan een optimale compensatie aan de fietser worden gegarandeerd. ${ }^{1.21}$

2. Wanneer echter wordt verondersteld dat de onzekerheid omtrent de zorgyl. digheidsnorm beter kan worden gecorrigeerd met een schadeverzekering dan ma een aansprakelijkheidsverzekering, ontstaat een lichte voorkeur voor een regel van foutaansprakelijkheid. Ten aanzien van de optimale compensatie geld dat bij foutaansprakelijkheid de fietser in beginsel schadeloos wordt gesteld via zijn eigen schadeverzekering. De autobestuurder zal in beginsel geen aansprakeli]. heidsverzekering afsluiten (omdat hij immers steeds de door het recht vereste zorg zal aanwenden), tenzij hij zich wil beschermen tegen vergissingen van de rechter of van hemzelf, waardoor hij toch aansprakelijk zou worden gehou. den. $^{1122}$

3. Een zuivere no-fault verzekering is geen aansprakelijkheidssysteem maar en vergoedingssysteem. Hiermee kan een optimale compensatie aan de fietser worden gegarandeerd, hoewel met de afschaffing van de aansprakelijkheid de corr trole op de zorgvuldigheid van de fietser wegvalt. ${ }^{1123}$

\section{Administratieve kosten (tertiaire ongevalskosten)}

\subsection{AANSPRAKELUKHEIDSREGELS}

In het economisch model wordt gesteld dat een regel van risicoaansprakelijheid met een absoluut eigen schuldverweer tot meer procedures zal leiden aangezien mogelijk elk verkeersongeval tot een gang naar de rechter leidt. Bij een gewone reggl van foutaansprakelijkheid zal alleen een procedure worden aangespannen, ondat de automobilist in beginsel minder dan de efficiënte zorg heeft aangewend. Tijdens etr gerechtelijk geschil zal echter de bepaling van de zorgvuldigheidsnorm voor de wtomobilist en fietser kostenverhogend werken, terwijl dit bij een risicoaanspreke

\footnotetext{
1120. Paragraaf 7.5 van hoofdstuk 6.

1121. Paragraaf 7.3.2 van hoofdstuk 6 .

1122. Paragraaf 7.3.3 van hoofdstuk 6.

1123. Paragraaf 8.1 van hoofdstuk 6.
} 
lijkheid met een absoluut eigen schuldverweer alleen voor de uitgeoefende zorg van de fietser geldt. Wanneer derhalve een hoger belang wordt gehecht aan een besparing op de informatiekosten (onderzoek door de rechter), gaat de voorkeur uit naar een risicoaansprakelijkheid met een absoluut eigen schuldverweer. Een regel van foutansprakelijkheid zal prevaleren wanneer de minimalisering van de gerechtskosten als doelstelling wordt gehanteerd. ${ }^{124}$

\subsection{AANSPRAKELIJKHEID EN VEILIGHEIDSREGULERING}

1. Met betrekking tot de keuze tussen veiligheidsregulering en het aansprakelijkheidsrecht geldt dat bij aansprakelijkheid enkel kosten worden gemaakt wanneer zich een verkeersongeval heeft voorgedaan. Deze kosten zijn laag omdat een verkeersongeval zich niet frequent voordoet. Daarnaast kan een verdere kostenbesparing worden bereikt wanneer het aantal schikkingen tussen partijen het aantal rechtszaken overstijgt. ${ }^{1125}$

2. Bij veiligheidsregulering worden kosten gemaakt ongeacht of zich een verkeersongeval voordoet. Deze kosten worden over de gehele gemeenschap verspreid. Daarnaast worden kosten gemaakt ten behoeve van een controle van de veiligheidsnorm. Wanneer de overheid echter beschikt over relevante informatie die de direct betrokken partijen ontberen, kan een besparing op de kosten worden bereikt. ${ }^{1126}$

\subsection{AANSPRAKELIJKHEID EN VERZEKERING ${ }^{1 / 27}$}

1. Een regel van risicoaansprakelijkheid met een absoluut eigen schuldverweer kan bij de anwezigheid van een verzekering hoge kosten meebrengen, wanneer door de fietser meer schadeclaims bij de automobilist of diens aansprakelijkheidsverzekeraar worden ingediend. Als gevolg van de aanwezigheid van een absoluut eigen schuldverweer kan echter een kostenbesparing worden bereikt, indien de fietser eerder een beroep doet op zijn eigen schadeverzekeraar, hoewel ook daarmee administratieve kosten zijn gemoeid.

2. Een regel van foutaansprakelijkheid kan in combinatie met een verzekering tot hoge kosten leiden. Wanneer de verzekeraars onderling niet tot een schikking komen dient de rechter te worden ingeschakeld, die opnieuw een onderzoek naar de zorgvuldigheid van de automobilist en de fietser moet verrichten. Bij onzekerheid omtrent de zorgvuldigheidsnorm zal het slachtoffer mogelijk eerder een

1124. Paragraf 12.3 van hoofdstuk 5.

1125. Paragraaf 3.1 .4 en 3.3.1 van hoofdstuk 7.

1126. Paragraaf 3.1.4 en 3.3.2 van hoofdstuk 7 .

1127. Paragraaf 8.3 van hoofdstuk 6. 

beroep doen op zijn eigen schadeverzekering, hetgeen echter ook administratieve
kosten meebrengt.

3. Een zuivere no-fault verzekering is het minst dure systeem, omdat de aan. sprakelijkheid is afgeschaft en de afwikkeling van de schade geheel via de nofault verzekeraar van de autobestuurder verloopt zodat in beginsel geen gerech. telijke kosten worden gemaakt. Daarnaast kunnen ook de kosten van contole voor de no-fault verzekeraar ten behoeve van een premieaanpassing lager zjp Daarbij is veelal geen onderzoek naar de aansprakelijkheid mogelijk, hoewel ook de controle van het morele risico gebaseerd op het schadeverleden van de autobestuurder of de eventueel gemaakte verkeersovertredingen kosten meebrengt.

\section{Aansprakelijkheid, verzekering en veiligheidsregulering gezamenlijk toegepast}

In het voorgaande is in het kader van de economische analyse van verkeerongevallen een aantal stellingen geformuleerd met betrekking tot (een combinatie van) aansprakelijkheid, verzekering en veiligheidsregulering. Daarbij is met name ingegaan op de verhouding tussen aansprakelijkheid en verzekering respectieveliji aansprakelijkheid en veiligheidsregulering. In deze paragraaf zal een aantal additionele factoren aan de orde komen die van belang zijn voor een gezamenlijk gebrulk van aansprakelijkheid, verzekering en veiligheidsregulering.

\subsection{EEN GECOMBINEERD GEBRUIK VAN INSTRUMENTEN}

Verzekering en veiligheidsregulering kunnen beide een aanvullende werking hebben op de informatietekorten bij de direct betrokken verkeersdeelnemers. Een autover. zekeraar maakt gebruik van informatie omtrent bepaalde voorzienbare ongevalsisico's, waarbij met behulp van statistische gegevens ten aanzien van verkeersongevallen gedifferentieerde verzekeringspremies kunnen worden aangeboden. Een ath toverzekeraar maakt daarnaast gebruik van regulering om het morele risico te corrtroleren. Verzekering en veiligheidsregulering hebben echter wel een ander doel. Verzekering is nodig ter bescherming van risicoaverse daders en voor de compenss. tie van verkeersslachtoffers. Veiligheidsregulering is nodig om bepaalde informatie beschikbaar te stellen waarover de direct betrokken verkeersdeelnemers niet beschikken. Het aansprakelijkheidsrecht tenslotte blijft nodig voor een ex post controle van het gedrag van verkeersdeelnemers. De overheid kan immers niet alles regule ren.

\section{2. 'PUBLIC INTEREST' THEORIE}

Met behulp van de 'public interest' theorie kan worden verklaard waarom velilig. heidsregulering, in het algemeen belang, nodig kan zijn waar een systeem van aar- 
sprakelijkheid en verzekering niet werkt of waarbinnen bepaalde verkeersgedragingen niet kunnen worden geregeld. Daarbij kan een ex ante veiligheidsnorm worden ingevoerd, die van belang is voor zowel de rechter, ex post oordelend over de aansprakelijkheid, als voor de verzekeraar ten behoeve van een ex post premieaanpassing. Daarnaast kan de overheid bijvoorbeeld een regel van risicoaansprakelijkheid invoeren met het argument dat autobestuurders een gevaar vormen voor de zogenaamde 'zwakke' weggebruikers, waarmee extra rekening dient te worden gehouden. Voorts kan veiligheidsregulering van belang zijn in die gevallen waarvan bij verkeersdeelnemers sprake is van een onderschatting van het ongevalsrisico.

\subsection{DE INVLOED VAN BELANGENGROEPEN}

Het bestaan en de inhoud van de veiligheidsregulering wordt mede bepaald door de aanwezigheid van belangengroepen die de betreffende regelgeving in hun voordeel trachten te beïnvloeden. Binnen het kader van veiligheidsregulering in het verkeer kan worden verwacht dat autoverzekeraars en autofabrikanten vooral de toegang tot de markt willen beperken, terwijl belangengroepen van automobilisten pleiten voor veiliger auto's en belangengroepen van verkeersslachtoffers streven naar een hoge mate van slachtofferbescherming. Deze conflicterende belangen binnen het lobbyproces kunnen maar op een beperkt aantal onderdelen van veiligheidsregulering tot overeenstemming worden gebracht. Veiligheidsregulering behoeft derhalve niet altijd tot een minimalisering van de ongevalskosten te leiden, in het bijzonder niet wanneer deze regulering het resultaat is van een succesvol lobbyproces van invloedrijke belangengroepen. ${ }^{1128}$ Dit is een belangrijk argument om het aansprakelijkheidsrecht (gecombineerd met verzekering) steeds een (aanvullende) rol te laten vervullen ter garantie van de preventie door dader en slachtoffer.

\subsection{ADMINISTRATIEVE KOSTEN}

Het voordeel van het aansprakelijkheidsrecht is dat dit instrument alleen wordt toegepast wanneer zich een verkeersongeval heeft voorgedaan, terwijl het ex ante toch prikkels tot preventie zal geven. De toepassing van het aansprakelijkheidsrecht kan echter hoge gerechts- en procedurekosten meebrengen. Met behulp van veiligheidsregulering, bijvoorbeeld ten aanzien van verkeerssituaties waarbij de wetgever over de betere informatie beschikt, kan echter worden voorkomen dat verkeersongevallen überhaupt ontstaan en derhalve het aansprakelijkheidsrecht moet worden toegepast. Daamaast kan met behulp van verzekering een kostenbesparing worden bereikt bij de regeling van aansprakelijkheid en de schade na een verkeersongeval. Verzekeraars hebben evenals de professionele rechtshulpverleners, zoals de (letselschade)

1128. Paragraaf 6 van hoofdstuk 7 
advocatuur, veel ervaring met schaderegelen. Zij kunnen gezamenlijk een kostbare gerechtelijke procedure vermijden.

\section{Aansprakelijkheid, verzekering, veiligheidsregulering en de optimale preventie en compensatie van verkeersongevallen}

Vanuit de economische analyse kan worden gesteld dat ten aanzien van de optimale preventie en compensatie van verkeersongevallen geen 'first best' oplossing mogelijk is. Dit hangt samen met de informatieproblemen, de invloed van belangengroepen en de administratieve kosten. In deze paragraaf zal derhalve een aantal 'second best combinaties van aansprakelijkheid, verzekering en veiligheidsregulering worden besproken.

1. In de eerste plaats kan worden geopteerd voor een regel van risicoaansprake. lijkheid met een absoluut eigen schuldverweer, waarbij aan de zijde van de autobestuurder een aansprakelijkheidsverzekering aanwezig is en de fietser beschilt over een schadeverzekering. Hierbij wordt verondersteld dat de invloed van de autobestuurder op het ongevalsrisico hoger is dan die van de fietser. Veiligheids. regulering is daarbij wenselijk op die terreinen die niet door aansprakelijkheid en verzekering worden geregeld maar wel voor een additionele preventie kunnen zorgen mits de handhaving (sancties) goed wordt geregeld. Voorbeelden hiervan zijn de regulering van de maximumsnelheid, alcoholgebruik, autoveiligheid en fietsverlichting, maatregelen met betrekking tot verkeersinstallaties en weginrichting en regelgeving (accijns, belasting) waarmee het activiteitsniveau van de autobestuurder kan worden gereguleerd.

2. In de tweede plaats zou van de hypothese kunnen worden uitgegaan dat de itvloed van de autobestuurder en de fietser op het ongevalsrisico als meer gelijkwaardig wordt verondersteld. Dit betekent dat kan worden gekozen voor een regel van foutaansprakelijkheid gecombineerd met een aansprakelijkheidsverze kering (autobestuurder) en een schadeverzekering (fietser). Veiligheidsregulering is daarbij noodzakelijk voor een verdere preventie van verkeersongevallen, marr ook om het suboptimale activiteitsniveau van de autobestuurder beter te kunnen sturen.

Met betrekking tot het onderscheid tussen risico- en foutaansprakelijkheid dient aanvullend te worden opgemerkt dat bij risicoaansprakelijkheid de fietser zjn schade in beginsel vergoed krijgt van de aansprakelijkheidsverzekeraar van de autobestuurder. Bij foutaansprakelijkheid doet de fietser eerder een beroep op zijn eigen schadeverzekering met dien verstande dat hij hiervoor zelf de premile betaalt. Voor de vraag of een verkeersslachtoffer (fietser) optimaal word gecompenseerd is het onderscheid tussen risico- en foutaansprakelijkheid derbalie van minder belang. Het is veeleer een distributionele kwestie wie de kosten vil 
de verzekering dient te dragen; onder beide aansprakelijkheidsregels kan echter een verzekeringsdekking worden gevonden die compensatie aan het slachtoffer biedt. Hierbij geldt overigens de veronderstelling dat met een schadeverzekering dezelfde schade wordt gedekt dan met een aansprakelijkheidsverzekering.

3. In de derde plaats kan worden gekozen voor een, via de private verzekeringsmarkt, aangeboden no-fault verzekering aan de zijde van de autobestuurder, gecombineerd met een strikte veiligheidsregulering. Daarbij ligt de nadruk op een optimale compensatie van zowel de fietser als de autobestuurder tegen de laagst mogelijke kosten en wordt verondersteld dat de autobestuurder een grotere invloed op het ongevalsrisico kan uitoefenen. Binnen een dergelijk systeem rust, als gevolg van de afschaffing van de aansprakelijkheid, een belangrijke verantwoordelijkheid bij de no-fault verzekeraar wat betreft de preventie van verkeersongevallen. Deze zal ten behoeve van een controle van het morele risico maatregelen moeten nemen die, los van de schuldvraag, het gedrag van de verzekerde autobestuurder kunnen beïnvloeden. Een strikte handhaving van de veiligheidsregulering is noodzakelijk om het gedrag van de autobestuurder verder te sturen, maar vooral ook om het niet-gemotoriseerde verkeer tot zorgvuldig gedrag aan te zetten. Bij dit laatste kan worden gedacht aan het direct beboeten van verkeersovertredingen, bijvoorbeeld het rijden zonder licht of het negeren van een rood verkeerslicht. In verband met de kosten van handhaving kan daarbij mogelijk alleen worden gekozen voor een steekproefsgewijze controle.

4. Een vierde optie, ten slotte, is een eerste partij no-fault verzekering voor alle verkeersdeelnemers, waarbij de nadruk ligt op een optimale compensatie van alle verkeersslachtoffers. De verantwoordelijkheid van de no-fault verzekeraar is bij een dergelijk systeem meer gespreid en de controle van het morele risico kan beter worden uitgevoerd, gegeven het eerste partij karakter van een dergelijke verzekering. Een strikte handhaving van de veiligheidsregulering blijft ook hier noodzakelijk om het gedrag van de verkeersdeelnemer verder te sturen.

\section{Belangrijke toetsvragen voor het empirisch onderzoek}

Naar aanleiding van de voorgaande theses en opmerkingen kan een aantal vragen Horden geformuleerd die, ten behoeve van het empirisch onderzoek, in het volgende deel nader zullen worden uitgewerkt.

1. Kunnen aansprakelijkheidsregels invloed uitoefenen op het gedrag van verkeersdeelnemers?

2. Wanneer het antwoord op de voornoemde vraag bevestigend luidt, is daarbij dan een onderscheid in aansprakelijkheidsregels van belang?

3. Op welke wijze wordt door een systeem van aansprakelijkheid en verzekering recht gedaan aan een optimale compensatie van verkeersslachtoffers? 
4. Wanneer wordt gesteld dat verzekering zowel de preventieve als compensatoin rol van het aansprakelijkheidsrecht heeft overgenomen, welke preventieve mas: regelen worden dan door autoverzekeraars genomen om het morele risico te $\mathrm{con}_{\mathrm{n}}$. troleren?

5. Wordt door autoverzekeraars voldoende gebruik gemaakt van een ex ante premiedifferentiatie en van een ex post controle van het verkeersgedrag?

6. Heeft de concurrentie binnen de markt voor autoverzekering een positieve invloed op de preventie van verkeersongevallen?

7. Welke vormen van veiligheidsregulering worden gebruikt om het verkeersgedrag te beïnvloeden en wat is het effect van deze maatregelen?

8. Zal de invoering van een no-fault verzekering leiden tot een stijging van het aantal verkeersongevallen en verkeersslachtoffers?

9. Welke voordelen heeft een no-fault verzekering ten opzichte van het aarsprakelijkheidsrecht met betrekking tot de vergoeding van verkeersslachtoffers en de administratieve kosten van het systeem? 


\section{Deel III: \\ Het economisch model empirisch getoetst}

In deel II van dit onderzoek is een theoretisch model ontwikkeld en gepresenteerd met betrekking tot de economische analyse van het verkeersongevallenrecht. In hoofdstuk 8 is naar aanleiding van deze analyse en binnen het kader van de probleemstelling een aantal conclusies gepresenteerd, alsmede een aantal vragen geformuleerd die in dit deel III empirisch zullen worden getoetst. Daarbij zal worden onderzocht of het recht, in de vorm van aansprakelijkheidsregels, verzekeringsvoorwaarden en veiligheidsregulering van invloed kan zijn op het gedrag van de verkeersdeelnemer. De centrale vraag die uiteindelijk ook in dit deel moet worden beantwoord is welke combinatie van aansprakelijkheid, verzekering en veiligheidsregulering kan bijdragen aan een optimale preventie van verkeersongevallen en aan een optimale compensatie van verkeersslachtoffers. Hierbij zal tevens worden nagegaan of de conclusies die naar aanleiding van het empirisch onderzoek worden gemaakt, overeenkomen met de theoretische conclusies van deel II of dat deze laatste mogelijk aanpassing behoeven.

Het empirisch onderzoek zal bestaan uit een weergave en een kritische bespreking van reeds beschikbaar onderzoeksmateriaal en niet uit eigen onderzoek, omdat dit laatste binnen het bestek van dit onderzoek niet mogelijk is. Het onderzoeksmateriala is onder andere afkomstig uit de Verenigde Staten, Canada, Australië, Nieuw Zeeland, Engeland en Nederland. Dit betekent dat het empirisch onderzoek mede een rechtsvergelijkende component bevat. Daarbij zullen de verschillende rechtsstelsels niet uitvoerig worden geanalyseerd, maar zal worden volstaan met een korte uiteenzetting van het relevante rechtssysteem. Met het empirisch onderzoek wordt slechts beoogd om aan de hand van statistisch materiaal na te gaan of de juridische instrumenten van invloed kunnen zijn op het gedrag van een verkeersdeelnemer, en op de kosten van verkeersongevallen. Daarbij zal steeds worden nagegaan bij welke van de theoretisch gemaakte veronderstellingen het empirisch onderzoek aansluiting vindt. Een in dat kader verricht literatuuronderzoek heeft geresulteerd in een kleine 100-tal artikelen uit de periode 1975-1996 waarvan de statistische data de periode 1967-1992 beslaan.

De structuur van het empirisch onderzoek zal sterk aansluiten bij dat van het voorgaande theoretische deel. Dit betekent dat de drie instrumenten uit de probleemstelling stapsgewijs zullen worden geanalyseerd. In de eerste plaats zal worden onderzocht of er bewijs voorhanden is voor de theoretische veronderstelling dat het aansprakelijkheidsrecht preventief kan werken ten aanzien van bepaalde verkeersgedragingen (hoofdstuk 10).

In de tweede plaats dient de vraag te worden beantwoord of, in het kader van het toenemende belang van de verzekering, de preventieve werking van aansprakelijkheidsregels door verzekering wordt overgenomen. Dit betekent dat de aandacht 
voornamelijk zal uitgaan naar de inhoud van de verzekeringsvoorwaarden. De va gen die daarbij in hoofdstuk 11 aan de orde komen, houden verband met de effect. viteit van de controle van het morele risico, de mate van risicodifferentiatie en de in. vloed van het regresrecht. Verder zal in dit hoofdstuk onderzoek aan de orde komen waarin de effecten van overheidsregulering op de werking van de verzekeringsmaris worden geanalyseerd.

In de derde plaats zal worden bekeken wat de invloed is van directe veiligheid. regulering op het gedrag van een verkeersdeelnemer (hoofdstuk 12). Daarbij zal de aandacht uitgaan naar de effecten van maatregelen die de passieve veiligheid var auto's kunnen verhogen, zoals het gebruik van de autoveiligheidsgordel en de airtag Daarnaast zal worden onderzocht wat de effecten zijn van bepaalde vormen van ver. keersregulering op het verkeersgedrag en het aantal verkeersongevallen, zoals en maximumsnelheid en het rijden onder invloed.

In de vierde plaats tenslotte, zal een overzicht worden geboden van de onderzoekssesultaten naar de effecten van de verschillende no-fault systemen (hoofdstuk 13.) Daarbij zal worden onderzocht welke voor- en nadelen een no-fault verzekerng heeft ten opzichte van het aansprakelijkheidsrecht op het terrein van de preventie, de compensatie en de administratieve kosten. ${ }^{1129}$

Na de voorgaande stapsgewijze behandeling, waarbij daar waar mogelijk reeds onderlinge verbanden zijn gelegd, zullen in hoofdstuk 14 de resultaten van het emplrisch onderzoek worden teruggekoppeld naar de centrale probleemstelling. Darabij zal worden nagegaan in hoeverre een gecombineerd gebruik van de drie juridische instrumenten, binnen het kader van preventie en compensatie, wenselijk is. Aan de hand van de conclusies van het empirisch onderzoek kan dan tevens de vraag worden beantwoord of een aanpassing van de theoretische conclusies van deel I noodiz. kelijk is.

1129. In paragraaf 6.4 van hoofdstuk 6 is reeds een theoretische uiteenzetting gegeven van een not. verzekering. 


\section{Hoofdstuk 9: Verkeersongevallen: algemeen}

\section{Inleiding}

Alvorens de preventieve werking van aansprakelijkheid, verzekering en veiligheidsregulering nader empirisch te toetsen, zal in dit hoofdstuk eerst een aantal algemene aspecten van verkeersongevallen aan de orde komen. Daartoe zal in paragraaf 2 worden aangevangen met een presentatie van een aantal statistische gegevens ten aanzien van het aantal verkeersongevallen en verkeersslachtoffers. Deze gegevens hebben met name betrekking op landen die verderop in het empirisch onderzoek uitgebreider aan bod zullen komen. In paragraaf 3 zal een aantal studies worden geanalyseerd die meer specifiek het verkeersgedrag en het ongevalsrisico onderzoeken. Daarbij zijn onder andere de volgende vragen van belang: Welke verkeersdeelnemers vormen een hoog ongevalsrisico? Hoe schat een verkeersdeelnemer bijvoorbeeld zijn eigen ongevalsrisico in? In paragraaf 4 tenslotte, zullen de resultaten van dit onderzoek worden vertaald naar de eerder gemaakte theoretische veronderstellingen, waarbij tevens de vraag zal worden beantwoord welke middelen kunnen worden aangewend om het verkeersgedrag te beïnvloeden.

\section{De cijfers omtrent verkeersongevallen}

Zoals aangegeven zal het empirisch materiaal voornamelijk afkomstig zijn uit de Verenigde Staten, Canada, Australië, Nieuw Zeeland, Nederland en Engeland, België en Frankrijk. In deze paragraaf zullen de cijfers omtrent verkeersongevallen van deze landen met elkaar worden vergeleken, waarbij de verschillende rechtssystemen derhalve in perspectief kunnen worden geplaatst. Voor de 'Europese' overzichtelijkheid zijn de gegevens van Denemarken, Duitsland, Zweden en Zwitserland toegeroegd.

De cijfers die ten aanzien van verkeersongevallen en verkeersslachtoffers worden gepresenteerd, zijn mede ontleend aan 'De statistieken van Verkeersongevallen in Europa en Noord-Amerika', samengesteld door de Verenigde Naties. ${ }^{1130}$ In dat kader is hiema in een drietal tabellen een aantal algemene statistische gegevens tegen elkaar afgezet. Bij elke tabel zal een korte inhoudelijke uitleg worden gegeven, waarna een analyse van de daarin opgenomen cijfers volgt. Ten aanzien van tabel 1 en 2 is geprobeerd om de verhouding in de tijd uiteen te zetten, namelijk de periode tus-

1130. Statistics of Road Traffic Accidents in Europe and North America, 1995, p. 1-121. 
sen 1980 en 1992. In tabel 3 is een aantal specifieke aspecten weergegeven betrekking hebben op het, willekeurig gekozen, jaar $1992 .^{1131}$

Tabel 1

\begin{tabular}{|c|c|c|c|c|c|c|c|}
\hline \multirow[t]{2}{*}{ Land } & \multirow[t]{2}{*}{$\begin{array}{l}\text { 1. Onge- } \\
\text { vallen }\end{array}$} & \multirow[t]{2}{*}{$\begin{array}{l}\text { 2. ver- } \\
\text { keers- } \\
\text { doden }\end{array}$} & \multirow[t]{2}{*}{$\begin{array}{l}\text { 3. wijzi- } \\
\text { ging au- } \\
\text { topark }\end{array}$} & \multicolumn{4}{|c|}{$\begin{array}{l}\text { 4. Verkeersdoden 1980/1992 naar att } \\
\text { gorie van verkeersdeelname }\end{array}$} \\
\hline & & & & $\begin{array}{l}\text { a. voet- } \\
\text { ganger }\end{array}$ & b. fietser & $\begin{array}{c}\text { c. bestuur- } \\
\text { der }\end{array}$ & $\begin{array}{l}\text { d. pars } \\
\text { segier }\end{array}$ \\
\hline Amerika & $\stackrel{+}{+}$ & $23, \overline{2} \%$ & & $31,3 \%$ & $25,2 \%$ & $21,6 \%$ & $\dot{2} \cdot 4 \%$ \\
\hline Canada & $5,0 \%$ & $35,9 \%$ & & --- & $\ldots$ & - & - \\
\hline België & $8,6 \%$ & $30,2 \%$ & $+27,3 \%$ & $54,0 \%$ & $39,0 \%$ & $19,6 \%$ & $27,0 \%$ \\
\hline Denemarken & $20,0 \%$ & $\overline{16,4 \%}$ & $+15,5 \%$ & $\overline{-}$ & $\overline{1,2 \%}$ & $4,3 \%$ & $42,6 \%$ \\
\hline Duitsland & $\begin{array}{c}+ \\
4,3 \%\end{array}$ & $-\overline{18,5 \%}$ & $+38,0 \%$ & $42,9 \%$ & $20,7 \%$ & $9,0 \%$ & $10,9 \%$ \\
\hline Engeland & $\overline{6,8 \%}$ & $29,8 \%$ & $+40,2 \%$ & $31,5 \%$ & $33,2 \%$ & $28,0 \%$ & $26,8 \%$ \\
\hline Frankrijk & $40,5 \%$ & $26,7 \%$ & $+25,6 \%$ & $46,7 \%$ & $\overline{47,0 \%}$ & $\dot{-}, 9 \%$ & $30,5 \%$ \\
\hline Nederland & $\overline{16,9 \%}$ & $35,7 \%$ & $+24,4 \%$ & $48,5 \%$ & $41,1 \%$ & $27,5 \%$ & $38,6 \%$ \\
\hline Zweden & $\begin{array}{c}+ \\
2,5 \%\end{array}$ & $10,5 \%$ & $+24,4 \%$ & $\begin{array}{l}+ \\
3,8 \%\end{array}$ & $32,1 \%$ & $\begin{array}{c}+ \\
5,2 \%\end{array}$ & $35,9 \%$ \\
\hline Zwitserland & $9, \overline{3} \%$ & $33,1 \%$ & $+37,9 \%$ & $43,5 \%$ & $28,6 \%$ & $25,8 \%$ & $40,5 \%$ \\
\hline
\end{tabular}

De eerste drie kolommen in tabel $1^{1132}$ geven een overzicht van de procentuele wijz gingen in respectievelijk het aantal verkeersongevallen met letsel, het antal vir

1131. Een argument voor het jaar 1992 zou kunnen zijn dat de Duitse eenwording reeds cen amatij ren een feit was, zodat de cijfers meer accuraat zijn. Daamaast kan gelden dat voor 1992 th meeste statistische gegevens voor de onderzochte landen voorhanden waren, noodzakelifi on een representatief beeld te kunnen schetsen.

Gegevens zijn ontleend aan Statistics of Road Traffic Accidents in Europe and North Amonit 1995 , p. 7-9 (kolom 1); p. 10-12 (kolom 2); p. 98-100 (kolom 3); p. $52-93$ (kolom 4). 
keersdoden en de omvang van het autopark in de genoemde landen tussen 1980 en 1992. Kolom 4 geeft de procentuele wijziging weer in het aantal verkeersdoden per categorie verkeersdeelnemer tussen 1980 en 1992 . Hierbij is onderscheid gemaakt naar voetganger, fietser, alsmede naar de bestuurder en passagier van een motorrijuig.

Narr anleiding van de cijfers uit tabel 1 kan allereerst kan worden gesteld dat het antal verkeersongevallen met letsel tussen 1980 en 1992 in vrijwel alle genoemde landen is gedaald (tabel 1, kolom 1). De stijging van het aantal verkeersongevallen in Duitsland kan mede worden verklaard door de samenvoeging van Oost- en WestDuitsland in 1990, waarmee het aantal verkeersongevallen in beide landen vanaf 1991 bij elkaar is opgeteld. ${ }^{1133}$ De relatief sterke stijging van het aantal verkeersongevallen in Amerika (161\%) en de relatief sterke daling in Frankrijk (40\%) is opvallend. Verder geldt dat tussen 1980 en 1985 en nà 1990 in de meeste landen het aantal verkeersongevallen met letsel daalde, terwijl tussen 1985 en 1990 sprake was van een toename van het aantal verkeersongevallen. ${ }^{1134}$

In de tweede plaats kan worden geconstateerd dat, ondanks een bijna evenredig sterke stijging van het aantal auto's (tabel 1, kolom 3 ), het aantal verkeersdoden in de geanalyseerde landen tussen 1980 en 1992 scherp is gedaald (tabel 1, kolom 2). Voor wat betreft het aantal verkeersdoden is in de meeste landen sprake van een dalende trend vanaf 1980, waarbij zich met name tussen 1980 en 1985 een relatief sterke daling voordeed. Vanaf 1985 was de daling minder scherp. Sommige landen hadden echter te maken met een meer grillig verloop van het aantal dodelijk verkeersslachtoffers. Dit uitte zich veelal in een sterke daling van het aantal verkeersdoden tot 1985 , een lichte stijging tot 1990 , waarna weer een scherpe daling volgde. ${ }^{1135}$

In de derde plaats is ook ten aanzien van het onderscheid naar categorie verkeersdeelnemer (tabel 1, kolom 4) sprake van een relatief sterke daling van het aantal dodelijke verkeersslachtoffers. Of ook hier gesproken kan worden van een trend is aan de hand van de beschikbare gegevens moeilijk te beoordelen. In een aantal landen zet de daling zich voort in 1993; in andere landen stijgt het aantal verkeersdoden

\footnotetext{
1133. Dit wordt ook in de statistieken aangegeven. Zie Statistics of Road Traffic Accidents in Europe and North America, 1995, p. 8, noot 1.

1134. Statistics of Road Traffic Accidents in Europe and North America, 1995, p. 7=9.

1135. Met name België, Engeland en Zwitserland vertoonden een grillig verloop in het aantal dodelijke verkeersslachtoffers. Mede als gevolg van de Duitse eenwording was in Duitsland voomamelijk tussen 1990 en 1992 sprake van een sterke stijging van het aantal verkeersdoden. Zie Statistics of Road Traffic Accidents in Europe and North America, 1995, p. 10-12. Recente cijfers geven aan dat tussen 1992 en 1997 in Belgie $(-31 \%)$, Duitsland $(-20 \%)$, Frankrijk $(-11,5 \%)$, Engeland $(-15 \%)$ en Nederland $(-9,5 \%)$ het aantal verkeersdoden verder is gedaald. Zie Comiteé Europeen des Assurance, ECO, nr. 6, 1998, p. 35
} 

weer, met name onder bestuurders en passagiers van respectievelijk een motor ta
een auto. ${ }^{1136}$

Tabel 2

\begin{tabular}{|c|c|c|c|c|c|c|c|c|c|c|}
\hline Land & VS. & CND. & BEL. & DK. & DLD. & ENG. & FRA. & NL. & ZWE. & $\mathrm{ZWl}$ \\
\hline \multirow{2}{*}{$\begin{array}{l}\text { 1. voetganger } \\
1980 / 1992 \\
\text { in } \%\end{array}$} & 15,8 & $\cdots$ & 21,2 & 20,0 & 23,7 & 32,9 & 17,6 & 14,8 & 15,7 & $2,1,0$ \\
\hline & 14,1 & 12,6 & 13,9 & 19,2 & 16,6 & 31,9 & 12,8 & 11,8 & 18,2 & 17,7 \\
\hline \multirow{2}{*}{$\begin{array}{l}\text { 2. fietser } \\
1980 / 1992 \\
\text { in } \%\end{array}$} & 1,9 & -- & 10,1 & 12,2 & 8,8 & 5,1 & 5,3 & 21,3 & 13,2 & 6,2 \\
\hline & 1,8 & 2,1 & 8,8 & 14,4 & 8,5 & 4,8 & 3,8 & 19,5 & 10,0 & 6,6 \\
\hline \multirow{2}{*}{$\begin{array}{l}\text { 3. passagier } \\
1980 / 1992 \\
\text { in } \%\end{array}$} & 25,9 & --- & 18,9 & 24,5 & 20,2 & 19,9 & 25,3 & 18,2 & 25,6 & 224 \\
\hline & 26,2 & 29,0 & 19,7 & 16,8 & 22,1 & 20,6 & 24,0 & 17,4 & 18,3 & 199 \\
\hline \multirow{2}{*}{$\begin{array}{l}\text { 4. bestuurder } \\
1980 / 1992 \\
\text { in } \%\end{array}$} & 56,4 & --- & 49,9 & 43,3 & 47,3 & 42,1 & 51,8 & 45,7 & 45,5 & 50,4 \\
\hline & 57,6 & 56,3 & 57,5 & 49,6 & 52,8 & 42,8 & 59,4 & 51,5 & 53,5 & 559 \\
\hline \multirow{2}{*}{$\begin{array}{l}\text { 5. 0-14 jaar } \\
1980 / 1992 \\
\text { in } \%\end{array}$} & 5,6 & -- & 7,3 & 7,2 & 7,8 & 8,1 & 6,8 & 10,2 & 8,4 & 6,3 \\
\hline & 6,8 & 6,7 & 5,4 & 5,0 & 4,5 & 6,4 & 4,4 & 7,2 & 4,9 & 412 \\
\hline \multirow{2}{*}{$\begin{array}{l}\text { 6. 15-24 jaar } \\
1980 / 1992 \\
\text { in } \%\end{array}$} & 28,8 & --- & 36,1 & 31,9 & 32,7 & 26,5 & 31,4 & 30,3 & 20,5 & 27,1 \\
\hline & 25,8 & 25,5 & 27,6 & 25,1 & 27,0 & 26,0 & 28,8 & 23,7 & 20,4 & 248 \\
\hline \multirow{2}{*}{$\begin{array}{l}\text { 7. } 25-64 \text { jaar } \\
1980 / 1992 \\
\text { in } \%\end{array}$} & 44,1 & --- & 45,4 & 36,1 & 38,5 & 36,7 & 45,3 & 36,4 & 46,8 & 425 \\
\hline & 50,9 & 51,8 & 49,8 & 45,4 & 51,8 & 44,1 & 51,3 & 44,7 & 46,8 & 48.2 \\
\hline \multirow{2}{*}{$\begin{array}{l}8.65+ \\
1980 / 1992 \\
\text { in } \%\end{array}$} & 20,6 & --- & 10,5 & 24,8 & 21,0 & 22,8 & 15,5 & 23,1 & 24,3 & 24. \\
\hline & 16,2 & 15,5 & 16,6 & 24,4 & 16,6 & 23,2 & 15,1 & 24,3 & 27,9 & 228 \\
\hline \multirow{2}{*}{$\begin{array}{l}\text { 9. per } 1000 \\
\text { auto's } \\
1980 / 1992\end{array}$} & 0,38 & 0,53 & 0,76 & 0,50 & 0,56 & 0,40 & 0,65 & 0,44 & 0,29 & 0,55 \\
\hline & 0,23 & 0,28 & 0,42 & 0,36 & 0,33 & 0,20 & 0,38 & 0,23 & 0,21 & 0.27 \\
\hline
\end{tabular}

Tabel $2^{1137}$ geeft een overzicht van het aantal verkeersdoden in verhouding tot tht totaal aantal verkeersdoden, waarbij onderscheid is gemaakt naar de wijze van ver

1136. Deze trend deed zich ondere andere voor in Denemarken, Frankrijk, Nederland en Amenta 2 Statistics of Road Traffic Accidents in Europe and North America, 1995, p. 52-93, in hel bjot: der p. 62, 65, 77 en 93 . 
keersdeelname en naar leeftijd. Verder is het aantal verkeersdoden per 1000 auto's in deze tabel opgenomen (rij 9). Bij alle categorieën is een vergelijking gemaakt tussen de situatie in 1980 en 1992. Ten aanzien van de wijze van verkeersdeelname is een onderscheid gemaakt naar voetganger, fietser, bestuurder en passagier van een motorrijtuig (rij 1-4). Ten aanzien van de leeftijd van de verkeersdeelnemer is een onderverdeling gemaakt in vier categorieën, namelijk 0-14 jaar, 15-24 jaar, 25-64 jaar en 65+(rij 5-8).

Uit de gegevens in tabel 2 blijkt onder meer dat het gezamenlijke aandeel van voetgangers, fietsers en passagiers (niet-gemotoriseerde verkeersdeelnemers) in verhouding tot het totaal aantal dodelijke verkeersslachtoffers in de meeste landen is gedaald. ${ }^{1138}$ Tegenover deze daling staat echter een stijging van het aantal dodelijke verkeersslachtoffers onder de bestuurders van een motorrijtuig. In 1992 was een meerderheid van het aantal dodelijke slachtoffers in alle landen, behalve in Denemarken en Engeland, bestuurder van een motorrijtuig.

Ook ten aanzien van de gemaakte onderverdeling naar leeftijd is tussen 1980 en 1992 een verschuiving opgetreden. In de meeste landen is het aantal dodelijke verkeersslachtoffers in de leeftijd van $0-24$ jaar gedaald. Hierbij moet wel worden opgemerkt dat het aantal dodelijke slachtoffers tussen 0 en 17 jaar in alle landen vrij scherp is gedaald. Het aantal dodelijke slachtoffers in de leeftijdsgroep van 18-24 jaar is echter naar verhouding licht gedaald en in sommige landen zelfs gestegen, met name onder bestuurders van een motorrijtuig in deze leeftijdsgroep. Ten aanzien van de grootste categorie verkeersdeelnemers, 25-64 jaar, is het aantal dodelijke verkeersslachtoffers daarentegen gestegen. Het aandeel van deze leeftijdsgroep in het totaal is daarnaast in een aantal landen zelfs gegroeid tot rond de $50 \%$. De categorie oudere verkeersdeelnemers, boven 65 jaar, vertoont een meer wisselend beeld. Binnen deze leeftijdsgroep is veelal sprake van een lichte stijging of daling van het aantal verkeersdoden. Met betrekking tot deze leeftijdsgroep valt verder op dat het percentage verkeersdoden in een aantal landen ongeveer $25 \%$ bedraagt, terwijl deze groep vermoedelijk minder dan een kwart van het aantal inwoners in een land telt ${ }^{1139}$

\footnotetext{
1137. Statistics of Road Traffic Accidents in Europe and North America, 1995, p. $52-93$ (rij 1-8); p.
$98-100$ (rij 9).

1138. Categorische

Zwitserland uitzonderingen worden gevormd door Zweden (voetgangers); Denemarken en

1139. Statistics (fietsers) en Amerika, Belgie, Duitsland, Engeland (passagiers).
} 
Tabel 3

\begin{tabular}{|c|c|c|c|c|c|}
\hline Land & $\begin{array}{c}\text { 1. Aantal } \\
\text { auto's per } \\
1000 \text { inwoners }\end{array}$ & $\begin{array}{c}\text { 2. Verkeersdo- } \\
\text { den per 1 mil- } \\
\text { joen inwoners }\end{array}$ & \multicolumn{3}{|l|}{$\begin{array}{c}\text { 3. Onderscheid naar type verkeers } \\
\text { ongeval, verhouding tot het total }\end{array}$} \\
\hline 1992 & $\begin{array}{c}\text { Totaal: } 523 \\
\text { Europa: } 397\end{array}$ & $\begin{array}{c}\text { Totaal: } 136 \\
\text { Europa: } 121\end{array}$ & $\begin{array}{c}\text { voetganger/ } \\
\text { voertuig }\end{array}$ & $\begin{array}{c}\text { voertuig/ } \\
\text { eenzijdig }\end{array}$ & $\begin{array}{c}\text { voertuig/ } \\
\text { voertuig }\end{array}$ \\
\hline Amerika & 650 & 152 & $1,4 \%$ & $29,5 \%$ & $70,0 \%$ \\
\hline Canada & 437 & 123 & $-\cdots$ & $\cdots$ & - \\
\hline België & 399 & 166 & $8,1 \%$ & $21,6 \%$ & $70,3 \%$ \\
\hline Denemarken & 310 & 111 & $13,7 \%$ & $23,3 \%$ & $63,0 \%$ \\
\hline Duitsland & 395 & 131 & $11,1 \%$ & $26,1 \%$ & $62,8 \%$ \\
\hline Engeland & 387 & 77 & $21,3 \%$ & $14,4 \%$ & $64,3 \%$ \\
\hline Frankrijk & 416 & 157 & $15,3 \%$ & $20,0 \%$ & $64,7 \%$ \\
\hline Nederland & 374 & 85 & $8,4 \%$ & $19,7 \%$ & $71,9 \%$ \\
\hline Zweden & 411 & 87 & $8,6 \%$ & $22,7 \%$ & $68,7 \%$ \\
\hline Zwitserland & 445 & 120 & $12,2 \%$ & $9,7 \%$ & $78,1 \%$ \\
\hline
\end{tabular}

De gegevens in tabel $3^{1140}$ zijn toegespitst op het jaar 1992. Kolom 1 en 2 geven fespectievelijk het aantal auto's per 1000 inwoners en het aantal verkeersdoden per ! miljoen inwoners weer. Kolom 3 bevat een overzicht van de verhouding tussen het aantal ongevallen van een bepaald type en het totaal aantal verkeersongevallen Hierbij is onderscheid gemaakt naar respectievelijk een ongeval tussen een votganger en een voertuig (inclusief fiets), een eenzijdig verkeersongeval van een voettil (inclusief fiets), en een ongeval tussen een of meerdere voertuigen (inclusief fiets).

Uit de gegevens in tabel 3 kan allereerst worden opgemaakt dat het gemiddeld antal auto's per 1000 inwoners (kolom 1) over alle Europese landen gemeten 397 be draagt. De meeste Europese landen bevinden zich voor wat betreft deze autodicht. heid rond het Europees gemiddelde, terwijl Denemarken (310) en Zwitserland(45) een duidelijk lagere respectievelijk hogere autodichtheid kennen.

In de tweede plaats is het aantal verkeersdoden per 1 miljoen inwoners van alle Europese landen in tabel 3 (kolom 2) gezamenlijk 121. België (166) en Frantitili

1140. Gegevens zijn ontleend aan Statistics of Road Traffic Accidents in Europe and North Amatio 1995, p. 98-100, 106-108 (kolom 1); p. 10-12, 106-108 (kolom 2); p. 38-51 (kolom 3). 
(157) zitten daarbij duidelijk boven dit gemiddelde, terwijl Engeland (77), Nederland (85) en Zweden (87) zich beneden het Europees gemiddelde bevinden.

In de derde plaats is in tabel 3 (kolom 3 ) met betrekking tot het totaal aantal verkeersongevallen een onderverdeling gemaakt naar ongevallen tussen een voetganger en een voertuig (inclusief fiets), eenzijdige voertuigongevallen (inclusief fiets) en ongevallen tussen twee of meerdere voertuigen (inclusief fiets). Over de cijfers in tabel 3 kan echter moeilijk een relevant oordeel worden gegeven ten aanzien van de oorzaak van bepaalde verschuivingen, aangezien deze niet altijd bekend zijn. Wanneer voomamelijk wordt gekeken naar de Europese landen kunnen in het kader van tabel 3 hooguit enkele opvallende aspecten worden genoemd. Deze hebben betrekking op het hoge percentage verkeersongevallen $(21,3 \%)$ tussen een voetganger en een voertuig in Engeland, ${ }^{1141}$ het lage percentage eenzijdige verkeersongevallen $(9,7 \%)$ in Zwitserland en het hoge percentage verkeersongevallen tussen een of meerdere voertuigen in Zwitserland $(78,1 \%)$ en Nederland $(71,9 \%)$. Dit laatste kan mogelijk worden verklaard doordat ook een fiets in deze gegevens als een voertuig wordt beschouwd, zodat ook het relatief hoge aantal verkeersdoden onder fietsers in Nederland in het genoemd percentage is verdisconteerd.

Samenvattend kan op grond van de statistische gegevens worden gesteld dat tussen 1980 en 1992 in alle geanalyseerde landen, met uitzondering van de VS en (Oost) Duitsland, het aantal verkeersongevallen met letsel en het aantal dodelijke verkeersslachtoffers, ondanks een toename van de autodichtheid, is gedaald. Daarbij is met name vanaf 1990 sprake van een algemeen dalende trend, die zich in de meeste landen ook in 1993 voortzet. Dat het aantal verkeersongevallen een dalende trend vertoont, is echter slechts één aspect dat bij de empirische analyse van het verkeersongevallenrecht een rol kan spelen. De werkelijke oorzaak van de daling van het aantal verkeersongevallen en verkeersslachtoffers zal in een latere fase van dit empirisch onderzoek naar voren komen. ${ }^{1142}$

\section{Verkeersgedrag en ongevalsrisico}

In deze paragraaf zal een aantal empirische studies met betrekking tot verkeersgedrag en ongevalsrisico aan de orde komen. Daarin wordt onderzoek gedaan naar het onderscheid in gedrag van bepaalde groepen verkeersdeelnemers, het ongevalsrisico waaraan verkeersdeelnemers blootstaan en hun houding ten aanzien van het ongevalsrisico. In paragraaf $4 \mathrm{zal}$ worden nagegaan wat de betekenis van de gepresenteerde onderzoeksresultaten is voor de eerder gemaakte theoretische veronderstel-

\footnotetext{
1141. Dit kan mogelijk in verband worden gebracht met het hoge percentage verkecrsdoden onder voetgangers in Engeland, namelijk 31,9\% opgenomen in tabel 2.

1142. Zie met name hoofdstuk 12 en 13 .
} 

lingen, bijvoorbeeld ten aanzien van het zorg- en activiteitsniveau van een verkeers-
deelnemer.

\subsection{INFORMATIE EN ONGEVALSRISICO}

In een empirisch onderzoek naar de verhouding tussen informatie enerzijds en be ongevalsrisico en het verkeersgedrag anderzijds wordt uitgegaan van de veronder. stelling dat een autobestuurder in het verkeer met een grote hoeveelheid risicoinformatie wordt geconfronteerd. ${ }^{1143}$ Deze moet onder andere rekening houden ma: de hoeveelheid verkeer, de snelheid van het verkeer, zicht, weersomstandigheden, de gesteldheid van de weg, zijn eigen fysieke en geestelijke toestand en die van zijn medeweggebruikers. Dit betekent dat het voor een autobestuurder niet eenvoudigi is om alle risico's te controleren. ${ }^{1144}$

Aan de hand van een tweetal visuele experimenten trachten de onderzoekers de vraag te beantwoorden in hoeverre een verkeersdeelnemer in staat is de risico's van het verkeer te bevatten. Daarbij werden autobestuurders in een gesimuleerde vorm (foto's) geconfronteerd met een veelheid aan risicosituaties, die door hen beoordeld dienden te worden op het risicogehalte. Deze experimenten leidden bij de onderzos. kers tot de conclusie dat minder ervaren bestuurders meer op de details van bepalde verkeerssituaties en verkeersrisico's letten. De meer ervaren autobestuurders darertegen weten de risico's van het verkeer beter in te schatten, doordat zij de versctillende aspecten van verkeerssituaties kunnen integreren. Naast deze ervaring zijn volgens de onderzoekers de gevaren in het verkeer afhankelijk van de beschilbare hoeveelheid risico-informatie aan de zijde van de verkeersdeelnemer. Naarmate de verkeerssituatie complexer wordt zal ook de informatie die een verkeersdeethemer in zich op kan nemen relatief gezien verminderen. ${ }^{1145}$

De conclusie van dit onderzoek is dat meer ervaring in het verkeer tot meer zorgywdigheid en daarmee tot een daling van het ongevalsrisico leidt. Hier staat tegenora dat meer ervaring ook een hoger activiteitsniveau meebrengt, waardoor de vragg rijs of een toename van de activiteit niet tot een hoger ongevalsrisico leidt. De ervera bestuurder zal, gegeven de beschikbare informatie, mogelijk wel meer zorg aaniwr den, maar wordt deze zorg niet minder naarmate zijn activiteit toeneemt? Zal ena varen bestuurder daarnaast niet teveel op routine aan het verkeer deelnemen, meth mogelijke gevolg dat hij minder oplettend wordt en daardoor minder zorguldig? 0 ? deze vragen wordt in dit onderzoek geen concreet antwoord gegeven.

1143. Von Benda and Hoyos, Ac. An. \& Prev., 1983, p. 1-9.

1144. Von Benda and Hoyos, Ac. An. \& Prev., 1983, p. 1.

1145. Von Benda and Hoyos, Ac. An. \& Prev., 1983, p. 8-9. 
Wel kan worden gesteld dat een autobestuurder in het verkeer met een grote hoevelheid informatie wordt geconfronteerd, in het bijzonder wanneer de verkeerssituatie complexer wordt. ${ }^{1146}$ Dit kan leiden tot een informatietekort aan de zijde van de automobilist, waardoor deze geen efficiënte zorg meer zal aanwenden. Wanneer als gevolg hiervan het ongevalsrisico toeneemt, is veiligheidsregulering nodig om dit risico te verminderen. ${ }^{1147}$

\subsection{ONGEVALSRISICO EN LEEFTUD: EEN OBJECTIEVE BENADERING}

Met betrekking tot de invloed van leeftijd op het verkeersgedrag en de houding ten aanzien van het ongevalsrisico zal in deze paragraaf een viertal studies aan de orde komen, ${ }^{1148}$ waarin globaal een onderscheid wordt gemaakt tussen twee leeftijdscategorieën, namelijk 16-24 jaar en 25-50 jaar. Daamaast wordt verondersteld dat jonge automobilisten, 16-24 jaar, naar verhouding een groter risico vormen om bij een verkeersongeval betrokken te raken dan hun oudere collega's. Dit blijkt ook uit de cijfers waarnaar in deze studies wordt verwezen. In 1979 bijvoorbeeld was $22 \%$ van de Amerikaanse autobestuurders jonger dan 25 jaar, terwijl hun aandeel in het totaal aantal dodelijke verkeersslachtoffers onder autobestuurders $37 \%$ bedroeg. ${ }^{1149}$ In 1992 was dit laatste percentage gedaald tot ongeveer $27 \%$ (15-24 jaar). ${ }^{1150}$

In Canada was in 1984 het aandeel van de leeftijdscategorie 16-24 jaar in de totale bevolking $17 \%$, terwijl hun aandeel in het totaal aantal dodelijke verkeersslachtoffers $31 \%$ bedroeg. ${ }^{1151}$ In 1992 droegen de autobestuurders in deze leeftijdsgroep (1524 jar) nog voor $26,7 \%$ bij aan het totaal aantal dodelijke slachtoffers onder auto-

1146. Zie bijvoorbeeld Peirson, Skinner and Vickerman, Economica, 1998, p. 429-440, voor een empirische analyse van het verkeersgedrag van automobilisten in reactie op de toename van de verkeersstroom.

1147. Zie paragraaf 3.3 van hoofdstuk 7 .

1148. Finn and Bragg, Ac. An. \& Prev,, 1986, p. 289-298; Jonah, Ac. An. \& Prev., 1986, p. 255-271 Hierin wordt overigens geen eigen empirisch onderzoek verricht, maar meet een analyse gegeven van eerdere experimenten op het terrein van verkeersgedrag en ongevalsrisico. Matthews and Moran, Ac. An. \& Prev, 1986, p. 299-313; Risser, Ac. An. \& Prev., 1985, p. 179-197. In deze studic wordt onderzocht welke verkeersdeelnemers meer typische verkeersfouten maken die tot een verkeerscontlict zouden kunnen leiden, waarbij een verkeersconflict wordt omschreven als een soort voorstadium van een werkelijk verkeersongeval. McCormick, Walkey and Green, Ac. An. \& Prev, 1986, p. 205-208. Hierin wordt geen onderscheid naar leeftijd gemaakt, marar word de vraag beantwoord in hoeverre een autobestuurder zich, in verhouding tot een gemiddelde verkeersdeelnemer ten aanzien van zijn eigen rijeigenschappen, bekwaam acht om aan

1149. Finn and Bragg, Ac. An. \& Prev., 1986, p. 289. Cijfers zijn ontleend aan U.S. Department of
Transportation, Fel tije

1150. Zransportation, Fatal Accident Reporting System, 1979, p. 3.
115!. Jonah, Ac. An of Road Traffic Accidents in Europe and North America, 1995, p. 93.

115!. Jonah, Ac. An. \& Prev., 1986, p. 255. 
bestuurders. ${ }^{1152}$ Een vergelijking met een aantal Europese landen leert dat de gege. vens voor 1992 niet veel afwijken van de cijfers in Amerika en Canada. Het percen. tage dodelijke verkeersslachtoffers onder autobestuurders in de leeftijdscategorie 18 . 24 jaar ten opzichte van het totaal aantal dodelijke slachtoffers onder autobestur ders was respectievelijk 26,3\% voor België, 25\% voor Frankrijk, 31\% voor Duits land, $23,5 \%$ voor Nederland en $27,1 \%$ voor Engeland. ${ }^{\text {IIS3 }}$

De bovengenoemde cijfers bevestigen de veronderstelling dat jonge autobesturder een relatief hoog ongevalsrisico vormen. Binnen de eerdergenoemde studies word vervolgens gezocht naar de oorzaak van deze oververtegenwoordiging van jongeavtobestuurders in het totaal aantal verkeersslachtoffers. Daarbij wordt aan de hand van een aantal experimenten de veronderstelling, dat jonge bestuurders geneigd zin meer risico's te nemen in het verkeer, getoetst. Bij deze experimenten word gebril gemaakt van foto's en video's van verkeerssituaties en van vragenlijsten, waarin gen met betrekking tot het ongevalsrisico en de rijvaardigheden van de proefperson aan de orde komen. ${ }^{1154}$ Daarnaast wordt in een onderzoek gebruik gemaakt van nij. testen, waarbij het gedrag van de bestuurders in werkelijke verkeerssituaties kon worden geobserveerd. ${ }^{1155}$

Naar aanleiding van hun onderzoek komen de auteurs tot min of meer gelijkluidende conclusies aangaande het verkeersgedrag van jonge autobestuurders ten opzichte van oudere bestuurders. Cijfermatig is reeds duidelijk geworden dat jonge autobestur. ders naar verhouding meer zijn betrokken bij verkeersongevallen. De oorzak hier. van moet volgens de auteurs worden gezocht in het risicovolle gedrag van de jonge autobestuurder in verhouding tot het gedrag van de oudere bestuurder.

Jonge autobestuurders, zo bleek uit de experimenten, onderschatten het risico om zelf bij een verkeersongeval betrokken te raken. $\mathrm{Zij}$ overschatten hun eigen njjar. digheden, vooral in verkeerssituaties met een laag risicogehalte. In hoge risicosinz. ties, bijvoorbeeld het rijden met hoge snelheid, is bij jonge bestuurders veeleer spror. ke van een onderschatting van het risico. ${ }^{1156}$ Jonge autobestuurders zijn daamass

1152. Statistics of Road Traffic Accidents in Europe and North America, 1995, p. 58.

1153. Statistics of Road Traffic Accidents in Europe and North America, 1995, p. 56, 65-66, 77 a $9 \%$ Zie voor wat betreft Nederland: Brouwer, in De mens in het verkeer: de zwakste schakel?, p 59-69. Hierin wordt onder andere aangegeven dat het aantal omgekomen autobestururder in the leeftijdscategorie 18-24 jaar in verhouding tot het aantal per miljard afgelegde kilometer in 199315,4 bedroeg. Bij de leeftijdscategorie $25-64$ jaar bedroeg dit cijfer gemiddeld 3,8. Zieal Evans, Traffic Safety and the Driver, p. 25-36, voor een statistische analyse van het effart in leeftijd op het ongevalsrisico.

1154. Matthews and Moran, Ac. An. \& Prev., 1986, p. 301-303; Finn and Bragg, Ac. An. \& Pro, 1986, p. 290-291.

1155. Risser, Ac. An. \& Prev., 1985, p. 182-183.

1156. Matthews and Moran, Ac. An. \& Prev., 1986, p. 310. 
onervaren, gebruiken teveel alcohol, rijden vaak harder, dragen minder vaak de autogordel en houden minder afstand tot hun voorganger, zo wordt door de onderzoekers geconstateerd. ${ }^{1157}$

In de studie van Risser wordt aan de hand van rijtesten een positief verband aangetoond tussen bepaalde typen verkeersgedragingen, zoals een te hoge snelheid, te weinig afstand houden, het frequent boven de maximumsnelheid rijden, en verkeersconflicten waaruit een verkeersongeval kan ontstaan. Daarnaast bleek uit het experiment dat ook bestuurders die (on)bewust onhandig rijgedrag vertonen, zoals te laat invoegen, afsnijden van bochten en rechts inhalen, een grotere betrokkenheid bij verkeersconflicten hebben. Een verkeersconflict wordt daarbij omschreven als:

'An observable event which would end in an accident unless one of the involved parties slows down, changes his direction, or accelerates to avoid a collision. The later one of the parties involved reacts correspondingly, the higher the danger of a collision.. ${ }^{1158}$

De onderzoeksresultaten worden vervolgens vertaald naar een indeling in 4 leeftijdscategorieën van autobestuurders met de bijbehorende typen verkeersgedragingen en verkeersconflicten. Een eerste groep bestuurders (17,9\% van de proefpersonen) vertoonde alle gedragskenmerken die verband houden met een hoog aantal verkeersconflicten en verkeersongevallen, gemeten over een periode van 5 jaar. Deze bestuurders bevonden zich voornamelijk in de leeftijdscategorie van 18-24 jaar.

Een tweede groep bestuurders $(30,1 \%)$ reed naar verhouding iets meer kilometers en was daarnaast meer ervaren dan de bestuurders uit de eerste groep. In deze groep bevonden zich voomamelijk bestuurders uit de leeftijdscategorie 25-34 jaar, die bij veel verkeersongevallen betrokken waren, vaak met hoge snelheid reden en onvoldoende afstand hielden. $\mathrm{Zij}$ makten daarentegen minder verkeersfouten en hadden relatief weinig verkeersconflicten.

Aan een derde groep bestuurders $(23,1 \%)$ werd veelal slechte en onhandige rijkwaliteiten toegedicht. Deze bestuurders kenmerkten zich door hun vele verkeersfouten, die overigens niet vaak tot een verkeersongeval hebben geleid. Daarnaast waren zij bij een groot aantal verkeersconflicten betrokken. Tot deze groep behoren voornamelijk beginnende bestuurders en personen boven de 60 jaar.

Een vierde groep bestuurders $(28,8 \%)$ tenslotte, bestond uit de 'ideale verkeersdeelnemer'. Deze pleegde zeer weinig verkeersfouten te maken, was nauwelijks bij

\footnotetext{
1157. Jonah, Ac. An. \& Prev., 1986, p. 267-268; Finn and Bragg, Ac. An. \& Prev., 1986, p. 296-297. Zie ook Brouwer, in De mens in het verkeer: de zwakste schakel?!, p. 64-65.

1158. Risser, Ac. An. \& Prev., 1985, p. 180.
} 
verkeersconflicten betrokken en had weinig verkeersongevallen in de afgelopen viif jaar. Tot deze groep bestuurders behoorden in meerderheid personen van boven de 35 jaar $(70 \%){ }^{1}$

Uit dit onderzoek kan worden opgemaakt dat jonge autobestuurders (18-34 jaar) met relatief weinig rijervaring, die als gevolg van bepaalde verkeersfouten in conflic komen met andere weggebruikers, een grotere kans lopen om bij een verkeersongeval betrokken te raken. ${ }^{160}$ Dit komt derhalve overeen met de cijfermatige gegevens waaruit blijkt dat jonge bestuurders een hoog ongevalsrisico vormen. Dit vind zijn belangrijkste oorzaak in het rijgedrag van deze bestuurders, dat vaak gepaard gaar met een veelheid aan verkeersfouten.

\subsection{DE SUBJECTIEVE BENADERING VAN HET ONGEVALSRISICO}

Zojuist werd aangegeven dat een deel van het empirisch onderzoek naar het ongevalsrisico volgens een 'objectieve' benadering plaatsvindt, omdat de hierboven vermelde studies objectief (los van het eigen oordeel van de bestuurder) de vraag bestuderen in hoeverre het ongevalsrisico door bepaalde factoren zoals leeftijd word beinvloed. $\mathrm{Bij}$ de subjectieve benadering van het ongevalsrisico, die in deze paragrast centraal staat, wordt daarentegen gekeken naar de wijze waarop een gemiddelde verkeersdeelnemer zijn eigen ongevalsrisico inschat. Daarbij wordt globaal een orderverdeling gemaakt in een algehele subjectieve inschatting van het risico om bij een verkeersongeval betrokken te raken en de subjectieve waarneming van het risico ten aanzien van specifiek verkeersgedrag of bepaalde verkeerssituaties. ${ }^{1161}$

In de studies die in paragraaf 3.2 aan de orde zijn geweest wordt ook ingegaan op de vraag hoe autobestuurders in bepaalde leeftijdscategorieën (jong: 18-24 jaar en order: 35-50 jaar) hun eigen ongevalsrisico inschatten. ${ }^{1162}$ Daarbij lag vooral de natrik op de groep jonge autobestuurders om aan te kunnen tonen dat zij naar verhouding bij meer verkeersongevallen zijn betrokken dan oudere bestuurders. Met gebriltmi king van vragenlijsten, foto's en video's komen de onderzoekers echter ook tot ten aantal conclusies aangaande de subjectieve inschatting van het ongevalsrisico door een autobestuurder. Hoewel deze conclusies soms tegenstrijdig waren, mede als ge.

1159. Risser, Ac. An. \& Prev., 1985, p. 189-193 en 196.

1160. Zie Jonah, Ac. An. \& Prev., 1986, p. 259, die na een analyse van verschillende empirinshe of dies tot een soortgelijke conclusie komt.

1161. Jonah, Ac. An. \& Prev., 1986, p. 263.

1162. Finn and Bragg, Ac. An. \& Prev., 1986, p. 289-298; Matthews and Moran, Ac. An. \& Prot 1986, p. 299-313. Zie ook Svenson, Fischhoff and MacGregor, Ac. An. \& Prev., 1985, p. It 133, waarin een verband wordt gelegd tussen het oordeel van de autobestuurder over het tigt rijgedrag en het gebruik van de autoveiligheidsgordel. 
volg van de toepassing van verschillende onderzoeksmethoden, kan toch een aantal algemene trends worden weergegeven.

In de eerste plaats bleek uit de experimenten dat jonge autobestuurders de kans om het eerstkomende jaar bij een verkeersongeval betrokken te raken voor henzelf in het algemeen groter achten dan oudere bestuurders dat ten opzichte van zichzelf deden. Jonge autobestuurders schatten hun risico lager in dan dat van hun leeftijdgenoten, terwijl zij de kans om zelf bij een ongeval betrokken te raken ongeveer gelijk inschatten als de kans voor oudere bestuurders. Oudere bestuurders schatten hun risico ongeveer gelijk aan dat van hun leeftijdgenoten, maar achtten de kans om zelf bij een verkeersongeval betrokken te raken kleiner dan voor jongere bestuurders. ${ }^{163}$

Vervolgens wordt aan de hand van een aantal experimenten, toegespitst op specifieke verkeerssituaties, de vraag onderzocht hoe autobestuurders hun eigen bekwaamheden in het verkeer inschatten. Hieruit bleek dat jonge autobestuurders hun eigen bekwaamheden in het algemeen even hoog inschatten als die van oudere bestuurders, terwijl zij hun eigen bekwaamheden superieur achtten ten opzichte van hun leeftijdgenoten. Van een dergelijke superioriteit was bij oudere bestuurders ten opzichte van hun leeftijdgenoten geen sprake, maar zij achtten zich duidelijk bekwamer dan jonge autobestuurders. ${ }^{1164}$

Naar aanleiding van de beschreven studies aangaande ongevalsrisico en verkeersgedrag, kan in de eerste plaats worden gesteld dat jonge bestuurders volgens de ongevalsstatistieken zijn oververtegenwoordigd in het aantal dodelijke verkeersslachtoffers onder automobilisten. In de tweede plaats is met behulp van een aantal experimenten vastgesteld dat jonge autobestuurders in verhouding tot hun oudere collega's meer risico's nemen in het verkeer, meer verkeersfouten begaan en hun eigen ongevalsrisico veelal onderschatten. $\mathrm{Bij}$ oudere bestuurders was sprake van een lage subjectieve inschatting van het ongevalsrisico en een gematigd positief oordeel ten aanzien van hun eigen rijvaardigheden. Oudere bestuurders blijken voorts minder verkeersfouten te maken en zijn in het algemeen bij minder verkeersconflicten betrokken.

\footnotetext{
1163. Matthews and Moran, Ac. An. \& Prev., p. 305; Finn and Bragg, Ac. An. \& Prev., p. 292.

Matthews and Moran, Ac. An. \& Prev., 1986, p. 307 en 310-311; Finn and Bragg, Ac. An. \& Prev., 1986, p. 294-295; Jonah, Ac. An. \& Prev., 1986, p. 263-265. Zie ook McCormick, Walkey and Green, Ac. An. \& Prev., 1986, p. 205-208, waarin bleek dat ongeacht leeftijd, bijna $80 \%$ van de autobestuurders zichzelf, ten aanzien van rij-eigenschappen, bekwamer en minder risicovol inschat dan een gemiddelde autobestuurder. $\mathrm{Bij}$ dit onderzoek werd echter geen onderscheid gemaakt naar leeftijd en meer dan de helft van de proefpersonen die bij het experiment waren betrokken was jonger dan 30 jaar, een kwart was zelfs jonger dan 21 jaar. Daarnaast wordt uit dit onderzoek niet duidelijk wat onder een 'gemiddelde autobestuurder' moet worden verstaan.
} 


\subsection{VOETGANGERS EN HUN ONGEVALSRISICO}

Tot slot van deze algemene analyse van verkeersgedrag zal aandacht worden besteet aan een onderzoek, waarin een methode wordt ontwikkeld voor de berekening van het relatieve ongevalsrisico van voetgangers. ${ }^{1165}$ Dit onderzoek, waarvan de gegęvens zijn ontleend aan politierapporten, omvat een analyse van ongeveer 475 verkeersongevallen waarbij een voetganger is betrokken. Deze ongevallen hadden plaats in het jaar 1979 in een middelgrote stad van de Canadese provincie Ontario. Daarnaast is in het onderzoek aandacht besteed aan de verhouding tussen de betrokkenheid bij een verkeersongeval en het activiteitsniveau (loopgedrag) van de voetganger van 3 jaar en ouder. In dat kader is in 1980 een kleine 1000 personen van? jaar en ouder gevraagd naar hun voetgangersactiviteit gedurende twee dagen vooraf. gaand aan het interview. ${ }^{166}$

Uit de ongevalsdata over het jaar 1979 kan volgens Jonah en Engel worden opge. maakt dat tweederde van het totaal aantal verkeersongevallen met voetgangers zich voordeed tussen 12.01 en 21.00 , waarvan het merendeel tussen 15.01 en 18.00 ur plaats had. Kinderen (3-12 jaar) waren bij een kwart van de ongevallen betrokken, ouderen $(65+)$ bij $12 \%$ van de ongevallen.

Het activiteitsniveau van de voetganger concentreerde zich voor de helft tussen 12.01 en 18.00 , waarvan $28 \%$ tussen 15.01 en 18.00 . De meest gangbare activitet had betrekking op het onderweg zijn naar huis vanuit school, werk of winkelcentrum, gevolgd door het onderweg zijn naar school (tot 18 jaar) of naar het werk (18-64 jaar). Daarbij diende door de meeste voetgangers een verkeersknising, mat en zonder verkeerslicht, te worden overgestoken. Tot slot vond meer dan tweederde van de voetgangersactiviteit bij daglicht plaats. ${ }^{1167}$

Uit het onderzoek blijkt verder dat met betrekking tot het type ongeval aannjdinget op verkeerskruisingen en bij onverwachte verkeerssituaties het meest voorkwanth Bij dit laatste type waren vooral veel uit school komende of op straat spelende lin deren in de leeftijdscategorie van 3-12 jaar (en in iets mindere mate 13-17 jarr) be trokken. De belangrijkste oorzaak hiervoor kan volgens Jonah en Engel worden ge vonden in het gegeven dat kinderen vaak zonder uit te kijken onverwachts de strat oprennen op locaties waar zij voor de automobilist niet of nauwelijks zichtbar zijn (bijvoorbeeld tussen of achter geparkeerde auto's). Volwassen voetgangers (18-44 jaar) waren, hoewel minder massaal, vooral bij aanrijdingen op verkeersknuisingen betrokken. De oorzaak hiervan is volgens Jonah en Lawson het risicogedrag val

1165. Jonah en Engel, Ac. An. \& Prev., 1983, p. 193-206. Zie ook Evans, Traffic Safety and to Driver, p. 39-41.

1166. Jonah and Engel, Ac. An. \& Prev., 1983, p. 196-197.

1167. Jonah and Engel, Ac. An. \& Prev., 1983, p. 200-202. 
volwassen voetgangers dat tot uiting komt in het negeren van een rood verkeerslicht en misschien de geringe aandacht voor de verkeersregels. Oudere voetgangers $(65+)$ bleken daarentegen in de meeste gevallen minder verwijtbaar te hebben gehandeld. ${ }^{1168}$

Tenslotte worden door Jonah en Engel ook verschillen tussen de leeftijdsgroepen geconstateerd ten aanzien van de kwantiteit en de kwaliteit van de voetgangersactiviteit. Met name jongere en volwassen voetgangers ontplooiden, in termen van aantal, afstand, duur en het aantal straten dat werd gekruist, een hoger activiteitsniveau dan kinderen en ouderen. De activiteiten van kinderen leken zich te concentreren in de buitenwijken van de stad met name gedurende de daguren en waren veelal beperkt tot het van en naar school gaan. Oudere voetgangers oefenden het grootste deel van hun activiteit uit in de ochtend en de middag op weg van en naar het winkelcentrum.

Concluderend stellen Jonah en Engel dat, wanneer vooral gebruik wordt gemaakt van bevolkingsdata, het relatieve ongevalsrisico het grootst is bij voetgangers tussen 18 en 24 jaar. Het relatieve ongevalsrisico ligt echter meer bij ouderen en kinderen wanneer gebruik wordt gemaakt van ongevalsdata, waarmee een direct verband kan worden gelegd tussen het risico en de activiteit (wandelen). ${ }^{1169}$

\section{Conclusie: verkeersgedrag en ongevalsrisico}

In het voorgaande is een aantal algemene risicofactoren geanalyseerd die van invloed kunnen zijn op het gedrag van de automobilist en de voetganger. Wat betekent dit nu voor de theorie van het verkeersongevallenrecht? Welke middelen kunnen worden gebruikt om het verkeersgedrag, zoals dat hier aan de orde is geweest, te beinvloeden?

In de eerste plaats kan worden geconstateerd dat het zorg- en activiteitsniveau van verkeersdeelnemers sterk uiteenloopt wanneer wordt gekeken naar leeftijd en de uitgeoefende zorg. Uit een viertal studies, ${ }^{1170}$ waarin het verkeersgedrag en het ongevalsrisico zowel objectief als subjectief worden geanalyseerd, kan worden opgemakt dat met name jonge autobestuurders moeite hebben om de vereiste zorg in het verkeer uit te oefenen. Objectief gezien is bij deze autobestuurders sprake van een onderschatting van het ongevalsrisico en zij nemen in het verkeer blijkbaar meer risico's dan oudere bestuurders. Vanuit een meer subjectief oogpunt kan worden beloogd dat jongere autobestuurders het eigen ongevalsrisico lager inschatten en zich-

\footnotetext{
1168. Jonah and Engel, Ac. An. \& Prev., 1983, p. 198-199.

1169. Jonah and Engel, Ac. An. \& Prev., 1983, p. 205-206.

1170. Finn and Bragg, Ac. An. \& Prev., 1986, p. 289-298; Matthews and Moran, Ac. An. \& Prev., 1986, p. 299-313; Jonah, Ac. An. \& Prev., 1986, p. 255-271; Risser, Ac. An. \& Prev., 1985, p.
179-197.
} 
zelf betere rijvaardigheden toedichten dan hun leeftijdgenoten. Bij oudere bestum ders was sprake van een lage subjectieve inschatting van het ongevalsrisico en uirde cijfers blijkt niet dat oudere bestuurders naar verhouding bovenmatig zijn verteger. woordigd in de ongevalsstatistieken.

Een onderzoek dat zich meer specifiek richtte op het ongevalsrisico en het actiri. teitsniveau van de voetganger, ${ }^{1171}$ leidt eveneens tot de conclusie dat leeftijd van invloed is op de bepaling van het ongevalsrisico van de voetganger. Daaruit bleek dar met name kinderen en ouderen, hoewel hun activiteitsniveau naar verhouding laag is, een relatief hoog ongevalsrisico lopen. Dit was voomamelijk het gevolg van etn verminderd besef van het verkeersgevaar, zij het dat een dergelijk besef meer op kinderen van toepassing was dan op ouderen. Jongere en volwassen voetgangers hadden daarentegen een hoger activiteitsniveau, waarbij hun relatief grote betrok. kenheid bij een verkeersongeval meer het gevolg was van hun eigen 'bewuste' risi. cogedrag.

De uitkomsten van deze studies zouden tot de conclusie kunnen leiden dat bij de be. paling van de zorgvuldigheidsnorm meer gedifferentieerd moet worden naar bij. voorbeeld leeftijd en verkeersgedrag. Een dergelijke differentiatie kan echter voor de rechter, die belast is met het oordeel over de juridische zorgvuldigheidsnorm, te hoge kosten meebrengen. De rechter zal eerder de neiging hebben om een gemiddelde zorgvuldigheidsnorm op te stellen, waaraan bepaalde risicogroepen alleen tegen boge kosten kunnen voldoen. $\mathrm{Zij}$ zullen mogelijk worden aangezet tot een activititswijziging.

Naast deze zorgvuldigheidsnorm kunnen twee andere instrumenten behulpzaam zijn bij de controle van het verkeersgedrag. In de eerste plaats kan een autoverzekenar, in het kader van de preventie, de premie differentiëren naar leeftijd. Aan jongere automobilisten wordt dan bijvoorbeeld een hogere premie opgelegd dan aan ouder bestuurders. Afhankelijk van de kosten daarvan kan, binnen de groep jonge autobestuurders, daarnaast mogelijk een verdere differentiatie worden toegepast. ${ }^{112}$ In de tweede plaats kunnen met behulp van veiligheidsregulering bepaalde informatielkorten bij de autobestuurder worden weggenomen. Door verkeersborden kan bijvoorbeeld een autobestuurder, wanneer hij zich met zijn voertuig in een woonvilis begeeft, worden gewaarschuwd voor spelende kinderen.

Regulering kan daarnaast ook anderszins van invloed zijn op het verkeersgedrag. De overheid zou bijvoorbeeld ten behoeve van een verbetering van het verkeergedtag van volwassen voetgangers kunnen overgaan tot een verscherping van de verkerks.

1171. Jonah and Engel, Ac. An. \& Prev., 1986, p. 193-206.

1172. Zie daarover uitvoerig paragraaf 4.2 .2 van hoofdstuk 6 . 
controle. In de uren dat de activiteit van deze voetgangers het hoogst is kan, door middel van een selectieve controle op bepaalde verkeerskruisingen en met behulp van boetes bij overtreding van de verkeersregels, worden bereikt dat volwassen voetgangers meer zorg betrachten.

Een verscherping van de verkeerscontrole met de daaraan verbonden sancties kan ook worden toegepast om automobilisten tot een zorgvuldiger verkeersgedrag aan te zetten. In één van de beschreven studies wordt een aantal concrete beleidsaanbevelingen gedaan om het gedrag van met name jonge autobestuurders in meer zorgzame banen te leiden. Daarin wordt onder andere aanbevolen om verkeersborden langs de autoweg te plaatsen, waarop is vermeld hoeveel verkeersongevallen op een bepaald traject hebben plaatsgevonden. Daarnaast kunnen verkeersborden worden geplaatst bij een bepaalde kruising of een ander gevaarlijk punt ('black spot') waar veel ongelukken gebeuren. ${ }^{1173} \mathrm{Bij}$ dit laatste dient echter de vraag te worden gesteld of de overheid als beheerder van de wegen niet dient in te grijpen wanneer een bepaalde kruising als gevaarlijk te boek staat. Tenzij alle financiële middelen daartoe zijn uitgeput, kan misschien worden gedacht aan het plaatsen van verkeerslichten indien daarin nog niet is voorzien.

Naast de bovengenoemde verkeersmaatregelen kan ook een verscherping van de sancties bij overtreding van de verkeersregels worden ingezet om het verkeersgedrag te controleren. Daarbij kan bijvoorbeeld worden gedacht aan een ontzegging van de rijbevoegdheid ingeval van een verkeersovertreding of het onder invloed van alcohol veroorzaken van een verkeersongeval. Een dergelijke sanctie zal niet alleen kunnen leiden tot meer zorgvuldigheid, maar kan de betrokken autobestuurder ook dwingen tot een tijdelijke activiteitswijziging. ${ }^{1174}$

Samenvattend kan worden gesteld dat vanuit de theorie een aantal middelen wordt aangedragen om het ongevalsrisico en het verkeersgedrag van bepaalde groepen verkeersdeelnemers te verminderen respectievelijk te verbeteren. In het vervolg van de empirische analyse, wanneer respectievelijk aansprakelijkheid (hoofdstuk 10), verzekering (hoofdstuk 11) en veiligheidsregulering (hoofdstuk 12) aan de orde komen, zal meer duidelijk worden wat de werkelijke effecten van de genoemde maatregelen kunnen zijn.

1173. Finn and Bragg, Ac. An. \& Prev., 1986, p. 297

Zie hoofdstuk 12 voor een empirische analyse van deze en andere sancties. 


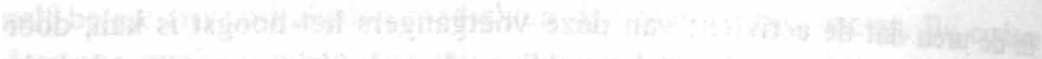

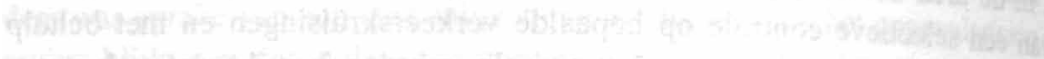

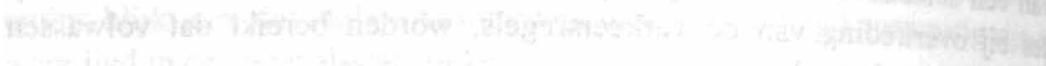

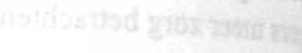

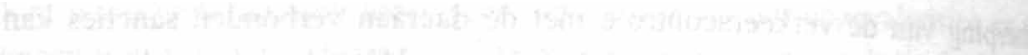

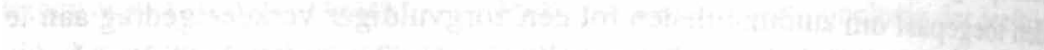

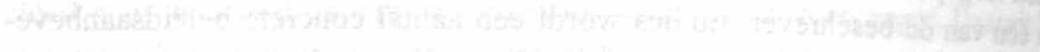

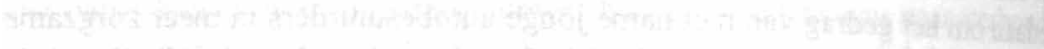

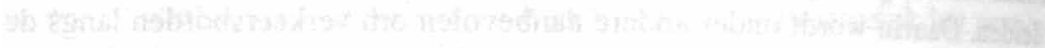

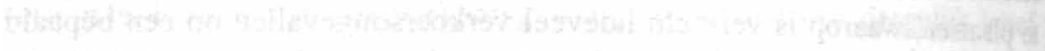

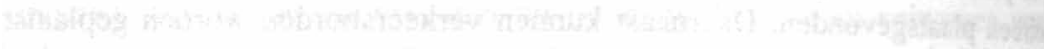

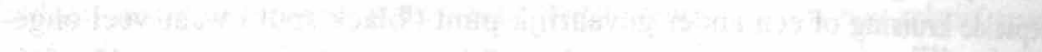
siblew

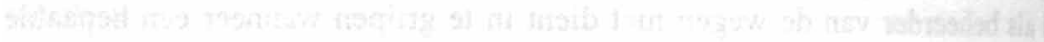

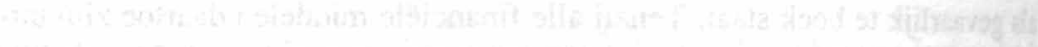

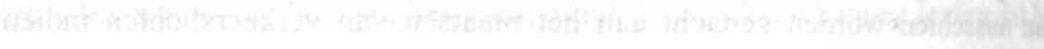

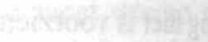

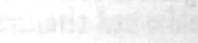
ㄴ.

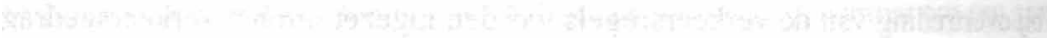

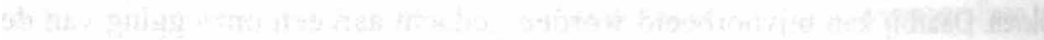

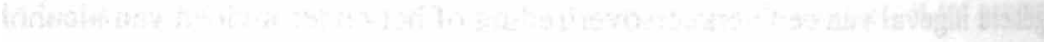

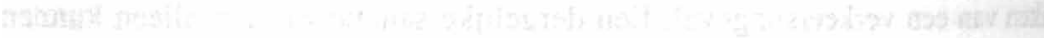

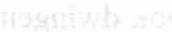

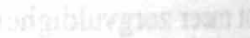

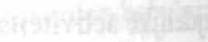

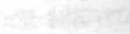




\section{Hoofdstuk 10: De empirische toetsing van aansprakelijkheidsregels}

\section{Inleiding}

Binnen de economische analyse van het aansprakelijkheidsrecht is onderzocht welke ansprakelijkheidsregels verkeersdeelnemers in een bilaterale ongevalssituatie aanzetten tot een optimaal zorg- en activiteitsniveau. In dat kader is enerzijds uitgegaan van een regel van risicoaansprakelijkheid met een absoluut eigen schuldverweer, warbij de autobestuurder in beginsel gehouden is om de gehele schade van de fietser te vergoeden, tenzij de laatste niet heeft voldaan aan de zorgvuldigheidsnorm wardoor de aansprakelijkheid van de autobestuurder in zijn geheel vervalt. Anderzijds werd aandacht besteed aan een gewone regel van foutaansprakelijkheid, waarbij de autobestuurder de schade van de fietser moet vergoeden, indien hij niet heeft voldaan aan de zorgvuldigheidsnorm. Vanuit de theorie is geconcludeerd dat in beginsel noch een regel van risicoaansprakelijkheid met een absoluut eigen schuldverweer, noch een gewone regel van foutaansprakelijkheid tot een efficiënte uitkomst leiden. In het kader van de preventiedoelstelling van het aansprakelijkheidsrecht is echter gesteld dat onder bepaalde omstandigheden een lichte voorkeur voor een risicoaansprakelijkheid met een absoluut eigen schuldverweer kan worden uitgesproken. Dit hing samen met de veronderstelling dat het vanuit maatschappelijk oogpunt belangrijker kan zijn om de gevaren van het autoverkeer te sturen, dan dat de fietser wordt aangezet tot een optimaal activiteitsniveau. Vanuit de compensatiedoelstelling is verder geconcludeerd dat een regel van risicoaansprakelijkheid met een absoluut eigen schuldverweer een betere schadevergoeding aan het slachtoffer garandeert dan een gewone regel van foutaansprakelijkheid. ${ }^{175}$

In dit hoofdstuk staat de vraag centraal of ten aanzien van het aansprakelijkheidsrecht empirisch bewijs voorhanden is, waaruit kan worden opgemaakt dat aansprakelijkheidsregels het gedrag van verkeersdeelnemers preventief kunnen beïnvloeden. Daarbij doet zich echter een probleem voor. Het aansprakelijkheidsrecht is reeds decennia lang dermate verweven geraakt met verzekering dat er bijna geen rechtsstelsels meer bestaan waarin nog enkel het aansprakelijkheidsrecht (zonder verzekering) ten aanzien van verkeersongevallen wordt toegepast. Daarnaast geldt dat de empirische studies die zich in het bijzonder richten op een analyse van de civielrechtelijke aansprakelijkheid bij verkeersongevallen vooral betrekking hebben op de jaren' 60 en ' 70 van de vorige eeuw. Dit betekent dat er weinig recent empirisch materiaal voorhanden is, waarin de preventieve werking van het aansprakelijkheidsrecht wordt onderzocht. Het wel aanwezige materiaal heeft daarbij, mede door de invloed 
van verzekering, veelal een indirect karakter. Daarnaast wordt met name in de jaren '80 van de vorige eeuw vooral de nadruk gelegd op empirisch onderzoek naar id preventieve effecten van een verschuiving van een derde partij aansprakelijbbei naar een eerste partij no-fault vergoeding. ${ }^{1176}$

Met inachtneming van het voorgaande zal in dit hoofdstuk aandacht worden besteet aan kwantitatief onderzoek naar de verkeersaansprakelijkheid. De studies die bierbij aan bod komen geven een empirische analyse van de werking van bet aansprakelijkheidsrecht, meer in bijzonder binnen het proces van de schaderegeling na een verkeersongeval. In dit kader zal in paragraaf 2 de praktische werking vande verkeersaansprakelijkheid in Nederland worden onderzocht. In paragraaf $3 z \mathrm{z}$ aandacht worden besteed aan de werking van aansprakelijkheidsregels in NoordAmerika en Canada. Dit hoofdstuk zal in paragraaf 4 worden afgesloten met ten aantal concluderende opmerkingen.

\section{De praktische werking van aansprakelijkheidsregels in Nederland}

In Nederland is gedurende de jaren zeventig van de vorige eeuw kwantitatief onderzoek verricht naar de praktische werking van de verkeersaansprakelijkheid, in ta: bijzonder ten aanzien van de schadeafwikkeling na een verkeersongeval. In datk der kan een drietal studies worden genoemd. Daarbij wordt de schaderegeling vanuil drie gezichtspunten benaderd, namelijk vanuit de positie van het slachtoffer, vanuil de positie van de rechter en vanuit de positie van de aansprakelijkhids verzekeraar. ${ }^{1177}$ In het onderzoek dat zich richt op de positie van de rechter worden alle civiele rechtbankvonnissen geanalyseerd die in de jaren 1967 en 1968 met betrekking tot verkeersongevallen werden gewezen. ${ }^{1178}$ Het onderzoek dat betrekking had op de positie van het slachtoffer concentreerde zich eveneens op de jaren 1967 en 1968 en betrof een steekproefsgewijze enquête onder alle emstig gewonde marr nelijke verkeersslachtoffers in de leeftijd van 16 tot en met 64 jaar. ${ }^{1.79}$ Het derde or. derzoek tenslotte, omvatte 196 casestudies naar de wijze waarop door een dretel

1176. Chapman and Trebilcock, Working Paper, 1991, p. 16.

1177. Bloembergen, Hers-van Oven, Vinke en Van Wersch, Duizend Botsingen, 1972 (rachion Bloembergen en Van Wersch, Verkeersslachtoffers en hun schade, 1973 (slachtoffer); De (rom Schaderegeling bij verkeersongevallen, 1979 (verzekeraar). Bij deze studies werd niet spertith een onderscheid gemaakt naar type ongeval, zoals motorrijtuig versus motorijtuig, motoriju-tuversus niet-gemotoriseerd, eenzijdige ongevallen en niet-gemotoriseerd versus thit gemotoriseerd.

1178. Bloembergen, Hers-van Oven, Vinke en Van Wersch, Duizend botsingen, p. 1-3.

1179. Bloembergen en Van Wersch, Verkeersslachtoffers en hun schade, p. 3. 
grote verzekeringsmaatschappijen de schadevergoeding naar aanleiding van een verkeersongeval wordt geregeld. ${ }^{1180}$

Hoewel binnen deze studies de nadruk ligt op de schaderegeling na een verkeersongeval, betekent dit niet dat de aansprakelijkheidsvraag binnen de procedure een ondergeschikte rol vervult. Voordat tot uitkering van de schade kan worden overgegaan, dient immers eerst de vraag naar aansprakelijkheid te worden beantwoord. In dat kader is binnen het Nederlandse stelsel van verkeersaansprakelijkheid, zoals dit in de jaren ' 60 en ' 70 van de vorige eeuw van toepassing was, in beginsel de schuldvraag van belang. ${ }^{1181}$

In het onderzoek dat hiema aan bod komt wordt in beginsel geen aandacht besteed aan de preventieve werking van aansprakelijkheidsregels. In paragraaf $2.4 \mathrm{zal}$ het belang van deze studies voor het onderhavige onderzoek worden belicht, meer in het bijzonder ten aanzien van de preventieve werking van het aansprakelijkheidsrecht.

\subsection{DE SCHADEREGELING VANUIT DE POSITIE VAN DE RECHTER}

In de studie waarin de schaderegeling vanuit de positie van de rechter centraal staat, wordt door de onderzoekers vastgesteld dat slechts $3 \%$ van het totaal aantal civiele rechtbankprocedures betrekking had op verkeersschade. ${ }^{182}$ Daarnaast bleek dat in de meeste gevallen (79\%) waarin een procedure werd aangespannen, sprake was van een geschil omtrent de schuldvraag, terwijl in $25 \%$ van de gevallen het geschil betrekking had op de schadeomvang. ${ }^{1183}$ Met de schuldvraag wordt volgens de onderzoekers niet de schuld in de enge juridische betekenis van verwijtbaarheid bedoeld. Bij schuld in het kader van dit onderzoek gaat het volgens de auteurs om alle gevallen waarin het ging om onrechtmatigheid of schuld in de zin van artikel 1401 oud $B W$. In de woorden van de auteurs:

'Onder schuld hebben we dus verstaan datgene wat men in het normale spraakgebruik bedoelt als men zegt, dat 'iemand schuld had aan het ongeluk'.184

De onderzoekers constateren naar aanleiding van de statistische gegevens dat de praktische problemen ten aanzien van verkeersaansprakelijkheid met name betrekking hadden op deze schuldvraag. Hierbij moet worden aangetekend dat slechts een

1180. De Groot, Schaderegeling bij verkeersongevallen, p. 3-5.

1181. Uit het feit dat in de onderzochte studies geen onderscheid wordt gemaakt naar type ongeval kan vernoedelijk worden opgemaakt dat aan artikel 31 WVW nog slechts een beperkte betekenis toekwam. Daamaast wordt voomamelijk artikel 1401 oud BW als uitgangspunt gehanteerd

1182. Bloembergen, Hers-van Oven, Vinke en Van Wersch, Duizend botsingen, p. 9.

1183. Bloembergen, Hers-van Oven, Vinke en Van Wersch, Duizend botsingen, p. 51-53.

Bloembergen, Hers-van Oven, Vinke en Van Wersch, Duizend botsingen, p. 36-37. 
klein deel van het totaal aantal geschillen omtrent verkeersongevallen voor de reet. ter komt. De meerderheid van de verkeersschades wordt blijkbaar door de verzeke raars afgewikkeld.

In de derde plaats bleek het aantal regresprocedures volgens de onderzoekers zer hoog, namelijk $57 \%$ van het totaal. Hiervan werd $81 \%$ door particuliere verzekerarar en $16 \%$ door sociale verzekeraars gevoerd. Daamaast werd $66 \%$ van de zaakschade. procedures aangespannen door een regresnemende instantie; bij procedures over le. selschade was dit percentage $29 \%$. Tenslotte wordt door de onderzoekers geconst. teerd dat een grote meerderheid $(77 \%)$ van de regresacties vorderingen betrof van minder dan Fl. 3.000,-. Dit betekent volgens hen dat de hieraan verbonden kosten re latief hoog zijn. ${ }^{1185}$ De onderzoekers concluderen naar aanleiding van deze statisische gegevens dat een afschaffing van het regres met de handhaving van de aansprkelijkheid kan leiden tot een halvering van het aantal gerechtelijke procedures over verkeersaansprakelijkheid en een vermindering van het aantal conflicten buiten de rechter om. ${ }^{1186}$

\subsection{DE SCHADEREGELING VANUIT DE POSITIE VAN HET SLACHTOFFER}

In het onderzoek waarin de positie van het slachtoffer centraal staat, word mode aandacht besteed aan de beschermingsomvang van het aansprakelijkheidsrech ak vergoedingsbron voor letselschade ten gevolge van een verkeersongeval. ${ }^{1187}$ Uit thi onderzoek blijkt dat de betekenis van het aansprakelijkheidsrecht gering is, voord bij die vormen van schade die reeds bij het slachtoffer zelf zijn gedekt (medistre kosten, inkomensschade). ${ }^{1188}$ Ook bij de schadesoorten die niet door een eigen ver. zekering worden gedekt of in het geheel niet zijn gedekt (smartengeld), bleek slechs een klein deel van de schade op basis van het aansprakelijkheidsrecht te worden ver goed. Binnen het totale bedrag dat aan schadevergoeding werd uitgekerd wa slechts in $15 \%$ van de gevallen sprake van een betaling door de WA-verzekeraar rat

1185. Bloembergen, Hers-van Oven, Vinke en Van Wersch, Duizend Botsingen, p. 17-20.

1186. Bloembergen, Hers-van Oven, Vinke en Van Wersch, Duizend botsingen, $p$. 60. De onderes kers gaan niet in op de vraag welke gevolgen een afschaffing van het regres heeft voor bjjwor beeld de premies van particuliere en sociale verzekeringen.

1187. Op basis van 452 interviews kan ten aanzien van het type verkeersdeelnemer worden gestell the $80 \%$ een bestuurder van een motorrijtuig betrof, $19 \%$ was een fietser of voetganger en 19 e $80 \%$ een bestuurder van een motorrijtuig betrof, $19 \%$ was een fietser of voetgangen schide
passagier van een auto. Zie Boembergen en Van Wersch, Verkeersslachtoffers en hun sch
29 .

1188. Hierbij moet worden aangetekend dat $1 / 5$ van het aantal geïnterviewde slachtoffers gen $19 \%$ partij had en dus ook niemand aansprakelijk kon stellen. Zie Bloembergen en Van Wersch, Ve keersslachtoffers en hun schade, p. 186. 
de tegenpartij aan het slachtoffer, waarbij het in meerderheid om kleine bedragen ging. ${ }^{1189}$

Ten aanzien van de praktische werking van het aansprakelijkheidsrecht is in het vorige onderzoek opgemerkt dat in een grote meerderheid van de gevallen de schuldvraag centraal stond. ${ }^{1190}$ In het onderhavige onderzoek wordt geconstateerd dat een belangrijk deel van de slachtoffers geen aansprakelijkheidsvordering instelden omdat zij meenden de aansprakelijkheid van de tegenpartij niet te kunnen bewijzen. Daamaast bleef de vergoeding van het slachtoffer vaak onvolledig, was de periode waarbinnen de schadevergoeding wordt uitgekeerd te lang en was met name bij ernstig letsel sprake van conflicten en langdurige juridische procedures. ${ }^{1191}$

In de slotbeschouwing bij hun onderzoek wordt door de auteurs geconcludeerd dat de rol van het aansprakelijkheidsrecht bij de rechtstreekse vergoeding van verkeersslachtoffers gering is. Dit geldt in het bijzonder ten aanzien van de vergoeding van letselschade. Het aandeel van het aansprakelijkheidsrecht in de totale vergoedingsstroom bedroeg ongeveer $10 \% .{ }^{192}$ Dit lage percentage is volgens de auteurs echter vooral het gevolg van de bij het slachtoffer aanwezige vergoedingsbronnen, waardoor de compensatoire werking van het aansprakelijkheidsrecht in die gevallen overbodig is. Ten aanzien van andere vormen van schade vervult het aansprakelijkheidsrecht nog wel een rol, zij het een beperkte. ${ }^{1193}$ Het onderhavige onderzoek dat betrekking had op de positie van het slachtoffer zelf kon geen informatie geven over de omvang van het regres, maar de auteurs menen op basis van ander onderzoek dat het regres bij letselschade zowel binnen als buiten het proces een belangrijke plaats inneemt. ${ }^{1194}$

Een belangrijke doelstelling van het aansprakelijkheidsrecht is de preventie van verkeersongevallen. Verkeersongevallen kunnen worden voorkomen wanneer een potentiêle schadeveroorzaker weet dat hij de ontstane schade zelf moet vergoeden. Volgens de onderzoekers was in dit experiment de aansprakelijkheid van de schadeveroorzaker echter veelal door een verzekering gedekt. In het beperkte aantal gevallen waarin de veroorzaker wel persoonlijk voor de schade moest opkomen ging het vaak om kleine bedragen. Het is volgens de onderzoekers wel mogelijk dat de schul-

\footnotetext{
1189. Bloembergen en Van Wersch, Verkeersslachtoffers en hun schade, p. 187-188.

1190. Bloembergen, Hers-van Oven, Vinke en Van Wersch, Duizend botsingen, p. $51-53$.

1191. Bloembergen en Van Wersch, Verkeersslachtoffers en hun schade, p. 189-190.

1192. Zie Bloembergen en Van Wersch, Verkeersslachtoffers en hun schade, p. 137-145

1193. Bij zaakschade lag het aandeel van het aansprakelijkheidsrecht op ongeveer $30 \%$, hoewel de bedragen gemiddeld lager waren dan bij letselschade. Zie Bloembergen en Van Wersch, Verkeersslachtoffers en hun schade, p. 186-188.

1194. Zij verwijzen hierbij met name naar Bloembergen, Hersch-van Oven, Vinke en Van Wersch, Duizend botsingen, p. 17-20, waarin werd berekend dat $29 \%$ van de gerechtelijke procedures over letselschade door een regresnemende instantie wordt gevoerd.
} 
dige de schade indirect draagt, namelijk via de premie van zijn WAM-verzeke ring. ${ }^{1195}$

\subsection{DE SCHADEREGELING VANUIT DE POSITIE VAN DE AANSPRAKELIJKHEIDSVERZEKERAAR}

Een derde praktijkonderzoek richt zich op de schaderegeling na een verkeerson geval, zoals deze bij een aantal grote aansprakelijkheidsverzekeraars verloopt. Hier uit blijkt dat de aansprakelijkheidsvraag in veel gevallen moeilijk te beantwoorden is. Dit is ten dele het gevolg van het feit dat een verzekerde zelf moeite heeft om te opzichte van zijn aansprakelijkheidsverzekeraar schuld te erkennen voor de schate die hij aan derden heeft veroorzaakt. De verzekerde is daarbij vooral bang voor en verlies van zijn no-claim korting, waardoor zijn verhaal over de toedracht van be ongeval niet zelden onbetrouwbaar is.

In de tweede plaats kan voor de beantwoording van de schuldvraag in veel gevallen de toedracht van het verkeersongeval niet meer precies worden achterhaald. Dit houdt verband met de complexiteit van bepaalde verkeerssituaties, waarbij de op eenvolgende gebeurtenissen zich veelal in een 'split second' afspelen. ${ }^{1196}$

Een derde oorzaak voor de problemen bij het schuldvraagonderzoek heef betrok king op het feit dat voor de beoordeling van de schuld veelal een politierappon noodzakelijk is. Aangezien de wachttijd voor de ontvangst van een afschrit van tet dergelijk rapport gemiddeld enkele maanden bedraagt, wordt hiervan weinig gebrul gemaakt. Wanneer ter beoordeling van de schuldvraag wel een proces-verbaal worit gebruikt, blijkt dat de inhoud daarvan op veel punten afwijkt van de bevindingen de de schaderegelaar op de plaats van het ongeval heeft gedaan. Daarnaast is nar ta: oordeel van de schaderegelaar een politierapport vaak onvolledig en niet altijd even betrouwbaar. ${ }^{1197}$

Uit dezelfde studie blijkt echter dat een actief schuldvraagonderzoek, warbij bruik wordt gemaakt van een politierapport, een onderzoek ter plaatse en het borth van het slachtoffer, een efficiënte beoordeling van de schuldvraag mogelijk mant Van de 135 onderzochte gevallen kon in $71 \%$ de schuldvraag moeiteloos worden vastgesteld, hetgeen betekent dat de aansprakelijkheidsvraag voor de verzekrert een duidelijk antwoord opleverde, dat ook voor het slachtoffer acceptabel was. Darnaast was in $68 \%$ van de onderzochte cases sprake van een duidelijke overtretim

1195. Bloembergen en Van Wersch, Verkeersslachtoffers en hun schade, p. 185-193. Zie hiems put graaf 2.4 voor een verder commentaar op deze doelstelling.

1196. De Groot, Schaderegeling bij verkeersongevallen, p. 33-34.

1197. De Groot, Schaderegeling bij verkeersongevallen, p. 34-36. 
treding van eenvoudige voorrangsregels. Tenslotte bleek in slechts $10 \%$ van de 117 gevallen waarin de aansprakelijkheid vaststond de eigen schuld een rol te spelen. ${ }^{1198}$

In het kader van het onderzoek naar de aansprakelijkheidsvraag bleek verder dat de intensiteit van een dergelijk onderzoek vooral afhankelijk is van de persoonlijke instelling van de schaderegelaar, die namens de verzekeraar de schade met het slachtoffer regelt. Bij verkeersongevallen met licht letsel, waarbij de aansprakelijkheid duidelijk uit de feiten kan worden afgeleid, gaat de schaderegelaar, namens de verzekeraar, veelal spoedig tot erkenning van de aansprakelijkheid over. Zelfs wanneer de ansprakelijkheid niet direct kan worden vastgesteld, wordt veelal overgegaan tot een schade-uitkering aan het slachtoffer. Hierbij wordt geen verdergaand onderzoek naar de schuldvraag ingesteld of wordt toch schadevergoeding betaald, ondanks het feit dat er geen sprake is van aansprakelijkheid. De factoren die bij een dergelijke keuze een rol spelen, zijn de schadeomvang, de kosten van verder onderzoek naar de schuldvraag of de verwachte weerstand bij geen uitkering. Ingeval van twijfel wordt veelal in het voordeel van het slachtoffer besloten. Alleen wanneer de schade een grotere omvang heeft, en er sprake is van een langdurig genezingsproces, volgt meestal wel een uitgebreid onderzoek naar de schuldvraag. Daarnaast wordt uit doelmatigheidsoverwegingen een beroep op de eigen schuld vaak achterwege gelaten. Wanneer duidelijk vaststaat dat sprake is van eigen schuld, wordt soms toch de uit te keren schade aangepast om tot een aanvaardbaar eindresultaat te komen. ${ }^{1199}$

Concluderend wordt door De Groot gesteld dat in theorie de schuldvraag en de schadevergoeding gescheiden grootheden zijn. In de praktijk van de schaderegeling blijken zij evenwel soms in elkaar over te lopen. Het schuldbegrip is in de schaderegelingspraktijk niet afgeschaft, maar het belang ervan wordt mede bepaald door bedrijseconomische afwegingen van de verzekeraar. Daarnaast wordt, economisch gezien door de schaderegelaar een kosten-baten analyse gemaakt van de vraag hoe diepgaand het onderzoek naar de schuldvraag moet plaatsvinden. Het gaat in de ogen van de verzekeraar immers om een efficiënte schadeafwikkeling. Wanneer daraij de schuldvraag niet teveel aan discussie onderhevig is en de schade snel kan worden geregeld, wordt bijvoorbeeld het opvragen van het proces-verbaal, waar maanden overheen kunnen gaan, uit kostenoogpunt achterwege gelaten. Er wordt daarnaast veel met waarschijnlijkheden gewerkt, waarvan de interpretatie veelal aan de schaderegelaar wordt overgelaten. ${ }^{1200}$

1198. De Groot, Schaderegeling bij verkeersongevallen, p. 36-37.
1199. De Groot, Schaderegeling bij verkeersongevallen, p. $36-44$.
1200. De Groot, Schaderegeling bij verkeersongevallen, p. 39 en 44 


\subsection{HET BELANG VAN DEZE STUDIES VOOR HET ONDERHAVIGE ONDERZOEK}

In het voorgaande is een drietal Nederlandse studies beschreven, waarbij in het ke der van de schaderegeling bij verkeersongevallen respectievelijk de rol van de rech ter, het slachtoffer en de verzekeraar aan bod zijn gekomen. Hoewel deze studies d2. teren uit de jaren ' 60 en ' 70 van de vorige eeuw, kan hieruit toch een aantal conclu. sies worden getrokken.

In het algemeen kan worden gesteld dat de invloed van het aansprakelijkheidsectu op de preventie van verkeersongevallen moeilijk empirisch kan worden getoets. $h$ de eerste plaats kan worden gesteld dat er geen empirisch materiaal voorhanden is om een dergelijke invloed aan te tonen. In de tweede plaats kan worden geconclu deerd dat als gevolg van de invloed van verzekering de toetsing van het aansprate lijkheidsrecht sec wordt bemoeilijkt. Uit het beschreven onderzoek bleek bijvor: beeld dat een grote meerderheid van de aansprakelijkheidsprocedures door de vere keraars wordt afgewikkeld.

In één van de studies die hiervoor aan bod is gekomen wordt, naar aanleiding vande gepresenteerde onderzoeksresultaten, geconcludeerd dat de preventiedoelstelling val het aansprakelijkheidsrecht bij verkeersongevallen een ondergeschikte rol vel vult. ${ }^{1201}$ Aangezien in de meeste aansprakelijkheidsprocedures de WAM-verzekeraz van de schadeveroorzaker wordt aangesproken, kan worden gesteld dat voor het ge ven van zorgprikkels veeleer deze verzekeraar de aangewezen instantie is. Deple ventie van aansprakelijkheidsregels wordt daarmee geïncorporeerd in de sch. deafwikkeling door de aansprakelijkheidsverzekeraar. Deze kan trachten om via de premie (bonus-malus) het gedrag van de schuldige dader te beïnvloeden. Het regres. recht kan daarbij een belangrijke rol vervullen, omdat het slachtoffer voor zijn iigan gedekte schade de veroorzaker niet aanspreekt. De verzekeraar van het slachtoffic kan voor de uitgekeerde schade verhaal nemen op de aansprakelijkheidsverzekeran van de dader. Wanneer de WAM-verzekeraar de schade vervolgens uitkeert, kan vis een premieaanpassing de invloed op het gedrag van de dader worden gehanihaafd. $^{1202}$

Uit de hiervoor besproken studies is gebleken dat in $29 \%$ van de gerechtelijke prot cedures ten aanzien van letselschade een regresnemende instantie de eisende partif was; bij procedures over zaakschade bedroeg dit percentage zelfs $66 \%{ }^{1203}$ Een arder

1201. Bloembergen en Van Wersch, Verkeersslachtoffers en hun schade, p. 185 en 192. Zij gan ovati gens niet in op de vraag of in het algemeen de preventie van verkeersongevallen een doestilitin van het aansprakelijkheidsrecht moet zijn.

1202. In hoofdstuk 11 zal de vraag aan de orde komen hoe in de praktijk de preventie van verkessolo gevallen via de verzekeringsvoorwaarden werkt.

1203. Bloembergen, Hers-Van Oven, Vinke en Van Wersch, Duizend botsingen, p. 60. 
re studie wees uit dat het aandeel van het aansprakelijkheidsrecht in de totale vergoedingsstroom voor letselschade gering was. In de woorden van de auteurs van dit onderzoek:

'Het aansprakelijkheidsrecht waarop de WAM inhaakt, neemt bij het opvangen van letselschade een uiterst bescheiden plaats in; slechts $15 \%$ van de door ons ondervraagde emstig getroffen slachtoffers ontving [afgezien van de rechtstreekse betalingen uit eigen bron $\mathrm{MvD}$ ] enige vergoeding voor letselschade'. ${ }^{1204}$

In dit onderzoek lag vooral de nadruk op een analyse van de betekenis van het aansprakelijkheidssysteem bij de vergoeding van letselschade, gezien vanuit de positie van het slachtoffer. De auteurs stellen dat het grootste deel van de vergoeding voor letselschade an het slachtoffer afkomstig was uit eigen bronnen, een gegeven dat volgens hen de onderschikte rol van het aansprakelijkheidsrecht mede verklaart. ${ }^{120.5}$

Recente gegevens omtrent de vergoeding van letselschade bij verkeersongevallen wijzen uit dat van de totale schadelast die door de WAM-verzekeraars wordt opgebracht, $40 \%$ ten goede komt aan de regresnemende instanties en $60 \%$ aan het slachtoffer zelf. ${ }^{1206}$ Deze cijfers geven echter geen uitsluitsel over de werkelijke rol van het ansprakelijkheidssysteem bij de vergoeding van letselschade, het deel van de vergoeding voor letselschade aan het slachtoffer dat gebaseerd is op het aansprakelijkheidsrecht en de mate waarin een individueel verkeersslachtoffer voor zijn letselschade überhaupt een vergoeding ontvangt van de WAM-verzekeraar.

In een recent verschenen studie van Weterings wordt op basis van een totaal aantal jaarlijkse verkeersslachtoffers van 650.000 , aangenomen dat in $60-70 \%$ van het total aantal verkeersongevallen een potentiële claim ontstaat. Het percentage verkeersslachtoffers dat ook daadwerkelijk een schadeclaim indient, wordt door hem op $10.15 \%(65.000-97.500)$ geschat. ${ }^{1207}$ Verder wordt door Weterings aan de hand van individuele interviews met (letselschade-)advocaten, schadebehandelaars en rechtsbulpverleners een beeld geschetst van de kosten die zijn gemoeid met de afwikkeling van letselschadeclaims bij verkeersongevallen, arbeidsongevallen, medisch let-

\footnotetext{
1204. Bloembergen en Van Wersch, Verkeersslachtoffers en hun schade, p. 194.

1205. Bloembergen en Van Wersch, Verkeersslachtoffers en hun schade, p. 187-188.

1206. Deze cijfers, die een prognose bevatten voor het jaar 1997, zijn afkomstig van het Centrum voor Verzekeringsstatistiek van het Verbond van Verzekeraars, geciteerd in de Memorie van Toelichting bij de Vaststelling en invoering van afdeling 8.14.1. (verkeersongevallen) van het Burgerlijk Weibock, TK, 1997-1998, 25759, nr. 3, p. 14. Mede naar aanleiding van deze gegevens heeft zich in de literatuur een discussie ontsponnen over de gevolgen van dit wetsvoorstel voor de positie van regresnemende instanties. Zie Van Maanen, NJB, 1998, p. 116-121 en Kremer versus Van Maanen in NJB, 1998, p. 609-611. 
sel en letsel door geweld. ${ }^{1208} \mathrm{Hij}$ maakt daarbij globaal onderscheid tussen de looster in respectievelijk het aansprakelijkheidstraject, het medische traject en het schad. bepalingstraject. ${ }^{1209}$ Voor deze trajecten komt Weterings uit op een schatting ant kosten van respectievelijk 235-245 miljoen gulden (aansprakelijkheid), 100-380 mi joen gulden (medisch) en 90-430 miljoen (schadebepaling). ${ }^{1210}$

Zoals aan het begin van deze paragraaf werd gesteld is er ten aanzien van Nederlant geen empirisch materiaal voorhanden waaruit de invloed van aansprakelijk en ver. zekering op de preventie van verkeersongevallen kan worden afgeleid. In de eerde beschreven studies lag de nadruk op de schadeafwikkeling na een verkeersongeve. waarbij een grote meerderheid van de procedures door de verzekeraars word gere geld en door hen ook de schade wordt uitgekeerd. ${ }^{1211}$ Hieruit kan worden geconch deerd dat als gevolg van de invloed van de verzekering de preventieve werking van aansprakelijkheidsregels sec beperkt is. Dit brengt mee dat aan de rol van de (am sprakelijkheids)verzekeraars op het terrein van de preventie van verkeersongevallen meer gewicht toekomt. De vraag in hoeverre verzekeraars via de polisvoorvarden het gedrag van de verzekerde (kunnen) beïnvloeden, zal echter in het volgend hoofdstuk aan de orde komen.

\section{De werking van aansprakelijkheidsregels in Noord-Amerika en Canada}

Ten aanzien van het onderzoek dat in Noord-Amerika en Canada naar de werking van aansprakelijkheidsregels in het verkeer is verricht, geldt ook dat het ansppalse lijkheidsrecht sterk verweven is geraakt met verzekering. Daarnaast wordt bimet het onderzoek naar de verkeersaansprakelijkheid in deze landen vooral een ver gelijking gemaakt met de toepassing van een no-fault verzekering, die in de jaren 70 van de vorige eeuw in 24 staten van Noord-Amerika en in een aantal Canadese provincies is ingevoerd. ${ }^{1212}$

In deze paragraaf zal een aantal studies aan bod komen die enerzijds de preventier werking van aansprakelijkheidsregels sec trachten te onderzoeken. ${ }^{1213}$ Anderzijds 21

1208. Weterings, Vergoeding van letselschade, 1999, p. 6-8.

1209. Weterings, vergoeding van letselschade, p. 51-101.

1210. Weterings, Vergoeding van letselschade, p. 113-118.

1211. Op het onderzoeksterrein van de schadevergoeding kan in dit verband nog worden venters naar het Nationale Platform Personenschade (NPP) en de Stichting Personenschade lnstituer rif Verzekeraars (PIV), die enkele jaren gelden zijn opgericht en mede tot doel hebben onderzod verrichten naar de schadevergoeding in het verkeer.

1212. Deze vergelijkende studies zullen in hoofdstuk 13 meer uitvoerig worden geanalyserd.

White, RJE, 1989, p. 308-330. Zie ook Komhauser and Schotter, JLS, 1990, p. 203-233 rapp tievelijk Wittman, Friedman, Crevier and Braskin, JLS, 1997, p. 145-164, voor een meer ets rimenteel onderzoek naar de preventieve werking van aansprakelijkheidsregels. 
ook een meer algemeen overzicht worden gegeven van de praktische werking van de civielrechtelijke aansprakelijkheid bij verkeersongevallen. ${ }^{1214}$ Daarbij zal met name de aandacht uitgaan naar de schaderegeling bij verkeersongevallen binnen een systeem van aansprakelijkheid en verzekering.

\subsection{DE PREVENTIE VAN AANSPRAKELIJKHEIDSREGELS IN HET VERKEER}

Michelle White heeft de werking van aansprakelijkheidsregels onderzocht aan de hand van een analyse van 582 kop-staart botsingen (auto's) in de Amerikaanse staat Californië, die hebben geleid tot een gerechtelijke procedure. ${ }^{1215}$ De ongevalsdata zijn afkomstig uit de jaren 1974-1976 en bevatten informatie omtrent de zorgniveaus van dader en slachtoffer, waarbij de dader degene is die met zijn voertuig achterop de auto van het slachtoffer botst. De centrale vraag bij dit onderzoek is de invloed van de verschuiving van een regel van foutaansprakelijkheid met een absoluut eigen schuldverweer ('contributory negligence') naar een foutaansprakelijkheid met een gradueel eigen schuldverweer ('comparative negligence'), ${ }^{1216}$ op de zorgniveaus van dader en slachtoffer. ${ }^{1217}$

Bij een foutaansprakelijkheid met een absoluut eigen schuldverweer is de schadeveroorzaker tot een volledige schadevergoeding gehouden indien hem enig verwijt kan worden gemaakt, tenzij het slachtoffer een verwijt kan worden gemaakt; dan heeft deze geen recht op schadevergoeding. De fout van het slachtoffer leidt derhalve tot een verval van zijn aanspraak op schadevergoeding. ${ }^{1218} \mathrm{Bij}$ een foutaansprakelijkheid met een gradueel eigen schuldverweer geldt dat de schadeveroorzaker aansprakelijk is voor de schade van het slachtoffer indien hem een verwijt kan worden gemaakt. Wanneer echter zowel de schadeveroorzaker als het slachtoffer niet hebben voldaan aan de zorgvuldigheidsnorm, volgt een verdeling van de schade, waarvan de hoogte afhankelijk is van het (on)zorgvuldige gedrag van zowel de schadeveroorzaker als het slachtoffer. ${ }^{1219}$

1214. Dewees, Duff en Trebilcock, Accident Law, p. 26-42.

1215. White, RJE, 1989, p. 308-330. De statistische gegevens zijn ontleend aan Wittman, JLE, 1986, p. $151-163$.

1216. Tussen 1971 en 1985 gingen 42 Amerikaanse staten over tot de invoering van foutaansprakelijkheid met een gradueel eigen schuldverweer. In Californië werd deze aansprakelijkheidsregel in 1975 van kracht. Zie White, RJE, p. 309; Curran, JRLE, 1992, p. 319-322; Schirmeister, Amerikaanse toestanden in het schadevergoedingsrecht?, p. 444-446.

1217. White, RJE, 1989, p. 318.

1218. White, RJE, 1989, p. 316 . Zij spreekt van een 'all or nothing' regel.

zicht van de mees. p. 311. Sloan, Reilly and Schenzler, IRLE, 1994, p. 556-57 geven een overeen aantal meest gangbare aansprakelijkheidsregels in de Verenigde Staten, waarbij met name sproken 2 varianten van foutaansprakelijkheid met een gradueel eigen schuldverweer wordt besproken. Zie ook Bolt, Loterij of rechtspraak?, p. 47-69. 
De zorgniveaus van dader en slachtoffer werden door White onderverdeeld in dit categorieën. De eerste categorie heeft betrekking op een laag niveau van zorg (ver bad driving'), waarbij de bestuurder zich bijvoorbeeld schuldig heeft gemaakt an het gebruik van alcohol of een sterke overschrijding van de maximumsnelheid. Bi de tweede categorie heeft de bestuurder gemiddelde zorg uitgeoefend ('medioner driving'), waarbij hem een licht verwijt kon worden gemaakt. Bij de derde categont werd een hoog niveau van zorg bij de bestuurder vastgesteld ('good driving'), thats: bij geen bewijs voor verwijtbaar gedrag kon worden geleverd. ${ }^{1220}$

De resultaten van het onderzoek wijzen in de eerste plaats uit dat een verschuiving van foutaansprakelijkheid met een absoluut eigen schuldverweer naar foutaanspon. kelijkheid met een gradueel eigen schuldverweer leidt tot een stijging (van .47 nar .66) van de verwachte aansprakelijkheid bij de dader, wanneer deze een gemiddeld zorgniveau uitoefent. De kans voor de dader om aansprakelijk te worden gestld leidt bij een laag zorgniveau tot een lichte daling (van .99 naar .98). ${ }^{1221}$

In de tweede plaats wordt door de onderzoeksdata aangegeven dat bij de toepassing van foutaansprakelijkheid met een absoluut eigen schuldverweer $33 \%$ van de daders gemiddelde zorg uitoefende, terwijl door $67 \%$ een laag zorgniveau werd aangewend $81 \%$ van de slachtoffers oefenden een hoog zorgniveau uit, terwijl door $19 \%$ een g middeld zorgniveau werd aangewend. $\mathrm{Bij}$ foutaansprakelijkheid met een graduel eigen schuldverweer oefende $46 \%$ van de daders een gemiddeld zorgniveau uit tan $54 \%$ lage zorg. $71 \%$ van de slachtoffers oefenden bij deze regel hoge zorg uit th $29 \%$ gemiddelde zorg. ${ }^{1222}$

In de derde plaats wordt door White een verband gelegd tussen de kans om aanspprt kelijk te worden gesteld en de uitoefening van een gemiddeld zorgniveau. Bij fortaansprakelijkheid met een absoluut eigen schuldverweer is de relatieve kans vor een bestuurder om als dader aansprakelijk te worden gesteld .30; bij foutansppratelijkheid met een gradueel eigen schuldverweer bedraagt deze kans $.40^{1223}$ Dit ver. schil kan volgens White worden verklaard uit het gegeven dat bij foutaanspraklilik. heid met een absoluut eigen schuldverweer strengere eisen worden gesteld an eth eventuele aansprakelijkheid van de dader. ${ }^{1224} \mathrm{Zij}$ bedoelt hier waarschijnlijk meed dat het bij foutaansprakelijkheid met een absoluut eigen schuldverweer voor een slacht-

1220. White, RJE, 1989, p. 318-319. Bij de rangschikking van dader en slachtoffer onder de vestit lende zorgcategorieèn bleek overigens dat aan de kant van de daders geen enkele besturriat in worden ondergebracht in categorie 3 ('good driving') en aan de zijde van de slachtoffers berm zich geen enkele bestuurder die zich schuldig had gemaakt aan 'very bad driving' (categorie l).

1221. White, RJE, 1989, p. 319-320.

1222. White, RJE, 1989 , p. 325-326.

1223. White, RJE, 1989 , p. 326.

1224. White, RJE, 1989, p. 326. 
offer moeilijker is om schadevergoeding te verkrijgen dan bij een foutaansprakelijkheid met een gradueel eigen schuldverweer. Bij foutaansprakelijkheid met een absoluut eigen schuldverweer mag aan het slachtoffer immers geen verwijt worden gemakkt, anders ontvangt hij in het geheel geen vergoeding. Uit de cijfers blijkt verder dat het slachtoffer bij foutaansprakelijkheid met een absoluut eigen schuldverweer (.46) minder geneigd is om naar de rechter te stappen dan bij foutaansprakelijkheid met een gradueel eigen schuldverweer (.66). ${ }^{1225}$

Naar aanleiding van haar onderzoeksresultaten tracht White een preventief verband aan te tonen tussen de uitoefening van verschillende zorgniveaus en een foutaansprakelijkheid met respectievelijk een absoluut en een gradueel eigen schuldverweer. Met behulp van een rechtseconometrische analyse stelt White dat bij beide aansprakelijkheidsregels de prikkels van zorg toenemen, wanneer het zorgniveau van de bestuurder daalt van hoge zorg naar gemiddelde zorg. Voor bestuurders met een gemiddeld of laag zorgniveau zijn daarnaast de prikkels om voorzichtig te rijden bij foutaansprakelijkheid met een absoluut eigen schuldverweer sterker dan bij foutaansprakelijkheid met een gradueel eigen schuldverweer. De resultaten van dit modelmatige onderzoek suggereren derhalve dat een verschuiving van foutaansprakelijkheid met een absoluut eigen schuldverweer naar foutaansprakelijkheid met een gradueel eigen schuldverweer bij de bestuurders tot een vermindering van de prikkels van zorg heeft geleid. ${ }^{1226}$

White concludeert naar aanleiding van haar onderzoek dat de empirische resultaten steun geven aan de theoretische veronderstelling dat foutaansprakelijkheid met respectievelijk een absoluut en een gradueel eigen schuldverweer tot verschillende gedragsprikkels leiden, hoewel deze verschillen volgens haar in de praktijk minder groot zijn dan theoretisch is gesuggereerd. Daarnaast heeft de overgang naar een foutaansprakelijkheid met een gradueel eigen schuldverweer mogelijk de prikkels van zorg verminderd, waardoor een stijging van de ongevalskosten kan worden verwacht. Het bewijs hiervoor is volgens White echter vrij zwak gebleken. ${ }^{1227}$

Samenvattend kan worden gesteld dat het belang van het onderzoek van White voural ligt op het terrein van de preventieve zorgvuldigheid, waarbij de toepassing van foutaansprakelijkheid met een absoluut eigen schuldverweer vermoedelijk tot meer zorgvuldigheid bij het slachtoffer leidt. Deze aansprakelijkheidsregel heeft ummers een alles of niets karakter, waarbij een licht verwijt van het slachtoffer reeds een blokkering van de schadevergoeding tot gevolg heeft. Uit het onderzoek van White bleek dat het slachtoffer bij foutaansprakelijkheid met een absoluut eigen

\footnotetext{
1225. White, RJE, 1989 , p. 319

1226. White, RJF, 1989, p. 328 . Zie ook Dewees, Duff and Trebilcock, Accident Law, p. 63-64 noot i227. White, RJE, 1989, p. 328-329.
} 
schuldverweer eerder hoge zorg (81\%) zal aanwenden dan bij foutaansprakelijkedi met een gradueel eigen schuldverweer (71\%). Bij de laatste regel zal de dader to meer zorgvuldigheid worden aangezet. Uit het onderzoek van White bleek dat de dader bij foutaansprakelijkheid met een gradueel eigen schuldverweer eerder eta gemiddeld zorgniveau uitoefent (46\%) dan bij foutaansprakelijkheid met een absoluut eigen schuldverweer (33\%). Daamaast loopt de dader bij foutaansprakelijkhei met een gradueel eigen schuldverweer een grotere kans om door het slachtoffer a as sprakelijk te worden gesteld. ${ }^{1228}$

In een later verschenen omvangrijk empirisch onderzoek is onder andere gearn lyseerd welke gevolgen een overgang van foutaansprakelijkheid met een absolver eigen schuldverweer naar foutaansprakelijkheid met een gradueel eigen schuldverweer heeft gehad op het aantal verkeersongevallen. ${ }^{1229}$ Daarbij is geconcludeerd dar deze verschuiving van aansprakelijkheidsregels geen invloed heeft gehad op het ar. tal dodelijke verkeersongevallen. Er bleken daarnaast geen aanwijzingen te zijn waaruit kon worden opgemaakt dat de overgang naar foutaansprakelijkheid met exn gradueel eigen schuldverweer de prikkels van zorg bij de autobestuurder heeft ver minderd. ${ }^{1230}$ De onderzoekers verwijzen naar het hiervoor besproken onderzoek ran White waarbij zij stellen dat:

'With the impact on injurers' incentives unclear and with victims better off under comparative negligence, it would appear that drivers' incentives to be careful are greater under contributory negligence. Nevertheless, choice of a comparative versus a contributory liability rule may have little effect on the decision to deviate substantially from the due care standard, such as to drink and drive, because in such cases one party's actions are likely to have been almost the entire cause of the accident'. ${ }^{1231}$

\subsection{DE SCHADEREGELING BIJ VERKEERSONGEVALLEN IN NOORD-AMERIKAEN CANADA}

In deze paragraaf zal aan de hand van een aantal empirische studies worden onderzocht op welke wijze de schaderegeling bij verkeersongevallen in de Verenigdes: ten en Canada verloopt. In deze landen is veel onderzoek verricht naar de praktistte werking van de aansprakelijkheid in het verkeer. Ten aanzien van de vergoeding val verkeersschade in de VS en Canada geldt overigens dat de gemiddelde aansprate lijkheidsvordering wordt gedomineerd door uitkeringen voor immateriele schade Uit onderzoek is gebleken dat gemiddeld meer dan $60 \%$ van de totale schadevergor

1228. White, RJE, 1989 , p. 325-326.

1229. Sloan, Reilly and Schenzler, IRLE, 1994, p. 53-71.

1230. Sloan, Reilly and Schenzler, IRLE, 1994, p. 67.

1231. Sloan, Reilly and Schenzler, IRLE, 1994, p. 58 en 69. 
ding die onder een derde partij aansprakelijkheidsverzekering voor verkeersschade is gedekt betrekking heeft op uitkeringen voor immateriële schade. ${ }^{1232}$

\subsubsection{De vergoedingsmogelijkheden voor een verkeersslachtoffer}

In de Amerikaanse staten waarbinnen nog een traditioneel aansprakelijkheidsregime voor verkeersschade geldt, ${ }^{1233}$ wordt deze globaal geregeld via het aansprakelijkheidsrecht ('tort'), gecombineerd met een 'verplichte' motorrijtuigverzekering tegen ansprakelijkheid ('bodily injury liability (BIL) insurance'). Daarnaast kan een autobestuurder een zogenaamde 'uninsured motorist' (UM) verzekering afsluiten, die dekking verschaft tegen het risico dat een schadeveroorzaker onverzekerd blijkt te zijn. ${ }^{134}$ Met betrekking tot de schaderegeling na een verkeersongeval wordt een foutaansprakelijkheid met zowel een absoluut als een gradueel eigen schuldverweer toegepast. ${ }^{1235}$

Een verkeersslachtoffer in een 'tort' staat kan zijn materiële en immateriële schade ('general damages') via een aansprakelijkheidsprocedure vergoed krijgen van de schadeveroorzaker wanneer deze laatste verantwoordelijk kan worden gesteld voor het ongeval. Daarnaast kan door de rechter aan het slachtoffer een zogenaamde privaatrechtelijke boete ('punitive damage') worden toegewezen, ter bestraffing en afschrikking van de schadeveroorzaker. ${ }^{1236}$ Het slachtoffer dient de schuld van de schadeveroorzaker aan te tonen. Wanneer deze schuld is bewezen heeft het slachtoffer recht op compensatie voor de geleden schade. De aansprakelijkheidsverzekering van de schadeveroorzaker keert, binnen de geldende polisvoorwaarden, zowel zaakschade ('property damage') als letselschade ('personal injury') uit. De laatste categone omvat materiële schade, zoals medische kosten en inkomensschade en immaterièle schade ('general damages') voor pijn en smart ('pain and suffering'). ${ }^{1237}$ Voor de

1232. All-Industry Research Advisory Council, Compensation for Automobile Injuries in the United States, 1989, p. 34 en Hammitt, Automobile Accident Compensation, Volume II: Payments By Auto Insurers, The Institute for Civil Justice, The Rand Corporation, R-3051-ICJ, 1985, p. 32 in Dewees Duff and Trebilcock, Accident Law, p. 32 noot 178.

123. Gedurende de jaren '70 van de vorige eeuw is een groot aantal Amerikaanse staten overgegaan tot de invoering van een no-fault verzekering. Zie daarover Van Wassenaer van Catwijck, VA 1988. p. 326-330. Voor een uitvoerige analyse van de verhouding tussen aansprakelijkheid en no-fault kan worden verwezen naar hoofdstuk 13.

1234. Zie Rolph, Hammit and Houchens, JRI, 1985, p. 672; Prosser and Keeton on the I aw of Torts, p 584-588 en p. 602-603; Van Wassenaer van Catwijck, VA, 1988, p. 329.

1235. Zie Curran, IRLE, 1992, p. 319-322 en Rolph, Hammitt and Houchens, JRI, 1985, p. 672 voor en overzicht van de staten waarbinnen een foutaansprakelijkheid met een absoluut respectievelijk een gradueel eigen schuldverweer toepasselijk is. Zie ook White, RJE, 1989, p. 309

1236. Zie daarover Schirmeister, Amerikaanse toestanden in het schadevergoedingsrecht, p. 139-141, p. 158-159 en p. 167-176.

1237. Camoll and Kakalik, JRI, 1993, p. 266; Cummins and Weiss, GPRI, 1991, p. 20; Rolph, Hammit and Houchens, JRI, 1985, p. 671. Zie ook Schirmeister, Amerikaanse toestanden in het schade- 
vergoeding van smartengeld zijn richtlijnen van toepassing die van staat tot stant verschillen, waarbij in sommige gevallen driemaal het totale bedrag aan materietle personenschade wordt uitgekeerd. Door een aantal Amerikaanse staten worden ech. ter, evenals aan de omvang van de privaatrechtelijke boete ('punitive damage'), ook beperkingen gesteld aan de vergoeding voor immateriële schade. ${ }^{1238}$

Naast de mogelijkheid om de aansprakelijkheidsverzekeraar van de schadever. oorzaker aan te spreken, zijn er ook aan de zijde van het potentïle verketrsslachtoffer meerdere vergoedingsbronnen beschikbaar. Ongeveer $85 \%$ van de Ame rikaanse bevolking beschikt over een of andere vorm van een particuliere ziektekos. tenverzekering ('private health insurance'). ${ }^{1239}$ Daarnaast zijn er vanwege de over. heid Medicare en Medicaid programma's beschikbaar voor de ergste noden. ${ }^{120}$ Voor wat betreft verkeersongevallen geldt echter dat minder dan $5 \%$ van de slachtoffers op grond van een dergelijke publieke verzekering compensatie ontvangt voor medische kosten, terwijl 1/3 van het aantal verkeersslachtoffers de medische kosten vis een particuliere ziektekostenverzekering krijgt vergoed. In Canada bestaat daarentegen een publieke ziektekostenverzekering die alle medische kosten en persoonlije schade vergoed. ${ }^{1241}$

Naast deze vergoedingsbronnen kan een potentieel verkeersslachtoffer in Noord Amerika een eerste partij verzekering ('med pay insurance') afsluiten die meer sperifiek de medische kosten tengevolge van een verkeersongeval vergoedt. Een onderzoek ten aanzien van het jaar 1970 heeft uitgewezen dat in New York 70\% van de auto-eigenaren dekking voor medische kosten heeft. De polislimieten voor een der.

vergoedingsrecht, p. 35-42; Bolt, Loterij of rechtspraak?, p. 179-216, voor een overzicht van de verschillende vergoedingsmogelijkheden.

1238. Dewees, Duff and Trebilcock, Accident Law, p. 17 en p. 64 noot 19; Van Wassenaer van Car wijck, VA, 1988, p. 331; Schirmeister, Amerikaanse toestanden in het schadevergoedingsreth p. 499-506.

1239. J. O'Connell and J. Guinivan, An Irrational Combination: The Relative Expansion of Liabilit Insurance and Contraction of Loss Insurance, Ohio State Law Joumal, 1988, p. 762 noot $13 \mathrm{~m}$ Dewees, Duff and Trebilcock, Accident Law, p. 26 en 70 noot 113.

1240. Zie Schirmeister, Amerikaanse toestanden in het schadevergoedingsrecht, p. 260-263; Bolt, bo terij of rechtspraak?, p. 191-194, voor de verschillende regelingen op het terrein van de vagk ding van medische kosten.

1241. R.L. Houchens, Automobile Accident Compensation, Volume III: Payments from All Sourtix The Institute for Civil Justice, The Rand Corporation, R-3053-ICJ, 1985, p. 26 (figure 4.1) o J.E. Rolph, J.K. Hammitt, R.L. Houchens and S. Segal Polin, Automobile Accident Compess tion, Volume 1: Who Pays How Much How Soon?, The Institute for Civil Justice, the Rat Corporation, R-3050-ICJ, 1985, p. 16 (table 5) in Dewees, Duff and Trebilcock, Accident Ls p. 26 en 70 noot 114. 
gelijke verzekering zijn relatief laag; in $90 \%$ van de polissen bedraagt de dekking \$ 5.000 of minder. ${ }^{124}$

De verzekeringsmogelijkheden voor inkomensschade zijn in Noord-Amerika en Canada minder omvangrijk. Werknemers die slachtoffer zijn geworden van een verkeersongeval kunnen een beroep doen op de zogenaamde 'Workers Compensation Scheme' voor verkeersschade die tijdens het werk is geleden. ${ }^{1243}$ Deze programma's betalen goed uit, maar deze beroepsschade omvat slechts een klein onderdeel van de totale verkeersschade. In Amerika is verder een sociaal zekerheidsprogramma beschikbaar. De belangrijkste regeling op dit terrein is de 'Social Security Act', een verplichte werknemersverzekering die inkomensschade ten gevolge van letsel of overlijden vergoedt. ${ }^{1244}$ De vergoedingen blijken in de praktijk echter laag (maximaal ongeveer $\$ 146$ per week) en zijn veelal beperkt tot langdurige of volledige arbeidsongeschiktheid. In Canada zijn de vergoedingen tengevolge van arbeidsongeschiktheid genereuzer (maximaal $\$ 318$ per week), maar is de periode waarbinnen een recht op uitkering geldend kan worden gemaakt beperkt (ongeveer 15 weken na een wachttijd van 2 weken). Vergoeding tegen langdurige arbeidsongeschiktheid is ook via de particuliere verzekeringsmarkt wel mogelijk. De lange termijn dekking voor arbeidsongeschiktheid bedraagt ongeveer $60 \%-70 \%$ van het inkomen, maar wordt door slechts $20 \%$ van de Amerikaanse werknemers en $40 \%$ van de werknemers in Ontario gebruikt. Een verzekering tegen tijdelijke arbeidsongeschiktheid, minder dan twee jaar, wordt door $56 \%$ van de Amerikaanse werknemers afgesloten (1984), maar de uitkering beslaat veelal een korte periode. ${ }^{1245}$

Tenslotte kan in het kader van de vergoeding van verkeersschade nog worden gewezen op de zogenaamde 'collateral source rule'. Deze regel verbiedt de jury in een aansprakelijkheidsprocedure om rekening te houden met additionele vergoedingsbronnen aan de zijde van het ongevalsslachtoffer. Dit betekent dat een slachtoffer meer vergoeding kan ontvangen dan zijn werkelijk geleden schade. ${ }^{1246}$

1242. Carroll and Kakalik, JRI, 1993, p. 266; All-Industry Research Advisory Counsil, Compensation for Automobile Injuries, 1989, p. 26 in Dewees, Duff and Trebilcock, Accident Law, p. 26 en p. 70 noot 115 .

1243. Zie daarover Bolt, Loterij of rechtspraak?, p. 181-187.

1244. Zie daarover Abraham and Liebman, CoLR, 1993, p. 78-85; Schirmeister, Amerikaanse toestanden in het schadevergoedingsrecht?, p. 196-198; Bolt, Loterij of rechtspraak, p. 189-191 en p. 194-198 voor aanvullende regelingen.

1245. Danzon, JLS, 1984, p. 519-524; Abraham and Liebman, CoLR, 1993, p. 81-82; O'Connell and Guinivan, Ohio State Law Joumal, 1988, p. 763 in Dewees, Duff and Trebilcock, Accident Law, p. 27 en 70 noot 124

1246. Cummins and Weiss, JRI, 1993, p. 256-257; Rolph, Hammit and Houchens, JRI, 1985, p. 671; Abraham and Liebman, CoLR, 1993, p. 94-98; Bolt, Loterij of rechtspraak?, p. 201-214. In een aantal Amerikaanse staten zijn overigens wettelijke regelingen getroffen om het gebruik van de 


\subsubsection{De compensatie van verkeersslachtoffers in de praktijk}

In een aantal empirische studies is een verband gelegd tussen de vergoedingsregels bij aansprakelijkheid en de mate waarin verkeersslachtoffers worden gecomper. seerd. Uit een studie in de Canadese provincie Ontario blijkt dat halverwege de jare ' 60 van de overige eeuw $43 \%$ van het aantal verkeersslachtoffers compensatic onl. ving op basis van foutaansprakelijkheid met een gradueel eigen schuldverweer. ${ }^{12}$ Een Amerikaanse onderzoek uit 1970 wijst uit dat $47,7 \%$ van het aantal dodelijke ernstig gewonde verkeersslachtoffers op grond van het aansprakelijkheidsrecht ten vergoeding ontving. ${ }^{1248}$ De overgang van een foutaansprakelijkheid met een absolutu eigen schuldverweer naar een foutaansprakelijkheid met een gradueel eigen schuld. verweer leidde tot een procentuele toename van het aantal verkeersslachtoffers del werd gecompenseerd met $10-25 \%{ }^{1249}$

Ten aanzien van de beschikbare dekking onder een aansprakelijkheidsverzekeng bij potentiële schadeveroorzakers, kan uit een aantal studies worden opgemaakt das de beschikbare verzekeringsdekking vaak onvoldoende is om emstig gewonde ver. keersslachtoffers te compenseren. Een studie in Ontario wijst uit dat bijna $85 \%$ van de schadeveroorzakers een aansprakelijkheidsdekking had van minimaal $\$ 500.000$. In de Verenigde Staten had slechts $32 \%$ van de betrokken motorijuigen de be. schikking over een aansprakelijkheidsdekking van meer dan $\$ 100.000$, terwij] $38 \%$ een dekkingslimiet had van $\$ 10.000$ of minder. ${ }^{1250}$

Daarnaast werden sommige delen van Noord-Amerika en Canada gekenmerk door een hoog percentage onverzekerde autobestuurders ('uninsured motorists'). In Noord-Amerika gold landelijk gezien een percentage onverzekerde autobesturders van $8-11 \%$. Dit percentage steeg echter van $20 \%$ in sommige staten tot meer din

'collateral source rule' terug te dringen. Zie daarover Schirmeister, Amerikaanse toestandan in het schadevergoedingstecht?, p. 517-522; Bolt, Loterij of rechtspraak?, p. 210-214.

1247. Ontario Law Reform Commission (OLRC), Report on Motor Vehicle Accident Compensotic Toronto: Ministery of the Attomey General, 1973, p. 51 (table 5) in Dewees, Duff and Trat cock, Accident Law, p. 29-30 en p. 71 noot 141.

1248. U.S. Department of Transportation, Compensating Accident Victims, Washington D.C., 1985, 73-74 in Dewees, Duff and Trebilcock, Accident Law, p. 30 en p. 71 noot 142.

1249. Rolph, Hammitt, Houchens and Segal Polin, Automobile Accident Compensation, Volume LP 18 en 31: Hammitt, Automobile Accident Compensation, Volume II, p. 49 en 52 in Denter. Duff and Trebilcock, Accident Law, p. 30 en p. 71 noot 143.

1250. Osborne Commission, Report of Inquiry into Motor Vehicle Accident Compensation in Onamh Toronto, Queen's Printer, 1988, 2:542 (question 6) en All-Industry Research Advisory Cuovith Compensation for Automobile Injuries in the United States, p. 26 in Dewees, Duff and Thith cock, Accident Law, p. 31 en p. 73 noot 166-167. Zie ook O'Connell, SDLR, 1989, p. 99/ Prosser en Keeton on the Law of Torts, p. 598. 
$70 \%$ in bepaalde stedelijke gebieden zoals Detroit en Los Angeles. ${ }^{1251}$ In de Canadese provincie Ontario was minder dan $2 \%$ van de autobestuurders onverzekerd, terwijl ten aanzien van de provincie Quebec onderzoek heeft uitgewezen dat tussen 1974 en 1977 16\% van de autobestuurders die betrokken waren bij een verkeersongeval niet verzekerd was. ${ }^{1252}$

Dewees, Duff en Trebilcock analyseren een aantal factoren die van invloed zijn op de omvang van de schadevergoeding die binnen een aansprakelijkheidsregime aan het verkeersslachtoffer ter beschikking komt. Deze factoren hebben betrekking op de eigen schuld van het slachtoffer, de immateriële schadevergoeding, de zogenaamde 'collateral sources' en de verhouding tussen kleine en grote schadebedragen en zullen hiema aan de hand van empirisch onderzoek worden uitgewerkt.

\subsubsection{De eigen schuld van het verkeersslachtoffer}

Een aantal Amerikaanse studies heeft aangetoond dat het verkeersslachtoffer ingeval van eigen schuld minder krijgt uitgekeerd dan zijn werkelijk geleden materiële schade. Het aantal aansprakelijkheidsclaims waarbinnen sprake was van eigen schuld bij het slachtoffer liep uiteen van 2\%-18\% voor heel Noord-Amerika, tot $28 \%$ in een onderzoek met betrekking tot de staat Californië, waar sinds 1975 een foutaansprakelijkheid met een gradueel eigen schuldverweer van toepassing is. ${ }^{1253}$ Uit een ander empirisch onderzoek blijkt dat in 'tort' staten verkeersslachtoffers die een verkeers-

1251. Zie Osbome Commission, Report of Inquiry into Motor Vehicle Accident Compensation in Ontario, 1988, 1:97 en 1:480; Hammitt, Automobile Accident Compensation, Volume 2, p. $19 \mathrm{en}$ U.S. Department of Transportation, Compensating Auto Accident Victims, p. 76 in Dewess, Duff and Trebilcock, Accident Law, p. 31 en p. 72-73 noot 158-161. Ter vergelijking in Europa, waar een verzekeringsplicht geldt, is het aantal onverzekerde autobestuurders gemiddeld 1 tot $2 \%$ (Groat-Brittanië, $6 \%$ ). Deze cijfers zijn ontleend aan een OECD-Rappon, Road Transpor Research, 1990 , p. 27-28.

1252. R.A. Devlin, Liability versus No-Fault Automobile Insurance Regimes: An Analysis of the Experience in Quebec, University of Toronto, 1988, p. 52 in Dewees, Duff and Trebilcock, Accident Law, p. 33 en p. 74 noot 200.

1253. Zie Hammitt, Automobile Accident Compensation, Volume 2, 1985, p. $29-30$ (2\%-10\%, niet meer dan $30 \%$ van het aantal verkeersslachtoffers die eigen schuld hadden aan het ongeval kregen in elke onderzochte staat minder dan hun werkelijk geleden materiële schade vergoed); AllIndustry Research Advisory Council, Compensation for Automobile Injuries, 1989, p. 129-130 (ten aanzien van aansprakelijkheidsclaims voor overlijden of ernstig letsel had in $17,4 \%$ van de aansprakelijkheidsclaims de eigen schuld van het slachtoffer tot gevolg dat hij minder dan zijn werkelijk geleden schade vergoed kreeg); Rolph, Hammitt, Houchens and Segal Polin, Automobile Accident Compensation, Volume 1, 1985, p. 20 (28\% voor Californiê). Deze studies worden geciteerd in Dewees, Duff and Trebilcock, Accident Law, p. 32 en p. 73 noot 170-173. 
overtreding hebben begaan gemiddeld $29 \%$ minder schadevergoeding kregen uitge. keerd dan alle slachtoffers die tenminste enige vergoeding ontvingen. ${ }^{254}$

\subsubsection{De immateriële schadevergoeding}

Een tweede factor die binnen een aansprakelijkheidsregime van invloed is op de omvang van de compensatie aan verkeersslachtoffers heeft betrekking op de uitkering voor immateriële schade ('non-pecuniary loss' of 'general damages'). In de Vs en Canada wordt de total uitgekeerde schadevergoeding veelal gedomineerd don de compensatie voor immateriële schade. Een Amerikaanse studie uit 1985 wijst ui dat op basis van het totale aantal aansprakelijkheidsclaims tussen de 70\% en $96 \%$ van de verkeersslachtoffers ook een uitkering voor immateriële schade ontvingen Volgens een aantal studies wordt meer dan $60 \%$ van de totale schadevergoeding die op basis van een derde partij aansprakelijkheidsverzekering ter beschikking korm uitgekeerd voor immateriële schade. ${ }^{1255}$

Uit een studie in de Canadese provincie Ontario, waarbij 1500 aansprakelij. heidsvorderingen uit het jaar 1986 werden onderzocht, blijkt dat $94,5 \%$ van het aartal verkeersslachtoffers een vergoeding voor immateriële schade ontving, terwi]. slechts $38,4 \%$ van bet aantal slachtoffers voor inkomensschade werd gecomperseerd. In zijn totaliteit bezien had $45,6 \%$ van alle aansprakelijkheidsbetalingen betrekking op uitkeringen voor immateriële schade. Hoewel dit percentage daalde bij een toename van de omvang (in dollars) van de aansprakelijkheidsvordering bleef de claim voor immateriële schade een belangrijk bestanddeel uitmaken van de totale schadevergoeding, zelfs voor claims die de $\$ 75.000$ te boven gingen. Bij schade-uitkeringen van $\$ 10.000$ of minder bedroeg de vergoeding voor immatenile schade meer dan $70 \%$ van de totale aansprakelijkheidssom. ${ }^{1256}$

\subsubsection{3. 'Collateral sources'}

Met betrekking tot de vergoeding van verkeersschade kan de aanwezigheid van 20 genaamde 'collateral sources', additionele vergoedingsbronnen, tot gevolg hebben dat het verkeersslachtoffer meer vergoeding ontvangt dan zijn werkelijk geldeten schade. Deze overcompensatie houdt mede verband met de eerdergenoende collz.

1254. Houchens, Automobile Accident Compensation, Volume 3, p. 21 in Dewees, Duff and Tnth cock, Accident Law, p. 32 en p. 73 noot 176.

1255. Hammitt. Automobile Accident Compensation, Volume 2, p. 25-26 en p. 32; All-industy Rs search Auvisory Council, Compensation for Automobile Injuries, 1989, p. 34 in Dewes, Dof and Trebilcock, Accident Law, p. 32 en p. 73 noot 177-178.

1256. De gegevens zijn ontleend aan Osborne Commission, Report of Inquiry into Motor Vehicle As cident Compensation in Ontario, 1988, 2:553 (question 30), 2:258-2:262 (figure 7.77.10) in Dewees, Duff and Trebilcock, Accident Law, p. 32 en p. 73 noot 179-182. 
teral source rule', die de jury verbiedt om in een aansprakelijkheidsprocedure rekening te houden met additionele vergoedingsbronnen aan de zijde van het ongevalsslachtoffer. ${ }^{1257}$ Volgens een Amerikaanse studie is $18 \%$ van de schadevergoeding die het slachtoffer bereikt een overlapping van de compensatie die voor het slachtoffer reeds uit andere bronnen beschikbaar is. ${ }^{1258} \mathrm{Er}$ is bij deze vergoedingsbronnen weliswaar sprake van een regresrecht, maar dit wordt vanwege de hoge transactiekosten nauwelijks uitgeoefend. Het gevolg hiervan is een overcompensatie van verkeersslachtoffers, hetgeen wordt bevestigd door een onderzoek in de Canadese provincie Ontario. Daarin blijkt dat ongeveer $30 \%$ van het aantal verkeersslachtoffers hun inkomensschade kreeg vergoed voor een bedrag dat bijna gelijk was aan $136 \%$ van het bruto inkomensverlies. Bij dit onderzoek werden alle beschikbare vergoedingsbronnen van het slachtoffer in aanmerking genomen bovenop de aanwezigheid van een 'add-on' no-fault verzekering, waarvan de uitkering wel in mindering wordt gebracht op de aansprakelijkheidsvergoedingen. ${ }^{1259}$

In een Amerikaanse studie wordt geconcludeerd dat $20 \%$ van het aantal verkeersslachtoffers uit meerdere bronnen een schadevergoeding ontving. Veel slachtoffers kregen daarbij hun materiële schade meer dan dubbel gecompenseerd. Daarnaast werd door ongeveer de helft van het aantal verkeersslachtoffers die beschikten over een particuliere ziektekostenverzekering geen aansprakelijkheidsvordering ingesteld, omdat zij reeds vanuit een andere bron hun schade vergoed kregen. ${ }^{1260}$

\subsubsection{De verhouding tussen kleine en grote schadebedragen}

Een vierde en laatste factor die bij de vergoeding van verkeersschade in de VS en Canada een rol speelt, houdt verband met de vraag of de geleden schade een grote of kleine omvang heeft. Data uit deze landen geven aan dat een groot aantal aansprakelijkheidsvorderingen werd ingediend voor relatief lichte materiële schade. Een studie van de Department of Transportation in de VS uit 1970 wijst uit dat $78,9 \%$ van de verkeersslachtoffers een materiële schade leed van $\$ 500$ of minder, slechts $11 \%$ had een schade van meer dan $\$ 1.000$ en $1,6 \%$ van de slachtoffers leed een schade van

1257. Rolph, Hammitt and Houchens, JR, 1985, p. 671. Zie ook paragraaf 3.2.1 van dit hoofdstuk.

1258. D.D. Caldwell, No-Fault Automobile Insurance: An Evaluative Survcy, Rutgers Law Review, 1977, p. 921 noot 52 in Dewees, Duff and Trebilcock, Accident Law, p. 33 en p. 74 noot 191.

1259. Osbome Commission, Report of Inquiry into Motor Vehicle Accident Compensation in Ontario, 1988, 1:430-435 in Dewees, Duff and Trebilcock, Accident Law, p. 33 en p. 74 noot 192-194.

126i. Houchens, Automobile Accident Compensation, Volume 3, p. 5, 27 en 31-32 in Dewees, Duff and Trebilcock, Accident Law, p. 33 en p. 74 noot 195-196. In een groot aantal Amerikaanse staten is in de jaren ' 70 en ' 80 van de vorige eeuw het gebruik van de 'collateral source rule' wettelijk beperkt. Zie daarover Schirmeister, Amerikaanse toestanden in het schadevergoedingsrecht?, p. 517-522; Abraham and Liebman, CoLR, 1993, p. 94-98; Bolt, Loterij of rechtspraak?, p. 201- 
$\$ 5.000$ of meer. ${ }^{1261}$ In een studie naar aansprakelijkheidsbetalingen in Florida tussen 1971 en 1973 wordt geconstateerd dat tussen $63,7 \%$ en $70,2 \%$ van de uitgekeerde bedragen minder dan $\$ 500$ bedroeg. ${ }^{262}$

Meer recente Amerikaanse studies geven een gelijkaardig patroon, hoewel de schadebedragen iets hoger liggen. Een studie in Californië wijst bijvoorbeeld uit dat in $197751 \%$ van de aansprakelijkheidsclaims betrekking had op bedragen van $\$ 1.000$ of minder en $11 \%$ op vorderingen van $\$ 5.000$ of meer. ${ }^{1263}$

In Ontario bleek dat van het aantal slachtoffers dat een aansprakelijkheidsvergoeding voor inkomensschade ontving (totaal: $56,9 \%$ ), $45 \% 4$ weken of minder arbeidsongeschikt was, terwijl slechts $19 \%$ hiervan 6 maanden of meer uit het arbeidsproces verdween. Daarnaast was in meer dan de helft van de uitbetaalde aansprakelijkheids. claims sprake van een bedrag van $\$ 3.000$ of minder $(27,7 \%$ was lager dan $\$ 1.000)$ en $21,7 \%$ betrof uitkeringen van meer dan $\$ 10.000$. $^{1264}$

In paragraaf 3.2.2.3 is gewezen op het feit dat als gevolg van de aanwezigheid van meerdere vergoedingsbronnen een groot deel van de verkeersslachtoffers wordt overgecompenseerd. Dit geldt echter niet voor verkeersslachtoffers die emstig tot zeer ernstig letsel hebben geleden. Bij verkeersslachtoffers met een omvangijke schadeclaim is eerder sprake van ondercompensatie. De oorzaak hiervan houd zowel verband met de praktijk van de schaderegeling als met de aanwezigheid van or voldoende aansprakelijkheidsdekking bij de schadeveroorzaker. ${ }^{1265}$

Een Amerikaanse studie wijst uit dat vooral verkeersslachtoffers met emstig to zeer ernstig letsel nadeel van de lage verzekeringsdekking bij de dader ondervonden. Een studie naar aansprakelijkheidsbetalingen in Californië concludeert dat $13 \%$ van de uitkeringen in de hoogste categorie van materieel geleden schade (boven $\$ 2814$ ) werden beperkt door een aanwezige polislimiet. Daarbij wordt verder geconstaterer

1261. U.S. Department of Transportation, Automobile Personal Injury Claims, 1970, p. 30 in Derres Duff and Trebilcock, Accident Law, p. 33 en p. 73 noot 184.

1262. J.W. Little, A Critique of No-Fault Reparation for Traffic Crash Victims, Indiana Law Journe p. 635 en 640 noot 9 in Dewees, Duff and Trebilcock, Accident Law, p. 33 en p. 74 noot 185 .

1263. Hammitt, Automobile Accident Compensation, Volume 2, 1985, p. 4 in Dewees, Duff and int bilcock, Accident Law, p. 33 en p. 74 noot 186.

1264. Osborne Commission, Report of Inquiry into Motor Vehicle Accident Compensation in Onturio 1988, 2:548-552 (question 24 en 28-29) in Dewees, Duff and Trebilcock, Accident Law, p..33e p. 74 noot $188-190$. 1265. Bombaugh, CoLR, 1971, p. 213. Ontario Law Reform Commission, Report on Motor Vethich
Accident Compensation, 1973 p. 51 (table 4) in Dewees, Duff and Trebilcock, Accident Lav, 33 en p. 74 noot 197-199. 
dat de onderzochte aansprakelijkheidsclaims gemiddeld $\$ 18.000$ bedroegen, terwijl van dit bedrag gemiddeld bijna $\$ 10.000$ niet werd uitgekeerd. ${ }^{1266}$

Een antal studies wijst verder uit dat aansprakelijkheidsclaims voor lichte materiële schade werden overgecompenseerd, terwijl de meer omvangrijke schadeclaims werden ondergecompenseerd. ${ }^{1267}$ Een studie van de Rand Corporation rapporteert dat binnen een aansprakelijkheidsregime verkeersslachtoffers met een claim van $\$ 5.000$ of minder hun materiële schade vaak twee tot drie maal vergoed kregen. Slachtoffers met een schadeclaim van $\$ 25.000$ tot $\$ 100.000$ ontvingen veelal compensatie ten bedrage van ongeveer de helft van hun geleden materiële schade. ${ }^{1268}$ Uit een andere Amerikaanse studie kan worden opgemaakt dat ten aanzien van aansprakelijkheidsclaims waarbij sprake was van licht letsel, gemiddeld tweemaal de werkelijke schade werd uitgekeerd, terwijl slachtoffers die ernstig letsel hadden geleden ongeveer $27 \%$ tot $30 \%$ van de werkelijke schade kregen vergoed. ${ }^{1269}$ Hieruit blijkt derhalve dat bij hoge aansprakelijkheidsclaims zonder voldoende (verplichte) WA-dekking 'tort law' niet het meest geschikte instrument is om ernstig gewonde verkeersslachtoffers te compenseren.

\subsection{Verkeersaansprakelijkheid: 'Corrective Justice'}

Naast de hiervoor beschreven factoren, die vooral van invloed zijn op de omvang van de schadevergoeding van verkeersslachtoffers, blijkt volgens Dewees, Duff en Trebilcock verder dat de werking van het aansprakelijkheidsrecht bij verkeersongevallen in de praktijk niet overeenstemt met de doelstelling van corrigerende rechtvaardigheid ('corrective justice'). Anders gesteld heeft een aantal ontwikkelingen er toe geleid dat in de praktijk de rol van de (fout)aansprakelijkheid bij de vergoeding van verkeersschade sterk is beperkt. ${ }^{1270}$

1266. Hammitt, Automobile Accident Compensation, Volume 2, p. 45 (table 4.12) en All-Industry Research Advisory Council, Compensation for Automobile Injuries, 1989, p. 129-130 in Dewees, Duff and Trebilcock, Accident Law, p. 33-34 en p. 74 noot 201-203.

1267. Zie onder anderen Bombaugh, CoLR, 1971, p. 213-214. Ontario Law Reform Commission, Report on Motor Vehicle Accident Compensation, 1973, p. $48-49$ en p. 54-55 (table 7 en 8); Rolph, Hammitt, Houchens and Segal Polin, Automobile Accident Compensation, Volume 1, 1985, p. 22; Hammitt, Automobile Accident Compensation, Volume 3, 1985, p. 18 in Dewees, Duff and Trebilcock, Accident Law, p. 35 en p. 75 noot 211. Zie ook O'Connell, SDLR, 1989, p. 993.

1268. S.J. Camoll and J.S. Kakalik, No-Fault Automobile Insurance: A Policy Perspective, Santa Monica, Califomië, Institute for Civil Justice, Rand Corporation, 1991, p. 11 in Dewees, Duff and Trebilcock, Accident Law, p. 35 en p. 75 noot 215.

1269. All-Industry Research Advisory Council, Compensation for Automobile Injuries, 1989, p. 42 en 44 in Dewees, Duff and Trebilcock, Accident Law, p. 35 en p. 75 noot 216.

1270. Dewees, Duff and Trebilcock, Accident Law, p. 39-40. 
Binnen de Canadese verkeersaansprakelijkheid is ten aanzien van ongevallen tussen een motorvoertuig en een voetganger bijvoorbeeld sprake van een omkering van de. bewijslast. De autobestuurder moet aantonen dat de schade niet door zijn schuld is veroorzaakt. ${ }^{1271}$ Door een aantal commentatoren is deze regel geïnterpreteerd als etn vorm van risicoaansprakelijkheid respectievelijk een regel die ligt op het grensgebied tussen fout- en risicoaansprakelijkheid. ${ }^{1272}$

Een tweede ontwikkeling is de invoering in Canada van een regel die bepaalt dat de eigenaar van het motorrijtuig (polishouder) respectievelijk zijn aansprakelij. heidsverzekeraar aansprakelijk is voor de schade veroorzaakt door fouten van indi. viduen die het betreffende voertuig met instemming van de polishouder besturden. ${ }^{1273}$ Met de invoering van deze zogenoemde 'vicarious liability' worden de ver. goedingsmogelijkheden van het verkeersslachtoffer verbeterd, omdat een fout van de polishouder die de auto niet bestuurde daarbij geen rol meer speelt. ${ }^{1274}$

Een derde ontwikkeling binnen de verkeersaansprakelijkheid in Canada houdt enerzijds verband met een zoektocht naar een zogenaamde 'deep pocket', warbij zlf5 onvoorzichtige autobestuurders hun schade trachten te verhalen op de cafehoude: die hen de alcohol heeft geserveerd, de overheid als wegbeheerder of de autofabrikant. Anderzijds geldt de erkenning dat veel autobestuurders tenminste een deel van hun aansprakelijkheid hebben verzekerd. Dit heeft er toe geleid dat de rechter wort aangemoedigd om de juridische zorgvuldigheidsnorm te wijzigen van een lage standaard, waarbij de redelijk handelende bestuurder gevoelig is voor onoplettendheid fouten en aandachtgebrek, naar een hogere zorgstandaard, waarbinnen een perfecte autobestuurder wordt verondersteld die niet over dergelijke menselijke eigenscharp. pen beschikt. $^{1275}$

1271. Highway Traffic Act, R.S.O., 1990, c. H.8., paragraaf 193. Deze regel werd voor het eerst ing voerd in Ontario in 1906 en in de 30 jaar hierna gevolgd door andere Canadese jurisdictis. E. Dewees, Duff and Trebilcock, Accident Law, p. 40.

1272. B. Dunlop, No Fault Automobile Insurance and the Negligence Action - An Expensive Anore aly, Osgoode Hall Law Journal, 1975, p. 439 en 444 (risicoaansprakelijkheid) en C. Broma, to Fault Automobile Insurance in Canada, Toronto, Carswell, 1988, p. 5 in Dewees, Duff and Ts bilcock, Accident Law, p. 40 en p. 77 noot 250-251.

1273. Highway Traffic Act, R.S.O., 1990, c. H.8., paragraaf 192 (1) In Dewees, Duff and Ireblioch Accident Law, p. 40.

1274. Osborne Commission, Report of Inquiry into Motor Vehicle Accident Compensation in Onimin 1988, 1:307-308 in Dewees, Duff and Trebilcock, Accident Law, p. 77 noot 257.

1275. Ontario Law Reform Commission, Report on Motor Vehicle Accident Compensation, 1973, P 23 en 32 in Dewees, Duff and Trebilcock, Accident Law, p. 40 en p. 77 noot 258 . In Now Amerika is sprake geweest van een gelijkaardige ontwikkeling met name op het terrein val a 'vicarous liability'. Zie daarover Prosser and Keeton on the Law of Torts, p. 522-528. Zij wow hier aan toe dat op degene (eigenaar/polishouder) die het gevaar (auto) aan de weg toeverturt een vermoeden van aansprakelijkheid rust. 
Deze uitdijende reikwijdte van de foutaansprakelijkheid is ook zichtbaar op het terrein van de schaderegeling bij verkeersongevallen. Volgens Dewees, Duff en Trebilcock is de regeling van de schadeclaims niet optimaal gerelateerd aan de toepasselijke aansprakelijkheidsregels; zij wijkt daarmee volgens hen af van wat op basis van rechtvaardigheid ('corrective justice') als ideaal kan worden beschouwd. Daarbij kan een onderscheid worden gemaakt tussen de rol van de rechtspraak, de aansprakelijkheidsverzekeraar van de dader en de rol van het slachtoffer.

Wanneer het na een verkeersongeval tot een rechtszaak komt, ${ }^{1276}$ ontstaan problemen bij de toekenning van de schadevergoeding mede als gevolg van onduidelijkheden met betrekking tot de oorzaak van het verkeersongeval. Binnen een aansprakelijkheidsprocedure wordt daardoor veel gespeculeerd, waarbij het bewijs veelal onbetrouwbaar is en de slachtoffers hun eigen bijdrage in een zo positief mogelijk daglicht proberen te plaatsen. Daarnaast blijkt dat de noodzakelijke beoordelingen ten aanzien van het ontstaan van een verkeersongeval (afstand, snelheid, tijd) moeilijk zijn te maken; herinneringen vervagen wanneer het uiteindelijk tot een proces komt. ${ }^{1277}$ Daamaast is sprake van een ontwikkeling, waarbij een jury de neiging vertoont om een oordeel in het nadeel van de schadeveroorzaker, die immers over een aansprakelijkheidsverzekering beschikt, uit te spreken. ${ }^{1278}$

Een meerderheid van het aantal verkeersongevallen eindigt in een schikking tussen het slachtoffer en de aansprakelijkheidsverzekeraar van de schadeveroorzaker. Daarbij wordt door de aansprakelijkheidsverzekeraar vooral gebruik gemaakt van praktijkregels die weinig overeenkomsten vertonen met het aansprakelijkheidsrecht. Het gevolg is dat de onrechtmatigheid (fout) een ondergeschikte rol vervult bij de compensatie van verkeersslachtoffers. Zelfs wanneer de onrechtmatigheid (fout) de grondslag is voor de schadevergoeding, dan nog is de aansprakelijkheidsverzekeraar degene die bepaalt wat de omvang van de te vergoeden schade is en de mate waarin

1276. Uit onderzoek in de VS en Canada blijkt dat een klein deel van het aantal aansprakelijkheidsprocedures bij verkeersongevallen uiteindelijk voor de rechter komt. Zie voor Noord-Amerika: All-Industry Research Advisory Council, Compensation for Automobile Injuries, 1989, p. 115; Rolph, Hammit, Houchens and Segal Polin, Automobile Accident Compensation, 1985, Volume 1, p. 10 en Volume 4, p. 3. Van het aantal aansprakelijkheidsclaims wordt totaal $18-20 \%$ een gerechtelijke procedure gestart, slechts $2,2 \%$ hiervan bereikt de rechter en $0,6-0,9 \%$ van de gedingen leidt tot een uitspraak. Zie voor Canada (Ontario) Osbom Commission, Report of Inquiry into Motor Vehicle Accident Compensation, 1988, 1:364-65. Van de 50\% aansprakclijkheidsclaims waarvoor een vordering werd ingesteld bleek $2 / 3$ reeds geschikt te zijn voordat een rechtszaak kon beginnen. Uiteindelijk kwam maar 2-3\% van de vorderingen voor de rechter. De vonomde studies worden geciteerd in Dewees, Duff and Trebilcock, Accident Law, p. 19 en p. 64 noot $32-33$.

1277. Zie Ontario Law Reform Commission, Report on Motor Vehicle Accident Compensation, 1973, p. 17; Dunlop, Osgoode Hall Law Joumal, 1975, p. 445-446 in Dewees, Duff and Trebilcock,

1278. Accident Law, p. 41 en p. 78 noot 263-265; Prosser and Keeton on the Law of Torts, p. 598-599. 
deze schade naar de veroorzaker (polishouder) ervan wordt 'gecorrigeerd'. De aanwezigheid van een aansprakelijkheidsverzekering betekent daarnaast dat de schadeveroorzaker niet zelf verantwoordelijk is voor de schade van het verkeersslachtoffer Dit leidt er volgens Dewees, Duff en Trebilcock toe dat het beginsel van persoodlij. ke verantwoordelijkheid gebaseerd op schuld binnen de verkeersaansprakelijkheid voor persoonlijke schade min of meer is verlaten. ${ }^{1279}$

Tot slot kan worden gesteld dat ook het verkeersslachtoffer zelf, ten behoeve van een soort morele bevrediging, weinig interesse blijkt te hebben voor de mogelijkeid van een aansprakelijkheidsprocedure. Een Britse studie onder verkeersslachtoffers die meenden dat een ander schuld had aan het ongeval wijst uit dat slechts $20 \%$ ran deze slachtoffers ook vond dat de schuldige partij moest opkomen voor hun schrade. ${ }^{1280}$ Volgens Dewees, Duff en Trebilcock geldt bij verkeersongevallen blijkbaar dat schuld in de ogen van het slachtoffer iets is dat iedereen kan overkomen. Het zjp veelal normale fouten, verband houdend met de dagelijkse activiteiten waarvan de verkeersdeelname een onderdeel vormt, die aan een verkeersongeval ten grondslag liggen. Dewees, Duff en Trebilcock concluderen dat een aansprakelijkheidsactie naar aanleiding van een verkeersongeval niet altijd wordt ingesteld ten behoeve van een corrigerende rechtvaardigheid ('corrective justice'), maar veeleer dienst doet als vergoedingsbron binnen de reeds beschikbare compensatiemechanismen. ${ }^{1281}$

\section{Conclusie}

In de vorige paragraaf is aandacht besteed aan de werking van het aansprakelijkheidsrecht bij verkeersongevallen in Noord-Amerika en Canada. Daanit kan zowel op het terrein van de preventie van verkeersongevallen als ten aanzien van de corr pensatie van verkeersslachtoffers een aantal conclusies worden geformuleerd.

In het kader van de preventie heeft Amerikaans onderzoek gesuggereerd dat foutaansprakelijkheid met een absoluut eigen schuldverweer een autobesturrder tot meer zorgvuldigheid aanzet dan foutaansprakelijkheid met een gradueel eigen schuldverweer. ${ }^{1282}$ Hieruit kon echter niet worden opgemaakt welke gevolgen eृn

1279. Zie onder anderen Dunlop, Osgoode Hall Law Journal, 1975, p. 445; Hammitt, Automobile A: cident Compensation, Volume 2, 1985, p. 30-31 in Dewees, Duff and Trebilcock, Accident Law, p. 41 en p. 78 noot 266-268; Prosser and Keeton on the Law of Torts, p. 590.

1280. D. Harris et al., Compensation and Support for Illness and Injury, Oxford, Clarendon Pres, 1984 , p. $149-150$ (34\% van het aantal verkeersslachtoffers in Groot-Britanniž trachten via ctr aansprakelijkheidsvordering schadevergoeding te krijgen) in Dewees, Duff and Trebilcok, Ac cident Law, p. 42 en p. 78 noot 273.

1281. Ontario Law Reform Commission, Report, 1973, p. 17-18; U.S. Department of Transportation Compensatin Auto Accident Victims, 1985, p. 10 in Dewees, Duff and Trebilcock, Accidel Law, p. 41-42 en p. 78 noot 270-272 en 274; Bombaugh, CoLR, 1971, p. 210.

1282. White, RJE, 1989 , p. 328-329. 
overgang van een foutaansprakelijkheid met een absoluut eigen schuldverweer naar een foutansprakelijkheid met een gradueel eigen schuldverweer heeft gehad voor het antal verkeersongevallen. Uit een ander onderzoek is gebleken dat een overgang naar foutaansprakelijkheid met een gradueel eigen schuldverweer niet heeft geleid tot een vermindering van de prikkels van zorg bij de autobestuurder noch tot een stijging van het aantal verkeersongevallen. ${ }^{1283}$ Dit betekent dat voor wat betreft de preventie van verkeersongevallen geen eenduidige conclusie kan worden gegeven in het voordeel van een toepasselijke aansprakelijkheidsregel.

Uit het gepresenteerde onderzoek met betrekking tot de vergoeding van verkeersslachtoffers in de VS en Canada, kan in de eerste plaats worden geconcludeerd dat de gemiddelde aansprakelijkheidsvordering wordt gedomineerd door uitkeringen voor immateriële schade en relatief lichte materiële schadeclaims. In de tweede plaats worden verkeersslachtoffers met een lage aansprakelijkheidsclaim, als gevolg van de aanwezigheid van genereuze uitkeringen voor immateriële schade en de beschikbaarheid van meerdere vergoedingsbronnen, veelal overgecompenseerd. In de derde plaats heeft onderzoek uitgewezen dat verkeersslachtoffers, die ten gevolge van een verkeersongeval ernstig tot zeer ernstig letsel hebben geleden, geen volledige vergoeding ontvangen. Dit laatste vindt onder andere zijn oorzaak in de aanwezigheid van lage polislimieten bij de aansprakelijkheidsverzekering van de schadeveroorzaker, of zelfs in de algehele afwezigheid van een dergelijke verzekering. ${ }^{1284}$

Gesteld kan worden dat in de VS en Canada de preventieve werking van aansprakelijkheidsregels sec onduidelijk is, althans dat daamaar niet voldoende onderzoek is gedaan. Aangezien ook in de VS en Canada het grootste deel van de aansprakelijkheidsprocedures bij een verkeersongeval door de aansprakelijkheidsverzekeraar van de dader wordt geregeld, is de beïnvloeding van het verkeersgedrag steeds meer een takk van de aansprakelijkheidsverzekeraar geworden. De vraag hoe de preventie via de verzekeringsvoorwaarden in de praktijk gestalte krijgt, zal in het volgende hoofdstuk worden onderzocht. Ten behoeve van een verbeterde vergoeding van verkeersslachtoffers is verder in een groot deel van Noord-Amerika en Canada gedurende de jaren ' 70 van de vorige eeuw een no-fault verzekering ingevoerd. De vraag in hoeverre deze verzekering onder andere de compensatie van verkeersslachtoffers positief heeft beïnvloed zal onderwerp zijn van hoofdstuk 13

1283. Stoan, Reilly and Schenzler, IRLE, 1994, p. 58 en 67.

1284. Zie Dewces, Duff and Trebilcock, Accident Law, p. 31-32. 


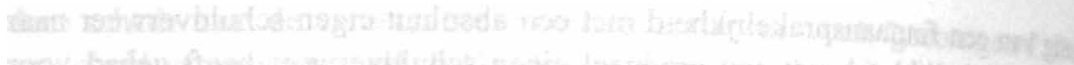

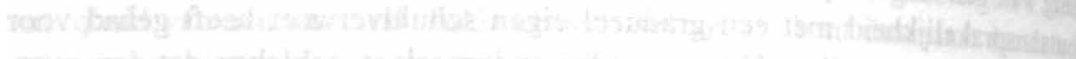

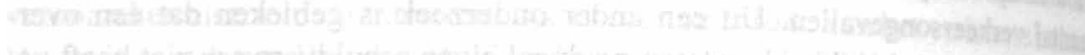

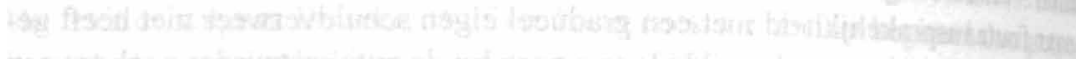

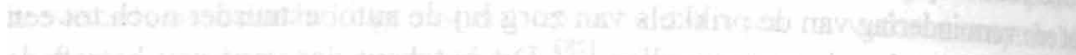

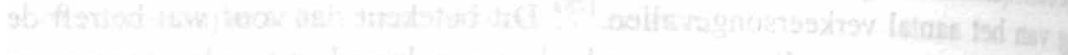

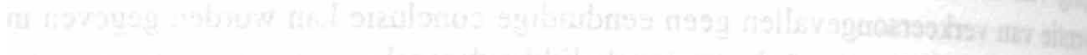

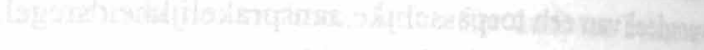

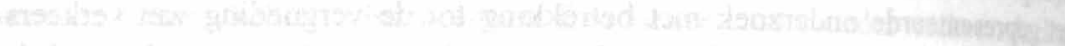

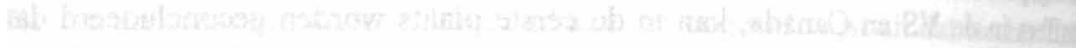

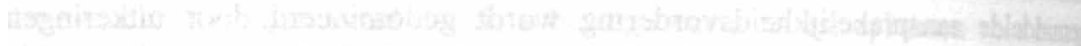

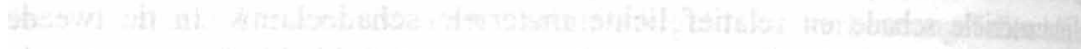

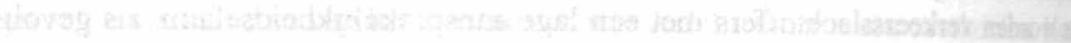

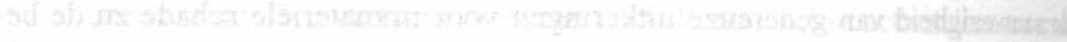

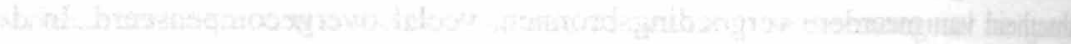

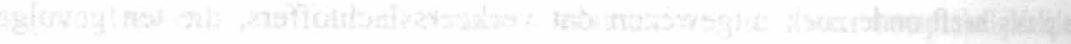

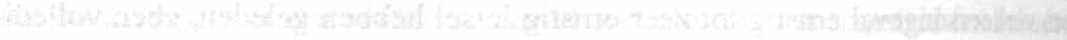

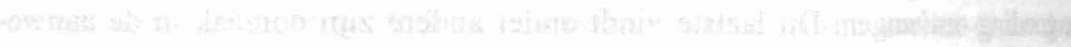

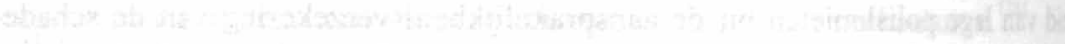

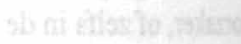

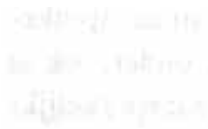

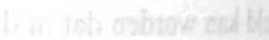

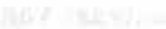




\section{Hoofdstuk 11: De empirische analyse van risico en verzekering}

\section{Inleiding}

In hoofdstuk 10 is empirisch onderzoek gepresenteerd met betrekking tot de werking van aansprakelijkheid in het verkeer. Daarbij kon geen eenduidig antwoord worden gegeven op de vraag of van het aansprakelijkheidsrecht een preventieve werking uitgaat op het gedrag van een verkeersdeelnemer. Uit het beschikbare empirisch materiaal is eerder gebleken dat, reeds in het begin van de jaren ' 70 van de vorige eeuw (en mogelijk ook daarvoor al) de invloed van verzekering op het aansprakelijkheidsrecht sterk is toegenomen. Daarnaast is geconstateerd dat met betrekking tot verkeersongevallen de aansprakelijkheidsverzekeraar van de autobestuurder zowel de preventieve als compenserende rol van het aansprakelijkheidsrecht heeft overgenomen.

Dit betekent dat moet worden onderzocht of, gegeven de toegenomen invloed van verzekering, de preventieve werking van het aansprakelijkheidsrecht inderdaad via de verzekeringsvoorwaarden gestalte krijgt. Deze vraag zal in dit hoofdstuk aan de hand van empirisch onderzoek worden uitgewerkt. Hierbij zullen tevens, rekening houdend met hetgeen in de theorie is geconcludeerd, ${ }^{1285}$ een aantal deelvragen aan de orde komen. Ten eerste is het van belang of een verzekeraar via de polisvoorwaarden, zowel ex ante als ex post invloed kan uitoefenen op het verkeersgedrag van de verzekerde. Daarbij zal ook worden nagegaan of de controle van het morele risico via de toepassing van een ex ante premiedifferentiatie en het gebruik van een ex post controle van het ongevalsrisico tot een vermindering van het aantal verkeersongevallen en verkeersslachtoffers kan leiden. In de tweede plaats zal worden onderzocht of verzekering de preventieve werking van het aansprakelijkheidsrecht ook werkelijk kan overnemen, zonder dat de controle van het morele risico te hoge kosten meebrengt.

In paragraaf 2 en 3 zal allereerst de mate van premiedifferentiatie en controle van het morele risico binnen de Amerikaanse markt voor autoverzekeringen worden geschetst en getoetst.

In paragraaf $4 \mathrm{zal}$ de effectiviteit van een aantal classificatiesystemen, in het bijzonder het in veel Europese landen verplichte bonus-malus systeem (BMS) bij autoverzekeringen worden geanalyseerd. Daarbij zal de aandacht met name uitgaan naar de BMS-structuur in Nederland, België en Frankrijk.

1285. Zie daanover paragraaf 4 van hoofdstuk 6 en paragraaf 4.1 van hoofdstuk 8 . 
In paragraaf $5 \mathrm{zal}$ een aantal aspecten van de markt voor autoverzekeringen aan de orde komen. Hierbij is de vraag van belang in hoeverre regulering van invloed is op de werking (concurrentie) van de autoverzekeringsmarkt en op de preventic van verkeersongevallen. In dat kader zal achtereenvolgens aandacht worden besteed aan de markt voor autoverzekeringen in Noord-Amerika, Duitsland en Engeland.

Dit hoofdstuk zal in paragraaf 6 worden afgesloten met enkele concluderende opmerkingen, rekening houdend met hetgeen uit de theorie naar voren is gekomen.

\section{De Amerikaanse markt voor autoverzekeringen}

Ter inleiding op het empirisch onderzoek naar de werking van premiedifferentiabie binnen de autoverzekering in Noord-Amerika, kan globaal een aantal kenmerken van de Amerikaanse markt voor autoverzekeringen worden opgesomd. Dit beteff met name de verschillende vormen van verzekering, alsmede de vergoedingsmoge. lijkheden voor verkeersschade waarover een autobestuurder in Amerika kan beschikken. ${ }^{1286}$ Vooropgesteld moet worden dat de markt voor autoverzekeringen in Amerika sterk van staat tot staat verschilt en mede afthankelijk is van het toepasselijke vergoedingsregime voor verkeersschade. In de woorden van Cummins en Tennyson:

'Private passenger auto insurance is actually a package of insurance coverage, some mandatory or quasi-mandatory and others optional, depending on the rules adopted by a given state'. ${ }^{1287}$

\subsection{DE VERSCHILLENDE BESCHIKBARE VERZEKERINGSVORMEN}

Met betrekking tot het afsluiten van een individuele verzekering worden ann een automobilist in Noord-Amerika verschillende dekkingsmogelijkheden geboden, waarbij een onderscheid kan worden gemaakt tussen een eerste partij en een derde partij verzekeringsdekking.

In het kader van een eerste partij verzekeringsdekking kan allereerst een ongevallenverzekering ('collision insurance') worden genoemd. Hiermee wordt de schaste aan de verzekerde auto vergoed, die ten gevolge van een botsing met een ander of ject is ontstaan. In de tweede plaats kan een autobestuurder de beschikking krijgen over een soort omni-verzekering ('comprehensive insurance'), die de niet-ongeralsschade van de verzekerde auto dekt, zoals ingeval van brand, diefstal en vandalisme. In de derde plaats heeft de autobestuurder de mogelijkheid om een zogenaande it insured- and underinsured-motorists coverage' (UM) af te sluiten. Deze verzekering

1286. In paragraaf $5 \mathrm{zal}$ de invloed van regulering op de markt voor autoverzekeringen aan bod kone

1287. Cummins and Tennyson, J. Ec. Persp., 1992, p. 95-115. 
vergoedt de schade van de autobestuurder die hij niet van een aansprakelijke derde krijgt uitgekeerd, omdat deze geen of een niet volledige verzekeringsdekking heef. ${ }^{1288}$ In de vierde plaats, ten slotte, kan een autobestuurder verzekeringsdekking krijgen voor medische kosten ('Medical Payments coverage') die hij tengevolge van een verkeersongeval lijdt. ${ }^{1289}$ Voor de geleden inkomensschade is veelal geen dekking onder een autoverzekering mogelijk. Daarvoor dient de automobilist een beroep te doen op andere verzekeringen. ${ }^{1290}$

In het kader van een derde partij verzekeringsdekking kan een autobestuurder voor de schade aan derden een aansprakelijkheidsverzekering overeenkomen. ${ }^{1291}$ Deze verzekering valt uiteen in een aansprakelijkheidsdekking voor letselschade ('bodilyinjury liability') ${ }^{1292}$ en een dekking voor zaakschade ('property-damage liability'). De aansprakelijkheidsverzekering, die in 18 Amerikaanse staten verplicht gesteld is, diende ter vervanging van de zogenaamde financiële aansprakelijkheidswetgeving ('financial responsibility laws'). Deze wetgeving werd ingevoerd om de positie van het slachtoffer van een verkeersongeval te verbeteren, die in geval van de insolventie van de dader zijn schade niet vergoed kreeg. De meest gangbare vorm van financiële aansprakelijkheidswetgeving die in een aantal Amerikaanse staten nog wordt toegepast is de 'Safety-Responsibility Act'. Hierin werd aan de autobestuurder de verplichting opgelegd om onder nader omschreven omstandigheden bewijs te leveren (met behulp van een aansprakelijkheidsverzekering of andere liquide middelen) dat bij over voldoende financiële middelen beschikt om toekomstige verkeersschade te kunnen vergoeden, alsmede 'zekerheid' te stellen voor schadeclaims die tengevolge van een verkeersongeval reeds zijn ontstaan. ${ }^{1293}$

1288. Keeton, Insurance Law, p. 245; Keeton, Keeton, Sargentich and Steiner, Cases and Materials on Tort and Accident Law, p. 889.

1289. Keeton, Keeton, Sargentich and Steiner, Cases and Materials on Tor and Accident Law, p. 890 en p. 516-518 geven een voorbeeld van een autoverzekeringspolis waarin de verschillende dekkingsmogelijkheden zijn opgenomen; Keeton, Insurance Law, p. 75-76. Zie ook Smith and Wright, Am. Econ. Rev., 1992, p. 758, voor een ovcrzicht van de dekkingsmogelijkheden binnen thin autoverzekering.

1290. Zie Dewees, Duff and Trebilcok, Accident Law, p. 27; Danzon, JLS, 1984, p. 522-523. Daarin wordt verwezen naar de 'Social Security Disability Income', een verplichte sociale verzekering, 'the private long-term disability (LTD) income protection' en de 'cmployment-related short-term disability income protection', die dekking verlenen tegen tijdelijke, langdurige of blijvende arbeidsongeschiktheid. Zie daarover ook paragraaf 3.2.1 van hoofdtuk 10.

1291. Zie daarover Prosser and Keeton on the Law of Torts, p. 584-588.

1292. Zie Keeton, Insurance Law, p. 83-85

Prosset and Keeton on the Law of Torts, p. 601-603; Keeton, Keeton, Sargentich and Steinet, Cases and Materials on Tort and Accident Law, p. 889; Cummins and Tennyson, J. Ec. Persp., 1992, p. 95; Sloan, Reilly and Schenzler, IRLE, 1994, p. 55. 


\subsection{DE OPKOMST VAN DE NO-FAULT VERZEKERING}

Met betrekking tot de verschillende verzekeringsmogelijkheden die aan een Amerikaanse autobestuurder ter beschikking staan, is één verzekeringsvorm nog niet ge noemd, namelijk de no-fault verzekering ('personal injury protection', PIP). Deze verplichte verzekering is gedurende de jaren ' 70 van de vorige eeuw in een grool aantal Amerikaanse staten ingevoerd met het primaire doel om tot een meer efficien-n te schadevergoeding te komen, doch die ook ten doel heeft de transactiekosten te reduceren, ${ }^{1294}$

Vanuit een rechtseconomisch perspectief kan een no-fault verzekering worden beschouwd als een combinatie van een eerste partij en een derde partij ver. goedingsmechanisme. Het eerste partij karakter van deze verzekering komt, nadat zich een verkeersongeval heeft voorgedaan, tot uiting in de vergoeding van medische kosten en inkomensverlies voor de verzekerde autobestuurder zelf. Het derde partij gedeelte van de no-fault dekking geldt voor de geleden personenschade van bijvoorbeeld de voetganger of passagier.

In geen enkele Amerikaanse staat is een zuiver no-fault regime van toepassing, waarbij de aansprakelijkheid voor verkeersschade geheel is afgeschaft. In de meete no-fault stelsels bestaat nog steeds de mogelijkheid om een derde voor de geleden schade aansprakelijk te houden. Een aansprakelijkheidsprocedure kan daarbij echter pas worden aangespannen wanneer de schade een bepaalde drempel heeft overschreden. Deze schadedrempels kunnen ofwel materieel zijn ofwel financiel (monetair). De financiële schadedrempels voor een aansprakelijkheidsvordering in no-fault staten lopen uiteen van $\$ 400$ voor medische kosten in de staat Connecticut tot $\$ 4.000$ in Minnesota. Een materiële schadedrempel is toepasselijk in Michign en bevat de voorwaarde dat het ongevalsslachtoffer is overleden, zwaar lichameliji letsel heeft of ernstig gehandicapt is. Afgezien van enkele uitzonderingen is een nofault verzekering uitsluitend van toepassing op personenschade. ${ }^{1296}$

In de praktijk wordt de no-fault verzekeringsdekking voor personenschade to gevoegd aan de bestaande autoverzekeringspolis waarin ook de eerdergenoemde verzekeringsvormen zijn opgenomen. Het doel is, als gezegd, te zorgen dat meer

1294. Tussen 1970 en 1980 hebben 24 Amerikaanse staten enigerlei vorm van een (verplichte) no-facl verzekering ingevoerd; de overige staten handhaafden een aansprakelijkheidsregime met tor derde partij aansprakelijkheidsverzekering. Zie Chapman and Trebilcock, Working Paper, 1991, p. 2-3; Prosser and Keeton on the Law of Torts, p. 606-608; Keeton, Keeton, Sargentich and Steiner, Cases and Materials on Tort and Accident Law, p. 894-895.

1295. Cummins and Tennyson, J. Ec. Persp., 1992, p. 96-97. Zie ook paragraaf 6.4 van hoofdstuk 6.

1296. Cummins and Tennyson, J. Ec. Persp., 1992, p. 97; Dewees, Duff and Trebilcock, Accident Las. p. 22 en p. 67 noot 65-69; Van Wassenaer van Catwijck, VA, 1988, p. 330-335; Bolt, Loteri of rechtspraak, p. 187-189. 
verkeersslachtoffers tenminste hun materieel waardeerbare schade vergoed krijgen. Daamaast wordt met de no-fault verzekering een besparing op de transactiekosten bereikt, omdat een meerderheid van de aansprakelijkheidsclaims een laag bedrag omvat $^{1297}$ en dus onder de schadedrempel van de no-fault dekking blijft. ${ }^{1298}$

\section{De controle van het morele risico binnen de Amerikaanse autoverzekering}

\subsection{INLEIDING}

Een van de gevolgen die het aangaan van een verzekeringsovereenkomst, waarbij het risico wordt weggenomen van een individu met een afkeer daarvan, kan hebben is in de economische theorie aangeduid als het morele risico. Dit probleem hangt samen met de veronderstelling dat het gedrag van de verzekerde zich zal wijzigen onder invloed van de aanwezigheid van een verzekering. Wanneer een verzekeraar onvoldoende informatie heeft om het gedrag van de verzekerde te controleren, zal hij gebruik maken van bepaalde mechanismen om een juiste verhouding tussen premie en verwachte ongevalskosten te bereiken. Deze mechanismen zijn in de theorie besproken en bestaan onder andere in een beperking van de dekking, een eigen risico en een ex post premieaanpassing. ${ }^{1299}$ Met behulp van deze financiële prikkels kan de verzekerde worden aangezet tot zorgvuldig gedrag. ${ }^{1300}$

In deze paragraaf zal worden onderzocht welke middelen Amerikaanse autoverzekeraar in de praktijk toepassen om het gedrag van de autobestuurder, zowel ex ante als ex post, te controleren. In paragraaf $3.2 \mathrm{zal}$ een overzicht worden gegeven van de classificatievariabelen en andere mechanismen die, als onderdeel van een ex ante risicodifferentiatie, in Amerika worden gebruikt. Daarnaast zal aandacht worden besteed aan de methode die Amerikaanse autoverzekeraars toepassen bij een eventuele ex post premieaanpassing. In paragraaf 3.3 zal empirisch onderzoek aan de orde komen, waarin de praktische effecten van het gebruik van classificatievariabelen, de toepassing van bepaalde classificatiesystemen en van een ex post premieaanpassing

1297. Keeton, Keeton, Sargentich and Steiner, Cases and Materials on Tort and Accident Law, p. 896897. Zie ook paragraaf 3.2.2.4 van hoofdstuk 10 .

298. Schirmeister, Amerikaanse toestanden in het schadevergoedingsrecht?, p. 40. Zie verder hoofdstuk 13 voor een meer uitvoerige analyse van de no-fault verzekering in Noord-Amerika.

1299. Zie daarover paragraaf 4.1 van hoofdstuk 6 .

1300. De vraag in hoeverre door een autoverzekeraar gebruik wordt gemaakt van mechanismen om het gedrag van de autobestuurder te controleren verschilt van staat tot staat is afhankelijk van de omvang van het morele risico, de kosten van invoering van dergelijke maatregelen en de struktuur van de betrokken verzekeringsindustrie. Zie Dewees, Duff and Trebilcock, Accident Law, p. 19 - 
worden onderzocht. In paragraaf 3.4 zal ten slotte worden teruggekoppeld naar de in de inleiding gestelde vragen.

\subsection{EX ANTE RISICODIFFERENTLATIE EN EEN EX POST PREMIEAANPASSING}

Alvorens kan worden vastgesteld in hoeverre een ex ante risicodifferentiatie en een ex post premieaanpassing van invloed kunnen zijn op bet gedrag van de autobestuurder, is het van belang te weten welke classificatievariabelen door de autoverzkeraars worden gebruikt om de omvang van de premie vast te stellen. Vervolgens dient te worden ingegaan op de methode die autoverzekeraars hanteren voor een es post aanpassing van de premie.

In het kader van een ex ante risicodifferentiatie is voor de Amerikaanse autoverzekraars een tweetal (hoofd)classificatievariabelen van belang, namelijk de plaats waar het voertuig staat geregistreerd ('territory') en bepaalde persoonlijk eigenschappen van de bestuurder ('driver class'). ${ }^{1301}$ Binnen deze classificatievariabelen word de omvang van de premie globaal vastgesteld aan de hand van de volgende factoren: leeftijd, geslacht, woonplaats, huwelijkse staat van de bestuurder, rijervaring, het th. pe auto, het aantal gereden automijlen per jaar, het aantal auto's binnen één huisholden, het geografisch gebied (stedelijk of landelijk) waarbinnen de auto word gbruikt en waarvoor (zakelijk of privé) de auto wordt gebruikt. ${ }^{1302}$

Ten behoeve van een verdere premiedifferentiatie en de controle van het gedrag van de autobestuurder nadat de verzekering is afgesloten, wordt gekeken naar het schadeverleden en het aantal verkeersovertredingen. Bij verkeersovertredingen worden door een aantal Amerikaanse staten verplichte premietoeslagen opgelegd. Voor wat betreft het schadeverleden van de autobestuurder wordt gebruik gemaakt van de 20 genaamde 'experience rate-making' of 'merit rating' methode, op grond waarvan de premie van de polishouder met behulp van toeslagen voor de toekomst word aange past. $^{130.3}$

In tabel $1^{1304}$ een overzicht opgenomen van de verplichte premietoeslagen ('merit 15: ting') die door autoverzekeraars in een viertal Amerikaanse staten worden opgleged naar aanleiding van respectievelijk een verkeersongeval waarvan de polishouder eel

1301. Fairley, Tomberlin and Weisberg, JRI, 1981, p. 505.

1302. Lemaire, JRI, 1988, p. 660; Dewees, Duff and Trebilcock, Accident Law, p. 20; Keton, Ketalo, Sargentich and Steiner, Cases and Materials on Tort and Accident Law, p. 495-496; Spatr ad Escolas, JRI, 1982, p. 91; Tryfos, JRI, 1987, p. 569.

1303. Keeton, Keeton, Sargentich and Steiner, Cases and Materials on Tort and Accident Law, $\mathrm{p} .49$. 498; Sloan, Reilly and Schenzler, IRLE, 1994, p. 55; Dewees, Duff and Trebilcock, Accilaril Law, p. 20 en p. 65 noot 44-46.

1304. Deze tabel, waarvan de gegevens betrekking hebben op de beginjaren ' 80 van de vorige ewwis, is ontleend aan Bruce, Law and Policy, 1984, p. 86. 
verwijt kan worden gemaakt ('fault accident') en van verkeersovertredingen. De premietoeslagen gelden voor een periode van 3 jaar of meer, waardoor de in de tabel genoemde bedragen betrekking hebben op een totale stijging van de premie gerekend over de periode waarop de toeslag betrekking heeft. De genoemde percentages geven de waarde van de toeslag aan als een percentage van de jaarlijkse premie. Alle cijfers en percentages hebben betrekking op toeslagen naar aanleiding van één gebeurtenis.

Tabel 1

\begin{tabular}{|l|c|c|c|c|c|}
\hline $\begin{array}{c}\text { type of accident or } \\
\text { conviction }\end{array}$ & \multicolumn{5}{|c|}{ State } \\
\hline & & Massachusetts $^{1305}$ & North Carolina & South Carolina & Texas \\
\hline $\begin{array}{c}\text { Fault' Accident } \\
\text { (over } 5200 \\
\text { damages) }\end{array}$ & 1 st & $\$ 50$ & $120 \%$ & $\$ 0$ & $45 \%$ \\
\hline & 2nd & $\$ 150$ & $180 \%$ & $\$ 90$ & $60 \%$ \\
\hline & 3 rd & $\$ 300$ & $210 \%$ & $\$ 180$ & $75 \%$ \\
\hline Drunken Driving & & $\$ 200^{1306}$ & $1050 \%$ & $\$ 1260$ & None \\
\hline Reckless Driving & & $\$ 100^{1307}$ & $300 \%$ & $\$ 360$ & None \\
\hline $\begin{array}{l}\text { Speeding (over 10 } \\
\text { m.p.h. over limit) }\end{array}$ & $\$ 75^{1308}$ & $120 \%$ & $\$ 180^{1309}$ & None \\
\hline
\end{tabular}

Hoewel de 'merit rating' systemen binnen de autoverzekering zijn gebaseerd op het foutbeginsel, wordt in de Amerikaanse praktijk in verband met de administratieve kosten veelal een objectief criterium toegepast om het schadeverleden van de autobestuurder te beoordelen. Daarbij wordt vooral gekeken naar de mogelijke betrokkenheid van de autobestuurder bij een verkeersongeval, zonder dat rekening wordt gehouden met de omvang van de verwachte schade of het inkomen van de autobe-

1305. Zie Keeton, Keeton, Sargentich and Steiner, Cases and Materials on Tort and Accident Law, p. 499-502, waarin met betrekking tot de 'Massachusetts Automobile Insurance Policy' ten voorbeeld van een standaardpolis voor een derde partij aansprakelijkheidsdekking is opgenomen.

1306. De toeslag stijgt naar $\$ 425$ bij de tweede overtreding en naar $\$ 675$ bij dric of meer overtrcdingen.

1307. De toeslag stijgt naar $\$ 225$ bij de tweede overtreding en naar $\$ 375$ bij drie of meer overtredingen.

1308. De toeslag blijft $\$ 75$ bij de tweede overtreding en stijgt naar $\$ 150$ bij drie of meer overtredingen.

Er is geen toeslag voor een eerste veroordeling, maar de tweede veroordeling wordt bestraft met een toeslag van $\$ 180$; bij drie of meer veroordelingen geldt voor elk een tweslag van $\$ 270$. 
stuurder. ${ }^{1310}$ Dit betekent dat de premie veelal niet in overeenstemming is met de verwachte ongevalskosten, waardoor een autobestuurder mogelijk minder zorgvwl. dig wordt dan wanneer een actuarieel juiste premie wordt opgelegd. In de woorden van Sloan, Reilly and Schenzler:

'The cost of an accident to a negligent injurer no longer equals the victim's loss, but rather the present value of the increase in premiums resulting from 'chargeable accidents'. Even if premiums are increased using standard actuarial principles, the increase in premiums that arises when a driver has been found liable for an accident may be appreciably less than the damages that are levied as a result of that accident. ${ }^{1311}$

\subsection{DE PRAKTISCHE EFFECTEN VAN EX ANTE RISICODIFFERENTIATIE EN EEN EX POST PREMIEAANPASSING}

In deze paragraaf zal een tweetal empirische studies worden gepresenteerd warbir. nen de effecten van een ex ante risicodifferentiatie en een ex post premieaanpassing worden geanalyseerd. In het ene onderzoek wordt, ten behoeve van de bepaling van de premie, een verband gelegd tussen bepaalde classificatievariabelen en respectievelijk de ongevalsfrequentie, de ernst van het ongevalsletsel en het aantal verkeersovertredingen. ${ }^{1312}$ In het andere onderzoek worden twee systemen van premiears. passing, gebaseerd op het schadeverleden van een autobestuurder, vergeleken. ${ }^{1313}$

\subsubsection{De effectiviteit van het gebruik van classificatievariabelen}

In een studie naar de praktische werking van het gebruik van ex ante classificatievariabelen wordt onderzocht of leeftijd, geslacht en de regio waarbinnen de verzkeringsnemer woont, effectieve classificatievariabelen zijn voor de bepaling vande premie. Deze variabelen worden daarbij afgezet tegen het aantal verkeersongevallen met letsel- en zaakschade in de Amerikaanse staat Wyoming in het jaar 1979.13.4

Ten aanzien van leeftijd wordt aan de hand van de ongevalsdata gesteld dat bestur: ders in de leeftijdscategorie $15-24$ jaar bij ongeveer $50 \%$ van het aantal verkersongevallen betrokken waren, terwijl deze leeftijdsgroep slechts $26 \%$ van de besturderspopulatie vertegenwoordigde. De leeftijdscategorie 35-64 jaar, die ruim 42\% van het totaal aantal autobestuurders uitmaakte, was bij ongeveer $20 \%$ van het antal verkeersongevallen betrokken. Dit betekent dat de groep jonge autobestuurders, op

1310. Keeton, Keeton, Sargentich and Steiner, Cases and Materials on Tort and Accident Law, p.998 Keeton, Insurance Law, p. 566.

1311. Sloan, Reilly and Schenzler, IRLE, 1994, p. 55.

1312. Spahr and Escolas, JRI, 1982, p. 91-103; Venezian, JRI, 1985, p. 571-584.

1313. Tryfos, JRJ, 1987, p. 569-581.

1314. Spahr and Escolas, JR, 1982, p. 91-103. 
basis van hun ongevalsfrequentie, een relatief hoog ongevalsrisico vormt. ${ }^{1315}$ Volgens de onderzoekers kan de leeftijd derhalve een betrouwbare ex ante variabele zijn voor de bepaling van de omvang van de premie van een autoverzekering. ${ }^{1316}$

Het onderscheid in geslacht is volgens Spahr en Escolas eveneens een effectieve varabele voor de bepaling van de premie. Uit de ongevalsdata blijkt dat mannelijke autobestuurders gemiddeld bij meer verkeersongevallen zijn betrokken dan hun rouwelijke collega's. Dit zou volgens Spahr en Escolas passen bij de veronderstelling dat het activiteitsniveau van de mannelijke autobestuurder hoger is dan dat van vouwen, hoewel zij daarvoor geen cijfermatig bewijs leveren. In het kader van de verhouding tussen leeftijd en geslacht blijkt uit het onderzoek verder dat mannelijke bestuurders jonger dan 25 jaar een aandeel van bijna $40 \%$ in alle verkeersongevallen hadden, terwijl zij slechts $14 \%$ van het totaal aantal autobestuurders vertegenwoordigden. $^{1317}$

Ten slotte wordt door Spahr en Escolas, gekeken naar regionale verschillen, in het bijzonder ten aanzien van factoren zoals bevolkingsdichtheid en verkeersmobiliteit. Hienuit blijkt dat in dichtbevolkte regio's meer verkeersongevallen plaatsvonden, terwijl de ongevallen in dunbevolkte gebieden in verhouding ernstiger van aard waren. De inwoners van dunbevolkte gebieden liepen weliswaar minder kans om bij een verkeersongeval betrokken te raken; de kans om bij een verkeersongeval ernstig letsel te lijden was echter even hoog als voor bewoners van dichtbevolkte gebieden. ${ }^{1318}$ Spahr en Escolas gaan echter niet in op de vraag welke betekenis moet worden gehecht aan voornoemde regionale verschillen bij de bepaling van de omvang van de premie.

\subsubsection{De werking van een aantal classificatiesystemen voor autoverzekering}

In deze paragraaf zal een onderzoek aan bod komen waarin een vergelijking wordt gemaakt tussen twee classificatiesystemen voor autoverzekering die in NoordAmerika en Canada worden toegepast. ${ }^{1319}$ Daarbij wordt onderzocht op welke wijze de geschatte premie, die een individuele autobestuurder binnen deze classificatiesystemen moet betalen, ex post kan worden vastgesteld. In dat kader wordt gebruik gemaakt van het aantal schadeclaims, het gemiddelde schadebedrag of het aantal jaren met een schadeclaim binnen een zekere historische periode.

\footnotetext{
1315. Zie paragtaaf 3.2 van hoofdstuk 9 voor een empirisch bewijs van deze stelling

1316. Spahr and Escolas, JRI, 1982, p. 101. Dit komt overeen met de analyse van ongevalsrisico en verkeersgedrag in paragraaf 3 van hoofdstuk 9.

1317. Spahs and Escolas, JRI, 1982, p. 101

1318. Spahr and Escolas, JRI, 1982, p. 101-102.

1319. Tryfos, JR, 1987, p. 569-581.
} 
Een eerste classificatiesysteem hanteert als uitgangspunt het aantal jaren waarin ee autobestuurder claimvrij is en wordt in de meeste Canadese provincies toegepas Het systeem bestaat uit 14 categorieën waarbinnen een autobestuurder op basis van leeftijd, geslacht, huwelijkse staat en de wijze van gebruik van het voertuig word ondergebracht en uit 5 categorieën waarin een autobestuurder afhankelijk van bet aantal claimvrije jaren terecht kan komen.

Een tweede classificatiesysteem dat door Tryfos wordt geanalyseerd, is gebaseerd op het aantal jaren waarin gemeten over een bepaalde periode minimaal één schade claim is ingediend en wordt door veel Amerikaanse verzekeraars gebruikt. ${ }^{1320}$

Hoewel het 'Amerikaanse' en het 'Canadese' systeem hetzelfde aantal premieklassen gebruiken is er een verschil tussen beide systemen. Dit kan met een voorbeeld vor. den verduidelijkt. Daarin wordt uitgegaan van twee autobestuurders, waarvan be. stuurder A zowel 2 jaar als 5 jaar geleden een schadeclaim heeft ingediend en be. stuurder B slechts één schadeclaim had in de laatste 5 jaar. Binnen het 'Canadese' systeem worden beide bestuurders in dezelfde premieklasse ingedeeld, terwijl bir. nen het 'Amerikaanse' systeem bestuurder A en B in verschillende premieklassen worden ondergebracht. ${ }^{1321}$

Naast een inhoudelijke analyse van het 'Amerikaanse' en 'Canadese' systeem word door Tryfos ook gekeken naar de 'equity' van beide classificatiesystemen. Een sjsteem wordt naar de mening van Tryfos als 'equitable' beschouwd, indien de geschatte zuivere premie voor de bestuurder zoveel mogelijk in overeenstemming is met de geschatte omvang van de schadeclaim (ongevalsrisico) die door de bestuurder word ingediend. Wanneer echter over een bepaalde periode gemeten sommige besturder meer en andere minder gaan betalen dan de geschatte omvang van de schadeclaim, is volgens Tryfos sprake van een 'inequitable' classificatiesysteem. ${ }^{1322}$ Tryfos concludeert dat beide onderzochte systemen voor wat betreft de 'equity' beter worden naarmate gebruik wordt gemaakt van meer premieklassen. Voor een gegeven antal premieklassen kan volgens hem het 'Amerikaanse' systeem echter als meer 'equitable' worden beoordeeld dan het 'Canadese' systeem. ${ }^{1323}$

De vraag is of de door Tryfos omschreven 'equity' als graadmeter kan dienen voor een effectief classificatiesysteem en de effectiviteit van de toepassing van premiedifi ferentiatie. In de verzekeringseconomische analyse is gesteld dat de omvang van de premie zoveel mogelijk in overeenstemming moet zijn met het individuele ongevals. risico van een autobestuurder. Dit ongevalsrisico is echter niet alleen afhankelijk va

1320. Tryfos, JRI, 1987, p. 573-574.

1321. Tryfos, JRI, 1987, p. 574.

1322. Trytos, JRI, 1987, p. 570-572.

1323. Trytos, JR, 1987. p. 578-579. 
de omvang van de geschatte schadeclaim, maar ook van andere factoren, zoals leeftijd, geslacht, type auto en het aantal schadeclaims. Ook de omschrijving die Tryfos van een 'inequitable' classificatiesystem geeft, betekent niet dat een dergelijk systeem vanuit verzekeringseconomisch oogpunt tot een minder goede controle van het morele risico leidt. In dat kader kan bijvoorbeeld worden geconcludeerd dat het 'Canadese' systeem, waarbij naast het schadeverleden ook andere differentiatievariabelen worden gebruikt, een betere controle van het morele risico waarborgt dan het 'Amerikaanse' systeem, dat enkel was gebaseerd op het schadeverleden. Voor een dergelijke conclusie is echter verder onderzoek noodzakelijk.

\subsection{AUTOVERZEKERING EN DE CONTROLE VAN HET MORELE RISICO}

In het voorgaande is onderzocht hoe binnen de Amerikaanse autoverzekering de controle van het morele risico gestalte krijgt. Daaruit kan worden opgemaakt dat autoverzekeraars bij het opstellen van de verzekeringspolis gebruik maken van zowel een ex ante risicodifferentiatie, gebaseerd op een groot aantal classificatievariabelen, als een ex post premieaanpassing op grond van het schadeverleden en het aantal verkeersovertredingen van de autobestuurder. Op basis van de beschreven empirische studies kunnen echter geen antwoorden worden gegeven op de eerder gestelde vragen naar de invloed van de verzekeringsvoorwaarden op het verkeersgedrag van de autobestuurder in Noord-Amerika. Deze vragen hadden in concreto betrekking op de preventieve effecten van een ex ante en een ex post controle van het morele risico en op de vraag of verzekering de preventieve rol van het aansprakelijkheidsrecht kan overnemen.

Voor een antwoord op met name de laatste vraag kan mogelijk worden verwezen naar hetgeen Bruce opmerkt over de rol van de verzekeraar bij de controle van het gedrag van de polishouder. ${ }^{1324}$ Hij geeft in het kader van een ex post premieaanpassing met behulp van toeslagen een voorbeeld van een willekeurige autobestuurder $\mathrm{A}$ die in de Canadese provincie 5 jaar schadevrij is. Zijn premie stijgt echter met $98 \%$ als gevolg van een verkeersongeval waar bestuurder A bij betrokken is geraakt en waaraan geen andere bestuurder schuld heeft. Voor bestuurder A geldt dat in de 5 jaar die hij nodig heeft om weer in de laagste premieschaal te komen, de totale premietoeslag tengevolge van één verkeersongeval gelijk is aan $231 \%{ }^{1325}$ van de premie die bestuurder B met een schadevrij verleden betaalt. Bestuurder A met een schaderije premie van bijvoorbeeld $\$ 300$, betaalt derhalve over een periode van 5 jaar, een toeslag van $\$ 693$ voor zijn eerste schadeclaim. Daarnaast kan volgens Bruce een premietoeslag worden opgelegd voor bepaalde verkeersovertredingen, bijvoor-

Bruce, Law and Policy, 1984, p. 85-87.

First Repart is ontleend aan Select Committee on Company Law, The Insurance Industry Bruce, Law Bruce, Law and Policy, 1984, p. 86, tabel 1. 
beeld een toeslag van $100 \%$ bij roekeloos rijgedrag, $50 \%$ bij onvoorzichtig rijgedrag en $25 \%$ bij een overtreding van de maximumsnelheid. Bruce concludeert dat een systeem van premietoeslagen een grotere invloed heeft op het verkeersgedrag dan een aansprakelijkheidssysteem. De veroorzakers worden direct in hun vermogenge raakt, hetgeen meer indruk maakt dan de dreiging met een aansprakelijkheids. vordering van een half miljoen dollar. ${ }^{1326}$

Bruce tracht vervolgens ook de vraag te beantwoorden hoe een autobestuurder 2$]$ reageren op premietoeslagen in verhouding tot andere, bijvoorbeeld strafrechtelijke, sancties. Bruce verwijst in dat kader naar een onderzoek van Grayston, waarin wordt aangetoond dat wanneer het aantal premieklassen ten behoeve van een risicodiffe. rentiatie wordt verhoogd, opdat de premie nog beter kan worden afgestemd op het individuele ongevalsrisico, het aantal verkeersongevallen per geregistreerd voertuig afneemt. Daarnaast blijkt uit het onderzoek van Grayston dat naar aanleiding van de invoering van een 'merit rating' systeem in 21 Amerikaanse staten het aantal ver: keersongevallen, alsmede het aantal verkeersgewonden per geregistreerd voertuig is afgenomen. ${ }^{1327}$ Hoewel deze uitkomsten een indicatie geven van het effect van een ex post controle op het aantal verkeersongevallen, is niet duidelijk in hoeverre premietoeslagen van invloed zijn op het verkeersgedrag. Daamaast is twijfelachig of de daling van het aantal verkeersongevallen in zijn geheel was te danken aan de in. voering van een 'merit rating' systeem binnen de autoverzekering.

Naar aanleiding van het voorgaande kan in de eerste plaats worden geconcluderd dat er geen empirisch onderzoek beschikbaar is waaruit een direct verband kan worden vastgesteld tussen een ex ante risicodifferentiatie respectievelijk een ex post premieaanpassing en een vermindering van het morele risico dan wel een daling van het aantal verkeersongevallen. De beschreven studies geven hooguit een indicatie dat voor een optimale preventie van verkeersongevallen een autoverzekeraar gebuil kan en moet maken van premiedifferentiatie. Daarbij geldt dat een betere preventie wordt bereikt wanneer, zowel goede als slechte, autobestuurders een premie betalen die zoveel mogelijk correspondeert met het individuele ongevalsrisico.

In de tweede plaats kan, ter inleiding op de volgende paragraaf, worden betoogd dat binnen de autoverzekering in Noord-Amerika, ten aanzien van de controle van tat gedrag van de autobestuurder, de nadruk ligt op een ex ante risicodifferentiatie bijte vaststelling van de polisvoorwaarden; een ex post premieaanpassing wordt wel toe gepast, maar daarvoor is geen gereguleerd systeem ontwikkeld. Dit is anders in

1326. Bruce, Law and Policy, 1984, p. 85. Zie ook Sloan and Githens, JRI, 1994, p. 33-58, vour then Bruce, Law and Policy, 1984, p. 85 . Zie ook Sloan and Githens, JR, 1994 , p. Jijden onder in
onderzoek naar de preventieve werking van premietoeslagen tengevolge van het rije
vloed.

1327. R. Grayston, Deterrence in Automobile Insurance, PH.D. Dissertation, Chicago, Universily of Chicago, 1971 in Bruce, Law and Policy, 1984, p. 87 en 96. 
Europa en Japan. Daar wordt binnen de ex post benadering (premieaanpassing) gebrik gemaakt van een geavanceerd bonus-malus systeem gebaseerd op het schadeverleden van de autobestuurder. De ex ante risicodifferentiatie is veelal beperkt tot enkele classificatievariabelen, waarvan de belangrijkste leeftijd, woonplaats, beroep en type auto zijn. ${ }^{1328}$

\section{Bonus-malus systemen in Europa}

In deze paragraaf ligt de nadruk op een analyse van het bonus-malus systeem (BMS) dat in de meeste Europese landen binnen de autoverzekering wordt toegepast. Dit BMS makt onderdeel uit van een derde partij aansprakelijkheidsverzekering voor motorijtuigbezitters, ${ }^{1329}$ die in veel ontwikkelde landen verplicht is gesteld. ${ }^{1330}$ In een onderzoek van Lemaire wordt een overzicht gegeven van bonus-malus systemen in 12 Europese landen en in Japan. ${ }^{133}$

Een BMS, ook wel 'merit rating' of 'no claim-discount' systeem genoemd, is een vorm van 'experience rating', waarbij de verzekerde aan de ene kant kan worden bestraft met een premieverhoging (malus) wanneer hij verantwoordelijk kan worden gehouden voor een of meer verkeersongevallen. Aan de andere kant krijgen polishouders, die gedurende een periode schadevrij aan het verkeer bebben deelgenomen, na een bepaalde periode (meestal een jaar) een korting (bonus) op hun premie. Binnen een BMS ligt derhalve de nadruk op een ex post premieaanpassing op basis van het schadeverleden van de autobestuurder. De belangrijkste doelstelling van een BMS is, naast het aanzetten van autobestuurders tot voorzichtig rijgedrag, een betere schatting van individuele risico's te bereiken. In de ideale situatie betaalt elke polishouder daardoor op termijn een premie die zoveel mogelijk in overeenstemming is met zijn schadeverleden. ${ }^{1332}$

1328. Lemaire, JRI, 1988, p. 660; OECD-rapport, 1990, p. 46. De verhouding tussen een ex ante risicodifferentiatie en een ex post premie-aanpassing binnen een BMS-regime zal in paragraaf 4.3 worden geanalyseerd.

1329. Hierbij moet worden aangetekend dat de bezitter van een motorrijtuig degene is die de autoverzekering afsluit. Dit betekent dat de fouten van een persoon die de bezitter/polishouder van het motorrijtuig laat rijden, aan deze bezitter/polishouder in de vorm van een malus worden aangerekend. In de economische analyse van de verschillende BMS-regimes zal er echter vanuit worden uitgegaan dat de bestuurder in de meeste gevallen ook de bezitter/polishouder van het motorrijtuig is.

1330. OECD-rapport, 1990, p. 21. Binnen de Europese Unie is deze verzekeringsplicht geregeld in de

1331. Lemaire, JRI, 1988, p. 660-681; Lemaire, Bonus-Malus Systems, p. 1-285 voor een analyse van

1332. Lemus-malus systemen uit alle werelddelen.
en p. $46-4$, 1988, p. 661; Lemaire, Bonus-Malus Systems, p. 3-6; OECD-rapport, 1990, p. 35 en p. $46-47$ 
Een BMS bestaat over het algemeen uit een eindig aantal klassen, elk met zijn eigen premieniveau. Nieuwe polishouders hebben toegang tot een specifieke premieklasse, afhankelijk van het type auto, het motorvermogen van de auto, het gebruik van de auto, leeftijd van de auto, het aantal afgelegde autokilometers, de leeftijd van de polishouder, geslacht, huwelijkse staat en woonplaats. ${ }^{133} \mathrm{Na}$ elke polisperiode, meestal een jaar, volgt een aanpassing van de premie naar boven of naar beneden volgens de gangbare regels. In sommige landen, zoals Frankrijk, België en Duitsland, zijn autoverzekeraars op basis van regulering verplicht om dezelfde BMS structuur toe te passen. Polishouders die naar een andere verzekeraar willen over. stappen hebben het recht om hun bonus- of malusschaal naar de andere verzekeras mee te nemen. In andere landen heeft elke autoverzekeraar de vrijheid zijn eigen BMS-structuur te kiezen. Binnen deze landen, zoals Nederland en Engeland, is vel. al sprake van een competitieve markt voor autoverzekeringen. ${ }^{1334}$

Een eerste kenmerk van een BMS hangt samen met de mogelijkheid om alle polissen van een gegeven tariefgroep onder te verdelen in een afgebakend aantal premieklassen, zodat de jaarlijkse premieaanpassing alleen afhangt van de betreffende premieklasse. Een tweede kenmerk is dat de premieklasse voor een gegeven periode enkel wordt bepaald door de premieklasse van de voorbije periode en het schadever. leden (aantal claims) gedurende die periode. Daarnaast wordt een BMS beïnloed door de volgende drie elementen, namelijk de premieschaal, de toegangsklasse ende overgangsregels die betrekking hebben op de overgang van de ene premieklasse naar een andere premieklasse indien het aantal claims bekend is. ${ }^{1335}$

Eerst zal een globaal inhoudelijk overzicht worden gegeven van de BMS-structur die in respectievelijk Frankrijk, België en Nederland van toepassing is (paragraaf 4.1). ${ }^{1336}$ Daarna zal in het algemeen een aantal praktische implicaties van een BMS worden belicht (paragraaf 4.2). Vervolgens zal aandacht worden besteed aan de vraag in hoeverre een BMS van invloed kan zijn op het verkeersgedrag en darmet op de preventie van verkeersongevallen (paragraaf 4.3). Daarnaast zal ook andarth worden besteed aan een aantal alternatieve controlemechanismen, zoals de toepasssing van een eigen risico binnen een BMS.

1333. OECD-rapport, 1990, p. 44-46.

1334. OECD-rapport, 1990, p. 47-48; Lemaire, JRI, 1988, p. 661.

1335. Lemaire, JRI, 1988, 660-66l; Lemaire, Bonus-Malus Systems, p. 3-9.

1336. Deze rechtsstelsels zijn eerder in dit onderzoek, in de vorm van een positiefrechtelijke analyse aan de orde geweest. Zie hoofdstuk I (Frankrijk), hoofdstuk 2 (Belgiê) en hoofdstuk 3 (Nader land). 


\subsection{DE BMS-STRUCTUUR IN NEDERLAND, BELGIË EN FRANKRIJK}

In Nederland zijn autoverzekeraars volledig vrij in de bepaling van de tariefstructuur van een BMS. Een grote meerderheid van de autoverzekeraars maakt in het kader van de ex ante risicodifferentiatie gebruik van 4 standaardvariabelen, namelijk gewicht van het voertuig, woonplaats, leeftijd en het jaarlijks aantal afgelegde kilometers. De laatste twee variabelen zijn van belang voor de bepaling van de toegangsklasse binnen het BMS. Deze toegangsklasse ligt tussen klas 10 en klas 13. Het Nederlandse BMS, wordt sinds 1981 toegepast en bestaat gemiddeld uit 14 premieklas$\operatorname{sen}^{1337}$ waarbinnen het premieniveau oploopt van $30 \%$ in klas 1 via $100 \%$ in klas 13 naar $120 \%$ in klas 14 . Bij een jaar claimvrij autorijden daalt de verzekerde autobestuurder 1 klasse en gaat hij derhalve minder premie betalen. Ingeval van 1 schadeclaim stijgt de verzekerde met drie klassen binnen het BMS, waardoor hij meer premie gaat betalen. Bij 2 schadeclaims volgt een verdere stijging met gemiddeld vier premieklassen, voor zover de malusklas 14 nog niet bereikt is. Ditzelfde geldt bij 3 of meer schadeclaims. ${ }^{1338}$

In België is in 1992 een nieuw BMS-regime ingevoerd, waarbij onder andere het antal premieklassen is uitgebreid. ${ }^{1339}$ De inhoud van het Belgische BMS-regime wordt sterk regulerend benvloed, waarbij de tariefstructuur bij 'Ministerieel Besluit' word vastgesteld en door alle autoverzekeraars dient te worden toegepast. Sinds 1991 behoeven de verzekeraars echter geen toestemming meer vooraf te vragen van de controlerende instantie, voordat zij tot invoering van bepaalde premietarieven kunnen overgaan. Het toezicht is hiermee gewijzigd van een ex ante ('a priori') controle in een ex post controle ('a posteriori'). ${ }^{1340}$

Binnen het Belgische BMS van 1992 is het toegestaan om de premie te bepalen aan de hand van de volgende ex ante classificatievariabelen: leeftijd, het vermogen van de motor, het aantal afgelegde kilometers, woonplaats en geslacht. In de praktijk wordt door de verzekeraars echter veelal alleen het vermogen van de motor als een ex ante classificatievariabele gebruikt. ${ }^{1341}$ Het BMS bestaat uit 22 klassen, waarbij het premieniveau oploopt van $54 \%$ in klas 0 via $100 \%$ in klas 14 naar $200 \%$ in klas 22. De verzekerde die zijn auto voor zakelijk gebruik heeft betreedt het BMS in klas $14(100 \%)$, terwijl privé-gebruikers in klas $11(85 \%)$ worden ingedeeld. Een jaar

\footnotetext{
1337. Dit aantal premieklassen is ontleend an Lemaire, JRI, 1988, p. 675; Lemaire, Bonus-Malus Systems, p. 146. Een rondgang langs een aantal Nederlandse autoverzekeraars leert dat deze in hun verzekeringspolis veelal gebruik maken van een 20 -tal bonus-malus-treden.

Lemaire, JRI, 1988, p. 675-676.

1330

Zie Lemaire, Bonus-Malus Systems, p. 11-17, voor een bondig historisch overzicht en voor verschillen tussen het oude BMS-regime (uit 1971) en nieuwe BMS-regime.

1340. Zie daarover, Cousy en Claassens, GPRI, 1994, p. 46-59; Cousy, in The Law and Practice of Insurance in the Single European Market, p. 97-103.

1341. Lemain Bo Single Euro

Lemaire, Bonus-Malus Systems, p. 121; Claasens, Dossier Bonus-Malus, 1996, p. 9.
} 
clainvrij autorijden resulteert in een daling met 1 tree binnen het BMS. De eerste schadeclaim in een gegeven jaar wordt bestraft met een stijging van 4 premieklas. sen. Elke volgende claim in hetzelfde polisjaar wordt bestraft met een toename vanj treden. Geen enkele polishouder kan, indien hij vier opeenvolgende jaren claimvi] is gebleven, echter verder dan klas 14 dalen. Een verzekerde die zich in klas 17 be vindt wordt bijvoorbeeld na een claimvrij jaar beloond met plaatsing in klas 16 of klas 14, afhankelijk van het aantal opeenvolgende claimvrije jaren. ${ }^{1342}$

In Frankrijk zijn verzekeraars redelijk vrij bij de bepaling van hun tariefstructurus voor de berekening van de premie voor autoverzekering. $\mathrm{Zij}$ dienen echter wel te voldoen aan bepaalde richtlijnen die door het Ministerie van Economische Zaken, Financiën en Budgettering worden uitgevaardigd. Deze richtlijnen stellen dat de volgende minimale ex ante criteria moeten worden toegepast bij de bepaling van de premie: eigenschappen van de auto, woonplaats, gebruik van de auto en jaarlijks aantal afgelegde autokilometers. Wanneer een verzekeraar andere criteria wenst te gebruiken dient hij hiervoor toestemming te vragen aan het eerdergenoemde Ministerie. ${ }^{1343}$

In de praktijk wordt de inhoud van de tariefsstructuur binnen de Franse markt voor autoverzekeringen veelal aanbevolen door de zogenaamde 'Groupement Technique Accidents'. Hiervan wordt door de meeste verzekeraars slechts in beperkte mate afgeweken. De belangrijkste ex ante classificatievariabelen die worden toegepast ziji: het type auto, het beroep van de polishouder en woonplaats. Daamaast worden andere differentiatievariabelen gebruikt, zoals de tijd die sinds het behalen van het nijewijs is verstreken (rijervaring) en de 'leeftijd' van de auto die wordt gebrikt als cen instrument voor de berekening van het jaarlijks aantal autokilometers. Voor het veroorzaken van uitzonderlijk grote risico's (rijden onder invloed, zware verkeersovertredingen, doorrijden na een aanrijding) worden zware straffen opgelegd, door middel van een premietoeslag van $50 \%$ tot $200 \%{ }^{1344}$

Het Franse BMS-regime, geldig sinds 1984, kenmerkt zich door een groot antal premieklassen, namelijk 301. Deze klassen komen overeen met het percentage arn premie dat een autobestuurder moet betalen. Dit betekent in het Franse geval dat de premie begint bij klas 50 (50\% premie) en via klas 100 (100\% premie) oploopt nar malus-klas 350 , waarin $250 \%$ extra premie moet worden afgedragen. De verzekerde begint bij de toetreding tot het BMS met het betalen van $100 \%$ premie, zijnde de toegangsklasse 100 , alsmede een toeslag voor nieuwkomers van $69,5 \%$. Bij elk jar dat een autobestuurder claimvrij blijft, krijgt hij een korting van $5 \%$ op zijn premlih tegelijk met een daling van 5 premieklassen. De premie wordt met $25 \%$ (25 klassent)

1342. Lemaire, Bonus-Malus Systems, p. 8-9 en p. 18-19.

1343. Zie Lambert-Faivre, Droit des assurances, p. 620-621; Lemaire, JRI, 1988, p. 669.

1344. Lambert-Faivre, Droit des assurances, p. 617-622 en p. 626; Lemaire, JRl, 1988, p. 669. 
verhoogd ingeval van een schadeclaim. Indien twee autobestuurders hebben bijgedragen aan een verkeersongeval worden zij beide bestraft met een premiestijging van $12,5 \%$. Stijgt de premie bij de eerste schadeclaim van bijvoorbeeld $100 \%$ naar $125 \%$, ingeval van een tweede schadeclaim in hetzelfde jaar stijgt de premie van $125 \%$ naar $156 \%$, een derde schadeclaim zorgt voor een toename van de premie naar $192 \%$. Wanneer een autobestuurder twee jaar claimvrij is gebleven, gaat hij terug naar het basisniveau van $100 \%$ premie. Het laagste premieniveau van $50 \%$ kan worden bereikt na 13 opeenvolgende jaren claimvrij te zijn gebleven, gerekend vanaf het toegangsniveau van $100 \%$. Ten slotte geldt ten aanzien van het Franse BMS dat een autobestuurder niet voor een eerste schadeclaim wordt gestraft, indien hij minimaal drie jaar op het laagste premieniveau van $50 \%$ heeft vertoeft. Daarnaast krijgt een autobestuurder geen malus wanneer hij twee jaar claimvrij is gebleven. ${ }^{1345}$

\subsection{ENKELE PRAKTISCHE IMPLICATIES VAN EEN BMS-REGIME}

Uit het voorgaande globale overzicht van de BMS-structuur in Nederland, Frankrijk en België kan worden opgemaakt dat deze regimes in essentie niet veel van elkaar verschillen. Elk van de beschreven systemen past een vorm van 'experience rating' toe, waarbij straffen (malus) en beloningen (bonus) worden opgelegd al naar gelang door de polishouder een schadeclaim wordt ingediend. Daarnaast wordt een polishouder zoveel mogelijk ex ante ingedeeld in een premieklasse, afhankelijk van bepaalde classificatievariabelen, zoals leeftijd, woonplaats, geslacht, type auto, jaarlijks aantal autokilometers. In de praktijk wordt, voor de bepaling van de premieklasse, echter in beperkte mate naar deze variabelen gedifferentieerd.

In deze paragraaf zal een aantal praktische aspecten van een BMS worden geanalyseerd. Daarbij zal gebruik worden gemaakt van een onderzoek van Lemaire, waarin deze met behulp van een aantal toetsingsinstrumenten een vergelijking maakt tussen een groot aantal BMS-structuren (30) binnen en buiten Europa. ${ }^{1346}$ Een deel van deze toetsingsinstrumenten heeft betrekking op de bonus-malus verdeling van de polishouders binnen de verschillende premieklassen van een BMS, de zogenaamde 'honger naar een bonus' bij de polishouder door een kleine schadeclaim voor eigen rekening te nemen en de relatieve omvang van de malus ingeval van een schadeclaim (elasticiteit). De resultaten van deze toetsing zullen hier worden gepresenteerd, waarbij tevens zal worden ingegaan op een aantal (rechts)economische gevolgen daarvan.

\footnotetext{
1345. Lambert-Faivre, Droit des assurances, p. 622-628; Lemairc, Bonus-Malus Systems, p. 138-139;

1346. Lemaire, JRI, 1988, p. 669-670. Zie ook Thiry, Risques, 1990, p. 113-122.
Lemaire, Bonus-Malus Systems, p. 57-131; Lemaire, JRI, 1988, p. 662-666.
} 


\subsubsection{De bonus-malus verdeling binnen een BMS}

In het kader van de bepaling van de bonus-malus verhouding binnen een BMS Wordt door Lemaire verondersteld dat de gemiddelde claimfrequentie binnen Europa $10 \%$ bedraagt. Dit betekent dat een autobestuurder gemiddeld 1 schadeclaim in 10 jarr autorijden zal indienen. ${ }^{1347}$ Een dergelijke claimfrequentie van $10 \%$ zal volgens $L$ e. maire binnen een BMS moeten leiden tot een bestraffing met een stijging van 9 premieklassen om een optimale verdeling van de polishouders over de verschillende premieklassen te kunnen waarborgen. Lemaire constateert echter dat dergelijk hoge straffen vanuit commercieel oogpunt vaak niet worden opgelegd, waardoor een corr centratie van polishouders in de laagste BMS-klassen ontstaat, de klassen derhalve waar een autobestuurder de hoogste premiekortingen krijgt. ${ }^{1348}$ Daarnaast kan wor. den gewezen op het gegeven dat het aantal autobestuurders dat schadeviij blijf vele malen hoger is dan het aantal bestuurders dat 1 of meer verkeersongevallen heef veroorzaakt. De extra premie die tengevolge van een schadeclaim wordt opgelegd weegt derhalve niet op tegen de bonussen (premiekortingen) die aan bestuurders net een schadevrij verleden worden afgegeven. ${ }^{1349}$

Volgens het onderzoek van Lemaire uit 1988 (cijfers zijn van 1986) bedroeg de corcentratiegraad van polishouders in de laagste BMS-klasse voor Nederland, Belgie en Frankrijk respectievelijk $28,3 \%, 58,9 \%$ en $33,9 \%$. In Nederland bevond $3,5 \%$ vande polishouders zich in het malusgedeelte van het BMS, terwijl deze percentages vor: België (oude systeem) $0,93 \%$ en voor Frankrijk 18,57\% (waarvan slechts $2,6 \%$ met dan $130 \%$ aan premie betaalt) bedroegen. ${ }^{1350}$ Ten aanzien van België word door Lemaire verder vermeld (gegevens uit 1986) dat meer dan $73 \%$ van de polishouders zich in de laagste drie premieklassen bevond. ${ }^{1351}$ In 1992, het jaar van invoering van een nieuw BMS-regime in België, bedroegen deze percentages, gebaseerd op het oude BMS-regime, respectievelijk 65\% (maximale premiekorting), $80 \%$ (aandel polishouders in de laagste drie premieklassen) en $0,42 \%$ (andeel polishouders dat een malus betaalt). ${ }^{1352}$

Een van de gevolgen van deze hoge concentratie van polishouders in de laggte premieklassen van een BMS, is dat verzekeraars verliezen leiden op hun autrverzekeringspolissen. Een grote verzekeraar in België had bijvoorbeeld in 1992 etn

1347. Lemaire, Bonus-Malus Systems, p. 60-61. Hij wijst echter op de verschillen in claimfrequatio binnen Europa, waarbij een Noorse autobestuurder gemiddeld eens in de 20 jaar (claimfrequenise $5 \%$ ) een schadeclaim heeft en een Italiaanse autobestuurder naar schatting om de 5 jar (cliam frequentie $20 \%$ ) een schadeclaim indient.

1348. Lemaire, Bonus-Malus Systems, p. 61-62.

1349. OECD-rapport, 1990, p. 34-35 en p. 47.

1350. Lemaire, JRI, 1988, p. 666.

1351. Lemaire, JRI, 1988, p. 662.

1352. Lemaire, Bonus-Malus Systems, p. 16-17. 
premie-inkomen van ruim 2,5 miljard BEF, gaf 866 miljoen BEF aan bonussen weg, terwijl de inkomsten aan malussen slechts 1,3 miljoen BEF bedroegen. Een verzekerde werd derhalve bevoordeeld met een korting van gemiddeld $34,4 \%$ ten opzichte van de basispremie van $100 \%{ }^{1353}$

De hoge concentratiegraad van polishouders binnen de laagste premieklassen kan ook gevolgen hebben voor de controle van het morele risico. Het lijkt vreemd dat een autoverzekeraar veel bonussen of minder malussen afgeeft aan polishouders, die op basis van hun claimverleden (volgens de cijfers) anders behandeld dienen te worden. Lemaire gaat niet concreet in op de invloed van een dergelijk beleid op de verkeersveiligheid. Indien echter minder malussen worden opgelegd zou dit aan de ene kant kunnen betekenen dat er sprake is van een grote mate van veiligheid in het verkeer. Aan de andere kant kan de vraag worden gesteld of commerciële overwegingen bij een verzekeraar niet doorslaggevend zijn bij het opleggen van een malus. Wanneer een verzekeraar bijvoorbeeld, ingeval van een schadeclaim waaraan de verzekerde autobestuurder schuld heeft, een autobestuurder binnen een BMS-regime onvoldoende bestraft, wordt de betreffende bestuurder niet genoeg geprikkeld om met meer zorguuldigheid aan het verkeer deel te nemen. Dit betekent dat een BMSregime, zoals dat hier is gepresenteerd, onvoldoende beantwoord aan het verzekeringseconomische uitgangspunt dat de premie zoveel mogelijk moet overeenstemmen met het ongevalsrisico van de individuele autobestuurder. Daarnaast wordt ook een andere belangrijke doelstelling van een BMS niet gehaald, namelijk dat op termijn de slechte autobestuurders substantieel meer premie betalen dan de goede autobestuurders. ${ }^{1354}$

\subsubsection{De 'honger naar een bonus'}

Een tweede aspect dat door Lemaire in het kader van een BMS wordt onderzocht is de zogenaamde 'honger naar een bonus' bij de polishouder. Deze zal een bepaalde schade voor eigen rekening nemen om toekomstige malussen te voorkomen. De polishouder maakt daarbij een afweging tussen de omvang van de schadeclaim ${ }^{1355}$ en de omvang van de malus, die er mede toe leidt dat de bestuurder een aantal jaren

\footnotetext{
1353. Lemaire, Bonus-Malus Systems, p. 13-14. Dit is een stijging ten opzichte van bijvoorbeeld de cijfers uit 1985, die respectievelijk 2,4 miljard BEF (premie-inkomen), 793 miljoen BEF (bonussen) en 2,3 miljoen BEF (malussen) waren. Zie Lemaire, JRI, 1988, p. 662

1354. Lemaire, Bonus-Malus Systems, p. 17

1355. Vanuit het perspectief van de verzekeraar speelt de omvang van de schadeclaim geen rol. In het kader van de 'honger naar een bonus' is bijvoorbeeld in Duitsland in de polisvoorwaarden opgenomen dat geen malus wordt opgelegd indien de polishouder vrijwillig de kosten van afhandeling van de claim voor zijn rekening neemt. Wanneer de schadeomvang de DM 1.000 ,- niet te boven gaat is de verzekeraar zelfs wettelijk verplicht om de polishouder te informeren omtrent zijn recht om af te zien van het indienen van de claim, met het risico van een malus. Zie Lemaire, Bonus-Malus Systems, p. 91
} 
schadevrij moet blijven om weer op dezelfde premiekorting uit te komen. Het be. staan van deze 'honger naar een bonus' heeft, bij een geringe omvang ervan, eenzelf. de effect als een eigen risico en kan derhalve tot een besparing van de transectie kosten leiden. De 'honger naar een bonus' mag echter niet te groot worden. Een be langrijke doelstelling van een BMS is immers een betere scheiding tussen goede slechte risico's te bereiken en de bestuurder aan te zetten tot voorzichtig nijgedran Een BMS heeft echter niet tot doel schadeclaims te transfereren van de verzekeram naar de verzekerde. Lemaire stelt dat wanneer een BMS-regime een besturude dwingt om schadeclaims van bijvoorbeeld meer dan $\$ 5.000$ zelf te dragen, dit ertoc leidt dat schadeclaims zwaar worden bestraft en daarmee hit-and-run gedrag in de hand kan werken. ${ }^{1356}$

De 'honger naar een bonus' kan door middel van de verzekeringsvoorwaarden wo: den teruggedrongen. Wanneer de 'honger naar een bonus' te groot wordt, is het in: mers de verantwoordelijkheid van een autoverzekeraar om, met behulp van bijvoor beeld een hoger eigen risico, een dergelijke honger te stillen. De omvang van hetegen risico kan daarbij afhankelijk worden gemaakt van een bepaalde premieklasse Een autoverzekeraar kan bijvoorbeeld het eigen risico laten oplopen naarmate een verzekerde, op grond van zijn schadeverleden, in een hogere premieklasse terecti komt.

Ten slotte zal de 'honger naar een bonus' zich minder snel voordoen bij een verzekeraar die uit commerciële overwegingen niet snel een malus oplegt. Een dergelije 'honger naar een bonus' ontstaat pas wanneer een verzekeraar een strikt beleid voet ten aanzien van het schadeverleden van een autobestuurder en derhalve veel malussen oplegt. De 'honger naar een bonus' is daarom afhankelijk van de strengheid van een BMS. Een BMS waarin sneller malussen worden opgelegd is echter weer valbaarder voor het niet aangeven van een relatief laag claimbedrag door de vera kerde. $^{1357}$

\subsubsection{De elasticiteit van een $B M S$}

Een derde aspect dat door Lemaire, in het kader van zijn analyse van een BMS wordt onderzocht houdt verband met een belangrijke doelstelling van een $B M S$, wh melijk het optimaal scheiden van de goede (premieverlaging) en slechte (premiertehoging) autobestuurders. Daarbij geldt dat de zorg die een autobestuurder in het ver. keer uitoefent wel van invloed is op zijn ongevalsfrequentie, maar niet op de ofl

1356. Lemaire, JRI, 1988, p. 662-664; Lemaire, Bonus-Malus Systems, p. 91-102. Zie ook Bijlenth Het effect van de bonus/malus-regeling op schademeldingen 1998, die naar anleiding van the onderzoek concludeert dat in het algemeen niet kan worden gesteld dat een bonus/malus-tegeint? leidt tot minder gerapporteerde schades en/of minder geleden WA-schade. 
vang van de ongevalskosten. Het ongevalsrisico van een autobestuurder binnen een BMS-regime wordt derhalve enkel berekend op basis van de individuele claimfrequentie. $^{1358}$

Met behulp van de claimfrequentie wordt door Lemaire de elasticiteit van de BMSregimes in Nederland, België en Frankrijk berekend. Deze elasticiteit wordt gemeten naar de gevolgen die een wijziging in de claimfrequentie heeft op de omvang van de premie. De premie die door een polishouder wordt betaald vertoont hierbij een lineair verband met de claimfrequentie. Een relatieve stijging van de claimfrequentie dient te resulteren in eenzelfde relatieve stijging van de premie. Wanneer bijvoorbeeld sprake is van een premietoename van $2 \%$, betekent dit dat de elasticiteit van een BMS $20 \%$ bedraagt. ${ }^{1359}$

Uitgaande van de eerder veronderstelde gemiddelde claimfrequentie van $10 \%$ zal volgens Lemaire de elasticiteit van het Nederlandse BMS 0,275 bedragen, wat betekent dat voor elke claim een polishouder $2,75 \%$ meer premie moet gaan betalen. Het Belgische BMS heeft een elasticiteit van 0,195 , waardoor een polishouder $1,95 \%$ meer premie betaalt ingeval van een schadeclaim. In Frankrijk bedraagt de elasticiteit 0,200. Dit betekent dat een polishouder ingeval van een schadeclaim een premiestijging van $2 \%$ tegemoet kan zien. ${ }^{1360}$

Deze cijfers wijzen uit dat in Nederland de relatieve premiestijging bij een schadeclaim het hoogst is, hoewel het verschil met België en Frankrijk niet groot is. Vanuit rechtseconomisch oogpunt is het echter van belang dat niet alleen rekening wordt gehouden met de claimfrequentie van de polishouder maar ook met de omvang van de ingediende schadeclaim. Binnen het huidige BMS-regime kan daarbij de situatie ontstaan dat een bestuurder A die een schade van 500.000 gulden heeft veroorzaakt dezelfde premietoeslag (malus) krijgt opgelegd als bestuurder B die een schade van slechts 1.000 gulden heeft veroorzaakt. Naast de omvang van de schadeclaim wordt door een aantal auteurs gepleit voor het gebruik van het inkomen als differentiatievariabele. Binnen het verzekeringssysteem als geheel wordt volgens hen immers eenzelfde premie gevraagd, ongeacht de vraag of een polishouder een jaarlijks inkomen geniet van 50.000 gulden dan wel van 500.000 gulden. Keeton et al verwoorden dit aldus:

Th is basically unfair to charge the same rate to $\$ 5.000$-a-year and $\$ 50.000$-ayear earners as it is to charge the same total fire insurance premium for full

\footnotetext{
1358. Lemaire, Bonus-Malus Systems, p. 71

1359. Lemaire, Bonus-Malus Systems, p. 71-72; Lemaire, JRI, 1988, p. 663

ernaire, Bonus-Malus Systems, p. 84-85.
} 
coverage on a $\$ 5.000$ house and a $\$ 50.000$ house. Yet that is just what the liability insurance does'. ${ }^{1361}$

Dit heeft ook tot gevolg dat voor een verzekerde met een laag inkomen een premis (verhoging) van bijvoorbeeld 1.000 gulden moeilijker is op te brengen dan voor eet verzekerde met een topinkomen.

Hierin ligt derhalve een argument voor de invoering van een eerste partij schadererzekering. Daarbij wordt in het kader van de schadevergoeding uitgegaan van het inkomen van de polishouder zelf, terwijl dit bij een aansprakelijkheidsverzekering hei inkomen van een onbekende derde is. In de theorie is gesteld dat met exn schadeverzekering een betere controle van het morele risico kan worden bereikt dan met een aansprakelijkheidsverzekering. Met name ten aanzien van het inkomen van de polishouder, maar ook met betrekking tot de omvang van de schade, geldt dat bij een schadeverzekering de premie tegen lagere kosten kan worden gedifferentieerd.

\subsection{BONUS-MALUS SYSTEMEN EN DE PREVENTIE VAN VERKEERSONGEVALLEN}

Het hiervoor besproken onderzoek van Lemaire had vooral betrekking op een berkening van de zogenaamde 'toughness' van een BMS. Naast de genoemde instrt. menten werden door Lemaire ook andere toetsingsvariabelen gebruikt om de relatie. ve zwaarte van een BMS te bepalen. Daarbij wordt door hem echter geen nomatief oordeel uitgesproken over de kwaliteit van een BMS. ${ }^{1362}$ Daarnaast geeft de zwarte van een BMS geen directe indicatie omtrent de vraag in hoeverre een BMS tot en betere controle van het morele risico of een preventie van verkeersongevallen leith Naar aanleiding van zijn onderzoek geeft Lemaire echter wel een aantal praktische aanbevelingen voor de toepassing van een effectief BMS-regime.

Deze aanbevelingen zullen hierna worden toegelicht waarbij eerst aandacht zal wor den besteed aan de achterliggende preventiedoelstelling van een BMS. Deze doelstelling zal vervolgens worden getoetst aan de BMS-structuren van Nederland, België en Frankrijk. Tenslotte zal naar aanleiding van de onderzoeksresultaten van Le maire worden onderzocht aan welke voorwaarden een effectieve BMS-structur vanuit preventief oogpunt moet voldoen.

\subsubsection{De preventiedoelstelling van een $B M S$}

Een belangrijke doelstelling van een BMS is om autobestuurders an te zetten tol voorzichtig rijgedrag. Daarnaast wordt getracht om een betere inschatting te maken van de individuele risico's, waardoor elke polishouder op termijn een premie betali

1361. Keeton, Keeton, Sargentich and Steiner, Cases and Materials on Tort and Accident Law, p. 915

1362. Lemaire, Bonus-Malus Systems, p. 61 en p. 111. 
die in overeenstemming is met zijn verwachte risico. Een belangrijk middel om dit te bereiken, is het scheiden van de goede en slechte autobestuurders door hen ex ante onder te brengen in verschillende premieklassen. Door een ex post premieaanpassing kan dan een verdere risicodifferentiatie worden bewerkstelligd. Hierbij wordt een autobesturder binnen een BMS op basis van zijn schadeverleden (claimfrequentie) in een hogere of lagere premieklasse ingedeeld.

Een vertaling van deze theoretische overwegingen naar de eerder besproken BMSregimes in Nederland, België en Frankrijk, leert in de eerste plaats dat in de ex ante fase van deze BMS-regimes slechts beperkt gebruik wordt gemaakt van variabelen die van belang zijn voor een optimale risicodifferentiatie. Binnen de theoretische analyse is bijvoorbeeld gesteld dat leeftijd een nuttige differentiatievariabele kan zijn voor het maken van een onderscheid tussen goede en slechte risico's. ${ }^{1363}$ Verder is empirisch aangetoond dat, naast de leeftijd, ook de woonplaats een effectief instrument kan zijn voor de bepaling van het ongevalsrisico. ${ }^{1364}$

In de praktijk blijkt dat alleen in het Nederlandse BMS zowel de leeftijd als de woonplaats van de autobestuurder worden gebruikt voor een ex ante risicodifferentiatie. Binnen het Franse BMS wordt alleen de woonplaats als variabele gebruikt. In Belgie is het toegestaan om woonplaats en leeftijd ter bepaling van de ex ante premie te gebruiken, maar in de praktijk wordt enkel het vermogen van de motor als een ex ante classificatievariabele gehanteerd. ${ }^{1365}$ Dit betekent dat, in tegenstelling tot bijvoorbeeld Noord-Amerika waar de premie vooraf wordt bepaald aan de hand van meerdere variabelen, binnen de voornoemde BMS-regimes de nadruk ligt op een ex post controle van het gedrag van de autobestuurder.

\subsection{Het belang van een ex ante premiedifferentiatie binnen een BMS}

Mede naar anleiding van het voorgaande kan de vraag worden gesteld wat de optimale verhouding is tussen een ex ante risicodifferentiatie en een ex post premieaanpassing ten behoeve van een controle van het morele risico. Hiervoor dient te worden terug gekoppeld naar de economische analyse van risico en verzekering. Daarin is onder andere gesteld dat een autoverzekeraar vaak onvolledig is geïnformeerd omtrent het gedrag van een autobestuurder, waardoor een ex ante controle van het ongevalstisico van een autobestuurder hoge kosten meebrengt. Daarbij is verder gewezen op het feit dat het gedrag van de autobestuurder zich na aankoop van een autorezzekering nog kan wijzigen. Binnen de economische theorie is in dat kader geconcludeerd dat vanuit kostenoogpunt de controle van het ongevalsrisico beter ex post

\footnotetext{
1363. Zie paragraaf 4.2 van hoofdstuk 6.

1364. Zie paragraaf 3.3.1 van dit hoofdstuk.
}

1365. Zie Lemaire, JRI, 1988, p. $665-670$ en p. 675 
kan plaatsvinden. ${ }^{1366}$ De veronderstelling dat een ex ante risicodifferentiatie hoge kosten meebrengt zal hier enigszins worden genuanceerd. Daarbij zal, aan de hand van het gebruik van classificatievariabelen en de toepassing van een eigen risico, worden ingegaan op het belang van een ex ante risicodifferentiatie binnen een BMS voor autoverzekering.

\subsubsection{Het gebruik van ex ante classificatievariabelen}

In het empirisch onderzoek, dat eerder werd gepresenteerd, is een verband aangetoond tussen enerzijds de leeftijd en de woonplaats van de autobestuurder en ander. zijds het ongevalsrisico. ${ }^{1367}$ Daarnaast beschikken de verzekeraars over ongevalssta. tistieken, die een breed scala aan gegevens verschaffen ten aanzien van verkeersisico's en verkeersgedrag. Hieruit kan derhalve informatie worden geput ten behoveve van de inschaling van een individuele autobestuurder binnen een bepaalde premieklasse. $^{1368}$

Weliswaar kan worden gesteld dat, in tegenstelling tot de leeftijd en de woonplaats, het werkelijke verkeersgedrag van een individuele bestuurder, in het bijzonder zjp reflexen en zijn rijvaardigheden, alleen tegen hoge kosten kan worden vastgesteld. Dit gegeven doet echter niet af aan het belang van een ex ante risicodifferentiatie, in het bijzonder binnen een BMS-regime. Wanneer een autoverzekeraar binnen ten BMS immers onvoldoende ex ante differentieert, kan het gevaar ontstaan dat een ifdividuele autobestuurder in een te hoge of een te lage premieklasse wordt ingedell. Dit kan leiden tot een probleem van moreel risico en tot een proces van anti-selectie. Ten aanzien van dit laatste kan worden verondersteld dat een autobesturder via een minimale risicodifferentiatie in een te hoge premieklasse wordt ingedeeld, terwijl tij op grond van een meer zorgvuldige risicodifferentiatie in een lagere premieklass thuishoort. In een dergelijke situatie kan een autobestuurder, wanneer de regulengg van de verzekeringsmarkt het toelaat, overwegen om van verzekeraar te switchen Wanneer meerdere bestuurders dit voorbeeld volgen zullen de slechte risico's act. terblijven en kan de verzekeraar, die een gemiddelde premie aanrekent, worden ge confronteerd met een tekort aan premie-inkomsten. ${ }^{1369}$ Door middel van een beter ex ante risicodifferentiatie kan een verzekeraar dit proces van anti-selectie echter of remmen, waarmee eveneens een kostbesparend effect wordt bereikt.

Naast het proces van anti-selectie leidt een minder zorgvuldige risicodifferentiate ook tot een probleem van morele risico. Een individuele bestuurder, die op grood van zijn werkelijke kwalificaties in een te lage premieklasse wordt ingedeeld, al

1366. Zie paragraaf 4.1.4 van hoofdstuk 6 .

1367. Spahr and Escolas, JRI, 1982, p. 91-103. Zie daarover paragraaf 3.3.1 van dit hooffistuk.

1368. OECD-rapport, 1990, p. 31.

1369. Lemaire, Bonus-Malus Systems, p. 3. 
misschien minder zorgvuldig worden bij zijn verkeersdeelname. Binnen een BMS wordt dit morele risico vooral ex post gecorrigeerd, namelijk door middel van een malus op grond van het schadeverleden van de bestuurder. Met behulp van een meer zorgvuldige ex ante differentiatie wordt echter voorkomen dat het morele risico ontstaat.

In de economische theorie is echter gesteld dat een ex ante risicodifferentiatie niet grenzeloos kan worden toegepast en efficiënt is zolang de kosten van differentiatie niet hoger worden dan de baten, namelijk de vermindering van het morele risico en het proces van anti-selectie. Wanneer de kosten van een verdere differentiatie derhalve niet meer opwegen tegen de aangeboden premie, kunnen andere risicovariabelen worden geïntroduceerd. Een voorbeeld hiervan is het eigen risico. Met een dergelijk instrument kan worden voorkomen dat de goede risico's de premiegroep verlaten, omdat voor hen een eigen risico lagere kosten meebrengt dan een hogere premie. Daarnaast wordt met behulp van een eigen risico een buffer ingebouwd tegen het morele risico. Ten slotte worden de polishouders door middel van een eigen risico geconfronteerd met een gedeeltelijke blootstelling aan het ongevalsrisico, waarvoor zij deels financieel verantwoordelijk blijven. Hiermee kunnen derhalve met name de slechte risico's worden aangezet tot een hogere zorgvuldigheid in het verkeer. ${ }^{1370}$

\subsubsection{De toepassing van een eigen risico binnen een BMS}

Voor de beantwoording van de vraag in hoeverre de toepassing van een eigen risico binnen een BMS-regime van belang is voor een optimale ex ante risicodifferentiatie kan worden verwezen naar een ander onderzoek van Lemaire. Hierin presenteert hij een voorstel om, in plaats van een BMS, een autoverzekering met een gedeeltelijke dekking in de vorm van een hoog eigen risico toe te passen. ${ }^{1371}$ Een eigen risico kan volgens Lemaire een aantal negatieve effecten van een BMS wegnemen. Deze hebben in de eerste plaats betrekking op de veronderstelling dat verzekeraars vanuit commercieel oogpunt te weinig malussen uitdelen, waardoor op termijn een concentratie van polishouders in de laagste BMS-klassen ontstaat en de verschillen tussen goede en slechte bestuurders worden genivelleerd. Een tweede neveneffect betreft de 'honger naar een bonus', waarbij een polishouder bij een kleine schade geen claim indient omdat hij anders wordt bestraft met een malus, onafhankelijk van de omvang van de schade. ${ }^{1372}$

In een systeem met een hoog eigen risico wordt slechts dekking beschikbaar gesteld voor de schade die het eigen risico te boven gaat. Polishouders die dit eigen risico

1370. Zie hierover paragraaf 4.2 van hoofdstuk 6

1371. Lemaire, Bonus-Malus Systems, p. 223-256

1372. Lemaire, Bonus-Malus Systems, p. 223-224. 
niet kunnen betalen, worden in de gelegenheid gesteld bij hun verzekeraar een le. ning af te sluiten, die vervolgens in een aantal jaren kan worden terugbetaald, Aan de hand van een rechtseconometrische analyse wordt door Lemaire onderzoch wat, in vergelijking met een BMS, de gevolgen zijn van de invoering van een hoog eigen risico, bijvoorbeeld $\$ 3.000$, voor de premiedifferentiatie tussen de poij houders en voor de elasticiteit van een dergelijk systeem. De resultaten van deze analyse wijzen uit dat de invoering van een hoog eigen risico in vergelijking met etn BMS een hoger niveau van premiedifferentiatie tussen de polishouders genereer. Dit is het gevolg van het feit dat een gemiddelde polishouder op grond van het hoge eigen risico voor een groter deel moet bijdragen aan de eventuele schade. Daamasst heeft een systeem met een hoog eigen risico bij een lage claimfrequentie een hogere elasticiteit dan een BMS. Naarmate de claimfrequentie stijgt daalt echter de elasticiteit. Dit betekent dat bij een laag aantal claims de polishouder meer premie gaat be talen ofwel zwaarder wordt bestraft. Deze premiestijging wordt relatief gezien kleiner bij een groter aantal claims. Lemaire gaat echter uit van een lage claimfrequentie bij een meerderheid van de polishouders, zodat een systeem met een hoog eigen risico zijns inziens efficiënter is dan een BMS. ${ }^{1374}$

Hoewel een systeem met een hoog eigen risico door Lemaire vooral is gepresenteerd als een alternatief voor een BMS, dient de vraag te worden gesteld in hoeverre de toepassing van een eigen risico binnen een BMS wenselijk en zo ja mogelijk is. Daarbij kan in de eerste plaats worden gesteld dat met een eigen risico kan worden voorkomen dat polishouders bij een geringe schade geen schadeclaim indienen, maar de schade zelf betalen. Binnen het kader van een BMS heeft de polishouder een 'honger naar een bonus', die leidt tot het zelf dragen van een geringe schade om een toekomstig malus te vermijden. Met een eigen risico wordt bereikt dat een polishouder zonder angst voor een malus een schadeclaim kan indienen bij zijn verze keraar. Zolang de schade binnen de omvang van het eigen risico blijt heeft dit geen gevolgen voor zijn no-claim korting. De omvang van het eigen risico dient voldoende hoog te zijn, maar niet zo hoog dat voor de polishouder de kosten (insolventie) hoger worden dan de baten, namelijk het vermijden van een malus.

Wanneer echter de 'honger naar een bonus' zou moeten worden beperkt, is het van belang dat het eigen risico niet al te hoog wordt gesteld. De invoering van een zeet hoog eigen risico kan er immers toe leiden dat de verzekerde systematisch ongeval-

1373. Het voorstel voor een hoog eigen risico gefinanciërd door de verzekeraar is afkomstig w J. Holtan Bonus Made Easy, ASTIN Bulletin, 1994, p. 61-74 in Lemaire, Bonus-Malus Systems, p. 224.

1374. Lemaire, Bonus-Malus Systems, p. 223-244. Hij wijst verder op de voordelen van de toepassint van een systeem met een hoog eigen risico binnen het 'concept' van de corntintis bank/verzekeraar. De reden is dat zowel verzekeringsexpertise (bovenop het eigen nisico) 250 lat bankexpertise (de lening voor het eigen risico) nodig is om het systeem uit te kunnen voerth 
len zou kunnen hebben, waarvan de schade steeds binnen de grens van het (te hoog) eigen risico zouden blijven, zodat de informatie over het schadeverleden nooit bij de verzekeraar komt. Daaruit volgt dat een eigen risico een remedie kan zijn voor de 'honger naar een bonus' op voorwaarde dat het eigen risico redelijk laag wordt gesteld, zodat de verzekerde nog steeds een prikkel heeft om op zijn verzekeringspolis te claimen.

In de tweede plaats lijkt het onderzoek van Lemaire aan te tonen dat de invoering van een eigen risico tot een hoger niveau van premiedifferentiatie tussen de polishouders leidt. Wanneer binnen een bepaalde premieklasse aan de slechtere bestuurders een eigen risico wordt opgelegd, dan betalen deze bestuurders, in vergelijking met de goede bestuurders een hogere eigen bijdrage aan de tengevolge van een verkeersongeval ontstane schade. Dit leidt derhalve, zo is eerder gesteld, tot een preventie van verkeersongevallen. Door een eigen risico zal immers aan de slechte autobestuurders een extra prikkel tot zorg in het verkeer worden gegeven.

In de derde plaats kan, met verwijzing naar een onderzoek van Lemaire, worden verondersteld dat een risicoaverse polishouder, ter vermijding van een gegeven bedrag aan schade, bereid is een hoger eigen risico te betalen. ${ }^{1375}$ In dit onderzoek werd een eerste partij cascoverzekering als uitgangspunt genomen, in de veronderstelling dat een polishouder bij eigen schade op een meer directe wijze financieel wordt getroffen. In de veronderstelling dat een eigen risico ook binnen een BMSregime kan worden gebruikt, kan de bereidheid tot het betalen van een hoog eigen risico ook bij een derde partij aansprakelijkheidsverzekering worden toegepast. Daamaast kan worden uitgegaan van het gegeven dat een verkeersongeval een vrij zeldzame gebeurtenis is. Dit betekent dat een eigen risico voor een goede autobestuurder eerder voordelig kan zijn indien hij wordt gecompenseerd door middel van een lagere premie.

Concluderend kan worden gesteld dat de toepassing van een eigen risico, naast andere variabelen zoals leeftijd, woonplaats en het aantal afgelegde kilometers, een belangrijke bijdrage kan leveren aan een optimale ex ante risicodifferentiatie. Dit betekent dat voor een derde partij aansprakelijkheidsverzekering een ex ante risicodifferentiatie binnen een BMS-regime van belang is. Een ex ante verzameling van zoveel mogelijk risico-informatie is zelfs noodzakelijk, wanneer wordt uitgegaan van het gegeven dat een verkeersongeval een relatief zeldzame gebeurtenis is.

\footnotetext{
1375. Lemaire, Bonus-Malus Systems, p. 251. Hij berekent dat een polishouder met een sterke afkeer van risico bereid is om, ter vermijding van een schade van $100.000 \mathrm{BEF}$, meer te betalen dan 15.000 BEF aan eigen risico.
} 


\subsubsection{De ex post controle van het ongevalsrisico}

Alvorens kan worden ingegaan op de vraag naar de optimale verhouding tussen een ex ante risicodifferentiatie en een ex post controle binnen een BMS, zal eerst de ex post controle van het verkeersgedrag worden getoetst. Volgens Lemaire heeft onderzoek uitgewezen dat niet leeftijd, geslacht of beroep van een autobestuurder bepalend zijn voor de voorspelling van het toekomstig aantal schadeclaims, maar eerder het schadeverleden van de autobestuurder. Dit heeft zijns inziens mede geleid tot de invoering van een BMS-regime, waarin de nadruk wordt gelegd op een ex post premieaanpassing. ${ }^{1376}$

Een ex ante risicodifferentiatie blijft met de invoering van een BMS-regime wel bestaan, maar zij heeft binnen BMS-praktijk slechts betrekking op een beperkt antal classificatievariabelen. De ex post controle binnen een BMS wordt vooral bepald door het schadeverleden van de polishouder, die op grond van het aantal jaarlijke schadeclaims wordt ingedeeld op de bonus-malusladder. Hierna zal aan de hand van een voorbeeld worden toegelicht hoe de ex post controle via een BMS, gebaseerd op de jaarlijkse claimfrequentie van de polishouder, in de praktijk werkt. Daarbij zal een voorzichtige vergelijking worden gemaakt tussen de BMS-regimes van Belgit, Nederland en Frankrijk, gemeten over een periode van 10 jaar.

In tabel $2^{1377}$ worden twee autobestuurders, $A$ en $B$, verondersteld die hun auto voor zakelijk gebruik hebben. $\mathrm{Zij}$ worden, afhankelijk van hun claimfrequentie, 10 jar lang gevolgd in hun weg door het BMS-regime van respectievelijk België, Nederland en Frankrijk. Bestuurder A heeft 5 schadeclaims in het eerste jaar, 8 schade claims in het tweede jaar en blijft vervolgens 8 jaar schadevrij. Bestuurder $B$ heef $!$ schadeclaim in het tweede jaar, 1 schadeclaim in het zesde jaar en blijt de overige jaren schadevrij. In tabel $2^{1378}$ is weergegeven in welke premieklasse van de gegerva BMS-regimes bestuurder A en B, op basis van hun respectievelijke claimfrequentie, jaarlijks terecht komen. De belangrijkste gebeurtenissen zijn daarbij vetgedrut Gemeten over een periode van 10 jaar worden in de bovenste rij per land deze ple mieklassen voor bestuurder A en B opgesomd; de daarbij behorende premiepercertages staan in de onderste rij.

1376. J. Lemaire, Automobile insurance: Actuarial Models, Boston, Kluwer, 1985, hoofdstuk 7 gs in Lemaire, Bonus-Malus Systems, p. 4 en 263.

1377. Het voorbeeld is ontleend aan Lemaire, Bonus-Malus Systems, p. 163.

1378. Zie voor een overzicht van deze gegevens: Lemaire, Bonus-Malus Systemes, p. 135 (Beget) 138-139 (Frankrijk) en 146 (Nederland) en Lemaire, JRI, 1988, p. 666 (Frankrijk) en 675 (kt derland). 
Tabel 2

\begin{tabular}{|c|c|c|c|c|c|c|c|c|c|c|c|}
\hline Jaar & 1. & 2. & 3. & 4. & 5. & 6. & 7. & 8. & 9. & 10. \\
\hline \multicolumn{8}{|c|}{ Beigië (Toegangsklasse 14) } \\
\hline A. & $22(5)$ & $22(8)$ & 21. & 20 & 19. & 14. & 13. & 12. & 11. & 10 \\
\hline$\%$ & 200 & 200 & 160 & 140 & 130 & 100 & 95 & 90 & 85 & 81 \\
\hline B. & 13. & $17(1)$. & 16. & 15. & 14. & $18(1)$ & 17. & 16. & 14. & 13 \\
\hline$\%$ & 95 & 117 & 111 & 105 & 100 & 123 & 117 & 111 & 100 & 95 \\
\hline & \multicolumn{7}{|c|}{ Nederland (Toegangsklasse 13$)$} \\
\hline A. & $14(5)$ & $14(8)$ & 13 & 12 & 11 & 10 & 9 & 8 & 7 & 6 \\
\hline$\%$ & 120 & 120 & 100 & 90 & 80 & 70 & 60 & 55 & 50 & 45 \\
\hline B. & 12 & $14(1)$ & 13 & 12 & 11 & $14(1)$ & 13 & 12 & 11 & 10 \\
\hline$\%$ & 90 & 120 & 100 & 90 & 80 & 120 & 100 & 90 & 80 & 70 \\
\hline & & \multicolumn{7}{|c|}{ Frankrijk (Toegangsklasse 100$)$} & & \\
\hline A. & $305(5)$ & $350(8)$ & 345 & 100 & 95 & 90 & 85 & 80 & 75 & 70 \\
\hline$\%$ & 305 & 350 & 345 & 100 & 95 & 90 & 85 & 80 & 75 & 70 \\
\hline B. & 95 & $119(1)$ & 114 & 100 & 95 & $119(1)$ & 114 & 100 & 95 & 90 \\
\hline$\%$ & 95 & 119 & 114 & 100 & 95 & 119 & 114 & 100 & 95 & 90 \\
\hline
\end{tabular}

Naar anleiding van tabel $2 \mathrm{kan}$ in de eerste plaats worden geconstateerd dat besturder B, hoewel hij in 10 jaar slechts 2 schadeclaims had, binnen de BMSregimes van zowel België, Nederland als Frankrijk in een hogere premieklasse eindigt dan bestuurder $A$, die over de periode van 10 jaar liefst 13 maal een schade heef geclaimd. Lemaire concludeert derhalve dat het voor een polishouder blijkbaar van belang is om zijn schadeclaims zoveel mogelijk binnen één jaar te clusteren. Om dit te voorkomen beveelt hij aan om, ten aanzien van de claimfrequentie van de polishouder, de premie afhankelijk te maken van het totaal aantal claims in een bepaalde periode en niet te kijken naar het aantal claims in één bepaald jaar. ${ }^{1379}$ Voor een autoverzekeraar betekent dit dat meer onderzoek moet worden gedaan naar het schadeverleden van een polishouder, een onderzoek dat niet beperkt moet blijven tot een paar jaar, maar eerder een periode van bijvoorbeeld 5 tot 10 jaar dient te omvat-

1379. Lemaire, Bonus-Malus Systems, p. 163.

1380. Zie OECD-rapport, 1990, p. 34. 
In de tweede plaats kan worden opgemerkt dat de binnen het Belgische BMS geldende regel, waarbij een bestuurder na 4 claimvrije jaren automatisch in premieklas. se 14 terechtkomt ${ }^{1381}$ in het voordeel werkt van bestuurder $\mathrm{A}$. Zonder deze regel zouden in het gegeven voorbeeld zowel bestuurder A als B na 10 jaar in dezelfde premieklasse zijn uitgekomen, namelijk klas 14 (100\%). Het Franse BMS-regime kent de regel, waarbij een bestuurder na 2 claimvrije jaren automatisch tengvalt naar de basispremie van 100\% (klas 100). ${ }^{1382}$ Wanneer deze regel niet van toepas. sing zou zijn, zal in tabel 2 bestuurder $\mathrm{A}$ na 10 jaar eindigen op een premiepercenta. ge van $310 \%$ en bestuurder B op een premiepercentage van $90 \%$.

Op basis van het voorgaande kan worden gesteld dat, wanneer enkel wordt gecontroleerd op de claimfrequentie van een polishouder, het Franse BMS, zonder toepassing van een bijzondere regeling, verhoudingsgewijs een strikter regime van straffen en belonen heeft. Deze uitkomst geeft echter geen indicatie omtrent de vraag of het Franse BMS ook werkelijk tot een betere preventie van verkeersongevallen leid. In vergelijking met Frankrijk en België is het Nederlandse BMS het slechtst af. Bestuurder B wordt te weinig beloond voor zijn geringe aantal schadeclaims en bestuurder A wordt onvoldoende gestraft voor zijn hoge claimfrequentie. Met het Belgische BMS wordt, zonder toepassing van een speciale regeling, ook geen optimale uitkomst bereikt. Bestuurder B zou hierin, ondanks zijn lage claimfrequentie over een periode van 10 jaar, in dezelfde premieklasse uitkomen dan bestuurder $A$, die duidelijk minder voorzichtig is geweest.

Lemaire formuleert naar aanleiding van zijn onderzoek een aantal voorwaarden waaraan zijns inziens een effectief BMS-regime minimaal moet voldoen. Deze heb. ben onder andere betrekking op het gebruik van een groot aantal premieklassen en het afschaffen van regelingen waarbij malussen sneller worden kwijtgeschoiden. Toegepast op de geanalyseerde BMS-regimes kan worden gesteld dat binnen hat Franse BMS sprake is van een groot aantal premieklassen, vooral aan de maluszijle. Zonder de kwijtscheldingsregel na 2 claimvrije jaren, zouden bestuurder A (premie $310 \%$ ) en B (premie $90 \%$ ) na 10 jaar duidelijk van elkaar gescheiden zijn geweest In het Nederlandse BMS worden relatief weinig premieklassen (slechts 1 malusklasse) gebruikt. Ondanks de afwezigheid van een kwijtscheldingsregel eindigt bestur. der B na 10 jaar autorijden in een hogere premieklasse dan bestuurder A. Het Belgische BMS kent een groot aantal premieklassen (22), met 8 premieklassen aan de maluszijde. Toch is hierbij de situatie voor bestuurder B ook niet optimal. Zonder toepassing van de kwijtscheldingsregel na 4 claimvrije jaren zullen besturder $A$ en $B$,

1381. Lemaire, Bonus-Malus Systems, p. 8-9.

1382. Lemaire, JRI, 1988, p. 670.

1383. Lemaire, JRI, 1988, p. 681. Andere voorwaarden hangen samen met het toepassen van een ziat? malus bij de eerste schadeclaim en het onderbrengen van jonge autobestuurders in een hoge tor. gangsklasse in plaats van het opleggen van ex ante toeslagen. 
hoewel hun respectievelijke claimfrequentie duidelijk verschilt, na 10 jaar autorijden in dezelfde premieklasse (14) uitkomen.

\subsubsection{Conclusie: ex ante risicodifferentiatie versus ex post controle}

In het voorgaande is onderzocht op welke wijze een ex ante risicodifferentiatie respectievelijk een ex post controle van het ongevalsrisico effectief zijn bij de toepassing van een BMS-regime. Naar aanleiding daarvan kan in de eerste plaats worden geconcludeerd dat het noodzakelijk is om ex ante voldoende te differentiëren, teneinde het morele risico en de anti-selectie te verminderen. In de tweede plaats is gebleken dat een ex post controle, gebaseerd op de jaarlijkse claimfrequentie van de polishouder, op termijn tot een ongelijkheid tussen de polishouders leidt. Daarmee is niet gezegd dat een ex post controle niet effectief zou kunnen zijn. Wanneer een dergelijke controle echter gepaard gaat met de toepassing van bijzondere regelingen, waardoor uiteindelijk minder malussen worden opgelegd, kan de doelstelling van een BMS, namelijk het scheiden van de goede en slechte risico's, in gevaar komen. Daarnaast worden slechte autobestuurders onvoldoende aangezet tot zorgvuldigheid in het verkeer, een gegeven dat een stijging van het aantal verkeersongevallen en de daarmee gepaard gaande schade tot gevolg kan hebben.

De vraag dringt zich derhalve op of een ex post controle van het ongevalsrisico wel wenselijk is en ook hoe een dergelijke controle zich verhoudt tot een ex ante risicodifferentiatie. Eerder ${ }^{1384}$ is gesteld dat een ex ante risicodifferentiatie niet alles kan omvatten en te hoge kosten meebrengt wanneer het werkelijke verkeersgedrag van een individuele autobestuurder moet worden bepaald. Daarom kan worden gesteld dat een ex post premieaanpassing noodzakelijk is om de controle te waarborgen van variabelen die niet ex ante kunnen worden ingeschat.

In het kader van een ex post premieaanpassing via een BMS-regime, zal met name moeten worden gekeken naar het schadeverleden van de autobestuurder. Daarbij zal een verzekeraar zich niet enkel dienen te baseren op het jaarlijks aantal claims van een polishouder, maar zal hij zich meer moeten verdiepen in de claimfrequentie van een polishouder gemeten over een langere periode. Daarnaast is het van belang dat een BMS is opgebouwd uit een groot aantal premieklassen, waarin het aantal op te leggen bonussen en malussen min of meer gelijk is verdeeld. Ten slotte kan ook de omvang van de schadeclaim een bijdrage leveren aan een optimalisering van een BMS-regime. ${ }^{1385}$

\footnotetext{
1384. Zie paragraaf 4.3.2 van dit hoofdstuk.

1385. Lemaire, Bonus-Malus Systems, p. 205-220. In het kader van het onderscheid tussen zaakschade en letselschade wordt door hem berekend dat binnen BMS een letselschadeclaim even zwaar moet worden bestraft als vier zaakschadeclaims. Daarnaast kan volgens hem ook rekening wor-
} 
Concluderend kan worden gesteld dat voor de toepassing van een effectief BMS een voldoende mate van ex ante risicodifferentiatie én een ex post correctie noodzakelij] is. Wanneer een ex ante differentiatie tekortschiet vanwege de hoge kosten, kan eer ex post controle bijdragen aan een verdere differentiatie. Het is echter van groot be lang voor de preventie van verkeersongevallen dat bij de premiebepaling, ex ante ex post, zoveel mogelijk informatie omtrent het gedrag van de polishouder word verzameld. In de woorden van Lemaire:

'As automobile accidents are rather rare events, fortunately, it is important to include in the rating all information known about policyholders' behavior, even if related to another coverage'. ${ }^{1386}$

\section{De regulering van de markt voor autoverzekeringen}

\subsection{INLEIDING}

In de vorige paragrafen is uitgegaan van de situatie, waarbinnen autoverzekeraars volledig vrij zijn bij de toepassing van een ex ante risicodifferentiatie en een ex post premieaanpassing. Ten aanzien van de BMS-regimes in Frankrijk en Belgiè is echter gememoreerd dat autoverzekeraars dienen te voldoen aan bepaalde richtlijnen, die minimale criteria voorschrijven ten behoeve van een invulling van de BMSstructuur.

In deze paragraaf zal de invloed van overheidsregulering op de markt voor autoverzekeringen worden uitgewerkt. Daarbij zal aan de hand van empirisch onderzokj worden nagegaan hoe in een aantal landen de regulering van de verzekeringsmatts in de praktijk functioneert. Daarnaast zal worden onderzocht of de werking van de autoverzekeringsmarkt door overheidsregulering moet worden bepaald, of dat binnen deze markt sprake dient te zijn van voldoende concurrentie om een betere pre ventie van verkeersongevallen te kunnen waarborgen.

In paragraaf $5.2 \mathrm{zal}$ eerst de Amerikaanse markt voor autoverzekeringen wordengeanalyseerd. $\mathrm{Na}$ een kort inhoudelijk overzicht van de belangrijkste kenmerken va deze markt, zal aandacht worden besteed aan een aantal empirische studies. Hiem worden de gevolgen onderzocht van een verregaande prijsregulering voor de concris: rentie en de omvang van de premie binnen de autoverzekeringsmarkt van de Amerikaanse staat Massachusetts. In paragraaf $5.3 \mathrm{zal}$ aandacht worden besteed ann

den gehouden met de 'loading costs', zijnde de commissies, belastingen en andere administre ve kosten die bovenop de nettopremie komen. Wanneer deze kosten proportioneel worden dor berekend naar de oplopende premieklassen, kan volgens Lemaire worden bereikt dat de sact risico's een hogere premie betalen dan de goede risico's.

1386. Lemaire, Bonus-Malus Systems, p. 181. 
vergelijking van de autoverzekeringsmarkt in Engeland en Duitsland. Deze markten worden gekenmerkt door respectievelijk een hoge mate van concurrentie (Engeland) en een hoge mate van regulering (Duitsland). Daarbij zal met name het onderzoek van Adams en Finsinger, dat binnen de theoretische analyse is aangehaald, ${ }^{1387}$ meer uitvoerig aan de orde komen.

\subsection{DE AMERIKAANSE VERZEKERINGSMARKT}

In paragraaf 2 van dit hoofdstuk is een overzicht gegeven van de Amerikaanse markt voor autoverzekeringen. Daarin lag vooral de nadruk op de vraagzijde van de verzekeringsmarkt door middel van een beschrijving van de instrumenten die aan een individuele autobestuurder ter beschikking staan om zich tegen de gevolgen van een verkeersongeval te verzekeren. In deze paragraaf zal de Amerikaanse autoverzekeringsmarkt meer vanuit de positie van de verzekeraar (de aanbodzijde) worden geanalyseerd.

\subsubsection{Regulering van de Amerikaanse verzekeringsmarkt ${ }^{1388}$}

De belangrijkste doelstellingen van verzekeringsregulering in Noord-Amerika hangen samen met het voorkomen van bedrog (bijvoorbeeld misleidende reclame) door verzekeraars, het waarborgen van de solvabiliteit van de verzekeraars en het opleggen van faire (niet-discriminerende) premies. De praktische uitwerking van deze doelstellingen heeft geleid tot een groot aantal wetgevende maatregelen die echter van staat tot staat verschillen. ${ }^{1389}$ Dit is mede het gevolg van de McCarran-Ferguson Act uit 1945. Deze wet bepaalde dat verzekeringsregulering primair de verantwoordelijkheid van de afzonderlijke staten is en niet van de federale overheid. Wanneer een staat echter verzuimt om wettelijke maatregelen te nemen, dan komt de verzekeringsbranche in de betreffende staat onder direct toezicht van federale wetgeving. ${ }^{1390}$

Naar aanleiding van de McCarran-Ferguson Act werden in een groot aantal staten wetgevende maatregelen uitgevaardigd, waarmee de verzekeringsbranche in meerdere of mindere mate werd gereguleerd. Deze wetgeving was gebaseerd op een door de 'National Association of Insurance Commissioners' (NAIC) ${ }^{1391}$ opgestelde modelwetgeving. Deze bevatte een tweetal belangrijke bepalingen, namelijk voorschrif-

\footnotetext{
1387. Zie paragraaf 5.4 van hoofdstuk 6 .

1388. Zie Skipper, in Policy Issues in Insurance, p. 75-143, voor een uitvoerig (historisch) overzicht van de regulering van de Amerikaanse verzekeringsmarkt.

1389. Keeton, Insurance Law, p. 554-557.

1390. Keeton, Insurance Law, p. 537-538 en p. 560; Schimeister, Amerikaanse toestanden in het

1391. Deze in 1871 opgerichte organisatie verzorgt de controle van de financiële huishouding van de in meerdere staten opererende verzekeringsmaatschappijen. Zie Schimeister, Amerikaanse toestanden in het schadevergoedingsrecht?, p. 459; Keeton, Insurance Law, p. 538.
} 
ten die tot doel hadden de solvabiliteit van de verzekeraars te waarborgen en regel. geving met betrekking tot het door de staten uit te oefenen toezicht op de tarieven van de verzekeraars. De uitvoering van de modelwetgeving was in handen van de 'state departments of insurance', die werden vertegenwoordigd door een benoemde of gekozen 'commissioner of insurance'. ${ }^{1392}$

Voor wat betreft de vaststelling van de verzekeringstarieven dient een onderscheid te worden gemaakt tussen 'rate making', waarbij een statelijk overheidsorgaan de omvang van de premies vaststelt, en 'rate regulation', waarbij individuele verzekernars of een groep van verzekeraars de omvang van de premie vaststelt. ${ }^{1393}$ In de meeste staten geldt dat verzekeraars van de autoriteiten, in casu de 'commissionar of insl. rance', vooraf toestemming nodig hebben voor een verhoging of verlaging van de premie ('prior approval laws'). In een minderheid van de staten mogen de verzekeraars zelfstandig hun tarieven vaststellen ('open competiton laws/open rating system'), waarbij soms nog wel een controle achteraf kan plaatsvinden. ${ }^{1394}$

In de praktijk bleek dat binnen de staten het toezicht op de verzekeringsbranche niet erg groot was. De meeste 'departments of insurance' waren onderbezet en ontbeerden de deskundigheid om ten behoeve van de vaststelling van de verzekeringstarieven de benodigde gegevens te verzamelen en te verwerken. Daarnaast waren de 'commis. sioners' veelal afkomstig uit de verzekeringsbranche zelf en bood de wetgeving in veel staten hen weinig houvast. Dit gebrek aan toezicht leidde tot concurentie. beperkende activiteiten in de vorm van zelfregulering door de verzekeringsbranche. Op landelijk niveau werd een particuliere organisatie, de 'Insurance Service Office', opgericht die zich ging bezighouden met de verzameling van gegevens ten behovere van de vaststelling van verzekeringstarieven. ${ }^{1395}$

De verzekeringscrisis in de jaren '80 van de vorige eeuw, ${ }^{1396}$ zorgde mede voor ent ommekeer in het toezicht op de verzekeringsbranche. Deze crisis werd gekennerkt door een sterke stijging van de premies voor aansprakelijkheidsverzekeringen, het opzeggen van bepaalde verzekeringspolissen en het feit dat voor bepaalde annspin. kelijkheidsrisico's geen betaalbare verzekeringsdekking meer werd angeboden.

1392. Schirmeister, Amerikaanse toestanden in het schadevergoedingsrecht?, p. 459; Keeton, Insurne? Law, p. 538.

1393. Keeton, Insurance Law, p. 559-560.

1394. Keeton, Insurance Law, p. 564; Schirmeister, Amerikaanse toestanden in het schadevergoeding. recht?, p. 459. Zie ook Cummins and Tennyson, J. Ec. Persp., 1992, p. 99.

1395. Schirmeister, Amerikaanse toestanden in het schadevergoedingsrecht?, p. 459-460; Ketton, inst rance Law, p. 542-543.

1396. Zie daarover uitvoerig: Priest, YLJ, 1987, p. 1521-1590; Viscusi, JLS, 1991, p. 147.177; Winto, J. Ec. Persp., 1991, p. 115-136.

1397. Schirmeister, Amerikaanse toestanden in het schadevergoedingsrecht?, p. 437; Harrington, in ti: ability: Perspectives and Policies, p. 42, waarin wordt gesproken over een stijging van de utito 
Over de oorzaken van de verzekeringscrisis lopen de meningen uiteen. In dit kader wordt onder andere het disfunctioneren van de verzekeringsbranche genoemd, ${ }^{1398}$ hoewel de verzekeraars op hun beurt de crisis wijten aan de stijging van het aantal en de omvang van de aansprakelijkheidsvorderingen. ${ }^{1399}$ Volgens anderen hebben echter ook externe factoren, zoals een dalende rente en hogere belastingtarieven, aan de verzekeringscrisis bijgedragen. ${ }^{1400}$

Onder invloed van deze verzekeringscrisis dreigde het Amerikaanse Congres aan het eind van de jaren ' 80 van de vorige eeuw de McCarran-Ferguson Act in te trekken en de controle van de verzekeringsmarkt weer onder federaal toezicht te plaatsen. Dit was voor de statelijke overheden de aanleiding om zich intensiever met de regulering van de verzekeringsbranche bezig te houden, zodat een effectiever en meer uniform toezicht kon worden bereikt. In sommige staten leidde dit tot wetgeving waarbij verzekeraars werden verplicht om gegevens te verstrekken aangaande de omvang van de premies. In andere staten werd via wetgeving een bevriezing of een verplichte daling van de premies afgedwongen. ${ }^{1401}$

Hetgeen hiervoor is opgemerkt omtrent de regulering van de Amerikaanse verzekeringsmarkt geldt ook ten aanzien van autoverzekeringen, met dien verstande dat de verzekeringscrisis in de jaren ' 80 van de vorige eeuw niet direct van invloed is geweest op de markt voor autoverzekeringen. ${ }^{1402}$ Gedurende de jaren ' 80 van de vorige eeuw is binnen de autoverzekering wel sprake geweest van een sterke toename van de premies, met name in de stedelijke gebieden. ${ }^{1403}$

schreven premies voor aansprakelijkheidsverzekering van $\$ 6,5$ miljard naar $\$ 20$ miljard tussen 1984 en 1986.

1398. Dit was de mening van de 'National Association of Attorneys General'. Zie daarover Schirmeister, Amerikaanse toestanden in het schadevergoedingsrecht?, p. 438.

1399. Tussen 1984 en 1989 steeg de omvang van de aansprakelijkheidsvorderingen voor letselschade, tezamen met de claimfrequentie, met ruim $11 \%$. Zie Cummins and Tennyson, J. Ec. Persp., 1992, p. 104-107. Zie ook Viscusi, JLS, 1991, p. 150; Schirmeister, Amerikaanse toestanden in het schadevergoedingsrecht?, p. 453-454.

1400. Cummins and Tennyson, J. Ec. Persp., 1992, p. 106-107; Priest, YLJ, 1987, p. 1529-1532; Schir-

1401. Schirmeister, Amerikaanse toestanden in het schadevergoedingsrecht?, p. 461 en p. $464-465$.

1402. Priest, YLJ, 1987, p. 1582.

1403. Cummins and Tennyson, J. Ec. Persp., 1992, p. 95 . In 1989 liep de gemiddelde premieomvang per voertuig uiteen van $\$ 353$ in lowa tot $\$ 1074$ in New Jersey. Uit andere gegevens blijkt dat in 1989 een 19-jarige mannelijke autobestuurder rijdend in een 1987 Chevrolet Caprice in Milwaukee een jaarlijkse premie betaalt van $\$ 1.500$, terwijl eenzelfde autobestuurder met eenzelfde auto in Los Angeles jaarlijks $\$ 5.000$ aan premie kwijt is. Zie Smith and Wright, Am. Econ. Rev., 1992, p. $757-758$ 


\subsubsection{Concurrentie op de markt voor autoverzekeringen in Noord-Amerika}

De particuliere markt voor autoverzekering in Amerika wordt als concurerend be. schouwd. ${ }^{1404}$ Er zijn vele ondernemingen op deze markt actief en de concentratiegraad is relatief laag. In de Verenigde Staten zijn ongeveer 500 autoverzekraars actief. De grootste autoverzekeraar controleerde in $198921 \%$ van de mark voor verzekeringspremies; de grootste vier verzekeraars hadden een marktaandeel van $43 \%$ en de grootste 20 verzekeraars beheersten tweederde van de Noord-Ame. rikaanse markt. ${ }^{1405}$ Op statelijk niveau is de concentratiegraad van autoverzekeraars hoger dan op federaal niveau, waarbij de vier grootste verzekeraars gemiddeld 55\% van de statelijke verzekeringsmarkt in handen hebben. Verzekeraars vertonen verder de neiging om de staten vanuit kosten- en marketingoogpunt onder te verdelen naar regio's, waardoor de concentratie in sommige regio's hoger is dan elders.

De verkoop van autoverzekeringen vindt in Amerika plaats langs drie belangijike distributiekanalen. Deze zijn respectievelijk de onafhankelijke tussenpersonen, de exclusieve agentschappen en de post- en telenetwerken. Ondernemingen die van de laatste twee genoemde verkoopkanalen gebruik maken worden ook wel 'direct wirters' of 'exclusive dealers' genoemd. De 'direct writers' (verzekeraars die zonder tissenpersoon klanten werven) zijn dominant binnen de private markt voor autoverzekeringen; hun aandeel in de totale premieopbrengsten bedroeg in 1989 ongever $66 \%{ }^{1406}$ Behalve ten aanzien van bepaalde minimale kapitaals- en vergunningsvereisten zijn er geen omvangrijke toegangsbarrières voor verzekeraars om tot de marks te kunnen toetreden. ${ }^{1407}$

\subsubsection{De invloed van regulering op de werking van de autoverzekeringsmarkt in Massachusetts}

De verzekeringscrisis in de jaren ' 80 van de vorige eeuw is voor een aantal Amerikaanse staten mede aanleiding geweest om ook in te grijpen in de markt voor attoverzekeringen. Door de statelijke wetgever is met een aantal beleidsmaatreglen

1404. De meningen lopen uiteen ten aanzien van de vraag of de Amerikaanse verzekeringsmaskt al gereguleerd of als competitief moet worden beoordeeld. Zie Pauly, Kunreuther and Kleindorfici in The Economics of Insurance Regulation, p. 65.

1405. Ter vergelijking: in 1985 waren deze percentages marktaandeel respectievelijk, $19 \%$ voor grootste onderneming, $40 \%$ voor de vier grootste ondernemingen en $62,5 \%$ voor de thintig grootste verzekeraars. Zie Harrington, in Liability: Perspectives and Policy, p. 43-44.

1406. Cummins and Tennyson, J. Ec. Persp., 1992, p. 98 . In 1981 lag het marktaandeel van de dirat writers', afhankelijk van het type autoverzekering dat wordt aangeboden, nog tussen $52 \%$ on $61 \%$. Zie Pauly, Kunreuther and Kleindorfer, in The Economics of Insurance Regulation, $\mathrm{p} .73$.

1407. Harrington, in Liability: Perspectives and Policy, p. 44-45. 
onder andere beïnvloed door referenda, ${ }^{1408}$ getracht de kosten van autoverzekering terug te dringen. Het merendeel van deze maatregelen had tot doel de premietarieven te verlagen en sterke beperkingen aan te brengen in het gebruik van een ex ante risicodifferentiatie. Voorbeelden van risicovariabelen die niet meer door autoverzekeraars mochten worden gebruikt waren de leeftijd, geslacht en huwelijkse staat. ${ }^{1409}$ Bij de invoering van deze wetgeving is door veel staten aansluiting gezocht bij de verzekeringsregulering van de staat Massachusetts, die reeds een decennium werd toegepast. ${ }^{1410}$ In de volgende subparagraaf zal een kort overzicht worden geschetst van de verzekeringswetgeving in Massachusetts. Daarna zal met behulp van empirisch onderzoek ${ }^{1411}$ worden nagegaan welke effecten de strikte regulering in Massachusetts ruim 10 jaar na de invoering ervan heeft gehad op de werking van de autoverzekeringsmarkt.

\subsubsection{Prijsregulering binnen de verzekeringsmarkt van Massachusetts}

Binnen de Amerikaanse markt voor autoverzekeringen bestaan voor wat betreft de omvang van verzekeringsregulering grote verschillen tussen de staten onderling. ${ }^{1412}$ Het is derhalve onmogelijk een adequate beschrijving te geven van de invloed van regulering op de gehele Amerikaanse autoverzekeringsmarkt. In deze subparagraaf zal de analyse daarom worden beperkt tot de werking van verzekeringsregulering in één enkele Amerikaanse staat, namelijk Massachusetts. In deze staat is in 1976 wetgeving ingevoerd die wordt gekenmerkt door een verregaande prijsregulering ten aanzien van de premies voor autoverzekering. Daarnaast is de controle van de verzekeringsmarkt geheel in handen van de statelijke overheid, waarbij concurrentie tussen verzekeraars nagenoeg afwezig is. ${ }^{1413}$ De wetgeving in de staat Massachusetts

1408. Zoals in 1988 in Californie geschiedde met 'Proposition 103', een systeem van prijs- en regulerende controle van onder andere de autoverzekering. Zie Zycher, Regulation, 1990, p. 67-77; Schirmeister, Amerikaanse toestanden in het schadevergoedingsrecht?, p. 462-464.

1409. Het gebnuik van deze variabelen bij de bepaling van de premie zou discriminerend en in strijd zijn met sommige grondwettelijke rechten en vrijheden onder de 'Fourteenth Amendment' dat bepaald dat elke staat gelijke rechten en bescherming moet geven aan haar inwoners. Het feit dat cen individuele verzekerde kan worden ondergebracht in een categorie met een discriminatoir karakter waarover hij geen of weinig controle heeft, zoals leeftijd, geslacht, en woonplaats, kan ertoe leiden dat de verzekerde in een premieklasse terecht komt die niet overeenstemt met het ongevalsrisico. Zie daarover, Spahr and Escolas, JRI, 1982, p. 91; Tryfos, JRJ, 1987, p. 569. Zie ook Dahlby, Joumal of Public Economics, 1983, p. 121-130, waarin ten aanzien van de Canadese autoverzekeringsmarkt wordt aangetoond dat afschaffing van het geslacht als risicovariabele ertoe zal leiden dat vrouwelijke autobestuurders in de leeftijd van 21-24 jaar een substantieel ho-

1410. gete premie zullen gaan betalen.

14!1. Blackmon Jr. and Zeckhauser, Am. Econ. Rev., 1991, p. 65.

1412. Zie daron and Zeckhauser, Am. Econ. Rev., 1991, p. 65-69; Derrig, GPRI, 1993, p. 158-173.

1413. Derrig GPer paragraaf 5.2.1 van dit hoofdstuk.

Derrig, GPRI, 1993, p. 158. 
heeft, als gezegd, voor andere Amerikaanse staten als voorbeeld gediend voor de op. lossing van het probleem van de sterk gestegen premies voor autoverzekering. ${ }^{144}$

In Massachusetts vervult de zogenaamde 'insurance commissioner' een centrale rol Hij heeft een directe controle over alle aspecten van de koop en de levering van verzekeringsdiensten, zoals de hoogte van de premie, vrijwillige en 'residual marktmechanismen en procedures betreffende het indienen van een rechtsvordering. De 'insurance commissioner' bepaalt tot in detail wat de prijs zal zijn die een autobestuurder in Massachusetts jaarlijks moet gaan betalen voor zijn verplichte aansprakelijkheidsverzekering. Bij de bepaling van de prijs houdt de 'insurance commissioner' onder andere rekening met de winsten van de verzekeraars, de maatregelen ten behoeve van een kostenbeheersing, het groeperen van steden in tariefsgebieden en een bonus-malusplan. ${ }^{1415} \mathrm{De}$ invloed van de 'insurance commissioner' reikt ver. Zo werd in een zeker jaar bepaald dat alle bestuurders bij hun aanvraag voor een autoverzekering (het ging niet om een levensverzekering) moesten melden of zij rookten, vermoedelijk om de niet-rokers een korting op de premie te kunnen geven. ${ }^{1416}$

Een van de belangrijkste onderdelen van de jaarlijkse premiebepaling ${ }^{1417}$ door de ir. surance commissioner', omvat de opzet van een eenvormig classificatiesysteem dat in het aankomende jaar door alle verzekeraars dient te worden toegepast. Binnen dit wettelijke classificatiesysteem is het slechts toegestaan om de volgende ex ante risicovariabelen te gebruiken: woonplaats van de bestuurder, premieklasse gericht naar de persoon van de eigenaar respectievelijk de gebruiker van het voertuig, rijervaring, leeftijd van de auto en het type auto. ${ }^{1418}$ Verzekeraars mogen de premie niet verder differentiëren, maar zij mogen een potentieel verzekerde wel weigeren.

Ten aanzien van dit laatste bestaat in een groot aantal Amerikaanse staten (40) een systeem, waarbij een verzekerde die niet bij een verzekeraar terecht kan aan een be.

1414. Blackmon and Zeckhauser, Am. Econ. Rev., 1991, p. 65.

1415. Derrig, GPRI, 1993, p. 158-159.

1416. Derrig, GPRI, 1993, p. 160. Ten aanzien van het roken als risico-variabele zou de insurnese commissioner' bijvoorbeeld van mening kunnen zijn dat roken tijdens het autorijden nadeliget fecten heeft op de verkeersveiligheid. De rook van een dikke sigaar zou het zicht op de wegknt nen belemmeren. Daarnaast zal het uitmaken van een sigaret nopen tot het sturen met ten hand Dit zijn inderdaad aspecten die de concentratie op het autorijden (deels) kunnen wegnemen. hi hoeverre zij echter tot een vermindering van de verkeersveiligheid zullen leiden is onderwer? van verder empirisch onderzoek.

1417. De jaarlijkse premievaststelling gaat gepaard met een omvangrijke procedure, de zogenamint 'public hearing', waarbij onder andere instanties zijn betrokken die de belangen van de verakes raars en de consumenten behartigen. Zie Derrig, GPRI, 1993, p. 160-161.

1418. Om redenen van anti-discriminatie is een differentiatie naar geslacht in 1977 afgeschaft, event het gebruik van de leeftijd van de autobestuurder. De laatste is vervangen door het antal jert dat een bestuurder in het bezit is van een rijbewijs. Zie Blackmon and Zeckhauser, Am. Em Rev., 1991, p. 65; Detrig, GPRI, 1993, p. 165-167. 
paalde verzekeraar wordt toegewezen. Deze herverzekeraar is geheel verantwoordelijk voor de kosten en verliezen die door de verzekerde op de autopolis worden gemaakt. ${ }^{149}$ In Massachusetts is daarentegen sprake van een herverzekeringsmechanisme binnen een zogenaamde gesubsidieerde 'residual' markt, de 'Common wealth Auto Reinsurers' (CAR). Op deze markt worden verzekeringspolissen afgegeven aan automobilisten (hoge risico's) die bij geen enkele individuele verzekeraar terecht kunnen. De kosten van deze 'residual' markt worden door alle verzekeraars gezamenlijk gedragen, naar rato van hun individuele marktaandeel binnen de vrije markt. Hoewel de 'residual' markt tot doel heeft om de hoge risico's, die nergens anders terecht kunnen, op te vangen, blijkt in de praktijk dat meer dan tweederde van de automobilisten in Massachusetts door de 'residual' markt wordt verzekerd. ${ }^{1420}$ Daar komt bij dat autobestuurders in zowel de 'residual markt' als de vrije markt een gelijke premie betalen. ${ }^{142}$

\subsubsection{De gevolgen van een strikte prijsregulering voor de werking van de verze-} keringsmarkt in Massachusetts

Met behulp van statistische gegevens is door een aantal onderzoekers getracht aan te tonen dat de verzekeringsregulering in Massachusetts tussen 1978 en 1990 vooral negatieve gevolgen heeft gehad voor de werking van de autoverzekeringsmarkt in deze staat. ${ }^{1422}$ In dat kader zal een viertal effecten worden opgesomd.

In de eerste plaats wordt door de onderzoekers geconstateerd dat gedurende de onderzochte periode de omvang van de 'residual' autoverzekeringsmarkt is toegenomen van $23 \%$ in 1977 naar $67 \%$ in 1989 , waarna in 1990 een daling volgde to $55 \%$. Dit heeft er volgens hen mede toe geleid dat deze 'residual' markt grote verliezen lijdt, die mede worden veroorzaakt doordat de opbrengst van de, relatief lage, premie ver achterblijf bij de uit te keren schadeclaims. Voor het jaar 1988 werd het verlies becijferd op 519 miljoen dollar ofwel 239 dollar per gesubsidieerd risico. De lekorten binnen de 'residual' markt worden, via een toeslag op de premie, gefinancierd door de autobestuurders in de vrije markt. ${ }^{1423}$

Fen tweede effect houdt verband met de resultaten van de gehele autoverzekeringsmarkt in Massachusetts. Tussen 1978 en 1989 bedroeg bet jaarlijks verlies ('underwriting loss') op de premie-inkomsten gemiddeld $11,5 \%$. Gedurende deze pe-

\footnotetext{
1419. Blackmon and Zeckhauser, Am. Econ. Rev., 1991, p. 69.

1420. In 1989 was $67 \%$ van alle autobestuurders via de 'residual markt verzekerd; in 1990 daalde dit percentage naar 55\%. Zie Derrig, GPRI, 1993, p. 168.

Cummins and Zeckhauser, Am. Econ. Rev., 1991, p. 69; Derrig, GPRI, 1993, p. 167-168;

1422. Blackmon and Tennyson, J. Ec. Persp., 1992, p. 113.

1423. Blackon and Zeckhauser, Am. Econ. Rev., 1991, p. 66-68; Derrig, GPRI, 1993, p. 161-169.

Blackmon and Zeckhauser, Am. Econ. Rev., 1991, p. 66; Derrig, GPRI, 1993, p. 168-169.
} 
riode steeg de jaarlijkse premieopbrengst van $\$ 700$ miljoen in 1978 naar $\$ 2,1 \mathrm{~m}]$. jard in 1989, terwijl de uitgaven op de autoverzekeringspolis toenamen van $\$ 720$ miljoen in 1978 naar \$ 2,5 miljard in 1989. In 1989 bedroeg het relatieve verlies op de autopolis $15,1 \%$. Uitschieters voor wat betreft het verlies op de autopolis vomden de jaren 1985-1987, waarin de premieopbrengst meer dan 20\% lager was dan de uitgaven op de polis. In de jaren 1987 en 1988 werden, op grond van een rechterlijke uitspraak, de premies met terugwerkende kracht $8 \%-9 \%$ verhoogd. Hierdoor steteg de totale premieopbrengst met $\$ 325$ miljoen, met als gevolg dat het polisverlies in 1987 daalde van $20,6 \%$ naar $11,6 \%$ en in 1988 van $16,8 \%$ naar $8,6 \%{ }^{1424}$

In de derde plaats vond een aantal verzekeraars dat de markt voor autoverzekeringen in Massachusetts overgereguleerd was. Dit had volgens hen mede een tekort aan premie-inkomsten en een sterke instroom op de 'residual' markt tot gevolg. In 1991 besloot derhalve een groot aantal verzekeraars (hun marktaandeel bedroeg 32\%), mede op basis van een negatieve winstverwachting, om de markt voor autoverzekring in Massachusetts te verlaten. De regulering van deze markt, in casu de invlood van de 'insurance commissioner', reikt echter dermate ver dat van een vije uittreding geen sprake kan zijn. De verzekeraars die in 1991 de markt verlieten moesten dararvoor hoge boetes betalen. Deze omvatten een contant bedrag plus het verbod om andere vormen van verzekering binnen de staat aan te bieden. ${ }^{1425}$

In de vierde plaats, ten slotte, heeft de strikte verzekeringsregulering in Massachusetts geleid tot een aantal herverdelingsmechanismen. Tussen de polishouders van een autoverzekering blijkt in de praktijk sprake te zijn van een omvangrijke orderlinge subsidiestroom. Deze zogenaamde 'trade-off' van subsidies loopt van autobestuurders in de landelijke gebieden naar bestuurders in de stedelijke gebieden, van vrouwen naar mannen, van ervaren bestuurders naar onervaren bestuurders en van bestuurders in de vrije markt naar bestuurders met een hoog ongevalsrisico in de tesidual' markt. ${ }^{1426}$

Dit kan met behulp van een cijfervoorbeeld ten aanzien van de marktsituatie in 1991 worden verduidelijkt. De volwassen ervaren autobestuurders vormden in dat jat binnen het classificatiesysteem van Massachusetts de grootste premieklasse, name lijk $74 \%$ van de totale markt. Deze autobestuurders betaalden echter $\$ 32$ meer dan op grond van hun claimdata als een faire premie kan worden beschouwd. De autobestuurders die tot de premieklasse met 0-3 jaar rijervaring (marktaandeel $1 \%$ ) be hoorden betaalden daarentegen ruim $\$ 637$ te weinig aan premie. Daarnaast blet dat de autobestuurders in de landelijke gebieden gemiddeld $\$ 70$ teveel premie, ter-

1424. Derrig, GPR], 1993, p. 161-162.

1425. Derrig, GPRI, 1993, p. 168-169; Blackman and Zeckhauser, Am. Econ. Rev., 1991, p.66.

1426. Derrig, GPRI, 1993, p. 165-167. 
will bestuurders in de steden gemiddeld meer dan $\$ 500$ te weinig premie betaal$\operatorname{den}^{1427}$

5.23.3. Verzekeringsregulering en de preventie van verkeersongevallen

In het voorgaande is een beeld geschetst van de regulering binnen de Amerikaanse markt voor autoverzekeringen. $\mathrm{Zij}$ levert echter geen oordeel op omtrent het verband tussen verzekeringsregulering en de preventie van verkeersongevallen. Daarvoor ontbreekt het noodzakelijke empirisch onderzoek. Verder kan de Amerikaanse verzekeringsmarkt moeilijk in een algemeen rechtseconomisch kader worden geplaatst, omdat daarvoor de omvang en de inhoud van de verzekeringsregulering teveel van staat tot staat verschilt. Aan de hand van de analyse van de autoverzekeringsmarkt in Massachusetts, zal daarom een aantal economische aspecten worden belicht die mede verband houden met hetgeen in de theorie over verzekeringsmarkten is opgemerkt. ${ }^{1428}$

Binnen de autoverzekeringsmarkt in Massachusetts wordt met behulp van een tarefsregulering de prijs van autoverzekering gecontroleerd. Dit heeft onder andere geleid tot een omvangrijke gesubsidieerde 'residual' markt, waarbinnen een gelijke premie wordt aangerekend voor verschillende risicogroepen. Deze factoren kunnen een negatief effect hebben op de preventie van verkeersongevallen.

In de eerste plaats kan worden geconstateerd dat verzekeraars in Massachusetts worden beperkt in hun vrijheid om een optimale ex ante risicodifferentiatie toe te passen. Zij dienen binnen de marges te blijven die door de 'insurance commissioner' jaarlijks worden vastgesteld. Daarnaast mogen verzekeraars geen gebruik maken van classificatievariabelen, zoals leeftijd en geslacht, waarvan echter empirisch is komen vast te staan dat zij van invloed kunnen zijn op het ongevalsrisico. Verzekeraars mogen binnen de toegestane marges niet verder differentiëren, maar zij kunnen een potentieel verzekerde wel weigeren. Dit kan leiden tot een verschuiving van de (hoge) ongevalsrisico's, waarvoor op de vrije markt geen verzekering beschikbaar is, naar de 'residual' markt, waar een gemiddelde premie wordt berekend. Binnen de vije markt blijven derhalve de goede risico's over, maar de premies van deze autobestuurder worden vervolgens 'belast' om de tekorten op de gesubsidieerde marktpool te dekken. Dit kan leiden tot een verminderde zorgvuldigheid bij de goede autobestuurders in de vrije markt, in het vooruitzicht dat de slechte autobestuurders in de 'residual' markt relatief gezien beter af zijn.

1427

1428. Derrig, GPRI, 1993, p. 167; Blackmon and Zeckhauser, Am. Econ. Rev., 1991, p. 65-66.

Zie paragraaf 5 van hoofdstuk 6 . 
In de tweede plaats geldt voor een individuele autobestuurder normalerwijze dat zip verzekeringspremie mede wordt bepaald aan de hand van zijn verwachte aansprake lijkheidsclaim bij de deelname aan een verzekerde activiteit (autorijden). Binnen de 'residual' markt in Massachusetts is de verzekeringspremie niet in overeenstemning met de verwachte ongevalskosten van de autobestuurder. Dit kan leiden tot een vom van anti-selectie. De autobestuurders die zich in de vrije markt bevinden en indiren de 'residual' markt subsidiëren maken mogelijk minder gebruik van hun autover zekering, hetzij door minder auto te rijden, hetzij door zich niet te verzekeren. De 'slechte' autobestuurders in de 'residual' markt zullen daarentegen hun activiteitsniveau opvoeren, waardoor het ongevalsrisico verder kan toenemen. ${ }^{1429}$

In de derde plaats hebben verzekeraars, gegeven de standaardisatie van de ex ante premiedifferentiatie en de omvang van de 'residual' markt, geen prikkel om de kos. ten van de autoverzekering te verminderen. De meerderheid van de schadeclaims wordt immers uit de gesubsidieerde marktpool vergoed. Een individuele verzekerarar zal hierdoor naar rato van zijn marktaandeel toch alle kosten dragen en geen inspan ningen verrichten om de kosten van een schadeclaim, bijvoorbeeld ingeval van frude, te controleren.

In de vierde plaats, ten slotte, kan worden gesteld dat de sterk gereguleerde verzekeringsmarkt van Massachusetts de concurrentie binnen deze markt sterk beperk. Dit is enerzijds het gevolg van de gestandaardiseerde polisvoorwaarden waardoor ver. zekeraars niet onderling kunnen concurreren op de prijs van een autoverzekering Anderzijds is binnen de autoverzekeringsmarkt in Massachusetts geen sprake ran een vrije uittreding. Een autoverzekeraar die de verzekeringsmarkt wenst te verlaten dient een hoge boete te betalen en krijgt tevens een verbod opgelegd om andert vormen van verzekering binnen de staat aan te bieden.

\subsection{DE REGULERING VAN DE MARKT VOOR AUTOVERZEKERINGEN IN ENGELAND EN DUITSLAND ${ }^{1430}$}

In deze paragraaf zal aandacht worden besteed aan de verzekeringsmarkten in the Europese landen, namelijk Duitsland en Engeland. Deze landen verschillen sterl voor wat betreft de omvang van de verzekeringsregulering versus de mate van con.

1429. Blackmon and Zeckhauser, Am. Econ. Rev., 1991, p. 66 en 69. Cummins and Tennyson, J. Ex Persp., 1992, p. 113.

1430. Hierbij dient te worden opgemerkt dat in Europa de regulering van de autoverzekeringmantik niet alleen wordt beĩnvloed door de landelijke overheden, maar ook door Europese wetgring Met name door Finsinger is op dit terrein veel onderzoek verricht. Zie onder anderen: Finsinger European Market Integration and the European Insurance Industry, Research Report, 1990, p. 33; Finsinger, European Integration of Insurance Markets, Working Paper, 1989, p. 1.14 Finsinger and Pauly (eds.), The Economics of Insurance Regulation, 1986. 
currentie binnen de verzekeringsmarkt, waardoor een goede vergelijking mogelijk is. In paragraaf 5.3.1 en 5.3.2 zal eerst een beschrijving worden gegeven van de verzekeringsmarkten in respectievelijk Engeland en Duitsland. Vervolgens zal aan de hand van empirisch onderzoek worden nagegaan welke rechtseconomische gevolgen de overheidsregulering versus de concurrentie heeft gehad voor de werking van de verzekeringsmarkt in deze landen (respectievelijk paragraaf 5.3.3 en 5.3.4). Dit empirisch onderzoek heeft betrekking op een vergelijking van de Duitse en Engelse verzekeringsmarkt gedurende de jaren ' 80 van de vorige eeuw. ${ }^{1431}$

\subsubsection{De Engelse markt voor autoverzekeringen}

De Engelse markt voor autoverzekeringen wordt gekenmerkt door een hoge mate van concurrentie en een relatief sterk 'gebrek' aan overheidsregulering. ${ }^{1432} \mathrm{De}$ invloed van de overheid op de autoverzekeringsmarkt is daarbij veelal beperkt tot regelgeving ten aanzien van de solvabiliteit van een verzekeraar. Deze wetgeving bevat onder andere garanties aan de polishouder, in het geval een verzekeraar ten gevolge van insolventie, niet meer aan zijn contractuele verplichtingen kan voldoen. ${ }^{1433}$ Naast deze overheidsregulering zijn binnen de Engelse verzekeringsmarkt ook organen met een zelfregulerende functie actief. ${ }^{1434}$

In het kader van de autoverzekeringen is de 'Road Traffic Act' van belang. ${ }^{1435}$ Hierin is onder andere geregeld dat autobestuurders verplicht zijn om een aanspra-

1431. Sindsdien is er, mede onder invloed van Europese regelgeving, het nodige gewijzigd. Zie daarover onder anderen: Cousy en Claassens, GPRI, 1994, p. 46-59; Cousy en Claassens, Het Europa van de verzekeringen, p. 17-43 en p. 261-276; Merkin and Rodger, EC Insurance Law, p. 1-17 en p. 45-73; Ottervanger, in Verzekering en Europa, p. 73-86.

1432. Zie voor een globaal (historisch) overzicht van de Engelse (auto)verzekeringsmarkt: Tapp, in The Economics of Insurance Regulation, p. 27-38; Finsinger, Hammond, Tapp, Insurance: Competition or Regulation?, p. 21-26; McGee, in The Law and Practice of Insurance in the Single European Market, p. 79-87.

1433. Dit is geregeld in de 'Insurance Companies Act uit 1982 en de 'Insurance Companies Regulations' uit 1981. Daarnaast kan worden gewezen op de 'Policy Protection Act' uit 1975, die naar asnleiding van een aantal faillissementen van (met name auto-) verzekeringsmaatschappijen werd ingevoerd en een verdere aanscherping van de solvabiliteitsregulering een verhoogde bescherming van de polishouders bevat. Zie daarover Tapp, in The Economics of Insurance, p. 35 40; Finsinger, Hammond, Tapp, Insurance: Competition or Regulation?, p. 26-27; Ivamy, General Principles of Insurance Law, p. 30-87.

1434. In dit verband kunnen worden genoemd de 'Insurance Ombudsman's Bureau', een klachtenorgaan ingeval van conflicten tussen een polishouder en zijn verzekeraar; de 'British Insurance Broker's Association' die een centrale rol vervult bij de zelfregulering van verzekeringstussenpersonen en 'Lloyd's of London'. Zie daarover Ivamy, General Principles of Insurance Law, p. 412 en p. 557. 581; Finsinger, Hammond and Tapp, Insurance: Competition or Regulation?, p. 30-49; Tapp, in

1435. Dit betreft de 'Road Traffic Act' 1988, die onder invloed van de tweede EG-richtlijn voor autoverzekering (Directive 84/5, O.J. L8/17), de 'Road Traffic Act' 1972 verving. In 1990 volgde nog 
kelijkheidsverzekering af te sluiten voor schade die zij aan derden kunnen toebrengen. Deze verplichte aansprakelijkheidsdekking geldt voor de volledige schade, 20wel zaakschade ('property damage') als letsel- en overlijdensschade ('death and bodily injury'), die door derden wordt geleden. ${ }^{1436}$ Het slachtoffer van een verkeersongeval heeft een rechtstreekse vordering op de aansprakelijkheidsverzekeraar van hel betrokken voertuig. De aansprakelijkheidsverzekeraar heeft verder, ten aanzien van de uitgekeerde schade een vorderingsrecht op de polishouder, wanneer deze de cortractuele voorwaarden van de verzekeringspolis heeft geschonden. ${ }^{1437}$

De verplichte aansprakelijkheidsverzekering heeft tot doel de bescherming van verkeersslachtoffers door aan hen een direct recht op schadevergoeding toe te kennen. Hierop gelden twee uitzonderingen. In de eerste plaats kan blijken dat de schadever. oorzaker niet verzekerd is en over onvoldoende vermogen beschikt om de schade te vergoeden. In de tweede plaats kan sprake zijn van een zogenaamd 'hit and ru' orgeval, met het gevolg dat de schadeveroorzaker niet meer kan worden achterhald. In deze gevallen komt de vergoeding van de schade van het slachtoffer voor rekening van het 'Motor Insurance Bureau', dat in 1946 werd opgericht. ${ }^{1438}$ Alle autoverzekeraars zijn bij het 'Motor Insurance Bureau' aangesloten, waarvan het lidmastschap een voorwaarde is om autoverzekeringspolissen te kunnen verkopen. ${ }^{1439}$

Engelse autoverzekeraars zijn voor wat betreft de vaststelling van de premie gehel vrij. ${ }^{1440}$ In de praktijk wordt door de autoverzekeraar gebruik gemaakt van een groot aantal ex ante risicovariabelen. Verder beschikt een meerderheid van de autobe stuurders over een zogenaamde 'comprehensive' verzekeringsdekking. Naast de verplichte aansprakelijkheidsdekking voor schade aan derden, omvat deze polis velal een eerste partijdekking tegen diefstal of brand, een eerste partij cascodekking en een eerste partij verzekeringsdekking waarbij ingeval van dood of letsel een verze.

een derde EG-richtlijn (Directive 90/232). Zie daarover Merkin and Rodger, EC Insurance Las, p. 53-56. Zie voor een analyse van deze wetgeving onder anderen: Colinvaux, The Law of has rance, p. 421-433; Birds, Modem Insurance Law, p. 293-306.

1436. 'Road Traffic Act' 1998, section 145. Zie Birds, Modem Insurance Law, p. 319; Merkin and Rodger, EC Insurance Law, p. 58-59.

1437. Road Traffic Act 1988, s.148 (1) en s.148 (7). Zie daarover Birds, Modern Insurance Law, 305-310; Colinvaux, The Law of Insurance, p. 430-433; Tapp, in The Economics of Insurnace Regulation, p. 44; Merkin and Rodger, EC Insurance Law, p. 65-66.

1438. Deze instelling kan worden vergeleken met het Waarborgfonds Motorverkeer in Nederland artikel 23-27 van de Nederlandse Wet Aansprakelijkheidsverzekering Motorrijtuigen (WAM).

1439. Colinvaux, The Law of Insurance, p. 433-447; Birds, Modem Insurance Law, p. 311-318 Merkin and Rodger, EC Insurance Law, p. 68-71; Finsinger, Hammond and Tapp, lnsurnax Competition or Regulation?, p. 24.

1440. Dit geldt in het bijzonder ten aanzien van de invulling van de BMS-structur. Zie Lemaine,, $\mathbb{R}$. 1988, p. 679. 
kerde som wordt uitgekeerd. ${ }^{1441}$ Ten aanzien van de 'comprehensive' verzekeringspolissen wordt, mede als gevolg van de concurrentie binnen de verzekeringsmarkt, een veelheid aan dekkingsmogelijkheden geboden. Sommige verzekeraars geven bijvoorbeeld een autobestuurder de mogelijkheid om, met behoud van zijn no-claim bonus, een gebroken ruit te laten vervangen. $\mathrm{Bij}$ andere polissen kan een autobestuurder de kosten van autoverhuur claimen, terwijl zijn eigen auto wordt gerepareerd. ${ }^{1442}$

Samenvattend kan worden gesteld dat de regulering van de Engelse markt voor autoverzekeringen is beperkt tot een controle van de economische prestaties van de verzekeraar. Het belangrijkste argument voor een dergelijke controle is de bescherming van de polishouders tegen de risico's dat een autoverzekeraar, als gevolg van financiële problemen niet meer aan zijn contractuele verplichtingen kan voldoen. Voor een autoverzekeraar gelden verder geen beperkingen met betrekking tot de prijzen van de autopolis of de toepassing van risicodifferentiatie. ${ }^{1443}$

De concentratiegraad op de Engelse autoverzekeringsmarkt is laag, waarbij een 13tal ongeveer gelijke verzekeraars met elkaar concurreren. In 1979 was het marktaandeel van de grootste verzekeraar $13 \%$, de 3 grootste verzekeraars hadden samen een marktaandeel van $28 \%$, de 5 grootste $41 \%$ en de 10 grootste verzekeraars controleerden $59 \%$ van de verzekeringsmarkt. ${ }^{1444}$

\subsection{De regulering van de autoverzekeringsmarkt in Duitsland}

De Duitse verzekeringsmarkt wordt gekenmerkt door een hoge mate van regulering, zowel wat betreft de binnen de markt opererende verzekeraars als met betrekking tot de verzekeringsvoorwaarden. Hierbij is het in 1901 ingevoerde 'Versicherungsaufsichtsgesetz' (VAG) van belang. Op grond van deze wetgeving moeten verzekeraars, alvorens een vergunning kan worden verkregen voor de uitoefening van het verzekeingsbedrijf, aan bepaalde voorwaarden voldoen. Deze vereisten, die betrekking hebben op de omvang van het minimumkapitaal, de omvang van de voorgestelde premies en op een prognose van de administratieve en commerciële kosten en de vereiste herverzekering, dienen door de verzekeraar in een businessplan ('Geschäfts-

144!. Tapp, in The Economics of Insurance Regulation, p. 48-51; Finsinger, Hammond and Tapp, Insurance: Competition or Regulation?, p. 73-77; Birds, Modem Insurance Law, p. 292-293. In paragraaf 5.3.3.2.1 zal worden ingegaan op de controle van het morele risico binnen de Britse autoverzekering.

1442. Birds, Modem Insurance Law, p. 293.

1443. Tapp, in The Economics of Insurance Regulation, p. 38-41.

1444. Dit is exclusief het marktaandeel van Lloyd's dat op $15 \%$ werd becijferd. Zie Tapp, in The Economics of Insurance Regulation, p. 58-59; Finsinger, Hammond and Tapp, Insurance: Competition or Regulation?, p. 26-29. 
plan') $)^{1445}$ te worden opgenomen. Dit plan moet worden voorgelegd aan 'Das Bunde. saufsichtsamt für das Versicherungswesen', ${ }^{1446}$ het wetgevend en controlerend or-
gaan in het kader van de VAG.

Ten aanzien van de regulering van de autoverzekering in Duitsland is een aantal controle-instrumenten van toepassing, namelijk solvabiliteitsregulering, prijs- en winstcontrole en de regulering van de verzekeringsvoorwaarden. ${ }^{148}$ In het kader van de solvabiliteitsregulering dienen de autoverzekeraars te beschikken over voldoende bezittingen en reserves om aan hun eventuele aansprakelijkheidsverplichtingen te kunnen voldoen. ${ }^{1449}$

Met betrekking tot de regulering van de verzekeringsvoorwaarden geldt dat de contracten voor autoverzekeringen verregaand zijn gestandaardiseerd. ${ }^{1450}$ Alle autoverzekeraars bieden een uniforme autopolis aan en zijn verplicht om de aangesloten isico's naar objectieve criteria te differentiëren. Naast de verplichte aansprakelijkheidsverzekering voor motorrijtuigen kunnen autobestuurders kiezen voor een eerste partij cascoverzekering ('Vollkasko' of 'Teilkasko') en een eerste partij schadeverze. kering. ${ }^{1451}$ Alle autoverzekeraars dienen bij de aansprakelijkheidsdekking en de cascodekking eenzelfde schema van ex ante risicodifferentiatie en ex post premieaar. passing toe te passen. ${ }^{1452}$

1445. Paragraaf 5 VAG in Prölss, Versicherunsaufsichtsgesetz, p. 149-155.

1446. 'Gesetz über die Errichtung eines Bundesaufsichtsamtes für das Versicherungswesen (BAG) von 31. Juli 1951 (Bundesgesetzblad I S. 480) in Prölss, Versicherungsaufsichtgesetz, p. 47.56.

1447. Paragraaf 81-81b VAG. Zie Finsinger, Versicherungsmärkte, p. 25-31 en ten aanzien van ḋ autoverzekeringsmarkt in het bijzonder, p. 61-64; Finsinger, in The Economics of Insurant Regulation, p. 111-113; Finsinger, Hammond and Tapp, Insurance: Competition or Regulation?, p. 50-56; Kaltenegger und Speyer, in The Law and Practice of Insurance in the Single Europer Market, p. 105-122.

1448. De regulering van de autoverzekering, uitgezonderd de solvabiliteitsregulering, is vastgelegd in het 'Pflichtversicherungsgesetz für Kraftahrzeughalter' (PfIVersG.) vom 5.4.1965 (BGBl.18. 213), ten aanzien van de verplichte aansprakelijkheidsverzekering voor motorrijuigen. Zie Finsinger, Versicherungsmärkte, p. 64-67.

1449. Paragraaf 53c VAG. Prölss, Versicherungsaufsichtsgesetz, p. 544-549; Finsinger, in The Evor nomics of Insurance Regulation, p. 114; Finsinger, Hammond and Tapp, Insurance: Competition or Regulation?, p. 55; Finsinger, Versicherungsmärkte, p. 34-37.

1450. Dit wordt geregeld in paragraaf 8-10 van de PflVersG.: 'Verordnung über die Tarife in der Kail' fahrtversicherung' (TVO) vom 20.11.1967 en 'Die Allegemeinen Bedingungen fur dir Kraftfahrtversicherung' (AKB) vom 18.12.1970. Zie Bäumer, Hat das deutsche Kraffahrzull: Haftpflichtversicherungs-System eine Zukunft?, p. 35-36; Prölss, Versicherungsaufsichtsgesth p. 256-281; Stiefel und Hofmann, Kraftfahrtversicherung, p. 1-26.

1451. Paragraaf 9 Abs. 3 PflVersG. Zie Bäumer, Hat das deutsche Kraftfahrzeug-Haftplicth versicherungs-System eine Zukunft?, p. 39.

1452. Paragraaf 6-8 TVO. Prolls, Versicherungsaufsichtsgesetz, p. 261-262; Finsinger, Versitito rungsmârkte, p. 64-65; Finsinger, in The Economics of Insurance Regulation, p. $114-116$; 
In het kader van de prijsregulering dienen verzekeraars de omvang van de premie voor autoverzekering te berekenen an de hand van strikt geformuleerde richtlijnen. ${ }^{1453}$ Deze hebben betrekking op de som van de risicopremie, een vast bedrag aan administratiekosten, een veiligheidsmarge, plus $3 \%$ van de totale omzet van de premieopbrengsten. Verzekeraars mogen niet afwijken van de toegestane tarieven en zij dienen zich ook te houden aan het vaststaande schema van ex ante risicodifferentiatie. ${ }^{154}$ Ten slotte mogen verzekeraars een potentieel verzekerde niet weigeren, ook niet indien deze een hoog ongevalsrisico vormt. ${ }^{1455}$

Met betrekking tot de autoverzekering is ook een regeling getroffen voor de omvang van de verwachte winst. ${ }^{1456}$ In dat verband wordt door het wetgevend orgaan jaarlijks het technisch overschot berekend. Dit overschot bestaat uit het verschil tussen enerzijds de totale premieopbrengsten en anderzijds de som van de verliezen (schade-uitkeringen), de administratieve kosten en de commissies aan tussenpersonen. Wanneer het overschot meer dan 3\% van de totale premieopbrengsten bedraagt moet dit, in de vorm van kortingen of dividenduitkeringen, met de polishouders worden gedeeld. $^{1457}$

Op basis van het aantal marktparticipanten is binnen de Duitse verzekeringsmarkt sprake van een lage concentratiegraad van verzekeraars. In 1980 had de grootste verzekeraar een marktaandeel van $12,1 \%$, de 4 grootste verzekeraars $26,6 \%$, terwijl de 8 grootste verzekeraars samen $39,5 \%$ van de markt controleerden. Deze cijfers geven echter onvoldoende antwoord op de vraag of binnen de Duitse autoverzekeningsmarkt sprake is van concurrentie. Volgens Finsinger is in de praktijk eerder sprake van een situatie, waarbij de gereguleerde verzekeraars rechtstreeks met de wetgever onderhandelen. Alle belangrijke beslissingen aangaande de gestandaardiseerde verzekeringscontracten en de premiestructuren worden daarbij door de verzekeraars en de wetgever gezamenlijk genomen. ${ }^{1458}$

Finsinger Hammond and Tapp, Insurance: Competition or Regulation?, p. 52-53. In paragraaf 5.3.3.2.2 zal worden ingegaan op de controle van het morele risico binnen de autoverzekering in Duitsland.

1453. Paragraaf 9-15 TVO. Prölss, Versicherungsaufsichtsgesetz, p. 262-265.

1454. Finsinger, in The Economics of Insurance Regulation, p. 116-117; Finsinger, Hammond and Tapp, Insurance; Competition or Regulation?, p. 53-54; Finsinger, Versicherungsmarkte, p. 6566.

1455. Becker und Böhme, Kraftverkehrs-Haftpflicht-Schăden, p. 502-504; Bäumer, Hat das deutsche Kraffahrzeug-Haftpflichtversicherungs-System eine zukunft?, p. 49-50.

Paragraaf 22-27 der TVO. Prölss, Versicherungsaufsichtsgesetz, p. 269-273.

Finsinger, in The Economics of Insurance Regulation, p. 117; Finsinger, Hammond and Tapp,

Finsinger, Hamptition or Regulation?, p. 54-55; Finsinger, Versicherungsmärkte, p. 66-67. 


\subsubsection{Het empirisch onderzoek van Finsinger en Adams}

Uit het voorgaande kan worden opgemaakt dat het belangrijkste doel van de verzekeringsregulering in Engeland en Duitsland is polishouders te beschermen tegen de gevolgen van een eventuele insolvabiliteit van zijn verzekeraar. Met betrekking tor de verzekeringsvoorwaarden bestaan echter belangrijke verschillen tussen beide landen. Terwijl in Engeland de autoverzekeraars geheel vrij zijn om de omvang van de premie vast te stellen, zijn de autoverzekeraars in Duitsland gebonden aan stikit geformuleerde richtlijnen daaromtrent.

In deze paragraaf zal in het kader van de analyse van de verzekeringsmark in Engeland en Duitsland empirisch onderzoek worden gepresenteerd. Daarbij zal allereerst een studie aan de orde komen, waarin wordt getracht een verband aan te tonen tussen het aantal verkeersongevallen in beide landen en de omvang van de verzekeringsregulering (paragraaf 5.3.3.1). ${ }^{1459}$ In paragraaf 5.3.3.2 zal aandach worden besteed aan een onderzoek naar de mate van productdifferentiatie binnen de autoverzekeringsmarkt in Duitsland en Engeland. ${ }^{1460}$ In paragraaf 5.3.4 zullen de resultaten van beide studies worden becommentarieerd.

\subsubsection{Ongevalsstatistieken in Duitsland en Engeland}

In het onderzoek van Adams wordt, in het kader van een vergelijking van de verzkeringsmarkten in Duitsland en Engeland, gebruik gemaakt van een aantal ongevals. statistieken. ${ }^{1461}$ Deze hebben globaal betrekking op de periode 1970-1979 en zjpin in tabel 3 weergegeven. Ten behoeve van de actualiteit en de overzichtelijkheid zjjin in deze tabel eveneens de cijfers voor 1992 opgenomen. ${ }^{1462}$

1459. Adams, Gefâhrdungs- und Verschuldenshaftung, p. 246-254; Finsinger, Hammond and Tapp, th. surance: Competition or Regulation?, p. 108-110.

1460. Finsinger, Hammond and Tapp, Insurance: Competition or Regulation?, p. 73-82, p. 104.123 E. p. 140-166; Finsinger, Versicherungsmarkte, p. 81-121; Finsinger, in The Economics of has ance Regulation, p. 118-138.

1461. Adams, Gefahrdungs- und Verschuldenshaftung, p. 246-247.

1462. De cijfers voor 1992 zijn ontleend aan Statistics of Road Traffic Accidents in Europe and North America, 1995, p. 11-12 en p. 98-105. Hierbij geldt ten aanzien van Duitsland dat de cijers 1992 betrekking hebben op Oost- en West-Duitsland gezamenlijk, dit in verband met de Duils eenwording van 1990. Ten opzichte van 1990 is in verhouding tot de drie variabelen uit de the sprake van een relatief lichte stijging van het aantal verkeersdoden. 
Tabel 3

\begin{tabular}{|c|c|c|c|c|c|c|c|c|c|}
\hline Land & \multicolumn{3}{|c|}{$\begin{array}{l}\text { Aantal verkeersdo- } \\
\text { den per } 100.000 \text { in- } \\
\text { woners }\end{array}$} & \multicolumn{3}{|c|}{$\begin{array}{l}\text { Aantal verkeersdoden } \\
\text { per } 100 \text { miljoen auto- } \\
\text { kilometers }\end{array}$} & \multicolumn{3}{|c|}{$\begin{array}{l}\text { Aantal verkeersdoder } \\
\text { per } 10.000 \text { motor- } \\
\text { voertuigen }\end{array}$} \\
\hline 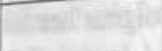 & $y$ & 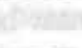 & & & & & & & \\
\hline & 1970 & 1979 & 1992 & 1970 & 1979 & 1992 & 1970 & 1979 & 1992 \\
\hline Duitsland & 31,8 & 21,6 & 13,1 & 8,3 & 4,1 & 2,0 & 11,5 & 4,7 & 2,9 \\
\hline $\begin{array}{l}\text { daling in } \% \\
\text { to.v. vorig jaar }\end{array}$ & & 32 & 39,4 & & 50,6 & 46,3 & & 59,1 & 38,3 \\
\hline Engeland & 13,9 & 11,7 & 7,7 & 3,7 & 2,4 & 1,1 & 5,0 & 3,4 & 1,7 \\
\hline $\begin{array}{l}\text { daling in } \% \\
\text { to.v. vorig jaar }\end{array}$ & & 15,8 & 34,2 & & 35,1 & 54,2 & & 32 & 50 \\
\hline
\end{tabular}

Aan de hand van tabel 3 kan worden berekend dat tussen 1970 en 1992 het aantal verkeersdoden per 100.000 inwoners in Duitsland en Engeland met respectievelijk $58,9 \%$ en $44,6 \%$ is gedaald. Het aantal verkeersdoden per 100 miljoen autokilometers (vrachtwagens, bussen en personenauto's) daalde in Duitsland tussen 1970 en 1992 met $75,9 \%$ en in Engeland met 70,3\%. Het aantal verkeersdoden per 10.000 motorvoertuigen, ten slotte, vertoonde tussen 1970 en 1992 in Duitsland en Engeland een daling van respectievelijk $74,8 \%$ en $66 \%$.

Deze cijfers tonen aan dat het aantal dodelijke verkeersongevallen, gemeten naar inwoners, autokilometers en aantal motorvoertuigen, in zowel Duitsland als Engeland tussen 1970 en 1992 relatief gezien sterk is gedaald. Toch blijkt uit de absolute cijfers dat de kans om bij een verkeersongeval (dodelijk) letsel op te lopen in Duitsland nog altijd groter is dan Engeland. Door Finsinger e.a. wordt in het kader van hun onderzoek verwezen naar ongevallencijfers uit 1982 . Hieruit blijkt dat het aantal verkeersongevallen met letsel in Duitsland 358.700 en voor Engeland 256.000 bedroeg. Per 1000 inwoners was dit aantal respectievelijk 5,84 en $4,57 .{ }^{1463}$ Het totaal aantal verkeersdoden bedroeg in 1982 in Duitsland (11.600) bijna 100\% meer ten oprichte van Engeland (5.900). ${ }^{1464}$

\footnotetext{
1463. Finsinger, Hammond and Tapp, Insurance: Competition or Regulation?, p. 109 395.462 (verkeersongevallen met letsel), 4,9 (per 1000 inwoners) en 10.631 (verkeersdoden) en voor Engeland respectievelijk 239.675, 4,2 en 4.379. Zie Statistics of Road Traffic Accidents in Europe and North America, 1995, p. 8-9, 11-12 en 106-108.
} 
Over de oorzaken van deze verschillen in ongevallencijfers bestaat echter geen over. eenstemming. De ongevalsratio, in de tijd bekeken, is in Duitsland weliswaar hoger dan in Engeland, maar dit wil niet zeggen dat er in Duitsland bijvoorbeeld ook tweemaal zoveel op een autoverzekeringspolis wordt geclaimd dan in Engeland Finsinger e.a. suggereren dat de verschillen deels kunnen worden verklaard uit de afwezigheid van een maximumsnelheid in Duitsland, maar het ligt volgens hen 2 . ker niet aan het onveranderlijk beleefde karakter van de Engelsen ${ }^{1465}$ Adams en Finsinger verwijzen naar onderzoek, waarin een vergelijking wordt gemaakt tussen een aantal factoren die de verkeersveiligheid kunnen beünvloeden. Deze factoren hadden betrekking op de veiligheid van de wegen, de veiligheid van de auto's en anderc maatregelen ter bevordering van de verkeersveiligheid. Uit deze vergelijkende studie kwam naar voren dat geen van de genoemde factoren een verklaring kon geven voor de verschillen in ongevalsstatistieken tussen Duitsland en Engeland. ${ }^{1466}$

Adams stelt dat sommige verschillen tussen de ongevallencijfers in Duitsland en Engeland mogelijk kunnen worden verklaard uit de werking van de verzekeringsmarkten in beide landen. De Engelse verzekeringsmarkt wordt gekenmerkt door een hoge mate van concurrentie, waarbij ten gevolge van een verfijnd systeem van risicoclassificatie, de premie zoveel mogelijk is afgestemd op het individuele ongevalrisico. De Duitse verzekeringsmarkt wordt door overheidsregulering beïnvloed, wart ten aanzien van de risicodifferentiatie bij de autoverzekering een vast omlijnd systeem wordt gehanteerd, zodat weinig ruimte overblijft voor een verdere differentiatie. Adams geeft echter aan dat de sterk gereguleerde verzekeringsmarkt in Duitsland slechts een van de mogelijke oorzaken is voor het hoge aantal verkeersslachtof. fers. Naar zijn inzicht is een meer omvattend rechtseconometrisch onderzoek nood. zakelijk om de werkelijke effecten van verzekeringsregulering op het aantal verkeersslachtoffers te kunnen toetsen. ${ }^{1467}$

\subsubsection{Productdifferentiatie binnen de markt voor autoverzekering in Engeland en Duitsland}

In het onderzoek van Finsinger e.a. worden een aantal toetsingsvariabelen gebrulkt om de mate van efficiëntie van de verzekeringsmarkt in Duitsland en Engeland to bepalen. In het kader van de economische analyse van verzekeringsmarkten is ectiter vooral de vraag van belang of concurrentie dan wel regulering tot een betere pre-

1465. Finsinger, Hammond and Tapp, Insurance: Competition or Regulation?, p. 108-109.

G. Grosse-Berndt, G. Weissbrodt und G. Zimmerman, Vier-Länder Vergleich von Kengrosse der Strassenverkehrssicherheit, Japan, Grossbritannien, Niederlande, Bundesrepublik Deutsch land, Köln, Bundesanstalt für Strassenwesen, 1981, p. 55-62 in Adams, Gefährdungs- und Vo Hammond and Tapp, Insurance: Competition of Regulation?, p. 109.

1467. Adams, Gefährdungs- und Verschuldenshaftung, p. 248-254. 
ventie van verkeersongevallen kan leiden. In het onderzoek van Finsinger e.a. wordt darop geen direct antwoord gegeven.

Eén aspect uit het onderzoek van Finsinger dat voor de economische analyse van verzekeringsmarkten van belang kan zijn heeft betrekking op de mate van productdifferentiatie binnen de autoverzekering in Engeland en Duitsland. Tussen Engeland en Duitsland bestaan voor wat betreft de toepassing van risicodifferentiatie binnen de autoverzekering belangrijke verschillen, die verband houden met de invloed van regulering op de materiële invulling van de autoverzekering. Deze verschillen zullen hier worden uitgewerkt.

\subsubsection{Risicodifferentiatie in Engeland}

In Engeland wordt ten behoeve van het differentiëren naar risico's door de meeste autoverzekeraars gebruik gemaakt van een viertal centrale classificatievariabelen, namelijk dekkingsniveau, persoonlijke eigenschappen van de autobestuurder (WA), de eigenschappen van het verzekerde voertuig (casco) en de plaats waar het voertuig staat geregistreerd. ${ }^{1468}$ Alleen bij de cascodekking kan een eigen risico worden overeengekomen. ${ }^{1469}$

Met betrekking tot de persoonlijke eigenschappen van de autobestuurders wordt binnen de aansprakelijkheidsdekking door de meeste verzekeraars gedifferentieerd naar leeftijd, schadeverleden en beroep van de polishouder. Het geslacht wordt veelal niet als een differentiatievariabele gebruikt. Bij de differentiatie naar leeftijd gelden 9 categorieën, waarbij met name jonge autobestuurders, globaal tot 30 jaar, als een hoog ongevalsrisico worden ingeschaald. Aan hen wordt in sommige gevallen een verplicht eigen risico opgelegd. ${ }^{1470} \mathrm{Bij}$ de berekening van het schadeverleden (ook bij casco) wordt het aantal jaren sinds de laatste schadeclaim, 'no-claim discount', als uitgangspunt genomen. Voor de ex post bepaling van dit schadeverleden wordt gebruik gemaakt van een BMS-regime. ${ }^{1471}$ Naast het schadeverleden wordt door de autoverzekeraars eveneens rekening gehouden met verkeersovertredingen van de polishouder. Daarbij wordt, afhankelijk van het aantal strafpunten, een premietoeslag opgelegd. Met betrekking tot het beroep van de autobestuurder geldt dat

\footnotetext{
1468. Finsinger, Hammond and Tapp, Insurance: Competition or Regulation?, p. 73.

1469. Tapp, in The Economics of Insurance Regulation, p. 48-49; Finsinger, Hammond and Tapp, Insurance: Competition or Regulation?, 74-75.

1470. Daamaast geldt dat het voor autobestuurder van beneden de 25 jaar onmogelijk is om een verzekering af te sluiten voor bijvoorbeeld een sportwagen. Dit wordt als een dermate hoog ongevalsrisico beschouwd dat hiervoor een exceptionele premie gevraagd moet worden. Weigering van cen dergelijke verzekeringspolis leidt volgens Adams tot een kostenbesparing en heef een dui-

1471. Deze omvat gemiddeld 7 premieklassen oplopend van $35 \%$ in klas 1 naar $100 \%$ in klas 7 , met als toegangsklasse 6 ( $80 \%$ premie). Zie Lemaire, JRI, 1988, p. 679-681.
} 
bijvoorbeeld een sporter of een kunstenaar als een hoger ongevalsrisico worden in geschaald dan een ambtenaar. ${ }^{1472}$

Wat betreft de eigenschappen van het verzekerde voertuig worden, voomamelijkin het kader van de cascodekking, 9 categorieën onderscheiden. Op basis van de koster van reparatie, de nieuwwaarde en de prestaties van de auto, wordt het voertuig ge rangschikt en ingedeeld in één van deze 9 categorieën. Bij de leeftijd van het te ver. zekeren voertuig geldt dat de waarde van de auto daalt naarmate de leeftijd toe neemt. Bij deze vorm van risicodifferentiatie wordt derhalve niet naar de veilighei van de auto gekeken. ${ }^{1473}$

Een laatste vorm van risicodifferentiatie, die zowel binnen de WA-dekking als de cascodekking van belang is, hangt samen met de regio of plaats waarbinnen he voertuig staat geregistreerd. Hierbij worden 7 zogenaamde risicoregio's onderscheiden. Deze lopen uiteen van Centraal-London, een regio met een veronderstel hoog ongevalsrisico, tot de dunbevolkte landelijke gebieden, waarbinnen het onge valsrisico lager is. ${ }^{1474}$

Finsinger e.a. concluderen dat de hoge mate van risicodifferentiatie die Engelse autoverzekeraars hanteren verband houdt met de sterke concurrentie op de verzeks ringsmarkt. Volgens hen zal een verzekeraar die binnen een concurrerende mart onvoldoende differentieert op termijn alleen de slechte risico's overhouden. Finsi ger e.a. gaan uit van de veronderstelling dat de kosten laag zijn, zodat een optimal niveau van risicodifferentiatie kan worden bereikt. Daarmee wordt een proces va anti-selectie vermeden. ${ }^{1475}$

\subsection{Regulering van de verzekeringsvoorwaarden in Duitsland}

In Duitsland wordt de premie binnen de autoverzekeringspolissen, die verregand zijn gestandaardiseerd, ${ }^{1476}$ gedifferentieerd naar objectieve matstaven die betrelk king hebben op auto en bestuurder. Bij de verplichte aansprakelijkheidsverzekerin

1472. Tapp, in The Economics of Insurance Regulation, p. 50; Finsinger, Hammond and Pawly, has ance: Competition or Regulation?, p. 75-76; Adams. Gefährdungs- und Verschuldenshafung? 251-252.

1473. Tapp, in The Economics of Insurance Regulation, p. 50; Finsinger, Hammond and Tapp, has ance: Competition or Regulation?, p. 77.

1474. Tapp, in The Economics of Insurance Regulation, p. 50-51; Finsinger, Hammond and Tapp, surance: Competition or Regulation?, p. 77. 'Verordnung über die Tarife der Kraftfahrtversicherung (TVO). Zie
Versicherungsmárkte, p. 65; Bäumer, Hat das deutsche Kraftahrzeug-Haftplichtversicheruy System eine zukunft?, p. 49. 
voor motorrijtuigen ${ }^{1477}$ wordt in dat kader gebruik gemaakt van vier variabelen, namelijk het dekkingsniveau, het vermogen van de automotor, de woonplaats en het beroep van de eigenaar van het voertuig en, in het kader van een ex post controle, het schadeverleden van de polishouder. ${ }^{1478}$

Bij het dekkingsniveau kan door een autobestuurder worden gekozen tussen 1 miljoen DM, 2 miljoen DM en een onbeperkte dekking. ${ }^{1479}$ Met betrekking tot het vermogen van de motor wordt onderscheid gemaakt naar 11 categorieën, waarbij geldt dat hoe krachtiger de motor hoe hoger de premie. Voor de bepaling van de woonplaats van de autobestuurder wordt gebruik gemaakt van 6 zogenaamde regionale risicoklassen, waarbij regionale verschillen in ongevalsfrequentie tot uitdrukking komen in de premie. Bij een autobestuurder die in een dunbevolkte regio woonachtig is wordt bijvoorbeeld een laag ongevalsrisico verondersteld, waardoor deze bestuurder een overeenkomstig lagere premie betaalt. Ten aanzien van het beroep van de autobestuurder gelden in beginsel drie categorieën, namelijk ambtenaren, agrariërs en alle andere beroepen. ${ }^{1480}$ Ten slotte is, in het kader van een (ex post) controle van het schadeverleden van de polishouder, een BMS-regime van toepassing. ${ }^{1481}$

Finsinger e.a. stellen dat de Duitse autoverzekering een homogeen product is, waarbinnen weinig risicodifferentiatie mogelijk is. Deze standaardisatie van verzekeringscontracten zal volgens hen leiden tot een vermindering van de prikkels van zorg bij de verzekerde. In de eerste plaats kan een potentieel verzekerde slechts kiezen uit drie dekkingsniveaus. Daarnaast is geen eigen risico of een vorm van medeverzekering mogelijk. Deze laatste twee instrumenten zijn volgens Finsinger e.a. echter bij

1477. Bij een eerste partij cascoverzekering worden de premietarieven bepaald aan de hand van paragraaf 12 van de 'Allgemeine Bedingungen für die Kraftfahrtversicherung'. Daarbij gelden 31 type auto's, twee dekkingsniveau's, vier vormen van eigen risico en 11 no-claim kortingsklassen variêtend van $40 \%$ tot $125 \%$. Zie Stiefel und Hofmann, Kraftfahrtversicherung, p. 12-16 en p. 584-596; Finsinger Hammond and Tapp, Insurance: Competition or Regulation?, p. 79.

1478. Finsinger, in The Economics of Insurance Regulation, p. 114-116; Finsinger Hammond and Tapp, Insurance: Competiton or Regulation?, p. 77-79. Finsinger, Versichenungsmărkte, p. 65.

1479. Paragraaf 8,2 TVO. Deze 'onbeperkte' dekking bedraagt 7,5 miljoen DM en wordt door het merendeel van de Duitse autobestuurders gekozen. Zie Schlesinger and Graf Von Der Schulenburg, JRI, 1993, p. 599; Prölss, Versicherungsaufsichtsgesetz, p. 261-262; Bâumer, Hat das deutsche kraffahrzeug-Haftpflichtversicherung-System eine zukunf?, p. 43-45.

1480. Voor taxichauffeurs, rijschoolhouders, buschauffeurs, eigenaren van leaseauto's en vrachtwagen chauffeurs gelden echter weer speciale tarieven. Zie Finsinger, Hammond and Tapp, Insurance: Competition or Regulation?, p. 92, noot 2; Finsinger, in The Economics of Insurance Regulation, p. 157, noot 10.

1481. Zie Lemaire, JRI, 1988, p. 670-671. In de jaren '80 van de vorige eeuw bestond het Duitse BMS uit 18 premieklassen, warbij de premie opliep van $40 \%$ in klas I, via $100 \%$ in klas 13 , naar $200 \%$ in premieklasse 18 . De toegangsklasse was 14 (premie $125 \%$ ), tenzij minder dan drie jaar rijervaring, in dat geval gold toegangsklasse 15 (premie 175\%). Begin jaren '90 van de vorige eeuw is het aantal premieklassen uitgebreid tot 22 , waarmee de te betalen premie overeenkomstig is gewijzigd. Zie Lemaire, Bonus-Malus Systems, p. 140 
uitstek geschikt voor een controle van het morele risico. Bij de toepassing van het BMS wordt weliswaar de mogelijkheid tot een klein eigen risico geboden, maar deze regeling is uniform zodat consumenten geen keuze kunnen maken tussen een boo of een laag bedrag aan eigen risico. Na een verkeersongeval dient de polishouder te besluiten of hij de schade zelf betaalt of dat hij de schaderegeling aan zijn verzekeraar overlaat. In het laatste geval daalt de polishouder op de BMS-ladder. Bij etn schadeclaim die minder bedraagt dan $1.000 \mathrm{DM}$ is de verzekeraar verplicht om de polishouder te wijzen op zijn recht om de schade, met behoud van de bonus, zelf te betalen. ${ }^{1482}$

In de tweede plaats geldt volgens Finsinger e.a. de eis dat alle verzekeraars een uni. form schema van risicodifferentiatie dienen toe te passen. Bij deze vorm van risicodifferentiatie worden bijvoorbeeld variabelen, zoals leeftijd, het aantal afgelegde al. tokilometers of het aantal verkeersovertredingen, genegeerd. Door een dergelijk uni. form schema ontstaat volgens Finsinger e.a. de situatie, waarbij slechte besturders door goede bestuurders worden gesubsidieerd en een zorgvuldige verkeersdeelnemer onvoldoende wordt beloond, terwijl een onzorgvuldige verkeersdeelnemer onvol. doende wordt gestraft. ${ }^{1483}$

\subsubsection{Concurrentie versus regulering en de preventie van verkeersongevallen}

Uit het voorgaande kan in de eerste plaats worden opgemaakt dat op basis van ds ongevalsstatistieken het aantal verkeersongevallen in Duitsland, ondanks een sterke daling tussen 1970 en 1992, op een hoger niveau ligt dan in Engeland. In de tweede plaats is gebleken dat autoverzekeraars in Engeland, mede als gevolg van de concurrentie, gebruik maken van een groot aantal differentiatievariabelen om de premie zo optimaal mogelijk af te stemmen op het individueel ongevalsrisico. In Duitsland zij autoverzekeraars voor de toepassing van risicodifferentiatie gebonden aan wettliji geformuleerde richtlijnen, waardoor een minder actuarieel juiste premie kan worden vastgesteld. ${ }^{1484}$

In het kader van de economische analyse van verzekeringsmarkten is de vraag val belang de vraag in hoeverre concurrentie dan wel regulering tot een betere preventis van verkeersongevallen kan leiden. Uit het voorgaande onderzoek kan geen dirat verband worden aangetoond tussen de mate van concurrentie en het aantal verkers ongevallen. De statistische cijfers geven aan dat in Engeland sprake is van een rela-

1482. Zie Lemaire, Bonus-Malus Systems, p. 91.

1483. Finsinger, in The Economics of Insurance Regulation, p. 115-116; Finsinger, Hanmond an Tapp, Insurance: Competition or Regulation?, p. 78-81; Zie ook Adams, Gefährdung- wh Verschuldenshaftung, p. 275-299 voor een rechtseconometrische analyse van de welvartsulalis zen tengevolge van prijs- en winstregulering in de markt voor autoverzekering.

1484. Finsinger, Hammond and Tapp, Insurance: Competition or Regulation?, p. 144-145. 
tief laag antal verkeersongevallen en verkeersdoden in verhouding tot Duitsland. Dit verschil kan volgens Adams mogelijk worden verklaard uit de werking van de verzekeringsmarkt in beide landen, maar een direct verband tussen de regulering van de Duitse verzekeringsmarkt en het relatief hoge aantal verkeersslachtoffer kon door hem niet worden aangetoond. Naar zijn inzicht is een meer omvattend rechtseconometrisch onderzoek nodig om de werkelijke effecten van verzekeringsregulering op het antal verkeersslachtoffers te kunnen toetsen. ${ }^{1485}$

In de theorie is gesteld dat verzekeraars, tengevolge van de afwezigheid van volledige informatie omtrent het individuele ongevalsrisico, mechanismen nodig hebben om het morele risico en het proces van anti-selectie te kunnen controleren. ${ }^{1486}$ Een van de remedies tegen een proces van anti-selectie is het differentiëren van ongevalsisico's. Daarbij geldt dat hoe verfijnder de differentiatie des te kleiner de kans dat zich een proces van anti-selectie voordoet. Verzekeringsvoorwaarden zijn volgens Finsinger e.a. onlosmakelijk verbonden met een effectieve risicoclassificatie, waarbij gedifferentieerde verzekeringsvoorwaarden leiden tot gedifferentieerde ongevalsrisico's. In Duitsland wordt bijvoorbeeld, met een beroep op de rechtvaardigheid en op het solidariteitsbeginsel, gelobbyd (meestal door belangengroepen die opkomen voor de bescherming van de consument) voor gestandaardiseerde verzekeringsvoorwaarden ongeacht het individuele risico. Volgens Finsinger e.a. kunnen premies die zijn afgestemd op het individuele ongevalsrisico echter prikkels afgeven ten behoeve van een preventie van verkeersongevallen en derhalve tot een vermindering van de totale ongevalskosten leiden. Finsinger e.a. verwijzen naar de Engelse autoverzekeraars die, om voorzichtig rijgedrag te bevorderen, de premie verhogen bij verkeersovertredingen. Daarnaast kan de premie worden aangepast aan het autogebruik (activiteitsniveau), waarmee een hoog ongevalsrisico kan worden vermeden. Met een meer verfijnde risicodifferentiatie en de toepassing van voomoemde premieanpassingen, kan derhalve niet alleen het proces van anti-selectie maar ook het probleem van morele risico worden gereduceerd. ${ }^{1487}$

Finsinger e.a. besteden in hun onderzoek nog aandacht aan de vraag of het verplichte karakter van de aansprakelijkheidsverzekering voor motorrijtuigen noopt tot een regulering van de premie. Een argument hiervoor is dat de overheid moet garanderen dat een dergelijke verzekering beschikbaar is, waarbij autoverzekeraars geen potentiêle verzekerde mogen weigeren. Een door de overheid ingesteld orgaan dient verder de premie ex ante goed te keuren en ervoor te zorgen dat een autoverzekeraar iedereen bedient, een verplichting derhalve tot het verlenen van een dienst. ${ }^{1488}$

\footnotetext{
1485.

1486. Adams, Gefährdungs- und Verschuldenshaftung. p. 248-254.

1487. Zie paragraaf 4 van hoofdstuk 6.

1488. Finsinger, Hammond and Tapp, Insurance: Competition or Regulation?, p. 176-177.

Finsinger, Hammond and Tapp, Insurance: Competition or Regulation?, p. 144
} 
Finsinger e.a. vinden deze argumentatie niet overtuigend. In Duitsland dienen bij. voorbeeld alle auto's voorzien te zijn van een autoveiligheidsgordel; toch word de prijs van een dergelijke veiligheidsgordel niet gereguleerd. Het verschil met een al. toverzekering is echter dat de prijs van de laatste afhankelijk is van het individule ongevalsrisico, waardoor volgens hen meer redenen zijn voor differentiëring dan bi autoveiligheidsgordels. Volgens Finsinger e.a. is bij een autoverzekering zonder premieregulering het ongevalsrisico bijna altijd definieerbaar. Zij geven daarbij het voorbeeld van een 18-jarige autobestuurder die een sportauto wil verzekeren. Wanneer het onmogelijk zou zijn om deze auto tegen een gematigde premie, of zelfs tegen een hoge premie te verzekeren, zal hij de sportauto mogelijk moeten opgeven voor een minder snelle auto. ${ }^{1489}$ Volgens Adams zal weigering van een dergelijke verzekeringspolis een preventief effect hebben en kunnen leiden tot een kostenbesparing. ${ }^{1490}$

Finsinger e.a. verwijzen in dit verband naar de ervaring in Engeland, waar ook voor de slechtste ongevalsrisico's verzekeringsdekking voorhanden is. Deze zijn onder. gebracht bij gespecialiseerde verzekeraars die een hoge premie vragen. Daarnasst geldt in Engeland ten aanzien van de autoveiligheidsgordel geen prijsregulering, maar ligt de nadruk op kwaliteitscontrole met behulp van een veiligheidsstandard Volgens Finsinger e.a. kan bij een verplichte autoverzekering ook worden volstan met een kwaliteitscontrole. Met behulp van het vereiste van een minimumkapital tn solvabiliteitsregulering worden consumenten naar hun mening effectief beschermi tegen een eventuele insolventie van een verzekeraar. Daarenboven is volgens hen geen verdere premieregulering noodzakelijk. ${ }^{1491}$

\section{Conclusie: autoverzekering en de preventie van verkeersongevallen}

In dit hoofdstuk is onderzocht in hoeverre een verzekeraar via de polisvoorwarden, zowel ex ante als ex post invloed kan uitoefenen op het gedrag van de verzekerde. Daarbij is nagegaan hoe in Noord-Amerika en een aantal landen in Europa, via eta ex ante risicodifferentiatie en een ex post premieaanpassing (BMS), de controle van het morele risico gestalte krijgt. Verder is aandacht besteed aan de vraag of de concurrentie binnen dan wel de regulering van de verzekeringsmarkt van invloed is op de controle van het morele risico, de differentiëring van ongevalsrisico's en de pro ventie van verkeersongevallen.

1489. Finsinger, Hammond and Tapp, Insurance: Competition or Regulation?, p. 145.

1490. Adams, Gefahrdungs- und Verschuldenshaftung, p. 252, verwijzend naar de praktijk in Engtim waar het voor een autobestuurder beneden de 25 jaar onmogelijk is om een verzekeringspoist te sluiten voor een sportwagen.

1491. Finsinger, Hammond and Tapp, Insurance: Competition or Regulation?, p. 144-145. 
Naar aanleiding van deze analyse kan in de eerste plaats worden gesteld dat niet in alle onderzochte rechtsstelsels de omvang van de ex ante risicodifferentiatie gelijk is. In Noord-Amerika wordt bijvoorbeeld, afhankelijk van de mate van verzekeringsregulering, ${ }^{1492}$ gebruik gemaakt van een groot aantal classificatievariabelen. In de onderzochte Europese landen is de ex ante risicodifferentiatie minder omvangrijk, hoewel Engeland, Nederland en in mindere mate Frankrijk hierop een uitzondering vormen. De vraag in hoeverre een ex ante risicodifferentiatie van belang is voor een controle van het morele risico ofwel voor het vermijden van een proces van antiselectie kon niet direct empirisch worden beantwoord. ${ }^{1493}$

In de tweede plaats kan worden gesteld dat in Noord-Amerika ten aanzien van een ex post controle van het morele risico geen vastomlijnd classificatiesysteem wordt toegepast. Autoverzekeraars werken vooral met toeslagen op de premie ('merit rating') in reactie op een door de polishouder veroorzaakt verkeersongeval of een door hem begane verkeersovertreding. Deze toeslagen kunnen flink oplopen, afhankelijk van het aantal verkeersovertredingen en verkeersongevallen. In Europa wordt ten behoeve van een ex post premieaanpassing gebruik gemaakt van een bonus-malus systeem, dat van land tot land verschilt. In alle besproken BMS-regimes wordt echter gebruik gemaakt van een vast aantal premieklassen, waarbinnen een polishouder, athankelijk van de omvang van de ex ante risicodifferentiatie, wordt ingedeeld. De ex post premieaanpassing binnen het BMS is enkel gebaseerd op het aantal schadeclaims van de polishouder.

In de derde plaats is in dit hoofdstuk onderzocht welke invloed regulering dan wel concurrentie kan hebben op de differentiëring van ongevalsrisico's en de preventie van verkeersongevallen. In Noord-Amerika is de regulering van de verzekeringsmarkten voornamelijk een taak van de statelijke overheden, waardoor de omvang van de verzekeringsregulering van staat tot staat kan verschillen. Binnen de verzekeringsmarkt van Massachusetts bijvoorbeeld is de controle van zowel de markt zelf als van de verzekeringsvoorwaarden geheel in handen van de overheid. In een vergelijkende analyse van de Engelse en Duitse markt voor autoverzekeringen is geconstateerd dat in beide landen sprake is van een strikte solvabiliteitsregulering om de polishouder tegen faillissementen van zijn verzekeraar te beschermen. Ten aanzien van de verzekeringsvoorwaarden kan de Engelse markt als concurrerend worden beschouwd, terwijl in Duitsland sprake is van door de overheid opgelegde uniforme verzekeringscontracten

\footnotetext{
1492. In Massachusetts geldt bijvoorbeeld een wettelijk beperkte tocpassing van risicu-differentiatic.

1493. Zie Spahr and Escolas, JRI, 1982, p. 91-103, die alleen aantoonden dat bepaalde risicovariabelen, zoals leeftijd, geslacht en woonplaats, effectieve instrumenten kunnen zijn voor de bepaling van de omvang van de premie.
} 
De strikte verzekeringsregulering in Massachusetts en in Duitsland beperkt de autoverzekeraars in hun vrijheid om een optimale ex ante risicodifferentiatie toe te pas. sen. Daarnaast kunnen verzekeraars ook niet onderling concurreren op de prijs van de autoverzekering.

Hoewel het gepresenteerde empirisch onderzoek geen direct antwoord heeft kunnen geven op de centrale vragen van dit hoofdstuk, zal aan de hand van de beschrijving van de werking van de autoverzekering in een aantal landen toch een aantal conclu. sies worden geformuleerd.

In de eerste plaats geldt dat ter vermijding van een proces van anti-selectie een verfijnde ex ante risicodifferentiatie gewenst is. Hoe meer classificatievariabelen daarbij worden gebruikt des te beter de premie kan worden afgestemd op het individuele ongevalsrisico. Wanneer, zoals in Duitsland en Frankrijk, bijvoorbeeld geen gebruilk wordt gemaakt van de leeftijd als differentiatievariabele dan kan de situatie ontstann waarbij een autobestuurder van 22 jaar in dezelfde premieklasse wordt ingedeeld als een ervaren bestuurder van 40 jaar. Dat is minder wenselijk nu empirisch onderzoek heeft aangetoond dat autobestuurders beneden de 25 jaar gemiddeld genomen een hoger ongevalsrisico vormen dan bestuurders van boven de 30 jaar. ${ }^{1494}$

In de tweede plaats dient voor een effectieve controle van het morele risico niet enkel gebruik te worden gemaakt van het aantal schadeclaims, maar kan het ook van belang zijn om rekening te houden met het aantal verkeersovertredingen en de omvang van de schade die door de polishouder is veroorzaakt. Bij beschouwing van een aantal BMS-regimes blijkt verder dat het aantal malusklassen niet opweegt tegen het aantal bonusklassen. ${ }^{1495}$ Dit heeft er mede toe geleid dat een meerderheid van de polishouders zich in de laagste premieklassen van een BMS bevindt. ${ }^{1496}$ Tot slot dient te worden geconcludeerd dat de werkelijke effecten van een BMS-regime op de preventie van verkeersongevallen onduidelijk zijn, ${ }^{1497}$ zodat verder onderzoek daromtrent nodig is.

Een derde conclusie, ten slotte, heeft betrekking op de invloed van verzekerings: regulering op de werking van de verzekeringsmarkt, de controle van het morele risit co en de differentiatie van ongevalsrisico's. Uit de beschrijving van de verzeke ringsmarkten in de Amerikaanse staat Massachusetts en Duitsland kan worden of gemaakt dat premieregulering de verzekeraars belemmert in de controle van het morele risico. In Engeland, daarentegen, is ten aanzien van de verzekeringsvolr.

1494. Spahr and Escolas, JRI, 1982, p. 91-103. Zie daarover ook paragraaf 3.2 van hoofdstuk 9.

1495. Binnen het Nederlandse BMS is bijvoorbeeld sprake van twee premieklassen waar een polisboder $100 \%$ of meer premie betaalt. Zie Lemaire, JRI, 1988, p. 675.

1496. Lemaire, Bonus-Malus Systems, p. 13-17; Lemaire, JRI, 1988, p. 662 en 666.

1497. OECD-rapport, 1990, p. 36. 
waarden sprake van concurrentie tussen de autoverzekeraars, die daardoor worden gedwongen een meer verfijnd systeem van risicodifferentiatie toe te passen. Het is verder opvallend dat in de vergelijking tussen de Engelse (concurrentie) en Duitse (premieregulering) verzekeringsmarkt, het aantal verkeersdoden in Engeland relatief lager ligt dan in Duitsland. Naar aanleiding hiervan wordt door een enkele auteur gesuggereerd dat een gereguleerde verzekeringsmarkt tot meer verkeersongevallen leidt en dat concurrentie binnen de verzekeringsmarkt van belang is voor de preventie van verkeersongevallen. Een direct verband tussen verzekeringsregulering en de preventie van verkeersongevallen kon echter niet worden aangetoond. 


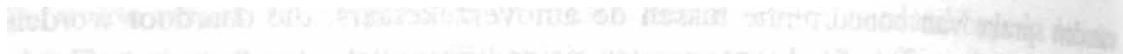

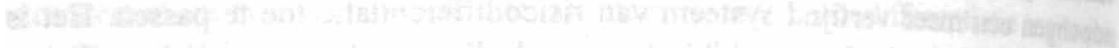

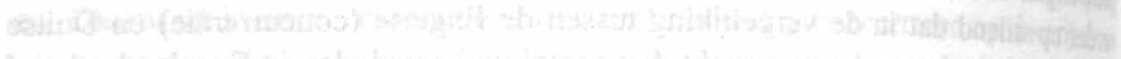

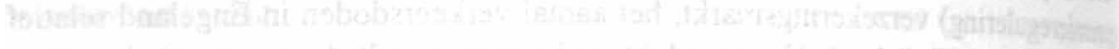

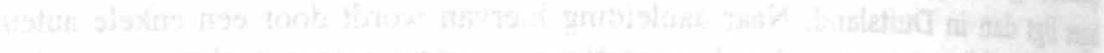

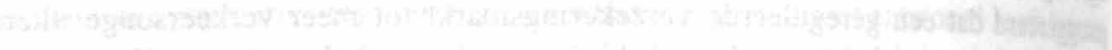

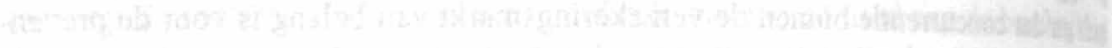

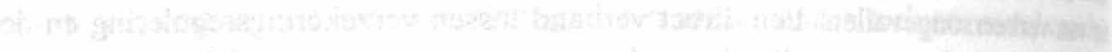

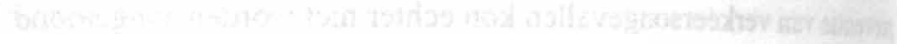

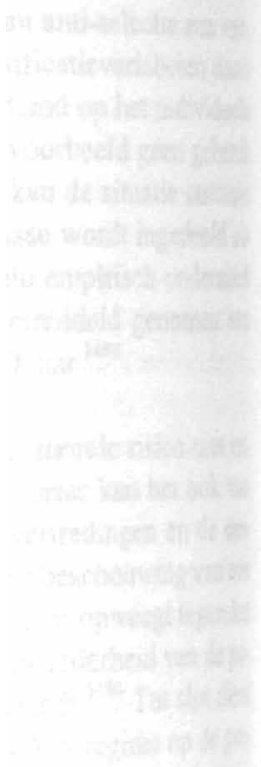




\section{Hoofdstuk 12: De empirische toetsing van veiligheids- regulering in het verkeer}

\section{Inleiding}

In hoofdstuk 10 en 11 is beschreven in hoeverre het aansprakelijkheidsrecht en de verzekering het gedrag van een verkeersdeelnemer op enigerlei wijze kunnen beïnvloeden. De centrale probleemstelling van dit onderzoek omvat echter de vraag welke combinatie van aansprakelijkheid, verzekering én veiligheidsregulering tot een optimale preventie van verkeersongevallen leidt. In dit hoofdstuk zal daarom de regulering van veiligheid in het verkeer, empirisch worden geanalyseerd.

In hoofdstuk 7 zijn drie theorieën van overheidsregulering beschreven, namelijk de 'public interest' theorie, de 'private interest' theorie en de theorie van veiligheidsregulering binnen het ongevallenrecht. Binnen de 'public interest' theorie is onderzocht welke mogelijkheden de overheid heeft om, in het kader van het algemeen belang, bepaalde marktfalingen te corrigeren. ${ }^{1498} \mathrm{Bij}$ de analyse van de 'private interest' theorie is gesteld dat de politieke besluitvorming, bijvoorbeeld met betrekking tot veiligheidsregulering, wordt beïnvloed door belangengroepen binnen de samenleving, die door middel van lobbying voor hen voordelige wetgeving tot stand trachten te brengen. ${ }^{1499}$ Ten slotte is onderzocht of met behulp van veiligheidsregulering een betere preventie van verkeersongevallen kan worden bereikt dan met het aansprakelijkheidsrecht, of dat een combinatie van beide instrumenten nodig is voor een optimaal resultaat. ${ }^{1500}$

In dit hoofdstuk zal worden ingegaan op een aantal specifieke beleidsaspecten van veligheidsregulering, die vooral betrekking hebben op de veiligheid in het verkeer. Dit betekent dat empirisch onderzoek zal worden beschreven, waarin wordt getoetst hetgeen binnen de theorie van de veiligheidsregulering in enge zin is opgemerkt. Daarbij is aan de hand van een aantal criteria onderzocht in hoeverre veiligheidsregulering een effectief instrument is om het gedrag van verkeersdeelnemers te sturen en daarmee een optimale preventie van verkeersongevallen te bereiken. ${ }^{1501}$ De centrale vraagstelling in dit hoofdstuk heeft derhalve betrekking op de effecten van veiligheidsregulering op verkeersgedrag, het aantal verkeersongevallen en het aantal verkeersslachtoffers.

\footnotetext{
Paragraaf 2 van hoofdstuk 7.

Paragraaf $4 \mathrm{v} / \mathrm{m} 6$ van hoofdstuk 7

Paragraaf 3 van hoofdstuk 7.

Zie paragraaf 3.3.2 van hoofdstuk 7 .
} 
In paragraaf $2 \mathrm{zal}$ een eerste beleidsaspect aan de orde komen, namelijk de veilig. heid van de inzittenden van een motorvoertuig en de gevolgen daarvan voor het aantal verkeersongevallen en het aantal verkeersslachtoffers. Het betreft hier autovelili. heidssystemen, zoals de autoveiligheidsgordel. Daarnaast zal aandacht worden besteed aan bepaalde passieve veiligheidsstandaarden ('passive restraints') in een auto. Deze treden automatisch in werking zodra de bestuurder in het voertuig heef plats. genomen of wanneer hij bij een botsing betrokken raakt. Voorbeelden van deze vejligheidsstandaarden zijn de automatisch werkende veiligheidsgordel ('passive bell') en de airbag.

Een tweede, aan het voorgaande verwant, beleidsaspect heeft betrekking op de discussie die met name door Peltzman ${ }^{1502}$ is ingezet. Hij stelt de vraag of meer velilig. heid voor de autobestuurder niet leidt tot een verminderde zorgvuldigheid in het verkeer. In paragraaf 3 zal dit zogenoemde 'Offsetting Behaviour'-probleem worden besproken. Daarbij zullen met name de empirische effecten van veiligheidsregulering op het verkeersgedrag centraal staan.

In paragraaf 4 en $5 \mathrm{zal}$ aandacht worden besteed aan een tweetal aspecten van velifiheidsregulering die direct betrekking hebben op de verkeersdeelname. In dat kader zal naast het alcoholgebruik ook het effect van de invoering van een maximum snelheid in het verkeer aan de orde komen.

In paragraaf 6 ten slotte, wordt een onderzoek gepresenteerd waaruit zal blijken di lobbygroepen binnen de samenleving belang kunnen hebben bij de invoering van aansprakelijkheidsregels en bepaalde vormen van veiligheidsregulering in het verkeer.

Dit hoofdstuk zal in paragraaf 7 worden afgesloten met een aantal concluderende opmerkingen.

\section{De veiligheid van de inzittenden van een auto}

Een eerste aspect van veiligheidsregulering heeft betrekking op de anwezigheid alsmede het gebruik van de autoveiligheidsgordel, de airbag en andere preventieve voorzieningen binnen de auto. Ten aanzien van het empirisch onderzoek ${ }^{1503}$ dat hier zal worden gepresenteerd gaan bijna alle auteurs uit van de veronderstelling dat de aanwezigheid van een autoveiligheidsgordel of een airbag de veiligheid sec vande

1502. Peltzman, JPE, 1975 , p. 677-725.

1503. In dat kader kunnen de volgende studies worden genoemd: Amould and Grabowski, BJE, 1981, p. 27-48; Evans, Ac. An. \& Prev., 1986, p. 229-241; Jonah and Lawson, Ac. An. \& Prev, 1984 p. 433-450; Loeb, Am. Econ. Rev., 1995, p. 81-84; Mannering and Winston, JLE, 1995, p. 265. 279; McCarthy, Ac. An. \& Prev., 1986, p. 425-438. 
inzittenden van een auto kan verhogen. ${ }^{1504}$ Voor het onderhavige onderzoek is echter vooral de vraag van belang of deze verhoogde veiligheid ook tot minder verkeersslachtoffers heeft geleid. Alvorens in paragraaf 2.2 op deze vraag wordt ingegaan, zal eerst worden onderzocht welk effect wetgeving met betrekking tot het verplicht dragen van de autoveiligheidsgordel heeft gehad op het gebruik ervan door de inzittenden (bestuurder) van de auto (paragraaf 2.1).

\subsection{HET GEBRUIK VAN DE AUTOVEILIGHEIDSGORDEL.}

Het kenmerkende van een autoveiligheidsgordel is dat de bestuurder een vrijwillige inspanning moet plegen om de gordel om te doen. ${ }^{1505}$ Een aantal empirische studies heeft aangetoond dat, ondanks de aanwezigheid ervan in het voertuig, de autoveiligheidsgordel door een grote meerderheid van de autobestuurders niet werd gebruikt. Gedurende de jaren ' 70 van de vorige eeuw lag het gebruik van de autoveiligheidsgordel in een aantal landen globaal tussen de $10 \%$ en de $25 \% .{ }^{1506}$

Vanaf het begin van de jaren ' 70 van de vorige eeuw werd in een groot aantal landen het gebruik van de autoveiligheidsgordel wettelijk verplicht gesteld. De Australische deelstaat Victoria was in 1970 de eerste jurisdictie waar een wettelijke draagplicht werd ingevoerd. Deze wetgeving kwam mede tot stand omdat een aantal artsen met steun van de media autobestuurders wezen op de verhoogde veiligheid van het dragen van een autoveiligheidsgordel. $\mathrm{Na}$ de invoering van de wettelijke draagplicht bleek dat het gebruik van de autoveiligheidsgordel onder de autobestuurders zeer hoog was $(75 \%)$ en het aantal dodelijke verkeersslachtoffers afnam (-12\%). Dit was voor andere Australische jurisdicties aanleiding om een paar jaar later eveneens tot invoering van een wettelijke draagplicht over te gaan. ${ }^{1507}$

In Noord-Amerika, daarentegen, werd de invoering van de wettelijke draagplicht van de autoveiligheidsgordel gedurende de jaren '60 en '70 van de vorige eeuw eerder vertraagd door een gebrek aan steun van belangrijke maatschappelijke groeperingen op het terrein van de verkeersveiligheid. Dit had mede tot gevolg dat pas in 1984 een aantal Amerikaanse staten overging tot invoering van een wettelijke draagplicht van de autoveiligheidsgordel. ${ }^{1508}$

\footnotetext{
5004 .

Zie daarover onder anderen, Amould and Grabowski, BJE, 1981, p. 27

Evans, Traffic Safety and the Driver, p. 219.

Amould and Grabowski, BJE, 1981, p. 27, met betrekking tot de Verenigde Staten; Jonah and Lawson, Ac. An. \& Prev., 1984, p. 433-436, met betrekking tot een aantal Canadese provincies; Garbacz, Economic Inquiry, 1991, p. 311, voor Nieuw-Zeeland. Evans, Traffic Safety and the Driver, p. 251-252 en p. 275-276; Jonah and Lawson, Ac. An. \&
Prev., 1984, p. 433 .
} 
Met betrekking tot een aantal jurisdicties is het effect van deze wetgeving, in de tijd gemeten, op het gebruik van de autoveiligheidsgordel onderzocht. In Canada, bij. voorbeeld, werd de wettelijke draagplicht van de autoveiligheidsgordel in 1976 ingevoerd in de provincies Ontario en Quebec en in 1977 in de provincies Saskachewan en British Columbia. Een onderzoek met betrekking tot de effecten van deze wetgeving heeft uitgewezen dat het werkelijk gebruik van de autoveiligheidsgordel gedurende de periode $1975-1982$ in al deze provincies is toegenomen. ${ }^{1509}$ Een aantal jaren na de invoering van de wettelijke draagplicht bleek het gebruik van de autovei. ligheidsgordel te zijn toegenomen tot gemiddeld $50 \%$. Als gevolg van een intensieve controle en het opleggen van boetes steeg het gebruik van de autoveiligheidsgordel verder naar ongeveer $65 \%$. In de niet-gereguleerde Canadese provincies daarentegen, bleef het aantal bestuurders dat de autoveiligheidsgordel gebruikte stabiel op $10 \%-15 \%{ }^{1510}$

In tabel 1 is met betrekking tot een aantal andere jurisdicties een overzicht gegeven van het aantal autobestuurders dat, voor en na invoering van een wettelijke draag. plicht de autoveiligheidsgordel gebruikt. Daarnaast zijn de procentuele gevolgen voor het gebruik van de autoveiligheidsgordel weergegeven na een striktere handhaving van de wettelijke draagplicht. ${ }^{1511}$ Uit deze tabel kan worden opgemaakt dat een wettelijke draagplicht tot een hoger gebruik van de autoveiligheidsgordel leidt. Een strikte handhaving en controle van de wettelijke draagplicht zorgt daarnaast voor een additionele stijging van het aantal bestuurders dat de autoveiligheidsgordel ge bruikt. ${ }^{1512}$

1509. Jonah and Lawson, Ac. An. \& Prev., 1984, p. 433-450.

1510. Jonah and Lawson, Ac. An. \& Prev., 1984, p. 436-437.

1511. De gegevens uit deze tabel zijn ontleend aan: Evans, Traffic Safety and the Driver, p. $251.253 \mathrm{e}$ p. 262; Dewees, Duff and Trebilcock, Accident Law, p. 44; M. Mackay, Seat Belt Use unter Voluntary and Mandatory Conditions and Its Effects on Casualties, in Human Behaviour and Traffic Safety, Evans and Schwing (eds.) New York, Plenum Press, 1985, p. 259-278 in Evals, Traffic Safety and the Driver, p. 262 en Dewees, Duff and Trebilcock, Accident Law, p.80, 1000 290-291. Zie ook Plaizier, Factoren die van invloed zijn op het autogordelgebruik, p. 56-67.

1512. Een voorbeeld van dit laatste is de staat North Carolina was een intensieve controle leide ti Een voorbeeld van dit laatste is de staat North Carolina waar een intensieve controle $p$. $p .24$
een toename van het gebruik met ruim $30 \%$. Zie Evans, Traffic Safety and the Drive, 2 .
255 . 
Tabel 1

\begin{tabular}{|c|c|c|c|c|c|c|c|c|c|c|}
\hline & 1974 & 1975 & 1976 & 1982 & 1983 & 1984 & 1985 & 1986 & 1987 & 1988 \\
\hline $\begin{array}{c}\text { Canada (Al- } \\
\text { berta) }\end{array}$ & & & & & & & & $27 \%{ }^{1513}$ & $74 \%$ & $83 \%$ \\
\hline Engeland & & & & $40 \%$ & $90 \%$ & & & & & \\
\hline W-Duitsland & & $32 \%$ & $50 \%$ & & & $58 \%$ & $92 \%$ & & & \\
\hline $\begin{array}{c}\text { Nederland } \\
\text { 1514 }\end{array}$ & $20 \%$ & $60 \%$ & & & & $60 \%$ & & & & \\
\hline $\begin{array}{c}\text { N-Amerika } \\
\text { (Michigan) }\end{array}$ & & & & & & $18 \%$ & $60 \%$ & $47 \%$ & & \\
\hline $\begin{array}{c}\text { N-Amerika } \\
\text { (Illinois) }\end{array}$ & & & & & & $15 \%$ & $40 \%$ & $35 \%$ & & \\
\hline
\end{tabular}

\subsection{DE INVLOED VAN DE AUTOVEILIGHEID OP HET AANTAL VERKEERSSLACHTOFFERS}

Gedurende de jaren ' 80 en ' 90 van de vorige eeuw is veel onderzoek gedaan naar de effecten van een veiliger auto op het aantal verkeersslachtoffers. ${ }^{1515}$ In deze subparagraaf zal een selectie van deze studies aan de orde komen. Daarbij ligt de nadruk op de vraag welke gevolgen een verhoogde veiligheid voor de autobestuurder heeft voor de emst van het verkeersongeval en voor het aantal verkeersslachtoffers. Naast het gebruik van de autoveiligheidsgordel heeft de genoemde veiligheid ook betrek-

1513. In de Canadese provincies waar een wettelijke draagplicht gold, werd in 1986 door ongeveer $68 \%$ van de autobestuurder de autoveiligheidsgordel ook daadwerkelijk gebruikt. Zie Dewees, Duff and Trebilcock, Accident Law, p. 44.

1514. In Nederland werd in juni 1975 de wettelijke draagplicht van de autoveiligheidsgordel ingevoerd. Het onderzoek naar het effect van de invoering van deze wettelijke draagplicht maakt onderscheid tussen het rijden binnen en buiten de bebouwde kom. In 1974, voor de invoering van wetgeving, werden bij autobestuurder draagpercentages van $28 \%$ buiten de bebouwde kom en $13 \%$ binnen de bebouwde kom waargenomen. Een maand na de invoering van de wettelijke dragplicht steeg het aantal autobestuurders dat de autogordel droeg tot respectievelijk $78 \%$ (buiten bebouwde kom) en $61 \%$ (binnen bebouwde kom). Vier maanden na invoering waren de percentages iets gedaald, namelijk naar $67 \%$ (buiten bebouwde kom) en $49 \%$ binnen bebouwde kom. Hiema bleven de draagpercentages min of meer stabiel tussen de $50 \%$ en $70 \%$. Zie daarover Plaizier, Factoren die van invloed zijn op autogordelgebruik, p. 1, en p. 68-69; Noordzij, Verkeerswetgeving, -gedrag en -veiligheid, p. 15 en 28 , onder verwijzing naar Amoldus en Scholtens, Aanwezigheid en gebruik van autogordels 1984 en Scholtens, Varkevisser, Arnoldus en Stolk, Aanwezigheid en gebruik van autogordels 1971-1977.

1515. Zie voor een overzicht van deze literatuur onder anderen: Dewees, Duff and Trebilcock, Accident Law, p. 44-45 en 79-80; Bruce, Law and Policy, 1984, p. 73-74; Evans, Traffic Safety and the Driver, p. 228-245 en p. 254-269. 
king op de zogenaamde passieve autoveiligheidsstandaarden ('passive restraints' zoals de airbag en de automatische veiligheidsgordel. ${ }^{1516}$ Deze zullen in paragraes 2.2.3 aan de orde komen.

\subsubsection{De preventieve effecten van de autoveiligheidsgordel in Canada}

Een Canadese studie geeft naast een onderzoek naar de wettelijke draagplicht van de autoveiligheidsgordel, een indicatie van de effecten daarvan op het aantal verkeerslachtoffers, ${ }^{1517}$ In dat kader wordt door de auteurs een vergelijking gemaakt tussen het aantal slachtoffers onder inzittenden en het aantal slachtoffers onder nietinzittenden van het voertuig gemeten in de periode na de invoering van de wettelijke draagplicht van de autoveiligheidsgordel.

Voor hun onderzoek, waarvan de resultaten in tabel $3^{1518}$ zijn weergegeven, worth door Jonah en Lawson gebruik gemaakt van ongevalsdata uit de periode 1971-1981. Hierbij wordt ten aanzien van de autoveiligheidsgordel onderscheid gemaakt tussen de periode voor invoering van de wettelijke draagplicht en de periode ema. ${ }^{\mathrm{B}}$ Daarnaast wordt een vergelijking gemaakt tussen het aantal verkeersslachtoffers in provincies met een wettelijke draagplicht van de autoveiligheidsgordel en provincies zonder dergelijke wetgeving.

1516. Amould and Grabowski, BJE, 1981, p. 28 en 35.

1517. Jonah and Lawson, Ac. An. \& Prev., 1984, p. 433-450.

1518. De gegevens in deze tabel zijn ontleend aan Jonah en Lawson, Ac. An. \& Prev., 1984, p. 45 tabel 4 .

1519. Voor Ontario en Quebec staat de ex ante periode gelijk aan de jaren 1971-1975 en de ex pos: 1 . riode aan de jaren 1976-1981. In Saskatchewan en British Colombia omvat de ex ante periodel jaren 1971-1976 en de ex post periode de jaren 1977-1981. Zie Jonah and Lawson, Ac. An d Prev., 1984, p. 444-445. 
Tabel 2

\begin{tabular}{|c|c|c|c|c|c|c|c|}
\hline & \multicolumn{3}{|c|}{$\begin{array}{c}\text { Aantal verkeersdoden } \\
\text { onder inzittenden }\end{array}$} & \multicolumn{2}{c|}{$\begin{array}{c}\text { Aantal verkeersdoden } \\
\text { onder niet-inzittenden }\end{array}$} & $\begin{array}{c}\text { 'Relative Ca- } \\
\text { sualty Change' }\end{array}$ \\
\hline Jurisdicties & ex ante & ex post & $\%$ & ex ante & ex post & $\%$ & $\%$ \\
\hline Ontario & 1342 & 1067 & $-20,5$ & 500 & 415 & -17 & $-13,7$ \\
\hline Quebec & 1161 & 1087 & $-6,4$ & 602 & 523 & $-13,1$ & $-3,5$ \\
\hline $\begin{array}{c}\text { Saskatchewan } \\
\text { British Columbia }\end{array}$ & 220 & 224 & $+1,8$ & 45 & 51 & $+13,3$ & $-21,7$ \\
\hline $\begin{array}{c}\text { Alle gereguleerde } \\
\text { provincies }\end{array}$ & 3284 & 2940 & $-10,5$ & 1314 & 1180 & $-10,2$ & $-10,5$ \\
\hline $\begin{array}{c}\text { Alle niet-geregu- } \\
\text { leerde provincies }\end{array}$ & 1007 & 1005 & $-0,2$ & 362 & 324 & $-10,4$ & n.b. \\
\hline
\end{tabular}

Uit tabel 2 kan worden opgemaakt dat alleen in Ontario sprake was van een relatief scherpe daling $(-20,5 \%)$ van het aantal verkeersdoden onder inzittenden; de andere provincies kenden een minder scherpe daling of zelfs een kleine toename van het aantal verkeersdoden onder inzittenden. Binnen de gereguleerde provincies gezamenlijk was sprake van een daling van het aantal verkeersdoden onder inzittenden met ruim $10 \%$, terwijl in de niet-gereguleerde provincies de daling slechts $0,2 \%$ bedroeg. Ten aanzien van het aantal verkeersdoden onder niet-inzittenden is tussen de vier gereguleerde provincies sprake van een scherp contrast. Terwijl in Ontario en Quebec het aantal dodelijke verkeersslachtoffers daalde, steeg het aantal slachtoffers in Saskatchewan en British Columbia. Voor alle gereguleerde provincies gezamenlijk bedroeg de daling van het aantal verkeersdoden onder niet-inzittenden $10,2 \%$, vergeleken met de niet-gereguleerde provincies $(10,4 \%)$ een ongeveer gelijke procentuele afname. ${ }^{1520}$

Uitgaande van de veronderstelling dat de autoveiligheidsgordel alleen van invloed is op de veiligheid van de inzittenden van een auto, wordt door Jonah en Lawson een wegingsfactor, 'Relative Casualty Change' (RCC), gebruikt om een verband aan te tonen tussen het gemiddeld aantal verkeersslachtoffers per jaar onder inzittenden en niet-inzittenden. De hoogte van deze RCC bepaalt het effect van de wettelijke dragplicht van de autoveiligheidsgordel. Uit deze berekening (laatste kolom in tabel

1520. Jonah and Lawson, Ac. An. \& Prev., 1984, p. 445-446. Deze uitkomsten lijken deels een 'offsetting behaviour' te suggereren, waarbij ten gevolge van de verhoogde autoveiligheid de zorgvuldigheid van de autobestuunder a fneemt. Zie over deze theorie verderop in paragraaf 3. 
3) blijkt dat in alle provincies, met uitzondering van Quebec $(-3,5 \%)$, het aantal ver. keersdoden relatief sterk is gedaald (met $13,7 \%, 21,7 \%$ en $24,2 \%)^{1521}$

Jonah en Lawson concluderen dat de wettelijke draagplicht van de autoveilig. heidsgordel in Ontario, Saskatchewan en British Columbia heeft geleid tot een da. ling van het aantal verkeersslachtoffers onder inzittenden, hoewel de omvang van de reductie minder was dan voorzien. De provincie Quebec heeft voor wat betreft het aantal verkeersslachtoffers het minste voordeel uit de wettelijke draagplicht van de autoveiligheidsgordel behaald. ${ }^{1522}$ Hoewel het (positieve) effect van een strikte preventieve controle van de wettelijke draagpiicht niet door Jonah en Lawson is onderzocht, wordt door hen de factor handhaving wel erkend wanneer zij stellen dat:

'The seat belt laws were not as effective as they could have been had they been adequately enforced and publicized to increase belt use by high risk drivers. The seat belt legislation could have been more effective if they had been enforced to attain and maintain an $80 \%$ usage rate., ${ }^{1523}$

\subsubsection{Amerikaans onderzoek naar de effecten van de autoveiligheidsgordel}

In een Amerikaans onderzoek van Evans naar de effecten van het gebriik van de a toveiligheidsgordel op het aantal verkeersslachtoffers, wordt gebruik gemaakt va (ongevals)data uit de periode $1974-1983 .{ }^{1524}$ Daarbij worden door hem twee vormen van ongevalsstatistieken geanalyseerd. Een eerste serie ongevalsstatistieken bevit verkeersongevallen, waarin de bestuurder een autogordel droeg en de passagier nie, en waarbij minimaal één dodelijk slachtoffer viel. Een tweede serie ongevalsstatitieken omvat verkeersongevallen, waarin de bestuurder en de passagier geen autogordel droegen. Het totaal aantal onderzochte dodelijke verkeersongevallen bedrotg ongeveer 30.000 . Hierbij waren ruim 15.000 bestuurders ( 711 droegen een autogordel, zijnde $4,6 \%$ ) en ruim 16.000 passagiers (waarvan 716 een autogordel droegen, zijnde 4,4\%) betrokken. Door Evans wordt verder een onderscheid gemaakt in ent drietal leeftijdscategorieën, namelijk 16-24 jaar, 25-34 jaar en 35+, en wordt darnaast rekening gehouden met het aantal inzittenden in een auto. ${ }^{1525}$

Evans tracht in zijn onderzoek een verband aan te tonen tussen het gebruik van de autoveiligheidsgordel en het aantal verkeersslachtoffers onder inzittenden van exn voertuig. Hieruit blijkt dat, wanneer ten aanzien van de groep inzittenden die getan autoveiligheidsgordel gebruiken een wettelijke draagplicht wordt ingevoerd, het an-

1521. Jonah and Lawson, Ac. An. \& Prev., 1984, p. 446.

1522. Jonah and Lawson, Ac. An. \& Prev., 1984, p. 446-447.

1523. Jonah and Lawson, Ac. An. \& Prev., 1984, p. 447 en 449.

1524. Evans, Ac. An. \& Prev., 1986, p. 229-241.

1525. Evans, Ac. An. \& Prev., 1986, p. 230-239. 
tal verkeersslachtoffers in deze groep, zonder dat zij hun verkeersgedrag anderszins wijzigen, met gemiddeld $41 \%$ zal kunnen dalen. ${ }^{1526}$

In een Amerikaans onderzoek van Loeb wordt eveneens getracht een verband aan te tonen tussen de verplichte autoveiligheidsgordel en het aantal verkeersslachtoffers. ${ }^{1527}$ Deze studie heeft betrekking op de staat Texas waar in 1985 een wettelijke draagplicht van de autoveiligheidsgordel werd ingevoerd, tezamen met een strikte handhaving daarvan via het opleggen van boetes. Voor een berekening van het effect van deze wettelijke draagplicht op het aantal verkeersslachtoffers wordt door Loeb gebruik gemaakt van politierapporten met betrekking tot verkeersongevallen gedurende de periode 1982-1987. De data, per maand opgemaakt, bevatten zowel eenzijdige als meerzijdige verkeersongevallen. Voor het onderzoek worden enkel de voertuigen gebruikt, die na het ongeval dienden te worden weggesleept. Tenslotte wordt een onderscheid gemaakt tussen verschillende vormen van letselschade, namelijk dodelijke letsel, ernstig letsel, gematigd letsel, licht letsel en geen letsel. Daarnaast wordt binnen een rechtseconometrisch model onder andere rekening gehouden met de opgelegde boete bij overtreding, met seizoensfactoren, aantal afgelegde automijlen en werkeloosheidscijfers. ${ }^{1528}$

De resultaten van de analyse wijzen volgens Loeb uit dat de wettelijke draagplicht van de autoveiligheidsgordel in Texas ertoe heeft geleid dat tengevolge van een verkeersongeval minder ernstig letsel wordt geleden. In het eerste kwartaal na invoering van de wetgeving was het effect nog niet zo groot. In het tweede kwartaal werd het effect groter, vooral door de invoering van een boete op het niet-dragen van de autogordel. ${ }^{1529}$

\subsubsection{Passieve autoveiligheidssystemen ('passive restraints')}

Nast de preventieve effecten van het gebruik van de autoveiligheidsgordel, is ook onderzoek gedaan naar de gevolgen van passieve veiligheidsstandaarden, zoals de airbag en de automatische autoveiligheidsgordel, ${ }^{1530}$ voor het aantal verkeersslachtoffers. Een airbag wordt opgeblazen zodra een voertuig in botsing komt met andere objecten; de automatische veiligheidsgordel omsluit de bestuurder zodra deze in de auto stapt. Het kenmerkende van deze systemen ('passive restraints') is dat zij de in-

\footnotetext{
1526. Evans, Ac. An. \& Prev., 1986, p. 239-241; Evans, Traffic Safety and the Driver, p. 228-229, 237. Zie ook p. 256-257, waarin door hem wordt berekend dat een bestuurder die geen autogordel draagt $53 \%$ meer kans loopt om betrokken te raken bij een verkeersongeval dan een bestuurder die wel een autogordel draagt.

1527. Loeb, Am. Econ. Rev., 1995, p. 81-84
}

1528. Loeb, Am. Econ. Rev., 1995, p. 81 .

1529. Loeb, Am. Econ. Rev., 1995, p. 83-84

1530. Zie daarover Amould and Grabowski, BJE, 1981, p. 35-39. 
zittenden van een auto bescherming geven zonder dat zij daar enige inspanning voor behoeven te doen. ${ }^{1531}$ Passieve veiligheidsstandaarden kunnen ook een optimale effectiviteit waarborgen, omdat er voor de overheid in beginsel geen handhavingsproblemen zijn.

Evans heeft berekend welk effect een airbag ${ }^{1532}$ kan hebben op de vermindering van de ernst van een verkeersongeval. Hierbij wordt uitgegaan van de veronderstelling dat een airbag zichzelf slechts opblaast ingeval van een (bijna) frontale botsing. Naar aanleiding van zijn berekening wordt door Evans geconcludeerd dat het effect van de airbag zich vertaalt in een daling van het aantal dodelijke verkeersslachtoffers met ongeveer $17 \%$ bij bestuurders en met ongeveer $13 \%$ bij passagiers. ${ }^{1533}$

In een aantal andere empirische studies is berekend welke effecten autoveiligheids. systemen hebben op het aantal verkeersslachtoffers. ${ }^{1534}$ Daaruit blijkt dat de invoering van een airbag, afhankelijk van de wijze waarop de diverse onderzoeken worden gewaardeerd, kan leiden tot een daling van het aantal dodelijke verkeersongevallen met $17-40 \% .{ }^{1535}$ De toepassing van een actieve autoveiligheidsgordel resulteert volgens deze studies in een daling van het aantal dodelijke verkeersslachtoffers met gemiddeld $40 \% .{ }^{1536} \mathrm{Na}$ de invoering van een automatische veiligheidsgordel zal het aantal dodelijke verkeersslachtoffers dalen met een percentage dat ligt tussen

1531. Evans, Traffic Safety and the Driver, p. 219. Zie ook Blomquist, Regulation of Motor Vehide and Traffic Safety, p. 81.

1532. Mannering and Winston, JLE, 1995, p. 266. De airbag is pas sinds het begin van de jaren 90 en standaard onderdeel van de auto geworden. In 1988 was nog slechts $2 \%$ van de nieuwe auths uitgerust met een airbag, in 1994 was dit percentage opgelopen naar ongeveer $60 \%$. Het Amrikaanse Congres heeft via de 'Intermodal Surface Transportation Efficiency Act' uit 1991 bepald dat alle personenauto's in 1997 uitgerust dienen te zijn met een airbag. Zie Dewees, Duff exd Trebilcock, Accident Law, p. 45.

1533. Evans, Traffic Safety and the Driver, p. 239-242.

1534. Daamaast wordt een kosten-baten analyse gemaakt van de verschillende veiligheidssystema. Zie onder anderen: de 'National Highway Traffic Safety Administration' (NHTSA), Final Reg. latory Impact Analysis, Amendment of FMVSS 208, Passanger Car Front Seat Occupant Prowo tion, Washington DC, July 1984; D. F. Huelke and J. O'Day, Passive Restraints: A Scientifi View, in The Scientific Basis of Health and Safety Regulation, R. Crandall and L. Lave (eds), The Brookings Institute, Washington DC, 1981. Deze studies worden geciteerd in Blomplish Regulation of Motor Vehicle and Traffic Safety, p. 84-91; Evans, Traffic Safety and the Drive, p. 244-247; Amould and Grabowski, BJE, 1981, p. 36-39.

1535. De NHSTA-studie (20-40\%), de studie van Huelke en O'Day (25\%) en de studie van Evats (17\%) geciteerd in Evans, Traffic Safety and the Driver, p. 245; Amould and Grabowski, BIE, 1981 , p. 37 en Blomquist, Regulation of Motor Vehicle and Traffic Safety, p. 84 en 89.

536. De NHTSA-studie (40\%-50\%), de studie van Huelke en O'Day (32\%) en de studie van Evas (41\%). Zie Evans, Traffic Safety and the Driver, p. 245, tabel 9-7. 
$28 \%$ en $50 \% .{ }^{1537}$ Een combinatie van een airbag en een actieve autoveiligheidsgordel ten slotte, leidt volgens deze studies tot een daling van het aantal dodelijke verkersslachtoffers met gemiddeld $50 \%{ }^{1538}$

Tot slot kan worden verwezen naar een aantal studies waarin de ontwikkeling van de airbag gedurende de jaren ' 90 van de vorige eeuw vanuit een marktperspectief is onderzocht. ${ }^{1539}$ Tussen 1988 en 1994 steeg het percentage auto's dat is uitgerust met een airbag van $2 \%$ naar ongeveer $60 \% .{ }^{1540}$ Winston en Mannering concluderen naar aanleiding van hun analyse van de markt voor airbags, dat de consument bereid is ('willingness to pay') om te betalen voor een airbag die door de fabrikanten ervan wordt aangeboden. Deze bereidheid neemt toe wanneer de consument informatie verkrijgt over de 'positieve' effecten van airbags. ${ }^{1541}$ Uit het onderzoek van Peterson en Hoffer blijkt onder andere dat de invoering van de airbag heeft bijgedragen tot een verdere differentiatie in de aankoop van automodellen. Als gevolg hiervan hebben vooral consumenten met een hoger ongevalsrisico in verhouding tot de gehele Amerikaanse bevolking meer auto's gekocht die zijn uitgerust met een airbag. ${ }^{1542}$

\subsection{CONCLUSIE: AUTOVEILIGHEIDSSYSTEMEN}

Uit het beschreven empirisch onderzoek kan worden geconcludeerd dat de toepassing van autoveiligheidssystemen (autoveiligheidsgordel, airbag), een positieve invloed heeft op de vermindering van het aantal verkeersslachtoffers onder met name inzittenden van een motorvoertuig. Een autobestuurder wordt met deze veiligheidssystemen beter beschermd, waardoor de kans om bij een verkeersongeval ernstig of zelfs dodelijk gewond te raken kleiner wordt. Ten aanzien van de actieve autoveiligheidsgordel geldt echter dat het gebruik ondanks de invoering van een wettelijke dragglicht niet maximaal is. Het dragen van de autoveiligheidsgordel dient derhalve te worden gestimuleerd door middel van een intensieve controle en de daarmee verbonden sancties. Met een verwijzing naar de theorie van veiligheidsregulering, ${ }^{1543}$

1537. De NHSTA-studie (50\%) geciteerd in Amould and Grabowski, BJE, 1981, p. 37. De studie van Huelke en O'Day (28\%) geciteerd in Blomquist, Regulation of Motor Vehicle and Traffic Safety, p. 84.

1538. De NHSTA-studie (45-55\%) en de studie van Evans (46\%) geciteerd in Evans, Traffic Safety and the Driver, p. 245. De studie van Huelke and O'Day berekent het effect van de combinatie van de airbag en de zogenaamde 'lap belt', die alleen de schoot van de inzittende beschermd, en komen naar aanleiding daarvan tot een vermindering van het aantal dodelijke verkeersslachtoffers met 34\%. Zie Amould and Grabowski, BJE, 1981, p. 37; Blomquist, Regulation of Motor Vehicle and Traffic Safety, p. 84

Mannering and Winston, JLE, 1995, p. 265-279; Peterson and Hoffer, Joumal of Consumer Research, 1994, p. 657-662.

[540. Mannering and Winston, JLE, 1995, p. 265-266.

1542. Mannering and Winston, JLE, 1995, p. 266-275.

543. Peterson and Hoffer, Journal of Consumer Research, 1994, p. 661.

Zie paragraaf 2.1.4 van hoofdstuk 7 
kan worden gesteld dat een autobestuurder klaarblijkelijk onvoldoende informatie heeft ten aanzien van de positieve effecten van de actieve autoveiligheidsgordel op de preventie van verkeersongevallen. Er is sprake van een marktfaling die door mid. del van overheidsregulering kan worden opgeheven, waarbij echter sancties noodza. kelijk zijn om de bestuurder aan te zetten tot het dragen van de autoveiligheidsgordel. Dit geldt niet voor de automatische veiligheidssystemen ('passive restraints') zoals de airbag en de automatische autoveiligheidsgordel ('passive belt'). De besissing om deze veiligheidssystemen te gebruiken wordt niet door de autobesturder genomen maar indirect door de fabrikant van de auto. Vanuit de positie van de wet. gever lijkt het derhalve wenselijk om via regulering de autofabrikanten te bewegen passieve veiligheidssystemen in auto's aan te brengen. Daarmee kan een bespaning op de kosten van handhaving worden bereikt, terwijl ten aanzien van deze veilig. heidssystemen een optimaal gebruik, mits het voertuig daarvan is voorzien, is gewaarborgd.

\section{De invloed van de autoveiligheid op het verkeersgedrag: 'offsetting behavior'?}

Hoewel in het voorgaande is aangetoond dat autoveiligheidsregulering tot meer veiligheid in de auto en tot minder verkeersslachtoffers leidt, is in de literatuur een discussie gaande over de vraag of een verhoogde veiligheid kan de autobesturder geen negatieve gevolgen heeft voor zijn verkeersgedrag. Daarbij wordt gesuggereerd dat een autobestuurder meer risico's in het verkeer zal nemen, waardoor bijvorbeeld het aantal verkeersslachtoffer onder niet-inzittenden, zoals voetgangers en fietsers, toeneemt. ${ }^{1544}$ In deze paragraaf zal dit zogenaamde 'offsetting behaviour', ook wel 'risk compensation theory' ${ }^{1545}$ genoemd, empirisch worden beschreven.

\subsection{HeT EMPIRISCH ONDERZOEK VAN PELTZMAN}

Sam Peltzman wordt beschouwd als een belangrijke exponent van de theorie van 'offsetting behavior'. ${ }^{1546}$ Peltzman stelt dat een autobestuurder in het algemeen niet ongevoelig zal zijn voor veranderingen in zijn rijomgeving, maar zijn gedrag eerder aan deze omgeving zal aanpassen. Dit betekent volgens hem niet dat de verhoging van de veiligheid van de auto of een verbetering van de infrastructuur ook tot minder verkeersslachtoffers leidt. ${ }^{1547}$

1544. Dewees, Duff and Trebilcock, Accident Law, p. 43; Bruce, Law and Policy, 1984, p. 74.

mquist, Regulation of Motor Vehicle and Traffic Safety, p. 29-30 0ok wel 'Risk Homeostatic Approach' genoemd.

1546. Peltzman, JPE, 1975, p. 677-725.

1547. Peltzman, JPE, 1975, p. 677. 
Voor een empirisch bewijs van zijn veronderstellingen wordt door Peltzman een onderzoek verricht naar de effecten van de Amerikaanse autoveiligheidsregulering ${ }^{1548}$ op het aantal verkeersslachtoffers. Hij maakt daarbij gebruik van ongevalsdata uit de periode 1947-1972, waaruit blijkt dat het aantal verkeersslachtoffers per 100 miljoen automijlen is gedaald. Peltzman vraagt zich echter af of deze daling te danken is aan de ingevoerde autoveiligheidsregulering. Bij zijn analyse wordt verder gebruik gemaakt van een aantal toetsingsvariabelen die mede van invloed kunnen zijn op een verkeersongeval. Deze factoren hebben betrekking op de kosten van een verkeersongeval, het aantal verkeersongevallen, inkomen, alcohol, snelheid en het percentage jonge autobestuurders (15-25 jaar). ${ }^{1549}$ De resultaten van dit onderzoek laten zich als volgt samenvatten.

Volgens Peltzman heeft de invoering van de autoveiligheidsregulering niet geleid tot een toe- of afname van het totaal aantal verkeersslachtoffers. De daling van het aantal dodelijke verkeersslachtoffers onder inzittenden kan volgens Peltzman mogelijk het gevolg zijn van de ingevoerde autoveiligheidsregulering. In de berekeningen van Peltzman is ten aanzien van het aantal dodelijke verkeersslachtoffers onder nietinzittenden, voetgangers, sprake van een lichte stijging. ${ }^{1550}$

Met betrekking tot het aantal verkeersgewonden wordt door Peltzman betoogd dat binnen de gemaakte veronderstellingen een verschuiving zou moeten optreden van lichte naar emstige verkeersongevallen. Uit de letselschaderatio's voor inzittenden blijkt dat na invoering van de veiligheidsregulering sprake is van een lichte daling van het aantal slachtoffers. Daamaast is bewijs gevonden voor de stelling dat voetgangers, ten opzichte van de situatie waarin er geen veiligheidsregulering zou zijn, enstiger letsel oplopen tengevolge van een verkeersongeval met een motorvoertuig. Pelteman stelt echter dat deze cijfers niet het averechtse effect zijn van de autoveiligheidsregulering, aangezien de ongevalsdata veruit worden gedomineerd door het aantal inzittenden. ${ }^{1551}$

Met een aantal toetsingsvariabelen wordt door Peltzman de veronderstelling dat een beschermde autobestuurder een hoger ongevalsrisico voor derden vormt, verder uitgewerkt. Voor wat betreft de invloed van autoveiligheidsregulering op de gereden snelheid kon door Peltzman geen empirisch bewijs worden gevonden. Het aantal

1548. In het bijzonder wetgeving die in 1966 van kracht werd onder de The National Traffic and Motor Vehicle Safety Act'. Deze wetgeving had betrekking op veiligheidsstandaarden voor auto's, zoals de autoveiligheidsgordel, stuurbekrachtiging, verbeterde remsystemen, windschermen tegen bepaalde weersinvloeden en hoofdsteunen. Zie voor een overzicht hiervan: Peltzman, JPE, 1975, p. 678; Blomquist, Regulation of Motor Vehicle and Traffic Safety, p. 10-20 alsmede p.

1549. $56-74$ voor een empirisch overzicht van de effecten van deze wetgeving.

1550. Peltzman, JPE, 1975, p. 688-692.

1551 Peltzman, JPE, 1975 , p. 696-700.

Pelizman, JPE, 1975, p. 700-703. 
jonge autobestuurders (beneden de 25 jaar) is na 1965 sterk toegenomen. Deze stij. ging kan volgens Peltzman een mogelijke verklaring zijn voor de toename van het aantal slachtoffers onder voetgangers, waarvan blijkbaar vooral jonge autobestur. ders de oorzaak zijn. Ten aanzien van het alcoholgebruik is volgens de cijfers een sterk verband aanwezig met het verhoogde ongevalsrisico onder autobesturders. Daarbij wordt door Peltzman aangetekend dat de totale alcoholconsumptie na 1965 bijna is verdubbeld. Daar staat tegenover dat de controlemogelijkheden voor de poli. tie sterk zijn toegenomen. Ten slotte wordt door Peltzman met behulp van data uit Canada en de Amerikaanse staat North-Carolina geconcludeerd dat de nieuwere beveiligde automodellen bij meer verkeersongevallen zijn betrokken dan de oudere al. tomodellen zonder veiligheidsstandaarden. Dit kan volgens hem echter ook zijn ver. oorzaakt door het feit dat ongevallen waarbij oudere auto's zijn betrokken niet altijd worden aangemeld. ${ }^{1552}$

Naar aanleiding van zijn onderzoek wordt door Peltzman, uitgaande van de theorie van 'offsetting behavior', geconcludeerd dat veiligheidsregulering niet heeft geleid tot een vermindering van het aantal dodelijke verkeersslachtoffers. Het totaal aantal verkeersdoden is in de onderzochte periode ongewijzigd gebleven. Volgens hem is dit mede het gevolg van de ingevoerde autoveiligheidsregulering, hoewel een dirett verband door hem niet kon worden aangetoond. ${ }^{1553}$

In zijn onderzoek heeft Peltzman geen direct bewijs gevonden voor een verschuiving van het aantal verkeersslachtoffers onder inzittenden naar bijvoorbeeld voetgangers, waarvoor het ongevalsrisico zou zijn toegenomen. Verder had zijn onderzoek be. trekking op een periode waarin autoveiligheidsstandaarden net nieuw waren en er nog geen wetgeving (naast de airbag) was ingevoerd die bijvoorbeeld het dragen van de autoveiligheidsgordel verplicht stelde.

\subsection{ANDER EMPIRISCH ONDERZOEK NAAR 'OFFSETTING BEHAVIOUR'}

In een aantal, voomamelijk Amerikaanse, empirische studies worden in grote lijent de conclusies van Peltzman met betrekking tot 'offsetting behavior' ten gevolge ran de invoering van autoveiligheidsregulering, ondersteund. Daarbij wordt uitgegzan van de veronderstelling dat autobestuurders niet passief zullen blijven ten opzichte van veranderingen in hun rijomgeving. Een autobestuurder zal bijvoorbeeld met tent hogere snelheid rijden. Een tweede veronderstelling heeft betrekking op het gegeren dat, ten gevolge van de toegenomen veiligheid in de auto, het aantal verkerssslachtoffers onder niet-inzittenden, fietsers en voetgangers, zal stijgen. Anders gesteld, de beoogde opbrengsten van deze autoveiligheidsregulering zullen niet oppie- 
gen tegen de kosten ervan, namelijk een toename van het aantal verkeersslachtoffers onder niet-inzittenden. ${ }^{1554}$

Een deel van de studies claimt een geringe mate van 'offsetting behavior', waarbij het aantal verkeersslachtoffers onder inzittenden is gedaald, terwijl het aantal verkersslachtoffers onder niet-inzittenden is gestegen. ${ }^{1555}$ De daling van het aantal verkeersslachtoffers onder inzittenden wordt echter niet geheel gecompenseerd door een toename van het aantal slachtoffers onder fietsers en voetgangers. ${ }^{1556}$

In een aantal andere studies worden de effecten van de invoering van de airbag op respectievelijk het relatief aantal letselschadeclaims, het absoluut aantal verzekeringsclaims en het rijgedrag van de autobestuurder onderzocht. ${ }^{1557}$ Hieruit kan worden opgemaakt dat het relatief aantal letselschadeclaims ten aanzien van automodellen die zijn uitgerust met een airbag hoger was dan bij automodellen zonder een airbag maar met een autoveiligheidsgordel. Daarnaast blijkt dat bestuurders in de staat Virginia, waarvan in de auto een airbag was geïnstalleerd, een agressiever rijgedrag vertoonden dan bestuurders die geen airbag in hun auto hadden. De onderzoekers zien hierin een bevestiging van de theorie van 'offsetting behavior', die kan leiden tot een toename van het ongevalsrisico voor niet-inzittenden en voor inzittenden van andere auto's. ${ }^{1558}$

Ten slotte kan worden verwezen naar een studie waarin de effecten van een wettelijke draagplicht van de autoveiligheidsgordel in Nieuw-Zeeland worden getoetst aan de theorie van 'offsetting behavior'. ${ }^{1559}$ Daarbij wordt verondersteld dat een autobesturder met een autoveiligheidsgordel meer verkeersrisico's zal nemen, in casu met een hogere snelheid zal rijden. Garbacz komt naar aanleiding van zijn onderzoek tot

1554. Zie Chirinko and Harper Jr., J. Pol'y Anal. \& Mgmt, 1993, p. 270-296; Crandall and Graham, Am. Econ. Rev., 1984, p. 328-331; Peterson and Hoffer, Journal of Consumer Research, 1994, p. 657-662; Peterson, Hoffer and Millner, JLE, 1995, p. 251-264; Keeler, Am. Econ. Rev., 1994, p. 684-693. Zie ook Plaizier, Factoren die van invloed zijn op autogordelgebruik, p. 100-105.

1555. Chirinko and Harper, J. Pol'y Anal. \& Mgmt., 1993, p. 291-293. Voor hun onderzoek maken zij gebruik van ongevalsdata uit de periode 1947-1985.

1556. Crandall and Graham, Am. Econ. Rev., 1984, p. 328-331. Zij maken voor hun analyse gebruik van ongevalsdata uit de periode 1966-1981.

1557. Peterson and Hoffer, Joumal of Consumer Research, 1994, p. 657-662. Zij maken gebruik van onderzoeksdata met betrekking tot letselschadegegevens uit de jaren 1989-1991 ten aanzien van specifieke automodellen; Peterson, Hoffer and Millner, JLE, 1995, p. 251-264. Hierin worden onderzoeksdata geanalyseerd van de verzekeringsindustrie (automodeljaren 1990-1993) en van

1558. Peterson and Hoffer, Joumal of Consumer

Millner 1145.

1559. Garbacz, Economic Inquiry, 1991, p. 310-316. De onderzoeksdata hebben betrekking op de periade 1960-1985. 
de conclusie dat de wettelijke draagplicht van de autoveiligheidsgordel heeft geleid tot een daling van het aantal dodelijke verkeersslachtoffers onder inzittenden van een auto. Dit ging echter ten koste van een stijging van het aantal verkeersslachtof fers onder fietsers en voetgangers. De uitkomsten geven volgens Garbacz derhalve steun aan de theorie van 'offsetting behavior'. ${ }^{1560}$

\subsection{KRITIEK OP DE 'OFFSETTING BEHAVIOR'-THEORIE EN HET ONDERZOEK VAN PELTZMAN}

In de literatuur is ook kritiek geuit op de resultaten van het onderzoek van Peltuman en de daaraan ten grondslag liggende veronderstelling van 'offsetting behavior'. De. ze kritiek, die voor een deel aan de hand van empirisch onderzoek wordt uitgewerk, kan als volgt worden samengevat.

In een drietal studies wordt het empirisch model van Peltzman aangepast, waarbij voor een berekening van het aantal dodelijke verkeersslachtoffers per 100 miljoen automijlen in de periode 1965-1972 een wijziging wordt aangebracht in de toetsings. variabelen. ${ }^{1561}$ Het aantal jeugdige autobestuurders (15-25 jaar) wordt bijvoorbeld niet gerelateerd aan de totale bevolking in deze leeftijdscategorie, maar aan het aandeel van jonge autobestuurders in het totaal aantal dodelijke verkeersslachtoffers. ${ }^{152}$ Daarnaast word door Kelley aan Peltzman verweten dat hij te weinig rekening houdt met het gegeven dat slechts een klein percentage van de autobestuurder de autovelligheidsgordel ook daadwerkelijk gebruikte (11\% in 1980). Wanneer autobesturders geen autoveiligheidsgordel dragen, kan volgens Kelley moeilijk worden aange. toond dat de autoveiligheidsregulering de oorzaak is van een 'offsetting behavior' bij de autobestuurder. ${ }^{1563}$ Graham en Garber verwijten Peltzman onder andere dat tij

1560. Garbacz, Economic Inquiry, 1991, p. 314-316. Daamaast geven de berekeningen volgens hem een lager gebruik van de autoveiligheidsgordel aan dan eerder werd gemeld. Zie ook C. Garboch More Evidence on the Effectiveness of Seat Belt Laws, Applied Economics, 1992, p. 313-315. Hierin wordt geconcludeerd dat met betrekking tot de wettelijke draagplicht van de autovelig. heidsgordel de voordelen voor de inzittenden werden opgeheven ten koste van niet-inzittenden, waardoor het uiteindelijke effect op het totaal aantal verkeersslachtoffers nihil was.

1561. L.S. Robertson, A Critical Analysis of Peltzman's 'The Effects of Automobile Safety Regulation', Joumal of Economic Issues, 1977, p. 587-600, geciteerd in Blomquist, Regulation of Motor Vehicle and Safety Regulation, p. 60-61; Kelly, Law and Policy, 1984, p. 130-135; Graham and Garber, J. Pol'y Anal. \& Mgmt., 1984, p. 206-224. Dit laatste onderzoek heeft betrekking op de periode 1947-1980.

1562. Andere toetsingsvariabelen die in deze empirische studies worden meegenomen hebben berrk. king op de bevolkingsomvang, de gemiddelde snelheid, de verhouding tussen het aantal afgeleft de automijlen op stedelijke en landelijke autowegen, het aantal autobestuurders, de omvang vat het autopark, het alcoholgebruik, de leeftijd en het inkomen. Zie Kelley, Law and Policy, 1944 p. 137-138; Graham and Garber, J. Pol'y Anal. \& Mgmt., 1984, p. 210-215.

1563. Kelley, Law and Policy, 1984, p. 136-137. 
spreekt van een stijging van het aantal verkeersslachtoffers onder niet-inzittenden, zonder een onderscheid te maken tussen voetgangers, fietsers en passagiers. ${ }^{1564}$

De resultaten van deze studies wijzen, ten aanzien van de toepassing van autoveiligheidsregulering, op een daling van het totaal aantal dodelijke verkeersslachtoffers (19\%). Daamaast is sprake van een afname van het aantal dodelijke verkeersslachtoffers onder zowel inzittenden (17-29\%) als onder voetgangers (16\%). ${ }^{1565}$ Graham and Garber hebben voor het jaar 1980 berekend dat mede tengevolge van de invoering van de wettelijke draagplicht van de autoveiligheidsgordel het aantal dodelijke verkeersslachtoffers met 11.000 tot 20.000 is verminderd. ${ }^{1566}$

Door Kelley wordt overigens erkend dat de uitkomsten van zijn onderzoek, evenals die van Peltzman en Robertson, voornamelijk zijn gebaseerd op empirische voorspellingen. Volgens hem zullen praktijkstudies noodzakelijk zijn om de werkelijke effecten van autoveiligheidsregulering te kunnen evalueren. Deze effecten zullen moeten bepalen wat er bijvoorbeeld precies gebeurt wanneer individuen in veiliger auto's rijden. ${ }^{1567}$

Met betrekking tot dit laatste kan worden verwezen naar een onderzoek waarin aan de hand van een individuele gedragsobservatie een verband wordt aangetoond tussen de bescherming van de autoveiligheidsgordel en het rijgedrag. ${ }^{1568}$ Daarbij wordt verondersteld dat de vraag of een autobestuurder zijn gedrag zal wijzigen onder bescherming van een autoveiligheidsgordel, afhankelijk is van zijn houding ten aanzien van risico. Singh en Thayer selecteren, niet geheel representatief voor de totale bevolking, een aantal individuele autobestuurders, waarvan een meerderheid een afkeer beeft van risico, een deel neutraal staat ten opzichte van het risico en een deel als risicozoekend kan worden beschouwd. Verder wordt voor de toetsing van een mogelijk 'offsetting behavior' gebruik gemaakt van het aantal verkeersovertredingen in de afgelopen drie jaar. Wanneer een bestuurder immers meer risico's neemt zal dit volgens Singh en Thayer tot uitdrukking moeten komen in een toename van het aantal verkeersovertredingen. ${ }^{1569} \mathrm{De}$ resultaten van hun onderzoek wijzen uit dat de risicozoekende bestuurders, in verhouding tot hun risicoaverse en risiconeutrale col-

\footnotetext{
1564. Graham and Garber, J. Pol'y Anal. \& Mgmt., 1984, p. 207.

1565. Robertson, Joumal of Economic Issues, 1977, in Kelley, Law and Policy, 1984, p. 134-135 en Blomquist, Regulation of Motor Vehicle and Traftic Safety, p. 60 en 70; Kelley, Law and Policy, 1984, p. 137-141.

1566. Graham and Garber, J. Pol'y Anal. \& Mgmt., 1984, p. 217-220.
1567. Kelley, Law and Policy, 1984, p. 137-142.

1568. Singh and Thayer, Economic Inquiry, 1992, p. 649-658. 'Offsetting behaviour' wordt door hen

1569. aangeduid als 'compensating-behaviour hypothesis'

Singh and Thayer, Economic Inquiry, 1992, p. 649-650. Andere individuele toetsingsvariabelen hebben betrekking op het aantal jaren dat een autoveiligheidsgordel wordt gedragen, de leeftijd, de afstand tot het werk, het opleidingsniveau, het geslacht en het inkomen.
} 
lega's, meer verkeersovertredingen begingen en in minder gevallen hun autoveiligheidsgordel droegen. Singh en Thayer concluderen daarom dat een 'offsetting be. havior' voornamelijk van toepassing zal zijn op individuele autobestuurders die geen sterke afkeer van risico hebben. Bij individuele autobestuurders die sterk risicoavers zijn is het dragen van de autoveiligheidsgordel eerder synoniem voor minder ver. keersovertredingen. ${ }^{1570}$

Naast de hiervoor besproken empirische studies wordt door een aantal wetenschap pers ook anderszins kritiek geuit op de bevindingen van Peltzman. Evans is bijvoor. beeld van mening dat het gebruik van ongevalsdata ten bewijze van een 'offsetting behavior' niet het juiste uitgangspunt is. Ten aanzien van de gevolgen van een ver. keersongeval bestaan volgens hem grote verschillen voor wat betreft letsel-, zaak- of overlijdensschade. Daarnaast kan worden gesteld dat autobestuurders gemiddelde risico's nemen die zich zowel in de tijd als onder invloed van bijvoorbeeld de rjomgeving of de vorm van de verkeerskruising kunnen wijzigen. ${ }^{1571}$ Dit betekent vol. gens Evans dat het aantal slachtoffers gemeten naar tijdseenheid of afstand in sommige gevallen afneemt en in andere gevallen zal stijgen. ${ }^{1572}$

Evans ontkent overigens niet dat het gedrag van een autobestuurder wordt beïnloed door de autoveiligheidsregulering, maar dit zal zijns inziens eerder tot een positieve gedragswijziging leiden. Daarbij wordt door hem verwezen naar een onderzoek waarin de effecten van de autoveiligheidsgordel op het gedrag van de autobesturder in de Canadese provincie Ontario (wettelijke draagplicht, gebruikersratio $51 \%$ ) en in de Amerikaanse staat Michigan (geen wettelijke draagplicht, gebruikersratio 14\%) werden berekend. Uit dit onderzoek bleek dat juist de autobestuurders die geen autoveiligheidsgordel droegen meer risico's namen in het verkeer. ${ }^{1573}$

Jonah en Lawson tenslotte, hebben berekend dat, als gevolg van de invoering van de wettelijke draagplicht van de autoveiligheidsgordel, het aantal verkeersslachtoffers met gemiddeld $50-60 \%$ is gedaald. ${ }^{1574}$ Wanneer sprake is van 'offsetting behavio' zal een autobestuurder derhalve een toegenomen betrokkenheid bij verkeersongevallen moeten vertonen van 50-60\%. Dit is volgens Jonah en Lawson een weinig realistische veronderstelling. Een ander probleem bij 'offsetting behavior' is het gebrek aan experimenteel bewijs dat bestuurders met een veiliger auto in het verkeer ook

1570. Singh and Thayer, Economic Inquiry, 1992, p. 654-658.

1571. Uit het onderzoek van Singh en Thayer, Economic Inquiry, 1992, p. 658, blijkt bijvoorbeeld dat een 'offsetting behavior' van de individuele autobestuurder in de tijd gemeten zal verminderan.

1572. Evans, Traffic Safety and the Driver, p. 299-304. Zie ook Lund and O'Neill, Ac. An. \& Prev, 1986, p. 367-370.

1573. L. Evans, P. Wasielewski and C.R. von Buseck, Compulsory Seat Belt Usage and Driver RiskTaking Behavior, Human Factors, 1982, p. $41-48$, in Evans, Traffic Safety and the Driver, P. 273-274.

1574. Jonah and Lawson, Ac. An. \& Prev., 1984, p. 448. Zie ook paragraaf 2.2 .1 van dit hoofdstuk. 
werkelijk meer risico's nemen. Jonah en Lawson menen dat een autobestuurder in het verkeer niet de ene risicoactiviteit inruilt voor een andere, maar bij zijn verkeersdeelname, naast het niet-dragen van de autoveiligheidsgordel, eerder te maken heef met een groot aantal risicofactoren, zoals snelheid, het rijden onder invloed en het onvoldoende afstand houden. ${ }^{1575}$

\subsection{CONCLUSIE: AUTOVEILIGHEIDSREGULERING}

Naar aanleiding van de gepresenteerde onderzoeksresultaten kan worden geconcludeerd dat de effecten van de autoveiligheidsregulering op het verkeersgedrag in bepaalde opzichten tegenstrijdig zijn. De meeste studies zijn het eens over het feit dat de autoveiligheidsregulering in Noord-Amerika de veiligheid van de inzittenden van een auto verhoogt. Het aantal dodelijke verkeersslachtoffers onder inzittenden is sinds de invoering van de autoveiligheidswetgeving ook gedaald, evenals het totaal aantal dodelijke verkeersslachtoffers.

De discussie in de literatuur spitst zich vooral toe op de vraag of de verhoogde veiligheid van de autobestuurder leidt tot een 'offsetting behavior', waarbij een autobesturder meer risico's neemt in het verkeer en daardoor het aantal verkeersslachtoffers onder niet-inzittenden toeneemt. Ten aanzien van deze categorie wordt in het empirisch onderzoek echter nauwelijks onderscheid gemaakt tussen voetgangers, fietsers en passagiers. De tegenstrijdigheid in de onderzoeksresultaten is verder het gevolg van de toepassing van een breed scala aan ongevalsdata, waarbij in de empinische studies steeds verschillende toetsingsvariabelen worden gebruikt. In de woorden van Evans:

There are so many choices of variables and of transformations at the discretion of the analyst that the detached reader rarely has any way of knowing whether the analysis is performed to discover new information or to buttress prior belief. The reader cannot generally check the calculation, or get a clear sense of the origin of the claimed effects'. ${ }^{1576}$

Graham and Garber stellen daarnaast dat beleidsmakers vaak worden geconfronteerd met een moeilijke taak, namelijk het juist interpreteren van statistische uitkomsten:

The nature of statistical results that are presented to the policymaker can depend substantially on the views of the statistical analyst concerning how the world works'. ${ }^{1577}$

1576. Jonah and Lawson, Ac. An. \& Prev., 1984, p. 448. Zie ook paragraaf 3.1 van hoofdstuk 9

1577. Evans, Traffic Safety and the Driver, p. 83.
}

1577. Graham and Garber, J. Pol'y Anal. \& Mgmt., 1984, p. 206 
Ten slotte kan worden gesteld dat de hypothese van 'offsetting behavior' niet daadwerkelijk empirisch wordt bewezen. De studies dienaangaande zijn voomamelijk gebaseerd op ongevalsdata en besteden weinig aandacht aan het gedrag van de auto. bestuurder zelf. Daarnaast blijkt dat de empirische resultaten vooral zijn gebasserd op schattingen. Een onderzoek dat meer specifiek de gevolgen van autoveiligheids. regulering op het verkeersgedrag analyseert, komt tot de conclusie dat met name autobestuurders die een voorkeur hebben voor risico hun verkeersgedrag wezedijk zullen wijzigen. Deze groep autobestuurders vormt echter al een hoog ongevalsrisi$\mathrm{co}$, zodat een veiliger auto vermoedelijk geen grote invloed zal hebben op hun rijgedrag. ${ }^{1578}$

\section{Alcohol en verkeersongevallen}

In deze paragraaf zal een volgend beleidsaspect van veiligheidsregulering aan bod komen, namelijk de invloed van alcohol op het ongevalsrisico en de preventie van verkeersongevallen. Daarbij zal de vraag centraal staan welk effect overheidsmaatregelen kunnen hebben op het rijden onder invloed en op het aantal verkeersongevallen.

In paragraaf 4.1 wordt een kwantitatief overzicht gegeven van de invloed van he al. coholgebruik op het ongevalsrisico. Vervolgens zal de aandacht uitgaan naar de ef. fecten van bepaalde overheidsmaatregelen die het alcoholgebruik in het verkee terugdringen. Daarbij kan een onderscheid worden gemaakt tussen een preventiebleid en een controlebeleid. ${ }^{1579}$ Met betrekking tot het preventiebeleid zullen in paragaaf 4.2 de effecten van administratieve en strafrechtelijke sancties op het antal verkeersongevallen worden onderzocht. In paragraaf 4.3 ligt de nadruk op een anayse van het controlebeleid, waarbij factoren zoals de prijs van alcohol en de toepasing van een minimumleeftijd voor het gebruik van alcohol aan de orde komen.

\subsection{ALCOHOLGEBRUIK EN ONGEVALSRISICO}

Volgens Evans ${ }^{1580}$ komt de invloed van alcohol op de verkeersveiligheid voora tot uiting in een verhoging van het ongevalsrisico. Het risico van letselschade tengerol. ge van een verkeersongeval stijgt daarbij met een toename van de alcoholconsumptie. Evans verwijst naar een onderzoek met betrekking tot de Amerikaanse saat North-Carolina waarin een verband wordt aangetoond tussen het alcoholgebruil en het ongevalsrisico. ${ }^{1581} \mathrm{De}$ algemene conclusie van dit onderzoek is dat een autobe-

1578. Singh and Thayer, Economic Inquiry, 1992, p. 649-658.

1579. Zie Kenkel, JLE, 1993, p. 877-913.

1580. Evans, Traffic Safety and the Driver, p. 163 en 170.

1581. P.F. Waller, J.R. Stewart, A.R. Hansen, J.C. Stutts, C.L. Popkin and E.A. Rodgman, The Pitentiating Effects of Alcohol on Driver Injury, Journal of the American Medical Association, 1986, 
stuurder die onder invloed van alcohol verkeerde bijna 4 maal zoveel kans had om dodelijk slachtoffer te worden van een verkeersongeval als een bestuurder die geen alcohol tot zich had genomen. ${ }^{1582}$

Het verband tussen alcoholgebruik en ongevalsrisico komt verder tot uitdrukking in de ongevalsstatistieken. Hieruit kan informatie worden geput ten aanzien van het antal verkeersongevallen waarbij sprake is van alcoholgebruik. Volgens Dewees, Duff en Trebilcock geldt echter dat alcohol niet in alle gevallen de belangrijkste oorzaak is van een verkeersongeval:

Traffic accidents are the result of many interactive conditions, and the most effective means of prevention is not always one that addresses the primary causal determinant of the accident'. ${ }^{1583}$

In een onderzoek uit 1987 wordt door Evans de rol van alcohol bij verkeersongevallen met dodelijke afloop geanalyseerd, waarbij de ongevalsdata betrekking hebben op 26 Amerikaanse staten. ${ }^{1584}$ Ten aanzien van de 26 staten gezamenlijk bleek dat in $49 \%$ van het totaal aantal verkeersdoden sprake was van alcoholgebruik. Voor heel Noord-Amerika wordt door Evans een percentage van 46,7\% berekend. Dit betekent volgens Evans dat wanneer alcohol de enige oorzaak is van het verkeersongeval en het alcoholgebruik geheel verdwijnt, het aantal verkeersdoden in NoordAmerika met 46,7\% kan verminderen. Dit komt voor het jaar 1987 overeen met een afname van het aantal verkeersdoden met 22.000 op een totaal van 46.000 . $^{1585}$

\subsection{DE PREVENTIE VAN ALCOHOLGEBRUIK IN HET VERKEER}

Naar aanleiding van het voorgaande rijst de vraag welke overheidsmaatregelen het njden onder invloed en daarmee het aantal verkeersongevallen kan terugdringen. In de rechtseconomische en medische literatuur is ruime aandacht besteed aan beleidsmaatregelen die het aantal alcoholgerelateerde verkeersongevallen kunnen verminderen. ${ }^{1586}$ Deze instrumenten kunnen globaal worden onderverdeeld in een preven-

p. 1461-1466, in Evans, Traffic Safety and the Driver, p. 170-171. De ongevalsdata in dit onderzoek hebben betrekking op de periode 1979-1983 en omvatten een analyse van politierapporten, medische dossiers bij overleden bestuurders, en een eigen onderzoek onder bestuurders met een objectief gemeten alcoholpromillage.

1582. Waller, Stewart, Hansen, Stutts, Popkin and Rodgman, Joumal of the American Medical Association, 1986 in Evans, Traffic Safety and the Driver, p. 171

1583. Dewees, Duff and Trebilcock, Accident Law, p. 81, noot 311 .

1534. L. Evans, The Fraction of Traffic Fatalities Attributable to Alcohol, Ac. An. \& Prev., 1990, p. 587-602 in Evans, Traffic Safety and the Driver, p. 183-187.

1595. Evans, Traffic Safety and the Driver, p. 186.
1586. National Highway Traffic

of the State of Traffic Safety Administration, Alcohol and Highway Safety 1984: A Review of the State of the Knowledge. Document DOT-HS-806-569. Washington DC, 1985 in Evans, 
tiebeleid en een controlebeleid. Binnen het preventiebeleid dat hier aan de orde is worden voornamelijk strafrechtelijke en administratieve sancties opgelegd, zoals een administratieve ontzegging van de rijbevoegdheid, een gevangenisstraf en boetes. Daarnaast speelt bij deze vorm van beleid de preventieve ademanalyse ten behoeve van de bepaling van het alcoholgebruik een rol. Dit instrument zal eerst apart worden behandeld. ${ }^{1587}$

\section{4,2.1. De ademanalysetest}

$\mathrm{Na}$ de ontdekking van technieken om het alcoholpercentage in het bloed van een au. tobestuurder te kunnen meten, is in de meeste Westerse landen overgegaan tot de invoering van zogenaamde 'per-se' wetgeving. ${ }^{1588}$ Daarmee kon het rijden onder invloed strafbaar worden gesteld indien het bloed-alcohol percentage (BAC) een bepaalde wettelijke limiet overschrijdt. Met behulp van een ademanalyse wordt vastge. steld of een autobestuurder alcohol heeft genuttigd. Vervolgens dient door middel van een bloedproef het juiste alcoholpercentage te worden vastgesteld om de bestuurder ook daadwerkelijk te kunnen vervolgen. In een aantal studies worden de effecten van deze administratieve wetgeving op het aantal verkeersslachtoffers geans. lyseerd. ${ }^{1589}$

Uit een onderzoek naar de effecten van de 'per-se' wetgeving in Engeland ${ }^{159}$ blijk dat tussen 1966 en 1970 het aantal verkeersdoden en gewonden in Engeland en Wales tijdens de nachtelijke uren van het weekend met $66 \%$ was afgenomen. ${ }^{1591}$ In Canada ${ }^{1592}$ was het effect van de 'per-se' wetgeving op het aantal verkeersslachtoffers

Traffic Safety and the Driver, p. 162. In het betreffende rapport worden 550 technische studis aangaande het verband tussen alcohol en autorijden geciteerd.

1587. Zie Kenkel, JLE, 1993, p. 877-9I3.

1588. Noorwegen was in 1936 het eerste rechtsgebied waarin deze wetgeving werd ingevoerd. Hiema volgden Zweden en Denemarken, terwijl aan het eind van de jaren '60 in ondere andere Canada en Groot-Brittanië 'per-se' wetgeving werd ingevoerd. In 1990 was in 45 Amerikaanse staten th de 'District of Columbia' sprake van 'per-se' wetgeving, waarbij het toegestane alcoholpromillage uiteenliep van 0,08-0,12\%. Zie voor een overzicht Evans, Traffic Safety and the Driver, p. 193194. In Nederland werd in 1974 een toegestaan alcoholpromillage van $0,05 \%$ in de Wegenver. keerswet (art. 26 lid 2 WVW oud) opgenomen. In 1987 werd in Nederland de ademanalyse als wettig bewijsmiddel ingevoerd. Zie daarover: Polak, Inleiding tot het wegenverkeersecht, $h \mathrm{p}$. 51-56 en III, p. 53-54; WVW 1994, Commentaar, art. 8, p. 3-4.

1589. Evans, Traffic Safety and the Driver, p. 192-193; Dewees, Duff and Trebilcock, Accident Law, p. $46-47$.

1590. Deze regeling werd in 1967 samen met de 'British Road Safety Act' ingevoerd, waarbij een toe gestaan alcoholpromillage gold van $0,08 \%$.

1591. H.L. Ross, Deterring the Drinking Driver, Lexington, MA, Lexington Books, 1984, p. 30, in Evans, Traffic Safety and the Driver, p. 193.

1592. In 1969 werd hier in navolging van de Britse wetgeving The Canadian Criminal Law Amendment Act' ingevoerd, waarin een toegestaan alcoholpromillage van $0,08 \%$ was opgenomen. 
minder groot. Dit is volgens Evans vermoedelijk het gevolg van het feit dat aan deze wetgeving minder publiciteit werd gegeven en ook de sancties op een overtreding daarvan niet werden aangescherpt. ${ }^{1593}$

In de Australische provincie New South Wales is in 1982, samen met een uitgebride publiciteitscampagne, de ademanalysetest ingevoerd. Met behulp van deze wetgeving werden, op een autodichtheid van ruim 3 miljoen, jaarlijks meer dan 1 miljoen alcoholcontroles verricht. Een empirisch onderzoek naar de effecten van deze vorm van alcoholcontrole wijst uit dat het aantal dodelijke verkeersslachtoffers in de periode 1979-1986 afnam met gemiddeld 19\% per maand. Het aantal dodelijke verkersongevallen waarbij alcohol in het geding was, daalde in dezelfde periode van $28 \%$ naar $22 \%{ }^{1594}$

Ten slotte kan nog worden gewezen op een Amerikaans onderzoek waarin de preventieve werking van de ademanalysewetgeving in de periode 1980-1985 empirisch is getoetst. ${ }^{1595}$ Daarbij wordt gebruik gemaakt van een groot aantal toetsingsvariabelen, waaronder het aantal verkeersdoden per 100.000 inwoners tussen middernacht en 4 uur's morgens, het aantal verkeersdoden in de leeftijdscategorie 15-24 jaar, het aantal afgelegde automijlen, de gemiddelde snelheid, inkomen en de accijns op bier. De empirische gegevens tonen aan dat de invoering van een ademanalysetest een preventief effect heeft gehad op het rijden onder invloed. Volgens een schatting van Saffer en Chaloupka kan, wanneer alle Amerikaanse staten een ademanalysewetgeving zouden invoeren, voor het jaar 1985 het aantal verkeersdoden met ruim 2000 worden verminderd. Dit betekent een relatieve daling van het aantal dodelijke verkeersslachtoffers met $4,5 \%$ op een totaal van 43982 verkeersdoden in 1985 . $^{1596}$

Volgens een aantal auteurs dienen de uitkomsten van de voomoemde studies enigszins te worden genuanceerd. In de eerste plaats kan volgens Evans een deel van de daling van het aantal verkeersslachtoffers ook door andere factoren zijn beïnvloed. De toegenomen pakkans ten aanzien van de preventieve ademanalyse in New South Wales, kan volgens Evans ook van invloed zijn op andere verkeersgedragingen die tot een dodelijke verkeersongeval leiden. Daarnaast kunnen bepaalde autobestuur-

1593. H.L. Ross, Deterrence-Based Policies in Britain, Canada and Australia, in Social Control of the Drinking Driver, Laurence, Snorum and Zinring (eds.), Chicago, University of Chicago Press, 1988, p. 64-78 geciteerd in Evans, Traffic Safety and the Driver, p. 193-194.

1594. Roads and Traffic Authority, Road Traffic Accidents in New South Wales 1988, Rosebury, Road Safety Bureau, 1989, p. 21 in Evans, Traffic Safety and the Driver, p. 195.

1595. Saffer and Chaloupka, Applied Economics, 1989, p. 901-912. De ongevalsdata van dit onderzoek zijn afkomstig uit 48 Amerikaanse staten.

15\%. Safter and Chaloupka, Applied Economics, 1989, p. 910. Zie ook Chaloupka, Saffer and Gossman, JLS, 1993, p. 179. Zij komen ten aanzien van de ademanalysewetgeving, tot een vermindering van het aantal dodelijke verkeersslachtoffers met $3,4 \%$, waarvan $20 \%$ voor rekening komt van de leeftijdscategorie 18-20 jaar. 
ders, bijvoorbeeld degene die een hoog ongevalsrisico vormen, besluiten om hun ac. tiviteitsniveau te verlagen door minder vaak aan het verkeer deel te nemen. ${ }^{159}$

In de tweede plaats zal de daling van het aantal verkeersslachtoffers, tengevolge van de ademanalysewetgeving, slechts een tijdelijk effect hebben. Naarmate de invoe. ring meer geschiedenis wordt, lijkt zich weer een stijging van het aantal verkeerson. gevallen voor te doen, omdat bestuurders ontdekken dat de pakkans gering is. ${ }^{1598}$ Onderzoek heeft bijvoorbeeld uitgewezen dat een autobestuurder een kans heef van 1 op 500-2000 uitstapjes om na het gebruik van alcohol te worden aangehouden. ${ }^{159}$

In de derde plaats bestaat in het algemeen twijfel over het effect van alcoholcontroles en de daarmee verbonden sancties op het aantal verkeersongevallen. Sommige studies suggereren dat de pakkans voor het rijden onder invloed kan worden verhoogd zonder dat dit enig effect heeft op het aantal alcoholgerelateerde verkeerson. gevallen. Een onderzoek in de Amerikaanse stad Phoenix wijst bijvoorbeeld uit dat waar het aantal aanhoudingen met $60 \%-75 \%$ werd verhoogd, slechts $29 \%$ van de autobestuurders geloofde dat de pakkans voor het rijden onder invloed hoog was. ${ }^{1600}$

\subsubsection{Het effect van administratieve en strafrechtelijke sancties}

Uit het voorgaande kan worden opgemaakt dat onder omstandigheden een preventieve ademanalyse tot een afname van het rijden onder invloed en tot een daling van het aantal verkeersslachtoffers kan leiden. Verder is gebleken dat voor het effectief gebruik van de ademanalysetest een reële pakkans voor de autobestuurder aanwerig moet zijn. Daarnaast dienen ook de sancties op overtreding van de 'per-se' wetgeving hoog genoeg te zijn om een optimaal preventief effect te kunnen genereren. In deze subparagraaf zal aandacht worden besteed aan de effectiviteit van strafrechtelijke en administratieve sancties op het rijden onder invloed en op het aantal verkeers. ongevallen. Deze sancties bestaan veelal uit boetes, een gevangenisstraf of een ontzegging van de rijbevoegdheid. In de meeste empirische studies die hierna aan bod komen worden de effecten van deze sancties veelal in samenhang met andere be leidsmaatregelen onderzocht, die eveneens tot doel hebben om het rijden onder itvloed te verminderen.

1597. Evans, Traffic Safety and the Driver, p. 193-196; Dewees, Duff and Trebilcock, Accident Law; p. 47 en $82-83$.

1598. Evans, Traffic Safety and the Driver, p. 197-198; Bruce, Law and Policy, 1984, p. 82-83; HL Ross, Law, Science and Accidents; The British Road Safety Act of 1967, JLS, 1973, p. 1 in Dewees, Duff and Trebilcock, Accident Law, p. 47 en 82, noot 316.

1599. Leban, The Canadian Drinking Driving Countermeasure Experience, Ac. An. \& Prev., 1987, P 159 en 164 in Dewees, Duff and Trebilcock, Accident Law, p. 47 en 82, noot 318.

1600. T. Clay and P. Swenson, Selective Enforcement of Drunken Driving in Phoenix, Arizona, Jour nal of Safety Research, 1978, p. 130 en 136 in Dewees, Duff and Trebilcock, Accident Law, P 47 en p. 82 noot 317. 
In een aantal Amerikaanse studies is onderzoek gedaan naar de effecten van boetes, gevangenisstraf en een ontzegging van de rijbevoegdheid op het rijden onder invloed en op aantal dodelijke verkeersongevallen. ${ }^{1601}$

Met betrekking tot het effect van boetes is door Chaloupka, Saffer en Grossman ${ }^{1602}$ een lichte daling $(-3,3 \%)$ van het aantal dodelijke verkeersongevallen vastgesteld bij een boete van $\$ 500 .^{1603}$ Wilkinson heeft berekend dat een boete van $\$ 100$ voor een eerste overtreding een miniem effect $(-0,08 \%)$ heeft op het aantal dodelijke verkeersongevallen. ${ }^{1604}$

Uit de studies van Chaloupka, Saffer en Grossman en die van Wilkinson blijkt dat het opleggen van een gevangenisstraf als zodanig voor het rijden onder invloed niet heeft geleid tot een daling van het aantal dodelijke verkeersongevallen. ${ }^{1605}$ Sloan, Reilly en Schenzler daarentegen constateren dat het opleggen van een gevangenisstraf voor een eerste overtreding kan leiden tot een vermindering van het aantal dodelijke verkeersongevallen onder met name oudere autobestuurders (25-64 jaar). ${ }^{1606}$

1601. Chaloupka, Saffer and Grossman, JLS, 1993, p. 161-186; Kenkel, JLE, 1993, p. 877-913; Wilkinson, Southem Econ. J., 1987, p. 322-334; Sloan, Reilly and Schenzler, IRLE, 1994, p. 53-71.

1602. Chaloupka, Saffer and Grossman, JLS, 1993, p. 164-171. Zij maken bij hun analyse gebruik van ongevalsdata uit 48 Amerikaanse staten in de periode 1982-1988. De toetsingsvariabelen binnen het model hebben onder andere betrekking op het aantal dodelijke verkeersongevallen tussen middemacht en 4 uur 's morgens, de maximumsnelheid, het aantal afgelegde automijlen, het aantal autobestuurders beneden de 25 jaar en het gebruik van de autoveiligheidsgordel.

1603. Bij alcohol-gerelateerde ongevallen bedroeg de procentuele afname zelfs $19 \%$. Zie Chaloupka, Saffer and Grossman, JLS, 1993, p. 180. In 1988 kon in 16 staten een boete worden opgelegd voor het rijden onder invloed, variërend van $\$ 50-\$ 500$. Zie Chaloupka, Saffer and Grossman, ILS, 1993, p. 168.

1604. Wilkinson, Southem Econ. J., 1987, p. 328-329. De data in dit onderzoek zijn afkomstig uit 50 Amerikaanse staten en hebben betrekking op 221 observaties in de periode 1976-1980. Voor het impinsch model worden een groot aantal toetsingsvariabelen gebruikt, waaronder het aantal dodelijke verkeersongevallen, de alcoholconsumptie, het aantal afgelegde automijlen binnen en buiten de bebouwde kom, de prijs van alcohol, de snelheid en het inkomen.

100 5. Wilkinson, Southem Econ. J., 1987, p. 324-326; Chaloupka, Saffer and Grossman, JLS, 1993, p. 168 en p. 180-182. Zij tekenen hierbij aan dat in 15 Amerikaanse staten een gevangenisstraf kon worden opgelegd, waarvan de omvang slechts 1 tot 3 dagen bedroeg. Wanneer deze sanctie zwaarder zou zijn, kan volgens hen wel een preventief effect ten aanzien van het rijden onder invloed worden bereikt.

1606. Sloan, Reilly and Schenzler, IRLE, 1994, p. 61, 67 en 69. Het betreft hier een omvangrijk empirisch onderzoek naar de effecten van een groot aantal beleidsmaatregelen met betrekking tot de verkeersaansprakelijkheid, waarbij een onderscheid wordt gemaakt naar aansprakelijkheid, verzekering en veiligheidsregulering. De data in dit onderzoek hebben betrekking op de periode 1982-1990. De toetsingsvariabelen omvatten onder andere het aantal dodelijke verkeersongevallen per 1000 inwoners, waarbij onderscheid wordt gemaakt naar drie leeftijdscategorieesn, namelijk 18-20 jaar, 21-24 jaar en 25-64 jaar. 
Kenkel ${ }^{1607}$ heeft berekend wat de invloed is van een gevangenisstraf bij een eerste overtreding op het rijden onder invloed, maar concludeert dat het preventieve effect minimaal is. ${ }^{1608}$

In de meeste studies wordt gesteld dat een ontzegging van de rijbevoegdheid zal lei. den tot een afname van het rijden onder invloed ${ }^{1609}$ en tot een vermindering van het aantal dodelijke verkeersongevallen. ${ }^{1610}$ Naar aanleiding van hun onderzoek wordt door een aantal auteurs ten slotte geconcludeerd dat ook een aanscherping van het preventiebeleid, in casu een verhoging van de pakkans, bet rijden onder invloed en het aantal (alcoholgerelateerde) verkeersongevallen verder kan verminderen. ${ }^{1611}$

\subsection{HET CONTROLEBELEID TEN AANZIEN VAN HET RIJDEN ONDER INVLOED}

Naast het hiervoor beschreven preventiebeleid kan de overheid ook gebruik maken van controlemaatregelen om het alcoholgebruik te reduceren. Dit controlebeleid omvat onder andere fiscale maatregelen, zoals een verhoging van de prijs (accijns) van alcohol, maar ook wetgeving waarmee de overheid kan trachten het alcoholgebruik ten aanzien van bepaalde groepen in de samenleving te sturen. Binnen de empirische literatuur die hier aan de orde zal komen, wordt niet alleen onderzoek gedaan naar de effecten van het controlebeleid op het alcoholgebruik, maar word ook gekeken naar de gevolgen ervan voor het aantal verkeersongevallen. Dit betekent dat binnen het controlebeleid ook een preventief element ligt besloten. In paragraaf 4.3.1 zal aandacht worden besteed aan het verband tussen de prijs van alcohol en het aantal verkeersongevallen. In paragraaf 4.3.2 wordt ingegaan op de vraag of

1607. Kenkel, JLE, 1993, p. 884-888. Zijn onderzoek richt zich op de effecten van 'The Alcohol Traffic Safety Act' uit 1983 en 'The Federal Uniform Drinking Age Act uit 1984. De data werden verzameld met behulp van de 'The Health Interview Survey' uit 1985, die individueel gerichte enquetegegevens bevat over de bevolking in de Verenigde Staten. Het empirisch onderzoek heef in totaal betrekking op 28.000 personen, onderscheiden naas mannen en vrouwen. De toetsingvariabelen omvatten de omvang van het alcoholgebruik en het aantal malen dat onder invioed van alcohol aan het verkeer werd deelgenomen.

1608. Kenkel, JLE, 1993, p. 891.

1609. Kenkel, JLE, 1993, p. 891.

1610. Chaloupka, Saffer and Grossman, JLS, 1993, p. 166-168 en p. 176-180. De verplichte ontees. ging van de rijbevoegdheid voor 1 jaar leidt tot een daling van het aantal alcohol-gerelaterente ongevallen met 6\%. Sloan, Reilly and Schenzler, IRLE, 1994, p. 64 en 67. Zij stellen dat het elfect van de verplichte rijontzegging groter is bij jongere autobestuurders (18-24 jarr) dan bij ow dere autobestuurders (25-64 jaar).

1611. Kenkel, JLE, 1993, p. 896-897 en 904. Volgens hem zal het rijden onder invloed met naar scht: ting $20 \%$ kunnen verminderen. Zie ook Wilkinson, Southern Econ. J., 1987, p. 324-330; Slome Reilly and Schenzler, IRLE, 1994, p. 69. Young and Likens, IRLE, 2000, p. 107-126, conciude ren naar aanleiding van hun onderzoek dat administratieve en strafrechtelijke sancties allenen fect hebben bij een substantieel hoge pakkans. Zie daarover Benson, Rasmussen and MAsh $\mathbb{R}$. LE, 1999, p. 205-225. 
een toepassing van een minimumleeftijd voor de consumptie van alcohol van invoed is op het alcoholgebruik en de preventie van verkeersongevallen.

4.3.1. De prijs van alcohol en verkeersongevallen

Ten behoeve van een controle van het alcoholgebruik kan de overheid in de eerste plaats de prijs van alcohol (accijns) verhogen. In een aantal studies is onderzocht welk effect deze maatregel heeft op de vraag naar alcohol, het rijden onder invloed en het aantal verkeersongevallen.

In het eerder genoemde onderzoek van Kenkel ${ }^{1612}$ wordt berekend wat de gevolgen zijn van een verhoging van de accijns op alcohol voor de vraag naar alcohol en het rijden onder invloed. Daaruit blijkt dat bij een toename van de accijns met $10 \%$ de vraag naar alcoholconsumpties met ongeveer $8 \%$ kan dalen. Ten aanzien van een vermindering van het rijden onder invloed wordt door Kenkel een vergelijkbaar percentage berekend. ${ }^{1613}$

In een aantal empirische studies is daarnaast onderzoek gedaan naar de gevolgen van een verhoging van de accijns voor het aantal verkeersongevallen. ${ }^{1614}$ Daarbij ligt veelal de nadruk op de leeftijdscategorie 15-24 jaar, omdat uit de ongevalsstatistieken blijkt dat jongeren naar verhouding bij veel alcoholgerelateerde verkeersongevallen. ${ }^{615}$ Uit de studies van Saffer en Grossman ${ }^{1616}$ blijkt dat een verhoging van de accijns indirect kan leiden tot een vermindering van het aantal verkeersongevallen. In het ene onderzoek worden de jongeren in drie leeftijdscategorieën onderverdeeld, namelijk 15-17 jaar, 18-20 jaar en 21-24 jaar. Een verhoging van de accijns op bier met $100 \%$ leidt dan tot een vermindering van het aantal dodelijke verkeersslachtoffers met $18 \%$ in de categorie $15-17$ jaar, met $27 \%$ in de categorie $18-20$ jaar $^{1617}$ en

\section{Zie paragraaf 4.2 .2 van dit hoofdstuk.}

1613. Kenkel, JLE, 1993, p. 890-893.

16́14. Zie onder anderen Saffer and Grossman, Economic Inquiry, 1987, p. 403-417; Saffer and Grossman, JLS, 1987, p. 351-374.

1615. Zie Saffer and Grossman, Economic Inquiry, 1987, p. 403-404.

1616. Zij gebruiken ongevalsdate gemeten over de periode 1975-1981 ten aanzien van jonge autobestuurders tussen 15 en 24 jaar in 48 Amerikaanse staten. De toetsingsvariabelen in het model hebben onder andere betrekking op het aantal verkeersongevallen per 100.000 inwoners, de accijns op bier, de minimumleeftijd voor het gebruik van alcohol, het inkomen, het aantal afgelegde automijlen en het percentage autobestuurders beneden de 25 jaar. Zie Saffer and Grossman, Economic Inquiry, 1987, p. 408-411; Saffer and Grossman, JLS, 1987, p. 357-364.

1617. Zie ten aanzien van deze leeftijdsgroep eveneens Chaloupka, Saffer and Grossman, JLS, 1993, p. 176-177 en 181. Volgens dit onderzoek zal binnen de leeftijdscategorie 18-20 jaar een verhoging van de accijns op bier, afhankelijk van de omvang van de prijstoename, leiden tot een daling van het aantal dodelijke verkeersslachtoffers met ruim 33\%. Sloan, Reilly and Schenzler, IRLE, 1994, p. 64 en 67, komen naar aanleiding van hun analyse ook tot de conclusie dat de prijs van alcohol een duidelijk preventief effect heeft op het aantal dodelijke verkeersslachtoffers onder 
met $19 \%$ in de categorie $21-24$ jaar. ${ }^{1618}$ In het andere onderzoek wordt door Saffer and Grossman gesteld dat de prijs van alcohol in de tijd gemeten relatief is gedaald mede als gevolg van het ontbreken van een inflatiecorrectie. ${ }^{1619}$ Door de omvang van de accijns op werkelijke waarde te schatten, berekenen zij het effect daarvan op het aantal verkeersslachtoffers onder jongeren. De resultaten van het onderzoek wijzen op een daling van het aantal dodelijke verkeersslachtoffers onder jongeren in de leeftijd van 15-24 jaar met 15\%. Een beleid waarbij de hoogte van de accijns op bier wordt gelijk gesteld met de hogere accijns op andere alcoholische dranken (wijn en likeur), resulteert volgens Saffer en Grossman in een daling van het aantal verkeersslachtoffers onder jongeren met $21 \%$. Een combinatie van beide factoren zal leiden tot een daling van het aantal verkeersslachtoffers onder jongeren met $54 \%{ }^{1620}$

\subsubsection{De toepassing van een minimumleeftijd voor de consumptie van alcohol}

Een tweede controlemaatregel heeft betrekking op de toepassing van een wettelijke minimumleeftijd voor de aankoop en de consumptie van alcohol ('minimum legal drinking age', MLDA). Deze maatregel, die met name in de Verenigde Staten strikt wordt toegepast, is vooral gericht op jonge autobestuurders in de leeftijd van 15-24 jaar. $^{1621}$

Gedurende de jaren ' 80 van de vorige eeuw werd in bijna alle Amerikaanse staten, vooral onder druk van de federale overheid, de wettelijke MLDA verhoogd naar 21 jaar. Tussen 1970 en 1976 was deze MLDA in veel staten nog verlaagd nar 18 jaar. ${ }^{1622}$ In de rechtseconomische literatuur is aan de hand van ongevalsdata onderzocht welke effecten een MLDA kan hebben op het aantal verkeersongevallen. De resultaten van deze studies geven in meerderheid een dalende trend aan in het antal dodelijke verkeersslachtoffers onder jongeren beneden de 25 jaar. Er is echter ook een aantal studies, die tot een andere uitkomst leiden. In tabel 5 zijn de resultaten van een viertal studies schematisch weergegeven. In de eerste kolom zijn de auturs van de verschillende studies opgesomd. In de tweede $t / m$ de vierde kolom is aange-

autobestuurders van 18-20 jaar. Zie echter, Young and Likens, IRLE, 2000, p. 107-126, warm voortbouwend op het onderzoek van Chaloupka, Saffer en Grossman, wordt aangetoond dat ext verhoging van de accijns op alcohol niet heef geleid tot een wezenlijk daling van het aantid dodelijke verkeersongevallen.

1618. Saffer and Grossman, Economic Inquiry, 1987, p. 411-415.

1619. Saffer and Grossman, JLS, 1987, p. 353-354.

1620. Saffer and Grossman, JLS, 1987, p. 373.

1621. Zie paragraaf 3.2 van hoofdstuk 9 voor een empirisch bewijs van de veronderstelling datjonge autobestuurders een hoog ongevalsrisico vormen.

1622. Evans, Traffic Safety and the Driver, p. 207; Cook and Tauchen, JLS, 1984, p. 169-170. Volges dit onderzoek zou een verlaging van de MLDA naar 18 jaar tussen 1970 en 1977 hebben gelel tot een stijging van het aantal dodelijke verkeersongevallen onder bestuurders van $18-20$ jas mat ongeveer $7 \%$. 
geven welk effect de verhoging van de MLDA naar 21 jaar heeft gehad op het aantal dodelijke verkeersslachtoffers bij 4 categorieën van autobestuurders, namelijk die van 18 jaar, 18-20 jaar, 19-20 jaar en autobestuurders in de leeftijd van 21 jaar. Uit de in tabel 3 genoemde studies blijkt dat na een verhoging van de MLDA naar 21 jaar, afhankelijk van de onderzochte leeftijdscategorie, in bijna alle gevallen een daling van het aantal dodelijke verkeersslachtoffers werd bereikt.

Tabel 3

\begin{tabular}{|c|c|c|c|c|}
\hline Onderzoek & \multicolumn{3}{|c|}{ Een verhoging van de MLDA naar 21 jaar } \\
\hline & 18 jaar & $18-20$ jaar & $19-20$ jaar & 21 jaar \\
\hline Figlio $^{1623}$ & $-26 \%$ & & $-19 \%$ & \\
\hline Saffer/Grossman $^{1624}$ & & $-8-11 \%$ & & \\
\hline Asch/Levy $^{1625}$ & & - & & \\
\hline Males $^{1626}$ & $-10 \%$ & & & $+5 \%$ \\
\hline
\end{tabular}

In aanvulling op tabel $3 \mathrm{kan}$ worden verwezen naar een aantal studies die eerder zijn beschreven en waarin ook de effecten van een verhoging van de MLDA naar 21 jaar worden onderzocht. De resultaten hiervan wijzen op een daling van het aantal dodelijke verkeersongevallen onder jonge autobestuurders met respectievelijk $1,2 \%,{ }^{1627}$ $3,5 \%{ }^{1628}$ en ongeveer $12,5 \% .{ }^{1629}$ Kenkel stelt dat met een federale MLDA van 21

1623. Figlio, J. Pol'y Anal. \& Mgmt., 1995, p. 555-566, met ongevalsdata uit de Amerikaanse staat Winsconsin in de periode 1976-1993. Binnen het empirisch model op p. 557-559 wordt verder een onderscheid gemaakt tussen de natuurlijke daling van het aantal alcohol-gerelateerde verkeersongevallen en de verkeersongevallen die direkt het gevolg zijn van een toename van de MLDA.

1624. Saffer and Grossman, Economic Inquiry, 1987, p. 403-412; Safter and Grossman, JLS, 1987, p. 351-374. In beide studies hadden de data betrekking op de periode 1975-1981, warin 15 Amerikaanse staten overgingen tot een verhoging van de MLDA naar 21 jaar. Zie ook paragraaf 4.3.1 van dit hoofdstuk

1625. Asch and Levy, J. Pol'y Anal. \& Mgmt., 1987, p. 180-192. Dit onderzoek omvat data die een vergelijking maken tussen de MLDA's in 50 Amerikaanse staten in het jaar 1978.

1626. Males, JLS, 1986, p. 181-211. Hierin wordt gebruik gemaakt van ongevalsdata ten aanzien van 14 Amerikaanse staten in de periode 1975-1983. Deze data worden vergeleken met data in staten waar de MLDA niet werd verhoogd.

1627. Wilkinson, Southern Econ. J., 1987, p. 329. De data in dit onderzoek hebben betrekking op de periode 1976-1980

1628. Chaloupka, Saffer and Grossman, JLS, 1993, p. 161-186. De data in dit onderzoek omvatten de periode 1982-1988

Sloan, Reilly and Schenzler, IRLE, 1994, p. 64 en 67. De data in dit onderzoek hebben betrekking op de periode $1982-1990$. 
jaar het rijden onder invloed onder jonge mannelijke autobestuurders met $13 \%$ zal dalen en onder jonge vrouwelijke autobestuurders met $21 \% .{ }^{1630}$

Door zowel Asch en Levy als door Males worden nuanceringen aangebracht op de 'positieve' uitkomsten van de vorenbedoelde studies. Hoewel ook zij tot een daling van het aantal dodelijke verkeersslachtoffers komen bij een MLDA van 21 jaar, is het uiteindelijke maatschappelijke effect van een MLDA op de preventie van verkeersongevallen volgens hen minder groot. Asch en Levy stellen dat eerder sprake is van onervarenheid met het gebruik van alcohol waardoor, ongeacht de leeftijd van de betrokkene, een negatieve invloed ontstaat op het ongevalsrisico. Daamaast is enkel een verhoging van de MLDA niet voldoende om het alcoholgebruik onder jongeren te verminderen. Daaraan dienen volgens hen ook opvoedingsprogramma's, een betere controle van de verkeersveiligheid en scherpere sancties een bijdrage te leveren. ${ }^{1631}$ Males concludeert naar aanleiding van zijn onderzoek dat de daling van het aantal dodelijke verkeersongevallen, tengevolge van de federale MLDA van 21 jar, met name plaatsvond in staten die voorheen een MLDA van 18 jaar hanteerden. Volgens een schatting van Males, gebaseerd op zijn onderzoeksresultaten in de onderzochte periode (1975-1983), zal, door de verhoging van de federale MLDA van 18 naar 21 jaar, de absolute netto toename van het aantal dodelijke verkeersslachtoffers onder autobestuurders beneden de 21 jaar jaarlijks tussen 40 en 250 bedragen. Een toename met 40 betekent een relatieve daling van het aantal slachtoffers onder 18 -jarigen met $10 \%$ en een relatieve stijging met $5 \%$ bij 21 -jarigen. Een absolute toename met 250 slachtoffers leidt in de berekeningen van Males tot een relatieve daling van $3 \%$ bij autobestuurders beneden de 21 jaar en een relatieve stijging met $14 \%$ bij 21 -jarigen in staten die hun MLDA verhogen naar 21 jaar. ${ }^{1632}$

\subsection{CONCLUSIE}

Naar aanleiding van het empirisch onderzoek naar de preventie van alcoholgerela. teerde verkeersongevallen, kan worden geconcludeerd dat in het kader van het preventiebeleid een administratieve ontzegging van de rijbevoegdheid een effectiever beleidsinstrument is dan een gevangenisstraf. De verplichte ontzegging van de rijbevoegdheid heeft, economisch gezien, mede tot doel om de activiteit autorijden te verminderen en kan ook de zorgvuldigheid van autobestuurder verhogen. Darbij] wordt verondersteld dat wanneer een autobestuurder besluit om, ondanks een rijerbod, toch aan het verkeer deel te nemen hij mogelijk een hogere zorgvuldigheid zal betrachten. ${ }^{1633}$ Verder kan worden geconcludeerd dat ook een omvangrijke adem-

1630. Kenkel, JLE, 1993, p. 894-895. De data in dit onderzoek hebben betrekking op de jaren 1983 . 1984. Zie ook paragraaf 4.2 .2 van dit hoofdstuk.

1631. Asch and Levy, J. Pol'y Anal. \& Mgmt., 1987, 184-190.

1632. Males, JLS, 1986, p. 203-204.

1633. Dewees, Duff and Trebilcock, Accident Law, p. 47 en 83. 
analysecampagne het rijden onder invloed kan reduceren. Met een dergelijke campagne wordt niet alleen de pakkans verhoogd, maar kan tevens een bijdrage worden geleverd aan een vermindering van het aantal alcoholgerelateerde verkeersongevallen. Daarbij dient echter te worden aangetekend dat deze daling mogelijk een tijdelijk effect zal hebben, omdat na verloop van tijd autobestuurders ontdekken dat de pakkans gering is zodat het aantal verkeersongevallen weer zal toenemen. ${ }^{1634}$

Met betrekking tot het controlebeleid kan worden gesteld dat een verhoging van de accijns op alcohol een effectief middel is om het rijden onder invloed en daarmee het aantal verkeersongevallen te verminderen. Daarnaast zal ook een verhoging van de MLDA naar 21 jaar volgens de meeste studies leiden tot een afname van het aantal dodelijke verkeersslachtoffers, met name binnen de leeftijdscategorie (18-20 jaar) warop de wetgeving betrekking heeft. Uit het empirisch onderzoek kan echter ook worden opgemaakt dat een verhoging van de accijns en de MLDA alleen niet voldoende zijn om het aantal alcoholgerelateerde verkeersongevallen te verminderen. ${ }^{1635}$ Naast opvoedingsprogramma's en scherpere sancties wordt door Dewees, Duff en Trebilcock als voorbeeld de zogenaamde automatische ademtest genoemd. Hierbij geldt dat een autobestuurder waarschuwingssignalen krijgt wanneer hij in zijn auto stapt en weigert zichzelf een test af te nemen of ingeval de ademtest een te hoog alcoholpercentage aangeeft. Daarnaast kan ook een verbetering van de veiligheid op de weg leiden tot een vermindering van het aantal alcoholgerelateerde verkersongevallen. ${ }^{1636}$

\section{Maximumsnelheid en de preventie van verkeersongevallen}

In deze paragraaf zal een laatste instrument van veiligheidsregulering aan de orde komen, namelijk de toepassing van een maximumsnelheid. Daarbij staat de vraag centraal welke effecten een maximumsnelheid heeft op het aantal verkeersongevallen. In dat kader zullen achtereenvolgens de gevolgen van een verhoging of verlaging van de maximumsnelheid voor het ongevalsrisico en de effectiviteit van de handhaving van de maximumsnelheid op het rijgedrag van de autobestuurder aan de orde komen.

\subsection{MAXIMUMSNELHEID EN HET ONGEVALSRISICO}

De gemiddelde snelheid waarmee door autobestuurders wordt gereden staat volgens Bruce in verband met het ongevalsrisico. Hij verwijst naar een Britse studie waarin is berekend dat een vermindering van de gemiddelde snelheid met $1 \%$ leidt tot een

\footnotetext{
1634. Tie Evans, Traffic Safety and the Driver, p. 197-198; Bruce, Law and Policy, 1984, p. 82-83.
1635. Asch and Levy, J. Pol'y Anal. \& Mgmt., 1987, 184-190. Zij noemen onder andere een verscher-

1636. Ding van de sancties als een belangrijke additionele maatregel.

Dewees, Duff and Trebilcock, Accident Law, p. 47-48 en 83.
} 
daling van het aantal dodelijke verkeersslachtoffers met $4,5 \% .{ }^{1637}$ In het eerder beschreven onderzoek van Peltzman ${ }^{1638}$ wordt gesteld dat een $1 \%$ lagere gemiddelde snelheid, op landelijke autowegen tijdens daluren, zal leiden tot een daling van het aantal dodelijke verkeersslachtoffers met $1,9 \% .{ }^{1639}$ Robertson, ten slotte, heeft berekend dat een verlaging van de gemiddelde snelheid leidt tot een daling van het aantal dodelijke verkeersongevallen met $2,8 \%$. $^{1640}$

Een onderzoek van Curran and Dwyer bevat een theoretische en empirische analyse van de 55 MPH maximumsnelheid, voorheen $65 \mathrm{MPH}$, die in 1973 in de VS is inge. voerd. ${ }^{1641}$ De centrale vraag in dit onderzoek is of de positieve effecten van de 55 MPH op het aantal dodelijke verkeersslachtoffers voortduurden in de eerste jaren na de invoering daarvan in 1973. Daarbij wordt uitgegaan van de veronderstelling dat een lagere maximumsnelheid geen permanent positief effect heeft gehad op het aantal verkeersslachtoffers. ${ }^{1642}$ De resultaten van dit onderzoek kunnen als volgt worden samengevat.

In de eerste plaats is volgens Curran en Dwyer op basis van de ongevalsdata sprake van een daling van het aantal dodelijke verkeersslachtoffers in 1974. Deze afname is volgens hen echter niet het directe gevolg van de invoering van de $55 \mathrm{MPH}-$ limiet in 1973. De oorzaak hiervan moet volgens hen worden gezocht in andere factoren 20als de prijs van benzine in verband met de oliecrisis. In dat kader wordt door Curran and Dwyer gesteld dat een stijging van de prijs van benzine ${ }^{1643}$ zal leiden tot een la.

1637. D. Gosh, D. Lees and W. Seal, The Economics of Personal Injury, Westmead, England, Saxon House, 1976 in Bruce, Law and Policy, 1984, p. 70.

1638. Zie paragraaf 3.1 van dit hoofdstuk.

1639. Peltzman, JPE, 1975, p. 677-725.

1640. L. Robertson, Joumal of Economic Issues, 1977, p. 587-600 in Bruce, Law and Policy, 1984, P. 70.

1641. Curran and Dwyer Jr., in Essays in Law and Economics, p. 117-161. In 1987 werd deze vetge ving door het Amerikaanse Congress herroepen, zodat opnieuw een maximumsnelheid an 6.5 MPH gold. Zie Curran and Dwyer, p. 117.

1642. Curran and Dwyer, in Essays in Law and Economics, p. 124 en 139-143. Bij hun analyse maken zij gebruik van data ten aanzien van het aantal dodelijke verkeersongevallen per 100 miljon ab tomijlen op bepaalde autowegen gedurende de periode 1947-1985. De toetsingsvariabela bif nen het model hebben betrekking op de ongevalskosten, de prijs van benzine, het inkoman, het aantal autobestuurders tussen 16 en 25 jaar en een snelheidsvariabele.

In dat verband kan worden verwezen naar een onderzoek van Leigh and Wilkinson, $J$. Poll Anal. \& Mgmt., 1991, p. 474-481. Hieruit blijkt dat een toename van de accijns op benzite met $10 \%$ kan leiden tot een afname van het aantal verkeersdoden met 1,8-2\%. Op jaarbasis betcken dit een absolute vermindering van het aantal dodelijke verkeersslachtoffers met 885 tot 1000 . 
ger activiteitsniveau (autorijden), met het gevolg een daling van het aantal verkeersongevallen. ${ }^{1644}$

In de tweede plaats wordt door Curran en Dwyer, gemeten over de periode 1967 1980, een empirische vergelijking gemaakt van ongevalsdata in een groot aantal jurisdicties in de wereld. Daaruit kan volgens hen worden opgemaakt dat het aantal dodelijke verkeersongevallen in Noord-Amerika na 1974 een ander patroon (stabilisering) volgt dan in de landen (daling van het aantal ongevallen) waar geen maximumsnelheid werd ingevoerd. Curran en Dwyer voorspellen dat een nieuwe maximumsnelheid van $65 \mathrm{MPH}$ geen wezenlijk effect zal hebben op het aantal dodelijke verkersslachtoffers. ${ }^{1645}$

De uitkomsten van het onderzoek van Curran en Dwyer worden bevestigd in een studie van 'The Brookings Institution' uit 1986. Daarin word geconcludeerd dat de invoering van een $55 \mathrm{MPH}$-limiet geen grote invloed heeft gehad op het aantal dodelijke verkeersslachtoffers in de jaren na de oliecrisis van $1974 .^{1646}$

Bruce verwijst echter naar een aantal studies uit de jaren ' 70 van de vorige eeuw, waarin wel wordt aangetoond dat de invoering of een verlaging van een maximumsnelheid kan leiden tot een afname van het aantal verkeersongevallen. Na de invoering van een maximumsnelheid zal volgens de berekening in deze studies, het aantal dodelijke verkeersongevallen met ongeveer $20 \%$ verminderen. ${ }^{1647}$

\subsection{DE HANDHAVING VAN DE MAXIMUMSNELHEID}

De vraag of de invoering van een maximumsnelheid ook tot een vermindering van het aantal verkeersongevallen leidt, is mede afhankelijk van de (mogelijkheden tot) handhaving van een bepaalde snelheidslimiet. In de VS is bijvoorbeeld uitgerekend dat elke politieambtenaar voor snelheidscontroles ongeveer 190 mijl autoweg tot

\footnotetext{
164t Curran and Dwyer, in Essays in Law and Economics, p. 123-131. Zie ook Dewees, Duff and Trebilcock, Accident Law, p. 45.

1645. Curran and Dwyer, in Essays in Law and Economics, p. 131-135 en p. 143-153.

:646. R.W. Crandall, H.K. Gruenspect, T.E. Keeler and L.B. Lave, Regulating the Automobile, Washington, The Brookings Institution, 1986, p. 65 en 67 in Dewees, Duff and Trebilcock, Accident Law, p. 45 en 81 , noot 304.

[6:7. H. Dawson, Analysis of Fatal Accident Trends on Maryland Highways 1970-1976, Public Roads 43, 1979, p. $62-68$ en P. Ellis, Motor Vehicle Mortality Reductions Since the Energy Crisis, Joumal of Risk and Insurance, 1977, p. 373-382 in Bruce, Law and Policy, 1984, p. 80. Zie ook J.H. Hedlund, Recent U.S. Traffic Fatality Trends, in Human Behavior and Traffic Safety, Evans and Schwing (eds.) New York, Plenum, 1985, p. 8-9, geciteerd in Dewees, Duff and Trebilcock, Accident Law, p. 45 en 81 noot 303 . Hierin wordt eveneens geconcludeerd dat, ten gevolge van de invoering van een maximumsnelheid, het aantal verkeetsongevallen, gemeten naar aantal af gelegde automijlen, aanzienlijk is gedaald.
} 
zijn beschikking heeft. ${ }^{1648}$ In de praktijk wordt de handhaving van de maximumsnelheid veelal geconcentreerd op rustige en veilige wegen, waarop de autodichtheid gering is en de autobestuurder naar verwachting zijn snelheid zal opvoeren. De politie kan op dergelijke wegen het meest effectief gebruik maken van de radar, waar. mee eenvoudig bepaalde handhavingsquota kunnen worden gehaald. ${ }^{1649}$

In het kader van dit onderzoek is met name de vraag van belang welke controlemaatregelen effectief zijn bij de handhaving van de maximumsnelheid. Experimenten met politiepatrouilles langs de kant van de weg hebben uitgewezen dat autobestuurders hun snelheid verminderen. In Californië kon door een intensieve politiecontrole de gemiddelde snelheid met $5 \%$ omlaag worden gebracht. Dit effect verdween, zodra de patrouilles waren beëindigd. ${ }^{1650}$

Wilkinson stelt naar aanleiding van zijn empirisch onderzoek dat een strikte handhaving van de maximumsnelheid leidt tot een vermindering van het aantal verkeersslachtoffers met 3\%. Daarnaast zal een strikte handhaving van de maximumsnelheid leiden tot een afname van de gemiddelde snelheid op autosnelwegen met ongeveer $2,5 \% .^{1651}$

In Nederland is ervaring opgedaan met het zogenaamd 'Gericht Verkeerstoezich' (GVT). Daarbij wordt een stuk autosnelweg geselecteerd waarop intensieve snelheidscontroles plaatsvinden. Op de A2 tussen Amsterdam en Utrecht is de weggebruiker met behulp van verkeersborden erop attent gemaakt dat de snelheid (maximum $100 \mathrm{~km} /$ uur) wordt gecontroleerd. Binnen een week bleek $84 \%$ van de automobilisten, mede ook door de aandacht in de landelijke media, op de hoogte te zijn van de controles. Uit onderzoek blijkt dat een dergelijk GVT op het traject Amsterdam-Utrecht heeft geleid tot een afname van het aantal verkeersongevallen met letsel met $15 \%{ }^{1652}$

In de Canadese provincie Ontario werd in 1976 de maximumsnelheid verlaggd van $70 \mathrm{MPH}$ naar $60 \mathrm{MPH}$, tegelijkertijd werd een wettelijke draagplicht van de autovelligheidsgordel ingevoerd. Deze maatregelen leidden tot een daling van het antit

1648. U.S. Transportation Research Board, 55 (MPH): A Decade of Experience, Special Repor 204, Washington, Government Printing Office, 1984, p. 13 en 147 in Dewees, Duff and Trebilook, Accident Law, p. 45 en 80, noot 299.

1649. Dewees, Duff and Trebilcock, Accident Law, p. 45.

1650. U.S. Transportation Research Board, 55 (MPH): A Decade of Experience, p. 147 in Dewes, Duff and Trebilcock, Accident Law, p. 45 en 81, noot 301.

1651. Wilkinson, Southern Econ. J., 1987, p. 328-329. Zie omtrent dit onderzoek ook paragraf 43 vim

1652. Visser, Politiecom Special, 1995, p. 18-19 en Bennink, Politiecom Special, 1995, p. 19. Hierin wordt overigens gesuggereerd dat na beëindiging van de controles de weggebruiker de maximumsnelheid gewoon weer zal negeren. 
dodelijke verkeersongevallen in 1974, maar dit was volgens de onderzoekers mede het gevolg van de prijsstijgingen (oliecrisis) waardoor het activiteitsniveau (autorijden) lager was. Dewees, Duff en Trebilcock stellen ook dat in 1976 het aantal verkeersongevallen in Ontario afnam, maar dit gold voor alle wegen, derhalve ook die warop geen maximumsnelheid van toepassing was. Dit betekent volgens hen dat de maximumsnelheid niet de enige factor is geweest die aan de daling van het aantal verkeersongevallen heeft bijgedragen. ${ }^{1653}$

In 1987 werd in de VS op de landelijke autosnelwegen de maximumsnelheid verhoogd van $55 \mathrm{MPH}$ naar $65 \mathrm{MPH}$. Een onderzoek in 22 staten naar de ervaringen met deze snelheidslimiet, gemeten over de periode mei 1987-juli 1987, wijst uit dat het aantal verkeersdoden op landelijke wegen met $52 \%$ is gestegen. Hoewel dit een aanzienlijke relatieve toename suggereert, is volgens Dewees, Duff en Trebilcock de algemene verkeersveiligheid eerder vergroot. Het genoemde percentage van $52 \%$ komt namelijk overeen met een absolute toename van het aantal verkeersdoden op landelijke wegen van 296 naar 450 . Op andere autowegen daalde het aantal verkeersdoden echter van 4830 naar 4350 (een relatieve daling van 10\%). Dit betekent volgens hen dat in staten die de maximumsnelheid verhoogden per saldo het absolut aantal dodelijke verkeersslachtoffers is afgenomen. ${ }^{1654}$

\subsection{CONCLUSIE}

Dewees, Duff en Trebilcock oordelen dat een verlaging van de maximumsnelheid in theorie zal leiden tot een afname van het aantal dodelijke verkeersongevallen. Bij een hoge snelheid zal immers het reactievermogen van de autobestuurder dalen, met als mogelijk resultaat dat de gevolgen van een verkeersongeval ernstiger zijn. Een lagere snelheid kan daarentegen leiden tot bijvoorbeeld slaperigheid. In de veronderstelling dat daarbij een langere tijd op de weg wordt doorgebracht, kan dit leiden tot een vermindering van de aandacht. ${ }^{1655}$

Binnen de empirische literatuur bestaat echter, ondanks het gegeven dat een lagere maximumsnelheid ook tot een lagere gemiddelde snelheid leidt, geen overeenstemming over het directe verband tussen snelheid en het aantal verkeersongevallen. Door Dewees, Duff en Trebilcock wordt daarom het volgende voorgesteld:

\footnotetext{
1653. M. Friedland, M. Trebilcock and K. Roach, Regulating Traffic Safety, Toronto, University of Toronto Press, 1990 in Dewees, Duff and Trebilcock, Accident Law, p. 45 en p. 81, noot 305.

1654. Insurance Institute for Highway Safety, Insurance Institute Status Report 22, nr. 4, december 1987, p. 1; Report 23, nr. 3, maart 1988, p. 7; Report 23, nr. 7, juli 1988, p. 3; Report 23, nr. 8, augustus 1988, p. 1 en Report 24, nr. 1, januari 1989, p. 1 in Dewees, Duff and Trebilcock, Accident Law, p. $45-46$ en p. 81, noot 306. Zie ook Michener and Tighe, Am. Ec. Rev., Papers and Proceedings, 1992, p. 452-456, die bij een maximumsnelheid van $65 \mathrm{MPH}$ op landelijke autowegen een lichte stijging $(0,8-3,4 \%)$ van het aantal dodelijke verkeersongevallen voorspellen.

1655. Dewees, Duff and Trebilcock, Accident Law, p. 46
} 
'Given the conflicting data, a sensible approach would be to set speed limits at a level that encourages a relatively moderate mean speed, but not so low as to encourage massive violations and higher variance in speed. Enforcement activity and severity of sanctions should be targeted to drivers who are guilty of substantial deviations from mean traffic speed'. ${ }^{1656}$

\section{Veiligheidsregulering in het verkeer en lobbying}

In de theorie is aandacht besteed aan de invloed die belangengroepen, autoverzekeraars, autofabrikanten en potentiële verkeersslachtoffers, kunnen uitoefenen op de totstandkoming en op de inhoud van bepaalde vormen van veiligheidsregulering in het verkeer. ${ }^{1657}$ Daarbij is veelal sprake van sterk conflicterende belangen die maar in een beperkt aantal situaties tot overeenstemming kunnen worden gebracht. Vanuit de economische analyse is daarnaast gesteld dat de uitkomsten van het lobbyproces ook een averechts effect kunnen hebben op de preventie van verkeersongevallen.

Ten aanzien van de invloed van lobbygroepen op de totstandkoming van autoveilig. heidsregulering kan worden verwezen naar een onderzoek van Kneuper en Yandle. Daarin wordt de rol van autoverzekeraars en autofabrikanten bij de invoering van de airbag in Amerikaanse auto's bestudeerd. ${ }^{1658}$ Volgens Kneuper en Yandle zijn de autofabrikanten in de VS in beginsel tegen een airbag en geven zij de voorkeur aan een verplichte 'actieve' autoveiligheidsgordel, hoewel beide instrumenten tot een vermindering van het aantal verkeersslachtoffers kunnen leiden. Een autovelligheidsgordel is volgens de autofabrikanten echter goedkoper en daarnaast zijn zij bevreesd voor productaansprakelijkheidsclaims in het geval een airbag niet zou werken. $^{1659}$

Volgens Kneuper en Yandle worden door de autoverzekeraars een drietal argumenten genoemd ten faveure van een airbag. In de eerste plaats zal een airbag een autoinzittende beter beschermen tegen letselschade, hetgeen weer kan leiden tot een afname van het aantal dure en onvoorspelbare aansprakelijkheidsprocedures. In de tweede plaats is een airbag een passief veiligheidsinstrument. Dit betekent dat de attobestuurder, ongeacht zijn houding ten aanzien van het ongevalsrisico en zonder enige inspanning van zijn kant, wordt beschermd. Daarnaast zijn vanuit het oogpunt van veiligheidsregulering ook geen handhavingsproblemen. In de derde plaats zal de werking van de airbag aan de autobestuurders bescherming kunnen geven tegenzeer ernstig letsel. Kneuper en Yandle verwijzen in dat kader naar een empirisch onderzoek waaruit blijkt dat zowel de airbag als het gebruik van de autoveiligheidsgordel

1656. Dewees, Duff and Trebilcock, Accident Law, p. 46.

1657. Zie paragraaf 6 van hoofdstuk 7.

1658. Kneuper and Yandle, JRI, 1994, p. 107-116.

1659. Kneuper and Yandle, JRI, 1994, p. 107-108. 
bescherming geven ingeval van een frontale botsing, maar de airbag is superieur wanneer de ernst van het ongeval toeneemt. ${ }^{1660}$

Kneuper and Yandle noemen ook een aantal verzekeringseconomische argumenten ten voordele van de invoering van een airbag. Verzekeraars pleiten namelijk, behalve voor een verhoging van de veiligheid, ook voor een betere voorspelbaarheid van het individuele ongevalsrisico, zodat de omvang van de verzekeringspremie daarop kan worden afgestemd. Een veiligheidsinstrument als de airbag dat standaard in alle auto's wordt aangebracht, betekent voor verzekeraars dat de voorspelbaarheid van het ongevalsrisico wordt verbeterd. ${ }^{1661}$

Samenvattend kan worden gesteld dat vooral de belangengroepen die goed zijn georganiseerd (verzekeraars, autofabrikanten) hun invloed aanwenden bij de totstandkoming van wetgeving. De rol van grote belangengroepen (consumenten) kon daarentegen niet voldoende worden onderzocht. Toch kan worden geconcludeerd dat de overheid met betrekking tot de invoering van de autoveiligheidsgordel en de airbag rekening heeft gehouden met zowel de belangen (bescherming) van de consument als met de belangen van de autoverzekeraars (airbag) en de autofabrikanten (autoveiligheidsgordel). ${ }^{1662}$

\section{Conclusie: veiligheidsregulering in het verkeer}

In dit hoofdstuk is aan de hand van de beschikbare empirische literatuur onderzocht welke invloed bepaalde vormen van veiligheidsregulering hebben op het verkeersgedrag en het aantal verkeersongevallen. Daaruit is in de eerste plaats duidelijk geworden dat bijvoorbeeld de autoveiligheidsgordel, de airbag en de controle van het rijden onder invloed een bijdrage kunnen leveren aan de daling van het aantal dodelijke verkeersslachtoffers. In de tweede plaats is gebleken dat een intensieve handharing en controle van de veiligheidsregulering nodig is om een hoog preventief effect te bereiken. In de derde plaats wordt gesuggereerd dat een administratieve ontzegging van de rijbevoegdheid een beter preventief effect heeft tegen het rijden onder invloed dan bijvoorbeeld een boete of een gevangenisstraf. Daarbij geldt dat de empirische uitkomsten ten aanzien van de effecten van een gevangenisstraf omstreden zijn, hoewel in één studie wordt gesuggereerd dat met een gevangenisstraf vooral bij oudere autobestuurders een preventief effect wordt bereikt, terwijl bij jonge autobe-

\footnotetext{
1660. P. Zador and M. Ciccone, Driver Fatalities in Frontal Impacts: Comparisons Between Cars with Airbags and Manual Belts, Arlington, Insurance Institute for Highway Safety, 1991 in Kneuper and Yandle, JRI, 1994, p. 111-113

1661. Kneuper and Yandle, JRI, 1994, p. 113-114.
1662. Kneuper and Yandle, JRI, 1994, p. 107-116.
} 
stuurders eerder een ontzegging van de rijbevoegdheid als een effectief instrument kan worden beschouwd. ${ }^{1603}$

In het algemeen kan worden gesteld dat met betrekking tot de meeste jurisdicties die in dit hoofdstuk aan de orde zijn geweest sinds 1970 sprake is van een daling vanhet aantal verkeersongevallen en verkeersslachtoffers. Een uitzondering hierop word gevormd door Noord-Amerika. Daar kenden de ongevalsstatistieken een grillig verloop, waarbij tussen 1970 en 1993 het aantal dodelijke verkeersslachtoffers is afgenomen maar het aantal verkeersgewonden sterk is gestegen. ${ }^{1664}$ De oorzaak van deze trends kan alleen met een uitvoerig statistisch en rechtseconometrisch onderzoel worden achterhaald. De dalende trend ten aanzien van het aantal verkeersslachtoffers kan worden verklaard uit de hoeveelheid maatregelen die op het terrein van de verkeersveiligheid zijn genomen. De verschillende empirische studies die in dit hoofdstuk aan de orde zijn geweest suggereren dat de meeste veiligheidsmaatregelen hebben geleid tot een vermindering van het aantal verkeersslachtoffers.

In de theorie is gesteld dat verkeersdeelnemers bij bun deelname aan het verker soms niet optimaal zijn geïnformeerd, een probleem dat door de invoering van vejligheidsregulering kan worden tegengegaan. ${ }^{1665}$ In dit hoofdstuk is gebleken dat een autobestuurder vaak niet op de hoogte is van het feit dat een autoveiligheidsgordel hem kan beschermen tegen ernstig ongevalsletsel. ${ }^{1666}$ Dit informatietekort, dat rede tot gevolg had dat een grote meerderheid van de autobestuurders geen autovelig. heidsgordel droeg, is door de overheid deels opgeheven door wetgeving wamee het gebruik van de autoveiligheidsgordel verplicht wordt gesteld. In een aantal jurisdicties ging de invoering van deze wetgeving samen met een uitgebreide pulliciteitscampagne, waardoor met name de eerste jaren het gebruik van de autoveligheidsgordel sterk toenam. Uit het beschreven empirisch onderzoek bleek echter ook dat een dergelijk hoog gebruik dient te worden vastgehouden met behulp van een strikte controle en de daarmee verbonden sancties. Wanneer immers de pakkans gering is zal een autobestuurder onvoldoende inspanningen verrichten om zijn eigen verhoogde veiligheid te handhaven.

Ten aanzien van het rijden onder invloed en de overtreding van de maximumnelheid geldt dat de autobestuurder die gedronken heeft of te hard rijdt het ongevalrisico zowel voor zichzelf als voor zijn medeweggebruikers verhoogt. Uit het empirisch onderzoek is gebleken dat regulering het rijden onder invloed en de overtreding var de maximumsnelheid kan verminderen en de autobestuurder kan aanzetten tot zorg-

1663. Zie Sloan, Reilly and Schenzler, IRLE, 1994, p. 64 en 67; Dewees, Duff and Trebilcock, Actdent Law, p. 53.

1664. Statistics of Road Traffic Accidents in Europe and North America, 1995, p. 7-12.

1665. Zie paragraaf 3 van hoofdstuk 7 .

1666. Zie paragraat 2 van dit hoofdstuk. 
vuldiger rijgedrag. Voorbeelden van deze regulering zijn een verhoging van de prijs (accijns) van alcohol, een verplichte ontzegging van de rijbevoegdheid (vermindering van het activiteitsniveau) en een strikte handhaving van de maximumsnelheid. Ten aanzien van dit laatste geldt dat de handhaving een permanent karakter moet dragen, anders zal een autobestuurder na beëindiging van de controle de neiging verronen om het gaspedaal weer wat verder in te trappen. 


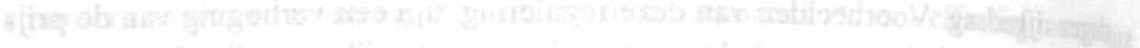

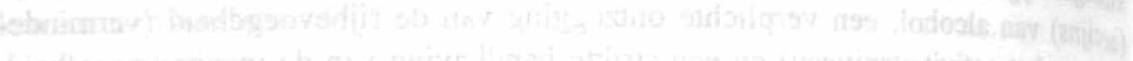

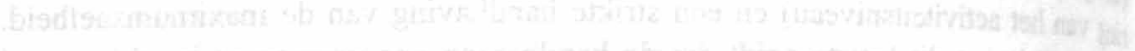

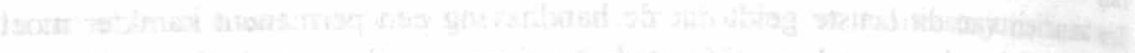

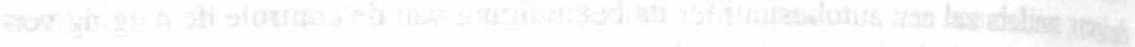

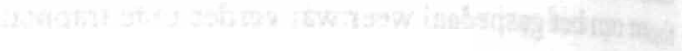

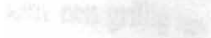

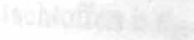

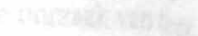

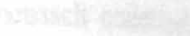

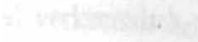

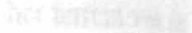

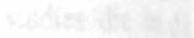

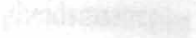

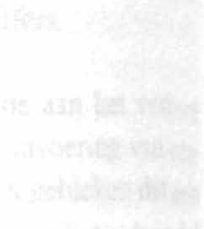
$x^{2}+x^{2}+x^{2} x^{2}=x^{2}$

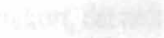

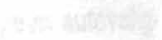

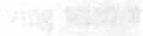

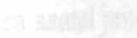

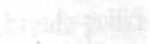

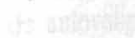
$x^{2}+6+2+4=$

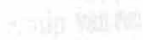




\section{Hoofdstuk 13: Een no-fault verzekering en andere compensatiemechanismen}

\section{Inleiding}

In de voorgaande drie hoofdstukken is empirisch onderzoek beschreven met betrekking tot de invloed van aansprakelijkheid, verzekering en veiligheidsregulering op de preventie van verkeersongevallen. In het kader van dit onderzoek staat de vraag centraal op welke wijze een optimale preventie van verkeersongevallen en een optimale compensatie van verkeersslachtoffers kan worden bereikt. Ten aanzien van dit latste is in hoofdstuk 10 aandacht besteed aan de vraag in hoeverre verkeersslachtoffers binnen een systeem van aansprakelijkheid en verzekering hun verkeersschade krijgen vergoed. In dit hoofdstuk zal de nadruk liggen op de, preventieve en compensatoire, werking van een no-fault verzekering.

In de Amerikaanse literatuur wordt een no-fault verzekering omschreven als een verzekering waarbinnen de autobestuurder, indirect via zijn of haar eigen verzekeraar, ongeacht de schuldvraag, financieel verantwoordelijk wordt gesteld voor de persoonlijk geleden materiële schade (medische kosten en inkomensschade) van de imittenden van de verzekerde auto, van de voetgangers waarmee de verzekerde auto in botsing komt en van de verzekerde autobestuurder zelf. ${ }^{1667}$ Uit deze omschrijving kan worden opgemaakt dat een no-fault verzekering zowel een eerste partij- (voor de schade van de inzittenden/autobestuurder) als een derde partij (voor de schade van de voetganger) karakter draagt.

Binen de theoretische analyse is gewezen op het feit dat een no-fault verzekering zich in vele vormen kan voordoen. ${ }^{1668}$ In dat kader wordt globaal het volgende onderscheid gemaakt.

Th haar meest pure vorm kan een no-fault verzekering ('comprehensive') worden beschouwd als een vergoedingsmechanisme, waarbij een ansprakelijkheidsvordering voor persoonlijke letselschade vrijwel geheel is uitgesloten. Daarbij is een soort van cormpensatiefonds opgezet, waaruit verkeersslachtoffers een vergoeding ontvangen die veelal is beperkt is tot een vast percentage van de materiële schade.

Een tweede vorm van no-fault creëert nog wel de mogelijkheid voor een aansprakelijkheidswordering, maar deze is veelal gebonden aan materiële of monetaire schadedrempels ('threshold'). Materiële schadedrempels hebben betrekking op de ernst van

\footnotetext{
1667. Witt and Urutia, JRI, 1983, p. 631; Kochanowski and Young, JRI, 1985, p. 270; Cummins and Weiss, GPRI, 1991, p. 21

1668. Zie paragraaf 6.4 van hoofdstuk 6
} 
het persoonlijk letsel tengevolge van een verkeersongeval. Financiële schadedrempels houden verband met het geldelijk niveau van de medische kosten en de inko. mensschade die door het verkeersslachtoffers zijn gemaakt respectievelijk geleden Ten aanzien van de verschillende jurisdicties die in dit hoofdstuk aan bod komen geldt dat de omvang van zowel de materiële als monetaire schadedrempels sterk uiteenlopen.

Een derde vorm van no-fault ('add-on') tenslotte, bevat, naast de handhaving van het aansprakelijkheidsrecht, een verplichte eerste partij verzekeringsdekking van een door de overheid te bepalen omvang. Dit betekent dat voor het slachtoffer de mogelijkheid voor het instellen van een aansprakelijkheidsvordering blijft bestaan. Wanneer het slachtoffer daarvoor kiest zullen de voordelen die hij van de no-fault verzekering geniet worden verrekend met de vergoeding die hij uit hoofde van zijn aansprakelijkheidsvordering ontvangt. ${ }^{1669}$

In dit hoofdstuk zal aan de hand van de beschikbare empirische literatuur de preventieve- en compensatoire werking van de no-fault verzekering en het ansprakelijkheidsrecht worden geanalyseerd. Daarbij zal in paragraaf 2 eerst een inhoudelijk overzicht worden geschetst van de verschillende vormen van no-fault zoals deze in Noord-Amerika, Canada, Nieuw-Zeeland en Australië worden toegepast. In paragraaf 3 staat de vraag centraal welke effecten deze no-fault regimes hebben op de preventie van verkeersongevallen, de compensatie van verkeersslachtoffers en de kosten van het systeem. Paragraaf 4 tenslotte, is ingeruimd voor een aantal concluderende opmerkingen ten aanzien van no-fault en aansprakelijkheid.

\section{Een overzicht van een aantal rechtstelsels met een no-fault verzekering}

In deze paragraaf zal een aantal no-fault systemen worden beschreven die in het verdere empirisch onderzoek een belangrijke rol vervullen. Daarbij is de positiefreshtelijke analyse beperkt tot een meer algemene weergave van de toepasselijke no-fault stelsels in respectievelijk Nieuw-Zeeland, Australië en de Canadese provincie Quebec. Ten aanzien van de Verenigde Staten geldt dat elke staat de vrijheid heef om de vergoeding van verkeersschade zelf te regelen. ${ }^{1670}$ In de meeste Amerikaanse staten wordt daarbij een vorm van no-fault toegepast.

1669. Zie voor een analyse van de verschillende vormen van een no-fault verzekering: Chapmin and Trebilcock, Working Paper, 1991, p. 1-15; Van Wassenaer van Catwijck, VA, 1988, p. 321-377. Zic ook Dewees, Duff and Trebilcock, Accident Law, p. 22 en 67 voor een overzicht vande job risdicties die een vorm van no-fault hebben ingevoerd.

1670. Dit geldt ook voor de provincies in Canada en Australie. Zie Van Wassenaer van Carwijch, $\mathrm{WA}$, 1988, p. 330. 
21. NIEUW-ZEELAND EN HET NO-FAULT COMPENSATIEFONDS VOOR VERKEERSSLACHTOFFERS

Met betrekking tot de verkeersaansprakelijkheid in Nieuw-Zeeland markeert het jaar 1974 de overgang van een aansprakelijkheidsregime naar een vergoeding van verkeersschade via een compensatiefonds ('comprehensive no-fault'). Vóór 1974 werd de verkeersaansprakelijkheid beheerst door een regel van foutaansprakelijkheid met een gradueel eigen schuldverweer, gecombineerd met een verplichte aansprakelijkheidsverzekering voor de autobestuurders, die een onbeperkte dekking bevatte voor schade van derden. Het slachtoffer diende voor een vergoeding van de schade, zowel materieel (letsel- en zaakschade) als immaterieel, een beroep te doen op de aansprakelijkheidsverzekeraar van de autobestuurder. Daarnaast beschikte het potentiële verkeersslachtoffer veelal over een vangnet van sociale en particuliere verzekeringen. ${ }^{167}$

In 1974 werd in Nieuw-Zeeland de 'Accident Compensation Act' ingevoerd ${ }^{1672}$ met het doel om slachtoffers van een ongeval te compenseren, ongeacht de vraag wie het ongeval had veroorzaakt. Deze wet is van toepassing op alle ongevallen waarbij persoonlijke schade ontstaat, zoals met betrekking tot het verkeer, consumenten, producten en medische behandelingen. In $1982^{1673}$ en $1992^{1674}$ is deze wet verder aangepast, waarbij met name de omvang van de uit te keren schadevergoeding werd beperkt. ${ }^{1675}$

Binnen de 'Accident Compensation Act' kan een verkeersslachtoffer voor zijn schadeloosstelling een beroep doen op 'The Accident Compensation Corporation'. Dit overheidsorgaan beheert een fonds waaruit alle medische kosten en een deel van de inkomensschade, $80 \%$ van het werkelijk geleden inkomensverlies, worden vergoed. Daamaast is een bedrag beschikbaar voor de vergoeding van immateriële schade. De mogelijkheid om een aansprakelijkheidsvordering in te stellen tegen de schade-

\footnotetext{
1671. Brown, CaLR, 1985, p. 980-982.

1672. New Zealand Accident Compensation Act 1972'. Deze wet werd in 1972 vastgesteld en in 1974 ingevoerd. Zie Palmer, American Journal of Comparative Law, 1977, p. 1-45, voor een overzicht van de toepassing van deze Wet in de eerste twee jaren na invoering.

De 'New Zealand Statutory Accident Compensation Act 1982'.

De 'New Zealand Statutory Accident Rehabilitation and Compensation Insurance Act 1992'.

Zie voor een positiefrechtelijke beschrijving van met name de 1982 Act en 1992 Act: Mahoney, American Joumal of Comparative Law, 1992, p. 159-211; Solender, The International Lawyer, 1993, p. 100; Keeton, Keeton, Sargentich and Steiner, Cases and Materials on Tort and Accident
Law, p. 875-882.
} 
veroorzaker, zelfs al had deze laatste schuld aan het ongeval, werd met deze wetge.
ving afgeschaft.

Vóór 1982 werd ten aanzien van verkeersongevallen nog onderscheid gemaakt tus. sen werknemers en niet-werknemers. Werknemers die tijdens het werk bij een verkeersongeval betrokken raakten dienden, voor een vergoeding van hun persoonlijke schade, een beroep te doen op een compensatiefonds dat door de werkgevers en zelfstandige ondernemers, door middel van heffingen, werd gefinancierd. Alle andere verkeersslachtoffers werden gecompenseerd door een motorrijtuigfonds dat, via heffingen, door de eigenaars van een motorvoertuig werd gesubsidieerd. Vanaf 1982 wordt de vergoeding voor alle verkeersschade via het motorrijtuigfonds geregeld. Voor de zaakschade bleef na 1974 het aansprakelijkheidsregime gelden. Een autobestuurder kan zich tegen deze vorm van schade vrijwillig verzekeren, waarbij hij in de praktijk is onderworpen aan een bonus-malussysteem. ${ }^{1677}$

\subsection{DE INVOERING VAN EEN VERPLICHTE EERSTE PARTIJ NO-FAULT VERZEKERING IN AUSTRALIË}

Voordat in de jaren '70 van de vorige eeuw in een aantal Australische jurisdicties een no-fault verzekering werd ingevoerd, was de vergoeding van verkeersschade geregeld via het aansprakelijkheidsrecht aangevuld met een verplichte derde partij verzekering. ${ }^{1678}$ Deze verzekering, die door de eigenaar van het motorvoertuig werd aangegaan, gaf dekking tegen verkeersschade van derden, ongeacht wie de bestur. der was ten tijde van een verkeersongeval. Voor de persoonlijke letselschade en zaakschade van de bestuurder was een aparte verzekering beschikbaar. De premie voor de aansprakelijkheidsverzekering was afhankelijk van het type auto en in sortmige staten van de woonplaats van de polishouder. Er was geen sprake van een eigen risico noch van het gebruik van premiedifferentiatie. Mede als gevolg van de weigering van de overheid om toe te stemmen in een (noodzakelijke) premieverhoging door de particuliere verzekeraars, had een groot aantal verzekeraars de Australische markt verlaten. Dit had tot gevolg dat de autoverzekeringsmarkt voornamelijk werd beheerst door overheidsinstellingen. ${ }^{1679}$

Hoewel de grondslag voor de vergoeding van verkeersschade in Australie een foutaansprakelijkheid met een gradueel eigen schuldverweer was, leidde $90 \%$ van de schadeclaims tengevolge van een verkeersongeval tot een schikking tussen het

1676. Section 27 van Accident Compensation Act 1982. Zie daarover Mahoney, American Joumal of Comparative Law, 1992, p. 159; Solender, The Intemational Lawyer, 1993, p. 97-99.

1677. Brown, CaLR, 1985, p. 982-984; Mahoney, American Joumal of Comparative Law, 1993, P 162-163.

1678. 'Compulsory Third Party (CTP) System'. Zie McEwin, IRLE, 1989, p. 14.

1679. McEwin, IRLE, 1989, p. 14-15. 
slachtoffer en de aansprakelijkheidsverzekeraar van de bestuurder. Ongeveer tweederde van het aantal verkeersslachtoffers ontving een vergoeding voor de geleden schade, die veelal bestond uit een bedrag ('lump sum') voor medische kosten, inkomensverlies en immateriële schade. In de praktijk van de verkeersschaderegeling bleek dat aansprakelijkheidsverzekeraars bepaalde verkeersslachtoffers, zoals passagers, volledig compenseerden. Uit onderzoek is ook gebleken dat sommige verzekeraars nog een stap verder gingen door ook voetgangers die het slachtoffer waren van enn verkeersongeval volledig te compenseren. Dit was opmerkelijk omdat in veel gevallen kon worden aangetoond dat een deel van de volwassen voetgangers onder invloed van alcohol verkeerden. ${ }^{1680}$

Australiè is verdeeld in meerdere provincies en regio's die naar eigen inzicht hun systeem van verkeersaansprakelijkheid kunnen regelen. In Tasmanië werd in 1976 een no-fault verzekering geïntroduceerd met handhaving van de mogelijkheid om ingeval van persoonsschade een aansprakelijkheidsvordering in te stellen ('add-on no-fault). ${ }^{1681}$ Victoria kent sinds 1974 een no-fault regime, waarbij een aansprakelijkheidsvordering kan worden ingesteld op voorwaarde dat de schade ernstig genoeg is en in omvang een bepaalde schadedrempel ('threshold') overschrijdt. De vergoedingen in het kader van een aansprakelijkheidsvordering zijn echter gebonden an maxima. ${ }^{1682}$ In de Northern Territory is in 1979 een meer zuiver no-fault systeem voor verkeersschade ingevoerd, waarbij de mogelijkheid tot het instellen van en aansprakelijkheidsvordering werd afgeschaft. ${ }^{1683}$

\subsection{HET 'ZUIVERE' NO-FAULT REGIME VAN DE CANADESE PROVINCIE QUEBEC}

De verschillende Canadese provincies hebben, evenals in Australië, autonome wetgeving op het terrein van de verkeersaansprakelijkheid. In de provincies Nova Scofia, New Brunswijk, New Foundland en Prince Edward Island is een traditioneel aansprakelijkheidssysteem samen met een derde partij aansprakelijkheidsverzekening gehandhaafd. Daamaast is een bescheiden no-fault vergoeding beschikbaar. In de provincie Ontario is in 1990 een 'threshold' no-fault regime ingevoerd, waarbinnen relatief hoge no-fault vergoedingen voor materiële schade mogelijk zijn. Verder kan pas een aansprakelijkheidsvordering worden ingesteld indien de ernst van de ge-

\footnotetext{
1680. McEwin, IRLE, 1989, p. 15.

168!. Motor Accident (Liabilities and Compensation) Act 1973 in Chapman and Trebilcock, Working Paper, 1991, p. 5.

1682. Transport Accidents Act 1986, section 93. De ernst van de schade wordt onder andere gedefinieerd als blijvend verlies van bepaalde lichamelijke functies. De schadedrempel voor het instellen van een aansprakelijkheidsvordering is bepaald op $\$ 20.000$. De maximale vergoedingen bij een actie uit onrechtmatige daad bedragen respectievelijk $\$ 450.000$ (materiële schade) en $\$ 200.000$ (immaterielle schade). Zie Chapman and Trebilcock, Working Paper, 1991, p. 5, noot 10.

Motor Accidents (Compensation) Act 1979 in Chapman and Trebilcock, Working Paper Series, 1991, p. 4-5; McEwin, IRLE, 1989, p. 19.
} 
leden schade een strikte materiële schadedrempel ('threshold') overschrijdt. ${ }^{169} \mathrm{De}$ provincies Saskatchewan, ${ }^{1685}$ Manitoba en British Colombia kennen een vanwege de overheid gereguleerd verzekeringssysteem, waarbij, naast ruime vergoedingsmogelijkheden uit een no-fault compensatiefonds, een aansprakelijkheidsvordering voor verkeersschade kan worden ingesteld. ${ }^{1686}$

In dit hoofdstuk zal voornamelijk aandacht worden besteed aan de provincie Quebec. Tót 1978 was met betrekking tot de vergoeding van verkeersschade in Quebec een systeem van foutaansprakelijkheid met een gradueel eigen schuldverweer van toepassing, aangevuld met een verplichte derde partij aansprakelijkheidsverzekering aan de zijde van de autobestuurder. De premie bij deze autoverzekering was sterk geïndividualiseerd en er was sprake van premieaanpassingen op basis van het schadeverleden van de autobestuurder. ${ }^{1687}$

Het no-fault stelsel dat in 1978 in Quebec werd ingevoerd ${ }^{1688}$ kenmerkt zich vooral door zijn zuivere karakter. Dit betekent dat, onder afschaffing van het ansprakelijkheidsrecht, een verkeersslachtoffer zijn schade (zowel materieel als immaterieel), op een foutloze basis, snel en vaak volledig vergoed krijgt. Met de invoering van deze no-fault wetgeving is een overheidsorgaan geïnstalleerd, de 'Regie de l'assurance automobile du Quebec' (de Regie). Dit administratieve orgaan stelt de verplichte nofault verzekering beschikbaar en draagt zorg voor de schadeloosstelling van verkeersslachtoffers. Daarbij geldt dat de no-fault vergoedingen worden verminderd met betalingen uit andere administratieve fondsen, zoals in het kader van de 'Workmen's Compensation Act'. ${ }^{169}$

1684. 'The Ontario Motorist Protection Plan: The Ontario Insurance State Law Amendment Act, 1990 (Bill 68) in Chapman and Trebilcock, Working Paper, 1991, p. 4. Het 'threshold' regime au, als gevolg van de aanwezigheid van een nieuwe provinciale regering, waarschijnlijk worden vevangen door een 'add-on' regime.

1685. De provincie Saskatchewan was in 1946 de eerste Engelstalige jurisdictie waar een no-fault compensatiefonds voor verkeersslachtoffers werd ingevoerd. Zie daarover O'Connell and Tense, San Diego L. Rev., 1987, p. 918, noot 5: Van Wassenaer van Catwijck, VA, 1988, p. 328-329: Prosser and Keeton on the Law of Torts, p. 604-605.

1686. Report of the Inquiry into Motor Vehicle Compensation in Ontario (ook bekend onder de nam 'Osborn Report'), Ontario, Queens Printer, 1988, volume II, p. 666 in Chapman and Trebilicock, Working Paper, 1991, p. 4.

1687. Devlin, IRLE, 1990, p. 194-197.

1688. Automobile Insurance Act ('Loi sur l'assurance automobile'), Quebec Rev. Stat. chapte A-25 (1977) in O'Connell and Tenser, San Diego L. Rev., 1987, p. 917, noot 2. Zie ook Van Wassenaer van Catwijck, VA, 1988, p. 340.

1689. Automobile Insurance Act, R.S.Q. 1977, A-25, paragraaf 3 in O'Connell and Tenser, SDLR, 1987, p. 918-919. Zie ook Dewees, Duff and Trebilcock, Accident Law, p. 54 en 87, noot 374 m 375 . 
De compensatie van verkeersschade onder het Quebec no-fault plan omvat ruime (periodieke) vergoedingen aan verkeersslachtoffers voor medische kosten (onbeperkt) en inkomensschade (gelimiteerd), alsmede compensatie voor nabestaanden bij bet overlijden van het slachtoffer. Daarnaast heeft het verkeersslachtoffer (niet zijn abestaanden) recht op een vergoeding ineens voor immateriële schade. De maximale omvang van deze vergoeding wordt door de Regie vastgesteld en is mede gebaserd op een soort schadetabel. De maximumbedragen voor smartengeld worden geregeld aangepast en waren bijvoorbeeld per 1 januari 1992 vastgesteld op $\$ 125.0000^{1690}$

Een autobestuurder betaalt voor zijn no-fault verzekering een vaste premie. Deze bestaat uit een eenheidspremie per motorvoertuig, een heffing per periodiek verlengd rijbewijs plus een accijns op benzine. ${ }^{1691}$ Premiewijzigingen worden vanwege de overheid gereguleerd en zijn niet gebaseerd op het schadeverleden van de bestuurder. Er is wel sprake van een individuele premieaanpassing bij verkeersovertredingen van de autobestuurder. Voor zaakschade blijft het aansprakelijkheidsrecht gehandhaafd aangevuld door een verplichte aansprakelijkheidsverzekering. ${ }^{1692}$

\section{AANSPRAKELIJKHEID VERSUS NO-FAULT IN DE VERENIGDE STATEN}

In Noord-Amerika heeft elke staat een autonome bevoegdheid om de vergoeding van verkeersschade te regelen. Gedurende de jaren ' 70 van de vorige eeuw is in dat kader een groot aantal Amerikaanse staten overgegaan tot de invoering van een nofault verzekering. De staat Massachusetts was hiermee in 1971 de eerste. ${ }^{1693}$ In de praktijk geldt dat in Amerika 50 verschillende systemen van verkeersaansprakelijkheid aanwezig zijn. Gegeven de onmogelijkheid om voor alle Amerikaanse staten het systeem van verkeersaansprakelijkheid tot in detail te beschrijven, zal de analyse in deze paragraaf worden beperkt tot de staten die een bepaalde vorm van no-fault kennen. Daarbij wordt zoveel mogelijk de indeling uit de inleiding van dit hoofdstuk arngehouden. In de volgende subparagraaf zal eerst de werking van het aansprake-

1690. Zie O'Connell and Tenser, SDLR, 1987, p. 919-927, voor een beschrijving van deze wet. Zie ook Van Wassenaer van Catwijck, VA, 1988, p. 332 en Van Wassenaer van Catwijck, VR, 1988, p. 374-375.

1691. Van Wassenaer van Catwijck, VA, 1988, p. 357.

1692. Devlin, IRLE, 1990, p. 196-197; Outreville, JRJ, 1984, p. 320-321; Van Wassenaer van Catuijck, VA, 1988, 341-343.

1693. Zie voor de geschiedenis van de no-fault in Noord-Amerika onder anderen: Keeton, Keeton, Sargentich and Steiner, Cases and Materials on Tort and Accident Law, p. 896-902; Prosser and Keeton on the Law of Torts, p. 606-608; Van Wassenaer van Catwijck, VA, 1988, p. 326-330: Schimeister, Amerikaanse toestanden in het schadevergoedingsrecht?, p. 39-40 en p. 446-449. 
lijkheidssysteem voor verkeersschade worden beschreven, dat nog altijd in 26 Ame-
rikaanse staten volledig wordt toegepast. ${ }^{1694}$

\subsubsection{Het aansprakelijkheidsregime voor verkeersschade}

In de Amerikaanse staten die geen no-fault verzekering hebben ingevoerd wordt de schade tengevolge van een verkeersongeval globaal geregeld via het aansprakeijjkheidsrecht ('tort'), gecombineerd met een verplichte motorrijtuigverzekering tegen aansprakelijkheid ('bodily injury liability (BIL) insurance'). Daarnaast kan een autiobestuurder een zogenaamde 'uninsured motorist'(UM) verzekering afsluiten, die dekking geeft tegen het risico dat een schadeveroorzaker onverzekerd blijkt te zijn. ${ }^{169}$

Met betrekking tot de schaderegeling na een verkeersongeval wordt zowel een regel van foutaansprakelijkheid met een absoluut eigen schuldverweer als een foulaansprakelijkheid met een gradueel eigen schuldverweer toegepast. ${ }^{169}$ De laatste regel is sinds de jaren '70 en ' 80 van de vorige eeuw het meest gangbaar in een groot deel van de Verenigde Staten. ${ }^{1697}$

Een verkeersslachtoffer in een 'tort'-staat heeft bij een aansprakelijkheidsprocedwe in beginsel recht op vergoeding van zijn gehele materiële en immateriële schade. Wanneer de schuld van de schadeveroorzaker vaststaat kan zijn aansprakelijkheids. verzekeraar, binnen de geldende polisvoorwaarden, overgaan tot uitkering van zowel zaakschade ('property damage') als letselschade ('personal injury'). De laatste catego-

1694. Zie paragraaf 3.2.1 van hoofdstuk 10 voor een meer uitvoerige beschrijving hiervan.

1695. Zie Van Wassenaer van Catwijck, VA, 1988, p. 329; Rolph, Hammit and Houchens, IR!, 1985, p. 672. De 'tort' staten met een verplichte aansprakelijkheidsverzekering zijn: Louisiana, Idaho, Montana, Nevada, Oklahoma, West Virginia, Arizona, Indiana en North Carolina. De 'tor' stater met een vrijwillige aansprakelijkheidsverzekering zijn: Alaska, California, Illinois, lowa, Missis sippi, New Mexico, Rhode Island, Maine, Nebraska, New Hampshire, Ohio, Vernont, Visowsin, Wyoming, Alabama, Missouri en Tennessee. Twee 'tort' staten, New Hampshire en Wisconsin, kennen daamaast een vorm van no-fault, op basis waarvan een minimale eerste partij ragoeding van $\$ 1.000$ mogelijk is. Zie U.S. Department of Transportation, Compensating Auto Accident Victims, Washington D.C. 1985, p. $41-49$ in Dewees, Duff and Trebilcock, Accident Law, p. 86, noot 369.

1696. De 'tort' staten met een foutaanspakelijkheid met een absoluut eigen schuldverweer pij: Atrzona, North Carolina, Indiana, Alabama, Missouri en Tennessee. De 'tort' staten met een foutansprakelijkheid met een gradueel eigen schuldverweer zijn: Louisiana, Alaska, Californis, thinois, lowa, Mississippi, New Mexico, Rhode Island, Idaho, Montana, Nevada, Oklahome, West Vir. ginia, Maine, Nebraska, New Hampshire, Ohio, Vermont, Wisconsin en Wyoming. Zit Ropht, Hammit and Houchens, JRI, 1985, p. 672; Curran, IRLE, 1992, p. 319-322.

1697. Tussen 1969 en 1985 werd door een grote meerderheid (44) van de Amerikaanse staten een foul. aansprakelijkheid met een gradueel eigen schuldverweer ingevoerd. Daaronder bevinden ich aansprakelijkheid met een gradueel eigen schuldverweer ingevoerd. Daaronder beving id 319 -
ook staten met een no-fault regime. Zie White, RJE, 1989, p. 30; Curran, IRLE, 1992,
322 . 
nie omvat materiële schade, zoals medische kosten en inkomensschade, en immatenielle schade ('general damages') of schade voor pijn en smart ('pain and suffering $\left.^{\prime}\right)^{1698}$

Naast de mogelijkheid om de aansprakelijkheidsverzekeraar van de schadeveroorzaker aan te spreken, zijn er ook aan de zijde van het potentiële verkeersslachtoffer meerdere vergoedingsbronnen beschikbaar. Deze bestaan in meer algemene zin uit een levensverzekering, een particuliere ziektekostenverzekering en een aanvullende, door de overheid beschikbaar gestelde, verzekering zoals de 'Medicare' en 'Medicaid' programma's. Daarnaast kan het potentiële verkeersslachtoffer een eerste partij ziektekostenverzekering ('med pay insurance') afsluiten die meer specifiek de medische kosten tengevolge van een verkeersongeval vergoedt. ${ }^{1699}$ Door werknemers kan een beroep worden gedaan op de zogenaamde 'Workers Compensation Scheme' voor de inkomensschade die naar aanleiding van een verkeersongeval wordt geleden. In een antal Amerikaanse jurisdicties is daarnaast een sociaal zekerbeidsprogramma beschikbaar voor blijvend inkomensverlies. Ten slotte wordt ook door de particuliere verzekeringsmarkt dekking geboden tegen langdurige arbeidsongeschiktheid. ${ }^{1700}$

\subsection{De verschillende no-fault systemen in de Verenigde Staten}

Tussen 1970 en 1980 hebben 24 Amerikaanse staten een vorm van no-fault ingevoerd, waarvan de inhoud echter van staat tot staat verschilt. Een belangrijk argument om tot invoering van een no-fault verzekering over te gaan, hing samen met het beperken van het aantal aansprakelijkheidsclaims voor immateriële schade ('general damages'). Daarnaast werd getracht een besparing te bereiken op de omvangrijke bedragen die in het algemeen voor smartengeld in de VS worden toegewezen. ${ }^{1701} 15$ no-fault staten hebben een zogenaamd 'threshold' systeem ingevoerd, waarbij een onrechtmatige daadsactie nog wel mogelijk is, maar gebonden is aan bapaalde financiële en materiële ('verbal') schadedrempels ('threshold'). ${ }^{1702}$ Daarnaast is de eerste partij no-fault verzekering ('personal injury protection') voor elke

1698. Camoll and Kakalik, JRJ, 1993, p. 266; Cummins and Weiss, GPRI, 1991, p. 20; Rolph, Hammit and Houchens, JRI, 1985, p. 671. Zie ook Schirmeister, Amerikaanse toestanden in het schadevergoedingsrecht?, p. 35-42, voor een overzicht van de verschillende vergoedingsmogelijkheden.

1699. Carroll and Kakalik, JRI, 1993, p. 266; All-Industry Research Advisory Counsil, Compensation for Automobile Injuries in the United States, Oak Brook III, 1989, p. 26 in Dewees, Duff and Trebilcock, Accident Law, p. 26 en 70 , noot 115.

1700. Danzon, JLS, 1984, p. 519-524; O'Connell and Guinivan, Ohio State Law Journal, 1988, p. 763 in Dewees, Duff and Trebilcock, Accident Law, p. 27 en 70 noot 124

Van Wassenaer van Catwijck, VA, 1988, p. 330-331.

Deze staten zijn: Colorado, Connecticut, Florida, Georgia, Hawaii, Kansas, Kentucky, Massachusetts, Michigan, Minnesota, New Jersey, New York, North Dakota, Pennsylvania (tot 1989) en Utah. Zie Dewees, Duff and Trebilcock, Accident Law, p. 67, noot 69; Rolph, Hammit and Houchens, JRI, 1985, p. 672; O'Connell, SDLR, 1989, p. 998. 
autobestuurder veelal verplicht gesteld. In drie staten, New Jersey, Kentucky en Pennsylvania, ${ }^{1703}$ wordt aan de autobestuurder de keuze gelaten om in het no-fiault systeem te participeren of om voor de geleden verkeersschade een aansprakelijk. heidsvordering in te stellen ('elective no-fault'). Wanneer de autobestuurder kiest voor de no-fault optie dan ontvangt hij een korting op zijn premie bij de aansprakelijkheidsverzekering. Er zijn verder 9 no-fault staten die een zogenaamd 'add-on' regime toepassen, waarbij een eventuele vordering uit onrechtmatige daad naast een beschikbare no-fault vergoeding blijft bestaan. ${ }^{1704}$ Hierna zullen de no-fault regimes in deze 24 Amerikaanse staten de worden uiteengezet, waarbij een onderscheid zal worden gemaakt naar 'threshold' en 'add-on' no-fault staten.

\subsubsection{No-fault staten ('threshold')}

Tabel $1^{1705}$ geeft een overzicht van 14 staten $^{1706}$ die in de jaren ' 70 van de vorige eeuw een no-fault systeem met een materiële ('verbal') of een financiële schadedrempel ('threshold') voor het instellen van een aansprakelijkheidsvordering hebben ingevoerd. De materiële ('verbal') drempel hangt samen met de ernst van de geleden schade. In Michigan, bijvoorbeeld, kan een verkeersslachtoffer alleen een anspprakelijkheidsvordering instellen, wanneer het ongeval de dood tot gevolg heeff, het slachtoffer ernstig lichamelijk gehandicapt raakt of het ongeval opzettelijk is veroorzaakt. In New Jersey brengt de materiële schadedrempel mee dat slachtoffers al bij lichte botbreuken een aansprakelijkheidsvordering kunnen instellen. Alle in tabel 1 genoemde financiële schadedrempels, medische kosten en revalidatie, bevatten een materiële component, die de ernst van het letsel specificeert waarboven een ansprakelijkheidsvordering kan worden ingesteld, zelfs indien de omvang van de medische

1703. In New Jersey is in 1989 de schadedrempel van $\$ 1.700$ vervangen door een strikte milerilte ('verbal') drempel. Kentucky kent nog een schadedrempel van $\$ 1.000$, waarbij de autobesturder echter de keuze heeft tussen no-fault en 'tort'. Kiest hij voor het laatste dan gelden er geen lexpeskingen. In Pennsylvania is in 1989 het 'threshold no-fault systeem (ingevoerd in 1974, threshotit $\$ 705$ ) vervangen door een 'add-on' systeem zonder een schadedrempel. Zie Powers, RR. 1992. p. 204-206; Chapman and Trebilcock, Working Paper, 1991, p. 25; Cummins and Weis, $1 / 2$. 1993, p. 258-259; Johnson, Flanigan and Winkler, JR, 1992, p. 116.

1704. Dit zijn: Arkansas, Delaware, Maryland, Oregon, South Carolina, South Dakota, Texas, Virginis en Washington en sinds 1989 Pennsylvania. Zie Dewees, Duff and Trebilcock, Accident Lar, ? 67, noot 65; Rolph, Hammit and Houchens, JRI, 1985, p. 672; Chapman and Trebllicwi. Wodsing Paper, 1991, p. 2-3.

1705. De gegevens in deze tabel zijn ontleend aan: O'Connell, SDLR, 1989, p. 998; U.S. Depstment of Transportation, Compensating Auto Accident Victims, 1985, p. 25-37 in Dewers, Duff and Trebilcock, Accident Law, p. 86-87, noot 370 en 371; Landes, JLE. 1982, p. 49, nool 1.

1706. Pennsylvania heeft in 1989 haar 'threshold' systeem gewijzigd in een 'add-on' regime en al daarom in de volgende subparagraaf aan de orde komen. 
kosten binnen de financiële drempel blijft. In Massachusetts is de schadedrempel bijvorbeeld vastgesteld op $\$ 500$ voor medische kosten of ernstig letsel. ${ }^{1707}$

Tabel

\begin{tabular}{|c|c|c|c|}
\hline Staat & $\begin{array}{c}\text { jaar van in- } \\
\text { voering }\end{array}$ & $\begin{array}{c}\text { Drempel } \\
\text { ('threshold') }\end{array}$ & vergoedingslimiet voor medische kosten \\
\hline Michigan & 1973 & 'verbal' & $\$ 10.000$ \\
\hline Florida & 1972 & 'verbal' & $\$ 50.000$ \\
\hline New York & 1974 & 'verbal' & $\$ 15.000$ \\
\hline Hawaì & 1973 & $\$ 5.600$ & $\$ 40.000$ \\
\hline Minnesota & 1975 & $\$ 4.000$ & $\$ 14.000$ \\
\hline Utah & 1974 & $\$ 3.000$ & $\$ 130.000$ \\
\hline Colorado & 1974 & $\$ 2.500$ & $\$ 30.000$ \\
\hline North Dakota & 1976 & $\$ 2.500$ & $\$ 10.000$ \\
\hline Kentucky & 1975 & $\$ 1.000$ & $\$ 5.000$ \\
\hline Georgia & 1975 & $\$ 500$ & $\$ 29.000$ \\
\hline Kansas & 1974 & $\$ 2.000$ & $\$ 2.000$ \\
\hline Massachusetts & 1971 & $\$ 500$ & $\$ 5.000$ \\
\hline Connecticut & 1973 & $\$ 400$ & onbeperkt \\
\hline New Jersey & $1973 / 89$ & 'verbal' & $\$ 1000$ \\
\hline
\end{tabular}

De 'threshold' no-fault staten hanteren naast schadedrempels ook maximumbedragen roor de vergoeding van de kosten van medische behandeling die als gevolg van een refkersongeval worden gemaakt. Een aantal staten kent ruime vergoedingsmogelijkheden voor medische kosten (New York, Michigan, Colorado en Jersey), ${ }^{1708}$ in de overige 'threshold' staten lopen de maximale vergoedingen voor medische kosten uiteen van $\$ 2.000$ (inclusief inkomensschade) in Massachusetts tot $\$ 40.000$ in Mirnesota. ${ }^{1709}$ In een aantal staten geldt verder dat een verzekerde autobestuurder

1707. Carroll and Kakalik, JRI, 1993, p. 267, noot 3; Cummins and Tennyson, J. Ec. Persp., 1992, p 97; U.S. Department of Transportation, Compensating Auto Accident Victims, 1985 in Dewees, Duff and Trebilcock, Accident Law, p. 86, noot 370; Van Wassenaer van Catwijck, VA, 1988, p. 332; Cummins and Weiss, GPRI, 1991, p. 30, noot 26.

1708. In New Jersey geldtee

new Jersey geldt een algehele polislimiet van $\$ 250.000$ voor medische kosten en inkomensschade. Zie Caroll and Kakalik, JRI, 1993, p. 267.

333, Hammit and Houchens, JRI, 1985, p. 672; Van Wassenaer van Catwijck, VA, 1988, p. 333; O'Connell, SDLR, 1989, p. 998-999; U.S. Department of Transportation, Compensating 
voor zichzelf en zijn inwonende gezinsleden een eigen risico kan bedingen dat kan oplopen van $\$ 100$ tot $\$ 2.500$. $^{1710}$

Voor de vergoeding van inkomensschade geldt veelal een vast bedrag per week of per maand, met een limiet ten aanzien van de periode waarbinnen de vergoeding kan worden verkregen of een vast percentage van het gemiddelde salaris binnen een staat. In sommige 'threshold' staten is de no-fault vergoedingslimiet ook van toepassing op inkomensschade (onder andere Massachusetts en New York). In andere 'threshold' staten is de vergoeding van inkomensschade ruim geregeld (Colorado, Michigan). Vergoedingen voor immateriële schade zijn gewoonlijk beperkt of uitgesloten tot beneden de gedefinieerde schadedrempel ('threshold'). Deze schadedrempels en de voorwaarden waaronder het verkeersslachtoffer een vordering voor immateriële schadevergoeding kan instellen verschillen daarnaast weer van staat tot staat. ${ }^{1711}$

Auto Accident Victims, 1985, p. 25 en 34 in Dewess, Duff and Trebilcock, Accident Law, p. 87, noot 371; O'Connell and Joost. Virginia Law Review, 1986, p. 64, noot 9.

1710. De staten die autoverzekeraars verplichten om een eigen risico aan te bieden zijn: Colondo (S 100 ), Florida (\$250 tot $\$ 2.000$ ), Hawaii (\$100-\$1.000), Kentucky (\$250-\$1.000), Massachusetts $(\$ 250-\$ 2000)$, Michigan $(\$ 300)$, New Jersey $(\$ 500-\$ 2.500)$, Utah $(\$ 500)$ en New York $(\$ 200)$. Zie U.S. Department of Transportation, 1985 in Dewees, Duff and Trebilcock, Accident Law, p. 68, noot 383.

1711. Witt and Urrutia, JRI, 1983, p. 634; U.S. Department of Transportation, 1985, p. 25 en 34 in Dewees, Duff and Trebilcock, Accident Law, p. 87, noot 371; Van Wassenaer van Catwijck, VA. 1988, p. 341. 
24.2.2. 'Add-on' no-fault staten

Tabel 2

\begin{tabular}{|c|c|c|c|}
\hline Staat & $\begin{array}{c}\text { jaar van invoe- } \\
\text { ring }\end{array}$ & $\begin{array}{c}\text { no-fault } \\
\text { karakter }\end{array}$ & $\begin{array}{c}\text { vergoedingslimiet voor medische } \\
\text { kosten }\end{array}$ \\
\hline Oregon & 1972 & verplicht & $\$ 20.000$ \\
\hline Delaware & 1972 & verplicht & $\$ 10.000$ \\
\hline Maryland & 1973 & verplicht & $\$ 2.500$ \\
\hline Pennsylvania & $1984 / 1989$ & verplicht & $\$ 15.000$ \\
\hline Arkansas & 1974 & vrijwillig & $\$ 16.000$ \\
\hline South Carolina & 1974 & vrijwillig & $\$ 1.000$ \\
\hline Texas & 1974 & vrijwillig & $\$ 2.500$ \\
\hline Washington & -- & vrijwillig & $\$ 25.000$ \\
\hline South Dakota & 1972 & vrijwillig & $<\$ 5.000$ \\
\hline Virginia & 1972 & vrijwillig & $<\$ 5.000$ \\
\hline
\end{tabular}

Tabel $2^{1712}$ geeft een overzicht van 10 Amerikaanse staten die een 'add-on' no-fault regime hebben ingevoerd. In een aantal van deze staten zijn autobestuurders verplicht om een eerste partij no-fault verzekering voor personenschade ('personal injury protection', PIP) af te sluiten. In de meeste andere staten geschiedt dit op vrijwillige basis. De uitkering onder de PIP-verzekering is beperkt tot materiële personenschade (in Delaware ook zaakschade), waarvoor vergoedingslimieten zijn opgenomen. De vergoeding voor inkomensschade is veelal beperkt tot een periode van 1 of 2 jaar, waarbij de maximale vergoeding tussen de $\$ 140$ en $\$ 200$ per week bedraagh

Nasst de PIP-verzekering blijft in de 'add-on' no-fault staten de mogelijkheid voor hat instellen van een aansprakelijkheidsvordering (voor materiële en immateriële schadevergoeding) onbeperkt openstaan. Van belang is verder dat in de meeste 'addon' no-fault staten de zogenaamde 'collateral source rule' onverminderd van toepassing bliff. Dit betekent dat de vergoeding op grond van de PIP-verzekering en naar anleiding van een aansprakelijkheidsvordering niet met elkaar worden verrekend, maar gewoon bij elkaar worden opgeteld. Aan deze regel zijn echter door een aantal

1712. De gegevens zijn ontleend aan: U.S. Department of Transportation, 1985, p. $41-49$ in Dewees, Duff and Trebilcock, Accident Law, p. 86, noot 368 en 369; Rolph, Hammit and Houchens, JR, 1985, p. 672; O'Connell, SDLR, 1989, p. 998-999; O'Connell and Joost, Virginia Law Review, 1986, p. 64, noot 9; Witt and Umutia, JRI, 1983, p. 634. 

staten weer beperkingen gesteld (onder andere in Delaware, Oregon en South Ca.
rolina). ${ }^{1713}$

\section{No-fault versus aansprakelijkheid: het empirisch onderzoek}

Ten aanzien van hiervoor beschreven no-fault regimes in Noord-Amerika, Canada, Australië en Nieuw-Zeeland kan, uitgaande van de verschillen tussen deze stelsels, een redelijke empirische vergelijking worden gemaakt. In deze paragraaf zal daarom empirisch onderzoek worden beschreven, waarin een aantal aspecten van een nofault systeem wordt vergeleken met het systeem van aansprakelijkheid en verzekering bij verkeersongevallen. Deze aspecten komen overeen met het onderscheid in ongevalskosten dat als een rode draad door dit onderzoek loopt en betrekking heeft op de primaire, secundaire en tertiaire ongevalskosten. ${ }^{1714}$ Door Chapman en Trebilcock wordt in een vergelijkbaar kader onderscheid gemaakt tussen individuele verantwoordelijkheid ('individual responsability ${ }^{1715}$ ), verdelende rechtvaardigheid ('distributive justice') en administratieve kosten ('administrative and premium costs'). ${ }^{1716}$

In paragraaf $3.1 \mathrm{zal}$ eerst aandacht worden besteed aan de vraag of een no-fault regime in vergelijking met het aansprakelijkheidsrecht tot een vermindering van het aantal verkeersongevallen kan leiden (primaire ongevalskosten, individuele verantwoordelijkheid). In paragraaf 3.2 wordt ingegaan op de vraag bij welk systeem, nofault of aansprakelijkheid, het verkeersslachtoffer een optimale compensatie ontvangt (secundaire ongevalskosten, verdelende rechtvaardigheid). Paragraaf 3.3 , tenslotte, is ingeruimd voor een vergelijking van de kosten van een no-fault regime met die van een aansprakelijkheidssysteem (tertiaire ongevalskosten, administratieve kosten).

1713. Witt and Urrutia, JRI, 1983, p. 634-635; U.S. Department of Transportation, 1985, p. $42-49$ in Dewees, Duff and Trebilcock, Accident Law, p. 86 noot 368 en 369; Rolph, Hammit and Houchens, JRI, 1985, p. 672; Van Wassenaer van Catwijck, VA, 1988, p. 332-333 en 34:; Chapman and Trebilcock, Working Paper, 1991, p. 3.

1714. Zie Calabresi, Costs of Accidents, 1970, p. 26-28.

17i5. Zij beschouwen de preventie ('individual responsability') in samenhang met een 'corrective jus. tice'-benadering. Daarin ligt niet zozeer de nadruk op een beînvloeding van het toekomstig gsdrag van andere schadeveroorzakers of op een vergoeding van het slachtoffer, maar veeleer in het corrigeren van het gedrag van de schadeveroorzaker zelf, waarbij een vergoeding wordt op gelegd voor het herstel van toegebracht leed. Zie Chapman and Trebilcock, Working Paptr, 1991, p. 10.

1716. Chapman and Trebilcock, Working Paper, 1991, p. 9-12. 
3.1. AANSPRAKELUKHEID VERSUS NO-FAULT: DE PREVENTIE VAN VERKEERSONGEVALLEN

Gesteld kan worden dat het empirisch onderzoek naar de preventieve effecten van de no-fault wetgeving tegenstrijdige uitkomsten vertoont. In een aantal studies wordt benadrukt dat de invoering van een no-fault verzekering heeft geleid tot een stijging Ian het aantal verkeersongevallen en verkeersslachtoffers. ${ }^{1717}$ Andere studies ontdekten geen negatief verband tussen de ingevoerde no-fault wetgeving en het aantal dodelijke verkeersslachtoffers. De uitkomsten van deze studies wezen eerder op een daling van het aantal verkeersslachtoffers na de invoering van een no-fault verzekeing. ${ }^{1.18}$ In deze paragraaf zal de empirische literatuur over de preventieve effecten van een no-fault verzekering worden geanalyseerd. Daarbij zal de aandacht uitgaan naar de eerder, positiefrechtelijk, beschreven no-fault stelsels in Noord-Amerika (paragraf 3.1.1), Nieuw Zeeland (paragraaf 3.1.2), Australië (paragraaf 3.1.3) en Quebec (paragraaf 3.1.4).

\subsection{De preventieve effecten van no-fault in de VS}

Bij de analyse van de effecten van een no-fault verzekering in de Verenigde Staten ul het onderzoek van Elisabeth Landes als uitgangspunt worden genomen. Volgens har berekening zal een no-fault verzekering leiden tot een stijging van het aantal rerkersongevallen respectievelijk een stijging van de ongevalskosten. $\mathrm{Na}$ de besshrijving van dit onderzoek zal in paragraaf 3.1.1.2 aan de hand van de literatuur een aantal kritische kantekeningen worden geplaatst bij de bevindingen van Landes. Daarbij komt een aantal empirische studies aan de orde waarin wordt geconcludeerd dat en no-fault verzekering niet heeft geleid tot een toename van het aantal verkeersongevallen.

\subsubsection{De visie van Elisabeth Landes}

Landes bestudeert in haar theoretisch en empirisch onderzoek de preventieve effecten van een no-fault verzekering in een aantal Amerikaanse staten die tussen 1971 en

\footnotetext{
1717. Medoff and Magaddino, Eval. Rev., 1982, p. 373- 392 (Amerika); Landes, JLE, 1982, p. 49-65 (Amerika); Sloan, Reilly, Schenzler, IRLE, 1994, p. 53-71 (Amerika); McEwin, IRLE, 1989, p. 13-24 (Australie); Devlin, IRLE, 1990, p. 193-205 (Quebec).

1718. Zador and Lund, JRI, 1986, p. 226-24l (Amerika); Kochanowski and Young, JRI, 1985, p. 269288 (Amerika); McEwin, IRLE, 1989, p. 13-24 (Australië); Brown, CaLR, 1985, p. 976-1002 (Nieuw Zeeland). Zie ook: Nentjes en Dijkstra, NJB, 1993 p. 954; Van den Bergh, in Verkeersaansprakelijkheid in Belgie en Nederland, p. 663-665; Visscher en Van den Bergh, NJB, 1998, p.
} 
1976 een vorm van no-fault hebben ingevoerd. ${ }^{1719} \mathrm{Zij}$ maakt in dat kader een vergelijking tussen de ongevalskosten van staten die een aansprakelijkheidsvordering heb. ben beperkt ('threshold') en staten die het instellen van een aansprakelijk. heidsvordering voor verkeersschade nog geheel openlaten ('tort'). De onderzoeksdata in deze studie hebben betrekking op een vergelijking van de statistieken van dode. lijke verkeersongevallen tussen alle Amerikaanse staten in de periode 1967-1976, Daarbij wordt ten aanzien van staten die tussen 1971 en 1976 een no-fault regime hebben ingevoerd een meer specifieke vergelijking gemaakt tussen het aantal dodelijke verkeersongevallen in de pre-no-fault fase respectievelijk de post-no-fault fase. Verder gaat Landes in haar empirische analyse uit van de veronderstelling dat staten die hun aansprakelijkheid voor personenschade tengevolge van een verkeersongeval beperken, te maken krijgen met een toename van het aantal verkeersongevallen. Daarbij geldt volgens haar dat een grotere beperking van de aansprakelijkheid zal leiden tot een additionele toename van het aantal verkeersongevallen. ${ }^{1720}$

De resultaten van het empirisch onderzoek geven volgens Landes aan dat een nofault regime heeft geleid tot een toename van het aantal dodelijke verkeersongevallen en daarmee ook van de totale ongevalskosten. In absolute cijfers is volgens Landes in de staten die tussen 1971 en 1976 een no-fault verzekering hadden ingevoerd sprake van een additionele toename van het aantal dodelijke verkeersongevallen met 376 tot 1009. Daarnaast wordt door Landes een verband aangetoond tussen de stijging van het aantal dodelijke verkeersongevallen en de omvang van de financiële schadedrempel ('threshold'), waar beneden voor de geleden schade geen aansprakelijkheidsvordering kan worden ingesteld. Een 'threshold' van $\$ 500$ voor medische kosten leidt dan tot een toename van het aantal dodelijke verkeersongevallen met ongeveer $4 \%$. Een 'threshold' van $\$ 1.500$ voor medische kosten leidt in de berekening van Landes tot een stijging van het aantal dodelijke verkeersongevallen met meer dan $10 \%$.

Volgens Landes is de omvang van de 'threshold' en het effect daarvan op de ongevalskosten mede afhankelijk van het aantal schadeclaims waarvoor als gevolg van d? 'threshold' geen aansprakelijkheidsvordering kan worden ingesteld. Wanneer bijvoorbeeld een verkeersongeval met een medische schadepost van minder dan $\$ 500$ bij afwezigheid van een 'threshold' niet leidt tot een aansprakelijkheidsvordering, zal naar de mening van Landes een 'threshold' van $\$ 500$ niet van wezenlijke invloed zijn op de preventieve werking van het aansprakelijkheidsrecht. De invloed van de

1719. Landes, JLE, 1982, p. 49-65. Zij concentreett zich daarbij op de 'threshold' no-fault staten, p. 49, noot 1. De 'add-on' staten worden buiten beschouwing gelaten met het argument dat binnen deze regimes de aansprakelijkheidsvordering in het geheel niet wordt beperkt. Zie p. 57 , nnot 8 . 
omvang van de 'threshold' is dan volgens haar eerder afhankelijk van de geneigdheid van het slachtoffer om een aansprakelijkheidsvordering in te stellen. ${ }^{1721}$

In een ander Amerikaanse onderzoek, met data uit het jaar 1977, wordt een verband gelegd tussen de omvang van de schadeclaim tengevolge van een verkeersongeval en de gemiddelde schaderegelingskosten per premie-dollar ('liability loss ratio'). ${ }^{1722}$ Medoff en Magaddino veronderstellen daarbij dat naarmate het aantal verkeersongevallen in een staat toeneemt, het aantal schadeclaims eveneens zal stijgen zodat een hogere schaderatio ontstaat. Daarnaast zal volgens hen een staat met een no-fault regime een hogere schaderatio moeten hebben dan een 'tort'-staat. ${ }^{1723}$

Door Medoff en Magaddino worden de no-fault staten onderverdeeld in een viertal vomen van no-fault. Deze worden omschreven als: 1. staten met een 'mandatory' no-fault regime, waarbij een verplichte aansprakelijkheidsverzekering en een nofault dekking van toepassing is, met beperkingen op het instellen van een aansprakeli.jkheidsvordering ('threshold' no-fault); 2. Staten met een 'compulsory' no-fault systeem, waarbij een aansprakelijkheidsverzekering en een no-fault dekking verplicht zijn en waarbinnen respectievelijk schadedrempels toepasselijk zijn en geen beperkingen aan een aansprakelijkheidsvordering worden gesteld (een combinatie van 'threshold' en 'add-on' no-fault); 3. Gelijk aan het vorige systeem, maar een aansprakelijkheidsverzekering en een no-fault dekking kunnen zowel verplicht als nietrerplicht zijn opgelegd; 4 . Staten met een 'pure' no-fault wetgeving. Dit zijn no-fault staten die in verhouding tot andere no-fault staten de meest uitgebreide no-fault dekking verschaffen. Hierbij is nog wel een aansprakelijkheidsvordering mogelijk maar hiervan zal, als gevolg van de genereuze vergoedingen onder de no-fault verzekering weinig gebruik worden gemaakt. ${ }^{1724}$

Uit de onderzoeksresultaten blijkt dat de gemiddelde schadeomvang in de no-fault staten ten opzichte van de 'tort' staten is gestegen. Deze toename bedroeg respectievelijk 7,4\% in de 'pure' no-fault staten (4), 6,3\% in de 'mandatory' no-fault staten (1) en $4 \%$ in de 'compulsory' no-fault staten (2). ${ }^{1725}$

\subsubsection{De kritiek op het onderzoek van Landes}

Door verschillende auteurs zijn kantekeningen geplaatst bij de onderzoeksresultaten ran Landes. Deze kritiek richt zich onder andere op het enkele gebruik van ongevalsdata als toetsingsvariabele, waarbij andere belangwekkende factoren die van in-

\footnotetext{
1721. Landes, JLE, 1982, p. 59-65.

1722. Medofi and Magaddino, Eval. Rev., 1982, p. 373-392

1723. Medoff and Magaddino, Eval. Rev., 1982, p. 378.

1725. Medoff and Magaddino, Eval. Rev., 1982, p. 379-380.

Medoff and Magaddino, Eval. Rev., 1982, p. 382 en 388
} 
vloed kunnen zijn op het aantal verkeersongevallen, zoals premietoeslagen en strafrechtelijke sancties, worden genegeerd. Daarnaast wordt door de critici gewezen op het korte termijn effect van de gebruikte ongevalsdata, omdat in sommige staten een no-fault regime nog maar een aantal jaren van kracht was. ${ }^{1726}$

In een tweetal empirische studies wordt getracht de onderzoeksresultaten van Landes meer direct te pareren door de effecten van een no-fault verzekering op het aantal dodelijke verkeersongevallen, respectievelijk het rijgedrag van de autobestuurder in de VS te bestuderen. ${ }^{1727}$ In het onderzoek van Zador en Lund wordt, in navolging van het model van Landes, een rangschikking gemaakt van de 16 'threshold' no-fault staten ('add-on' no-fault staten worden niet meegerekend). Daarbij wordt onder andere de financiële waarde van de 'threshold', waarboven pas een aansprakelijkheidsvordering kan worden ingesteld, gecorrigeerd naar de verschillen in kosten van de gezondheidszorg tussen de 'threshold' no-fault staten. Tevens wordt per no-fault staat het percentage van de schadeclaim berekend dat niet voor een aansprakelijkheidsvergoeding in aanmerking komt. Vervolgens wordt bepaald in welke mate de wijziging in frequentie van het aantal dodelijke verkeersongevallen kan worden toegeschreven aan de invoering van de no-fault verzekering. ${ }^{1728}$

Beide studies komen enerzijds tot de conclusie dat de invoering van een no-fault verzekering niet tot een toename van het aantal dodelijke verkeersongevallen heeft geleid. Anderzijds blijkt uit beide studies dat een no-fault verzekering ook niet tot een wezenlijke daling van het aantal dodelijke verkeersongevallen leidt. ${ }^{1729}$ Uit het onderzoek van Zador en Lund blijkt dat in no-fault staten met een relatief lage 'threshold', waarbij de mogelijkheid van een aansprakelijkheidsvordering nog ruim aanwezig is, het aantal verkeersdoden daalde, terwijl in no-fault staten met een hoge 'threshold' het aantal verkeersdoden ongeveer gelijk bleef. Dit betekent volgens hen dat een sterke beperking van de aansprakelijkheidsvordering (een hoge 'threshold') ook niet in verband staat met een toename van het aantal dodelijke verkeersengeval. len. ${ }^{1730}$ In het onderzoek van Kochanowski en Young lijken de onderzoeksresultaten te suggereren dat een no-fault verzekering ook niet leidt tot een veiliger rijomgeving.

1726. Zie onder anderen Sloan, Reilly and Schenzler, IRLE, 1994, p. 56 voor een overzicht van deas kritiek.

1727. Zador and Lund, JRI, 1986, p. 226-241. In dit onderzoek wordt gebruik gemaakt van ongevalsdata uit 50 Amerikaanse staten in de periode 1967-1980. Verder worden gegevens verameld ten aanzien van de bevolkingsdichtheid en wordt rekening gehouden met regionale verschillen tussen staten. Kochanowski and Young, JRI, 1985, p. 269-288. In dit onderzoek worden cen antal specifieke toetsingsvariabelen, zoals de rijomgeving en de samenstelling van de bevolking in een staat, tezamen met een groot aantal andere variabelen gerelateerd aan het aantal verketrsongevallen (in de periode 1975-1977) per 100 miljoen afgelegde automijlen in alle Amerikaanse staten-

1728. Zador and Lund, JRI, 1986, p. 230-233.

1729. Zador and Lund, JRI, 1986, p. 234; Kochanowski and Young, JRI, 1985, p. 284-285

1730. Zador and Lund, JRI, 1986, p. 234-235. 
Zij stellen dat de vraag of een staat wel of geen no-fault verzekering heeft ingevoerd, derhalve weinig verband houdt met data ten aanzien van het aantal dodelijke verkersongevallen. ${ }^{1731}$

Zador en Lund hebben verder geen statistisch bewijs gevonden voor de veronderstelling dat een no-fault verzekering leidt tot minder zorgvuldigheid bij de autobesturder, waardoor het aantal dodelijke verkeersongevallen zal toenemen. Hiervoor worden een drietal verklaringen aangedragen.

In de eerste plaats blijkt niet dat de no-fault wetgeving in de onderzochte periode heeff geleid tot een vermindering van de kosten van de autoverzekering.

In de tweede plaats wordt de mate waarin slechte bestuurders worden gestraft met een hogere premie niet beïnvloed door de invoering van een no-fault verzekering. In no-fault staten met een sterke beperking van het vorderingsrecht (hoge 'threshold') werden premieaanpassingen in verhouding tot de individuele rijervaring beperkt toegepast.

Inde derde plaats wordt door Zador en Lund gewezen op het veronderstelde verband tussen financiële prikkels en het niveau van de door de bestuurder uitgeoefende zorg, zijnde een specifiek geval van de zogenaamde risicocompensatie ('offsetting behavior') theorie. Deze stelt dat het rijgedrag kan worden beschouwd als een soort veiligheidsruil tussen een verhoogde autoveiligheid of een daling van de vezzekringspremie en een minder zorgvuldig rijgedrag. Volgens Zador en Lund is et echter geen wetenschappelijk bewijs met betrekking tot een dergelijke 'trade off worhanden. ${ }^{1732}$

Dewees, Duff and Trebilcock gaan, evenals de voorgaande auteurs, in op een aantal 'tekorkomingen' in het onderzoek van Landes. Zij verwijzen daarbij naar een artikel

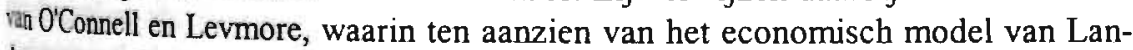
des eveneens kritiek wordt geuit op het enkele gebruik van ongevalsdata als toetsingsvariabele. Gegeven het feit dat alle door Landes onderzochte schadedrempels bij een dodelijk verkeersongeval worden overschreden, kan volgens O'Connell en Lamore de vraag worden gesteld waarom no-fault jurisdicties met een stijging van het aantal dodelijke verkeersongevallen zijn geconfronteerd. ${ }^{1733}$ Daarnaast maakt Landes volgens O'Connell en Levmore gebruik van toetsingsvariabelen die specifiek

\footnotetext{
Kochanowski and Young, JRI, 1985, p. 286-287.

Zador and Lund, JRI, 1986, p. 234-235. Zie paragraaf 3 van hoofdstuk 12 voor een empirische analyse van 'offsetting behaviour'.

J. O'Connell and S. Levmore, A Reply to Landes: A Fault Study of No-Fault's Effect on Fault?, Missouri Law Review, 1983, p. 650-651 in Dewees. Duff and Trebilcock, Accident Law, p. 6768 , noot 80
} 
betrekking hebben op staten alsmede op een bepaalde tijdsperiode. Daarbij worden volgens hen echter actuele data ten aanzien van bijvoorbeeld weersomstandigheden, de toestand van het wegennet, politiecontrole en verschillen tussen stedelijke en lan-
delijke regio's genegeerd.

Sugarman, tenslotte, wijst ten aanzien van het onderzoek van Landes op de afwezigheid van empirisch bewijs voor de conclusie dat de effecten van de invoering van een no-fault verzekering uitsluitend zijn terug te voeren op een vermindering van de zorgvuldigheid bij de autobestuurder. Daarbij wordt volgens hem geen rekening gehouden met de mogelijkheid dat, naar aanleiding van de invoering van een no-fault verzekering, een wijziging in het activiteitsniveau van de autobestuurder kan optreden die wordt veroorzaakt door een verandering in de premiestructurur. Wanneer de invoering van een no-fault verzekering bijvoorbeeld heeft geleid tot lagere verzekeringskosten (premie), kan dit volgens Sugarman tot gevolg hebben dat een autobestuurder een hoger activiteitsniveau uitoefent, zodat het aantal verkeersongevallen zal toenemen. ${ }^{1735}$

\subsubsection{Het onderzoek van Sloan, Reilly and Schenzler}

In een meer recent empirisch onderzoek wordt aan de hand van een omvangrijk model onderzocht welke juridische instrumenten hebben bijgedragen aan een stijging of daling van het aantal verkeersongevallen in de VS. ${ }^{1736}$ De effecten van de no-fault verzekering worden in dit onderzoek getoetst met behulp van twee variabelen. De eerste variabele heeft betrekking op het aantal verkeersongevallen met letselschade waarvoor geen aansprakelijkheidsvordering kan worden ingesteld. De tweede variabele heeft betrekking op staten die het instellen van een aansprakelijkheidsvordering onbeperkt openlaten, maar wel de aankoop van een eerste partijverzekering voor persoonlijke letselschade ('personal injury protection', PIP) verplicht opleggen. ${ }^{1737}$

Met betrekking tot de effecten van een no-fault verzekering wijst dit onderzoek uit dat het aantal dodelijke verkeersongevallen ten aanzien van een no-fault wetgeving, waarbinnen $25 \%$ van alle aansprakelijkheidsvorderingen is uitgesloten, met $18 \%$ is gestegen. Bij deze toename worden door Sloan, Reilly en Schenzler echter een twee-

1734. O'Connell and Levmore, Missouri Law Review, 1983, p. 652 in Dewees, Duff and Trebilcock, Accident Law, p. 24 en p. 68, noot 82.

1735. Sugarman, CaLR, 1985, p. 589-590. Hij stelt dat wanneer een goedkopere autoverzekering leid tot een inefficiènt hoog aantal verkeersongevallen, het activiteitsniveau mogelijk of zelfs betc kan worden beïnvloed door middel van bijvoorbeeld een belasting op auto's, een benzitneatijins of met heffingen op de registratie van auto's.

1736. Sloan. Reilly and Schenzler, IRLE. 1994, p. 53-71. De data in dit onderzoek hebben betrekking op verkeersongevallen per Amerikaanse staat in de periode 1982-1990. Verder worden drie leet: tijdscategorieën onderscheiden, namelijk 18-20 jaar, $21-24$ jaar en 25-64 jaar.

1737. Sloan, Reilly and Schenzler, IRLE, 1994, p. 58-60. 
tal kanttekeningen geplaatst. Allereerst blijkt volgens hen dat gedurende de onderzochte periode het effect van een 'threshold', waarbinnen geen aansprakelijkheidsvordering kan worden ingesteld, enigszins was uitgehold. Daarmee doelen zij op het gegeven dat gedurende de jaren ' 80 van de vorige eeuw geen enkele staat overging tol de invoering van nieuwe no-fault wetgeving en slechts in 1 staat de no-fault verzekering werd afgeschaft. Daarnaast traden er in de jaren ' 80 van de vorige eeuw, vergeleken met de jaren ' 70 van de vorige eeuw, slechts kleine wijzingen op binnen de verschillende no-fault regimes. Een tweede kanttekening houdt volgens Sloan, Reilly en Schenzler verband met het feit dat in de Verenigde Staten, in tegenstelling tot bjyoorbeeld Canada en Nieuw-Zeeland, nooit werkelijk is geëxperimenteerd met een zuivere no-fault verzekering, waarbij het aansprakelijkheidsrecht volledig is afgeschaft. De VS is volgens hen derhalve niet de meest geschikte locatie om de effecten van een no-fault verzekering op het aantal verkeersongevallen te bestuderen. ${ }^{1738}$

Uit dit onderzoek blijkt verder dat ook bij een verplichte no-fault verzekering voor letselschade (PIP), waarbij de mogelijkheid voor een aansprakelijkheidsvordering nog onbeperkt openstaat, het aantal dodelijke verkeersongevallen is gestegen. Deze loename was echter lager dan de stijging ten aanzien van no-fault wetgeving waarbij het recht op een aansprakelijkheidsvordering is beperkt. In het kader van voornoemde PIP-verzekering wordt verder ingegaan op het gebruik van premietoeslagen masr aanleiding van verkeersovertredingen en andere verwijtbare gedragingen bij exn verkeersongeval. Daanuit blijkt dat premietoeslagen wel worden toegepast, zij het niet frequent en voor een relatief klein bedrag. Sloan, Reilly en Schenzler beschikken echter over onvoldoende empirische gegevens om het effect van dergelijke premietoeslagen op de uitgeoefende zorg door de autobestuurder ook daadwerkelijk te kunnen toetsen ${ }^{1739}$

\subsection{Preventie binnen het no-fault compensatiefonds in Nieuw-Zeeland}

In een omvangrijk theoretisch en statistisch onderzoek is door Brown getracht de effecten van de invoering van het no-fault compensatiefonds in Nieuw Zeeland te berekenen. ${ }^{1740}$ Daartoe wordt door hem een vergelijking gemaakt van de periode vóór 1974, warin nog een systeem van aansprakelijkheid en verzekering van toepassing was en de periode na 1974, het jaar waarin het aansprakelijkheidsrecht geheel werd verrangen door een compensatiefonds voor verkeersslachtoffers. ${ }^{1741}$ Naast de invoe-

Sioan, Reilly and Schenzler, IRLE, 1994, p. 66 en 68-69.

Stoan, Reilly and Schenzler, IRLE, 1994, p. 60, 67 en 69.

Zie paragraaf 2.1 van dit hoofdstuk voor een positiefrechtelijke beschrijving van het no-fault systeem in Nieuw-Zeeland.

1741. Brown, CaLR, 1985, p. 976-1002. De data in dit onderzoek hebben globaal betrekking op de periode 1964-1982. Daarnaast worden statistische gegevens gepresentecrd met betrekking tot het 
ring van het no-fault compensatiefonds wordt in dit onderzoek eveneens rekening gehouden met een aantal wetgevende maatregelen die gedurende de onderzochte periode door de overheid zijn uitgevaardigd. Dit betreft onder andere een reductie van de maximumsnelheid van 55 MPH naar $50 \mathrm{MPH}$ in 1973, een verscherping van de wetgeving ten aanzien van het gebruik van de autoveiligheidsgordel in 1975 en de invoering van de preventieve ademanalyse in 1978, tegelijk met een verlaging van het toegestane alcoholpromillage. ${ }^{1742}$

Tabel 3

\begin{tabular}{|l|c|c|c|c|}
\hline \multicolumn{1}{|c|}{ Statistische variabelen } & 1966 & 1973 & 1974 & 1980 \\
\hline $\begin{array}{l}\text { 1. Geregistreerde motorvoer- } \\
\text { tuigen/hoofd van bevolking }\end{array}$ & 0,39 & 0,48 & 0,49 & 0,56 \\
\hline 2. Verkeersongevallen & 12484 & $\begin{array}{c}15571 \\
+24,7 \%\end{array}$ & $\begin{array}{c}14109 \\
-9,4 \%\end{array}$ & $\begin{array}{c}10787 \\
-23,7 \%\end{array}$ \\
\hline 3. Verkeersdoden & & 843 & 676 & 596 \\
& 549 & $+53,6 \%$ & $-19,8 \%$ & $-11,8 \%$ \\
\hline 4. Verkeersgewonden & 18194 & 23385 & 20829 & 15957 \\
& & $+28,5 \%$ & $-10,9 \%$ & $-23,4 \%$ \\
\hline 5. Autokilometers (miljoen) & 11230 & 16749 & 17318 & 16545 \\
& & $+49,1 \%$ & $+3,4 \%$ & $-4,5 \%$ \\
\hline 6. Verkeersongevallen/100 & 111,2 & 93 & 81,5 & 65,2 \\
miljoen autokilometers & & $-16,4 \%$ & $-12,4 \%$ & $-20 \%$ \\
\hline 7. Verkeersslachtoffers/100 & 166,9 & 144,7 & 124,2 & 100 \\
miljoen autokilometers & & $-13,3 \%$ & $-14,2 \%$ & $-19,5 \%$ \\
\hline 8. Verkeersdoden/100 miljoen & 4,9 & 5,0 & 3,9 & 3,6 \\
autokilometers & & $+2 \%$ & $-22 \%$ & $-7,7 \%$ \\
\hline
\end{tabular}

Tabel 3 bevat een overzicht van de resultaten van het onderzoek van Brown. Daaruit kan worden opgemaakt dat het aantal verkeersongevallen, verkeersdoden en verkeersgewonden in 1980, ten opzichte van 1973 , met respectievelijk $30,7 \%, 29,3 \%$ en $31,8 \%$ is gedaald. Het aantal verkeersongevallen, verkeersdoden en verkeersgewonden per 100 miljoen autokilometers daalde in 1980 , in verhouding tot 1973 , met respectievelijk $30 \%, 30,9 \%$ en $28 \% .{ }^{1743}$ Tenslotte kan naar aanleiding van tabel 3 worden opgemerkt dat de meeste statistische variabelen in 1974, het jaar van invoering

aantal geregistreerde voertuigen per hoofd van de bevolking, het aantal verkeersongevallen en het aantal verkeersdoden en verkeersgewonden per 100 miljoen afgelegde autokilometers.

1742. Brown, CaLR, 1985, p. 984 en 994-995.

1743. Brown, CaLR, 1985, p. 984-994. 
ran het no-fault compensatiefonds, relatief sterk afnamen (tussen 10 en $20 \%$ ) ten opzichte van 1973.

Brown concludeert uit de beschikbare statistische gegevens dat er geen sprake is van en anwijsbare toename in de activiteit autorijden, zoals berekend aan de hand van het antal geregistreerde auto's en het totaal aantal afgelegde autokilometers. Brown onkent verder niet dat de daling van het aantal verkeersongevallen en verkeersslachtoffers mede het gevolg is van andere preventieve maatregelen, zoals ten aanjien van de maximumsnelheid, de autoveiligheidsgordel en het alcoholgebruik in het verkeer. Het precieze effect van al deze maatregelen, inclusief de invoering van een no-fault compensatiefonds, op de daling van het aantal verkeersongevallen is volgens Brown echter onmogelijk vast te stellen. ${ }^{1744}$ Brown is ten slotte van mening dat, met betrekking tot het no-fault compensatiefonds, ook moeilijk kan worden vastgesteld of de daling van het aantal verkeersongevallen groter zou zijn geweest bij de handhaving van het aansprakelijkheidsrecht. Aan de andere kant heeft de afschaffing van de ansprakelijkheid volgens hem niet geleid tot een toename van het onzorgvuldige verkeersgedrag, zoals in de traditionele economisch theorie van het ongevallenrecht wordt voorspeld. ${ }^{1745}$

Zoals door Brown zelf al wordt aangegeven is in zijn onderzoek niet komen vast te stan welke invloed de invoering van een no-fault compensatiefonds daadwerkelijk heeff gehad op het aantal verkeersongevallen. Hij stelt aan de hand van statistische cijfers vast dat het aantal verkeersongevallen is gedaald, zonder daarbij te onderzoeken welke factoren daaraan specifiek een bijdrage hebben geleverd. Door Brown word derhalve geen rechtseconometrische analyse uitgevoerd, waarin mogelijk een causale relatie kan worden aangetoond tussen bepaalde wetgevende maatregelen en de daling van het aantal verkeersongevallen. Bij afwezigheid van een dergelijke anayee dient volgens Dewees, Duff en Trebilcock aan de resultaten van het onderzoek van. Brown dan ook een beperkte waarde te worden toegekend. ${ }^{1746}$

\subsection{De preventieve werking van de no-fault verzekering in Australië}

Bij de positiefrechtelijke beschrijving van de verkeersaansprakelijkheid in Australië upgemerkt dat niet alle staten/territories eenzelfde no-fault systeem hebben ingevoerd. Victoria en Tasmanie, bijvoorbeeld, handhaafden het recht om, naast een nofault vergoeding, een aansprakelijkheidsvordering voor verkeersschade in te stellen, temwijl in de Northern Territory deze optie geheel werd geblokkeerd. De invoering van ein no-fault systeem in Australië werd in het algemeen gekenmerkt door een ditital maatregelen. In de eerste plaats werd een derde partij aansprakelijkheids-

174. Brown, CaLR, 1985, p. 995

774. Brown, CaLR, 1985, p. 1001-1002.

45. Dewees, Duff and Trebilcock, Accident Law, p. 69, noot 97 
verzekering voor verkeersschade vervangen door een eerste partij no-fault verzekering voor letselschade gecombineerd met een aansprakelijkheidsverzekering voor zaakschade. In de tweede plaats diende de no-fault verzekering de schade van de voetganger en de inzittenden van de auto van de polishouder te vergoeden. Een derde kenmerk was dat in zowel het oude als het nieuwe verzekeringssysteem geen risicodifferentiatie noch premieaanpassingen werden toegepast. ${ }^{174}$

McEwin heeft bestudeerd welke effecten de no-fault wetgeving in Australië en Nieuw-Zeeland heeft gehad op het aantal verkeersongevallen. ${ }^{1748}$ Binnen het empirisch model worden een groot aantal toetsingsvariabelen gebruikt, waaronder het aantal dodelijke verkeersongevallen per hoofd van de bevolking bij autobestuurders, passagiers, motorbestuurders, fietsers en voetgangers. ${ }^{1749}$ Daarnaast wordt onderscheid gemaakt tussen no-fault jurisdicties die de aansprakelijkheidsvordering voor verkeersschade geheel hebben afgeschaft (zuivere no-fault) en jurisdicties die de aansprakelijkheidsvordering handhaafden ('threshold' en 'add-on' no-fault). ${ }^{1750}$

De resultaten van het empirisch onderzoek suggereren in de eerste plaats dat de afschaffing van een aansprakelijkheidsvordering voor verkeersschade heeft geleid tot een stijging van het aantal dodelijke verkeersongevallen per hoofd van de bevolking met $16 \%$. Aan deze stijging dient volgens McEwin, gegeven de problemen met het statistisch in kaart brengen van verkeersongevallen, geen al te grote waarde te worden gehecht. In de tweede plaats blijkt dat de invoering van een zuiver no-fault regime heeft geleid tot een toename van het ongevalsrisico met 0,04 per 1000 inwoners. In de derde plaats wordt door McEwin gesteld dat staten die nog wel de mogelijkheid voor een aansprakelijkheidsvordering openlieten ('add-on' no-fault) niet met een toename van het aantal verkeersongevallen werden geconfronteerd. In de vierde plaats tenslotte, heeft de invoering van een verplichte no-fault verzekering, onder handhaving van een aansprakelijkheidsvordering, geen wezenlijke invloed gehad op het aantal verkeersongevallen. McEwin concludeert dat ter bevordering van zorgvuldig verkeersgedrag in zijn algemeenheid de handhaving van de mogelijkheid om

1747. Zie paragraaf 2.2 van dit hoofdstuk

1748. McEwin, IRLE, 1989, p. 13-24. De ongevalsdata in dit onderzoek zijn afkomstig uit verschillende staten binnen Australiě plus Nieuw-Zeeland en hebben betrekking op de periode 1970-1981.

1749. McEwin, IRLE, 1989, p. 19 en p. 21-22. Verder wordt gebruik gemaakt van andere variabelen die van invloed zijn op het ongevalsrisico, zoals politiecontroles, het aantal auto's voorzien var een veiligheidsgordel, het totale premievolume voor de autoverzekering in de verhouding tot de totale schadelast, een indeling in leeftijdscategorieên, het aantal afgelegde autokilonketers (activiteitsniveau) en de verschillen tussen staten ten aanzien van de rijcondities en eigenschappen vas de autobestuurder.

1750. MeEwin, IRLE, 1989, p. 21-22. 
op basis van aansprakelijkheid in rechte schadevergoeding te vorderen een belangrijke factor blijft.

Dewees, Duff and Trebilcock stellen dat de conclusies van McEwin voor wat betreft de effecten van het aansprakelijkheidssysteem niet geheel duidelijk zijn. Het is bijroobeeld niet mogelijk gebleken om de effecten van de afschaffing van de aansprakelijkheidsvordering sec te berekenen. Dit nog los van de niet-gedifferentieerde premiestructuur en van de hoge kosten die volgens hen met de overgang van aansprakelijkheid naar no-fault gepaard gingen. ${ }^{1752}$

31.4. De preventieve effecten van het zuivere no-fault systeem in Quebec

In Quebec geldt sinds 1978 een no-fault systeem voor verkeersschade. Het kenmerkende van dit regime is dat er geen mogelijkheid meer bestaat om op basis van het ansprakelijkheidsrecht een vordering tot vergoeding van de verkeersschade in te stellen; deze wordt alleen vergoed door de no-fault verzekering. Daarom wordt wel gesproken van een zuiver no-fault regime. In Quebec wordt de verplichte no-fault verzekering, zonder toepassing van risicodifferentiatie en tegen een vast premiebedrag door de overheid aangeboden.

Rose Ann Devlin heeft getracht de effecten van een overgang naar een zuiver nofult regime in Quebec op het aantal van verkeersongevallen te berekenen. Zij maakt in dat kader een vergelijking tussen de periode vóór 1978 , waarin nog een aansprakelijhkeidssysteem van toepassing was en de periode nà 1978 , toen een zuiver nofault regime was ingevoerd (1971-1984). ${ }^{1753}$ In het empirisch model worden respectivelijk het aantal dodelijke verkeersongevallen, het aantal verkeersongevallen met letselschade en het aantal verkeersongevallen met zaakschade als belangrijkste toetsingsvariabelen gebruikt. ${ }^{1754}$

De onderzoeksresultaten wijzen volgens Devlin uit dat na de invoering van het zuiFet no-fault regime in Quebec sprake is geweest van een geschatte jaarlijkse toeName van het aantal dodelijke verkeersongevallen met ongeveer $6 \%$. Het aantal veriersongevallen met letsel- en zaakschade steeg daarnaast volgens haar berekening met ongeveer $10 \%$. Deze toename van het aantal verkeersongevallen kan volgens

McEwin, IRLE, 1989, p. 23-24.

Dewees, Duff and Trebilcock, Accident Law, p. 25. zoek verschenen in R.A. Devlin, Liability versus No-Fault Automobile Insurance Regimes: An Analysis of the Experience in Quebec, University of Toronto, Department of Economics, 1988.

Devlin, IRLE, 1990, p. 202-204. Andere toetsingsvariabelen hebben betrekking op het aantal afvan het gebrio autokilometers, het aandeel van bestuurders beneden de 25 jaar, wetgeving ten aanzien van de maxim van de autoveiligheidsgordel, het aantal verkeersovertredingen en een verlaging 
Devlin worden toegeschreven aan de afschaffing van het aansprakelijkheidsrecht en de overgang naar een zuiver no-fault regime. Devlin heeft ten slotte berekend welke gevolgen de veronderstelde reductie in de uitgeoefende zorg van de autobesturder heeft voor het aantal verkeersongevallen. Uit deze berekening blijkt dat het aantal dodelijke verkeersongevallen en het aantal verkeersongevallen met letsel- en zaakschade met $9,6 \%$ is toegenomen. ${ }^{1755}$

De verminderde zorgvuldigheid bij de autobestuurder (morele risico) is volgens Devlin te wijten aan de niet-gedifferentieerde premiestructuur ('flat rate') en de automatische schadevergoeding ongeacht de schuld waarvan onder het nieuwe no-fault regime sprake is. De platte premiestructuur houdt in dat een autobestuurder met een hoog ongevalsrisico in het nieuwe no-fault regime eenzelfde en dus relatief lagere premie zal betalen dan een autobestuurder met een laag ongevalsrisico. In dat kader kan wordt verondersteld dat na invoering van een no-fault verzekering de premiedaling voor de hoge ongevalsrisico's $24 \%$ bedraagt en de premiestijging voor de lage ongevalsrisico's $1 \%$. Dit betekent volgens Devlin dat een no-fault verzekering met een niet-gedifferentieerde premiestructuur ('flat-rate') leidt tot een relatieve toename van het aantal bestuurders met een hoog ongevalsrisico, waardoor het aantal verkeersongevallen kan stijgen. ${ }^{1756}$

Devlin verwacht overigens niet dat met een aangepaste premiestructuur waarbij meer wordt gedifferentieerd naar het individuele ongevalsrisico de toename van het aantal verkeersongevallen geheel kan worden geneutraliseerd. Individuele verkeersslachtoffers worden immers nog steeds schadeloos gesteld zonder dat rekening wordt gehouden met de uitgeoefende zorg ten tijde van het verkeersongeval. Een betere premiedifferentiatie binnen een no-fault verzekering zal derhalve wel de zorgvuldigheid van de verzekerde autobestuurder kunnen verhogen, maar niet noodzakelijk die van het slachtoffer. ${ }^{1757}$

Volgens Dewees, Duff en Trebilcock dienen de conclusies van Devlin met de nodige voorzichtigheid te worden benaderd. Devlin besteedt bijvoorbeeld geringe aandacht aan de toepassing van premiedifferentiatie bij een no-fault verzekering. Volgens Dewees, Duff en Trebilcock is echter een belangrijke rol weggelegd voor het verzkeringsregime bij de sturing van het zorg- en activiteitsniveau van de autobestrurder. Devlin legt wel een verband tussen de verminderde zorgvuldigheid van de autobestuurder en de afschaffing van het aansprakelijkheidsrecht, maar zij besteedt volgens hen ten onrechte slechts indirect aandacht aan een mogelijke relatie tussen de

1755. Devlin, IRLE, 1990, p. 197 en 201

1756. Devlin, IRLE, 1990, p. 197 en 201; Devlin, Liability versus No-Fault, p. 170-220 in Dewees, Duff and Trebilcock, Accident Law, p. 69, noot 104-106.

1757. Devlin, IRLE, 1990, p. 200-202. Zij stelt echter dat het effect van een gedifferentieerde premic structuur op de preventie van verkeersongevallen zeer moeilijk empirisch kan worden bepasld. 
zorgvuldigheid van de autobestuurder en de platte premiestructuur onder het no-fault regime. Door Devlin wordt derhalve niet berekend welke invloed een gedifferentieerde premiestructuur binnen een no-fault verzekering daadwerkelijk kan hebben op het aantal verkeersongevallen. ${ }^{1758}$

Gaudry heeft eveneens de effecten van het no-fault regime in Quebec op het aantal verkersongevallen berekend. De data in dit onderzoek hebben betrekking op de eerste 12 maanden na invoering van het nieuwe systeem in 1978. Hieruit blijkt dat zowel het totaal aantal verkeersongevallen $(+26,9 \%)$, het aantal verkeersongevallen $(+26,3 \%)$ met een materiële schade boven een bepaalde financiële omvang $(\$ 250)$, het antal verkeersongevallen met letsel $(+31,8 \%)$ en het aantal dodelijke verkeersongevallen $(+7 \%)$ is gestegen. ${ }^{1759}$

Gaudry wijdt de resultaten van zijn onderzoek niet aan het no-fault regime zelf, als wel deels aan de strikte handhaving van de verplichte verzekering na 1978, waardoor voorheen onverzekerde bestuurders minder zorgvuldig aan het verkeer deelnemen (morele risico). Daarnaast zorgde de aanwezigheid van een niet-gedifferentieerde premiestructuur binnen de no-fault verzekering ervoor dat de kosten van atorijden voor bestuurders met een hoog risico afnamen. Gaudry concludeert dat de bijdrage van een no-fault verzekering sec aan de vermindering van de zorgvuldigheid en de preventie vrij laag is. Dit is zijns inziens het gevolg van het reeds aanwezige morele risico bij de verplichte derde partij autoverzekering die voor de invoering van het no-fault regime van toepassing was. ${ }^{1760}$

\subsection{Conclusie: no-fault versus aansprakelijkheid en de preventie van verkeersongevallen}

In het voorgaande is de vraag aan de orde geweest of een no-fault verzekering, in rerhouding tot het aansprakelijkheidsrecht, tot een betere preventie van verkeersongevallen en derhalve tot een vermindering van de primaire ongevalskosten kan leiden. De resultaten van het empirisch onderzoek geven geen uniform beeld met be-

\footnotetext{
1758. Dewees, Duff and Trebilcock, Accident Law, p. 25-26 en p. 69, noot 109. Chapman and Trebilrock stellen dat ook de toepassing van een volledige risico-differentiatie binnen de analyse van Devlin zal leiden tot een vermindering van de zorgvuldigheid bij de autobestuurder. Zie Chapman and Trebilcock, Working Paper, 1991, p. 17.

1759. M. Gaudry, The Effects on Road Safety of the Compulsory Insurance, Flat Premium Rating and No-Fault Features of the 1978 Quebec Automobile Act, in Osborne Commission, Report of Inquiry into Motor Vehicle Accident Compensation in Ontario, Toronto, Queen's Printer, 1988, vol. Il, p. 1-28 in Dewees, Duff and Trebilcock, Accident Law, p. 25.

176. Gaudry, Osbome Commission/Report, 1988, vol. II, p. 20-24 in Chapman and Trebilcock, Working Paper, 1991, p. 16-17 en Dewees, Duff and Trebilcock, Accidents Law, p. 25. Deze laatste concluderen dat niet het aansprakelijkheidssysteem maar eerder het verzekeringsregime centraal staat in de conclusies van Gaudry.
} 
trekking tot de preventieve effecten van een no-fault verzekering. Een groot deel van de uitkomsten is onderling tegenstrijdig. Daarnaast kunnen als gevolg van verschillen in interpretatie van de onderzoeksresultaten ook geen eenduidige conclusies worden gegeven. Een verklaring biervoor is dat de verschillende studies steeds een ander onderzoeksobject hebben. Ten aanzien van alle no-fault regimes in de VS geldt bijvoorbeeld dat zij de mogelijkheid voor het instellen van een aansprakelijkheids. vordering openhouden ('threshold en add-on no-fault'), waardoor in geen enkele staat een zogenaamd zuiver no-fault regime wordt toegepast.

Dewees, Duff en Trebilcock wijzen verder nog op enkele methodologische tekortkomingen van een aantal door hen besproken studies. Zij menen dat het niet eenvoudig is om een onderscheid te maken tussen het effect van no-fault op het aansprakelijkheidsrecht enerzijds en op het verzekeringssysteem anderzijds. Veel studies maken volgens Dewees, Duff en Trebilcock zelfs in het geheel geen onderscheid tussen aansprakelijkheid en verzekering. Het empirisch onderzoek toont volgens hen wel aan dat zonder aanvullende preventieve maatregelen een no-fault systeem zal leiden tot meer verkeersongevallen en verkeersslachtoffers. ${ }^{1761}$

Volgens Chapman en Trebilcock is het een feit dat een no-fault verzekering de onzorgvuldige autobestuurder ten opzichte van derden 'bescherming' geeft tegen de financiële gevolgen van een verkeersongeval. Autobestuurders worden zelfs binnen een 'add on' no-fault systeem, waarbij een aansprakelijkheidsvordering mogelijk blijft, aangezet om lichte schadeclaims met de eigen no-fault verzekeraar te schikken. Dit betekent volgens hen dat, bij afwezigheid van een regresrecht bij de no-fault verzekeraar, een verkeersdeelnemer die juridisch gezien aansprakelijk is, voor het no-fault deel niet meer verantwoordelijk kan worden gehouden voor zijn activiteiten ten opzichte van derden. ${ }^{1762}$

Concluderend kan worden gesteld dat er geen eenduidig antwoord bestaat op de vraag of een no-fault verzekering tot meer verkeersongevallen en verkeersslachtoffers leidt. Een deel van de beschreven studies concludeert dat geen preventieve werking uitgaat van een no-fault verzekering; in een ander deel wordt geconcludeerd dat de invoering van een no-fault verzekering niet heeft geleid tot een stijging van het aantal verkeersongevallen.

Het voorgaande brengt mee dat bij de keuze voor een no-fault verzekering, warbij door het (gedeeltelijk) wegvallen van de aansprakelijkheid de preventieve werking ten opzichte van derden wordt gemist, aanvullende maatregelen noodzakelijk zijn. Deze kunnen in de eerste plaats worden gevonden binnen de no-fault verzekering

1761. Dewees, Duff and Trebilcock, Accident Law, p. 26. Zie ook Van Velthoven, VR, 2000, p. 319.

1762. Chapman and Trebilcock, Working Paper, 1991, p. 18. 
zell. De no-fault verzekeraar kan met een optimale premiedifferentiatie het gedrag ran autobestuurders controleren. De verzekeraar kan bijvoorbeeld aan de hand van bepaalde standaarden onderzoeken of het gedrag van de autobestuurder (verkeersvertredingen) bij een schadeclaim aanleiding geeft tot een premieaanpassing. Met een dergelijke controle kan de verzekerde autobestuurder ook worden gewezen op zijn verantwoordelijkheid ten opzichte van derden, zoals fietsers en voetgangers. Nasst deze no-fault verzekering zelf zullen ook aanvullende maatregelen op het terrein van de veiligheidsregulering (administratieve en strafrechtelijke sancties) nodig zjjn om het gedrag van de autobestuurder te sturen.

\section{NO-FAULT VERSUS AANSPRAKELJJKHEID: DE VERGOEDING VAN VERKEERSSCHADE}

In deze paragraaf zal de werking van een no-fault verzekering op een tweede aspect morden beoordeeld, namelijk de compensatie van verkeersslachtoffers (secundaire ongevalskosten, 'distributive justice'). Daarbij zal een aantal, voornamelijk Amerikanse, studies worden geanalyseerd waarin de vergoeding van verkeersschade onder een aansprakelijkheidssysteem respectievelijk een no-fault regime tegen elkaar worden afgezet. Dit empirisch onderzoek concentreert zich rond twee hoofdlijnen, namelijk de omvang van de schadevergoeding en de tijdspanne waarbinnen het verkeersslachtoffer de geleden schade vergoed krijgt. Bij deze analyse geldt dat de specifieke effecten van een no-fault systeem ten aanzien van de compensatie van verkeersslachtoffers sterk verschillen en afhankelijk zijn van de hoogte van de schadedrempel ('threshold') en de vergoedingslimiet binnen een eerste partij no-fault verzekering.

\subsection{De omvang van de schadevergoeding binnen een no-fault regime}

321.1. Het empirisch onderzoek van Carroll en Kakalik

Een eerste empirisch onderzoek waarin de vraag naar de omvang van de schadevergooding binnen een no-fault regime wordt vergeleken met de compensatie onder een ansprakelijkheidssysteem maakt gebruik van data uit het jaar 1987. Deze gegevens hibben betrekking op letselschadeclaims afkomstig van 34 verzekeraars, die ten tijde van het onderzoek ongeveer $60 \%$ van de markt voor particuliere autoverzekerngen beheersten. ${ }^{1763}$ Aan de hand van voornoemde data wordt door Carroll en Rakalik een model ontwikkeld waarmee het effect van een specifiek no-fault regime in een bepaalde 'aansprakelijkheidsstaat' kan worden berekend. Dit model wordt revrolgens gebruikt om te bepalen welke vergoeding het verkeersslachtoffer in deze 'tor'-staat zou hebben ontvangen. In het empirisch model worden daarnaast variabe-

Camoll and Kakalik, JRl, 1993, p. 265-287. 
len ingebracht die verband houden met de medische kosten, de inkomensschade, het type en de ernst van de ongevalsschade, de materiële schade, de mate waarin de schadedrempel ('threshold') werd overschreden, type aansprakelijkheid, de leeftijd, het geslacht en het schadeverleden van de autobestuurder. ${ }^{1764}$

Carroll en Kakalik stellen dat de effecten van de invoering van een no-fault verzekering in zogenaamde 'tort'-jurisdicties sterk kunnen verschillen. Dit hangt samen met de ernst van de geleden schade bij het verkeersslachtoffer en met de omvang van de compensatie die het slachtoffer van de aansprakelijkheidsverzekeraar van de schadeveroorzaker ontvangt. Carroll en Kakalik weten echter tot een aantal gemeenschappelijke effecten van no-fault vergoedingssystemen te komen. In dat kader wordt een no-fault regime met een materiële ('verbal') schadedrempel ('threshold') en een vergoedingslimiet van $\$ 15.000$ als uitgangspunt genomen. ${ }^{1765}$

De resultaten van het onderzoek van Carroll en Kakalik kunnen als volgt worden samengevat. Bij het traditionele aansprakelijkheidssysteem ontving $7 \%$ van alle verkeersslachtoffers een vergoeding die overeenstemde met de werkelijk geleden materiële schade. Van het aantal slachtoffers kreeg $62 \%$ meer dan een volledige vergoeding voor de geleden materiële schade. Daarbij is echter een omvangrijk deel aan immateriële schadevergoeding verdisconteerd. Gebleken is dat een verkeersslachtoffer met een schade van bijvoorbeeld $\$ 2.000$ onder een aansprakelijkheidssysteem het 2,5-voudige van dit bedrag ontving. Daarnaast ontving $27 \%$ van het aantal slachtoffers binnen het aansprakelijkheidssysteem minder dan een volledige vergoeding voor materiële schade. Hieronder vallen ook slachtoffers met een hoge materiële schadeclaim, die mede als gevolg van de lage polislimieten binnen de aansprakelijkheidsverzekering (BIL), gemiddeld een lager bedrag kregen uitgekeerd. Een verkeersslachtoffer met een materiële schade van meer dan $\$ 100.000 \mathrm{kreeg}$ bijvoorbeeld slechts $9 \%$ van dit bedrag vergoed. ${ }^{1766}$

In het veronderstelde no-fault systeem met een materiële ('verbal') schadedrempel ('threshold') en een vergoedingslimiet van $\$ 15.000$, kreeg $22 \%$ van het aantal verkeersslachtoffers meer dan een volledige schadevergoeding. Van het aantal verkeersslachtoffer ontving $16 \%$ minder dan de werkelijk geleden materiële schade. Tenslotte kreeg $59 \%$ van alle verkeersslachtoffers onder het genoemde no-fault systeem de daadwerkelijk geleden materiële schade volledig vergoed kreeg. ${ }^{176}$

Carroll en Kakalik concluderen naar aanleiding van het bovenstaande dat, in vergelijking met een aansprakelijkheidssysteem, een uitkering op basis van een no-fault

1764. Carroll and Kakalik, JRI, 1993, p. 266-269.

1765. Carroll and Kakalik, JRI, 1993, p. 276.

1766. Carroll and Kakalik, JRI, 1993, p. 278-279.

1767. Carroll and Kakalik, JRI, 1993, p. 280. Zie ook Cummins and Weiss, JRI, J993, p. 233 
verzekring meer overeenstemt met de door het verkeersslachtoffer materieel geleden schade. Verkeersslachtoffers met een lage schadeclaim krijgen de medische kosten plus de inkomensschade bijna volledig vergoed. Slachtoffers met een hoge claim krijgen een groter deel van hun schade vergoed, omdat zij, afhankelijk van het toepasselijke no-fault regime, zowel een beroep kunnen doen op hun eigen no-fault verzekering als op de aansprakelijkheidsverzekering van de schadeveroorzaker. ${ }^{1768}$

3.2.1.2. Het empirisch onderzoek van Rolph, Hammit en Houchens

Een tweede Amerikaans onderzoek dat aandacht besteedt aan de omvang van de schadevergoeding (anders dan voor zaakschade) bij verkeersongevallen, hanteert als centrale vragstelling wie betaalt, hoeveel wordt betaald en hoe snel wordt bebald. ${ }^{1769}$ Daarbij wordt een vergelijking gemaakt tussen de vergoeding van schade in staten met een no-fault verzekering en staten met een aansprakelijkheidssysteem (tor'). Dit onderzoek van Rolph, Hammit en Houchens bevat een statistische analyse van gegevens die werden verzameld met behulp van een studie uit 1977 naar de vergoeding van verkeersschade. ${ }^{1770}$ Daamaast wordt door hen gewerkt met twee typen onderzoeksdata. Een eerste heeft betrekking op informatie ten aanzien van schadeclaims onder een aansprakelijkheidsverzekering respectievelijk een no-fault verzekering. Een tweede type onderzoeksdata omvat een nationale enquête onder Amerikanse huishoudens ten aanzien van hun betrokkenheid bij een verkeersongeval in de 24 maanden voorafgaand aan de interviews. ${ }^{1771}$

Verder worden ten behoeve van het onderzoek de 50 Amerikaanse staten onderverdeeld in een tiental clusters, gebaseerd op de toepasselijke vergoedingsregels voor wiveersschade in het jaar 1983. Dit leidt tot een onderscheid in vier categorieën van regelgeving, namelijk een beperking van de aansprakelijkheidsvordering ('threshold"), de beschikbaarheid en de omvang van een no-fault dekking, (fout) aansprakelijheidsregels en regelgeving ten aanzien van de verplichte aansprakelijkheidsver-

1768. Camoll and Kakalik, JRI, 1993, p. 285-286.

1769. Rolph, Hammit and Houchens, JRI, 1985, p. 667-685. Dit onderzoek is ontleend aan een omrangrijke studic van de Rand Corporation, Rand-I $/ \mathrm{m}-\mathrm{IV}$, Automobile Accident Compensation, The Rand Corporation, Santa Monica Californie, The Institute for Civil Justice, 1985. Volume I: J.E. Rolph, J.K. Hammit, R.L. Houchens and S.S. Polin, Who Pays How Much How Soon?, R3050-ICJ; Volume II: J.K. Hammit, Payments by Auto Insurers R-3051-ICJ; Volume III: R.L. Houchens, Payments from All Sources, R-3052-ICJ; Volume IV: J.K. Hammit, R.L. Houchens, J.E. Rolph and S.S. Polin, State Rules, R-3053-ICJ. Dit rapport wordt ook geanalyseerd in onder anderen: Van Wassenaer van Catwijck, VA, 1988, p. 321-377; Dewees, Duff and Trebilcock, Accident Law, p. 26-39 en p. 54-62 en Chapman and Trebilcock, Working Paper, 1991, p. 18-23. Een studie die is verricht door de 'All-Industry Research Advisory Council (AIRAC), een adviesorgaan binnen de Amerikaanse verzekeringsindustrie. Zie Rolph, Hammit and Houchens, JRI, 1985, p. $667-668$.

177. Rolph, Hammit and Houchens, JRJ, 1985, p. 668-669. 
zekering (BI). Aan de hand van deze onderverdeling en van de eerder genoemde data (schadeclaims) worden ten behoeve van het empirisch onderzoek een 11-tal staten geselecteerd. Dit betreft 6 staten met aansprakelijkheidsclaims, namelijk California, Washington, North Carolina, Maryland, Massachusetts and New Jersey en 5 staten met no-fault claims, namelijk Michigan, Pennsylvania, New Jersey, Massachusetts en Maryland. ${ }^{1772}$

Een van de hoofdvragen in dit onderzoek heeft betrekking op de omvang van de schadevergoeding die aan het verkeersslachtoffer, op basis van een aansprakelijkheidsverzekering respectievelijk een no-fault verzekering, wordt uitgekeerd. Uit de onderzoeksresultaten blijkt dat in een traditionele 'tort'-staat, zoals Califomia, gemiddeld $90 \%$ van de verkeersslachtoffers die werden vergoed voor hun materiële schade op basis van een BI-dekking, deze schade ook volledig kregen uitgekeerd. De andere $10 \%$ van de slachtoffers kreeg minder dan een volledige schadevergoeding. Deze uitkomst houdt volgens Rolph, Hammit en Houchens verband met de toepasselijke aansprakelijkheidsregel, waarbij het slachtoffer in sommige gevallen vanwege eigen schuld recht heeft op een minder dan volledige schadevergoeding.

In een no-fault-staat, zoals New Jersey, kreeg $61 \%$ van de verkeersslachtoffers die op basis van een BI-verzekering claimen, minder dan de werkelijk geleden materielle schade vergoed. De meeste verkeersslachtoffers $(51 \%)$ ontvingen in het geheel geen vergoeding voor materiële schade onder een BI-dekking. Dit laatste kan volgens Rolph, Hammit en Houchens worden verklaard uit het gegeven dat veel slachtoffers in New Jersey hun schade reeds vergoed kregen op basis van hun eigen no-fault (PIP) verzekering. ${ }^{1773}$

Uit het onderzoek van Rolph, Hammitt en Houchens blijkt verder dat het percentage verkeersslachtoffers dat geen uitkering kreeg voor medische kosten of inkomensschade in no-fault-staten lager is dan in 'tort'-staten. Bij inkomensschade zijn de percentages $24 \%$ (no-fault), $32 \%$ ('add on') en $37 \%$ ('tort'). Bij medische kosten bedraagt het aantal verkeersslachtoffers dat geen vergoeding ontving respectievelijk $18 \%$ (no-fault), $13 \%$ ('add on') en $22 \%$ ('tort'). $^{1774}$

Een no-fault verzekering dient volgens Rolph, Hammitt en Houchens aan de volgende doelstellingen te beantwoorden: 1. de afschaffing of een beperking van de aansprakelijkheid; 2 . de substitutie naar een alternatief compensatiemechanisme en 3. een algehele toepassing van dit compensatiemechanisme. In de VS blijkt geen van de ingevoerde no-fault regimes aan al deze doelstellingen te voldoen, hoewel de 'threshold' no-fault dicht in de buurt komt. In de berekening van Rolph, Hammit en

1772. Rolph, Hammit and Houchens, JR, 1985, p. $671-672$ en 678.

1773. Rolph, Hammit and Houchens, JRI, 1985, p. 675-677.

1774. Rolph, Hammitt and Houchens, JRI, 1985, p. 673 en p. 679. 
Houchens blijkt dat afhankelijk van de omvang, schadedrempels ('threshold') in de onderzochte no-fault staten hebben geleid tot een reductie van het aantal ansprakelijkheidsvorderingen (BI-claims) met $50 \%$ tot $90 \%$. Een no-fault verzekring leidt volgens hen in zowel 'add-on' als in 'threshold' no-fault staten tot en bijna volledige schadevergoeding van het verkeersslachtoffer. Onderzoek heeft ulgewezen dat $90 \%$ van de slachtoffers die op basis van een no-fault verzekering chimden, hun materiële schade volledig kregen vergoed. ${ }^{1775}$

Concluderend kan worden gesteld dat, gelet op de omvang van de schadevergoeding an verkeersslachtoffers, zowel bij een no-fault verzekering als bij een systeem met en aansprakelijkheidsverzekering de materiële schade bijna volledig aan het slachtoffer wordt vergoed. Uit het onderzoek komt echter ook naar voren dat in 'tort'saten het percentage verkeersslachtoffers dat in het geheel geen schadevergoeding onvangt hoger ligt dan in no-fault-staten. Dit betekent derhalve dat een verkeerssachtoffer bij een no-fault verzekering meer zekerheid heeft dat hij voor zijn geleden schade een vergoeding zal ontvangen.

\subsubsection{De empirische analyse van Dewees, Duff en Trebilcock}

Dewees, Duff en Trebilcock verwijzen in hun empirisch overzicht van het verkersongevallenrecht naar een aantal Amerikaanse studies waarin de omvang van de shadevergoeding op basis van no-fault respectievelijk aansprakelijkheid werd onderzocht. Daaruit blijkt onder andere dat slechts tweederde van het aantal verkerrsslachtoffers dat binnen een no-fault regime wordt gecompenseerd ook binnen en aansprakelijkheidssysteem voor een vergoeding in aanmerking zou komen. Dit beteknt volgens Dewees, Duff en Trebilcock dat ongeveer 33\% van de verkeerssachtoffers niet-ontvankelijk is voor een vergoeding onder een derde partij aansprakelijkheidsverzekering (BI). De reden hiervoor is dat er geen schuldige dader aanmijbaar is of dat de eigen schuld van het slachtoffer aan een vergoeding in de weg seat:

Yolgens Dewees, Duff en Trebilcock heeft onderzoek verder uitgewezen dat zowel ansprakelijkheidsvergoedingen als no-fault uitkeringen worden gedomineerd door relatief lage schadebedragen. In een onderzoek met betrekking tot het jaar 1977 bleek dat de no-fault uitkeringen in de 'threshold' staten Massachusetts en Michigan

\footnotetext{
Rolph, Hammit and Houchens, JRI, 1985, p. 684.

Rolph, Hammit, Houchens and Polin, Who Pays How Much How Soon?, Rand-I, p. 17; Hammit, Payments by Auto Insurers, Rand-II, p. 48; U.S. Department of Transportation, Compensating Auto Accident Victims, 1985, p. 8 en 73-74; All-Industry Research Advisory Council, Compensation for Automobile Injuries in the United States, Oak Brook, III, 1989, p. 150 in Dewees, Duff and Trebilcock, Accident Law, p. 89-90, noot 395 en Chapman and Trebilcock, Working Paper, 1991, p. 19, noot 32
} 
in respectievelijk $34 \%$ en $40 \%$ van de gevallen lager waren dan $\$ 100$. Gemiddeld $70 \%$ van de no-fault uitkeringen in deze staten was lager dan $\$ 500$. In Califomia, een 'tort' staat, werd bij $12 \%$ van de aansprakelijkheidsclaims een bedrag uitgekeerd dat lager was dan $\$ 100$, bij 37\% van aansprakelijkheidsvergoedingen was het bedrag lager dan $\$ 500$ en $51 \%$ van het totaal aantal uitkeringen bedroeg minder dan $\$ 1.000$. Slechts $11 \%$ van het totaal aantal aansprakelijkheidsvergoedingen had betrekking op een hoger bedrag dan \$ 5.000. In het Canadese Ontario, een 'add-on' provincie, bleek dat meer dan $60 \%$ van het aantal no-fault uitkeringen minder dan $\$ 1.000$ bedroeg, terwijl dit bij aansprakelijkheidsvergoedingen slechts $27 \%$ was. ${ }^{1 m}$

Een negatief aspect bij de invoering van een no-fault verzekering is volgens Dewees, Duff en Trebilcock dat verkeersslachtoffers met een ernstig letsel, waarvan de omvang de no-fault limiet ruimschoots overschrijdt, minder volledig worden gecompenseerd dan bij een aansprakelijkheidssysteem. Deze tendens verschilt echter van jurisdictie tot jurisdictie. In staten met een hoge polislimiet, zoals Quebec (\$125.000) en Michigan (onbeperkt) worden verkeersslachtoffers met emstig letsel in beginsel volledig gecompenseerd. In andere staten met een lage vergoedingslimiet, zoals Massachusetts ( $\$ 2.000$ ) en Maryland (\$ 2.500), krijgen slachtoffers met ernstig letsel, mede als gevolg van deze lage limiet, minder uitgekeerd dan hun werkelijke materiële schade. Zelfs wanneer schadeclaims bij overlijden of blijvende invaliditeit buiten beschouwing blijven, blijkt volgens Dewees, Duff en Trebilcock dat verkeersslachtoffers hun materiële schade niet volledig krijgen vergoed. In een Amerikaanse studie is berekend dat de gemiddelde no-fault vergoeding $65 \%$ bedroeg van de totale materiële schade van slachtoffers met een schadeclaim tussen $\$$ 25.000 en $\$ 100.000$ en $52 \%$ van de materiële schade voor slachtoffers met een schadeclaim van meer dan $\$ 100.000$. Het is echter onzeker in hoeverre deze slachoffers de overblijvende schade via een aansprakelijkheidsclaim vergoed hebben kunnen krijgen. ${ }^{1778}$

Met betrekking tot de omvang van de schadevergoeding aan verkeersslachtoffers wordt door Dewees, Duff en Trebilcock verwezen naar een Amerikaans onderzoek, waarin de zogenaamde uitkeringsratio binnen een no-fault regime respectievelijk een aansprakelijkheidssysteem wordt berekend. Deze uitkeringsratio heeft betrekking op de gemiddelde schadevergoeding per premiedollar die aan het verkeersslachtoffer ter

1777. Hammit, Payments by Auto Insurers, Rand-II, p. 4 (tabel 1.1.) en p. 32; Osborne Commission, Report of Inquiry into Motor Vehicle Accident Compensation in Ontario, Toronto, Queen's Printer, volume 2, 1988, p. 576 in Dewees, Duff and Trebilcock, Accident Law, p. 92, noot 428 429 en Chapman and Trebilcock, Working Paper, 1991, p. 20, noot 41-44.

1778. All-Industry Research Advisory Council, Compensation for Automobile Injuries, 1989, p. 156; Hammit, Payments by Auto Insurers, Rand-II, p. 21 (tabel 4.4.); U.S. Department of Transportation, Compensating Auto Accident Victims, 1985, p. 33 en 44; Ontario Task Force on Insuranct, Final Report of the Ontario Task Force on Insurance, Toronto, Ministry of Financial Institutions, 1986, p. 322 en 334 in Dewees, Duff and Trebilcock, Accident Law, p. 92, noot 431-435. 
beschikking komt. Uit dit onderzoek van de 'U.S. Department of Transportation' blijkt dat in een gemiddelde no-fault-staat $50,2 \%$ van elke betaalde premiedollar aan het verkeersslachtoffer werd uitgekeerd; in een gemiddelde 'tort'-staat bedroeg deze uitkeringsratio $43,2 \%$. Ten aanzien van het onderscheid tussen de verschillende nofault regimes is in dit onderzoek verder berekend dat in 'add-on' staten met een verplichte no-fault (PIP) verzekering 53,6\% van elke premiedollar aan het verkeersslachtoffer werd uitgekeerd; in 'add-on' staten waarbinnen een no-fault verzekering vijwillig kan worden afgesloten bedroeg het uitkeringsratio $51 \%$. In 'threshold' nofault staten werd een uitkeringsratio van $49,8 \%$ berekend. Binnen deze 'threshold' jurisdicties blijkt verder dat in staten met een financiële schadedrempel ('threshold') een hoger percentage $(50,3 \%)$ per premiedollar aan het verkeersslachtoffer ter beschilking kwam dan in no-fault staten met een materiële ('verbal') schadedrempel $(47,8 \%) .{ }^{1779}$ Daarnaast wordt volgens Dewees, Duff en Trebilcock in dit onderzoek een positief verband aangetoond tussen het uitkeringsratio en de vergoedingslimiet bimen het betreffende no-fault regime. In 1983 was daarbij sprake van een uitkeringsratio van $48,7 \%$ in no-fault staten met een vergoedingslimiet tot $\$ 50.000$ en een ratio van $52,7 \%$ in staten met een vergoedingslimiet van meer dan $\$ 50.000$. $^{1780}$

Dewees, Duff en Trebilcock verwijzen tenslotte naar een empirisch onderzoek met betrekking tot de Canadese provincie Quebec, waar in 1978 een no-fault regime werd ingevoerd. Daarin wordt aangetoond dat de nettovergoeding voor verkeersslachtoffers in verhouding tot de betaalde premies toenam van $58 \%$ in de periode $1973-1978$ tot $67 \%$ in de periode $1979-1984 .^{1781}$ Daarnaast bleek dat na invoering tan het no-fault regime in Quebec een verkeersslachtoffer vrijwel geen proceskosten meer heeft. Een onderzoek van Devlin suggereert dat hierdoor 10-15\% extra schadevergoeding aan het slachtoffer ter beschikking komt. ${ }^{1782}$

32.1.4. Conclusie

Naar aanleiding van het voorgaande kan worden geconcludeerd dat een no-fault verzekering ten opzichte van een aansprakelijkheidssysteem aan het verkeersslachtoffer meer zekerheid geeft dat hij (een deel van) zijn schade vergoed krijgt. Bij no-fault uitkeringen gaat het echter om gemiddeld lagere bedragen dan bij aansprakelijkheidsvergoedingen. Dit kan worden verklaard door het feit dat op basis van een no-

1779. U.S. Department of Transportation, Compensating Auto Accident Victims, 1985, p. 83-84 in Dewees, Duff and Trebilcock, Accident Law, p. 76, noot 232 en p. 93, noot 441 en Chapman and Trebilcock, Working Paper, 1991, p. 23, noot 54.

1780. U.S. Department of Transportation, Compensating Auto Accident Victims, 1985, p. 25-40 in Dewees, Duff and Trebilcock, Accident Law, p. 60 en p. 93, noot 442.

1781. Ontario Task Force on Insurance, 1986, p. 332 in Dewees, Duff and Trebilcock, Accident Law, p. 92 , noot 437.

1782. Devlin, Liability versus No-Fault, p. 278 en 281 in Dewees, Duff and Trebilcock, Accident Law, p. 60 en p. 93 , noot 440 . 
fault verzekering alleen de materieel geleden schade wordt vergoed, terwijl in de aansprakelijkheidsvergoeding ook een bedrag voor immateriële schade is verdisconteerd.

De studies geven geen uitsluitsel over de vraag of met de uitgekeerde lage bedragen een verkeersslachtoffer ook volledig wordt gecompenseerd. Wanneer een slachtoffer ernstig letsel heeft geleden en de schadeomvang als gevolg daarvan aanzienlijk is, zal bij een no-fault verzekering geen volledige schadevergoeding aan het slachtoffer ter beschikking komen. Dit is echter weer afhankelijk van de toepasselijke vergoedingslimieten die in veel Amerikaanse staten niet hoog zijn. In staten met een hoge vergoedingslimiet zal daarentegen sprake zijn van een hogere uitkering onder een no-fault verzekering, hetgeen betekent dat meer verkeersslachtoffers volledig worden gecompenseerd.

Tenslotte kan worden geconcludeerd dat de (gedeeltelijke) afschaffing van de aansprakelijkheid binnen een no-fault jurisdictie leidt tot een besparing op de proceskosten.

\subsubsection{De afwikkeling van de schade binnen een no-fault regime}

Naast de omvang van de vergoeding van verkeersschade, wordt in een aantal studies ook onderzoek gedaan naar de gemiddelde termijn waarbinnen verkeersslachtoffers een schade-uitkering ontvangen. Ook hierbij wordt een vergelijking gemaakt tussen een no-fault verzekering en het aansprakelijkheidssysteem.

Rolph, Hammit en Houchens ${ }^{1783}$ stellen voorop dat in Noord-Amerika deze vergoedingssystemen verschillen met betrekking tot de wijze waarop de uitkering van de schade plaats heeft. Bij het aansprakelijkheidsrecht wordt vaak een bedrag ineens uitgekeerd, zodat de schadeveroorzaker en zijn aansprakelijkheidsverzekeraar zjjn gevrijwaard van verdere claims. Een no-fault verzekering kent veelal een vergoeding in termijnen, omdat het werkelijke bedrag aan medische kosten vaak niet direct kan worden vastgesteld. Dit betekent volgens Rolph, Hammit en Houchens dat voor een grote meerderheid van de no-fault claims de periode tot aan de finale betaling van het slachtoffer ongeveer even lang duurt als voor de helft van het aantal claims binnen het aansprakelijkheidssysteem. Meer dan de helft van de slachtoffers met een no-fault claim ontvangt reeds een bedrag voor deze finale uitkering, terwijl driekwart van de verkeersslachtoffers al een uitkering ontvangt binnen 60 dagen na het verkeersongeval. ${ }^{1784}$

1783. Zie paragraaf 3.2.1.2 van dit hoofdstuk voor een overzicht van hun onderzoeksgegevens.

1784. Rolph, Hammit and Houchens, JRI, 1985, p. 680-681. 
In tabel $4^{1785}$ is, in het kader van een vergelijking tussen no-fault en aansprakelijkheid, een overzicht opgenomen van de duur van de schade-uitkering alsmede het percentage verkeersslachtoffers dat binnen een gegeven tijdsbestek een vergoeding ontvangt. De studies in deze tabel geven aan dat de schade-uitkering via een no-fault verzekering aanmerkelijk sneller plaatsvindt dan bij een aansprakelijkheidsverzekeing. De vertragingen ten aanzien van de vergoedingen op basis van een aansprakelijkhidsverzekering doen zich volgens Dewees, Duff en Trebilcock met name voor bij verkeersslachtoffers met ernstig letsel die een hoog bedrag aan materiële schade claimen. Hierbij is volgens hen de kans op de betrokkenheid van advocaten en daarmee een proces groter. De 'vertragingen' bij een no-fault verzekering zijn voornamelijk gebaseerd op de tijd die wordt gemeten tussen het indienen van de schadeclaim en de eerste betaling.

Deze tabel is (gedeeltelijk) ontleend aan Dewees, Duff and Trebilcock, Accident Law, p. $37 \mathrm{cn}$ Chapman and Trebilcock, Working Paper, 1991, p. 22.

1786. Devlin, Liability versus No-fault, p. 74 in Chapman and Trebilcock, Working Paper, 1991, p. 22. De data van haar onderzoek suggereren volgens hen dat een no-fault verzekering een verkeersslachtoffer in meer gevallen een uitkering verschaft, maar ook dat deze uitkering sneller beschikbaar komt. 
Tabel 4

\begin{tabular}{|c|c|c|c|c|c|}
\hline \multicolumn{6}{|c|}{$\begin{array}{l}\text { Afwikkelingsduur van de schade en het percentage verkeersslachtoffers dat binnen } \\
\text { de genoemde periodes een vergoeding ontvangt. }\end{array}$} \\
\hline Studie & $\begin{array}{l}\text { Minder dan } \\
1 \text { maand }\end{array}$ & $\begin{array}{l}\text { Minder dan } \\
2 \text { maanden }\end{array}$ & $\begin{array}{l}\text { Minder dan } \\
3 \text { maanden }\end{array}$ & $\begin{array}{l}\text { Minder dan } \\
6 \text { maanden }\end{array}$ & $\begin{array}{l}\text { Meer dan } \\
6 \text { maanden }\end{array}$ \\
\hline \multicolumn{6}{|l|}{$\begin{array}{l}\text { Aansprakelijkheids- } \\
\text { claims }\end{array}$} \\
\hline $\begin{array}{l}\text { 1. Quebec } \\
\text { (1970/71) }\end{array}$ & $5 \%$ & $12 \%$ & $18 \%$ & $35 \%$ & $65 \%$ \\
\hline $\begin{array}{l}\text { 2. DOT }{ }^{1788} \\
(1985)\end{array}$ & $28,6 \%$ & -- & $46,2 \%$ & $61,9 \%$ & $38,1 \%$ \\
\hline $\begin{array}{l}\text { 3. Ontario } \\
\text { (1987) }\end{array}$ & $14,2 \%$ & $19,7 \%$ & $25,2 \%$ & $38,4 \%$ & $61,6 \%$ \\
\hline \multicolumn{6}{|l|}{ No-fault claims } \\
\hline $\begin{array}{l}\text { 1. Quebec } \\
\text { (1983/84) }\end{array}$ & $32 \%$ & $70 \%$ & $84 \%$ & $96 \%$ & $4 \%$ \\
\hline $\begin{array}{l}\text { 2. } \text { DOT }^{1791} \\
(1985)\end{array}$ & $37,1 \%$ & - & $80,6 \%$ & $93,5 \%$ & $6,5 \%$ \\
\hline $\begin{array}{l}\text { 3. Ontario } \\
(1987)\end{array}$ & $34,8 \%$ & $57,7 \%$ & $69,9 \%$ & $86,7 \%$ & $13,3 \%$ \\
\hline
\end{tabular}

In een Amerikaans onderzoek dat niet in tabel 4 is opgenomen, wordt ook gewezen op een relatief snellere schadeafwikkeling bij een no-fault verzekering dan binnen een aansprakelijkheidssysteem. ${ }^{1793}$ Volgens de berekeningen van Carroll en Kakalik krijgt bij het aansprakelijkheidsrecht $45 \%$ van de verkeersslachtoffers een uitkering binnen drie maanden na het ongeval. Een additionele $23 \%$ ontvangt een uitkering in 4-6 maanden na het verkeersongeval. $22 \%$ van de slachtoffers moest 7-12 manden wachten op een uitkering en $10 \%$ meer dan 1 jaar. Bij een no-fault verzekering ontvangt, volgens Carroll en Kakalik, $46 \%$ van de verkeersslachtoffers een eerste betaling binnen 3 maanden, terwijl een additionele $39 \%$ een uitkering ontvangt in 4.6

1787. Devlin, Liability versus No-Fault, p. 74.

1788. U.S. Department of Transportation, Compensating Auto Accident Victims, 1985, p. 79.

1789. Osborne Commission, 1988, volume 2, p. 546 en 569.

1790. Devlin, Liability versus No-Fault, p. 74.

179i. U.S. Department of Transportation, Compensating Auto Accident Victins, 1985, p. 79.

1792. Osbome Commission, 1988, Volume 2, p. 546 en 569.

1793. Carroll and Kakalik, JRI, 1993, 265-287. Zie ook paragraaf 3.2.1.1 van dit hoofdstuk voor een overzicht van hun onderzoeksgegevens. 
maanden na het verkeersongeval. Slechts $15 \%$ van de verkeersslachtoffers moest meer dan 6 maanden wachten op een eerste uitkering en minder dan $1 \%$ meer dan 1 jar. Carroll en Kakalik concluderen dat in een no-fault regime $85 \%$ van de verkeersslachtoffers binnen 6 maanden na het ongeval een vergoeding ontvangt voor de geleden schade, terwijl dit binnen een aansprakelijkheidssysteem voor $68 \%$ van het antal slachtoffers geldt. ${ }^{1794}$

In een andere Amerikaanse studie ${ }^{1795}$ die ook niet in tabel 4 is opgenomen, wordt een omgekeerd evenredig verband aangetoond tussen de snelheid van een aansprakelijkheids- respectievelijk een no-fault uitkering en de omvang van de materiële schadeclaim. Hieruit blijkt dat aansprakelijkheidsclaims met een laag schadebedrag ( 5500 of minder) relatief snel ( $66 \%$ binnen drie maanden, $43 \%$ binnen 1 maand) worden geschikt. Bij aansprakelijkheidsclaims van $\$ 500$ of meer blijkt het maanden te duren voordat een schade-uitkering volgt. $\mathrm{Na}$ een jaar is iets meer dan $50 \%$ van de schadeclaims ten bedrage van meer dan $\$ 2.500$ afgewikkeld. Bij een no-fault verzekeringsclaim was daarentegen sprake van een snellere uitkering, waarbij $79 \%$ van de claims voor materiële schade ten bedrage van minder dan $\$ 500$ binnen drie maanden wordt geregeld ( $35 \%$ binnen 1 maand). Ruim $96 \%$ van de claims van $\$ 2.500$ of meer is na 1 jaar afgehandeld ( $72 \%$ binnen drie maanden). Dewees, Duff en Trebilcock concluderen naar aanleiding van dit onderzoek dat een no-fault systeem, voor wat betreft de schade-uitkering, in het algemeen ongeveer twee maanden sneller is dan een aansprakelijkheidssysteem. ${ }^{1796}$

Concluderend kan worden gesteld dat een verkeersslachtoffer op basis van een nofault verzekering zijn volledige materiële schade relatief sneller krijgt uitgekeerd ian bij een aansprakelijkheidsverzekering. Bij een no-fault verzekering zijn alle (lagere) schadeclaims binnen een jaar afgewikkeld, terwijl dit bij een aansprakelijkheidsverzekering slechts voor de helft van de schadeclaims geldt. Dit kan worden rerklaard uit het feit dat bij een no-fault verzekering de aansprakelijkheidsvraag niet aan de orde komt, zodat direct kan worden overgegaan tot de vaststelling van de omlang van de schade. Bij een aansprakelijkheidssysteem dient echter, alvorens de schadeomvang kan worden vastgesteld, eerst de aansprakelijkheidsvraag te worden onderzocht. Daarnaast zal bij aansprakelijkheid een discussie kunnen ontstaan over de eigen schuld van het slachtoffer en de omvang van de immateriële schade.

1794. Carroll and Kakalik, JRI, 1993, p. 281.

1795. All-Industry Research Advisory Council, Compensation for Automobile Injuries in the United States, 1989, p. 50 in Dewees, Duff and Trebilcock, Accident Law, p. 36. De data in dit onderzoek hebben betrekking op het jaar 1987.

1796. Dewees, Duff and Trebilcock, Accident Law, p. 36 met een verwijzing naar S.J. Carroll and J.S. Kakalik, N.M. Pace and J.L. Adams, No-Fault Approaches to Compensating People Injured in Automobile Accidents, Santa Monica Califomie, Institute for Civil Justice, Rand Corporation, 1991, p. 44. Zie ook Carroll and Kakalik, JRI, 1993, p. 281. 


\subsubsection{Conclusie}

Naar aanleiding van het hiervoor beschreven empirisch onderzoek op het terrein van de compensatie van verkeersslachtoffers, kan in het algemeen worden geconcludeerd dat zowel bij een no-fault regime als bij een aansprakelijkheidssysteem verkeersslachtoffers hun materieel geleden schade bijna volledig vergoed krijgen. Bij het aansprakelijkheidsrecht krijgen verkeersslachtoffers hun materiële schade vaak meer dan volledig vergoed, maar dit komt omdat binnen het uitgekeerde bedrag een belangrijk deel aan immateriële schade is verdisconteerd.

Een no-fault verzekering geeft het slachtoffer meer zekerheid dat zijn materiële schade ook daadwerkelijk wordt vergoed. Daarbij is de uitkering op basis van de nofault verzekering in vergelijking met het aansprakelijkheidsrecht ook meer in overeenstemming met de materieel geleden schade. Of de schadevergoeding aan het slachtoffer volledig is hangt af van het toepasselijke no-fault regime. In een aantal Amerikaanse staten zijn de vergoedingslimieten onder een no-fault verzekering vrij laag, hetgeen meebrengt dat met name slachtoffers die ernstig letsel hebben geleden geen volledige vergoeding ontvangen. Daar staat tegenover dat in veel Amerikaanse staten, naast een vergoeding op grond van de no-fault verzekering, de mogelijkheid bestaat om voor de overige schade een aansprakelijkheidsvordering in te stellen.

Met betrekking tot de materieel geleden schade kan verder worden gesteld dat in vergelijking met het aansprakelijkheidsrecht onder een no-fault verzekering meer verkeersslachtoffers een uitkering ontvangen die gelijk is aan of meer bedraagt dan hun werkelijk geleden materiële schade. Tenslotte wordt de materiële schade bij een no-fault verzekering ook relatief sneller uitgekeerd dan bij een aansprakelijkheidsverzekering.

\subsection{NO-FAULT VERSUS AANSPRAKELIJKHEID: DE KOSTEN}

Een derde toetsingscriterium in de verhouding tussen no-fault en aansprakelijkheid houdt verband met de kosten die met de toepassing van de beide systemen gepaard gaan. In dat kader wordt binnen de empirische literatuur een onderscheid gemaakt tussen een tweetal typen kosten. Een eerste type houdt verband met de regeling van de schade na een verkeersongeval en worden ook wel schaderegelings- of transactiekosten genoemd. Binnen deze transactiekosten wordt een verder onderscheid gemaakt tussen de kosten voor een verzekeraar en het slachtoffer alsmede de proceskosten in de gevallen dat een schadeclaim voor de rechter komt. In de tweede plaats zijn er de kosten van de autoverzekering zelf, in het bijzonder de stijging of 
daling van de premiekosten na de invoering van een no-fault verzekering. ${ }^{1797}$ In deze paragraaf zal met behulp van empirisch onderzoek worden onderzocht of de invoeing van een no-fault verzekering, ten opzichte van het aansprakelijkheidsrecht, tot een besparing op de schaderegelingskosten (paragraaf 3.3.1) respectievelijk de premiekosten heeft geleid (paragraaf 3.3.2).

\subsection{De kosten van de schaderegeling binnen no-fault en aansprakelijkheid}

In het eerder beschreven onderzoek van Carroll en Kakalik ${ }^{1798}$ wordt ook het verschil in schaderegelingskosten tussen een no-fault regime en een aansprakelijkheidssysteem bestudeerd. Daarbij wordt een no-fault verzekering verondersteld met een materiële ('verbal') schadedrempel ('threshold') en een vergoedingslimiet van $\$$ 15.000. Uit hun berekening blijkt dat in 'tort' staten de totale schaderegelingskosten bijna $22 \%$ hoger waren dan in vorenbedoeld no-fault regime. De kostenreductie bij een no-fault verzekering bleek echter samen te gaan met een gemiddeld lager bedrag aan schadevergoeding dat aan het verkeersslachtoffer ter beschikking komt. Door Caroll en Kakalik wordt daamaast de omvang bepaald van de transactiekosten, die per schadeclaim door een verzekeraar en een slachtoffer worden gemaakt. In 'tort'staten bedroegen deze transactiekosten per schadeclaim 33\% van de totale schaderegelingskosten; in het veronderstelde no-fault systeem omvatten deze kosten $26 \%$ van het totaal. ${ }^{1799}$

Carroll en Kakalik leiden hieruit af dat een no-fault verzekering tot een besparing op de totale schaderegelingskosten kan leiden. De omvang van deze kostenbesparing is echter afhankelijk van het toepasselijke no-fault regime. Volgens Carroll en Kakalik hunnen sommige no-fault regimes, waarbij een PIP-verzekering met een hoge vergoedingslimiet geldt, zelfs leiden tot een toename van de kosten. In een no-fault systeem met een schadedrempel ('threshold') van $\$ 1.000$ en een vergoedingslimiet van $\$ 250.000$ werd door hen een stijging van de schaderegelingskosten met $13 \%$ berekend. Een zuiver no-fault regime, daarentegen, met een afschaffing van de aansprakelijkheid en een onbeperkte no-fault vergoeding, zal kunnen leiden tot een relatieve daling van de schaderegelingskosten met $29 \%$. Ten aanzien van de transactiekosten, als onderdeel van de totale schaderegelingskosten, wordt door Carroll en Kakalik gesteld dat alle vormen van no-fault kunnen leiden tot een kostenbesparing ongeacht de toepasselijke polisvoorwaarden. Volgens hen zullen in staten waar veronderstellenderwijs de aansprakelijkheidsvordering voor immateriële schade geheel is uitgebannen de transactiekosten met $80 \%$ dalen. In no-fault staten die nog wel een aansprakelijkheidsvordering toelaten zullen de transactiekosten, in verhouding tot 'tort'-

\footnotetext{
1797. Zie daarover Dewees, Duff and Trebilcock, Accident Law, p. 36-38 en p. 60-62; Chapman and Trebilcock, Working Paper, 1991, p. 23-27.

1798. Carroll and Kakalik, JRU, 1993, p. 265-287.

1799. Carroll and Kakalik, JRI, 1993, p. 277-278.
} 
staten, met $20-40 \%$ dalen. Deze laatste uitkomst leidt volgens Carroll en Kakalik tot een geschatte daling van de totale schaderegelingskosten met ongeveer $10 \% .{ }^{1800}$

Ten slotte kan worden verwezen naar een aantal empirische studies met betrekking tot de kosten van het no-fault regime in de Canadese provincie Quebec. Devlin heeff berekend dat binnen dit zuivere no-fault stelsel de afschaffing van de aansprakelijkheid zal leiden tot een kostenbesparing van $10-24 \% .{ }^{1801}$ Een andere onderzoek schat deze kostenreductie op ongeveer $5 \%$. $^{1802}$

\subsubsection{De (premie)kosten van een autoverzekering binnen no-fault}

Een ander kostenaspect heeft betrekking op de kosten van de autoverzekering, in het bijzonder de wijziging in de premiekosten na invoering van een no-fault verzekering. Dewees, Duff en Trebilcock refereren aan een Amerikaanse onderzoek waarin is berekend dat tussen 1976 en 1987 de gemiddelde premie voor autoverzekering in een gemiddelde no-fault staat bijna twee keer zo snel ( $91 \%$ versus $50 \%)$ is gestegen dan in een gemiddelde 'tort'-staat. In 'add-on' staten steeg de premie met gemiddeld $40,7 \%$ in vergelijking met een toename van $35,5 \%$ in 'tort'-staten. ${ }^{1803}$ In Canada heb. ben studies volgens hen aangetoond dat het zuivere no-fault regime van Quebec heeft geleid tot een afname van de kosten van autoverzekering in vergelijking met andere Canadese provincies. Tussen 1978 en 1984 steeg de gemiddelde premie in Quebec (gebaseerd op 'registration fee', 'driving permits' en 'gasoline tax') minder snel dan in Ontario gemeten over dezelfde periode. ${ }^{1804}$

O'Connell heeft voor een groot aantal no-fault jurisdicties in kaart gebracht welke wijzigingen zijn opgetreden in de premiekosten voor autoverzekering. ${ }^{1805}$ Daarbij wordt voor het jaar 1987 een vergelijking gemaakt van de geschatte premie die binnen een aansprakelijkheidssysteem zou moeten worden betaald en de werkelijke premie die voor een no-fault verzekering wordt gerekend. In tabel 5 zijn de resulta-

1800. Carroll and Kakalik, JRI, 1993, p. 281-286. Zic ook Carroll, Kakalik, Pace and Adams, No.Faul! Approaches to Compensating People, p. 29-39 in Dewees, Duff and Trebilcock, Accident Law, p. 76 , noot 233 en p. 93, noot 449.

1801. Devlin, Liability versus No-Fault, p. 249-257 in Dewees, Duff and Trebilcock, Accident Law, $p$ 38 en p. 76, noot 234 en Chapman and Trebilcock, Working Paper, 1991, p. 23, noot 55.

1802. Osborne Commission, 1988, volume 1, p. 528 in Dewees, Duff and Trebilcock, Accident Law, p. 38 en p. 76, noot 235 en Chapman and Trebilcock, Working Paper, 1991, p. 23, noot 56.

1803. U.S. Department of Transportation, Compensating Auto Accident Victims, 1985, p. 67 in Dewees, Duff and Trebilcock, Accident Law, p. 93, noot 446-447 en Chapman and Trebilcock, Working Paper, 1991, p. 23, noot 58.

1804. Devlin, Liability versus No-Fault, p. 62-63 in Dewees, Duff and Trebilcock, Accident Law, P. 93, noot 445 en Chapman and Trebilcock, Working Paper, 1991, p. 23, noot 57.

1805. O'Connell, SDLR, 1989, p. 993-1015. 
tea van het onderzoek van O'Connell weergegeven. ${ }^{1806}$ In de tweede kolom van deze abel is aangegeven of de betreffende no-fault staat een schadedrempel ('threshold') heet ingevoerd en de hoogte daarvan. De derde kolom geeft de vergoedingslimiet weer die binnen het betreffende no-fault regime van toepassing is. In de vierde kolom is door $\mathrm{O}^{\prime}$ Connell een schatting gemaakt van de zuivere premie ${ }^{1807}$ die voor een ansprakelijkheidsverzekering zou moeten worden betald wanneer geen no-fault wetgeving van toepassing zou zijn. In de vijfde kolom is de totale zuivere premie roor de autoverzekering weergegeven. Deze bestaat uit respectievelijk een aansprakelijkheidsdekking voor letselschade (BI), een dekking in verband met onverzekerde autobestuurders (UM) en een no-fault dekking. In de zesde kolom is een opsomming gegeven van de zuivere no-fault premie die binnen het betreffende no-fault regime mot worden betaald. In de zevende kolom, tenslotte, is berekend welke wijziging in de premiekosten is opgetreden wanneer de totale zuivere premie voor autoverzekering (kolom 5) wordt afgezet tegen de geschatte zuivere 'tort' premie (kolom 4). In New York is bijvoorbeeld sprake van een zuivere premie die $30 \%$ lager ligt dan wanneer geen no-fault wetgeving zou zijn ingevoerd $(198.48-138.12=60.36 / 198.48$ $=0.30)^{1.808}$

De gegevens in deze tabel zijn ontieend aan O'Connell, SDLR, 1989, p. 998-999. Voor alle nofault regimes in tabel 5 geldt dat zij tussen 1971 en 1976 zijn ingevoerd. In Pennsylvania werd in 1989 een 'add on' regime ingevoerd en in New Jersey werd de financiêle 'threshold' vervangen door een materiêle 'verbal' 'threshold' in 1989.

1807. De zuivere premie wordt omschreven als het deel van de premie dat wordt aangewend om de schade te vergoeden. Hieronder vallen derhalve niet de administratieve kosten van de verzekeraar en de proceskosten.

1808. Zie O'Connell, SDLR, 1989, p. 997. 
Tabel 5

\begin{tabular}{|c|c|c|c|c|c|c|}
\hline Staat & 'threshold' & $\begin{array}{l}\text { no-fault } \\
\text { 'benefits' }\end{array}$ & $\begin{array}{l}\text { tort pure } \\
\text { premium }\end{array}$ & $\begin{array}{c}\text { BI/UM/N-F } \\
\text { pure premium }\end{array}$ & $\begin{array}{l}\text { N-F pure } \\
\text { premium }\end{array}$ & $\begin{array}{l}\text { wijzigiog in } \\
\text { premiekosten }\end{array}$ \\
\hline & & 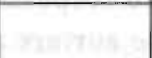 & 1987 & 1987 & 1987 & 1987 \\
\hline Florida & 'verbal' & $\$ 10.000$ & $\$ 187.32$ & $\$ 157.45$ & $\$ 41.11$ & $-16 \%$ \\
\hline Michigan & 'verbal" & onbeperkt & 171.67 & 116.57 & 74.93 & $-32 \%$ \\
\hline $\begin{array}{l}\text { New } \\
\text { York }\end{array}$ & 'verbal' & 50.000 & 198.48 & 138.12 & 49.78 & $-30 \%$ \\
\hline Hawai & $\$ 5.600$ & 15.000 & 141.49 & 147.82 & 62.74 & $+4 \%$ \\
\hline $\begin{array}{l}\text { Minne- } \\
\text { sota }\end{array}$ & 4.000 & 40.000 & 138.97 & 112.59 & 43.88 & $-19 \%$ \\
\hline Utah & 3.000 & 14.000 & 82.22 & 85.00 & 22.87 & $+3 \%$ \\
\hline Colorado & 2.500 & 130.000 & 90.70 & 131.86 & 64.22 & $+45 \%$ \\
\hline $\begin{array}{l}\text { North } \\
\text { Dakota }\end{array}$ & 2.500 & 30.000 & 66.11 & 49.81 & 17.17 & $-25 \%$ \\
\hline Kentucky & 1.000 & 10.000 & 93.96 & 75.06 & 28.79 & $-20 \%$ \\
\hline Georgia & 500 & 5.000 & 91.32 & 107.24 & 39.97 & $+17 \%$ \\
\hline Kansas & 500 & 29.000 & 74.90 & 58.87 & 14.64 & $-21 \%$ \\
\hline $\begin{array}{l}\text { Massa- } \\
\text { chusetts }\end{array}$ & $\overline{500}$ & 2.000 & 231.70 & 173.99 & 21.32 & $-25 \%$ \\
\hline $\begin{array}{l}\text { Connec- } \\
\text { ticut }\end{array}$ & 400 & 5.000 & 162.54 & 170.92 & 24.02 & $+5 \%$ \\
\hline $\begin{array}{l}\text { New Jer- } \\
\text { sey }\end{array}$ & 200 & onbeperkt & 183.59 & 226.77 & 91.17 & $+24 \%$ \\
\hline Oregon & geen & 20.000 & 113.62 & 110.01 & 25.26 & $-3 \%$ \\
\hline Delaware & geen & 10.000 & 108.56 & 173.13 & 53.53 & $+50 \%$ \\
\hline Maryland & geen & 2.500 & 134.63 & 170.10 & 38.73 & $+26 \%$ \\
\hline $\begin{array}{l}\text { Pennsyl- } \\
\text { vania }\end{array}$ & geen & 15.000 & 118.61 & 162.78 & 61.78 & $+37 \%$ \\
\hline
\end{tabular}

Naar aanleiding van tabel 5 kan worden geconcludeerd dat de wijziging in premiekosten ten aanzien van de Amerikaanse no-fault staten in het algemeen sterk uiteenloopt. Met betrekking tot de 'add-on' systemen geldt dat, naast een no-fault vergoeding, voor het verkeersslachtoffer een additionele vergoedingsbron beschikbaar is, namelijk een uitkering op basis van het aansprakelijkheidsrecht. Mede als gevolg 
hiervan kan een 'add-on' systeem volgens Dewees, Duff en Trebilcock als redelijk kostbaar worden beschouwd. Uit tabel 5 kan worden opgemaakt dat ten aanzien van Delaware, Maryland, en Pennsylvania sprake is van een toename van de premiekosten die mogelijk het gevolg is van de invoering van een 'add-on' no-fault regime. Voor de lichte daling van de totale zuivere premie ten opzichte van de geschatte tort' premie in Oregon kon echter geen verklaring worden gevonden. ${ }^{1809}$

In 'threshold' no-fault staten is een eventuele wijziging in de premiekosten afhankelijk van de omvang van de no-fault vergoedingen en van de hoogte van de schadedrempel ('threshold'). Staten met een hoge no-fault vergoeding (Colorado, Michigan, New Jersey en Pennsylvania) zijn vatbaar voor een stijging van de premiekosten. Deze toename kan volgens Dewees, Duff en Trebilcock mogelijk worden gerelateerd aan de invoering van een no-fault verzekering in deze genoemde staten met uitzondering van Michigan. De daling van premiekosten (-32\%) in deze staat wordt volgens hen veroorzaakt door de aldaar geldende hoge materiële ('verbal') schadedrempel ('threshold'), waardoor ongeveer $90 \%$ van de verkeersslachtoffers van een aansprakelijkheidsvordering is uitgesloten. ${ }^{1810}$

Staten met een minder hoge no-fault vergoeding (Florida, Hawaï, Kansas, Kentucky, Minnesota, New York, North Dakota, Utah), hebben op basis van tabel 5 verschillende ervaringen met betrekking tot een wijziging van de premiekosten. In het merendeel van deze staten is sprake van een lagere zuivere premie ten opzichte van de geschatte zuivere 'tort' premie. In Hawaï heeft de invoering van een no-fault verzekering echter geleid tot een lichte toename van de premiekosten met $4 \%$, dit ondanks de relatief hoge no-fault vergoeding $(\$ 15.000)$ en de relatief hoge financiële schadedrempel $(\$ 5.600)$. $^{1811}$

In twee van de drie staten met een lage no-fault vergoeding (Connecticut en Georgia, maar niet in Massachusetts), heeft de invoering van een no-fault verzekering gelid tot een toename van de premiekosten. Deze uitkomst kan volgens Dewees, Duff in Trebilcock, deels worden verklaard door de hogere vergoedingslimiet in Connecticut en Georgia (\$5.000) versus Massachusetts (\$2.500). Een andere verklarende factor is dat de lage financiële schadedrempel het in deze staten ( $\$ 400$ in Connecticut, $\$ 500$ in Massachusetts en Georgia) toelaat dat een groot aantal verkeersslacht-

Dewees, Duff and Trebilcock, Accident Law, p. 61; Chapman and Trebilcock, Working Paper, 1991, p. 24.

1810. U.S. Department of Transportation, Compensating Auto Accident Victims, 1985, p. 84; Hammit, Payments by Insurers, Rand-II, p. 52 in Dewees, Duff en Trebilcock, Accident Law, p. 93, noot 443.

1811. Dewees, Duff and Trebilcock, Accident Law, p. 61; Chapman and Trebilcock, Working Paper, 1991 , p. 26. 
offers een aansprakelijkheidsvordering kan instellen. ${ }^{1812}$ De daling van de premiekosten in Massachusetts kan volgens Dewees, Duff en Trebilcock verder worden verklaard uit het feit dat verzekeraars in deze staat verplicht zijn om een eigen risico $(\$ 250, \$ 500, \$ 1.000$ of $\$ 2.000)$ aan de autobestuurder aan te bieden. Daamaast geldt in Massachusetts de regel dat no-fault vergoedingen in mindering dienen te worden gebracht op de aansprakelijkheidsuitkeringen. ${ }^{1813}$

\subsubsection{Conclusie}

Naar aanleiding van het beschreven empirisch onderzoek kan worden geconcludeerd dat een no-fault verzekering op het terrein van de kosten bepaalde voordelen heeft ten opzichte van een aansprakelijkheidssysteem. In 'tort'-staten waren de schaderegelingskosten bijvoorbeeld hoger dan in een verondersteld no-fault regime. De kostenvoordelen van een no-fault verzekering zijn ook hier weer afhankelijk van het toepasselijke regime. Een zuiver no-fault regime leidt op het terrein van de schaderegelingskosten tot een belangrijke kostenbesparing. Bij een gemengd systeem van nofault en aansprakelijkheid wordt niet in alle gevallen een kostenbesparing bereikt. Een hoge schadedrempel leidt bijvoorbeeld tot een aanzienlijke kostenbesparing. Een hoge vergoedingslimiet gecombineerd met een lage schadedrempel leidt daarentegen tot een kostenstijging, terwijl een systeem met een hoge vergoedingslimiet en een hoge schadedrempel een minder hoge kostenstijging meebrengt. De kostenbesparing bij een no-fault verzekering kan deels worden verklaard uit het feit dat aan verkeersslachtoffers gemiddeld een lagere schade vergoeding wordt uitgekeerd. Voor een ander deel geldt dat er minder wordt geprocedeerd over de immateriele schadevergoeding. ${ }^{1814}$

Met betrekking tot de premiewijziging van de autoverzekering na invoering van een no-fault verzekering kunnen geen eenduidige conclusies worden gegeven. Ook kan niet voor elke premiewijziging een verklaring worden gevonden. Het lijkt erop dat een 'add-on' regime voor wat betreft de premieomvang als het meest dure systeem kan worden beschouwd. Bij een 'threshold' regime leidt een hoge schadedrempel

1812. In 1987 had 53,5\% van de verkeersslachtoffers in Massachusetts de mogelijkheid tot het instel. len van een aansprakelijkheidsvordering; in Connecticut en Georgia waren deze percentages respectievelijk $49,4 \%$ en $41,4 \%$. In Florida en New York waarbinnen een strenge materiële ('verbal') drempel geldt kregen respectievelijk $32,5 \%$ en $28,7 \%$ van de verkeersslachtoffers toegang tot het aansprakelijkheidssysteem. Zie J. O'Connell, A Draft Bill to Allow Choice Between NoFault and Fault-Based Auto Insurance, Harvard Joumal of Legislation, 1990, p. 143 en 146, noot 16 in Dewees, Duff and Trebilcock, Accident Law, p. 94, noot 457 en Chapman and Trebilcock. Working Paper, 1991, p. 26, noot 67.

1813. Dewees, Duff and Trebilcock, Accident Law, p. 61-62; Chapman and Trebilcock, Working Paper, 1991, p. 24-27.

1814. Rolph, Hammitt en Houchens, JRI, 1985, p. 684, wijzen op een reductie van het aantal aansprakelijkheidsvorderingen met $50-90 \%$. 
(verbal') tot een daling van de premie. $\mathrm{Bij}$ een no-fault regime met een lage schadedrempel zal eerder een aansprakelijkheidsvordering worden ingesteld, hetgeen weer tot een hogere premie kan leiden. In een aantal Amerikaanse staten wordt de stijging van de premie tegengegaan met aanvullende maatregelen die de kosten verminderen, zoals het aanbieden van een eigen risico en het in mindering brengen van de no-fault vergoedingen op de aansprakelijkheidsuitkeringen.

\section{Conclusie: no-fault verzekering versus aansprakelijkheid}

In dit hoofdstuk is onderzocht welke voor- en nadelen een no-fault regime, ten opzichte van het traditionele aansprakelijkheidsysteem, heeft op het terrein van de preventie, de compensatie en de (administratieve) kosten. In het algemeen kan worden gesteld dat een eerste partij no-fault verzekering tot een relatief snellere vergoeding van verkeersslachtoffers tegen lagere kosten leidt. Daarnaast moet worden geconcludeerd dat ten aanzien van de preventie van verkeersongevallen niet is komen vast te staan dat een no-fault regime tot meer verkeersongevallen leidt dan een aansprakelijkheidssysteem. Hoewel er aanwijzingen zijn voor het tegendeel, kan uit het beschreven empirisch onderzoek geen eenduidige conclusie worden getrokken.

In deze afsluitende paragraaf zullen de verschillende no-fault systemen ('add-on', threshold' en zuiver no-fault) en het aansprakelijkheidsrecht worden beoordeeld op de effecten ten aanzien van preventie, compensatie en kosten. ${ }^{1815}$

Met betrekking tot de preventie is in het beschreven empirisch onderzoek niet duidelijk geworden of de invoering van een zuiver no-fault regime tot meer of minder verkeersongevallen en verkeersslachtoffers leidt. Ook heeft het empirisch onderzoek diet kunnen aantonen dat de gedeeltelijke handhaving van het aansprakelijkheidsrecht in een groot aantal Amerikaanse staten tot minder verkeersongevallen heeft geleid. $^{1816}$

Een no-fault verzekering heeft het nadeel dat door de afschaffing van de aansprakelijkheid de prikkels van zorg tegenover derden afnemen. Een deel van de kosten die lengevolge van het eigen onzorgvuldig rijgedrag ontstaan, kunnen echter in een nofault systeem, waarbij een juiste risicodifferentiatie wordt toegepast, worden geïntemaliseerd. De kosten die aan derden worden toegebracht zullen echter niet in de no-fault premie tot uitdrukking komen.

1815. Zie ook Chapman and Trebilcock, Working Paper, 1991, p. 27-34, die een rangschikking maken van de verschillende no-fault regimes en van het aansprakelijkheidsrecht, getoetst aan de preventie, de compensatie en de kosten.

1816. Zie paragraaf 3.1 van dit hoofdstuk. 
De onzekerheif ten aswien van de effecten vas een no-fault werzekering geldt ook

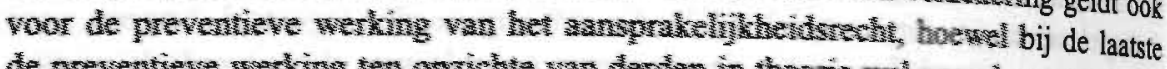
de preventieve werking ten copziche van derden in theorie wel onverkort van kracht bijf. Een deel van het empirisch onderzol suggereert dat zonder ansprakelijkheid, in casu de invoering van een no-fanlt verzekcring, het aantal rexkeersongevallen zal toenemen. Toch kan ook worden gesteld bat de pevertieve werking van het aansprakelijheidsrecht zich heft verplastat nas de nezekeringswoorwaarden ${ }^{1817}$ In hoofdstuk 11 is daaromitrent geconciudiend dat de coutrute van bet morele risico binnen een derde partij asnsprakelikheidsversekering wor moturijtuigen veelal

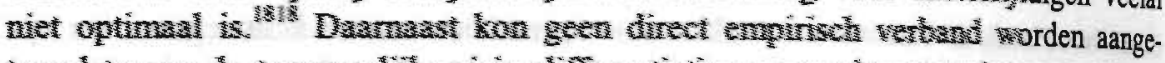
coond tussen de toepasselijle risicodifferentiatie en premiessngassing enerzijds en een wijziging in de zorgvuldigheid van de verzekerto of het aantal verkeersongevallen anderajds. Henit tan worden afgeleid dat vour de hexetrsch gemakte weronderstellingen fen aanzien wan de preventiewe werking van asasprakelijkheidsregels in de prakting het darecte empiriseh bewijs ontweekt.

Het voorgaande brengt mee dat bij een aanswrakelijkheidssysteem de verzekeringsvoorwaarden een belangrijke rol spelen. Dit geldit echter nog meer wor een no-fault regime. Bij een no-fault verzekering is het van groot belang đat een effectief systeem van risicodifferentiatie en premieaanpassing wordt toegepast en bijvoorbeeld ook gebruik wordt gemaakt van heffingen (belastingen/benzineaccijns) op de activiteit autorijden. De risicodifferentiatie kan onafhankelijk van het toepasselijke aansprakelijkheids- en verzekeringsregime worden uitgevoerd. Bij een aansprakelijkheidsverzekering wordt in het ideale geval de eventuele premieaanpassing gebaseerd op de mate waarin de verzekerde autobestuurder schuld heeft an een verkeersongeval, op grond waarvan hij een stijging van zijn premie tegemoet kan zien. In hoofdstuk 11 is echter gebleken dat bij de premieaanpassing binnen de autoverzekering voornamelijk wordt gekeken naar het schadeverleden van de verzekerde autobestuurder, in het bijzonder het aantal (niet de omvang van de) schadeclaims dat door hem in een gegeven periode wordt ingediend. ${ }^{1819}$ Binnen een no-fault verzekering kan een premieaanpassing niet op aansprakelijkheid worden gebaseerd. Wel kan door de verzekeraar worden onderzocht of ingeval van een schadeclaim het gedrag van de autobestuurder aanleiding geeft tot een premieaanpassing. Andere instrumen-

1817. Zie daarover hoofdstuk 10 en 11 .

1818. Dit gold met name binnen het kader van een bonus-malus systeem. Zie paragraaf 4 van hoofdstuk 11.

1819. Zie paragraaf 3 en 4 van hoofdstuk 11. Keeton, Keeton, Sargentich and Steiner, Cases and Materials on Tort and Accident Law, p. 912-913 stellen dat: 'To some extent, it is true, the negligence liability insurance system imposes higher costs on wrongdoers by charging them higher insurance premiums, but it does not so only in very rough terms, and to whatever extent this serves as a deterrent to dangerous driving the same could be accomplished through insurance rating even if compensation were paid without regard of fault'. 
ten die het gedrag van de verzekerde autobestuurder kunnen beïnvloeden zijn het aantal verkeersovertredingen of het gebruik van strafpunten. ${ }^{1820}$

Ondat de preventieve werking van een no-fault regime en van een aansprakelijkheidssysteem empirisch onzeker is, dient te worden onderzocht of de keuze voor een bepaald vergoedingssysteem kan worden gebaseerd op de criteria van compensatie en (administratieve) kosten.

Met betrekking tot de omvang van de compensatie van verkeersslachtoffers heeft empirisch onderzoek uitgewezen dat zowel een no-fault verzekering als een aansprakelijkheidssysteem in de meeste gevallen de materieel geleden schade volledig vergoedt. Bij een no-fault verzekering heeft het slachtoffer echter meer zekerheid op een vergoeding. In het aansprakelijkheidsrecht krijgen de meeste slachtoffers hun materiële schade meer dan volledig vergoed, omdat daarbinnen een belangrijk deel aan immateriële schadevergoeding is verdisconteerd.

Het empirisch onderzoek heeft ook aangetoond dat een no-fault regime hoger scoort ten opzichte van het aansprakelijkheidsrecht voor wat betreft de snelheid van uitkeren, de vermindering van de schaderegelingskosten en de reductie van de premiekosten. Dit kan worden verklaard uit het feit dat de vergoeding van immateriële schade in Noord-Amerika niet onder de dekking van een no-fault verzekering valt. De vergoeding van immateriële schade kan echter een argument zijn voor de handhaving ran het aansprakelijkheidsrecht, met name om aan blijvend gehandicapte verkeersslachtoffers een additionele compensatie voor het gederfde levensgenot te verschaffen.

De vraag is of de immateriële schadevergoeding kan worden geïntegreerd in het nofault regime, zoals in de Canadese provincie Quebec is gebeurd. ${ }^{1821}$ Dit heeft ten opichte van het aansprakelijkheidsrecht het voordeel dat geen onzekere procedure behoeft te worden gevoerd, waarbij de vergoeding afhankelijk wordt gemaakt van de schuldvraag. Het nadeel van een integratie binnen een no-fault regime is dat de omrang van de immateriële schadevergoeding veelal gelimiteerd is, teneinde het systeem betaalbaar te houden.

Wanneer het derhalve van belang is om de vergoeding voor immateriële schade te handhaven, lijkt een gecombineerd systeem van no-fault en aansprakelijkheid het meest wenselijk. In dat kader hebben verkeersslachtoffers bij een 'add-on' no-fault jysteem de meeste kans op de vergoeding van hun schade. Bij dit regime blijft immers de aansprakelijkheidsvordering gehandhaafd zodat voor het slachtoffer een zo

1820. Zie daarover Devlin, IRLE, 1990, p. 201.

1821. Zie daarover Dewees, Duff and Trebilcock, Accident Law, p. 62 en p. 94 noot 463. 
volledig mogelijke schadevergoeding, inclusief smartengeld, beschikbaar komt. Een 'add-on' regime heeft echter door een combinatie van een no-fault vergoeding en een onbeperkt vorderingsrecht op basis van aansprakelijkheid zeer hoge administratieveen premiekosten.

Dit betekent dat een voorkeur kan uitgaan naar een 'threshold' no-fault regime. Dit systeem lijkt het best in staat om genereuze schadevergoedingen te verschaffen tegen acceptabele kosten. Een 'threshold' no-fault regime doet ook het meest recht aan de bescherming van verkeersslachtoffers, in de zin dat het zekerheid geeft dat het slachtoffer zijn materiële schade vergoed krijgt. Voor verkeersslachtoffers met zeer ernstig lichamelijk letsel zal dan als gevolg van een overschrijding van de schadedrempel ('threshold') een aansprakelijkheidsprocedure de aangewezen weg zijn, teneinde hun materiële en immateriële schade volledig vergoed te krijgen.

Afsluitend kan worden gesteld dat bij de keuze tussen no-fault en aansprakelijkheid preventieve, compensatoire maar vooral ook kostenaspecten een rol spelen. Met betrekking tot de preventie is de uitkomst onzeker. $\mathrm{Bij}$ de compensatie lijkt de vergoeding in het kader van no-fault sneller en zekerder maar gemiddeld lager dan bij aansprakelijkheid. Een no-fault regime kan tenslotte ook tot een kostenbesparing leiden ten opzichte van een aansprakelijkheidssysteem. 


\section{Hoofdstuk 14: Conclusie empirie en theorie}

\section{Inleiding}

Naar aanleiding van het beschreven empirisch onderzoek in dit deel III kan worden geconcludeerd dat de in hoofdstuk 8 gestelde vragen niet allemaal kunnen worden beantwoord. Dit wordt enerzijds veroorzaakt door de afwezigheid van het noodzakelijk empirisch onderzoek en anderzijds door het feit dat een deel van het gepresenteerde empirisch materiaal tegenstrijdige uitkomsten vertoont of anderszins omsteden is. Daarnaast dient te worden opgemerkt dat een groot deel van het beschreven onderzoek betrekking had op de verkeersaansprakelijkheid in Noord-Amerika en Canada. Binnen deze jurisdicties is echter een ander systeem voor de vergoeding van verkeersschade van toepassing dan bijvoorbeeld in Nederland, waar sprake is van een breed vangnet van sociale-, particuliere- en volksverzekeringen. Dit betekent dat de uitkomsten van het empirisch onderzoek niet direct kunnen worden gespiegeld aan de Nederlandse verkeersaansprakelijkheid.

De theses op basis waarvan in dit hoofdstuk het empirisch onderzoek wordt samengevat hebben derhalve een algemeen karakter, waarbij met name zal worden nagegaan of de conclusies van de rechtseconomische theorie onder invloed van het empirisch onderzoek zijn gewijzigd. Daamaast wordt aansluiting gezocht bij de centrale probleemstelling van het onderhavige onderzoek (waarin het gaat om de vraag naar de optimale werking van aansprakelijkheid, verzekering en veiligheidsregulering in het licht van de preventie en compensatie van verkeersongevallen). In dat kader zal in paragraaf 2 de preventie van verkeersongevallen aan de orde komen, terwijl in paragraaf 3 de compensatie van verkeersslachtoffers centraal staat. In paragraaf 4 volgt een samenvattende vergelijking tussen no-fault en aansprakelijkheid ten aanzien van preventie, compensatie en administratieve kosten. Tenslotte zal in paragraaf 5 een antal combinaties van aansprakelijkheid, verzekering en veiligheidsregulering worden getoetst aan de centrale vraag van dit onderzoek.

De vraag in hoeverre de conclusies van dit hoofdstuk in samenhang met die van hoofdstuk 8 van invloed zijn op (de toetsing van) de verkeersaansprakelijkheid in Frankrijk, België en Nederland zal in hoofdstuk 15 aan de orde komen. 


\section{De preventie van verkeersongevallen}

\subsection{AANSPRAKELLJKHFIDSREGELS ${ }^{1822}$}

1. Er is onvoldoende empirisch bewijs voor.een antwoord op de vraag of aansprakelijkheidsregels sec tot zorgvuldig verkeersgedrag dan wel tot een vermindering van het aantal verkeersongevallen kunnen leiden.

2. Ten aanzien van het onderscheid in aansprakelijkheidsregels kan in theorie worden gesteld dat een foutaansprakelijkheid met een absoluut eigen schuldverweer tot meer zorgvuldigheid zal leiden bij het slachtoffer, terwijl een foutaansprakelijkheid met een gradueel eigen schuldverweer meer prikkels van zorg geeft aan de schadeveroorzaker. Het is echter empirisch niet komen vast te staan dat de overgang van een foutaansprakelijkheid met een absoluut eigen schuldverweer naar foutaansprakelijkheid met een gradueel eigen schuldverweer heeft geleid tot minder zorgvuldigheid bij de autobestuurder dan wel tot een stijging van het aantal verkeersongevallen.

\subsection{PREVENTIE VIA DE VERZEKERINGSVOORWAARDEN}

1. Aangezien de aansprakelijkheid van de schadeveroorzaker tot op zekere hoogte (verplicht) door een verzekering is gedekt, wordt de persoonlijke verantwoordelijkheid van de dader voor de schade van het slachtoffer op de aansprakelijkheidsverzekeraar afgewenteld. De meeste aansprakelijkheidsprocedures naar aanleiding van een verkeersongeval worden door de aansprakelijkheidsverzekeraar van de dader geregeld. Dit brengt mee dat de beïnvloeding van het verkeersgedrag een belangrijke taak van de aansprakelijkheidsverzekeraars is geworden. $^{1823}$

2. Verzekeringsvoorwaarden zijn veelal verbonden met een effectieve risicoclassificatie, waarbij gedifferentieerde ongevalsrisico's leiden tot gedifferentieerde polisvoorwaarden. Wanneer de verzekeringsvoorwaarden (premie) zoveel mogelijk zijn afgestemd op het individuele ongevalsrisico, kan een verzekeraar het verkeersgedrag van de verzekerde beünvloeden. Met behulp van deze financiële prikkels kan uiteindelijk een vermindering van de totale ongevalskosten worden bereikt. ${ }^{1824}$

1822. Paragraaf 3.1 van hoofdstuk 10.

1823. Paragraaf 2 en 3 van hoofdstuk 10.

1824. Zie paragraaf 4 van hoofdstuk 6 . 
3. Hoewel de directe effecten van een ex ante risicodifferentiatie en een ex post controle van het verkeersgedrag op de preventie van verkeersongevallen onduidelijk zijn, is niettemin uit het empirisch onderzoek het belang van een differentiatie van ongevalsrisico's komen vast te staan.

\subsection{Een ex ante risicodifferentiatie}

1. Aangezien een verkeersongeval een gebeurtenis is die zich per persoon relatief zelden voordoet, zal het voor de bepaling van de ex ante premie noodzakelijk zijn dat door een verzekeraar zoveel mogelijk informatie wordt verzameld over factoren die relevant zijn om het ongevalsrisico en de corresponderende premie in te schatten.

2. Een verfijnde ex ante risicodifferentiatie is gewenst om het morele risico ${ }^{1825}$ te verminderen en een proces van anti-selectie ${ }^{1826}$ te vermijden. Hoe meer classificatievariabelen daarbij worden gebruikt des te beter de premie kan worden afgestemd op het individuele ongevalsrisico en des te kleiner de kans dat zich een proces van anti-selectie voordoet. Uit (Amerikaans) empirisch onderzoek kan worden opgemaakt dat onder bepaalde voorwaarden leeftijd, geslacht en woonplaats belangrijke ex ante classificatievariabelen kunnen zijn voor het bepalen van de premie. Deze variabelen kunnen worden beschouwd als zichtbare risicoindicatoren, die tegen lage kosten kunnen worden gebruikt. ${ }^{1827}$

3. De toepassing van een eigen risico kan, naast andere risicovariabelen, een belangrijke bijdrage leveren aan een hoger niveau van premiedifferentiatie tussen de polishouders. ${ }^{1828}$

4. Hoewel een ex ante risicodifferentiatie in de praktijk wordt begrensd door de kosten die dat meebrengt, beschikken verzekeraars over ongevalsstatistieken die

1325. Dit probleem hangt samen met de situatie waarin de verzekeraar over onvoldoende informatie beschikt om het risico van de verzekerde juist in te schatten, waardoor de laatste bij een volledige verzekeringsdekking minder zorgvuldig zal worden. Zie paragraaf 4.1 van hoofdstuk 6.

1826. Dit proces kan ontstaan wanneer een verzekeraar door een gebrek aan informatie slechts een premie kan vaststellen die overeenkomt met het gemiddelde risico binnen een bepaalde rísicogroep. Binnen deze risicogroep kunnen zich echter verzekerden bevinden voor wie de premie, in verhouding tot hun individuele risico, te hoog is. Deze 'goede' risico's zullen de risicogroep te verlaten, waardoor de 'slechte' risico's overblijven. Dit kan leiden tot een premiestijging, die voor een deel van de overgebleven risico's te hoog kan zijn, waardoor zij op hun beurt de risicogroep zullen verlaten. Uiteindelijk ontstaat de situatie waarin alleen de slechte risico's overblijven, die over het algemeen een sterke vraag naar verzekering hebben. Zie paragraaf 4.1 en 4.2 van hoofdstuk 6.

1627. Paragraaf 3.3.1 van hoofdstuk 11.

Paragraaf 4.3.2.2 van hoofdstuk 11 
een breed scala aan informatie bevatten ten aanzien van ongevalsrisico's en verkeersgedrag. Daarbij geldt vermoedelijk dat de beoordeling van het werkelijke verkeersgedrag van de polishouder alleen tegen hoge kosten kan worden vastgesteld. ${ }^{1829}$

\subsubsection{Een ex post aanpassing van de polisvoorwaarden}

1. Met betrekking tot de ex post controle van het morele risico worden door autoverzekeraars onvoldoende maatregelen genomen om het gedrag van de polishouder te corrigeren.

2. In de praktijk wordt veelal niet voldaan aan de belangrijkste doelstelling van een bonus-malussysteem (BMS), namelijk het op termijn scheiden van de goede en slechte ongevalsrisico's. Binnen een BMS wordt een schadeclaim, veelal vanuit doorslaggevende commerciële overwegingen, onvoldoende bestraft, waardoor op termijn de aangesloten polishouders zich concentreren in de BMS-klassen waar de hoogste premiekortingen (bonussen) worden gegeven. Daarnaast is in de meeste BMS-regimes sprake van een laag aantal malusklassen, waarbinnen een premietoeslag wordt opgelegd, ten opzichte van een hoog aantal bonusklassen, waarbinnen de polishouder een premiekorting ontvangt. Dit heeft tot gevolg dat de totale extra premie (toeslag) die tengevolge van een schadeclaim aan polishouders wordt opgelegd niet opweegt tegen de totale premiekorting (bonussen) die aan polishouders met een schadevrij verleden wordt gegeven. ${ }^{1830}$

3. De ex post controle binnen een BMS, gebaseerd op de jaarlijkse claimfrequentie van de polishouder, leidt op termijn tot een onvoldoende scheiding van de goede en slechte risico's. Dit wordt veroorzaakt door de toepassing van bijzondere regelingen binnen een BMS-regime, zoals het eerder kwijtschelden van een malus waardoor de slechte risico's op termijn eerder worden beloond dan bestraft. Uit onderzoek is gebleken dat, gemeten over een periode van tien jaar, een polishouder met minder schadeclaims gedurende deze periode in een hogere premieklasse eindigt dan een polishouder die een groot aantal schadeclaims concentreert in één bepaald jaar. ${ }^{1831}$

4. In het kader van de ex post aanpassing van de polisvoorwaarden kan het gebruik van premietoeslagen in het algemeen effectief zijn, waarbij niet alleen wordt gelet op de claimfrequentie van de polishouder, maar waarbij ook op basis van het 
aantal verkeersovertredingen de premie wordt aangepast in het nadeel van de polishouder. ${ }^{1832}$

5. Voor een effectieve controle van het morele risico binnen een BMS-regime dient gebruik te worden gemaakt van een groot aantal premieklassen, waarbij sprake is van een evenredige verhouding tussen de bonusklassen en de malusklassen. Daarnaast kan het afschaffen van regelingen waarbinnen malussen sneller worden kwijtgescholden leiden tot een betere scheiding van de goede en de slechte risico's. Bij de beoordeling van het schadeverleden van de polishouder dient de autoverzekeraar zich te verdiepen in de claimfrequentie van een polishouder gemeten over een langere periode. Daarnaast kunnen ook het rekening houden met de omvang van de schadeclaim, het inkomen van de polishouder en het aantal verkeersovertredingen, een bijdrage leveren aan een optimalisering van een BMS-regime. $^{1833}$

\subsubsection{Een combinatie van een ex ante risicodifferentiatie en een ex post controle}

Het is van belang dat een optimale combinatie van een ex ante risicodifferentiatie en een ex post controle wordt gevonden. Wanneer vanuit kostenoogpunt een summiere ex ante risicodifferentiatie onvoldoende ex post wordt gecorrigeerd, kan de zorgvuldigheid in het verkeer dalen en het aantal verkeersongevallen toenemen. Wanneer een ex ante differentiatie te hoge kosten meebrengt, zal een ex post controle dienen bij te dragen aan een verdere premiedifferentiatie. Ten behoeve van een optimale preventie van verkeersongevallen is het verder van belang dat bij de premiebepaling, ex ante én ex post, zoveel mogelijk informatie omtrent het gedrag van de polishouder wordt verzameld. ${ }^{1834}$

\section{VEILIGHEIDSREGULERING EN DE PREVENTIE VAN VERKEERSONGEVALLEN}

1. De overheid beschikt over een veelheid aan instrumenten, waarmee de verkeersveiligheid kan worden bevorderd. Uit empirisch onderzoek is gebleken dat een groot deel van deze veiligheidsmaatregelen een positief effect heeft gehad op de preventie van verkeersongevallen. ${ }^{1835}$

2. De toepassing van autoveiligheidssystemen (autoveiligheidsgordel, airbag) leidt tot een vermindering van het aantal verkeersdoden en het aantal emstig gewonden onder inzittenden van een auto. Daarbij is echter niet duidelijk geworden of deze verhoogde veiligheid een negatief effect had op de zorgvuldigheid van de

1832. Paragraaf 3.3 van hoofdstuk 11.

Paragraaf 4.3 van hoofdstuk 11 .

Paragraaf 3.4 en 4.3 .4 van hoofdstuk 11

Zie hoofdstuk 12. 
autobestuurder ('offsetting behaviour') en op het aantal verkeersslachtoffers onder niet-inzittenden (fietser, voetganger). ${ }^{1836}$

3. Ten aanzien van de verplichte autoveiligheidsgordel geldt dat, naast een campagne om het publiek te wijzen op de verhoogde veiligheid, een intensieve controle samen met de toepassing van sancties noodzakelijk is om een optimaal gebruik van de autoveiligheidsgordel te garanderen. Dit geldt niet voor een passief autoveiligheidssysteem als de airbag. De beslissing voor het gebruik hiervan wordt indirect door de autofabrikant genomen. Via regulering kunnen deze producenten worden bewogen om airbags in de auto aan te brengen, waarmee een kostenbesparing op de handhaving kan worden bereikt en een optimaal gebruik is gewaarborgd. ${ }^{1837}$

4. Een omvangrijke preventieve ademanalysecampagne kan het rijden onder invloed reduceren, hoewel deze daling ook door ander factoren kan worden beïnvloed. Met een dergelijke campagne wordt niet alleen de pakkans voor het rijden onder invloed verhoogd, maar kan ook een bijdrage worden geleverd aan een vermindering van het aantal alcoholgerelateerde verkeersongevallen. Deze daling zal echter een tijdelijk effect hebben wanneer de ademanalysecampagne niet wordt doorgezet en de autobestuurders na verloop van tijd ontdekken dat de pakkans afneemt, waardoor het aantal verkeersongevallen weer kan stijgen. ${ }^{1838}$

5. Het rijden onder invloed kan ook worden tegengegaan met behulp van administratieve en strafrechtelijke sancties, zoals een gevangenisstraf, een ontzegging van de rijbevoegdheid en een boete. Uit Amerikaans onderzoek is gebleken dat met een ontzegging van de rijbevoegdheid een betere preventie van verkeersongevallen wordt bereikt dan met een gevangenisstraf of een boete. (Daarnaast zal een hoge boete tot een betere preventie leiden dan een lage boete). Ten aanzien van de gevangenisstraf zijn de uitkomsten van het empirisch onderzoek omstreden, hoewel dit instrument met name bij oudere autobestuurders aanleiding geeft tot een vermindering van het rijden onder invloed. ${ }^{1839}$

6. In het kader van een controlebeleid kan uit het (Amerikaans) empirisch onderzoek worden opgemaakt dat de consumptie van alcohol en het rijden onder invloed effectief kunnen worden bestreden met behulp van een verhoging van de accijns op alcohol. Daarnaast leidt een verhoging van de 'minimum legal drinking age' (MLDA) tot een afname van het aantal dodelijke verkeersongevallen

1836. Paragraaf 2 en 3 van hoofdstuk 12.

1837. Paragraaf 2 van hoofdstuk 12.

1838. Paragraaf 4.2.1 van hoofdstuk 12.

1839. Paragraaf 4.2.2 van hoofdstuk 12 . 
binnen de leeftijdscategorie waarop deze wettelijke maatregel betrekking heeft. $^{1840}$

7. Hoewel een direct verband tussen de snelheid en het aantal verkeersongevallen niet in alle gevallen kon worden aangetoond, blijkt uit onderzoek dat de invoering van een maximumsnelheid van belang kan zijn voor de preventie van verkeersongevallen. Daarbij kunnen echter ook andere factoren een rol hebben gespeeld, zoals een stijging van de prijs van benzine. Dit leidt tot een lager activiteitsniveau en daarmee tot een daling van het aantal verkeersongevallen. ${ }^{1841}$

8. Ten aanzien van een effectieve handhaving van de maximumsnelheid kan worden gewezen op het belang van intensieve politiecontroles, het gebruik van radar en op verkeersborden waarmee de weggebruiker erop attent wordt gemaakt dat zijn snelheid wordt gecontroleerd. Deze controlemaatregelen leiden tot een vermindering van het aantal snelheidsovertredingen en (daarmee) tot een daling van het aantal verkeersongevallen, mits de handhaving een permanent karakter draagt, omdat anders het effect na de beëindiging van de controle verloren gaat. ${ }^{1842}$

\subsection{DE INVLOED VAN BELANGENGROEPEN ${ }^{1843}$}

1. In het empirisch onderzoek kon niet worden aangetoond of de invloed van belangengroepen op de totstandkoming van wetgeving ook effect heeft gehad op de preventie van verkeersongevallen. Uit de gepresenteerde studies is wel naar voren gekomen welke belangen en preferenties de verschillende lobbygroepen vertegenwoordigen ten aanzien van bepaalde vormen van regulering.

2. Met betrekking tot de autoveiligheidsregulering is gebleken dat autofabrikanten de voorkeur geven aan een verplichte autoveiligheidsgordel boven een airbag, omdat het eerste veiligheidsinstrument goedkoper is en bij de airbag de kans op aansprakelijkheidsclaims groter is wanneer een airbag niet werkt. Verzekeraars zijn daarentegen vóór een airbag, omdat dit instrument betere bescherming geeft aan een inzittende van een auto, met als gevolg een vermindering van het aantal dure en onvoorspelbare aansprakelijkheidsclaims. Daarnaast kan een airbag als een homogeen veiligheidsinstrument worden beschouwd, waardoor in het kader van de actuariële voorspelbaarheid van het ongevalsrisico een betere differentiatie kan worden bereikt.

1840. Paragraaf 4.3 van hoofdstuk 12.

1841. Paragraaf 5.1 van hoofdstuk 12.

1842. Paragraaf 5.2 van hoofdstuk 12.

1843. Paragraaf 6 van hoofdstuk 12. 
3. De invloed van consumentengroepen op de totstandkoming van wetgeving is niet duidelijk geworden, maar bij de invoering van de autoveiligheidsgordel en de airbag is de overheid niet alleen tegemoet gekomen aan de belangen van autoverzekeraars en autofabrikanten, maar heeft vermoedelijk ook de bescherming van de consumenten (autobestuurder) voorop gestaan.

\subsection{VERZEKERINGSREGULERING EN DE PREVENTIE VAN VERKEERSONGEVALLEN ${ }^{1844}$}

1. Hoewel geen direct empirisch verband kon worden aangetoond tussen de concurrentie binnen dan wel de regulering van de autoverzekeringsmarkt en de preventie van verkeersongevallen, kan ten aanzien van de analyse van de verzekeringsregulering toch een aantal opvallende aspecten worden belicht.

2. Tariefsregulering binnen de autoverzekering, waarbij de vrijheid om een optimale risicodifferentiatie toe te passen ontbreekt, heeft tot gevolg dat de goede en slechte ongevalsrisico's onvoldoende van elkaar worden gescheiden. De creatie van een gesubsidieerde marktpool waarin de hoge ongevalsrisico's worden opgevangen, leidt daarnaast tot minder zorgvuldigheid in het verkeer. De slechte autobestuurders binnen deze marktpool betalen een gemiddelde premie die niet in overeenstemming is met hun individuele ongevalsrisico, waardoor zij hun activiteitsniveau zullen opvoeren en het ongevalsrisico verder toeneemt. ${ }^{1845}$

3. Uit Amerikaans onderzoek kan worden opgemaakt dat verzekeraars bij een gesubsidieerde marktpool geen prikkels krijgen om de kosten van autoverzekering te verminderen, omdat een meerderheid van de schadeclaims via de marktpool wordt vergoed en de individuele verzekeraar naar rato van zijn marktaandeel toch voor de kosten van deze claims moet opkomen. Daarnaast is gebleken dat als er gestandaardiseerde polisvoorwarden worden gebruikt, verzekeraars onderling onvoldoende kunnen concurreren op de prijs van de autoverzekering. ${ }^{1846}$

4. De Britse verzekeringsmarkt wordt gekenmerkt door een hoge mate van concurrentie, waarbinnen een verfijnd systeem van risicoclassificatie is ontwikkeld en de premie derhalve zoveel mogelijk is afgestemd op het individuele ongevalsrisico. Daarnaast worden premietoeslagen opgelegd bij verkeersovertredingen om voorzichtig rijgedrag te bevorderen. De Duitse verzekeringsmarkt wordt daarentegen sterk door overheidsregulering beïnvloed, waarbij ten aanzien van de risi-

1844. Paragraaf 5 van hoofdstuk 11.

1845. Paragraaf 5.2.3.2 van hoofdstuk 11

1846. Paragraaf 5.2.3.3 van hoofdstuk 11 . 
codifferentiatie binnen de autoverzekering een vastomlijnd systeem wordt gehanteerd, waarin weinig ruimte is voor verdere differentiatie. ${ }^{1847}$

5. Premieregulering belemmert de verzekeraars in de controle van het morele risico, terwijl bij concurrentie verzekeraars worden gedwongen een meer verfijnd systeem van risicodifferentiatie toe te passen. Het gegeven dat in Duitsland het ongevalsrisico bijna tweemaal zo hoog is als in Engeland, lijkt te suggereren dat regulering tot meer verkeersongevallen leidt dan concurrentie, hoewel een direct verband tussen de regulering van autoverzekeringen in Duitsland en het relatief hoge aantal verkeersslachtoffers ontbreekt. ${ }^{1848}$

\subsection{VERPLICHTE VERZEKERING ${ }^{1849}$}

1. Bij de aanwezigheid van een verplichte autoverzekering kan worden volstaan met solvabiliteitsregulering, waarbij de consument wordt beschermd tegen een eventuele insolventie van de verzekeraar. Daarenboven is geen verdere premieregulering noodzakelijk om te garanderen dat een autoverzekeraar de verplichte verzekering aan iedereen beschikbaar stelt. De verplichte autoverzekering kan verder worden aangevuld met een waarborgfonds waarmee het slachtoffer wordt beschermd tegen onverzekerdheid van de dader.

2. De prijs van een autoverzekering is afhankelijk van het individuele ongevalsrisico. Aan autobestuurders kan daarbij een bepaalde verzekering worden geweigerd indien kan worden vastgesteld dat deze bestuurders een hoog ongevalsrisico vormen. Daarnaast kunnen slechte ongevalsrisico's worden ondergebracht bij gespecialiseerde verzekeraars die een hoge premie vragen.

\section{De rol van aansprakelijkheid binnen de vergoeding van verkeersschade}

1. Uit het onderzoek naar de Nederlandse verkeersaansprakelijkheid blijkt dat de rol van het aansprakelijkheidsrecht bij de rechtstreekse vergoeding van verkeersschade geringer wordt. Daarbij is met name gesteld dat de schuldvraag en de schadevergoeding, in theorie gescheiden begrippen, in elkaar overlopen. ${ }^{1850}$

2. De geringe rol van het aansprakelijkheidsrecht vond mede zijn oorzaak in het gegeven dat een belangrijk deel van de vergoeding van letselschade aan het ver-

1847. Paragraaf 5.3.1 en 5.3.2 van hoofdstuk 11.

1848. Paragraaf 5.3.3 van hoofdstuk 11.

1849. Paragraaf 5.3.1 en 5.3.3.3 van hoofdstuk 11 .

1850. Paragraaf 2.3 van hoofdstuk 10. 
keersslachtoffer afkomstig was uit eigen bron. Ook de schade die niet door eigen verzekering werd gedekt of waarvoor geen verzekeringsdekking voorhanden was, werd slechts voor een deel op basis van het aansprakelijkheidsrecht vergoed. Daamaast was in een minderheid van de gevallen sprake van een rechtstreekse betaling van de aansprakelijkheidsverzekeraar van de schadeveroorzaker aan het slachtoffer. ${ }^{1851}$

3. Een klein deel van het aantal geschillen omtrent verkeersongevallen komt uiteindelijk voor de rechter. Dit betekent dat de meerderheid van de verkeersschades blijkbaar wordt afgewikkeld tussen het slachtoffer of zijn verzekeraar en de WAverzekeraar van de schadeveroorzaker. Uit onderzoek blijkt dat de aansprakelijkheidsverzekeraars daarbij gebruik maken van praktijkregels, waarin de schuldvraag (aansprakelijkheid) vooral een feitenkwestie is. Door de schaderegelaar wordt veelal een kosten-baten analyse gemaakt ten aanzien van de schuldvraag, waarbij een efficiënte schadeafwikkeling voorop staat. Uit doelmatigheidsoogpunt wordt ook in veel gevallen tot uitkering van de schade overgegaan zonder dat sprake is van aansprakelijkheid dan wel de aansprakelijkheid niet direct kan worden vastgesteld. Daarnaast wordt veel met waarschijnlijkheden gewerkt, waarvan de interpretatie aan de schaderegelaar wordt overgelaten. ${ }^{1852}$

4. Uit een Brits onderzoek kan worden afgeleid dat een verkeersslachtoffer vooral is geïnteresseerd in de vergoeding van zijn schade en weinig behoefte heeft aan een aansprakelijkheidsprocedure, waarin de 'fout' van de dader moet worden vastgesteld. Een verkeersongeval is immers iets is dat iedereen kan overkomen. Het zijn de normale fouten, verband houdend met de dagelijkse activiteiten waarvan de verkeersdeelname een onderdeel vormt, die aan een verkeersongeval ten grondslag liggen. Aansprakelijkheid bij een verkeersongeval doet derhalve veeleer dienst als vergoedingsbron naast de reeds beschikbare compensatiemechanismen. ${ }^{1853}$

\section{No-fault versus aansprakelijkheid}

\subsection{PREVENTIE VAN VERKEERSONGEVALLEN ${ }^{1854}$}

1. Op basis van het gepresenteerde empirisch onderzoek (Noord-Amerika, Canada en Australië) blijft onduidelijkheid bestaan met betrekking tot de preventieve effecten van een no-fault regime. Enerzijds kan worden gesteld dat de invoering van een zuivere no-fault verzekering niet heeft geleid tot meer verkeersongeval-

1851. Paragraaf 2.2 van hoofdstuk 10.

1852. Paragraaf 2.1 en 2.3 van hoofdstuk 10.

1853. Paragraaf 4.2.3 van hoofdstuk 10.

1854. Paragraaf 3.1 van hoofdstuk 13. 
len en verkeersslachtoffers. Anderzijds blijkt uit studies dat een combinatie van een no-fault verzekering en een gedeeltelijke handhaving van het aansprakelijkheidsrecht ook niet tot een daling van het aantal verkeersongevallen leidt.

2. Bij een no-fault verzekering valt in beginsel de veronderstelde preventieve werking van het aansprakelijkheidsrecht weg. De kosten die aan derden worden toegebracht komen in beginsel niet in de no-fault premie tot uitdrukking. Met een no-fault verzekering kunnen echter vergelijkbare preventieve effecten worden bereikt als met een aansprakelijkheidsverzekering, indien binnen de nofault verzekering aanvullende maatregelen worden genomen die de polishouder tot meer zorgvuldigheid kunnen aanzetten.

\subsection{COMPENSATIE VAN VERKEERSSLACHTOFFERS ${ }^{1855}$}

1. Uit onderzoek blijkt dat binnen het Amerikaanse aansprakelijkheidssysteem ongeveer $1 / 3$ van het aantal verkeersslachtoffers niet of minder volledig wordt gecompenseerd voor de materieel geleden schade. Met name slachtoffers die ernstig tot zeer ernstig letsel hebben geleden ontvangen geen volledige schadevergoeding. Daarnaast geldt dat door de aanwezigheid van genereuze vergoedingen voor immateriële schade (Amerika) de situatie ontstaat, waarbij slachtoffers met een lage schadeclaim meer dan volledig worden vergoed (overcompensatie) terwijl slachtoffers met een hoge schadeclaim met een groot deel van hun schade blijven zitten (ondercompensatie).

2. Amerikaanse onderzoek heeft aangetoond dat binnen een no-fault regime een meerderheid van het aantal verkeersslachtoffers volledig wordt gecompenseerd. Verkeersslachtoffers die een ernstig letsel hebben geleden, waarvan de omvang de no-fault limiet ruimschoots overschrijdt, ontvangen een minder dan volledige schadevergoeding. In jurisdicties met een hoge of onbeperkte vergoedingslimiet worden slachtoffers met ernstig letsel echter in voldoende mate gecompenseerd.

3. Ten aanzien van de afwikkeling van de schade is gebleken dat bij een no-fault verzekering gemiddeld eerder tot uitkering van de schade wordt overgegaan dan bij een aansprakelijkheidssysteem. Na een jaar heeft bijna elk verkeersslachtoffer binnen een no-fault regime zijn schade vergoed gekregen, terwijl binnen het aansprakelijkheidssysteem nog $1 / 3$ van het aantal slachtoffers wacht op een uitkering.

4. De voorgaande conclusies hebben uitsluitend betrekking op de situatie in NoordAmerika en Canada. Dit brengt enerzijds mee dat de toepassing daarvan op de

1855. Paragraaf 3.2 van hoofdstuk 13 
Nederlandse verkeersaansprakelijkheid niet zonder meer mogelijk is, ook wanneer in aanmerking wordt genomen dat de no-fault verzekering in NoordAmerika mede door afwezigheid van voldoende sociale voorzieningen is ingevoerd. Anderzijds kunnen de uitkomsten wel van indirect belang zijn voor de te maken keuze tussen een aansprakelijkheidssysteem en een verkeersverzekering voor de vergoeding van verkeersschade. ${ }^{1856}$

\subsection{DE ADMINISTRATIEVE KOSTEN ${ }^{1857}$}

1. Naar aanleiding van het empirisch onderzoek kan worden gesteld dat een nofault regime leidt tot een kostenbesparing ten opzichte van een aansprakelijkheidssysteem. Een zuiver no-fault regime zal tot de grootste kostendaling leiden, terwijl een no-fault verzekering gecombineerd met een onbeperkte handhaving van de aansprakelijkheid als het duurste systeem kan worden beschouwd.

2. In de meeste jurisdicties waarin een no-fault verzekering is ingevoerd is sprake geweest van een daling van de premiekosten voor autoverzekering. Dit was mede het gevolg van de beperking van de mogelijkheid tot vergoeding van immateriële schade en 'punitive damages'. Met name in no-fault staten met een sterke beperking van de aansprakelijkheid en een hoge no-fault vergoedingslimiet daalde de premiekosten. In no-fault staten waar het aansprakelijkheidsrecht onbeperkt bleef gehandhaafd of waar de aansprakelijkheid minder sterk werd beperkt en een lage no-fault vergoedingslimiet gold, was echter sprake van een stijging van de premiekosten. In sommige staten zijn de premiekosten gereduceerd door binnen de no-fault verzekering een eigen risico aan te bieden en door de no-fault vergoedingen in mindering te brengen op de aansprakelijkheidsuitkeringen.

3. Bij een zuiver no-fault regime zijn de administratieve kosten het laagst en kan een besparing worden bereikt op de premiekosten wanneer de vergoeding voor immateriële schade is uitgesloten. Een aansprakelijkheidssysteem en een no-fault regime met een onbeperkt vorderingsrecht kennen daarentegen hoge administratieve- en premiekosten.

\section{Aansprakelijkheid, verzekering, veiligheidsregulering en de optimale preventie en compensatie van verkeersongevallen}

In het voorgaande is naar aanleiding van het gepresenteerde empirisch onderzoek een aantal theoretische vragen beantwoord, waarbij tevens is aangegeven in hoeverre de conclusies van de theorie onder invloed van de empirie zijn gewijzigd. In deze 
slotparagraaf zal worden nagegaan welke van de in de theorie besproken combinaties van aansprakelijkheid, verzekering en veiligheidsregulering, rekening houdend met preventie, compensatie en kosten, het meest aan de uitkomsten van de empirie beantwoordt.

1. Uit het empirisch onderzoek is gebleken dat voor de theoretisch gemaakte veronderstellingen met betrekking tot de preventieve werking van aansprakelijkheidsregels in de praktijk bij verkeersongevallen het directe empirisch bewijs ontbreekt. Daarnaast kan worden gesteld dat de eventueel aanwezige preventieve werking van het aansprakelijkheidsrecht is verschoven naar de verzekeringsvoorwaarden. Dit betekent dat niet de schadeveroorzaker (persoonlijk) verantwoordelijk is voor de schade van het slachtoffer, maar veeleer zijn aansprakelijkheidsverzekeraar. Ten slotte kan naar aanleiding van het empirisch onderzoek worden geconcludeerd dat een systeem van aansprakelijkheid en verzekering geen optimale compensatie aan het verkeersslachtoffer garandeert en tot hoge administratieve kosten leidt.

2. Hoewel ook de uitkomsten van het empirisch onderzoek naar de preventieve werking van een no-fault regime omstreden zijn, is niet gebleken dat de invoering van een no-fault verzekering tot meer verkeersongevallen heeft geleid. Dit betekent dat wanneer onder afschaffing van het aansprakelijkheidsrecht een zuivere no-fault verzekering wordt ingevoerd, binnen een dergelijke verzekering een verfijnd systeem van risicodifferentiatie dient te worden toegepast ofwel gebruik moet worden gemaakt van heffingen op de activiteit autorijden.

3. Een ex ante premiedifferentiatie binnen een no-fault regime kan onafhankelijk van het toepasselijke aansprakelijkheids- of verzekeringsregime worden uitgevoerd. Voor een ex post aanpassing van de verzekeringsvoorwaarden kan gebruik worden gemaakt van strafpunten, het schadeverleden en het aantal verkeersovertredingen van de autobestuurder.

4. Met betrekking tot de keuze voor een bepaald vergoedingssysteem voor verkeersschade zijn naast de preventie ook de compensatie van verkeersslachtoffers en de kosten van het systeem van belang. In dat kader zal de voorkeur uitgaan naar een zuiver no-fault systeem, omdat hiermee de hoogste besparing op de administratieve- en premiekosten wordt bereikt en de uitkering van de schade sneller plaatsheeft dan bij andere vergoedingsystemen.

5. Het voorgaande brengt mee dat een zuivere no-fault verzekering het meest lijkt te beantwoorden aan de uitkomsten van de empirie, vooral op het terrein van de compensatie en de kosten. Dit betekent dat kan worden gekozen voor hetzij een via de particuliere verzekeringsmarkt aangeboden no-fault verzekering aan de zijde van de autobestuurder of een no-fault verzekering voor alle verkeersdeel- 
nemers. Deze no-fault verzekering dient echter te worden gecombineerd $\mathrm{m}_{\mathrm{let}}$ een strikte handhaving van de veiligheidsregulering om het gedrag van de verkeersdeelnemer verder te sturen.

6. In de meeste landen die in het empirisch onderzoek aan bod zijn gekomen is sprake van een dalende trend ten aanzien van het aantal verkeersongevallen en verkeersslachtoffers. Deze afname kan deels worden verklaard uit de hoeveelheid maitregelen die op het terrein van de verkeersveiligheid zijn genomen. De empirische studies die in dat kader aan de orde zijn geweest suggereren dat de meeste veiligheid smaatregelen hebben geleid tot een vermindering van het aantal (dodelijke) verkeersslachtoffers. Daarbij kan de handhaving van de veiligheidsregulering een steekproefsgewijs (plaatselijke controles op fietsverlichting) dan wel een permanunt karakter (vaste camera's voor snelheidscontrole) dragen. 


\section{Deel IV}

\section{Hoofdstuk 15: De toetsing van de Franse en Belgische en Nederlandse verkeersaansprakelijkheid aan de economische en empirische analyse}

\section{Inleiding}

In het onderhavige onderzoek is een positiefrechtelijke (deel I), een rechtseconomische (deel II) en een empirische (deel III) analyse van het verkeersongevallenrecht gepresenteerd. Binnen de rechtseconomische en empirische analyse is getracht aan te tonen dat een combinatie van aansprakelijkheid, verzekering en veiligheidsregulering noodzakelijk is om de totale maatschappelijke kosten van verkeersongevallen te reduceren. Deze maatschappelijke ongevalskosten zijn daarbij onderverdeeld in primaire (preventie), secundaire (schadespreiding) en tertiaire (administratieve) kosten. Bij de positiefrechtelijke analyse lag vooral de nadruk op de secundaire ongevalskosten, de spreiding van de schade, en deels op de tertiaire kosten, de kosten van een bepaald vergoedingssysteem voor verkeersschade. De primaire ongevalskosten zijn daarbij overigens niet genegeerd, maar door een deel van de juridische literatuur wordt aan de preventie in het verkeer veelal geen belangwekkende rol toebedeeld. ${ }^{1858}$ Andere auteurs menen echter dat preventie binnen het kader van aansprakelijkheid en verzekering een rol speelt of kan worden toegeschreven aan maatregelen in de sfeer van het strafrecht en de veiligheidsregulering. ${ }^{1859}$

In dit afsluitende hoofdstuk zal aan de hand van het eerdergenoemde onderscheid in ongevalskosten een aantal positiefrechtelijke regelingen en voorstellen worden getoetst aan de uitkomsten van de rechtseconomische en empirische analyse. In dat kader zullen de Franse 'loi Badinter', de Belgische art. 29bis WAM-regeling, het Ne-

1858. Zie bijvoorbeeld Kremer, Hennekam en Van der Harst, VR, 1998, p. 292-293 die stellen dat ongemotoriseerden onder dreiging van aansprakelijkheid niet voorzichtiger worden omdat fietsers en voetgangers, zelfs bij gevaarlijk gedrag ervan uitgaan dat hen niets overkomt.

1859. Zie onder anderen Hartlief, VR, 1998, p. 261; Hartlief, in Verkeersaansprakelijkheid in Belgie en Nederland, p. 196; Hartlief, oratie, p. 20-21. Elzas, Special Handboek, p. 15-16, meent dat er meer interesse voor preventie dient te zijn niet alleen met het oog op de beperking van de schade maar ook uit financieel belang. Hij wijst op de grote bijdrage van jeugdige verkeersslachtoffers aan de totale schadelast waarvoor zijns inziens concrete preventieve maatregelen gerechtvaardigd zijn. 
derlandse wetsvoorstel verkeersongevallen $(1997)^{1860}$ en de Nederlandse voorstellen tot invoering van een verkeersverzekering aan de orde komen.

Ten aanzien van vorenbedoelde toetsing moet in de eerste plaats worden vooropgesteld dat het in deel III geanalyseerde empirisch onderzoek voor een groot deel betrekking had op de verkeersaansprakelijkheid in Noord-Amerika, Canada, Australië en Nieuw-Zeeland. Dit betekent dat rekening moet worden gehouden met de aanwezige verschillen in aansprakelijkheidsregimes maar vooral ook in de systemen van verzekering met betrekking tot de compensatie van verkeersslachtoffers. In Europa is, in tegenstelling tot Noord-Amerika, bijvoorbeeld sprake van een breed vangnet van particuliere-, sociale- en volksverzekeringen. ${ }^{1861}$ Daarnaast speelt binnen Europa met betrekking tot de vergoeding van verkeersschade en de discussie ten aanzien van een systeem van verkeersaansprakelijkheid het regres van particuliere en sociale verzekeraars een prominente rol. ${ }^{1862}$

In de tweede plaats zal in dit hoofdstuk, evenals in de economische analyse, gelden dat een verkeersongeval een bilateraal karakter draagt, waarbij zowel dader als slachtoffer invloed kunnen uitoefenen op het ongevalsrisico. Wanneer bijvoorbeeld wordt gesproken over een systeem van risicoaansprakelijkheid, komt de invloed van het slachtoffer op het ongeval tot uitdrukking in een absoluut eigen schuldverweer. Dit betekent rechtseconomisch gezien dat de aansprakelijkheid van de dader geheel vervalt wanneer het slachtoffer niet de voor hem efficiënte zorg heeft nageleefd. Gegeven deze invloed van het slachtoffer op het ontstaan van een verkeersongeval zal bij de toetsing in dit hoofdstuk worden uitgegaan van een eigen schuldverweer in hoofde van het slachtoffer.

In de derde plaats tenslotte, zal bij de economische toetsing worden verondersteld dat alleen het slachtoffer schade lijdt, hetgeen past binnen het kader van artikel 185 WVW en het Nederlandse wetsvoorstel. Daarin wordt de bescherming van het niet-

1860. Inmiddels is dit wetsvoorstel door de huidige Minister van Justitie ingetrokken en heeft hij in een brief aan de Tweede Kamer zijn ideèen omtrent een stelsel van verkeersaansprakelijkheid neergelegd, maar halverwege het jaar 2001 hebben deze plannen nog niet tot een concreet wetsvoorstel geleid. Zie brief van 16 juni 1999, TK 1998-1999, 25759, nr. 5 (H); NJB, 1999, p. 12921293. Zie voor commentaar op deze voorstellen: Hartlief, TVP, 1999, p. 73-74; Engelhard en Van Maanen, VR, 1999, p. 353-357; Nieuwenhuis, RM Themis, 1999, p. 357-358. Naast het wetsvoorstel en de plannen van Korthals zal ook aandacht worden besteed aan een recent gepresenteerd voorstel, waarmee een gedifferentieerd vergoedingsregime voor verkeersslachtoffers gebaseerd op aansprakelijkheid wordt beoogd. Zie Van Maanen, RM Themis, 1999, p. 54-56; Van Maanen en Engelhard, VR, 1999, p. 135-139.

1861. Hoewel daaraan bijvoorbeeld in Nederland via overheidsmaatregelen (privatisering) geleidelijk aan meer beperkingen worden gesteld.

1862. Ten aanzien van Nederland kan dit worden afgeleid uit de beschrijving van een aantal empirische studies in hoofdstuk 10. Zie ook Memorie van Toelichting, TK, 1997-1998, 25759, nr. 3, p. 
gemotoriseerde verkeersslachtoffer benadrukt, door middel van een verscherpte aansprakelijkheid ten laste van de bezitter van een motorrijtuig voor de schade van het niet-gemotoriseerde verkeersslachtoffer. ${ }^{1863}$

In paragraaf 2 zullen de eerdergenoemde regelingen en voorstellen inzake verkeersaansprakelijkheid worden samengevat en vertaald naar de in de rechtseconomische analyse gehanteerde omschrijvingen. Daarbij zal de nadruk liggen op de grondslagen van ansprakelijkheid en verzekering. Vervolgens zal in paragraaf 3 worden nagegaan in hoeverre deze systemen van verkeersaansprakelijkheid overeenstemmen met de uitkomsten van de rechtseconomische theorie en het empirisch onderzoek. Daarbij zal rekening worden gehouden met de genoemde verschillen tussen Noord-Amerika en Europa ten aanzien van de vergoeding van verkeersschade. In paragraaf 4 zal naar aanleiding van de economische toetsing van de verkeersaansprakelijkheid een vergelijking worden gemaakt tussen een stelsel met aansprakelijkheid en een systeem van verzekering. In paragraaf 5 tenslotte, zal met betrekking tot het onderhavige onderzoek een aantal aanbevelingen worden geformuleerd.

\section{De verkeersaansprakelijkheid in Frankrijk, België en Nederland}

De stelsels van verkeersaansprakelijkheid in Frankrijk, België en Nederland (wetsvoorstel) vertonen grote overeenkomsten. De bescherming van verkeersslachtoffers staat centraal, in het bijzonder van de niet-gemotoriseerden en de passagiers van een motorijtuig. De bestuurders van een motorrijtuig zijn daarbij het slechtst af; zij worden in 2 van de 3 landen buiten de bijzondere bescherming van de geldende of beoogde wettelijke regeling gehouden. ${ }^{1864}$

\subsection{DE VERGOEDING VAN VERKEERSSLACHTOFFERS IN FRANKRIJK ${ }^{1865}$}

In de 'loi Badinter' is een risicoaansprakelijkheid ten behoeve van alle verkeersslachtoffers, inclusief bestuurders en passagiers van een motorrijtuig, geregeld. Ten aanzien van niet-gemotoriseerde verkeersslachtoffers geldt slechts het absolute verweer van een 'faute inexcusable'. Dit laatste verwijst naar een algeheel verval van aansprakelijkheid van de motorrijtuigbezitter wanneer het slachtoffer een 'faute inexcusable' heeft begaan. Deze fout moet de enige oorzaak van het verkeersongeval

1863. Daarmee is niet gezegd dat de motorrijtuigbezitter geen schade lijdt. Deze zogenaamde reflexwerking van artikel 185 WVW, die in het wetsvoorstel niet is geregeld, zal bij de economische toetsing echter buiten beschouwing worden gelaten. Zie daarover paragraaf 6.5 van hoofdstuk 3 .

1864. In Frankrijk geniet ook de bestuurder van een motorrijtuig een extra bescherming. Zie paragraaf 2.1.

1865. Zie paragraaf 4 van hoofdstuk 1 voor een uitwerking van deze wetgeving. 
zijn geweest. ${ }^{1866}$ De rechtspraak, in casu van het Franse Hof van Cassatie, heeft dit verweer echter dermate beperkt uitgelegd dat daarop in de praktijk bijna geen beroep meer kan worden gedaan. Daarnaast wordt ook de betrokkenheid van een motorrijtuig bij een verkeersongeval zeer ruim uitgelegd. Dit heeft tot gevolg dat, hoewel het verweer van een 'faute inexcusable' als zodanig wel bestaat en ook de betrokkenheid moet worden vastgesteld, de 'loi Badinter' de vorm van een vergoedingssysteem heeft gekregen, waarbij overigens de bijna absolute aansprakelijkheid nog niet is afgeschaft. De formele vorm van het systeem blijft derhalve aansprakelijkheid, terwijl het in feite om een compensatieregeling gaat.

Voor de schade van de motorrijtuigbestuurder geldt ook een bijna risicoaansprakelijkheid, waarbij voor de eigen 'faute' van de bestuurder een objectief criterium wordt gehanteerd. Daarnaast kunnen bestuurders een eerste partij verzekering afsluiten. Met deze zogenaamde PACS ('Protection assurée du conducteur et des siens') verkrijgt een bestuurder, tegen een additionele premie, volledige dekking voor zijn eigen letselschade. Het aantal bestuurders dat over deze PACS-verzekering beschikt wordt geschat op ongeveer $50 \%$.

\subsection{DE BELGISCHE WAM-REGELING (ART. 29BIS) ${ }^{1867}$}

De Belgische regeling heeft het karakter van een vergoedingssysteem voor de schade van niet-gemotoriseerde verkeersslachtoffers en van de passagiers van een motorrijtuig. ${ }^{1868}$ De vergoedingsplicht van de aansprakelijkheidsverzekeraar van de motorrijtuigbestuurder vervalt pas wanneer het slachtoffer het ongeval en zijn gevolgen gewild heeft'. ${ }^{869}$ Het gaat daarbij om gedragingen van het slachtoffer die grenzen aan zelfmoord. ${ }^{1870}$ Aan de betrokkenheid bij een verkeersongeval zal, geïnspireerd door de Franse rechtspraak, naar de mening van de Belgische doctrine een ruime uitleg worden gegeven. ${ }^{1871}$ De bestuurder van een motorrijtuig is in België voor de ver-

1866. Voor bepaalde groepen verkeersslachtoffers, personen beneden de 16 jaar, boven de 70 jar en voor slachtoffers die ten tijde van het ongeval reeds $80 \%$ invalide waren, geldt dat alleen bij opzet de aansprakelijkheid van de bestuurder of houder van het motorrijtuig vervalt (artikel $32 \mathrm{e}$ alinea 'loi Badinter').

1867. Zie paragraaf 4 van hoofdstuk 2 voor een uitwerking van deze regeling.

1868. Aanvankelijk kon dit stelsel, gegeven de kennelijke achtergrond van het aansprakelijkheidsrecht, nog als een aansprakelijkheidsregeling worden beschouwd. Na de recente wetswijziging, waarbij de 'onverschoonbare fout' in hoofde van het slachtoffer is afgeschaft, is daarvan eigenlijk geen sprake meer. Zie daarover paragraaf 6 van hoofdstuk 2.

1869. Aldus het nieuwe lid 5 van artikel 29 bis paragraaf 1 WAM-wet na de recente wetswijziging. Zie Belgisch Staatsblad 21 februari 2001. Zie daarover Simoens, RW, 2001, p. 1577-1586.

1870. Zie de toelichting bij het wetsvoorstel van 29 oktober 1999 in DOC $50210 / 001(1999-2000) \mathrm{p}$ 5-6.

1871. Zie daarover Decroés, RW, 2001, p. 1257-1263. 
goeding van zijn schade aangewezen op de foutaansprakelijkheid van artikel 1382 $\mathrm{BW}$.

\section{HET NEDERLANDSE WETSVOORSTEL $(1997)^{1872}$}

Het Nederlandse wetsvoorstel kan worden beschouwd als een risicoaansprakelijkheid ten behoeve van het niet-gemotoriseerde verkeer, in casu fietsers, voetgangers, passagiers. De aansprakelijkheid van de motorrijtuigbezitter vervalt geheel indien een geslaagd beroep wordt gedaan op opzet of bewuste roekeloosheid van het slachtoffer, ook wanneer de bestuurder zelf een fout heeft gemaakt. Ten aanzien van het begrip 'betrokkenheid' wordt aansluiting gezocht bij de 'loi Badinter'. Daarnaast wordt ook de werknemer-bestuurder bijna volledig beschermd, omdat voor de vergoeding van zijn verkeersschade op de werkgever een risicoaansprakelijkheid rust, met uitzondering van opzet of bewuste roekeloosheid aan de zijde van de bestuurder-werknemer.

De bestuurder van een motorrijtuig valt verder buiten de bescherming van het beoogde wetsvoorstel, zodat deze een vordering tot schadevergoeding dient te baseren op artikel 6:162 BW (foutaansprakelijkheid).

\subsection{DE NEDERLANDSE VOORSTELLEN VOOR EEN VERKEERSVERZEKERING}

In de Nederlandse literatuur wordt al vele jaren gepleit voor de invoering van een verkeersverzekering. Bloembergen en Van Wassenaer van Catwijck zijn hiervan lange tijd de belangrijkste vertegenwoordigers geweest. ${ }^{1873}$ Het gaat daarbij in beginsel om een aanvullende verzekering boven op de vergoeding die verkeersslachtoffers van hun eigen particuliere en sociale verzekeraar ontvangen. De verkeersverzekering dient verplicht te worden afgesloten door de eigenaar van het motorrijtuig. De schade van de bestuurders en inzittenden van het motorrijtuig wordt vergoed door de eigen verkeersverzekeraar van het motorrijtuig en de schade van de fietser of voetganger door de verkeersverzekeraar van het betrokken motorrijtuig. De civiele aansprakelijkheid kan, met uitzondering van de opzettelijk toegebrachte schade, worden afgeschaft. Dit geldt evenzeer voor het regres. Om de verkeersverzekering, in het bijzonder de premie daarvan, betaalbaar te houden, zullen beperkingen moeten worden gesteld aan de omvang van de te vergoeden schade.

1872. Zie paragraaf 6 van hoofdstuk 3 voor een uitwerking van dit wetsvoorstel.

1873. Zie paragraaf $5.2 \mathrm{t} / \mathrm{m} 5.4$ van hoofdstuk 3 voor een uitwerking van hun voorstellen en van de voorstellen van andere auteurs. 


\subsection{HET SYSTEEM 'VAN MAANEN ${ }^{\text {1874 }}$}

In zijn recent gepresenteerd voorstel wordt door Van Maanen de invoering beoogd van een gedifferentieerd verkeersaansprakelijkheidsregime gebaseerd op artikel 185 WVW. Daarin wordt, uitgaande van het uiteenlopende Betriebsgefahr van een voertuig (vrachtwagen/bus, auto, motor/bromfiets, fiets en voetganger), een ruimere aansprakelijkheid opgelegd. Daarbij geldt het vermogen van het voertuig primair als maatstaf voor de gevaarzetting die bepalend is voor de aansprakelijkheid. Naarmate het verschil in Betriebsgefahr groter wordt geldt een ruimere aansprakelijkheid, in casu oplopend van een gewone foutaansprakelijkheid naar een eenzijdige risicoaansprakelijkheid zonder eigen schuldverweer.

Binnen het systeem 'Van Maanen' geldt voor een aanrijding tussen gelijkwaardige gemotoriseerden een gewone foutaansprakelijkheid. Bij een aanrijding tussen ongelijkwaardige motorrijtuigen wordt uitgegaan van een verscherpte aansprakelijkheid (weerlegbare foutpresumptie) in het nadeel van het zwaardere motorrijtuig. Bij een aanrijding tussen een motorrijtuig en een fietser geldt een risicoaansprakelijkheid met een beperkt beroep op overmacht en een normaal eigen schuldverweer jegens de fietser. Bij een voetganger wordt uitgegaan van een (eenzijdige) risicoaansprakelijkheid ten laste van het motorrijtuig, tenzij de voetganger een ernstige fout heeft begaan die de enige oorzaak van het ongeval is geweest (bijvoorbeeld plotseling voor een auto springen). $\mathrm{Bij}$ een aanrijding tussen een fietser en een voetganger geldt een risicoaansprakelijkheid met een normaal overmachts- en eigen schuldverweer.

\section{De economische toetsing van het positieve recht en aanverwante voorstellen}

\subsection{INLEIDING}

Naar aanleiding van het voorgaande kan worden gesteld dat binnen de juridische discussie over de verkeersaansprakelijkheid de nadruk ligt op de keuze tussen een stelsel met (risico) aansprakelijkheid en een systeem met een verkeersverzekering.

In België is na de recente wijziging van artikel 29 bis WAM geen sprake meer van een aansprakelijkheidsregeling. Nu alleen nog de gedragingen van het slachtoffer die grenzen aan zelfmoord tot een verval van de schadevergoedingsplicht leiden, is in feite een verkeersverzekering voor de vergoeding van zwakke weggebruikers gecreëerd. De wetgeving in Frankrijk en Nederland (wetsvoorstel) kan, vertaald naas de in de economische analyse gehanteerde omschrijvingen, worden beschouwd als een stelsel van risicoaansprakelijkheid met een absoluut eigen schuldverweer. Dit

1874. Van Maanen, RM Themis, 1999, p. 54-56; Engelhard en Van Maanen, VR, 1999, p. 135-139. 
eigen schuldverweer is zeer beperkt, omdat alleen opzet of bewuste roekeloosheid of een 'faute inexcusable' als enige oorzaak van het ongeval aan de zijde van het slachtoffer tot een algeheel verval van de aansprakelijkheid van de motorrijtuigbezitter leiden. De risicoaansprakelijkheid van de bezitter van het motorrijtuig is daarnaast bijna absoluut, aangezien geen beroep op overmacht mogelijk is.

De voorstellen voor een verkeersverzekering komen dicht in de buurt van een nofault verzekering, waarbij de aansprakelijkheid uit onrechtmatige daad (gedeeltelijk) is afgeschaft. Het gaat dan om een verzekering die door de eigenaar van het motorrijuig wordt afgesloten mede ten behoeve van de schade van de bestuurder, de inzittenden, de fietser en de voetganger. Het verschil tussen een no-fault verzekering en een verkeersverzekering is dat de eerste bij een gebrek aan sociale voorzieningen de schade vergoedt, terwijl de verkeersverzekering een aanvullende gelimiteerde vergoeding verschaft bovenop de reeds aan de zijde van het slachtoffer aanwezige voorzieningen. In Noord-Amerika en Canada geldt verder dat, met uitzondering van de provincie Quebec, de no-fault verzekering aan de voet een basisbedrag uitkeert. Wanneer de omvang van de schade deze limiet overschrijdt, is het verkeersslachtoffer aangewezen op een aansprakelijkheidsprocedure om de overige schade tezamen met de immateriële schade vergoed te krijgen.

In deze paragraaf zal worden nagegaan hoe de positiefrechtelijke regelingen en voorstellen zich verhouden tot de conclusies uit de rechtseconomische analyse en het empirisch onderzoek. ${ }^{1875}$ Deze toetsing zal worden verricht aan de hand van de centale probleemstelling van het onderhavige onderzoek en met behulp van het onderscheid tussen primaire, secundaire en tertiaire ongevalskosten. Uitgaande van hetgeen in de vorige paragraaf is opgemerkt zullen in beginsel twee systemen aan bod komen, namelijk een risicoaansprakelijkheid met een eigen schuldverweer en een verkeersverzekering. Verder zal voor wat betreft de uitkomsten van het empirisch onderzoek rekening worden gehouden met de tussen Noord-Amerika en Europa aanwezige verschillen op het terrein van de verkeersaansprakelijkheid.

\subsection{PRIMAire ONGEVALSKOSTEN (PREVENTIE)}

\subsubsection{Een systeem van risicoaansprakelijkheid met een eigen schuldverweer}

\subsubsection{De resultaten van het theoretisch en empirisch onderzoek}

In de economische theorie van deel II is geconcludeerd dat uit preventieoogpunt de voorkeur uitgaat naar een systeem van risicoaansprakelijkheid met een absoluut

1875. Zie voor een rechtseconomische kritiek op de regeling van de verkeersaansprakelijkheid in Frankrijk, Belgiẻ en Nederland: Van den Bergh, in Verkeersaansprakelijkheid, p. 27-74; Van den Bergh, RW, 1994-1995, p. 1313-1323; Visscher en Van den Bergh, NJB, 1998, p. 122-127. 
eigen schuldverweer boven een gewone regel foutaansprakelijkheid. Bij de keuze voor een regel van risicoaansprakelijkheid wordt een groter belang gehecht aan het terugdringen van de gevaren van het gemotoriseerde verkeer dan van het nietgemotoriseerde verkeer. Gegeven het bilaterale karakter van een verkeersongeval is de toevoeging van een eigen schuldverweer echter nodig om ook het niet-gemotoriseerde slachtoffer tot optimale zorg aan te zetten. Daarbij dient in het kader van het eigen schuldverweer de zorgvuldigheid van het gedrag van het slachtoffer zoveel mogelijk te worden meegewogen.

Bij de analyse van het empirisch onderzoek in deel III is de werking van aansprakelijkheidsregels in de praktijk onderzocht. Uit de beschreven studies kon niet overtuigend worden opgemaakt dat van het aansprakelijkheidsrecht een preventieve werking uitgaat. Dit wordt enerzijds veroorzaakt door het feit dat er weinig tot geen empirisch materiaal voorhanden is om de invloed van het aansprakelijkheidsrecht op de preventie van verkeersongevallen te kunnen aantonen. Anderzijds geldt dat niet de dader zelf maar zijn aansprakelijkheidsverzekeraar de schade vergoedt die het slachtoffer heeft geleden, waardoor als gevolg van de invloed van verzekering de toetsing van het aansprakelijkheidsrecht sec wordt bemoeilijkt. Dit betekent echter niet dat aansprakelijkheidsregels geen preventieve werking kunnen hebben. Immers, via de verzekering (bijvoorbeeld door premiedifferentiatie) kan een aansprakelijkheidsstelling een indirecte invloed hebben op het gedrag van de bestuurder.

\subsubsection{De economische toetsing van de (voorstellen van) verkeersaansprakelijkheid}

In het Nederlandse wetsvoorstel verkeersongevallen is gekozen voor een risicoaansprakelijkheid ten laste van de motorrijtuigbezitter met een eigen schuldverweer in hoofde van het slachtoffer dat is beperkt tot opzet of bewuste roekeloosheid. ${ }^{1876}$ In Frankrijk is dit eigen schuldverweer nog beperkter, aangezien de 'faute inexcusable' ook de enige oorzaak van het verkeersongeval moet zijn geweest.

De beoogde risicoaansprakelijkheid is economisch gezien juist omdat daarmee rekening wordt gehouden met de gevaren van het gemotoriseerde verkeer en de dader in theorie tot een optimaal zorg- en activiteitsniveau wordt aangezet. ${ }^{1877}$ Weliswaar zal

1876. In het systeem 'Van Maanen' geldt deze regel voor een aanrijding tussen een motorrijtuig en een voetganger, met dien verstande dat de fout van de voetganger de exclusieve ooraak van het ongeval moet zijn geweest. Bij een aanrijding tussen een motorijtwig en een fietser geldt een regel van risicoaansprakelijkheid met een normaal eigen schuldverweer. Zie Engelhard en Van Maanen, VR 1999, p. 137-138; Van Maanen, RM Themis, 1999, p. 357-358.

1877. De automobilist (dader) is immers in beginsel ansprakelijk voor de schade van de fietser (slachtoffer), waardoor hij de juiste keuze zal maken bij de uitoefening van zijn zorg- en activiteitsniveau. Zie daarover paragraaf 8.2 van hoofdstuk 5. In het systeem 'Van Maanen' geldt het vermogen van het voertuig primair als maatstaf voor de gevaarzetting die bepalend is voor de 
zorgvuldig gedrag de bestuurder niet bevrijden van aansprakelijkheid, maar het janwenden van een optimaal zorg- en activiteitsniveau is voor de bestuurder bij een regel van risicoaansprakelijkheid het middel om zijn eigen verwachte kosten te minimaliseren.

De beperking van het eigen schuldverweer tot opzet of bewuste roekeloosheid betekent in theorie echter dat de zorgvuldigheid van het slachtoffer onvoldoende wordt meegewogen. ${ }^{1878}$ Het slachtoffer zal geen optimale zorg uitoefenen omdat zijn schade in beginsel wordt vergoed. Daarnaast zal het slachtoffer geen optimaal activiteitsniveau uitoefenen, omdat het eigen schuldverweer te beperkt is. Vanuit preventief oogpunt lijkt daarom, rekening houdend met het bilaterale karakter van een verkeersongeval, een ruimer eigen schuldverweer wenselijk. ${ }^{1879}$ Daarbij kan worden gedacht aan door het slachtoffer begane verkeersovertredingen, bijvoorbeeld het rijden door rood licht, het rijden zonder verlichting, voorrang nemen, dronken op de fiets zitten of zonder uitkijken de straat oversteken. ${ }^{1880}$ Uitbreiding van het eigen schuldverweer naar de vraag of het slachtoffer ten opzichte van de dader een onrechtmatige daad heeft begaan past niet in het gehanteerde uitgangspunt dat alleen het slachtoffer schade lijdt. Bepaalde fouten (verkeersovertredingen) van het slachtoffer dienen te worden meegewogen bij de vraag naar de omvang van de aansprakelijkheid van de dader. Het zal dan niet mogen gaan om een alles of niets verweer, maar wellicht kunnen bepaalde standaarden worden gebruikt om het eigen schuldverweer in het hoofde van het slachtoffer te bepalen.

aansprakelijkheid. Dit betekent dat ten opzichte van de fietser of voetganger, rekening houdend met het grote verschil in Betreibsgefahr tussen een motorijtuig en een fietser of voetganger, de gevaarzetting van het motorrijtuig in beginsel doorslaggevend is voor de vestiging van de risicoaansprakelijkheid.

1878. Dit geldt in versterkte mate bij een aanrijding tussen een motorrijtuig en een voetganger in het systeem 'Van Maanen'. De voetganger moet immers een emstige fout hebben begaan die ook nog de enige oorzaak van het ongeval moet zijn geweest. Zie Engelhard en Van Maanen, VR, 1999, p. 137.

1879. De plannen van de huidige Minister Korthals lijken hieraan tegemoet te komen door de roekeloosheid van het slachtoffer voldoende te achten voor een verval van de aansprakelijkheid van de houder van het motorrijtuig. Zie TK 1998-1999, 25759, nr. 5 (H), p. 2-5; NJB, 1999, p. $1292-$ 1293. In het systeem 'Van Maanen' geldt dat fouten aan de kant van de fietser in het eigen schuldverweer aan de orde komen. Hoewel daarbij wordt verwezen naar artikel 6:101 BW, dient dit verweer te worden 'beperkt tot eigen schuld die de invloed van de gevaarzetting van de bezitter van het motorrijtuig relativeert'. Zie Engelhard en Van Maanen, VR, 1999, p. 137 en p. 356357. Niet duidelijk is op welke gedragingen van het slachtoffer (de fietser) dit eigen schuldverweer precies betrekking heeft.

1880. Zie daarover ook Korthals TK, 1998-1999, 25759, nr. 5 (H), p. 2. 
In haar verweer tegen de rechtseconomische kritiek $^{1881}$ dat het wetsvoorstel tot minder prikkels van zorg zal leiden, heeft de Minister gesteld dat voor slachtoffers reeds een krachtige prikkel uitgaat van de vrees voor ingrijpende letselschade. ${ }^{1882}$ Dit is op zich juist maar de vrees voor letselschade is slechts een van de factoren die de zorg c.q. het gedrag van het slachtoffer in het verkeer bepalen. Daarnaast kan er van worden uitgegaan dat de gemiddelde verkeersdeelnemer niet volledig is geïnformeerd omtrent de eventueel te lijden schade. Wanneer het slachtoffer echter weet dat zijn schade bijna automatisch wordt vergoed zal hij zich mogelijk minder aan de verkeersregels houden, zodat hij toch enigszins tegen zichzelf in bescherming moet worden genomen. ${ }^{1883}$ Voor deze stelling is in dit onderzoek weliswaar geen empirische ondersteuning gevonden, maar toch kan worden aangenomen dat de prikkels tot zorgvuldig gedrag bij het slachtoffer ingeval van een volledige vergoeding minder sterk zullen zijn dan wanneer het slachtoffer zelf ook een deel van het risico draagt. De daders (automobilisten) van hun kant zullen enerzijds voorzichtiger worden, maar kunnen anderzijds ook eerder besluiten om door te rijden na een verkeersongeval in de wetenschap dat zij toch bijna automatisch aansprakelijk zijn. ${ }^{1884}$ Deze laatste stelling is weliswaar van een geheel ander kaliber, omdat een toegenomen aansprakelijkheid altijd wel het risico meebrengt dat daders aan hun aansprakelijkheid zullen trachten te ontsnappen, maar dat is op zich geen argument tegen aansprakelijkheid.

Het voorgaande brengt mee dat nu de preventieve werking van het aansprakelijkheidsrecht vooralsnog beperkt lijkt, het aangewezen is dat het verkeersgedrag mede wordt beïnvloed door verzekering en veiligheidsregulering. Uit het empirisch onderzoek is niet gebleken dat ten aanzien van de preventieve maatregelen die een verzekeraar toepast (bonus-malus, premiedifferentiatie) een positief effect op het verkeersgedrag uitgaat, dan wel heeft geleid tot een daling van het aantal verkeersongevallen. ${ }^{1885}$ Daarnaast is de vraag of nog wel kan worden gesproken van een aansprakelijkheidsverzekering voor motorrijtuigen nu de aansprakelijkheid van de bezitter ervan jegens niet-gemotoriseerden bijna absoluut is. Het voor Nederland beoogde

1881. Zie met name Van den Bergh, RW, 1994-1995, p. 1313-1323; Van den Bergh, in Verkeersaansprakelijkheid, p. 27-74; Visser en Van den Bergh, NJB, 1998, p. 122-127.

1882. Memorie van Toelichting, TK, 1997-1998, 25759, nr. 3, p. 18.

1883. Van den Bergh, RW, 1994-1995, p. 1322, betoogt in dat verband dat mensen wel degelijk onder de indruk komen van het vooruitzicht een bepaalde schadelast te moeten dragen, omdat het anders onduidelijk is waarom verzekeringscontracten worden afgesloten. Zie ook Van den Bergh, in Verkeersaansprakelijkheid, p. 57.

1884. Bockwinkel en Van Gessel, AA, 1998, p. 39-40. Zij verwijzen naar de media waar het wetsvoorstel uiterst kritisch is ontvangen. Met name van de zijde van de automobilisten werd betoogd dat zij nu voor de fouten van de fietser en voetganger aansprakelijk waren.

1885. Zie paragraaf 3 en 4 van hoofdstuk 11 . 
stelsel, ${ }^{1886}$ dat betrekking heeft op ongeveer $30 \%$ van het totaal aantal verkeersongevallen, krijgt daarmee het karakter van een automatische vergoeding van de schade van niet-gemotoriseerde verkeersslachtoffers op een wijze waaraan inmiddels door de Belgische WAM-regeling een invulling wordt gegeven. ${ }^{1887}$ Hieruit blijkt dat in een dergelijk stelsel al van 'aansprakelijkheid' sprake is in gevallen waarin niet vaststaat dat de bezitter van het motorrijtuig enige invloed op het verkeersongeval kon hebben. Of in een dergelijk regime de vergoedingsplicht nog wel een preventieve werking heeft, kan derhalve worden betwijfeld.

De voorgestelde risicoaansprakelijkheid ten laste van de motorrijtuigbezitter heeft gevolgen voor het bonus-malussysteem, dat is gebaseerd op het aantal schadeclaims dat de verzekerde automobilist in een bepaalde periode bij zijn verzekeraar indient. De verzekerde motorrijtuigbezitter loopt bijvoorbeeld de kans dat zijn premie stijgt tengevolge van een ongeval met een fietser waarbij hem absoluut niets te verwijten viel. Een aantal verzekeraars heeft naar aanleiding van het Nederlandse wetsvoorstel besloten om geen premieverhoging op te leggen wanneer de verzekerde geen schuld had aan het ongeval. ${ }^{1888}$ Vanuit preventieoogpunt is dit een wenselijke ontwikkeling nu de verzekerde wat hemzelf betreft via een op schuld gebaseerde premiecorrectie kan worden aangezet tot zorgvuldig verkeersgedrag. Dit zou ook betekenen dat bij het voorgestelde aansprakelijkheidsregime steeds schuldelementen zullen blijven bestaan, met name bij een eventuele premiecorrectie door de verzekeraar. Uit het vergelijkend onderzoek is gebleken dat in bijna alle systemen waarbij het slachtoffer zijn schade vergoed krijgt, zonder dat een fout van de automobilist behoeft te worden aangetoond, op een of andere wijze rekening zal worden gehouden met het gedrag van de automobilist, hetzij bij regres, hetzij bij een ex post risicodifferentiatie (bijvoorbeeld een premieverhoging).

Voor een verdere beïnvloeding van het verkeersgedrag van de motorrijtuigbezitter kan naast verzekering ook veiligheidsregulering nodig zijn. Een belangrijk voordeel van veiligheidsregulering is dat maatregelen kunnen worden genomen ongeacht of zich een verkeersongeval heeft voorgedaan of zal voordoen. Verder is in de economische theorie het argument gebruikt dat een verkeersdeelnemer omtrent bepaalde verkeerssituaties vaak onvolledige informatie bezit, die door veiligheidsregulering kan worden aangevuld. ${ }^{1889}$ Voor verzekeraars geldt dat zij niet alle informatie hebben om het gedrag van de verzekerde te controleren en ook veelal pas in beeld ko-

1886. C.C. van Dam, VR 1998 , p. 358 , beschouwt het Nederlandse wetsvoorstel als een verzekeringsdekking voor personenschade in het verkeer.

1887. In het bijzonder na de recente wijziging van artikel 29bis WAM-wet, Belgisch Staatsblad 21 februari 2001.

1888. Zie daarover Bockwinkel en Van Gessel, AA, 1998, p. 39; Kremer, Hennekam, Van der Harst, VR, 1998, p. 293.

1889. Paragraaf 3.3 van hoofdstuk 7. 
men wanneer zij worden aangesproken tot vergoeding van schade naar aanleiding van een verkeersongeval. Een verzekeraar kan bijvoorbeeld wel uitsluitingen opnemen voor bepaalde gedragingen, zoals het rijden onder invloed, dan wel (financiële) sancties aan de verzekerde opleggen, bijvoorbeeld in de vorm van een strafpuntensysteem bij verkeersovertredingen. Het opleggen van administratieve en strafrechtelijke sancties, zoals een ontzegging van de rijbevoegdheid, maar ook wetgeving voor bijvoorbeeld het veiliger maken van auto's is echter voorbehouden aan de overheid.

Uit het empirisch onderzoek kan worden opgemaakt dat bepaalde maatregelen op het terrein van de verkeersveiligheid hebben bijgedragen aan de vermindering van het aantal verkeersongevallen en verkeersslachtoffers. In dat kader kan worden verwezen naar de regulering met betrekking tot het veiliger maken van auto's, bepaalde administratieve en strafrechtelijke sancties en het streng bestraffen van het rijden onder invloed. ${ }^{1890}$ Dit empirisch bewijs is veel sterker en overtuigender dan het bewijs van de preventieve effecten van het aansprakelijkheidsrecht. Daaruit kan worden geconcludeerd dat het vanuit kostenoogpunt effectief lijkt om veiligheidsregulering in het verkeer toe te passen met ondersteuning van administratieve en strafrechtelijke sancties.

Vanuit de positie van het slachtoffer is gesteld dat de beoogde invoering van een eigen schuldverweer dat is beperkt tot opzet of bewuste roekeloosheid in theorie een negatieve invloed kan hebben op zijn gedrag. Dit brengt mee dat verzekering en veiligheidsregulering nodig zijn om het gedrag van slachtoffer te beïnvloeden. Ten aanzien van het verzekeringsaspect geldt dat het slachtoffer de beschikking heeft over een breed scala aan eerste partij verzekeringen die zijn schade direct vergoeden. Deze sociale en particuliere verzekeraars zullen vervolgens de schade van het slachtoffer willen verhalen op de veroorzaker (motorrijtuigbezitter) dan wel zijn aansprakelijkheidsverzekeraar. Met behulp van dit regres kan de aansprakelijkheidsverzekeraar de door hem te vergoeden schade doorberekenen in de verzekeringspremie van de motorrijtuigbezitter (dader).

In de praktijk blijkt echter dat de controle van het morele risico en de toepassing van premiedifferentiatie bij de sociale en particuliere verzekeraars van het slachtoffer, hoewel wenselijk, in beginsel ontbreekt. Het slachtoffer krijgt veelal een standaardpakket aangeboden, waarbinnen de omvang van de premie niet wordt geïndividualiseerd. Daarnaast speelt bij de acceptatie van een verzekeringspakket binnen de sociale zekerheid het verschaffen van informatie en het bestaan van eventuele risicofactoren aan de zijde van het slachtoffer ook geen doorslaggevende rol. ${ }^{1891}$ Daarbij

1890. Zie daarover hoofdstuk 12.

1891. Zie Elzas, Special Handboek, p. 26. 
moet worden aangetekend dat de sociale en particuliere verzekeringen aan de zijde van het slachtoffer niet alleen de schade tengevolge van een verkeersongeval uitkeren, maar dat deze verzekeringen vaak ook dekking bieden tegen letselschade die het gevolg is van andere ongevallen.

Omdat de controle op het morele risico van het slachtoffer binnen de sociale en particuliere verzekering ontbreekt, althans niet volledig op het verkeersgedrag kan worden afgestemd, zullen andere maatregelen nodig zijn. Dit betekent dat met betrekking tot de Nederlandse verkeersaansprakelijkheid zowel in het huidige systeem als in een toekomstig stelsel ook veiligheidsregulering nodig zal zijn om het slachtoffer tot zorgvuldig verkeersgedrag aan te zetten. Hoewel het empirisch onderzoek voornamelijk betrekking had op de controle van het gedrag van de dader, kan veiligheidsregulering ook bij potentiële verkeersslachtoffers (fietsers en voetgangers) de ongevalsrisico's verminderen, door van hen, in sterkere mate dan tot op heden het geval is, te eisen dat zij de verkeersregels naleven. Daarvoor is dan wel vereist dat de sancties na een effectieve controle ook daadwerkelijk worden toegepast. De wijze жаarop bijvoorbeeld in Nederland door fietsers met het rode verkeerslicht wordt omgesprongen, illustreert dat op dat terrein nog veel kan worden bereikt voor wat betreft de vermindering van de veiligheidsrisico's in het verkeer. Ook voor voetgangers lijkt een rood verkeerslicht nauwelijks een barrière te vormen. Voorts kan worden gewezen op het kennelijk ingeburgerde gebruik om te fietsen zonder licht. Dit zijn voorbeelden van situaties waar potentiële slachtoffers (fietsers en voetgangers) onbewust het ongevalsrisico verhogen.

Het lijkt derhalve van belang dat in het kader van de verhoging van de verkeersveiligheid niet alleen de aandacht wordt gericht op de dader (autobestuurder) die via een combinatie van aansprakelijkheid, verzekering en veiligheidsregulering tot zorgvuldig verkeersgedrag dient te worden aangezet. Ook het gedrag van potentiële verkeersslachtoffers moet op deze wijze worden beïnvloed. Het zou immers juist in het belang van deze potentiële verkeersslachtoffers zelf zijn om verkeersregels die vooral hun bescherming tot doel hebben, preventief te handhaven.

\subsubsection{Een verkeersverzekering}

\subsubsection{De resultaten van het theoretisch en empirisch onderzoek}

Wanneer, onder gelijktijdige afschaffing van het aansprakelijkheidsrecht, wordt gekozen voor een verkeersverzekering aan de zijde van de eigenaar van het motornijuig, kan de controle van de zorgvuldigheid van de autobestuurder in beginsel niet meer worden gebaseerd op (fout)aansprakelijkheid ten opzichte van derden. Wel kan de verkeersverzekeraar na een schadeclaim het gedrag van de verzekerde autobestuurder controleren door te onderzoeken of het gedrag (verkeersovertredingen) van de autobestuurder aanleiding geeft tot een premieaanpassing. Daarnaast zou het ook 
mogelijk moeten zijn om een systeem te ontwikkelen waarbij aan de hand van strafpunten verkeersovertredingen van de verzekerde in de premie tot uitdrukking worden gebracht. Tenslotte zou binnen de verzekeringsvoorwaarden nadrukkelijk rekening moeten worden gehouden met het schadeverleden van de autobestuurder.

Bij een verkeersverzekering valt de controle van de zorgvuldigheid van de niet-gemotoriseerden weg, omdat deze in beginsel de schade krijgt vergoed van de verzekeraar van het betrokken motorrijtuig. Wanneer deze schadevergoeding echter niet volledig is kunnen daarmee aan niet-gemotoriseerden prikkels worden gegeven. Omdat bij een verkeersverzekering de aansprakelijkheid is afgeschaft, zal ook veiligheidsregulering nodig zijn om de niet-gemotoriseerden aan te zetten tot zorgvuldig verkeersgedrag.

Het empirisch onderzoek met betrekking tot een vergelijking van het aansprakelijkheidsrecht en een no-fault verzekering in onder andere Noord-Amerika en Canada heeft tot tegenstrijdige uitkomsten geleid. Daarbij kon enerzijds niet worden aangetoond dat van het aansprakelijkheidsrecht een preventieve werking uitgaat. Anderzijds is ook niet gebleken dat een no-fault verzekering, al dan niet gecombineerd met een gedeeltelijke handhaving van het aansprakelijkheidsrecht, daadwerkelijk tot minder verkeersongevallen heeft geleid. Dit betekent dat in de praktijk geen keuze kan worden gemaakt tussen aansprakelijkheid en een no-fault verzekering. Bij een keuze voor een no-fault verzekering is, als gevolg van het wegvallen van de aansprakelijkheid, in ieder geval een versterkte controle van het gedrag van de verzekerde noodzakelijk.

\subsubsection{De economische toetsing van de voorstellen tot 'verkeersverzekering'}

De verkeersverzekering zoals deze in de Nederlandse literatuur wordt verdedigd beoogt een vergoeding aan verkeersslachtoffers te garanderen voor zover zij hun schade niet uit eigen bron, in casu een eerste partij sociale of particuliere verzekering, vergoed krijgen. Daarmee verschilt deze aanvullende verkeersverzekering van de no-fault verzekering in Noord-Amerika die immers de schade van het verkeersslachtoffer vergoedt omdat deze veelal niet over eigen voorzieningen beschikt. De no-fault verzekering dekt doorgaans ziektekosten en inkomensschade (een bestaansminimum) die in de Nederlandse context primair door de sociale zekerheid wordt gedekt. Verder geldt dat in Noord-Amerika in veel staten een verschillend no-fault regime van toepassing is. Dit betekent dat enige voorzichtigheid moet worden betracht bij het onverkort toepassen van de resultaten van het Amerikaans onderzoek op de voorstellen voor een aanvullende verkeersverzekering. 
De verkeersverzekering dekt ook de schade van de bestuurder van het motorrijtuig. Dit betekent dat, gezien het eerste partij karakter van deze dekking, dat de verzekerde bestuurder ${ }^{1892}$ voor de vergoeding van zijn schade direct onderhandelt met zijn verkeersverzekeraar. Dit heeft het voordeel ten opzichte van een aansprakelijkheidsrerzekering dat bij de controle van het gedrag van de verzekerde bestuurder in beginsel geen rekening behoeft te worden gehouden met het gedrag van derden.

Het nadeel is dat de zorgvuldigheid van de niet-gemotoriseerde die met het verzekerde motorrijtuig in botsing komt niet via de verzekeringsvoorwaarden van de verkeersverzekering kan worden gecontroleerd. In de vorige paragraaf ${ }^{4893}$ is opgemerkt dat binnen de sociale zekerheid in beginsel niet wordt gedifferentieerd, de schade van het slachtoffer veelal uit verschillende bronnen wordt uitgekeerd en de sociale en particuliere verzekeringen ook dekking verlenen tegen letsel dat niet het gevolg is van een verkeersongeval. Daarmee krijgt de controle van de zorgvuldigheid van het slachtoffer via de eigen verzekeringsvoorwaarden een complex karakter.

Een oplossing hiervoor is in de eerste plaats een niet volledige schadevergoeding van het slachtoffer. Een dergelijk vooruitzicht kan aan het slachtoffer prikkels van zorg geven. In de tweede plaats is ook hier een aanvullende strikte veiligheidsreguleing noodzakelijk teneinde het verkeersgedrag van niet-gemotoriseerden te beïnvloeden. Hoewel daaromtrent geen empirisch onderzoek kon worden gepresenteerd, kan daarbij worden gedacht aan preventieve maatregelen op het terrein van de verkeersveiligheid. Verkeersovertredingen van niet-gemotoriseerden kunnen, mits de controle effectief is, worden bestraft met hoge boetes. Daarnaast kan aan notoire overtreders bijvoorbeeld een dienstverleningsmaatregel worden opgelegd waarbij deze worden geconfronteerd met de mogelijke gevolgen van hun verkeersgedrag. Voorts kan ook het onder invloed deelnemen aan het verkeer, hoewel dit misschien niet in alle gevallen een direct gevaar voor andere weggebruikers oplevert, worden bestraft door bijvoorbeeld inneming van het rijbewijs om de fietser en voetganger bij te brengen dat het onder invloed deelnemen aan het verkeer niet wordt getolereerd, dan wel hen te beschermen tegen de mogelijke gevaren die zij met hun gedrag kunnen veroorzaken.

1892. Hierbij wordt ervan uitgegaan dat de bestuurder ook de eigenaar van het motorrijtuig is, hoewel dit in werkelijkheid niet altijd dezelfde personen zijn.

1893. Paragraaf 3.2.1.2. 


\subsection{SECUNDAIRE ONGEVALSKOSTEN (SCHADEVERGOEDING)}

\subsubsection{Een systeem van risicoaansprakelijkheid met een eigen schuldverweer}

\subsubsection{De resultaten van het theoretisch en empirisch onderzoek}

In de economische theorie is gesteld dat een systeem van risicoaansprakelijkheid gecombineerd met een aansprakelijkheidsverzekering aan de zijde van de dader een betere schadevergoeding aan het slachtoffer kan garanderen dan een stelsel dat uitgaat van foutaansprakelijkheid. Dit geldt evenzeer wanneer het slachtoffer met betrekking tot het eigen schuldverweer in onzekerheid verkeert omtrent de zorgvuldigheidsnorm en derhalve een schadeverzekering zal afsluiten.

In een aantal Nederlandse studies met betrekking tot de schadevergoeding aan verkeersslachtoffers wordt geconcludeerd dat de directe rol van het aansprakelijkheidsrecht beperkt is. ${ }^{1894}$ Veel slachtoffers krijgen hun schade in eerste instantie uitgekeerd van de eigen sociale en particuliere verzekeraar. Uit het Nederlands onderzoek is gebleken dat ondanks de aanwezige eerste partij voorzieningen met name slachtoffers die ernstig letsel hebben geleden hun schade niet volledig krijgen uitgekeerd. ${ }^{1895}$ Dit betreft dan met name de schade aan de top van het inkomen en het smartengeld, hoewel daarover concrete cijfers ontbreken. Verkeersslachtoffers in Nederland lijken het aansprakelijkheidsrecht dan ook voornamelijk te gebruiken in situaties waarin zij hun schade niet (volledig) vergoed krijgen van hun sociale en particuliere verzekeraars.

\subsubsection{De economische toetsing van de (voorstellen van) verkeersaansprakelijk- heid}

In het Nederlandse wetsvoorstel wordt de invoering van een risicoaansprakelijkheid met een beperkt eigen schuldverweer beoogd. Een dergelijk systeem impliceert dat, in combinatie met de aanwezige verplichte WAM-verzekering aan de zijde van de bezitter van het motorrijtuig, aan het slachtoffer (fietser, voetganger en passagier) een schadeloosstelling kan worden gegarandeerd. Dit effect wordt versterkt wanneer ook rekening wordt gehouden met de aanwezige eerste partij voorzieningen aan de zijde van het slachtoffer, waarbij tevens het regres van deze verzekeraars blijft ge-

1894. Zie hoofdstuk 10. Deze studies dateren echter uit een periode, begin jaren '70 van de vorige eeuw, waarin de bescherming van verkeersslachtoffers via artikel 31 WVW oud (artikel 185 WVW) nog onvoldoende was uitgekristalliseerd en ten aanzien van de grondslag van verkeersongevallen nog werd uitgegaan van een schuldaansprakelijkheid.

1895. Zie hoofdstuk 10 voor een beschrijving van deze studies. 
handhaafd. ${ }^{1896}$ In het beoogde wetsvoorstel geeft het vergoedingsargument de doorslag omdat wordt gestreefd naar de bescherming van bepaalde groepen verkeersslachtoffers die daar volgens de Minister, mede gezien hun 'kwetsbaarheid' het meeste behoefte aan hebben. ${ }^{1897}$

De vraag of binnen een systeem van risicoaansprakelijkheid de schadevergoeding aan het verkeersslachtoffer ook volledig zal zijn kan niet uit recent empirisch onderzoek worden opgemaakt. De Nederlandse studies die in het onderhavige onderzoek zijn beschreven concluderen dat in de meeste gevallen verkeersslachtoffers hun schade volledig vergoed krijgen maar dat met name voor verkeersslachtoffers die emstig letsel hebben geleden de schadevergoeding niet volledig is. Dit kan het gevolg zijn van het feit dat in deze studies de grondslag van de schadevergoeding een regel van schuldaansprakelijkheid was, zodat bewijsproblemen en de eigen schuld tot een minder dan volledige vergoeding aanleiding kunnen geven.

Ook in het huidige stelsel van artikel $185 \mathrm{WVW},{ }^{1898}$ waarin aan de motorrijtuigbezitter ten opzichte van het (volwassen) verkeersslachtoffer nog bepaalde verweermiddelen (overmacht en eigen schuld) openstaan, is niet in alle gevallen een volledige schadeloosstelling gegarandeerd. De voorgestelde regel van risicoaansprakelijkheid met een beperkt eigen schuldverweer zal ten opzichte van bijvoorbeeld het huidige stelsel van artikel $185 \mathrm{WVW}$ aan het verkeersslachtoffer in beginsel meer zekerheid geven op een (volledige) schadeloosstelling. Hoewel sprake is van een alles-of-niets stelsel, waarin opzet of bewuste roekeloosheid tot een algeheel verval van de (risico)aansprakelijkheid leidt, zal dit verweer jegens het slachtoffer in de meeste gevallen niet slagen. ${ }^{1899}$

De vraag of het slachtoffer binnen een stelsel van risicoaansprakelijkheid ook sneller wordt gecompenseerd, zou in vergelijking met het huidige stelsel (art. $185 \mathrm{WVW}$ ) in beginsel bevestigend kunnen worden beantwoord. Wanneer immers vaststaat dat het motorrijtuig betrokken is bij een verkeersongeval is de aansprakelijkheid gegeven. Binnen het stelsel van artikel $185 \mathrm{WVW}$ dient nog te worden vastgesteld of aan de

1896. Op grond van deze overwegingen kan ook binnen het systeem 'Van Maanen aan nietgemotoriseerde verkeersslachtoffers in beginsel een optimale schadeloosstelling worden gegarandeerd.

1897. Memorie van Toelichting, TK, 1997-1998, 25759 , nr. 3, p. 2 en p. 12.

1898. Zie daarover paragraaf 3 van hoofdstuk 3.

1899. Dit zal mogelijk anders zijn wanneer de plannen van Korthals worden omgezet in een concreet wetsvoorstel. In dat geval zal het (alles-of-niets) eigen schuldverweer jegens het verkeersslachtoffer worden bepaald door gewone roekeloosheid, zodat het slachtoffer ten opzichte van het beperkte verweer van opzet of bewuste roekeloosheid minder zekerheid heeft op een (volledige) vergoeding. In het systeem 'Van Maanen' geldt dat, voor wat betreft de vraag of de schadevergoeding aan het niet-gemotoriseerde verkeersslachtoffer ook volledig is, de voetganger in beginsel beter af is dan de fietser, waarbij het eigen schuldverweer de schadevergoeding kan beperken. 
motorrijtuigbezitter een (beperkt) beroep op overmacht toekomt. Voorts is het antwoord op de vraag of sprake is van opzet of bewuste roekeloosheid aan de zijde van het slachtoffer vermoedelijk eenvoudiger vast te stellen dan de eigen schuld op basis van artikel 6:101 BW in het huidige stelsel (art. 185 WVW). Wel kan zich vertraging voordoen bij de beoordeling van de opzet of bewuste roekeloosheid van het slachtoffer zelf. ${ }^{1990}$ De regresnemende verzekeraars zijn voor hun vordering aangewezen op de gewone foutaansprakelijkheid van artikel 6:162 BW, maar deze procedure tussen de verzekeraars onderling, zal voor de snelheid van de schadevergoeding van het slachtoffer zelf waarschijnlijk geen gevolgen hebben. ${ }^{1901}$

Hoewel bij een stelsel van risicoaansprakelijkheid is dat een snellere vaststelling van de aansprakelijkheid wordt bereikt, moet daarbij worden aangetekend dat belangrijke vertragingen kunnen optreden bij de vaststelling van de omvang van de schade. Of het slachtoffer zijn schade sneller krijgt uitgekeerd dan in het huidige stelsel, is mede afhankelijk van de discussie over de eindtoestand, periodieke uitkeringen of een som ineens. ${ }^{1902}$ De tijdwinst wordt derhalve geboekt bij de vaststelling van de aansprakelijkheid; deze kan echter teniet worden gedaan door vertragingen bij de vaststelling van de omvang van de schade.

\subsubsection{Een verkeersverzekering}

\subsubsection{De resultaten van het theoretisch en empirisch onderzoek}

Een no-fault verzekering, waarbij de aansprakelijkheid is afgeschaft en de schade geheel via de verzekeraar van de motorrijtuigbezitter wordt geregeld, kan een optimale schadevergoeding van het slachtoffer, inclusief de verzekerde bestuurder zelf, garanderen. In het empirisch onderzoek is gebleken dat een no-fault verzekering ten opzichte van een systeem met aansprakelijkheid in beginsel meer zekerheid aan het slachtoffer geeft op een (snellere) schadevergoeding. Daarbij moet echter worden

1900. Bij gewone roekeloosheid zal deze discussie zich versterkt kunnen voordoen, hoewel het slachtoffer zelf hiervan geen wezenlijke vertraging zal ondervinden. Zie TK 1998-1999, 25759, nr. 5 (H), p. 2-5; NJB, 1999, p. 1292-1293, in verband met de plannen van Korthals.

1901. In het systeem 'Van Maanen' zal de fietser geen snellere vergoeding ontvangen dan in het beoogde wetsvoorstel. Het beperkte overmachtsverweer aan de zijde van de motorrijtuigbestuurder en het eigen schuldverweer in hoofde van het slachtoffer kunnen naast de vaststelling van de omvang van de schade voor bewijsproblemen en vertragingen zorgen. Dit geldt in mindere male voor de voetganger waar zich een vertraging kan voordoen bij de vraag of deze een emstige fout heef begaan die de enige oorzaak was van het ongeval, hoewel dit vermoedelijk minder vertraging zal geven dan het criterium van opzet of bewuste roekeloosheid in het wetsvoorstel.

1902. Zie daarover Van Dijk, VR, 1998, p. 131; Kremer, Hennekam en Van der Harst, VR, 1998, p. 293: 'Het realiseren van slachtofferbescherming door risicoaansprakelijkheid verandert niets aan de verhoudingsgewijs tot veel meer conflictstof aanleiding gevende vragen inzake de schadeomvang'; Bloembergen, NTBR, 1998, p. 173-174: 'Gaat het echter wel zo goed met de afwikkeling van de letselschade? Als het zo goed gaat zou dan een PIV zijn opgericht?' 
opgemerkt dat het hier de situatie in Noord-Amerika en Canada betrof. Bij afwezigheid aldaar van een breed stelsel van sociale voorzieningen zal een no-fault verzekeing al snel tot een betere vergoeding leiden.

Uit het empirisch onderzoek in Noord-Amerika kan voorts worden opgemaakt dat in staten met een no-fault verzekering de periode waarbinnen aan het verkeersslachtoffer de volledige schade wordt uitgekeerd in het algemeen korter is dan in staten met een aansprakelijkheidssysteem. Dit verschil wordt mede verklaard door het feit dat in de meeste 'tort'-staten een regel van foutaansprakelijkheid met een gradueel eigen schuldverweer van toepassing is. Binnen deze staten zal enkel de discussie over de vaststelling van de aansprakelijkheid al tot vertragingen in de uitkering van de schade leiden. De vraag of een verkeersslachtoffer in een no-fault staat zijn schade ook volledig krijgt vergoed, is afhankelijk van de omvang van de geleden schade en de hoogte van de vergoedingslimiet. In geen enkele Amerikaanse staat geldt een no-fault regime waarin de aansprakelijkheid volledig is afgeschaft. De meeste Amerikaanse staten hebben een systeem waarbij op basis van de no-fault verzekering de schade tot een bepaalde limiet wordt uitgekeerd, terwijl het slachtoffer voor de overige schade (materieel en immaterieel) een aansprakelijkheidsvordering kan instellen.

\subsubsection{De economische toetsing van de voorstellen tot 'verkeersverzekering'}

In de voorstellen voor een aanvullende verkeersverzekering zal, mede door de afschaffing van de aansprakelijkheid, een schadeloosstelling aan het slachtoffer zijn gegarandeerd. Anders gezegd, het slachtoffer heeft een grote mate van zekerheid dat hij een vergoeding krijgt. Dit geldt evenzeer voor de bestuurder van een motorrijtuig die schade lijdt tengevolge van een verkeersongeval. De voorgestelde aanvullende verkeersverzekering dient voor alle verkeersdeelnemers te gelden. Daarbij komt echter niet in alle gevallen een volledige schadevergoeding aan het slachtoffer ter beschikking, omdat beperkingen worden gesteld aan de omvang van de vergoeding.

De vraag of een aanvullende verkeersverzekering ook tot een snellere uitkering leidt is niet eenduidig te beantwoorden. Bij een verkeersverzekering zal geen discussie ontstaan over de aansprakelijkheid, maar kan in beginsel direct worden overgegaan tot vaststelling en uitkering van de schade. Dit laatste kan echter een knelpunt blijven omdat in de huidige Nederlandse praktijk de vaststelling van de omvang van de schade tot vertragingen leidt. Ook bij een verkeersverzekering ontstaan discussies over de eindtoestand, periodieke uitkeringen of een som ineens. Een verkeersverzekering heeft derhalve het voordeel boven een stelsel met aansprakelijkheid dat daarbij snel tot de vaststelling van de omvang van de schade kan worden overgegaan. Ten opzichte van het huidige stelsel van artikel $185 \mathrm{WVW}$ is dit een voordeel. In het voorgestelde systeem van een risicoaansprakelijkheid wordt dit voordeel 
met betrekking tot de snelheid van uitkeren al minder, omdat bij dit systeem ook de aansprakelijkheid relatief snel vaststaat.

\subsection{TERTLAIRE KOSTEN (ADMINISTRATIEVE KOSTEN)}

\subsubsection{Een systeem van risicoaansprakelijkheid met een eigen schuldverweer}

\subsubsection{De resultaten van het theoretisch en empirisch onderzoek}

In de economische theorie is geconcludeerd dat een regel van risicoaansprakelijkheid met een absoluut eigen schuldverweer ${ }^{1903}$ hoge kosten kan meebrengen. Dit geldt zowel voor de vestiging van de aansprakelijkheid en de beoordeling van het eigen schuldverweer als voor de vaststelling van de schadeomvang. Daarnaast is in de theorie geconstateerd dat, uitgaande van de veronderstelling dat elk verkeersongeval tot een procedure leidt, een stelsel van risicoaansprakelijkheid met een absoluut eigen schuldverweer hoge gerechtelijke kosten heeft. In de praktijk dient dit laatste te worden gerelativeerd omdat bij een risicoaansprakelijkheid de informatiekosten voor de rechter worden verlaagd. Hij behoeft immers niet meer na te gaan of de bestuurder zorgvuldig heeft gehandeld. Vanuit slachtofferperspectief kunnen de hoge kosten van een systeem met risicoaansprakelijkheid worden gerelativeerd, omdat voor hen in beginsel het vooruitzicht van een volledige schadevergoeding geldt. Daarbij moet echter worden bedacht dat dit vanuit rechtseconomisch oogpunt niet tot de beoordeling van de tertiaire kosten behoort.

Uit het empirisch onderzoek ten aanzien van Nederland en Noord-Amerika kan worden opgemaakt dat een schadevergoedingsprocedure gebaseerd op het (fout)aansprakelijkheidsrecht veelal een kostbare en langdurige aangelegenheid is. ${ }^{1904}$ In dit verband dient te worden opgemerkt dat de betreffende procedures veelal op een schuldaansprakelijkheid waren gebaseerd, zodat de kosten als gevolg van bewijsproblemen sterk kunnen oplopen. Dit geldt ook voor de vaststelling van de omvang van de schade. Een verschil met Noord-Amerika is dat in Nederland het aantal gerechtelijke procedures ongeveer $1 \%$ van het totaal aantal verkeerszaken bedraagt. ${ }^{1905}$ In Noord-Amerika is dit percentage mede als gevolg van het ontbreken van een sociaal vangnet aan de zijde van het slachtoffer vele malen hoger. Het relatief lage antal gerechtelijke procedures in Nederland betekent overigens niet dat de administratieve kosten van de schaderegeling niet aanzienlijk kunnen zijn. Deze administratieve kos-

1903. Hierbij geldt dat het niet voldoen aan de efficiente zorgstandaard door het slachtoffer tot een algeheel verval van zijn aanspraken op schadevergoeding leidt. Zie daarover paragraaf 6 van hoofdstuk 5 .

1904. Zie voor Nederland paragraaf 2 van hoofdstuk 10 en voor Noord-Amerika paragraaf 4.2 van hoofdstuk 10 en paragraaf 3.2 van hoofdstuk 13.

1905. Notitie Verkeersaansprakelijkheid, TK, 1989-1990, 21528, nr. 1, p. 15 en p. 23. 
ten ontstaan vooral binnen de schadeafwikkeling tussen het slachtoffer zelf en de veroorzaker (of zijn aansprakelijkheidsverzekeraar) en de regresprocedure tussen de verzekeraar van het slachtoffer en de veroorzaker dan wel diens aansprakelijkheidsverzekeraar.

Samenvattend kan worden gesteld dat over de relatieve kosten van een systeem van risicoaansprakelijkheid noch vanuit de theorie, noch vanuit het empirisch onderzoek eenduidige conclusies kunnen worden geformuleerd. In theorie leidt een regel van risicoaansprakelijkheid tot relatief veel procedures (elk schadegeval leidt in beginsel tot een procedure of een schikking). Hoewel daarbij de kosten van de foutbeoordeling wegvallen, dient de mate van eigen schuld nog steeds te worden vastgesteld. De empirische gegevens uit Noord-Amerika zijn niet bijzonder bruikbaar voor de $\mathrm{Ne}$ derlandse context. Enerzijds zijn de Amerikaanse data op schuldaansprakelijkheid gebaseerd (terwijl het in Nederland juist gaat over een oordeel omtrent risicoaansprakelijkheid) en anderzijds zijn de kosten in Noord-Amerika vermoedelijk veel hoger omdat het aansprakelijkheidsrecht daar juist ook als sociaal vangnet voor de slachtoffers fungeert. Dit leidt er dan ook toe dat slachtoffers in Noord-Amerika vermoedelijk claims zullen instellen, ook in gevallen waarin de Nederlandse slachtoffers dat niet zouden doen. ${ }^{1906}$

3.4.1.2. De economische toetsing van de (voorstellen van) verkeersaansprakelijkheid

Het Nederlandse wetsvoorstel zal voor wat betreft de vestiging van aansprakelijkheid vermoedelijk minder discussie geven dan het huidige stelsel (artikel 185 WVW). Toch zal de uitleg van de begrippen 'betrokkenheid' en 'opzet of bewuste roekeloosheid' door de Nederlandse rechter moeten worden vastgesteld, hetgeen aanvankelijk additionele administratieve kosten mee kan brengen. In dit verband kan worden verwezen naar Frankrijk, waar het Hof van Cassatie zich 10 jaar na de invoering van de 'loi Badinter' opnieuw moest buigen over de uitleg van de begrippen 'implication' en 'faute inexcusable'. Daarnaast is het niet uit te sluiten dat in Nederland meer gerechtelijke procedures gevoerd gaan worden om uitleg te krijgen omtrent andere bepalingen van het wetsvoorstel.

Met de invoering van het Nederlandse wetsvoorstel geldt verder dat regresnemers hun vordering dienen te baseren op artikel 6:162 BW, hetgeen een achteruitgang betekent ten opzichte van het huidige stelsel (artikel $185 \mathrm{WVW}$ ). ${ }^{1907}$ Dit zal tot een additionele kostenstijging kunnen leiden, omdat twee procedures naast elkaar gaan lo-

\footnotetext{
1906. Zie Faure en Hartlief, NJB, 1999, p. 2007-2015 en de reactie daarop van Bergkamp, NJB, 2000, p. 273-276.
}

1907. Zie daarover Van Maanen en Nelissen, in Verkeersaansprakelijkheid, p. 197-216; Van Maanen, NJB, 1998, p. 116-121. 
pen, namelijk die met betrekking tot de vergoeding van het slachtoffer zelf en de vordering van de regresnemer. Door de beoogde afschaffing van artikel $185 \mathrm{WVW}$ dient de rechter mogelijk nieuwe regels te ontwikkelen voor de vordering van de regresnemer. ${ }^{1908}$ Omdat bij een regresprocedure de belangen van het slachtoffer in beginsel geen rol meer spelen en er in ieder geval een strikte scheiding wordt aangebracht tussen de belangen van het slachtoffer en die van de regresnemer, kan bijvoorbeeld met standaarden worden gewerkt tussen de verzekeraars onderling. ${ }^{1009} \mathrm{Dit}$ zou op termijn, met medewerking van de betrokken verzekeraars, tot een kostenbesparing kunnen leiden. ${ }^{1910}$

\subsubsection{Een verkeersverzekering}

\subsubsection{De resultaten van het theoretisch en empirisch onderzoek}

Een zuivere no-fault verzekering is een vergoedingssysteem waarbinnen geen onderzoek naar de aansprakelijkheid behoeft te worden verricht. Dit leidt tot een kostenbesparing ten opzichte van een aansprakelijkheidsstelsel, hoewel de schadeafwikkeling zeker bij ernstige verkeersongevallen hoge kosten mee kan brengen. Uit het empirisch onderzoek kan worden opgemaakt dat een no-fault verzekering in Noord-Amerika relatief gezien tot een snellere afwikkeling van de schade tegen lagere kosten leidt dan een systeem met aansprakelijkheid. Daarbij is echter wel het toepasselijke no-fault stelsel van belang. Geen enkele Amerikaanse staat kent namelijk een zuiver no-fault regime, terwijl de vergoedingslimieten onder de no-fault verzekering niet overal even hoog zijn en de mogelijkheid tot het instellen van een aansprakelijkheidsvordering voor de geleden verkeersschade in veel staten mogelijk blijft.

\subsubsection{De economische toetsing van de voorstellen tot 'verkeersverzekering'}

In de voorstellen voor een verkeersverzekering behoeft in beginsel alleen een onderzoek te worden verricht naar de 'betrokkenheid' van het motorrijtuig. Dit leidt tot een

1908. Daarbij kan vermoedelijk aansluiting worden gezocht bij het arrest Puts/Ceha HR 15 januari 1993, NJ 1993, 568, waarin de vordering naar aanleiding van een verkeersongeval tussen een motorrijtuig en een volwassen fietser was gebaseerd op de onrechtamtige daad van artikel 1401 BW (oud). De Hoge Raad ging op basis hiervan uit van een strenge zorgvuldigheidsnorm voor de motorrijtuigbestuurder, waarbij verwezen werd naar het in de rechtspraak van artikel 185 WVW (artikel 31 WVW oud) ontwikkelde overmachtscriterium.

1909. Zie daarover Hartlief, VR, 1998, p. 259

1910. Met betrekking tot de administratieve kosten geldt dat het systeem 'Van Maanen' vrij kostbaar is. De vaststelling van de aansprakelijkheid zal met name bij verkeersongevallen tussen een motorrijtuig en een fietser hogere kosten meebrengen dan het wetsvoorstel. In het systeem 'Van Maanen genieten de regresnemers dezelfde bescherming als het verkeersslachtoffer zelf, hetgeen kostenverlagend werkt. Zie Engelhard en Van Maanen, VR, 1999, p. 357. 
kostenvoordeel ten opzichte van het beoogde Nederlandse wetsvoorstel, waarbinnen ook de opzet of bewuste roekeloosheid van het slachtoffer moet worden meegewogen. Daar staat tegenover dat binnen een verkeersverzekering ook uitsluitingen voorkomen waarover discussie kan ontstaan, bijvoorbeeld in geval van opzet van de bestuurder. De verkeersverzekering geldt voor alle verkeersdeelnemers, dus ook voor de inzittenden van een motorrijtuig. Dit heeft een kostenvoordeel nu de motorrijtuigbestuurder zijn schade van de eigen verkeersverzekeraar vergoed krijgt en hij deze derhalve niet op een aansprakelijke wederpartij behoeft te verhalen. Hoewel ook de afschaffing of collectivering van de regresrechten tot een kostenbesparing kan leiden, is dit niet typisch voor een verkeersverzekering. Een collectivering van de regresrechten is namelijk ook buiten de invoering van een verkeersverzekering mogelijk. $^{1911}$

\section{Een verkeersverzekering of (risico)aansprakelijkheid?}

In de voorgaande economische toetsing zijn de primaire-, secundaire- en tertiaire ongevalskosten separaat besproken. Daarbij is gebleken dat in beginsel noch een stelsel van risicoaansprakelijkheid met een eigen schuldverweer, noch een verkeersverzekering tot een minimalisering van deze ongevalskosten zal leiden. In het kader van het onderhavige onderzoek geldt echter dat de som van de ongevalskosten moet leiden tot een minimalisering van de maatschappelijke ongevalskosten. Dit betekent dat de vraag moet worden beantwoord welk vergoedingssysteem leidt tot een optimale preventie van verkeersongevallen en een optimale compensatie van verkeersslachtoffers tegen zo laag mogelijke kosten.

\subsection{PREVENTIE}

Hoewel in de economische theorie wordt gesteld dat aansprakelijkheidsregels in het verkeer preventieve werking kunnen hebben, heeft het empirisch onderzoek deze stelling niet kunnen bevestigen. Dit betekent dat vooralsnog alleen theoretische conclusies kunnen worden verbonden aan de werking van de Nederlandse verkeersaansprakelijkheid. Daarbij kan enerzijds worden gesteld dat bij een risicoaansprakelijkheid met een eigen schuldverweer de zorgvuldigheid van het slachtoffer zoveel mogelijk moet worden meegewogen. In de huidige en de toekomstige praktijk in Frankrijk, België en Nederland is het eigen schuldverweer in hoofde van het slachtoffer te beperkt om aan het slachtoffer voldoende prikkels van zorg te geven. ${ }^{1912}$ Anderzijds

\footnotetext{
1911. Zie daarover Van Boom, Hartlief en Spier, Regresrechten, afschaffen, handhaven of uitbreiden, 1996; Van Boom, Verhaalsrechten van verzekeraars en risicodragers, p. 116-122.

1912. De huidige Minister Korthals komt in zijn plannen voor de Nederlandse verkeersaansprakelijkheid tegemoet aan voomoemde bezwaren door de aansprakelijkheid niet pas te laten vervallen bij opzet of bewuste roekeloosheid doch reeds bij gewone roekeloosheid. Zie TK 1998-1999, 25759, nr. 5 (H), p. 2-5; NJB, 1999, 1292-1293.
} 
kan ook worden betoogd dat met het Nederlandse wetsvoorstel een stap wordt gezet in de richting van afschaffing van de aansprakelijkheid. Mede door de aanwezigheid van de verplichte WAM-verzekering die de schade aan het slachtoffer uitkeert, heeft het wetsvoorstel nog de schijn van aansprakelijkheid. In werkelijkheid kan worden beredeneerd dat de betrokkenheid van het motorrijtuig reeds de aansprakelijkheid vestigt en alleen de opzet of bewuste roekeloosheid van het slachtoffer, dat strikt moet worden uitgelegd, aan de motorrijtuigbestuurder een soort overmachtsverweer geeft om aan zijn aansprakelijkheid te ontkomen.

Het voorgaande brengt mee dat een motorrijtuigbestuurder bijna absoluut aansprakelijk is voor de schade van de niet-gemotoriseerde. Dit heeft tot gevolg dat de zorgvuldigheid van de bestuurder toch tot zijn aansprakelijkheid voor de schade van het slachtoffer zal leiden. De bestuurder heeft echter nog wel een prikkel om zijn eigen verwachte kosten te minimaliseren. Verder wordt ook de rol van de WAM-verzekeraar, die de schade van het slachtoffer uitkeert, belangrijker teneinde de controle van het gedrag van de motorrijtuigbestuurder te waarborgen. Voor de niet-gemotoriseerden geldt in beginsel dat zij geen prikkels van zorg gebaseerd op het aansprakelijkheidsrecht hebben. Daarmee wordt de rol van de veiligheidsregulering belangrijker om de niet-gemotoriseerden tot zorgvuldig gedrag in het verkeer aan te zetten. Daarbij kan worden gedacht aan de strafrechtelijke en administratieve handhaving van verkeersregels. Dit kan echter tot hoge kosten leiden, die mogelijk niet opwegen tegen een verbetering van het gedrag van de niet-gemotoriseerden dan wel een vermindering van het aantal verkeersongevallen. Een dergelijke handhaving kan misschien wel bijdragen aan een bewustwordingsproces bij de niet-gemotoriseerden. Onderzoek zal moeten uitwijzen of dit daadwerkelijk het geval is. Een alternatief is om bij de vaststelling van de aansprakelijkheid en de schadevergoeding het gedrag van het slachtoffer een rol te laten spelen. Overtreding van verkeersregels zal dan tot een vermindering van de schadevergoeding moeten leiden.

Wanneer wordt gekozen voor een verkeersverzekering onder afschaffing van de aansprakelijkheid, zal de preventie in beginsel van de verzekeringsvoorwaarden moeten uitgaan althans voor de bestuurder/inzittenden. De niet-gemotoriseerden krijgen hun schade vergoed van de verkeersverzekeraar van het betrokken motorrijtuig, zodat voor hen veiligheidsregulering, handhaving van verkeersregels, van belang is om hun zorgvuldigheid te bevorderen. Hoe dit laatste uitpakt is nog een vraag. In het onderhavige onderzoek was geen empirisch materiaal voorhanden waaruit de invloed van veiligheidsregulering met de daaraan verbonden sancties op het gedrag van nietgemotoriseerden kon worden afgeleid. In de literatuur wordt gepleit voor meer controle op de naleving van verkeersregels, met name bij jonge fietsers en voetgan- 
gers. ${ }^{1913}$ In dat kader wordt genoemd het opleggen van hoge boetes bij het rijden door rood licht, gekoppeld aan een hoge pakkans. ${ }^{1914}$

Empirisch onderzoek met betrekking tot het gemotoriseerde verkeer heeft uitgewezen dat handhaving van veiligheidsregulering en het opleggen van sancties tot meer veiligheid en zorgvuldigheid en tot een vermindering van het aantal verkeersongevallen leidt. ${ }^{1915}$ Soortgelijk empirisch onderzoek zal ook ten aanzien van nietgemotoriseerden dienen te worden verricht, waarbij moet worden onderzocht wat, rekening houdend met de handhavingskosten, het effect is van bepaalde maatregelen op het verkeersgedrag van niet-gemotoriseerden. Fietsers rijden door rood licht, maar blijven zij dit ook doen wanneer zij voor overtreding van deze verkeersregel een (hoge) boete krijgen opgelegd? Wat is bijvoorbeeld het effect van het opleggen van een sanctie voor het dronken op de fiets zitten, die daarin bestaat dat het rijbewijs of de fiets zelf in beslag wordt genomen?

\subsection{COMPENSATIE}

Wanneer de nadruk ligt op de compensatie van verkeersslachtoffers staat het Nederlandse wetsvoorstel met een bijna absolute aansprakelijkheid garant voor een optimale vergoeding van het slachtoffer. De vraag of het slachtoffer ook daadwerkelijk wordt gecompenseerd is echter afhankelijk van een aantal factoren, waarbij met name moet worden gedacht aan het optreden van vertragingen met betrekking tot de wijze van uitkering van de schade, de discussie over de omvang van de schade en de bepaling van de eindtoestand.

Een verkeersverzekering heeft ten opzichte van een aansprakelijkheidsregime het voordeel dat in beginsel het enkele feit dat het motorrijtuig schade heeft doen ontstaan, meebrengt dat de verzekering tot uitkering komt. Vertraging kan ontstaan bij de vaststelling van de omvang van de schade en de bepaling van de eindtoestand. Teneinde de premie voor een verkeersverzekering niet te hoog te laten worden, dienen beperkingen te worden gesteld aan de omvang van de uit te keren schade. Dit is een nadeel ten opzichte van een aansprakelijkheidsregime, omdat vergoedingslimieten ertoe leiden dat het slachtoffer in beginsel geen volledige schadevergoeding krijgt. De vraag is echter of dit in de praktijk ook werkelijk het geval is. Amerikaans onderzoek heeft immers uitgewezen dat de meeste slachtoffer onder een no-fault verzekering hun schade, mits deze niet een hoge omvang had, volledig kregen vergoed. Voorts geldt dat de verkeersverzekering in de Nederlandse voorstellen vooral

1913. ANWB, VR, 1998, p. 35: 'Handhaving van verkeersregels en educatie dienen zo vroeg mogelijk hand in hand te gaan'.

1914. Kremer, Hennekam en Van der Harst, VR, 1998, p. 293.

1915. Zie daarover hoofdstuk 12. 
een aanvullend karakter heeft bovenop de aan de zijde van het slachtoffer aanwezige voorzieningen.

\subsection{ADMINISTRATIEVE KOSTEN}

Bij de keuze tussen een stelsel van risicoaansprakelijkheid met een beperkt eigen schuldverweer versus een verkeersverzekering zijn tenslotte ook de uitvoeringskosten van belang. Voor beide systemen geldt dat de afwikkeling van de schade tot kosten leidt, die sterk kunnen oplopen in verband met de discussie over de omvang van de schade en de bepaling van de eindtoestand.

Het voorgestelde systeem van risicoaansprakelijkheid met een beperkt eigen schuldverweer heeft hoge uitvoeringskosten. Niet alleen de discussie over de 'betrokkenheid', de 'opzet of bewuste roekeloosheid' en de vaststelling van de schadeomvang kan tot hoge kosten leiden. Ook de keuze om regresnemers te laten ageren op basis van artikel 6:162 BW zal aanvankelijk tot een kostenstijging leiden. Daarbij ontstaat tevens een tweedeling in het aansprakelijkheidsrecht met enerzijds de afwikkeling van de schade van het slachtoffer zelf en anderzijds de beoordeling van de vordering van de regresnemer. ${ }^{1916} \mathrm{Bij}$ de laatste kan standaardisatie mogelijk tot een kostenbesparing leiden.

Bij een verkeersverzekering behoeft in beginsel alleen maar onderzoek te worden verricht naar de betrokkenheid van het motorrijtuig bij het ongeval, hetgeen tot een serieuze kostenbesparing kan leiden. Bij een verkeersverzekering is de discussie echter niet beperkt tot de betrokkenheid van het motorrijtuig bij het verkeersongeval, maar kan ook betrekking hebben op de vraag in hoeverre bepaalde uitsluitingen van toepassing zijn. Essentieel voor een verkeersverzekering is immers dat de voorwarden voor dekking (behoudens ingrijpen door de wetgever) in de verzekeringspolis wordt bepaald. De wetgever kan wettelijk ingrijpen bij een verkeersverzekering door bijvoorbeeld de voorwaarden te regelen waaronder een verkeersverzekeraar dekking dient te verlenen. Daarbij zou kunnen worden bepaald dat bepaalde uitsluitingsgronden niet aan het slachtoffer kunnen worden tegengeworpen. Dit beperkt het probleem van de administratieve kosten, maar lost het niet helemaal op. De uitsluiting kan immers nog steeds een rol spelen wanneer de verzekeraar weliswaar het slachtoffer diende te vergoeden, maar vervolgens regres neemt op zijn verzekeringnemer.

Er dient voorts nog met een ander aspect van de administratieve kosten rekening te worden gehouden. Bij de onderhavige analyse werd er namelijk steeds vanuit gegaan dat de wetgever niet met een bestaande situatie te maken zou hebben, maar kan

1916. Zie daarover Van Maanen en Nelissen, in Verkeersaansprakelijkheid, p. 197-216 en Van Maanen, NJB, 1998, p. 116-121. 
kiezen welk stelsel hij zou invoeren met het oog op de verhoging van de sociale welvaart. In Nederland heeft de wetgever bij de invoering van een bepaald regime, steeds met een bestaande situatie te maken. Dat brengt mee dat de hervorming van het bestaande stelsel (van aansprakelijkheid) naar een verkeersverzekering niet zonder invoeringskosten zal verlopen. Deze kosten kunnen op korte termijn zeer hoog zijn, hoewel terzake onmogelijk een concrete inschatting kan worden gemaakt. Dit kan de wetgever er wellicht van weerhouden een systeem van verkeersverzekering in te voeren. Daar staat tegenover dat ook met de lange termijnvoordelen rekening dient te worden gehouden. Het is mogelijk dat de voordelen op het terrein van een effectievere compensatie en een reductie van de overige administratieve kosten op lange termijn zo hoog zijn dat deze de invoeringskosten op korte termijn overstijgen. Derhalve dient ook naar de lange termijneffecten te worden gekeken, omdat anders de discussie over de invoeringskosten elke wijziging onmogelijk zou maken. Dat geldt overigens niet alleen bij de invoering van een verkeersverzekering, maar bij elk voorstel tot een ingrijpende wijziging van de geldende wetgeving. ${ }^{1917}$

\subsection{REGRESRECHTEN EN VERZEKERINGSPREMIES}

In het Nederlandse wetsvoorstel is ervoor gekozen de regresnemer in het vervolg te laten ageren op basis van artikel 6:162 BW, opdat de regresnemers niet langer de bescherming genieten van artikel $185 \mathrm{WVW}$ en ook niet profiteren van de bescherming van de verkeersslachtoffers zelf in het wetsvoorstel. Daarnaast kan worden gewezen op de uitbreiding van de regresrechten naar de volksverzekeringen. ${ }^{1918}$

In de Memorie van Toelichting wordt bij een stelsel van risicoaansprakelijkheid een stijging van de WAM-premie met $23-30 \%$ voorspeld. Deze stijging is gebaseerd op een schatting van de toename van de schadelast wanneer de bescherming van verkeersslachtoffers, met uitzondering van de bestuurders van een motorrijtuig, in het voorstel wordt uitgebreid. De vraag is of daarbij rekening is gehouden met het feit dat de regresnemers hun vordering dienen te baseren op artikel 6:162 BW. Dit zou namelijk ook kunnen betekenen dat, ondanks de uitbreiding van het regres naar de volksverzekeringen, de premies dalen, ook al omdat volgens de Memorie van Toelichting $95 \%$ van de regresacties betrekking heeft op ongevallen in het verkeer. ${ }^{1919}$ Tenslotte wordt de schade van de bestuurders van een motorrijtuig bewust buiten de bescherming van het wetsvoorstel gehouden. Naar de mening van de Minister kan

1917. Zie Frenk, NJB, 1999, p. 1547-1554, voor een beschrijving van de 'ingrijpende' gevolgen van een overstap van het aansprakelijkheidsrecht naar een directe schadeverzekering.

1918. Zie daarover onder anderen Janssen, VA, 1997, p. 155-162 en paragraaf 6.1 van hoofdstuk 3.

1919. Zie daarover Memorie van Toelichting, TK, 1997-1998, 25759, nr. 3, p. 14-15 en p. 30. 
daarmee de premiestijging beperkt blijven, ${ }^{1920}$ maar deze bedraagt desondanks 23 $30 \%$.

Bij de invoering van een stelsel waarin ook de motorrijtuigbestuurders onder alle omstandigheden hun personenschade vergoed krijgen, hetzij via een risicoaansprakelijkheid, hetzij via een verkeersverzekering zullen de verzekeringspremies met 35 $40 \%$ stijgen. Gecombineerd met de uitbreiding van het regres (premietoename 9$17 \%$ ) leidt dit tot een premiestijging van $44-57 \% .{ }^{1921}$ De vraag is of deze premiestijging tengevolge van de invoering van een verkeersverzekering wel zo hoog is als in de Memorie van Toelichting bij het Nederlandse wetsvoorstel wordt beweerd. De daarin genoemde premiestijging is enerzijds gebaseerd op schattingen met betrekking tot de toename van de WA-schadelast en anderzijds op de veronderstelling dat de schade van de bestuurder onder de dekking van de in te voeren verkeersverzekering valt.

In de voorstellen voor een verkeersverzekering geldt deze voor alle verkeersdeelnemers, dus ook voor de bestuurders van een motorrijtuig, zodat de premiestijging ten opzichte van het huidige stelsel (art. $185 \mathrm{WVW}$ ) aanzienlijk is. Deze premiestijging kan worden beperkt wanneer de vergoeding van de inkomensschade en het smartengeld worden gelimiteerd. In de ideeën van Bloembergen en Van Wassenaer dient de invoering van een verkeersverzekering ook gepaard te gaan met een totale afschaffing van het regres. Met name Bloembergen heeft zich in verscheidene geschriften een groot tegenstander van regres getoond. Het gaat hier naar zijn mening slechts om een zinloos 'rondpompen van geld' zonder enig compenserend voordeel. Toch ziet Bloembergen zelf ook in dat een pleidooi voor een afschaffing van regresrechten politiek gevoelig ligt omdat regresnemers, in de woorden van Bloembergen, deze 'duiten' niet willen missen. ${ }^{1922}$ Daar komt bij dat een pleidooi voor een afschaffing van regres, zoals hierboven werd toegelicht, haaks staat op de tendens in de wetgeving om het aantal regresrechten juist uit te breiden. Een alternatief voor een (politiek onhaalbare) afschaffing van regresrechten zou een collectivering ran het regres kunnen zijn. Dit heeft immers het voordeel dat wel een verschuiving van de schadelast plaatsvindt, derhalve een correcte kostenallocatie, ${ }^{1923}$ terwijl anderzijds de hoge administratieve kosten van het individuele regres kunnen worden vermeden. ${ }^{1924}$

1920. Memorie van Toelichting, TK, 1997-1998, 25759, nr. 3, p. 14-15.

1921. Dit blijkt uit berekeningen van het Centrum voor Verzekeringstatistiek van het Verbond van Verzekeraars. Zie Memorie van Toelichting, TK, 1997-1998, 25759, nr. 3, p. 14-15.

1922. Zie daarover Bloembergen, NTBR, 1998, p. 170: 'Politieke realiteit botst met de juridische rationaliteit'.

1923. Zie Van Maanen en Nelissen, in Verkeersaansprakelijkheid, p. 212.

1924. Zie over de voordelen van collectivering van regres: Faure, in Regrestechten, afschaffen, handhaven of uitbreiden, p. 60-69. 


\section{Conclusie en aanbevelingen}

In de meeste Europese landen is de laatste decennia het aantal verkeersongevallen en verkeersslachtoffers ondanks de toename van het aantal auto's relatief sterk gedaald. ${ }^{1925}$ Dit is mede het gevolg van een groot aantal fysieke (veiliger (snel) wegen) en wetgevende maatregelen die in de betreffende landen zijn ingevoerd met het doel de verkeersveiligheid te bevorderen. ${ }^{1926}$ De vraag welke van deze maatregelen concreet aan de vermindering van het aantal verkeersongevallen heeft bijgedragen is moeilijk te beantwoorden. Ook de invoering van een bepaald systeem voor de vergoeding van verkeersschade zal bij de daling een rol kunnen hebben gespeeld, maar een rechtstreeks verband met de vermindering van het aantal verkeersongevallen is nog niet empirisch vastgesteld. De empirische studies waarin een causaal verband tussen bepaalde maatregelen en een daling van het aantal verkeersongevallen wel wordt aangetoond hebben vooral betrekking op de veiligheid in de auto, de autoveiligheidsgordel en de airbag, en het effect van administratieve en strafrechtelijke sancties in het verkeer, zoals bij het rijden onder invloed. ${ }^{1927}$

In het onderhavige onderzoek stond de vraag centraal welke combinatie van aansprakelijkheid, verzekering en veiligheidsregulering kan leiden tot een optimale preventie en compensatie van verkeersongevallen tegen zo laag mogelijke kosten. Binnen het kader van deze probleemstelling is geconcludeerd dat van het aansprakelijkheidsrecht sec in theorie een preventieve werking op het gedrag van dader en slachtoffer kan uitgaan, maar dat deze veronderstelling niet empirisch kon worden bevestigd voor wat betreft de dader en niet kon worden beantwoord ten aanzien van de positie van het slachtoffer. Dit leidt tot de conclusie dat meer empirisch onderzoek noodzakelijk is om de preventieve werking van aansprakelijkheidsregels in het verkeer te kunnen vaststellen.

In het beschreven empirisch onderzoek is niet alleen gebleken dat de rol van het aansprakelijkheidsrecht binnen de preventie van verkeersongevallen onzeker is, maar ook dat de rol van het aansprakelijkheidsrecht bij de compensatie van verkeersslachtoffers is verwaterd. Dit wordt vooral veroorzaakt door de toegenomen invloed van verzekeringen. Verzekeringen zijn in Nederland inmiddels dermate wijdverbreid dat deze een centrale plaats hebben ingenomen dan wel behoren in te nemen met betrekking tot preventie van verkeersongevallen en de vergoeding van verkeersslachtoffers. In het onderhavige onderzoek is daarbij betoogd dat verzekeringsvoorwaarden van invloed kunnen zijn op het verkeersgedrag. Uit het empirisch onderzoek kon echter niet worden opgemaakt dat autoverzekeraars een economisch juiste

1925. Zie voor een cijfermatig overzicht hiervan paragraaf 2 van hoofdstuk 9.

1926. Zie daarover het SER-advies d.d. 15 oktober 1999, p. 36-41, waarin tevens een schets wordt gegeven van mogelijke toekomstige ontwikkelingen.

1927. Zie daarover hoofdstuk 12. 
premiedifferentiatie toepassen. ${ }^{1928}$ Ook kon geen causaal verband worden aangetoond tussen verzekeringsvoorwaarden en de invloed daarvan op het verkeersgedrag dan wel de vermindering van het aantal verkeersongevallen. Dit betekent dat ook op het terrein van de verzekering meer empirisch onderzoek noodzakelijk is.

Uit het voorgaande volgt dat in het kader van de preventie en de compensatie niet duidelijk is of met een combinatie van aansprakelijkheid en verzekering een optimaal resultaat wordt bereikt. Om deze vraag te kunnen beantwoorden is additioneel onderzoek noodzakelijk. Op basis van de onderzoeksresultaten zal veiligheidsregulering daarbij een belangrijke (aanvullende) rol dienen te vervullen. Uit empirisch onderzoek is immers gebleken dat bepaalde veiligheidsmaatregelen van invloed zijn op de vermindering van het aantal verkeersongevallen. Dit onderzoek had echter voornamelijk betrekking op de gedragingen van de automobilist en niet op die van de fietser of voetganger. ook hier geldt dat aanvullend empirisch onderzoek noodzakelijk is om de invloed van veiligheidsregulering (administratieve en strafrechtelijke sancties) op met name het gedrag van niet-gemotoriseerden te kunnen bepalen. Naast onderzoek naar de daadwerkelijke (niet-)naleving van de verkeersregels door fietsers en voetgangers, kan ook worden onderzocht of nieuwe regelgeving op het terrein van de schadevergoeding waarin fietsers en voetgangers verregaand worden beschermd een negatieve invloed heeft op hun verkeersgedrag. Wordt er meer door rood licht gereden of gelopen, zo ja dan zal via het administratieve- en strafrecht de nadruk moeten liggen op meer controle en het opleggen van sancties.

Op basis van de conclusies van het onderhavige onderzoek en de toetsing aan de $\mathrm{Ne}$ derlandse verkeersaansprakelijkheid kan worden geconcludeerd dat bij de uiteindelijke keuze voor een bepaald vergoedingsstelsel met vele juridische, economische en politieke factoren rekening moet worden gehouden. Binnen de Nederlandse (juridische) discussie ligt vooral de nadruk op de compensatie (bescherming) van verkeersslachtoffers. Daarbij wordt enerzijds gepleit voor een stelsel van een verkeersverzekering. ${ }^{1929}$ Anderzijds wordt vastgehouden aan de aansprakelijkheid als grondslag voor de vergoeding van verkeersschade. ${ }^{1930}$

Van groot belang is dat bij de uiteindelijke keuze voor een stelsel van verkeersaansprakelijkheid (verder) onderzoek noodzakelijk is. Het onderhavige onderzoek heeft bijvoorbeeld geen duidelijkheid kunnen geven omtrent de daadwerkelijke rol van het

1928. Uit onderzoek is bijvoorbeeld gebleken dat het huidige bonus-malus systeem bij autoverzekeringen niet de juiste financiële prikkels aan de verzekerde autobestuurder geeft om zich in het verkeer zorgvuldig te gedragen. Zie paragraaf 4.3 .3 van hoofdstuk 11.

1929. Zie daarover bijvoorbeeld: C.C. van Dam, VR, 1997, 358; Hartlief, in Verkeersaansprakelijkheid, p. 187-192; Elzas, Special Handboek, p. 17-18, p. 23-24 en p. 44-45; ANWB, VR, 1998, p. 33-34; Hartlief, RM Themis, 1999, p. 52-53.

1930. Zie Van Maanen en Engelhard, VR, 1999, p. 135-139. 
aansprakelijkheidsrecht in het verkeer, de preventieve werking van de verzekeringsvoorwaarden en de invloed van veiligheidsregulering op het gedrag van niet-gemotoriseerde verkeersdeelnemers. Met betrekking tot de vergoeding van verkeersschade in Nederland dateert het laatste grootschalig gerichte onderzoek alweer uit $1973 .{ }^{1931}$ In Noord-Amerika en Canada zijn in dat verband reeds een aantal uitgebreide studies op het terrein van de verkeersaansprakelijkheid verschenen. ${ }^{1932}$ Naast de schadevergoeding in het verkeer zelf wordt in deze studies bijvoorbeeld ook een vergelijking gemaakt tussen verschillende vergoedingsstelsels.

Met betrekking tot de Nederlandse situatie moet een dergelijk grootschalig onderzoek ook mogelijk zijn, hetgeen wel de medewerking c.q. samenwerking vraagt van een groot aantal betrokken instanties. Daarbij kunnen naast de eerder genoemde preventieve aspecten ook bijvoorbeeld de concrete gevolgen van een bepaald vergoedingsstelsel voor de verzekeringspremie worden berekend. Verder kan aandacht worden besteed aan de schadevergoedingsprocedure, de invloed van het regres hierop, de belasting van de rechterlijke macht en de omvang van de uitgekeerde schade.

Het onderhavige onderzoek heeft aangetoond dat alleen met behulp van een grondig statistisch en empirisch onderzoek naar de aansprakelijkheid, de verzekering en de veiligheidsregulering in het verkeer het juridische, het economische maar vooral ook het politieke verkeersdebat op een juiste wijze kan worden gevoerd. In een dergelijk debat dient met name vanuit preventief oogpunt een gecombineerde toepassing van aansprakelijkheid, verzekering en veiligheidsregulering tot uitgangspunt te worden genomen. Dit onderzoek heeft immers aangetoond dat voornoemde juridische instrumenten niet separaat kunnen worden bediscussieerd, zij beïnvloeden elkaar. Bij de keuze voor een stelsel met aansprakelijkheid en verzekering is kennis nodig van de preventieve werking van aansprakelijkheidsregels en van de rol van verzekeringen op preventief en compensatoir vlak. Een preventieve werking van aansprakelijkheidsregels kan niet worden bereikt zonder de invloed van de verzekeringsvoorwaarden daarbij te betrekken. Veiligheidsregulering (administratieve en strafrechtelijke sancties) tenslotte, is van belang daar waar de preventieve werking van de markt van aansprakelijkheid en verzekering niet tot een optimaal resultaat leidt.

1931. Bloembergen en Van Wersch, Verkeersslachtoffers en hun schade, 1973; Bloembergen e.a., Duizend botsingen, 1972. In Nederland zijn pas recent het Nationaal Platform Personenschade (NPP) en de Stichting Personenschade Instituut van Verzekeraars (PIV) opgericht die mede tot doel hebben om onderzoek te verrichten naar de schadevergoeding in het verkeet. Verder kunnen in het kader van de verkeersveiligheid ook de onderzoeksrapporten van de Stichting Wetenschappelijk Onderzoek Verkeersveiligheid (SWOV) worden genoemd.

1932. Bijvoorbeeld: Osborne Commission, Report of Inquiry into Motor Vehicle Accident Compensation in Ontario, 1988; Ontario Law Reform Commission, Report on Compensation for Personal Injuries and Death, 1987; U.S. Department of Transportation, Comepnsating Auto Accident Victims, 1985; The Rand Corporation, Automobile Accident Compensation, Volume I-IV, 1985. Deze studies zijn in hoofdstuk 13 aan de orde geweest. 


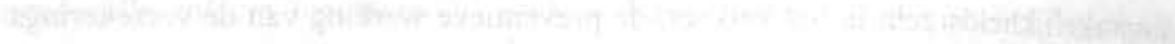

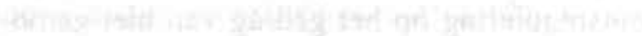

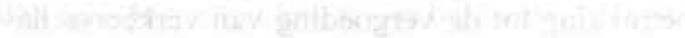

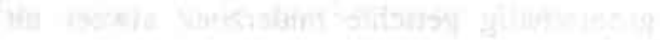

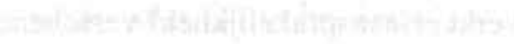

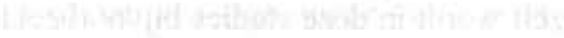

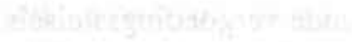

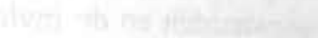

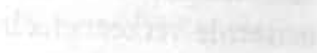

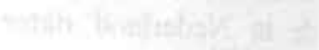

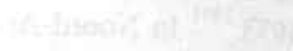

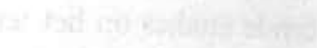

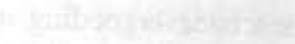

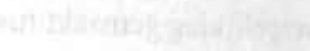

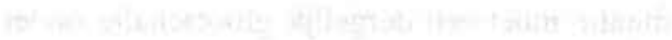

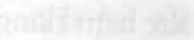

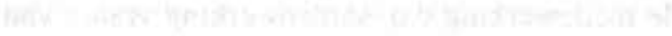

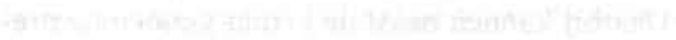




\section{Samenvatting}

Dit boek is een verslag van een onderzoek dat is verricht naar verkeersongevallen. De centrale vraag daarbij is welke combinatie van aansprakelijkheid, verzekering en veiligheidsregulering leidt tot een optimale preventie van verkeersongevallen en een optimale compensatie van verkeersslachtoffers tegen zo laag mogelijke kosten. Preventie heeft daarbij betrekking op de economische doelstelling van minimalisering van de maatschappelijke kosten van verkeersongevallen. Compensatie ziet op de vraag hoe verkeersslachtoffers schadeloos kunnen worden gesteld. Met dit onderzoek is beoogd een additionele bijdrage te leveren aan de Nederlandse discussie omtrent de verkeersaansprakelijkheid door naast compensatie ook preventie en kosten centraal te stellen.

Verantwoording. Aan de hand van een opsomming van en een toelichting op de knelpunten binnen de huidige Nederlandse verkeersaansprakelijkheid wordt het belang van het onderzoek aangegeven. Verder wordt de probleemstelling toegelicht en worden de methode en indeling van het onderzoek gepresenteerd.

De probleemstelling wordt uitgewerkt aan de hand van een positiefrechtelijke analyse (deel I) en een rechtseconomische analyse (deel II), die samen met een empirische analyse van het economisch model (deel III) de basis vormt voor de toetsing van het positieve recht en aanverwante voorstellen (deel IV). In de positiefrechtelijke analyse wordt, naast de Nederlandse verkeersaansprakelijkheid, in een rechtsvergelijkend perspectief aandacht besteed aan de verkeersaansprakelijkheid in Frankrijk en België. In de rechtseconomische analyse wordt aan de hand van het economisch model van het ongevallenrecht onderzocht op welke wijze het recht de gedragingen van de bij een verkeersongeval betrokken partijen kan beïnvloeden. Daarbij wordt nagegaan of de juridische instrumenten uit de probleemstelling in theorie van invloed kunnen zijn op de preventie en compensatie van verkeersongevallen. Aangezien het van belang is om de theoretische conclusies van de rechtseconomische analyse te toetsen aan de praktijk, wordt vervolgens kritisch aandacht besteed aan het empirisch onderzoek dat op het terrein van het verkeersongevallenrecht is verricht. Op deze wijze kan worden beoordeeld of het recht, in de vorm van aansprakelijkheidsregels, verzekeringsvoorwaarden en veiligheidsregulering, ook daadwerkelijk van invloed is op het verkeersgedrag en het aantal verkeersongevallen.

\section{Deel I: De positiefrechtelijke analyse.}

Hoofdstuk 1. In Frankrijk is sinds 1986 de 'loi Badinter' van kracht. Met deze bijzondere wet wordt onder andere een risicoaansprakelijkheid gevestigd op de bezitter of houder van een motorrijtuig voor de schade van de fietser, voetganger en passagier. Is de betrokkenheid van het motorrijtuig bij een verkeersongeval vastgesteld dan is de aansprakelijkheid van de motorrijtuigbezitter gegeven. Een beroep op de 
eigen schuld ('faute inexcusable') van het slachtoffer is niet mogelijk, tenzij de schuld onverschoonbaar is en als enige oorzaak van het ongeval kan worden aangemerkt. Personen beneden de 16 jaar, personen boven de 70 jaar en personen die voor het ongeval reeds $80 \%$ invalide waren, worden altijd volledig schadeloos gesteld. Voor alle slachtoffers geldt dat bij een opzettelijke fout de vergoedingsplicht vervalt. Als gevolg van de ruime uitleg van de 'betrokkenheid' en een strikte uitleg van de 'faute inexcusable' door het Franse Hof van Cassatie, heeft de grondslag van de 'loi Badinter' zich ontwikkeld van een aanvankelijke risicoaansprakelijkheid met een eigen schuldverweer naar bijna absolute aansprakelijkheid voor de bezitter van een motorrijtuig. De bestuurder van een motorrijtuig is voor de vergoeding van zijn schade aangewezen op een regel van foutaansprakelijkheid. Hierbij wordt voor de eigen 'faute' van een slachtoffer-bestuurder een objectief criterium gehanteerd, waardoor hij niet geheel van schadevergoeding verstoken blijft.

Een belangrijk aspect van de 'loi Badinter' is de verplichte transactieprocedure, waarbij de verzekeraar verplicht is om binnen 8 maanden na het ongeval aan het slachtoffer dat lichamelijke schade heeft geleden een definitief aanbod tot schadevergoeding ('l'offre d'indemnité') voor te leggen. Hoewel met de 'loi Badinter' de vergoeding van niet-gemotoriseerde verkeersslachtoffers is verbeterd, blijkt in de praktijk dat de schadevergoeding, ondanks de verplichte transactieprocedure, niet veel sneller wordt uitgekeerd.

Met betrekking tot de regresprocedure is naast de 'loi Badinter' ook het tussen sociale- en motorrijtuigverzekeraars gesloten 'Protocole d'Accord' (dat is aangepast aan de termijnen van de 'loi Badinter') van toepassing. Deze regeling uit 1983 heeft betrekking op een vereenvoudigde afhandeling van individuele regresdossiers volgens een vaste procedure met een geheel eigen karakter. Daarbij wordt gebruik gemaakt van een abstract baremastelsel, waarbinnen de omvang van de schadevergoeding wordt berekend aan de hand van standaarden ten aanzien van aansprakelijkheid, letselschade en eventuele kosten.

Hoofdstuk 2. In België is de wet van 13 april 1995 van belang die op 1 juli 1995 van kracht is geworden. Deze wet, die veelal wordt aangeduid als de 'artikel 29 bis WAM-regeling', omvat de vergoeding van bepaalde slachtoffers van verkeersongevallen, in het bijzonder de zogenaamde zwakke verkeersdeelnemers, zijnde fietsers, voetgangers en passagiers. De aansprakelijkheid voor de schade van deze slachtoffers rust op de aansprakelijkheidsverzekeraar van de bestuurder of bouder van het betrokken motorrijtuig.

Tot aan de invoering van deze regeling werd in België de aansprakelijkheid en de schadevergoeding naar aanleiding van een verkeersongeval geregeld door artikel $1382 \mathrm{BW}$. Het verkeersslachtoffer diende de veroorzaker van de schade aan te spreken op grond van onrechtmatige daad. Het slachtoffer moest de schuld van de veroorzaker en het causaal verband tussen de fout en de schade aantonen. Het enkele 
feit dat door een bepaald risico, bijvoorbeeld autorijden, schade werd veroorzaakt, leverde daarbij nog geen bewijs van een fout op. De schadeveroorzaker kon een beroep op overmacht doen en eigen schuld aan de zijde van het slachtoffer kon leiden tot een overeenkomstige vermindering van de schadevergoeding. Fietser en voetganger en de bestuurder van een motorrijtuig werden als min of meer gelijkwaardige verkeersdeelnemers beschouwd.

Sinds 1995 geldt dat de bezitter van een motorrijtuig via zijn aansprakelijkheidsverzekering in bijna alle gevallen verantwoordelijk wordt gehouden voor de schade van de niet-gemotoriseerde verkeersdeelnemer. De bestuurder van een motorrijtuig is voor de vergoeding van zijn schade aangewezen op de foutaansprakelijkheid van artikel $1382 \mathrm{BW}$, de beschikbare sociale verzekeringen en eventueel zelf af te sluiten schadeverzekering.

Artikel 29bis WAM is grotendeels gebaseerd op en geïnspireerd door de Franse 'loi Badinter'. Ook in de Belgische regeling nemen de begrippen 'betrokkenheid' en 'onverschoonbare fout' een centrale plaats in, waarbij voor een uitleg wordt verwezen naar de jurisprudentie van het Franse Hof van Cassatie. Met betrekking tot de onverschoonbare fout is België begin 2001 wettelijk nog een stap verder gegaan dan de Franse 'loi Badinter', door te bepalen dat alleen verkeersslachtoffers die het ongeval en zijn gevolgen hebben gewild (zelfmoord) geen beroep kunnen doen op de bescherming van artikel $29 \mathrm{bis}$. Daarmee is deze regeling vanuit het oogpunt van slachtofferbescherming verder geperfectioneerd en is in feite een verkeersverzekering voor de schadevergoeding van zwakke weggebruikers gecreëerd.

Hoofdstuk 3. Het uitgangspunt binnen de Nederlandse verkeersaansprakelijkheid is dat de schade tengevolge van een verkeersongeval wordt vergoed op basis van de schuldaansprakelijkheid van artikel 6:162 BW. Dit regime is van toepassing op verkeersongevallen tussen motorrijtuigen onderling, fietsers onderling en ongevallen tussen fietsers en voetgangers.

Met betrekking tot verkeersongevallen tussen gemotoriseerd en niet-gemotoriseerd verkeer is de bijzondere regeling van artikel 185 WVW (artikel 31 WVW oud) van toepassing. Op grond van deze bepaling is de houder van een motorrijtuig aansprakelijk voor de schade van de fietser of voetganger, tenzij hij overmacht aannemelijk maakt. Ingevolge de jurisprudentie van de Hoge Raad geldt bij overmacht dat aan de bestuurder rechtens geen enkel verwijt kan worden gemaakt en dat de fout van de fietser of voetganger voor hem zo onwaarschijnlijk was dat hij daar in de concrete omstandigheden geen rekening mee kon houden. Wanneer geen overmacht aannemelijk is, doch er wel een fout van de fietser of voetganger is, zonder dat sprake is van opzet of aan opzet grenzende roekeloosheid eist de billijkheid (artikel 6:101 $B W$ ), dat bij ongemotoriseerden van 14 jaar en ouder tenminste $50 \%$ van de schade ten laste van het motorrijtuig wordt gebracht wegens de verwezenlijking van het daaraan verbonden gevaar. Het risico (100\%-regel) van een aanrijding met een kind 
beneden de 14 jaar is door de Hoge Raad geheel voor rekening van de bestuurder van het motorrijtuig gebracht. Dit betekent dat bij een aanrijding tussen motorrijtuig en een kind, de eigen schade van het kind volledig zal worden vergoed, tenzij het gedrag van het kind opzet of aan opzet grenzende roekeloosheid oplevert.

Regresnemende verzekeraars profiteren niet van de door de Hoge Raad ten behoeve van het slachtoffer zelf ontwikkelde billijkheidsregels. De vordering van de regresnemers dient te worden beoordeeld aan de hand van de overmacht van artikel 185 WVW en de eigen schuld van artikel 6:101 BW. Hierbij geldt dat na het oordeel over de causale verdeling voor een billijkheidscorrectie ten behoeve van het slachtoffer doorgaans een beperkte ruimte bestaat.

Vanuit de wetenschappelijke literatuur wordt sinds een aantal decennia getracht de wetgever te bewegen tot een hervorming van de verkeersaansprakelijkheid, waarbij vooral de nadruk ligt op een betere bescherming van verkeersslachtoffers. Dit pleidooi is voor een belangrijk deel op gang gebracht door Bloembergen en Van Wassenaer van Catwijck en heeft later bij andere auteurs navolging gevonden. Een meerderheid van de rechtsgeleerde auteurs spreekt een voorkeur uit voor een oplossing van de verkeersschadeproblematiek buiten het aansprakelijkheidsrecht om. Daarbij wordt veelal gekozen voor een vorm van een verkeersverzekering, die de personenschade van het slachtoffer vergoedt, voorzover deze niets reeds uit eigen bronnen beschikbaar komt.

De wetgever is de doctrine echter niet gevolgd en is blijven vasthouden aan het aansprakelijkheidsrecht als grondslag voor de vergoeding van verkeersschade. In dat kader is eind 1997 door de toenmalige Minister van Justitie Sorgdrager een wetsvoorstel Verkeersongevallen ingediend. Dit voorstel is door haar opvolgster Korthals echter weer ingetrokken, waarbij hij plannen voor nieuwe wetgeving aankondigt die niet veel afwijken van het eerdere wetsvoorstel. In beide gevallen wordt een vestiging van een risicoaansprakelijkheid van de bestuurder of houder van een motorrijtuig voor de personenschade van de fietser, voetganger en passagier beoogd. Verder is de werkgever risicoaansprakelijk voor de personen- en zaakschade die zijn bestuurder-werknemer tengevolge van een verkeersongeval lijdt. De bestuurder van een motorrijtuig, niet zijnde een werknemer, valt buiten de bescherming van deze voorstellen. Is de betrokkenheid van het motorrijtuig bij een verkeersongeval vastgesteld dan is de aansprakelijkheid van de motorrijtuigbezitter gegeven. Alleen wanneer het gedrag van het slachtoffer verwijst naar 'opzet of bewuste roekeloosheid' (wetsvoorstel), of 'gewone roekeloosheid als enige oorzaak van het ongeval' (plannen Korthals), vervalt de schadevergoedingsplicht van de bezitter, ook wanneer deze zelf een fout heeft begaan. De bescherming van verkeersslachtoffers ingevolge het wetsvoorstel komt niet ten goede aan de regresnemende verzekeraars. Als gevolg van de beoogde afschaffing van artikel 185 WVW zijn deze instanties, evenals de bestuurder van het motorrijtuig, aangewezen op artikel 6:162 BW. 
Deel II: De rechtseconomische analyse van het verkeersongevallenrecht.

Hoofdstuk 4. De rechtseconomie kan worden beschouwd als een vakgebied, waarin wordt getracht met behulp van economische begrippen en instrumenten het recht te analyseren. De rechtseconomie is daarnaast een verklarende wetenschap waarbij ten anzien van het ongevallenrecht het efficiëntiecriterium een belangrijke rol vervult. Aan de hand van dit criterium wordt onderzocht in hoeverre rechtsregels kunnen bijdragen aan de verhoging van de maatschappelijke welvaart, dan wel of bepaalde regels deze welvaart, economisch gezien, verminderen of zelfs leiden tot verspilling.

De economische doelstelling van het verkeersongevallenrecht is de minimalisering van de maatschappelijke kosten van verkeersongevallen en komt overeen met het efficiëntiecriterium. Deze kosten kunnen worden onderverdeeld in primaire, secundaire en tertiaire ongevalskosten. De primaire kosten hangen samen met een vermindering van het aantal en de ernst van ongevallen en komen overeen met preventie. De secundaire ongevalskosten zien op een optimale spreiding van de schade die ten gevolge van het ongeval is ontstaan en hangt samen met een optimale compensatie aan slachtoffers van een ongeval. De tertiaire ongevalskosten hebben betrekking op de administratieve kosten van de behandeling van ongevallen en ontstaan bij de uitvoering van de primaire en secundaire ongevalskosten.

Binnen het economisch model van het ongevallenrecht zoals dat in dit onderzoek wordt uitgewerkt, wordt uitgegaan van twee typen van actoren, namelijk daders en slachtoffers. Daders worden daarbij voorgesteld als automobilisten die schade toebrengen aan bijvoorbeeld een fietser als zijnde het slachtoffer. Dader en slachtoffer nemen twee soorten van besluiten, namelijk of en hoe vaak zij aan een bepaalde activiteit deelnemen en het besluit ten aanzien van de mate van zorg die zij uitoefenen bij de deelname aan een activiteit. De optimale zorg, het economisch optimum, van dader en slachtoffer wordt bereikt op het punt waar de marginale kosten van de laatst toegevoegde eenheid zorg precies gelijk zijn aan de marginale opbrengst in termen van de vermindering van de verwachte schade die met deze toegevoegde eenheid zorg in verband staat.

Als uitgangspunt voor de economische analyse kan het Coase-theorema worden genomen. Dit is van toepassing wanneer een klein aantal partijen, ingeval van een potentieel verkeersongeval, door middel van onderhandelingen tegen lage transactiekosten tot een optimale afspraak kunnen komen over de aan te wenden preventieve maatregelen. Verkeersdeelnemers zijn echter vreemden van elkaar, waardoor de transactiekosten zo hoog kunnen zijn dat het onderling afsluiten van een contract met betrekking tot de gevolgen van een verkeersongeval onmogelijk wordt. $\mathrm{Bij}$ verkeersongevallen wordt derhalve niet meer aan de voorwaarden van het Coase-theorema voldaan, zodat een ingrijpen van het recht nodig is in de vorm van aansprakelijkheid of (veiligheids)regulering. 
Hoofdstuk 5. De economische analyse van het aansprakelijkheidsrecht omvat de vraag welke aansprakelijkheidsregel een verkeersdeelnemer aanzet tot een optimaal zorg- en activiteitsniveau. In deze fase van het onderzoek wordt verondersteld dat de aanwezigheid van een verzekering en de veiligheidsregulering nog geen rol spelen.

In een unilateraal model wordt verondersteld dat alleen de dader invloed kan uitoefenen op het ongevalsrisico, waarbij alleen het slachtoffer schade lijdt. In dit model zal de dader bij een regel van risicoaansprakelijkheid een optimaal zorg-en activiteitsniveau aanwenden, omdat hij aansprakelijk is voor de totale ongevalskosten. Bij een regel van foutaansprakelijkheid zal de dader een optimaal zorgniveau uitoefenen, mits de efficiënte zorg gelijk is aan de juridische zorgvuldigheidsnorm. Wanneer de dader de zorgvuldigheidsnorm naleeft is hij van aansprakelijkheid bevrijd, zodat hij geen optimaal activiteitsniveau zal aanwenden.

In een bilateraal model wordt verondersteld dat zowel dader als slachtoffer invloed uitoefenen op het ongevalsrisico, waarbij alleen het slachtoffer schade lijdt. In dit model is de dader bij een regel van risicoaansprakelijkheid met een absoluut eigen schuldverweer in beginsel aansprakelijk voor de schade van het slachtoffer, tenzij de laatste de zorgvuldigheidsnorm niet naleeft. Bij een regel van foutaansprakelijkheid moet de dader de schade van het slachtoffer vergoeden indien hij niet de door het recht vereiste zorg in acht neemt. Beide aansprakelijkheidsregels leiden tot de uitoefening van een optimaal zorgniveau bij dader en slachtoffer. Bij een regel van risicoaansprakelijkheid met een absoluut eigen schuldverweer zal de dader een optimaal activiteitsniveau aanwenden, het slachtoffer kan volstaan met de uitoefening van een efficiënt zorgniveau, waardoor hij een te hoog activiteitsniveau uitoefent. $\mathrm{Bij}$ een regel van foutaansprakelijkheid zal de dader geen optimaal activiteitsniveau uitoefenen. Het slachtoffer, wetende dat de dader door uitoefening van optimale zorg van aansprakelijkheid is bevrijd zal wel een optimaal activiteitsniveau aanwenden omdat hij anders zijn eigen schade moet dragen.

Een verfijning van het economisch model leert dat sprake kan zijn van informatieproblemen met betrekking tot de zorgvuldigheidsnorm. De rechter kan zich vergissen bij de bepaling van de zorgvuldigheidsnorm, evenals dader en slachtoffer zich kunnen vergissen ten aanzien van de toepasselijke zorgvuldigheidsnorm. Ook kunnen problemen ontstaan bij de classificatie van zorgniveaus, omdat de inspanningen (kosten) en de kennis en bekwaamheden van dader en slachtoffer om het ongevalsrisico te reduceren niet van een gelijk niveau zijn. Deze problemen compliceren de vergelijking tussen aansprakelijkheidsregels en maakt deze afhankelijk van het belang dat aan bepaalde factoren van onzekerheid wordt gehecht.

In het kader van de reductie van de primaire ongevalskosten (preventie) gaat de voorkeur uit naar een regel van risicoaansprakelijkheid wanneer het vanuit maatschappelijk oogpunt belangrijker wordt gevonden om de gevaren van het autover- 
keer te sturen, dan dat de fietser wordt aangezet tot een optimaal activiteitsniveau. Wanneer het maatschappelijk gezien belangrijker is om het gedrag van de fietser te controleren, zal een gewone regel van foutaansprakelijkheid efficiënt kunnen zijn. De fietser zal een optimaal zorg- en activiteitsniveau aanwenden, de automobilist zal een optimaal zorgniveau uitoefenen, maar geen optimaal activiteitsniveau.

In het kader van de reductie van de secundaire ongevalskosten (compensatie) geldt dat een risicoaansprakelijkheid met een absoluut eigen schuldverweer eerder een vergoeding van de schade aan de fietser garandeert dat een gewone regel van foutaansprakelijkheid. Op het terrein van de inkomensverdeling is een regel van risicoaansprakelijkheid met een absoluut eigen schuldverweer vooral in het voordeel van de fietser, wanneer hij ervan mag uitgaan dat hij in de meeste gevallen zijn schade vergoed krijgt. Bij een gewone regel van foutaansprakelijkheid geldt dat de fietser veelal zijn eigen schade draagt, tenzij de automobilist, ongeacht het gedrag van de fietser, de zorgvuldigheidsnorm niet naleeft.

In het kader van de minimalisering van de tertiaire ongevalskosten geldt dat voor wat betreft de vermindering van de kosten van aansprakelijkheidsprocedures een gewone regel van foutaansprakelijkheid de voorkeur heeft boven een regel van risicoaansprakelijkheid met een absoluut eigen schuldverweer, die tot meer rechtsgedingen leidt. Ten behoeve van een reductie van de informatiekosten, in verband met het onderzoek door de rechter naar de zorgvuldigheidsnorm, kan een risicoaansprakelijkheid met een absoluut eigen schuldverweer tot een kostenbesparing leiden.

Hoofdstuk 6. Binnen de economische analyse van het aansprakelijkheidsrecht is verondersteld dat dader en slachtoffer neutraal staan ten opzichte van het ongevalsrísico. Ten aanzien van het verkeer kan echter worden verondersteld dat fietser en automobilist een afkeer hebben van het risico om bij een verkeersongeval betrokken te raken. Deze risicoaversie kunnen zij afschuiven door het aangaan van een verzekeringsovereenkomst, waarbij een verzekeraar tegen betaling van een som geld (premie) bereid is het risico van de verzekerde over te nemen.

De aanwezigheid van een verzekering leidt tot informatieproblemen, namelijk moreel risico en anti-selectie. Het morele risico ziet op de situatie waarin een verzekeraar over onvoldoende informatie beschikt om het risico van de verzekerde juist in te schatten, waardoor deze bij een volledige verzekeringsdekking minder zorgvuldig wordt. Een verzekeraar kan het morele risico bij de verzekerde reduceren met behulp van een gedeeltelijke dekking of een eigen risico en een aanpassing van de polisvoorwaarden.

Het proces van anti-selectie ontstaat wanneer een verzekeraar door een gebrek aan informatie ten aanzien van de aangesloten risico's, slechts een premie kan vaststellen die overeenkomt met het gemiddelde risico binnen een bepaalde groep. Verzekerden binnen deze groep, voor wie de premie te hoog is in verhouding tot hun persoonlijk risico, kunnen besluiten om de risicogroep te verlaten, waardoor de minder goede risico's overblijven. Dit kan leiden tot een premiestijging, met het gevolg dat 
andere verzekerden de groep verlaten. Uiteindelijk blijven alleen de slechte risico's over. De verzekeraar kan het proces van anti-selectie vertragen door een sterke differentiatie van goede en slechte risico's en met behulp van aanvullende maatregelen die de goede risico's binnen de groep houden en slechte risico's aanzetten tot zorgvuldigheid. Daarbij worden genoemd een verhoging van het eigen risico, een verlaging van het verzekerd bedrag en het opnemen van specifieke uitsluitingen, zoals bijvoorbeeld het rijden onder invloed.

Een derde partij aansprakelijkheidsverzekering dekt de aansprakelijkheid van de dader die schade toebrengt aan het slachtoffer. Een eerste partij schadeverzekering dekt de schade van het slachtoffer zelf.

Een schadeverzekeraar beschikt over meer directe en betrouwbare informatie ten aanzien van het ongevalsrisico van de individuele verzekerde, waardoor deze beter in staat is om het morele risico en het proces van anti-selectie te reduceren. De aansprakelijkheidsverzekeraar dient echter naast het gedrag van de autobestuurder ook rekening te houden met het gedrag van het slachtoffer, die veelal door een toeval bij een verkeersongeval met de verzekerde autobestuurder betrokken raakt.

Een verplichte verzekering is van belang om informatieproblemen aan de zijde van de dader ten aanzien van het ongevalsrisico weg te nemen. Een verplichte aansprakelijkheidsverzekering kan daamaast een goede remedie zijn tegen de 'underdeterrence' die door de insolventie van de dader wordt veroorzaakt, op voorwaarde dat de verzekeringsplicht samengaat met een effectieve controle van het morele risico. Een alternatief voor een verplichte verzekering is een schadeverzekering aan de zijde van het slachtoffer.

De markt voor autoverzekeringen dient voldoende concurrerend te zijn om de verzekeraar aan te zetten tot een juiste afstemming van de premie op het individuele ongevalsrisico van de autobestuurder. Door een individualisering van de polisvoorwaarden kan zowel het morele risico als het proces van anti-selectie worden tegengegaan.

Wanneer de vergoeding via een systeem van aansprakelijkheid en verzekering niet mogelijk is, hetzij vanwege insolventieproblemen, hetzij omdat voor bepaalde risico's geen verzekeringsdekking kan worden afgegeven, kan een waarborgfonds een goede aanvulling zijn ten behoeve van een optimale compensatie van verkeersslachtoffers.

Een no-fault verzekering, waarbij de aansprakelijkheid geheel is afgeschaft, is een vergoedingssysteem dat enerzijds de schade van de inzittenden van het voertuig, bestuurder en passagiers, en anderzijds de schade van de fietser en voetganger vergoedt. De ex ante risicodifferentiatie binnen deze verzekering kan worden gebaseerd op de individuele eigenschappen en op het rijgedrag van de autobestuurder. Een ex post premieaanpassing zal niet op basis van aansprakelijkheid kunnen worden uitge- 
voerd, maar kan worden gebaseerd op het schadeverleden van de autobestuurder en het aantal verkeersovertredingen.

De uitoefening van regres heeft op het terrein van de preventie het voordeel dat de ongevalskosten aan de schadeveroorzaker kunnen worden doorberekend. Wanneer door de eerste partij verzekeraar van het slachtoffer regres wordt uitgeoefend op de schadeveroorzaker of zijn aansprakelijkheidsverzekeraar, kan de laatste via de polisvoorwaarden invloed uitoefenen op de zorgvuldigheid van de autobestuurder. Regres leidt ook tot een betere spreiding van het risico, omdat de kosten worden gelegd bij de verzekeraar van de schadeveroorzaker. Wanneer echter de administratieve kosten van regres hoger zijn dan de baten op het terrein van de preventie, kan worden gepleit voor een collectivering van regres teneinde een kostenbesparing te bereiken.

In het kader van de koppeling tussen aansprakelijkheid en verzekering is verondersteld dat de dader met een afkeer van risico een aansprakelijkheidsverzekering met volledige dekking afsluit, terwijl het slachtoffer met een afkeer van risico een schadeverzekering aangaat. De vraag of dader en slachtoffer een verzekering afsluiten, is afhankelijk van de toepasselijke aansprakelijkheidsregel. Verder is uitgegaan van de veronderstelling dat geen optimale controle van het morele risico mogelijk is en er onzekerheid is ten aanzien van de zorgvuldigheidsnorm.

Op basis van deze veronderstellingen zal met betrekking tot de reductie van de primaire ongevalskosten geen optimale combinatie van aansprakelijkheid en verzekering kunnen worden gevonden.

Een regel van risicoaansprakelijkheid met een absoluut eigen schuldverweer heeft de voorkeur wanneer belang wordt gehecht aan de risicoverhogende activiteit van de autobestuurder. In de veronderstelling dat de controle van het morele risico beter kan worden uitgevoerd bij een schadeverzekering dan bij een aansprakelijkheidsverzekering, kan worden gekozen voor een regel van foutaansprakelijkheid. Bij een no-fault verzekering zal, als gevolg van de afschaffing van de aansprakelijkheid, de preventie van verkeersongevallen exclusief door de no-fault verzekeraar moeten worden gegarandeerd. Deze preventie kan niet worden gebaseerd op aansprakelijkheid en voorts geldt dat de fietser te weinig prikkels van zorg heeft omdat zijn schade automatisch wordt vergoed.

Ten aanzien van de vermindering van de secundaire ongevalskosten geldt dat een regel van risicoaansprakelijkheid met een absoluut eigen schuldverweer de voorkeur kan hebben wanneer wordt verondersteld dat de autobestuurder, hetzij beter in staat is om de schade te vermijden, hetzij een hoger ongevalsrisico vormt dan de fietser. Wanneer belang wordt gehecht aan de veronderstelling dat de automobilist en de fietser in gelijke mate bijdragen aan het ongevalsrisico en de controle van het morele risico beter mogelijk is bij een schadeverzekering dan bij een aansprakelijkheidsverzekering, zal een regel van foutaansprakelijkheid een lichte voorkeur genieten. Een no-fault verzekering heeft het voordeel dat, afhankelijk van de omvang van de ver- 
zekeringsdekking, de schadevergoeding aan de fietser optimaal is gewaarborgd. Deze compensatie is echter in beginsel niet gebaseerd op het gedrag van de automobilist of de fietser. De controle van het gedrag van de automobilist wordt daardoor bemoeilijkt en is bij de fietser geheel afwezig.

Met betrekking tot de vermindering van de tertiaire kosten is geconcludeerd dat een risicoaansprakelijkheid met een absoluut eigen schuldverweer een lichte voorkeur kan hebben boven een regel van foutaansprakelijkheid, wanneer het geschil zonder rechterlijke tussenkomst wordt beslecht. Een no-fault verzekering leidt tot minder hoge administratieve kosten. Omdat de aansprakelijkheid is afgeschaft en de afwikkeling van de schade geheel via de no-fault verzekeraar loopt, zijn er in beginsel geen proceskosten.

Hoofdstuk 7. Hierin wordt een aantal economische theorieën van (overheids)regulering beschreven. De 'public interest' theorie heeft betrekking op het uitvaardigen van regelgeving, die tot doel heeft de maatschappelijke welvaart te verhogen. De overheid gaat vanuit het algemeen belang tot regulering over om bepaalde tekortkomingen van het marktmechanisme te corrigeren. Deze marktfalingen, die een optimaal functionerend marktmechanisme verstoren, kunnen niet door de markt zelf of via het privaatrecht worden weggenomen. Voorbeelden van marktfalingen zijn externaliteiten, de verkeersonveiligheid die door het rijden met een auto mogelijk kan worden veroorzaakt en informatie-asymmetrie, bijvoorbeeld ten aanzien van de werkwijze van een verzekeringsmaatschappij.

In een tweede theorie worden aan de hand van een aantal criteria de preventieve effecten van aansprakelijkheid en veiligheidsregulering vergeleken. Ten aanzien van het verkeer is gesteld dat een gecombineerd gebruik van ansprakelijkheid en veiligheidsregulering ten behoeve van een optimale preventie wenselijk is. Verkeersdeelnemers hebben als direct betrokkenen betere informatie ten aanzien van het ongevalsrisico. Veiligheidsregulering is, afhankelijk van de handhaving en controle van veiligheidsnormen, nodig om deze informatie verder te optimaliseren. Veiligheidsregulering kan worden gebruikt bij de bepaling van de aansprakelijkheid naar aanleiding van een verkeersongeval. Wanneer de schadeveroorzaker een veiligheidsnorm heeft overtreden, bijvoorbeeld de maximumsnelheid, kan deze standaard door de rechter worden gebruikt voor de bepaling van de aansprakelijkheid.

De 'private interest' theorie verklaart waarom de politieke besluitvorming soms leidt tot wetgeving die niet in het algemeen belang is, maar eerder onder invloed van bepaalde belangengroepen tot stand komt ('public choice'). Met name kleine belangengroepen met een hoge mate van zelfregulering, die gebruik maken van strenge toegangsregels tot de groep, kunnen effectief invloed uitoefenen op het wetgevingsproces. De belangen van grote consumentengroeperingen zijn meer algemeen geformuleerd. Toch is hun invloed niet te onderschatten nu zij een groot aantal potentiele kiezers verenigen. 
Met betrekking tot de veiligheidsregulering in het verkeer kan worden verwacht dat de autoverzekeraars en autofabrikanten vooral de toegang tot de markt en de concurrentie op de markt willen beperken, terwijl belangengroepen van automobilisten pleiten voor veiliger auto's en belangengroepen van verkeersslachtoffers streven naar een hoge mate van slachtofferbescherming. Deze conflicterende belangen binnen het lobbyproces kunnen maar op een beperkt aantal onderdelen van veiligheidsregulering tot overeenstemming worden gebracht. Een voorbeeld met betrekking tot de belangen van verkeersslachtoffers en autoverzekeraars leert, dat regulering van bijvoorbeeld opzet of dronken rijden vanuit 'public interest'-perspectief de efficiënie kan bevorderen, waarbij een betere preventie van verkeersongevallen mogelijk wordt. De belangengroepen van verkeersslachtoffers hebben, vanuit beschermingsoogpunt, belang bij dergelijke veiligheidsregulering. Voor de autoverzekeraars kan dergelijke regulering de mogelijkheden tot een controle van het morele risico van roekeloze chauffeurs verbeteren en de concurrentie op de markt verder beperken.

Hoofdstuk 8. In dit hoofdstuk wordt de rechtseconomische analyse in de vorm van stellingen samengevat en wordt tevens een aantal mogelijke combinaties van aansprakelijkheid, verzekering en veiligheidsregulering besproken.

In de eerste plaats kan worden gekozen voor een regel van risicoaansprakelijkheid met een absoluut eigen schuldverweer, waarbij aan de zijde van de autobestuurder een aansprakelijkheidsverzekering aanwezig is en de fietser beschikt over een schadeverzekering. Hierbij wordt verondersteld dat de invloed van de autobestuurder op het ongevalsrisico hoger is dan die van de fietser. Veiligheidsregulering is wenselijk op terreinen die niet door aansprakelijkheid en verzekering worden geregeld, maar kan wel voor een additionele preventie zorgen, mits de handhaving (sancties) goed wordt geregeld. Voorbeelden hiervan zijn de regulering van de maximumsnelheid, alcoholgebruik en autoveiligheid.

In de tweede plaats kan van de hypothese worden uitgegaan dat de invloed van de autobestuurder en de fietser als meer gelijkwaardig wordt verondersteld. In dat geval kan worden gekozen voor een regel van foutaansprakelijkheid gecombineerd met een aansprakelijkheidsverzekering (automobilist) en een (fietser). Veiligheidsregulering is noodzakelijk voor een verdere preventie van verkeersongevallen, maar ook om het sub-optimale activiteitsniveau van de automobilist beter te kunnen sturen.

In de derde plaats kan worden gekozen voor een via de particuliere verzekeringsmarkt aangeboden no-fault verzekering aan de zijde van de autobestuurder, gecombineerd met een strikte veiligheidsregulering. Daarbij ligt de nadruk op een optimale compensatie van de fietser en de automobilist tegen de laagst mogelijke kosten en wordt tevens verondersteld dat de automobilist meer invloed heeft op het ongevalsrisico dan de fietser. De no-fault verzekeraar zal ten behoeve van de controle van het morele risico maatregelen moeten nemen die het gedrag van de verzekerde autobestuurder kunnen beïnvloeden. Een strikte handhaving van veiligheidsregulering is noodzakelijk om het gedrag van de automobilist verder te sturen, maar vooral ook om het niet-gemotoriseerde verkeer tot zorgvuldig gedrag aan te zetten. 
In de vierde plaats kan worden gekozen voor een no-fault verzekering voor alle verkeersdeelnemers, waarbij de nadruk ligt op een optimale compensatie van verkeersslachtoffers. De verantwoordelijkheid van de no-fault verzekeraar is bij een dergelijk systeem meer gespreid en de controle van het morele risico kan beter worden uitgevoerd. Een strikte handhaving van de veiligheidsregulering blijft ook hier noodzakelijk om het gedrag van de verkeersdeelnemer verder te sturen.

Deel III: De empirische toetsing van het economisch model.

Het empirisch onderzoek bestaat uit een weergave en een kritische bespreking van reeds beschikbaar onderzoeksmateriaal. Met het empirisch onderzoek is voorts beoogd aan de hand van statistisch materiaal na te gaan of de juridische instrumenten van invloed kunnen zijn op het gedrag van een verkeersdeelnemer en op de kosten van verkeersongevallen. Daarbij wordt steeds aansluiting gezocht bij de theoretisch gemaakte veronderstellingen.

Hoofdstuk 9. Hierin komt een aantal algemene aspecten van verkeersongevallen aan de orde. In het kader van de cijfers omtrent verkeersongevallen is een vergelijking gemaakt tussen een aantal Europese landen, Noord-Amerika en Canada. Uit deze statistische gegevens, die globaal betrekking hebben op de periode 1980-1995, blijkt dat het aantal verkeersongevallen met letsel en het aantal verkeersdoden, ondanks een toename van de autodichtheid, sterk is gedaald. Voorts is het aantal verkeersdoden onder fietsers, voetgangers en passagiers in de meeste landen gedaald, terwijl het aantal verkeersdoden onder bestuurders van een motorrijtuig steeg.

Vervolgens is aandacht besteed aan een aantal empirische studies met betrekking tot verkeersgedrag en ongevalsrisico. Uit deze studies blijkt dat jonge en onervaren autobestuurders moeite hebben om de vereiste zorg in het verkeer uit te oefenen. Bij deze autobestuurders is sprake van een onderschatting van het ongevalsrisico en zij nemen in het verkeer blijkbaar meer risico's dan oudere bestuurders. Bovendien dichten zij zichzelf betere rijvaardigheden toe dan hun leeftijdgenoten. Bij oudere en ervaren bestuurders is ook sprake van een lage subjectieve inschatting van het ongevalsrisico, terwijl uit de cijfers niet blijkt dat oudere bestuurders naar verhouding bovenmatig zijn vertegenwoordigd in de ongevalsstatistieken. Een onderzoek dat zich richt op het ongevalsrisico en het activiteitsniveau van de voetganger leidt ook tot de conclusie dat leeftijd van invloed is op de bepaling van het ongevalsrisico. Met name kinderen en ouderen lopen, ondanks hun relatief lage activiteitsniveau, een hoog ongevalsrisico. Bij kinderen was dit het gevolg van een verminderd besef van het verkeersgevaar. Jongere en volwassen voetgangers hadden een hoger activiteitsniveau, waarbij hun relatief grote betrokkenheid bij een verkeersongeval meer het gevolg was van hun eigen 'bewuste' risicogedrag.

Hoofdstuk 10. In het kader van de praktische werking van aansprakelijkheidsregels is gesteld dat de invloed van het aansprakelijkheidsrecht op de preventie van ver- 
kersongevallen moeilijk empirisch kan worden getoetst. Er is onvoldoende empirisch bewijs voorhanden om een dergelijke invloed aan te tonen en als gevolg van de invloed van verzekering wordt de toetsing van het aansprakelijkheidsrecht sec bemoeilijkt. De beïnvloeding van het verkeersgedrag is daardoor een belangrijke taak van de (aansprakelijkheids)verzekeraars geworden.

onderzoek heeft gesuggereerd dat foutaansprakelijkheid met een absoluut eigen schuldverweer een autobestuurder tot meer zorgvuldigheid aanzet dan foutaansprakelijkheid met een gradueel eigen schuldverweer. Het is echter empirisch niet komen vast te staan dat de overgang van een foutaansprakelijkheid met een absoluut eigen schuldverweer naar een foutaansprakelijkheid met een gradueel eigen schuldverweer heeft geleid tot een vermindering van de zorgvuldigheid bij de autobestuurder dan wel tot een stijging van het aantal verkeersongevallen.

In dit hoofdstuk is verder aandacht besteed aan kwantitatief onderzoek naar het proces van de schaderegeling na een verkeersongeval. Het onderzoek met betrekking tot Nederlandse verkeersaansprakelijkheid dateert van de jaren ' 70 van de vorige eeuw. Het belang van de besproken studies is gelegen in de veronderstelling dat het aansprakelijkheidsrecht sec een geringe rol speelt bij de afwikkeling van verkeersschade. Het grootste deel van de vergoeding van letselschade aan het slachtoffer was afkomstig uit eigen beschikbare voorzieningen. Verder wordt een grote meerderheid van de procedures door de aansprakelijkheidsverzekeraars van de schadeveroorzaker geregeld.

Uit onderzoek met betrekking tot de vergoeding van verkeersslachtoffers in de VS en Canada is geconcludeerd dat de gemiddelde aansprakelijkheidsvordering wordt gedomineerd door uitkeringen voor immateriële schade. Verder worden verkeersslachtoffers met een lage schadeclaim, als gevolg van de aanwezigheid van genereuze uitkeringen voor immateriële schade en de beschikbaarheid van meerdere vergoedingsbronnen veelal overgecompenseerd. Verkeersslachtoffers die ten gevolge van een verkeersongeval ernstig tot zeer ernstig letsel hebben geleden, ontvangen geen volledige vergoeding. Dit is te wijten aan de lage polislimieten bij de aansprakelijkheidsverzekering van de schadeveroorzaker of aan de algehele afwezigheid van een dergelijke verzekering.

Hoofdstuk 11. Hierin is allereerst de vraag aan de orde of, gegeven de toegenomen invloed van verzekering, de preventieve werking van het aansprakelijkheidsrecht daadwerkelijk via de verzekeringsvoorwaarden gestalte krijgt. Verder wordt aan de hand van empirisch onderzoek onderzocht of de controle van de verzekeraar van invloed is op het verkeersgedrag van de verzekerde en op het aantal verkeersongevallen en verkeersslachtoffers.

Binnen de Amerikaanse autoverzekering ligt in het kader van de controle van het morele risico de nadruk op een ex ante risicodifferentiatie bij de vaststelling van de polisvoorwaarden. Daarbij wordt gebruik gemaakt van veel classificatievariabelen. Ten aanzien van de ex post premieaanpassing wordt geen vast omlijnd systeem toe- 
gepast. Autoverzekeraars werken vooral met toeslagen op de premie in reactie op een door de polishouder veroorzaakt verkeersongeval of een door hem begane verkeersovertreding. Deze toeslagen kunnen flink oplopen, afhankelijk van het aantal verkeersovertredingen en verkeersongevallen. Er is echter geen empirisch onderzoek beschikbaar waaruit een direct verband kan worden vastgesteld tussen risicodifferentiatie respectievelijk een premieaanpassing en een vermindering van het morele risico dan wel een daling van het aantal verkeersongevallen. Uit het beschreven onderzoek kan hooguit worden afgeleid dat ten behoeve van een preventie van verkeersongevallen een premiedifferentiatie noodzakelijk is, waarbij goede en slechte autobestuurders een premie betalen die zoveel mogelijk correspondeert met het individuele ongevalsrisico.

In Europa en Japan wordt ten behoeve van een premieaanpassing gebruik gemaakt van een bonus-malus systeem (BMS), gebaseerd op het schadeverleden van de autobestuurder. De ex ante risicodifferentiatie is veelal beperkt tot enkele classificatievariabelen, waarvan de belangrijkste leeftijd, woonplaats, beroep en type auto zijn. Een BMS is een vorm van 'experience rating' waarbij de verzekerde aan de ene kant kan worden bestraft met een premieverhoging (malus) wanneer hij verantwoordelijk kan worden gehouden voor één of meer verkeersongevallen. Aan de andere kant krijgen polishouders die gedurende een periode schadevrij aan het verkeer hebben deelgenomen, na een bepaalde periode (meestal een jaar) een korting (bonus) op hun premie. De doelstelling van een BMS is, naast het aanzetten van autobestuurders tot voorzichtig rijgedrag, een betere schatting van individuele risico's te bereiken, waardoor elke polishouder op termijn een premie betaalt die zoveel mogelijk in overeenstemming is met zijn verwachte risico. Een belangrijk middel om dit te bereiken is het scheiden van de goede en slechte autobestuurders door hen ex ante onder te brengen in verschillende premieklassen.

Een studie naar de BMS-structuur in Frankrijk, België en Nederland leert dat in de ex ante fase slechts beperkt gebruik wordt gemaakt van variabelen die van belang zijn voor een optimale risicodifferentiatie. Dit betekent dat binnen deze BMSregimes de nadruk ligt op een ex post controle van het gedrag van de autobestuurder. Uit onderzoek blijkt echter dat de toepassing van een eigen risico, naast andere variabelen zoals leeftijd, woonplaats en het aantal afgelegde kilometers een belangrijke bijdrage leveren aan een optimale ex ante risicodifferentiatie binnen een BMS. De verzameling van zoveel mogelijk informatie is zelfs noodzakelijk, uitgaande van het gegeven dat een verkeersongeval een relatief zeldzame gebeurtenis is. Een ex ante risicodifferentiatie kan echter niet alles omvatten en kan te hoge kosten meebrengen wanneer het werkelijke verkeersgedrag van een individuele autobestuurder moet worden bepaald. Een ex post premieaanpassing is noodzakelijk om de controle te waarborgen van variabelen die niet ex ante kunnen worden ingeschat.

Een premieaanpassing, gebaseerd op de jaarlijkse claimfrequentie van de polishouder, leidt echter op termijn tot ongelijkheid tussen de polishouders. Door de toepassing van bijzondere regelingen waarbinnen malussen sneller worden kwijtgeschol- 
den, kan de doelstelling van een BMS, namelijk het scheiden van de goede en slechte risico's in gevaar komen. Bij een ex post premieaanpassing dient de autoverzekeraar zich bij de beoordeling van het schadeverleden van de autobestuurder te verdiepen in de claimfrequentie van een polishouder gemeten over een bepaalde periode. Daarnaast is het van belang dat een BMS is opgebouwd uit een groot aantal premieklassen, waarbij sprake is van een evenredige verhouding tussen de bonusklassen en de malusklassen. Tenslotte kan ook de omvang van de schadeclaim, het inkomen van de polishouder en het aantal verkeersovertredingen een bijdrage leveren aan de optimalisering van een BMS-regime.

In het kader van de invloed van overheidsregulering op de markt voor autoverzekering is onderzoek gedaan naar de Amerikaanse, Engelse en Duitse markt voor autoverzekeringen. In Noord-Amerika is de regulering van de verzekeringsmarkten voornamelijk een taak van de statelijke overheden, waardoor de omvang van de verzekeringsregulering van staat tot staat verschilt. Binnen de verzekeringsmarkt van Massachusetts bijvoorbeeld is de controle van zowel de markt zelf als van de verzekeringsvoorwaarden geheel in handen van de overheid. In Engeland en Duitsland is sprake van een strikte solvabiliteitsregulering om de polishouder tegen faillissementen van zijn verzekeraar te beschermen. Ten aanzien van de verzekeringsvoorwaarden kan de Engelse markt als concurrerend worden beschouwd, waardoor de verzekeraars worden gedwongen een meer verfijnd systeem van risicodifferentiatie toe te passen. In Duitsland is sprake van door de overheid opgelegde uniforme verzekeringsvoorwaarden. De strikte verzekeringsregulering in Massachusetts en Duitsland beperkt de autoverzekeraars in hun vrijheid om een optimale ex ante risicodifferentiatie toe te passen en daarmee het morele risico te controleren. Daarnaast kunnen verzekeraars ook niet onderling concurreren op de prijs van de autoverzekering. Een vergelijking van de Engelse en Duitse verzekeringsmarkt leert verder dat het aantal verkeersdoden in Engeland relatief lager ligt dan in Duitsland. Door een enkele auteur is gesuggereerd dat een gereguleerde verzekeringsmarkt tot meer verkeersongevallen leidt en dat concurrentie binnen de verzekeringsmarkt van belang is voor de preventie van verkeersongevallen. Een direct verband tussen verzekeringsregulering en de preventie van verkeersongevallen kon echter niet worden aangetoond.

Hoofdstuk 12. Hierin wordt aan de hand van de beschikbare empirische literatuur onderzocht welke invloed bepaalde vormen van veiligheidsregulering kunnen hebben op het verkeersgedrag en het aantal verkeersongevallen. Met betrekking tot de veiligheid van de inzittenden van een motorvoertuig is aandacht besteed aan de autoveiligheidssystemen, zoals de autoveiligheidsgordel en de airbag. Uit onderzoek blijkt dat de toepassing van deze autoveiligheidssystemen leidt tot een vermindering van het aantal verkeersdoden en het aantal ernstig gewonden onder inzittenden van een auto. Ten aanzien van de verplichte autoveiligheidsgordel geldt dat, naast een campagne om het publiek te wijzen op de verhoogde veiligheid, een intensieve controle samen met de toepassing van sancties noodzakelijk is om een optimaal gebruik van de autoveiligheidsgordel te garanderen. Dit geldt niet voor een passief auto- 
veiligheidssysteem als de airbag. Via regulering kunnen autofabrikanten worden bewogen om airbags in de auto aan te brengen, waarmee een kostenbesparing op de handhaving kan worden bereikt en een optimaal gebruik is gewaarborgd. Uit het empirisch onderzoek is niet duidelijk geworden of de verhoogde veiligheid in de auto een negatief effect had op de zorgvuldigheid van de autobestuurder ('offsetting behavior') en op het aantal verkeersslachtoffers onder niet-inzittenden.

Het rijden onder invloed kan worden gereduceerd door een omvangrijke preventieve ademanalysecampagne. Deze daling zal echter een tijdelijk effect hebben wanneer de campagne niet wordt doorgezet en de autobestuurders na verloop van tijd ontdekken dat de pakkans afneemt. Het rijden onder invloed kan ook worden tegengegaan door een verhoging van de accijns op alcohol en met behulp van administratieve en strafrechtelijke sancties. Uit onderzoek blijkt dat een administratieve ontzegging van de rijbevoegdheid (vermindering van het activiteitsniveau) een effectiever beleidsinstrument is dan bijvoorbeeld een boete of een gevangenisstraf. De empirische uitkomsten ten aanzien van een gevangenisstraf zijn omstreden, hoewel in één studie wordt gesuggereerd dat met een gevangenisstraf vooral bij oudere bestuurders een preventief effect wordt bereikt.

De invoering van een maximumsnelheid kan van belang zijn voor de preventie van verkeersongevallen. Ook hierbij geldt dat een (permanente) effectieve handhaving, bijvoorbeeld met intensieve politiecontroles of het gebruik van radar, kan leiden tot een vermindering van het aantal snelheidsovertredingen en daarmee tot een daling van het aantal verkeersongevallen.

Hoofdstuk 13. Hierin wordt aan de hand van de beschikbare empirische literatuur de preventieve en compensatoire werking van de no-fault verzekering en het aansprakelijkheidsrecht onderzocht. Drie vormen van een no-fault verzekering zijn hierbij van belang. $\mathrm{Bij}$ een zuivere no-fault verzekering is de aansprakelijkheid geheel afgeschaft en is sprake van een compensatiefonds, waaruit verkeersslachtoffers een vergoeding ontvangen die veelal beperkt is tot een vast percentage van de materiële schade (Quebec, Nieuw-Zeeland). Bij een threshold no-fault verzekering is de mogelijkheid tot het instellen van een aansprakelijkheidsvordering gebonden aan materiële of monetaire schadedrempels (Australië, Noord-Amerika). Een add-on no-fault regime bevat, naast de handhaving van het aansprakelijkheidsrecht, een verplichte eerste partij verzekeringsdekking van een door de overheid bepaalde omvang (Australië, Noord-Amerika).

Het empirisch onderzoek naar de preventieve effecten van de no-fault wetgeving in verhouding tot het aansprakelijkheidsrecht vertoont tegenstrijdige uitkomsten. Daarnaast kunnen als gevolg van verschillen in interpretatie van de onderzoeksresultaten geen eenduidige conclusies worden gegeven. Enerzijds kan worden gesteld dat de invoering van een zuivere no-fault verzekering niet heeft geleid tot meer verkeersongevallen en verkeersslachtoffers. Anderzijds blijkt uit studies dat ook een combinatie van een no-fault verzekering en een gedeeltelijke handhaving van het aanspra- 
kelijkheidsrecht niet tot een daling van het aantal verkeersongevallen leidt. Het empirisch onderzoek toont wel aan dat zonder aanvullende preventieve maatregelen een no-fault systeem zal leiden tot meer verkeersongevallen en meer verkeersslachtoffers.

Met betrekking tot de omvang van de compensatie van verkeersslachtoffers heeft empirisch onderzoek aangetoond dat zowel een no-fault verzekering als een aansprakelijkheidssysteem in de meeste gevallen de materieel geleden schade volledig vergoedt. Bij een aansprakelijkheidssysteem krijgen de meeste verkeersslachtoffers hun materiële schade meer dan volledig vergoed, omdat daarbinnen een belangrijk deel aan immateriële schadevergoeding is verdisconteerd. Bij een no-fault verzekering heeft het slachtoffer meer zekerheid dat zijn materiële schade daadwerkelijk wordt vergoed. Ook wordt de schadevergoeding binnen een no-fault regime relatief sneller uitgekeerd dan bij een aansprakelijkheidsverzekering.

Ten aanzien van de vermindering van de schaderegelingskosten en een reductie van de premiekosten is uit empirisch onderzoek gebleken dat een no-fault verzekering bepaalde voordelen heeft ten opzichte van een aansprakelijkheidssysteem. Deze kostenvoordelen zijn afhankelijk van het toepasselijke regime. Een zuiver no-fault regime leidt dan tot een belangrijke kostenbesparing, terwijl bij een gemengd systeem van no-fault en aansprakelijkheid niet in alle gevallen een kostenbesparing wordt bereikt. De kostenbesparing bij een no-fault verzekering kan deels worden verklaard uit het feit dat aan verkeersslachtoffers een lagere vergoeding wordt uitgekeerd. Verder geldt dat de vergoeding voor immateriële schade in Noord-Amerika niet onder de dekking van een no-fault verzekering valt.

Hoofdstuk 14. Dit hoofdstuk bevat een samenvatting van de uitkomsten van het empirisch onderzoek. Daarbij is ook nagegaan welke van de in de theorie besproken combinaties van aansprakelijkheid, verzekering en veiligheidsregulering, rekening houdend met preventie, compensatie en kosten, het meest aan de uitkomsten van de empirie beantwoordt.

Omdat de preventieve effecten ten aanzien van no-fault en aansprakelijkheid onzeker zijn, is onderzocht of de keuze voor een bepaald vergoedingssysteem kan worden gebaseerd op de criteria van compensatie en (administratieve) kosten.

Empirisch onderzoek heeft uitgewezen dat een systeem van aansprakelijkheid en verzekering geen optimale compensatie aan het slachtoffer garandeert en tot hoge administratieve kosten leidt.

In het kader van de compensatie van verkeersslachtoffers en de kosten van het systeem is uiteindelijk gekozen voor een zuivere no-fault verzekering, omdat hiermee de hoogste besparing op de administratieve en premiekosten wordt bereikt en de uitkering van de schadevergoeding sneller plaatsvindt dan bij andere vergoedingssystemen. De no-fault verzekering dient echter te worden gecombineerd met een strikte handhaving van veiligheidsregulering om het gedrag van de verkeersdeelnemer verder te sturen. 
Deel IV: de toetsing van de Franse, Belgische en Nederlandse verkeersaansprakelijkheid aan de uitkomsten van de rechtseconomische analyse en het empirisch onderzoek.

Hoofdstuk 15. Hierin is vorenbedoelde toetsing uitgewerkt, waarbij de verschillende regelingen en voorstellen zijn samengevat en vertaald naar de in de rechtseconomische analyse gehanteerde omschrijvingen. Vervolgens is nagegaan in hoeverre deze systemen van verkeersaansprakelijkheid overeenstemmen met de uitkomsten van de rechtseconomische theorie en het empirisch onderzoek. Naar aanleiding van deze toetsing is een vergelijking gemaakt tussen een stelsel met aansprakelijkheid en een systeem van verkeersverzekering. Tenslotte is met betrekking tot het onderhavige onderzoek een aantal aanbevelingen geformuleerd.

Van groot belang voor de uiteindelijke keuze voor een stelsel van verkeersaansprakelijkheid is dat (verder) onderzoek noodzakelijk is. Het onderhavige onderzoek heeft geen duidelijkheid kunnen geven omtrent de daadwerkelijke rol van het aansprakelijkheidsrecht in het verkeer, de preventieve werking van verzekeringsvoorwaarden en de invloed van veiligheidsregulering op het gedrag van niet-gemotoriseerde verkeersdeelnemers. Het onderhavige onderzoek heeft aangetoond dat alleen met behulp van een grondig statistisch en empirisch onderzoek naar de aansprakelijkheid, de verzekering en de veiligheidsregulering in het verkeer het juridische, het economische maar vooral ook het politieke verkeersdebat op een juiste wijze kan worden gevoerd. In een dergelijk debat dient met name vanuit preventief oogpunt een gecombineerde toepassing van aansprakelijkheid, verzekering en veiligheidsregulering tot uitgangspunt te worden genomen. Dit onderzoek heeft immers aangetoond dat voornoemde juridische instrumenten niet separaat kunnen worden bediscussieerd, zij beïnvloeden elkaar. Bij de keuze voor een stelsel met aansprakelijkheid en verzekering is kennis nodig van de preventieve werking van aansprakelijkheidsregels en van de rol van verzekeringen op preventief en compensatoir vlak. Een preventieve werking van aansprakelijkheidsregels kan niet worden bereikt zonder de invloed van de verzekeringsvoorwaarden daarbij te betrekken. Veiligheidsregulering tenslotte, is van belang daar waar de preventieve werking van de markt van aansprakelijkheid en verzekering niet tot een optimaal resultaat leidt. 


\section{Summary}

This book deals with a research on traffic accidents. It focuses on the question which combination of liability, insurance and safety regulation will lead to an optimal prevention of traffic accidents and an optimal compensation of traffic victims at the lowest possible costs. Prevention focuses on the economic aim of minimising the social costs of traffic accidents. Compensation focuses on the question in which way traffic victims can be compensated. This research aims at providing an additional contribution to the Dutch discussion on traffic liability by focusing, next to compensation, on prevention and costs.

Justification. On the basis of an enumeration and explanation of the pressure points within the actual Dutch traffic liability, the importance of the research is emphasised. Furthermore, the problem is defined and the methodology and classification of the research introduced.

The problem is defined on the basis of a judicial analysis (part I) and an economic analysis (part II) which together with the empirical analysis of the economic model (part III) form the basis for the review of the law and related propositions (part IV). In the judicial analysis, attention is drawn to Dutch traffic liability, and from a comparative perspective on traffic liability in France and Belgium. In the economic analysis, the research is based on the economic model of accident law and focuses on how the law can influence the behaviour of the parties involved in traffic accidents. Verifications are thereby made whether the legal instruments from the problem influence in theory the prevention and compensation of traffic accidents. As it is important to compare the theoretical conclusion of the economic analysis with the practical experience, subsequently critical attention will be paid to empirical research on traffic accidents. In this way, it is possible to judge if the law, in the form of liability regulation, insurance conditions and safety regulation, can be of actual influence on traffic behaviour and the number of traffic accidents.

\section{Part I: The judicial analysis}

Chapter 1. In France, the 'loi Badinter' has been effective since 1986. Within this special Act, the owner of a motor vehicle is strictly liable for the damage of the cyclist, the pedestrian and the passenger. When the involvement of the motor vehicle in a traffic accident has been established, the liability of the owner is given. There is no plea for a defence of contributory negligence of the victim, unless the negligence is inexcusable and can be regarded as the only cause of the accident. Persons below the age of sixteen, persons above the age of seventy and those with a disability of $80 \%$ before the accident are always fully compensated. For all victims applies that when the accident has been intentionally caused, the duty for compensation is deteriorated. As a result of the broad explanation of 'involvement' and the strict inter- 
pretation of the 'faute inexcusable' by the Supreme Court of France, the basis of the 'loi Badinter' has developed from a initial strict liability with a contributory negligence to an almost absolute liability for the owner of a motor vehicle. The driver of a motor vehicle must for his loss rely on a negligence rule. For the negligence of the driver-victim an objective criterion is used, which makes it that the driver is not deprived of compensation.

An important aspect of the 'loi Badinter' is the mandatory transaction procedure. The insurer is obliged to make the victim a final offer for compensation within 8 months after the accident has occurred. Although the compensation of non-motorised victims has improved with the 'loi Badinter', in practice the damages, in spite of the transaction procedure, are not paid out faster.

With respect to the recourse procedure, next to the 'loi Badinter', also the 'Protocol d'Accord', an arrangement between the social and motor insurers, applies. This regulation from 1983 refers to a simplified settlement of individual recourse files according to a fixed procedure having its own character. In this procedure an abstract system is used, whereby the magnitude of the compensation is counted on the basis of standards with regard to liability, bodily injury and possible costs.

Chapter 2. In Belgium, the Act of 13 April 1995, which came into effect on 1 July 1995, is important. This act, often denoted as the 'artikel 29bis WAM-regeling', contains the compensation of certain victims of traffic accidents, especially the socalled weak traffic participants, namely cyclists, pedestrians en passengers. The liability for the loss of these victims rests on the liability insurer of the owner of the involved motor vehicle.

Until this Act came into force in Belgium, the liability and the compensation as a result of a traffic accident was regulated in article 1382 Civil Code. The traffic victim had to hold the injurer liable for his loss on the basis of a tort. The victim had to prove the fault of the injurer and the causality between the negligence and the loss. The only fact that damage was caused by a certain risk, for instance driving a motor vehicle, was insufficient evidence for negligence. The injurer could plea force majeure, and negligence on the side of the victim could lead to a corresponding reduction of the compensation. Cyclist, pedestrian and driver of a motor vehicle were considered more or less equal.

Since 1995, the owner of a motor vehicle is through his liability insurance in almost all cases held responsible for the damage of non-motorised traffic participants. The driver of a motor vehicle must for his loss rely on the negligence of article 1382 Civil Code, the available social insurance and an alternative first party loss insurance.

Article $29 \mathrm{bis}$ WAM is to a large extent based on and inspired by the French "loi Badinter'. The Belgium Act also focuses on the concepts 'involvement' and 'inexcu- 
sable negligence'. For the interpretation of these concepts they refer to the jurisprudence of the Supreme Court of France. At the beginning of 2001 an amendment of the Belgium Act with respect to the inexcusable negligence came into force. This provision states that only traffic victims who are suicidal can not rely on the protection of this Act. This means that the Belgium Act is brought to perfection with respect to the protection of victims and that in fact a no-fault insurance for the compensation of weak traffic participants is created.

Chapter 3. The starting point of the Dutch traffic liability is that damages due to traffic accidents are compensated on the basis of the negligence of article 6:162 Dutch Civil Code. This regulation applies to traffic accidents between motor vehicles, between cyclists and accidents between cyclists and pedestrians.

With respect to traffic accidents between motorised and non-motorised traffic participants, the special regulation of article $185 \mathrm{WVW}$ applies. On the basis of this regulation, the owner of a motor vehicle is liable for the loss of the cyclist and pedestrian, unless force majeure is made plausible. In accordance with the jurisprudence of the Dutch Supreme Court, force majeure is only plausible when the driver is not to blame legally and the fault of the victim was so unlikely for him that he could not take this into account in the concrete circumstances. When force majeure is not plausible, although there is a fault of the victim, without being intentional or reckless, it is only fair that the owner of a motor vehicle is at least liable for $50 \%$ of the loss of a non-motorised victim above the age of fourteen. The risk of a traffic accident with a child below the age of fourteen is put entirely on the owner of a motor vehicle. This means that in an accident between a motor vehicle and a child, the loss of the child will be fully compensated, unless the behaviour of the child was intentional or reckless.

Recovering insurers do not profit from these equity rules which are for the protection of the victim itself. The claim of these insurers must be judged on the basis of force majeure and negligence.

The academic literature has for some decades tried to induce the legislator for a reform of the traffic liability in which the protection of victims is emphasised. This plea has been started for an important part by Bloembergen and Van Wassenaer van Catwijck and was recently followed by other scholars. A majority of these academic scholars shows a preference for a solution of the issue of traffic accidents outside liability and chooses a form of no-fault insurance, which compensates the loss of the victim, as far as these losses are not paid through the own sources of the victim.

The legislator did not follow the academic literature and adheres to liability as the basis for the compensation of traffic losses. At the end of 1997 the former Minister of Justice Sorgdrager introduced a bill on traffic accidents. This bill has been withdrawn by her successor Korthals. Instead he announced his plans for a possible new 
bill. Both the former bill and the plan of Korthals intend to establish a strict liability on the owner of a motor vehicle for the personal loss of the cyclist, pedestrian and passenger. Furthermore the employer is strictly liable for the loss of the driveremployee caused by a traffic accident. The driver of a motor vehicle, not being an employee, falls outside the scope of these propositions. When the involvement of the motor vehicle in a traffic accident is established, then the liability of the owner is given. Only when the behaviour of the victim refers to 'intention or conscious recklessness' (bill) 'or recklessness as the only cause of the accident' (Korthals), the duty to compensate for the owner of the motor vehicle is deteriorated, even though he has been negligent himself. Recovering insurers will not profit from the protection of traffic victims. As a result of the repeal of article $185 \mathrm{WVW}$, they must, just as the driver of a motor vehicle, rely on article 6:162 Dutch Civil Code.

\section{Part II: The economic analysis of the law on traffic accidents}

Chapter 4. Law and economy can be considered a discipline, which by means of economic concepts and instruments tries to analyse the law. Furthermore, law and economy is an explanatory discipline in which with respect to accident law the efficiency criterion has an important role. On the basis of this criterion it will be examined how legal rules can contribute to the increase of social welfare, or that some rules, considered economically, decrease this welfare or even lead to dissipation.

The economic aim of the law on traffic accidents is the minimisation of the social costs of traffic accidents. These costs can be divided in primary, secondary and tertiary costs of accidents. The primary costs are connected with the reduction of the number and the gravity of accidents and correspond with prevention. The secondary costs refer to an optimal loss spreading following the accident and correspond with compensation. The tertiary costs refer to the administrative costs of settling the accidents and arise from the performance of the primary and secondary costs of accidents.

In this research the economic model of accident law will be started with two types of actors, namely injurers and victims. Injurers will be presented as motorcar divers who inflict losses upon a cyclist, as being the victim. Injurer and victim make two kinds of decisions, namely of and how often they participate in certain activities and the decision with regard to their taking care while participating in an activity.

The optimal care, the economic optimum, of injurer and victim is found at the point where the marginal costs of the latest added unit of care exactly equals the marginal revenue in terms of reducing the expected loss which is connected with this added unit of care. 
The starting point of the economic analysis is the Coase-theorem. This theorem applies when, in the event of a traffic accident, a small number of parties through negotiation against low transaction costs can reach an optimal arrangement as to whether preventive measures should be taken. However, traffic participants are strangers to each other, as a result of which the transaction costs become exceptional and it will be impossible to enter into a contract with regard to the consequences of a traffic accident. In case of traffic accidents, the conditions of the Coase theorem are not fulfilled anymore, so that the law has to intervene in the form of liability or (safety) regulation.

Chapter 5. The economic analysis of liability law deals with the question which liability rule will induce a traffic user to an optimal care and activity level. In this stadium of the research it is assumed that the availability of insurance and existence of safety regulation do not play a part.

In an unilateral model it is assumed that only the injurer can influence the accident risk, whereby only the victim will suffer loss. In this model a strict liability rule will induce the injurer to an optimal care and activity level, because he is liable for the total sum of accident costs. In case of a negligence rule, the injurer will exercise an optimal care level, provided that the optimal care equals the standard of due care. When the injurer complies with the standard of due care he is not liable, so that he will not be induced to an optimal activity level.

In a bilateral model it is assumed that both the injurer and the victim can influence the accident risk, whereby only the victim will suffer loss. In this model at a rule of strict liability with a contributory negligence, the injurer is in theory liable for the loss of the victim, unless the latter did not comply with the due care standard. At a negligence rule the injurer must pay the loss of the victim when he does not comply with the due care standard. Both liability rules will lead injurer and victim to exercise an optimal level of care. At a strict liability with a contributory negligence the injurer will exercise an optimal activity level. For the victim exercising an optimal care level is sufficient, so that his activity level will be too high. At a negligence rule the injurer will not be induced to an optimal activity level. The victim, knowing the injurer by exercising due care is not liable, will exercise an optimal activity level because otherwise he has to bear his own loss.

A refinement of the economic model shows that there are information problems with regard to the due care standard. The court could be mistaken at determining the due care standard just as injurer and victim can be mistaken with regard to the applicable due care standard. Problems can also arise with the classification of care levels, because the efforts (costs) and the knowledge and skills of injurer and victim to reduce the accident risk are not at the same level. These problems complicate the 
comparison between liability rules. This comparison is then depending on the significance that is attached to certain factors of uncertainty.

Within the scope of the reduction of the primary costs (prevention), preference is given to a rule of strict liability when, from a social perspective, it is more important to control the risks of the motor traffic than to induce the cyclist to an optimal activity level. When it is socially more important to control the behaviour of the cyclist, the negligence rule could be efficient. The cyclist will exercise an optimal care and activity level, the motorcar driver will exercise an optimal level of care, but not an optimal activity level.

As part of the reduction of the secondary costs (compensation) it applies that a strict liability with a contributory negligence more likely compensates the damage of the cyclist than a regular negligence rule. In the field of the distribution of incomes a strict liability with a contributory negligence in particular benefits a cyclist, when he takes for granted that in most cases his loss will be compensated. With a negligence rule it applies that the cyclist usually bears his own loss, unless the motorcar driver, regardless of the behaviour of the cyclist, did not comply with the due care standard. As part of the minimisation of the tertiary costs it applies that with regard to the reduction of the costs of liability procedures a negligence rule is preferable to a strict liability with a contributory negligence, that leads to more lawsuits. For the purpose of the reduction of the information costs, in connection with the court's inquiry for the due care standard, a strict liability with a contributory negligence can result in a saving of costs.

Chapter 6. Within the economic analysis of liability law it is assumed that injurer and victim are neutral in relation to the accident risk. However, with regard to traffic it can be expected that the cyclist and the motorcar driver are risk averse to be involved in a traffic accident. They can shift away this risk aversion by entering into an insurance contract, in which the insurer is prepared to take over the risk from the insured against a sum of money (premium).

The availability of an insurance leads to information problems, namely moral hazard and adverse selection. Moral hazard sees to the situation where an insurer has not enough information to make a correct estimation of the risk of the insured, as a result of which he will be less careful in case of a full insurance coverage. An insurer can reduce moral hazard with the insured through a partial coverage or a deductible and an adjustment of the terms/conditions of the insurance policy.

The process of adverse selection arises when an insurer by lack of information with regard to the subscribed risks, can only offer an average premium which corresponds with the average risk within the group. Some insured persons within this risk group for whom the premium is too high compared to their personal risk, can decide to leave the risk group, as a result of which the less good risks will be left. This can lead to an increase in the premium which results in the abandonment of other 
insured persons. Finally only the inferior risks remain. The insurer can slow down the process of adverse-selection by a strong differentiation between good and bad risks and through additional measures which keep the good risks within the group and induce the bad risks to carefulness. In this respect an increase of the deductible, a decrease of the insurance coverage and admitting exclusions, for instance driving while intoxicated is mentioned.

A third party liability insurance covers the liability of the injurer who inflicts harm to the victim. A first party loss insurance covers the loss of the victim itself. A loss insurer has more direct and reliable information with respect to the accident risk of the individual insured, so that he is more able to reduce moral hazard and the process of adverse-selection. The liability insurer must besides the behaviour of the motorcar driver also take into account the behaviour of the victim, who is usually by coincidence involved in a traffic accident with the insured motorcar driver.

A compulsory insurance is important to remove information problems alongside the injurer with respect to his accident risk. A compulsory liability insurance can furthermore be a good remedy against the underdeterrence caused by the insolvency of the injurer, provided that the compulsory insurance goes together with an effective supervision of the moral hazard. An alternative for a compulsory insurance is a loss insurance alongside the victim.

The market for motor insurance must be sufficiently competitive to induce the insurer to harmonise the premium with the individual accident risk of the motorcar driver. Through a individualisation of the terms of the contract both the moral hazard and the process of adverse-selection can be prevented.

When the compensation through a system of liability and insurance is not possible, either because of insolvency problems, or because there is no insurance coverage for certain risks, a guarantee fund can be a good addition for the benefit of an optimal compensation of traffic victims.

A no-fault insurance, whereby the liability is fully abolished, is a compensation mechanism that indemnifies on the on hand the loss of the occupants of the vehicle, the driver and the passenger, and on the other hand the loss of the cyclist and the pedestrian. The ex ante risk differentiation at this insurance can be based on the individual skills and on the driving behaviour of the motorcar driver. An ex post adjustment of the premium cannot be based on the liability, but can instead be based on the loss history of the motorcar driver and the number of traffic violations.

The taking of recourse has a preventive advantage because the costs of accidents are being passed on to the injurer. When a first party insurer of the victim is taking recourse on the injurer or his liability insurer, the latter can influence the carefulness of the motorcar driver through the terms of the contract. Taking recourse also leads to a better spreading of the risk, because the costs are put on the insurer of the 
injurer. However, when the administrative costs of taking recourse are higher than the benefits in the field of prevention, a collective recourse in order to reach a costs saving can be argued for.

Within the scope of relating liability and insurance it is assumed that the risk averse injurer will enter into a liability insurance with full coverage, while the risk averse victim will enter into a loss insurance. The question whether injurer and victim will enter into an insurance contract depends on the applicable liability rule. It was further assumed that an optimal supervision of moral hazard is not possible and that there is uncertainty with regard to the due care standard.

On the basis of these assumptions with respect to the reduction of the primary accident costs there could not be found an optimal combination of liability and insurance.

A strict liability with a contributory negligence is preferred when importance is attached to the risk raising activity of the motorcar driver. A negligence rule is preferable when it is assumed that supervising the moral hazard can better be executed with a loss insurance than with a liability insurance. With a no-fault insurance the prevention of traffic accidents is, due to the abolishing of liability, exclusively guaranteed by the no-fault insurer. This prevention cannot be based on liability and moreover it counts that the cyclist has inadequate incentives of care because his loss is automatically compensated.

With respect to the reduction of the secondary accident costs it counts that a strict liability with a contributory negligence can be preferable when it is assumed that the motorcar driver, either is more able to avoid the loss, or is considered a higher accident risk than the cyclist. When importance is attached to the assumption that the motorcar driver and the cyclist equally contribute to the accident risk and the supervision of moral hazard is better executed with a loss insurance than with a liability insurance, a negligence rule is preferable. A no-fault insurance is advantageous because, depending on the magnitude of the insurance coverage, the compensation of the victim is optimally guaranteed. However, in principle this compensation is not based on the behaviour of the motorcar driver or the cyclist. The supervision of the behaviour of the motorcar driver becomes complicated and is entirely absent at the cyclist.

With regard to the reduction of the tertiary costs it is concluded that strict liability with a contributory negligence is lightly preferable to a negligence rule, when the dispute is solved without intervention of the court. A no-fault insurance reduces the administrative costs. Because liability is abolished and the loss is entirely settled by the no-fault insurer, there are in theory no legal costs.

Chapter 7. In this chapter three economic theories of (government) regulation are described. The public interest theory is related to enact rules, which aim at the increase of the social welfare. The government regulates from a public interest perspective certain failures of the market mechanism. These market failures who 
disturb an optimal operating market mechanism, cannot be taken away by the market itself nor through private law. Examples of market failures are external effects, for instance the danger in traffic that can be caused by driving a motorcar, and asymmetric information, for instance the operation of an insurance company.

In a second theory the preventive effects of liability and safety regulation are compared on the basis of a number of criteria. With regard to traffic it is put forward that for optimal prevention a combination of liability and safety regulation is advisable. Traffic participants have as being directly involved better information with regard to the accident risk. Depending on the enforcement of safety standards, safety regulation is needed to optimise this information. Safety regulation can be used for the determination of liability as a result of a traffic accident. When the injurer violates a safety standard, for instance the speed limit, this standard can be used by the court for the determination of liability.

The private interest theory explains why the decision-making process in politics sometimes leads to legislation which is not in the public interest, but rather comes into effect under the influence of certain interest groups. Especially small interest groups with a high degree of self regulation, who are using strict entrance rules to the group, can exercise real influence on the process of legislation. The interests of large consumer groups are more generally formulated, still the influence of such groups must not be underestimated while they unite a great number of potential voters.

With respect to traffic safety regulation it can be expected that motorcar insurers and car manufacturers will limit the entrance to and the competition on the market, whereas interest groups of motorcar drivers plead for safer cars and interest groups of traffic victims aim at a large degree of victim protection. These conflicting interests within the lobby process can only be brought together on limited parts of safety regulation. An example with respect to the interests of traffic victims and motorcar insurers shows that regulation of driving under influence of alcohol can, from a public interest perspective, improve the efficiency, whereby also a better prevention of traffic accidents is possible. The interest groups of traffic victims are, for reasons of protection, concerned with this kind of regulation. For motorcar insurers however this kind of regulation can improve the possibilities of controlling the moral hazard of reckless motorcar drivers and limit the entrance to the market.

Chapter 8. This chapter summarises the economic analysis by statements. This chapter also reviews a number of possible combinations of liability, insurance and safety regulation.

In the first place it is possible to opt for a strict liability with a contributory negligence, by which the motorcar driver has a liability insurance and the cyclist has a loss insurance. In this case it is supposed that the influence from the motorcar 
driver on the accident risk is higher than the influence from the cyclist. Safety regulation is desirable on areas which are not ruled by liability and insurance, but can provide additional prevention, subject to good enforcement. Examples of this safety regulation are regulation of the speed limit, use of alcohol in traffic and motorcar safety.

In the second place it can be assumed that the influence of the motorcar driver and the cyclist are supposed to be more equal. In that case it is possible to opt for a negligence rule combined with a liability insurance (motorcar driver) and a loss insurance (cyclist). Safety regulation is necessary for further prevention of traffic accidents, but also to guide the sub-optimal activity level from the motorcar driver.

In the third place a choice can be made for no-fault insurance on the side of the motorcar driver, offered by the private insurance market, combined with a strict safety regulation. This system emphasises optimal compensation of the cyclist and the motorcar driver against the lowest possible costs and it is also assumed that the motorcar driver has more influence on the accident risk than the cyclist. On behalf of supervising the moral hazard the no-fault insurer should take measures to influence the behaviour of the insured motorcar driver. Strict enforcement of safety regulation is essential for additional control of the behaviour of the motorcar driver, but moreover to induce the non-motorised traffic to careful behaviour.

In the fourth place a choice can be made for a no-fault insurance for all traffic participants. This system emphasises optimal compensation of traffic victims. The responsibility of the no-fault insurer is more spread and the supervision of the moral hazard can better performed. A strict enforcement of safety regulation is also essential for additional control of the road user.

\section{Part III: The empirical test of the economic model}

The empirical research consists of a reproduction and a critical review of already available research material. Moreover the empirical research contemplates to examine, by statistic material, if legal instruments can influence the behaviour of traffic participants and costs of traffic accidents. On this examination reference will be made to theoretical assumptions.

Chapter 9. In this chapter several general aspects of traffic accidents are under discussion. With reference to marks of traffic accidents a comparison is made between a number of European countries, North-America and Canada. From these statistical data, which roughly relate to the period $1980-1995$, appears that the number of traffic accidents with injury and the number of traffic fatalities went down, in spite of an increase of the motorcar density. Moreover the number of traffic fatalities among cyclists, pedestrians and passengers went down in most countries, while the number of traffic fatalities among drivers of motorcars increased. 
Also a couple of empirical studies referring to traffic behaviour and accident risk is dealt with. From these studies it appears that young and inexperienced motorcar drivers have difficulty with practising the required care in traffic. These motorcar drivers underestimate the accident risk and apparently take more risks in traffic than older motorcar drivers. Besides that, they overestimate their own driving proficiency in comparison to motorcar drivers from their age-group. Older and more experienced motorcar drivers also underestimate the accident risks, while it does not appear from the marks that older motorcar drivers are, proportionally, exceedingly represented in the traffic accident statistics. The examination referring to the accident risk and the activity level of pedestrians also leads to the conclusion that age is of influence on the determination of the accident risk. Especially children and old people are at high risk of accidents, despite their relatively low activity level. With children, this is the result of less awareness of the traffic danger. Younger en adult pedestrians have a higher activity level, but their relatively big involvement with traffic accidents is the result of their own knowingly risk behaviour.

Chapter 10. In accordance with the practical efficacy from liability rules it is argued that the influence of liability law on prevention of traffic accidents can be hardly empirically examined. There is not enough empirical proof to prove such an influence and as a result of the influence of insurance the examination of just the liability law is hindered. Because of that the influence on the traffic behaviour has become an important task of (liability) insurers.

Research has suggested that a negligence rule with a contributory negligence induces a motorcar driver to more care than a negligence rule with a relative negligence. However, it is not empirically proven that the change from a negligence rule with a contributory negligence to a negligence rule with a relative negligence has lead to a reduction of care from the motorcar driver or an increase of the number of traffic accidents.

This chapter also pays attention to a quantitative research to the process of settlement of damages after a traffic accident. The research referring to Dutch traffic liability dates back to the seventies of the past century. The importance of the reviewed studies lies in the assumption that just the liability law plays a small part in the settlement of damage. The biggest part of compensation of injury to the victim came down from own available provisions. Further, a large majority of the procedures is taken care of by the liability insurers from the damage originator.

Research referring to the compensation of traffic victims in the United States and Canada concludes that the average liability claim is dominated by payments for intangible injury. Further, traffic victims with a small claim for damages are, as a result of the presence of generous payments for intangible injury and the availability of several compensation sources, mostly overcompensated. Traffic victims who have 
suffered serious to highly serious injury, as a result of a traffic accident, do not receive full compensation. The low policy limit with the third party liability insurance from the injurer or the complete absence of such an insurance is to blame for this.

Chapter 11. This chapter deals with the question if, given the increased influence of insurance, the preventive efficacy of the liability law actually takes shape through the insurance conditions. Moreover it will be examined, judging from empirical research, if the supervision of the insurer influences the traffic behaviour of the insured, the number of traffic accidents and the number of traffic victims.

Within the American motorcar insurance the accent is, in accordance with the supervision of the moral hazard, laid on an ex ante risk differentiation with the determination of the policy conditions. With this determination a lot of classification variables will be used. With regard to the ex post premium adjustment no clearly defined system is applied. Motorcar insurers mostly work with additional charges on the premium in reaction to a traffic accident caused by the policy holder or a traffic offence made by him. These additional charges can rise highly, depending on the number of traffic offences and traffic accidents. However, there is no empirical research available from which a direct connection can be determined between risk differentiation respectively a premium adjustment and a reduction of the moral hazard or a fall of the number of traffic accidents. At most it can be concluded from the reviewed research that, on behalf of the prevention of traffic accidents, a premium differentiation is necessary, in addition to which good and bad motorcar drivers pay a premium that corresponds as much as possible with the individual accident risk.

Europe and Japan use, on behalf of the premium adjustment, a bonus-malus system (BMS), based on the damage history of the motorcar driver. The ex ante risk differentiation is mostly limited to a few classification variables, of which the most important are age, place of residence, profession and type of car. A BMS is a form of 'experience rating' by which the insured on the one hand can be punished with a premium raising (malus) when he can be held responsible for one or more traffic accidents. On the other hand policy holders who have participated damage free to the traffic during a certain period, receive a discount (bonus) on their premium, after a certain period (mostly a year). Besides putting up motorcar drivers to careful behavior, the aim of a BMS is to reach a better valuation of individual risks, through which each policy holder on term pays a premium according as much as possible to his expected risk. An important means to achieve this is the separation of the good and the bad motorcar drivers by placing them ex ante in different premium classes.

A study to BMS structure in France, Belgium and the Netherlands shows that in the ex ante phase there is only made limited use of the variables that are of importance 
to an optimal risk differentiation. This means that within these BMS-rules the ex post supervision of the behaviour of the motorcar drivers is emphasised. However, from research appears that the application of a deductible, besides other variables like age, place of residence and the number of covered kilometres, contributes to an optimal ex ante risk differentiation within a BMS. The collection of as much information as possible is even necessary, assuming that a traffic accident is a relatively rare occasion. An ex ante risk differentiation cannot enclose everything and can bring high costs when the real traffic behaviour of an individual motorcar driver has to be determined. Ex post premium adjustment is necessary to guarantee a supervision of variables which cannot be valued ex ante.

Premium adjustment, based on the yearly claim frequency of the policy holder, leads to inequality between policy holders on term. Also the application of special rules in which premium raises are being remitted more quickly, can endanger the aim of a BMS, the separation of the good and the bad risks. With an ex post premium adjustment the motorcar insurer needs, with the judgement of the damage history of the motorcar driver, to indulge in the claim frequency of an policy holder measured over a certain period. Besides that, it is important that a BMS is devided in a large number of premium classes with a proportional connection between the bonus classes and the malus classes. Finally also the extent of claim for damages, the income of the policy holder and the number of traffic offences can contribute to maximise a BMS regime.

In accordance with the influence of government regulation on the motorcar insurance market, there has been an examination of the American, English and German motorcar insurance market. In North-America the regulation of insurance markets is mainly a task from the stately governments, through which the extent of the insurance regulation differs from state to state. Within the insurance market from Massachusetts for example, the supervision of the market itself as well as the insurance conditions is in hands of the government. In England and Germany there is a sirict solvability regulation to protect the policy holder against bankruptcy of his insurer. With regard to the insurance conditions the English market can be seen as competitive, through which the insurers are induced to apply a more defined system of risk differentiation. In Germany the insurance conditions are imposed by the government. The strict insurance regulation in Massachusetts and Germany limits the motorcar insurers in their freedom to apply an optimal ex ante risk differentiation in order to supervise the moral hazard. Besides that insurers cannot compete on the price of the motorcar insurance. A comparison between the English and the German insurance market shows that the number of traffic fatalities in England is relatively lower than in Germany. Just one author suggests that a regulated insurance market leads to more traffic accidents and that competition within the insurance market is significant for the prevention of traffic accidents. A direct connection between insurance regulation and prevention of traffic accidents could not be demonstrated. 
Chapter 12. This chapter examines, on the basis of the available empirical literature, which influence certain forms of safety regulation might have on the behaviour in traffic and the number of traffic accidents.

Referring to the safety of the occupants of a motorcar attention is paid to motorcar safety systems, like safety belt and airbag. From research appears that the use of these motorcar safety systems leads to a reduction of the number of traffic fatalities among occupants of a motorcar. For the compulsory safety belt it goes that, besides a campaign to point out the increase of safety to the public, an intensive supervision together with the application of sanctions is necessary to guarantee optimal use of the safety belt. This does not go for a passive motorcar safety system like the airbag. By regulation car manufacturers can be brought to install airbags into cars, by which a saving in costs on the enforcement can be achieved and optimal use is guaranteed. Empirical research has not shown if the increased safety in cars has a negative influence on the car of motorcar drivers (offsetting behavior) and on the number of traffic victims among non-passengers.

Driving under influence of alcohol can be reduced by an extensive preventive breath test campaign. However, this reduction will have a temporary effect when they won't go through with the campaign and motorcar drivers discover after a certain period that the chances of being caught are reducing. Driving under the influence of alcohol can also be reduced by raising the excise on alcohol and by administrative and criminal sanctions. From research appears that an administrative injunction on using one's driver's licence (reduction of the activity level) is a more effective policy instrument than for example a fine or imprisonment. The empirical results regarding imprisonment are controversial, although one research suggests that especially with older drivers imprisonment achieves a preventive effect.

The introduction of a maximum speed limit can be significant to the prevention of traffic accidents. Also for this goes that a permanent effective enforcement, for example by intensive police controls or the use of a radar, can lead to a reduction of the number of speed limit offences and with that a reduction of the number of traffic accidents.

Chapter 13. On the basis of the available empirical literature this chapter examines the preventive and the compensatory effects of the no fault insurance and the liability law. Three forms of no fault insurance matter in this examination. Within a pure no fault insurance, liability is completely abolished. There is a compensation fund, from which traffic victims receive a compensation which is mostly limited to a fixed percentage of the material damage (Quebec, New Zealand). Within a threshold no fault insurance there is a possibility to put in a claim, bound to material or financial thresholds (Australia, North-America). An add-on no fault insurance contains, besides the maintaining of the liability law, a compulsory first party 
insurance coverage of a size determined by the government (Australia, NorthAmerica).

The empirical research to the preventive effects of the no fault legislation in relation to the liability law, shows contradictory results. Besides that it is not possible to give unequivocal conclusions as a result of the differences in interpretation of the research results. On the one hand it is possible to state that the introduction of a pure no fault insurance has not lead to more traffic accidents and traffic victims. On the other hand studies point out that also a combination of a no fault insurance and a partly enforcement of the liability law does not lead to a reduction of the number of traffic accidents. However, the empirical research does show that without additional preventive measures a no fault system will lead to more traffic accidents and more traffic victims.

With regard to the size of the compensation of traffic victims, empirical research has shown that as well a no fault insurance as a liability system in most cases fully compensate the suffered material loss. Within the liability law most traffic victims are more than fully compensated, because in this compensation an important part of intangible damages has been calculated. Within a no fault insurance the victim has more security that his material loss will actually be compensated. Also the compensation within a no fault regime will be paid out relatively more quickly than within a liability insurance.

With regard to the reduction of claim settlement costs and the reduction of the premium costs, empirical research has shown that a no fault insurance has certain advantages compared to a liability system. These cost advantages depend on the applicable regimen. A pure no fault regimen leads to an important saving of costs, while a mixed system of no fault and liability doesn't achieve in all cases a saving of costs. The saving of costs within a no fault insurance can partly be explained from the fact that traffic victims are less compensated. Furthermore goes that the compensation for intangible loss in North-America is not covered by a no fault insurance.

Chapter 14. This chapter contains a summary of the results of the empirical research. In this chapter is also examined which of the theoretically reviewed combinations of liability, insurance and safety regulation, taking into account the prevention, compensation and costs, complies the most with the results of the empirical researches.

Because the preventive effects with regard to the no fault and liability insurance are insecure, it has been examined if the choice for a certain compensation system can be based on the criteria of compensation and (administrative) costs.

From empirical studies appears that a system of liability insurance does not guarantee an optimal compensation to the viction and leads to high administrative costs. 
Within the scope of the compensation of traffic victims and the costs of the system is finally chosen for a pure no fault insurance, because this insurance achieves the highest saving of administrative costs and premium costs and the payment of compensation occurs more quickly than with other compensation systems. However, the no fault insurance needs to be combined with a strict enforcement of safety regulation to guide the behaviour of the traffic participant.

Part IV: The test of the French, Belgian and Dutch traffic liability to the results of the economic analysis and the empirical research

Chapter 15. In this chapter the test mentioned above is worked out and the different regulation and proposals are summarised and translated into the descriptions used in the economic analysis. Furthermore it is examined to what extent these systems of traffic liability correspond to the results of the economic theory and the empirical research. As a result of this test the liability system and the traffic insurance system are compared. Finally, with regard to the mentioned research, a few recommendations are phrased.

For the final choice for one of the traffic liability systems, further research is necessary. The research was not able to give any evidence about the actual part in traffic of the liability law, the preventive effect of insurance conditions and the influence of safety regulation on the behaviour of non-motorised traffic participants. The research in question has shown that only with help of thoroughly statistic and empirical research to the liability, the insurance and the safety regulation in traffic, the legal, economic but particularly the political traffic debate can be held in a right way. From a preventive point of view a combined application of liability, insurance and safety regulation needs to be taken as a basic assumption in such a debate. For this research has shown that the legal instruments mentioned above cannot be discussed separately, they have an influence on each other. To make a choice for a system with liability and insurance, knowledge of the preventive effect of liability rules and the part of insurances on preventive an compensatory area is necessary. A preventive effect of liability rules cannot be achieved without involving the influence of insurance conditions. Safety regulation finally, matters there where the preventive effect of the market of liability and insurance does not lead to an optimal result. 


\section{Literatuurlijst}

Abraham, K.S. and L. Liebman, "Private Insurance, Social Insurance, and Tort Reform: Toward a New Vision of Compensation for Illness and Injury", Columbia Law Review, 1993, p. 75-118.

Adams, M., Ökonomische Analyse der Gefahrdungs- und Verschuldenshaftung, Heidelberg, R. v. Deckers's Verlag, 1985.

Akerlof, G.A., "The Market for 'Lemons': Quality Uncertainty and the Market Mechanismen", Quarterly Journal of Economics, 1970, p. 488-500.

ANWB, "Wetsvoorstel verkeersongevallen", VR, 1998/2, p. 33-37.

Appietto, J., "Fonds de garantie et loi Badinter, la détérioration du sort des victimes", Gaz. Pal., 1988, p. 121-127.

Arlen, J.H., "Re-Examining Liability Rules When Injurers As Well As Victims Suffer Losses", International Review of Law and Economics, 1990, p. 233-239.

Arnould, R.J. and H. Grabowski, "Auto Safety Regulation: An Analysis of Market Failure", Bell Journal of Economics, vol. 12, 1981, p. 27-48.

Arrow, K.J., "Aspects of the Theory of Risk-Bearing", Helsinki, Yrjö Jahnsson Lectures, 1965 , p. $28-45$.

Arrow, K.J., "Uncertainty and the Welfare Economics of Medical Care", American Economic Review, 1963, p. 941-973.

Asch, P. and D.T. Levy, "Does the Minimum Drinking Age Affect Traffic Fatalities?", Journal of Policy Analysis and Management, vol. 6, 1987, p. 180-192.

Asser, C., "Handleiding tot de beoefening van het Nederlands burgerlijk recht", Verbintenissenrecht, deel 3, De verbintenis uit de wet, bewerkt door A.S. Hartkamp, Zwolle, Tjeenk Willink, 1998, p. 205-222.

Atiyah, P.S., Accidents Compensation and the Law, London, 4th edition by Peter Cane, 1987.

Badinter, R., "Introduction", Resp. civ. et ass., 1996, p. 1-3.

Baird, D.G., R.H. Gertner and R.C. Picker, "Game Theory and the Law", Cambridge, Harvard University Press, 1998, p. 6-31 
Bancel, J-L., "Le point de vue de l'assureur", Resp. civ. et ass., 1996/4, p. 22-23.

Bartels, S. en M. Leijten, "Met het aansprakelijkheidsrecht kan niet alles", Interview met A.R. Bloembergen, $A A, 1994 / 4$, p. 217-223.

Bäumer, T., "Hat das deutsche Kraftfahrzeug-Haftpflichtversicherungs-System eine Zukunft?", Karlsruhe, Verlag Versicherungswirtschaft, 1982, p. 29-57.

Beard, T.R., "Bankruptcy and Care Choice", Rand Journal of Law and Economics, Winter 1990, p. 626-634.

Becker, G.R., "A Theory of Competition Among Pressure Groups for Political Influence", Quarterly Journal of Economics, 1983, vol. 58, p. 371-400.

Becker, G.R., "Crime and Punishment: An Economic Approach", Joumal of Political Economy, 1968, p. 169-217.

Becker, H. und K.E. Böhme, "Kraftverkehrs-Haftpflicht-Schäden", Heidelberg, C.F. Müller Juristischer Verlag. 1983, p. 495-535.

Belgische Kamer van Volksvertegenwoordigers, "Wetsontwerp tot wijziging van diverse bepalingen betreffende de regeling inzake automatische vergoeding van de schade, geleden door zwakke weggebruikers en passagiers van motorijtuigen", DOC 50 210/007 (1999-2000).

Belifante, A.D., De burgerrechtelijke gevolgen van de aanrijding met automobielen, 's-Gravenhage, 1936.

Benda, H. von and C.G. Hoyos, "Estimating Hazards in Traffic Situations", Accident Analysis and Prevention, vol. 15, 1983, p. 1-9.

Benson, B.L., D.W. Rasmussen and B.D. Mast, "Deterring Drunk Driving Fatalities: An Economics of Crime Perspective", International Review of Law and Economics, 1999, p. 205-225.

Bentley, A.F., The Process of Government, Chicago, University of Chicago Press, 1908.

Bergkamp, L., "Aansprakelijkheid is geen schadeverzekering", $N J B, 2000$, p. 273276.

Bernstein, M., Regulating Business by Independent Commission, Princeton, Princeton University Press, 1955. 
Bier, L., "Veranderingen in de werkgeversaansprakelijkheid", $V R, 1998 / 1$, p. 1-4.

Bier, L., "Eigen schuld werknemer: opzet of bewuste roekeloosheid", NTBR, 1993/1, p. 22-24.

Bijl, P. de en E. van Damme, Regulering en zelfregulering in markten met kwaliteitsonzekerheid, Rapport in het kader van het OCFEB-onderzoeksproject "Marktwerking in Nederland", Tilburg, CentER for Economic Research, 1997 p. 1-57.

Bijleveld, F.D., "Het effect van de bonus/malus-regeling op schademeldingen", Leidschendam, SWOV, 1998, R-98-47, p. 1-52.

Birds, J., "Modern Insurance Law", London, Sweet and Maxwell, 1988, p. 293-306.

Blackmon Jr., B.G. and R. Zeckhauser, "Mispriced Equity: Regulated Rates for Auto Insurance in Massachusetts", American Economic Review, Papers and Proceedings, 1991, vol. 81, p. 65-69.

Blees, F., "Schuld en boete", $V r b, 1995$, p. 9-12.

Bloembergen, A.R., "Vrijheid, gelijkheid en broederschap in het wetsvoorstel verkeersaansprakelijkheid", $N T B R, 1998 / 6$, p. 169-174.

Bloembergen, A.R., "Eigen schuild bij letselschade: een verweer op zijn retour", in Eigen schuld bij onrechtmatige daad, Lelystad, Vermande, LSA 1997, p. 5-13.

Bloembergen, A.R., "Collectivering van regres", in Regresrechten, afschaffen, handhaven of uitbreiden, W.H. van Boom, T. Hartlief en J. Spier (red.), Zwolle, Tjeenk Willink, 1996, p. 73-79.

Bloembergen, A.R., "Verkeersaansprakelijkheid en preventie", $V R$, 1995/1, p. 1-4.

Bloembergen, A.R., "Het SER-rapport over regresrechten: een fout verhaal", $N J B$, $1994 / 4$, p. 117-123.

Bloembergen, A.R., "Het regresrecht van de sociale verzekeraar", in Schadeverhaal, BW-krant Jaarboek, Leiden, 1987, nr. 3, p. 13-36.

Bloembergen, A.R., Schadevergoeding: Algemeen deel I, Monografieën Nieuw BW B-34, Deventer, Kluwer, 1982, p. 2-10.

Bloembergen, A.R., "Rapport van de Studiegroep Verkeersaansprakelijkheid; deel II: Blikschade", $N J B, 1980 / 36$, p. 925-938. 
Bloembergen, A.R., "Het rapport over het verkeersongevallenrecht", NJB, 1978/33, p. 693-708.

Bloembergen, A.R., "Naar een nieuw verkeersongevallenrecht (II-slot)", NJB, 1973/32, p. 998-1009.

Bloembergen, A.R., "Naar een nieuw verkeersongevallenrecht (I)", $N J B, 1973 / 31$, p. 961-97.1.

Bloembergen, A.R., Dient de wettelijke aansprakelijkheid bij verkeersongevallen vervangen te worden door een stelsel van verzekering?, preadvies N.J.V., Zwolle, Tjeenk Willink, 1967, p. 1-145.

Bloembergen, A.R., Naar een nieuw ongevallenrecht, Deventer, Kluwer, oratie, 1965, p. 3-31.

Bloembergen, A.R., Schadevergoeding bij onrechtmatige daad, Utrecht, diss., 1965, nr. 250.

Bloembergen, A.R., en P.J.M. van Wersch, Verkeersslachtoffers en hun schade, Deventer, Kluwer, 1973.

Bloembergen, A.R., J.C. Hersch-van Oven, P. Vinke en P.J.M. van Wersch, "Duizend botsingen: een kwantitatieve analyse van civiele rechtbankvonnissen in verkeerszaken", Deventer, Kluwer, 1972, p. 1-75.

Blomquist, G.C., The Regulation of Motor Vehicle and Traffic Safety, Boston/Dordrecht, Kluwer, 1988.

Bocken, H., "Van fout naar risico", TvP, 1984, p. 329-415.

Bocken, H. en I. Geers, "De vergoeding van letselschade en schade door overlijden bij verkeersongevallen", preadvies, $T_{v} P, 1996 / 3$, p. 67-131.

Bockwinkel, J. en S. van Gessel, "Wetsvoorstel Verkeersongevallen", $A A$, 1998/1, p. 34-42.

Boden, L., "Comment on Epstein", Journal of Legal Studies, 1984, p. 515.

Bolt, A.T., "Schadevergoeding (losbladig)". Art. 108 Schadevergoeding bij overlijden, suppl. 20 (oktober 1998), aant. 89. 
Bolt, A.T., "Opzet en bewuste roekeloosheid in het wetsvoorstel verkeersongevallen", $V R, 1998 / 6$, p. $161-165$.

Bolt, A.T., "Ontwikkelingen rondom artikel 31 WVW", $V R, 1992 / 7-8$, p. 175-180.

Bolt, A.T., "Loterij of rechtspraak: een rechtsvergelijkend onderzoek naar het Amerikaanse recht inzake schadevergoeding bij letsel en overlijden", Deventer, Kluwer, 1992, p. 47-71 en p. 179-216.

Bombaugh, R.L., "The Department of Transportation's Auto Insurance Study and Auto Accident Compensation Reform", Columbia Law Review, vol. 71, 1971, p. 207-240.

Boom, W.H. van, Verhaalsrechten van verzekeraars en risicodrageers, Deventer, W.E.J. Tjeenk Willink, 2000.

Boot, P.P.H., "Regres en volksverzekering", in Regresrechten. Afschaffen, handhaven of uitbreiden, W.H. van Boom, T. Hartlief en J. Spier (red.), Deventer, Tjeenk Willink, 1996, p. 81-93.

Bouma, H.Th., "De gevolgen van de Tijdelijke regeling verhaalsrechten", in (Nieuw) BW en personenschade, Lelystand, Vermande, LSA 1992, p. 27-41.

Bouman, H.A., "De billijkheidscorrectie tegen het licht", in Eigen schuld bij onrechtmatige daad, Lelystad, Vermande, LSA 1997, p. 25-56.

Bouman, H.A., "Reflex-billijkheid-verzekering", $V R$, 1994/2, p. 33-38.

Bouman, H.A., "Reflex-billijkheid-verzekering", In Volle Verzekerdheid, opstellen sangeboden aan Prof. mr A.J.O. baron van Wassenaer van Catwijck, Zwolle, Tjeenk Willink, 1993, p. 199-211.

Bouman, H.A., "Risico-aanvaarding bestaat niet. Wat nu?", Vrb, 1992, p. 1 en p. 911 .

Bouman, H.A., "De ontmoeting met het benzinemonster", in Een Salomons oordeel, Zwolle, Tjeenk Willink, 1991, p. 35-46.

Bouman, H.A., "Artikel 31 WVW: Van bewijslast naar bescherming", $V R, 1987 / 4$, p. $85-89$.

Bouman, H.A. en A.J.O. baron van Wassenaer van Catwijck, Verkeersaansprakelijkheid op de helling, $V R$, 1993/7-8, p. 221-227. 
Bowles, R., Law and the Economy, Oxford, Martin Robertson, 1982.

Brenninkmeijer, A.F.M., "Advocatentarieven niet op prijs gesteld", $N J B, 1994$, p. 1239-1246.

Brink, V. van den, "Vier ongelukken, vier arresten", $N b B W, 1998 / 2$, p. 26-28.

Brouwer, W.H., "Leeftijd en rijvaardigheid", in De mens in het verkeer: de zwakste schakel?!, J. Snel en P.T. Kempe (red.), Assen, Van Gorcum, 1995, p. 59-69.

Brown, C., "Deterrence in Tort and No-Fault: The New Zealand Experience", California Law Review, vol. 73, 1985, p. 976-1002.

Brown, J.P., "Toward an Economic Theory of Liabilty", Journal of Legal Studies, vol. 2,1973 , p. 323-349.

Bruce, C.J., "The Deterrent Effects of Automobile Insurance and Tort Law: A Survey of the Empirical Literature", Journal of Law and Policy, vol. 6, 1984, p. 67-100.

Buchanan, J.M., "The Public Choice Perspective", Journal of Public Finance and Public Choice, 1983, p. 7-15.

Buchanan, J.M., "Rent Seeking and Profit Seeking", in Toward a Theory of RentSeeking Society, J.M. Buchanan, R.D. Tollison and G. Tullock (eds.), Texas, A \& M University Press, 1980, p. 3-15.

Buchanan, J.M. and G. Tullock, The Calculus of Consent: Logical Foundations of Constitutional Democracy, University of Michigan Press, 1962/ Ann Arbor Paperback, 9e druk 1983.

Burrows, P., "Analyzing Legal Patemalism", International Review of Law and Economics, 1995, p. 489-508.

Calabresi, G., "Optimal Deterrence and Accidents", Yale Law Journal, 1975, p. 656-671.

Calabresi, G., The Cost of Accident: A Legal and Economic Analysis, New Haven, Yale University Press, 1970.

Calabresi, G. and J.T. Hirschoff, "Toward a Test for Strict Liability in Torts", Yale Law Journal, 1972, p. 1055-1085. 
Calabresi, G. and A.D. Melamed, "Property Rules, Liability Rules and Inalienability: One View of the Cathedral", Harvard Law Review, vol. 85, april 1972, p. 1089 1128.

Carr, J.L., "Giving Motorists a Choice Between Fault and No-Fault Insurance: An Economic Critique", San Diego Law Review, 1989, p. 1087-1094.

Carroll, S.J. and J.S. Kakalik, "No-Fault Approaches to Compensating Auto Accident Victims", Journal of Risk and Insurance, vol. 60, 1993, p. 265-287.

Carter, R.L., "Reinsurance", Brentford, Kluwer, 1983, p. 40-42.

Cave, M., "Market Models and Consumer Protection", Journal of Consumer Policy, 1985, p. 335-351.

Centraal Bureau voor de Statistiek/Ministerie van Verkeer en Waterstaat, Verkeersongevallen 1997, publ. N-84, Assen, Van Gorcum, 1998.

Chabas, F., "L'interprétation des art. 2 à 6 de la loi du 5 juillet 1985 et la question des recours", Gaz. Pal., Spécial responsabilité civil, 1995, p. 17-27.

Chabas, F., "Le droit des accidents de la circulation après la reforme du 5 juillet 1985", Paris, Gaz. Pal., 2e édition, 1988.

Chaloupka, J., H. Saffer and M. Grossman, "Alcohol-Control Policies and MotorVehicle Fatalities", Journal of Legal Studies, 1993, vol. 22, p. 161-186.

Chapman, B. and M.J. Trebilcock, "Making Hard Social Choices: Lessons from the Auto Accident Compensation Debate", Law and Economics, Working Paper Senies, 1991, p. 1-83.

Chelius, J.R., "Liablility for Industrial Accidents: A Comparison of Negligence and Strict Liability Systems", Journal of Legal Studies, 1976, p. 293-309.

Chirinko, R.S. and E.P. Harper Jr., "Buckle Up or Slow Down? New Estimates of Offsetting Behavior and Their Implications for Automobile Safety Regulation", Journal of Policy Analysis and Management, vol. 12, 1993, p. 270-296.

Claassens, H., De prijs van de vrijheid: bonus-malus in de autoverzekering, $\mathrm{ABB}$ verzekeringen, Dossier Bonus-Malus, 1996, p. 9.

Claassens, H., "Verplichte verzekeringen: Een nieuw verschijnsel in België", $R W$, $1977 / 3$, p. 146-154. 
Claassens H. en C. Van Schoubroeck, "Praktische ervaring met de Belgische schadevergoedingsregeling voor zwakke weggebruikers in de autoverzekering", in Verkeersaansprakelijkheid in België en Nederland, M.G. Faure en T. Hartlief (red.), Groningen-Antwerpen, Intersentia, 1998, p. 75-111 en p. 253-291.

Claassens, H. en C. van Schoubroeck, "De Belgische schadevergoedingsregeling voor zwakke weggebruikers in de verplichte autoverzekering", $V R$, 1997/12, p. 359363.

Clausing, P., "Verkeersaansprakelijkheid en verzekering", preadvies, $T y P, 1978, \mathrm{p}$. 1019-1021.

Coase, R.H., "The Problem of Social Cost", Journal of Law and Economics, vol. III, 1960 , p. $1-44$

Colinvaux, R., "The Law of Insurance", London, Sweet and Maxwell, 1984, p. 421433.

Comite Europeen des Assurance, "The European Motor Insurance Market in 1997", CEA ECO, november 1998, nr 6, p. 20-21 en p. 34-35.

Cook, P.J. and G. Tauchen, "The Effect of Minimum Drinking Age Legislation on Youthful Auto Fatalities, 1970-1977", Journal of Legal Studies, 1984, vol. 13, p. 169-190.

Cooter, R.D., "Economic Theories of Legal Liability", Journal of Economic Perspectives, summer 1991, vol. 5, p. 11-30.

Cooter, R.D., L. Kornhauser and D. Lane, "Liability Rules, Limited Information, and the Role of the Precedent", Bell Journal of Economics, 1979, p. 366-373.

Cooter, R.D. and Th.S. Ulen, Law and Economics, Addison/Wesley, $3^{\text {rd }}$ edition, 2000.

Cornelis, L., "De objectieve aansprakelijkheid voor motorrijtuigen", $R W, 1998$ 1999/16, p. 521-537.

Cornelis, L., "Extra-contractuele aansprakelijkheid voor zaken", TvP, 1984, p. 299327.

Cousy, H., "The Implementation of the Directives in Belgium", in The Law and Practice of Insurance in the Single European Market, Trier, Series of Publications by the Acadamy of European Law, 1995, p. 97-103. 
Cousy, H. en H. Claassens, "Ex Post Control of Insurance in Belgium", Geneva Papers on Risk and Insurance, vol. 19, 1994, p. 46-59.

Cousy, H. en H. Claassens, "Het Europa van de verzekeringen", Antwerpen-Apeldoorn, Maklu, 1992, p. 17-43 en p. 261-276.

Cousy, H. en H. Claassens (ed.), Verkeersschade en verzekering: Revolutie of evolutie?, Tweede Leuvense Verzekeringsdagen, K.U. Leuven, Afdeling Economisch Recht - Instituut voor Actuariële Wetenschappen, Antwerpen-Amsterdam, Maarten Kluwer, 1981.

Cramton, R.C., "Driver behaviour and legal sanctions: A study of deterrence", Michigan Law Review, 1969, p. 421-454.

Crandall, R.W. and J.D. Graham, "Automobile Safety Regulation and Offsetting Behavior: Some New Empirical Estimates", American Economic Review, Papers and Proceedings, vol. 74, 1984, p. 328-331.

Crew, M.A. and C.K. Rowly, "Toward a Public Choice Theory of Monopoly Regulation", Public Choice, 1988, p. 49-67.

Cummins, J.D. and S. Tennyson, "Controlling Automobile Insurance Costs", Journal of Economic Perspective, 1992, vol. 6, p. 95-115.

Cummins, J.D. and M.A. Weiss, "The Stochastic Dominance of No-Fault Automobile Insurance", Journal of Risk and Insurance, vol. 60, 1993, p. 230-264.

Cummins, J.D. and M.A. Weiss, "The Effects of No Fault on Automobile Insurance Loss Costs", Geneva Paper on Risk and Insurance, 1991, p. 20-38.

Curran, C., "The Spread of the Comparitive Negligence Rule in the United States", Iniemational Review of Law and Economics, 1992, vol. 12, p. 317-332.

Curran, C. and G.P. Dwyer Jr., "The Effect of the Double Nickel Speed Limit on Death Rates", in Essays in Law and Economics; Corporations, Accident Prevention and Compensation for losses, M.G. Faure and R. Van den Bergh (eds), AntwerpenApeldoorn, Maklu, 1989, p. 117-161.

Dahlby, B.G., "Adverse Selection and Statistical Discrimimation: An Analysis of Canadian Automobile Insurance", Journal of Public Economics, 1983, p. 121-130. 
Dalcq, R.O., "La loi du 13 avril 1995 replacant l'article 29 bis et abrogeant l'article 29ter inséré par la loi du 30 mars 1994 dans la loi du 21 novembre 198.9", R.G.A.R., $1995,12484 / 1-4$.

Dalcq, R.O., "L'indemnisation des dommages corporels des piétons et des cyclistes", J.T., 1994, p. 665-672.

Dalcq, R.O., "La faute de la victime", J.T., 1983, p. 317-322.

Dam, C.C. van, Aansprakelijkheidsrecht, Den Haag, Boom Juridische uitgevers, 2000.

Dam, C.C. van, "Bewijs bij verkeersongevallen", in Bewijs en letselschade, Lelystad, Vermande, LSA 1998, p. 23-45.

Dam, C.C. van, "Het wetsvoorstel verkeersongevallen", $V R$, 1997/12, p. 353-358.

Dam, C.C. van, "Beperking van de regresvordering bij verkeersaansprakelijkheid", $N b B W, 1995 / 9$, p. 96-98.

Dam, C.C. van, Verzekering naar komend recht, preadvies van de Vereeniging 'Handelsrecht' en de Vereniging voor Verzekeringswetenschap, Zwolle, Tjeenk Willink, 1995, p. 72-74.

Dam, C.C. van, "Nogmaals: Onrechtmatige daad, eigen schuld van een kind, billijkheidscorrectie; Kolkman", Kwartaalbericht Nieuw BW, 1990/4, p. 127-130.

Dam, C.C. van, "Onrechtmatige daad; Eigen schuld van een kind; Billijkheidscorrectie; Lars Rurode", Kwartaalbericht Nieuw BW, 1990, p. 90-94.

Dam, C.C. van, Zorgvuldigheidsnorm en aansprakelijkheid, Deventer, Kluwer, diss., 1989.

Dam, C.C. van, "De Hoge Raad op zoek naar de perfecte automobilist", VR, 1985, p. 261-264.

Damme, E. van, "Veiligheidsmaatregelen reduceren de veiligheid", ESB, 1995, p. 114-1145.

Danzon, P.M., "Tort Reform and the Role of the Government in Private Insurance Markets", Journal of Legal Studies, vol. 13, 1984, p. 519-524. 
Decroës, A., "De vergoeding van de zwakke weggebruikers (art. 29bis W.A.M.wet)", $R W, 2001$, p. 1257-1267.

Dekyndt, C., "Voomaamste bibliografische gegevens; beknopt overzicht", in De vergoeding van de zwakke weggebruikers in de autoverzekering: een praktische handleiding, Bull. Ass. - De Verz., Antwerpen, Story-Scientia, Dossier 3, 1995, p. $30-41$.

Demsetz, H., "When Does the Liability Rule Matter?" Journal of Legal Studies, 1972, p. $13-28$.

Demsetz, H., "Why Regulate Utilities?", Journal of Law and Economics, 1968, p. 55-65.

Denoël, N., "L'indemnisation des usagers faibles en assurance automobile: étude détaillée de trois cas pratique", in De vergoeding van de zwakke weggebruikers in de autoverzekering: een praktische handleiding, Bull. Ass. - De Verz., Antwerpen, Story-Scientia, Dossier 3, 1995, p. 67-96.

De Rode, H., "Les limites du droit à l'indemnisation, catégories de victimes, Fautes inexcusables", in L'indemnisation automatique de certaines victimes d'accidents de la circulation, B. Dubuisson (ed.), Brussel, Academia-Bruylant, 1995, p. 75-106.

Derrig, R.A., "Price Regulation in US Automobile Insurance; A Case Study of Massachusetts Private Passenger Automobile Insurance 1978-1990", Geneva Papers on Risk and Insurance, 1993, no 67, p. 158-173.

Devlin, R.A., "Some Welfare Implications of No-Fault Automobile Insurance", $I n$ fernational Review of Law and Economics, 1990, p. 193-205.

Dewees, D., D. Duff and M. Trebilcock, "Exploring the Domain of Accident Law; Taking the Facts Seriously", New York/Oxford, Oxford University Press, 1996, p. 394 en p. $412-439$.

Diamond, P., "Single Activity Accidents", Journal of Legal Studies, vol. 4, 1974, p. 107-164.

Dijk, Chr.H. van, "De toekomst van de reflexwerking na invoering van het wetsvoorste! verkeersongevallen", $V R, 1998 / 5$, p. 132-133.

Dijk, Chr.H. van, "Gevolgen voor de schadeafwikkeling bij inwerkingtreding van het wetsvoorstel Verkeersongevallen", VR, 1998/5, p. 129-131. 
Doel, J. van den en B.C.J. van Velthoven, "Democratie en welvaartstheorie", Alphen aan den Rijn, Samson H.D. Tjeenk Willink, 1990, p. 43-51.

Dommering, E.J., "Informatie tussen economie en cultuur", in Informatierecht: Fundamentele rechten voor de informatiesamenleving, Amsterdam, Otto Cramwinkel, 2000 , p. $475-485$.

Downes, T.A., "French Lessons on Motor Accident Compensation", in Current Issues in European and International Law; Essays in Memory of Frank Dowrick, R. White and B. Smythe (eds.), Sweet and Maxwell, London, 1990, p. 173-189.

Drion, H., Verzekering en aansprakelijkheid, Rotterdam, oratie, 1955.

Dubuisson, B., "La loi sur l'indemnisation automatique de certaines victimes d'accidents de la circulation ou l'art du "clair obscur", in L'indemnisation automatique de certaines victimes d'accidents de la circulation, B. Dubuisson (ed.), Brussel, Academia-Bruylant, 1995, p. 9-49.

Durieux, A.M., "Wegenverkeerswet 1994", Commentaar, Artikel 8, p. 3-4.

Durry, G., "Het Franse Waarborgfonds Motorverkeer na de Wet 'Badinter' van 5 juli $1985^{\prime \prime}, V R, 1991 / 2$, p. 29-34.

Edlin, A.S., "Efficient Standards of Due Care: Should Courts Find More Parties Negligent under Comparative Negligence?" International Review of Law and Economics, 1994, vol. 14, p. 21-34.

Ehrenzweig, A., "Assurance Oblige. A Comparative Study", Law and Contemporary Problems, 1950, p. 445-455.

Elzas, R.Ph., Handboek Schaderegeling Motorijtuigen, mei 2000, 205-1 t/m 205-7 en 211-1 t/m 211-38.

Elzas, R.Ph., Special Handboek Schaderegeling Motorrijtuigen: Wetsontwerp verkeersongevallen, Alphen aan den Rijn, Samson, 1998.

Elzas, R.Ph., "Personenschade: enkele ontwikkelingen en suggesties, VA, 1998/1, p. 2-7.

Emons, W., An Introduction to the Legal and Economic Theories of Torts, Working Paper, 1991, Universität Basel, 1-25. 
Endres, A., Ökonomische Grundlagen des Haftungsrecht, Heidelberg, Physica-Verlag, 1991.

Engelhard, E.F.D. en G.E. van Maanen, "Nieuw voorstel verkeersaansprakelijkheid in de maak", $V R, 1999$, p. 353-357.

Engelhard, E.F.D. en G.E. van Maanen, "Naar een gedifferentieerd vergoedingsregime voor verkeersslachtoffers; een nieuw wetsvoorstel", $V R, 1999$, p. 135-139.

Engelhard, E.F.D. en G.E. van Maanen, Aansprakelijkheid voor verkeersongevallen, Nijmegen, Ars Aequi Libri, 1998.

Evans, L., Traffic Safety and the Driver, New York, Van Nostrand Reinhold, 1991.

Evans, L., "The Effectiveness of Safety Belts in Preventing Fatalities", Accident Analysis and Prevention, vol. 18, 1986, p. 229-241.

Fagnart, J-L., "L'indemnisation des vitimes d'accidents de la circulation après la réforme baclée du 30 mars 1994", RGAR, 1994, 12388/1-16.

Fairley, W.B., T.J. Tomberlin and H.I. Weisberg, "Pricing Automobile Insurance Under a Cross-Classification of Risks: Evidence from New Jersey", Journal of Risk and Insurance, vol. 48, 1981, p. 505-514.

Faure, M.G., "Regres in een rechtseconomisch perspectief", in Regresrechten, afschaffen, handhaven of uitbreiden, W.H. van Boom, T. Hartlief en J. Spier (red), Zwolle, Tjeenk Willink, 1996, p. 45-71.

Faure, M.G., "Over beschermde slachtoffers, vrijgevige rechters en zuchtende verzekeraars", $N J B, 1995$, p. 1227-1235.

Faure, M.G., "Rechtseconomische kanttekeningen bij de deregulering van de arbeidsomstandighedenwetgeving", Sociaal Recht, 1995, p. 140-149.

Faure, M.G., Rechtseconomische beschouwingen over aansprakelijkheid, verzekering en fondsen, Rapport voorbereid voor de werkgroep Superfund van het Verbond van Verzekeraars, Maastricht, april 1995, p. 1-20.

Faure, M.G., "The Influence of Insurance on Liability Issues", in Series of Publications by the Acadamy of European Law, Trier, 1994, vol. 11, p. 190. 
Faure, M.G., "De verzekering van het nucleair risico", In Volle Verzekerdheid, opstellen aangeboden aan Prof. mr A.J.O. baron van Wassenaer van Catwijck, Zwolle, Tjeenk Willink, 1993, p. 247-260.

Faure, M.G., "Ongevallenpreventie door efficiente aansprakelijkheidsregels en verzekeringspolissen op competitieve verzekeringsmarkten", Het Verzekerings-Archief, 1993, p. 3-22.

Faure, M.G., "Rechtseconomie en privaatrecht: Kunnen rechtsregels bijdragen tot de reductie van ongevalskosten", in Rechtseconomie en Recht; Kennismaking met een vakgebied in opkomst, E.H. Hondius, J.J. Schippers en J.J. Siegers, Zwolle, W.E.J. Tjeenk Willink, 1991, p. 51-93.

Faure, M.G., "Milieubescherming door aansprakelijkheidsrecht of regulering?", Ars Aequi, 1990, vol. 39, p. 157-167.

Faure, M.G. en R.J. Van den Bergh, "Restrictions of Competition on Insurance Markets and the Applicability of EC Antitrust Law", KYKLOS, Vol. 48, 1995. p. 6585 .

Faure, M.G. en R.J. VandenBergh, "Het toelaten van kartels op de Europese verzekeringsmarkt", $N J B, 1993$, p. 261-267.

Faure, M.G. en R.J. Van den Bergh, "Self-Regulation of the Professions in Belgium", International Review of Law and Economics, 1991, p. 165-182.

Faure, M.G. en R.J. Van den Bergh, De invloed van verzekering op de civiele aansprakelijkheid. Een rechtseconomische analyse, Preadvies, Lelystad, Koninklijke Vermande, 1990, p. 9-53.

Faure, M.G. en R.J. Van den Bergh, Objectieve Aansprakelijkheid, Verplichte Verzekering en Veiligheidsregulering, Antwerpen-Apeldoorn, MAKLU uitgevers, 1989.

Faure, M.G. en R.J. Van den Bergh, "Efficienties van het foutcriterium in het Belgisch aansprakelijkheid", Rechtskundig Weekblad, 16 april 1988, p. 1105-1119.

Faure, M.G. en R.J. Van den Bergh, "Liever geen slachtoffer dan een door het recht beschermd slachtoffer", Intermediair, 18 december 1987, p. 9-13.

Faure, M.G. en R.J. Van den Bergh, "Negligence, Strict Liability and Regulation of Safety under Belgian Law: An Introductory Economic Analysis", Geneva Papers on Risk and Insurance', 1987, p. 95-110. 
Faure, M.G. en T. Hartlief, "Het kabinet en de claimcultuur", $N J B, 1999$, p. 20072015.

Faure, M.G. en T. Hartlief, "Verzekering en financiering van beroepsziekten: enkele tips voor de SER", $N J B, 1998$, p. 1139-1142.

Faure, M.G. en T. Hartlief, "Een schadefonds als alternatief voor aansprakelijkheid en verzekering, $R M$ Themis, 1998, p. 211-228.

Faure, M.G. en T. Hartlief, "Compensation Funds versus Liability and Insurance for Remedying Environmental Damage", Review of European Community \& International Environmental Law (RECIEL), 1996, p. 321-327.

Faure, M.G. en T. Hartlief, Verzekering en de groeiende aansprakelijkheidslast, Deventer, Kluwer, 1995, p. 291-301.

Faure, M.G. en T. Hartlief, "Een nieuwe regeling van de verkeersaansprakelijkheid in België: lessen voor Nederland?", $V R$, 1995/9, p. 257-262.

Faure, M.G. en M. Ruegg, "Standard Setting Through General Principles of Environmental Law", in Environmental Standards in the European Union in an Interdisciplinary Framework, M.G. Faure, J. Vervaele and A. Weale (eds), Antwerpen, Maklu, 1994, p. 52-58.

Figlio, D.N., "The Effect of Drinking Age Laws and Alcohol-Related Crashes: Time-Series Evidence from Wisconsin", Journal of Policy Analysis and Management, vol. 14, 1995, p. 555-566.

Finn, P. and B.W.A. Bragg, "Perception of the Risk of an Accident by Young and Older Drivers", Accident Analysis and Prevention, vol. 18, 1986, p. 289-298.

Finsinger, J., "The Choice of Risky Technologies and Liability", International Review of Law and Economics, 1991, p. 11-22.

Finsinger, J., European Market Integration and the European Insurance Industry, Research Report: Centre For European Policy Studies, Üniversität Hohenheim, Sturtgart, August 1990, p. 1-33.

Finsinger, J., European Integration of Insurance Markets, Preliminary but Novel Perspectives, Working Paper, Universität Lüneburg, nr. 75, 1989, p. 1-14. 
Finsinger, J., E. Hammond and J. Tapp, Insurance: Competition or Regulation?, A Comparative Study of the Insurance Markets in the United Kingdom and the Federal Republic of Germany, London, The Institute of Fiscal Studies, Report Series, nr. $19,1985$.

Finsinger, J., "A State Controlled Market: The German Case", in The Economics of Insurance Regulation: A Cross-National Study, J. Finsinger and M.V. Pauly (eds.), Basingstoke/New York, MacMillan, 1986, p. 111-160.

Finsinger, J., "Versicherungsmärkte", FrankfurtNew York, Campus Verlag, 1983, p. 25-37, p. 61-67 en p. 81-121.

Fredericq, S., "Belgique. Assurance automobile. Protection des piétons et des cyclistes. Une loi révolutionnaire: la loi du 30 mars 1994", Bulletin d'information de l'AIDA, nr. 45, 1994, p. 70-71.

Fredericq, S., "De Pacs-verzekering in Frankrijk en België", in Een Salomons oordeel, Zwolle, Tjeenk Willink, 1991, p. 49-54.

Frenk, N., "De directe schadeverzekering als vervanging van aansprakelijkheid", $N J B, 1999$, p. $1547-1554$.

Frenk, N., "Bespreking van het wetsvoorstel verkeersongevallen", NTBR, 1998/6, p. 199-207.

Frenk, N., "Het Nederlandse wetsvoorstel in het licht van de Belgische regeling", in Verkeersaansprakelijkheid in België en Nederland, T. Hartlief en M.G. Faure (red.), Groningen-Antwerpen, Intersentia, 1998, p. 113-130.

Frenk, N., "Het wetsvoorstel verkeersongevallen bij de Tweede Kamer ingediend", $N b B W, 1998 / 1$, p. 6-10.

Freriks, D. en A. Diercxsens, "De nieuwe vergoedingsregel ten voordele van fietsers en voetgangers", $V R, 1995 / 6$, p. 168-169.

Garbacz, C., "More Evidence on the Effectiveness of Seat Belt Laws", Applied Economics, vol. 24, 1992, p. 313-315.

Garbacz, C., "Impact of the New Zealand Seat Belt Law", Economic Inquiry, vol. 29,1991, p. $310-316$.

Geest, G. de, Economische analyse van het contracten- en quasi contractenrecht, diss., Serie Recht en Economie, Antwerpen-Apeldoorn, Maklu, 1994. 
Gerven, W. van, "De invloed van de verzekering op het verbintenissenrecht", Rechtskundig Weekblad, 1962-63, p. 777-792.

Göhler, E., "Ordnungswidrigkeitengesetz", München, Verlag C.H. Beck, 8. Auflage, 1987, p. 103-120.

Gomez, F., Insurance Benefits, Insurance Subrogation and Imperfect Liability Rules, Paper, University of Madrid, 1996, p. 1-24.

Graham, J.D. and S. Garber, "Evaluating the Effects of Automobile Safety Regulation", Journal of Policy Analysis and Management, vol. 3, 1984, p. 206-224.

Gravelle, H.S.E., "Insurance Law and Adverse Selection", International Review of Law and Economics, 1991, vol. 11, p. 23-45.

Green, J., "On the Optimal Structure of Liabilty Laws", Bell Journal of Economics, 1976, p. 553-574.

Groot, G.R.J. de, Schaderegeling bij verkeersongevallen, Zwolle, W.E.J. Tjeenk Willink, 1979.

Grout, P., I. Jewitt, C. Pong and G. Wittington, "Auditor Professional Judgment: Implications for Regulation and the Law", Economic Policy, 1994, p. 308-351.

Haas, S.P. de en T. Hartlief, Verkeersaansprakelijkheid: vergoeding van personenschade in Europees perspectief, Deventer/Den Haag, Kluwer/Stichting Personenschade Instituut van Verzekeraars (PIV), 1998.

Haas, S.P. de en T. Hartlief, Collectivering en institutionalisering van regres: instrumenten voor kostenbeheersing, Deventer/Den Haag, Kluwer/Verbond van Verzekeraars, 1996.

Haddock, D. and C. Curran, "An Economic Theory of Comparitive Negligence", Journal of Legal Studies, 1985, vol. 14, p. 49-72.

Hagg, P.G.T., "Theories on the Economics of Regulation: A Survey of the Literature from a European Perspective", European Journal of Law and Economics, 1997, p. 337-370.

Hahn, R.W., "The Political Economy of Environmental Regulation: Towards a Unifying Framework", Public Choice, 1990, vol. 65, p. 21-47. 
Handelingen Tweede Kamer, Vaststelling en invoering van afdeling 8.14 .1 (verkeersongevallen) van het Burgerlijk Wetboek, 1998-1999, 25759, nr. 5 (H).

Handelingen Tweede Kamer, Vaststelling van de begroting van de uitgaven en de ontvangsten van het Ministerie van Justitie (VI) voor het jaar 1998, 1997-1998, 25600 VI, nr. 74.

Handelingen Tweede Kamer, Vaststelling en invoering van afdeling 8.14.1 (verkeersongevallen) van het Burgerlijk Wetboek, 1997-1998, 25759, nr. 1-3 en B.

Handelingen Tweede Kamer, Notitie verkeersaansprakelijkheid, 1989-1990, 21528, nr. 1-2.

Harrington, S.E., "Prices and Profits in the Liability Insurance Market", in Liability: Perspectives and Policy, R.E. Litan and C. Winston (eds.), Washington D.C., The Brookings Institute, 1988, p. 42-45.

Harrington, S.E. and H.I. Doerpinghaus, "The Economics and Politics of Automobile Insurance Rate Classification", Journal of Risk and Insurance, 1993, p. 5984.

Hartlief, T., "Van slachtoffer en 'daders: op weg naar een afnemende reikwijdte van het aansprakelijkheidsrecht", in Het belang van de dader, Lelystad Vermande, LSA 1999 , p. $1-27$.

Hartlief, T., "De plannen van Korthals met betrekking tot het wetsvoorstel verkeersongevallen", TVP, 1999, p. 73-74.

Hartlief, T., "Verkeersongevallen: aansprakelijkheid of verzekering?", $R M$ Themis, 1999 , p. 52-53.

Hartlief, T., "De positie van regresnemers: van art. $185 \mathrm{WVW}$ naar art. IIB in het wetsvoorstel Verkeersongevallen", VR, 1998/9, p. 257-261.

Hartlief, T., "De positie van bestuurder en inzittende in het Nederlandse wetsvoorstel", in Verkeersaansprakelijkheid in België en Nederland, T. Hartlief en M.G. Faure (red.), Groningen-Antwerpen, Intersentia, 1998, p. 147-196.

Hartlief, T., Ieder draagt zijn eigen schade, Deventer, Kluwer, oratie, 1997.

Hartlief, T., De zwakke verkeersdeelnemer, preadvies, TvP, 1996, nr. 3, p. 12711335. 
Hartlief, T., "Subrogatie in zieligheid", NJB, 1996/27, p. 1047-1050.

Hartlief, T., "De individuele afhandeling van regresdossiers: een stand van zaken" in Regresrechten. Afschaffen, handhaven of uitbreiden, W.H. van Boom, T. Hartlief en J. Spier (red.), Deventer, Tjeenk Willink, 1996, p. 1-33.

Hartlief, T., "Iudex non calculat", NJB, 1994/11, p. 353-356.

Hartlief, T., "Art. 31 WVW en de schade van de automobilist", WPNR 6062, 1992, p. 663-667.

Hartlief, T., "Kinderen, art. 31 WVW en overmacht", NTBR, 1992/2, p. 70-73.

Hartlief, T. en G.E van Maanen, Regres bij volksverzekeringen: de dader heeft het gedaan, $N T B R, 1994 / 4$, p. $75-78$.

Hartlief, T. en R.P.J.L. Tjittes, "Verkeersaansprakelijkheid", NTBR, 1996/1, p. 3134.

Hartlief, T. en R.P.J.L. Tjittes, Verzekering en aansprakelijkheid, Deventer, Kluwer, Serie Recht en Praktijk, nr. 79, 1999.

Hartlief, T. en R.P.J.L. Tjittes, "Verkeersaansprakelijkheid: Quo Vadis?", NTBR, $1992 / 4$, p. $115-123$.

Hartlief, T. en R.P.J.L. Tjittes, "Overmacht bij verkeersaansprakelijkheid ex art. $31 \mathrm{WVW}, N b B W, 1992 / 6$, p. 67-68.

Hartlief, T. en R.P.J.L. Tjittes, "Kinderen en eigen schuld", VR, 1991/1, p. 1-5.

Hartlief, T. en R.P.J.L. Tjittes, De invloed van verzekeringen op de civiele aansprakelijkheid, preadvies N.J.V., 1990, p. 77-79.

Hauferlin, J.M. en H. Claassens, "Le regime belge d'indemnisation des usagers faibles en assurance automobile: le cadre general", in De vergoeding van de zwakke weggebruikers in de autoverzekering: een praktische handleiding, Bull. Ass. - De Verz., Antwerpen, Story-Scientia, Dossier 3, 1995, p. 9-27.

Hijma, Jac., "Verkeer, verhaal, verwijt", WPNR 6216, 1996, p. 199-200.

Hijma, Jac., "Marloes de Vos", $A A$, 1996/1, p. 35-40.

Hijma, Jac., "Anja Kellenaers", $A A, 1994 / 6$, p. 445-450. 
Hijma, Jac., "IZA/Vrerink", $A A$, 1992/9, p. 497-505.

Hijma, Jac., "Ingrid Kolkman", AA, 1991/1, p. 64-71.

Hoekema, A., Vergoeding van verkeersschade, Deventer, Kluwer, 1976.

Holzhauer, R.W. en R. Teijl (red.), Inleiding rechtseconomie, Amhem, Gouda Quint, 1995.

Holzhauer, R.W. en R. Teijl, "Rechtseconomie in Nederland", Ars Aequi, april 1989 , p. 248-252.

Hondius, E.H., J.J. Schippers en J.J. Siegers, "Rechtseconomie: Brug tussen twee disciplines, in Rechtseconomie en Recht: Kennismaking met een vakgebied in opkomst, Zwolle, W.E.J. Tjeenk Willink, 1991, p. 1-3.

Hoogenboom, J.M., "De maatschappelijke kosten van verkeersongevallen", VR, 1992, p. 317-321.

Horst, N.M. van der, "Verkeersverzekering", In Volle Verzekerdheid, opstellen aangeboden aan Prof. mr A.J.O. van Wassenaer van Catwijck, Zwolle, Tjeenk Willink, 1993, p. 277-286.

Hulst, E.H., "Een nieuwe grondslag voor aansprakelijkheid", NJB, 1992/22, p. 693700 .

Huys, J. en D. Simoens, "De nieuwe verkeersongevallenwet: repercussies op de sectoren ziekteverzekering en arbeidsongevallen", TSR, 1994, p. 230-245.

Ivamy, E.R.H., General Principles of Insurance Law, London, Butterworths, 1986, p. $30-87$.

Jaffer, S.M. and J.A. Kay, "The Regulation of Shop Opening Hours in the United Kingdom", in Law and Economics and the Economics of Legal Regulation, J-M. Graf von der Schulenburg and G. Skogh (eds.), Boston/Dordrecht, Kluwer, 1986, p. 169-183.

Janssen, P.L.M., "Verhaalsrechten in de sociale zekerheid", VA, 1997/4, p. 155162.

Jeschek, H.H. und T. Weigend, "Lehrbuch des Strafrechts", Berlin, Duncker und Humblot, 5. Auflage, 1996, p. 56-60 en p. 770-774. 
Jonah, B.A., "Accident Risk and Risk-Taking Behavior Amoung Young Drivers", Accident Analysis and Prevention, vol. 18, 1986, p. 255-271.

Jonah, B.A. and G.R. Engel, "Measuring the Relative Risk of Pedestrian Accidents", Accident Analysis and Prevention, 1983, p. 193-206.

Jonah, B.A. and J.J. Lawson, "The Effectiveness of the Canadian Mandatory Seat Belt Use Laws", Accident Analysis and Prevention, vol. 16, 1984, p. 433-450.

Johnson, J.E., G.B. Flanigan and D.T. Winkler, "Cost Implications of No-Fault Automobile Insurance", Journal of Risk and Insurance, vol. 59, 1992, p. 116-123.

Jordaans, J.P., "Kroniek Vermogensrecht", Advocatenblad, 1992, p. 277-281.

Jost, P-J., "Limited Liability and the Requirement to Purchase Insurance", International Review of Law and Economics, 1996, p. 259-276.

Jourdain, P., "Domaine et conditions d'application de la loi du 5 juillet 1985", Gaz. Pal., Spécial responsabilité civil, 1995, p. 3-16.

Kahan, M., "Causation and incentives to take care under the negligence rule", Journal of Legal Studies, 1989, vol. 18, p. 427-447.

Kaltenegger, A. und S. Speyer, "Deutsches Recht", in The Law and Practice of Insurance in the Single European Market, Trier, Series of Publications by the Acadamy of European Law, 1995, p. 105-122.

Kaplow, L. and S. Shavell, "Property Rules versus Liability Rules: An Economic Analysis, Harvard Law Review, 1996, vol. 109, p. 715-790.

Keeler, T.E., "Highway Safety, Economic Behavior and Driving Environment", American Economic Review, 1994, p. 684-693.

Keenan, D. and P.H. Rubin, "Shadow Interest Groups and Safety Regulation", International Review of Law and Economics, 1988, p. 21-36.

Keeton, P., R.E. Keeton, L.D. Sargentich and H.J. Steiner, Cases and Materials on Tort and Accident Law, St. Paul, Minn., West Publishing Co., 1983.

Keeton, R.E., Basic Text on Insurance Law, St. Paul, Minn., West Publishing Co., 1971. 
Keeton, W.P., D.B. Dobbs, R.E. Keeton and D.G. Owen, Prosser and Keeton on the Law of Torts, St. Paul, Minn., West Publishing Co., 1984, 5th edition.

Keeton, W.R. and E. Kwerel, "Externalities in Automobile Insurance and the Underinsured Driver Problem", Journal of Law and Economics, 1984, p. 149-179.

Kelly, H., "Testing Peltzman's Theory of Driver Intensity", Law and Policy, vol. 6, 1984, p. $129-143$.

Kenkel, D.S., "Drinking, Driving and Deterrence: The Effectiveness and Social Costs of Alternative Policies", Journal of Law and Economics, vol. 36, 1993, p. 877 913.

Kerkmeester, H.O., "De betekenis van het waarschijnlijkheidsbegrip voor de aansprakelijkheid uit onrechtmatige daad: Meijers geactualiseerd", WPNR, 1993, nr. 6111, p. 767-773.

Kimball, S.L., "The Context of "No Fault", Journal of Risk and Insurance, 1985, p. 662-666.

Klaassen, C.J.M., "Risico-aansprakelijkheid als eigen schuld: heroverweging van heersende leer", in Eigen schuld bij onrechtmatige daad, Lelystad, Vermande, LSA 1997, p. 61-69.

Kneuper, R. and B. Yandle, "Auto Insurers and the Air Bag", The Journal of Risk and Insurance, vol. 61, 1994, p. 107-116.

Kochanowski, P.S. and M.V. Young, "Deterrent Aspects of No-Fault Automobile Insurance: Some Empirical Findings", The Journal of Risk and Insurance, 1985, p. 269-288.

Kolstad, C.D., Th.S. Ulen and G.V. Johnson, "Ex Post Liability for Harm vs. Ex ante Safety Regulation: Substitutes or Complements?", American Economic Review, vol. 80,1990 , p. $888-901$.

Kornhauser, L. and A. Schotter, "An Experimental Study of Single-Actor Accidents", Journal of Legal Studies, 1990, p. 203-233.

Kortmann, S.C.J.J., "Gaflic-Mulder", $A A$, 1987/10, p. 638-643. 
Kottenhagen-Edzes, P.A., "De positie van de ongemotoriseerde verkeersdeelnemer in Nederland op grond van het wetsvoorstel verkeersongevallen", in Verkeersaansprakelijkheid in België en Nederland, T. Hartlief en M.G. Faure (red.), GroningenAntwerpen, Intersentia, 1998, p. 131-146.

Kottenhagen-Edzes, P.A., "Het wetsvoorstel verkeersongevallen: een aanvaardbaar compromis?", $N J B, 1998 / 3$, p. 109-115.

Kottenhagen, R.J.P. en P.A. Kottenhagen-Edzes, "Eindelijk naar een nieuw verkeersongevallenrecht (?)", $N J B, 1995 / 30$, p. 1115-1123.

Kremer, F.Th., J.F.M. Hennekam en J. van der Harst, "De bescherming van de zwakke(re) verkeersdeelnemer: een kostbare zaak", $V R, 1998$, p. 289-293.

Lambert-Faivre, Y., "Perspectives de réformes: Les objectifs prioritaires", Resp. civ. et ass., 1996/4, p. 18-21.

Lambert-Faivre, Y., Droit des assurances, Paris, Dalloz, 1995.

Landes, E.M., "Insurance, Liability and Accidents: A Theoretical and Empirical Investigation of the Effect of No-Fault Accidents", Journal of Law and Economics, vol. 25, april 1982, p. 49-65.

Landes, E.M., "Compensation for Automobile Accident Injuries: Is the Tort System Fair?", Journal of Legal Studies, 1982, p. 253-259.

Landes, W.M. and R.A. Posner, The Economic Structure of Tort Law, Cambridge, Harvard University Press, 1987.

Landes, W.M. and R.A. Posner, "The Positive Economic Theory of Tort Law", Georgia Law Review, vol. 15, 1981, p. 851-924.

Latin, H.A., "Problem-Solving Behavior and Theories of Tort Liability", California Law Review, 1985, vol. 73, p. 677-746.

Leigh, J.P. and J.T. Wilkinson, "The Effect of Gasoline Taxes on Highway Fatalities", Journal of Policy Analysis and Management, 1991, p. 474-481.

Lemaire, J., Bonus-Malus Systems in Automobile Insurance, Boston/Dordrecht, Kluwer, 1995.

Lemaire, J., "A Comparative Analysis of Most European and Japanese BonusMalus Systems", Journal of Risk and Insurance, vol. 55, 1988, p. 660-681. 
Leong, A.K., "Liability Rules When Injurers as well as Victims Suffer Losses", International Review of Law and Economics, 1989, vol. 9, p. 105-111.

Levitt, S.D., "Incentive Compatibility Constraints as an Explanation for the Use of Prison Sentences Instead of Fines", International Review of Law and Economics, 1997, p. 179-192.

Loeb, P.D., "The Effectiveness of Seat-Belt Legislation in Reducing Injury Rates in Texas", American Economic Review, AEA-paper, 1995, p. 81-84.

Lund, A.K. and B. O'Neill, "Perceived Risks and Driving Behavior", Accident Analysis and Prevention, 1986, p. 367-370.

Maanen, G.E. van, "Onrechtmatige daad (losbladig)". Art. 197 Tijdelijke regeling verhaalsrechten, suppl. 39 (juli 1998), aant. 1-13.

Maanen, G.E. van, "Wetsvoorstel verkeersongevallen: dwaling of boerenbedrog?", $N J B, 1998 / 3$, p. 116-121.

Maanen, G.E. van, Onrechtmatige daad, Zwolle, W.E.J. Tjeenk Willink, diss., 1986 , p. $38-43$ en p. $192-195$.

Maanen, G.E. en E. Nelissen, "De positie van regresnemers in het wetsvoorstel verkeersongevallen", in Verkeersaansprakelijkheid in België en Nederland, T. Hartlief en M.G. Faure (red.), Groningen-Antwerpen, Intersentia, 1998, p. 197-216.

Maanen G.E. van en P. Römers, De Tijdelijke regeling verhaalsrechten. Verhaalsmogelijkheden voor verzekeraars en uitkeringsinstanties, Nijmegen, Ars Aequi Libri, 1994.

Maanen, G.E. van en P. Römers, "Eigen schuld en art. 31 WVW; Frank Randag", Kwartaalbericht Nieuw BW, 1991/3, 95-96.

Maanen, G.E., J. Spier en C.H.W.M. Sterk, "Van schuld naar risico?", in Aansprakelijkheden. Opstellen rond het thema ontwikkelingen in het aansprakelijkheidsrecht, M.J.G.C. Raaijmakers, R. van Rooij en J. Spier (red.), Deventer, Kluwer, 1990, p. $65-143$.

Mackaay, E., "Verschuivingen in de rechtseconomie; Kroniek over de jaren 19881990 ", NJB, 24 oktober 1991, afl. 37, p. 1505-1521.

Mackaay, E., "Het aansprakelijkheidsrecht", Ars Aequi, oktober 1990, p. 141-147. 
Mackaay, E., "Het recht bezien door de bril van de economist", RM Themis, november 1988, nr. 9, p. 411-452.

Mackaay, E., "Veranderingen in het stelsel van vergoeding en verhaal van schade", NJB, 1980, Afl. 32, p. 813-825.

Mackaay, E., "Economics of Information and Law", Montreal, Groupe de recherche en consommation, 1980 , p. 172-208.

Mahony, R., "New Zealand's Accident Compensation Scheme: A Reassessment", American Journal of Comparative Law, vol. 40, 1992, p. 159-211.

Males, M.A., "The Minimum Purchase Age for Alcohol and Young-Driver Fatal Crashes: a Long-Term View", Journal of Legal Studies, 1986, vol 15, p. 181-211.

Maloney, M.T. and R.E. McCormick, "A Positive Theory of Environmental Quality Regulation", Journal of Law and Economics, 1982, vol. 25, p. 99-123.

Mannering, F. and C. Winston, "Automobile Air Bags in the 1990s: Market Failure or Market Efficiency?", Journal of Law and Economics, 1995, vol. 38, p. 265279.

Marshall, J., "Moral Hazard", American Economic Review, 1976, p. 889-890.

Matthews, M.L. and A.R. Moran, "Age Differences in Male Drivers' Perception of Accident Risk: The Role of the Perceived Driving Ability", Accident Analysis and Prevention, vol. 18, 1986, p. 299-313.

McCarthy, P.S., "Seat Belt Usage Rates: A Test of Peltzman's Hypothesis", Accident Analysis and Prevention, vol. 18, 1986, p. 425-438.

McCormick, I.A., F.H. Walkey and D.E. Green, "Comparative Perceptions of Driver Ability - A Conformation and Expansion", Accident Analysis and Prevention, vol. 18,1986 , p. 205-208.

McEwin, R.I., "No-Fault and Road Accidents: Some Australasian Evidence", International Review of Law and Economics, 1989, p. 13-24.

McGee, A., "English Law", in The Law and Practice of Insurance in the Single European Market, Trier, Series of Publications by the Acadamy of European Law, Vol. 11, p. 79-87. 
McLean, I., Public Choice, An Introduction, Oxford/New York, Basil Blackwell, 1987 , p. $9-28$ en p. $62-81$.

Medoff, M.H. and J.P. Magaddino, "An Empirical Analysis of No-Fault Insurance", Evaluation Review, vol. 6, 1982, p. 373-392.

Meier, K.J., "The Politics of Insurance Regulation", Journal of Risk and Insurance, 1991, p. 700-713.

Mendel, M.M., "Bewijs van opzet en bewuste roekeloosheid", in Bewijs en letselschade, Lelystad, Vermande, LSA 1998, p. 59-70.

Mendel, M.M., "Enkele aspecten van opzet en grove schuld in het schadeverzekeringsbedrijf", In Volle Verzekerdheid, opstellen aangeboden aan Prof. mr A.J.O. baron van Wassenaer van Catwijck, Zwolle, Tjeenk Willink, 1993, p. 113-124.

Merkin, R. and A. Rodger, EC Insurance Law, London/New York, Longman, 1997.

Meza, D. de, "The Efficiency of Liability Law", International Review of Law and Economics, 1986, p. 107-113.

Michener, R. and C. Tighe, "A Poisson Regression Model of Highway Fatalities", American Economic Review, Papers and Proceedings, 1992, p. 452-456.

Mitchell, W.C. and M.C. Munger, "Economic Models of Interest Groups: An Introductory Survey", American Journal of Political Science, 1991, p. 512-546.

Mueller, D.C., "Public Choice: A Survey", Journal of Economics Literature, 1976, p. 395-433.

Mulder, J.A.G. en P. Wesemann, De snelheidsclausule in de verzekeringsvoorwaarden, Leidschendam, SWOV, 1994, R-94-29.

Nat, P. van der, "Wijziging in de behandeling van artikel 31 (Wegenverkeerswet) zaken", in (Nieuw) BW en personenschade, Lelystad, Vermande, LSA 1992, p. 6583.

Neher Schraub, N., "Bilan et perspectives: le point de vue du magistrat", Resp. civ. et ass., 1996/4, p. 14-16. 
Nell, M. and A. Richter, "Optimal Liability: The Effects of Risk Aversion, Loaded Insurance Premiums, and the Number of Victims", The Geneva Papers on Risk and Insurance, 1996, p. 240-257.

Nelson, P., "Information and Consumer Behavior", Journal of Political Economy, 1970 , p. 311-329.

Nentjes, A. en J. Dijkstra, "Verkeersaansprakelijkheid: slachtoffercompensatie of ongevallenpreventie?, $N J B, 1993$, p. 951-954.

Nentjes, A., "Van wie is het milieu?", Ars Aequi, 1990, p. 708-709.

Nieuwenhuis, J.H., "De wet van het uitgesloten midden", RM Themis, 1999, p. $357-$ 358.

Niskanen, W.A., "Bureaucrats and Politicians", Journal of Law and Economics, 1975 , p. 617-643.

Noordzij, P.C., Verkeerswetgeving, -gedrag en -veiligheid, Rijksuniversiteit Leiden, Werkgroep Veiligheid, R-87/12.

Notitie Verkeersaansprakelijkheid, $V R$, 1990/11, p. 281-293.

O'Connell, J., "No-Fault Auto Insurance: Back By Popular (Market) Demand?", San Diego Law Review, 1989, p. 993-1015

O'Connell, J. and R.H, Joost, "Giving Motorists a Choice Between Fault and NoFault Insurance", Virginia Law Review, vol. 72, 1986, p. 61-89.

O'Connell, J. and C. Tenser, "North America's Most Ambitious No-Fault Law: Quebec's Auto Insurance Act", San Diego Law Review, vol. 24, 1987, p. 917-928.

0'Connell, J.F., Welfare Economic Theory, Boston, Auburn House Publishing Company, 1982.

OECD-Rapport, Automobile Insurance and Road Accident Prevention, Road Transport Research, 1990, p. 1-128.

Ogus, A.I., Regulation: Legal Form and Economic Theory, Oxford, Clarendon Press, 1994.

Ogus, A.I., "Information, Error Costs and Regulation", International Review of Law and Economics, 1992, p. 411-421. 
Ott, C. und H-B Schafer, "Negligence as Untaken Precaution, Limited Information, and Efficient Standard Formation in the Civil Liability System", International Review of Law and Economics, 1997, p. 15-29.

Ottervanger, T.R., "Mededingingsrecht en de verzekeringssector", in Verzekering en Europa, preadvies Vereniging voor Verzekeringswetenschap, Zwolle, Tjeenk Willink, 1994, p. 73-86.

Outreville, J-F., "The Impact of the Government No-Fault Plan for Automobile Insurance in the Province of Quebec", Journal of Risk and Insurance, vol. 51, 1984, p. $320-335$.

Overeem, R., "Recente rechtspraak en een opmerkelijk wetsvoorstel ter bescherming van verkeersslachtoffers in Frankrijk", $V R, 1985$, p. 99-103.

Overeem, R., "Beperking van het beroep op eigen schuld van verkeersslachtoffers naar Frans recht. Een revolutionair arrest", $V R, 1984 / 3$, p. 49-55.

Palmer, G.W.R., "Accident Compensation in New Zealand: The First Two Years", The American Journal of Comparative Law, 1977, p. 1-45.

Parisi, F., "Private Property and Social Costs", European Journal of Law and Economics, 1995, p. 149-173.

Parlementaire Handelingen Belgische Senaat, Wetsontwerp tot wijziging van diverse bepalingen betreffende de regeling inzake automatische vergoeding van de schade, geleden door zwakke weggebruikers en passagiers van motorijtuigen, zitting 2000-2001, Verslag, 6 december 2000, nr. 2-478/3.

Pauly, M.V., H. Kunreuther and P. Kleindorfer, "Regulation and Quality Competition in the US Insurance Industry", in The Economics of Insurance Regulation: A Cross National Study, J. Finsinger and M.V. Pauly (eds.), Basingstoke New York, MacMillan, 1986, p. 65-107.

Pauly, M.V., "Overinsurance and Public Provision of Insurance: The Rules of Moral Hazard and Adverse Selection", Quartely Journal of Economics, 1974, p. 4462.

Pauly, M.V., "The Economics of Moral Hazard: Comment", American Economic Review, 1968, p. 531-537.

Peirson, J., I. Skinner and R. Vickerman, "The Microeconomic Analysis of the External Costs of Raod Accidents", Economica, 1998, p: 429-440. 
Peltzman, S., "Toward a More General Theory of Regulation", Journal of Law and Economics, 1976, p. 211-240.

Peltzman, S., "The Effects of Automobile Safety Regulation", Journal of Political Economy, vol. 84, 1975, p. 677-725.

Perez, L., "Commentaar op de Franse wet van 5 juli 1985 betreffende de schadeloosstelling van verkeersslachtoffers", $V R, 1986 / 7-8$, p. 169-173.

Perron, E. du en K. Verduyn, "Een regel te veel?", VR, 1994/3, p. 65-68.

Peterson, S.P., G. Hoffer and E. Millner, "Are Drivers of Air-Bag-Equipped Cars more agressive? A Test of the Offsetting Behavior Hypothesis", Journal of Law and Economics, 1995, vol 38, p. 251-264.

Peterson, S.P. and G. Hoffer, "The Impact of Airbag Adoption on Relative Personal Injury and Absolute Collision Insurance Claims", Journal of Consumer Research, vol. 20, 1994, p. 657-662.

Philippe, D., "Les conditions d'application de la nouvelle loi. L'implication du véhicule automoteur", in L'indemnisation automatique de certaines victimes d'accidents de la circulation, B. Dubuisson (ed.), Brussel, Academia-Bruylant, 1995, p. 52-73.

Philippe, D.M. en M. Meysmans, "De betrokkenheid van het motorrijtuig in de nieuwe wet tot bescherming van zwakke weggebruikers", $T v P, 1995 / 2$, p. 405-438.

Picker, R.C., An Introduction to Game Theory and the Law, Chicago, Law and Economics Working Paper, nr. 22, 1993, p. 1-20.

Plaizier, P.C., Factoren die van invloed zijn op autogordelgebruik, Rijksuniversiteit Leiden, Werkgroep Veiligheid, R-87/14.

Polak, R.J., Inleiding tot het wegenverkeersrecht, Deel I: Materieel verkeersrecht, Zwolle, W.E.J. Tjeenk Willink, 1996, p. 51-56.

Polak, R.J., Inleiding tot het wegenverkeersrecht, Deel III: Strafrechtelijke afwikkeling, Zwolle, W.E.J. Tjeenk Willink, 1989, p. 53-63.

Polak, R.J., Inleiding tot het wegenverkeersrecht", Deel II: Civielrechtelijke afwikkeling, Zwolle, W.E.J. Tjeenk Willink, 1987. 
Polborn, M.K., "Mandatory Insurance and the Judgment-Proof Problem", International Review of Law and Economics, 1998, p. 141-146.

Polinsky, A.M. and S. Shavell, "On Offense History and the Theory of Deterrence", International Review of Law and Economics, 1998, p. 305-324.

Polinsky, A.M. and S. Shavell, "A Note on Optimal Fines When Wealth Varies Among Individuals", American Economic Review, 1991, p. 618-621.

Polinsky, A.M., An Introduction to Law and Economics, Boston, Little, Brown and Company, 2e edition, 1989.

Posner, R.A., The Economic Analysis of Law, New York, Aspen Law \& Business, $5^{\text {th }}$ edition, 1998.

Posner, R.A., "An Economic Theory of the Criminal Law", Columbia Law Review. 1985, p. 1193-1231.

Posner, R.A., "Theories of Economic Regulation", The Bell Journal of Economics, 1974, p. 335-358.

Posner, R.A., "A Theory of Negligence", Journal of Legal Studies, 1972, p. 29-96.

Poté, R., Handboek verkeerswetgeving, deel 3, Leuven/Amersfoort, Acco, 1985, p. 759-771.

Powers, M.R., "Equity in Automobile Insurance: Optional No-Fault", The Journal of Risk and Insurance, vol. 59, 1992, p. 203-220.

Priest, G.L., "The Current Insurance Crisis and Modern Tort Law", The Yale Law Journal, 1987, vol. 96, p. 1521-1590.

Prölss, E.R., Versicherungsaufsichtgesetz, Bearbeitet von R. Schmidt und P. Frey, München, C.H. Beck'sche Verlagsbuchhandlung, 1983, p. 47-57, p. 149-155, p. 256281 en p. 544-549.

Putto, Th.M., "Verplichte verzekering voor 'eigen schade', een Amerikaanse modelwet", $V R, 1973$, p. 25-28.

Quant, J.M., "Alles heeft zijn prijs, reactie op Brenninkmeijer, NJB, 1994, p. 13761380.

Raad voor de Verkeersveiligheid, Schuld en boete, 1994, p. 1-28. 
Rasmussen, E., "How Optimal Penalties Change with the Amount of Harm", International Review of Law and Economics, 1995, p. 101-108.

Raviv, A., "The Design of an Optimal Insurance Policy", American Economic Review, 1978, p. 84-96.

Redmond-Cooper, R., "The Relevance of Fault in Determining Liability for Road Accidents: The French Experience", I.C.L.Q., vol. 38, 1989, p. 502-521.

Reehuis, W.H.M. en E.E. Slob, Parlementaire geschiedenis van het nieuwe burgerlijk wetboek (Invoering Boeken 3, 5 en 6), Boek 6, Algemeen gedeelte van het verbintenissenrecht, Deventer, Kluwer, 1990, p. 1404.

Renckens, M.L.M. en R. van Leeuwen, "Van Wassenaer van Catwijck over verkeersverzekering", Interview, $V R, 1996 / 9$, p. 249-251.

Renckens, M.L.M., "Schuld en boete", De beursbengel, 1995, p. 18-20.

Risser, R., "Behavior in Traffic Conflict Situations", Accident Analysis and Prevention, vol. 17,1985 , p. 179-197.

Roger, W.V.H., Winfield and Jolowicz on Tort, London, Sweet \& Maxwell, 1984, p. 147-149.

Rolph, J.E., J.K. Hammit and R.L. Houchens, "Automobile Accident Compensation: Who Pays How Much How Soon?", Journal of Risk and Insurance, vol. 52, 1985 , p. $667-685$.

Rose-Ackerman, S., Rethinking the Progressive Agenda. The Reform of the American Regulatory State, New York, The Free Press (Mac Millan), 1992, p. 118131.

Rose-Ackerman, S., "Tort as a Regulatory System; Regulation and the Law of Torts", American Economic Review, vol. 81, 1991, p. 54-58.

Rubenfield, D.L., "The Efficiency of Comparative Negligence", Journal of Legal Studies, 1987, vol. 16, p. 375-394.

Saffer, H. and F. Chaloupka, "Breath Testing and Highway Fatality Rates", Applied Economics, vol. 21, 1989, p. 901-912.

Saffer, H. and M. Grossman, "Drinking Age Laws and Highway Mortality Rates: Causes and Effect", Economic Inquiry, vol. 25, 1987, p. 403-412. 
Salomons, R.A., "Verzekering voor de schade van verkeersslachtoffers", $V R$, 1980/4, p. 73-78.

Salomons, R.A., "Verzekering voor de schade van verkeersslachtoffers", $V R$, $1978 / 6$, p. $125-131$

Salomons, R.A., "Verkeersverzekering", VA, 1974, p. 197-202.

Schäfer, H-B. und A. Schonenberger, Strict Liability versus Negligence, Universität Hamburg, Diskussionsbeiträge Recht und Ökonomie, August 1997, nr. 34.

Schäfer, H-B. und C. Ott, Lehrbuch der ökonomischen Analyse des Zivilrechts, Berlin, Springer, 1995.

Schilfgaarde, E. van, "Economische analyse van de Nederlandse aansprakelijkheid uit onrechtmatige daad", Ars Aequi, oktober 1990, p. 148-156.

Schirmeister, F.C., Amerikaanse toestanden in het schadevergoedingsrecht?, Lelystad, Koninklijke Vermande, 1996.

Schlesinger, H. and J-M. Graf von der Schulenburg, "Consumer Information and Decisions to Switch Insurers", Journal of Risk and Insurance, vol. 60, 1993, p. 591615.

Schmit, J.T., "A New View of the Requisites of Insurability", The Journal of Risk and Insurance, 1986, vol. 53, p. 320-329.

Schoorens, G., Verkeersongevallen met "zwakke weggebruiker"; Het nieuwe vergoedingssysteem van art. 29bis WAM-wet. Het kwalificatieprobleem, R.G.A.R., $1995,12443 / 1-10$.

Schuermans, L. en D. Simoens, "Verkeersaansprakelijkheid en verzekering naar Belgisch recht", $T v P, 1978$, p. 1123-1139.

Schut, G.H.A., Onrechtmatige daad, Deventer, Tjeenk Willink, 1997.

Schwartz, A. and L.L. Wilde, "Intervening in Markets on the Basis of Imperfect Information: A Legal and Economic Analysis", University of Pennsylvania Law Review, 1979, p. 630-682. 
Schwartz, G.T., "Mixed Theories of Tort Law: Affirming Both Deterrence and Corrective Justice", Texas Law Review, vol. 75, 1997, p. 1801-1834.

Schwartz, G.T., "The Ethics and the Economics of Tort Liability Insurance", Cornell Law Review, 1990, p. 313-365.

Shavell, S., "Specific versus General Enforcement of Law", Journal of Political Economy, 1991, p. 1088-1108.

Shavell, S., Economic Analyses of Accident Law, Harvard University Press, Cambridge, 1987.

Shavell, S., "The Judgement Proof Problem", International Review of Law and Economics, 1986, p. 45-58.

Shavell, S., "Criminal Law and the Optimal Use of Nonmonetary Sanctions as a Deterrent", Colombia Law Review, 1985, vol. 85, p. 1232-1262.

Shavell, S., "Uncertainty over causation and the determination of civil liability", Journal of Legal Studies, oktober 1985, p. 587-609.

Shavell, S., "Liabilty for Harm versus Regulation of Safety", Journal of Legal Studies, 1984, p. 357-374.

Shavell, S., "On the Optimal Use of Liability and Safety Regulation", Rand Journal of Economics, 1984, p. 271-280.

Shavell, S., "On Liabilty and Insurance", The Bell Journal of Economics, vol. 13, 1982, p. 120-132.

Shavell, S., "Strict Liablity versus Negligence", Journal of Legal Studies, 1980, p. $1-25$.

Shavell, S., "On Moral Hazard and Insurance", The Quartely Journal of Economics, 1979 , p. 541-562.

Simoens, D., "Het verkeersongevallenartikel 29 bis W.A.M.: stand van zaken na de wetswijziging van 19 januari 2001", $R W, 2001$, p. 1577-1586.

Simoens, D., "De gewijzigde vergoedingsregel ten voordele van voetgangers, fietsers en passagiers", $R W, 1995-1996 / 7$, p. 218-223. 
Simoens, D., "Objectieve aansprakelijkheid inzake wegverkeer", J.F., 1994, p. $532-$ 546.

Simoens, D., "De nieuwe vergoedingsregel ten voordele van voetgangers en fietsers", $R W, 1994-1995 / 4$, p. 114-120.

Simoens, D., "Ongevallenrecht: grensgebieden van aansprakelijkheid, verzekering en sociale zekerheid", $T v P, 1984$, p. 417-460.

Simoens, D., "Invloed van verzekering op aansprakelijkheid", $R W, 1981-82$, p. 1282-1285.

Simoens, D., "Hoofdlijnen in de evolutie van het aansprakelijkheidsrecht", $R W$, 1980-1981/30-31, p. 1961-1990 en p. 2025-2036.

Simoens, D., Vergoeding voor verkeersslachtoffers. Naar een grondige hervorming?, Antwerpen-Amsterdam, Maarten Kluwer, diss., 1979.

Singh, H. and M. Thayer, "Impact of Seat Belt Use on Driving Behavior", Economic Inquiry, vol. 30, 1992, p. 649-658.

Skipper, H.D., "Insurer Solvency Regulation in the United States", in Policy Issues in Insurance, Organisation for Economic Co-operation and Development, 1993, p. 75-143.

Skogh, G., "The Combination of Private and Public Regulation of Safety", in Essays in Law and Economics, M.G. Faure and R. Van den Bergh (eds.), AntwerpenApeldoorn, Maklu, 1989, p. 87-101.

Skogh, G., "The Transactions Cost Theory of Insurance: Contracting Impediments and Costs", Journal of Risk and Insurance, 1989, p. 726-732.

Skogh, G., "Public Insurance and Accident Prevention", International Review of Law and Economics, 1982, p. 67-80.

Sloan, F.A., B.A. Reilly and C.M. Schenzler, "Tort Liability versus Other Approaches for Deterring Careless Driving", International Review of Law and Economics, 1994, p. 53-71.

Sloan, F.A. and P.B. Githens, "Drinking, Driving, and the Price of Automobile Insurance", Journal of Risk and Insurance, 1994, p. 33-58. 
Smith, E. and R. Wright, "Why is Automobile Insurance in Philadelphia So Damn Expensive", American Economic Review, vol. 82, 1992, p. 756-772.

Sociaal Economische Raad, Investeren in verkeersveiligheid, publicatienummer 13, 15 oktober 1999.

Sociaal Economische Raad, Regresrechten in de sociale verzekeringen, publicatienummer 14, 17 september 1993.

Solender, E.K., "New Zealand's No-Fault Accident Compensation Scheme Has Some Unintended Consequences: A Caution to U.S. Reformers", The International Lawyer, vol. 27, 1993, p. 91-111.

Spahr, R.W. and E.L. Escolas, "1979 Automobile Accident Reports: Do Driver Characteristics Support Rate Discrimation?", Journal of Risk and Insurance, vol. 49, 1982, p. 91-103.

Spier, J., Een nieuwe dageraad voor het aansprakelijkheidsrecht?, Deventer, W.E.J. Tjeenk Willink, afscheidsrede, 1999, p. 1-18.

Spier, J., "De causale maatstaf van art. 6:101 BW", in Eigen schuld bij onrechtmatige daad, Lelystad, Vermande, LSA 1997, p. 15-23.

Spier, J., De uitdijende reikwijdte van de aansprakelijkheid uit onrechtmatige daad, preadvies, N.J.V, 1996, Zwolle, Tjeenk Willink, p. 207-234.

Spier, J., "De grenzen van subrogatie in zieligheid", in Regresrechten. Afschaffen, handhaven of uitbreiden, W.H. van Boom, T. Hartlief en J. Spier (red.), Deventer, Tjeenk Willink, 1996, p. 41-44.

Spier, J., Schadevergoeding. Algemeen, deel 3, Monografieën Nieuw BW B36, Deventer, Kluwer, 1992.

Stephen, F.H., "Expected Damage and Due Care", European Journal of Law and Economics, 1994, p. 23-31.

Sterk, C.H.W.M., "Het begrip "betrokkenheid" in het wetsvoorstel verkeersongevallen $1997, V R, 1998 / 3$, p. 65-69.

Sterk, C.H.W.M., "De Loi Badinter: onverdeeld positief beoordeeld", $V R, 1997 / 7-$ 8. p. 197-201. 
Sterk, C.W.H.M., Verhoogd gevaar in het aansprakelijkheidsrecht. Een rechtsvergelijkend onderzoek naar aansprakelijkheid voor zaken, stoffen en motorrijtuigen, Deventer, Kluwer, diss., 1994.

Stiefel, E. und E. Hofmann, Kraftfahrtversicherung: Kommentar zu den Allgemeinen Bedingungen für die Kraftfahrtversicherung - $A K B$, München, C.H. Beck'sche Verlagsbuchhandlung, 1986, p. 1-26 en p. 584-597.

Stigler, G.J., "The Theory of Economic Regulation", The Bell Journal of Economics, 1971, p. 3-21.

Stigler, G.J., "The Economics of Information", The Journal of Political Economy, 1961, p. 213-225.

Storme, M.E., "Kausaliteit in het Belgische aansprakelijkheids- en verzekeringsrecht", $V R, 1990 / 9$, p. 225-231.

Studiegroep Verkeersaansprakelijkheid, Vergoeding van zaakschade, rapport, deel II, Staatsuitgeverij, Den Haag, 1980.

Studiegroep Verkeersaansprakelijkheid, Vergoeding van schade door dood en letsel", rapport, deel I, Staatsuitgeverij, Den Haag, 1978.

Sugarman, S., "Auto Insurance Reform: Should We 'Pay at the Pump?", Law and Economics, Working Paper Series, University of California, 1993, nr 93-14, p. 1-31.

Svenson, O., B. Fischhoff and D. MacGregor, "Perceived Driving Safety and Seatbelt Usage", Accident Analysis and Prevention, 1985, p. 119-133.

Symposium verkeersaansprakelijkheid, VR, 1990/12, p. 309-333.

Tapp, J., "Regulation of the UK Insurance Industry", in The Economics of Insurance Regulation: A Cross-National Study, J. Finsinger and M.V. Pauly (eds.), Basingstoke/New York, MacMillan, 1986, p. 27-61.

Teijl, R. en R.W. Holzhauer, Wisselende perspectieven in de rechtseconomie, Rotterdam, Sanders Instituut/Gouda Quint, diss., 1997.

Thiry, G., "Le cout du risque automobile, les pratiques de tarification et d'indemnisation", Risque, 1990, p. 113-128.

Tjittes, R.P.J.L., "De Tijdelijke Regeling Verhaalsrechten", $N b B W, 1992 / 1$, p. 1012. 
Tollison, R.D., "Public Choice and Legislation", Virginia Law Review, 1988, p. 339-371.

Tollison, R.D., "Rent Seeking: A Survey", Kyklos, vol. 35, 1982, p. 575-602.

Tourneau, Ph. le et L. Cadiet, Droit de la responsabilité, Paris, Édition Dalloz, 1998.

Trebilcock, M., The Role of Insurance Considerations in the Choice of Efficient Liability Rules, Joumal of Law, Economics and Organisation, 1988, p. 243-265.

Tryfos, P., "The Equity of Classification Systems in Automobile Insurance", Journal of Risk and Insurance, vol. 54, 1987, 569-581.

Tuerlinckx, B., "Artikel 29bis W.A.M.-Wet: Toepassing in de praktijk na de wetswijziging van 13 april 1995", TvP, 1996/1, p. 3-69.

Tunc, A., "Traffic Accident Compensation", in Towards a European Civil Code, A.S. Hartkamp (ed.), Dordrecht/Boston, Kluwer, 1998, p. 461-471.

Tunc, A., "The 'Loi Badinter': Ten Years of Experience", MJ, 1996/3, p. 329-340.

Tunc, A., La responsabilité civil, Paris, Economica, 1981.

Tunc, A. (dir.), Pour une loi sur les accidents de la circulation, Paris, Economica, 1981, p. 13-16.

Tunc, A., "Traffic Accident Compensation: Law and Proposal", Ch.14. in (Torts) of the International Encyclopedia of Comparative Law, Vol. XI, Tunc (ed.), Nijhoff, 1970 and Supp. 1980.

Tunc, A., "La sécurity routière, esquisse d'une Loi sur les accidents de la circulation 1966" en 'Sur un projet de loi en matière d'accidents de la circulation', Rev. Trim. Dr. Civ., 1967, 82.

Ulen, Th.S., Rational Victims - Rational Injurers; Cognition and the Economic Analysis of Law, Paper, p. 1-52.

Ulrix, R., "Om en bij de Franse wet Badinter", $R W, 1985-1986$, p. 1622-1632.

United Nations, Statistics of Road Accidents in Europe and North America, New York/Geneve, European Commission for Europe, vol. 40, 1995, p. 1-121. 
Utton, M.A, The Economics of Regulating Industry, Oxford, Basic Blackwell, 1986.

Van den Bergh, R.J., "Automatische vergoeding van schade geleden door zwakke verkeersdeelnemers: een rechtseconomische kritiek", in Verkeersaansprakelijkheid in België en Nederland, T. Hartlief en M.G. Faure (red.), Groningen-Antwerpen, Intersentia, 1998, p. 27-74.

Van den Bergh, R.J., "Is verkeersveiligheid te duur?, $R W, 1994-1995$, p. 13131323.

Van den Bergh, R.J., "Self-Regulation in the Medical and Legal Professions and the European Internal Market in Progress", in Regulation of Professions, serie Law and Economics, M.G. Faure, J. Finsinger, J, Siegers and R. Vanden Bergh (eds.), Antwerpen/Apeldoorn, Maklu, 1993, p. 21-43.

Van den Bergh, R.J., "Wat is Rechtseconomie?", Rechtseconomie en Recht; Kennismaking met een vakgebied in opkomst, Zwolle, W.E.J. Tjeenk Willink, 1991, p. 9-49.

Van den Bergh, R.J., "Belgian Public Policy Towards the Retailing Trade", in Law and Economics and the Economics of Legal Regulation, J-M. von der Schulenburg and G. Skogh (eds.), Boston/Dordrecht, Kluwer, 1986, p. 185-205.

Van den Bergh, R.J., "Het misbruiktoezicht op ondernemingen in machtspositie naar Europees en Belgisch recht: Beschouwingen bij recente ontwikkelingen", Tijdschrift voor Privaatrecht, 1986, p. 157-246.

Van den Bergh, R.J., M.G. Faure en J. Lefevere, "The Subsidiarity Principle in European Environmental Law: An Economic Analysis in Law and Economics of the Environment", R. Van den Bergh en E. Eide eds., Oslo, Juridisk Forlag, 1996, p. 138.

VandenBerghe, H., "De grondslag van kontraktuele en extra-kontraktuele aansprakelijkheid voor eigen daad", $T v P, 1984$, p. 127-154.

VandenBerghe, H., M. Van Quickenborne, K. Geelen, en S. Decoster, "Overzicht van Rechtspraak (1979-1984). Aansprakelijkheid uit onrechtmatige daad", $T v P, 1987$, p. 1255-1615.

VandenBerghe, H., M. Van Quickenborne en P. Hamelink, "Overzicht van rechtspraak (1964-1978). Aansprakelijkheid uit onrechtmatige daad", TvP, 1980, p. $1139-1475$. 
VandenBerghe, H., M. Van Quickenborne en L. Wynant, "Overzicht van rechtspraak (1985-1993). Aansprakelijkheid uit onrechtmatige daad", $T v P, 1995$, p. 1115-1534.

Vanden Borre, T., Efficiënte preventie en compensatie van catastroferisico's - het voorbeeld van schade door kernongevallen, dissertatie, Antwerpen, Intersentia, 2001.

Van de Sype, P., "De vergoeding van de zwakke weggebruikers in de autoverzekering: een algemene situering", in De vergoeding van zwakke weggebruikers in de autoverzekering: een praktische handleiding, Bull. Ass. - De Verz., Antwerpen, Story-Scienta, Dossier 3, 1995, p. 47-64.

Van Schoubroeck, C., G. Joque, A. Verspikken en H. Cousy, "Overzicht van rechtspraak verzekering motorrijtuigen (1980-1997)", $T \nu P, 1998$, p. 316-327.

Veljanovski, C.G., The New Law and Economics: A Research Review, Oxford, Centre for Socio-Legal Studies, 1982, p. 5-16.

Veljanovski, C.G., "The Economic Theory of Tort Liablity - Toward a Corrective Justice Approach", in: The Economic Approach to Law, P. Burrows and C.G. Veljanovski, Butterworths, 1981, p. 125-150.

Velthoven, B.C.J. van, "Veiliger verkeer in Nederland?, $V R$, 2000, p. 313-322.

Velthoven, B.C.J. van en P.W. van Wijck, Recht en efficiëntie, Deventer, Kluwer, 1997.

Venezian, E.C., "Interactions in Insurance Classification", Journal of Risk and Insurance, vol. 52,1985 , p. 571-584.

Verbond van Verzekeraars, "Raad voor de verkeersveiligheid op het verkeerde been", Het Verzekeringsblad, 1994, p. 1470-1471.

Vickrey, W., "Automobile Accidents, Tort Law, Externalities, and Insurance: An Economist's Critique", Law and Contemporary Problems, 1968, p. 464-487.

Viney, G., "La place du droit à indemnisation dans la loi du 5 juillet 1985", Resp. civ. et ass., 1996/4, p. 4-10.

Viney, G., L'indemnisation des victimes d'accident de la circulation, Paris, L.G.D.J., 1992. 
Viney, G., "La faute de la victim d'un accident corporel: le présent et l'avenir", J.C.P., 1984, I, no. 3155, noot 19-20.

Viney, G. et P. Jourdain, Traité de droit civil: les conditions de la responsabilité, Paris, L.G.D.J., 1998.

Viscusi, W.K., "The Dimensions of the Product Liability Crisis", Journal of Legal Studies, 1991, p. 147-177.

Visser, L.T., en R.J. Van den Bergh, Over fietsende juristen en autorijdende rechtseconomen of een nieuwe fase in het debat over verkeersaansprakelijkheid, $N J B$, 1998 , p. 122-127.

Visser, S., "Ook GVT-2 (Utrecht-Zaltbommel) slaat aan", Politiecom (special), juni 1995, p. 18-19.

Wachter, B., "Van aansprakelijkheids- naar verkeersverzekering? -Of niet?", $R M$ Themis, 1975, p. 227-271.

Wachter, B., "Van aansprakelijkheids- naar verkeersverzekering? -Of niet?", $V A$, 1974, p. 191-196.

Wagenaar, W.A., "Gedrag, de oorzaak van verkeersonveiligheid", $V R, 1988$, p. $57-$ 59.

Wassenaer van Catwijck, A.J.O. baron van, "Artikel 185 WVW 1994, het nieuwe artikel 31 WVW", $V R, 1995 / 7-8$, p. 197-199.

Wassenaer van Catwijck, A.J.O. baron van, "Zes vrouwen in het verkeer", VR, 1994/9, p. 253-260.

Wassenaer van Catwijck, A.J.O. baron van, "Vijf vrouwen in het verkeer", in: CJHB, Brunner-bundel, Deventer, Kluwer, 1994, p. 429-440.

Wassenaer van Catwijck, A.J.O. baron van, Naar een Europees verkeersschaderecht, Deventer, Kluwer, afscheidsrede, 1993, p. 1-27.

Wassenaer van Catwijck, A.J.O. baron van, "Een kwart eeuw eigen schuld", $V R$, 1992/7-8, p. 181-185.

Wassenaer van Catwijck, A.J.O. baron van, "Slachtofferbescherming", VR, $1989 / 10$, p. 253-255. 
Wassenaer van Catwijck, A.J.O. baron van, "Aansprakelijkheidsverzekering of niet; is alles wel in orde met de WAM", $V R$, 1989/2, p. 60-63.

Wassenaer van Catwijck, A.J.O. baron van, Verkeersverzekering in Nederland: Is no-fault geschikt voor export naar Nederland?, Reeks studiekring Drion, nr. 8, Deventer, Kluwer, 1989, p. 1-63.

Wassenaer van Catwijck, A.J.O. baron van, "Betreft: treinen in de USA: No-fault in Quebec, $V R, 1988$, p. 374-375.

Wassenaer van Catwijck, A.J.O. baron van, "Aansprakelijkheid en de grenzen der verzekerbaarheid, $V R, 1988$, p. 367-371.

Wassenaer van Catwijck, A.J.O. baron van, "Verkeersverzekering in NoordAmerika", VA, 1988, p. 321-377.

Wassenaer van Catwijck, A.J.O. baron van, Verkeersverzekering, Alphen aan den Rijn, Tjeenk Willink, oratie, 1977, p. 1-78.

Wassenaer van Catwijck, A.J.O. baron van, "Verkeersschade en eigen schuld", in Symposium Verkeersschade, aansprakelijkheid en verzekering, Deventer, Kluwer, 1972, p. $21-43$.

Wassenaer van Catwijck, A.J.O. baron van, Eigen schuld, Zwolle, Tjeenk Willink, diss., 1971.

Wassenaer van Catwijck, A.J.O. baron van en R.H.C. Jongeneel, Eigen schuld en mede-aansprakelijkheid, Zwolle, Tjeenk Willink, 1995.

Weterings, W.C.T., Vergoeding van letselschade en transactiekosten; een kwalitatieve en kwantitatieve analyse, Deventer, W.E.J. Tjeenk Willink, 1999.

White, M.J., "An empirical test of the comparitive and contributory negligence rules in accident law", Rand Journal of Economics, 1989, vol. 20, p. 308-330.

Wijffels, A.A., Inkomensderving als geldstraf, Antwerpen/Arnhem, Kluwer/Gouda Quint, Interuniversitaire reeks criminologie en strafwetenschappen, 1983, p. 91-93.

Wilkinson, J.T., "Reducing Drunken Driving: Which Policies are Most Effective?", Southern Economic Journal, vol. 54, 1987, p. 322-334.

Wilson, G.H., "Social Regulation and Explanations of Regulatory Failure", Journal of Political Studies, 1984, p. 204 en p. 210-211. 
Winter, R.A., "The Liability Insurance Market", Journal of Economic Perspectives, 1991, vol. 5, p. 115-136.

Witt, R.C. and J. Urrutia, "A Comparative Economic Analysis of Tort Liability and No-Fault Compensation Systems in Automobile Insurance", Journal of Risk and Insurance, 1983, p. 631-669.

Wittman, D., D. Friedman, S. Crevier and A. Braskin, "Learning Liability Rules", Journal of Legal Studies, 1997, p. 145-164.

Wittman, D., "Why Democracies Produce Efficient Rules", Journal of Political Economy, 1989, p. 1395-1424.

Wittman, D., "The Price of Negligence under Differing Liability Rules", Journal of Law and Economics, april 1986, vol. XXIX, p. 151-163.

Wittman, D., "Prior Regulation Versus Post Liability: The Choice Between Input and Output Monitoring", Journal of Legal Studies, 1977, p. 193-211.

Young, D.J. and T.W. Likens, "Alcohol Regulation and Auto Fatalities", International Review of Law and Economics, 2000, p. 107-126.

Zador, P. and A. Lund, "Re-Analysis of the Effects of No-Fault Auto Insurance on Fatal Crashes", Journal of Risk and Insurance, vol. 53, 1986, p. 226-241.

Zeven, P.J., "Verkeersaansprakelijkheid en preventie", reactie, $V R, 1995 / 5$, p. 136137.

Zycher, B., Automobile Insurance Regulation, Direct Democracy, and the Interests of Consumers, Regulation/Cato Review of Business and Government, summer 1990, p. 67-77. 


\section{Curriculum Vitae}

Martien van Dam werd geboren op 30 augustus 1966 te Eindhoven. In 1985 behaalde hij zijn VWO-diploma aan het Eindhovens Protestants Lyceum, thans het Constantijn Huygens Lyceum. Van 1985-1992 studeerde hij rechten aan de Erasmus Universiteit te Rotterdam. In 1992 behaalde hij zijn doctoraal-examen Nederlands Recht, bedrijfsjuridische afstudeerrichting. Van 1993 tot 1997 was hij als OIO werkzaam aan het Maastrichts Europees Instituut voor Transnationaal Rechtswetenschappelijk Onderzoek (METRO) te Maastricht. Thans is hij als advocaat werkzaam te Rotterdam.

Martien van Dam is lid van de Werkgroep Aansprakelijkheid en Verzekering van de Ius Commune Onderzoeksschool (een samenwerkingsverband tussen de juridische faculteiten van de Universiteit Maastricht, Katholieke Universiteit Leuven en Universiteit Utrecht). 
Dit boek is een verslag van een onderzoek dat is verricht naar verkeersongevallen. De verkeersaansprakelijkheid staat in Nederland al meer dan 35 jaar in de belangstelling van de wetenschap, de rechtspraktijk en de politiek. Hierbij ligt de nadruk op de bescherming van het verkeersslachtoffer. Met dit onderzoek wordt een additionele bijdrage geleverd aan de Nederlandse discussie omtrent de verkeersaansprakelijkheid en wordt tegelijk een leemte opgevuld door naast de compensatie van verkeersslachtoffers ook de preventie en kosten van verkeersongevallen centraal te stellen. $\mathrm{Na}$ een weergave van de historische ontwikkeling van de verkeersaansprakelijkheid in Nederland, Frankrijk en België wordt aandacht besteed aan de rechtseconomische analyse van het verkeersongevallenrecht. Daarbij wordt onderzocht welke combinatie van aansprakelijkheid, verzekering en veiligheidsregulering leidt tot een optimale preventie van verkeersongevallen en een optimale compensatie van verkeersslachtoffers tegen zo laag mogelijke kosten. De theoretische conclusies van deze analyse worden vervolgens getoetst aan de praktijk, waarbij kritisch aandacht wordt besteed aan het empirisch onderzoek dat op het terrein van het verkeersongevallenrecht is verricht. Op deze wijze kan worden beoordeeld of het recht in de vorm van aansprakelijkheidsregels, verzekeringsvoorwaarden en veiligheidsregulering ook daadwerkelijk van invloed is op het verkeersgedrag en op het aantal verkeersongevallen en verkeersslachtofiers. Ten slotte wordt aan de hand van een toetsing van de Nederiandse, Franse en Belgische verkeersaansprakelijkheid onderzocht welk systeem voor de vergoeđing van verkeersschade, een stelsel met aansprakelijkheid of een verkeersverzekering, het best beantwoordt aan de uitkomsten van de rechtseconomische analyse en het empirisch onderzoek. Het boek wordt afgesloten met een aantal aanbevelingen. 